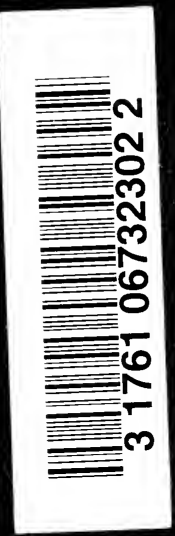


<smiles>CC#CC(CCC)CCCCCCC</smiles> 



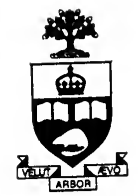

Presented to the

LIBRARIES of the

UNIVERSITY OF TORONTO

by

Hugh Anson-Cartwright 


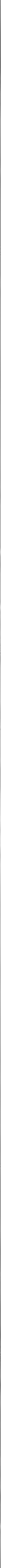


GLOSSARY

OF

TERMS AND PHRASES 


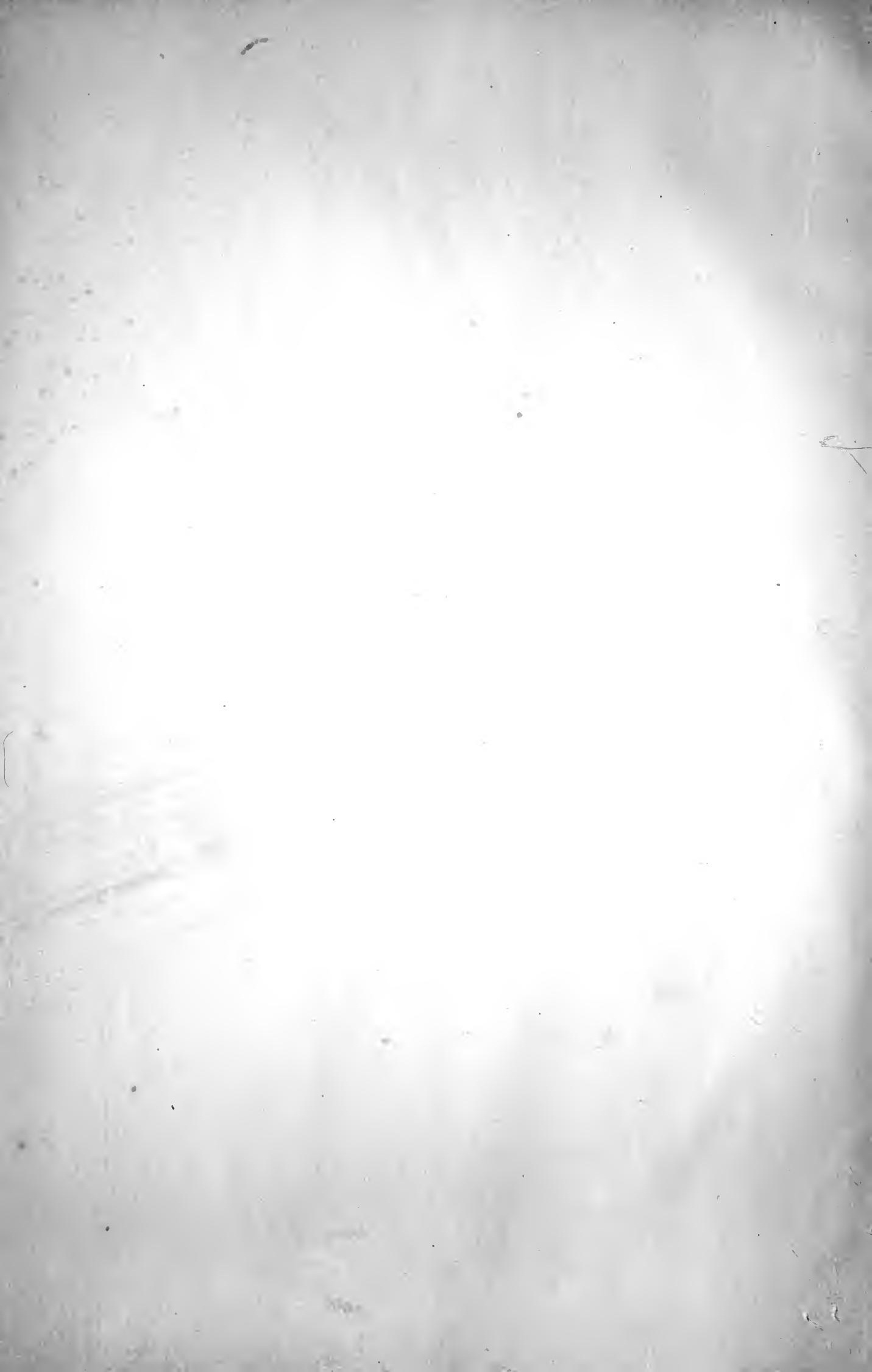




\title{
GLOSSARY
}

\author{
OF

\section{TERMS AND PHRASES}

EDITED BY THE

REV. H. PERCY SMITH, M. A.

OF BALLIOL COLLEGE, OXFORD, CHAPLAIN OF CHRIST CHURCH, CANNES

\section{NEW YORK}

D. A P PLETON AND COMPANY

I, 3, AND 5 BOND STREET

1883 
LBRAAY

OCT 052005

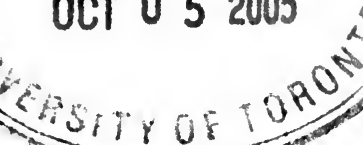




\section{CONTRIBUTORS.}

The Rev. H. PERCY SMITH, M.A., late "Vicar of Great Barton, Chaplain of Christ Church, Cannes, Editor.

ASSISTED BY

The Rev. Sir GEORGE W. COX, BART., M.A., Rector of Scrayingham, author of the "Mythology of the Aryan Nations," etc., and joint-editor of Brande's "Dictionary of Science, Literature, and Art."

The Rev. J. F. TWISDEN, M.A., late scholar of Trinity College, - Cambridge, Professor of Mathematics in the Royal Staff College.

C. A. M. FENNELL, M.A., late Fellow of Jesus College, Cambridge, Editor of Pindar.

Colonel W. PATERSON, late Professor of Military Surveying at the Royal Military College, Sandhurst.

The Rev. C. P. MILNER, M.A., Vice-Principal of Liverpool College ;

AND OTHERS. 



\section{PREFACE.}

ThE "Glossary of Terms and Phrases" is intended to bring together such words, expressions, quotations, etc., English or other, as are among the more uncommon in current literature, and require, not for the scientific but for the ordinary reader, explanations, for the want of which the meaning of a sentence or a paragraph, even the drift of an argument, is often missed; explanations, moreover, not to be obtained without reference to, and perhaps tedious search among, a large and varied number of books, many of them not easily accessible. In short, the editor indulges the hope that this Glossary may supply all the information needed by general readers, who may wish to have a fair understanding of the text of any work in ordinary English literature.

Of these terms and expressions some are purely, some are more or less, technical and scientific; some are simply uncommon; some contain allusions mythological, historical, geographical; some fall under a very large class, which must be styled miscellaneous; some belong to other languages than our own.

But in explaining the words themselves, no attempt has been made to enter further than is necessary into the nature of the things named. At the same time, the amount of general added to glossarial information must necessarily be very different in different cases. Words, therefore, are omitted ( $\mathrm{I}$ ) of whose actual signification there is no doubt-this book being a glossary, and not as it were a miniature encyclopædia; (2) which imply a special 
knowledge of the art or science to which they belong; (3) which, occurring in writers such as Spenser, Burns, etc., are explained in glossaries attached to them. It is plain, however, that the exact limits of an ordinary reader's needs cannot be defined, and there must be many terms as to the inclusion or rejection of which the editor must exercise his judgment in a Glossary intended as much for the mechanics' institute as for the general reader or the man of education. But his estimate of these needs may, it is hoped, be not very far wrong, while of the real need of some such Glossary experience leaves no doubt whatever. As to the etymological explanations given, it may be well to say. that very often the nearest cognate form simply has been set down-not as implying, by any means, that in all such cases the word has been necessarily borrowed from the one to the other.

The references given to books are made, as far as it was possible to make them, to works not difficult of access.

For the explanation of American terms found in the Glossary, the editor begs to express his obligation to the work entitled Mr. Jolnn Russell Bartlett's “Dictionary of Americanisms.”

H. PERCY SMITH. 


\section{ABBREVIATIONS USED IN THIS WORK.}

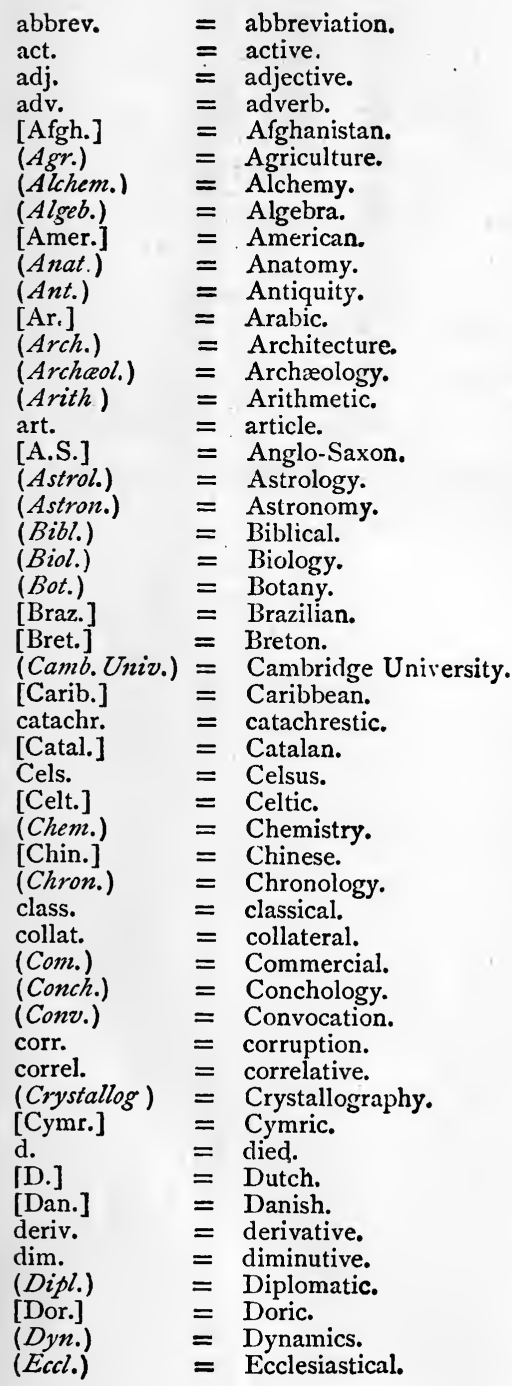

\begin{tabular}{|c|c|c|}
\hline (Eccl. Arch.) & $=$ & Ecclesiastical Architecture. \\
\hline (Eccl. Hist.) & $=$ & Ecclesiastical History \\
\hline [Eccl. L.] & $=$ & Ecclesiastical Latin. \\
\hline [Egypt.] & $=$ & Egyptian. \\
\hline [Eng.] & $=$ & English. \\
\hline (Eng. Hist.) & $=$ & English History. \\
\hline (Entom.) & $=$ & Entomology. \\
\hline (Ethn.) & $=$ & Ethnology. \\
\hline (Etym.) & $=$ & Etymology. \\
\hline fam. & $=$ & family. \\
\hline (Farr.) & $=$ & Farriery. \\
\hline fem. & $=$ & feminine, \\
\hline (Fieud.) & $=$ & Feudal. \\
\hline fig. & $=$ & figure. \\
\hline [Flem.] & $=$ & Flemish. \\
\hline (Fortif.) & $=$ & Fortification. \\
\hline [Fr.] & $=$ & French. \\
\hline freq. & $=$ & frequentative. \\
\hline (Fr. Hist.) & $=$ & French History. \\
\hline [Gadh.] & $=$ & Gadhelic. \\
\hline [Gael.] & $=$ & Gaelic. \\
\hline [Gasc.] & $=$ & Gascon. \\
\hline gen. & $=$ & genus. \\
\hline$(G e o g)$. & $=$ & Geography. \\
\hline (Geol.) & $=$ & Geology. \\
\hline [Ger.] & $=$ & German. \\
\hline [Goth.] & $=$ & Gothic. \\
\hline [Gr.] & $=$ & Greek. \\
\hline (Gram.) & $=$ & Grammar. \\
\hline [Hayt.] & $=$ & Haytian. \\
\hline [Heb.] & $=$ & Hebrew. \\
\hline (Her.) & $=$ & Heraldry. \\
\hline [Hind.] & $=$ & Hindu. \\
\hline (Hist.) & $=$ & History. \\
\hline [Icel.] & $=$ & Icelandic. \\
\hline (Ichth.) & $=$ & Ichthyology. \\
\hline [Ir.] & $=$ & Irish. \\
\hline iron. & $=$ & ironical. \\
\hline [It.] & $=$ & Italian. \\
\hline [Jap.] & $=$ & Japanese. \\
\hline (Zurisp.) & $=$ & Jurisprudence. \\
\hline kingd. & $=$ & kingdom. \\
\hline [L.] & $=$ & Latin. \\
\hline (Lang.) & $=$ & Language. \\
\hline (Leg.) & $=$ & Legal. \\
\hline [L.G.] & $=$ & Low German. \\
\hline$\left(\right.$ Lit. $\left._{*}\right)$ & $=$ & Literature. \\
\hline Lit. & $=$ & literally. \\
\hline [L.L.] & $=$ & Low Latin. \\
\hline$(\log \cdot)$ & $=$ & Logic. \\
\hline (Mag.) & $=$ & Magnetisin. \\
\hline
\end{tabular}




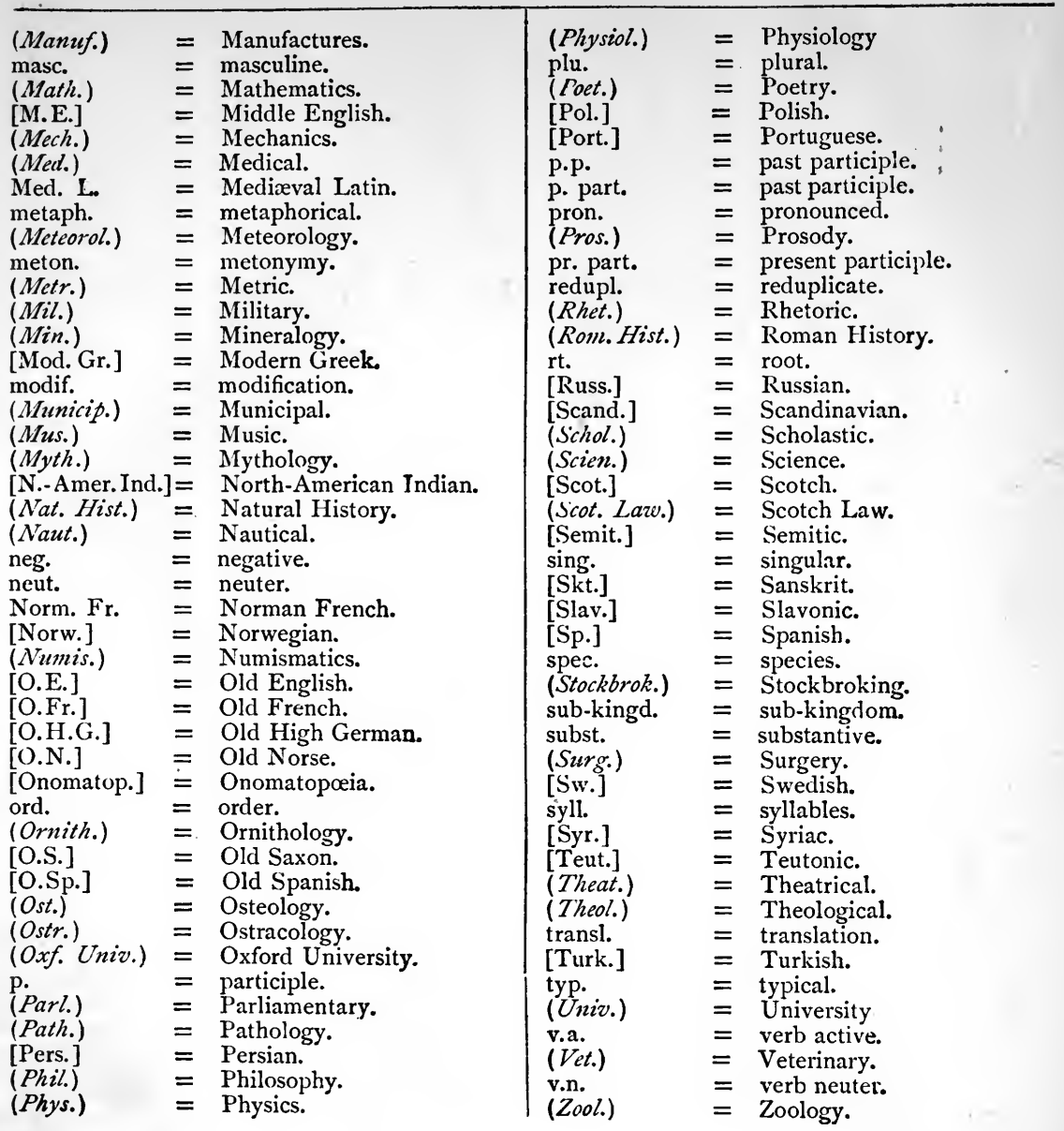




\section{GLOSSARY OF TERMS AND PHRASES.}

ABBE

A. With the Romans, usually stood for the prænomen Aulus; in inscriptions, often for Augustus, A.A. being duo Augusti, A.A.A., tres Augusti ; in epitaphs, for Annus ; upon votingtablets at the Comintǐa, for Antīquo, I reject (U.R.) ; in judicial trials, for Absolvo, I say " not guilty," as opposed to C., Condemno, I say "guilty," and to N.L. (q.v.). As a numeral, $\mathrm{A}$ is $500, \overline{\mathrm{A}} 5000$.

A 1. In Lloyd's Register of Shipping (q.v.), indicates, to shippers and insurers, a first-class vessel, thoroughly equipped. A refers to hull, I to anchor, cables, etc. Hence A I, in slang, $=$ first-rate.

-a, -ay. Norse suffix. 1. = island in the sea, as in Staff-a, Colons-ay. 2. = river, as in Gret-a, Rattr-ay. [A.S. ea, O.H.G. aha, Goth. ahva, L. aqua, water.] (-ea; ey.)

$\mathbf{A b}$. Eleventh month of civil, fifth of ecclesiastical, Jewish year; July-August.

A.B. (Naut.), i.e. able-bodied; a first-rate, as distinguished from an ordinary, seaman.

Aback. (Naut.) Position of sails when the wind bears on their front. They are Taken or Laid $A$. by accident or design respectively.

Abacot. A spurious word, given in all dictionaries, and said to mean "a cap of State, wrought up into the shape of two crowns, worn formerly by English kings." But both word and thing are delusions. The true word, Bycocket [O.Fr. bicoquet, the peak of some kind of lady's head-dress], not uncommon up to and after 1500 , after undergoing a series of corruptions, appears in Spelman's Glossärium (1664) as "Abacot," with the above explanation ; whence it has been copied from one dictionary into another ever since. Its primitive meaning probably survives in the $\mathrm{Sp}$. bicoquin, a cap with two points. As Henry V. on his bassinet at Agincourt, and as Richard on his helmet at Bosworth, wore a gold crown; so Henry VI. (crowned King of England and of France) wore at Hedgley Moor two crowns upon his bycocket-but in no sense as part of it. (See Dr. Murray's Letter to the Athenaum, February 4, I882.)

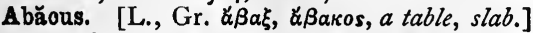
1. The tablet on the top of the capital of a column, which supports the entablature. 2. With Greeks and Romans, a wooden tray for arith- metical computation; divided by parallel lines, and having in the spaces pebbles, representing units, tens, etc. Similarly, 3, a framework with parallel wires, strung with beads, to render calculations palpable, used in infant schools; and by the Chinese, with whom all calculations of weights, measures, etc., are decimal.

-abad. [Hind., dwelling.] Part of names ; as in Hyder-abad, the abode of Hyder; Murshedabad, etc.

Abaddon. [Heb., the destroyer.] Name for the angel of the bottomless pit, Rev. ix. II ; in Milton, the pit itself. (Apollyon.)

Abaft (prefix $a$, i.e. on, and -baft, i.e. by aft). (Naut.) Behind the object mentioned.

Abandon. [Fr.] Freedom from restraint, careless ease of manner.

Abandonment. (Naut.) By a written notice, conveys to the underwriters an insured ship, when a "constructive total loss," i.e. so damaged that repair would cost more than she is worth.

A bas le, les. [Fr.] Down with.

$\mathrm{Ab}$ assuētis non fit injūria [Leg. L., wrong does not arise from what one is accustomed to], i.e. one has no claim at law in respect of a nuisance or damage which has been long borne without complaint.

Abătis. [Fr.] (Mil.) An obstacle formed of trees felled [Fr. abattu]; their stems being placed close together in the ground, with the ends of the branches sharpened and pointed towards an enemy.

Abattoir. [Fr. abattre, to knock dozon.] A public slaughter-house.

A battúta. [It., at the beat.] (Mus.) Revert to strict time.

Abb. [A.S. ab, and ob.] Yarn of a weaver's warp.

Abbasides. (Hist.) Caliphs of Bagdad (7491258), claiming descent from Abbas, uncle of Mohammed. To this line belonged Haroun-alRaschid, contemporary of Charlemagne.

Abbé. [Fr.] A word applied not only to the abbots or heads of conventual houses, but to all persons vested with the ecclesiastical habit (Littré). Before the French Revolution, many such men rose to eminence in the world of letters and fashion. The $A$. commendataires, nominated 
by the king, drew one-third of the revenues of their abbeys, as sinecurists.

Abbot of Joy. [Fr. Abbé de Liesse, L. Abbas Latitia.] A master of revels, formerly, in some French towns.

Abbot of Misrule. In Med. Hist., the master of the revels; called in Scotland the Abbot of Unreason (see Sir W. Scott's Monastery). (Boy Bishop, The; Feast of Fools ; Saturnalia.)

Abbot of the People. Formerly a chief magistrate among the Genoese.

Abbots, Mitred. In Eng. Hist., twenty-four in number, ecclesiastical dignitaries, who held of the king in capite per baroniam, and sat and voted in the House of Lords.

Abbreviations, Symbols, etc. [Eccl. L: abbrěviātio, -nem, a shortening.] $\mathbb{R}$, Chr., is an A., 1 , for $\chi \rho \eta \sigma \tau \delta \nu$, excellent (Chrestomathy); and,

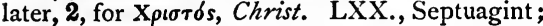
A.U.C., ab urbe condita, in the - year from the building of Rome ; S.P.Q.R., sĕnātus pŏpŭlusque Romānus, the senate and people of Rome ; S.D., sălūtem dīcit, sends greeting; D.D.D., dōno dědit, dǐcāvit, gave, dedicated, as a gift ; D.O.M., Deo Optímo Maxĭmo, to Grod, the Best, the Greatest; M.S., měmoririæ sacrum, sacred to the memory of ; H.S.E., hic sĕpultus (situs) est, here is buried; R.I.P., rĕquiescat in pāce, may he rest in peace ; S.T.T.L., sit tibi terra lěvis, light be the earth upon thee; I.H.C. and I.H.S. are the first three letters, I, H, $\mathbf{\Sigma}(\mathrm{I}, \mathrm{E}, \mathrm{S})$-which last was at one time written very like our C-

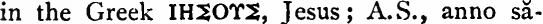
lütis, in the year of our salvation, = anno Domini ; B.V.M., beata Virgo Maria, the blessed Virgin Mary; S.J., of the Society of Jesus.

Astronomy: 1. Members of the solar system : $\odot$, The Sun ; $\mathbb{8}$, the Moon ; $\Varangle$, Mercury ; $q$, Venus; $\Theta$ or $t$, the Earth ; $\delta$, Mars; 24 , Jupiter; $\boldsymbol{b}$, Saturn; $\mathbf{H}$, the Georgian. 2 . Signs of the Zodiac: 1 . $\Upsilon$, Aries, $0^{\circ} ; 2 . \gamma$, Taurus, $30^{\circ}$; 3. $\mathbf{\Pi}$, Geminni, $60^{\circ}$; 4 . 0 , Cancer, $90^{\circ}$; 5. $\Omega$, Leo, $120^{\circ} ; 6$. mh, Virgo, $150^{\circ} ; 7$. $\bumpeq$, Libra, $180^{\circ} ; 8 . \mathrm{m}$, Scorpio, $210^{\circ} ; 9.1$, Sagittārius, $240^{\circ}$; 10 . $\vee{ }^{\circ}$, Capricornus, $270^{\circ}$;

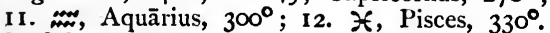
3. Other symbols are : $\delta$, conjunction; $\square$, quadrature ; 8, opposition; 8, ascending node; 8 , descending node.

In Bishops' signatures : Cant. or Cantuar. is Cantuariensis, of Canterbury; Ebor., Ebŏrăcensis, of Eborăcum or Eburăcum, York ; Dunelm., Dunelmensis, of Durham; Winton., Wintoniensis, of Wintonia, Winchester ; Sarum, of New Sarum, i.e. Salisbury; Vigorn., Vigornensis, of Worcester ; Oxon., Oxoniensis, of Oxford; Exon., Exoniensis, of Exeter; Roffen., Roffensis, of Rochester ; Cicestr., Cicestrensis, of Chichester; Menev., sometimes, for Menevensis, of Menevia, now St. David's. Similarly, Cantab., Cantabrigiensis, of Cambridge ; Eblan., Fblanensis, of Ėblāna, 1)ublin. Ch. Ch. is Christ Church; C.C.C., Corpus Christi College, Oxford; F.T.C.D., Fellow of Trinity College, Dublin. S.P.G., 'S.P.C.K., C.M.S., A.C.S., are the Societies for Propagation of the Gospel, for Promoting Christian Knowledge, Church Missionary, Additional Curates'; E.C.U., English Church Union; A.P.U.C., Association for Promoting Unity of Christendom.

Botany: $\delta$, male; $\$$, female ; $\Varangle$, hermaph. or bisexual ; $\delta-\not \gamma-q$, polygamous ; $\delta$ ชุ, diœecious; $\delta-\not$, monoecious ; (1) or $O$, annual; (2) or $\hat{\delta}$, biennial ; $\boldsymbol{4}$, perennial ; $\mathbf{h}$, a tree or shrub; v.v., visum vivum, seen alive ; v.s., siccum, seen in a dried state ; v.c., cultum, seen cultivated; v.sp., sporădĭcum or spontāneum, seen wild.

Chemistry: The chemical symbol for aluminium is $\mathrm{Al}$; for silver [L. argentum], $\mathrm{Ag}$; arsenic, $\mathrm{As}$; gold [L. aurum], Au ; boron, B ; bărium, Ba ; bismuth, $\mathrm{Bi}$; bromine, $\mathrm{Br}$; carbon, $\mathrm{C}$; calcium, $\mathrm{Ca}$; cadmium, $\mathrm{Cd}$; cerium, $\mathrm{Ce}$; chlorine, $\mathrm{Cl}$; cobalt, Co ; chromium, $\mathrm{Cr}$; cæsium, Cs ; copper [L. cūprum], $\mathrm{Cu}$; didymium, $\mathrm{D}$; erbium, $\mathrm{E}$; fluorine, $\mathrm{F}$; iron [L. ferrum], $\mathrm{Fe}$; glucinum, $\mathrm{Gl}$; hydrogen, $\mathrm{H}$; mercury [L. hydrargy̆rum], $\mathrm{Hg}$; iodine, $\mathrm{I}$; indium, In ; iridium, Ir ; potassium [L.L. kalium, from Ar. alkali], $K$; lan thănum, $\mathrm{La}$; lithium, $\mathrm{Li}$; magnesium, $\mathrm{Mg}$; manganese, Mn ; mŏlybdenum, Mo ; nitrogen, $\mathrm{N}$; sodium, $\mathrm{Na}$ (Natron) ; niobium, $\mathrm{Nb}$; nickel, $\mathrm{Ni}$; oxygen, $\mathrm{O}$; osmium, Os ; phosphŏrus, $\mathrm{P}$; lead [L. plumbum], $\mathrm{Pb}$; pallădium, $\mathrm{Pd}$; platînum, $\mathrm{Pt}$; rubidium, $\mathrm{Rb}$; rhodium, $\mathrm{Rh}$; ruthenium, Ru ; antimony [L. stibium], Sb; sělēnium, $\mathrm{Se}$; silǐcon, $\mathrm{Si}$; strontium, $\mathrm{Sr}$; tin [L. stannum], $\mathrm{Sn}$; sulphur, $\mathrm{S}$; tantălum, Ta ; tellürium, Te ; thorium, Th ; tītānium, Ti ; thallium, Tl ; ūrănium, U ; vanadium, V ; tungsten, W (Wolfram); yttrium, $\mathrm{Y}$; zinc, $\mathrm{Zn}$; zirconium, $\mathrm{Zr}$.

Of the principal Coaices or MSS. of the Neru Testament: A. is the Alexandrine, or Cōdex Alexandrinus, in the British Museum, probably fifth century; B., Cōdex Vaticānus, in the Vatican, probably fourth century; C., Cod. Ephraemi, at Paris, i.e. of Ephraem the Syrian, a palimpsest, probably fifth century; D., Cod. Cantabrigiensis, or Bezæ, at Cambridge, probably end of fifth century or beginning of sixth century ; $\aleph$, Cod. Sinaitǐcus, found by Tischendorf, 1859, in a monastery on Mount Sinai, probably fourth century.

On English Coins are: A.C., A.D., A.T., Arch-Chancellor, -Duke, -Treasurer; D.G. Dei grātĭa, by the grace of God; F.D., fiděi deffensor, Defender of the Faith; S.R.I., Sanctum Romānum Impěrium, Holy Roman Empire; M.B.F. et H., Magnæ Britanniæ, Franciæ, et Hiberniæ, of Great Britain, France, and Ireland.

In Dignities, Degrees, Professions, etc. : H.M., S.M., His or Her Majesty, Sa Majesté ; S.A.R., S.A.I., Son Altesse Royale, Impériale, His or Her Royal, Imperial, Highness; D.N.P.P., Dominus noster Papa Pontifex, our Lord the Pope. K.C.H. is Knight Commander of Hanover; K.G., K.H., K.M., K.P., K.T., K.M.G., are Knights of the Garter, of Hanover, of Malta, of St. Patrick, of the Thistle, of St. Michael and St. George ; K. B. not now in use, Knight of the Bath, of which order 
(as of S.I. and M.G.) there are now three classes, viz. G.C.B. Grand Cross, K.C.B. Knight Commander, and C.B. Companion; C.I.E. is Companion of the Order of the Indian Empire; C.S.I., K.C.S.I.; G.C.S.I., Commander, Knight Commander, Grand Cross, of the Star of India; L.C.J. and L.C.B. are Lord Chief Justice, -Baron ; P.C., Privy Councillor; H.E.I.C., Honourable East India Company; S.T.P., Sanctæ Theologiæ Prŏfessor, is the L. translation of D.D., Doctor of Divinity; LL.D., Lēgum Doctor, Doctor of Laws, the equivalent in Cambridge and Dublin of the Oxford D.C.L., Doctor of Civil Law ; A.A. is Associate of Arts ; B.M., Bachelor of Medicine ; S.C.L., B.C.L., Student, Bachelor, of Civil Law; A.K.C., Associate of King's College; B. ès $\mathrm{L}$. is the French Bachelier ès, i.e. en les, Lettres; F.R.S., properly Frāternitātis Rēgiæ Sŏcrus, has adapted itself to the Eng. translation, Fellow of the Royal Society; similarly, F.G.S., F.L.S., F.R.A.S., F. R.G.S., are Fellows of the Royal Geolog., Linnæan, Royal Astron., Royal Geog., Societies; R.A., Royal Academy, Royal Academician; A.R.A., Associate of ditto; P.R.A., President of ditto A.E.R.A., Associate Engraver of Royal Acad. ; M.I.C.E., Member of the Institute of Civil Engineers; M.R.C.S. is Member of the Royal College of Surgeons; M.R.C.V.S., Member of Veterinary ditto; F.R.I.B.A., Fellow of the Royal Institute of British Architects. R.M., usually Royal Marines, is, in Ireland, Resident Magistrate. D.L., Deputy-Lieutenant of the County; J.P., Justice of the Peace, i.e. a magistrate; W.S., Writer to the Signet, i.e. one of a body of legal practitioners in Edinburgh, corresponding generally to the highest class of attorneys in London; M.F.H., Master of the Fox-hounds ; M.C., master of the ceremonies. Amongst Naval $A$. are : R.N., Royal Navy ; H.M.S., Her Majesty's ship; A.B., able-bodied seaman; C.G., coastguard ; C.P., sent by the civil power; D., in Complete Book, dead or deserted; D.S.Q., discliarged to sick quarters ; F.G., on a powder cask, fine grain; and L.G., large grain. (For L., $v$. L's, Three; and $v$. A 1.) Amongst Military $A$. are : F.M., FieldMarshal ; A.D.C., Aide-de-Camp ; Q.M.G., Quarter-Master-General ; R.A., R.E., R.H.A., R.M., are Royal Artillery, Engineers, Horse Artillery, Marines ; C.O., Commanding Officer ; S.C., Staff Corps ; S.C., Staff College ; R.M.C. and R.M.A., Royal Military College, Sandhurst, and Academy, Woolwich.

In referring to Languages: Sansk., Skr., or Skt., is Sanskrit ; A.S., Anglo-Saxon; O.H.G. and M.H.G., Old, and Middle, High German; Pl.D., Platt Deutsch, Low German; O.E., O.F., O.N., O.S., Old English, Old French, Old Norse, Old Saxon; L.L., Low Latin; Prov., Provençal ; $\mathbb{N}=$ root of a word.

Mathematics: Q.E.D., quod erat dēmonstrandum, which was to be proved; Q.E.F., făciendum, to be done. Letters of the alphabet are used to denote numbers or numerical quantities; but $a, b, c$, etc., denote constant or known numbers ; $u, x, y, z$, variable or unknown numbers ; $m, n, p$, etc., simple numerical coefficients, or exponents : thus, a certain power of a known number $(a)$ would be written $a^{m}$; $a b$ is $a \times b$; $\frac{a}{b}, a \div b ; a>b$ means $a$ is greater than $b$; $a<b$, less; $a^{4}$ means $a \times a \times a \times a$, and the 4 is called an exponent of $a ; \sqrt{ }$, formerly $r$, i.e. L. rādix, is the sq. root of a number; but $\sqrt[3]{a}$ or $a_{3}^{\frac{1}{3}}, \sqrt[4]{a}$ or $a \frac{1}{4}$, mean the cube root, the fourth root, of $a ; \therefore$ stands for therefore, $\because$ for because; cos., tan., log., are cosine, tangent, logarithm. When the variations of one quantity (ii) follow those of another quantity $(x)$ the former is said to be a function, $f, F$, or $\phi$, of the latter, written $u=f(x) ; \Delta$ indicates the finite change which a variable undergoes, as $\Delta u$; but if the change is indefinitely small, $d u, \delta u ; \Sigma$ means the sum of a number of quantities which differ from each other by finite differences; $\int$, the sign of integration, denotes the total result of a variation, the rate of which is continually changing, as the distance described by a body moving with a velocity that continually varies. When a group of quantities of the same kind is considered, it is convenient to denote them all by the same letter, and to distinguish the members of the group by figures, $1,2,3$, etc., to the right and below, called suffixes; thus, the group of forces which keep a body at rest may be denoted by $\mathrm{P}_{1}, \mathrm{P}_{2}, \mathrm{P}_{3}$.

Medicine: $\overline{\mathrm{A}}$, a, or aa, is ănă, i.e. àvá, again, an equal quantity; AAA, amalgama; F., Ft., fiat, fiant, let it, them, be made ; M., sometimes mănǐpŭlus, a handful, sometimes miscē, mix ; P., pŭgillus, a handful ; P.Æ., partes æquāles, equal parts ; P.R.N., pro rē nātā, according to the occasion; Q.S., quantum suffícit, as much as is sufficient; $R$, rěcı̌pě, take.

Miscellaneous: i.e., id est, that is ; L.S., lŏcus sigilli, place for the seal; loc. cit., or l.c., locco cítāto, in the passage quoted; e.g., exempli grātiā, for example; v.l., văria lectio, a different reading ; cf. is for $\mathrm{L}$. confer, compare ; crim. con., criminal conversation; id., idem, the same; ibid., íbidem, in the same place; s.v., sub vōce, or verbo, under the word, in the dictionary ; s.h.v.,

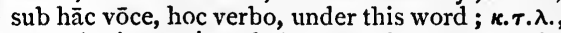

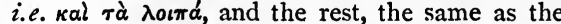
L. etc., i.e. et cætĕra; q.v., quod vĭde, i.e. which see, refers the reader to the word last mentioned; p.r.n., pro rē nātā, according to circumstances, lit. for the matter or occasion arising ; M., in the Marriage Service, a printer's correction introduced after 1726, from the Act prescribing the form of banns, should be N. for Nomen; D.M., Dîs Manibus (Manes) ; ob., obiit, died; A.S., anno salütis, in the year of Redemption; Ca. Sa., capias ad satisfaciendum (q.v.) ; fi. fa., fieri facias (q.v.) ; pxt., pinxit, painted ; nem. con., nēmine contrădicente, no one saying No, is = carried unanimously; no., for number, is the It. numero; sp.g., specific gravity ; c.g.s. are the Fr. centimetre, gramme, second; m.s.l. mean sea-level; x.d., exclusive of dividend ; ult., inst., prox., are mense ultrmo, instanti, 
proximo, in the last, in the present, in the next, month; p.p.c., pour prendre congé, to take leave; in France, s.g.d.g., sous garantié du gouvernement, under the guarantee of the government, i.e. patented; Ent. Sta. Hall, entered at the Stationers' Hall ; R.S.O., railway sub-office, for letters ; F.P., fire-plug; N.S. is New Style, O.S. Old Style, i.e. respectively after and before the alteration of the calendar by Gregory XIII. in 1582, adopted in England 1751. Doubled letters indicate a plural; as LL.D., Legum Doctor; MSS., manuscripts ; reff., references; N. or M., i.e. N. or NN., nōmen or nōmŭna, name or names ; and many others.

Musical: $\mathrm{Adg}^{\circ}$ or $\mathrm{ad}^{\mathrm{o}}$, adagio, slowly ; Ad lib., ad libirtum ; $\mathrm{Ag}^{\circ}$, agitāto, in an agitated, restless style ; All' ott., or All' $8^{\text {va }}$, all' ottāva, at the octave higher or lower than it is written; $\mathrm{Al}$ seg., al segno, to the sign, i.e. go back to the 8:; A t., or A tempo, in time (A battuta); C.D., colla destra, with the right hand; C.S., colla sinistra, with the left hand; Cal., calando, lit. loweringly, with decreasing tone and pace; Can., cantoris, the chanter's, precentor's (side); Cello., violoncello ; Cor., cornet or horn ; D., déstra, or droite, right; D.C., da capo, over again, lit. from the head or beginning; Dec., děcāni, the dean's (side) ; D.S., from the sign (see Al seg.) ; F., forte, loud ; FF., or Fff., or Ffor., fortissimo, very loud; F.O., full organ; G., gauche, left ; G.O., great organ ; L., left ; L.H., left hand; MM. $\mathcal{J}=92$, the crotchet-heat being equal to the pendulum-pulse of Mälzel's metronome, with the weight set at 92 (remembering that, "to be correct, the metronome should beat seconds when set at 60 " (Stainer and Barrett. Dictionary of Music); M.V., mezza vóce, with half the power of the voice; Obb., obbligato, i.e. important, and that cannot be dispensed with ; P., piano, soft ; P.F., più forte, louder ; PP., pianissimo, very soft; PPP. and PPPP. are used for pianississimo; Rall., rallentando, gradually slower; R.H., right hand; Ritar., ritardando, gradually slower and still slower; Riten., ritenendo or ritenuto, holding back the pace ; S., senza, without ; :\$; segno, sign, pointing the extent of a repeat; Sfz., sforzando, forced, i.e. emphasizing the note or chord; S.T., senza tempo, without definite, marked, time Tem. $\mathbf{I}^{\mathbf{0}}$, tempo primo, resume the original pace; Va., viola; Vo., violina ; V.S., volti subito, turn i.e. turn over, quickly ; with very many others.

Abbreviators. [L. abbrěvio, $I$ abridge.] In the papal court, condense documents, for the preparation of bulls.

A.B.C. process of deodorizing impurities, i.e. by alum, blood, charcoal.

Abd. [Ar., servant.] Abd-Allain, servant of God. Abdērite, The. The laughing philosopher Dēmocrǐtus, born at Abdēra, in Thrace.

Abdiel. [Heb., servant of God.] The angel of Jewish tradition, who alone withstood Satan's rebellious designs.

Abdömen. [L.] In the animal body, the lower of two cavities, the upper being the thörax, or chest, and the diaphragm in mam malia being the partition between the two. In insects, it is the last of three portions into which the body is divided.

Abductor muscles draw away from, Adductor $M$. draw back to, the mesial (q.v.) line of the body. [L. abdūco, I drazw azvay, addūco, $I$ bring to.] Muscles which close the valves of the shell of Lamellibranchiăta are called $A d$ ductor $M$.

A-beam. (Naut.) In a line drawn at right angles to the vertical plane through the ship's keel, and passing through the centre of her side. Abaft the B., any point within the right angle contained by this line and the line of the ship's keel in a direction opposite to her course. $B e$ fore the $B$., neither $a \cdot B$., nor abaft the $B$., nor ahead (in a line with the keel forward), nor astern (in a line with the keel aft). Starboard $B$., on the right; Larboard $B$., or Port $B$., on the left hand, looking forward. Weather $B$., the windward ; Lee $B$., the other side.

Abecedarian hymns. Hymns in which the first verse or stanza began with the first, and succeeding verses or stanzas with the succeeding, letters of the alphabet, in imitation of Heb. acrostic poetry, e.g. Ps. cxix.

Abecedary circles. Rings of letters described round magnetized needles, by which friends were supposed to be able to communicate, looking at them at certain fixed times.

Abelardians. Followers of Abelard, a distinguished Schoolman of the twelfth century, whose opinions brought on him the censure of St. Bernard. (Nominalists.)

Abele (2 syl.). The Pōpŭlus alba, white poplar.

Abelians, Abelites. An African sect, fourth century, who enjoined the separate state of the married, to avoid handing down original sin ; after an assumed example of Abel.

Abelmoschus. [Ar. habb-el-misk, grain of musk.] A tropical genus of mallow. The seeds of A. moschatus are used in perfumery, and in medicine; and the pods of A. escullentus, the W. Indian ochro or gobbo, mucilagınous and nutritive, are used in soups.

A bĕnĕ placĭto. [L.L.] (Mus.) The time, amount, of grace notes, etc., left to the choice and the good pleasure of the performer.

Aber-. Cymric prefix, meaning, like Erse and Gaelic inver, a meeting of waters, either stream and stream, or stream and sea.

Aberrant group. [L. aberrantem, part. of aberro, I stray from.] One differing widely from the type of the natural group to which they apparently belong; e.g. Lemurs compared with Quadrumăna.

Aberration; Annual A. ; Chromatic A. ; Circle of A.; Diurnal A.; Planetary A.; Spherical A. [L. aberrātio, -nem, aberro, I stray from.] The apparent displacement of a heavenly body, caused by the composition of the velocity of light with that of the earth. The velocity of light is about 10,000 times greater than that of the earth in her orbit, so that the stars appear displaced through an angle of about $20^{\circ} 5^{\prime \prime}$, the displace. 
ment taking place in a plane passing through the star and the direction of the earth's motion; this is called the Aberration, and sometimes the Annual $A$. The Diurnal $A$. is a very minute displacement of a like kind due to the composition of the velocity of light with that of the earth's rotation. When the heavenly body has a motion of its own, as is the case with a planet, its velocity has to be taken into account, and then we have the Planetary $A$. When a ray of light undergoes reflexion or refraction, its Spherical $A$. is the distance between the geometrical focus and the point in which it cuts the axis of the reflecting or refracting surface supposed to be spherical. When white light passes directly through a lens, the distance between the geometrical foci of the most and the least refracted coloured rays is the Chromatic $A$. The Circle of Chromatic $A$. is the smallest circle through which all the coloured rays pass near their geometrical foci.

Aberuncate. [L. ab, from, e, out, runco, I zoeed.] To pull up by the roots.

Abhorrers. In Eng. Hist., the name given, in 1680 , to those who expressed abhorrence of encroachments on the royal prerogative, while those who demanded the summoning of Parliament were called Petitioners. It was at this time that the words Whig and Tory came into use.

Abib. Exod. xiii., xxiii., xxxiv, ; Deut. xvi. ; the month of green ears, seventh of Jewish civil year, but first of ecclesiastical, as being that in which the Passover fell; the post-Babylonian Nisan, March-April.

Abies. [L.] Fir; is distinguished in a general way from Pinus (q.2\%) by leaves growing singly around the stem, by character of fructification, and by general pyramidal form. Silver fir, Norway spruce, larch, and cedar of Lebanon, are representatives of its four natural divisions.

Abigail. A waiting-maid (? from Abigail Hill, afterwards Mrs. Masham; rather than from Nabal's wife; see Latham's Dict., s.v.).

Abiit, excessit, ēvāsit, ērūpit. [L., he has gone away, retired, escaped, gone tearing off.] Originally said by Cĭcěro of Cătĭline's precipitate departure from Rome.

$\mathrm{Ab}$ Initio [L., from the beginning]; as, proceedings void $a b$ initio.

Abiogenesis. (Biogenesis.)

Abjuration of the realm. An oath to leave it for ever. [L. abjūrātio, -nem, a forswearing.]

Ablactation. [L. ablactātio, -nem, weaning.] The separation of an inarched graft from its parent stock, but not before some union with the new has taken place.

Ablaqueātion. [L. ablăqueātio, -nem.] An opening of the ground at the roots of trees, to let in air.-Evelyn.

Ablepsia. [Gr. à $\beta \lambda \epsilon \psi_{i ́ a}$, blindness, à neg., $\beta \lambda \epsilon ́ \pi \omega, I$ see.] Incorrect term for colour-blindness. (Dyschromatopsy.)

Ablepsy. (Dipl.) Wrong reading by a scribe of that which he is copying.

Abnormal. [L. ab, from, norma, carpenter's rule, a pattern.] Deviating from rule or law, e.g. in the development of living things.
Abnormis săpiens. [L.] Wise, but of no sect or school ; naturally shrewd.-Horace.

Abolitionist. One who is for abolishing slavery immediately and entirely.

Abolla. [L., Gr. å $\nu \alpha \beta o \lambda$ 斤.] A woollen cloak, scarlet or purple, worn by Roman soldiers, opposed to toga, the outer garment worn in time of peace; hence attributed, derisively, to the Stoics, whose philosophy was essentially polemical, controversial.

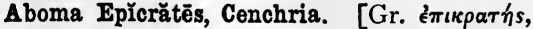
one who overmasters, $\kappa \in \gamma \chi$ pias, spotted like millet

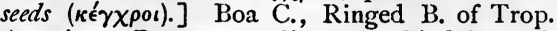
America. Possesses rudimentary hind legs ; it was worshipped by the ancient Mexicans. Fam. Pȳthōnĭdæ.

Abŏmäsus. Fourth stomach of a ruminant.

$\hat{A}$ bon chat bon rat. [Fr., to good cat good rat.] The parties are well matched.

Abŏriğnes. [L.] Inhabitants ab ŏrīgine, prehistoric. (Antochthŏnĕs.)

Abortion. [L. ăbortio, -nem.] 1. An unnatural expulsion of the foetus after the sixth week and before the sixth month. 2. In Law, the crime of producing this by drugs or instruments.

Abortive. [L. ăbortivus, ăb-ŏrior, I fail to rise, miscarry.] (Bot.) Imperfectly formed. $A$. branches, woody nodules in the bark of some trees, e.g. cedar.

Abou-Hannes. Spec. of bird, identified by Cuvier with Ibis Rēlugiǒosa, Sacred Ibis, of Egypt. Nümēnǐus I., gen. Nūmēnǔus, fam. Scŏlopäcǐdæ, ord. Grallæ.

About, To go. (Naut.) To put a ship's head to the wind, and fill on the other tack. Ready about and about ship are orders to go about.

$A b$ ovo usque ad mäla. [L.] From the beginning to the end; lit. from the egg, the first dish, to the apples, the last, in a Roman meal.

\section{Abox. (Naut.) (Brace.)}

Abracadabra. An ancient mystic word of unknown origin ; a charm against fevers, written on paper, folded up, and worn a certain time in the bosom, then thrown into a stream. The word was in the form of an equilateral triangle inverted, each line being shorter by one letter than the preceding, and the letter A only remaining as the apex. Perhaps Pers. abrasas, a mystical term for Deily, and Heb. dabar, Divine Word; the $\mathrm{C}$ is really the $\mathrm{S}$ of the word in its Greek form (Littré). (Abraxas.)

Abrahamites. Bohemian deists of the last century, who professed the faith of Abraham before circumcision. Their existence was short.

Abraham Man. An impostor, who personated "poor Tom of Bedlam," i.e. the harm. less incurable lunatic, who went about in squalid dress, singing songs and driving a good trade. (See Edgar's account of himself in King Lear.) Shamming Abraham is still slang.

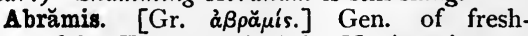
water fish ; Europe, W. Asia, N. America ; as the common bream (Abramis Bräma). Fam. Cyprinǐdæ, ord. Physostŏmi, sub-class Tělěostěi.

Abranchian, Abranchiate. [Gr. à neg., $\beta \rho a ́ r \chi \check{\imath} a$, gills.] Without gills. Among Verte- 
brates-reptiles, birds, and mammals; among Annelids-leeches and earthworms.

A bras ouverts. [Fr.] With open arms.

Abraxas, or Abrasax Stones. A word first used by the Basilidians, a Gnostic sect, as expressing the number of spirits or deities subject to the supreme deity, 365 . The letters which make up the word $A$. stand in Greek numerals for I, 2, I00, 1, 60, 1, 200 $=365$. [Pers. Abraxas or Abrasas, God.] (Abracadabra.) Stones have been found bearing this name written, together with an emblem, the body of a man, or serpent, or fowl.

Abreuvoir. [Fr. from L. adbǐběrāre, to give drink.] 1. A drinking-place for cattle, etc. 2. A joint between stones, to be filled in with mortar.

Abrogation. [L. abrŏgātio, -nem.] The repeal of a law by competent authority; the inversion of the process by which, in the Roman comitia, the votes of the curies or tribes were asked for a measure.

Abscissa. (Co-ordinates.)

Absentee. One who derives his income from one country, but resides and spends it in another.

Absentem laedit cum ēbrǐo qui litĭgat. [L.] He injures the absent who quarrels with a drunken man; the absence of sense being tantamount to personal absence.

Absinthe. An aromatic liqueur prepared from some of the small alpine species of Artemisia.

Absinthine. The bitter principle of wormwood

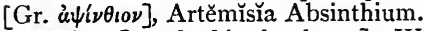

Absit. [L., let him be absent.] Written leave to be absent for one night from college, during a term of residence.

Absit ömen. [L., may the omen be absent.] God forbid !

Absolute, Sir Anthony. A character in The Rivals of Sheridan ; generous, irritable, over-bearing. Captain $A$., a bold, adroit, determined man.

Absolve a doubt or difficult passage, = clear up, explain. [L. absolvo, I unloose.]

Absolvi ănimam meam, or līběrāivi animam meam. [L.] I have relieved my soul (conscience), especially by an ineffectual protest.

Absonous. [L. absŏnus.] Discordant, contrary to, not in harmony with.

Absorbents. [L. absorbentes, part. of absorbeo, I suck up.] A system of delicate vessels, pervading the entire body, whose function is to take up substances and convey them into the mass of the circulating fluid. Of these, the Lacteals [L. lac, milk] convey the chyle from the stomach and intestines; the Lymphatics [L. lympha, water] absorb all redundant matter throughout the body (Lymph). A drug which stimulates such vessels is called absorbent, e.g. calomel.

Absorbing wells are sunk through retentive ground into permeable ground, to get rid, by infiltration, of liquids thrown in.

Absque imputätione vasti. [Leg. L., without impeachment of waste.] Said of life tenure; a reservation securing tenant against being sued for (non-malicious) waste.
Abstention. In Politics, refraining from the exercise of public rights, especially from voting.

Abstersive. [L. abs, from, of, tergeo, I wipe.] Able to wipe away, cleanse.

Abstinence, Days of. [L. abstinnentia, the holding off from anything.] In the Roman Church, days on which the eating of flesh is forbidden, as distinguished from days of fasting, when only one meal is allowed during the twenty-four hours.

\section{Abstraction. (Predicable.)}

Abstract number. A number the unit of which denotes no particular thing; e.g. twelve as distinguished from twclve apples.

Abstract of title. (Leg.) Epitome of evidence of ownership.

Absurdum, Reductio ad. (Reductio.)

Abudah. In Ridley's Tales of the Genii, a merchant of Bagdad, driven by a little old hag to search for Oromanes' talisman.

Abuna. Abyssinian high priest.

$\mathbf{A b}$ üno discé omnes. [L., fiom one (man) know all (his) associates.] Take this as a specimen.

A-burton. (Naut.) Spoken of casks stowed athwart ships.

Abuse of process. (Les.) Obtaining advantage by some intentional irregularity in the form of legal proceedings.

Abuttal. The boundary of land; land is said to abut on this road or that river.

Academics. (Academy.)

Academy figure. A drawing generally made in black and white chalk from a living model, as by students at an Academy of Arts.

Academy, Philosophy of, i.e. Platonism. The Acădēmia (called after its supposed owner, the hero Acadēmos), being a garden in the suburbs of Athens, where Socrates discoursed, and Plato taught for nearly half a century. Hence A. = seat of learning.

Acadia. Indian name of Nova Scotia.

Acajou. 1. Mahogany; the word originally American, and introduced with the article, eighteenth century. 2. Applied also to the Cashew nut (Anacardium occìdentāle).

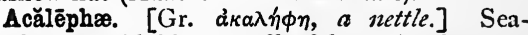
nettles, sea-blubbers, jelly-fish. A class (in Cuvier's system) of Rădiäta (q.v.), soft and gelatinous, mostly with stinging hairs; e.g. Mědūsæ.

Acanthion. [Gr. ă $\kappa \alpha \nu \theta \alpha, a$ thorn.] Gen. of flat-spined porcupine; two species. India and Islands. Fam. Hystrícĭdæ, ord. Rōdentia.

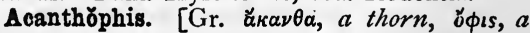
serpent.] Gen. of venomous serpents, allied to vipers, having a horny spur at the end of the tail. Australia, Moluccas, New Guinea.

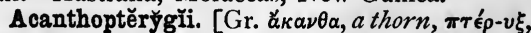
-vyos, a fin.] Ord. of fish, with some of their fin rays spinous, as perch. $A$. Phăryngognăthi have anchylosed pharyngeal bones, and are generally provided with teeth, as the wrasse; subclass Tělěostěi.

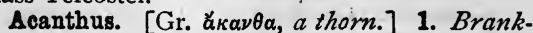
ursine, Bear's breech, Bear's foot, type gen. of Acanthaceæ. 2. Sometimes also the gum-pro- 
ducing Acacia vēra of Africa (Virgil, Geo. i. I19, and Milton, Paradise Lost, iv. 696). 3. (Arch.) In Cor. and Comp. orders, the foliage of the capital ; suggested, according to Vitruvius, by the leaves of some acanthous plant.

A cappella. [It.] 1. In old Church style, unaccompanied, as in the Sistine Chapel. 2. Alla Breve (q.v.).

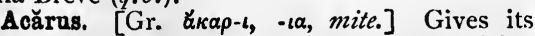
name to fam. Acărĭda, containing mites, ticks, water-mites, as cheese-m., itch-m., nose-worm (Děmŏdēx follǐcŭlōrum); class Arachnĭda.

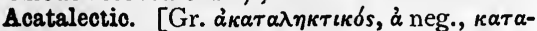
$\lambda \hbar \gamma \omega$, I leave off.] In Prosody, a verse in which a syllable is not wanting at the end. Catalectio

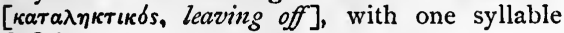
deficient.

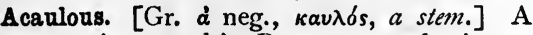
term sometimes used in Bot. to mean having no stem, or a short concealed one.

Accadian. A name denoting the language of the primitive inhabitants of Chaldæa, found in cuneiform inscriptions. It is agglutinative.

Accelerating force. [L. accělěro, I hasten.] Force considered simply with reference to the rate at which it increases the velocity of a moving body; called also the accelerating quantity, the accelerative effect, and sometimes merely the acceleration of the force.

Acceleration of sidereal on mean solar time. When the same portion of time is estimated both in mean solar units and in sidereal units, the numerical excess of the latter over the former is called the Acceleration; thus, $2 \mathrm{~h}$. $30 \mathrm{~m}$. of mean solar (ordinary clock) time equals $2 \mathrm{~h}$. $30 \mathrm{~m}$. $24^{\circ} 64$ s. of sidereal time-the $24^{\circ} 64$ seconds being the acceleration.

Accoleration of the moon's mean motion. A minute secular diminution in the length of the lunar month, which becomes appreciable only after centuries.

Acceleration of a force. (Accelerating force.)

Accent. [L. accentus; ad, to, cantus, melody.] 1. (Gram.) Stress laid on a syllable in a word, or word in a sentence. 2. Melodic $A$. The relative pitch of syllables according to special laws in certain languages, as Greek, Latin, Sanskrit, Hebrew, Chinese. In Greek, there are three accents : acute (high), as $\lambda \delta$ rov; grave (low), as $\tau \delta \nu \lambda \delta \gamma o \nu$; circumflex (from high to low), as $\tau \hat{\eta} s$. In French, the accents, acute ', grave ', circumflex ${ }^{\wedge}$, vary the pronunciation, not the melodic pitch of vowels.

In Math. a mark put above a letter or figure : 1. To distinguish between quantities that are alike in certain respects; thus, in a dynamical question it may be convenient to indicate a number of distinct portions of time by the letters $t^{\prime}, t^{\prime \prime}, t^{\prime \prime \prime}$, etc. 2. To indicate the minutes and seconds of an angle, as $15^{\prime} 37^{\prime \prime}$. 3. Sometimes minutes and seconds of time are thus indicated. 4. To indicate feet and inches in working drawings, as $5^{\prime} 7^{\prime \prime}$ for $5 \mathrm{ft} .7$ in.

Acceptance. An engagement by one upon whom a bill of exchange is drawn, to pay it when due according to the terms expressed.

Acceptilation. [L. acceptilātiō, -nem; lit. $a$ carrying away of the thing received.] Acknowledgment of receipt, and release from debt, though not really paid.

Acceptor. [L.] A drawee who accepts (admits his liability for the amount of) a bill of exchange (q.v.).

Accessary, subst., Accessory, adj. [L. accessārius, from accessor, one who drazus near to (Ducange).] 1. Contributing to a design, or to the character and quality of a thing, either in a good or a bad sense ; especially, 2, one not present at the commission of a crime, yet in some way acceding to it, consentient, either before or after.

Accessio cēdit princĭpäli. [L.] A maxim of law; an accessory thing when annexed to a principal thing becomes part and parcel of the latter : so the trees go with the soil. Accessio, in Rom. Law, is a mode of acquisition of property by natural means; in Eng. Law, Accretion.

Accessory stops. (Mus.) Pedals, e.g. couplers, composition pedals, which act mechanically upon others, and have no pipes in connexion with them.

\section{Acciatura. (Appoggiatura.)}

Accidenoe. An elementary book, teaching the accidents, i.e. modification of words, as by inflexion, declension.

Accĭdens, Per. [L.] By an accidental, not an essential, characteristic ; opposed to per se: the sun shines per se, the moon per accidens.

\section{Accident. (Predicable.)}

Accidental colours. Colours depending on the affections of the eye. If after looking steadily at a coloured window we look at a white wall, we see a ghost of the window in complementary colours; this is an A. image of the window, and its colours are A. colours.

Accidental point. In perspective, the vanishing point, that is, the point in the perspective plane where any given set of parallel stiaight lines in the object viewed appears to meet. It is found by drawing a straight line from the spectator's eye to the perspective plane, parallel to the given lines. It is called accidental to distinguish it from the principal point, or point of sight, which is the point where a perpendicular line from the spectator's eye meets the perspective plane.

Accipitres. [L. accipiter, bird of prey.] Ord. of birds. Birds of prey, as eagles, owls, vultures. Obvious external characteristics-powerful, crooked beak, and talons.

Accite. [L. accitus, summoned.] To summon.

Acclamation. [L. acclāmātio, -nem.] In the language of the Conclave, a pope is said to be elected by acclamation when he is proclaimed by the voices of a sufficient number of cardinals at once; he is elected by Adoration when a cardinal kneels before him, and the necessary number follow his example.

Acclimatize. [Gr. $\kappa \lambda$ i $\mu \alpha, a$ climate.] To accustom a plant or animal to a climate other than its natural one.

Accolade. [Fr.] The slight blow on the neck [Fr. col] or shoulder; as the last insult to be 
endured (?) ; which afterwards became an embrace in dubbing a knight. (J'adoube.)

Accolent. [L. accolentem, part. of accǒlo, $I$ dwell near.] A borderer.

Accommodation. [L. accommŏdātio, -nem.] Bill of exchange; a bill accepted, drawn, or endorsed by $\mathrm{A}$ to accommodate $\mathrm{B}$, who engages to pay the bill when due, or at least that $A$ shall not be loser on the bill.

Accost. [L. ad costam, at or to the side.] Now meaning to address, had an earlier meaning, to adjoin; at the shore, land accosts the sea. So (Her.) Accosted or Cottised, said of a bend, etc.; when placed hetween cottises, or narrow bends.

Account, Stockbroking. The fortnightly settlement on the Stock Exchange, when all bargains not settled off-hand should be concluded ; but vide

Backwardation; Contango; Continuations.

Accoutrements. (Mil.) Belts and pouches of a soldier. [Fr. accoutrer, to dress $u p$, perhaps $=$ L. L. accustōdire, to take care of ; the coustre, or sacristan, having the care of vestments.-Skeat, Etymological English Dictionary.

Accrescent. [L. accrescentem, part. of accresco, $I$ groze on to.] (Bot.) Said of an organ persistently growing larger, e.g. a calyx after the flowering.

Accretion. (Accessio cedit principali.)

Accroach. [Fr. accrocher, to hook on to, croc, $a$ hook.] To encroach upon royal prerogative.

Accruing costs. (Leg.) Expenses incurred after judgment.

Accrüment. [Fr. accrû, part. of accroître, to increase.] Addition.

Accubation [L. accubātio, -nem, accŭbo, $I$ recline at or near] or accumbent posture ; that of the Romans who, at meals, reclined on the left elbow.

Accumulation, Argument by. (Soritic.)

Ace. 1. A unit [L. ās]. 2. A card marked with a single point or figure, as an ace of hearts. Sometimes = the smallest quantity ; "not an ace."

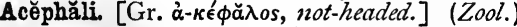

Bivalve molluscs proper (Lamellíbranchīāta), as the oyster, clam, and terrēdo.

Acěphăli. [Gr. àkéфŏ入os, without a head.] 1. An Egyptian Eutychian sect, fifth century, separated from the Patriarch of Alexandria, who had subscribed Zeno's Hěnōtǐcon. 2. Said of bishops exempt from metropolitan or patriarchate jurisdiction.

Acerraceæ. An ord. of trees, of which the common maple (ăcer campestre) is the type.

Acerio. [L. ăcěr, -is.] Obtained from the maple.

Acerose. [L. acerösus, ăcus, ăcěris, $a$ pointed thing.] (Bot.) Needle-shaped, like the leaves of a fir.

Acerra. 1. A box for incense, at Roman funerals. 2. An altar on which incense was burnt.

Acëtabŭlum. [L.] 1. A small cup for vinegar [ăcētum] in Roman antiquities; in Gr. ỏ $\xi \tilde{v}$ -

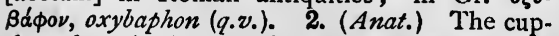
shaped cavity in the pelvis, into which the head of the femur is articulated. Acetabuliferous, having cups or suckers, like cuttle-fish.
Acotarious. [L. acētārius.] Used in salad [L. acetaria, plu.], as lettuce, etc.

Acetic acid. An acid formed by the oxidation of alcohol. It derives its name from vinegar [L. ăcētum], which is a weak impure acetic acid. Its salts are called acetates.

Acetone. A volatile, inflammable fluid, also called pyroacetic acid.

Achaemenidean inscriptions. Records inscribed in old Bactrian or old Persian, of a later period than the Zend-Avesta, relating to Darius (descendant of Achaeměnes) and his dynasty.

Achaian (Achæan) League. A confederacy of the twelve Achaian towns in the north of the Peloponnesus, which rose into great historical importance after B.C. 280.--Freeman, History of Federal Government, vol. 1. ch. 5.

Achātēs. [Gr.] The Achātēs of the ancients was i.q. modern Jasper. (Agate.)

Achātes, Fidus, = a faithful companion, as Achātēs was of Aneas.

Acheenese, or Atcheenese, of Acheen, or Atcheen. Small independent kingdom in northwest of Sumatra.

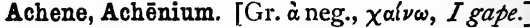
(Bot.) Small brittle seed-like fruit, e.g. the socalled "seed" of the strawberry. (Indehiscent.)

Achěrōn. [Gr., from a root which has given the names Achelôus, Axius, Exe, Usk, Usque[baugh], whiskey, and many others denoting water.] A river (I) in Thesprotia, (2) in Italy, (3) in the nether world of Hades, mistakenly supposed in this instance to be so named as flowing with aches, grief, and pains, as if from axos, ache, pain, and $\rho$ éw, I flow. (Lethe; Phlegethon; Styx.)

À cheval. [Fr., on horseback.] (Mil.) Said of troops placed so that a river or road passing through the centre is at right angles with the front.

Achievement. [Fr. achever, to bring to a head or end.] Any sign, ensign, of deeds performed; now corrupted into hatchment.

Achilleine. The bitter principle of milfoil, or yarrow, Achillěa millefŏlĭum, ord. Composĭtæ. Achilles. (Nereids.)

Achlamydeous. [Gr. $\chi \lambda$ ă $\mu u_{s}, a$ cloak.] Plants without calyx or corolla, having no floral envelope, e.g. willow.

Achne. [Gr. $a \chi \nu \eta$, a particle on the surface.] Small hard inflamed tubercles on the skin. Often written, incorrectly, acne.

Achromatic. [Gr. à neg, $\chi \rho \hat{\omega} \mu \alpha$, colour.] Not showing colour, as A. lenses, A. telescopes, etc., in which chromatic dispersion is wholly or nearly corrected.

Acicular. [L. ăcĭcŭla, a small pin or needle.] (Bot. and Min.) Slender and pointed.

Acidimetry. [L. ăcĭdus, acid, and Gr. $\mu \in \tau \rho \in \hat{\imath} v$, to measure.] The art of measuring the free acid contained in any liquid.

Aciform. [L. ăcus.] Of the shape of a needle.

Acinaciform. [L. ăcinăces.] Of the shape of a scimitar.

Aolniform. [L. ăcĭnus.] Of the shape of a grapestone.

Acker, i.e. Eager, or Eagor. (Bore.) 
Aolinic line. [Gr. \& neg., $\kappa \lambda i ́ \nu \omega, I$ make to slant.] The magnetic equator, or line joining all those places on the earth where the magnetic needle has no inclination or dip, i.e. where it is horizontal.

Acmē. [Gr.] (Rhet.) The extreme height of pathos or sentiment to which the hearer is led by a climax [Gr. $\kappa \lambda \hat{i} \mu \alpha \xi$, a ladder] or series of impressions, each more intense than the preceding.

Acœmëtæ. [Gr. àkoí $\mu \eta \tau$ os, sleepless.] An order of nuns of the fourth century; so called because, in their convents, the offices were said without interruption day and night. In the following century an order of monks was established at Constantinople, for the like purpose.

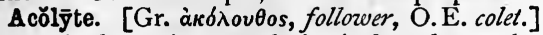
One of the minor. ecclesiastical orders who attends the priest in the ministry of the altar.

Acon. (Naut.) A flat-bottomed boat; Mediterranean.

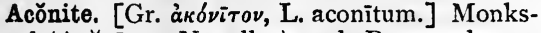
hood (Acŏnītum Napellus), ord. Ranunculaceæ. A poisonous plant, with long tapering root, divided leaves, and tall stems bearing racemes of purple flowers ; cultivated in gardens for ornament and for medicinal purposes ; root sometimes mistaken for horse-radish, with fatal results.

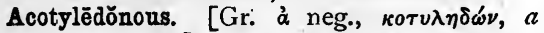
cup-shaped, cavity.] (Bot.) Vegetating without the aid of cotyledons, or seed-lobes ;=Linnæan Cryptogamia, e.g. ferns, lichens, mosses.

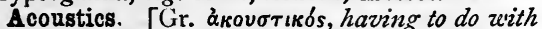
hearing.] The theory of sound.

Acquest. [L. acquîro, I acquire.] Acquisition ; in Law, property not inherited.

Acquittance roll [ $\mathrm{Fr}$. acquitter, L adquietāre] shows the debts and credits of each noncommissioned officer and soldier of a regiment, and is signed monthly by him in acknowledgment of its accuracy.

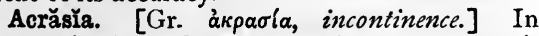
Spenser's Faëry Queen, an enchantress, personifying want of self-control.

Acre. [L. ăger, $a$ field.] An area of 4840 square yards. The Scotch acre is 1.27 of an English acre, the Irish nearly $I \cdot 62$.

Acre-fight. A border combat between the English and the Scotch.

Acre, God's. [Ger. Gottes-acker.] A burialground.

Acrita [Gr. akeprios, not exercising judgment, i.e. being almost destitute of sensation], i.q. Protozoa (q.v.).

Acrito-chromacy. The being unable to distinguish [Gr. ăкрітоs] colour $[\chi \rho \hat{\omega} \mu \alpha]$. (Dyschromatopsy.)

Acro-. [Gr. ärpos.] Topmost, extreme.

Acroāma. (Anagnostes.)

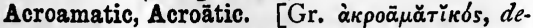
signed for hearing, à pod́oual, I hear.] The oral teaching of philosophers, for intimate friends only. (Esoteric.)

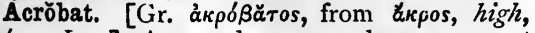
$\beta a i v \omega, I$ go.] A rope-dancer; and so a gymnast generally.

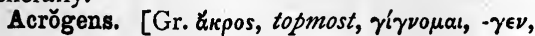

I am produced.] (Bot.) One of the primary classes of the vegetable kingdom, according to the Natural system, = the Cryptogams of the Linnæan. The term applies literally to those plants whose stems increase by growth at the summit, e.g. tree-ferns, club-mosses, etc., as distinguished from the manner of growth of Exogens and of Endogens.

Acroleine. [L. ācrĕ ǒlěum, acrid oil.] A pungent volatile fluid, produced by the action of heat on fats.

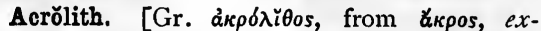
treme, $\lambda i \theta$ os, stone.] A name given to the oldest Greek statues, the body being still of wood and draped, but the extremities, head, arms, feet, of marble; marking the transition into marble statuary.

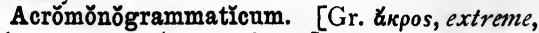
$\mu \delta \nu o s$, only, $\gamma \rho \alpha \dot{\mu} \mu \alpha, a$ letter.] A poetical composition of which every verse begins with the last letter of the preceding line.

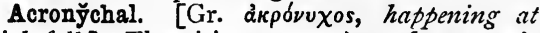
nightfall.] The rising or setting of a star is A. when it rises as the sun sets and sets as the sun rises. The Cosmical rising and setting is the opposite, viz. the star rises as the sun rises and sets as the sun sets. Also spelt, incorrectly, Acronical.

Acrŏpŏlis. [Gr.] The citadel, or upper town of a Greek city.

Acrospire. The slight coil or curve [Gr.

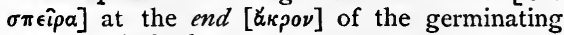
seed, e.g. in barley.

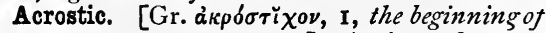
a verse, 2, an acrostic poem.] A piece of poetry in which the first letters-or, according to modern use of the word A., the first, or the last, or some central one-of every line, taken consecutively, make a word or a sentence.

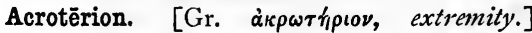
(Arch.) A short pedestal for a statue, at the apex and the extremities of a pediment.

Act, Acta. In Rome, records of public proceedings, as $A$. populi, Senatus, etc., at one time published as a kind of newspaper. Hence, in later times, Philosophical "Transactions," Acts of Parliament, Fr. acte authentique ; and to keep an act, i.e. perform a public exercise, for a degree.

Acta Diurna. [L.] The records of the daily acts of the Senate, published by the order of Julius Cæsar.

Acta Martyrum. [L.] Records of the suffer. ings of the nartyrs. St. Augustine speaks of these records as being read to the people on their festival days.

Acta Sanctorrum. [L.] A title given to the records of the lives of saints, the most celebrated collection being that of the Bollandists. (Banctorale.)

Actes. [Fr.] In Fr. Law, documents (Act), e.g. A. de décès, de mariage, certificates of death, marriage.

Actian Games. (Hist.) Games celebrated at Actium, on the Ambracian Gulf, in honour of Apollo, and renewed with increased splendour by Octavius after his victory over M. Antonius.

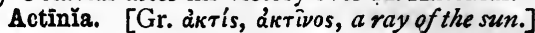


Sea-anemone, giving its name to fam. Actīň̆dæ, class Actīnozōa, sub-class Cœlentěrāta.

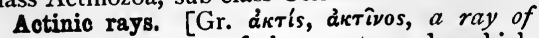
the sun.] The rays of the spectrum by which chemical changes are produced, as in photo. graphy.

Actinograph. [Gr. àkris, $\gamma \rho \alpha \phi \omega$, I write.] An instrument for registering variations in the intensity of the actinic rays.

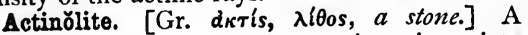
crystallized mineral, green; a prismatic variety of hornblende.

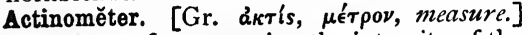
An instrument for measuring the intensity of the sun's radiant heat.

Action. [L. actǐo, -nem.] (Mil.) An engagement of minor proportions to those of a battle.

Action of a moving system, or Quantity of Action, is a quantity proportional to the average kinetic energy of the system during a certain time, multiplied by the time. (For Action and Reaction, vide Reaction.)

Act of God, By the. In Law; caused by something beyond human control, as a lightning stroke, a hurricane.

Actuality. [L. actuālis, belonging to an act.] Real existence of some state, quality, or action; opposed to Potentiality (q.v.), and to that which is Virtual (q.v.).

Actuary. [L. actuārius.] 1. In the Roman courts, an officer who drew up contracts and other instruments in the presence of the magistrate. 2. The registering clerk of Convocation. 3. A calculator of the value of life interests, annuities, etc.

Actum est de. [L.] All is over with.

Aotus non făoit reum, nǐsi mens sit rea. In Law ; the act does not make a man a criminal, unless the intention be criminal.

Aculeate. [L. ăcūlěus, $a$ sting, sharp point.] (Bot.) Covered with prickles, which are cellular; while thorns or spines grow from the wood, and are stiff shortened branches.

Acūminnate leaf [L. acūmen, $a$ point $]$ has a projecting, tapering point, e.g. the common reed ; Acute being simply pointed.

Acupressure. (Med.) The occlusion of an artery by the pressure [L. pressüra] of a netalle [ăcus] in such a way as to arrest the circulation through, or the hemorrhage from it.

Acupuncture. (Med.) Pricking [L. punctūra] of the affected parts with a needle [ăcus], for remedial purposes.

Acute disease [L. ăcūtus, sharp] is opposed to Chronic; acute sound or accent to grave; acute angle is less than, obtuse more than, $90^{\circ}$.

Aonyari. (Bot.) The wood of the Icica altissima, a resinous tree of Guiana.

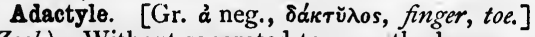
Zool.) Without separated toes, as the hurse.

Adage. [L. ădăgium.] A proverb.

Adagio. [It.] (Mus.) Slowly, leisurely.

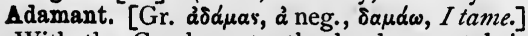
1. With the Greek poets, the hardest metal, it is not certain what. 2. The diamond. Adămas, both in $\mathrm{Gr}$. and in $\mathrm{L}$., has both meanings. Another form of the word is diamond, through
Fr. diamant ; and another is Fr. aimant, a loadstone.

Adamantine spar. Brown sapphire.

(Corundum.)

Adamites. A name applied to sects which, in the early Christian centuries, and again in the twelfth and fifteenth, professed to imitate Adam's primitive state of innocence.

Adam's apple. The prominence in men's throats, made by the top front angle of the thyroid cartilage of the larynx. (Thyroid.)

Adam's needle. (Yucca.)

Adams, Parson. A poor curate and scholar in Fielding's Foseph Andrews; type of a thoroughly simple manly Christian.

Adam's Peak. A mountain in Ceylon, associated with the name of Adam and of Buddha, whose supposed foot-print, seen near the summit, attracts yearly thousands of pilgrims.

Ad ămussim. [L.] Lit. to the carpenter's rule; exactly.

Adansonia. (Baobab.)

Adar. [Heb., (?) fire, splendour.] Esth. iii., ix.; sixth month of Jewish civil, twelfth of ecclesiastical year; February--March. Ve-adar, i.e. additional $A .=$ intercalary month.

Adatis. A fine cotton cloth of India.

Adawlut, Sudder. (Sudder.)

Ad Călendas Græcas [L., to the Greek Calends], i.e. never. (Calends.)

Ad captandum. [L., for catching.] Addressed to prejudice, fancy, ignorance, rather than to well-informed reason.

Ad crŭmēnam, Argumentum. [L., argument to the purse.] An argument addressed to one's power of or interest in spending.

Adda. Small burrowing lizard (Scincus offícinālis), supposed to be remedial in leprosy and all cutaneous diseases. Arabia, Egypt, Nubia.

Addendum. [L., $a$ thing to be added.] In mechanics, the distance by which the teeth of a toothed wheel project beyond the pitch circle.

Adder. [A.S. nædre, an adder, properly nadder, a swimming or water-snake; some refer it to A.S. attor, poison ] (Bibl.). Four Heb. words are in the Authorized Version represented by adder or asp. I. Pěthen, the cobra. 2. Shĕphiphon, the cerrastēs, or horned viper. 3. Akshub, a species of viper. 4. Tsiphōnl, cockatrice (Isa. xi. 8), perhaps the cěrastēs.

Adder's tongue. (Bot.) Opȟ̌ğglōssum vulgātum, the type of an order of ferns; so named from the shape of the spike into which the spore-cases are collected.

\section{Addicti. (Nexi.)}

Addiction. [L. addictio, -nem.] In Rom. Law, the assignment of goods or slaves to another by sale or the legal sentence of the prætor.

Addison's disease (described by Dr. Addison, of Guy's Hospital), or Bronzed skin. 'A state of anæmia, languor, irritable stomach, etc., associated with disease of the supra-renal capsules.

Additament. [I. addǐtus, added.] An addition.

Addition. [L. addítio, -nem.] (Her.) Any mark of honour added to a coat of arms. 
Addled Parliament. A Parliament of 1614; so called because it had passed no Acts before it was dismissed by James I. (Parliament.)

Addlings. (Naut.) Savings of pay. In Lincolnshire phrase, to addle is to earn.

Addorsed. [L. ad, to, dorsum, a back.] (Her.)

Back to back.

\section{Adductor. (Abductor.)}

Adelantado. [Sp., one who is promoted.] A governor of a province in the Spanish kingdom.

Adelphi. A district south of the Strand, close to Charing Cross ; so called from the architects, four Scotch brothers [Gr. di $\delta \in \lambda \phi o i]$ Adams.

Adelphia. (Bot.) Linnæan name for a col-

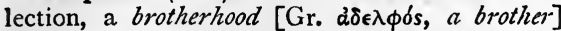
of stamens united by filaments in a bundle. If all are in one bundle, Linnæean class xvi., the plants are Monadelphia; if in two, class xvii.,

Diadelphia; if in three or more, class xviii., Polyadelphia.

A demi jeu, - oix. [Fr.] With half the power of the instrument, -the voice.

Ademption. [L. ademptio, -nem, a taking away, a seizure.] (Leg.) Alienating the subject of a legacy during testator's life.

Aden-, Aděno-. (Med.) Having to do with a gland [Gr. à $\delta \dot{\eta} \nu]$.

Adept. Skilled. [L. ădeptus, one who has acquired, i.e. the art of alchemy; part. of ădípiscor, I acquire.]

Adessenarians. [L. adesse, to be present.] (Eccl. Hist.) Persons holding that there is a real presence of Christ in the Eucharist, but denying that it is effected by transubstantiation.

Ad eundem. [L.] Said of a graduate of one university admitted to the same degree [grădum] at another.

Adhesion. [L. adhæsio, -nem, from adhæreo, I stick to.] 1. The force of attraction exerted between the surfaces of bodies in contact. 2 . (Surg.) The reunion of parts that have been severed. 3. (Path.) The morbid union of parts naturally separated, but contiguous.

Ad höc, Argümentum [L., argument for this], i.e. of particular not general application.

Ad hŏminem, Argumentum. [L., argument to the man.] Addressed to a man's special interest or feelings.

Adhūc sub jūdice liss est. [L.] The matter in dispute is not yet decided; is still under the judge.

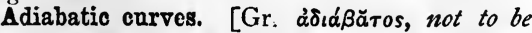
passed.] Show the relation between the volume and pressure of vapour when no heat is allowed to pass in or out of the vessel containing it.

Adiantum. [Gr. dólavrov, unzetted, à neg., sıaivw, $I$ wet.] A gen. of ferns; so called by the Greeks because the leaves are not readily wetted by water. The number of the spec. is very great. (Maidenhair.)

Adiaphŏrites, -ists. Melanchthon's party, who assented to Charles V.'s Edict, the Augsburg Interim, A.D. I 548, settling things indifferent

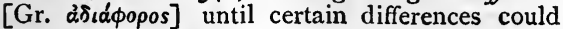
be settled by a Council.

Adiaphŏrous. [Gr. à ıı́́фoposs.] 1. Indifferent.
2. (Chcm. and $M e d$.$) Not acting one way or$ the other, e.g. not as acid or as alkali.

Ad intĕrim. [L.] In the mean while.

Adīpǒcēre. [L. ădeps, fat, cēra, zvax.] A fatty, waxy result of the decomposition of animals in moist places or under water.

Adipose tissue. [L. ădeps, soft fat, opposed to sēbum, hard fat.] An aggregation of minute spherical closed vesicles of fat.

Adit. [L. ădǐtus, an approach.] A horizontal entrance to a mine.

Adjective. (Substantive, Nouns.)

Adjective colours [L. adjectivus, that which is added] require some base or mordant to fix them for dyeing.

Adjustment. (Naut.) Insurance ; the process by which the net amount receivable under a policy is determined.

Adjustment of compass. 1. The rearranging of deranged parts of it. 2. Compensation, i.e. the correction, by observation, of the error in the deflexion of the needle caused by the attraction of the ship, or of objects in her.

Adjutant. [L. adjūto, $I$ assist.] An officer, lieutenant or captain, acting as assistant to the commanding officer; charged with instruction in drill ; with the interior discipline, duties, and efficiency of the regiment; the control of the staff-sergeants and band; and having the charge of all documents and correspondence, as well as being the channel of communication for all orders.

Adjutant bird. (Argala.)

Adjutant-General. A field officer or general officer, performing similar but superior duties to those of an adjutant (q.v.), for a general commanding either a division (q.v.) or a whole army.

Ad leōnes. [L., to the lions.] A cry often raised against those of the early Christians who would not sacrifice to the deified Cæsar.

Ad lib., i.e. ad libĭtum. [L.] At pleasure.

Admeasurement. The art or practice of measuring according to rule.

Adminicular. [L. admĭnı̆cŭlum, a prop, ad, to, mănus, $a$ hand.] Supporting, helping.

Adminnicŭlum. [L., a prop, support.] Generally used $=$ evidence in support of other evidence.

Administration, Letters of. 1. Granted by the Probate Court, formerly by the ordinary, to one appointed to distribute the effects of an intestate person. 2. In Politics, the $A$. is the executive power, as distinguished from the constitution; but is generally used as $=$ the Cabinet or the Ministry.

Admirable Crichton. (Crichton.)

Admirable Doctor, The. Doctor Mīrābǐlis, Friar Roger Bacon (1214-1 292).

Admiral. [O.Fr. amirail, Ar. amír, prince, chief.] Formerly often $=$ the leading vessel in a fleet.

Admiral; Vice-A.; Rear-A.; A. of Fleet. (Rank.) In the Newfoundland fisheries, the first three vessels to arrive are the $A$., Vice-A., and Rear $-A$., respectively.

Admittātur. [L.] In some American colleges, a certificate of admission; let him be admitted. 
Admonitionists. A name denoting those Puritans who, in $\mathbf{1} 571$, sent an "admonition" to Parliament, condemning everything in the Church of England which did not harmonize with the doctrine of Geneva.

Admonitions to Parliament, First and Second. A volume of addresses, drawn up under Cartwright (1535-1603), sometime Margaret Professor at Cambridge, bitterly denouncing Church doctrine and discipline. Bishop Cooper, of Winchester, answered in an Admonition to the People of England, at Whitgift's suggestion.

Admortization. [L. ad, to, mortem, death.] In feudal times, reduction of property to mortmain (q.v.).

Adnate. [L. adnātus, grozen to.] (Bot.) Growing to anything by the whole surface, e.g. an ovary united to the side of a calyx.

Ad nausĕam. [L.] To a sickening degree; lit. to sea-sickness [Gr. vavoía, vavis, a ship].

Adobe. [Sp. adobár, Fr. adouber, to prepare, dress.] A sun-dried brick.

Adolescence. [L. ădŏlescentia, ădŏlesco, I grow $u p$.] The period between fourteen in males, twelve in females, and twenty-one years of age.

Adonic verse. The last line of a Sapphic stanza, consisting of a dactyl and a spondee.

Adonize. To deck one's self like Adōnis, the darling of Aphrŏdīte (Venus), who died from a wound inflicted by the tusk of a wild boar. Aphrŏdite changed his blood into flowers: hence the name Adonis given to a gen. of ord. Ranunculaceæ.

Adopter, or Adapter. (Chem.) A two-necked receiver, placed between a retort and another receiver, increasing the length of the neck of the retort, and giving more space to elastic vapours.

Adoptians. A name given to the followers of some Spanish bishops in the eighth century, who maintained that as to His humanity Christ was only the adopted Son of the Father.-Milman, History of Latin Christianily, bk. v. ch. i.

Adoration. (Acclamation.)

Adpressed. (Bot.) Brought into contact without adhering.

Ad quod damnum. [L.] A writ to the sheriff, to inquire to what damage to the king or the public the granting of certain liberties might be.

Ad rem. [L., to the thing.] To the purpose, point.

Adscititious, Ascititious. [L. adscisco, sup. adscitum, I receive, adopt.] Taken in so as to complete ; supplemental.

Adscriptus glebæ. [L.] One who is attached to the soil ; a serf. (Villein.)

Adsum. [L., I am here.] Answer to one's name at some schools, as at Charterhouse; "calling over" or " roll-call."

Adullamites. A term applied by Mr. Bright in the session of 1866 to Mr. Horsman and the members who joined him in his objections to the Reform Bill then before the House of Commons ; in reference to the action of David in the cave of Adullam (I Sam. xxii. I, 2).

Adulterine guilds. Unchartered trading societies, acting as a corpuration and paying annual fines.
Adumbration. [L. ădumbrātio, -nem, an outline, sketch in shadowv.] An imperfect account. Adunation. [L. ădünātio, -nem.] A making into one.

Aduncity. [L. ăduncĭta, -tem.] (Zool.) Hookedness, crookedness, as in the beak of the eagle or claw of the tiger.

Ad unguem. [L.] To a nicety; lit. to the nail, with which sculptors tested the smoothness of surface in their finished works.

Adust. [L. ădustus, ădūro, I scorch.] Burnt up, scorched.

Ad valörem. [L.] In Finance, a term denoting the market value of commodities imported and liable to a customs rate, varying according to the quality of the article or the measure of its supply.

Advanced guard. A detachment preceding the main body of troops on a march, for the purpose of guarding against surprise.

Advanced works. Constructed beyond the glacis of a fortification, but still capable of being defended from the body of the place.

Advance money. (Naut.) Wages advanced to a sailor previous to his embarkation. To work up the dead horse is to clear off this advance.

Advance note. (Naut.) A written promise to pay a part of a sailor's wages at a given time after his sailing. It was negotiable ; but it ceased to be so after August I, I88I, by 43 and 44 Vict., c. 16.

Adventitious. [L. adventǐcius, foreign, strange.] 1. Added from without, not inherent in the thing itself; as the dread of an idol. 2 (Bot.) Appearing in an unusual way, e.g. root fibres from the stems of ivy, banyan. 3. (Med.) Foreign to the structure or tissue in which it is found.

Adventure, Bill of. (Com.) A signed declaration that shipped goods belong to another person who takes the hazard of transport.

Adversäria. [L., i.e. scripta, writings, turned adversus, towards one's self.] A commonplace book ; memoranda lying in front of one.

Adversifoliate. [L. adversus, opposite, fŏlium, a leaf.] (Bot.) Having opposite leaves. (Alternate.)

Advertise. [L. ad, to, verto, l turn.] To give notice or information to.

Advertisements of Elizabeth. May, 1566. Injunctions, monitions, for attainment of uniformity in public worship; having the force of law, according to Ridsdale judgment, May, 1877 ; but this decision is questioned, and the matter not unlikely to be reconsidered.

Advice. [L. ad, to, vīsum, opinion, through O.Fr. à vis, It. avviso.] Commercial and journalistic notice, information.

Ad vivum. [L.] To the quick.

Advocate. In Theology. (Paraclete.)

Advocate, Iord. Chief Crown lawyer in Scotland.

Advocates, Ecclesiastical. (Doctors' Commons.) Advǒcātus drăbǒli. [L., It. Avvocāto del diav̌lo.] . Devil's advocate. One who brings forward every possible objection to a proposed canonization, and is answered by $A$. Dei; hence 
$=$ one who brings a charge in order to give opportunity of vindication.

Advowson. [L. advǒcātio, -nem, the act or relation of advócātus = patrōnus.] (Eccl.) The right in perpetuity to present to a living; appendant, when annexed to land ; in gross, when it has become separated.

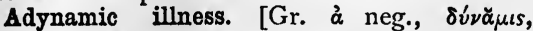
power.] (Med.) Illness characterized by want of power.

Ady̆tum. [L., Gr. åvrov, not to be trodden.] The shrine of an ancient temple; called Secos in the temples of Egypt. Cf. Holy of holies.

Adze, Addice. [A.S. adese, an axe; cf. L. ascia, Gr. $\alpha \xi i \nu \eta$.] Wood too rough, or not conveniently placed, for planing, is dressed with an A., a mattock-like instrument, with blade arching inwards, the edge being at right angles to the handle.

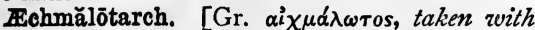
the spear, ap $\chi \omega, I$ rule.] (Hist.) The governor of the captive Jews in Chaldæa and elsewhere, called by the Jews themselves Rosch-galuth or Resch Glutha, chief of the Captivity.

Ėdile. [L. ædīlis, from ædēs, a building.] A Roman magistrate who had charge of buildings, public works, theatrical performances, games, and markets, and of the registers of legislative measures. There were first two Plebeian Adiles; afterwards two Curule (q.v.) E. were added.

Egilops. [Gr. ai $\gamma i \lambda \omega \psi$, goat-eyed.] 1. (Med.) An ulcer in the eye. 2. A grass supposed to have the power of healing this disease.

IIginētan marbles. Figures-pre-Phidianfrom pediment of a temple of Athēna in Egina, now restored, in the Glyptothēkē at Munich. They represent the goddess and eight chief heroes of the Trojan war.

Egis. [Gr. airis.] The mythic shield of Zeus (Jupiter), covered with the skin of the goat Amalthrea, which had nursed him, and given by him to Athēna, who by fixing on it the head of Medusa gave to it the power of petrifying all who looked at it. (Gorgon.)

Esgrescit mĕdendo. [L.] Lit. he grozes worse by the healing; the remedy makes matters worse. -Virgil.

IEgrōtat. [L., he is sick.] He cannot attend examination for honours, lectures, hall, etc.

Aei-parthěnos. [Gr., ever virgin.] A title of the Virgin Mary.

Ael, Eal, Al, i.q. all [A.S. eal]; as Aelwin $=$ all-conquering ; Albert, all-bright, illustrious.

Elf- = help, Aelfwin = helping in victory. [A.S. helpan, to aid.]; also = elf, as Elfgifu, sift of the elves, like the Gr. Nymphodōros.

Emilian Provinces. (Emilian.)

Inneid. The great poem of Virgil, relating the wanderings of Eneas after the fall of Troy, and his settlement in Italy. As compared with the genuine epic poems which have sprung from the traditions of the people, the $Æ$. is an artificial epic.

ÆExlian. Anything relating to the Greek windgod Aiǒlos, AEolus, the guardian of the winds, which he kept pent up in bags in his vast cave.
Eolian attachment. [L. Eŏlus, god of winds.] Converts a piano into a wind instrument by bellows attached to the pedal. (E્olian harp.)

Æelian harp. Eight or ten strings of catgut in unison, stretched across a light wooden box, placed in a current of air and producing harmonic sounds.

Exolian mode. (Greek modes.)

Folic. In Gr. Hist., a name by which some tribes were known who did not belong to the Doric or Ionic stock.

Folipile, Eolipile. [L. Ěŏlus, god of winds, pila, a playing-ball, a globe. $] \mathrm{A}$ hollow globe mounted so as to be capable of rotation round a diameter, containing water and furnished with two nozzles in opposite directions at right angles to a diameter and at opposite ends of it. When the water is heated, jets of steam come out of the nozzles, and make the sphere turn round the diameter, round which it is free to move. Often spelt Eolipyle, incorrectly.

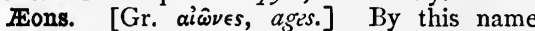
the Gnostics, referring to an order of time in their generation, designated the genealogies of superior intelligences, among these being the

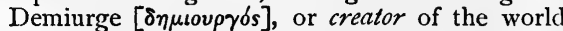
out of matter, who was regarded as proceeding from the evil principle.

Era, Era. [L.] In Chronology, the amount of time reckoned from some given epoch, the Christian era dating from the birth of Christ. (Hegira; Nabonassar, Era of; Yezdigerd, Era of.)

Frārian. [L. ærārǐus.] A Roman citizen who had become a mere payer of money [æs, æris] for the support of the State; in other words, had been degraded to the lowest rank. (Proletarian.)

Erärŭum. [L.] The public treasury of the Roman plebs, or commonalty.

$\Delta$ ërated waters. Charged with gas, usually carbonic acid, under pressure.

Aerial perspective. [L. aěrius, from aër, air.] The art of expressing the relative distance of objects in a picture by such faintness of colour as may answer to the amount of air or distance between them and the spectator.

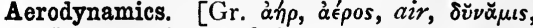
power.] The science of air currents or winds.

Aerography. [Gr. àn $\rho$, air, $\gamma \rho \alpha ́ \phi \omega, I$ zurite, draw.] The science of describing the atmosphere.

Aerolith, -lite [Gr. a'n $\rho$, the atmosphere, $\lambda$ ínos, a stone], or Meteorite [ $\mu \in \tau$ téwpos, htgh in the air]. A body, stony or metallic, which, coming within the earth's attraction, and ignited by friction with the atmosphere, appears as a "falling star."

\section{Aerophytes. (Epiphytes.)}

Aery. (Eyry.)

EEruginous. [L. ærūgĭnem, copper rust.] Partaking of verdigris, rust (carbonate) of copper.

Esculapian. Anything relating to Asculāplus [Gr. Asklēpios], son of Apollo, worshipped as the god of surgery and medicine.

Escŭlus. [L.] A gen. of plants, ord. Hippócastăneæ; the best known species is the AE. Hippŏcastănum, horse chestnut. 
Esir. (Asuras.)

Aesthetic. [Gr. ai $\sigma \theta \eta \tau \iota k \delta s$, belonging to perception or feeling.] In Art, having reference to the feeling and perception of the beautiful, as distinct from objective knowledge.

Estīmatio căpirtis. [L., the value of an individual life.] King Athelstan fixed a tariff of fines. pro $\mathscr{E}$., i.e. according to the rank of the wounded or slain; and in Justinian's Institutes the punishment of an injüria was to be graduated according to the rank and the worthiness of the injured.

\section{Aestivation. (Vernation.)}

Etheling. [A.S., from rthel, noble.] In Eng. Hist.; before the Norman Conquest, the presumptive heir to the crown.

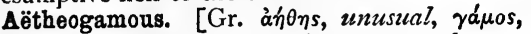
marriage.] (Bot.) Unusually propagated.

Ethiops mineral. [Gr. Aioio $\psi$, an Ethiopian.] A black sulphide of mercury.

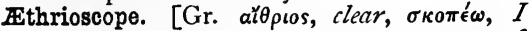
view.] An instrument showing the changes of temperature produced by a clear or clouded sky.

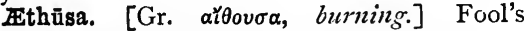
parsley ; E. cy̆năpium, ord. Umbelliferæ.

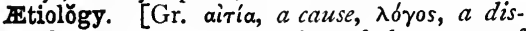
course.] (Med.) The doctrine of the causes of disease.

Etolian League. (Gr. Hist.) A league of the Etolian tribes to the north of the Corinthian gulf. - Freeman, History of Federal Government.

Affeer. [O.Fr. affeurer, from feur, Sp. fuero, an assize, tax.] (Leg.) To fix a sum for a fine.

Afferent. [L. afferentem, part. of affĕro, from ad, to, ferro, $I$ bear.] 1. (Anat.) Carrying from the surface to the centre, as opposed to efferent. 2. (Physiol.) Afferent, sensory, or excitor nerves, convey sensational impressions from the various parts of the body to the ganglionic centres; Efferent or motor nerves convey from these centres to the muscles the impressions which call forth contraction.

Affridāvit. [L.L., he has sworn to.] An exparte written statement, made on oath or solemn affirmation before an authorized magistrate, as evidence to be laid before a court or a judge.

Affiliated societies. In Politics, societies depending on a central society, from which they receive directions.

Affinity. [L. affīnı̌tā,-tem.] 1. Relation by marriage; Consanouinity [L. consanguĭnĭtā, -tem], by blood: 2. (Zool. and Bot.) A. expresses a marked resemblance in important organs; Analogy referring to less important organs or to outward form. 3. (Chem.) The tendency of different substances to enter into chemical combinations with each other.

Affix. [L. affixus, part. of affigo, from ad, to, fixus, part. of fïgo, I fix.] (Gram.) An element added to the beginning (Prefix) or end (Suffix) of a word.

Afflātus. [L.] Inspiration.

Affluent. [L. affluentem, part. of affluo, I flow or stream to.] A smaller or secondary river, flowing into a larger or primary river, or into a lake. An important aftuent is called a tributary, as the Drave of the Danube, the Jumna of the Ganges.

Afforage. [Fr.] A duty paid in France on the sale of liquors.

Afforest. [L. L. foresta, $a$ wood.] To convert ground into forest; the converse being to disafforest.

Affreight. [O.H.G. freht, a cargo.] To hire a ship for conveyance of goods.

Affrontée. (Her.) Facing each other.

Affusion. [L.L. affüsio, -nem, a pouring upon.] Baptism administered by the pouring of water is called baptism by affusion, as distinguished from baptism by immersion, in which the whole body of the baptized is plunged under water.

Afore. (Naut.) Contrary of Abaft (q.v.).

A fortiori. [L.] All the more; lit. by $a$ stronger argument.

Afrancesãdos. [Sp.] The Spanish party which attached itself to the cause of the French (1808-r8I4).

Afrit. [Ar.] An evil genius in Arabic mythology. (Jin.)

Aft. (Naut.) I.q. Abaft (q.v.).

After-birth. (Placenta.)

After-body. (Naut.) That part of a ship which is abaft her greatest wiclth.

After-damp. (Fire-damp.)

Aftermath. [A.S. aefter, after, maér, a mowing, máwan, to movv ; cf. mead; L. měto, etc.] The second crop on permanent grasslands.

After-piece. A short, light play, performed after the principal piece of a theatrical entertainment.

Aga. (Effendi.)

Agacerie. [Fr.] Provoking coquetry. Littré refers Fr. agacer, to provoke, to Norm. agasser, to chase away with clamour, hence to irritate.

Agallochum. (Aloes-wood.)

Agăma. Gen. of lizards, giving its name to the fam. Agamidce, closely allied to, and the Eastern representatives of, the Iguanide of the western hemisphere. This fam. contains the flying dragons (Drăco) of E. India and the Indian Archipelago.

Agămi. Gold-breasted trumpeter of S. America. Gregarious bird, about the size of the pheasant, easily tamed (Psǒphřa crěpitans). (Psŏphĭdæ.)

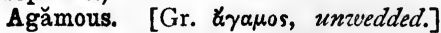

Having no visible organs of fructification.

Agăpæ. [Gr. áyámi, love.] The love-feasts of the early Christian Church. They were held in the church in connexion with the Lord's Supper, but not as a necessary part of it. They were ultimately forbidden on account of the irregularities to which they led.

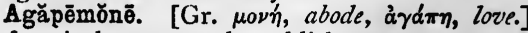
A fanatical conventual establishment set up near Bridgewater, about 1849 , by "Brother Prince," a clergyman, calling himself Witness of the First Resurrection.

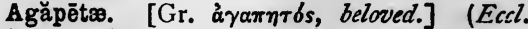
Hist.) In the first centuries, women under vows of virginity, who attended on the clergy.

Agar. [Malay word.] Edible seaweed. 


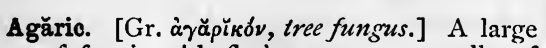
gen. of fungi, with fleshy cap on a stalk, of which $A$. campestris, common mushroom, may be taken as a type.

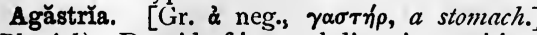
(Physiol.) Devoid of internal digestive cavities.

Agate. [L. ăchātes.] 1. (Geol.) Found in R. Achātes, Sicily. Chalcedonic nodules and geodes in amygdaloidal lavas. Algerian $A$. is a calcareous stalagmite. 2. A small printing type.

Agăthŏdæmon. [Gr. à $\gamma \alpha \theta 0 \delta \alpha^{\prime} \mu \nu \nu$.] The good genius or spirit, probably at first only an epithet of Zeus (Jupiter).

Agávê. [Gr. àravós, admirable.] A gen. of plants; American; ord. Amaryllidacex; e.g. American aloe.

Agenda. [L., things to be done.] 1. A list of things to be considered at a public meeting. 2 . Matters of duty, Crédenda being matters of faith.

Age of Reason. The age in which reason is supposed to exclude faith, and which was thought to have been reached by the triumph of the French Revolution.

Ager Publicus. [L., The territory of the Roman state acquired by conquest; $A g e r ~ R o$ mānus being the original territory.

Ages, The four. An old tradition represents the existence of mankind as starting with a Golden Age, in which the earth yielded its fruits of its own accord, and pain and sickness were unknown. This was followed by the Silver Age, the men of which were punished for their impiety to the gods. After which came the Brazen and the Iron Ages, each worse than the preceding. Between these two last the Hesiodic theogony inserted the Heroic Age, or the age of the heroes who fought at Troy.

Agger. [L.] 1. In a Roman camp, the earth dug out from the fossa, or trench, and placed on the bank; on its outer edge was the z'allum, or stockade. 2. A mound erected before the walls of a besieged city to sustain the battering engines.

Agglomerate. [L. agglomerātus, agglŏmĕro, $I$ collect into a body.] (Geol.) With Lyell = accumulations of angular fragments showered round a volcanic cone or crater.

Agglomerative languages. Such as tend to combine many elements into one long agglutinated or inflected word, as the dialects of American Indians.

Agglutinative languages. The languages or the nomadic Turanian tribes, in which the modifying suffixes are glued on to the root. To this family belongs the Basque language of S. France and N. Spain. (Aryan languages.)

Aggregate. [L. aggrěgātus, flocked together.] 1. A mass formed of homogeneous particles clustered together, as distinguished from a compound. 2. (Bot.) Flower, one of several florets within one calyx or receptacle, e.g. daisy, chrysanthĕmum. 3. (Geol.) A rock, the components of which can be separated mechanically, as granite.

Aggregate corporations. (Corporations.)

Aggregations, Various. Apiary of bees [L. apiārium]. Army of rats. Band of robbers, smugglers. Bevy of girls, larks, quails, roes. Brood of chickens. Burrow of conies. Clack of women. Clutch of eggs. Colony of rooks, or rookery. Columbary of pigeons [L. cŏlumbārium, a dove-cote]. Covey of partridges [Fr. couvée, brood]. Crew of sailors, wretches. Cry of falcons. Drove of horses, asses, camels, pigs, geese. Eyry (q.v.) of hawks, eagles. Fall of woodcocks. Flight of geese, wild ducks, woodcocks, starlings. Flock of sheep, geese, turkeys, pigeons, fieldfares, sparrows. Fry of small young tishes, of children [Fr. frai, spazen]. Gang of workmen, navvies, gipsies, thieves, convicts. Herd of deer, cattle, goats, swine, swans. Horae of brigands. Kennel of hounds [Fr. canaille]. Mew (q.v.) of falcons. Muster of peacocks. Nest of wasps, hornets, rabbits.

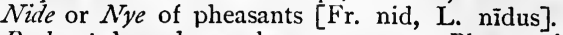
Pack of hounds, wolves, grouse. Plump of spears. Pod of seals, sea-elephants. Pride of lions. Rascall of boys. Rout of wolves. School of whales. Shoal of fish [A.S. scolu]. Siege of herons [Fr, siège, a sitting]. Singular of boars. Skein of wild geese. Skulk of foxes. Slouth of bears. Sounder of wild swine. String of red deer or of horses. Stud of horses, greyhounds. Swarm of insects. Whisp or Walk of snipes. Vaccary of cows [L. vacca, a cow]. Vespary of wasps [L. vespa, a wasp]. Warren of rabbits. Yard of poultry

-agh, -auch. [CJ. Erse achadh, field.] A level place, as in Balbaugh.

\section{Agila wood. (Aloes.)}

Agio. [It.] Generally, the difference between current and standard moneys ; also, the premium paid by one who prefers payment in a metal other than that which he can legally claim. So in France, there is an A. on gold.

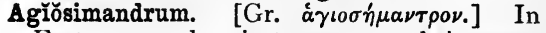
the East, a wooden instrument used in summoning the people to the church instead of bells.

Agiotage. [Fr.] Manœuvres for raising or lowering the price of funds.

Agistment. [Fr. giste, gîte, L. jăcĭta, $a$ lyins-place, lodging.] 1. The taking in of cattle to pasture. Tithe of A., tithe upon profit made by A. 2. (Naut.) An embankment to keep out the sea or a river.

Aglet, Aiglet. [L. ăcus, a needle, dim. ăcǐcŭla, Fr. aiguille, aiguillette.] The tag of a point of the lace or string formerly used for gathering together the different parts of a dress.

Agnail, Angnail. Probably two distinct words run into one (?). 1. A swelled gland in the groin [L. inguen, inguĭnalia, Fr. angonailles]. 2. A sore under the nail [A.S. ang-nægle, troubled nail].

Agnate. [L. agnātus.] In Rom. Law, related on the father's side. Cognate [cognātusj, on the father's or the mother's.

Agnition. [L. agnitio, -nem.] An obsolete word for acknowledgment.

Agnǒētæ. [Gr. à $\gamma \nu$ ó́ $\omega, 1$ am ignorant of.] Heretics: 1. Fourth century, who questioned the omniscience of God. 2. Others, sixth century, who held that Christ knows not when the day of judgment shall be. 
Agnōmen. [L.] All Romans of good family bore three names : Pranomen, of the individual; Nomen, of the class, gens; Cognomen, of the house, or familia; e.g. Publius Cornelius Scipio. A fourth, Agnömen, was sometimes added on account of some personal distinction, e.g. Afrícānus. Some even had a second A. [Cf. Fr. prénom, a Christian name.]

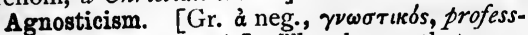
ing knowlenge $(\gamma \nu \hat{\omega} \sigma \iota s)$.$] The theory that man$ has insufficient evidence or insufficient power for judgment concerning Divine truth.

Agnus castus. [L.] A shrub, the Vittex agnus castus of botanists, the branches of which were strewed by matrons on their beds at the Thesmŏphŏrĭa, a festival of Dēmēter (Ceres).

Agnus Dei. [L., Lamb of God.] In the Roman Church, cakes of wax are so called, which are stamped with the figure of a lamb bearing the banner of the cross.

Agog = a-going, i.e. on-going; on the alert.

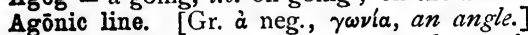
The line joining all those places on the earth where the magnetic needle has no declination, or variation, i.e. deviation from the true $\mathrm{N}$.

Agony column of an advertisement sheet, generally the second, headed by notices of disappearances and losses, mysterious appeals and correspondence.

$\Delta$ gorra. [Gr., from à $\gamma \in \hat{l} \rho \omega, I$ bring together.] The market-place, and so the "forum," of a Greek town.

Agouti. Gen. of rodent, ranging in size between the hare and the rabbit; speckled brown fur, long hind legs. Trop. America and Islands. Dăsy̆prōcta, fam. Cavŭĭdæ, ord. Rōdentia.

Agrarian laws. [L. lëges agrāriæ.] (Rom. Hist.) Laws proposed or carried by the plebeians against the patricians, with reference to the distribution of public lands acquired by conquest.

Agreement. (Naut.) The master of a vessel exceeding eighty tons must enter into an $\mathrm{A}$. in a special form with each of his crew carried from a British port.

Agricultural Holdings Act, of 38 and 39 Vict., has for its object the securing to tenants compensation for unexhausted improvements.

Agricultural Returns. A yearly return of the acreage in Great Britain under cultivation, and of the nature of the crops, distinguishing meadowland, orchards, gardens, and woods, supplying also the number of horses, cattle, sheep, and pigs.

Agrimony. [L. agrĭmōnia, properly argĕmōnia.] (Bot.) A. Eupătŏria, ord. Rosāceæ, is a common wild plant, with long spikes of small yellow-scented flowers, and unequally pinnate leaves ; it is much used in " herb teas.

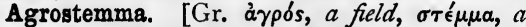
crown.] A gen. of Caryophyllaceæ; Lychnis A. Githago being the well-known corn-cockle.

Agrōstis. [L., Gr. ă $\gamma \rho \omega \sigma \tau \iota s$.$] A gen. of$ grasses, known by the name of Bent grasses, having numerous spec.

Agrypnotics. [Gr. arpvinos, sleepless.] Tending to prevent sleep, e.g. strong tea.
Ague-cake. A tumour arising from enlarged spleen, sometimes following protracted ague. Ague-cheek, Sir Andrew. A meek docile simpleton in Shakespeare's Twelfth Night.

Ahead. (Naut.) - Abeam.

Ahold. (Naut.) An old term for bringing a hip close to a wind and holding it.

Ahriman. In the Zend-Avesta, or sacred books of the Persians, the evil god or principle is called Angrô-Mainyus (spirit of darkness), a word of which Arimanes and Ahriman are the Latin and English forms. This evil god was opposed to Spento-Mainyus (spirit of light), a name for Ahuro-mazdao, or Ormuzd, in Skt. Asuromedhas [Gr. $\mu \hat{\eta} \tau \iota s$, zisdom], the wise spirit, or Supreme and good God; the strife between these two principles being the dualism which characterizes the theology of Zoroaster.

Ahull. (Naut.) 1. The condition of $\cdot$ a vessel with bare poles, and helm a-lee (q.v.). 2. Abandoned and drifting.

Ai. 1. (Aye-aye.) 2. The three-toed sloth (Brădy̆pus trìdacty̆lus); S. America ; ord. Edentäta. 3. Spec. of wild dog (Dăsǐcy̆on Silvestris) ; Guiana, occasionally domesticated by Arecuna Indians.

Aid. [Fr. aide, L.L. adiuda, L. adjŭvo, $I$ help.] Originally a benevolence; afterwards an exaction from a tenant to his lord, in cases of emergency.

Aide-de-Camp. [Fr.] An officer on the personal staff of a general; in the field carrying orders, at other times acting as secretary. 2 . The sovereign also appoints $A$. to herself, who rank as colonels, from amongst distinguished officers.

Aide-toi et le ciel t'aidera. [Fr.] Help thyself and Heaven will help thee. The motto of a French political society, whose influence with the middle classes helped to bring about the Revolution of 1830 .

\section{Aiery, Aire, Airy. (Eyry.)}

Aigrette, Egret. [O.H.G. hiegro, L. aigrōnem, heron, Fr. aigre, aigrette.] 1. Gen. of lesser white heron. 2. (Bot.) I.q. pappus (q.v.) 3. Head-dress of feathers, or plume-like ornament.

Aiguilles. [Fr., L. ăcǐcŭla, a needle.] Sharp, lofty, serrated peaks; e.g. A. Vertes, A. Rouges, Mont Blanc.

Aiguillette. [Fr. dim. of aiguille, L. ăcǐcŭla, a needle.] Shoulder-knot composed of long gold cords with tags, formerly worn on the right shoulder by generals and some staff and cavalry officers, now only by Queen's aides-de-camp.

Ailantus. A tree, native of China, with very long pinnate leaves, naturalized in S. Europe, upon the leaves of which some silkworms feed (A. glandǔlosa). Ord. Simarabaceæ.

Ailettes. [Fr., little wings.] Small leathern armour worn by knights, thirteenth century, behind or at the side of the shoulders, probably both as protection and a mark for followers; seen in brasses, stained windows, etc.

Ailürus. [Gr. athoupos, the wavy-tailed one.] Chitwa, Panda, Wali, a cat-like animal, with rich chestnut and black fur, allied to the 
bears. Thibet and Himalayas. Fam. Flūrǐdæ, ord. Carnivŏra.

Air-chamber. A cavity in pumps, fireengines, and other hydrostatic machines, containing compressed air for keeping up a continuous flow of the water by its elastic force. Called also an Air-vessel.

Air-engine. An engine moved by heated or compressed air.

Air-gun. An instrument for propelling bullets or other missiles by the force of condensed air.

Air martyrs. (Pillar saints ; stylites.)

Air plants. Popular name for orchids when first introduced into England.

Air-pump. 1. An engine for exhausting air from a closed space, or receiver, so as to obtain a more or less perfect vacuum. 2. A pump for removing from the condenser of a steam-engine the condensed steam, the water that has produced the condensation, and any air that may have got into the condenser.

Airt. Direction; the point from which the wind blows. [Cf. Ger. ort, place.]

Air thermometer. (Thermometer.)

Aise. (?) A linen napkin to cover the chalice. Ait, Eyot. [A.S. ey, island.] An islet in a river or lake.

Aitchbone. Properly edgebone of the rump; i.e. presented edgewise, when dressed.

Aix-la-Chapelle, Peace of. 1. A treaty relating to the Spanish Netherlands, made in I668, between Louis XIV. and Carlos II. 2. A second and better-known treaty, between Great Britain, France, Germany, Holland, and Spain, confirming previous treaties, was signed in 1748 .

A Jŏvĕ principium. [L., the beginning (is) trom Fupiter.] Said of a grand opening to a narrative or poem.

Ajutage. [L. adjūto, I assist.] 1. The brass nozzle placed at the end of a tube for regulating the discharge of the water which forms a fountain or jet d'eau. 2. A short tube of a tapering or conical form placed in the side of a reservoir to facilitate the discharge of the water.

-al. Often ends Shropshire names; said to be Cymric $=$ high, e.g. Erc-al.

Al-. At the beginning of a word or name : 1. Often Arabic for the, e.g. Alcoran = the Koran (Alcoran). 2. White, Celtic, as in Aln for al-aon, white river, All-wen, Al-an, All-an, All-en, all meaning white rivers.

Alabarchēs [Gr.], perhaps more properly Arabarches. The chief magistrate of the Jews at Alexandria.

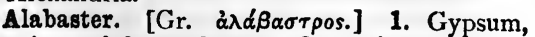
massive sulphate of lime. 2. Anciently, a subtranslucent, yellowish, banded, calcareous stalagmite, like the "Algerian agate," was called A.

A la carte. [Fr.] According to the card. Of meals $=$ as specified in bill of fare.

Aladdin. In the Arabian Nights' Tales, a poor widow's son, who gets a magic lamp and ring, on rubbing either of which, a djin appears ready to work miracles for the rubber, like the ring of Gyges.

\footnotetext{
A la lanterne. [Fr., to the lamppost.]
}

French phrase for execution by Iynch law; a cry of the Revolution.

A la mise en scéne. [Fr.] Lit. according to the getting up of the play.

A la mode. [Fr.] Ascording to the fashion.

Alamoth. [Heb.] Title of Ps. xlvi., and in

I Chron. xv. 20. Virgins, probably $=$ "for altos or sopranos" (Speaker's Commentary).

Al Araf. [Ar. arafa, to distinguish.] The Mohammedan Limbus, or Limbo, for spirits who are excluded both from paradise and from hell.

Alarm-post. Rendezvous for troops on the occurrence of any sudden danger, announced by bugle-call or beat of drum.

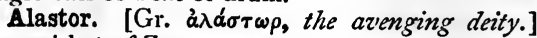
An epithet of Zeus.

\section{A lătěre. (Legate.)}

Alb. [L. albus, white.] (Eccl.) A linen vestment, fitting closely to the body, and tied by a girdle.

\section{Albany. (Albyn.)}

Albārium ŏpus. [L.] In Roman architecture. probably a superior kind of stucco.

Albāta. One of the many white [L. albus] metals made at Birmingham.

Albāti. [L.] Christian hermits, who came down from the Alps, A.D. 1399, to Italy, dressed in white, living on the highways, sorrowing for sins of the age ; dispersed by Boniface IX.

Albigenses. Certain religionists, numerous and influential, in and near Alby, S. France, twelfth century, protesting against Roman corruptions, but charged with Paulicianism.

Albino. 1. White negro of the African coast ; so named by the Portuguese voyagers. And 2, generally, persons having white skin and hair and redness of eyes, from absence of pigment cells. The same thing is found in cats, rabbits, birds, and elephants. Albinism, the state of an A.

Albion. [L. albus, white, or some Celtic equivalent.] England, said to be so named from the white cliffs seen from the French coast.

Albion, Now. The name given by Sir F. Drake (1 578 ) to California.

Albis, Dominica in. [L., the Lord's day in white (robes).] A name for Low Sunday, or the Sunday following Easter Day, because then the persons baptized on Easter Eve laid aside their white garments. (Quasimodo.)

Albite. [L. albus, white.] Soda-felspar.

Albūgo. [L., whiteness.] A dense whitening of the cornea of the eye, generally resulting from an inflammatory attack.

Album. [L.] In Rome, an official white tablet, on which the Pontifex Maximus recorded the events of the year; or prætors wrote edicts ; or senators' names were enrolled; hence its modern meaning, a blank book for inscriptions, photographs, etc.

Album calcŭlum addĕre. [L.] To put (into the urn) a white stone; to approve.

Album Græoum. [L., Greek white.] The white fæces of dogs, chiefly bone-earth, used in tanning.

Albümen. [L., white of egg.] 1. One of the protein [Gr. $\pi \rho \hat{\omega} \tau o s$, first] or elementary sub. 
stances of the animal body, represented by white of egg, serum in the blood, etc. ; others are fibrin, represented by muscular tissue; casein is the basis of cheese [L. cāsěus] ; legumin is in the seeds of all leguminous plants. 2. In Plants, Pcrisperm, or Endosperm [Gr. $\pi \in \rho l$, around,

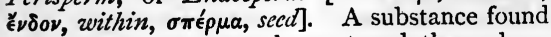
in some seeds between the coat and the embryo which it is to nourish; e.g. flour of corn.

Alburnum. [L.] Sap-wood, immediately below the bark; opposed to heart-wood, or dürāmen [L., hardiness].

Albus liber. [L.] Title of an old compilation of the laws and customs of the city of London.

Albyn, Albin. [Alp, or alb, which seems to be Celtic for high; ynys, Cymric for island.] The Highlands of Scotland, or Scotland generally. Albany is an old name for Scotland.

Alca. [L. L. auca, goose, i.e. ăvǐca, from ăvis ; so It. oca, Fr. oie.] Auk, gren. of marine webfooted birds; wings very short, used for swimming under water. N. Temp. and Arctic zones. Fam. Alcŭdæ, ord. Ansĕres.

Alcabala. (Hist.) A heavy tax on sales of property, imposed in Spain and the Spanish colonies, and payable as often as the land was sold.

Alcaio verse. A metre, consisting of a stanza of four lines attributed to the Greek poet Alcæus.

Alcaide, Alcalde. [Sp., Ar, káda, head.] Military governor of a fortress or gaol. (Alguazil.)

Alcarraza. [Sp., from Ar. alcurrâr, an earthen jar.] A porous earthenware vessel, used for cooling water by evaporation.

Alcêdinĭdæ. (Alcēdo.) Kingfishers. Fam, of birds universally distributed, having only one American gen. Ceryle, ord. Pícārǐæ.

Alcēdo. [L., kingfisher.] Alcy̆on, Halcy̆on; gen. of Alcēdinnĭdæ $(q . v$.$) .$

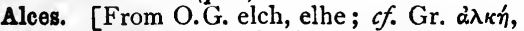
an elk, and perhaps $\alpha \lambda \kappa h$, sirength.] Elk, moose; largest of deer kind, dark brown. N. of Europe, Africa, and America. Gen. and sjec. Alces, fam. Cervǐdæ, ord. Ungŭlāta.

Alceste. Hero of Molière's Le Misanthrope; type of stern unconventional uprightness.

Alchemy. [A word compounded of the Ar. defin. art. al, and Gr. $\chi \eta \mu \in i \alpha$.$] The supposed$ art of the land of Chemi, or Ham, its object being the production of the precious metals, into which it was thought that the lower metals might be converted.

Alcinous. [Gr. 'A $\lambda \kappa$ кเঠos.] In the Odyssey, the King of the Phreacians.

Alcluyd. Old name of Dumbarton. [(?) Alt, sieep place, cluyd = Clyde; cf. clith, Gaelic, strong.]

Alcmanian metres. Those introduced by Alcman of Sparta, lyrist, the earliest Greek poet of love-song, seventh century B.C. ; especially the iambic trimeter brachycatalectic, or iambic of five feet.

Alco. A name for some varieties of shepherd's dog. Peru and Mexico.
Alcŏran. [Ar., the book̉.] The Mohammedan scriptures, which are said to have been dictated to Mohammed by the angel Gabriel.

Alcornoque bark. An astringent bark, generally cork, used in tanning.

Alcove. [Ar. el kauf, a tent, Sp. alcoba.] A recess, in a bedroom, for the bed ; and so, anv recess, for books, etc. ; a covered garden seat.

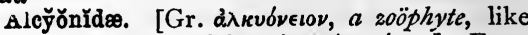

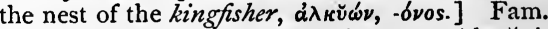
of Alcy̌ŏnārĭa, or Asteroid Polypes, as Alcy̆ŏnium, "Dead men's fingers."

Aldehyde, i.e. alcohol dehydrogenatus, deprized of its hydrogen, partly. A pungent volatile liquid, consisting of two atoms of carbon, four of hydrogen, and one of oxygen; i.e. alcohominus two atoms of hydrogen.-Brande and Cox, Dictionary of Art and Science.

Alderman. [A.S. ealdorman, elder-man.] The original title of the officer afterwards called earl; also of the chief magistrates of minor districts; now applied to the municipal officers in a borough next in order to the mayor.

Aldine editions. Editions of the classics publ lished by the three Manutii, the eldest of whon, Aldo-Manuzio, set up a press at Venice in $\mathbf{1 4 9 0 .}$ (Elzevirs.)

Ale. A rustic merry meeting; as Churchale, Whitsun-ale. (Church-ales.)

Alea belli. [L.] Lit. the hazard of war.

Ale-conner, or -kenner, taster, -founder. Gustātor cervisǐæ, taster of beer; one who "kens" good ale ; in very ancient times chosen in each manor, and sworn to examine the purity and price of ale, and to present defaulters.

Alectryomanoy. Divination [Gr. Mavreía] by means of a $\operatorname{cock}[\dot{\alpha} \lambda \epsilon \kappa \tau \rho \tilde{\omega} \omega \nu]$. Grains of corn being placed upon letters of the alphabet, prophetic words were formed out of the letters underlying the grains which he picked up.

A-lee. (Naut:) The position of the helm, when the tiller is put down to leeward, i.e. away from the wind.

Alegar. Vinegar made from sour beer. (A catachrestic word ; of Peterloo, q.v)

Alemanni. (?) All men. Germans, probably a confederacy of different tribes, within the limits of the Rhine, Main, and Danube ; first heard of A.D. 214 , in Caracalla's treacherous massacre.

Alembic. [Ar. al, and ambeeg, a corrupt form of Gr. $\alpha_{\mu} \beta \iota \xi, a c u p$.] A form of still, now obsolete.

Alexandrian Codex. (Codex.)

Alexandrian school. A school for learning of all kinds, instituted at Alexandria by Ptolemy, son of Lagos. It became especially celebrated for its grammarians and mathematicians.

Alexandrine. An Eng. iambic of twelve syll., e.g. the last line of the Spenserian stanza, in imitation of the French heroic verse, first employed in a French translation of a Latin poem, The Alexandriad; or (?) in an original work on A. the Great.-English Cyclopadia, i. 195 .

Alexipharmic $=$ antidote. $[\mathrm{Gr} . \grave{a} \lambda \epsilon \xi \iota \phi a ́ \rho \mu \alpha \kappa o s$,

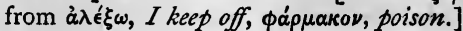


Alexitërics, properly Alexeterics. [Gr, $\alpha \dot{\lambda} \in \xi \eta$ th́pıs, able to keep off.] Preservatives against poison.

Al fresco. [It.] In the open air.

Algæ. [L. alga, seaweed.] (Bot.) A tribe of Cryptogams, comprehending seaweeds and fresh-water submersed spec.' of similar habits, besides some terrestrial spec.

Algaroba. [Sp., Ar. kharoób.] The bean tree of the Mediterranean, with sweet pods (Cěrătōnia sĭlĭqua); called also St. Fohn's Bread, as if it were the "locust" of Matt. iii. The pods are also used in tanning.

Algaroth, Powder of. An oxychloride of antimony, discovered by Algarotti of Verona.

Algebra. [Ar. al jebr'e al mokābalah, restoration and reduction.] The science of general numerical operations and results; a generalized arithmetic ; whereas in arithmetic the operations are performed on, and the results are expressed in, specific numbers $(\mathbf{r}, 2,3$, etc. $)$; in $A$. the operations are performed on, and the results are expressed in, general numbers $(a, b, c$, etc.) connected by the symbols $(t,-$, etc.) of elementary operations (addition, subtraction, etc.).

Algor. [L., coldness.] (Med.) A sudden chill ; Rigor, if attended with shivering.

Algorithm. [Corr. from Ar. al khowārezmī ; originally the tables used in trigonometry, which, in the thirteenth century, came to mean Arithmetic in Arabic numerals : see Littré, Supplement.] The Arabic notation of numbers; the science of calculation by nine figures and zero.

Alguazil. A Spanish officer answering to the English bailiff. The name is Arabic, as is that of Alcalde, or the Kadi, the magistrate or judge.

Alhambra. [Ar. al hamra, the red castle.] The palace of the Moorish kings in Granada, begun 1248, completed 1313. Resigned to Ferdinand and Isabella by Boabdil, I492.

Alias. [L.] Otherwise.

Ali Baba. In the Arabian Nights' Tales, a man who enters the cave of the Forty Thieves by means of the magic word Sesame.

safras; Saxifrage.)

Alibi. [L., elsewhere.] Not near the scene of a crime at the time of committal.

Alicant, or Vino tinto, from its colour. Wine of Alicante, in Spain.

Alidad. [L.L. alidada, Ar. al, the, hadât, rule.] The index of an instrument which is capable of an angular motion; rarely used, except of the line of sights of an azimuth compass.

Aliēnâ optîmum frui insāniâ. [L.] It is an excellent thing to profit by another's error.

Alienation in mortmain. The making over of lands, tenements, etc., to a religious or other corporate body. (Mortmain.)

Aliēnā vīèrĕ quādrā. [L.] To live from another's table; i.e. as a parasite, sponge.-Juvenal.

Alien priories. (Hist.) Inferior monasteries in England, belonging to foreign religious houses.

Alignment. [Fr. aligner, to dress in line, L. linea.] (Mil.) Manœuvre by which the same relative parts of any body of troops are brought into the same line.
Alimony. [L. ălĭmōnium, sustenance, from ălo, I nourish.] Allowance made to a wife out of her husband's estate during or after a matrimonial suit.

Aliped. [L, āla, wing, pes, pědis, foot.] Wingfooted, as the bat.

Alǐquandŏ bŏnus dormītăt Hŏmērus. [L.] Lit. now and then our friend Homer goes to sleep; i.e. there are dull passages in the best works. Horace.

Alĭquot part. [L. ălĭquot, some, several.] A part of a whole, expressible by a fraction having unity for its numerator; thus Is. $8 d$. is an aliquot part of $£ \mathrm{I}$, viz. 1 .

Alisma plantāgo. [Gr. \& $\lambda_{\lambda} \iota \mu \mu$.] (Bot.) Waterplantain ; once thought a cure for hydrophobia ; the gen. A. being typical of ord. Alismacex.

Alizarine. The chief colouring agent in madder [Sp. alizari]; now obtained from coal-tar.

Alkahest. An imaginary universal solvent of the alchemists.

Alkali. [Ar. al qali, kelp.] Any caustic base which changes red litmus to blue. Fixed A., potash and soda, volatile A., ammonia. (Caustic.)

Alkalimětry, [Alkali, and Gr. $\mu \in \tau \rho \epsilon ́ \omega, I$ measure.] The art of measuring the amount of pure alkali contained in commercial potash or soda.

Alkaloids. So called from their power of forming definite salts with the acids; substances remarkably affecting the human system; having alkaline properties in a low degree ; mostly vegetable, as morphia, strychnine, nicotine, caffeine; but there are animal A. also, as urea, kreatine.

Alkanet [Fr. arcanète], or Bugloss. (Anchūsa.) Dyer's $A$., the root of which yields the fine red dye for colouring oils, wax, etc.

Alkanna, or Al-henna. (Henna.)

Alkermes. A cordial distilled from bay leaves and various spices, and flavoured with syrup of kermes and orange-flower water.

Alla breve. [It.] In Mus., = the notes individually to be made shorter, i.e. the pace to be quicker than usual. It is a kind of common time marked $\&$ used in church music, each bar being $=$ a breve $=2$ semibreves $=4$ minims, but the minims being played as if they were crotchets. The division of the bar into two parts each = two minims is called alla cappella time. But the use of the term is not always clear.

Allah. [1.r.] God: as Allah Akbar, God is great; akin to Heb. El.

Alla prima. A method of painting in which the colours are applied all at once [It.] to the canvas, without retouching.

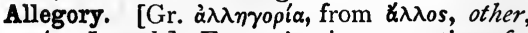

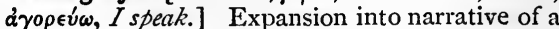
sense-representation of some moral or spiritual truth, of which the leading idea would be a Metaphor; as Pilgrim's Progress; Parable being a kind of A., but more concise and didactic ; Fable, again, differing as admitting the nonnatural, e.g. trees and animals talking.

Allegro. [It., gay, cheerful.] (Mus.) A 
quick movement. Allegretto, dim. of A., not quite so quick. A. assai, fast enough, quicker than A. A. con brio, with spirit; con fuoco, with fire.

Allemande, i.e. German dance. Introduced from Alsace, temp. Louis XIV. ; a kind of slow, graceful walt $z$, the arms entwined and detached in the different steps.

Allerion. [L.L. ālārio,-nem, from āla, $a$ wing.] (Her.) An eagle displayed, without beak or feet.

All-fours. In cards, a game of chance in which four points may be made : (I) by highest trump; (2) by lowest; (3) by knave of trumps ; (4) by majority of pips from tricks taken.

All-hallows, All-hallowmas, Hallowmas. Old English names for All Saints' Day, November I.

Allice. [Ger. alose, else, ils ; $c f$. L. ălausa, ălōsa, $a$ fish found in the Moselle (?) ; probably a Gallic word.] The larger (two feet long) of the shads, the other being the twaite. Like herring, but larger. British waters. Gen. Clŭpěa, fam. Clŭpěĭdæ urd. Phȳsostŏmi, subclass Tělěostěi.

Alliciency. [L. allicio, I allure.] The power of attraction, e.g. in a magnet.

Alligation. [L. alligatio, -nem, $a$ bending or tying to.] (Arith.) A rule by which the value of mixtures is found from the known values and quantities of the component parts.

Alligator apple. (Cnstard apple.)

Alligator pear. (Avocado.)

Alligator water. The brackish, white, and muddy water at the mouths of tropical rivers.

Alliteration. [L. ad, to, literra, a letter.] The recurrence of the same letter, generally at the beginning of words, for rhetorical effect; $e . g$. in Ancient Mariner, "The fair breeze blew, the white foam flew." Labōräre est ōrāre $=$ Work is worship. (Assonance.)

Alliterative poems. Poems in metres, the rhythm of which depends on the recurrence of sounds in the initial letters of words. To this class belong the old English poems, such as Piers Floughman's Vision. The practice was maintained as late as the sixteenth century.

Allium. [L.] (Bot.) A gen. of bulbous plants, ord. Liliaceæ, to which belong onion, leek, shallot, garlic, chive.

Allocate. To set apart, as if to a particular place [L. ad lŏcum]. Generally applied to sums of money, fees, " allowances."

Allocatur [L., it is allowed] = the amount of an attorney's claim, after the costs have been taxed. (Taxing-masters.)

Allochroite. [Gr. ă $\lambda \lambda$ os, other, xposá, colour.] A variety of garnet, with iron, exhibiting a variety of colours. (Garnet.)

Allocution. [L. allǒcūtio, -nem.] 1. An address, especially of a Roman imperator to his army, or of the pope to the Sacred College. 2. Bidding Prayer (q.v.).

Allodium, Allodial tenure. Land held by a man in his own right, and free from all feudal burden : opposed to fee, fief, feud. Some connect with O.N. odal, Dan. Sw. odel, an estate, and Gothic alldha, odhol, ancient inheritance.
Others with A.S. leod, the people. Blackstone gives all, whole, and odh. Ger. od, property. Wollaston, that of which a man has the all, or all-hood. (Frank-aleu.)

Allonge. [Fr. allonger, to lengthen.] 1. (Leg.) Slip attached to a bill of exchange for supernumerary endorsements, if there is no more room on the bill. 2. To make a "lunge," in fencing.

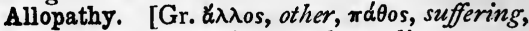
affection.] A name given to the ordinary practice by homœopathists. (Homœopathy.)

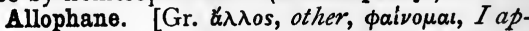
pear.] A mineral, one of the aluminous silicates, of which clay is another; the proportion of water large; pale blue, green, brown; changed in appearance before the blowpipe.

Allotment. (Naut.) That portion of the pay of a sailor, or marine, on foreign service, allotted monthly to his wife and family.

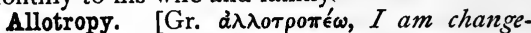
able.] (Chem.) The same element sometimes exists, no extraneous substance being added, in various forms, which exhibit different properties. So, ozone is an allotropic form of oxygen. Phosphorus is a remarkable example; sulphur also.

Alloy. A combination of two or more metals, except when one of them is mercury. Originally such debasement of metal as is according to law [Fr. à loi]

Allspice, or Jamaica pepper. The berry of a handsome tree, Pimenta offícīnālis; S. America and W. Indies; ord. Myrtaceæ.

All the Talents. The Fox and Grenville Coalition Ministry, formed on the death of $\mathrm{Mr}$. Pitt, January, I806.

All-to brake. Judg. ix. (To-brake.)

Allumette. [Fr. allumer, to kindle.] A match.

Alluvion. [L. adlŭvio, -nem, flood, from ad, to, luo, lăvo, I wash.] Land added to an estate by alluvial deposit from sea or stream.

Allŭvium. [Neut. of L. allŭvius, alluvial.] Earth, etc., brought down by rivers and floods, and deposited upon land not permanently submerged; e.g. many river-plains, meadow-lands.

Allux, Allex. (Hallux.)

Allworthy, Mr. In Fielding's Tom fones; type of modest worth and benevolence.

Allyl. A hypothetical substance, supposed to exist in oil of garlic [L. allium].

Almack's. A suite of rooms, in King Street, St. James's, London; so called as having been built by a Scotchman named Macall, who transposed his name. Balls of a very exclusive character were held in these rooms, which are now known as Willis's.

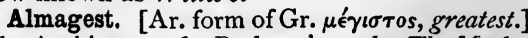
The Arabic name for Ptolemy's work, The Mathematical Construction of the Heavens, which contains a complete account of the state of astronomy in his time-the first half of the second century-and from which is drawn a large part of our knowledge of ancient astronomy.

Alma Mater. [L.] Fostering mother; generally applied to one's university or school.

Almanac. [Ar. al manack, the diary.] A 
calendar wherein are noted down the days, weeks, and months of the year; the most remarkable phenomena of the heavenly bodies, etc. In the Nautical $A$. are given the daily positions of the sun, moon, planets, and certain stars, the lunar distances of certain stars for every third hour of Greenwich mean time, and other information of a like kind very useful to travellers by land and sea.

Almanach de Gotha. Published yearly at Gotha since 1764 , and giving a large amount of information upon the principal affairs, political and statistical, of every civilized country.

Almandine. Red transparent varieties of iron and garnet $(q . v$.$) .$

Alme, Al-mai. [Ar. âlmet, instructed, alam, to know.] Singing girls of Egypt, who live in bands, and attend marriages, funerals, etc., singing pathetic ballads; something like the Roman præfícæ. (A mbubaiæ.)

Almery. [Fr. armoire, L. armārium, $a$ cupboard.] An older form of the word ambry (q.v.) or aumbry.

\section{Almohades. (Almoravides.)}

Al molino, ed alla sposa, sempre mancha qualche cosa. [Sp.] $A$ mill and a wife always want something.

Almonry. A room in which are kept the alms gathered for the poor. In many monasteries the almonries had special endowments. [Fr. aumône,

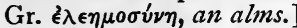

Almoravides. An Arab dynasty of N.W. Africa, founded in the eleventh century. They overthrew the Almohades in Africa and Spain in the following century.

Almuce. (Amice.)

Almug, I Kings x.; Algum, 2 Chron. ii. [? A corr. of Indian name valguka.] Probably red sandalwood (Pterocarpus santalinus).

Alnager. [L. ulna, an ell.] (Eng. Hist.) A sworn officer, whose duty it was to examine into the assize of cloth and collect the alnage duty on cloths sold.

Alnaschar. A poor delf-seller in the Arabian Nights' Tales, whose dream of wealth vanishes on his smashing a mirror, which is really his basket kicked over in waking.

\section{Aloadæ. (Mars.)}

Aloes. The bitter inspissated juice of several species of Aloe, succulent plants with fleshy, prickly margined leaves, and erect spikes of red or yellow flowers. The lign aloes [L. lignum aloës] of Scripture (Numb. xxiv. ; Ps. xlv.) is the resinous wood of Aquilaria agallocha, a drug once generally valued for use as incense.

Alogians. [Gr. à neg., $\Lambda$ byos, the WoRD.] Heretics, second century, who denied the Divine Logos, or Word ; they attributed St. John's Gospel to Cerinthus.

\section{Alogon. (Neat.)}

\section{Alonsine. (Alphonsine Tables.)}

Alp. Any lofty mountain, particularly the mountains of Switzerland. Also, a mountain pasture. The word is found in Albion, Albyn, Albania, etc. (Southern Alps.)

Alpaca. A stuff made of the wool of the alpaca, mixed with silk or cotton. (Auchenia.)
Alpenstock. [Ger.] A staff used by mountaineers.

Alphonsine Tables. Tables of the motions of the sun, moon, and planets, in A.D. 1253 and subsequent years, by Alphonso, King of Castile.

Alquifou. [Fr. alquifoux.] A lead ore, used for green varnish on pottery.

Al Rakim. In the legend of the Seven Sleepers, a dog who has care of all letters and correspondence.

Al root. A red dye-stuff used in India.

Alsatia. Once a name for Whitefriars, an asylum for debtors and those who had broken the law.

Al-sirat. [Ar.] The path, narrow as a sword-edge, over the abyss of hell, to the Mohammedan paradise.

Altaic. [From Altai Mountains in N. Asia.] Generic name for the Tungusic, Mongolic, Turkic, and Samoyedic groups of agglutinative languages.

Altarage. [L. obventio altāris.] Profits arising to the parish priest, for services at the altar. (Obvention.)

Altar tombs. Tombs in churches, which in shape resemble an altar.

Al-taschith. Title of Pss. lvii., lviii., lix., and of Ps. lxxv., which is similar in spirit, i.e. destroy not; alluding to David's answer to Abishai (I Sam. xxvi. 9).

Alterative. Medicine modifying a morbid condition by gradual change.

Alter ĕgo. [L., another 1.] A second self. Alter idem [L.], a second same one; an intimate, true friend.

Alternate. [L. alternātim.] In Bot., placed on opposite sides of an axis, but on different levels, as the leaves of laurel, etc. ; or between other bodies of the same whorl, or of different whorls, as the stamens of an umbellifer, between the petals, and A. with them. A. leaves are distinguished from opposite, which are set on the same level ; e.g. jessamine, which is, therefore, an adversifoliate plant.

Alternate angles, etc., lie on opposite sides of the same straight line, as in Euclid, i. 27.

Alternate generation. That process of reproduction in which one impregnation supplies two or more generations, called Nursing generations. Reproduction by impregnation then recurs. Probably it is an internal budding or fission. Most striking in Hydrōzōa, but Entōzōa and Molluscoids supply instances.

Althæa. [Gr. à $\lambda \theta a i ́ \alpha$, marsh mallowe, á $\lambda \theta \omega, l$ heal.] (Bot.) A gen. of plants, ord. Malvaceæ; including marsh mallow, hollyhock.

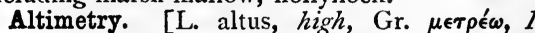
measure.] The art of measuring heights by instruments.

Altis. [Gr.] The sacred enclosure of Zeus at Olympia.

Altitude and azimuth instrument, or Altazimuth instrument. (Azimuth.)

Altitude of a heavenly body. [L. altǐtūdo, height.] The angular distance of its centre above the horizon measured on a vertical circlc.

Alto-relievo. (Mezzo-relievo.) 
Altruism. The doing to another [It. altrui] as one would be done by ; opposed to egoism. The term for the so-called religious system adopted by Comte. (Comtism; Positivism.)

Alŭla. [L.] Winglet, dim. of āla, zving. (Wing.)

Alum. [L. ălümen.] Sulphate of alumina, combined with sulphate of potash or some other alkali. Roman $A$. is extracted from volcanic rocks near Naples. $A$. ore, an aluminous slate, containing sulphide of iron.

Alumina. Sesquioxide of aluminium, the chief constituent of clays.

Aluminium. [L. ălūmen, alıım.] (Min.) A bluish-white metal obtained from alumina, remarkable for its lightness. $A$. bronze is a gold-coloured alloy of copper and aluminium.

Alumnus. [L.] Pupil, nursling.

Alure. [L.L. allorium.] (Arch.) A gangway or passage.

Alūta. [L.] Leather softened by means of alum.

Alva-marina. Dried seaweed [L. alga mărīna], used for stuffing mattresses.

Alveolar. [L. alveŏlus, dim. of alveus, channel.] Relating to sounds formed by bringing the side and tip of the tongue near or up to the upper gums before articulating the consonant (q.v.) or vowel (q.v.).

Alveolar processes of the maxillary bones. Those from which the teeth spring.

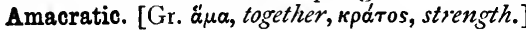
Concentrating actinic rays to a focus; also termed amasthenic [ása, together, $\sigma \theta$ évos, strensth].

Amadis. The name of several heroes of chivalric poetry, the chief of whom was A. the Lion, Knight of Gaula, i.e. Wales.

Amadou. German tinder, prepared from a fungus of the cherry, ash, etc., Bōlētūs ignīārius. [Amadouer, to coax ; cf. esca, L. and It., meaning both bait and touchwood.]

Amalfian Code. A collection of marine laws, compiled by the people of Amalfi, in Italy, about the eleventh century. (Oleron, Laws of; Wisby, Ordinances of.)

Amalgam. [Gr. $\mu a ́ \lambda \alpha \gamma \mu a$, a thing softened.] A combination of metals, into which mercury generally enters, rubbed together while in a powdery state, afterwards becoming hard, generally used for filling up the cavities of decayed teeth, and for purposes of reparr.

Amaltheia, Horn of. [Gr. ả $\mu a ́ \lambda \theta \in i a$.$] The$ horn of the goat which suckled Zeus (IEgis), and from which flowed Nectar. Hence, a horn of plenty, or cornucopiæ.

Amantium İræ ămöris integrātio est. [L.] Lovers' quarrels are the renewal of love. - Terence. Amănnensis. [L.] Originally a slave copyist ; $\bar{a}$ mănu, from, or by means of, the hand; as $\bar{a}$ pědǐbus, a footman; ab ěpistŏlis, a sccretary, etc.

Amaranth. 1. (Poet.) [Gr. áuápavtos, un-

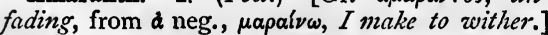
2. (Bot.) A gen. (Amaranthus) to which belong love-lies-bleeding, cockscomb, etc.

Amaritude. [L. amārĭtūdo.] Bitterness.

Amăryllīdaceæ (Ămăryllis). (Bot.) An ord. of plants, mostly bulbous, and with poisonous pro- perties; to which belong narcissus, daffodil, snowdrop, amaryllis, Guernsey lily, agave, etc.

Amăryllis. Proper name of women in Latin poetry ; meton., a rustic lass.

Amassette. [Fr.] A horn instrument used to collect [Fr. amasser] a painter's colours on the stone during the process of grinding.

Amasthenic. (Amacratic.)

Amate. To make, or to be, stupid, senseless. [Cf. Ger. matt and Fr. mat, dull, languid; and It. matto, mad.]

Amati. Meton. for a violin. In Cremona, seventeenth century, the Amati family were famous makers of violins; even surpassed by one of their pupils, Straduarius, also of Cremona.

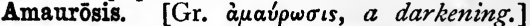
Blindness, arising not from injury, but from a paralysis of the retina.

Amazonian. As applied to fighting women, extraordinarily strong; from the Amāzons.

Amazons $=$ Sisters. $[\mathrm{Gr} . \dot{\alpha} \mu \alpha \zeta \dot{\omega} \nu$ being one nourished at the same breast; cf. $\dot{\alpha} \delta \in \lambda \phi \delta s$, one from the same womb.] The legend of Scythian women, who removed the right breast that they might use the bow, arose from the error of $\dot{\alpha}$ being considered privative instead of copulative. Amazon stone. Green felspar from Siberia.

Ambarvālia. [L., from ambire arva, to go round the fields.] Religious feasts of the Romans, in which the victims were led round the fields. They were celebrated by the twelve Arval Brothers (Arvāles Fratres), at the end of May.

Ambassador. [Fr. ambassadeur.] A foreign minister of the first grade, representing personally the dignity of his sovereign, and communicating with the sovereign or head to whom he is sent. England sends $A$. to France, Russia, Austria, the German Empire, and the Sultan.

Ambassy. [Hind.] A State howdah (q.v.), with a canopy.

Amber. [Ar. anb'r, introduced at the time of the Crusades.] A fossil resin, washed by the Baltic out of a Tertiary lignite formed of Pinus sucč̆nǐfĕra. Also found on east coast of England, between Southwold and Aldeburgh.

Ambergris. [Fr. ambre gris, grey amber.] Found on the sea, or shore, of warm climates chiefly; a fatty substance, morbid (?), in the intestines of the sperm whale ; used as a perfume, and to flavour wine.

Ambidextrous. [L. ambo, both, dextra, the right hand.] 1. Using the left hand as usefully as the right. 2. Shuffling, untrustworthy, equally ready to take either of two sides.

Ambisexual words. [L. ambo, both, sexus, $a$ sex.] Equally applicable to either sex; so damsel [O.Fr. damoisel, L. dŏminnicellus], girl, man, and L. hŏmo, were all of them originally both masc. and fem.

Ambritus. [L.] Of a tone, in Plain song, is its compass; the ascent and decent between its extreme limits.

$\Delta$ mbo. [L., Gr. $\gamma_{\mu \beta} \beta \omega \nu$.] A kind of pulpit in the choir, from which the choir sang, Epistie and Gospel were read, and sometimes sermons preached.

Ambreada. [Fr. ambréade.] Artificial amber 
Ambrŏsia. [Gr., immortal.] The food of the Olympian gods, which preserves them from death. Called by the Hindus Amrita. (Nectar.)

Ambrosian Office. One partly composed, partly compiled, by St. Ambrose, at the end of the fourth century; it withstood all attempts to substitute the Roman order; confirmed by Alexander VI., I497.

Ambrosin. Early Milanese coin, with figure of St. Ambrose on horseback.

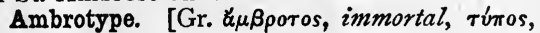
type.] A photographic picture on glass, the lights of which are in silver, and the shades formed by a dark background seen through the glass.

Ambry, Almery, Aumery, Aumbry. [Fr. armoire, L. armārium, a closet for, L. arma, utensils.] 1. A niche or cupboard near an altar, for utensils belonging thereto. 2. A larger closet for charters, vestments, etc.

Ambübaim. [L.] Syrian singing women, who performed in public at Rome.

Ambulance. [Fr.] Hospital waggon following troops in the field. Hospitals attached to an army, with their staff of surgeons, etc., have lately been called Ambulances.

Ambulance classes. Formed in connexion with the Ambulance Department of the Order of St. John of Jerusalem, in England ; to teach so much of anatomy and medicine as may serve to give first aid to the sick and injured-the apparently drowned, poisoned, hung, suffocated, etc. - pending the arrival of a doctor.

Amedians. An Italian congregation of the fifteenth century, united by Pius $V$. with the Cistercians. They are also called Amis de Dieu (Amedieu), Friends of God.

\section{Ameer, Amir. (Emir.)}

Amelia, from which character Fielding's novel is named, = a tender and true wife.

Amen. [Heb.] So be it ; verily.

Amende honorable. [Fr.] An open, unreserved acknowledgment of error; formerly, in France, a confession of offences against some laws of order or morality, made by the criminal, kneeling, in open court ; sometimes in his shirt, with torch in hand, and rope round the neck.

Amenity. [L. ămœnĭtātem.] Pleasantness ; amenities often ironical for bitter, abusive remarks.

A mensā et thŏro. [L., from board and bed.] A legal separation; husband and wife no longer living together, but the marriage tie remaining.

Amentācěæ. [L. āmentum, a thong.] (Bot.) Catkin-bearing tribe, a nat. ord. ; willow, alder, white birch, etc., are genera.

Amenthes, Amenti. (Osiris.)

Amentia. [L., folly, madness.] As now applied, is = congenital imbecility. (Dementia.)

Amercement, Amerciament. A fine imposed by a court of justice, the offender being at the mercy [Fr. mercie] of the king or other lord. Merces = penalty, or a fine as an alternative punishment, being a mercy. Amerce, to punish by fine (Deut. xxii.).

American organ. A musical instrument, the chief characteristic of which is that the air is sucked through the reeds into the bellows, not blown from bellows through reeds as in a harmonium.

A merveille. [Fr.] To perfection.

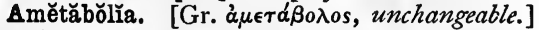
In wingless insects (Aptěra), absence of observable metamorphosis (q.v.).

Amethyst. [Gr. ảué $\theta v \sigma \tau o s$, not drunken, as supposed to guard the wearer against drunkenness.] 1. A purple variety of rock-crystal.

2. Oriental amethyst, purplish sapphire.

Amhario language. (Semitic.)

Amianthus. [Gr. duíavros, undefiled.] Moun. tain flax, a delicate kind of asbestos (q.v.); sometimes woven into cloth; easily cleansed by fire, if soiled.

Amice, Amictus, Amicia, Almutium, Almnce, Aumusse. [L. ămīcio, I clothe.] A square linen collar worn over the shoulders and neck by priests in the early Churcl. The "grey amice" is a cape of fur, now sometimes worn over the arm.

Amīus cürìæ. [L., a friend of the court.] A member of the bar, not retained in the case, who makes a suggestion for the benefit of the court.

Amidine. The soluble part of starch.

Amidships. 1 The centre point of the line of a ship's greatest length or breadth. 2. The centre part of a ship.

Amiens, Peace of. A peace made between England and France, I802, leaving France practically paramount on the Continent, and tending to the exaltation of Napoleon, who now became consul for life.

Amis de Dieu. (Amedians.)

Ammâh. [Heb.] A Jewish measure of length, from the elbow to the end of the middle finger; a cubit.

Ammergau Play. At A., a village in the extreme S. of Bavaria, a dramatic representation of the Crucifixion is given once in every ter. years. One of the very few remaining examples of the mysteries (q.v.), once the only kind of dramatic performance, and so popular from the eleventh century to the end of the fourteenth century.

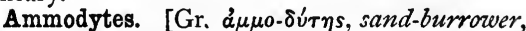
a kind of serpent.] (Zool.) Sand-eels, sandlaunces ; small, silvery, eel-like fishes; the latter spec. is the smaller. Fam. Öphĭdŭdæ, ord. Annăcanthĭni, sub-class Tělěostěi.

Ammonia, Volatile alkali, Spirits of harts horn. (First procured from sal ammoniac.) A gaseous alkali, the oxide of a hypothetical metal, ammonium. A. is a compound of one of nitrogen and three of hydrogen ; obtained in this country chiefly from pit-coal and refuse animal substances,-hence the word hartshorn; and $A$. because obtained from camels' dung burnt near the temple of Jupiter Ammon.

Ammoniac, Sal. (First made, it is said, from camels' dung, near the temple of Jupiter Ammon.) Chloride of ammonium. Ammoniac gum, a resinous gum from Persia, used in medicine.

Ammonites. (Geol.) Fossil molluscs, cephalo- 
podous, allied to the nautilus; in shape like the curved horn of Jupiter Ammon; characteristic of the Trias (of Alps), Lias, and Oolite.

Ammonium. (For derıv, vide Ammonia.) A quasi-metal, consisting of four equivalents of hydrogen and one of nitrogen; not yet obtained by itself, but known in an amalgam with mercury.

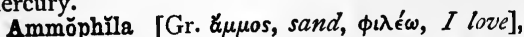
or Arundo Arēnāria. 1. Sea-reed, sand-reed-. the Marum, Marrum, of English and Scotch laws-valuable as fixing shifting sand. 2. (Entom.) Sand-wasps.

Amnesty. [Gr. ¿ $\mu \nu \eta \sigma \tau i \alpha, a$ forgetting.] A pardon of political offences, e.g. at the Restoration; or, as part of a treaty, of offences committed in war.

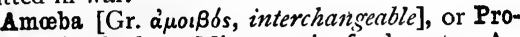
teus animalcule. Microscopic fresh-water A., consisting of a living, structureless, albuminous substance (sarcode, protoplasm), of no particular shape, but protruding any part as a pseudŏpŏdion, to serve as a hand or a foot, and extemporizing any part as a mouth and digestive cavity. Subkingd. Prōtōzōa.

Amcbean ode. [Gr. ámoเßaîs, alternate.] One sung by two persons in alternate strains, e.g. Virgil, $E c l$. i., iii., etc.

Amömum. [L., $\mathrm{Gr} \not \mu \omega \mu o \nu]$ (Bot.) A gen of plants, ord. Zingiberaceæ, yielding aromatic seeds, as grains of paradise, cardamom : mostly tropical.

Amorphous rocks and minerals. (Geol.) Those which have not determinate form [ $\mathrm{Gr} \mu \rho \rho \phi \eta ்]$ or structure.

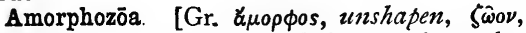
an animal.] Sponges, the skeletons of amœb1form bodies, which invest them when living Sub-kingd. Prōtōzōa. (Amœba.)

Amortissement. [Fr., from amortir, to deaden.] The extinguishing of debt, as by a sinking fund.

Amortize. [Fr. amortir, to deaden.] Alienation of lands in mortmain.

Amour propre. [Fr.] Self-love, often $=$ selfrespect.

Amphibălum. (Chasuble.)

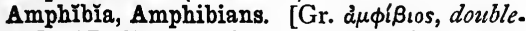
lived.] (Zool.) Vertebrates, when immature, possessing gills, which in maturity are in the Perennibranchiates supplemented, and in the Caducibranchiates superseded, by lungs. They are classified as follows :-Ord. i., Pseudŏphìdia

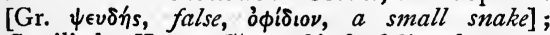
Cæciliadæ [L. cæcillia, a kind of lizard, cæcus, blind], worm-like animals, burrowing in tropical

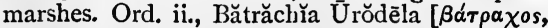
a frog, oùá, a tail, $\delta \hat{\eta} \lambda o s$, visible], as newts. Ord. iii., Bătrăchĭa Ănoura [áv neg., oủó, $a$ tail], as frogs.

Amphǐbǒly. [Gr. å $\mu \phi i \beta o \lambda i ́ a, a ̊ \mu \phi i \beta a ́ \lambda \lambda \lambda \omega, I$ toss to and fro.] Ambiguity.

Amphǐbrăchys, Amphibrach. In Prosody, a foot, $\checkmark-\checkmark$, having one long syll. and a short

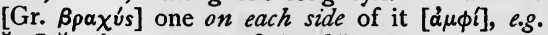
ămārě; the converse of $A m p h i m a c e r$.

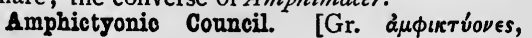

meaning most probably dwellers round about.] Any council of Greek confederated tribes. The most important was that of the twelve northern tribes, which met alternately at Delphi and Thermopylæ.

Amphigore. Nonsense verse, as Pope's Song by a Person of Quality. [Fr. amphigoure, nonsense, rigmarole; an eighteenth century word, origin unknown.]

Amphimacer [ $\mathrm{Gr}$ a $\mu \phi i \mu a k \rho o s$, long both ways], or Crētǐcus. A foot, - - , having one short

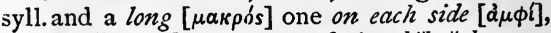
e.g. dignǐtās; the converse of Amphìbrăchys.

Amphipnoust. [Gr. $\dot{\alpha} \mu \phi i ́$, twofold, $\pi \nu \in \dot{v} \sigma \tau \eta s$, a breather.] Perennibranchiate, tailed, Batrachians, as Prōteūs anguřněus $(q v$. $)$.

Amphiprostyle. [Gr à $\mu \phi i$, , on both sides, $\pi \rho \delta$, before, $\sigma \tau \hat{v} \lambda o s, a$ pillar.] Having a portico at each end; said of a temple.

Amphisbæna, Amphisbænĭdæ. [Gr. ả $\mu$ фísBatva, a kind of serpent going both ways.] (Zool.) Fam. and gen of snake-like, footless, burrowing lizards. Spain, Asia Minor, N. and Trop. Africa, and Trop. S. America.

Amphiscii = living in the Torrid zone, and casting a shadow [Gr. $\sigma \kappa \iota a ́$ ] on both sides [ả $\mu \phi i s]$, sometimes north, sometimes south. ['A $\mu \phi i \sigma \kappa \iota$ s in class. Gr. is shaded around, or on both sides.]

Amphitritē. 1. (Zool.) Tubicolous annelid. (Tŭbicŏlæ.) 2. In Myth. (Nereids).

Amphrüma. (Zool.) Gen. of eel-like Amphǐbĭa, with rudimentary feet. Southern U.S.A. Ord. Bătrăchřa Ūrŏdēla.

Amphŏra. [L.] A clay pitcher, two-handled [Gr. á $\mu \phi^{\prime}$, on both sides, $\phi^{\prime} \dot{\rho} \rho \omega, I$ carry] , used as a liquid measure. Gr. =9 gall. ; Rom.=6. Also as a cinerary urn.

Amplexicaulis, Amplexicaul. [L. amplector, $I$ embrace, caulis, a stem.] (Bot.) Said of a leaf, which at its base embraces the stem; e.g. upper leaves of shepherd's-purse (Capsella bursapastōris).

Amplification. [L. amplificātio, -nem, from amplïfico, I make large.] (Rhet.) An enrichment of discourse by epithet and image and graphic detail ; word-painting. (Auxetic.)

Amplitude. [L. amplĭtūdo, wide extent.] The angular distance of a heavenly body, when rising or setting, from the east or west points of the horizon. If the angular distance is taken from the magnetic east or west, it is the Magnetic $A$.

Ampulla. [L., $c f$. amphŏra, a two-handled iar.] 1. A narrow-necked, globular, two-handled bottle, for unguents ; and (Eccl.) for oil at coronations. 2. (Anat.) The globular termination of one of the semicircular canals of the ear.

Ampyx. [Gr a ${ }^{\prime} \mu \pi v \xi$.] A head-band or fillet worn anciently by Greek women of rank.

Amrita. (Ambrosia.)

Amuck. A Malay, in a mad fit of rage or revenge, runs "amuck," amok, seeking the life of any one he meets, until he is killed by their efforts at self-preservation.

Amulet. [L.L. amulētum, Ar. hamalet $=a$ thing suspended.] A talisman; a gem, ornament, figure, scroll, etc., worn to avert evil. Oriental, Egyptian, Jewish, Greek, Roman, modern. 
Amy. [Fr. ami, friend.] (Naut.) A friendly alien serving on board ship.

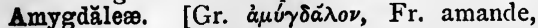
almond.] (Bot.) A sub-ord. of Rosaceæ, including peach, plum, cherry, etc. ; with fleshy fruit and resinous bark.

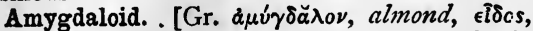
shape.] (Geol.) A variety of igneous rock, in which are embedded almond-shaped bodies, agate, calcspar, or zeolites, filling holes once occupied by steam.

Amyläceous. Of the nature of starch [L. ămy̆lum].

Ană. [Gr. ává, again.] In prescriptions, or $\bar{a},=$ equal quantity.

-āna. Originally neut. plu. ; e.g. Scaliger-āna, Renthami-ana, $=$ loose thoughts, sayings, and leading passages of S. or B., collected.

Anabaptist. [Gr. à $\alpha \beta \alpha \pi \tau i \zeta \omega, I$ rebaptizc.] 1. One who, denying infant baptism, is for rebaptizing adults. 2. Fanatical lawless sect, sixteenth century, in Germany.

Anăbas. [Gr. à $\nu a-\beta a i v \omega$, to go $u p$, second aor. part. àvaßás.] (Zool.) Perca scandens, climbing perch. Its pharyngeal bones are so modified as to retain moisture for its gills, enabling it to remain long out of water, when it travels considerable distances, and, according to some, climbs trees. Fam. Percĭdæ, ord. Ăcanthoptěry̆ğii, sub-class Tĕlěostěi.

Anăbăsis. [Gr., a going up.] A work in which Xenophon relates the attempt of Cyrus the younger to wrest the Persian crown from his brother, and his consequent march or ascent to the field of Cunaxa, where he was slain.

Anăbathmi. Certain Greek antiphons, the words being from Pss. cxx. to cxxxiv., or the Songs of Degrees (q.v.). [Gr. a $v a \beta a \theta \mu o l$, LXX.]

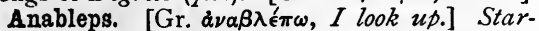
gazer. (Zool.) A gen. of fresh-water fish, about twelve inches long, having eyes with double pupils, and frequently swimming with the head out of water. Trop. America. Fam. Cyprinodontiadæ, ord. Phȳsostomi, sub-class Tĕlěostěi.

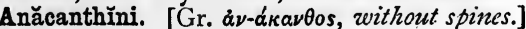

(Zool.) Ord. of fish without spinous rays to the fins, as the cod and sole.

Anacards, or Cashew tribe. (Bot.) An ord. of woody plants, W. Indies and S. America, yielding acrid resin, used as varnish; as sumach, pistachio, mango.

Anăcharsis, meton. $=$ a traveller. A. a famous Scythian traveller, who visited Athens in the time of Solon; and the only barbarian who ever received the Athenian franchise (see Herod., iv. 46, 76). (Seven Rishis.)

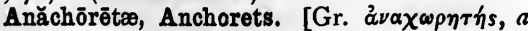
dzeller apart.] Hermits dwelling alone and

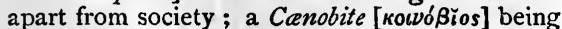
one who lives in a fraternity [koเvós Bíos, life in common]

Anachrŏnism. [Gr. à $\nu \alpha \chi \rho o \nu t \sigma \mu \delta s$, from à $\nu \alpha ́$, back, xpóvos, time.] A confusion of time, representing things as coexisting which did not coexist ; e.g. ancients painted in modern costume. (Parachronism.)

Anaclastics. (Dioptrics.)

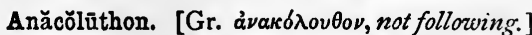
In Gram., a term denoting the want of strict sequence in a sentence, the members of which belong to different grammatical constructions.

Anaconda, Anacondo, Anacunda. (Zool.) One of the largest snakes, non-venomous, killing its prey by constriction. Trop. America. Fam. Pythōnî̀dæ.

Anacreontic verse. An iambic of three and a half feet, spondees and iambuses, an anapæst being sometimes substituted for the first foot; that of Anacreon of Teos, an amatory lyric poet, sixth century B.C.

Anadem. [Gr. à $\nu \alpha ́ \delta \eta \mu \alpha, \grave{a} \nu \alpha-\delta \epsilon^{\prime} \omega, I$ bind or tie up.] A fillet, wreath.

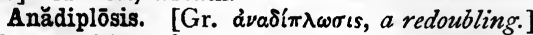
The repetition of a word in the last sentence as the starting-point, exegetically, of a new thought, as, "The mouse ran up the clock; the clock struck ;" etc.

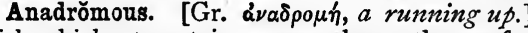
Fish which at certain seasons leave the sea for rivers, as the salmon, are sometimes so termed.

Anădyŏměnē. [Gr.] An epithet of Aphrodītē,

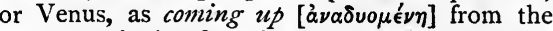
sea, or springing from its foam.

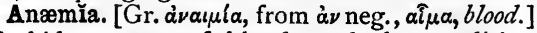
Morbid poverty of blood, and the condition consequent.

Anæsthësia. (Pathol.) Insensibility [Gr. duat$\sigma \theta \eta \sigma \iota a$, from a' $\nu$ neg., ai $\sigma \theta$ ávo $\mu \alpha \iota$, I feel]; is opposed to Hyperasthēsia [ivé́ $\rho, a b o v e]$, unnaturally acute sensibility.

Anăgallis. [Gr. a $\nu \alpha \gamma \alpha \lambda \lambda(s$.$] (Bot.) A gen. of$ plants, ord. Primulaceæ; of which the type is the pimpernel, or shepherd's weather-glass.

Anaglyphic, Anaglyptic. [Gr. àvá, up, $\gamma \lambda \hat{v} \phi \omega, I$ engrave.] Embossed, in relief; sunk

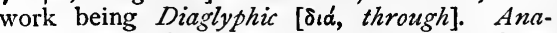
glyptography, the art of giving an embossed appearance to engravings.

Anagnōstes. A reader [Gr. à $\nu \alpha \gamma \nu \omega ́ \sigma \tau \eta \eta$, $\dot{\alpha} \nu \bar{a} \gamma(\gamma \nu \omega \sigma \kappa \omega, I$ redd] at meals, amongst the Romans; the thing read or sung being Acrōam

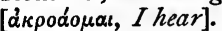

Anagram. [Gr. $\alpha \nu \alpha ́ \gamma \rho \alpha \mu \mu \alpha$.$] A transposition of$ letters of one word or more, so as to make a new word or new words; a connexion in meaning

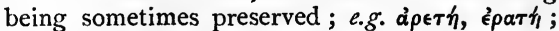
Horatio Nelson, honor est a Nilo.

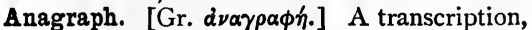
copy of a record, etc.

Anal. (Zool.) Near the ānus ; e.g. anal fin.

Anălecta. [Gr., from $\alpha \nu \alpha-\lambda \epsilon ́ \gamma \omega, I$ gather up.] Literary fragmmts, selections.

Analemma. [Gr. à $\nu a ́ \lambda \eta \mu \mu a, a$ thing taken up.] 1. The orthographic projection of the great sphere on the plane of a meridian or of the solstitial colure (q.v.). 2. An astrolabe (q.v.). 3. = L. substructio, a base; e.g. for a sun-dial.

Analeptios. [Gr. ¿ $\nu a \lambda \eta \pi \tau \iota k \delta s$, fit for restoring.] Restorative medicine or diet.

Anal glands. In Comp. Anat., organs, presenting every grade of glandular structure, secreting substances, sometimes attractive, as in the civet; sometimes repulsive, and applied to purposes of defence ; e.g. the sweet fluid ejected 
by some aphids, the acrid vapour of "bombardiers," the inky fluid of some molluscs.

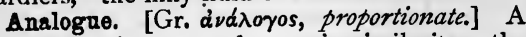
term indicating general organic similarity : the tapir is an A. of the elephant; a gill, of a lung. Sometimes, less strictly used, as the "wing " of a bat; but the wing of a bird, compared with an arm or with the paddle of a whale, is a

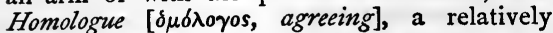
similar development.

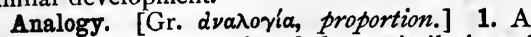
method of argument founded on similarity of relations, where induction is not complete. 2 . Title of Bishop Butler's work in defence of revealed religion. 3. Proportion : the equality or similarity of ratios; thus, the ratio of 2 lbs. of butter to $3 \mathrm{lbs}$. is equal or similar to the ratio of 4 in. to 6 in., consequently the two ratios form an analogy or proportion.

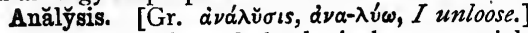
1. Resolution of a whole, logical or material. into its parts; opposed to Synthěsis [ $\sigma \dot{v} \nu \theta \in \sigma \iota s$, from $\sigma \dot{v} \nu$, together, $\theta \in$ é $\sigma s$, a placing]. A., from examining facts, arrives at principles; S. assumes principles, and proceeds to work out results. 2. In Physics, the resolving of a compound substance into its constituent parts; it is called proximate when the substance is resolved into components which are themselves compound; ultimate, when it is resolved into its elements. Qualitative $A$. determines the nature, Quantitative $A$. the amount, of the various ingredients. Volumetrc $A$. is a method of quantitative A. by the use of measured volumes of reagents of known strength. (For Spectral A., vide Spectral.) 3. The solution of geometrical problems, by treating them as particular cases of more general problems; a process commonly performed by the aid of algebraical equations ; whence algebraical geometry is often called analytical geometry. 4. In Language, the substitution, as in English, of prepositions, auxiliaries, etc., for inflexions.

Analyzer. The part of a polariscope by which, when light has been polarized, its properties are tested.

Anamnēsis. [Gr.] Plato held that knowledge was a reminiscence [ả $\nu a$ ' $\mu \nu \eta \sigma s]$ of the knowledge possessed in some former state.

Anamorphösis. [Gr., a forming anezv.] 1. The process taking place in a certain toy, by which the true form of an object is obtained from a distorted picture by reflexion in a properly curved mirror. 2. (Nat. Hist.) Change in form (usually progressive), traceable from species to species, either contemporaneous or successive.

Ananas. A Brazilian name; the plant which produces the pine-apple (Ananassa sătiva).

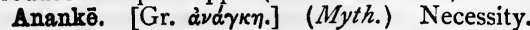

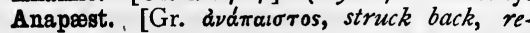
sounding.] A metrical foot, $\checkmark \sim-$, as, "Nŏt ă drūin |... nŏt ă fū | něrăl nōte;" perhaps meaning a dactyl reversed.

Anăphŏra. [Gr., a carrying back.] In Rhetoric, a repetition of a word at the beginning of consecutive clauses or verses; e.g. "Sic vos non vobis," etc.

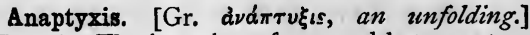
(Etym.) The insertion of a vowel between two consonants in a word, as in Eng. boraugh, Goth. burg.

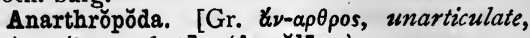
$\pi o u ́ s, \pi \delta \delta$ os, $a$ foot.] (Annŭlōsa.)

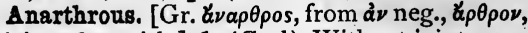
a joint, the article.] 1. (Zool.) Without joints, e.g. a mollusc. 2. (Gram.) Without the article, $\delta, \dot{\eta}, \tau \delta$.

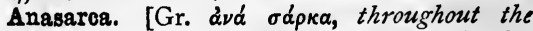
flesh.] (Physiol.) A collection of serrum in the cellular tissues of the body and limbs; pop. dropsy.

Anastasius, or Memoirs of a Modern Greek, written at the close of the eighteenth century. The celebrated Oriental romance of Mr. Thos. Hope.

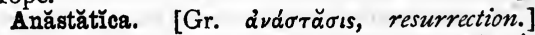
Rose of Fericho, Resurrection flower, Mary's flozeer, a small woody annual (A. hïĕrŏchuntǐca), ord. Crucifereræ. Its flower, dried up into a small ball, will, for years after being gathered, expand, if wetted, and close again.

Anastatic printing. The printing of engravings, etc., which are first steeped in an acid, then pressed on a zinc plate. The acid, eating away the plate where not covered by an oily ink, leaves the engraving in relief.

Anastŏmōsis. [Gr., opening as by a mouth.] 1. (Anat.) The junction of blood-vessels, being generally the branches of separate trunks. 2. (Bot.) The growing together of two parts meeting from different directions.

Anastrŏphē. (Inversion.)

Anăthěma. [Gr.] Properly a thing dedicated or devoted. Hence $=$ under a ban or curse. (Maranatha ; Raca.)

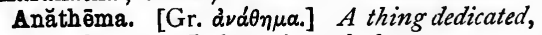
in a good sense; Luke xxi., and class.

Anătĭdæ. [L. ănătem, duck; $c f$. O.E. ened, enid, Ger. ente.] (Zool.) Fam. of web-footed birds, as ducks ; cosmopolitan ; ord. Ansěres.

Anatomy. [Gr. àvarouń, dissection.] Formerly, often (I) the thing dissected, (2) a skeleton.

Anatomy of Melancholy, by Robert Burton (1576-1640). A remarkable work, with a singular charm, professing to analyze and to remedy M.; quaint, learned, and abounding in quotations from authors, medical and other.

Anatron. [Ar. al-nitrûn, from Gr. vicpov, soda.] Glassgall (q.v.).

Anbury, Ambury. 1. In horses and cows, a soft, bloody tumour. 2. From the shape, a disease in turnips, Club-root, or "fingers and toes."

\section{Anchoret. (Anachoretæ.)}

Anchors. [L. anchŏra, Gr. đ̆ $\gamma \kappa \bar{u} p a$, an anchor.] Bower, the four large equal-sized anchors kept ready for use on board ship. They are : Best, or Starboard $B$., and Small or Port $B$., in the bows ; Sheet $A$. and Spare $A$., kept to starboard and port, abaft the fore-rigging. Stream $A$., a third of the size of the $B . A$. Kedge, smaller than a Stream. Grappling A., or Grapnel, a boat's anchor, with four flukes. The Floating $A$., a fourfold piece of canvas, on an iron frame, 
suspended in the water, so as to diminish a ship's drift to leeward.

Anchor watch. A portion of the watch constantly on deck while a ship is at single anchor, ready to attend to it, let go another, set headsails, etc., as required.

Anchūsa [Gr. ă $\gamma \chi x o v \sigma \alpha$, alkanct], Buggioss [Boú $\lambda \lambda \omega \sigma \sigma o s$, ox-tongue]. (Bot.) A gen. of plants, ord. Boraginaceæ; including Dyer's alkanet, or Anchūsa tinctōria.

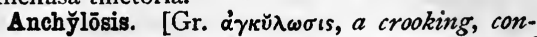
traction of limbs.]. (Med.) Unnatural unior of two bones, resulting in more or less stiffening; applied to joints.

Ancien regime. [Fr., the old rule.] The system maintained by the French monarchy and aristocracy before the Revolution.

Ancient. Corr. of ensign [L. insignĕ].

Ancient demesne. Lands named in Domes. day Book as Terra Regis.

Ancientry. Antiquity of lineage.

Ancients. [Fr. anciens.] Gentlemen of the Inns of Court and Chancery.

Ancilia. [L.] Shields; i.e. the shield of Mars which fell in Numa's time, and eleven others made like it that the true one might not be stolen; carried yearly round the city, which could not be taken while the shield was in Rome. Corssen derives from an, on both sides, cile = cut out, root skar, to cut, the A. being panduriform (q.v.).

Ancillary. [L. ancilla, a handmaid.] Subservient to ; assisting.

Ancipital. [L. anceps, ancřp̌tis, an for amphi, on both sides, căput, $a$ head.] (Bot.) Two-edged, compressed, so as to form two opposite angles or edges, e.g. stem of iris.

Ancǐpìtis ūsûs. (Contraband.)

Ancon. [Gr. á $\gamma \kappa \omega \dot{\nu}, a$ bent arm.] 1. A corner or quoin of a wall. 2. A bracket supporting a cornice.

Anconj. [Gr. á $\gamma \kappa \omega ́ v$.$] A bar ot iron un.$ wrought at the ends.

Ancora. [It. i.q. Fr. encore, once more, lit. to this hour; L. hanc höram.] A call for the repetition of a song.

Andabatism. [L. andăbăta, a gladiator, who wore a helmet without holes for the eyes.] Lit. blindfold fighting; incertainty, wild argumient.

Andante. [It.] Going, i.e. evenly ; (Mus.) in rather slow time.

Andirons, also written Aundirons and Handrons. Fire-dogs. An ornamental standard of iron, with a cross-bar, used to support the $\operatorname{logs}$ of a wood fire.

Andreada Forest. The southern and central parts of Sussex in the period before the Norman Conquest.

Andrew. In nautical parlance : 1. A manof-war. 2. The Government, and Government authorities.

Andrew, Cross of St. (Cross.)

Andrews, Joseph. Fielding's novel and its hero, a virtuous footman.

-andria. [Gr. ảvíp, a man, àvốós.] (Bot.) The first eleven of the twenty-four (Linnæan) classes into which vegetables are primarily divided, are characterized solely by the number of stamens. Mon-andria $=$ having 1 stamen; Di-, 2 ; Tri-, 3 ; Tetr-, 4 ; Pent-, 5 ; Hex-, 6 ; Hept-, 7 ; Oct-, 8 ; Enne-, 9; Dec-, 10; Dōdec-, 12 to 19. Classes 12 and 13 are Ikos-andria, with 20

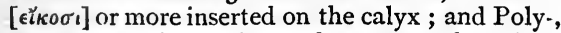
20 or more inserted on the receptacle. Gy̆n-

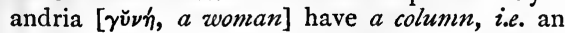
insertion of stamens on the pistil.

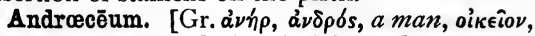
neut. adj., domestic.] (Bot.) The male system of a flower.

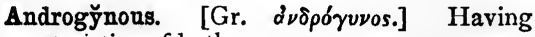
characteristics of both sexes.

Anele. [A.S. ele, oil.] To give extreme unction.

Anelectric. [Gr. $\dot{\alpha} \nu$ neg., and electric.] A body not easily electrified by friction.

Anelectrode. [Gr. ásó, $u p$, and electrode $(q . v)$.$] The positive pole of a galvanic battery.$

Anemia. (Anæmia.)

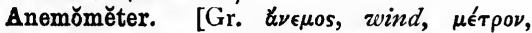
measure.] An instrument for ascertaining and registering the pressure of wind.

Anemophylous flowers. Those which are fertilized by the action of the wind carrying the pollen from one to another. [Gr. $z_{\nu \in \mu}$ s, wind, $\phi \iota \lambda \epsilon \in \omega, I$ love.]

Anent, Anenst. [A.S. on efen, on even, on even, on a level zith.] Over against, close by, concerning.

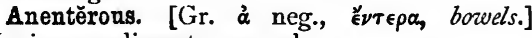
Having no alimentary canal.

Aneroïd barometer. [Gr. à neg., v $\eta$ ós, wet, $\epsilon \hat{\imath} \delta o s$, form, as not making use of mercury.] A cylindrical metallic box, partially exhausted of air, with a top made to yield very easily under varying external pressure ; the motion of the top is transmitted to a pointer which shows its extent, and therefore the variation in the atmospheric pressure producing it.

Anēthum. (Anise.)

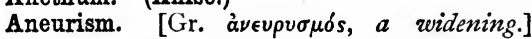
(Med.) A pulsating tumour, consisting of an artery preternaturally enlarged. (Varix.)

Anfractuous. [L. anfractus, a bending round.] 1. Winding about. 2. (Bot.) Sinuous, doubling abruptly in different directions.

Angeiology, Angiology. [Gr. à $\gamma \gamma \in \hat{\imath} \hat{0} \nu, a$ vessel.] (Anat.) Knowledge of the vessels of the body.

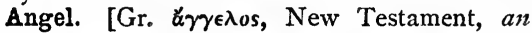
angel.] An old coin worth ten shillings, marked with the figure of an angel.

Angel Doctor. (Doctor.)

Angel, Order of Golden. An order of knighthood, said to have been instituted by Constantine. It was revived by the Emperor Charles V.

Angĕlica. [Gr. a' $\gamma \gamma \in \lambda \iota k \delta s$, from its properties (?).] (Bot.) A gen. of plants, ord. Umbelliferæ; the hollow stalks of A. Archangelica are candied and eaten.

Angelical hymn. (Eccl.) In the Eucharistic Office, the hymn beginning with the words, "Glory be to God on high;" L. "Gloria in Excelsis." 
Angelology, Demonology, of a people, or period. The current belief respecting angels and evil spirits, [Gr. a $a \gamma \gamma \in \lambda o s$, New Testament, angel ; $\delta$ ai $\mu \omega \nu$, New Testament, evil spirit.]

Angelot. [Fr.] A small rich Norman cheese (originally stamped with a figure of St. Michael).

Angèlus bell. The bell rung at the time appointed for the recitation of the Ave Maria, or the angel's annunciation to the Virgin.

Angevin. Belonging to Anjou.

Angina pectoris. [L., tightening of the chest.] (Med.) A nervous disease of the heart, attended with sudden excessive pain in the lower part of the chest; ascribed to a bony degeneration of the cardiac vessels.

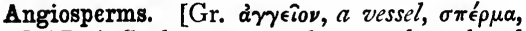
seed.] (Bot.) Such exogens as have seeds enclosed

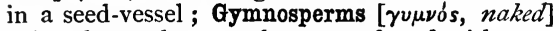
being those whose seeds are perfected without a seed-vessel.

Angle; Acute A. ; Dihedral A.; Obtuse A.; A. of friction; A. of incidence; $\mathbf{A}$. of reflexion; $\mathbf{A}$. of refraction; A. of traction; Right A.; Solid A.; Visual A. [L. angŭlus, an angle, corner.] The difference of direction of two intersecting straight lines. When the adjacent angles made by two such lines are equal, each angle is a Right $A$.; an Acute $A$. [ăcütus, sharpened] is less, and an Obtuse $A$. [obtūsus, blunted] is greater, than a right angle. A Dihedral $A$. [Gr. $\delta i \epsilon \delta \rho o s$, not in its class. sense, but as if $=$ having two bases, sides] is that contained by two intersecting planes; a Solid $A$. is the angular space at the vertex of a pyramid enclosed by three or more plane angles meeting at a point; the Visual $A$. of an object is the angle subtended at the eye by the line joining its two extreme points; the $A$. of repose is the $A$. of friction (Friction). (For $A$. of incidence, reflexion, refraction, traction, vide Reflexion; Refraction; Traction.)

Angle-iron. Pieces of iron of an angular form, used for joining, at an angle, the plates of which tanks, etc., are built up.

Angle of leeway. The difference between the seeming and the actual course of a ship when sailing near the wind.

Anglia, East. Name for Norfolk with Suffolk and Cambridgeshire.

Anglo-Sax on Chronicle. A narrative, in the Anglo-Saxon language, extending from Cæsar's invasion to the death of Stephen, I I 54. A very important work, mostly in prose; the work, apparently, of many successive hands ; the latter part, at least, by contemporary anthors with the events related.

Anglo-Saxon language: English language. While no exact date, of course, can be assigned to the change of Anglo-Saxon into English, it has been proposed by the late Mr, T. Shaw, in Student's English Literature, p. I 7, to arrange, approximately, the chief alterations under the following epochs :-I. Anglo-Saxon, from A.D. 450 to I J50. 2. Semi-Saxon, from A.D. I I 50 to 1250; from the reign of Stephen to the middle of that of Henry III. 3. Old English, from A.D. 1250 to 1350, the middle of the reign of Edward I.1. 4. Middle English, from A.D. I350 to 1550 , the reign of Edward VI. 5. Modern English, from A.D. I 550 to the present day. Dr. Morris gives a somewhat different division:-I. A.D. 450 to I100. 2. A.D. 1100 to I250. 3. A.D 1250 to 1350 . 4. A.D. I 350 to 1460 . 5. A.D. 1460 to the present time; under the titles of Engiish of the First Period; of the Second Period, etc. (Morris's English Accidence, p. 48).

Angōla cat; A. goat. (Angōra.)

Angōra cat. [Gr. 'A $\gamma \kappa u ́ p a$, now Angora, in Asia Minor.] Variety of cat, with long silky fur, and frequently with eyes of different colours. Fêlis cătus Angorensis (Linnæus, Buffon).

Angöra cloth. Made from the silky wool of the goat of Angora, ancient Ancȳra, Asia Minor. (Tentmaker.)

Angöra goat. (A. cat.) Variety of goat, with long silky hair, generally white.

Angostura bark; A. bitters. The bark of the Gulipea cuspāria, a S. American tree, common around Angostura, in Columbia.

Angsana. A red gum from Hindostan, like dragon's blood.

Anguilla. [L. dim. of anguis, snake, Gr. '́ $\left.\gamma \chi \chi^{\epsilon} \lambda v s, e e l.\right]$ Gen. of fish, as the common eel ; only gen. found in fresh water of fam. Mürænĭdæ, ord. Phȳsostŏmi, sub-class Tĕlěostěi.

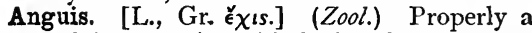
snake of the constrictor kind ; but designating a gen. of footless lizards, as A. frăgĭlis [L., fragile], the blind-worm, fam. Scincĭdæ.

Angular velocity. The rate at which a body turns round an axis.

Angus. Division of Scotland, from Saxon to Stuart periods, nearly coincident with County Forfar.

Angusticlave. The tunic of the Equites, with narrow [L. angustus] purple stripe [clāvus]; opposed to Laticlave [lātus, broad], that of the senators.

Anhelation. [L. ănhēlo, I pant.] Difficulty of breathing.

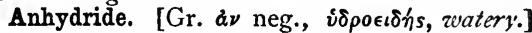
Any oxygenated compound, which by reaction with the elements of water forms an acid.

Anhydrous. [Gr. aै $\nu=v \delta \rho o s$, wanting water.] Deprived of, or not containing, water. An anhydrous acid is called an anhydride.

Anicut. In the Indian rivers, a dam with bottom sluice, which regulates irrigation.

Aniline. [First obtained from indigo, Ar. an nil.] A colourless liquid, the source of many brilliant dyes ; which, or some of which, readily absorb moisture from the air, so that the dyed substances keep moist.

Anima mundi. [L., the soul of the zvorld.] With some early philosophers, a force, not material, but of the nature of intelligence, the source of all sentient life.

Anime, or African copal. A gum-resin obtained from an African tree, Trachylobium Hornemannianum ; nat. ord. Leguminosæ.

Anı̌mus. [L., intent.] In libel, malicious purpose.

Animus fürandi. [L.] The intention of stealing

Anion. [Gr. ávíws, going up, from àvá, up, and iéval, to go.] The element which goes to 
the positive pole, when a substance is decomposed by electricity. (Cation.)

Anise, or Aniseed. [Ar. anisun, Gr. ă $\nu$. á $\nu \eta \theta 0 \nu$.] Fruit of Pimpinella anisum (nat. ord. Umbelliferæ), which is among the oldest of medicines and spices; aromatic stimulants and carminative ; used as a cattle medicine.

Anisette. [Fr.] A cordial flavoured with aniseed.

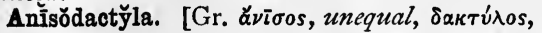
finger or toe.] (Zool.) Having an uneven number of toes, as the feet of the horse among Ungulata.

Anjou. Old province of France, capital Angers.

Anlace. A short dagger, worn in the fourteenth and fifteenth centuries.

Annandale. The larger and eastern part of Dumfriesshire, from Norman to Stuart periods ; the less and west part being Nithsdale.

Annat. [L. annus, a year.] A half-year's stipend due by Scotch law, A.D. I672, to a minister's next of kin, not to his estate, after his death.

Annates [L. annus, a year], or First-fruits. A moiety of the full value of one year's profits at first of every vacant bishopric, afterwards of every other vacant benefice also, claimed by the pope, as a beneficiary fee ; afterwards by Henry VIII. ; given by Queen Anne to the Governors of Q.A.B. $(q . v$.$) , for augmentation of the maintenance of$ poor clergy. The valuation is that of Liber Regis (q.2\%), A. D. 1535 .

Annealing. [O.E. anælan, to kindle.] 1. The melting and gradually cooling of glass or metal, to remove brittleness. 2. The heating of glass or tiles, to fix colours.

Annelids. [Fr. annélides, id., from L. ānellus, dim. of ānǔlus, a ring.] (Zool.) Annulose, or ringed worms, distinctly segmented, as leeches and earth-worms.

Annex. [L. annexus, part. of annecto, I join on to.] 1. A room or gallery adjoining a larger covered area, especially in exhibition buildings. 2. A paper joined to a diplomatic document.

Annihilationists [Eccl. L. annǐhǐlo, I bring to nothing] understand the death which is the wages of $\sin$ to be a gradual extinction of all existence.

Annomination. [L. ad, to, nomen, a name.] Emphatic opposition of words of same sound, but different sense or use; e.g. "The parson told the sexton, And the sexton tolled the bell," "And leaves begin to leave the shady tree." The tone of a piece alone determines whether A. = punning or not.

Annöna. [L.] Yearly produce; and so a contribution of corn due from a Roman province for the use of the army and the city.

Annotta, Annotto, Arnotto, Roucou. A thin yellowish-red coating of waxy pulp, which covers the seeds of Bixa orellana. It is separated and used for colouring cheese, etc.

Annual Register. Published since 1759, gives principal events of importance, political and miscellaneous, in the year.

Annual Returns, H.M. Navy. A report of (I) sailing qualities of ship ; (2) state of crew ; (3) progress of young officers in navigation. Sent to the Admiralty from every ship on commission.

Annuent muscles [L. annuo, I nod to] throw the head forwards.

Annular eclipse. (Eclipse.)

Annŭlāta, Annulates. [L. ānnŭlāta, ringed, from ānnŭlus, $a$ ring.] (Ânnelids.)

Annulate. [L. annŭlātus.] Having ringed form or marks ; e.g. an antelope's horn.

Annulet. 1. (Arch.) A small flat fillet encircling a column; e.g. those under the Doric capital. 2. (Her.) A ring [L. annǔlus] borne (I) as a charge, or (2) as difference in the fifth son's escutcheon.

Annŭlŏïda, or Echīnōzōa. Provisional subkingd. of Invertebrates, including Ëchīnŏdermăta (as star-fish) otherwise reckoned with the Rădĭanta; and Scōlēcĭda (as the tapeworm and vinegar eel), otherwise reckoned with the Annǔlōsa.

Annŭlōsa. [L. ānnŭlus, a ring.] Sub-kingd. of certain Invertebrates, which are composed of definite ringed segments, "somites" [Gr. $\sigma \hat{\omega} \mu \alpha$, a body], and containing (I) Arthrŏpǒda, or Arť̌cŭlāta, with jointed locomotive appendages, as crabs, barnacles, spiders, centipedes, and insects ; and (2) Ănarthrǒpóda, without such appendages, as spoon-worms, leeches, earth-worms.

Annŭlus et băcŭlum. [L.] The bishop's ring and pastoral staff, given in granting investiture.

Annunciation, Order of the. An order founded in Savoy, 1535, as the order of the Collar, by Amadeus VI. ; received its present name from Charles III.

Annus mīābrlis. [L.] Year of wonders, 1666, i.e. of the Great Fire, and of our successes over the Dutch. Title of a poem by Dryden.

Anoa. (Zool.) Gen. and spec. of wild oxen, allied to buffalo, but small. Cělěbes, sub-fam. Bŏvīnæ, fam. Bŏvĭdæ, ord. Ungŭlāta.

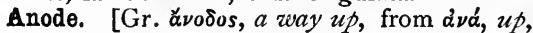

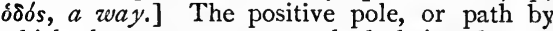
which the current enters a body being decomposed by electricity.

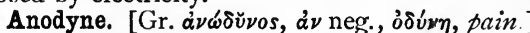
A sedative, narcotic, etc., which assuages pain.

Anolis. (Zool.) Gen. of lizard with expansile, coloured throat. Trop. America to California. Fam. Iguānĭdæ.

\section{Anomalistic year. (Year.)}

Anomăly, Eccentric; Mean A.; True A. [Gr. à $\nu \mu a \lambda i a$, irregularity, anomaly.] The True $A$. of a planet is its angular distance, measured at the sun, from perihelion. The Eccentric $A$. is a like angle measured from perihelion to the planet's place referred (by a perpendicular to the axis) to the circle described on the major axis of its orbit (Ellipse). The Mean $A$. is a like angle measured to the place the planet would occupy if it moved on the circle with its mean velocity.

Anomœans. [Gr. àóposos, unlike.] Arians, fourth century, who held the essence of the Son to be unlike that of the Father, and rejected the term Homoiousios. (Homœusians.)

Anon. [A.S. on án $=$ in one, i.e. instant.] 1. Quickly; as in Matt. xiii. 20. 2. Sometimes. 
Anona. (Bot.) The custard apple; type of ord. Anonacex, W. Indies and S. American trees, aromatic, and yielding delicious fruit.

Anonymous. (Pseudonym.)

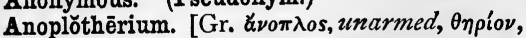
beast.] (Geol.) An extinct pachyderm, between the swine and ruminants ; tuskless, two-tued, gramınivorous. There are some spec. of Tertiary age.

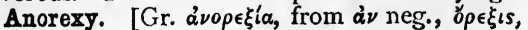
desire.] Loss of appetite.

Anorthite. [Gr. $\alpha \nu$ neg., ’’ $\rho \theta \dot{\eta}$, sc. $\gamma \omega \nu i ́ a$, right angle.] (Min.) A variety of lime-felspar; named from its cleavage.

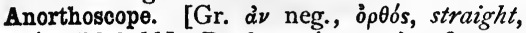
$\sigma \kappa o \pi \epsilon^{\prime} \omega, I$ behold.] Produces interesting figures, etc., by means of two discs rotating rapidly one before the other; the anterior opaque with vertical slits, the other transparent with distorted figures. (Zoetrope.)

Anosmĭ. [Gr. $\dot{\nu} \nu$ neg., $\dot{o} \sigma \mu \hat{\eta}$, smell.] Loss of the sense of smell.

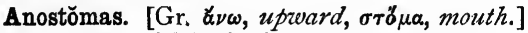
(Zool.) Gen. of fish, freshwater, with under jaw so projecting that the mouth seems placed vertically. Trop. America. Fam. Chărăcǐnı̆dæ, ord. Phȳsostŏmi, sub-class Tělěostěi.

Another place. (Parl.) The conventional way, in either House, of referring to the other

Anoura. [Gr. àv neg., oủ $\rho \alpha$, a taul.] (Zool.) The third ord of Amphibia, tail-less Batrachians, as frogs.

Ansāted. Having handles [L. ansæ].

Ansæ of Saturn's rings. Projections resembling handles [L. ansæ].

Anse de panier. [Fr, basket handle.] Elliptical arch of a bridge.

Ansěres. [L. ansĕr, goose, gander, Ger. gans, Gr. $\chi \dot{\eta} \nu$.$] (Zool.) Ord. of web-footed and lobate-$ footed birds, as ducks, grebes. Cosmopolitan.

Answer the helm, To. To obey the rudder.

Anta, Antæ. [L.] The end of a wall terminating in a pillar; the terminations of the ptĕrōmăta, or side walls, of a temple, when prolonged beyond the face of the end walls

Antæus. [Gr. 'Avraios.] (Myth.) A giant, invincible so long as he remained in contact with the earth. Heracles (Hercules) lifted him and crushed him in the air

Antagonist muscles. [Gr. ả $\nu \tau a \gamma \omega \nu เ \sigma \tau \eta \dot{n}$, one who contends against.] In their actions opposed to each other; e.g. the form of the mouth in health is due to such combined action; the opposite is seen in paralysis:

Antalgics [Gr. ăd $\gamma o s$, pain], i.q. Anodynes (q.v.).

Antănăclăsis. [Gr., a reflexion, an echo.] (Rhet.) The pointed use of the words of a previous speaker in a different sense.

Antarctic. (Zone.)

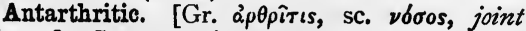
disease.] Counteracting gout.

Antatrophic. Overcoming or counteracting atrophy.

Antebrāchium. The forearm [made up of $L$. ante, before, and brāchium, which is sometimes the whole arm, sometimes the lower arm from the fingers to the elbow].
Antecedent. (Conditional proposition; Ratio.) Antediluvian. 1. Before the Flood [L. ante dīlǔvium]. 2. Old-fashioned, very antiquated.

Antefixes. (Arch.) Carved blocks.

Antelūcan [L. antělūcānus] worship, i.e. before dayllight [antě lūcem].

Antěnate. [L.] Born before the union of English and Scottish crowns (James I.), and so not English in law; post-nate, born after, i.e. claiming the rights of native English.

Antenicene. Before the Council of Nice or Nicæa, in Bithynia, A.D. 325.

Antepagment. [L. antepagmentum.] Doorways or architrave of doorway.

Antepaschal. Relating to the time before Easter [ $\Pi \alpha \sigma \chi \alpha$, the Passover].

Antěpast. A foretaste [L. ante, before, pastus, a feeding].

Antependium. [L. ante, before, pendeo, to hang:] The frontal or covering of the altar, in churches, usually made of cloth, silk, or velvet, and embroidered.

Antepenultimate. [L. ante, before, pæne, almost, ultimus, the last.] The last but two; generally said of a syll. or a letter.

Antepilāni. [L.] In the Roman legion, the Hastāti and Principes, as being drawn up before the Triārii, who were armed with pila, long spears.

Anteport. Uutward gate or door [L. porta].

Antēridĕs. [Gr., props.] (Arch.) Buttresses.

Antěro-postěrior. Forwards from behind; e.g. compression of the skull.

Antesignāni. [L.] In the Roman legion, the Hastāti, as standing in front of the standards [ante signa].

Anteversion. [L. anteversio, -nem.] ( $M e d$.) The tilting forwards of a part which is naturally inferior. Retroversion, the backward and downward depression of a part naturally superior.

Antevert. [L. antěverto, I go before, place before.] Prevent.

Anthelion. A bright spot, connected with a halo, nearly opposite to the sun [Gr. à $\nu \theta \dot{\eta} \lambda \iota s$ ]

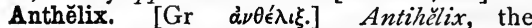
curved ridge of the external ear within the helix $(q . v$.

Anthelmintio. [Gr. "̈ $\lambda \mu \iota \nu s$, a worm.] (Med.) Destroying or removing worms.

Anthem. (Antiphon.)

Anthěmis. [Gr. à $\nu \theta \epsilon \mu l s$, chamomile.] (Bot.) A gen. of plants, ord. Compositæ, of which the Chamomile (q.v.) (A. nobilis) is the type.

Anther. [Gr àvinpós, flowery.] (Bot) That part of the stamen which is filled with pollen; the pollen-case.

Anthërǐdǐa. [Dim. coined from anther.] (Bot.) Organs of Cryptogamous or flowerless plants, supposed to represent anthers of Phanerogamous or flowering plants.

Anthestēriŏn. [Gr. á $\nu \theta \in \sigma \tau \eta \rho \iota \omega$.] Eighth Attic month, beginning 197 days after summer solstice.

Antho-. [Gr. àvos.] Flower.

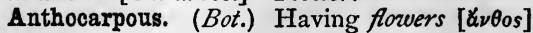

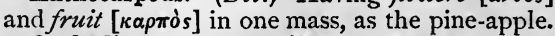
Anthōdium [Gr. $\omega \nu \theta \omega \delta \eta s$, like flowers], or 
Căpĭtŭlum [L., liitle head]. (Bot.) The head of flowers of a composite plant, as daisy, aster, chamomile.

Anthŏlites. [Gr. avios, a flower, $\lambda i$ íos, stone,] (Geol.) Fossil inflorescence; e.g. of the Carboniferous period.

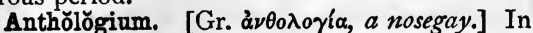
the Greek Church, a book, in two six-monthly parts, containing the offices sung through the year on special festivals.

Anthology. A collection by an editor of Greek epigrams and other short poems ; the first known being that of Meleager, circ. B.C. 100. There are also others, Arabic, Indian, Persian, Chinese, etc.

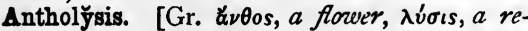
solving.] (Bot.) Defined by Dr. Lindley, "the retrograde metamorphosis of a flower; as when carpels change to stamens, stamens to petals, petals to sepals, and sepals to leaves, more or less completely."

Anthŏrismus. [Gr. à $\nu \theta o \rho t \sigma \mu \delta ́ s$, from à $\nu \tau i$, against, $\delta p i \zeta \omega, I$ define.] (Rhet.) A counterdefinition.

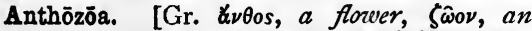
animal.] (Zool.) I.q. Actīnōzōa (Actinia), corals and sea-anemones, sub-kingd. Cælentěrāta.

Anthrăcite [Gr. ¿̌ $\nu \rho a \xi$, coal, charcoal], Blindcoal, Glance-coal. A black, light, lustrous substance, burning slowly, without flame, with intense heat ; a natural carbon, formed by pressure and heat from coal.

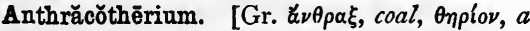
wild beast.] (Geol.) An extinct pachyderm, near to swine; its remains first found in Ligurian brown coal or lignite.

Anthrax. [Gr. á $\theta \rho a \xi$, coal, a carbuncle.] A malignant boil ; a carbuncle.

Anthropography. [Gr. á $\nu \theta \rho \omega \pi o s, \operatorname{man}, \gamma \rho \alpha \dot{\phi} \omega$, $I$ write.] Adescription of the physical character of man; his language, customs, distribution on the earth, etc.

Anthrōpǒlă̈træ. [Gr. ă $\nu \theta \rho \omega \pi o s$, man, $\lambda \alpha \tau \rho \epsilon \iota \alpha$, worship.] Man-worshippers; name given to the orthodox Christians by the Apollinarians, who denied Christ's perfect humanity.

Anthrōpolites [Gr. ä $\nu$ $\theta \omega \pi$ os, man, $\lambda$ i $\theta o s$, stone $]=$ fossil human remains ; e.g. in the coral sand of Guadaloupe.

Anthropology. The science of $\operatorname{man}$ [Gr. a $\nu \theta \rho \omega \pi$ os] under every aspect of his nature.

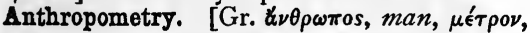
measure.] The systematic examination of the heights, weights, etc., of human beings, in connexion with other physical characteristics, and with age, race, locality, occupation, etc.

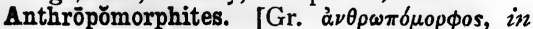
human form.] Persons who regard the Deity as having a human shape. The name is applicable to heathens generally, and to some Christian sects.

Anthropopăthy. (Rhet.) The ascription to God of human passion [Gr. $\pi \alpha \dot{\theta} \theta o s]$.

Anthropophăgy. [Gr. à $\nu$ pwroфoría.] Cannibalism.

Anthurium. (Bot.) A gen. of Araceæ, one of which (A. Scherzerianum) is much grown in hot- houses under the name of the Flamingo plant; it has a large scarlet spathe and a twisted spadix, and is very handsome.

Antiarin. Poisonous principle of the upas tree; the gum resin being used for poisoning arrows. (Ūpas.)

Anti-attrition. A preparation of black lead and lard with a little camphor, which lessens friction in machinery. [Coined from Gr. á $\nu \tau i$, against, and L. attrīio, friction.]

Ant.i-bacchius. (Bacchius.)

Anti-burghers. (Burghers.)

Antical, Anticous. [L. anticus, that which is before.] (Bot.) Placed in the front part of a flower, i.e. furthest from the axis.

Antichlore. [Gr. à $\nu \tau i$, against, and chlorine (q.v.).] Any substance used to remove the excess of chlorine from bleached rags.

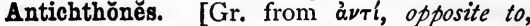
$\chi \theta \omega \nu$, the earth, the ground.] Inhabitants of opposite hemispheres.

Anti-civism. A spirit hostile to the rights of fellow-citizens [L. cives].

Anti-climax. (Climax.)

Anticlinal line [Gr.ả $\nu \tau i$, against, $\kappa \lambda i \nu \omega$, I make to bend], or Saddleback. (Geol.) The ridge line, or axis of elevation, from which strata dip in oppo-

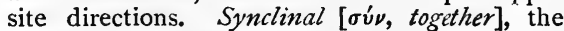
furrow line towards which they dip.

Anticor. [Fr. anticœur.] A swelling of the breast, opposite the heart.

Anti-Corn-Law League. An association formed in 1836, chiefly through the energy of Richard Cobden, to procure the repeal of the laws regulating or forbidding the exportation or importation of corn. These laws were abolished in 1846 .

Anticum. [L., in front.] The front or entrance of a church.

Anticy̆ra. Name of two Greek towns famed for hellebore, an old remedy for lunacy ; meton.. a retreat for those who act madly (vide Horace, Sat. ii. 3, 83).

Anti-dactyl. An anaprst (q.v.).

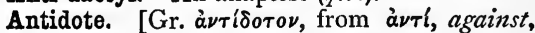
$\delta i \delta \omega \mu l, I$ give.] That which counteracts evil effects.

Anti-friction wheels or rollers. Placed between two surfaces which pass over each other, to convert a rubbing into a rolling contact.

Anti-gallicans. (Naut.) Extra backstays. (Stays.)

Antigraph. [Gr. à $\nu \tau \iota \gamma \rho \alpha \phi \eta, a$ reply, a copy.] A copy, transcript.

Anti-hělix. (Anthelix.)

Anti-hypnōtic (more correctly Anthypnotic). [Gr. ínów, I lull to sleep.] Preventive of sleep.

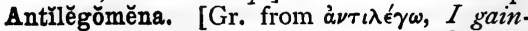
say.] Things spoken against; books at first not admitted to be canonical-2 Peter, James, Jude, Hebrews, 2 and $3 \mathrm{John}$, and Apocalypse.

Antilibrätion. [Coined from Gr. à $2 \tau \imath$, opposite to, and L. librātio, a levelling.] Of words, sentences, counterbalancing.

Antilithic. [Gr. $\lambda$ íos, a stone.] Preventive or destructive of gravel or urinary calculi.

Antilogarithms, Table of. [Gr. avil, over 
against, and logarithm (q.v.).] The number corresponding to a logarithm. A Table of $A$. gives a series of logarithms, each differing from the one before it by a unit in a certain decimal place, and the numbers corresponding to them.

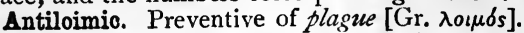

Antimacassar. [Coined from Gr. àvil, against, macassar, a hair oil, named from a district in the island of Celebes.] A fancy-work cover for a chair-back or sofa.

Antimony. [Ar. al ithmidun.] A brittle bluishwhite metal. In commerce, its native tersulphide is called antimony, the metal itself regulus of antimony. White $A$. is the native oxide. Glass of $A$. is an artificial oxysulphide.

Antinephritic. Counteractive of kidney disease [Gr. $\nu \in \phi \rho \hat{\imath} \tau \iota s]$.

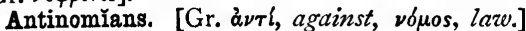
Opposers of law. This name was applied by Luther to John Agricola and his followers, on the ground that they denied to the Law all authority as a rule of life, and asserted the entire uselessness of good works (Solifidians). Generally the word is regarded as designating those who hold that the wicked actions of the elect are not sinful.

Antinŏmy. [Gr. à $\tau_{i}^{\prime}$, opposite, vómos, law.] 1. A law opposed to another law. 2. The natural contradiction of logical conclusions about matters beyond experience, as that of the doctrine of eternal necessary causation, and the doctrine of a personal First Cause absolutely free.

Antǐnǒus. [L.] A beautiful Bithynian youth, deified after his death by the Emperor Hadrian. Hence the name is applied sometimes to denote singular beauty in the young.

Anti-pædobaptist. One who opposes infant baptism. (Pædobaptist.)

Antiperiodic. Preventing a fit [Gr. $\pi \epsilon \rho$ loosos] of intermittent fever ; as quinine does.

Antiperistaltic. Opposing peristaltic motion (q.v.).

Antĭpěristăsis. [Gr. à $\nu \tau i ́$, against, $\pi \epsilon \rho i \sigma \tau \alpha \sigma \iota s$, a standing round.] Opposition to one quality by a contrary quality, by which the former becomes more intense; as quicklime is heated by cold water, or as one ethical extreme seems to beget the other. A principle of $\mathrm{A}$. was once imagined as existing in nature.

Antiphlogistic. [Gr. $\phi \lambda \circ \gamma\llcorner\sigma \tau \delta s$, set on fire.] Checking inflammation.

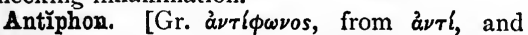
$\phi \omega \nu \eta$, voice.] Corr. into Anthem, the meaning also being changed. 1. In Gr. Mus., = unison. 2. (Eccl.) Antiphonal singing, i.e. side answering side, as in cathedrals. See something of this kind, Exod. xv. 21 ; I Sam. xviii. 7.

Antiphōnal, or alternate singing. (Antiphon.)

Antiphonar. In the unreformed ritual, the book of invitatories (q.v.), responsories (q.v.), verses, collects, and whatever else is sung in the choir; but not the hymns peculiar to the Communion Service. (Gradual.)

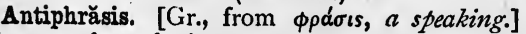
The use of words in an opposite sense to the proper one; e.g. Jeddart justice, i.e. hanging first and trying afterwards.
Antipope. One who assumes the office of pope in the Latin Church without a valid election. The antipopes belong chiefly to the fourteenth and sixteenth centuries.

Antipyretic. [Gr. $\pi u p \in \tau \delta s$, fever.] Remedying fever.

Antīquĭtas sæcŭli, jŭventūs mundi. [L.] Ancient times were the world's youth; what is very old to us is very young in the history of the world.

Antirrhīnum, Snapdragon. (Bot.) A gen. ot plants which has, as it were, two noses [pives] opposite, in allusion to the shape of the flowers. Ord. Scrophulariaceæ.

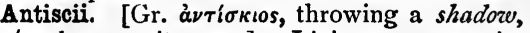
$\sigma \kappa ı$, the opposite way.] Living on opposite sides of the equator.

Antiscorbutic. Preserving from scurvy [scorbutus] (q.v.).

Antiseptic. Preventing putrefaction [Gr. $\sigma \eta \dot{n} \pi \omega$, I make rotten].

Antispast. A four syll. foot, $\checkmark--\checkmark,=$ iambus + trochee, and so, one drawn in $d_{i j}$.

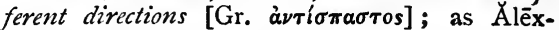
āndĕr, rědūcētŭr.

Antistăsis. [Gr.] A party, faction, political opposition.

Antistes. [L., one who stand's bejore another.] Chief priest, prelate.

Antistrǒphē. (Strophe.)

Antithĕsis. [Gr., opposition, change, transposition.] 1. Contrast, in word or sentiment, as "sōlĭtūdĭnem făciunt, pācem appellant." 2. In Gram., change of letter, as illi for olli. (Metaplasm.)

Anti-trades. Winds extending from the tradewind regions to near the poles; very variable; but their general direction is towards the poles. In the $N$. regions, S.W. currents of air prevail, called the S.W. Anti-trades; in the $\mathrm{S}$. regions, the prevalent winds are from the N.W., forming the N.W. Anti-trades. (See a useful manual of Physical Geography by S. Skertchly.)

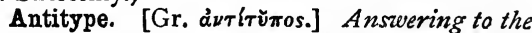
type or figure [rũos], as "Christ Jur Passover" (I Cor, v.).

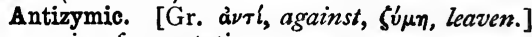
Preventing fermentation.

Antlers. [Cf. Fr. andouiller and entoillier, the first horns, (?) ante, before, œil, eye (vide Littré).] The male Cervidæ, or true deer (and, in the case of the reindeer, the females also) have solid bony horns or antlers, shed yearly. Beginning with a single "dag," they add a fresh "tine," or "tyne," on each renewal till the eighth year, after which the additions are less regular. (Deer, Stages of growth of.)

Antœcians. [Gr. ả $\nu \tau i$, and oîkos, a house.] In Geog., those who live under the same meridian but on opposite parallels of latitude.

Antonine, Itinerary of. An ancient geographical work, giving the distances on all the provincial roads, and from post to post, throughout the whole Roman empire. (Itinerary.)

Antonines. Antōninus Pius, Roman emperor, and his successor, M. Aurēlius A. ; types of good 
rulers (A.D. 138-180); reign of first peaceful, of second victorious.

Antonine, Wall of. From Firth of Clyde to Firth of Forth ; built about A.D. 140.

Antŏnŏmăš̌a. [Gr.] The use of an epithet, patronymic, etc., instead of a proper name, as the "Son of Peleus," the "Iron Duke," the "Sick Man," for Achilles, Wellington, the

Turkish sultan.

\section{Antony, Cross of st. (Cross.)}

Antony, Fire of St. A name for erysipelas.

Antrustions. Among the Franks, personal dependents of the kings and counts ; so called, beyond doubt, from the trust placed in them. They were also known as Fideles, faithful, and Leudes, people.

Anūbis. An Egyptian deity, Kneph, with the body of a man and the head of a dog.

Anus. [L.] The opening at the lower extremity of the alimentary canal.

Anversois. The inhabitants of Antwerp [Fr. Anvers].

Aonian. 1. Bœotian, Āŏnła being part of Bootia. 2. Belonging to the Muses; Mount Hělícon, and its inspiring fountain, Ăgănippē, in Aonia, being sacred to the Muses.

Aŏrist. [Gr. ảb the tense which leaves undefined the time of the action denoted by it.

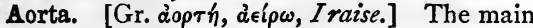
trunk of the arterial system, from which every artery of the body arises, except those which supply the lungs.

A outrance. [Fr.] To the uttermost.

Ap. Welsh prefix to names = son of, as in Ap Thomas, P-rice (Ap Rhys), P-ugh (Ap Hugh).

Apagogical argument. [Gr. a $\pi a \gamma \omega \gamma \eta$, in the sense of a leading away, not $=$ abduction in scientific logic.] Proves indirectly, by proving that the contradictory is impossible, e.g. Euclid, bk. iii. 9, 10, I I, etc.

\section{Apanage. (Appanage.)}

Apanthropy. [Gr. $\dot{\alpha} \pi \alpha \nu \theta \omega \pi_{i} \alpha$, from $a \pi b$, from, $\left.\&_{\nu} \theta \rho \omega \pi o s, \operatorname{man}.\right]$ Aversion to society.

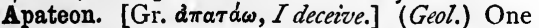
of the oldest known salamandroid Amphibia from the coal measures. (Batrachia.)

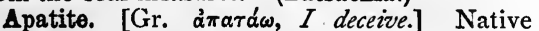
phosphate of lime, frequently found in greenish six-sided prisms, and resembling other minerals.

Apătūria. [Gr. ḋazoúpıa, from $\alpha=\alpha^{\prime \prime} \mu \alpha$, together, and $\pi a \tau \rho \iota \alpha$; $c f$. Adelphi; Amazons.] An Athenian festival, denoting the meeting of the people in their Phratries. (Phratry.)

Apaumé. [Fr. paume, palm.] (Her.) Having a hand opened, so as to show the whole palm.

A-peek, A-peak, i.e. on peak. (Naut.) When a ship is directly over her anchor it is $A$-peek. Short-stay $P$. and Long-stay $P$. when the cable is in a line with the fore and main stays respectively.

Apellæans. (Eccl. Hist.) A sect of the second century, who are said to have maintained that the body of Christ perished at $\mathrm{His}$ ascension.

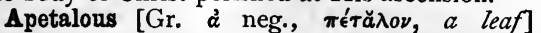
flowers = having calyx, as anemone, but not corolla ; or having neither, as in willows.

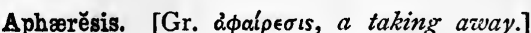
In Gr., the cutting out of a letter or syll. at the beginning of a word. (Metaplasm.)

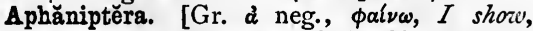
$\pi \tau \epsilon \rho o ́ v, a$ zving.] (Entom.) Ord. of insects with no perceptible wings, as fleas.

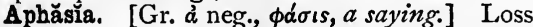
of memory for the names of things, which things are, nevertheless, in themselves as well understood as before.

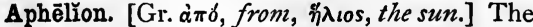
point of a planet's orbit most distant from the sun.

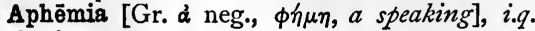
Aphasia.

Aphid, Aphis. Plant-louse, gen. of Hemipterous insects, with enormous number of spec. Females parthenogenetic to the ninth generation. (Parthenogenesis.)

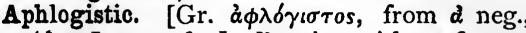
$\phi \lambda \operatorname{\gamma }^{\prime}[\omega, I$ set on fire.] Burning without flame.

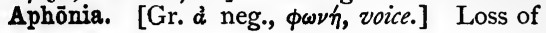
voice.

Aphŏrism. [Gr. ảфopı $\sigma \mu \delta s, a$ definition, à $\pi \delta$, from, $\delta \rho i \zeta \omega, I$ mark off by limits.] A short comprehensive maxim.

Aphrǒdïtē. (Anadyomene.)

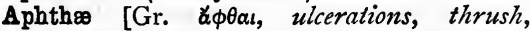

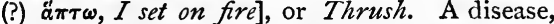
mostly of infancy, characterized by small white ulcers on the tongue, palate, and gums.

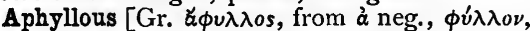
a leaf $]$ plants $=$ plants not having leaves ; e.g. mushroom.

Apiaceæ. [L. ăpĭum, parsley.] (Bot.) Another name for Umbellifěræ.

À piacère. [It.] At pleasure.

Apiary. [L. ăpīārium, ăpis, $a$ bee.] A place where bees are kept.

Apicēs jūris nōn sunt jura. [Leg. L.] Nice points of law are not laws; i.e. laws deal with broad principles, not with minute details.

Apician food. (Ǎpīcius, a notorious epicure of Rome, in the time of Tiberius.) Expensive, luxurious.

A picillary. At or near the ăpex.

Apiculate. (Bot.) Abruptly pointed. [Ăpicŭlus, dim. coined from L. ăpex, a point, summit. ]

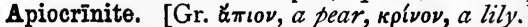
(Grol.) A pear-shaped encrinite (q.v.) ; found in Oolite; near allies are found in the chalk, and exist now.

Apis. In Egyptian religion, a bull which was supposed to represent the god Apis. By the Greeks it was called Epaphos, and was said to be the son of Io. (0siris.)

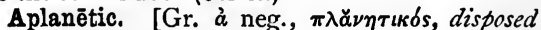
to wander.] When light, diverging from a point, enters a refracting medium having a surface so formed that the rays converge accurately to a point, the surface is A.

Aplastic. [Gr. à neg., $\pi \lambda \alpha ́ \sigma \sigma \omega, I$ form, shape.] Not easily moulded.

Aplomb. [Fr., lit. perpendicularity, à plomb, according to the plummet.] Stability, selfpossession.

Aplustrĕ. [L., Gr. $\not \phi \lambda \alpha \sigma \tau o \nu$.$] The carved$ stem, with its ornaments, of a Roman ship. 
Apncos. [Gr. đanoเa, from à neg., $\pi \nu$ éw, $I$ breathe.] A suspension of respiration, in real or apparent death.

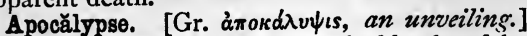
The title of the last of the canonical books of the New Testament. The term Apocalyptic literature is applied to works treating of this book.

Apocalyptio writings, The. Portions of Scripture which teach by visions, like in character to the Apocalypse; as Daniel and 2 Esdras. The $A$. number is 666 (Rev. xiii.).

Apocarpous pistil. [Gr. àmb, away from, $\kappa \alpha \rho \pi \delta s$, fruit.] (Bot.) One in which the carpels $(q . v$.$) remain distinct; e.g. ranuncŭlus. (Syn-$ carpous.)

Aросо̆рё. [Gr. а̇локолй, a cutting off.] (Gram.) Loss of the beginning, more often of the end, of a word. (Metaplasm.)

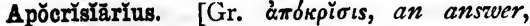
decision.] (Eccl. Hist.) The representative at the imperial court of a foreign Church or bishop ; at length $=$ papal nuncio.

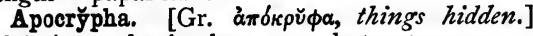
Claiming to be in the canon, but put away; or as "read not publicly, but in secret" (Preface to A., 1539).

Apocrypha of New Testament. The PseudoGospels, or Apocryphal Gospels. (Gospels.)

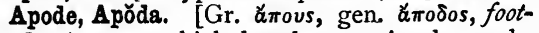
less.] A term which has been variously used : with Cuvier, $=$ the eel family ; with others, = sand-eels; with some old authors, the Ophiomorpha, including Cæcilǐ; with Mr. Darwin, one of the orders of Cirripedia; with others, again, some worm-like animals linking the worms to Echinoderms. It has also been applied to some intestinal worms, etc. Birds of paradise were so called, when known only by their skins.

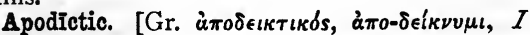
show forth.] In Aristotle and some moderns, demonstrative, not empirical, judgment.

Apodŏsis. (Protasis.)

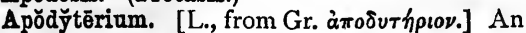
undressing-room in Roman baths.

Apǒgee. [Gr. $\tau \delta$ a $\pi o_{\gamma} \alpha \iota \nu \nu$, from à $\pi \delta$, from, $\gamma \hat{\eta}$, the earth.] The point of the moon's orbit furthest from the earth. When the earth is in aphelion, the sun is sometimes said to be in A.

Apollinarians. (Eccl.) The followers of Apollinaris, Bishop of Laodicea, who in the fourth century maintained that the Logos supplied the place of the human soul in Christ. The doctrine was denounced by the Council of Constantinople, A.D. 38r.

Apollinaris water. Effervescing mineral water from Apollinarisberg, on the Rhine, near Bonn. Apollo. (Phobus Apollo.)

Apollo Belvidere, i.e. in the Belvidere of the Vatican. A Greek work, found at Antium, 1503 . Apollȳon. [Gr. a $\pi 0 \lambda \lambda \omega \omega, I$ destroy.] The destroyer. (Abaddon.)

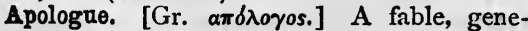
rally with special application; e.g. the belly and the members.

Apology for the Bible, etc. $=$ a defence.

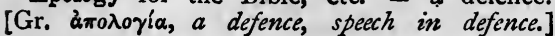

Apologetics, the scientific defence of Christianity; cf. I Pet. iii. 15.

Apomuios Zeus. [Gr. 'A $\delta \delta \mu v i o s$, from $\alpha \pi \delta$, from, $\mu v \hat{\imath} a, a f l y$.$] Averter of flies. (Beelzebub;$ Mniagros.)

Aponeurōsis. [Gr.] (Anat.) Expansion of a muscle into a tendon [ $\nu \in \hat{v} \rho o \nu]$.

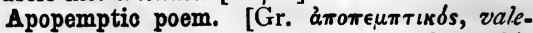
dictory.] Addressed to one about to leave his country on a journey; e.g. Horace, Od. i. 3.

Apophthegm. [Gr. $\dot{a} \pi \delta \phi \theta \in \gamma \mu \alpha$.] A terse, sententious saying; a maxim.

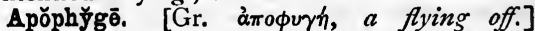
(Arch.) A curve connecting a shaft with a fillet, either at the top or at the bottom of a column (Brande and Cox).

Apoph y̆sis. [Gr. ànó $\phi \check{v} \sigma \iota s$.$] (Anat.) A pro-$ cess or prominence of a bone ; e.g. for the insertion of a muscle. (Bot.) A fleshy tubercle ; e.g. from which an urn moss grows.

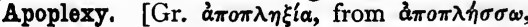
$I$ strike off or dozen.] A sudden extravasation of blood or serum in the brain, characterized by loss of sensation and voluntary motion.

Apǒsiōpēsis. [Gr.] A figure in Rhetoric, by which a sentence breaks off abruptly, leaving the hearer or reader to supply the rest, as; "Quos ego-Sed "(Virgil).

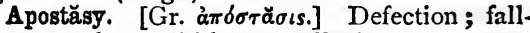
ing away from a faith or an allegiance.

Apostēme. [Gr. ả $\pi \delta \sigma \tau \eta \mu \alpha$, an interval.] A separation of purulent matter, an abscess ; corr. into Apostume and Imposthume.

Apostil. A marginal to a book or document. (Fr. apostille, à $=$ ad, and post illa, sc. verba.] (Postil.)

Apostle spoon. Of old silver : the handle ending in the figure of an Apostle; generally presented at christenings.

Apostles. (Naut.) (Rnight-heads.)

Apostolical Canons, and (2) Ap. Constitutions. Two collections-(?) Antenicene, authorship unknown- of rules concerning Christian duty, Church constitution, government, ministry, worship; the latter ascetic, and exalting the priesthood excessively.

Apostolical Majesty, His. A title of the King of Hungary, who is also called Emperor of Austria. Pope Sylvester II. so named St. Stephen, first King of Hungary, after his conversion; crowned A.D. I000.

Apostolio Fathers, i.e. contemporary with, or living just after, the apostles; they are five : Clement of Rome, Barnabas, Hermas, Ignatius, Polycarp.

Apostölici. (Apotactíci.)

Apostrŏphë. [Gr.] 1. (Rhet.) A sudden breaking off from the previous method of an address, in order to address, in the second person, some person or thing absent or present. 2. (Gram.) The mark (') of a letter or letters omitted ; as o'clock.

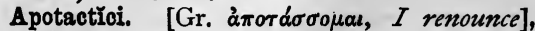
Apostolirici. A sect of the third century, revived in the twelfth century; they professed to renounce marriage, wealth, etc.

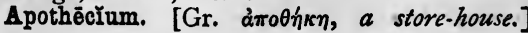


(Bot.) A flat disc, containing the asci of lichens; often called a Shield.

Apǒthĕösis. [Gr.] Deification.

Apŏtŏmē. [Gr.] In Geonı., the difference between two lines represented by numbers, one or both of which are.quadratic surds.

Apozem. [Gr. àmó $\epsilon \mu a$, from $\alpha \pi \delta$, from, off, Séw, I boil.] A decoction.

Appair, v.a. to impair; and v.n. to become worse. [Fr. à pire, to worse.]

Appalement. [Fr. pâlir, to grow pale.] Depression, from fear.

Appănage. [L.L. appanagium, an allowance for bread (panis).] (Feud.) An allowance to the younger branches of a sovereign's house from the revenues of the country. A district thus conferred was called panagium.

Apparel. [Preserving the meaning of preparation in Fr. appareil, appareiller, to make things matched, pareil, L.L. părĭcŭlus.] (Naut.) Masts, yards, sails, ground gear, etc. Apparelled, fully equipped.

Apparent, Heir. Certain heir, in whom, if he live, the succession vests absolutely; opposed to $H$. Presumptive, i.e. presumed, in the absence of A., and dependent upon contingencies.

Apparent time. (Timo.)

Appārítor. [L.] 1. An attendant on a Roman magistrate or judge, to receive orders, etc. 2. In ecclesiastical courts, an officer who attends in court, receives the judge's instructions, cites defendants, sees to the production of witnesses (see Canon CXXXVIII.).

Appaumé. (Apaumé.)

Appellant. [L. appellantem, appealing.] (Leg.) A party appealing from the judgment of an inferior court. His opposer is Respondent.

Appellate jurisdiction. (Leg.) Power of a judicial body or a judge to hear appeals from the decision of inferior courts. In England, the House of Lords has A. J., but modified by the Judicature Act.

Appendicŭlate. [L. appendix, an addition.] (Bot.) Added appendage, or appendicle ; accompanying, but not essentially; e.g. stipules, tendrils, hairs, etc.

Appentis. [Fr., L.L. appendǐcium.] A shed, pent-house, upon columns, or brackets.

Appian Way. Made by Appius Claudius the censor, A.U.C. 442, from the Porta Căpēna, at Rome, through the Pontine Marshes to Căpua ; afterwards extended to Brundŭsium (Brindisi).

Applegath's maohine. The first verticalcylindrical printing-machine ; used for the Times since 1848 .

Apple, Prairie. (Bread-root.)

Apples of Sodom. (Sodom, Vine of.)

Appliqué. [Fr.] In needlework, a pattern cut out from one foundation, and applied to another.

Appoggiatura. [It. appogiare, to lean upon.] (Music.) A note of grace or embellishment, leant upon, and borrowing one-half from the time of the more important note which it precedes, and with which it is now very often written as incorporated. It differs from the Acciatura [It. acciare, to mince], which is simply a grace note, without any recognized time.
Appraise. [Fr. apprécier, L. prětium, value.] 1. To value goods sold under distress $(q . v$.$) .$ 2. To praise.

Apprecation. [L. apprěcor, $I$ worship.] Earnest prayer.

Apprehension, simple. [L. apprehensio, -nem, a seizing on.] (Log.) The notion of objects as received by the mind. It is said to be incomplex when it is of separate objects; complex when of objects related to each other.

Apprentice. [Fr. apprendre, to learn.] (Leg.) Formerly a barrister under sixteen years' standing ; after which he might be a Serjeant-at-law.

Appropriation. [L. adpropriātio, -nem, from proprius, proper.] (Eccl.) Perpetual annexation of a benefice to a corporation sole or aggregate, i.e. a parson, college, etc. Impropriation [improprius, unsuitable], the holding by a layman of the profits of ecclesiastical property.

Appropriätion Clauses, The. An expression common in the discussions in Parliament, 1833 38 , referring to certain proposed methods of dealing with the Irish Church temporalities.

Approver. In Law, one who, being arraigned for treason or felony, confesses the indictment, and takes an oath to reveal all treasons or felonies known to him as committed by others.

Approximätions, Successive. A series of numbers which approach more and more nearly to the actual numerical value of a quantity ; thus, the ratio of the circumference to the diameter of a circle is expressed more and more nearly by the following numbers : $-3, \frac{22}{7}, \frac{355}{113}$, etc., and these are $S$. A. to its actual value.

Appui. [Fr., L.L. appŏdiäre, to support, pǒdǐum, an elevated place, a balcony.] A support.

Appurtenances. (Law.) Things belonging or appertaining to another thing as principal.

Apres moi (nous) lo déluge. [Fr.] After me (us) the flood.

A primo. [L.] Lit. from the first.

A princǐpio. [L.] From the beginning.

A priori [L.] reasoning is from the former, i.e. the known fact, principle, law, intuitive conception, to the result; so from knowledge of astronomy an eclipse is predicted. A posteriöri, from the latter fact or event, etc., we reason back to its cause ; as from the fact of an eclipse, to its cause and explanation.

Apron, or Stomach-piece. (Naut.) A strength. ening timber, shaped to fit the sides of the bows, scarfed to the fore dead-wood knee (q.v.), slanting upwards, and fitting to the stem above the end of the keel.

A propos de bottes. [Fr.] Lit. in reference to boots $=$ having no connexion with the matter.

Apsăras. [Skt. apa, L. aqua, water.] The Nymphs of the Rig Veda.

Apse, Apsis, or Absis. [Gr. ả $\psi(s$, an arch.] 1. (Arch.) The end of the choir of a church, whether it be circular, polygonal, or even rectangular. In the early Christian churches, the bishop's throne was placed in the apse behind the altar, and upon the axis of the church. Usually the word is taken to mean any polygonal termination of a building. 2. (Astron.) A point in 
a planet's orbit where it moves at right angles to the radius vector; the apses are the aphelion and perihelion, and the line joining them is the line of apsides.

Apsidal. Belonging to an apse.

Apsides, Line of. (Apse.)

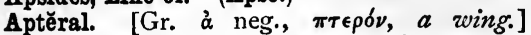

(Arch.) A building without lateral columns, and therefore not peripteral (q.v.).

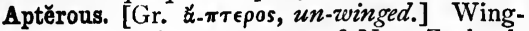
less, as the kiwi, or apteryx of New Zealand, among birds, and the flea among insects.

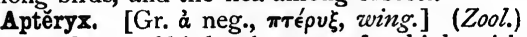
Fam. and gen. of birds, about two feet high, with brown, hair-like plumage, and rudimentary wings. Kiwi, New Zealand. Ord. Strūthǐōnes.

Aptōte. [Gr. ă $\pi \tau \omega \tau o s$, not fallen or declined.] In Gram., a noun without distinction of cases ; indeclinable.

Apuleius. (Golden ass.)

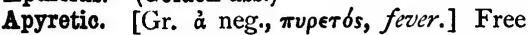
from fever.

Apy̆rous. [Gr. ă $\pi v \rho o s$, from à neg., $\pi \hat{v} \rho$, fire.] Incombustible, unsmelted.

Aqua fortis. [L., strong water.] Nitric acid. A. rēgia, a mixture of one of nitric acid, to two or more of hydrochloric acid; royal water, because dissolving gold, the king of metals. A. Toffana (prepared by a woman so named), or Aquetta, little water, a celebrated poison used in Rome about the end of the seventeenth century ; (?) a solution of arsenic.

Aqua mărina. [L., sea-water.] Aquamarine, some blue and sea-green varieties of beryl (q.v.).

Aquam perderre. [L.] To lose time; lit. the water of the water-clock, Clepsydra (q.v.), which regulated the length of speeches.

Aquārius. [L.] The water-bearer; the eleventh sign of the Zodiac, through which the sun moves in January and February. Also, one of the twelve Zodiacal constellations.

Aquatinta. [L. aqua tincta, water-dyed.] A mode of etching on copper, producing imitations of drawings in India ink, bister, and sepia.

Aque. [Cf. Acon.] A Rhine boat with flat sides and bottom.

Aqueous humour of the eye occupies the anterior chamber of the eye, i.e. the space between the cornea and the front of the lens.

Aqueous rocks. In Geol., rocks derived from the action of water. These include the whole series of fossiliferous rocks in all parts of the world.

Aquilæ. [L. for à $\epsilon \dot{\omega} \mu a \tau a$, parts adorned with (Gr. à $\in$ rol) eagles.] (Arch.) The pediment of a Grecian temple.

Aquilla non căpit muscas. [L.] An eagle does not catch fies.

Aquilěgìa. [L., water-gatherer, in the hollow of its leaves.] (Bot.) Columbine, a gen. nearly related to aconite; ord. Ranunculācěæ.

Aquilo. [L., root ak=sharpness.] The north wind.

Aquitaine. Old province of France, S. of Brittany and Anjou.

-ar. [Indo-Europ.] 1. Name or part name of rivers = flowing (?), e.g. Ar-ar, Ar-ây, Ar-bach,
Tam-ar, Aar (?). 2. Celtic $=a t, o n, e . g$. Armorici, on (by) the sea, Armagh, on the plain, Arles (Ar-laeth), on the marsh.

Arab, street. A homeless child in a city.

Arăba. In Turkey, plain rough cart, or box, on four wheels, drawn by bullocks.

Arabesque. Properly of an Arabian or Saracenic style, in which the decorations of walls consist of fruits, flowers, and foliage, curiously interlaced. But the term is also applied to styles more or less resembling it, which existed long before the rise of the Saracenic.

Arabian Nights' Tales. (Thousand and One Nights.)

Arabii. An Arabian sect in Origen's time, who believed the soul to be dissolved with the body by death, but given back at the resurrection.

Arabin. Chief constituent in gum-arabic.

Arabo-Tedesco. [It., Arab-German.] A term sometimes used to denote Byzantine art, and the combination of Moorish and Gothic art in N.Italy.

Araceæ, or Aroidea. (Bot.) An ord. of plants, of which arum is the type gen.

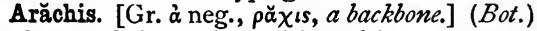
A plant, ord. Legumin., cultivated in warm parts of America, Asia, Africa; which matures its pea-like, oily, edible fruits underground. American name, Mandubi; also called Pea-nut or Monkey-nut.

Arachnē. [Gr., a spider.] A Lydian girl, changed to a spider for vieing with Athena in weaving; meton., a good weaver.

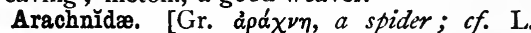
ărāněa.] (Zool.) Class of Annulōsa or Arthrŏpŏda, including mites, spiders, and scorpions.

Aræostyle. [Gr. ápaıó $\sigma \tau \bar{v} \lambda o s$, with columns far apart.] (Arch.) A building, of which the columns are separated from each other by four or five diameters.

Aræosystyle. (Arch.) A building in which the columns are arranged in pairs, with space of three diameters and a half between the pairs.

Aragonite. (Min.) Prismatic carbonate of lime; abundant in a ferruginous clay in Aragon.

Arak, Arrack, Araki, Raki. [Ar. arak = exudation.] A spirit distilled from various substances-fruits, rice, palm sugar ; but principally from the juice of the Areca palm.

Aramaic languages. The northern branch of the Semitic family of languages, which includes the Chaldee and Syriac dialects.

Arāněous. [L. ărāněōsus, ărāněa, $a$ spider; cf. Gr. àpá $\chi \nu \eta$.] Cobweb-like, e.g. the membrane enclosing the crystalline humour of the eye.

Arango. [Native name.] A rough carnelian bead, used in trading with Africans.

Aräre liitus. [L.] Lit. to plough the sea-shore; to labour in vain.

Arbalist. [O.Fr. arbaleste, cross-bow, L. arcubalista.] Cross-bow formed of a wooden stock with a bow of steel, and fired by means of a small lever.

Arbiter bilbendi. [L.] Master of the drinking feast. (Symposiarch.)

Arbǐter elĕgantiärum. [L.] $A$ master of the ceremonies; an authority on matters of etiquette and taste. 
Arbor. (Shaft.)

Arbor Diānæ. [L. for tree of Diana, i.e. silver.] Tree-shaped crystals of silver. Similar crystals of lead are called arbor Saturni [L., tree of Saturn].

Arborētum. [L.] A place set apart for the special cultivation of trees [arbores] of different kinds.

Arborization. A tree-like appearance; of blood-vessels, or in minerals, etc.

Arbor vitæ. [L.] (Bot.) Thuja, a gen. of trees, ord. Conı̌ferræ, allied to the cypress; evergreens, with compressed or flattened branchlets.

Arbuscular. Like a shrub or small tree [L. arbuscǔla].

Arbŭtus. [L.] (Bot.) A gen. of evergreen shrubs, ord. Ericeæ; its fruit a rough berry with five many-seeded cells. A. unèdo, the strawberry-tree, is a characteristic feature of the rocks at Killarney.

Arc. [L. arcus, $a$ bozv.] A portion of a curved line; as an arc of a circle. Sometimes called an Arch.

Arcăděs ambo. [L.] Virgil, $E c l$. vii. 4, both Arcadians; simple shepherds, both of them; often used unfavourably, a pair of them.

Arcadia, The Countess of Pembroke's. Sir Philip Sidney's romance, published A.D. 1590.

Arcadian simplicity, etc. Like that of Arcădia, in Peloponnesus, mountainous and central, therefore not conquered by the Dorians, nor open to the sea, nor to other states.

Arcāna. [Neut. plu. of L. arcānus, hidden.] Mysteries (q.v.).

Arcāni Disciplīna. [L., discipline of the secret.] A name given to a supposed system in the primitive Church, by which its most important doctrines were divulged only to a select class; called also the Economy, or the principle of reserve in the communication of religious doctrine.

Arc-boutant. [Fr. bouter, to set, push.] A flying buttress.

Arch. [L. arcus, $a$ bow.] In Building, a structure disposed in a bow-like form, the materials of which support each other by their mutual pressure. An arch described from a single centre is semicircular. If from two centres, each at the spring of the arch, it is equilateral. If the centres are without the spring, it is an acute-angled $A$. If they are within it, it is obtuse-angled. Arches of three and four centres are lower than arches described from two centres, and are used chiefly in the Later Continuous or Perpendicular work of this country. The Tudor arches are chiefly of this kind. A segmental $A$. is one, the curve of which is less than a semicircle. A stilted $A$. is one which starts from a centre or centres placed above the capital. Foil arches are those which are foliated in outline without a rectilineal A. to cover them. Ogee arches are those which have their sides formed of two contrasted curves.

Arch-. [Gr. à $\rho \chi \omega, I$ rule.] First or most prominent.

Archæolithic. (Prehistoric archæology.)

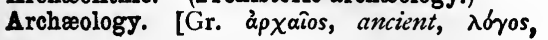

discourse.] The scientific study of antiquities of art, etc.

Archæoptĕryx [Gr. à $\rho \chi a \hat{\imath} o s$, ancient, $\pi \tau$ té $\rho v \xi, a$ wing] macroura [uakpós, long; oủá, tail]. (Geol.) A fossil bird, very rare, about the size of a rook, with some twenty free caudal vertebræ. Oolite of Solenhofen.

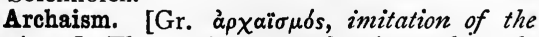
ancients.] The employment of antiquated words and phrases.

Arch-chancellor. Under the Empire, an officer who presided over the secretaries of the court.

Arch-chemic. A name applied by Milton to the sun, as having the greatest chemical power.

Arches, Court of Arches. [L. Cürǐa dē arcŭbus.] (Leg. Eccl.) Court of appeal, whose judge (dean) used to sit in the Church of St. Mary-leBow (so called from the arcüs, arches, bows, on which the steeple was reared). (Court, Christian.)

Archĕtype. [Gr. á $\rho \chi \chi^{\prime} \tau$ v̌mos.] 1. The original idea of the work as it exists in the workman's mind before its execution. With Plato, the cosmos as it existed before creation in the Divine Mind. (Ideas.) 2. In Palæography, an older MS. to which extant MSS. can be traced, not being the original author's $\mathbf{M S}$.

Archil. (Litmus.)

Archilochian verse. The dactylic semipentameter, $-\checkmark v 1-v v 1-\|$, much used by Archǐlŏchus of Paros, circ. 700 B.c. ; said to be the earliest Greek lyrist, and to have invented iambic verse ; bitter and satirical ; hence "Archilochian bitterness," and "Parian verse" (Horace, Art. Poet., 79).

Archimago. [As if from a Gr. word à $\rho \chi i ́ \mu a \gamma o s$, meaning chief-wizard.] In Spenser's Faëry Queen, an impersonation of Hypocrisy and Deceit.

Archimandrite. A title of the Greek Church, equivalent to abbot in the Latin; the word mandra, in the language of the Lower Empire, signifying a monastery.

Archimejdean screw (said to have been invented by Archĭmēdes while in Egypt). A pipe, with one end in water, wound spirally round a cylinder which is held in an inclined position; when the cylinder is made to turn on its axis water is raised along the pipe. There are several forms of this machine.

Arching, or Hogging. (Naut.) The falling of the stem and stern of a vessel when brokenbacked.

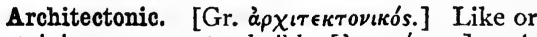

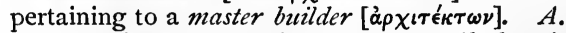
art, or science, one which organizes all that is beneath it.

Architrave. (Order.)

Architriclinos. (Bymposiarch.)

Archives. [L. archīvum, from Gr. à $\rho \chi \in \hat{\imath} \mathrm{o} \nu, a$ public building, town hall, etc.] 1. Places for public records. 2. The records themselves. Archivist, a keeper of A.

Archivolt. [It. archivolto, vault, arch.] 1. An arched vault. 2. Renaissance term for the ornamented band of mouldings round the voussoirs $(q . v$.$) of a classical arch; sometimes the$ 
mouldings occupying the face and soffits of a mediæval arch.

Arch-lute. A double-stringed theorbo (q.v.), an Italian instrument, with fourteen notes, the lowest being the bass $G$, for accompanying bass voices; very powerful; about five feet long; employed by Corelli, Handel, etc.

Arch-marshal. [Ger. erz-marschall.] Grandmarshal of the empire; a dignity once attached to the Elector of Saxony.

Archöns. [Gr., a ruler.] The chief magistrates in ancient Athens, chosen yearly, nine in number : the first called Epony̆mos, as giving his name to the year; the second, Basileus, king, as being the high priest; the third, Polemmarch, ruler in war, as commanding the army. The other six were called Thesmorthĕtæ, setters forth of the law.

Archontics. A sect of the second century; so called from the Gr. $a \rho \chi \omega \nu, a$ ruler, as holding strange notions respecting the Deity and the origin of the world.

Arcite. In Chaucer's Knight's Tale, Emily's lover, killed by a fall in the lists just as he had won her hand.

Arcograph. [A word made up from' L. arcus, $a$ bow, and Gr. $\gamma \rho a ́ \phi \omega, I$ write.] An instrument for describing arcs of circles in cases in which compasses cannot be used.

Arctic Zone. (Zone.)

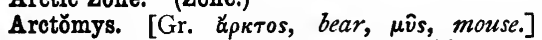
(Zool.) Marmot, gen. of Rodent, something like a rabbit; several spec. in Europe, Asia, and N. America, at high altitudes. Fam. Sciūrǐdæ, squirrel-kind.

Arctūrus. (Myth.) (Rishis, The Seven.)

Arcuate. In the form of a bow [L. arcus].

Arcuātion. [L. arcuatio, -nem, an arching, arcading.] The bending of branches into the ground as layers, which take root and become separate plants.

Arcubălist. (Arbalist.)

-ard. An element in names. 1. Celtic, high; e.g. Ard-rossan, Liz-ard. 2. Teutonic, strong [Goth. hardus, A.S. heard], as in Godd-ard Bern-ard ; exceeding in, as in slugg-ard, drunkard, dot-ard.

Ardassine. Very fine Persian silk.

Arden, The Forest of. The scene of cheerful exile and of love-making, in Shakespeare's $A s$ You Like It.

Are. [Fr., L. ärea, an open space.] One hundred square mètres or $119^{\circ} 6033$ square yards.

Arĕa. [L., an open space.] The extent of the surface of any plane figure; to find the A. of a plane figure or of a curved surface (as of a sphere) is to find the square, or the number of square units, having the same extent as the figure or surface.

Aread, Arede. [A.S. aredan, ræd, counsel.] To declare, direct, explain.

Arëca, Areek. A beautiful gen. of palms, ord. Palmaceæ. A. catechu produces the betelnut, universally chewed in E. India. (Arak.)

Areek, i.e. on-reek. [A.S. rec, Ger. rauch, smoke.] Reeking.

Areffy. [L. ārěo, I am dry.] To make dry.
Arēna. [L., sand.] 1. The sanded floor of the amphitheatre; and so the floor or body of a public building. 2. (Metaph.) Contest; place of contest or debate, etc.

Arendator. [L.L. arrendo, I pay rent.] $\mathbf{A}$ contractor with the Russian Government for rents of farms.

Areng. A palm of the Indian Archipelago, yielding sago, and from which the palm wine is made.

Arěŏla. [Dim. of L. ārěă.] A small space; interstice ; variously applied in Bot. and Anat.; and, especially, to the coloured ring round the nipple, or manmilla.

Areolar tissue, formerly called Cellular $T$. That which is found investing and forming the basis of all tissues.

Areolate. Divided into small spaces [L. äreŏlæ].

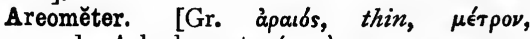
measure.] A hydrometer (q.v.).

Arēŏpăgitǐca. (Areopagus.) Milton's speech for the liberty of unlicensed printing, addressed to Parliament, I644.

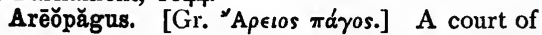
judicature at Athens; so called as meeting on the Hill of Ares. Its power was greatly increased by Solon.

Arête. [L. ărista, in the sense of a fish-bone.] The narrow ridge of a mountain rock. (Arris.)

Arethūsa. (Ortygia.)

Aretine ware. Ancient red pottery of Arētium (Arezzo) ; made, on the decline of Greek and Etruscan work, of a darker red and higher finish than the Samian (q.v.).

Aretinian syllables : Ut, $\mathrm{Re}, \mathrm{Mi}, \mathrm{Fa}$, Sol, $\mathrm{La}$, Si. (Sol fa.)

Arètology. The science of moral virtue

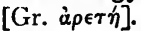

Argála. (Marabou.)

Argali (Mongolia). Wild sheep.

Argan. In Molière's Le Malade Imaginaire, the hypochondriacal hero.

Argand lamp. (From M. Argand, the inventor.) A lamp having a ring-shaped burner covered by a chimney, so that the flame has a current of air both on the inside and the outside.

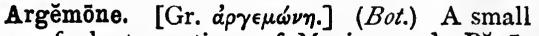
gen. of plants, natives of Mexico, ord, Păpāvěrāceæ. A. mexicana has seeds narcotic, purgative, diuretic, and yielding a valuable oil to painters. It is often a noxious weed in the tropics.

Argent. [Fr., from L. argentum, silver.] (Her.) White or silver, represented in engraving by a plain white surface.

Argentan. German silver [L. argentum]; an alloy of two parts of copper, one of nickel, one of tin.

\section{Argentěus Cōdex. (Codex.)}

Argentine. [L. argentum, silver.] (Min.) 1. A white variety of crystallized calcareous spar, laminated, and somewhat siliceous. 2. A white variety of shale.

Argentine Republio. A confederation occupying the valley of the Rio de la Plata, S. America. 
Arghool. An Egyptian wind instrument, a kind of flute made of a cane or bundle of canes; there are different kinds.

Argil. [L. argilla.] Clay, or the pure earth of clay, trisilicate of alumina.

Argillaceous. (Geol.) Clayey, having the characteristics of clay [L. argilla]. A. rocks, having clay as the principal ingredient ; e.g. clay, shale, loam, marl, etc.

Argillite. [L. argilla, clay.] Clay-slate.

Argive. In the Iliad, the collective name of the tribes who followed Agamemnon to the attack of Troy.

Argo. (Argonants.)

Argol. The crust deposited inside wine-casks. It is an impure salt of tartar, and is used in dyeing, etc.

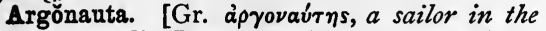
Argo.] (Zool.) Paper-nautilus, gen. of mollusc. Female (poulpe) occupies single-chambered shell, unattached; and advances by ejecting jet of water. Male is smaller (not one inch long), and has no shell. Ord. Dibranchǐăta, class Cěphălŏpŏda.

Argǒnauts. (Gr. Myth.) The chieftains who went with Jason in the ship Argo to Colchis, to recover the golden fleece of the ram which had borne away Phrixus and Hellê from Orchŏmĕnos.

Argonyn, Argnesyn. One in charge of galleyslaves.

Argǒsy. (Probably from the mythical ship Argo.) A merchant-ship, generally from the Levant.

Argot. [Fr] Slang, cant phraseology. Origin of the word unknown.

Argument. . [L. argūmentum.] (Log:) The reasoning involved in the premisses and conclusion of a Syllogism.

Argümentum ad hominem. [L.] An argument pressed home for personal application. $A$. ad ignorantiam, one founded upon your adversary's ignorance. $A$. ad věrēcundiam, one addressed to the sense of shame. $A$. bäcülinum [coined from L. băcŭlus, $a$ stick], an appeal to force.

Argus, or Argos Panoptes. [Gr., the bright, all-seeing one.] In Gr. Myth., the being with a thousand eyes, guardian of the horned maiden Io, i.e. the moon; killed by Hermes, the messenger of the morning. The eyes of Argus are the stars.

Argute. [L. argūtūs.] Subtle, acute.

Arĭa. [It.] The air of a song.

Ariadne. In Gr. Myth., the danghter of Minos, and wife of Dionysus or Bacchus.

Arians [Arius, Alexandrian priest] denied the three Persons in the Holy Trinity to be of the same essence, affirming the Word to be a creature; condemned by Council of Nice, A.D. 325.

Ariel [Heb., lion of God, or (?) hearth of God], i.e. Jerusalem (Isa. xxix.).

Ariel. In Shakespeare's Tempest, a good spirit who works wonders for Prospero.

Aries, First point of. The vernal equinox (Equinox). The Ram (Aries) is the constellation in which the vernal equinox was situated in the time of Hipparchus ; but now, in consequence of precession, the bright star of the Ram is about $30^{\circ}$ to the east of the first point of Aries.

Arietta. [It.] Dim. of Aria.

Aril, Arillus. [L.L. arilla, a piece of red cloth.] (Bot.) A covering to the seed, derived from expansion of the placenta; the mace of the nutmeg. Adj., Arillate.

Arimanes, Areimanios. Gr. corr. of Ahri$\operatorname{man}(q . v$.$) .$

Ariolation, Hariolation. [L. harı̌olus, $a$ soothsayer.] Soothsaying.

Arioso. [It.] Marked by melody as distinguished from harmony.

Arista. [L.] (Bot.) The Awn, the pointed beard issuing from the glume, or floral scales of grasses ; probably lengthened rib of the envelope of the flower. Aristate, having an A. [Awn, (?) a contraction of $\mathrm{L}$. ăvēna, oats; or cf. $\mathrm{Gr}$.

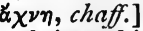

Aristarchian criticism. Bold and severe, like that of the Alexandrian grammarian, Aristarchus, circ. 160 B.C. He edited Homer, and obelized numerous verses [Gr. o’ $\beta \in \lambda \delta \delta s, a$ pointed instrument]; an horizontal line, _, being used to denote a spurious passage; hence to obelize, to mark something censurable in a book by a dagger $t$ in the margin.

\section{Aristocracy. (Oligarchy.)}

Aristŏgeiton. (Harmodius.)

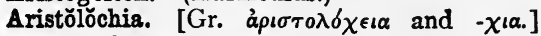
(Bot.) Birthwort, a gen. of plants, found mostly in hot countries; ord. Aristolochiäceæ; herbaceous plants or shrubs, often climbing.

Aristolögy. [Gr. a $\rho$ เ $\sigma \tau o \nu$, the déjeuner.] A facetious word $=$ science of breakfasts or luncheons.

Aristophanic. In the style of Aristŏphănes ; witty and humorous, but highly personal and somewhat coarse.

Aristotelian. Of or after Aristotle [Gr. 'A $\left.\sigma \tau \sigma \tau \epsilon^{\lambda} \eta s\right]$, the great analytical philosopher of Greece, the first European to systematize logic, ethics, metaphysics, and to study natural philosophy practically. (Causes.)

Aristotle's lantern, i.e. shaped like a lantern, and described by A. A unique arrangement, in the mouth of the globular sea-urchin, of five three-sided teeth set circularly, which triturate food.

A rivedersi. [It.] Till we meet; (good-bye) till we again see each other; so Fr. au revoir; Ger. auf wiedersehen.

Ark of the covenant. In the Jewish tabernacle, a coffer under the mercy-seat, containing the golden pot of manna, with Aaron's rod and the tables of the covenant.

Arkose. (Geol.) Débris of granite, reconstructed into a rock. [A most unsatisfactory term : said to be from a supposed Gr. adv. à $\rho \kappa \hat{\omega} s$, sufficiently, i.e. to resemble granite; or from a $\rho$ kos, another form of apктos, the north; because first studied in Sweden!]

Arles. [A.S. earles.] Earnest money, to bind a bargain. (Fessen-penny.)

Armāda. [Sp., armed.] In Eng. Hist., the fleet with which Philip II. of Spain proposed to 
conquer England. Called by the Spaniards the "Invincible A."

Armatŏli. A Greek national militia, known in the Middle Ages, and in the war of the Greeks rising against the Turks.

Armature. [L. armātūra.] 1. Body armour. 2. The pieces of soft iron placed at the extremities or poles of magnets to preserve their magnetic power. 3. Iron bars used as supports for the columns or other parts of a building.

Armed. (Her.) Having horns, beak, talons, etc., differing in colour from the body.

\section{Armenian Liturgy. (Liturgy.)}

Armenians. Christians of Armenia, the first country in which Christianity was recognized as a national religion, in the fourth century; at a later time adopted Eutychian (q.v.) or Monophysite heresy.

\section{Armeria. (Thrift.)}

Armida. The fair enchantress in Tasso's Ferusalem Delivered (transl. by Fairfax, A.D. 1600), who detained Rinaldo in voluptuous ease. Her chief means of captivating was a magic girdle.

Armiger. [L., bearing weapons.] (Her.) An esquire ; one having a right to armorial bearings. Armilla. [L., bracelet.] (Ornith.) Circular mark at base of tibia of birds. Armillated, provided with an $\mathrm{A}$.

Armillary sphere. [L. armilla, a circular ornament, bracelet.] An astronomical instrument, consisting of a set of concentric rings representing the meridian of the station, the ecliptic, and a meridian of celestial longitude, with an auxiliary circle turning round the points representing the north and south poles, and carrying the poles of the ecliptic. It was formerly used, e.g. by Tycho Brahe, for observations made out of the plane of the meridian.

Armillus. Jewish name for final Antichrist.

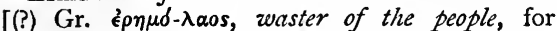

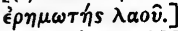

Arming. (Naut.) Tallow placed on a sounding-lead, to pick up objects from the sea-bottom. Arming-press. A bookbinder's tool.

Armings. (Naut.) Red cloths, hung fore and aft on holidays by foreigners.

Arminians. (Eccl. Hist.) The followers of Arminius, a Dutch divine of the sixteenth century, who opposed the doctrine of an absolute predestination of the elect. They were also called Remonstrants, from a writing which they presented in protest against this doctrine to the States of Holland in 1609.

Armistice. [L.L. armistǐtı̌um.] A suspension of hostilities by agreement.

Armoric, or Breyonec. Language of Brittany, representing the Gadhelic or first great Celtic branch of the two which came westward across the Continent. It is still spoken by a million and a half of French subjects. Armorica = the land upon the sea (Taylor's Words and Places).

Armour-clad. (Naut.) A ship having her sides covered with iron or steel plates.

Armourer. 1. One who makes arms. 2. One who has the care of arms.

Armours. (Tor A-)
Army Discipline and Regulation Act. Passed by Parliament in A.D. I879, to supersede the Mutiny Act (q.v.) and Articles of War (q.v.).

Army Service Corps includes the present Commissariat, Transport, and Ordnance Store Departments of the Army.

Arnaa, Arnee, Arni. The Indian buffalo, nearly seven feet high, black, inhabiting forests at the base of the Himalayas. Būbălus, Buftălus. Sub-fam. Bǒvinnæ, fam. Bǒvǐdæ, ord. Ungŭlāta.

Arnica, Leopard's bane. (Bot.) A gen. of plants, ord. Compositæ. Tincture of A. montāna, used in medicine, as a remedy for bruises. A handsome perennial, with yellow marigold-like flowers ; native of mountains of Europe.

Arnoldists. (Eccl. Hist.) The followers of Arnold of Brescia, who, in the twelfth century, protested against the abuses of the papal court. He was burnt at the desire of the English pope, Adrian IV. (Nicolas Breakspear).

Arnot, Arnut, i.e. Earth-nut. (Pig-nut.)

Arnotto. (Annotta.)

Aroba. [Ar. ar-rub.] The fourth part.

Aroideæ. (Araceæ.)

Aroint thee. Aroynt $=$ gnawed. $\quad[$ Fr. ronger, according to Richardson.] Generally considered =begone, and etym. unknown ; but Skeat, Etym. Dict., gives Icel. rýma, to make room ; rime ta, make room, becoming rýnt ye by an easy corruption.

A Roland for an Oliver. A phrase equivalent to "Tit for tat," a blow from Roland being equal to one from his fellow-paladin Oliver. (Paladin.)

Aroph, i.e. Ărōma philosophōrum, one of several pretentious titles of medicine used by Paracelsus and others, who pretended to possess the elixir of life, etc.

Arpeggio. [It., harping.] The playing of the notes of a chord not together, but in rapid succession, as on a harp.

Arpent. [L. arepennis, a Gallic word, a halfacre.] The old French acre; the A. de Paris was 32,400 French square feet or $\frac{5}{6}$ of an English acre ; the $\mathrm{A}$. des eaux et forêts or mesure royale was $4 \delta, 400$ French square feet, or about $1 \frac{1}{4}$ English acres.

Arquebus. [Fr. arquebuse, introduced irom It. archibuso.] The first invented firelock, with match fixed in cock, and fired by a trigger lifting the pan to ignite the priming. It was supported on a rest whilst being fired.

Arquifoux. [Sp. arquifol.] A Cornish kind of lead-ore, which gives a green varnish to pottery ; "potter's ore."

Arra. (Arrha.)

Arrack. (Arak.)

Arragonite. (Aragonite.)

Arraigns, Clerk of. [O.Fr. aresner, arraisonner, from ad rationem, to account.] Assistant or deputy to the clerk of assize, who calls over the jury pannel, recites charges, and generally acts as chief officer of the court.

Arrant, i.q. errant, and so, thorough-going (?) ; or with Wedgewood, $c f$. Ger. arg, Dan, arrig, Eng. arch, mischievous, troublesome.

Arras. Hangings for rooms, covered with a 
pattern like wall paper (first woven at Arras, in France).

Arrayer, or Commissary of Musters. Title given early in the fifteenth century; a militia inspector, of which there were two in each county, perhaps the precursor of the modern lord-lieutenant.

Arrearage. [Fr. arrière, behind.] The unpaid remainder of a debt.

Arrect. [L. arrectus, part. of arrigo, I set up.] Set up straight, attentive.

Arrectary. [L. arrectāria, plu., upright posts.] An upright beam, e.g. of a cross.

Arrectis aurǐbus. [L.] Lit. with pricked-up ears; all attention.

Arrentation. [L.L. arrendo, I let for rent, Fr. arrenter.] Licensing an owner of forest land to enclose by low hedges and small ditches under a yearly rent.

Arreoy. In Tahiti, an association (described by Cook and by Ellis) of the principal persons of both sexes, regarded as married to one another; connected with almost universal infanticide (Lubbock, Prehistoric Times, p. 487).

Arreptitious. [L.L. arreptícius, arrǐpio, I seize.] Seized in mind, possessed, irrational.

Arrest. [O.Fr. arrester, to stop, arrest, L.L. adrestare.] Confinement of an officer pending judicial inquiry as to misconduct. $\mathrm{He}$ is required to give up his sword whilst under A., and his word of honour is trusted as to not leaving his quarters.

Arrestation. The act of arresting.

Arrha. [L.] Earnest money; a law term. "If but a penny, it is emptionis, venditionis, contractæ argumentum" (Blackstone, Commentaries).

Arride. [L. arrīečo, I smile at, please.] To please.

Arrière. [Fr.] Of an army, the rear. A.ban (Ban). A. pensée, mental reservation.

Arrière-fief. [Fr.] (Hist.) A feudal term, answering to the English sub-infeudation (q.v.).

Arris. The edge of a stone, or piece of wood [Fr. arête].

Arroba. [Sp. and Port.] Weight and measure. (Aroba.)

Arrogätion. [L. arrogātio, -nem, from ad, to, rŏgo, $I$ ask.] Adoption of a person of full age, [sui jūris]; because the consent of the cormitia cūriāta at Rome had to be asked.

Arrondissement. [Fr.] A city ward or an electoral district. (Prefect.)

Arrow-headed writing. (Cuneiform letters.)

Arrow-root. Starch of the tuberous root-stock of maranta, especially Ǎrundinnācěa of W. Indies. Ord. Marantaceæ. The native Indians used it with success against the poison of their arrows; hence the name.

Arsenic. [Gr. à $\rho \sigma \epsilon i k o ́ v$, strong.] (Min.) A brittle steel-grey metal. The white arsenic of commerce is its trioxide, which is also called arsenious acid, and forms salts called arsenites.

Arsenicismus. Poisoning by arsenic.

Ars est celäre artem. [L.] The aim of art is to hide art, i.e. to leave no trace of the workman. (Artis.)
Arshine. A Russian measure of length equal to $2 \mathrm{ft} .4$ in.; also Archine and Arschine.

Arsis and Thěsis. [Gr. ka $\theta$ é $\sigma s$, a laying down.] With the old Greek orchestric musicians, the raising of the foot on short syllables, and the lowering on long. In Latin and modern prosody, arsis is = metrical accent, or " ictus" stroke, i.e. the stroke of the foot on the ground which marked it; thesis being of the weak syllable. But A. and T. having been used sometimes of metrical scansion, sometimes of accent or elevation of voice, much difficulty has arisen. (See Stainer and Barrett, Dictionary of Musical Terms.)

Ars longa, vītă brěvis. [L.] Art is enduring, life is short.

Arson. [L. ardeo, I burn, am on fire.] The maliciously setting fire to a building; substantive to Incendiary.

Ars Poêtica. [L.] The poem of Horace on the "art of poetry."

Art and part. [From artǐfex et partǐceps, contriver and partaker.] (Scot. Law.) Contrivance and participation in a crime.

Artegal. In Spenser's Faëry Queen, the champion of true justice.

Artěmis, Arrows of. Arrows which never miss their mark. Artemis, in Gr. Myth., is the sister of Apollo.

Artěmǐsia. (Bot.) Extensive gen. of plants, ord. Compositæ, many species intensely bitter; e.g. A. absinthium, wormwood.

Arterial system includes all the arteries from the origin of the aorta to the beginning of the capillaries.

Arteriotŏmy. [Gr. à $\rho \tau \eta \rho i a$, an artery, $\tau{ }^{\prime} \mu \nu \omega$, I.cut.] The opening of an artery.

Artërītis. Inflammation of an artery.

Artery. [Gr. à $\rho \tau \eta \rho i ́ x$.$] A ramification of the$ aorta. Arteries carry the blood from the left ventricle of the heart to the tissues. Veins, most of them, carry back blood from the capillaries, enlarging as they proceed, and pour it into the right auricle of the heart. Arteries, being found void of blood after death, were anciently considered as air-ducts ; hence the erroneous notion of the word

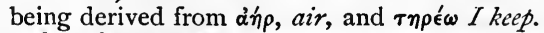

Artesian wells. [Long known in Artois, L. Artesia.] Borings or pipe-wells which allow water to come up to or near the surface in places where it has accumulated in basin-shaped strata.

Arthritis. [Gr.] 1. Inflammation of a joint [a $\rho \theta \rho o v]$. 2. Gout.

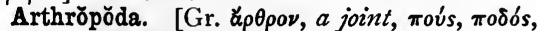
a foot.] (Annŭlōsa.)

Arthur, King. The great hero of British tradition, the son of Uther Pendragon, and the husband of Guenevere whose love for Lancelot marred the harmony of the society of knights who feasted at his Round Table. He was slain by his son Mordred, but the story went that he would come forth alive in due time to rescue his country from thraldom.

Articles of War. Certain regulations made by the sovereign and confirmed annually by Parlia. ment in the Mutiny Act, for the government of 
all persons subject to military discipline. (Army Discipline and Regulation Act.) The same rules are applied to the army since 1879 , but changed in construction.

Articles, Statute of the Six. (Sir Articles.)

Articŭlāta. [L., jointed, from articulus, dim. of artīs, joints, limbs.] (Annŭlōsa.)

Articulātion. [L. artícŭlus, dim. of artus, $a$ joint.] (Anat.) The joinings of bones. (Bot.) The connexion of the parts of a plant by joints ; e.g. grasses, canes. (Node.)

Articulli clèri. [L.L.] Statutes relating to the clergy, passed on their petition.

Artioulo mortis, In. [L.] At the point of death.

Artificial grasses. Green crops, such as clover, sainfoin, lucerne.

Artillery. [L. ars, artis, used, like machineGr. $\mu \eta \chi \alpha \nu \eta$-in the sense of any engine of war.] I Sam. xx. ; instruments, bows and arrows.

Artillery, Royal Marine. Formerly a part of Royal Marine Regiment, now a separate corps.

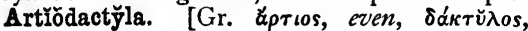
finger or toe.] (Zool.) Division of Ungŭlāta; having an even number of toes, as the deer.

Artis est cēläre artem. [L.] It is the province of art to conceal art. (Ars.)

Artiste. [Fr.] One who uses knowledge or power of any kind dexterously; e.g. as of dancing, cooking, etc.

Art of war. The efficient arrangement and ordering of troops under every circumstance, and the control of all military appliances.

Arundelian marbles. A collection of statues, inscriptions, etc., brought to England from Greece in 1627, by the Earl of Arundel, many of which are now at Oxford. (Parian Chronicle.)

Arundo. [L., reed.] (Bot.) A gen. of grasses ; tall, growing in wet places, and with hard, almost woody, culm. A. aønax of S. Europe, the tallest of European grasses; six to twelve feet high; with thick, hollow, woody culms, used for reeds of clarionets, fishing-rods, etc.

Arusha. (Erotio.)

Aruspices, Haruspǐces. [L.] Roman soothsayers, who professed to foretell the future by examining the entrails of sacrificial victims. The last part of the word contains the root spec, to see; the former part may be from haruga, a victim.

Aruspicy. The art of prognosticating. (Aruspices.)

Arval Brothers. [L. Fratres Arvāles, brothers of the fields.] Amongst the ancient Latins, a college of twelve priests, dedicated to the service of Ceres, in whose honour they carried victims round the fields in the festival hence called Ambarvalia.

Arvǐcŏla. [L. arvum, arable land, cŏlo, I inhabit.] (Zool.) Vole, gen. of small rodents, like rats and mice ; allied to the beaver; as water-rat and short-tailed field-mouse. Fam. Mürĭdre.

Arvil supper. A funeral feast in N. of England.

Aryan. [Skt. ărya, noble.] General name of the family of nations of Eurnpe and Asia to which the Celts, Teutons, Sclavs, Italians, Greeks, Persians, and Hindus belong ; = IndoEuropean.
Aryan languages. The dialects spoken by the various branches of the Aryan family of mankind. They are all inflexional-that is, the root and the termination may both be modified or corrupted, in contrast with the Turanian or Agglutinative languages, in which the root must remain unchanged.

As. [L.] 1. Roman copper coin weighing half a Roman ounce, about 0.487 of an avoirdupois ounce-from B.C. 217 to A.D. 14 aboutworth about $8 d$. 2. A Roman pound, about 0.7375 of an avoirdupois pound; also called libra.

Asa dulcis. [L., sweet asa.] A drug sold among the ancients for its weight in gold, as having all but miraculous virtues; from the Thapsia, a gen. of ord. Umbelly̌fěræ.

Asa fœtida, or Assa f. [L., fetid asa.] A drug, the gum resin of the root of the Narthex or Ferŭla Asa fotǐda of Persia, N.W. India, etc. ; ord. Umbellĭfĕræ.

Asărōtos. [Gr.] With the ancients, a room paved in mosaic, so as to look as if unswept

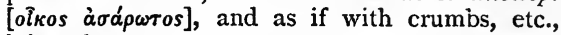
lying about.

Asbestos. [Gr., unquenched, indestructible bv fire.] A form assumed by some hornblendic minerals, as actinolite, tremolite, etc. ; a fibrous mass of parallel capillary crystals; such as Mountain flax.

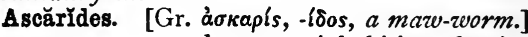
The common round worms inhabiting the intestines of man and some other mammals. Ord. Nēmătōda [ $\nu \eta \mu \alpha \tau-\omega \delta \eta n s$, thread-like], class Scōlēcĭda [ $\sigma \kappa \omega ́ \lambda \eta \xi, a$ worm], sub-kingd. Annŭloida.

Ascendant. The sign of the Zodiac which is rising above the horizon at the time of a child's birth.

Ascension, Right. The arc of the equinoctial between a star's declination circle and the first point of Aries, measured from that point from west to east.

Ascensum, Per. [L., by ascent.] By distillation in a retort, so that the vapour ascends.

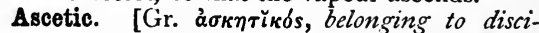
pline.] One who leads an austere, solitary, devotional life; e.g. Essenes and Therapeutæ among the Jews, and monks of Egyptian and Syrian deserts in early Christian times.

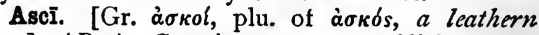
bag.] (Bot.) Certain spore-cases of lichens and fungi.

Ascĭans, Askians. [Gr. ă $\sigma \kappa \iota$ s, shacieless.] Inhabitants of the Torrid zone, who, when the sun is in the zenith, cast no shadow.

Ascidians [Gr. à $\sigma \kappa i \delta ı \nu, a$ small leather botıle], Tŭnǐcāta. A class of marine Molluscoida, resembling a double-necked leather bottle, of a leathery or gristly nature. In A., some have seen a stage of evolution from Mollusca towards Vertebrata.

Ascǐdrum. [L.] A petiole or leaf-stalk which has become leaf-like, and of which the margins are folded in so as to form a kind of urn or pitcher, is, if closed, an ascídium [Gr. a $\sigma \kappa i \delta เ o \nu$, a small leather botlle]; if open-e.g. the pitcherplant-an ampulla [L., a narrow-necked bottle]. 
Ascitēs. [Gr.] Dropsy of the abdomen [from

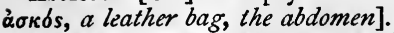

Asclepiad verse. Metrum Asclēpiădēum, invented by Asclēpiădes, Greek poet, some time after Alcæus and Sappho. A choriambic verse, of which there are many variations; as "Mæcenas atavis," etc. (Horace); "Sic te, diva potens Cypri" (Horace); "Grato, Pyrrha, sub antro" (Horace); and others. (Choriambus.)

Ascræan Poet, The. Hesiod; born at Ascra, near Mount Helicon, in Bœotia, circ. B. C. 850.

Aseptic. [Gr. à neg., $\sigma\lceil\pi \alpha, I$ make rotien.] Not liable to decay.

Asgard. In Teut. and Scand. Myth., the abode of the Asir, the gods whose name answers to the Asuras of the Rig Veda, from the root as, to breathe, hence to be.

Ashĕra. [Heb.] The word translated grove, in the Authorized Version of the Old Testament, 2 Kings xxiii. 7, etc. It answers to the Linga of Hindus and the Phallos of the Greeks.

Ashes. Commercial name for alkalies such as pot-ash, wood-ash, etc.

Ashlar, Ashler, Aslure, Estlar: (Arch.) The name for hewn or squared stones used in building.

Ashtorreth, Astarte. Chief female Phœnician divinity ; Ashtaroth (plu.), images of A.

Asia, in New Testament, the western part of Asia Minor, about = Mysia, Lydia, Caria ; which became a Roman province, Asia Propria, when Attalus III. left all his dominions to the Romans, B.C. 133 .

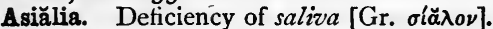

Asianism. A florid style of rhetoric, mostly cultivated in Asia Minor; opposed to Atticism, the correct, natural style of the best Athenian orators.

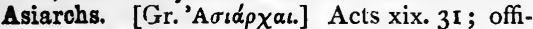
cers chosen annually by the cities of $A$ sia (q.v.) ; having the charge, and bearing the expense, of public games, of religious and theatrical

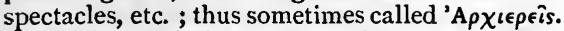

Asiatic Societies. Of Calcutta, Bombay, Ceylon, and others, founded in Europe, arose out of the Calcutta Society formed under Warren Hastings, at Sir W. Jones's desire, for the purpose of "inquiring into the history, civil and natural; the antiquities, arts, sciences, and literature of Asia."

Asinego. [Port.] Young ass; simpleton.

Asitia. [Gr.] (Mcd.) Not in its proper sense of want of food, but = loathing for food [à neg., oîros, food].

Asklēpios. (Essculapian.)

Asleep. (Naut.) Said of a sail just filled with wind.

Asmodeus. The unclean spirit mentioned in Tobit iii. The word is a corr. of the Aêshma-daêva of the Zendavesta.

Asōmătous. [Gr., from à neg., $\sigma \hat{\omega} \mu \alpha, b o d y$. Bodiless, unsubstantial.

Aspălăthus. [Gr. à $\sigma \pi a ́ \lambda \alpha \theta o s$.$] Ecclus, xxiv, ;$ a prickly shrub, yielding fragrant oil.

Aspect. [L. aspectus, appearance.] (Astron.) The angular distance of one planet or star from another; it was either conjunction, opposition, trine, quadrate (quartile), or sextile, according as the angle was $0^{\circ}, 180^{\circ}, 120^{\circ}, 90^{\circ}$, or $60^{\circ}$.
Aspectant. [L. aspectare, to gaze at.] (Her.) Facing each other.

Aspergilliform. (Bot.) Shaped like $a$ brush [L.L. aspergillum].

Aspergillum. [L. aspergo, I sprinkle.] A kind of brush used for sprinkling holy water.

Aspěrífŏliø of Linnæus. [L. asper, rough, fŏlium, $a$ leaf $]$ = Boraginaceæ.

Aspersion. A sprinkling [L. aspersio, -nem] ; as distinct from Immersion. (Affusion.)

Aspersively. By way of aspersion, censure, slander [L. aspergo, I sprinkle, stain].

Aspersōrium. (Benitier.)

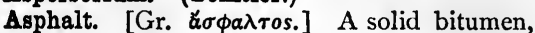
produced by the agency of heat. and pressure upon lignitic and coal-bearing strata; generally black, and more or less lustrous; found at the Dead Sea, or Lăcus Asphaltites; in Trinidad; Texas; Val Travers and Seyssel, Switzerland; and other places.

Asphŏdel meadows. (Myth.) The meadows of Elysium, adorned with asphodels, flowers of the lily kind. (Elysian.)

Asphŏdělus, Asphodel. [Gr. ג̇ $\sigma \phi b \delta \in \lambda o s$.$] (Bot.)$ the gen. of Liliaceæ, having fleshy roots, long narrow leaves, and a simple or branded scape, bearing close racemes of white star-like flowers. A. albus was formerly common in gardens, and is very ornamental.

Asphyxia. [Gr. à $\sigma \phi v \xi \xi i \alpha$, lack of pulse.] (Bot.) A temporary cessation of respiration and circulation; often applied to a state arising from air either vitiated or insufficient.

Aspic. [Gr. $\dot{a} \sigma \pi i s$.$] 1. An asp. 2. Savoury$ meat jelly, containing pieces of meat, fish, etc. 3. A gun carrying a $12 \mathrm{lb}$. shot.

Aspĩdium. (Bot.) Shield fern; a gen. of Ferns, of which common male-fern is the type; formerly including ferns in which the dot-like sōri were covered by a roundish cover, or, as it were, shield [Gr. à $\sigma \pi i s]$.

Aspidorhynchus. [Gr. dorís, a shield, píryos, a beak, snout.] (Geol.) A gen. of fossil Ganoid fishes; with long bony covering to the upper jaw ; in the Lias and Oolite.

Aspirate. [L. ăd, to, spīro, I breathe.] 1. (Etym.) A mute or momentary consonant, with a breath immediately following it, as in Irish b'hoy, for boy. Such consonants are common in Eastern languages. The chief are $k^{\prime} h, g^{\prime} h$, $t^{\prime} h, d^{\prime} \dot{h}, p^{\prime} h, b^{\prime} h, c^{\prime} h, j ' h$. 2. (Surg.) To evacuate the fluid contents of a cavity, such as an abscess or the pleural cavity of the chest, by a hollow needle, or canula, connected with an exhausted air-chamber.

Aspiration. [L. aspirätio, -nem.] (Etym.) The change of an unaspirated consonant to an aspirate

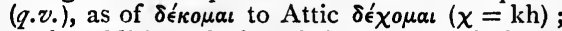
or the addition of a breath (an $h$ sound) before a word that began with a vowel, as in London and Bucks, e.g.

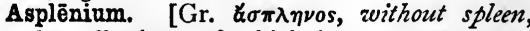
for the affections of which it was a supposed cure.] Spleenwort, a gen. of plants, ord. Ferns, including asplenium, adiantum nigrum, common spleenwort, wall-rue (Rūta-mūräria), etc.

Asportation. [L. asportatio, a carrying away.] 
(Naut.) The illegal taking away of a ship or cargo ; removal of goods, essential to larceny.

Assai. A beverage much used on the Amazon, prepared from the assai palm fruit.

Assapan. (Zool.) Scǐuroptěrus vǒlŭcella. (Flying squirrel.)

Assart, Essart. [L.L. assartum, from ex, out, sarrio, I hoe.] The offence of total destruction of trees or shrubs in a forest.

Assassin. Originally one of a military and religious order of Ismailites $\left(q . v v_{0}\right)$, formed in Persia by Hassan-ben-Sabbah, in the latter part of the eleventh century, and so called from their immoderate use of haschish, an intoxicant made from Indian hemp (Cannăbis).

Assassination Plot. A plot for a Jacobite rising in England, together with an invasion from France, to be followed by the assassination of William III. ; entrusted to Sir G. Barclay. Conspirators executed March, I696.

Assation. Roasting [L. asso, $I$ roast].

Assault. [O.Fr. assalt, L. assaltus, from ad, to, saltus, a leaping.] Rapid attack over open ground on any fortified post.

Assaying. [Fr. essai, a trial, from L.L. exashum, $a$ standard weight.] The determination of the quantity of any metal in its ore or alloy.

Assegai. Short spear used by natives of $\mathrm{S}$. Africa, with a very thin shaft of about five feet in length and an iron blade secured by a strip of raw hide. When used for throwing, the blade is convex on one side and concave on the other, for the purpose of transmitting a rotary motion.

Assegai tree. Curtisia fāğnea-a Cape treeord. Coruaceæ, of which the shafts for javelins or assegais are made.

Assembly. [Fr. assemblée.] 1. (Hist.) The four legislative bodies of the first French Revolution: r. The Constituent A., 1789-91. 2. The Legislative A., 1792. 3. The Convention, 1792-95. 4. The Corps Lésislatif, 1795, which appointed the Directory. (Consul.) 2. (Mil.) Bugle-call for collecting together the whole of the officers and soldiers of a regiment.

Assembly, General. The highest court of the Presbyterian Church, having both lay and clerical elements, and possessing supreme legislative and judicial authority in all matters purely ecclesiastical.

Assembly of Divines, i.q. Westminster A (q.v.).

Assentātion. [L. assentātio, -nem, assentor, $I$ flatter.] Insincere, flattering assent.

Asses' Bridge, Pons Asinorum [L.], i.e. the first difficulty in geometry; the fifth proposition of book i. of Euclid, the figure somewhat suggestive of a bridge.

\section{Asses, Feast of. (Fools, Feast of.)}

Assessor. [L. from adsĭděo, ad, near, sědeo, $I$ sit.] 1. A person who sits near judges in court, to advise them or take part in their decisions. 2. A valuer of property for taxation or rating.

Assets. [Norm. Fr. assetz, Fr. assez, enough, from ăd, to, sătis, enough.] 1. The entire property which can be realized for distribution among creditors. 2. (Leg.) The chargeable property of a deceased person.

Asseverātion. [L. assěvērātio, -nem, assěvēro, I affirm strongly.] Strong, positive assertion.

Assibilation. [L. ăd, to, sibillo, $I$ hiss.] The change of $t$ or $d, k(c)$ or $g$ to a sibilant $(s, s h, z$, Fr. $j$ ), before a $y, i$, or $u(v)$, as in Eng. -shun or -shon for -tion, Attic $\sigma \dot{v}$, thou, for $\tau \dot{v}$.

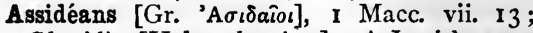
i.q. Chasidim [Heb., the pious]. A Jewish party (? bound by some vows as to external obedience), brought into prominence at the Maccabæan rising ; devoted, in after times, to ceremonial.

Assìdent signs [L. assideo, $I$ sit by] of a disease, are those usually, but not necessarily and always, concomitant.

Assientos. [Sp., agreements.] (Hist.) Treaties made by Spain with Portugal, France, and England, for supplying her American colonies with negro slaves from Africa.

Assignats. [L. assignātus, allotted, assignid.] Paper money issued by the French Government during the Revolution, on security of unsold Church property, lands of emigrant nobles, etc.

Assignee, Assign. [L. assignātus.] A person appointed by or for another, to transact the business connected with property in place of the appointer. Lessees are assignees by deed, executors and trustees in bankruptcy by law.

Assimilate. [L. assimŭlo, I make like to.] To change into like substance, as we assimilate food, etc.

Assimilaticn. [L. adsimilatio, -nem.] (Etym.) The process or tendency by which different sounds in a word come to be pronounced more like to each other; as "cubburd" for cup-board (vide also Sandhi).

Assistant. [L. assisto, I assist.] (Mil.) The officer holding the appointment next under the deputy to the head of any branch of the army.

Assize [O.Fr. assis, (I) an assembly of judges, (2) a tax], is, in Scotland, the jury, fifteen in criminal cases. The word also denoted formerly (I) a royal ordinance, as the Assize of Jerusalem; (2) an ordinance regulating the price of victuals, assisa venalium ; (3) Grand A., a jury of sixteen knights, by whom a writ of right was tried.

Assizement. [Norm. Fr. assize, L. assessio, $a$ sitting by or near.] Inspection of weights and measures.

Assize of Jerusalem. A code of laws drawn up in 1100 , under Godfrey of Bouillon, for the administration of the Latin kingdom of Palestine.

Association. [L. adsociāre, to join with.] In Psych., the tendency by which later objects or states of consciousness recall earlier objects or states with which they have some connexion. This principle has been applied by Hartley, Mackintosh, Bain, and others, to explain our more complex emotions, and especially what are termed our moral sentiments.

Assoil. To soil, stain. [L. (?) assŏlo, postclass., I throw to the ground, sollium ; or (?) cf. souiller, L.L. sŭcŭlare, to wallow like a pig.]

Assoil, Assoilzie. [O.Fr. assoiller, L. absolvěre, to acquit.] Assoilment, acquittal.

Assommoir. [Fr.] A weapon for dealing the 
death-blow to animals. Hence, any overwhelming event.

Assŏnance. [L. assŏno, 1 resound to.] Likeness of sounds; e.g. see Mrs. Browning's Dead Pan. (Alliteration.)

Assuetude. [L. assuētūdo.] Custom, habit.

Assūment. [L. assūmentum, assŭo, $I$ serv on.] A patch, something added on.

Assumpsit. [I.., he undertook.] (Leg.) An action, or a verbal promise, or agreement.

Assumpt. In argument, an assumption ; a thing granted. [L. assümo, I take to myself.]

Assumptive arms. Those assumed without sanction of the Heralds' College.

Assurance. [L.L. assecūro, I make safe.] In Law, a contract for the payment of a certain sum on the occurrence of a certain event.

Assurgency. [L. assurgo, $I$ rise up.] A rising upward.

Assurgent. [L. assur-gent-em, rising up.] (Her.). Rising from the sea.

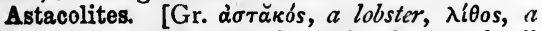
stone.] (Geol.) A name formerly given to fossil remains of the long-tailed or lobster-like Crustaceans.

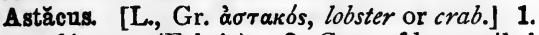
Gen. of insects (Fabric). 2. Gen. of long-tailed Decapod Crustaceans, as river crayfish; giving its name to fam. Astăcĭdæ, as lobsters. Subkingd. Annŭlōsa.

Astartē. 1. A Phœenician goddess, called in Old Testament, Ashtoreth. (Ostara.) 2. (Zool.) A gen. of bivalve molluscs-N. and Arctic Seas - fam. Cyprinĭdæ, class Conchĭfěra.

Astatic. [Gr. à neg., I $\sigma \tau \eta \mu \iota$, place or weigh.] Without weight, imponderable.

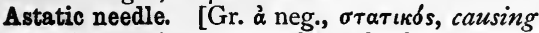
to stand.] An instrument formed of two equal magnetic needles with their poles turned opposite ways, so that its motion is uninfluenced by the earth's magnetism.

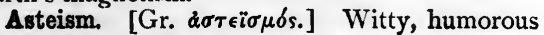
conversation ; good-natured banter.

\section{Asteriadæ. (Asteroidea.)}

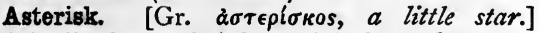
Originally the mark *, by which the early grammarians noted omissions, additions, or anything remarkable in manuscripts. (Aristarchian.)

Asterism. 1. A group of stars, whether forming a constellation or not. 2. A marking with an Asterisk. [Gr. $\dot{\alpha} \sigma \tau \epsilon \rho \sigma \sigma \mu \delta s$, the same in both meanings.]

\section{Astern. (Naut.) (A-beam.)}

Asteroid. (Planetoid.)

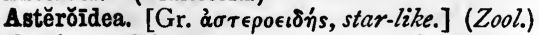
Ord. of star-fishes, whose arms are an immediate continuation of the central disc. It contains five families : Astĕrŭădæ [Gr. à $\sigma \tau \epsilon \rho i \alpha s$, starred], Astrŏpectinn̆dæ [L. astrum, $a$ star, pectǐnem, $a$

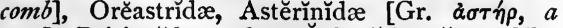
star], Brisingĭdæ; class Ěchīnǒdermăta. The name Astěriădæ is also given by some authorities to corals with star-like polypes.

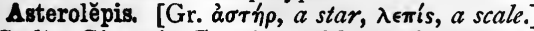
(Geol.) Gigantic Ganoids, with star-like markings on the dermal plates of the head; in the Old Red Sandstone.

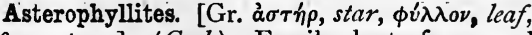
$\lambda$ íos, stone.] (Geol.) Fossil plants from coal formations.

Asthenio diseases. [Gr. ’̀ neg., oóénos, strength.] (Med.) Diseases characterized by great loss of power.

Astigmatism. [Gr. à neg., $\sigma \tau \hat{\imath}(\gamma \mu \alpha, a$ mark.] 1. The fact that, after reflexion or refraction, the rays, which before formed a pencil, no longer pass through a common point. 2. (Med.) A defect of the eye, which, not having the normal spherical form, cannot see a lucid point, e.g. a puncture in a card, as a point $[\sigma \tau i \gamma \mu \alpha]$, or cannot see it continuously, but more or less as an elongation.

Astolpho. A boastful paladin of Charlemagne, noted for a magic horn.

Astor, J. Jao. Fur trader, founder of $A$. Library, New York; richest American of his time; died 1848 .

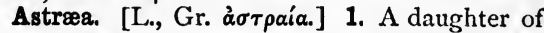
Zeus and Eos, or, as others said, of Thĕmis, law, who sojourned on earth during the Golden Age, and was then placed among the stars. 2. (Geol.) Gen. of coral, studded with star-like polypes.

Astræa Rĕdux. [L.] Astraa returning; title of Dryden's poem, celebrating the Restoration.

Astragal. (Bead-moulding.)

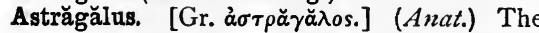
ankle-bone, one of seven composing the tarsus ; that on which, through the tibia, the weight of the body first falls.

Astral. [L. astrum, $\boldsymbol{a}$ star.] Starry; starlike; having to do with the stars.

Astrict. To bind, compel [L. astringo, $I$ draw tight, p. part. astrictus].

Astringents. [L. astringo, $I$ draw tight.] Medicines which contract organic fibre, and diminish excessive discharges.

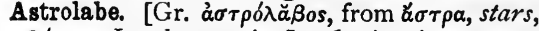
$\lambda \alpha \mu \beta a ́ \nu \omega, I$ take, receive.] 1. An instrument closely resembling the armillary sphere $(q . v$.$) .$ 2. A stereographic projection of the sphere on the equator or on a meridian.

Astrology, Apotelesmatic; Judicial A.; Natural A. [Gr. $\left.\dot{\alpha} \sigma \tau \rho o \lambda o \gamma^{\prime} \alpha_{\text {. }}\right]$ 1. The science of astronomy. 2. More commonly a superstition embodied in rules by which it was supposed that a man's fortune could be predicted from the configuration of the heavenly bodies at the time of his birth; sometimes called Apotelesmatic [àmore$\lambda \in \sigma \mu \alpha \tau$ ‘́ós, belonging to completion] or Fudicial $A$., to distinguish it from Natural $A$., which essayed to trace the dependence of the weather on the heavenly bodies.

Astronomy, Physical; Plane A.; Spherical A. [Gr.

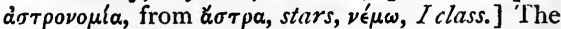
science which treats of the magnitudes, distances, arrangements, and motions of the heavenly bodies ; their constitution and physical condition ; and their mutual actions on each other, so far as can be inferred from observed facts. Physical $A$. deduces the observed movements of the members of the solar system, from the general laws of dynamics and the special law of universal gravity. Formal, or Plane, or Spherical, $A$. 
treats of the methods and principles of making and reducing astronomical observations.

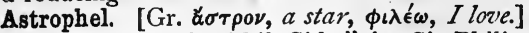
A Grecized form of " Phil. Sid.," i.e. Sir Philip Sidney, in Spenser's elegy.

Astrophic. [Gr. à neg., $\sigma \tau \rho o \phi \hat{n}$, turning, strophê.] Not divided into strophē and antistrophē, with or without epode ; said of a lyric poem of continuous rhythm.

Asŭras. [Skt., beings.] In the Rig Veda, a general name for the gods, from the root as, to be, answering to the Teut. Esir.

Asȳlum. [Gr. à $\sigma \bar{u} \lambda o s$, safe from violence, from à neg., $\sigma v \lambda a ́ \omega, I$ plunder.] 1. A sanctuary, place of refuge ; and so, 2. For the blind, etc., a place of protection.

Asymptōte. [Gr. à $\sigma \dot{u} \mu \pi \tau \omega \tau o s$, not falling together.] (Math.) A line which a branch of a curve continually approaches, but never actually touches ; commonly a straight line ; but there are A. curves : thus, certain spirals have A. circles.

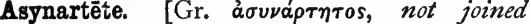
together.] (Gram.) Clauses or sentences not grammatically connected.

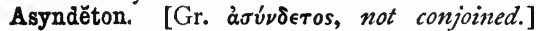
(Rhet.) The omission of connecting particles, as "Veni, vidi, vici ;" the union of clauses by many

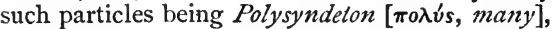
a word formed by analogy, the Greek word being

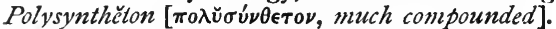

Atăbal. A Moorish tabor, kettledrum.

Atăbeks. A title given to rulers of several of the small principalities into which the empire of the Seljuk Turks became divided; eleventh, twelfth, and thirteenth centuries.

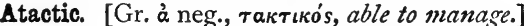
Marked by Ataxy; i.e. (I) irregularity in bodily functions; or (2) want of co-ordinating (q.v.) power in movements.

Ataman. (Hetman.)

Atăraxia. Freedom from mental disturbance

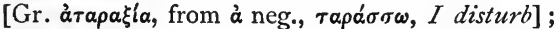
perfect calmness. The great end aimed at by Epictētus.

A-taunto, or All a-tannto. (Naut.) The condition of a ship, when the masts are in position and fully rigged.

Atavism. [L. ătăvus, an ancestor.] In animals and plants, the reappearance in a descendant of some ancestral peculiarity. (Reversion.)

Ataxy. (Atactic.)

Atē. [Gr., mischief, hurt.] In the Miad, the spirit of mischievous folly, whom Zeus seizes by the hair and hurls from Olympus. With the Attic tragedians, the spirit which exacts vengeance for bloodshed, and to which even Zeus is compelled to submit. (Erinyes; Fates.)

-ate, -ite. (Chem.) Terminations denoting the presence of oxygen, as sulph-ate, sulph-ite, of potassium. Each of these salts consists of sulphur, oxygen, potassium, but a salt in -ate contains more oxygen than the salt in -ite

Atelettes. (Hâtelettes.)

Atelier. [Fr.] Workshop; also a studio. [O.Fr. astelier, L. hastellārius, a place for making hastellæ, splints.]
Atellan Fables, i.e. Plays, Atellānæ Fābŭlæ, or Iudi Osci. Ancient rustic comedies of Ātella, in Campania ; played as interludes, or afterpieces, on the Roman stage. A kind of harlequin, exciting laughter by his old Oscan dialect, is probably the prototype of the modern harlequin or clown.

Ateshaja. The place of fire; i.e. of blue flame of naphtha, issuing from the soil, about a mile in diameter, on W. of Caspian Sea ; visited by the Persian fire-worshippers.

Athanor. [Heb. tannûr, an oven.] With the alchemists, a self-feeding furnace of equable heat.

\section{Atharva Veda. (Veda.)}

Athĕling, Æthĕling = heir-apparent or presumptive. [A.S. Athel, Athel, Ethel =noble; and -ing, the usual A.S. patronymic $=$ son..$]$

Athënæum. [Originally, temple of Athèna.] 1. A school at Rome, founded by Hadrian. 2. A literary association. 3. The building used for it.

Athenian Bee, The. Plato.

Athermănous. [Gr. à neg., $\theta \in \rho \mu \alpha i ́ \nu \omega, I$ make warm.] Opaque to radiant heat.

Athĕroïd. In shape like an ear of corn [Gr.

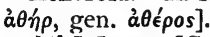

Athēröma. [Gr.] A tumour having matter

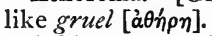

Athlete. [Gr. $\dot{\alpha} \theta \lambda \eta \tau \eta^{\prime} s$, from $\hat{a} \theta \lambda o s, a$ contest.] (Gr. Hist.) One who took part in the public games, especially in the Pentathlon, which consisted of boxing, wrestling, throwing quoits, leaping, and running. (Palæstra.)

Athwart. (Naut.) Across the line of a ship's course. $A$. her hawse (Hawse). A. ship, from side to side; in opposition to fore and aft.

Atlantěs. [Gr., plu. of Atlas (q.v.).] Greek columns, shaped like men, as supports of entablatures; the Romans used the name Tĕlămōněs $[\tau \in \lambda \alpha \mu \hat{\omega} \nu \in s]$. (Caryatid.)

Atlantis. An island mentioned by Plato as having existed in the Atlantic Ocean, beyond the pillars of Heracles (Hercules), and as having been submerged by earthquakes. (Thulē.)

Atlantis, New. Lord Bacon's imaginary island, also in the Atlantic, with a philosophical commonwealth, devoted to art and science.

Atlas. 1. (Myth.) A brother of Promètheus. He held up the pillars which support the heaven, and was turned into stone when Perseus held before him the face of the Gorgon Medūsa. Hence Atlas Mountains, Atlantic Ocean. (Gorgons, Promethean.) 2. (Anat.) The first of the cervical vertebræ. 3. A kind of Indian silk or satin, curiously inwrought with gold and silver.

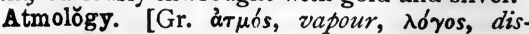
course.] The part of meteorology which treats of aqueous vapours.

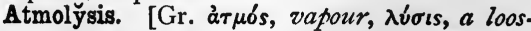
ing.] The separation of the constituents of a mixed gas by passage through a porous substance.

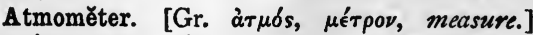
An instrument for measuring the rate of evaporation.

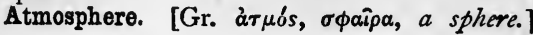


The pressure of the air per unit of area on the surface of the earth; as, a pressure of three atmospheres, i.e. a pressure three times as great as that of the atmosphere on the earth, or one at the rate of about 45 lbs. per square inch.

Atmospherio dust. (Meteorio dust.)

Atmospheric engine. A primitive sort of steam pumping-engine; the piston in the first place was forced up by steam, and then, the steam being condensed within the cylinder, was forced down by atmospheric pressure.

Atmospherio line. The line of an indicator diagram which. would be traced out by the pencil if the steam pressure within were exactly balanced by the atmospheric pressure without.

Atmospheric railway. A project for locomotion, the movement being produced by atmospheric pressure against a surface which has a vacuum on the other side.

Atocha grass. [Sp.] (Esparto.)

Atoll. [Maldive word.] A coral island, consisting of a circular rim, surrounding a circular piece of salt water.

Atom. [Gr. aropos, indivisible.] 1. One of the ultimate portions into which matter is divisible, and which are assumed to be incapable of further division. 2. A molecule (q.v.).

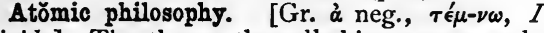
divide.] The theory that all things were made by the concourse of indivisible, eternal atoms, [ö.rouol, ai] of different shapes; held chiefly by the Greeks Leucippus, Democritus (B.C. 46036I), Epicurus (B.C. 342-270).

Atomic theory. In Physics, every element consists of indivisible particles called atoms, of size and weight invariable in the same element. The atomic weight of an element is the weight of one of its atoms as compared with the weight of an atom of hydrogen; this is also called its combining weight.

Atŏmy = an atom.

Atŏnio. [Gr. à neg., Tóvos, tension.] (Med.) Marked by atony, i.e. want of energy.

I tort et à travers [Fr.] At cross purposes.

Atrabilarian, Atrabilious. Melancholy [L. ātra bïlis, black choler, an imaginary secretion, with the ancients].

Atră cüră, Post èquirtem sědet. [L.] Black care sits behind the horseman or knight (Horace) ; i.e. care attends the great and successful.

Atramental. Of the nature of ink [L. ātrāmentum].

Atrēto-. [Gr. \& $\tau \rho \eta \tau$ os, not perforated.] (Anat.)

A-trip. (Naut.) An anchor is $A$. when it breaks the ground in weighing. Sails are $A$. when ready for trimming. Yards are $A$. when in position, and ready to have the stops cut for crossing. An upper mast is $A$. when ready for lowering.

Atrinm. [L.] The hall, or principal room in a Roman house.

Atrŏpa. [Gr. ătponos, inflexible.] (Bot.) A gen. of plants, ord. Sōlānaceæ. A. belladonna [It., beautiful lady], the deadly nightshade, is a tall shrubby plant, with large egg-shaped entire leaves, dull purple bell-shaped flowers, and shining black berries; it is very poisonous, and is employed in medicine.

Atrophy [Gr. àrpoфía, a wasting away] of the body ; defective nutrition.

Atropism. (Med.) The state induced by continual use of Atropa, i.e. of belladonna.

Atrŏpos. [Gr., inflexible.] (Myth.) One of the three Fates $(q . v$.$) .$

Attaché. [Fr.] One attached to an embassy.

Attachment. [It. attaccare, to fasten.] (Leg.)

1. A writ or precept for apprehension of a person for contempt of court. 2. An order for the securing of a debtor's goods or debts due to him. 3. = Woodmote, the lowest of the three ancient forest courts.

Attăgēn. [L., heath-cock, or perhaps goawit.] (Frigate-bird.)

Attaghan. (Yataghan.)

Attainder. [Fr. atteindre, from attingere, to touch.] The status of a criminal condemned to death ; corruption of blood.

Attar, 0tto, Uttar. [Ar. itr, perfume.] A strong-smelling essential oil obtained from roses.

Attemperate, adj. [L. attempěro, I fit, adjust.] Properly adapted, proportionate to.

Attenuants. [L. attĕnuantes, making thin.] (Med.) Diluent medicines, rendering the humours less dense and viscid.

Attestation. [L. attestātio, -nem, testimony.] In the army, a recruit's voluntary oath of allegiance to the sovereign, taken before a justice of the peace.

Attic Bee. (Athenian Bee.)

Attic faith, Atť̌kē pistis. (Punica fides.)

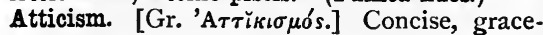
ful diction.

Attic salt. Wit, elegance, like that of the Athenians.

Attřcus. A name given to Addison, by Pope, after A., the intimate friend and correspondent of Cicero.

Attire. [Ger. zier, adornment.] (Her.) The horns (of a stag),

Attle. [O.E. adl, ailing.] Mining rubbish, consisting of valueless pieces of rock.

Attollent [L. attollo, I lift up] muscles, or Levator muscles [lěvo, I raise], raise some part ; e.g. upper eyelid.

Attorneys. (Solicitors.)

Attraction. [L. adtractio, -nem, I draw together.] The tendency which each of two bodies has to make the other approach it. When the bodies are at sensible distances, there is the A. of gravitation, or in other cases magnetic and electrical A. ; at minute or insensible distances there are cohesive A., capillary A., etc. (Gravity ; Magnetism.)

Attrăhent medicine [L. attrăho, I draw towards] draws the fluids to the place where it is applied.

Attrap. To put trappings upon.

Attrỉbute. [L. attrībūtum, a thing ascribed, a predicate.] 1. In Art, a distinguishing symbol, as a trident, of Neptune; a gridiron, of St. Giles. 2. (Log.) A quality, furnishing matter for a predicate ; as the justice of Aristides.

Attrition. [L. attrītio, -nem, attěro, I rub 
against.] 1. A wearing away. 2. (Theol.) Grief for sin, not yet change of heart.

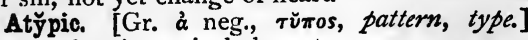
Having lost its typical character.

Atzereth. [Heb.] The name given, in later times, to the Day of Pentecost; meaning, probably, a closing festival; and originally applied to the "holy convocation," "the solemn assembly," held on the day after the week of the Feast of Tabernacles.

Aubade. [Fr. aube, dazon, L. alba.] 1. Openair morning concert; a kind of huntsup (q.v.). 2. Sometimes, rough music.

Aubaine, Droit d'. In Fr. Law, the right of the sovereign to succeed to the goods of a deceased foreigner, not naturalized. Aubain, $a$ foreigner, in O.Fr. is said to be alibi natus.

Auberge. [Fr.] An inn; originally herberge, i.e. a military station, from Ger. heriberge. So the Ger. herberg has similarly changed meaning (Littré).

Aubin. [Fr., probably from L. ambulare, to walk.] An amble; Canterbury gallop.

Auburn. Oliver Goldsmith's Deserted Village.

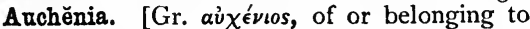
the neck $(\alpha \dot{v} \chi\{v)$.] (Zool.) Gen. of Cămëlĭdæ, smaller than true camels. S. America. Two spec. (llama and alpaca) domesticated, the former introduced into Australia.

Au courant. [Fr.] Lit. keeping up with the stream-with what is passing ; acquainted with it. Audentes or Audāces fortuna juvat. [L.] Fortune favours the bold.

Audi alterram partem. [L.] Hear the other side.

Audit. [L. auditus, hearing, examination.] 1. Periodical investigation of the accounts of a firm or society, by or for them. 2. A banquet in connexion with the above in colleges.

Audītā quěrēlā. [L.] After listening to the complaint.

Auditōriom. [L., lecture-room, audience.] The part of a theatre or assembly-room designed for the audience.

Au fait. [Fr.] Lit. to the fact; conversant with the circumstances, at home in a subject.

Au fond. [Fr.] At bottom.

Angean. Filthy, like the stables of Augěas, King of Ëlis, which Hercules cleansed.

Angite [Gr. av̉ń, a bright light], or Pyroxene. (Geol.) A black or green mineral ; one of the principal in many lavas and dolerites; nearly allied to hornblende.

Augment. [L. augmentum.] (Gram.) Syllabic A., a vowel prefixed to past tenses, as $a$-bhût, he became. Temporal A., lengthening of an initial vowel in past tenses, as èdit (èdo), Skt. āda (root ăd), he has eaten.

Augmentation. [L. augmentum, from augēre, to increase.] (Her.) A charge added to a coat of arms, as a mark of honour.

Angmentation of moon's semi-diameter. [L. augmentatio, -nem, an increasing.] The excess of the angle subtended by the moon's semi-diameter, as seen by a spectator at any instant, above what it would be if seen by a spectator at the same instant in the position occupied by the earth's centre; it is this latter angle which is given for every day of the year in the Nautical Almanac.

Augmentations, Court of, of the king's revenue; consisted of a chancellor and thirtytwo other members, with its seal, and full power to dispose of abbey lands and buildings most profitably to the king; A.D. 1538 .

Au grand complet. [Fr.] In full muster; none wanting ; entire completion.

Augsburg Confession. (Confession of Faith.) Angsburg Interim. (Interim.)

Augurs. [L. augŭres.] Roman soothsayers, who professed to read the future in the flight, the cries, or the numbers of birds, as seen on the right hand or the left (Sinister). In so doing they were said to take the auspices (Aruspices). Augars, The two. (Cato.)

Augusta. [L.] The title of the wife of the Roman emperor.

Angustan age. The reign of Octavius, commonly known as Augustus; rendered illustrious by the writings of Virgil, Horace, and other great poets, and by the labours of great lawyers in codifying the civil law.

Augustan history. A series of histories of the Empire, ranging from A.D. I 57 to 285 .

Augustine, or Austin, Friars. One of the minor mendicant orders; first entered England A.D. 1252; famo is disputants. Keeping of Ausustines meant th : performing an act for M.A. degree at Oxford. (Orders, Mendicant.)

Augustines, Austin Canons, Black Monks (wearing a black hood over the white rochet). A religious order in the Roman Church, following the supposed rule of St. A., established or remodelled in the eleventh century; their discipline something between monastic and secular.

Augustinians. Divines who, professing to follow St. Augustine, have held that grace is absolute rather than conditioned.

Auk. (Alca.)

Aulæum. [L.] The curtain of a theatre.

Aula Rëgis. [L.] The court of justice of the king, i.e. before the king himself ; the origin of all our courts (Stephen's Blackstone, bk. v. ch. iv.). Aularian. A member of a hall [L. aula] at Oxford, as distinguished from a college.

Auld lang syne. Time long past, lang syne being the Scottish form of long since.

Auld Reekie. Edinburgh, i.e. the old town, often reeking with dirt and smoke; $c f$. Ger. raïchig, smoky. (Areek; Gardiloo.)

Aulio Council. [Gr. aìnttobs, of the court, aủ $\eta^{\prime}$.] The Reichofsrath, the second chamber under the Empire; at first the personal council of the Emperor Maximilian, 150I. This council and the Reicliskammergericht, or Imperial Chamber, were the two supreme courts. (Emperor; Empire.)

Aulnager. (Alnager.)

Aumbry. (Ambry.)

Au naturel. [Fr.] In its natural state.

Aune. [Fr.] An ell; of different lengths in different places; not in use now. [O.Fr. alne, L.L. alena ; $c f$. ulna.]

An pied de la lettre. [Fr.] To the foot of letter; literally. 
Aura. [L., air.] 1. A supposed electric emanation from a body, forming an atmosphere round it. 2. (Path.) The sensation of air breathing or blowing; e.g. that from below upwards, sometimes before an attack of hysteria or epilepsy.

Aurantiacěæ. (Bot.) An ord. of plants, of

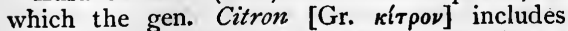
orange, lime, shaddock, etc. [from Ar. nâranj, Eng. orange, Latinized aurantium].

Anrea Iegenda. (Golden Iegend.)

Aurēlia. [L. aurum, gold, from its colour, as chrȳsalis, Gr. $\chi \rho \bar{v} \sigma a \lambda \lambda i s$, from $\chi \rho \bar{v} \sigma \delta s$, gold.] (Entom.) 1. Chrysalis ; the gold-coloured pupa of certain Lěpǐdoptěra. 2. Spec. of Lŭcernārĭda, or Umbrella Hydrōzōa (sea-blubbers), sub-kingd. Cælentěrāta.

Aureole. [Fr., L. aureŏlus, dim. of aureus, golden, from aurum.] 1. A golden halo. 2. The glory round the heads of saints in pictures. (Nimbus.)

Au reste. [Fr.] As to what remains to be said ; in L., quod restat.

Aurĕus. [L.] A Roman coin.

Au revoir.' (A rivedersi.;

Auric acid. Sesquioxide of gold [L. aurum] Its salts are called Aurates.

Auricle. [L. auricŭla, dim. of suris, an ear.] 1. (Anat.) That part of the ear which projects from the head. 2. Auricles, two upper cavities of the heart. 3. (Zool.) Gen. of Pulmoniferous Gasteropoda (G. with lungs, as the snail). Malay and Pacific Islands only; but fossil in Europe. Fam. Aurǐcŭlǐdæ, ord. Pulmōnǐfèra, class Gastěrǒpŏda.

Auricled. [L. auricŭla.] Having ear-like appendages.

Auricŭlar confession. (Eccl.) Lit. confession made into the ear [L. auricula] of the priest. One of the seven sacraments of the Latin Church. The need of such confession was formally laid down by the Fourth Council of Lateran, 1215. (Penitence; Penance.)

Auriflamme. The ancient royal banner of France. The origin of the word is uncertain; but some suppose it to be from the $L$. auri flamma, a golden flame. It was at first the banner of the abbey of St. Denis. By some it is said to have been lost at Agincourt; others affirm that it was last seen in the reign of Charles VII.

Auri pigmentum. (Orpiment.)

Auri sacra fămes. [L.] Accursed hunger for gold

Aurochs. [Ger. auer-ochs, L. ürus, a Celt. word, Cæsar; the wild ox.] The wild Polish and Caucasian Bison, six feet high, grey and brown, with shaggy mane and shoulders. Bos bonassus, fam. Bǒvìdæ, ord. Ungŭlāta.

Aurŏra. The Latin goddess of the morning, called by the Greeks Eos. (Eos, Tears of.)

Aurōra boreālis [L., northern dazen], or Northern light. An appearance of streams of light shooting up from the northern horizon; probably due to an electrical disturbance in the upper regions of the atmosphere; though most frequent in high latitudes $\mathrm{N}$. or $\mathrm{S}$. It is seen from time to time in all parts of the earth.

Aurum musīvum. [I.] Mosaic gold, a bisulphide of tin.

Auscultā filli [L., hearken, my son], or Greater Bull. Pope Boniface VIII.'s censure of Philip of France, reasserting the claims of the Lesser Bull (q.v.); burnt publicly at Paris, January, 1302.

Auscultation. [L. auscultatio, -nem, from ausculto, I listen.] The investigation of disease by means of hearing, with or without an instrument.

Auspices. (Augurs.)

Auster. [L.] The hot south wind. Austral, southern. Australasia = S. Asia. (Winds.)

Austrian Netherlands. About the middle of the eighteenth century, comprised most of Belgium and Luxemburg.

Aut Cæsăr aut nullus. [L.] Lit. either Casar or nobody; either supreme success or nothing at all.

Authentio [Gr. à่ $\theta \epsilon \nu \tau \iota k \delta s]=$ authoritative. Bishop Watson distinguishes between an A. work, i.e. containing a true statement of facts; and a Genuine, i.e. coming from him whose name it bears. But this is not accurate. Archbishop Trench (Select Glossary) points out the

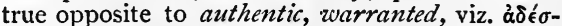

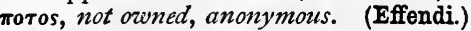

Authentic Doctor, The. Gregory of Rimini, died A.D. 1357.

Authentic modes. The earlier existing modes in plain song, on which the Plagal were constructed. (Greek modes.)

Authentics. (Rom. Law.) An anonymous collection of Justinian's novels.

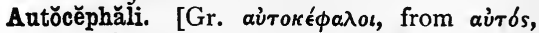

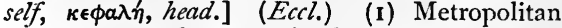
bishops not under a patriarch; also (2) bishops immediately under a $\mathrm{P}$. and having no $\mathrm{M}$.

Autochthons. [Gr. aùtó $\theta \dot{\nu} \nu \in s$.$] The Greek$ name for the aborigines of any country. The Athenians claimed to be such.

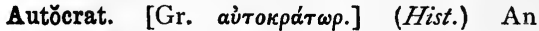
Athenian general, invested with full powers, like the $\mathrm{R}$. Consul with his imperium. Hence any despotic sovereign, as the Czar of Russia.

Auto da Fé. [Sp., Act of Faith.] In Spain, Portugal, and their colonies, a solemn delivery of heretics by the Inquisition to the civil power, for punishment.

Autogěnous. [Gr. aùrb́s, self, $\gamma \in \nu \nu a ́ \omega, I$ generate.] (Anat.) Developed from a distinct centre.

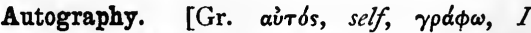
write.] A process in lithography, by which the characters on paper are made to inscribe themselves on the stone,

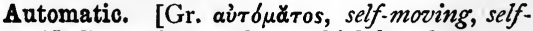
moved.] Properly, anything which has the power of regulating its own actions. Applied wrongly and unfortunately to things which have not this power. Human actions, as springing from freewill, are the true automatic actions.

Automatism. Properly free volition. Wrongly used to denote the modern theory respecting 
actions in which each condition follows on the last by suggestion and without will.

Automăton. [Gr.] A puppet, called from its resembling that which is really an automaton, or self-moved thing. (Automatic.)

Automerdon. [Gr., self-ruling.] In the Iliad, the charioteer of Achilles. Hence any one skilled in driving.

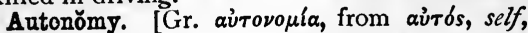
$\nu \delta \mu o s$, law.] Self-government of a state.

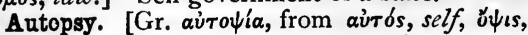
$a$ seeing.] Personal inspection; often = postmortem examination.

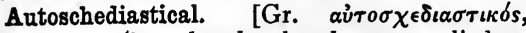

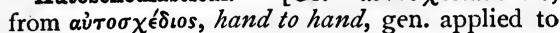
fight, fray.] Extemporaneous, impromptu.

Autotypography. (Nature-printing.)

Autre-fois acquit. (Leg.) At other time acquitted; having been tried already.

Autumnal equinox. (Equinox.)

Auvergne, Arverni. An old province of France, comprising the departments of Cantal, part of Haute-Loire, and Puy-de-Dôme.

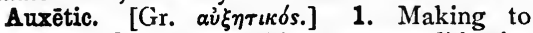
increase. 2. (Rhet.) Given to amplification (q.v.) ; in Gr. àे $\eta \sigma \iota s$.

Auxiliary scales. (Music.)

Auxiliary screw. (Naut.) A vessel rigged for sailing, and also fitted with a screw-propeller.

Ava. [The native name.] A fermented drink made from the root of the long pepper by the South Sea Islanders.

Avalanche. [Fr.] A huge mass of snow which descends from the higher parts of mountains into their valleys [L. ad vallem, whence Fr. avaler, to descend].

Avale. To descend, sink. (Avalanche.)

Avalon. (Avilion.)

Avant-projet. [Fr.] Rough draft.

Avanturine. (Geol.) A variety of quartz, reflecting light from fine spangles of mica; resembling A. glass, which is brown-red and spangled, and was invented accidentally [Fr. par aventure] by the falling of copper filings into melted glass.

Avast! [Cf. It. basta, enough! hold!] (Naut.) Hold hard I stop!

Avätär. [Skt., a descent.] (Hind. Myth.) The descent or incarnation of a deity for a special purpose. Thus there are ten avatars of Vishnu.

Avaunt! = begone ! lit. forward. [Fr. avant, L. ăbante.]

Avē! [L., hail thou!] Short for Ave Măria ! the invocation to the B.V. Mary beginning thus.

Avebury, Abury. A village twenty-five miles north of Salisbury, remarkable as having the largest so-called druidical temple in Europe.

Âvē Cæsar! mŏrĭtūiri tē sălūtāmus. [L.] Lit. Hail, Casar! we, just about to die, greet thee; acidress of gladiators to the Roman emperor before they fought.

Avellane. (Her.) Composed of four filberts [L. ăvellānæ] enclosed in their husk.

Aven, or Herb benet. (Bot.) A plant [Fr. benoîte], aromatic, tonic, astringent; Gëum urbānum, ord. Rosācěæ.
Avenaceous. Having to do with oats [L. ăvēna].

Avênage. [L. avēnagium, from avēna, oats.] Payment of rent by a farmer in oats, i.e. in kind. Average. [L.L. averagium.] (Naut.) 1. The contribution borne by the ship and cargo, or portions thereof, for anything done to ensure safety. 2. The quotient obtained by dividing the sum of a set of numbers by the number of the numbers.

Avernus. [L.] A bituminous lake in Campania, with high banks, supposed to be connected with the infernal regions. Hence the expression of Virgil, "Facilis descensus Averni," for the downward course which is not easily retraced.

\section{Averroism. (Monopsychism.)}

Averse feet. [L. āversus, turned away.] Feet of birds, when set so far back that the bird sits upright ; e.g. auks.

Avertin. [Fr., L. āverto, I turn away, estrange.] 1. A form of vertigo, especially a vertiginous disease of sheep. 2. A popular term for a crazy, sullen state, breaking out into occasional fury.

Avĭcŭlǐdæ. [L., dim. of ăvis, bird.] Wingshells; fam. of molluscs, properly with wing-like extensions at the hinge, as pearl oysters. Warm and tropical seas. Class Conchǐfěra.

Avignon berries. Yellow berries of the buckthorn, used in dyeing (from Avignon, in France).

Avilion. In the Arthurian legends, the spot where Arthur was buried. Said to be Glastonbury.

A vincŭlo mātrimōnii. [L.] From the bond of marriage; a total divorce.

Avis. [Fr.] A notice, advice, i.e. à vis [L. ad visum], according to the view of him who gives it. Aviso, Avviso. (Naut.) An advice-boat.

Avizandum. (Scot. Law.) To take time to consider judgment.

Avocado pear, Alligator P. (Bot.) Persēa gratissima, ord. Lauraceæ; a tree of the warm parts of America; its fruit, which is like a large pear in shape, and contains a large quantity of firm buttery pulp, is called Vegetable inarrow, or Mictshipman's butter.

Avocet. [Fr. avosette, It. avoselta.] (Ornith.) Spec. of black and white wading bird, about eighteen inches in length, with long, upcurved bill. Now rare in Great Britain. Gen. Rěcurvirostra [L. re-curvus, recurved, rostrum, beak], fam. Scŏlōpācĭdæ, ord. Grallæ.

Avoidance. [L.L. ex-viduare, to empty, whence Eng. avoid.] (Leg.) 1. The period when a benefice is void of an incumbent; opp. to Plenarty. 2. The setting aside an opponent's pleading by introducing new matter. 3. (Parl.) A formal mode of dismissing a measure without decision on its principle, as "that this Bill be read this day six months."

Avoirdupois [Fr., to have aveight] ; also written Averdupois. The system used in England for expressing the weight of all heavy articles, and all metals except gold and silver. The fundamental unit of mass is the pound avoirdupois. (Pound.) 
Avon, Afon. [Celtic, river or water.] Name or part of name of many rivers.

Avowry. (Leg.) The plea of one who justifies the fact of having taken a distress in his own right when sued in Replevin.

Avulsion. [L. avulsiō, -nem, from ā, from, vello, I tear.] (Leg.) Land taken from one estate and added to another by inundation or change of a river's course.

Avvocato del diavolo. (Advǒcātus dĭăbŏli.)

Away there! (Naut.) The mode of giving an order to a boat's crew on a man-of-war.

A-weather. (Naut.) When the tiller is to windward, the contrary of $A$-lee (q.v.).

\section{A-weigh. (Naut.) (A-trip.)}

\section{Awn. (Arista.)}

Axil, Axilla. [L. axilla, armpit.] (Bot.) The upper angle formed by the separation of a leaf from its stem. Adj., Axillary, that which grows at that angle.

Axillary thermometer. A thermometer placed under the armpit, sometimes in the mouth or elsewhere, to ascertain the heat of the body.

Axiom. [Gr. à $\xi \hat{\imath} \omega \alpha$.] In Geom., a proposition which it is necessary to take for granted, and which therefore admits of no demonstration; as, "the whole is greater than its parts."

Axis. [L.] (Anat.) The second vertebra of the neck, upon which the Atlas moves.

Axis; Major A.; Minor A.; A. of a lens; A. of a telescope. [L., axle-tree; hence the axis of the earth.] 1. The line within a turning body round which the rotation takes place, and which remains at rest during the rotation. 2. A line with reference to which all the points of a body or curved line are symmetrically arranged; as, the axis of a cylinder, the axis of a parabola. The $A$. of $a$ lens is the line passing through the centres of its surfaces. The $A$. of a telescope or microscope is the axis of the object-glass, with which the axis of the eye-piece should coincide. (For Major A. and Minor A., vide Ellipse.) 3. (Bot.) The root and stem of the whole plant. The plumule and radicle are the axes of growth, around which all other parts are arranged.

Axis of a crystal. Through any point within a crystal let planes be drawn parallel to its faces and cleavage planes; any three lines of intersection of these planes are axes of the crystal, provided they are not in one plane. The positions of the faces can be determined with reference to the axes, and if known with reference to one set of axes, they can be determined with reference to any other set: In most cases, however, one particular set is selected and spoken of as the axes; thus, if any three intersections are mutually at right angles, they would be called the axes of the crystal.

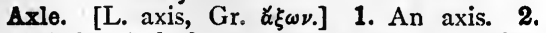
A cylindrical shaft on which a wheel or other body turns, or which turns with the wheel on the bearings. An axis is a geometrical abstraction, an axle its concrete realization. (Shaft.)

Axle-box. A peculiarly formed journal-bearing, by which the weight of locomotive engines or railway carriages is transmitted to the axles, and within which the axles turn.

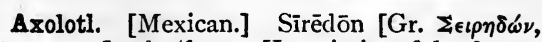
sīren, q.v.] piscíforme [L. piscis, fish, forma, form]. (Zool.) Tailed Batrachian, retaining or losing its gills according to circumstances. Possibly it is the larval stage of a salamander. It is twelve or fourteen inches long. Mexican lakes.

Ayah. An Indian native waiting-maid or nurse.

Aye-aye. [Onomatop.] (Zool.) 1. A quadrumanous animal, somewhat resembling a large squirrel, and with its mammæ on the abdomen ; "one of the most extraordinary of the mammalia now inhabiting the globe" (Wallace); classed in a fam. by itself. Madagascar. Cheirŏmys Madagascanensis [Gr. $\chi \in i ́ \rho$, hand, $\mu \hat{v} s$, mouse], sub-ord. Lěmūrǒìděa, ord. Prīmātēs. 2. I.q. $\mathrm{Ai}(q . v$.$) .$

Aye, aye, sir (Naut.) = "I understand." As an answer from a boat, it shows that a commissioned officer is in her. The addition of a ship's name indicates a captain, and of "flag," an admiral.

Ayegreen. The houseleek [L. sempervivum (q.v.).].

Ayrshire Ploughman, The. Robert Burns.

Ayuntamiento. [Sp.] The council of a town or village ; also called justicia, concejo, cabildo, regimiento.

Azamoglans. Foreign children brought up among the Turks as Mohammedans and soldiers.

Azazel. Lev. xvi. 8, Io; transl. scapegoat, but meaning quite uncertain.

Azi-dahaka. (Zohak.)

Azimuth. [Ar. as-samt, a way or path.] (Astron.) The arc of the horizon intercepted between the meridian and a vertical circle drawn through the centre of a heavenly body; it may be reckoned from the north point, but in northern latitudes it is most convenient to reckon it from the south point westward from $0^{\circ}$ up to $360^{\circ}$. The Magnetic $A$. is a similar arc measured from the magnetic meridian; it is, in fact, the bearing of a point from the magnetic south.

Azimuth and altitude instrument. An instrument consisting of a horizontal circle moving round a vertical axis in fixed supports, and a vertical circle moving round a horizontal axis which is rigidly attached to the former axis. The vertical circle carries a telescope whose axis coincides with a diameter. The altitude and azimuth of a heavenly body can be observed by it when properly adjusted.

Azimuth compass. A compass furnished with sights for observing the bearing of points from the magnetic north or south.

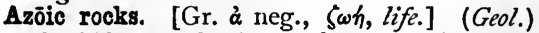
Non-fossiliferous, destitute of life. This term, and Hypozoic $=$ under [i $\pi \dot{6}]$ life, are obsolete as systematic terms. (Neozoic.)

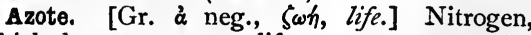
which does not support life.

Azoth. Paracelsus' panacea, or elixir of life.

Azrael. [A Semitic word.] With Jews and Mohammedans, the angel of death, once visible to those whom he took away, now invisible, by reason of Mohammed's prayer. 
Aztecs. A dwarfish people of considerable civilization, in the high-land of Anahuac, in S. America; now extinct. Two children, said to belong to this race, were exhibited in London in I853; but Professor Owen pronounced them to be dwarfs, probably from S. America.

Azulejo. An enamelled tile. The Moors introduced this kind of work into Spain in the eighth century ; examples of A. of the thirteenth century are found in the Alhambra.

Azuline. A coal-tar dye, giving a fine blue colour with a shade of red in it.
Azure. [Pers, eâzur, blue.] (Her.) The blue colour in coats of arms, represented in engraving by horizontal lines.

Azure stone. (Lapis lazuli.)

Azurite. 1. (Lapis lazuli.) 2. Blue carbonate of copper.

Azygous. [Gr. ávoros, not paired.] (Anat.) Said of muscles, bones, etc., that are single.

Azymite. One who uses unleavened [Gr. $\varangle \zeta \bar{v} \mu o s]$ bread in the Eucharist. So the Latins and others have been termed by the Greek Church.

\section{B.}

B is used as an abbreviation for before, as B.C., before Christ; or for bachelor, as B.A., Bachelor of Arts. Among the Greeks and Hebrews, B denoted 2 ; among the Romans, 300, with a dash over it, 3000 . It is also the name of one of the notes in the musical scale, answering to the French $S i$.

Baal, Bel. [Heb., lord, master.] The Semitic sun-god, worshipped as the embodiment of mere power. (Moloch.)

Baalzěbub, Baalzebul. (Muiagros.)

Babes or Children in the Wood. Children of the "Norfolk gentleman" of an old favourite ballad. Their guardian uncle hired two ruffians to kill them ; one, relenting, slew the other, and deserted the children, who, dying in the night, were covered with leaves by robin redbreast. (Cf. the "Two Wanderers," in Grimm's Household Stories.)

Babies in the eyes. Reflexions of one's self in the eyes of another.

Babington's Conspiracy (named from one of the number). That of some English gentlemen, with some priests of an English seminary at Rheims; one John Savage was hired to kill Queen Elizabeth, and an insurrection was to be raised, aided by a Spanish invasion. Fourteen were executed, September, 1586.

Bâbism, Bâbi. Persian pantheistic heresy from Mohammedanism, founded, A. D. 1843, by Seyud Mohammed Ali of Shiraz.

Bablah bark. [Pers. babûl, a mimosa.] The shell of the fruit of a kind of mimosa, used in dyeing drab.

Baboon. [Cf. Fr. babouin, from the same root as Ger. bäppe, thick-lipped (I.ittré).] (Zool.) Gen. of monkey, with dog-like nose, bare (frequently bright-coloured) nasal callosities, generally short tail; some (as mandrill) very large. Africa. Cy̆nǒcěphalus, fam. Cy̆nǒpĭthēcĭdæ, ord. Prīmātēs.

Baboon, Iouis = the French, in Dr. Arbuthnot's Fohn Bull. (Bull, John.)

Bacca, or Berry. In Bot., = succulent fruit, having seeds in a pulpy mass; e.g. gooseberry, grape, potato-berry; the hawthorn raspberry rose, not having true berries. Adj., Baccate, Faccated.
Baccalaureat. The first or lower degree in any faculty conferred in universities.

Baccarat. A gambling game at cards.

Bacchanälia. [L.] A festival to Bacchus, god of wine, at which the celebrants were called bacchanals.

Bacchanalian. Relating to Bacchus or Dionȳsos, a Semitic deity representing the powers of the Cosmos generally, whose orgiastic worship was introduced into Greece against strong opposition from the people. The name Bacchus, which appears as Bocchus, the title of the Mauretanian kings, is a corr. of Malchus, Malek, Moloch (Brown, Great Dionysiak Myth, ii. 10o).

Bacchante. [Fr.] A female worshipper of Bacchus; hence a termagant.

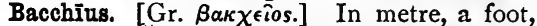
$\checkmark$ - ; e.g. Ülȳssēs. Anti-bacchius being the opposite to B., i.e. - - v ; e.g. dīlēctě $(q . v$.$) .$

Bacchns. (Bacchanalian.)

-bach. [Cymric, little.] Part of names, as Penmaen-bach.

Bachelor [L.L. baccălarius, from which this word has been obtained] denotes a farm servant; hence, as some have supposed, any young man; and so a younger student, or one who has received a lower degree in any faculty, e.g. B.A., B.D., as distinct from M.A. and D.D. The word also denotes a lower knighthood, which some have explained, however, as = bas chevalier (?). The Latinized baccalaureus gave rise to the notion which explained the word as = baccis laureis donatus, crozened with a laurel wreath (see Littré and Brachet, s.v.).

Bacile, Bacino. [It., basin.] A glazed plate, of uncertain origin, encrusted upon church walls in Italy. B. Amatorio, a faience plate, with a portrait and posy.

Băcillärĭæ. [L. băcillum, dim. of băcŭlum, $a$ staff.] A small group of Diătòmācěce. (Desmidǐācěæ.)

Back. [D. bac, a tray or bowl.] A large vessel used in brewing.

Back-bond. (Scot. Law.) A deed of declaration of trust.

Backing, i.q. endorsement. B. a warrant, endorsement by a justice of a warrant granted in another jurisdiction. 
Backing and filling. (Naut.) Getting to windward by sailing and backing alternately, with a favourable tide, in a channel too narrow for turning.

Back-lash. The space allowed for play between the teeth of wheels, to enable them to work in either direction without wedging themselves,

Back-painting. A method of staining the backs of mezzotinto prints affixed to glass, so as to give them the appearance of stained glass.

Back-pressure. The resistance offered by the air and waste steam to the motion of the piston of a steam-engine.

Back-raking a horse. The removal of hardened frees by the greased hand and arm.

Backs. Leather made of the strongest oxhides.

Backshish, Bakshish. [Ar.] A gratuity.

Back-sight. In levelling along a line, suppose the staff to be held at points $A, B, C, D$, etc., successively, the level is first placed between $A$ and $B$, then between $B$ and $C$, then between $C$ and $D$, and so on; in these positions the surveyor looks back to A, B, C, etc., and forward to $B, C, D$, etc., and in each case reads the staff; the former readings are called backsights, the latter fore-sights.

Back-staff. An instrument formerly used for taking the sun's altitude at sea.

Backstays. (Stays.)

Back, To. (Naut.) To go stern first.

Backwardation. (Stockbrok.) Consideration paid on settling day by bears (q.v.), for carrying over their bargains. (Continuations.)

Back-water. 1. Water held back by a dam or other obstruction. 2. Water thrown back by the turning of a water-wheel, and moving up stream.

Back water, To. In rowing, to work the oar the reverse way.

Baconian method = inductive ; Lord Bacon, although not the inventor, having been first to lay down rules of experiment and observation.

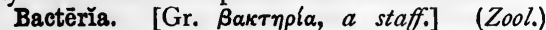
Short, staff-shaped, microscopic organisms, of disputed origin and nature, found in organic infusions, but not appearing if, after boiling, none but thoroughly filtered air is admitted. They are accompanied by thread-like vibrionenes [L. vibro, $I$ vibrate], and are, after an interval, succeeded by active, single-ciliated, spherical monads, perhans the larvie of infüsōria (q.v.).

Badaud. [Fr.] Idler.

Badenoch. District in Inverness, at foot of Grampians.

Badger. [Heb. tachash ; Exod. xxv. 5, etc.] (Bibl. and Zool.) 1. Probably Dugong (q.v.), or, as some, the badger [cf. L. taxus, Ger. dachs]. 2. A licensed dealer in corn, etc.

Badger-bag. (Naut.) He who represents Neptune when a ship crosses the line.

Badigeon. [Fr., stone-coloured; origin unknown.] A fine plaster, for filling holes in statuary.

Badinage. [Fr. badiner, to jest.] Trifling; playful talk, "chaff."

Badminton. 1. Outdoor game with battledores and shuttlecocks. 2. Also a drink, a kind of claret-cup.

Baffling winds. (Naut.) Shifty W.

Bagala. [Ar., mule.] (Naut.) A highsterned vessel of Muscat, of from 50 to 300 tons, built rather for carrying than sailing.

Bagasse. [Fr.] (Cane-trash.)

Bagatelle. [Fr., little bundle, O.Fr. bague.] 1. A trifle. 2. A game played on a long board with nine holes at further end, with balls and cue.

Bagaudæ. A name given to peasants in Gaul, who rose against the Romans in the third century.

Bagnes. [Fr.] Hulks, convict prisons,

Bag on a bowline, To. (Naut.) To fall of one's course.

Bagshot-sand. (B., village in Surrey.) The lowest series of strata in the Middle Eocene group of the English Tertiaries.

Baguette. [Fr., $a$ wand.] (Arch.) A small round moulding. (Bead-moulding.)

Bahadúr [Pers.] = worshipful.

Bahr. [Âr., sea.] Lake, large river, as Bahr Tubairyeh, the Sea of Tiberias or Lake of Galilee.

Baidar. (Naut.) An Arctic canoe manned by six or twelve paddles.

Bailee. One who is in temporary possession of goods committed to him in trust.

Bailey. [L.L. ballium, Fr. baille.] A castle court between the walls surrounding the keep. In the Old Bailey, London, the name survives after the castle has disappeared.

Bailie. In Scotland, a municipal magistrate = alderman.

Bailiwick. [Fr. bailli, bailiff, and Saxon vic = vicus, street or dwelling.] The district within which authority is exercised ; so a county is the B. of a sheriff, or a particular liberty is the B. of some lord.

Bairam. The Mohammedan feast which follows the Ramădan, or month of fasting. Owing to the use of the lunar months, these periods range round the whole year in a cycle of thirty-three years.

Bajaderes. Indian dancing women, who may be compared with the Ambubaiæ.

Bajocco. [It.] A papal copper coin, worth about a halfpenny; said to be from bajo, baycoloured ; $c f$. " a brown," slang for a penny or a halfpenny. No longer current.

Bajǔlus. [L.] Lit. one who carries anything. (Eccl.) Bajulus aquæ, the bearer of holy water in processions.

Baker's dozen. Colloquial for thirteen.

Bal-, Balla-, Bally-. [Gadhelic baile, an abode.] In Ireland, Scotland, and Wales, = stockade, abode, enclosure, as in Bal-moral, Bally-shannon; cf. bailey [L. ballum, Eng. wall].-Taylor, Words and Phrases.

Bala-. Cymric name or part of name ; effluence of a stream from a lake, as Bala.

Balance of power. A fictitious diplomatic phrase, = absence of any specially predominant power; disturbance of the status quo in Europe is said to affect the $B$. of $P$. 
Balance of watch. The part which, by its motion, regulates the beat.

Balandra. (Naut.) 1. A lighter. 2. A kind of schooner. 3. A Spanish pleasure-boat. [Sp. form of Eng. bilander (q.v.), D. bijlander, Fr. bélandre.]

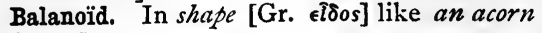

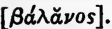

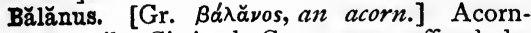
shell ; cessile Cirriped Crustacean, affixed by head to rock, etc., protected by calcareous shell. Larva (Nauplüus) and pūpa free. Gives its name to fam. Bălănĭdæ.

Balas ruby. (Ruby.)

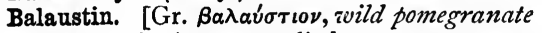
flower.] (Bot.) A term applied to pomegranatelike fruit; i.e. with leathery rind, and drupes arranged in cells within.

Balcar. (Balkers.)

Baldachino [It.], Baldachin, Bawdequin. A canopy, originally of rich silk from Baldacco, i.e. Bagdad; hence a piece of furniture fixed over the principal altar of a church or carried over sacred persons or things; the modern form of Ciborrum. The most celebrated is at St. Peter's, Rome.

Balder. The white sun-god of Teut. Myth. The first syllable of the name is found in Bjelbog, the pale or white spirit. (Tschernibog.)

Balderdash. 1. Senseless talk, jargon. 2. A trashy worthless mixture of liquor. [According to Latham, from Welsh balldorddus, imperfect

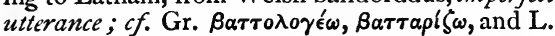
balbūtio.]

Baldric. [L.L. baldrellus.] 1. A girdle used by feudal warriors. 2. A bell-rope. 3. The leather strap connecting the clapper with the crown of the ball. 4. Broad leather belt crossing the body, for suspending the sword from the right shoulder.

Baldwin's phosphorus. (Phosphorus.)

Bale. [Goth. balwjan, torquere (Richardson).] Writhing, misery, calamity. Bale-fire, a fire signalling alarm.

Bale, selling under the. Selling goods unopened, wholesale. [Bale, a package, Fr. bale, one of the many variants of the word which in Eng. is ball.]

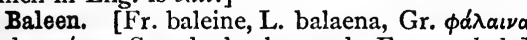
and $\phi \alpha \dot{\lambda} \eta$, Scand. hvalo, and Eng. zvhale.] Whalebone, the horny laminæ through which the whale strains its food.

Balinger, or Balangha. (Naut.) 1. A small sloop. 2. A barge. 3. A small war-ship without forecastle, formerly in use.

Baling-strips. Strips of thin iron for binding bales.

Balister. A cross-bow. [L.L. bălistārius, i.e. arcus.] (Arcubalist; Ballista.)

Balistraria [L.], Arbalestria [L.], Arbalisteria [L. N. Narrow apertures in the walls of a fortress, for the discharge of arrows from the cross-bow; often cruciform; thirteenth, fourteenth, and fifteenth centuries.

Balk. [A.S. bælc.] 1. A strip or ridge of land purposely lef? out in ploughing. 2. Spelt aiso baulk; the sqi ared trunk of the fir; a large beam of timber; $c f$. Ger. balken, a beam. [Query : Are these two words or only one with some radical meaning of straightness, whence to balk = (I) to check, disappoint ; (2) to heap up in a ridge? $C f$. a billiard ball "in balk."]

Balkers. Watchers on heights for shoals of herring.

Ballast. [Of doubtful origin.] (Niaut.) Weighty materials, as iron, gravel, casks of water, carried below to keep a vessel's centre of gravity down. A ship in $B$. = laden with $B$. only. Shifting of $B$. is its getting out of its proper position through rolling.

Ballătoon. (Naut.) A small Indian schooncr without topsails.

Ballerina. [It.] A female dancer.

Ballet. [It. palletta, a little ball.] 1. (Her.) A roundlet or small disc. (Pallet.) 2. A theatrical representation by means of movements and dances accompanied by music.

Ball-flower. (Arch.) An ornament shaped like a globular flower, frequently used in buildings of the Geometrical and Continuous styles of English architecture.

Balling process. The process by which saltcake is converted into ball-soda. The furnace used is called the balling furnace. (Salt-cake; Black-ash.)

Ballista, Balista. [L., from Gr. $\beta a ́ \lambda \lambda \omega, I$ throw.] A large military engine, used by the ancients for throwing stones, etc., as the Cătăpulta, a kind of powerful cross-bow [Gr. $\kappa a \tau a \pi \epsilon ́ \lambda \tau \eta s]$, was for heavy darts, arrows, etc. Its construction, of which there were several varieties, is not very well known.

Ballistics. [From Ballista (q.v.).] The doctrine of the motion of projectiles in a resisting medium, such as the air.

Balloen. (Naut.) A Siamese State galley, shaped as a sea-monster, with from 140 to 200 oars.

Ball-soda. (Black-ash.)

Balluster has been corr. into banister. [It. balestriera, a loop-hole for the cross-bow (L. bălista); afterwards applied to the columns themselves.]

Balm, Common. A plant with lemon-scented leaves and stem, which yield oil of B. ; Mělissa officinālis, ord. Lab. An infusion of B. is a popular remedy in fevers.

Bal masque.. [Fr.] Fancy ball.

Balnëum. [L.] Among the Romans, in the singular, a private bath, as distinguished from the Balneæ, or public baths.

Balsa. S. American float or raft, resting partly on air-tight skins; for landing goods through a heavy surf.

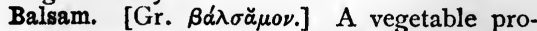
duct, containing benzoic acid. Balsams of Peru and of Tolu are S. American balsams, used as stimulants and expectorants. Canada balsam and balsam of copaiba (Canada balsam; Copaiba) are not true balsams, but oleo-resins.

Balsamo, Jos. A famous charlatan and mes. merist of the last century; also called Cagliosiro.

Balzarine. A light material of worsted and cotton for ladies' dresses.

Bambino. [It., $a$ child.] A representation 
of the infant Jesus; sometimes, but not necessarily, wrapped in swaddling clothes.

Bambocciata. [It., from bamboccio, a puppet, from bambo, an infant (Bambino).] A picture, generally grotesque, of common rustic life, such as those of Peter van Lear, seventeenth century, nicknamed the Cripple [It. il Bamboccio].

Bambusa, Bamboo. Arborescent grasses, Asiatic and American, having many spec.

Bampton Ieotures. Founded by Canon B. ; a yearly course of eight sermons at St. Mary's, Oxford, by the Lecturer of the year; since 1780 .

Ban-. [Gaelic and Erse, white.] Name or part name of rivers, as Bann, Ban-don.

Ban. 1. [In Slav., master.] Lords of some frontier provinces were so called; the Ban being the Viceroy or Governor of Croatia. Banat, Bannat, the lordship of a B. (Tabernicus.) 2. [Fr.] A national levy of soldiers in feudal times. Lever le ban et l'arrière ban, a summons of the feudal lords and the tenants under them; arrière ban being a corr. of heribannum, from Ger. heer, an army.

Ban, Banns. [H.G. bannan, to publish a decree.] Originally simply a proclamation, as in Gaelic and modern Welsh; hence banish, banditti; ban in the sense of a curse ; ban, a levy; banns of marriage.

Banana. (Plantain.)

Banco. [It.] 1. (Leg.) 2. In Commerce, Bank money, standard money; as opposed to the inferior coinage which may be current; and which was received, in early banking times, at this its intrinsic value only. B. now refers generally to the Hamburg bank accounts, which are not represented in corresponding coinage.

Banco, Banc, sittings in. [L.L. bancus, bench.] Sittings of a superior court of common law as a full court.

Band; Crossed B.; Direct B.; Endless B. A broad leather strap having its ends joined and passing over two wheels fixed on parallel shafts, to communicate the motion of the one to the other. The term is also applied to cords and other wrapping connectors. A band is sometimes called an Endless $B$., and is either direct, when its straight parts are parallel, or crossed; a direct B. makes the wheels turn in the same, a crossed B. in opposite, directions.

Bandanna. 1. Peculiar silk handkerchief made in India. 2. Similar calico printing in England.

Bandeau. [Fr.] A band or fillet, principally as a head-dress or part of a head-dress.

Banded. (Her.) Tied with a band.

Bande Noire. [Fr.] German foot-soldiers, part of the Grand Companies employed by Louis XII. in his Italian wars : they carried a black ensign when a favourite general died. The name was similarly borne by other soldiers, both French and Italians; it was given also, in the first French Revolution, to some societies which bought confiscated property of the Church, of emigrants, etc.

Banderol. [Fr. banderolle, from It. banderuola.] Flag about two feet square, for signalling, and also for marking the points during military mancuvres.
Bandfish. Gen. of fish (Cēpŏla), of ribbonlike form. One spec. colour rel, length about fifteen inches (C. rŭbescens) [L., reddening]. British ; most others, Japanese. Fam. Cēpŏlĭdæ, ord. Ăcanthoptěry̆grii, sub-class Tělěostei.

Bandicoot. [Telinga, pandi-koku, pig-rat.] Fam. of rat-like insectivorous marsupials. Australia and islands. Pērămělĭdæ [coined from Gr. $\pi \dot{n} \rho \alpha$, a pouch, L. měles or mëlis, $a$ marten or badger]

Banditti. [It.] Properly, persons put under a $b a n$ and outlawed. But the word has now much the same meaning as robber. (Ban.)

Ban-dog; i.e. band-dog; any large watchdog, kept ticd $u p$.

Bandoleers. Small wooden cases covered with leather, for holding the charges of a musket, and suspended from a shoulder-belt. [Fr. bandoulière, from It. bandoliera.]

Bandore, Pandore. [Gr. $\left.\pi a \nu \delta o v \rho \alpha_{\text {. }}\right]$ A kind of lute with twelve wire strings. The word has been corr. into Banjo.

Bang, Bhang. A narcotic made of the larger leaves and seed capsules of Indian hemp; i.q. Haschish. (Assassin.)

Bangle. 1. A plain, or somewhat plain, metal bracelet. 2. To waste by little and little, to squander carelessly; in Dr. Johnson's time a colloquial word only.

Bangorian Controversy, The. Upon the relations of civil and ecclesiastical authority, between Bishop Hoadley of Bangor, and W. Law, author of Serious Cail, with others, A.D. I7I 7 .

\section{Bangor Use. (Use.)}

Bania, or Bunnea. [Hind.] A money-lender, banker.

Banian. A merchant class among the Hindus; mostly very strict in observance of fasts : hence "Banian days," in nautical slang, = days on which meat is not served.

Banjo-frames. (Naut.). Frames by which screw-propellers are raised on deck, and in which they work.

Banked fires. (Naut.) Fires drawn forward, and covered with ashes, so as just to keep the water in the boilers hot.

Banker. (Naut.) A vessel employed on the Newfoundland Bank, i.e. in cod-fishery.

Bank Holidays. Easter Monday, Monday in Whitsun week, first Monday in August, and December 26.

\section{Bank money. (Banco.)}

Bank rate. The variable rate at which the Bank of England advances money.

Bank stock. Shares in the property of a bank, especially Bank of England.

Ban lieue. [L.L. banleuca, ban (q.v.), and leuca, Celtic, a league, an indcfinite amount of territory.] Land outside the walls of a town, but subject to its law.

Bannatyne Club. Instituted I 823 , by Sir W. Scott; its object the printing in a uniform manner of rare works of Scottish history, topography, poetry, etc. Geo. B., antiquary, collector of "Ancient Scottish Poems," I 568.

Bannerer. In mediæval times, bore the banner of the city of London in war. 
Banneret. A feudal lord who led his men to battle under his own banner. The privilege of so leading them was often awarded on the battle-field to those who had there distinguished themselves.

Bannering. Beating the bounds [L.L. banna].

Bannerole. (Banderol.)

Bannimus. [L.L., we banish.] Form of expulsion from Oxford University.

Bannock. In Scotland, a home-made cake, generally of pease-meal, or pease and barley mixed, baked on a girdle, i.e. circular iron plate.

Banquette. [Fr., $a$ bench, dim. of banque, $a$ bank, from It. banca.] (Fortif.) Low bank of earth, placed on the inside at a suitable height, to enable the defenders to fire over the parapet.

Banshie. In Irish Myth., a phantom in female form, supposed to announce the approaching death of living persons, and answering to the Grey spectre or Bodach Glas of Scotland (Scott, Waverley, ch. xxx.).

Banstickle. Spec. of stickleback, three-spined.

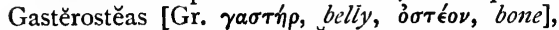
fam. Gastěrostěr̆dæ, ord. Ácanthoptěry̆gii, subclass Tělěostěi. (Stickleback.)

Bantine Table. [L. Tabŭla Bantǐna.] A bronze tablet, with an Oscan inscription of thirtythree lines, found A.D. I793, near Bantia, in Apulia.

Banting. One who diets himself to prevent fatness, or the diet of such, from W. Banting, notorious (A.D. 1863) for having thus become thin.

Bantling. [Probably $=$ bandling, an infant in swaddling clothes.] A child; meton., an author's pet work.

Banyan tree of India. Ficus Indica, ord. Urticaceæ ; a native of most parts of India.

Baobab, or Adansonia dĭgütäta (Adanson, Fr. naturalist). Monkey-Bread, Sour Gourd, an extraordinary tree of Trop. Africa, nat. ord. Bombaceæ; the only spec. known; in Humboldt's opinion, "the oldest organic monument of our planet."

Baphic. Belonging to dyes or dyeing [Gr. $\beta \alpha \phi \eta ́$ ].

Baphomet. [Corr. of Mahomet.] Some kind of figure or symbol, which the Templars were accused of using in magical rites.

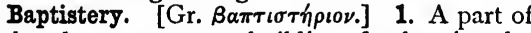
a church, or a separate building, for baptism by immersion. 2. A canopied enclosure containing the font.

Bar. (Her.) An ordinary bounded by two horizontal lines drawn across an escutcheon, so as to contain one-fifth part of it. In popular language, Bar sinister = Bâton $(q . v$.$) .$

Bar, Confederation of. An unsuccessful association of some Polish nobles, formed at Bar, 1767 , for the purpose of freeing their country from foreign influence.

Bar, Trial at. Trial before the judges of the superior court instead of at nisi prius (q.v.), generally before a special jury.

Baragouin. [Fr.] Jargon, gibberish ; originally the Bas-Breton language, of which the words bara, bread, and gwin, wine, occurred most frequently in conversations between the BasBretons and the French (Littré, Brachet).

Barataria. Sancho Panza's island-city, in Don Quixote. [Sp. barato, cheap.]

Barb. An Arabian or Barbary horse.

Barba. [L., beard.] (Bot.) A sort of down found on the leaves of some plants. Barbate, having a $B$.

Barbados leg. (Elephantiasis.)

Barbarian. A word used by the Greeks to designate all who were not Greeks. It represents the Skt. varvara, applied by the Aryan invaders of India to the negro-like aboriginal inhabitants whom they found there. Another Greek form of the word is Belleros. (Bellerophon's letters.) Max Müller, Chips, vol. ii. Bellerophon.

Barbecue. A beast, especially hog, stuffed and roasted whole. [(?) Fr. barbe à queue, snout to tail.]

Barbed horse. [Fr., L. barba, a beard.] Completely equipped with armour. Barb means a hooked point, armour for horses.

Barbel. [O.Fr., L. barbellus, dim. of barbus, $i d$., from barba, a beard.] Numerous gen. of fish, with four barbules, two at tip of nose, two at corners of mouth. Europe, Asia, Africa; one spec. British. Barbus, fam. Cyprinĭdæ, ord. Physostŏmi, sub-class Tělěostěi.

Barberini vase. (Portland vase.)

Barberry. [Ar. barbāris, L.L. berbĕris vulgāris.] 1. Ord. Berberideæ; a British shrub with racemes of yellow flowers; the fruit is used as a preserve. 2. Another kind, B. aquifơlum, is the well-known plant of English shrubberies.

Barber-surgeons. Corporations with certain privileges, from Edward IV.'s time, 146I, till I8 George II. dissolved the connexion. The barber's pole still represents the ribbon wound round the arm before blood-letting.

Barbet. [Fr., dim. of barbe, beard.] 1. The poodle dog, especially the small breed. 2. (Bucconidæ.)

Barbette. [Fr., barbe, beard, parce que le canon fait la barbe, rase l'épaulement (Littré).] Elevation of earth placed in salient works of a fortification to give guns freer range, by being fired without embrasures.

Barbican. Masonry fortification, formerly used to protect the drawbridge leading into a town; also as a watch-tower. [Fr. barbacane, Ar. barbak-khaneh, a rampart; introduced, like many other military words, by the Crusaders.]

Barbiton. [Gr. BápBitos and -ov.] Some kind of lyre, seven-stringed, used by the ancient Greeks.

Barca-longa. [Sp.] 1. A Spanish coasting lugger, undecked and pole-masted, and fitted with sweeps for rowing. 2. A Spanish gun-boat. Barcarolle, Barquerolle. [Fr. barque, a bark.] Song of Venetian gondoliers, or one of the same character.

Barcone. A short lighter; Mediterranean.

Bard. [L.L. bardæ.] Horse-trapping, armour.

Barděsănites. In Eccl. Hist., the followers of Bardesanes, in the second century, who regarded the devil as a self-existent being. (Ahriman.)

Bards. (Minstrels.) 
Bare-bone. Lean, so that the bones show.

Barebone's Parliament. (Hist.) A nickname for the council summoned by Cromwell, I653, from Praise-God Barebone, one of the members.

Baréges [Baréges, H. Pyrenees], or Crêpe de Baréges. Mixed tissues for dresses, usually of silk and worsted; made really at Bagnères.

Bare poles, Under. (Naut.) With no sails set.

Barge [see Bark; L.L. barga], Captain's, or Admiral's. A man-of-war's boat for the use of those officers. State B., a large boat sumptuously fitted. Trading $B$. (variously named) is flat-bottomed, and usually fitted with a spritsail and a mast to lower; used on rivers and canals. Also an east-country vessel peculiarly constructed. Bread-B., the bread or biscuit tray or basket.

Bargeboard. Probably $=V$ crge-board ; the ornamental woodwork carried round under a gable roof.

Barguest. [Guest, another form of ghost, Ger. geist.] A horrible goblin, toothed and clawed, in the $\mathbf{N}$. of England; supposed to shriek at night.

Barilla. [Sp.] Impure carbonate of soda, alkali produced by burning salsola (q.v.).

Bărium. [Gr. Bapús, heav'y.] A malleable yellowish-white metal, the basis of the alkaline earth băry̆ta.

Bark. (Cinchona tree.)

\section{Bark, or Barque. (Barque.)}

Barkantine, or Barquantine. A three-masted vessel, carrying only fore-and-aft sails on her main and mizzen.

Bark-bound. Having the bark too firm or close for healthy growth.

Barker's mill. An elementary kind of turbine. It is capable of rotation round the axis of a vertical tube having two horizontal tubes or arms at the lower end, the whole being like an inverted $\mathrm{T}$; there are openings in the horizontal tubes near their ends, but on opposite sides; water flows down the vertical tube and comes out at these holes in two horizontal jets; the reactions of the jets form a couple which causes the mill to turn in a direction opposite to the jets.

Barking smack. A smack hailing from Barking Creek, in Essex.

Barlaam and Josaphat. A very popular mediæval religious romance, in which the hermit B. converts the Indian Prince J. Originally Sanskrit, but transl. into many languages.

Barlaamites. (Eccl. Hist.) Followers of Barlaam, a Latin monk of fourteenth century; known chiefly from their controversy with the Quietist monks of Mount Athos (Gibbon, Roman Empire, ch. lxiii.).

Barley. Pot $B$, of which the husk only has been removed : Pearl $B$., of which the pellicle also has been removed, and the seed rounded.

Barley-corn, John, or Sir J. A humorous personification of malt liquor ; from an old tract, The Arruigning and Indicting of Sir F. B., Kt.

Barley-mow. A heap of stored barley. (Mow.) Barmecide feast = unreal, imaginary : such as the Barmecide prince first set before the hungry Schacabac in the Arabian Nights' Tales.

Barmote, Barrmote, Barghmote, Berghmote. [A.S. berg, hill, gemote, assembly.] A Derbyshire court for miners.

Barnabee. Popular name for the lady-bird.

\section{Barnack stone. (Bath-stone.)}

Barnacle goose. Spec. of goose, about two feet long, plumage black, white, and grey. Temperate regions. Gen. Barnicla, fam. Ănătĭdæ, ord. Ansĕres (Lepas.) They were supposed to be produced from shells found on certain trees in Scotland and elsewhere. This absurd notion rose from a confusion of the name with that of the cirriped Barnacle, the bird being originally called Hĭbernicŭla, as being found in Hibernia (Ireland), then Bernicula, and lastly Barnacle (Max Miiller, Lectures on Language).

Barnacles. 1. [From the likeness to spectacles.] Pincers enclosing the muzzle of a horse, to keep him quiet for any slight operation; the Trvitch $(q . v$.$) is better. 2. Spectacles; (?) a corr. of$ binocle, as binnacle also is; or (?) connected with obsolete bernlein, of the same meaning; and this with bēryllus.

Barometer; Aneroid B.; Marine B. ; Mountain B,; Siphon B.; Wheel B. [Gr. Bápos, weight, $\mu$ é $\tau$ pov, measure.] An instrument for measuring the pressure of the atmosphere. It consists of a tube containing mercury, about thirty-four inches long, held in a vertical position, with its open end dipping into a basin of mercury; the space within the upper part of the tube being a vacuum, the height of the column above the surface of the mercury in the basin is an exact measure of the atmospheric pressure. In the Siphon $B$. the lower end of the tube is bent up, instead of dipping into a basin of mercury. In the Wheel $B$. the motion of the mercurial column, due to changes in the atmospheric pressure, is communicated to a hand which shows the variations on an enlarged scale. The Marine $B$. is a barometer hung on gimbals, and otherwise protected from disturbance caused by the ship's motion, firing of guns, etc. The Mountain $B$. is adapted for being carried from place to place by travellers; from the readings of a barometer at two stations, the vertical height of the one above the other can be inferred, since, all other circumstances being the same, the weight of a column of air of that vertical height equals the difference between the weights of the barometric columns at the two stations. In an Aneroid $B .(q . v$.$) the variations in the pressure of$ the air are measured by the movements of the elastic top of a small box, which are communicated to a hand like the hand of a clock.

Barometz fern. [Russ. boranez, little lamb.] Scythian lamb; the prostrate hairy rhizome of the Dicksonia barometz, whose appearance has given rise to many fabulous stories.

Baron. (Hist.) Lit. the man of the Liege lord or king. This title displaced that of Thane in this country on the full establishment of the Feudal system after the Norman Conquest, the Ceorls and Thralls being now known as Freemen and Villeins.

Baron and Feme, or Femme. 1. In Norm. 
Fr. Law, = man and wife. 2. (Her.) Husband and wife. When one shield bears the husband's arms on the dexter side and the wife's arms on the sinister side, it is said to be parted per pale, baron and feme.

Baron of beef. A double sirloin.

Barony, in Ireland, = hundred, or wapentake, in England.

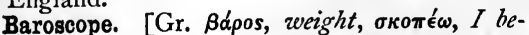
hold.] An instrument for showing that bodies are supported by the buoyancy of air, in the same manner as they are by that of water, though in a much less degree.

Barouche. [F., from L. bĭrŏta, a two-wheeled carriage.] A four-wheeled carriage, having a top that can be raised, and front and back seats facing each other, each seat holding two persons.

Barque, Bark. [A word common to most Aryan languages; L. barca, through It. or Sp. barca.] Generally any small ship, square-sterned, without headrails ; but especially a two or three masted vessel with only fore-and-aft sails on her mizzen-mast. Bark-rigged, having no squaresails on the mizzen-mast.

Barra-boats. Vessels of the Scotch Western Isles, sharp at both ends, and with no floor, so that their transverse section is $\mathrm{V}$-shaped.

Barracan. [Ar. barrakân, a coarse gozwn.] A coarse strong camlet, used for cloaks, etc.

Barracoon. Depôt for slaves newly captured. [Fr. baraque, from It. baracca, barracks; and Gael, barrachad, a hut, barrach, branches of trees (Littré).]

Barras. [Fr.] The resin of the Pinus măritima; the base of Burgundy pitch. [Having a barred or streaked appearance when dried, Fr. barré (Littré).]

Barrator, Barretor. One guilty of Barratry.

Barratry. [Cf. It. barratrare, L.L. baratare, to cheat, O.Fr. barat, barete, fraud, quarrel.] (Leg.) 1. Exciting others to suits or quarrels. 2. Fraudulent conduct towards owners or insurers of a ship by master or crew.

Barrel [Fr. baril] of beer is thirty-six gallons.

Barrel-bulk. (Naut.) A measure of capacity $=$ five cubic feet. Eight barrel-bulk $=$ one ton measurement.

Barren flowers bear only stamens without a pistil, as in the cucumber.

Barret-cap. [Fr. barrette.] A cap formerly worn by soldiers.

Barrier Treaty. (Hist.) A treaty, made I715, between the Emperor, the King of England, and the States-General of the United Provinces, giving to the latter the right of holding certain fortresses in the Spanish Netherlands.

Barring-out. "A savage licence practised in many schools to the end of the last (i.e. seventeenth) century," "the boys taking possession of the school when the vacation drew near, and barring out the master." (See Johnson's account, in his Life of Addison.)

Barrique. [Fr., L.L. barrica, connected with baril (Littré).] A French barrel of wine or brandy, of different capacity in different places.
The barrique of Cognac is $45^{\circ} 22$ English gallons, and is divided into 27 veltes.

Barris. Spec. of Baboon (q.v.).

Barrow. [A.S. beorg, beorh, a hill, mound; cf. burgh, borough, Gr. múpros, a tower.] 1. A burial-mound. [L. tumŭlus, a mound tomb.] 2. Intrenched hill, for a fenced town.

Barrulet. (Her.) A diminutive of the bar, being one-fourth its thickness.

Barry. [Fr. barré, barred.] (Her.) Covered with horizontal stripes alternately of two tinctures. (Bar.)

Barry Cornwall. Properly Barry Peter Cornwall; a pseudonym and anagram of Bryan Waller Procter, poet.

Barry Lindon. An Irish adventurer and gambler ; hero of Thackeray's tale so named.

Bar-shoe. A horseshoe with a complete ring of iron forming a bar across the opening; distributing the pressure, and relieving a tender part. (See Stonehenge on the Horse, p. 563.)

Bar-shot. Used sometimes in naval warfare for destroying masts and rigging; a bar with a half-ball at each end; in shape like a dumb-bell.

Barter. [O.Fr. bareter, It. barattáre ; words meaning both to barter and to deceive.] Originally, the simple exchange of one commodity for another; secondarily, $=$ loss of credit. Mr. Huskisson, in 1825 , said that the panic placed England within forty-eight hours of B. ; i.e. of such loss of credit that its notes would not have been received, or its coin, except for its intrinsic value as an article of exchange.

Bartholomew, St., Massacre of. (Fr. Hist.) A terrible massacre of the Huguenots in Paris, August 24, 1572, in which the Admiral Coligny was the first victim. Similar massacres took place at the same time in the larger French towns.

Bartizan. A small overhanging turret, a stone closet, projecting from an angle at the top of a tower, or from a parapet, or elsewhere ; as in medireval castles.

Barton. 1. A grange, courtyard. [A.S. bear $=$ crop, or bere, barley, and tun or ton, enclosure.] 2. A certain combination or system of pulleys.

Barton, Elizabeth, Holy Maid of Kent, brought forward as a prophetess, denounced the divorce of Henry VIII. and his second marriage, and was executed for high treason, 1534

Baru. A woolly substance from the leaves of Saguerus sacchăriffer, a sago palm ; used in caulking ships, stuffing cushions.

Barwood. A red African wood used for dyeing and turner's work (imported in short bars).

Băry̆ta, Bărytes. [Gr. Bă Oxide of bărŭum; an alkaline earth, grey, poisonous ; the heaviest of known earths.

Bary̆tone, Bariton. (?) Of heavy low tone

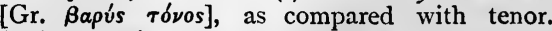
1. A voice in compass, and still more in character, something between tenor and bass. 2. The Viola de bardone, or V. di fagotto of Haydn, now obsolete. 3. In Pros., having the low melodic accent, which is not generally marked. (Oxytone.) 
Basalt. [L. basaltes, probably an African word, = hard dark marble.] Hard dark-coloured rock, of igneous origin, often columnar and hexagonal, from geometric cracks in cooling. (Fissures-of-retreat.)

Basanite, Touchstone, Iy̆dŭus lăpis, or Iydite. A black siliceous sclist, on which pure gold rubbed leaves a certain mark. [Gr. $\beta \tilde{\alpha} \sigma a ̆ \nu o s, a$ touchstone.]

Bas bleu. [Fr.] A Blue-stocking.

Bas chevalier. A knight of the lowest rank of knighthood. (Bachelor.)

Bascinet, Basinet, Basnet. Medireval helmet, light, somewhat basin-shaped, introduced temp. Edward I. [Fr. bassin, a basin.]

Base. [Gr. Báaıs, a step.] 1. (Her.) (Escutcheon.) 2. (Chem.) A body which unites with acids to form salts; as silver unites with nitric acid to form the salt called nitrate of silver. 3. (Dyeing.) A substance used as a mordant.

Base-ball. The national game of the U.S. of America, somewhat like our rounders; so called from the four bases, one at each corner of a square, whose side is thirty yards ; the first, second, and third being canvas bags, painted white, filled with some soft material, and the home base marked by a flat plate painted white. (See full account, English Cyclopadia, i. 255.)

Base-court. [Fr. basse cour.] 1. The outer court of a feudal mansion, containing the stables, accommodation for servants, etc. 2. (Leg.) An inferior court not of record, as court-baron, court-leet.

Base-fee. (Leg.) An inheritable freehold terminated on some special qualifying contingency, such as the fall of a certain tree, failure of issue under an entail, the ceasing to be lord or tenant of a certain manor.

Base line. 1. In Perspective, the line where the plane of the picture intersects the ground plane. 2. In Surveying, an accurately measured line on which a network of triangles is constructed, whose angular points are conspicuous places, and whose distances from each other are calculated from the base and measured angles only.

Base of operations. The portion of country, sea-coast, river, or the strong towns, either on the flanks or rear of an army in the field, from which its resources are drawn, and to which it can retreat in case of reverse.

Bashaw. Pasha $=$ head or master; a Turkish title of honour, given to viceroys, provincial governors, generals, etc.: hence a swaggering bully.

Bashi-Bazouks. Irregular troops in the Turkish service.

Basic. (Chem.) Relating to, or acting as, the base of a salt.

Basil. 1. [Fr. basane, from Ar. bithānet.] The skin of a sheep tanned. (Bezel.) 2. [Fr. basile, from base.] The angle to which the edge of a cutting tool is ground.

Basil, Liturgy of. (Liturgy.)

Basilian Order. (Orders, Religious.)

Basilic (Anat., Med.) = most important or

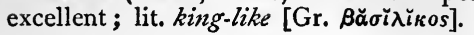

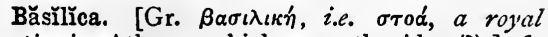
portico in Athens, which gave the idea (?).] 1. A public court of justice and of exchange, in Rome, with wide porticoes, and a raised tribunal at the end; whence arose the form of a church, with nave, aisles, chancel. Some Basilicas became churches. 2. In Jurisp., the name of a digest of laws in sixty books, by the Byzantine Emperor Basilius, 867-88o; chiefly an adaptation of Justinian's Code.

Basilidians. In Eccl. Hist., a Gnostic sect, who maintained the mystical system of Basileides, and asserted that Simon of Cyrēnē suffered on the cross in place of our Lord.

Basĭlǐkon Dörŏn. [Gr., a royal gift.] The title of a book written by James I. of England for the benefit of his son Henry, Prince of Wales.

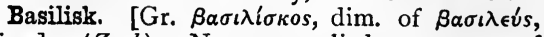
king.] (Zool.) Name applied to gen. of American lizard, fam. Igǔănìdæ; one spec. has a crest or crown. (Bibl.) (Cockatrice.)

Basin, River. The whole area drained by a river and its tributaries.

Baskerville editions. Much admired as specimens of printing. John B., typemaker, of Birmingham, raised the art of printing to a degree of perfection previously unknown in England; died 1775.

Basket-fish. The starfish.

Basle, Confession of. The Calvinistic Confession of faith, drawn up in 1530 , and called also the Helvetic Confession.

Basque. A language still spoken in the Spanish and French Pyrenees, belonging, like the Finnic, to the Agglutinate or Turanian group, called by the people Escuara; the same root appearing in "Basque," "Escuara," "Esquimaux," and "Gascony."

\section{Bas-relief. (Basso-relievo.)}

Bass, Bast. The inner fibrous bark of the limestree, of which the Russian matting used in gardens is made. Bast is also obtained from the leafstalks of two Brazilian palms, Attalea funifĕra and Leopoldinia Piassaba; and Cuba bast from the inner bark of Paritium elatum.

Basset. [Fr. bassette.] A game of cards, invented at Venice, fifteenth century ; introduced into France, seventeenth century ; forbidden by Louis XIV., after he had lost largely by false cards.

Basset, Bassetting edge. (Min., Geol.) When a slanting vein or bed shows itself at the surface, its edge is called the Basset-edge, or outcrop.

Basset horn. A rich melodious kind of clarionet, between a clarionet and a bassoon, embracing nearly four octaves.

Bassia. A gen. of trees, ord. Sapotaceæ; tropical. One kind, the Indian butter tree, yields from its pressed seeds a white, fatty, lard-like substance, keeping fresh for many months; another, the African butter tree, yields the Galam butter mentioned by Mungo Park, an important article of commerce in Sierra Leone (7reasury of Botany, i. 127, and Chamber' Encyclopadia).

Bassinet. [Dim. of Fr. bassin, a basin, possibly a corr. of Fr. berceaunette.] A hooded cradle, of wickerwork. 
Bassoon. A kind of bass oboe of four tubes bound together [It. fagotto, i.e. a bundle], of rich tone, very valuable to the composer. Double $B$., introduced 1784 , reached an octave lower, but did not answer; its place is supplied by the serpent.

Bassŏra gum. (Sometimes shipped from Bussorah.) A gum, said to be the exudation of almond and plum trees; by some supposed to be the produce of a cactus or mesēmbryanthěmum.

\section{Basso-relievo. (Mezzo-relievo.)}

Basta. [It., enough.] (Music.) When the leader stops some performer.

Bastard eigné. [L.L. basta, bastum, packsaddle, muleteer's bed; $c f$. O.Fr. fils de baste; for termination, $c f$. -ard; for eigné, $c f$. O.Fr. aisné, ainsné, eldest, Fr. antné, L. ante nātus.] An eldest illegitimate son whose mother is afterwards married to the father.

\section{Bastard-wing. (Wings.)}

Bastille. [Fr.] 1. Any fort or tower outside the walls of a city. 2. More particularly the fortress, so called, built originally outside the city of Paris, and destroyed by the people, I 789 .

Bastinado. [Sp.] 1. An Eastern punishment, of beating the soles of the feet. 2. Generally, cudgelling, beating.

Bastion. [Fr., It. bastione.] Interior work in permanent fortification, consisting of two faces joined together in a salient angle, with two flanks retired from their other extremities. A demi-bastion has one face and one flank.

Baston. (Bâton.)

Basuto. A S. African tribe, lying between Natal and the Orange River Free State.

Bat. 1. Shale. 2. Cotton wool in sheets. 3. A piece of brick less than half its length.

Batardean. [Fr., dim. of O.Fr. bastard, $a$ dyke.] (Fortif.) Wall placed across a wet ditch to retain the water; provided with sluices and surmounted by a conical turret to prevent access along the top.

Batata, Patata. Batatas ědūlis. (Bot.) A convolvulaceous plant with tuberons edible roots, the sweet potato; its name now transferred to the Sōlānum tūběrōsum.

Batavian. [L. batăvus, adj.] Dutch; Batăvi, the Batavians, Hollanders.

-batch, -bach (Mercia), -beck, -bec (Northumbria). Part name of streams $=$ brook [Norse beck], as Wood-batch, Birk-beck (birch-brook).

Batean. [Fr., L.L. batus, from A.S. bât.] 1. A heavy, flat-bottomed, sharp-ended boat, used on Canadian rivers and lakes. 2. A peculiar kind of army pontoon.

Bat-fowling. Catching birds at night by a light within a net, to which they fly when the bushes are beaten; hence the term.

Bath. A Hebrew liquid measure $=e p h a h, a$ dry measure (see Ezek. xlv. II). (Cab.)

Bath Col, Bath Kol. [Heb., daughter of the voice,$=$ secret inspiration, post-prophetic, upon which most Jewish traditions were founded.] A fantastic divination of the Scriptures, like Sortes Virgilianæ (q.v.).

Bath-metal. An alloy of nine parts of zinc to thirty-two of copper.
Bath, Order of the. (Hist.) An English order of knighthood, instituted by Henry IV. and revived by letters patent of George I.

Băthos. [Gr. Bátos, depth.] An absurd descent from lofty to mean thoughts or language ; a more than anti-climax, e.g. "And thou, Dalhousie, thou great God of War, lieutenantcolonel to the Earl of Mar."

Bath-stone. Fine-grained, cream-coloured, Oolitic limestone, from the Lower Oolite of the West ; easily wrought, hardening with exposure, not very durable. From Oolitic strata come also Caen stone, Kettering stone, Portland stone, Barnack rag, etc.

Bathybius. [Gr. Batús, deep, Bíos, life.] Professor Huxley's proposed term for a very low form of life found in ooze dredged from the Atlantic; one not yet widely accepted.

Batiste. Fine linen cloth of French make; so called from the first maker of it, Batiste of Cambray.

Bat-man. [Fr. bât, pack-saddle, L. bastum.] Soldier-servant of a non-commissioned officer also one who attends an officer's horse, or the bat-horses provided with pack-saddles for carrying the tents and light baggage of troops.

Bâton. [Fr.] 1. (Music.) I. A conductor's wand. 2. In written music, a pause of two or more bars. [From the same root as bâtir, Gr. $\beta \alpha \sigma \tau \alpha ́ \zeta \epsilon \iota \nu$, to hold in one's hands, etc.] 2. (Her.) An abatement in coats of arms to denote bastardy, a kind of diminutive of the bend sinister. (Bend.) 3. Staff of a field-marshal.

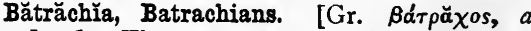
frog.] 1. The second and third ord. of Amphibia, comprising B. urŏdēla (Tailed B.), as newts, and B. ănoura (Tailless B.), as frogs. 2. Animals having the external characteristics of frogs.

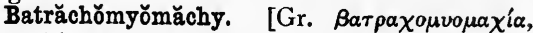

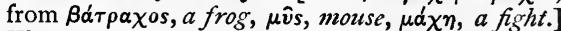
The so-called Homeric poem describing the battle of the frogs and the mice-a satire on the Trojan war and on the action of the gods in that struggle.

Batta. [Hind. bat, a weight.] Certain extra pay allowed to troops in India to cover exceptional expenses.

Battalion. [Fr. bataillon, from It. battaglione.] Body of infantry commanded by a lieutenant-colonel, and composed of a variable number of companies, but with a complete staff

Battel. Adj., fruitful, fertile; v.a. to make or to become fat or fertile; cf. bait, bit, bite, according to Richardson.

\section{Battel, or Battle, Wager of. (Wager.)}

Batteloe. An Indian vessel, lateen-rigged.

Battels. [Said to be from A.S. bat, to increase, and dæl, deal or portion.] Accounts due to a college from a member for food supplied, and other expenses.

Batten. [O.E. bat, a staff; cf. Fr. bâton,

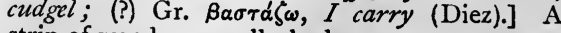
strip of wood; a small plank.

Batten-down hatches, To. (Naut.) To fasten tarpaulins over them by battens, i.e. long, thin strips of wood nailed down. 
Battering walls. (Arch.) The walls of a building whose sides converge.

Battery. [Fr. battre, to beat.] 1. Any number of guns grouped together, and having a separate equipment and organization of gunners. 2. The fortification behind which guns are mounted.

Battery, Electric. A group of electric jars, so arranged that they can be charged and discharged as one machine. A galvanic or voltaic battery is an arrangement for producing an electric current by chemical action.

Battle of the Books. (Boyle Controversy.)

Battle of the Spurs. (Hist.) The name given to the victory of Henry VIII. at Guinegate, 1513, from the hasty flight of the French.

Battle of the standard. (Hist.) The name given to the battle of Northallerton, 1138 , in which David I. of Scotland was defeated by the English.

Battology. [Gr. Bátros, onomatop. for stammerer.] Stammering talk, senseless repetition (Matt. vii. 7). But there is said to have been a poet, Battus, who composed in this style.

Battue. [Fr.] The beating or shooting down of game which has been driven to one spot by a circle of beaters. (Tinchell.)

Battuta. [It., $a$ beat.] In Music, the measuring of time by beating.

Baubee. [Said to be Fr. bas billon, bad copper coin.] In Scotland, a halfpenny; first applied to a copper coin of James VI.

Baulk, Balk. [A.S. balc, a beam.] Joist placed between the pontoons of a military bridge to support the flooring.

Bavaroy. [Fr. Bavarois, Bavarian.] A kind of cloak, originally of Bavarian make.

Bavieca. The steed of the Cid.

Bavins. [O.Fr. baffe, a faggot.] Brush faggots.

Bawboard, i.e. larboard. (A-beam.)

Bawdequin. (Baldachino.)

Bawn. In Ireland, an earthwork round a house or castle ; an enclosure with mud or stone walls for the protection of cattle.

Bawson, Bawsin, Bawsand. The badger, as having white streaks on a dark face [from Ar. ablaq, fem. balqā, a pie-bald (horse)]. (Vide Devic's Supplement to Littré's Dictionary, s.v. "Balzan.")

Bay. [Cf. Fr. aboyer, L. baubor, Gr. $\beta \alpha \hat{v} \zeta \omega$, Ger. bellen, to bark.] To bark loudly and in an hostile manner.

Bayadères. (Bajaderes.)

Bayard. 1476-1524. The Chevalier sans Peur et sans Reproche, who distinguished himself in the Battle of the Spurs. A type of the ideal knight.

Bayard. 1. A bay horse. 2. The name of more than one noted horse of old romance.

Bayardly. [O.Fr. bayard, a gaper.] Blindly unreasoning, stupid; like the leap of Bayard in terror.

Bayberry Candleberry, Wax-myrtle. (Bot.) My̆rīca cërífĕra, small spreading shrub of $\mathrm{N}$. America, ord. Amentācěæ ; its drupes covered with wax, used for candles.

Bay-cherry. Name of the common laurel, Cěrăsus lauro-cerasus, when first introduced into
England about the beginning of the seventeenth century.

Bayes. Champion of rimed (rhymed) drama (meant for Dryden) in The Rehearsal, a farce ascribed to George Villiers, Duke of Buckingham.

Bayeux Tapestry. (Hist.) A piece of needlework, 214 feet long, ro inches broad, said to have been wrought by Matilda, wife of William the Conqueror, representing the history of the invasion of England in 1066. Still preserved at Bayeux.

Bayou State. State of Mississippi, from its creeks (bayous).

Bay state. Massachusetts.

Bay, To stand at, To be brought to. [Fr. aux abois, lit. at or to the barking. (Bay.)] Spoken of a hunted animal when, as a last resource, it turns round and faces the baying hounds. Fig., to turn upon one's enemies when unable to escape them.

Bazaras. A flat-bottomed boat used on the Ganges ; it sails and rows. Corr. into budgerow.

Bdellium. [L.] Gen. ii. 12 ; probably pearls or some precious stone. LXX. has $a \nu \theta \rho a \xi[\mathrm{Gr}$., carbuncle]. B. [Gr. $\left.\beta \delta \delta^{\prime} \lambda \lambda_{\iota} \iota \nu\right]$ is the transparent gum of the Borassus flābellyformis ; of no great value, and not likely to be meant here (Speaker's Commentary).

Bdellometer. [Gr. $\beta \delta \epsilon ́ \lambda \lambda \alpha, a$ leech, $\mu \epsilon ́ \tau \rho o \nu, a$ measure, as if = artificial leech.] A cupping glass with an exhausting syringe.

Beaches, Raised, Shingle B. Accumulations of water-worn stones, piled up by wave and tide, in exposed districts, the sand, etc., being swept onwards to more sheltered parts; e.g. Northam, $\mathrm{N}$. Devon. When to this movement is added a lateral tide current, they move along the coast as Travelling $B . ;$ e.g. Chesil Bank [cf. Ger. kiesel, flint, pebbles], on the Dorset coast.

Bead. An Old Eng. word, signifying prayer. Hence bidding the beads, i.e. the desiring the prayers of the congregation. The word is also applied to the perforated balls on a string, by which prayers are told or counted. (Chaplet; Rosary.)

Beadle. (Bedell.)

Bead-moulding. (Arch.) A moulding, the vertical section of which is semicircular. Called also Astragal.

Bead-roll. The list of dead persons for whom mass was to be said. Hence any list. "Fame's eternal bead-roll" (Spenser).

Beadsmen, or Bedesmen. Persons maintained by alms, professedly for the purpose of praying for the dead. Hence the word came to mean simply almsmen.

Bead-tool. A cutting tool, having a curved edge, for making beading.

Bead trec. (Bot.) Persian lilac, Pride of India; Mělǐa [Gr. $\mu \in \lambda i ́ a$ ], Azed arach; an ash, of which one spec. resembles a gen. of the nat. ord. Meliacæ.

Beagle. A small hound used for hare-hunting.

Beaker. [Ger. becher.] A well-annealed thin glass tumbler, used by chemists for boiling, etc.

Beal. [Cf. ball, and many similar words.] (Med.) To suppurate, to come to a head. Bealing formerly = pregnant. 
Beam-engine. A large iron lever, capable of movement round a central axle; by one end it is attached to the piston-rod of a steam-engine; by the other it works a pump or drives the main shaft. A steam-engine in which a beam is used for transmitting the steam power is a Beam-E.

Beam, Before the. Lee, weather. (A-beam.)

Beam-compasses. A rod on which are two sliding points, adjusted by screws, by which greater distances can be set off or transferred than by an ordinary pair of compasses.

Beam-ends. (Naut.) A ship is on her beamends when heeled over so much that the deck is nearly perpendicular; beams being the transverse, timbers the vertical, parts of a ship's frame work.

Beamfleet. The north part of the estuary of the Thames.

Beam tree. [The word beam, Ger. baum, $a$ tree, is common to many Aryan languages.] White beam is a tree from twenty to forty feet high; a native of almost all parts of Europe. Py̆rus aria, ord. Rosaceæ; having very hard wood, used for cogs ; with scarlet fruit in autumn.

Bean-cod. A small Spanish or Portuguese fishing-boat, sharp forward, with a curving bow, usually lateen-rigged.

Bean goose. (Zool.) Wild goose, Anser fĕrus, Anas sěgětum; about thirty-four inches long, plumage brown and grey. N. Temp. and Arctic regions. Gen. Anser, fam. Ănătĭdæ, ord. Ansěres.

Bean-King's Festival. A German social rite, derived from France. A cake, in which a bean has been hidden, is cut on the evening of Three Kings' Day (q.v.); the recipient holds a court, etc., and gives the next year's festival : a supposed relic of the Roman Saturnalia.

Bear. A term used for a speculator who sells stocks or shares, speculatively, which he does not pussess, in the hope of being able to repurchase again at a lonver figure, and thereby make a paying transaction of the concern. (Bull.)

Bear, Bere. 1.q. Barley.

Beard. (Printing.) The part of a type between the shoulder of the shank and the face.

Beardil. The loach.

Bearing. (Mech.) 1. A cylindrical hole, in which a shaft is supported and on which it moves. 2. A surface which guides the motion of the piece which it supports.

Bearing the bell. Taking the lead, gaining the first place; an expression said to have been derived from the giving a small bell of gold or silver to the winner at a horse-race, early in the seventeenth century.

Bear-leader. 1. One who leads about a dancing bear. 2. Hence, by meton., a facetious term for a discreet person in charge of a youth of rank in travelling, etc.

Bearnais, Ie. Henri IV. of France and Navarre ; born at Pau, in the Bearn, 1553.

Bear's-breech. [L.L. branca, claw.] (Acanthus; Brankursine.)

Bear's-foot. 1. Bear's-breech. 2. Hellěbŏrus fœetǐdus, ord. Ranunculācěæ.

Bear, To (Naut.) $N$. or $S_{.}$, etc., is to be in a line with the named point of the compass. $B$. down upon, to approach from windward. $B . u p$ or away, to go to leeward. B. up round, to put her right before the wind. $B$. off from or in with the land, to sail from or towards the shore. $B$. sail, to carry canvas well.

Beasts, Wild, of the desert. [Heb. isiim.] Hyanas. Isa. xxxiv. I4.

Beasts, Wild, of the island. [Heb. iyim.] Fackals. Isa. xxxiv. 14

Beatific. [L. běătǐfícus.] Making happy or blessed. B. vision, that seeing of God which is the blessedness of heaven.

Beatification. Papal declaration that a certain deceased person may be honoured by a particular religious worship without incurring the penalty of superstitious worship.

Beatitudes. [L. beātitūdo, blessing.] 1. The nine sentences of blessing with which the Sermon on the Mount begins (Matt. v. 3-II). 2. In the Greek Church, hymns commemorating the saints.

\section{Beating the bounds. (Perambulation.)}

Beating the bush. (Met.) 1. From fowling, $=$ having all the labour, while another catches the birds and has all the gain. 2. From hunting, = not going straight to the point of discussion; as hunters move in a roundabout way, not straight to the object.

Beating to windward. (Naut.) Getting to windward by tacking in a heavy wind. (Tack.)

Beāti possìdentes. [L., happy are they who have.] A phrase of much the same meaning as the saying that " possession is nine points of the law."

Beatrice. Dante's saintly love, and guide through Paradise.

Beats. The alternations in the intensity of the sound produced by two notes nearly in unison.

Beau Brummel. George Bryan B., friend and companion of the Prince Regent ; died insane, I840.

Beau ideal. [Fr.] Conception of perfection.

Beau monde. Lit. the fine world; the world of fashion.

Beau Nash. Master of the ceremonies at Bath in the last century.

Beauséant. (Bawson.) The black-and-white banner of the Templars.

Beauté de diable. [Fr., fiend's beauty.] Beauty that suggests no goodness of character; beauty symptomatic of disease ; or the fugitive beauty of early youth.

Beaux yeux. [Fr.] Iovely eyes.

Beaver. 1. [Fr. bavière, baver, to slobber, because when down it occupied the place of a child's bib.] Part of a helmet covering the mouth, and movable on pivots at the jaws; being let down, it enables the wearer to drink. 2. An amphibious rodent quadruped, of the gen. Castor. N. America. The name is found in many of the Aryan languages.

Bebirine. A tonic and febrifuge, like quinine in action, from the bark of the biburu or greenheart of Guiana (Nectandra rodiæi), a valuable timber tree ; ord. Lauraceæ. 
Bebisation. (Solmization.)

\section{Beccabunga. (Brooklime.)}

Beccafico. [It., fig-pecker, Fr. becque-figue, Ger. feigen-drossel.] A name applied to almost any warbler (Sylvia), or other small garden bird, when fat.

Bechamel. A fine, white broth, named from the Marquis of Bechamel, steward of Louis XIV.

Bêche-de-mer. [L. beca, fem. form of beccus.] Lit. sea-spade (Holothuroidea). (Trepang.)

Bechic remedies. (Med.) For the relief of

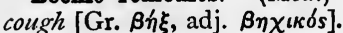

Beck. A brook [cf. Ger. bach, a brook, and perhaps Gr. $\pi \eta \gamma \dot{\eta}$, a spring] ; as in Wans-beckwater, where the place has received three names of the same meaning, and kept them all ( $c f$. Balalake).

-beck, -bec. (-batch.)

Becket's Crown. The circular or apsidal building to the east of the choir in the Cathedral of Canterbury is so called.

Bed. [A word common to the Teut. and Scand. languages.] (Mech.) The foundation or fixed part of a machine.

Bedchamber, Lords of the. Officers, generally twelve, of the royal household, under the groom of the stole, during a king's reign, waiting in turn upon the sovereign.

Bedeguar. [Ar.] A shaggy excrescence on the wild rose, produced by a gall insect (Cynips rosæ); once considered diuretic, more recently a vermifuge.

Bedell. [L.L. bedellus, A.S. bydel, messenger.] In the university and elsewhere, the officer who attends the vice-chancellor. (Bead.)

Bedford Level. A tract on the east coast, nearly = the Fens ; so called from the Earl of Bedford, who, with others, made the first successful effort to drain it in 1634 .

Bedford Ministry. In I 763 , a mixed Ministry of the followers of Grenville (First Lord) and Bedford, with Halifax and Sandwich as Secretaries of State.

Bedight, Dight. [A.S. dihtan, to arrange.] Adorned, dressed out.

Bedlam, i.e. Hospital of St. Mary of Beth. lehem; converted into an asylum by the city of London, after the dissolution of monasteries. $B$. beggars, its out-patients, real or pretended. (Abraham man.)

Bed of justice. [Fr. lit de justice.] A proceeding by which the French kings were able to override the rejection of their decrees by the Parliament, by mounting their throne, called lit, and causing the decrees in question to be registered in their presence-the Parliament usually entering a protest.

Bedouin, Beduin. [Ar. bedawi, dwellers in the desert.] Nomad Arabs ; said to be descended from Ishmael ; and aboriginal Moors, who have become settled Arabs.

Bedstraw, Ladies' B., Cheese rennet (Gălium

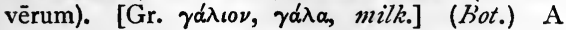
branched herb, with whorled leaves and small yellow flowers in numerous dense panicles; ord. Rubiaceæ.

Beebee, Bibi. [Hind.] Lady.
Bee-bread. A brown substance, the pollen of Howers, collected by bees as food for their young.

Bee-eater. Fam. of birds, mostly in Africa and the East. One British spec., Merops ăpiaster [Gr. $\mu \epsilon ́$ po $\psi$, articulate-voiced, L. ăpiaster, ăpis, a bee], eleven inches long, brown back, greenish blue quill feathers.

Beef-brained, Beef-witted. Heavy-headed ; dull of apprehension.

Beef-eater. [Corr. of Fr. buffetier.] A yeoman of the king's guard, whose place was once near the table or side-board [buffet] at ceremonial feasts.

Beef-wood of Australia. Hard, heavy timber, like raw beef in colour, of the Casuarina.

Bee-glue. (Propolis.)

Bee hawk-moth, Bee-moth. Sesia ăpiformis. (Entom.) A moth with rapid flight, and beelike wings and body; feeds on the poplar. Ord. Lěpĭdoptěra.

Bee in one's bonnet, To have a. To be rather mad.

Beeld refuge. [A.S. byld.] Place of shelter.

Bee-line. A direct line, like that of bees returning to the hive or nest from their utmost distance ; a faculty ascribed to their power of sight.

Beelzebub. (A pomuios; Muiagros.)

Bees, Fable of the, or Private Vices made Pub. lic Benefits. A poem by Bernard Mandeville (I670-I733). An attempt to show that human passions and evil tendencies work unconsciously towards the welfare of society, which, as at present constituted, is inconceivable without them. He was opposed by Bishop Berkeley.

Beestings. (Biestings.)

Beetle. 1. [A.S. bytl.] A wooden mallet for driving in wedges, stakes, etc. 2. [A.S. beotan, beotjan, to threaten.] To hang over or forward, as of cliffs or eyebrows.

Beetling. [O.E. bytl, a mallet.] The production of figured fabrics by means of corrugated or indented rollers.

Beetrave. Beetroot [from Fr. bette-rave, bētā, beet, and rāpa, turnit].

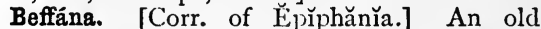
woman, the fairy of Italian and German children, who puts presents or else ashes into children's stockings on Twelfth Night, while she is looking out for the returning Magi, whom she missed as they returned home "another way."

\section{Reffroi. (Belfry.)}

Before the mast. The working seaman, as distinguished from an officer.

Beg, Bey. A Turkish title of State officers, $=$ prince, chief ; not very definitely used.

Beggar of Bethnal Green, The Blind. Henry de Montfort, in disguise after the battle of Evesham. Percy gives the ballad of Bessie, his daughter.

Beggar's Opera, The. A play by John Gay.

Beghard. Societies of laymen in Germany, France, and the Netherlands, first appearing in the thirteenth century, subsisting mostly by mendicancy, and little esteemed; disappearing in the latter part of the fourteenth century. But the 
correct use of the word is uncertain, and their history very obscure. [L.L. beggardus, Flem. beggen, Eng. big (Littré).] (Orders, Mendicant; Tertiaries.)

Begler-beg $=a$ chief of chiefs, governorgeneral of a province, next in rank to the Vizier. (Beg.)

Beguinages. Societies of women, called Beguines, in Holland, Belgium, and Germany, not bound by vows ; their mode of life, like that of the Beghards (q.v.), neither clerical nor lay. Their principal institution is at Ghent.

Beguines. (Beguinages.)

Begum. In India, a princess or lady of high rank.

Behemoth. Jobxl.; the hippopotamus. [(?) An Egyptian word ; if Heb., = great beast, or becist of beasts.]

Beit. [Ar., i.q. beth, Heb., tent or hut.] Abode or abodes. Beit al — may be a temple or town of -

Belay, To. (Naut.) To fasten a rope by taking several turns round a cleat, belaying-pin, etc. B. there! stop!

Belaying-pins. Wooden pegs or short iron bars.

Belcher. A blue handkerchief with white spots; named after a pugilist.

Beldam. [Fr. belle dame.] Originally a term of respect, especially to elders, has come to mean hag.

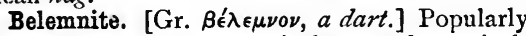
Thunderbolts and St. Peter's fingers; the conical, internal-shell remains of a gen. of extinct Cephalopodous molluscs.

Bel esprit. [Fr.] A sprightly, clever writer or conversationalist.

Belfry. M.H.G. ber vrit, a watch-tower, became berfrēdus, berfroi, beffroi, i.e. a movable breaching tower used in sieges; then, from the resemblance, a turret, and more particularly a bell turret; written belfry, though having nothing really to do with bells.

Belial, Sons of. A general name for worthless persons, as men of recklessness or lawulessness; this being the meaning of the Heb. word represented by Belial, which is certainly not a proper name, although the etymology is uncertain. As Beliar (2 Cor. vi.), it is personified, = Satan.

Belinda. Pope's name for Arabella Fermor in The Rape of the Lock.

Bell. 1. $(A r c h$.$) The capital of a Corinthian$ or Composite column, without the foliage; which is like a bell reversed. 2. (Naut.) Watch.

Bell, Acton, Currer, Ellis. Names assumed by Anne, Charlotte, Emily Bronté, authoresses.

Belladonna. [It., beautiful lady.] Deadly nightshade, comimon in hedges; a spec. of Atrŏpa, ord. Sölānāceæ. Most spec. are poisonous. - Bella, horrida bella. [L.] Wars, dread wars.

Bell and Lancaster system, i.e. that of mutual instruction, by aid of the boys themselves ; first used I790, by Rev. Dr. B., in E.I.C. Madras schools, there being no qualified ushers; perfected by L. as the monitorial system, in England, in the next generation.
Bellarmine. (Cardinal B., died 1621.) A stoneware jug, big-bellied, with a bearded face on its neck; sixteenth century ; made in Holland.

Bell-bird. (Zool.) 1. White bird, about as large as a pigeon, with a black protuberance from its forehead, about three inches long, usually pensile, but erected when the bird utters its note, like the toll of a church bell. Trop. America. Fam. Cotingr̆dæe, ord. Passěres. 2. Spec. of Honey-eater, with a note like the tinkling of a small bell. Australia. Fam. Mělı̆phăgĭdæ [Gr. $\mu \in \lambda^{\prime} l$, honey, $\phi a \gamma \in \hat{\imath} \nu$, to eat], ord. Passěres.

Bell, book, and candle. A mode of excommunication, chiefly between the seventh and tenth centuries, in the R. C. Church. After sentence read, the book is closed, a lighted candle thrown to the ground, and a bell tolled as for one dead.

Bell-crank. A bent lever, with its arms nearly at right angles to each other, for changing the direction of the motion of a link when that motion is of limited extent; it resembles the crank placed at the corner of a room, where the bell wire goes off at right angles to its first direction.

Belle Allianoe. [Fr.] A farm, the centre of the French position, at Waterloo.

Belle de nuit. [Fr., beauty of the night.] The Marvel of Peru (Mirabilis Jalapa).

Belles lettres. [Fr.] Polite literature ; literature of refining, elevating character generally; not with reference to subject-matter.

Bell' éta dell' oro. [It.] The fair age of gold.

Belle étage. [Fr.] The best story in a house, the second.

Bellerophon's letters. Letters which carry the death-warrant of the bearer; the Greek story being that Prœtus, whose wife had conceived for Bellerophon a passion like that of Potiphar's wife for Joseph, and with the same consequences, sent B. to Iobātes, King of Lycia, with letters requesting him to put $B$. to death. (Barbarian.)

Bell-flower. Popular name for the campanulas.

Bellibone. A woman beautiful and good. [A corr. of Fr. belle et bonne.]

Bellio, Bellique. Warlike. [L. bellicus, pertaining to war, and, in poetry, warlike.]

Bellis. [L. bellus, pretty.] (Bot.) A gen. of plants, ord. Compositæ. B. perrennis, the common daisy.

Bellman. A name applied to watchmen in the streets.

Bell-metal. 80 of copper to 20 of tin ; sometimes 77 to 23. (Bronze.)

Bell of arms. (From the generally round shape.) (Mil.) Separate building for storing the arms of a regiment.

Bell-ringing. Changes rung on 3 bells are Rounds; on 4, Changes or Singles; on 5, Doubles or Grandsires; on 6, Bobs minor; on 7, Triples; on 8, Bobs major; on 9, Caters; on 10, Bobs royal; on 11, Cinques; on 12, Bols maximus. A bell is set when having the mouth upwards; at handstroke, when set up so far only as that the tuffing or sallic is held by the ringer; at backstroke, when rung 
round so far that the end of the rope is held. Treble is the highest, Tenor the lowest, of a set. Position of rounds, is that of B. struck thus-12345; in any other order, they are in changes. 5000 changes are a peal; any smaller number a touch or flourish, i.e. a practice rather than a performance. A bell is going $u p$ when changing its position from that of treble in rounds towards that of tenor, e.g. the treble in 12345, 21435, 24135; and down, vice versâ. Place-making is striking two blows in succession in any one place, e.g. No. 4 in 15432, 51423. $\mathrm{Bob}$ and single, called out by the conductor, produce certain changes in the courses of the B., other than those caused by the fact of the treble leading. In Stedman's method (1640) the principle is that three $B$. should go through their changes, one bell coming down from behind to take its part in the changes, and one going up behind to take its part in the dodging. (See Troytes' Change-Ringing.)

Bellōna. [L.] The Latin goddess of war.

Bell tent. Conical dwelling of canvas, supported on one pole in the middle.

Bell the cat, To. To run a great risk for others, from the fable in which an old mouse proposes that a bell should be hung on the cat's neck that the mice may have warning.

Bellua, or Bēlua, multōrum căpǐtum (Horace). The many-headed monster; the mob.

Belluine. Beastly, brutal. [L. belluinus, bellua, a beast, generally = a monster, brute. $]$

Bell-wether. The leader of a flock, which wears a bell; meton. the leader of a subsequent party.

Belly. [A.S. bælg, a pouch.] (Naut.) 1. The swell of a sail. 2. The hollowed part of a shaped timber. To $B$. a sail is to fill it with wind, with bellying canvas, going free. $B$. to the breeze, the sails filling with wind. $B$. to windzuard, carrying too much sail.

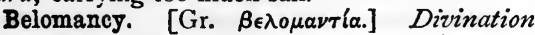

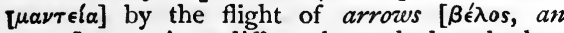
arrow], sometimes differently marked, and taken at random from the quiver.

Bëlŏnē. [Gr., a sharp point.] (Gar-fish.)

Belphœbe. A chaste, beautiful huntress in Spenser's Faëry Queen; meant for Queen Elizabeth as woman. (Gloriana.)

Belt. [L. balteus.] A Band.

Beltane, Belteine, Bealtine. [Ir.] Said to mean (it can scarcely be doubted, erroneously) fire of Baal, the worship of whom is supposed to liave exisited in these islands in the remotest Druidical times; name of a festival once observed in Ireland and the Scotch Highlands.

Belted Will. Lord W. Howard, Warden of the Western marches, seventeenth century.

Bĕlūga. [Russ. name.] Gen. of whale, white whale. Arctic and Australian seas. Fam. Delphinĭdæ, ord. Cētācěæ.

Bêlus. The Grecized form of the Syrian Bel. (Baal.)

Belvedere. [It. bello, beautiful, vedere, to see.] A room above the roof of a house, for fresh air and prospect.

Belvedere, Apollo. A beautiful statue of
Apollo, found towards the end of the fifteenth century, in the ruins of Antium, and placed in the Belvedere of the Vatican (q.v.) at Rome, whence it has its name.-Perry, Grcek and Roman Sculpture.

Bëma. [Gr., a stcp, a place for stepping.] 1. The tribune or pulpit for speakers in a Greek assembly. 2. (Eccl. Ant.) The raised platform containing the altar, with the seats of the bishop and clergy. (Apse; Pnyx.)

Bembridge beds. (Geol.) A division of the Upper Eocene, principally developed in the Isle of Wight. The Bembridge limestone is the equivalent of the Montmartre deposits, and yields remains of some species of palæothërium, etc.

Bémol [Fr.] (Music) is h, a flat note, i.e. the $b$-like sign which makes flat [mol]. Ger. mol is minor, from the difference between major and minor thirds; dur or durum, hard, is in mediæval music natural, and so major as compared with moll, or L. mollis, soft.

Ben-. [Gael., mountain.] Part of Highland names, as Ben-more, great mountain.

Benbow, John, Admiral, I650-I 702, kept up for four days, off St. Martha, W. Indies, a running fight with a superior French force, when almost deserted by the rest of his squadron, August, I702. He died of his wounds in November of the same year.

Bencher. Senior members of Inn of Court, who have control over students for the bar.

Benchmare. [(?) Welsh pwncmawr, big point.] The broad arrow.

Benchmark. In Surveying, shows the startingpoint of a long line of levels, and is affixed to permanent objects, showing exactly where the level was held.

Bench warrant. (Leg.) A warrant, signed by a judge or two justices, for the apprehension of one against whom a true bill has been found, or who has committed contempt of court.

Bend. (Her.) An ordinary bounded by two parallel lines drawn from the dexter chief to the sinister base. If charged with any device, it occupies one-third part of the shield; if uncharged, one-fifth. Figures occupying its place are said to be in bend. A bend sinister has the lines drawn from the sinister chief to the dexter base. (Escutcheon.)

Bendlet. (Her.) A diminutive of the bend, being one-half its thickness.

Bends. (Naut.) (Wales.)

Bend, To. (Naut.) To fasten ropes together, or to an anchor. B. a sail, fasten it to its yard, or stay, ready for setting.

Bendy. (Her.) Covered with bands alternately of two tinctures, slanting like a bend.

Benedick $=a$ confirmed bachelor, who marries after all, as B. marries Beatrice, in Much Ado about Nothing.

Bene decessit. [L., he has left satisfactorily.] Certificate of good conduct on leaving a college or school.

Benedictines. (Eccl. Hist.) An order of monks distinguished for their learning. They follow the rule of St. Benedict, who founded his 
first house at Subiaco, early in the sixth century. To this order belonged Pope Gregory the Great and the monks whom he sent to England under Augustine, first Archbishop of Canterbury.Milman, Hist. of Latin Christianity, bk. iii. ch. vi.

Benediction. [L. benedictio, -nem, a speaking well of.] 1. Any form of blessing. 2. In the Latin Church, specially the blessing of the people with the reserved sacrament, which is held up by the priest in the monstrance.

Benedict medicines $=$ gentle remedies ; opposed to Drastic, heroic.

Benefice, popularly a living, is, according to Coke, "a large word," = "any ecclesiastical promotion whatsoever." (Beneficium.)

Beneficiary. Holding a dependent, feudatory office; without independent power.

Bĕněficium. 1. Under the Romans, a grant of land to a veteran soldier. 2. At the beginning of the feudal system, an estate conferred by the sovereign and held under him, which as a hereditary thing became a fief. 3. (Eccl.) A living, preferment; on the assumption of its being held under the pope as a superior lord.

Beneficium invito non datur. [L.] A benefit is not conferred against one's will.

Benefit of clergy. [L. prǐvǐlēgium clērǐcāle.] Withdrawal of the clerical order, and eventually of all who could read, from civil to ecclesiastical tribunals in all capital charges except high treason. Not wholly abolished till 7 and 8 George IV.

Benefit societies, or Friendly s. Associations for mutual benefit among the labouring class, a small weekly payment insuring a certain weekly sum during sickness; in some cases a payment at death; also in some cases a pension after a certain age.

Bene merĭtus. [L.] Well-deserving.

Benet, Herb. [Fr. benoîte.] (Aven.)

Benevolence. [L. benevǒlentia, good will.] (Eng. Hist.) A tax levied by the sovereign, under the name of a gratuity. No voluntary aid can now be raised on behalf of the Crown without authority of Parliament, the breach of this condition being declared illegal by the Bill of Rights.

Bengal-lights. Used during shipwreck, = nitre 6 , sulphur 2, tersulphuret of antimony $\mathbf{I}$.

Benign, Benignant growths, etc. [L. běnignus.] $(M e d$.$) Local growths, not returning if removed,$ not destructive of life ; opposed to Malignant [L. mălignus], cancerous and destructive of life.

Benison. [O.Fr. beneison, benaiçon, L. benedictiōnem.] A blessing ; $c f$. malison, orison, i.e. maledictionem, orationem.

Benitier. [Fr.] A vessel for holy water, as a font ; an aspersorium or sprinkler, or a stoup attached to a wall.

Benjamin, Benzoin. [Fr. benjoin, from Ar. loubbân djaoni, Fapanese incense.] A dry fragrant balsam obtained from the benjamin tree, and used for making incense, etc.

Benjamin tree. Corr. of Benzoin (q.v.).

Ben, Oil of. A clear sweet oil, much used in chemistry, perfumery, and by watchmakers; obtained from the seeds of the Moringa ptěry̆gosperma, a tree of $\mathrm{E}$. Indies and Arabia. Ben trovāto. (Si non è vero.)

Bents, or Bent grass. A term of general significance, applied usually to the old stalks of various grasses.

Benzoio acid. An aromatic acid prepared from benzoin. Its salts are called benzoates.

\section{Benzoin. (Benjamin.)}

Benzole, Benzine, Benzine collas. (Benzoin.) Bicarburetted hydrogen, a colourless liquid, obtained from coal tar. It dissolves fats, and is a source of aniline.

Beowulf. An Anglo-Saxon epic, of great literary and philological value. [Beo or Bewod, with the old Saxons, the harvest month; probably the name of a god of agriculture (Cham. bers's Encyclopadia).]

\section{Berbĕris. (Barberry.)}

Berceaunette. [Dim. of Fr. berceau, a cradle.] A wicker basket with a hood over the head, used as a cradle.

Berceuse. [Fr., a cradle song, from berceau, a cradle, L.L. bersa, wickerwork hurdle.]

Bereans. An obscure Scottish sect, A.D. I773, who professed to reject all religion, except credence of the written Word; claiming to be like B. (Acts xvii. II).

Berengarians. Followers of Berengar, Archdeacon of Angers, eleventh century, who protested against the current doctrine of the Real Presence; recanted; retracted; and again recanted.

Bergamot. [Port. bergamota.] (Bot.) 1. A name borne by very many different kinds of pear, not having, however, any common distinctive character ; from Bergamo, Lombardy. 2. Also a garden name for Monarda didyma.

Bergamot orange. (Bot.) A fragrant spec. (Bergamia) of Citrūs, ord. Aurantiaceæ; its greenish-yellow rind contains an essential oil.

Berg-mehl. [Ger.] (Geol.) Mountain meal, Tripoli, Polier schiefer, Kiesel-guhr, Diatomaceous earth, etc. Recent and Tertiary deposits of whitish fine powder, almost entirely from the frustules or siliceous cell-walls of Diatomaceæ; some varieties are mixed with food, increasing the bulk, and, perhaps, slightly nutritious; used for polishing metals. Found in Norway, Tripoli, Richmond, U.S., Mull, Dolgelly, Mourne Mountains, etc.

Bergmote. [A.S. berg, hill, mot, gemot, meeting.] Court for decision of matters connected with mining.

Berlin. A four-wheeled covered carriage, seating two persons (invented at Berlin).

Berm. [Fr. berme, pathway on a bank, from Ger. berme.] (Fortif., Mil.) Narrow level space left outside a rampart or parapet, to diminish the pressure of earth on the escarp of the ditch.

Bernardines. (Feuillans.)

Bernicia, Berneich. The north part of Northumbria in the Saxon period.

Berniole goose. (Barnacle goose.)

Bernoose. (Bournouse.)

Berretta. (Biretta.)

Berry. (Bacca.) 
-berry, -berie, -bery. [L.L. beria, a large open field.] Part of names, as in Dol-berry, a word made up of two synonyms. (Dol-, Dal-.)

Bersaglieri. Sharp-shooters; riflemen of the Sardinian army, introduced $\mathbf{1} 848$.

Berserkers. [Icel.] In Icelandic tradition, wearers of bearskins acks or coats; noted for their frantic outbursts of rage. (Grettir Saga.)

Berth. (Naut.) 1. A sleeping-place on board ship. Hence, 2, the place where a ship lies. 3. A place to which any one is appointed. To give $a$ wide $B$., to keep well away from anything.

Bertholletia. (Brazil nuts.)

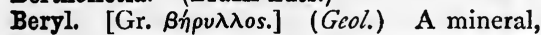
hexagonal, of various shades of green and blue, found in Primary rocks of O. and N. World; consists of silica, alumina, and glucina. Amongst its varieties are emerald and precious B., or Aquamarine.

Beshrew thee $=$ be thou syrewe [A.S., sorrowed, vexed $]$; hence = I curse thee, wish thee evil.

Besprent. Besprinkled. [A.S. besprengan, to sprinkle over.]

Bessemer steel. Steel made by passing a blast of air through molten cast iron, so as to get rid of the carbon and silicon, and then adding enough pure cast iron to supply carbon for the formation of steel. (Named after the inventor.)

Bessus. In Beaumont and Fletcher's King and no King, a cowardly captain.

Bestead. To be in stead or in place ; and so, 1. To profit ; 2. To be circumstanced-" "hardly bestead" (Isa. viii. 2I). But this should rather be translated = hardened, hardening themselves (Speaker's Commentarv).

Bestiaires. [Fr.] Written books, of the eleventh, twelfth, and thirteenth centuries, describing the animal world, real and fabled, with drawings and symbolical explanations, in prose and in verse, Latin and English.

Bestow. Sometimes to bury; so Felix-stow, burial-place of Bishop Felix.

Beteem. 1. To deign, think fit, to suffer. [Cf. A.S. tamian, to tame; or D. betaemen, to be suitable (Wedgwood).] 2. [A.S. tyman.] To teem ; to bear abundantly.

Betel, Piper betel. A spec. of Piper, ord. Piperācěæ, the leaves of which are chewed by the inhabitants of many parts of India with the nuts of the Areca (q.v.) catechu. B. nut. (Areca.)

Bête noire. [Lit. black beast.] A bugbear; something one dreads or shrinks from.

Beth-, Bedd-. [Cymr.] 1. Grave, as in Beddgelert, grave of St. Kelert. 2. Beth-[Heb.], house, as in Beth-el, house of God.

Bêtise. [Fr.] Stupidity.

Beton. The French name for concrete; but as the mode of preparing it is very different, it is well to retain the use of the two names.

Betony. (Bot.) Native plant, Stăchys betonǐca, ord. Lăbiatæ ; formerly much used in medicine; a popular remedy still for some complaints.

Better equity, To have. To be second incumbrancer of an estate with security, if there be a prior incumbrancer without.

Betty, sometimes Bess. A thieves' instrument for wrenching doors, drawers, etc. ; a jimmy ; instruments of all kinds being frequently personified, as spinning-jenny, boot-jack, etc.

Bĕtŭla. [L.] (Bot.) Gen. of Amentaceous trees, ord. Betulācěæ. B. alba, the common birch. B. păpyrācĕa, Canoe $B$. or Paper $B$. of N. America, is very valuable, on account of its durable bark, used for boxes, thatching, canoes, etc.

Bever. [Fr. breuvage, for bevrage, L. bǔběre.] With labourers, a drinking between meals, generally at eleven o'clock, elevens, and at four o'clock, fours.

Bevil, Bevel. [Fr. biveau.] A kind of carpenter's square that may be set to any required angle. A $B$. angle is any angle except a right angle and half a right angle.

Bevile. (Bevil.) (Her.) A chief broken or opening like a carpenter's bevel.

Bevil-wheels. Two portions of cones on which teeth are cut so as to work together and transmit motion from one axis to another intersecting it and inclined to it at any angle. These axes coincide in direction with the axes of the cones; and the wheels move on each other just as two cones would do if rolling on each other.

Bevis of Hampton (Southampton), Sir. A knight of romance (Drayton's Polyolbion, bk. ii.). Bewpar. (Naut.) (Buntine.)

Bewray. [A.S. wregan.] To accuse, to show, to make evident ; $c f$. Ger. regen, to stir.

Bey. (Murza.)

Bey, Beg. A Turkish or Tartar title, meaning lord, prince, or chief.

Bezan. [Fr.] A white or striped cotton cloth from Bengal.

Bezant. 1. A gold coin struck at Byzantium, current in England in the time of Edward III. (Dinar.) 2. (Her.) A golden disc, named from the Byzantine coin so called.

\section{Beza's Codex. (Codex.)}

Bezel, Basil. [Fr. biseau, a slant, bevil.] The slope or angle to which the cutting edge of a tool, e.g. a plane, is ground; a sloping edge to a frame, or to that which is set in it; the ledge in a ring which secures the stone.

Bezique. A game of cards, generally played by two persons.

Bezoar stones. [Pers. pâd, relieving, curing, zahr, poison.] Concretions found in the first stomach of some ruminants, especially goats ; of hair, fibre, stony matter; once thought alexipharmic.

Bezonian. [It. bisogno, want.] A beggar, low fellow.

Bhagavadgita. [Skt., sacred poem.] An exposition of Brahmanic doctrine in a dialogue between Krishna and Arjuna in the Mahābhārata.

Bhang. (Haschish; Assassin.)

Bhisti. [Hind.] (Water-carrier.)

Bhowaní. (Thugs.)

Bi-. [L. bis, bi-.] As a prefix, implies that something is doubled, as a bichloride is a salt con. taining twice as much chlorine as the chloride.

Biacuminate. [L. bi-, two, ăcümĭnātus, pointed.] (Bot.) Having two diverging points. Biadetto. (Bice.) 
Bianchi and Neri. [It., White and Black.] Parties or factions in the Florentine Republic in the fourteenth century. Dante belonged to the Bianchi, and, being banished, wrote his great work in exile.

Biauriculate. [L. bi-, two, auricŭla, ear.] 1. (Anat.) Said of the heart; having two auricles or cavities. 2. (Bot.) Having a pair of earlike leaflets.

Bibasic. [L. bi-, two, and Gr. Bárts, base.] Capable of combining with two equivalents of a base.

Biberon. [L. büběre, to drink.] A water-pot with one or more conical or cylindrical spouts.

Bibiri, or Beebeeree, of Guiana. Commonly called the Greenheart. A kind of Nectandra, ord. Lauraceæ; a large tree of sixty or seventy feet, yielding the bibiru bark, a tonic and febrifuge; and, more particularly, a very valuable timber for ship-building, strong and durable, cutting into great lengths, placed in the first class at Lloyd's, called the twelve-year class.

Bible, English. The first Bible in English was that translated by Wyclif, about A.D. I360. The first printed English Bible is that of Tindal, who was assisted by Coverdale. After Tindal's death, the work was carried on by John Rogers, who dedicated the book to Henry VIII., under the assumed name of Thomas Matthews : hence commonly called Matthews' Bible. 'Tindal's version, amended by Coverdale and examined by Cranmer, who wrote a preface for it, was the first Bible set forth by authority, and is known as Cranmer's Bible, or the Great Bible. The paraphrase of the New Testament by Erasmus was set forth in an English version in 1547 , a copy being ordered to be placed in every parish church. In 1560 some English exiles published at Geneva a translation, with marginal readings, which is thus known as the Geneva Bible. The great English Bible, commonly called the Bishops' bible, was printed in folio in 1568 , the translation having been made by the bishops and others engaged to aid them, acting under the authority and supervision of Archlishop Parker. In the following year this translation was published in 8vo, the chapters being divided into verses as in the Geneva Bible. The folio reprint of this version, in $\mathbf{I 5 7 2}$, is known as Parker's Bible. A Roman Catholic translation of the New Testament was published in 1584 , at Rheims, and is hence called the Rhemish bible; a second, giving the Old Testament also, was published at Douay in 1609-10. In 1603 King James I., at the Hampton Court Conference, ordered a new translation to be made. Fortyseven translators were engaged upon it. This Bible, commonly called King fames's Bible, or the Authorized Version, was published in I611. A revised version of the New Testament, as given in the Authorized Version, was published in 1881. (Breeches Bible.)

Bible in Spain, 1844, describes the personal adventures of George Borrow, travelling in Spain as agent of the Bible Society.

Biblia paupěrum, or B. paupěrum Christi. The books of the poor of Christ, i.e. the preaching clergy ; a kind of mediæval picture-book, of forty or fifty pages, each giving, with a text, some leading event of human salvation. A similar book in rime was Specuilum Humance Salvationis. These were amongst the first books printed.

Bibliomancy. Divination [Gr. $\mu \alpha \nu \tau \in\{\alpha$ ] from passages in the Bible $\left[\beta_{\iota} \beta \lambda\{0 \nu, a\right.$ book] taken at random. (Sortes Virgilianæ.)

Bibliomania. A passion for possessing old or rare books. [Gr. $\beta \iota \beta \lambda i o \nu, a$ book, $\mu \alpha v^{\prime} \alpha$, madness.]

Bibliophile. [Gr. $\beta \iota \beta \lambda l o \nu, a$ book, $\phi \check{\imath} \lambda \epsilon \omega, I$ love.] A lover of rare editions, curious copies, etc., of books.

Bibliopōle. [Gr. $\left.\beta \iota \beta \lambda \iota \iota^{\prime} \omega \lambda \eta s.\right]$ A bookseller. Bibulous. [L. biburlus.] Able to imbibe fluid or moisture ; as sand.

Bicalcarate limb. [L. calcar, a spur.] (Bot.) Furnished with two spurs.

Bicameral. [L. bi-, twoo, cămĕra, a chamber.] Having two legislative chambers.

Bicarinate. [L. bi-, two, cărīnatus, keeled.] (Bot.) Having two elevated ribs or keels on the inner side, as some Pales (q.v.) have.

Bice. [Ger. beis.] A pigment, blue and green, known to artists from early times; native carbonate of copper; artificially prepared also. Hambro' blue, Paul Veronese green, etc., are B.

Bǐceps, Biclpitous. (Anat.) Having two heads [L. capita] or origins, as a muscle; having a double insertion.

Biche. [Fr. ; $c f$. Ger. bitze, Eng. bitch; vide Littré (s.v.).] Hind, roebuck.

Biconjugate. [L. bis, trvice, conjŭgatus, joined together.] (Bot.) Having a pair of leaflets on each of two secondary petioles.

Bidale, i.e. Bid-ale. An invitation to drink at a poor man's house, and make a subscription for him there. (Bead.)

Biddery-ware. Metallic ware, made at Biddery, in India.

Bidding Prayer [A.S. biddan, to pray], sometimes Allocution, before the sermon, e.g. at the universities, and in cathedrals, specifies certain persons and objects to be prayed for, by Canon LV. and by very ancient custom.

Bidding the beads. (Bead.)

Bidet. A little nag. [Fr. bidet, from Gael. bîdeach, diminutive.]

Bidpai, Fables of. (Hitopadesa.)

Bien chaussée. [Fr.] Wearing neat boots.

Biennial. [L. biennium, a space of two years.] 1. Occurring every two years. 2. (Bot.) Requiring two seasons for flower and fruit, then dying.

Bienséance. [Fr.] Decency, propriety.

Biestings, Beestings. (Colostrum.)

Bifarious. [L. bîfărĭus, tzuofold.] Generally in Anat. pointing two ways, and in Bot. arranged in two rows.

Biffin, Beaufin. A spec. of apple grown in Norfolk; said to be so called from its likeness to the colour of raw beef. The apples are slowly dried in an oven and pressed for keeping.

Bifid. [L. bufídus, bi-, two, findo, $I$ cleavc.] Cleft, divided into two part of the way down. 
Bifilar magnetometer. [L. bǐ-fīlum, lit. $a$ double thread.] A bar magnet suspended horizontally by two threads of equal length, and so adjusted that each supports half the weight, is the essential part of a Bifilar magnetometer or Bifilar; when the bar turns, the threads becoming inclined to the vertical, it must rise, and thus the magnetic force is compared with the weight of the magnet.

Biforate. [L. bi-, two, foro, I bore, pierce.] Having two perforations.

Bifurcation. (Crystal.)

Biga. [L.] A two-horse chariot.

Bigaroo, Bigaroon. [Fr. bigarreau, from bigarré, streaked $=$ white and red.] The large white-heart cherry.

Big Ben. The great bell at Westminster.

Bigendians, in Lilliput, made it a matter of conscience to break their eggs at the big end; heretics in the eyes of the orthodox Littleendians. (See Gulliver's Travels.)

Bigenous shoot. [L. bi-, two, gěnitus, begotten.] (Bot.) Midsummer shoot; a second feeble shoot of leaves in summer.

Bigg, Big, or in Scot. Bere. (Bot.) Horděum hexastíchon. A grain hardier than barley, and ripening more rapidly.

Biggin. [Fr. béguin.] A cap or hood; lit. like one worn by a Beguine $(q \cdot v$.$) .$

Bight. [Cf. Goth. biugan, bend, D. bogt, Dan. bught, $a$ bend, bay.] A bend in a coastline, an open bay.

Bight of a rope. Any part not an end.

Biglow, Mr. Hosea. Pseudonym of James Lowell, author of satirical poems against slavery.

Bignonia. (Abbé Bignon, temp. Louis XIV.)

(Bot.) The Trumpet flower, typ. gen. of ord. Bignoniaceæ ; trop. or sub-trop. ; elegant climbing plants ; the stems used as ropes.

Bijouterie. [Fr., jewellery.] Small articles of vertu.

Bijugous leaf. (Bot.) [L. bijŭgus, two yoked together, doubled.] A pinnate leaf having two pairs of leaflets.

Bikh, Bish, Vish, Atavisha. Hindu name for a most destructive vegetable poison, Ăcŏnitum fĕrox.

Bilabiate flower. [L. lăbŭum, $a$ lip.] (Bot.) Having parts in two separate parcels or lips, as the snapdragon and dead-nettle.

Bilamellate. [L. lāmella, a small plate of metal.] (Bot.) Formed of two plates or layers, e.g. stigmas, placentæ, etc.

Bilander. [D. bijlander, Fr. belandre.] Small flat-bottomed merchant vessel used on the coast of Holland, keeping close by land.

Bilateral contract. (Leg.) One by which both parties [L. latěra, sides], enter into obligations towards each other, as a C. of sale.

Bilateral symmetry. (Med.) Said of organs situated on each side of the mesial line (q.v.).

Bilberry, Common, or Bleaberry. [Blueberry (?) $c f$. Ger. blaubeere.] Vaccinium myrtillus, ori. Vaccīniācěæ. A small bush with dark berries, used for tarts, etc. Other spec. are whortleberry, cowberry, etc.

Bilbo. (Made at Bilbao, in Biscay.) A rapier, sword,
Bilboes. (First made at Bilbao, in Biscay.) Long iron bars with shackles sliding on them and a lock at the end; used to confine the feet of prisoners on board ship.

Bilge, or Bulge. [Cf. ball, bole, bowl, belly, and many other like words having the idea of roundness or swclling.] The bottom of a vessel, where it is nearly flat, on each side of her keel. B.-water, rain or sea water collected in the $B$.

Bilingual. [L. bilinguis.] Speaking in, or written in, two languages.

Biliteral. [L. bi-, two, litěra, letter.] Consisting of two letters ; as the roots i, go (the smooth breathing before an initial vowel being counted), ki, move. 2. Containing two consonants of roots belonging to languages with syllabaria. (Syllabarium ; Triliteral.)

Bilk. To cheat, disappoint, deceive; originally a slang word: some connect it with balk.

Bill. [A.S. bile, the bill of a bird.] Used as a weapon by yeomen of the time of Plantagenets; consisting of a curved blade with spike at top and back, mounted on a six-foot staff.

Billet. [Fr. billet, $a$ note; the mediæval L. billa being the class. bulla.] 1. (Her.) An oblong shape, resembling a letter or brick. 2. Quarter compulsorily provided for troops, by the inhabitants of a country, including the provisioning of them at a fixed rate.

\section{Billet-doux. [Fr.] A love-letter.}

Billet-moulding. (Arch.) A round moulding cut in notches so as to resemble billets, or pieces of stick.

Bill in equity. Plaintiff's statement, written or printed, addressed as a petition to the Court of Chancery.

Billingsgate. Coarse rough language (like that of B. Market).

Billion. With French and other continental arithmeticians, a thousand million, not as with us a million million; so a trillion is a thousand billion, etc. (Numeration.)

Bill, or Declaration, of Rights. (Hist.) The declaration of the Lords and Commons of Great Britain, presented to the Prince of Orange, February, 1688, setting forth the rights and privileges of the people which had been violated by James II. This Bill became law November, I689. (Petition of Right.)

Bill of exchange. A negotiable security in the form of a written request signed by $A$ (drawer) that B (drawee) will pay C (payee) the sum mentioned, by endorsement. $C$ can assign the bill to $\mathrm{D}$ (endorsee or holder), and $\mathrm{D}$ to another, ad lib.

Bill of health. A certificate given to the masters of ships clearing out of port, certifying the state of health in the vessels at the time of their leaving.

Bill of indemnity. A name given to laws passed for the relief of persons who have acted in an illegal manner.

Billon. [Fr. copper coin, origin unknown.] A composition of gold or silver with a larger quantity of copper; once common in France, from about I200; coined-or somethi.1g very 
like it-by Henry VIII. and by Elizabeth, for Ireland. The groschen of N. Germany is of B. Billot. [Fr., a block of wood.] Gold or silver in bars or masses.

Billyboy. A kind of sea-barge on the $\mathrm{E}$. coast.

Bimăoŭlate. Marked with two spots [L. bi-, - two, măcŭla, a spot].

Bĭmăna. [L. bi-, two, mănus, hand.] (Zool.) Two-handed. The human race, viewed as possessing two hands on the anterior extremities.

Bimbashi. A Turkish provincial dignitary.

Bimestral. [L. bǐ-mestris.] (Bot.) Lasting for two months only.

Bimetallism, Theory of. The theory that the national, and if possible international, standard of value should be not that of silver only or of gold only, but a mixed standard of gold and silver, the relative value of the metals being determined; and this probably being $15 \frac{1}{2}: \mathbf{I}$, "which has been maintained for nearly the whole of the present century by the French bimetallic arrangement" (Nineteenth Century, June, I88I).

Bims. Slang for inhabitants of Barbadoes.

Binary; B. arithmetic; B. logarithm; B. star. [L. bini, two each.] Two; double. In B. arith metic the radix is 2 , so that all numbers can be expressed by two symbols, viz. I and o; for in B. arithmetic 2 plays the part which ro plays in ordinary arithmetic ; thus, I IOOI, which in the latter would mean $1 \times 10^{4}+1 \times 10^{3}+\mathrm{I}$, means in the former $I \times 2^{4}+1 \times 2^{3}+1$, or 25 . In $B$. logarithms the base is 2. A B. star is a double star whose constituents revolve round a common centre of gravity.

Binate. [L. bini, two apiece.] (Bot.) Growing in pairs.

Bin, Bing. 1. Properly a heap; and so 2, a receptacle for things stored. Wedgwood compares Sw. binge, and O.N. bunga, a heap; and Fr. bigne, a bump, tumour.

Bind. A miner's term for shales in the coalmeasures.

Bindweed. Popular name for wild convolvulus.

Bing. [Dan. binge.] A heap of alum thrown together to drain.

Binnacle, Bittacle. [Corr. of Fr. habitacle, L.L. hăbĭtāculum, a place, habitation, for steersman and pilot.] The case or box on deck, in which the compass and a light are placed.

Binomial theorem. [Fr. binôme, L. bis, twice, Gr. $\nu \circ \mu \eta$, distribution.] A formula for expressing any power of the sum of two numbers by means of a sum of the powers and products of powers of the numbers severally; thus, $(a+b)^{15}=a^{15}+15 a^{14} b+105 a^{13} b^{2}+$, etc.

Bio-. [Gr. Bíos, life.]

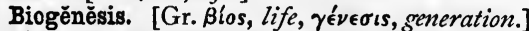
Generation of (all) life from living germs, opposed to spontaneous evolution of life from dead germless matter, on Bastian's theory. (Abiogenesis.)

Bio-geolŏgy. [Gr. Bios, life, yî, earth.] The science which treats of the distribution of plants and animals over the globe and the causes. of that distribution. .. (See Kingsley, Health and Education, p. 173.)

Biology. The science of life [Gr. Bíos], and of the forces and phenomena of life ; these including the sciences of Zool. and Bot.

Biolytio. [Gr. $\lambda u ́ \omega, I$ loose.] Tending to destroy life.

Biotaxy. The arrangement [Gr. $\tau \alpha \dot{\xi} \iota s]$ or classification of animate beings according to their outward organization.

Biparietal diameter. [L. părǐes, -ětis, $a$ wall.] (Anat.) The diameter between the parietal bones; applied to the crānium.

Bipărous. [L. părio, I bring forth.] Bringing forth two at a birth.

Bipeltate. [A word made up from L. bi-, two, and Gr. $\pi \epsilon ́ \lambda \tau \eta$, pelton, $a$ shield.] Protected as by a double shield or buckler.

Bipinnate. [L. bi-, two, pinna, a feather.] (Bot.) Twice pinnate; e.g. the frond of bracken. Bipontine editions of classics. Published A.D. 1779, at Deuxponts, or Zueibrïcken, a town of Rhemish Bavaria, formerly capital of an independent duchy. [L. bi-, two, pons, pontis, $a$ bridge.]

Bipupillate. [L. bi-, two, puipilla, the pupil of the eye.] (Entom.) Applied to a spot with two differently coloured dots, on the wing of a butterfly.

Biquadratic. [L. bis, twice, quadratus, squared.] Of or belonging to the fourth power of a number; in a $B$. equation, the fourth is the highest power of the unknown quantity; as $x^{4}-7 x=103$.

Bird-bolt. An arrow broad at the ends, for shooting birds.

Bird-cherry. Prunus padus, native tree, with long white racemes of flowers; ord. Rosacer.

Bird-lime. A glutinous substance from the boiled middle bark of the holly; it may be obtained also from the mistletoe.

Bird of paradise. A gen. of birds, Paradi. seĭdæ, fam. Corvĭdæ. The males are characterized by gorgeous accessory plumes, springing in some spec. from the sides or rumps, in others from the head, bust, or shoulders. The natives usually cut off their legs: hence the notion of their being legless (Butler, Hudibras). New Guinea and neighbouring islands.

Bird's-eye. A kind of tobacco, cut so that the sections of the stalk resemble a bird's eye.

Bird's-nest. (Naut.) A look-out place at the masthead.

\section{Birds' wings. (Wings.)}

Bird-witted. Desultory in thought, flighty, having no concentration.

Bireme. [L. bĭrēmis, bi-, two, rēmus, an oar.] A vessel with two tiers of oars; trireme, one with three tiers; so quadrireme, quinquireme, with four, with five tiers.

Biretta. [L.L. birretum, $a$ cap.] A square black cap, rounded at the top, worn by priests.

Birk, Birken. Birch, birchen.

Birmingham system. (Caucus meeting.)

Birthwort. (Aristolochia.)

Biscuit [Fr., from L. bis coctus, twice cooked; of. Ger. zwieback] is, in pottery, somewhat a 
misnomer. The first baking, to preserve shape and texture, gives the likeness, in colour and texture, to ship biscuit; the second firing vitrifies the glaze, and brings out the metallic colours.

Bis dat qui cito dat. [L.] He gives twice who gives promptly.

Bise. [Fr.] A cutting N. wind prevalent on the northern shores of the Mediterranean.

Bisect. [L. bi-, two, sěco, I cut.] To divide into two equal parts.

Bisetous. [L. bis, twice, sētōsus, bristled, sēta, a bristle.] Having two bristles.

Bishop. As a drink, hot port wine flavoured with lemon and cloves.

Bishop Barnaby. The may-bug or lady-bird.

Bishopping the teeth of horses. A method of passing off an aged horse for a six-year-old. The nippers are shortened to the required length, and an oval cavity is scooped in the corner nippers, which is then made black by burning.

Bishops' Bible. (Bible, English.)

Bishops' Book, or Institution of a Christian Man. A primer of doctrine and instruction, A.D. I 538; the culminating point of the Reformation during the reign of Henry VIII. (Blunt's Preface).

Bishops in partibus. (In partibus infidelium.)

Bisk, Bisque. [Fr. bisque.]. Soup of several kinds of meat boiled together.

Bismillah. [Ar.] A form in use with Moslems ; in the name of God.

Bismuth. [Ger. wismuth.] A metal, crystalline, reddish-white, brittle ; found native in Cornwall, Germany, Sweden, France, and combined with oxygen, sulphur, arsenic ; useful in the arts and in medicine.

Bǐsōma. [L. bi-, two, Gr. $\sigma \hat{\omega} \mu \alpha$, body.] A sarcophagus, or urn, or coffin, to hold two bodies.

Bison. [L. bison, Gr. Bı $\sigma \omega \nu$.] 1. Gen. of Bǒvĭdæ. 2. Spec. Aurochs (q.v.), and American bison.

Bis peccāre in bello non licet. [L.] One cannot make more than one mistake in war; i.e. one mistake is (generally) fatal.

Bisque. 1. [Fr.] Unglazed porcelain. 2. [Fr. (?) It. bisca, a gaming-house.] A term differently used in different games, meaning odds, an advantage given to one player over another.

Bissextile. Leap year, i.e. L. annus bissextus or bissextîlis ; so called because in the Julian calendar the 24th of February (ante-diem sextum Kalendas Martias) was reckoned twice over in the leap year.

Bister, Bistre. [Fr., origin unknown.] A pigment, warm brown, prepared from soot of wood, especially beechwood.

Bistoury. [(?) Pistoia, where they were made.] A small surgical knife.

Bisulcate. [L. bi-, two, sulco, I furrow.] 1. Having two furrows. 2. (Zool.) Clovenfooted, with two-hoofed digits.

Biting in. Fating away, by an acid, the parts of the plate not covered by the etching ground. (Etching.)

Bitter end. (Naut.) The part of a cable abaft the Bitts.

Bittern. 1. A bitter compound of quassia, etc., $f(r$ adulterating beer. 2. The liquor left after salt has been crystallized out from seawater.

Bittern, Bittour. [Etym. unknown ; cf. Fr. butor, L.L. bitorius ; bos taurus seems to be an error (Littré).] Night-feeding gen. of heron tribe, distinguished by greater length of toe, and by being feathered to the tarsus. Cosmopolitan; three spec. found in Great Britain. Gen. Bōtaurus, fam. Arděľdæ, ord. Grallæ.

Bitter-sweet. (Bot.) Sōlānum dulcămāra. Ord. Sōlānācěæ. A common hedge climber, with potato-like violet flowers and red berries.

Bitts. [Dan. bitte, Fr. bitte.] (Naut.) Two upright pieces of timber in the fore-part of a ship, to which cables are fastened. There are minor B., as the topsail-sheet B., to which the topsail sheet is fastened.

Bitūmen. [L.] Includes the liquid mineral substances, naphtha, pětrŏlěum, etc., as well as the solid mineral, pitch, asphalt, mineral caoutchouc, etc. (Asphalt.)

Bituminous shale. Thin-bedded clays, sufficiently rich in hydrocarbon to yield paraffin, etc., by distillation.

Bivalve. [L. bi, two, valvæ, doors.] Possessing two valves, or doors ; term applied to shells of certain molluscs, as cockles and small Crustaceans.

Bivouac. [The French form of Ger. beiwache, by-zuatch.] In warfare, the halting of soldiers at night in the open air.

Bixa. (Annotta.)

Bizarre. [Sp. bizarro, valiant.] Capricious, fantastic.' Originally, valiant ; then, angry, headlong ; lastly, strange, capricious.

Bjelbog. (Tschernibog.)

Black Act. A statute passed, 9 George I., against the Waltham Blacks, who infested the forest near Waltham, Hants. The Act was repealed in $\mathrm{I} 828$.

Black art. Mediæval name for necromancy, as if derived from $\mathrm{L}$. niger, black.

Black-ash. A mixture of impure carbonate and sulphide of sodium, obtained from salt-cake $(q . v$.$) by roasting it with chalk and coal.$

Black Assize. A name given to an assize at Oxford in 1577 , from a pestilence which broke out while it was held.

Black-band. A valuable carbonaceous ironstone in the coal-measures of Scotland and S. Wales.

Black Book of Admiralty. 1. A book of ancient Admiralty statutes and ordinances. 2. A mythical record of offences.

Black cap. Assumed by a judge, that he may be in full dress.

Black chalk. A kind of shale or clay-slate, containing much carbon; used for drawing, and ground down for paint ; in Carnarvonshire, Isle of Islay, Spain.

Black Country. The district between Birmingham and Wolverhampton, full of coal-pits and furnaces.

Black Death. (From black spots on the body). The Oriental plague which desolated Asia and Europe in the middle of the fourteenth century.

Black dose, or draught. Sulphate of magnesia 
and infusion of senna, with aromatics to render it palatable ; Epsom salts.

Black flux. A mixture of charcoal and carbonate of potash. (Flux.)

Black Friars. A mendicant order, called from their habit, B. F. in England; in France, Facobins, as living in Rue St. Jacques; Preaching $F$., from their office of converting Jews and heretics; and Dominicans, as founded by St. Dominic, a Spaniard, early in the thirteenth century.

Black game. Heath-fowl; opposed to red game, as grouse.

Black-hole. Place of solitary confinement for soldiers.

Black Hole of Calcutta. (Hist.) A dungeon in which Suraj-u-Daula, 1756, shut up 146 English prisoners taken in the defence of the city, of whom all but sixteen were stifled to death.

Black-lead, Plumbāgo, properly Graphite into which no lead enters. A greyish-black mineral, chiefly carbon, but containing alumina, silica, etc.; used for making pencils.

Black-letter. The old English or Gothic letter, generally used in manuscript writing before the introduction of printing, and continued in types to the end of the sixteenth century, and in many instances later.

Black-letter saints' days. In the Calendar of the Book of Common Prayer, the commemoration days of saints whose names are not rubricated, and for whom no special Collect, Epistle, and Gospel are provided.

Black list. A list of the insolvent, bankrupt, swindlers, etc., printed for the private use and protection of the trading community.

Black mail. An impost in the Highlands and bordering Lowlands of Scotland, in the earlier part of the eighteenth century, submitted to as a compromise with robbers. (Mails.)

Black Monday. 1. The cold Easter Monday of 1360, April 14 ; when many of Edward III.'s soldiers died before Paris. 2. The first Monday of work after holidays.

\section{Black Monks. (Augustines.)}

Black quarter, Black spald, Quarter evil. An apoplectic disease in cattle, especially young cattle; caused by rich pasture on stiff undrained soil, by change from poor to rich pasture, etc.

Black Rod, Usher of the. Chief gentlemanusher to the sovereign; summons the House of Commons to the Peers when the royal assent is given to Bills ; takes into custody any peer guilty of breach of privilege. He belongs to the Urder of the Garter.

Black Rood of scotland. "A piece of the true cross," in ebony gilt, brought in the eleventh century by the wife of King Malcolm, and left as an heirloom of the Scottish kingdom. It was lost by David II. at Durham, and was placed in the cathedral, whence it disappeared at the Reformation.

Black rubrio, i.e. a statement, not really a rubric or direction. The declaration at the end of the Communion Office, respecting kneeling : in rubricated Prayer-books printed black; in others printed in Roman type, not in italics.

Blacks. 1. A kind of ink for copper-plate printing, made by charring the refuse of a winepress. 2. (Bianchi and Neri.)

Black ships. Indian vessels built of teak.

Blackstone's Commentaries on the Laws of England. Published I 765-69. Originally lectures at Oxford, by Blackstone, the first Vinerian Professor of Law; appointed judge, 1770.

Black Watch. The 42nd Kegiment, into which companies were enrolled, 1737 , who had watched the Highlands, dressed in dark tartan.

Bladud. In British legend, the father of King Lear. He is said to have built the city of Bath, where he was cured of his leprosy by its medicinal waters.

Blague. [Fr.] Humbug, brag, intended to mystify; its earlier meaning, a tobacco-pouch. Littré refers to Gael, blagh, to blow, inflate.

\section{Blaize. (Fake.)}

Blano coursier. [Fr., white horse.] The herald of the Order of the Bath (from the white horse of Hanover).

Blanch-holding. (Scot. Law.) A tenure for a peppercorn duty.

Blanching. 1. Whitening metal for coinage.

2. Coating iron plates with tin.

Blanching-liquor. A solution of chloride of lime for bleaching.

Blanchisseuse. [Fr.] Washerwoman.

Blanket. [Fr. blanchet.] Woollen cloth to lay inside the tympans in printing.

Blanketeers. Were to have marched, taking blankets, etc., with them, to petition for reform, to the Prince Regent in London, March, 1817 . (Peterloo.)

Blank verse. The unrimed heroic verse of five feet, or ten syllables, each foot being in general either an Iambus or a Spondee.

Blarney stone, To have kissed the. To be extremely persuasive, to be an adept at soft sawder. Cormack Macarthy, Lord of Blarney, duped Carew, A.D. 1602.

Blasé. Satiated, cloyed ; etym. unknown. Littré compares blaser, to burn, blaze, a provincial use of which is $=$ dessécher, to $d r y u p$, from excessive use of stimulants.

Blast, Blast-pipe. The waste steam from a high-pressure engine is driven through the Blast-pipe into the chimney, and, causing a partial vacuum in the smoke-box, increases the draught through the furnace.

Blastēma. [Gr.] 1. (Anat.) The albuminous formative element in animal tissue. 2. (Bot.) The axis of an embryo.

Blast-furnace. A furnace for smelting iron ores, an operation requiring a very high temperature, which is obtained by a strong blast of air forced into the furnace from beneath.

Blasto-. [Gr. $\beta \lambda \alpha \sigma \tau o s$, bud, sprout.]

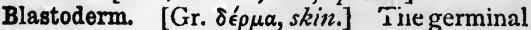
membrane of the ovum.

Blastǒgěněsis. In plants, multiplication by

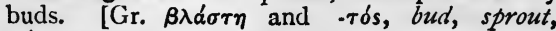
$\gamma^{\prime} \nu \in \sigma t s$, origin.]

Blatant. Onomatop. roaring, bellowing; 
cf. blare, blatter. B. Beast is Rumour or Slander, of "vile tongue" and "hellishe race" (Faëry Queen, bk. vi.).

Blateroon. [L. blătěro, -nem.] A babbler, idle talker.

Blatter. [L. blătěro, verb.] To prate, talk idly.

Blazonry. [Fr. blason, a coat of arms.] The art of painting or describing coats of arms according to heraldic rules.

Bleb, Blab, Blob. Originally a drop of water, a blister; generally an air-bubble in glass, ice, etc. [Cf. Ger. blähen, to swell.]

Blechnum. [Gr. $\beta \lambda \eta \dot{n} \chi \omega \nu$.] (Bot.) A gen. of plants, ord. Ferns. B. borēāle, Hard fern, the only British spec. Common in woods.

Blee. [A.S. bleoh, blewan, to blow, bloom.] Complexion, colour.

Blench. [Collateral form of blanch, to grow pale.] To avoid, elude, start from.

Blende. [Ger. blenden, to dazzle.] (Min.) Zinc B., Garnet B., Black-jack. 1. Properly sulphide of zinc; in Cornwall, Cumberland, etc., and many parts of Europe and N. America. 2. Popularly applied to many other lustrous minerals.

Blenn-. [Gr. $\beta \lambda \epsilon ́ v \nu \alpha$, phelgm, mucus.] (Med.)

Bless [akin to bliss, blithe], from the action of the hand in making + , sometimes $=$ to brandish.

Blessed thistle (from its supposed medicinal virtue). Carduus benedictus of old writers and of Med. ; gen. ord. Compǒsǔtæ.

Blets. [Fr. blet, overripe.] Spots of decay in apples, pears ; the work of a low form of fungus.

Bleu dn roi. [Fr., king's blue.] In china, a deep cobalt blue.

Bleu, Gros. [Fr.] The darker variety of B. du roi.

Bleyme. In a horse, inflammation between the sole and bone of the foot. [(?) Corr. of Fr. flegme, Gr. $\phi \lambda \epsilon ́ \gamma \mu \alpha$, inflammation.]

Blindage. Building of strong beams leaning close together against a wall, or against another set of beams, and covered with fascines and earth, for the protection of troops and stores.

\section{Blind-coal. (Anthracite.)}

\section{Blind-fish. (Hag.)}

Blind Harry. Scotch minstrel of fifteenth century. Author of the romance of Wallace.

Blind hockey. A gambling game with cards.

Blindman. At the General Post Office, a decipherer of illegible or misspelt addresses.

Blind story. (Eccl. Arch.) A name for the Triforium, or second story above the Pier arches, and below the Clerestory.

Blind-worm. Anguis frăgĭlis [L., fragile snake]. Harmless spec. of footless lizard, frequently taken for venomous snake. Fam. Scincidæ.

Blink. The dazzling whiteness about the horizon, caused by reflexion of light from fields of ice.

Blistered steel. Steel produced by heating to redness bars of pure iron, surrounded by powdered charcoal, etc., till they have absorbed sufficient carbon. When taken out, the bars are covered with blisters.
Blister-fly. [O.E. blaesan, to blow ; cf. Ger. blase, blister, D. bluyster, id.] Spanish fly, Can-

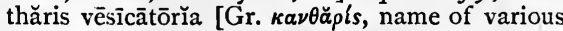
beetles, L. vēsīca, a bladder, blister]. A beetle, about one inch long, green, with gold reflexions; rare in England. Ord. Cǒlěoptěra.

Block. [A Teut. and scand. word.] 1. Two or more pulleys or sheaves placed side by side on a common axle in parallel mortices cut in a properly shaped piece of wood. 2. (Naut.) A pulley made in four parts : (I) the shell, or outside ; (2) the sheave, or wheel ; (3) the pin, or axle ; (4) the strop, a piece of rope or iron by which the block is made fast. Building $B$., tranverse pieces of timber to support a ship when building, or in a dry dock.

Block-house. (Fortif.) Covered fieldwork, composed of trunks of trees, with a shell-proof roof of earth.

Block machinery. A system for manufacturing the shells and sheaves of blocks for ship tackle, set up in Portsmouth Dockyard by Sir M. I. Brunel, 1802-8, and at Chatham in 1807 .

Blomary. The first forge through which iron passes, after it is melted from the ore. (Bloom.)

Blonde. [Fr. blond, fair.] A fine kind of lace, made of silk (from its colour).

Blood and Iron, The Man of. Prince Bismarck.

Blood money. Money earned by giving information or by agreeing to help in bringing a capital charge against another.

Blood murmurs. (Med.) Heard in certain portions of the arterial system, especially in cases of anæmia (q.v.).

Blood-root of N. America, or Puccoon. (Bot.) Sanguǐnāria Canadensis, ord. Păpāvěraceæ; its fleshy root-stalk and its leaf-stalks abound in a red juice; acrid, narcotic, emetic, purgative ; much used in United States.

Blood-stone. (Heliotrope.)

Bloodwit. [From A.S. blod, blood, wyte, pity.] A fine for bloodshed.

Bloody Assizes. Those held by Judge Jeffreys in 1685, after the suppression of Monmouth's rebellion.

Bloom. 1. [A Teut. and Scand. word.] A clouded appearance, like the bloom on fruit, sometimes assumed by the varnish on a painting. 2. [From O.E. blôma, a mass.] A mass of crude iron from the puddling furnace, while undergoing its first hammering.

Bloomer costume. A dress for females, devised in America in 1848 , approaching as nearly as possible to that of men. The attempt to introduce it into England was unsuccessful.

Blooming. (Shingling.)

Blowing lands. (Agr.) Lands liable to have their surface blown away.

Blow-pipe. An instrument which, by driving a blast through a flame, concentrates its heat on any object. The oxy-hydrogen blow-pipe is one in which a mixture of oxygen and hydrogen is used for the blast instead of air.

Blowsalinda. In Gay's Shepherd's Week, a rustic lass.

Blow the gaff, To. (Naut.) To let the cat out of the bag. 
Blubber. [Akin to blob, bleb, drop, lump.] 1. A bubble. 2. The oil-bearing fat of whales and other fish.

Blue and Green factions. (Factions.)

Bluebell. (Bot.) Wild hyacinth (Scilla nūtans) or Campanŭla rŏtundifŏlǐa.

Blue-book, The, on any subject, is the report or paper published by Parliament; in blue paper covers.

Bluebottle. (Bot.) Of corn-fields, sometimes cultivated for its coloured flower-heads; Centaurēa cy̆ănus, ord. Compǒsĭtæ.

Blue-gowns-in Scot.-or King's Bedesmen, i.e. praying for him; and receiving a small bounty, with a blue gown, and badge " pass and repass ;" and so = privileged mendicants, such as Edie Ochiltree (Walter Scott, Antiguary). None appointed since 1833 ; all have now died out.

Blue-john. The blue variety of fluor-spar.

Blue Laws. A derisive name for certain regulations in the early government of $\mathrm{New}$ Haven plantation, which punished breaches of good manners and morality; "blue" being an epithet applied to the Puritans, after the Restoration.

Blue Mantle. The second pursuivant (so named by Edward III., from the French coat which he assumed, being blue).

Blue-peter. [Origin doubtful.]. (Naut.) A blue flag with a white square in the centre. When flown at the foretop-masthead, it indicates that the vessel is ready to sail.

Blue-pill. (Med.) Pilăla hydrargy̌ri; mercury in the metallic form, very finely subdivided; mixed with conserve of roses, to form a pill.

Blne-stocking. A literary lady, but pedantic, unpractical. About I78I, B. S. Clubs, according to Boswell, arose, of literary persons of both sexes ; at which Mr. Stillingfleet, gravely dressed and in blue stockings, was one of the most constant.

Bluff. The precipitous face presented by a high bank to the sea or to a river.

Blunderbuss. 1. A noisy blunderer. 2. A short, wide-mouthed, noisy gun.

Boa. [L. bǒa and bova, a serpent; or a water-snake, said to suck cows.] Name of a non-venomous gen. of serpents, killing its prey by constriction. Trop. America. Fam. Py̆thōnìdæ.

Boabdil. (Bobadil.)

Board, By the. (Naut.) Almost level with the deck. Board and board, side by side, and touching. Board. (Leg.)

Boart, Bort, Carbonādo. Black diamond, rarely in perfect crystals ; used for boring, etc. (Diamond.)

Boast. To block out stone into a simple, rough boss-like form, leaving the carving, etc., for future work, the rough projection itself being Bossage.

Boatila. (Naut.) A flat-bottomed narrowsterned boat. Gulf of Manar, between Ceylon and India.

Boatswain. [From boat, and swain = A.S. swán, $a$ lad.] (Naut.) The officer of the first lieutenant; he gives no orders, but reports defects, and has charge of the ship's rigging, anchors, etc. He also pipes hands to their duties. $B$. captain, nickname for one thoroughly acquainted with his duties. $B$.'s mate, assistant to $\mathrm{B}$.

Bobadil. An Anglicized form of the Ar. Abu Abdallah, or father of Abdallah. Also written Boabdil. (Matămöros.)

Bobadil, Captain. In Ben Jonson's Every Man in His Humour, a bragging coward.

Bobbin. [Fr. bobine.] A wooden pin or reel for winding thread on.

Bobbinet [i.e. bobbin net]. ' $\mathbf{A}$ kind of machine-made lace.

Bobibation. (Solmisation.)

Bobo'link, Rice troopial, Rice bird, Reed bird, Reed bunting (of U.S.A., not that of Britain). (Ornith.) Butter bird of Jamaica, Skunk bird of Cree Indians. Gen. and spec. of American Hang-nests ; migratory ; length, seven or eight inches; plumage, black, white, and

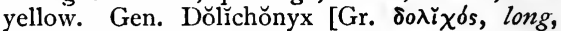

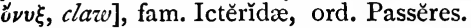

Bobstay. (Stays.)

Bocal. [Gr. Bavkă入ís, a water-cooler.] A cylindrical glass vessel with a wide short neck.

Bocardo. The building at Oxford in which Cranmer was imprisoned, by which Ridley and Latimer passed on their way to be burned in the city ditch opposite Balliol College, October I6, 1555. So named from an impracticable figure in Logic.

Bocasine. [O.Fr, boccasin.] A sort of fine buckram.

Bocca. [It., mouth.] In glass-making, the round hole through which the glass is removed from the furnace.

Boccaccio. (Decameron.)

Bocedisation. (Solmisation.)

Bocking. A kind of coarse baize made at Bocking.

Bocland. [A.S.] Land held by book, charter, or deed, and so continuing in perpetual inheritance, while the Folc-lands, at the end of a given term, reverted to the community. The only burdens on Bocland were those of the Trinoda Necessitas, that is, the duty of contributing to the costs of war, and the repair of castles and bridges.

Bodach Glas. (Banshie.)

Bod-, Bos-. A house; part of Cymric names, as in Bod-min, Bos-cawen.

Bode's law. (Astron.) An arithmetical formula, expressing approximately the distances of the planets from the sun.

Bodleian Library. The L. of the University of Oxford; so called from Sir Thomas Bodley, 1597 , its restorer and benefactor.

Body. A term used for the paste as mixed for manufacturing pottery or porcelain.

Body colours. Water-colours mixed with white, consistent, opaque; opposed to transparent tints and washes.

Body of the place. (Mil.) Enceinte or circuit of a fortress, comprising the interior rampart immediately surrounding the town fortified [Enceinte is L. incincta, pregnant.] 
Boëdromīon. [Gr.] Third Attic month, beginning fifty-nine days after the summer solstice.

Bootian = stupid, dull, foggy-minded, as the inhabitants of Bœotia- "crasso āěrě nāti" (Horace)-were said to be, untruly.

Bog-butter. In Ireland, a peculiar substance, seventy-four per cent. carbon, formed by decomposition of peat ; in colour and consistency like butter; liquid at $124^{\circ} \mathrm{F}$.

Bogle. (Bogy.)

Bogomiles. [Slav. Bog, God, miloric, have mercy.] A Bulgarian sect of the twelfth century, who are said to have been Manicheans.

\section{Bog-spavin. (Spavin.)}

Bog-trotter. One of the lower Irish peasantry, who traverse bogs with singular speed and safety, and often elude justice.

Bogue, To. (Naut.) To drop off a wind. Used only of clumsy craft.

Bogus. [Amer.] Spurious; originally of counterfeit coin.

Bogy, Bogle. (Myth.) Fairies or supernatural beings, amongst whom are included the Brownies, who answer to the Latin Lares, or household spirits. (Puck.)

Bohemian. 1. A gipsy. 2. One of unsettled habits, mentally. [Fr. Bohémien, as coming into France from Bohemia ; cf. gypsy; i.e. entering Europe by Egyptus, a district at the mouth of the Danube.]

Bohemian Brethren. A sect which sprang up in Bohemia in the latter part of the fifteenth century. In I 535 they renounced Anabaptism, and were united first with the Lutherans and afterwards with the Zuinglians. The Moravians seem now to be their nearest representatives. (Taborites.)

Bohemian glass. 1. A hard, scarcely fusible glass, consisting of silicates of lime and potash. 2. Ornamental glass, containing in addition silicate of alumina.

Boidæ. (Boa.)

Boiling point. The temperature at which a given substance passes into vapour, and beyond which its temperature cannot be raised under given circumstances of atmospheric pressure, purity of the substance, etc.; the B. P. of a thermometer is the temperature of steam arising from boiling water under a pressure of $29^{\circ} 905$ inches of mercury.

Bold boat. (Naut.) One that stands a sea well.

-bold, -bottle. A house; part of A.S. or Norse names. [A.S. botl, house, bytkan, to build.]

Bole. 1. The stem of a tree, from the idea of roundness ; $c f$. v. to boll, Ger. bollig, bowl, ball, etc. 2. [Gr. $\beta \hat{\omega} \lambda$ os, a clod, earth.] (Geol.) An earthy mineral, like clay in structure, of silica, alumina, and red oxide of iron ; found amongst basalt and other trap rocks of the $\mathrm{O}$. and $\mathrm{N}$. World. Armenian B. is used in colouring anchovies.

Boléro. (Said to be name of inventor.) Spanish dance, in triple time, with marked rhythm, representing various phases of love.
Bōlētus. [L.] An extensive gen. of Fungi, resembling agarics, but having, beneath the cap or pileus, not gills but pores or small tubes; some are edible.

Bolio. [Hind.] Indian river boat, longer and narrower than a budgerow. (Bazaras.)

Bollandists. (J. Bolland, I643.) A succession of associated Jesuits, in Antwerp, who published Acta Sanctorum, I643-I794; the work, more than once interrupted, is now carried on by aid of the Belgian Government.

Bolled. Exod. ix.; generally understood to mean rounded, swollen; i.e. in the seed-vessel. [D. bol, bolle, a head; cf. ball, bowl, bulla, etc.] Johnson, loc., gives " to rise in a stalk;" Spcaker's Commentary, "in blossom."

Bolognese school. A school of painting, the first being founded in the fifteenth century by Marco Troppo, its great master being Francia ; the second, in the sixteenth, by Bagnacarallo ; the third, at the end of the same century, by the Caracci.

Bolsover stone. Yellow limestone of B., in Derbyshire, of which the Houses of Parliament are built; a combination of carbonate of magnesia with carbonate of lime.

Bolster, i.e. boltster. A smith's tool, used for punching holes and making bolts.

Bolter. A kind of sieve, which bolts or sifts coarser from finer parts of meal. [Cf. Ger. beutelen, to shake, to bolt, and L. pulto, I strike, knock.] Bolting; the act of sifting.

Bolt-head. A glass globe with a long, straight neck, used by chemists in distilling.

Bolt-rope. (Naut.) The rope round the edge of a sail.

Bōlus. [Gr. $\beta \hat{\omega} \lambda$ os, clod, lump of earth.] A medicinal preparation in a large, soft mass, to be divided into pills.

Bomba, King, i.e. the Liar King. Ferdinand, King of the Two Sicilies. B. is the puff of the distended cheek, expressive, in Italy, of disbelief of the thing said.

Bombardier. [Fr. bombarder, to bombard.] Non-commissioned officer in the artillery, ranking immediately after a corporal.

Bombardier beetle. (Entom.) Brăchinus crěpŭtans, one of the ground beetles (Cărăbĭdæ). When handled, it discharges a volatilized acid with an explosion. Common in England. Ord. Cŏlěoptěra.

Bombardo. [It.] A wind instrument of former times, large and rude, upon which the modern oboe, clarionet, etc., have been improvements.

Bombardon. A large brass bass wind instrument, having a tone somewhat like that of an ophicleide.

Bombasin, Bombazine. [L. bombȳcĭnus, made of silk or of fine cotton.] A fabric, of silk and worsted mixed.

Bombast. [Gr. $\beta \delta \beta \mu \nu \xi$, silkworm, raze silk.] Padding; and so turgid language.

Bombastes Furioso. The hero of a burlesque opera, by Rhodes, in ridicule of modern tragedy, Bombax. [Gr. $\beta \delta \mu \beta v \xi$, silk, with which cotton was at first confounded.] (Bot.) A 
gen. of plants, B. ceiba, common silk-cotton tree.

Bombǐdæ, Bombus. [Onomatop. ; $c f$. similar words in Gr., L., Fr., It.; Ger. hummel, Eng. humble-bee.] (Zool.) Humble-bees, Bumble-bees. Fam. of bees with thick hairy bodies, making nests underground. Ord. Hy̆mĕnoptěra.

Bomb-ketch. (Ketch.)

Bombǒlo. [It. bombǒla, a bottle.] A glass globe with a short neck, used in refining camphor.

Bombȳcĭdæ, Bombyx. [Gr. $\beta$ ó $\mu \beta \nu \xi$.] (Entom.) Silkworm moths. Sub-fam. of Lěpĭdoptĕra.

Bombycilla, Bombycǐvŏra. [Gr. $\beta \delta \mu \beta v \xi$, silkworm, L. voro, 1 devour.] (Ornith.) Names applied by Brisson and 'Temninck respectively to a portion of fam. Ampělǐdæ, including Bohemian chatterer. (Chatterer, B.)

Bombycĭnous. Silken, in colour like a silkworm. (Bombasin.)

Bŏna Dĕa. [L., the good goddess.] A Latin goddess, whose rites were celebrated only by women.

Bǒnā fĩdē. [L.] With good faith, fair and straightforward.

Bonair. Complaisant, yielding. In the espousals of the Sarum Manual, a wife promises to be "bonere and buxum." (Debonair.)

Bona notābǔlia. In Law, goods exceeding $£ 5$ in value, belonging to a person dying in another diocese.

Bonassus. [L. bŏnāsus, Gr. ßóvāooos.] (Aurochs; Bison.)

Bŏna vacantia. [L.] In Rom. Law, goods lying ownerless; in Eng. Law, goods in which the king only claims a property: royal fish, shipwreck, treasure trove, etc., personal property of an intestate who leaves no next of kin.

Bon avǒcat, mauvais voisin. [Fr.] $A$ good lazeyer is a bad neighbour.

Bond. [A.S.] (Arch.) The arrangement of materials in a wall-"tied" together-in a way which shall show harmony of structure; known as English and Flemish B. (Stretcher.)

Bondager. [A.S. bonda ; $c f$. Icel. bóndi, $a$ husbandman.] (Hind.)

Bond-stone. One reaching through the whole thickness of a wall, and so binding together its two faces.

Bond-timber is worked into a wall longitudinally; to tie the work as it is setting, and permanently.

Boneblack. Animal charcoal, made by calcining bones in closed vessels.

Bone-caves. (Caves.)

Bone earth. The ash left when bones are burnt, consisting chiefly of phosphate of lime; used as manure and for cupels.

Boneset. (Comfrey.)

Bon Gaultier. Pseudonym of Professor Aytoun, author of Lays of the Scottish Cavaliers, and Theodore Martin, who published a volume of ballads under this name.

Bon gré, mal gré. [Fr.] Willing or unwilling, L. nōlens vŏlens; gré, accord, being from L. grātum.

Bon homme Jacques. [Fr.] A name given to the peasantry of the Jacquerie (q.v.).
Bonlface. In Farquhar's Beaux' Stratagem, an ideal innkeeper.

Bonito. [Sp.] Two spec. of Tunny fish. (Zool.) (I) Thynnus Pělămys. (2) Scomber Rochei, about two feet and a half long, mottled blue back, white belly; this has four dark lines lengthwise each side of the belly. May be caught with artificial flying-fish. Mediterranean and Atlantic, occasionally British coasts. Fam. Scombrĭdæ, ord. Àcanthoptěry̆gŭi, sub-class Tělěostěi.

Bon marché. [Fr., good market, cheapness.] Adopted as the name of the vast business of the late Achille Boucicault.

Bonne. [Fr.] Nursemaid, nursery governess.

Bonne bouche. [Fr.] A daintymorsel.

Bonnet. [Fr. bonnet, cap, L.L. boneta, some kind of cloth.] 1. (Mil.) Small raised work of two faces, placed on the salients in fortification, to increase the height of the parapet. 2 . (Anat.) Rètǐcülum [L., little net], Honey-comb bag. Second stomach of a ruminant. 3. (Naut.) (Preserving the original idea of Fr. bonnet, stuff; etymology unknown.) A piece of canvas, laced to the bottom of fore-and-aft sails in a light wind.

Bonnet laird. Owner of a cottage and an acre or two of land; who wore, till lately, the old braid bonnet of the Lowland Scottish peasantry, broad, round, blue, with red tuft.

Bonnet piece. A beautiful native gold coin of James V. of Scotland; with bonnet instead of crown.

Bonnet rouge. [Fr.] The red cap of Liberty. (Liberty, Cap of.)

Bonnibel. [Fr. bonne et belle.] A girl fair and good.

Bono Johnny. Pigeon English (q.v.) for Englishman.

Bon ton. [Fr., good tone.] Good breeding.

Bonus. [L., good.] A premium or advantage. In Insurance, a share of profits given to policy-holders.

Bon vivant. [Fr.] A freeliver.

Bonze. (Talapoins.)

Bonzes. The European name for the priests of the religion of Fo or Buddha in the Chinese, Birman, and Japanese empires. [Skt. bandya, i.e. vandya, deserving praise.]

Booby-hatch. (Naut.) A smaller companion, lifting off in one piece.

Bookland. (Bocland.)

Book of Sports. Proclaimed at Greenwich by James I., May, 16r8, sanctioning certain amusements for Sunday after service; revived by Charles I., 1633; ordered by Lords and Commons, 1643 , to be publicly burnt.

Boom. 1. (Naut.) [Cf. beam, Ger. baum, $a$ tree or pole.] A long spar used to extend the foot of a sail. $B$. forwards, carry all possible sail. $B$. off, keep off with spars. To top one's $B$., start off. Booms of a ship. (Docks.) 2. Any obstacle across a river or harbour, for protection in war, as spars, an iron chain, etc.

Boomerang. Bow-shaped Australian missile, of hard wood, for war, sport, or chase, about two inches and a half broad, two feet long; with one side flat, the other rounded. On failing 
to strike its mark it returns in its flight to the thrower.

Boon. [Gael. bunach.] The refuse from dressed flax.

Boot and saddle. (Mil.) Preparatory trumpetcall for cavalry mounted parade.

Bootikin, Boot, Boots. Used judicially in Scotland-not after 1690. A case of wood for the leg, into which wedges were driven, to extort confession.

Boots. (Cinderella.) life.

Booty. In Ireland, one of nomadic, unsettled

Borachio. 1. A bottle or cask. [Sp. borracha, a pig-skin bottle.] 2. A drunkard.

Borage, Common. A spec. (Offícīnalis) of Borāgo, a gen. of plants, ord. Boragineæ, growing wild in many parts of Europe. Its flowers and leaves are used in flavouring claretcup.

Borassus fläbelliformis, or Fan palm. [L. flābellum, $a$ fan.] (Bot.) The only spec. of the gen. B. or Skt. Tala, or Palmyra, the finest of palms ; the sap yields palm wine, or toddy, and sugar.

Borax. [Heb. borak, white.] Biborate of soda, used as a flux and in soldering. (Boron; Tincal.)

Border justice. Feddart justice, hanging first and trying afterwards. (Antiphrasis.)

Bord-service. Tenure of bordlands, from which is maintained the lord's board or table.

Bordure. [Fr.] (Her.) A border round an escutcheon, containing the fifth part of the field.

Bore. [Ger. bor.] (Naut.) A tidal wave of great height, confined to certain rivers and inlets of the sea, e.g. Severn. It comes suddenly with a peculiar roar, and returns as suddenly. In the Petticodiac, Bay of Fundy, it is seventy-two feet high.

Bŏreas. [Gr.] The $\mathrm{N}$. wind, or rather N.N.E. ; Ãquilo. (Wind.)

Borecole, or Sprouts. A variety of Brassǐca ŏběrācěa, ord. Crucĭfĕræ. [Corr. of broccoli (?).] Boree. An Irish dance.

Borel, Borrel. [O.Fr. burel, coarse cloth for peasantry, L. burra.] Rude, illiterate, clownish.

Borer-fish. (Hag.)

Born alive. In Law, manifesting life after the extrusion of the whole body.

Boron. An infusible element of a dark olive colour, resembling carbon in its properties. It was first obtained from boracic acid, its trioxide, the salts of which are called borates. (Borax.)

Borough English. A mode of descent in some ancient boroughs and manors, in which the owner's youngest son, or his youngest brother (if he has no issue), is the heir. (Gavelkind.)

Borrowing days. Three days of April, which before the change of style were April I, 2, 3, and so seemed more properly to belong to March.

Borsholder. [A.S. burh-ealdor.] (Hist.) The elder or chief of a borough or tything.

Bort. The smaller fragments removed from diamonds in cutting them. (Boast.)

Borten. A narrow wooden staff.
Bosa. [Pers. bôzâ.] An Eastern drink made from fermented millet seed.

Boscage. Underwood, land covered with thickets. [Fr. bocage, O.Fr. boscage, boscātȟcum, from L.L. boscus, wood.] Bosky, containing thickets, copses.

Boshes. [Ger. boschung, slope.] The lower part of a blast furnace, sloping inward to the hearth.

Bos in linguâ. [L.] An ox is on his tongue, i.e. some weighty reason for silence (or, less probably, a bribe, a coin stamped with an ox); $c f$.

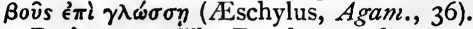

Bosjesman. 'The Dutch name for some African tribes, akin to the Hottentot, called by the English Bushmen.

Bosky. (Boscage.)

Boss. [An Amer. word.] 1. A master workman; said to be D. baas, master. 2. One who is superior, in any way, to his fellows.

Bossage. (Boast.)

Bot. [Gael. botus, boiteag, a magrot.] (Entom.) Larva of botfly. Estrus ěqui [Gr. ol $\sigma \tau$ \%os] deposits its eggs on the horse's hairs; by his licking the place they are transferred to lis intestines, where they are hatched. CE. bǒvis burrows in the skin of the cow. $\mathrm{E}$. ǒvis infests the frontal sinus of sheep. Ord. Dipterra.

Botănomancy. Divination [Gr. $\mu \alpha \nu \tau \epsilon l \alpha]$ by means of plants, flowers [Botá $\eta$, herb, grass], practised by the ancients to discover their loves; and by Teutonic nations; e.g. Marguerite and the star-flowers in Faust.

Botargo. [Sp. botarga.] A sausage, made with mullet roe, inducing thirst.

Bote. [A.S. bot, from betan, to repair.] 1. Necessaries used off an estate for its mainten ance; as hay-bote, wood for repairing hedges. 2. Reparation, as in bootless.

Botellifěrous sponges. Having straight swelled branches. [L. bŏtellus, dim. of bŏtŭlus, a sausage.]

Bothie. [Gael. bothag, a cottage.] This word has come to mean a house or barrack of lodgings for unmarried labourers in E. and N.E. parts of Scotland.

Botree of Ceylon, Peepul of India. Fìcus rēlǐgiōsa, somewhat like the banyan; held sacred by Buddhists, planted near every temple.

Botryoïdal. (Bot., Min.) Having the shape or likeness [Gr. €íos] of a cluster of grapes

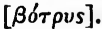

Bottcher ware. (From its discoverer.) A kind of reddish-brown pottery, unglazed, but polished by a lathe, and afterwards covered with a dark varnish and painted or gilded.

Bottom. (Naut.) Hull of a ship; put by Synecdoche (q.v.) for the ship itself; thus, British B. means British ship, Dutch B. Dutch ship, etc.

Bottom, Nick. The silly conceited weaver with an ass's head, with whom Titanı in Shakespeare's Midsummer Night's Dream fell in love.

Bottomry. Hypothecation of a vessel (a bottom) as security for money lent, which is lost to lender if the vessel be totally lost.

Bottonny. [Fr. bontonné.] (Her.) Having 
each arm terminated with three semicircular buds [Fr. boutons], arrayed like a trefoil.

Botǔlǐform. [L. bōtŭlus.] Shaped like a sausage.

Bouge. [(?) Fr. bouche, a mouth; $c f$. bonne bouche, a dainty morsel.] Victuals, allowance of food.

Bouget. [Fr.] (Her.) An ancient vessel for carrying water.

Bought, or Bout, of the plough. [A.S. beogan, bigan, bugan, to bend; cf. bight; Dan. bagt, a bay, Ger. biegen, to bend.] The course of the plough both up and down the space cultivated.

Bought-note. Transcript of a broker's signed entry of a contract given to the seller. Soldnote, ditto to the buyer.

Bougie. [Fr., a wax-candie, first made at B., in Algiers.] (Med.) A small rod, metal or other, for distending contracted mucous canals in various parts of the body.

Boulder-clay. (Geol.) An important member of the Glacial deposits, Northern drift, Erratics, etc., of the post-Tertiary system. The glacial beds, produced from glaciers, coast-ice, and icebergs, differ in the several parts of England. They comprise the Lower B. clay (a sandy clay, with pebbles and boulders of granite, greenstone, grit, etc.), the Middle drift of sands and gravels, and the Great Upper B. clay. Arctic shells occur in some places. In Scotland, the Till, a dark clay with boulders of old hard rocks, is the chief member.

Boulders, Erratio blocks. (Geol.) Large angular or subangular masses of rock, often striated, which have been carried by ice to great distances from the parent rocks.

Boule. [Fr.] Inlaid work in wood, gilt-metal, or tortoiseshell ; so called from a cabinet-maker or ébeniste of the time of Louis XIV., whose name has been corrupted into Buhl.

Boulevard. [Fr., O.Fr. boulevart, from Ger. boll-werk, a fortification.] Formerly a broad rampart, but now any open promenade in a town.

Bouleversement. [Fr.] An upsetting, overturning of one's plans; bouleverser, to make to turn [L. versare] like a ball [bulla].

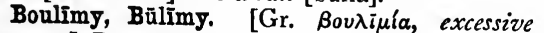
hunger.] Ravenous insatiable appetite; a disease, lit. ox-hunger [Bov̂s, an ox] ; so bul-rush, ox-daisy, horse-chestnut, horse-laugh, etc., = on a large scale. (Bucephalus.)

Boulogne sore-throat. Original name some twenty-five years ago for diphtheria $(q . v$.$) .$

Bounty Board. The trustees, governors, of Queen Anne's Bounty. (Queen Anne's Bounty.) Bounty money. Gratuity given to soldiers after their enlistment.

Bouquotin. [Fr.] The ibex (q.z\%). [(?) Dim. of bouc, buck; or (?) corr. of bouc-estain, the Ger. stein-bok.] jest.

Bourd. [Fr. bourde, a falsehood, sham.] A

Bourdon. [Fr.] 1. A droning bass sound; a burden or drone accompaniment, as in a bagpipe. 2. A stop on an organ, or imitation of it on a harmonium.
Bourgeois. 1. [Fr.] Properly, any member of a borough or burg, i.e. a fortified town [Gr. $\pi$ úpros, a lofty place, or stronghold]; hence akin probably to the Teut. berg, $a$ hill. (Bourgeoisie.) 2. (Probably from the inventor.) A kind of type, as-

\section{London.}

Bourgeoisie. [Fr.] The class of citizens including the merchants, manufacturers, and master tradesmen.

Bourgeon. [Fr. subst. bourgeon, from O.H.G. burjam, to lift, push.] (Bot.) To sprout, put forth buds and leaves.

Bourn, i.q. Burn. A stream, rivulet. [A.S. byrna ; $c f$. Ger. brunnen, a well, spring.]

Bourne. [Fr. borne.] Limit, boundary.

Bournouse. [Ar.] 1. A large woollen mantle with hood, N. African. 2. An adaptation of it worn in France and England, after the conquest of Algeria.

Bourrée. [Fr.] A jig, in common time; often employed formerly as one of the movements of a sonata.

Bourse. [Fr.] $A$ purse, and so, Exchange. [L. byrsa, Gr. $\beta \dot{v} \rho \sigma \alpha$, a hide.]

Bouse. (Naut.) To haul up with pulleys. $B$. up the jib, to tipple.

Bov̂s é $\pi i \quad \gamma \lambda \omega \sigma \sigma \eta$. (Bos in lingua.)

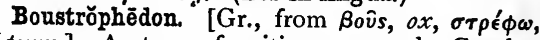
I turn.] A stage of writing among the Greeks, in which the words were written alternately from right to left, and from left to right, after the fashion of ploughing. This stage was intermediate between the Semitic form, which went only from right to left, and the European form, which goes only from left to right.

Bout. A turning, winding, one of several similar turns; $c f$. bow, bough, and obsolete bought, viz. a bending, twisting.

Boutade. [Fr.] A whim, freak ; from a sense of attacking, pushing [bouter, to push].

Boutique. [Fr.] A shop; corr. formed from

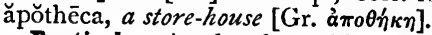

Boutisale. A sale where things go for as little as in the sale of booty.

Bouts-rimés. [Fr.] A social amusement; rimed endings are given, and verses constructed by each person present.

Bovate. (Carucate.)

Bovey-coal. (B., in Devon.) A variety of lignite (q.v.), of the Tertiary age.

Bŏvĭdæ. [L. bǒves, oxen.] Hollow-horned Ruminants. A fam. of R., comprising sheep. goats, antelopes, oxen, and buffaloes. Absent from Madagascar and adjacent islands, Australia, New Zealand, and Polynesia, Central and S. America, and adjacent islands. Ord. Ungŭlāta.

Bow bells. The bells of Bow Church, in London, mentioned in the legend of Whittington as cheering him with the chime, "Turn again, Whittington, Lord Mayor of London." Those born within the sound of Bow bells are called Cockneys (q.v.).

Bow china. That made at the earliest (1730) English porcelain manufactory; having various marks-anchor, dagger, arrow, bow and arrow moulds, etc., transferred to Derby about 1776 . 
Bow-compass pen. The instrument or pen used in mechanical drawing, with a ruler or straight edge for inking-in straight lines, is a Bow-pen; when one leg of a compass is replaced by a bow-pen we have a Bow-compass, which is used for inking-in circles. The bowcompass is often called simply a Bow, and the bow-pen simply a Drawing-pen.

Bowdlerism. (From Bowdler's family edition of Shakespeare.) Literary prudery.

Bower. [Ger. bauer, knave.] The best card in the game of euchre.

\section{Bower anchors. (Anchors.)}

Bowers. [A.S. búr.] In the house of an Old English noble, separate sleeping-chambers for the ladies, built apart from the great wooden hall, in the berths of which the men slept. (Tun.) In Scotland, a bouroch is a shepherd'shut. $(C f$. Byre.)

Bowie-knife. [Amer.] A large clasp-knife, called after Colonel Bowie, a Western trapper.

Bowline. (Naut.) The rope by which the weather edge of a squaresail is kept taut forward, when sailing on a wind.

Bowling, Tom. A British sailor in Smollett's Roderick Random, and in a popular song.

Bow of a ship. (Naut.) 'The part towards the stem, from where the planks arch inwards. Bold $B$. a wide, Lean $B$. a narrow, one. On the port $B$. or Starboard $B$., within an angle of forty-five degrees, contained by the line of the ship's course and a line drawn from the stem forward to the left or right respectively.

Bowsprit, sometimes written Boltsprit. (Naut.) A large spar extending over the bows. Beyond it are the jibboom and flying-jibboom.

Bowtell, Boutell, Bottle, Boltell (? like a bolt). An old term for a round moulding, or bead; also for the small shafts of clustered pillars, jambs, mullions, etc.; the Eng. term for the tŏrus and astrăgal of classical architecture.Parker's Glossary of Architecture.

Bowyer. One who uses a bow; formerly, also, a maker of bows.

Box-hauling. (Naut.) A method of turning a vessel in a small space by putting her helm a-lee, bracing the head yards aback, squaring the after yards, taking in the mizzen or spanker, and then, as she comes to the wind, hauling the sheets of the headsails to windward. As she gathers stern-way, the helm is shifted and sails are trimmed.

Box the compass, To. (Naut.) To repeat its thirty-two points, backwards and forwards, and to answer any question about them.

Boyard, Boyar. General name for Slavonic fief-holders by tenure of military service.

Boyau. [Fr., lit. an intestine; O.Fr. boyel, L. bōtellus, a sausage.] (Mil.) Trench by which the besiegers approach under cover in a zigzag direction towards a fortress.

Boy Bishop, The. 1. St. Nicholas, Bishop of Myra, in Lycia, famed for early piety; patron saint of boys and scholars. 2. One of the choristers, chosen yearly, in mediæval times, to act the part of a bishop in mimic ceremonies; buried in bishop's robes if he died $\mathrm{a}$ B. B. The tomb of a B. B. may be seen in Salisbury Cathedral.

Boycotting. An excommunication, ordering tradesmen to refuse supplies to a purchaser. (From an Irish landlord, named Boycott, who was so treated in 5880 .)

Boyle Controversy. Respecting the so-called Epistles of Phălăris; their genuineness maintained, I695, by Hon. C. Boyle, afterwards Earl of Orrery, with the help of Atterbury; disproved by Bentley. Dean Swift, who took the wrong side, satirized the B. C., in his Battle of the Books.

Boyle Lectures. Founded by Hon. R. Boyle, in defence of Christianity ; eight delivered yearly since 1692 .

Boyle's law. (Hon. R. Boyle, I627-1692.) The fact that the volume of a given quantity of gas varies inversely as the pressure per square inch that it exerts, provided the temperature continues constant ; thus, if the volume is halved, the pressure per square inch is doubled.

Brabantine. Relating to Brabant; old name of the middle of Belgium, between the rivers Scheld and Meuse.

Braccate. [L. braccæ, breeches.] (Ornith.) Having feathers descending from the tibia and concealing the feet.

Brace. [Fr. bras, an arm, L. brāchium.] A slanting piece in a trussed partition or roof, designed to give stiffness to the joints; a brace is commonly in a state of compression.

Brace, To (Naut.), yards, bring them to either side with the Braces, i.e. ropes, one at each end of a yard, either fastened to it or rove through blocks. To $B$. sharp, to bring the yards as nearly as may be in a line with the keel, and still hold a wind. To $B . a-b o x$, to $B$. them square.

Brach. [Fr. braque, from Ger. braccho.] A kind of hunting dog.

Brachely̆trous, Brachyĕly̆trous. [Gr. Bpăxús,

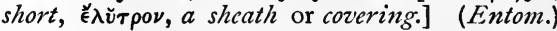
Insects whose elytra do not cover more than one-third of the abdomen, as Devil's coachhorse, Stăphy̆lĭnus ǒlens.

Brachiate branches. [L. brächium, an arm.] (Bot.) Standing opposite to each other, nearly at right angles to the stem from which they proceed.

Brāchiŏpŏda, Brachiopods. (Zool.) Bivalve molluscoids, with dorsal and ventral valves; as Těrebrātulæ, or lampshells [L. brāchium, an

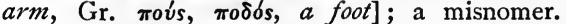
Called also Pallio-branchs, i.e. mantle-gills [L. pallǐum, a mantle, Gr. $\beta \rho \alpha \dot{\gamma} \chi\llcorner\alpha$, gills], the mantle serving for gills.

\section{Brachistochrone. (Curve.)}

Brachycatalectic. (Catalectic.)

Brachycephălic. [Gr. Bpăxús, short, and $\kappa \epsilon \phi \check{a} \lambda \dot{\eta}$, head.] A term applied by some to skulls whose transverse diameter is more than $\frac{8}{10}$ of their longitudinal diameter. Such are generally the skulls of the Turanian nations. Skulls which exhibit a less proportion between the two diameters are known as Dolichocephalic [Gr. $\delta \circ \lambda ı \chi \delta ́ s, l o n g]$. 


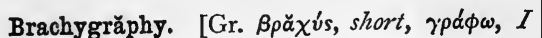
write.] Shorthand, stenography.

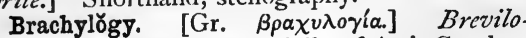
quentia, in a writer-especially of Attic Greek conciseness, pregnancy of expression ; as, $\dot{\epsilon} \tau \epsilon-$

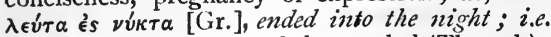
lasted into the night, and then ended (Thucyd.).

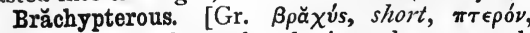
wing.] Birds whose closed wings do not reach the base of the tail ; as auks, penguins, etc.

Bracklesham beds. (B., in Hants.) A highly fossiliferous member of the nummulitic series, and equivalent to the Middle Bagshot sands.

Bract. [L. bractea, thin plate of metal.] The leaf or leaflet at the base of the flower-stalk; dim. Bracteole [bracteǒla].

Brad-, Broad-. Part of Saxon names, as in Brad-ford; i.e. broad ford.

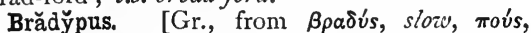
foot.] Gen. of sloth, arboreal mammal, about two feet long. Trop. America. Fam. Brădy̆pŏdı̆dæ, ord. Ėdentāta.

Braggadocio. In Spenser's Faëry Quecn, the braggart and impostor.

Brahmanas. (Veda.)

Brahmans, or Brahmins. The first or highest of the four castes of Hindus. The priesthood is confined to this caste, which is said to have proceeded from the mouth of Brahm, the seat of Wisdom. (Caste.)

Braiard. A promising growth of seed, etc., [A Scot. word.]

Braid. Generally, as by Dr. Johnson, understood as deceitful, fickle, with the notion of entangling ( $c f$. brede, to deccive, obsolete); but by Wedgwood (s.v. "Bray") = resembling; "Frenchmen so braid," in Diana's speech in All's Well that Ends Well, being = thus mannered.

Braidism (i.e. so called after Mr. Braid). Hypnotism (q.v.).

Braille. [Fr.] (Invented by Louis Braille, a blind Frenchman.) A method of writing words or music for the blind, by means of raised dots only, the number and position of which denote the required character. Simple, inexpensive; largely used on the Continent.

Brails. [O.E. brayle; O.Fr. braiel ; Ir. brog, a girdle, breeches, breeks.] (Naut.) Ropes working in pulleys, and fastened to the outer leech of a sail, by which it can be trussed up close to the mast and gaff, or to the stay.

Brake, All to-. Judges ix. To-brake is perf. of to-breken; all or al being an adv. = utterly; and "all to-brake his skull "is, therefore, broke it utterly in pieces. To is a particle common in O.E., meaning asunder; it is sometimes intensive, as to-bite, to-cleave, etc. (see Morris's English Accidence, p. 226).

Brake, Break [akin to L. frango, frac, -tum,

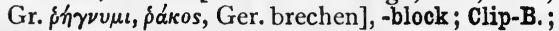
Friction-B.; Slipper-B. An instrument for arresting or regulating the motion of a body, as a train; the Brake-B. is the piece pressed (by levers, atmospheric pressure, etc.) against the circumference of the wheel of a railway carriage; a Slipper-B. is pressed by levers against the top of the rails, so as to take some of the weight off the wheels, and cause a considerable friction; in the Clip-B. the two sides of the rail are gripped. The Friction- $B$. is a band or wrought iron surrounding, without touching, a wheel (as in a crane, etc.), until by pressure on the end of a lever it is made to clasp the wheel with a great and easily regulated friction. All these brakes act by friction. There are also Atmospheric Brakes, Continuous B., Pump-B., Fan-B., etc.

Brake, Common bracken. (Bot.) Ptěris ăquillina; the most abundant British spec. of the ord. Fullices, Ferns; covering large spaces, sometimes in parks, heaths, hillsides.

Bramah's press. (Hydraulic press.)

Bran. Fingal's dog.

Brancard. A horse litter; originally a Fr. word, a brancard being a branche stripped of its leaves, a stick, a shaft ; then a litter macle of crossed sticks. - Brachet, Etym. Dict.

Brancher. [Fr. branchier, probably from branche, in the sense of a branch (Littré); It. branca, talon, brancare, to gripe.] A young hawk that has begun to perch.

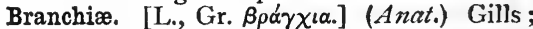
an apparatus for breathing in amphibia and fishes, containing cartilaginous leaflets, through which the blood, circulating, is purified by the oxygen contained in water.

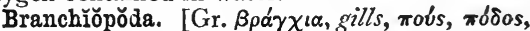
the foot.] (Entom.) Div. of small Crustaceans, breathing by their feet, as Daphniă pūlex, branch horned water-flea, common in ponds. Sub-class Entŏmostrăca.

Brandenburg Confession. A document drawn up to end the disputes occasioned by the Confession of Augsburg. (Confession of Faith.)

Brangle. [Fr. branler, to move, shake (?), or obrandiller, to brandish (?) or be-urangle (?), or perhaps a modification of wrangle.] To dispute, menace, quarrel.

Brank. Buckwheat. [Brācē or brancē, a Gallic term for some kind of white corn.]

Brank, Branks, Scold's bridle. A hoop of iron, with hinges at the sides, a plate of metal projecting inwards, and a padlock at the back; passing over the head and gagging the tongue. Formerly a punishment for scolding women, and sometimes for immorality. [Cf. Brank in Scotland, and Teut. pranghe, $=a$ bridle.] Hence Branks, in Scotland = mumps.

Brankursine. [L.L. branca ursīna, bear's claw, Ger. bären klau.] (Acanthus.)

Bransle. [Fr.] Corr. into Brawl; a countrydance of the time of Queen Elizabeth.

Brash. (Pyrosis.)

Brash, Shivers, Rubbles. (Geol.) Masses, layers of angular fragments of rock, often derived from an underlying rock.

Brass. 1. [A.S. bræs.] An alloy of copper and zinc ; misused sometimes in old writings for Bronze, as in Exod. xxxviii. 2, and elsewhere ; sometimes for Copper, as in Job xxviii. 2, and elsewhere. 2. A brass sleeve, or Bush.

Brassage. A deduction, in former times, from the value of the coin, for the expense of coinage ; 
said to be from bras, an arm, as if brāchiōrum, labour.

Brassart, Brasset. [Fr. brassard, from bras, an arm.] The piece of armour which protected the arm above the elbow.

Brasses, Monumental. Slabs of brass, bearing in outline the effigies of the dead, or some other device. The earliest known is that of Sir John d'Abernon, who died 1277, and was buried at Stoke d'Abernon, in Surrey.

\section{Brassset. (Brassart.)}

Brassǐca. [L., cabbage.] (Bot.) A remarkable group of plants, ord. Cruciferæ, including common cabbage; borecole, turnip, rape, etc., and probably the mustards. Brassícācea is, with some, another name for Crŭcǐfěræ.

Brattice, Bretise. 1. Corr. of bretage, any boarded defence, as a testūdo, parapet [Fr. bretesche]; now, 2 , boarding round machinery or in a mine ; 3 , any partition between an upcast and a down-cast shaft. [Scand. bred, Ger. brett, D. berd, a plank or board (Wedgwood).]

Brattishong, Brandishing, Bretise, Bretisement. A crest, battlement, or other parapet. [Fr. bretéche.] (Brattice.)

Bravest of the Brave. Marshal Ney's title with the French army, after the defeat of the allied Russians and Prussians at Friedland, June $14,1807$.

Bravo. Formerly in Italy, especially in Venice; a hired assassin, who undertook any danger for money. Plu., Bravi.

Bravüra. [It., dash, brilliancy.] ' (Music.) An air containing difficult passages, with a large proportion of notes, requiring volubility, accuracy, and spirit in the execution.

Brawling. [Fr. brouiller, to embroil; or (?) Fr. bransle, branle, from branler, to shake.]. In Church Law, the molestation of a clergyman or preacher during any ministration in any place licensed for service.

Braxy, Braxes, Bracks. In sheep, generally a plethora or a disease of the intestines, caused probably by food too nitrogenous; lasting from one to six hours; marked by staring look, laboured breathing, and convulsions. But the term is used vaguely.

Bray, Scot. Brae; (?) cf. brow. Raised ground, bank, overlooking ground used in fortitication.

Bray, Vicar of. Lived, according to tradition, from Henry VIII. to Elizabeth; according to the song, from Charles II. to George I. ; trimming to suit Court religion and retain his benefice.

Brazen Age. (Ages, The four.)

Braziline, Breziline. The colouring matter in Brazil wood.

Brazil nuts. The seeds, in a large woody shell, of the magnificent Bertholletia excelsa (from Berthollet, chemist) of the Orinoco and N. Brazil ; 100 to I 20 feet high.

Brazil wood. Dark red and yellowish brown, valuable in dyeing, the produce of Cæsalpinia echināta and other spec. S. America and W. Indies. Brazil is said to be named from B. W., of which the old native name was Braxilis (see Chambers's Encyclopadia).
Brazing. Soldering with an alloy of brass and zinc.

Bre-. [Celt., promontory.] Part of names, as in Bre-don.

Breach of close. (Leg.) Wrongful entry of or trespass on another's land, whether enclosed or not.

Breadalbane. District of Scotland in Tudor period, mostly included in W. Perthshire.

Bread-fruit. The fruit of Artocarpus incisa

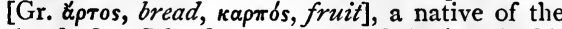
South Sea Islands and parts of Indian Archipelago : about the size of a child's head; when baked, like the crumb of a wheaten loaf.

Bread-root of N. America, or prairie apple,

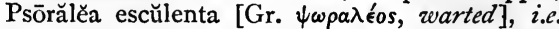
having tubercles. A papilionaceous plant, grown along the Missouri, with tuberous carrot-like farinaceous roots.

Breadth. That treatment of the subject painted which shows at once the leading idea, without over-finish of details.

Break. A large four-wheeled carriage, with a straight body, seats for four, with calash top, and seats for driver and footmen.

Break bulk, To. (Naut.) To open the hold and begin to unlade the ship.

Breakers. (Naut.) 1. Waves breaking over reefs, etc., either at or immediately below the surface of the water. 2. Small casks used on board ship.

Break-ground. (Mil.) The opening of the first trench of a siege.

Breaking the line. (Naut.) Advancing in column, and cutting the enemy's line in two; then enveloping one half with the whole fleet; e.g. Rodney's defeat of the French off Dominica, April, 1782.

Break-water. A structure such as a mound, a wall, etc., placed near the mouth of a harbour, to break the force of the waves coming in.

Bream, To. (Naut.) To clean a ship's bottom by fire.

Breast. [A Teut. and Scand. word.] The curved trough extending from the sluice to the tail-race, within which a breast-wheel turns, and which prevents the escape of water from the buckets until they are over the tail-race.

Breastplate of Jewish high priest ; described Exod. xxviii. 15, et seq.

Breast-plough. A kind of plough, driven by the breast, for cutting turf.

\section{Breast-summer. (Bressumer.)}

Breast-wheel. (Water-wheel.)

Breastwork. Earthen parapet sufficiently low to admit of being fired over from the level of the adjacent ground.

Breath figure, Roric figure. A likeness of itself, impressed by a coin, etc., on a plate with which it has been left nearly or quite in contact. An electrical B. F. is formed by passing an electric current from the coin through the plate. By breathing on the plate these figures are rendered visible. [L. ros, rōr-em, dew.]

Breccia. [It.] (Geol.) Angular breakings of pre-existing rock, not far distant, cemented into a new rock; rounded pebbles form Conglomerate. 
Breda, Declaration of. (Hist.) A document sent by Charles II. from Breda, I660, promising that no man shall be disquieted for differences of opinion in matters of religion which do not disturb the peace of the kingdom.

Brede. [A.S. bredan.] Another form of braid, to knit together, weave.

Breeches Bible, or Geneva B., 1557. Translated there by English divines, in Queen Mary's reign. So called from the word used in the translation of Gen. iii. 7, "made themselves breeches." (Bible, English.)

Breeching-rope for gun. (Naut.) A rope, one end fastened to a vessel's side, the other to the breech of a gun; long enough to allow the gun to be run in and loaded, and to stop excessive recoil.

Breech-loader. Firearm, with its barrel open at the stock, through which aperture the charge can be inserted.

Breem. [A.S. bremman, to be violent; (?) of. Gr. $\beta \rho \epsilon ́ f \omega$, L. frĕmo.] Furious, excessive, fierce.

Breeze-fly. [Onomatop.; $c f$. Ger. bremse, O.E. brimse, briose.] (Entom.) Gad-fy, Cleg, Dipterous insect, with blood-sucking females. Tăbānus bǒvinus [L. bǒvīnus, belonging to oxen], fam. Tăbānı̆dæ.

Brĕgma. [Gr., from $\beta \rho \epsilon ́ \chi \omega, I$ moisten.] The top of the head, because in infancy this part is longest in hardening.

Brehon laws. Ancient Irish laws; so called from a word signifying judges; some being as old, perhaps, as the first centuries of the Christian era. (Pale.)

Breme. To bring forth young abundantly; to teem.

Brentford, The two Kings of, = once rivals, now reconciled; like the two kings in the Rehearsal, a farce by George Villiers, Duke of Buckingham.

Bressumer, Breast-summer. [Fr. sommier, a pack-saddle, a lintel.] (Arch.) A beam or summer, like a lintel, but supporting the whole front, or nearly so, of a wall; e.g. over a shop-front.

Bretage, Bretise. (Brattice.)

Bretexed. Embattled. (Brattice.)

Brethren, Elder and Younger. House.)

Bretigny, Peace of. A treaty between France and England, I360, by which Edward III. renounced his pretensions to the crown of France. (Balic law.)

Bretwalda. In O.Eng. Hist., the title of an office which assured a certain supremacy to one of the Anglo-Saxon princes. According to Beda, the first who held this office was Ceawlin, the grandson of Cerdic.

Breve. [L. brěvis, short, as compared with long (q.v.) and with maxim (q.v.).] (Music.) The average whole note of the sixteenth century, as the semibreve is of our own time. "It is certain that a sound lasting four beats may be expressed and has been expressed by six different formsthe maxim, the long, the breve, the semibreve, the minim, the crotchet" (Hullah, quoted by Stainer and Barrett).
Brevet. [Fr., from L.L. brevetum, L. brěvis, short.] (Mil.) An honorary rank conferred on officers in the army above that which they hold in their own corps.

Breveté. [Fr.] A patentee, from brevet, $a$ patent.

Breviärum of Alaric. A collection of laws, Roman and Teutonic, for the Goths in Italy.

Breviary. [L. brěviārĭum.] An abstract of various books before used; a daily office of prayer, praise, and instruction in the Roman Church, made up of : (I) Vespers, at sunset. (2) Compline [complētōrium], about 9 p.m., a completing of the day's devotion. (3) Nocturns, or Matins, at midnight. (4) Lauds, or Matin Lauds, before break of day. (5) Prime, at sunrise, or at six o'clock. $(6,7,8)$ Tierce, Sext, None, every third hour afterwards. Recited daily, by all ecclesiastical persons, in public or private, at some time; at the canonical hours by many religious orders.

Breviary of Quignon. A breviary, published at Rome by Cardinal Quignonex, in 1536 . It is said to have been used in the compilation of the Book of Common Prayer of the Church of England.

Breviate. [L. breviātum, from brěvio, I abbreviate.] An abstract summary abridgment.

Brevier. A kind of type, as-

Inclusive.

\section{Brěvilŏquentia. (Brachylogy.)}

Brĕvipennate. [L. brěves pennæ, short wings.] (Ornith.) 1. Swimming birds whose wings do not reach to the tip of the tail. 2. With Cuvier, short-winged birds, as the ostrich.

Brĕvis esse lăbōro, obscūrus fīo. [L.] I try to be concise, and 1 become obscure (Horace).

Brewer of Ghent. Jacob van Artevelde, popular leader in Flanders, who declared for Edward III. ; murdered in a tumult at Ghent, 1345 .

Brewis. 1. Pieces of bread, soaked in gravy. 2. Broth, pottage ; íom A.S. bríw, brezvis, A.S. breowan, to brew; or (?) $c$. Welsh briw, broken; and Eng. bribe, which originally, both in Fr. and in E.ng., meant $a$ sop, a hunch of bread.

Breziline. (Braziline.)

Brezonic, i.q. Armoric. Language of Brittany.

Briarean. Like the giant Briăreōs, Briareus, with his hundred arms.

Bric-à-brao. [Fr.] Odds and ends; old stores, articles of curiosity ; a word formed from de bric et de broc, one way or another (see Littré, s.v. "Broc").

Brickle. Vessels and graven images (Wisd. xv. 13), easy to break, brittle, as the word is now written.

Brick-nogging. (Arch.) Brickwork carried up and filled in between timber framing.

Brick tea. Tea made into cakes, with fat, etc. ; used in Thibet.

Bride of the Sea. Venice, whose doges every year, on Ascension Day, were married to the Adriatic, throwing a ring into the sea; on the 
first occasion, as a privilege, granted by Pope Alexander III., II77, when the League of Lombardy had defeated the Emperor Frederic Barbarossa.

Bridewell. A house of correction. B., a palace, built $\mathbf{1 5 2 2}$, by Henry VIII., to receive Charles V. ; given, I 533 , to the city as a house of correction. Near the well of St. Bridget, or Bride, between Fleet Street and the Thames.

lar.)

Bridge. (Girder; Skew ; Suspension; Tubu-

Bridge of Sighs. (Hist.) The Venetian Porta de Sospiri, leading from the lower part of the ducal palace to a prison, the door of which is now walled up.

Bridgewater Treatises, "On the Power, Wisdom, and Goodness of God, as manifested in Creation," by eight different authors ; for which $£ 8000$ was left by Earl of B., I829.

Bridlegoose, Judge. In Rabelais's Pantagruel,

Juge Bridoye ; he decides causes by dice.

Bridle-port. (Naut.) A port in the bows for taking in Bridles, i.e. the upper part of moorings.

Briefs [L. brěvě, a document, epistle] and Bulls [bulla, $a$ boss, the seal of lead]. 1. Pontifical letters : (I) less ample and solemn, more like letters to individuals, or to bodies; (2) solemn decrees of the pope, as head of the Roman Catholic Church. They differ in many ways (see Hook's Church Dictionary; English Cyclopadia, i. 365). 2. In Prayer-book, Church Briefs, or Queen's Letters, letters patent, authorizing collections for charitable purposes : now discontinued.

Brig [an abbrev. of brigantine] is a twomasted, square-rigged vessel. B. schooner (Hermaphrodite).

Brigade [Fr. brigade, from It. brigāta.] 1 Body of troops, composed of from two to four battalions of infantry, with a relative proportion of cavalry and artillery. 2. In the artillery branch alone, $B$. corresponds with a battalion of infantry. 3. The officer who commands a B. in the English army is called a Brigadier. 4. In the French army, a Brigadier means a corporal.

\section{Brigadier. (Brigade.)}

Brigandine. Jer. xlvi. 4 and li. 3 ; coat of mail, equipment of a brigand; formerly = a light-armed soldier. [It. and Med.L. briga, strife.]

Brigantine. [It. brigantine, akin to brigand, a piratical vessel.] A vessel rigged as a brig, except the mainsail, which is like a schooner's.

Bright's disease. A name for several forms of disease of the kidneys; with urine generally albuminous, and other important signs of structural change. First described by Dr. Bright, of Guy's Hospital.

Brigue. To contest, canvass. (Brigandine.)

Brilliant diamond. So called from the effect of the facets, 56-64 generally, with upper octagonal face, into which it is cut ; only a good stone being thus treated. Rose $D$., broad in proportion to their depth, have a flat base, with two rows of triangular facets, and six upper- most, uniting in a point. Stones still thinner are cut as Table $D$.

Brills. [(?) $C f$. Ger. brille, spectacles.] The hair on the eyelids of a horse.-Johnson.

Bring-to, To. (Naut.) To bend or fasten a sail to a yard. B.-to a ship, to stop her way by letting the sails counteract each other. B.-to an anchor, to let go the anchor. To bring $u p$, to come to an anchor.

Bring up with a round turn, To. (Naut.) 1. To stop a running rope by taking a turn round a cleat, etc. 2. To do a thing effectually, but suddenly. 3. To bring a man to his senses by a rating.

Brioche. [Fr., connected with broyer, to crush (Littré).] 1. A kind of cake. 2. A circular sofa-cushion.

Brisket. The breast-piece of meat ; probably the same word as breast [A.S. brest, or = breast-steak].

Bristol board. A thick, stiff paper, for drawing ; first made at $B$.

Bristol Boy. The poet Thomas Chatterton, who died at eighteen, A.D. I770.

Bristol diamonds. Bright crystals of colourless quartz (q.v.), found near B. and elsewhere ; called also Cornish D., Bagshot D., Irish D., Diamants d'Alençon, etc.

Bristol riots. The most prominent of the riots which have occurred at Bristol took place in 1831 , during the agitation for reform in Parliament. The city was set on fire, and many houses were burnt.

Brisure. [Fr. briser, to break.] (Fortif.) Break in the rampart of a fortress, where the enceinte is withdrawn to form a concave flank.

Britannia metal averages, of tin $85 \frac{1}{2}$ parts, antimony $10 \frac{1}{2}$, zinc 3 , copper $\mathrm{I}$.

British gum. A brown, soluble substance, formed by heating dry starch, and used for stiffening calicoes, etc. It is also called Dextrine, from its power of rotating a polarized ray of light to the right [L. dextra].

British seas. (Quatuor Maria.)

British ship. One owned by a British subject, registered, and flying the flag.

Britomart. The impersonation of chastity, in Faëry Queen, bk. iii.

Britzska. [Pol. bryczka, dim. of bryka, freight-waggon.] A long, four-wheeled travelling carriage, with a movable hood.

Briza. (Bot.) A gen. of grasses, belonging to the tribe Festūcěæ; amongst them are the quaking grasses.

Broach. [Fr. broche, a spit, L.L. brocca.] The morse or clasp of a cope is sometimes so called.

Broach spires. Spires, the junction of which with the tower is not marked by any parapet or other division.

Broach-to, To. Unintentionally to let a ship come head to wind.

Broad arrow, $\uparrow$ [origin quite uncertain], de notes Crown property; is used also to mark Ordnance Survey stations, and property under arrest by Customs' officers; and, in other ways, 
by Government officials. It is illegal -9 and io William III., I698 - to use, for private ownership, the B. A. Said by some to have been suggested by the three nails of the cross.

Broad Bottom Administration. That of $\mathrm{H}$. Pelham, I744; a grand coalition of all parties of weight, in which nine dukes were placed.

Broadcloth. Fine woollen cloth, over twentynine inches broad.

Broad gauge. (Gauge of railways.)

Broad pennant. (Flag.)

Broadpiece. The name of any coin wider than a guinea.

Broadside. 1. Any large page printed on one side of a sheet of paper; and, strictly; not divided into columns. 2. (Naut.) The side of a ship above the water. The simultaneous discharge of all the guns from the whole side.

Broadsword. Straight, double-edged sword, with a broad blade.

Brobdingnagian. Gigantic. (Gulliver's Travels.)

Brocade. [Fr. brocher, to prick, to figure.]

A thick silk stuff, with a raised pattern.

Brocage, Brokage, Brokerage. The business of a broker.

Brocard. In Fr. a taunt, jeer; in Eng. a principle, maxim [Brocard, Bishop of Worms, author of Regule Eccles., eleventh century (Littré)].

Brocatel. [Fr. brocatelle.] A kind of imitation brocade made of cotton.

Brochure. [Fr. brocher, to stitch.] A pamphlet, a short treatise.

Brock. [A.S. broc.] The badger, Mělēs taxus, gen. Mĕlēnīnæ, fam. Mustēlĭdæ, ord. Carnĭvŏra.

Brocken spectre, Brockengespenst. The shadow of objects, magnified, thrown at sunset upon the mists of the Blocksberg, the highest summit of the Harz Mountains.

Brocket. [Fr. brocart, id., from broche spike.] (Deer, stages of growth of.) A small spec. of deer (Subulo), with horns consisting of a single dag. S. America.

Brog. A kind of bradawl.

Brogue, Brog. 1. A rude coarse shoe of the early Irish and Scottish Highlanders. 2. By meton. $=$ the pronunciation of the wearer

Brokage, i.q. Brocage.

Broken-backed. (Naut.) (Arching.)

Broken wind. In a horse, a rupture, in curable, of some of the air-cells ; from inflammation, too much chaff, exertion just after feeding, etc. ; expiration has become a double effort, inspiration being still a single one.

Brokerage. Commission charged to investors by brokers, for ordinary shares and stocks.

Bromby. [(?) Name of person or place from which its progenitors escaped.] The wild horse of Australia.

Brome, Brŏmns. [Gr. Bpómos, a kind of oats.] A gen. of grasses, belonging to the tribe Festuceæ. About eight spec. are natives of Britain.

Bromio acid. (Chem.) An acid composed of bromic and oxygen, the salts of which are called Bromates. (Bromine.)
Bromine. [Gr. $\beta \rho \hat{\omega} \mu o s$, stink.] A liquid, reddish-brown element, found in sea-water.

Bronchi. [Gr. Bpórxos, windpipe.] (Anat.) The bifurcations of the trachea, or windpipe, and their division into smaller tubes; ramifying into the lungs. Bronchitis, inflammation of the bronchial tubes.

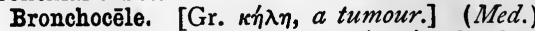
Goître, Derbyshire neck; a swelling in the fore part of the neck, being a morbid enlargement of the thyroid gland.

Bronchotŏmy. The making an opening into the air-passages to prevent suffocation. (Bronchi.)

Bronze. An alloy of copper and tin, i.q. Gun-metal, Bell-metal, etc., with sometimes a little zinc or lead; i.q. Gr. $\chi^{\alpha \lambda \kappa} \delta$ śs and L. æs ; used from very remote antiquity.

Bronze, Age of. (Prehistoric archæology.)

Brooch. A painting all in one colour, as a sepia painting.

Brooklime. (Bot.) Plant common in ditches, with opposite leaves and small blue flowers. Beccabunga veronica, ord. Scrophulariaceæ.

Broom at masthead. Shows that the vessel is for sale. B., To. (Bream.)

Broom-rape, Orŏbanche. [Gr. o’ $\rho \circ \beta a ́ \gamma \chi \eta$, from ǿoßos, bitter vetch, á $\gamma \chi \omega, I$ strangle.] (Bot.) Parasitical gen. of plants, ord. Orobancheæ.

Brose. Boiling broth, or water, poured on oatmeal, pease-meal, stirred into a lumpy consistency. (Brewis.)

-brough. (-bury.)

Brown-coal. (Lignite.)

Brownie. In Scotland, a character like Robin Goodfellow and the Ger. kobold; a good. humoured goblin in farmhouses, who drudges for the family when they are in bed. (Bogy.)

Browning. The process of colouring gun barrels, etc., brown, to keep off rust.

Brownists. Certain Puritans of the sixteenth century, follower of Robert Browne, who denounced all Church government, and the use of all forms in prayer, etc. (Independents.)

Brown spar. (Geol.) Certain crystallized varieties of dolomite ; reddish, brownish ; owing to oxide of iron.

Bruin. [D.] Quasi-personal name for the bear [brun, the brown one], in the mediæval popular Ger. epic, Reinecke the Fox.

Brumaire. [Fr., foggy, misty, L. brüma, winter.] The second month in the calendar of the first French Republic; October 22-November 20 .

Brumal. [L. brumālis.] Belonging to winter or winter solstice [brūma].

Brummagem. [Corr. of Birmingham, "Bermingeham " in Domesday Book.] A sham article.

Brunonian theory. That of J. Brown, M.D., Edinburgh, I733-I788, that life is sustained during health by external exciting agents in equilibrium; if these agents exhaust excitability too rapidly, asthenic diseases (q.v.) arise, requiring alcohol; if excitability accumulate, sthenic diseases [Gr. $\sigma \theta$ évos, strength] arise, requiring opiates.

Brunswick-green. Oxychloride of copper. 
Brush-wheel. Wheels working under inconsiderable forces, like toothed wheels, but in which sliding is prevented by bristles or buff leather on the circumferences.

Brusquerie. [Fr.] Abruptness, bluntness of manner.

Brussels spronts. A cultivated variety of cabbage, having the stem covered with little close heads.

Brutte. [Fr. brouter, to eat the shoots or brouts.] To browse.

Brūtum fulmen. [L.] A harmless thunderbolt, i.e. a great but ineffectual threat; the first meaning of L. brutus being unzvieldy, ponderous;

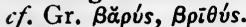

Bryolŏgy. [Gr. Bpv̌ov, tree-moss.] (Bot.) The science of mosses.

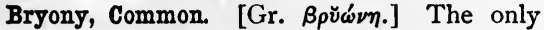
British spec., Dioica, of the gen. Bryonia, ord. Cŭcurbitācěæ; the root purgative, and used for bruises.

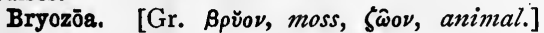
(Entom.) An ord. of compound polypes, which incrust foreign bodies like moss, as the Flustra, or sea-mat.

Bry̆um. [Gr. Bpứov.] A gen. of mosses ; abundant in Britain.

Būbălus. [L., which originally, like Gr.

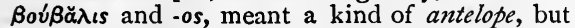
came to mean, i.q. ürus.] Buffalo. Gen. of hollow-horned ruminant, wild and domesticated. Africa and India (as the Arnaa, q.v.), and S. Europe. Sub-fam. Bǒvinæ, fam. Bŏvĭdæ, ord. Ungŭlāta. Not to be confounded with Bison.

Bubble, South Sea. (South Sea Company.)

Bubbles. Financial or commercial projects started to cheat investors.

Buccaneers. Associated pirates, mostly English and French, of the sixteenth and seventeenth centuries, in the Caribbean Sea, who attacked Spanish ships and settlements. The Caribbee boucan is a place for smoke-dried meat ; so $\mathrm{B} .=$ meat-preserving W.-Indian settlers. The French called themselves filibustier, i.e. freebooter.

Buccina famæ. [L.] The trumpet of fame.

Buccinator. [L., trumpeter.] Muscles in the substance of the cheek, the contractions of which force out the cheeks when distended with air.

Buccōnìn. [L. bucca, the puffed cheek; if there was the It. word buccone, it would mean the big puffed cheek.] (Ornith.) Puff-birds, brabers. Fam. of climbing and fly-catching small birds, like kingfishers, but dull-plumaged. Trop. America. Ord. Pīcārǐæ.

Bucentaur. [Gr. Boús, an ox, אévtavpos, $a$ centaur.] An imaginary monster, the name being chiefly known as that of the galley of the Venetian doges, in which, by the dropping of a ring into the water, they yearly espoused the sea in the name of the republic. (Bride of the Sea.)

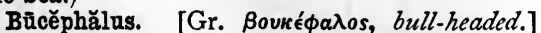
The horse which Alexander the Great broke in, fulfilling, it is said, the condition of the oracle necessary for gaining the Macedonian crown.

Buchan. District of Scotland from Saxon to
Tudor period, north part of Banffshire and Aberdeenshire.

Buchanites. Vicious fanatics in W. Scotland, A.D. I783, followers of Mrs. or Lucky Buchan, who gave herself out as the woman of Rev. xii. The last is said to have died in 1846 .

Buck. [Cf. Fr. bouc, Ger. bock.] The male of several animals connected with sport, as fallow deer and ferrets. Buck, To, to soak linen in a solution of wood ashes. [Gael. adj. bog, soft, moist; but see Wedgwood.]

Buck, Complete. (Deer, Stages of growth of.)

Bucket. The vessels on the circumferences of an overshot wheel which contain the water by whose descent the wheel is turned.

Buck-eye, A. 1. = belonging to Ohio, where the buck-eye, or Æsculus Ohiotensis, American horse-chestnut, is abundant (Webster). 2. In the horse, a too convex cornea, causing indistinctness of the image falling upon the retinna ; congenital.

Bucking. 1. [Ger. bochen, to beat.] Crushing ore by hammering it on a flat plate. 2. (Capriole.)

Buckle. [(?) Fr. boucle, the boss of a shield, or (?) A.S. bugan, to bend; $c f$. bough.] To bend, shrivel up, as scorched paper; or become hollow from pressure, as a weakened wall.

Buckler. [Fr. boucle, L. bücǔla, boss of $a$ shield.] Shield of stout leather, worn on the left arm and sometimes studded with metal bosses.

Buckra. With negroes, $=a$ white man; in the language of the Calabar coast, $a$ demon, a powerful and superior being.-Webster.

Buckram. [Fr. bougran.] A coarse linen cloth, stiffened with glue.

Buckwheat [Ger. buchweizen], i.e. Beech wheat, the seed being like beech-mast; a plant valuable as food for game, growing on very poor soil. Fägŏpȳrum escŭlentum, ord. Polygŏnaceæ.

Bucolics. [Gr. Bоvко入ıкós, pastoral.] Poems which were supposed to be the songs of herdsmen, as the Eclogues of Virgil.

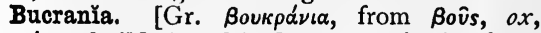
кpaviov, skull.] (Arch.) Ornaments in the shape of an ox's head, on the walls of buildings.

\section{Buddha. (Buddhism.)}

Buddhism. A religion which numbers a large majority of the whole human race as its adherents. The name Buddha (or the enlightened, from the same root with $L$. videre, and Eng. wit) was given to the traditional founder, Gautăma, whose system was publicly recognized by Asoka in the third century.B.C. Buddhism was expelled from India by the Brahmans, between A.D. 500 and 700. It teaches especially the necessity of separation from the world by prayer and contemplation, in order to exempt the soul after death from renewed imprisonment in matter, and to secure for it Nirvāna, i.e. absorption into the divine essence from which it sprang.

Budding. In Zool., i.q. gemmation (q.vo).

Buddle. [Ger. butteln, to shake.] A large trough for washing ore in.

Bude light. A very bright light made by 
supplying an argand gas-jet with oxygen (first used at Bude, in Cornwall).

Budge. [L. bulga, a leathern bag.] Lambskin fur.

\section{Budgerow. (Bazaras.)}

Budget. [Fr. bougette; and this from Gael. bouge, whence L. bulga, a leatinern bag.] 1. A portable bag; and so, 2, a stock store. 3. The yearly statement of the Chancellor of the Exchequer.

Buffa. [It., funny.] Comic; as aria buffa, opera buffa.

Buffalo chips. Dry dung used as fuel.

Buffer, Buffing apparatus. A plate or cushion projecting from the frame of a railway carriage. Buffers are placed in pairs at each end of the carriage, and are fastened by rods to a spring of flat steel plates or other material under the framework, to deaden the concussions caused when the velocity of part of the train is checked. The buffers, rods, and springs are sometimes called the Buffing apparatus or Buffing arrangement.

Buffet. [Fr.] Counter for refreshment.

Buffet a billow, To. (Naut.) To go against wind and tide.

Buffy coat. (Med.) On blood drawn in a diseased condition, a crust of greyish corpuscles, the red particles sinking.

Bug, Bugbear. A spectre or some other frightful appearance; $c f$. Welsh bwg. (Puck;

\section{Bogy.)}

Buggy. A name used in India for a light vehicle, with four wheels and one seat, drawn by one horse.

Bugle. [Lit. the horn of a bugle; L. būcŭla, a young cow.] Military trunipet without keys, used for sounding the different calls in an infantry regiment.

\section{Bugloss. (Anchusa.)}

Bühlwork, Boulework, Boolwork. (Boule.)

Buhr-stone, Burr-stone. (Geol.) A siliceous rock, hard, cellular ; very valuable for millstones ; the best from the Paris basin.

Build a chapel, To. (Naut.) Suddenly to turn a ship by careless steering.

Bul. [Heb.] I Kings vi. $3^{8}$; month of rain, second of civil, eighth of ecclesiastical, Jewish year; the post-Babylonian Marchesvan; October -November.

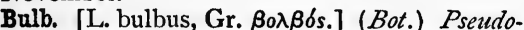
$B$. [Gr. $\psi \in v \delta \eta \dot{s} s$, false]-e.g. some orchids-is an aboveground tuber, the stem being thickened by deposit of bassorine (q.v.).

Bulbul. [Pers. name for nightingale.] 1. Fam. of birds, Fruit-thrushes, Pycnŏnōtĭdæ

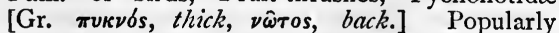
confounded with the nightingale, Currüca luscinňa. Africa and the East. 2. With Byron and Moore, the nightingale.

Bulimus, properly Bulinus. (Zool.) A very extensive gen. of Pulmoniferous molluscs, most abundant in Trop. S. America. Fam. Hělǐcĭdæ (snails).

Bulimy, Būlīmīa. (Boulimy.)

Bulkheads. (Naut.) Wooden or metal partitions between decks to separate one part from another. Compartment $B$., extra strong bulkhead, separating the vessel into water-tight compartments. By this means a vessel (although struck and filling) may be kept afloat, the water being unable to get through the compartment bulkheads to the rest of the vessel.

Bull. 1. (Briefs.) 2. A term used for a speculator who buys stocks or shares in the hope of selling at a higher figure, thereby taking a cheerful view of things; being the exact opposite of the Bear, who takes a gloomy view of the situation. 3. Irish bull, a sentence expressing ideas which a moment's consideration shows to be incompatible and their conjunction absurd.

Bulla. [L.] A boss or stud, mostly of gold, worn by noble Roman youths, till I 7, and then consecrated to the Lares, at the putting on of the tŏga virinlis.

Bullace. [Prūnus insǐtǐtǐa, plum, as if $=$ used for grafting (?).] A wild plum.

Bull and Mouth. Sign of an inn, i.e. Boulogne mouth, or harbour.

Bullārǔum, Bullary. A collection of bulls. (B :iefs.)

Bull-dog, or Muzzled bull-dog. (Naut.) 1. The great gun in the wardroom cabin. 2. Maindeck guns.

Bull-dogs. University proctor's servants, who arrest or summon disorderly persons in the streets, and chase students if they run from a proctor.

Bulletin. [It. bulletina.] Originally a general's despatch ; report of the health of some royal or eminent person ; sometimes a document from a scientific society.

Bullet-tree, Bully-tree. (Bot.) A tree of Guiana, a spec. of Mimusops, ord. Sapotaceæ; having very solid heavy wood, and cherry-like delicious fruit.

Bullet-wood. (Bullet-tree.)

Bullhead, Miller's thumb. (Zool.) Large-headed fish, four or five inches long, dark brown, with spotted sides and white belly. Fresh-water streams ; Europe. Cottos gōbǐo, fam. Trighĭdæ, ord. Ǎcanthoptery̆ğii, sub-class Tělěostěì.

Bullion. [Fr. billon, copper.] Uncoined gold and silver after smelting, often in bars or ingots. Bull, John, = the English ; from the History of Fohn Bull; or, Law is a Bottomless Pit, by Dr. Arbuthnot, friend of Swift and Pope ; a political jeu d'esprit, satirizing national quarrels ; Lewis Baboon being the Frenchman, Nick Frog the Dutchman.

\section{Bull, Papal. (Briefs.)}

Bull's-eye. (Naut.) 1. A block made without a sheave. 2. Hemispherical pieces of ground glass to admit light below. 3. The central point of a target.

Bull, wild. [Heb. tô, or têô ; Isa. li. 20.] (Bibl.) Spec. of large bovine antelope, probably Alcěphălus būbălis.

Bulrush, i.e. large rush. If any particular one be meant, it is Scirpus lācustris, ord. C.y̆perāceæ; its root astringent and diuretic, once used in medicine. The name is often applied to Typha latifólǐa.

Bulwark. [Ger. bollwerk, a fortification.] 1. 
Any artificial defence to keep off invaders. 2. In a ship's sides, it means the protection raised above the upper deck to keep off the waves.

Bum-bailiff. [Bound (?) and L.L. bailivus, porter, lit. walker, errand-runner; root ba, go.] Sheriff's officer, who serves writs and arrests for debt.

Bumboat. A clumsy boat used in traffic between shore hucksters and vessels.

Bummaree. 1. In Billingsgate, one who buys from the salesmen and retails bonne marée [Fr.], good fresh fish. 2. In a bad sense, a middle man who makes too much out of both producer and consumer.

Bumpkin, Bumking, or Bormikin. (Naut.) 1. A small boom; one projects over each bow of the ship, to extend the clew of the foresail to windward. 2. Those on the quarters for the blocks of the main brace. 3. A small outrigger over the stern of a boat, on which a mizzen is usually extended.

Bungalow. In India, a kind of rural villa or house, generally of one story, but of all sizes and styles.

Bunkum, Bnncombe. 1. = Constituent body, as distinguished from Congress. A tedious member for Buncombe, U.S., once, as members left the House, continued the speech which " $B$. expected." Hence, 2, mere speech-making.

Bunsen's burner. A tube in which, by means of holes in the side, the gas becomes mixed with air before consumption, so that it gives a nonluminous, smokeless flame.

Bunt. 1. (Smut.) 2. Of a sail, the middle part, made slightly baggy (as it were bent) to gather wind. 3. In a furled sail, that part which is furled over the centre of the yard. B.-lines, ropes to turn up the foot of a course, or topsail, forward, and thus diminish the effect of the wind.

Bunter. A woman who picks up rags, and so a low woman. Bunts are perhaps bent or broken bits (Richardson).

Buntine, Bunting. Thin woollen material, of which ships' flags and signals are made (to bunt being to sift meal ; the loose open cloth used is a bunting-cloth. - Wedgwood).

Buoyancy; Centre of B. [Fr. bouée, originally baje, a buoy; fastened by a chain or rope, L.L. boja.] The upward pressure of a fluid on a body wholly or partly immersed in it, which equals the weight of the fluid displaced. The centre of gravity of the immersed part of the body supposed of uniform density, i.e. of the fluid displaced, is the Centre of $B$. (Rankine, I22, I23).

Bur, Burr, Common. [Fr. bourre, hair, flock.] (Bot.) 1. The rough fruit of the burdock, Arctium lappa, ord. Compositæ, abundant in waste places throughout Europe. 2. Rough edge left in turning, engraving, etc., metal. 3. The lobe of the ear. 4. The rough annular excrescence at the root of a deer's horn. All these, with similar words, from Gael. root borr = protrude, swell.-Wedgwood.

Burdelais, Burlace. A sort of grape (Johnson).

Burden, or Burthen. (Naut.) The amount of tons weight which a ship can carry; rather less than twice her tonnage.
Burden. [Fr. bourdon, the drone stop in an organ.] 1. Of a song, the refrain at the end of each stanza. 2. The bass of the bagpipe.

Bureaucrăcy. Government by officials. [Coined from Fr. bureau, a writing-table, an office, and Gr. крátos, pozver, rule.]

Burette. [Fr., dim. of O.Fr. bure, a bottle.] 1. A cruet. 2. A graduated glass tube, used by chemists for pouring out measured quantities of liquid.

-burg. (-bury.)

Burgage holding. Scotch tenure by which lands in royal boroughs are held of the sovereign under service of watch and ward.

Burgage tenure. Tenure of old borough lands, site of houses, of a lord for rent; a kind of free socage.

Burgee. (Flag.)

Burgeon. (Bourgeon.)

Burghbote. An ancient impost for maintaining the defences of a city.

Burgers; Anti-burghers. The Session Chamber of Scotland, A.D. I 745, who were for election $v$. patronage, but divided (1747) as to the lawfulness of the oath taken by burgesses, to which the $\mathrm{A}$. objected. Reunited in 1820 , they are now the United Presbyterian Church.

Burgh-mails. (Scot. Law.) Yearly payments to Crown, like Eng. fee-farm rents.

Burghmote. The old English name for the borough court.

Burgomaster, Bürgermeister. [Ger. and D.] Chief magistrate of a municipal town, $=$ mayor.

Burgonet, Burganet (Bourgogne). [O.Fr. bourguignote.] Burgundian helmet.

Burgoo. With sailors, oatmeal gruel seasoned.

Burgrave. [Ger. burg-graf.] Under the Empire, a castellan having the right of private justice and of imposing taxes, etc.

Burgundy. (From Burgundi, a tribe of Vandals.) There were two kingdoms, Upper and Lower B., before A.D. 1032 ; a third, nearly the same as the province of B., from A.D. 880-1361 it then became a dukedom. Upper B. became Franche-Comté. B. forms the departments of Yonne, Cote-d'Or, Saône-et-Loire, and Aix in the E. of France.

Burgundy pitch. The purified resin of the spruce fir, used for making plasters.

Buridan's ass. The ass between two bundles of hay. John Buridan, Schoolman, fourteenth century, propounded the problem that if the bundles be equidistant from the ass, he will starve from indecision, or else of two equal attractions one is greater, or, thirdly, the ass has free-will.

Burin. 1. A graver, the principal instrument used in engraving on copper. Used, 2, meton. $=$ a style, a clear $B .$, a soft $B . \quad[C f$. bore, $\mathrm{L}$.

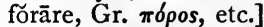

Burking. A name for the practice of providing subjects for medical dissection, from a man named Burke, who in 1820 obtained some by murder. Hence to burke is to bring anything suddenly or violently to an end, and hush it up.

Burl. [Fr. bourre, hair, flock, bourreler, to rack.] To dress cloth, clearing it of the knots. 
Burlace. (Burdelais.)

Burleigh's nod, Lord. In Sheridan's Critic, Lord B. says nothing, but gives his head a shake, to which Puff gives an absurd amount of meaning.

Burletta. A comic operetta.

jest, from which also burlesque.]

Burling. (Burl.)

-burn, -bourne. [A.S. byrna, Ger. brunnen.]

Stream; part of Saxon names, as in Ty-burn, Brox-bourne.

Burnet, Common. (Bot.) Sanguisorba officicinālis, ord. Rosācěæ; a native plant. Potērǔum sanguisorba is salad B., once grown for salads.

Burning-house. The furnace in which tin ore is burnt to remove the sulphur.

Burnish. [Fr. brunir, to polish.] To polish ; as a neut. verb, to grow bright. (Varnish.)

Burnisher. A tool with smooth hard round surface, generally agate, for rubbing and brightening gold leaf.

Burnt-ear. In corn. (Smut.)

Burrel. A pear, the red butter pear.

(Bury pear.)

Burrock. [A.S. burh, beorh, hill, -ock, dim. suffix.] A small dam or weir for fishing purposes.

Bursars. [L.L. bursārius, a purser.] 1. In the English universities, the treasurers of colleges and halls. 2. In the Scottish and foreign universities, persons aided in the costs of their residence by grants from a burse or fund set apart for that purpose. Bursary, in Scotland, the grant or exhibition thus received.

Burschenshaft. [Ger.] An association formed in 1815 , among students in German universities, for the liberation and union of Germany.

Burt. [Cf. Ger. butte, D. bot, a flat-fish.] (Zool.) Fish of turbot kind, fam. Pleuronectǐdæ, ord. Änăcanthĭnæ, sub-class Tělěostěĩ.

-bury, -burg, -burgh, -brough, -borough, -berry. [Goth. baurgi-s, O.S. burg, A.S. byrig, fortified post.] Part of Teutonic names. Often marks site of a camp; -bury is distinctively Saxon.

Bury pear, i.e. Beurré, as if butter pear.

Busby. (Mil.) The head-dress worn by hussars, artillerymen, and engineers in the army, and consisting of a fur hat with a bag hanging from the top on the right side.

Bush. [A Teut. and Scand. word.] The brass or white metal lining of the bearing of an axle or journal box, with which the revolving piece is actually in contact, and which takes the wear caused by friction.

Bushel. [Fr. boisseau, L. buscellus, a vessel for measuring grain.] A measure of eight gallons or 2218.2 cubic inches; a Winchester $B$. was $2150^{\circ} 4$ cubic inches, and a heaped $B$. one third more.

Bushman. (Bosjesman.)

Bushranger. One who roams about the woods ; generally in a bad sense, as an escaped criminal

Busiris. In Egypt. Myth., a being of whom the most contradictory accounts are given by ancient writers, some speaking of him as a king, others affirming that the name meant simply the tomb of Osiris.
Busk. To prepare, get one's self ready.

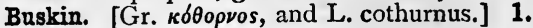
The high-soled boot, reaching to the middle of the leg, worn by tragic actors. 2. By meton. $=$ tragedy; so soccus, the flat-soled shoe of comedians and slaves, $=$ comedy. $[C f$. Flem. brosekin, from which also It. borzacchino, and Fr. brodequin.]

Busking. (Naut.) 1. Piratical cruising. 2. Beating to windward along, or standing on and off from; the coast.

Buss. 1. A kiss [L. bäsium]. 2. (Naut.) A two-masted Dutch fishing-boat, from 50 to 70 tons burden. 3. A herring-boat (British), from Io to 15 tons.

Bustard. : [L. ăvis tarda, slow bird, Sp. avutarda or abutarda.] (Ornith.) Fam. of birds. Inhabits open districts in E. hemisphere. Two spec. occasionally visit Great Britain : (I) Ōtis [Gr. 'ंtis, the eared one] tarda, Great bustard, about forty-five inches long; plumage of male white, pale chestnut, and black. (2) Otis tetrax, little bustard, about seventeen inches long, black throat, with white collar and gorget. Ord. Grallæ.

But and ben. A Scotch term, applied to the two rooms of a cottage, kitchen and parlour, opposite to each other; the speaker considers himself as being in but.

Butcher-bird. (Shrike.)

Butcher's broom. Formerly used for sweeping blocks; a native plant, in bushy places and woods, shrubby, evergreen; Ruscus ăcūleātus, ord. Lïliācěæ.

Butt. 1. Of beer, is 108 gallons. 2. [Fr. butte, rising ground, knoll.] Earthen mound placed behind a target for the purpose of checking the further progress of balls.

Butte. [Fr.] An isolated high hill ; originally the rising knoll on which the butt or mark stood.

Butter and eggs. Popular name for Narcissus incompărābullis of the Mediterranean, common in gardens; also for the toad-flax (Linaria vulgāris), in allusion to the two shades of yellow in the flowers.

Butter-box. (Naut.) 1. A lumpy brig. 2. A Dutchman.

Butter of antimony, tin, zinc. (Chem.) The trichloride of antimony, bichloride of tin, chloride of zinc, being semi-fluid buttery substances.

Butter tree. Indian B., the kernels of which yield a firm, white, rich butter, keeping fresh for months. Bassia butyrācěa, ord. Sapotācěæ. The African B., or Shea, is B. Parkii.

Button. The round mass of metal left in a cupel after fusion.

Button's. A coffee-house in Russell Street, Covent Garden, where wits assembled in Addison's time.

Buttress. [Fr. buttée.] A projection from a wall, giving it greater strength ; so called from its butting or pushing. Flying buttresses, i.e. buttresses connected by an arch either with other buttresses or with the wall of the building, seem first to have been used in the Lancet or Early English style. (Geometrical style.) 
Butts. 1. The stoutest part of tanned oxhides, used for harness, etc. 2. A kind of doorhinges (from being screwed on to the part which butts against the casing).

Butyric acid. An acid found in butter [L. būtyrum].

Buxom. In O.E., bough-some [cf. Ger. biegsam, compliant, obedient, easily bowed, and so flexible, brisk, lively ; but the word may be connected with the Scand. pege, a maiden]. (Bonair.)

By. In competitions, the position of the odd competitor drawn without a match in a heat or tie.

-by. [Norse, abode, village, O.N. bŷ, I dzuell, bû, drvelling-place; cf. A.S. bûan, to dwell, Gr. $\phi v$, make to be, become.] Part of names in Danish and Norwegian districts.

By-and-by. Mark vi. 25 ; Luke xxi. 9 ; imme-

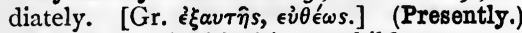

By-blow. An illegitimate child.

By-law, Bye-law. [Cf. Sw. by-lag.] 1. A law for a particular "by," or town; and so, 2 , laws for any special association, as a particular railway. (-by.)

By, or surprise, Plot. A plot, formed in I603, for seizing James I., and compelling him to grant free exercise of religion; so called to distinguish it from the Main Plot, formed at the same time by George Brooke and others for placing Arabella Stuart on the throne.

Byre. [A.S. búr, a chamber, from búan, to dwell; $c f$. bower.] Cow-shed.

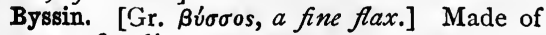
bysse, or fine linen.

Byssus. [L., Gr. $\beta v$ voos, a fine flax.] With Greeks and Romans, as with us, the bundle of silky filaments by which many bivalves adhere to rocks, etc. The beautiful silky $B$. of the Pinna was once woven into cloth, highly valued.

\section{Byzant. (Bezant.)}

Byzantine architecture includes the several styles from the foundation of Constantinople, A.D. 328 , to its conquest by the Turks, I 453 . Its typical ecclesiastical form, a Greek cross with central cupola and apse, was fixed by the church of St. Sophia at Constantinople, now the Great Mosque.

Byzantine empire. The E. Roman, Eastern, or Greek empire.

Byzantine historians. Greek historians, living between the sixth and fifteenth centuries. Their works were collected and published by order of Louis XIV., in thirty-six vols., folio.
C. This letter is used in ancient MSS. as an abbrev. for Caius, Cæsar, Consul, Civitas, etc. ; in the Roman law courts it was the sign of condemnation, in contradistinction to $\mathbf{A}$, for $\mathbf{A b s o l v o ,}$ $I$ acquit, the former being therefore called Literra tristis, the latter Litěra salūtāris. As a numeral, it denotes 100.

Caaba. The temple of Mecca ; so called from the black stone worshipped there before the time of Mohammed, and now seen in the northeast corner of the building. The stone is probably an aerolite.

Cab. Mentioned only in 2 Kings vi. 25; the smallest dry measure with the Jews; according to Josephus, = about two quarts.

Cabal. [Fr. cabale.] In Eng. Hist., a name given to the five Cabinet ministers of Charles II. - Clifford, Arlington, Buckingham, Ashley, and Lauderdale-r667-74, because the initials of their names happened to form the word.

Cabăla. A Hebrew word, denoting the general body of tradition interpreting the canonical books in their figurative as well as their direct sense, the Masorah, or unwritten tradition, setting forth its literal meaning. (Pharisees; Sadducees; Talmud.) As dealing with the secondary meanings of Scripture, the Cabala became associated with magic, and the Christian Cabalists made a profession of divining by combinations of scriptural characters. (Sortes.) Caballine. [L. căballinus.] 1. Belonging to a horse [căballus]. 2. As a subst., horse-aloes.

Cabăret. [A Fr. word, of unknown origin, with various meanings.] 1. A set of tea-things; properly, including a china tray. 2. A tavern, public-house.

Cabas. [Fr.] A flat basket,

Cabbage. To steal pieces of cloth, said or tailors; hence to pilfer generally.

Cabbling. Breaking up flat masses of iron to be reheated and wrought into bars.

Cabinet-picture. A small picture, generally of a finished character, suitable for a small room [Fr. cabinet].

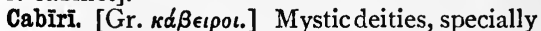
worshipped in the northernmost islands of the Egean. Like that of Bacchus or Dionysos, their worship was introduced from Syria, and their name is identified with the Hebrew word Gibborim, the mighty ones (Brown, Great Dionysiak Myth). (Bacchanalian.)

Cable. (Naut.) The rope, or chain, to which an anchor is made fast. $A$ shot of $C$., two spliced together. $C$. length in charts, i.e. accurately $=607.56$ feet, or $\frac{1}{10}$ of a sea mile. C. distance, roughly about 600 feet. In making, 600 to 690 feet. A cablet, 720 feet. Ditto, hazeser laid, 780 feet. Cables are named after the anchor with which they are used, as Stream cable.

Cable-moulding. A bead-moulding, in later Norman work, cut in imitation of the twisting of a rope.

Cable's length, sometimes Cable-tow. Generally, 120 fathoms $=720$ feet.

Cabling. A round moulding frequently 
worked in the flutes of columns, pilasters, etc., in classical architecture.-Parker's Gloss. of Architecture.

Cablish. [Gr. кат $\alpha \beta 0 \lambda$, a throwing down, through Fr. accabler, to overwhelm.] Brushwood, windfalls of wood.

Cabob. [Pers. cobbob, roast meat.] A small piece of meat roasted on a skewer.

Caboched, Cabashed. [Fr. caboche, head.] (Her.) Full-faced, and without neck.

Caboose, more correctly Camboose. kombnis, a cook's room.] (Naut.) The kitchen of a merchant ship.

Cabriolet. [Fr., from cabrioler, to bound.] A one-horse carriage, having a hood and a seat for two persons.

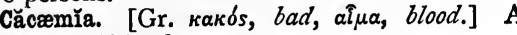
bad state of blood.

Cacao, or Cocoa. The ground seeds of the Thěŏbrōma C., ord. Sterculācěæ. In W. Indies, Brazil, etc. They contain a peculiar principle, called Theobromine.

Cachalot. [From the Catal. quichal, Sp. quircal, a tooth (Littré).] (Zool.) Physetēr ma-

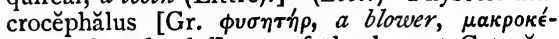
$\phi a \lambda o s$, long-headed], one of the largest Cetacěa, yielding ambergris, as well as spermaceti, but no whalebone.

Cachectic. [Gr. $\kappa \alpha \chi \in \xi\{$, a bad state or habit

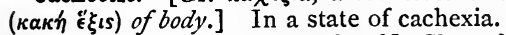

Cache-mari. [Fr., hide husband.] Slang for an épergne, or large flower-stand, on a dining-table.

Cachepot. [Fr. cacher, to hide, pot, a pot.] An ornamental case to hold a flower-pot.

Cachet, Lettres de. [Fr.] In France, before the Revolution, letters under the private seal [cachet] of the king, used at first to interfere with the ordinary course of justice, and afterwards for the illegal detention of citizens.

Cachinnation. [L. căchinnātio, -nem, căchinno, I laugh aloud; cf. Gr. $\kappa \alpha \gamma \chi \not{\alpha} \lambda \alpha ́ \omega$ : onomatop.] Loud, excessive laughter.

Cachiri. A liquor like perry, made in Cayenne from the manioc root.

Cacholong. (Geol.) A beautiful hard white opaque mineral, probably a variety of opal ; from river Cach, Bokhara, cholong, (?) precious stone, in Kalmuc. Faroe Islands, Greenland, etc.

Cacholot, or Spermaceti whale. (Cachalot.)

Cacique, Caxique. [Hayt. word, adopted by the Sp.] A name for chiefs of Indian tribes of Central and S. America.

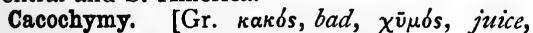
liquid.] (Med.) Bad condition of the juices or humours.

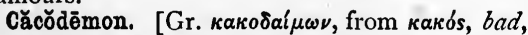
$\delta \alpha i \mu \omega \nu$, as used in New Testament.] Evil spirit.

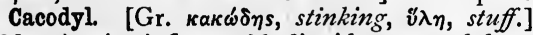
(Chem.) An inflammable liquid, prepared from zinc and chloride of arsenic, and acting as a base.

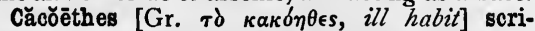
bendi. An itch, or passion, for scribbling.

Cacogrăphy. 1. Bad handwriting [Gr. какós,

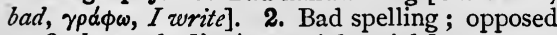
to Orthography [opobs, straight, right].

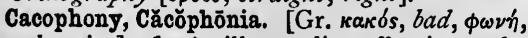
sound, voice.] 1. An ill-sounding effect in words.
2. Harshness in musical effect. 3. $(M e d$.$) A$ depraved state of voice.

Cadastral Survey. [Fr. cadastre.] A survey of an extensive tract of country, made with exact instruments, such as the Ordnance Survey ; originally, one serving as a register [L. căpitastrum], regulating the imposition of taxes on real property.

\section{Cădāvěr. [L.] A corpse.}

Caddis worm, Case worm. Larva of Phry-

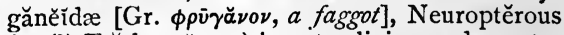
(or (?) Trĭchoptěrous) insects ; living under water in tube constructed of fragments of rush, stone, etc.

Caddow, Caddess, Cadow. The young of the crow. Richardson mentions the suggestion caw, and daw or dow.

Cade. [L. cădus.] A cask.

Cade lamb. [(?) Fr. cadet; or cf. Dan. kaad, wanton, frolicsome (Wedgwood).] A pet lamb, a somewhat spoilt child.

Cadence. [L. căděre, to fall.] 1. (Her.) Family descent; cadency. 2. (Music.) The close of a musical passage or phrase. If harmonized, a Perfect $C$. is when the chord of the key-note is preceded by the chord of the dominant; a Plagal $C$. is when the key-note is preceded by the chord of the subdom., major or minor. All other cadences are termed imperfect.

Cadene. [Fr. cadène, from L. catêna, chain.] An inferior Levantine carpet.

Cadet. [Fr. cadet, younger, L.L. capitettum, little head.] Formerly meant the younger branches of any noble family, but now applied to young gentlemen who are being trained for the profession of arms. Naval C., one training for a midshipman on board a man-of-war.

Cadi, Kádee. [Ar., a judge.] (Alcaide.) With Mohammedan nations, a judge, who passes sentence in all cases of law; in India, chief judge ; in the dominions of the Ottoman sultan, subject to the mufti.

Cadis. [Fr.] A coarse serge.

Cadit quæstio. [L.] The matter for discussion falls to the ground; there is an end of it.

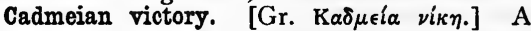
victory won to one's own ruin, referring to the story of the armed men who sprang up when Cadmus sowed the dragon's teeth, and who slew each other; or, as some have said, to the fratricidal war of Eteocles and Polyneikes, the sons of Edipus.

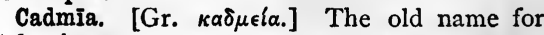
Calamine.

Cadmium. [Gr. $\kappa \alpha \delta \mu i \alpha$.$] A soft white metal,$ generally found in zinc ores, such as calamine. C. yellow, used as a pigment, is its sulphide.

Cadogan. A teapot, filled from below.

Cadre. [Fr., frame, outline, from It. quadro.] The nominal establishment of officers of a regiment.

Caducary. [L. cădūcus, falling.] (Leg.) Relating to lapse, escheat, forfeiture, or confiscation.

Cādūceus. (Myth.) The staff of Herměs. The word is probably a Latinized form of the Gr.

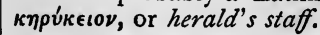


Caducibranchiate. [L. cădīcus, liable to fall, Gr. Bpá $\gamma \chi \iota \alpha$, gills.] (Amphibia.)

Caducity. [L. cădūcus, falling or fallen.]

1. A tendency to fall ; e.g. Bot., in the petals of the cistus. 2. Feebleness.

Cădus. [L.] A large jar, especially of earthenware, for wine.

Cæcŭban wine. The choicest Roman wine before the age of Augustus.

Cæcum. [L. cæcus, blind.] A blind sac or bag ; in man, the first portion of the colon.

Cædmon. An Old English poet of the seventh century, who sang of the mysteries of creation and redemption in alliterative $(q . v$.) verse.

Cælātūra. [L.] The Roman term for working raised, or partly raised, figures in metal.

Caen stone. From the quarries of C., Normandy; a member of the Oolitic group. (Bathstone.)

Caer-. [Cf. Erse cathair, fortress.] Part of Cymric names, as in Caer-marthen.

Cæsărem vehis, Fortūnamque ejus.

Thou carriest $C$. and his fortune. An apostrophe spoken to the ship in which C. sailed; applied to any vessel, carriage, train, etc., carrying some one precious in the eyes of the speaker.

Cæsarian operation (Pliny's belief being that Cæsar was named "a cæso matris ǔtèro"). Extraction of the fotus by incision of the abdomen. The same story is told of Macduff, and of many of the large group of Fatal children.

Cæsarism. The theory of irresponsible despotism.

Cæsium. An alkaline metal, having a pair of blue [L. cæsius] lines in its spectrum.

Cæstus. [L. cædo, I strike, slay.] A Roman pugilist's leather strap of bull's hide, often weighted with balls of lead or iron, bound round the hands and arms ; a gauntlet.

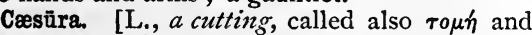

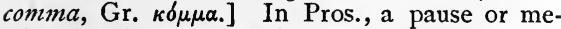
trical break near the middle of the line, caused by the separation of the first syllable of a foot, forming the last of a word, from the next syllable, which forms the first of another word; as in the Latin hexameter, e.g. "Arma virumque cano | Trojæ qui primus ab oris."

Cætĕra dessunt. [L.] At the end of an incomplete copy of a work: the remainder is wanting.

Cætĕris părìbus. All other things being equal; e.g. C. P. a preference to natives of awarding a scholarship.

Caffeine. [Fr. caféine, from café, coffee.] The essential principle of coffee and tea, also called theine [theine, from thé, tea]. (Alkaloids.)

Caftan, Kaftân. [Turk. gaftān, a robe of honour.] A robe, cloak, presented by the sultan to visitors of distinction, especially to ambassadors.

Cage. [Fr. cage, L. căvěa.] (Mech.) A piece put over a valve, which, while giving the valve freedom of motion, prevents it from being displaced.

Cagliostro. (Balsamo.)

Cag-mag. [(?) Onomatop. from the effort of eating.] Coarse, tough meat; properly a tough old goose.

Cagots. Gipsy-like people (? descendants of ancient leper communities ?) in Bearn and other parts of Gascony ; once badly treated, and still socially degraded. Similar are the Caqueux in Brittany, and the Colliberts in Poitou, Maine, Anjou. [Câ, Prov. = canis, $\operatorname{dog}$ (I. Taylor).]

Cahar. [Hind.] Palanquin-bearer.

Cahier. In Fr. Hist., a report of certain assemblies and their proceedings; e.g. of the States-General, clergy, etc. ; lit. a writing.book, of four leaves [L. quăternum].

Caimacan. (Kaimakan.)

Cainites. Gnostics of the second century, who held Cain to have been the work of a mighty power, Abel of a weak one; and that the way to be saved was to make trial of all things, evil as well as good.

\section{Cainozoic, Cænozoic. (Neozoic.)}

Caique, or Kaique. A small vessel of the Levant. The Constantinople skiff, fast but crank, whose traditional wave-line is the same as the one reckoned a triumph of modern marine architecture.

Ca ira. [Fr., that will go on, i.e. succeed.] The refrain of the Carillon National, or Kevolutionary song of 1790 .

Caird. [Ir. ceard.] A tinker, vagrant, tramp.

Cairn. [Gael. kaern, $a$ heap.] 1. A heap of stones, piled in memory of the dead over stone chests, urns, etc., containing their remains; Keltic. 2. Similar heaps used as marks in trigonometrical surveys; called in S. Africa a pile. (Tumulus.)

Cairngorm stone. (Geol.) A brown or yellow quartz crystal, having a little oxide of iron or manganese ; when brown-black it is called Morion. In C. Mountains of Aberdeen; near Orleans ; in Brazil. (Quartz.)

Caisse. [Fr., L. capsa, a chest, case.] Case, strong box, cashier's office. Livre de C., Compte de C., cash-book, cash account. C. d'amortissement, sinking fund.

Caisson. [Fr. caisson, wagron, caisse, a chest, L. capsa.] 1. (Arch.) Sunk panels, lacūnārǐa, of flat or arched ceilings, etc., or of Soffits. 2 A flat-bottomed frame of large timbers, used for laying the foundations of a bridge. 3. Case containing receptacles for shells, when they are buried for explosion. 4. Ammunition-waggon.

Cajeput oil. The pungent, aromatic, volatile oil of the Melaleuca C. of the Moluccas; ord. Myrtācěæe.

Calabar, or Ordeal, bean. The seeds of Physostigma věnēnōsum, a plant resembling our scarlet runner, but with a woody stem ; employed as an ordeal in W. Trop. Africa in the case of persons suspected of witchcraft.

Calabar skin. The skin of the Siberian squirrel.

Calabash [Sp. calaboza]; for goblets, cups, etc. 1. The hard shell of the fruit of the Trop. American tree Crescentia, ord. Bignoniācěæ. 2. Vessel made of a dried gourd.

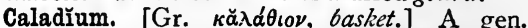
of plants, ord. Aroideæ. W. Indian and S. 
American. Cultivated in hot-houses for their beautiful spotted leaves, etc.

Calamanco. [Sp. calamaco.] A glossy woollen stuff.

Calamander wood. (Coromandel wood.)

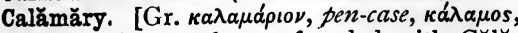
reed, pen.] Not to be confounded with Călămaria, which is a gen. of dwarf ground-snakes. (Squid.)

Calambac. (Eagle-wood.)

Calambour. [Pers. halambak.] A fragrant aloe-wood used by cabinet-makers.

Calamifěrous plant. Producing a hollow, knotted stem like a reed [L. călămus].

Calamine. [L. călămus, a reed.] (Min.) Carbonate of zinc; adhering in a reed-like form to the base of the furnace when smelted. Electric calamine is native trisilicate of zinc, which is electric when heated. (Cadmia.)

Calamint. [Gr. $\kappa a \lambda a \mu i \nu \theta \eta$.] (Bot.) A gen. of plants, ord. Lamiācěæ, to which belong cat-mint, basil, thyme, etc.

Calamite. [L. călămus, a reed.] (Geol.) A frequent and characteristic gen. of fossil plants, found chiefly and abundantly in the coal-measures ; resembling Equisēta.

Călămus. [L., reed.] 1. A gen. of grass-like palms, E. Indian mostly, which furnish the rattan canes of commerce. 2. In Exod. xxx. 23; Song of Sol. iv. I4; Ezek. xxvii. 19; the sweet cane; probably the root-stock of an aromatic reed, the Ǎcŏrus [Gr. ăkopos] călămus.

Călămus root. Used with oils of cloves, lavender, rosemary, in aromatic vinegar; the rhizome of Ăcŏrus [Gr. ăkopos] călămus, or Sweet flag, ord. Aroidex. Brought from Asia in the fifteenth century; now naturalized in Europe.

Calando. [It. calare, to decrease.] (Music.) Decreasingly, both as to sound and as to time.

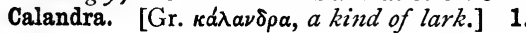
(Ornith.) A short-billed lark, the largest European spec. (Cuvier). 2. (Entom.) C. grānärìa [L. grānum, grain], C. ŏrȳze [ö $\rho v \zeta a$, rice], etc., Corn wecvil, Rice W., etc. Gen. of

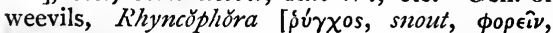
wear], long-snouted beetles, whose larvæ are destructive of corn, rice, etc.

Calash. [Slav. kolaska.] 1. A four-wheeled carriage, opened or shut by a movable hood. 2 . The hood itself. 3. A large hood, protecting the head, for going out at night; worn by ladies.

Calathrorm. Of the shape of a basket [L. călăthŭs].

Calatrava, Order of. An order of Spanish knighthood, instituted by Sancho III. of Castile, II 58 .

Calcaire grossier. [Fr., coarse limestone.] (Geol.) A member of the Middle Eocene of the Paris basin, and representative of Bracklesham Eocene, is composed of fossil marine molluscs and foraminiferra, and is the building stone of Paris.

Calcāneum, or 0s calcis. [L.] The heel-bone.

Calcar. [L. calcārǐa, limekiln.] An oven used for calcining sand and potash in glassmaking.

Calcarate flower. Having a spur [L. calcar].
A hollow projection from the base of the petals; as in larkspur and some orchids.

Calcareous. [L. calcārius, of or belong to lime.] (Geol.) Containing a considerable amount of lime.

Calcoolate. (Bot.) Of the shape of a slipper or small shoe [L. calcěŏlus]; e.g. calceolāria.

Calcination. (Calx.)

Calcitration. [L. calčrtro, I kick.] The act of kicking.

Calcium. A malleable pale yellow metal, the basis of lime [L. calx].

Calcium light. A white dazzling light; that of the melting at red heat, under a current of air, of calcium, a metal present in various compounds of lime [L. calx, calcis].

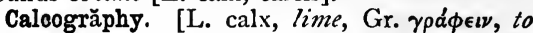
write.] The art of drawing with chalk.

Calc-sinter. [Ger. sinter, dross.] Incrustations deposited by siliceous and by calcareous springs are Siliceous sinter and Calc-sinter.

Calc-spar, Calcareous spar, Calcite. (Geol.) Crystallized carbonate of lime; found in numerous forms and degrees of purity.

Calc-tuft, Calcareous tuft. Chemically, nearly i.q. marble; but cellular, spongy, generally friable; sometimes good for building, e.g. the Travertine at Rome.

Calculating-machine. A mechanical contrivance by which arithmetical operations (addition, multiplication, etc., of numbers) can be performed. Napier's rods (or Napier's bones) are an early form of machine for multiplying and dividing numbers. Another was Pascal's. Of later forms, the best known is Babbage's C.-M., which is, strictly speaking, a difference machine, i.e. it is adapted for calculating a series of numbers separated from each other by a common difference ; by means of subsidiary contrivances, the common difference can be varied; the machine is therefore adapted for the calculation of mathematical tables, such as tables of the logarithms of numbers, etc. Another wellknown modern machine is that of M. Thomas, of Colmar.

Calcŭlus. [L., a small stone.] (Med.) A hard, stony secretion in any part; most frequently applied to a concretion in the bladder.

Calculus of finite differences; Differential C.; Integral C. ; C. of variation. A collection of rules or theorems applicable to calculations performed with certain defined classes of magnitudes. Conceive two magnitudes connected in such a manner that a change in the one necessitates a corresponding change in the other, e.g. the radius and the area of a circle. Any corresponding changes which these two magnitudes undergo are called their differences. If these differences are finite, a collection of theorems may be formed having reference to the relations existing between them, and such a collection of theorems is called the $C$. of finite differences. If the differences are indefinitely small, such as would occur when the change takes place continuously, we have the Differential $C$. The theorem of the Integral $C$. relates to the total finite result of a continuous change, 
the rate of which at each point is known, i.e. to the determination of functions from their differential coefficients. These and similar calculi are commonly carried out into numerous details ; and, in particular, most treatises on the Differential and Integral $C$. explain the applications of these calculi to questions of geometry, etc. It is not unusual to speak of the differential and integral calculus as The $C$. , on account of its numerous applications to physical questions, most changes in nature being continuous. (For C. of variation, vide Iso-.)

Calda. [L. and It.] Warm spiced wine and water.

Caldārium. [L.] In the Roman baths, the chamber containing the warm bath.

Caldas, Caldelas. In Spain and Portugal, warm springs, from which many places are named ; e.g. C. da Rainha, etc.

Calèche, Calash. [Fr. calèche.] A light carriage for four, with movable top and separate seat for driver.

Cälëdŏnia. Scotland, north of Firths of Clyde and Forth, under the Romans.

Calefacient. [L. călěfăcientem, making warm.] Causing a sensation of warmth; e.g. a mustard poultice.

Calembeg. A kind of olive-green sandalwood. Calembour. [Fr.] A pun: "le nom de l'abbé de Calemberg, personnage plaisant ${ }^{\circ} \mathrm{de}$ contes allemands," Littré; who compares espiègle, sprightly, harmlessly mischievous, espièglerie, sharp saying - a word which passed into Fr. from a translation of the life of Till Eulenspiegel, Owl's Looking-glass, a German, circ. 3480, famous for petites fourberies ingénzeuses.

Calendar, Julian, Gregorian. (Calends.) 1. A register or list of things, as a $\mathrm{C}$. of State papers. 2. A book or table containing the order and sequence of all the days of the year; an almanac; an Ěphēměris [Gr.]. In the Fulian $C$. the year is $=365$ days; but every fourth year has an additional day, $=366$ days. In the Gregorian or Reformed C., three of these additional days are omitted in the course of 400 years ; so that only 97 years in the 400 are 366 days long. The rule is that the year consists of 366 days when its number is divisible by 4 , as A.D. I880, 1884, etc.; but it consists of 365 days when its number, though divisible by 4 , consists exactly of centuries and is not divisible by 400 ; thus, A.D. I900 will have only 365 days, but A.D. 2000 will have 366 days.

Calendars, The three. In the Arabian Nights' Tales, sons of kings disguised as begging dervishes.

Calendering. The process of passing linen or calico between cylinders, so as to flatten out the threads and give a closer texture.

Calends. [L. calendæ.] In the Roman calendar, the first days of each month. The Greek month had no Calends : hence the phrase "Greek Calends" is equivalent to the 3oth of February, iron., $=$ never.

Calenduline. Mucilaginous matter found in the leaves of common marigold (Calendŭla offĩcinālis).
Calenture. [Sp. calentūra.] An ardent fever, mostly attacking seamen when sailing into hot climates, the sufferer often imagining the sea a green field; the term nearly obsolete.

Calfat. (Naut.) (Caulk.)

Calf's skin = part of a fool's dress, in Shakespeare's time.

Cali. (Kali.)

Calibre. [(?) Fr. of the sixteenth century, équalibre, L. æquilibrium; Littré suggests Ar. kalib, a form, mould.] 1. The bore of a gun, diameter of a bullet. 2. Meton. quality, power. $C$. of a ship, the known weight represented by her armament. 3. To calibrate a thermometer-tube is to ascertain the size of its bore.

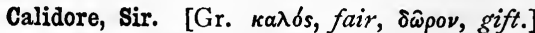
In Spenser's Faëry Queen, type of courtesy, meant for Sir Philip Sydney.

Caliduct. [L. călídus, hot, duco, I lead.] A flue for hot air or water. (Caloriduct.)

Caligation. [L. cālīgātio, -nem.] Darkness, mistiness.

Caligorant. In Ariosto's Orlando Furioso, a giant entangled in his own net, and captured by Astolpho; type of a sophistic heretic.

Caligraphy. Not so correct as Calligraphy (q.v.).

Calila and Dimna. (Panchatantra.)

Calin. [Fr.] An alloy of lead and tin, used by the Chinese for tea-canisters, etc.

Calipash and Calipee. (Callipash.)

Caliph [Ar. khalif] = a lieutenant or deputy, i.e. of Mohammed; a title at first given to the sovereigns of the Muslim Arabs, as successors, vicars, spiritually, of the prophet; but generally applied to certain dynasties only of Mohammedan sovereigns.

Caliphat. In the Hist. of Islam. 1. The office of the successor and vicegerent of Mohammed. But the question of the true representation of the prophet has been often fiercely debated. (Abbasides; Fatimites; Ommiad Caliphs; Shia; Suni.) 2. The country subject to the caliph. Calippic. (Cycle.)

Calisaye bark. One of the best kinds of Peruvian bark, valuable as a source of a quinine. Caliver. An old word for a musket (q.v.). (Another form of Calibre.)

Calixtines. 1. A branch of Hussites ; called also Utraquists, who demanded the cup [L. călix] for the laity, or administration in each part [in utrâque parte] of the sacraments. 2. Followers of George Calixtus, or Callisen, Lutheran divine, seventeenth century, who was for reuniting Roman Catholics, Lutherans, etc., on the basis of the Apostles' Creed.

Calk. [Probably from L. calco, I tread in, stuff.] 1. To stop with tow the seams, or leaks, of vessels. Calkers, Ezek. xxvii. 9. 2. 1.q. calculate [L. calcŭlus, $a$ pebble]. Calkings, i.e. calculations, as of nativities, etc.

Calk, Calkin. In the heel [L. calx] of a horseshoe, a sharp-pointed armature to prevent slipping on ice, etc.

Call. 1. A demand from shareholders of a public company for an instalment if the capital 
is not all paid up. 2. (Stockbrok.) (Put and call.)

Callidity. [L. callǐdĭtā,-tem.] Shrewdness; lit. as of a practised, hardened person [callum, thick skin].

Calligraphy. [Gr. $\kappa \alpha \lambda \lambda \iota \gamma \rho \alpha \phi i ́ a$, from $\kappa a ́ \lambda \lambda o s$, beauty, $\gamma \rho \alpha ́ \phi \omega, I$ write.] Good, beautiful handwriting.

Callǐŏē. [Gr., beautiful-voiced.] The Muse of epic or heroic poetry.

Callipash and Callipee. [(?) Corr. of Carapace (q.v.), or (?) of Calabash.] 1. The turtle's upper and under shell respectively. 2. The green fat of the one, and the yellow flesh of the other, in Chĕlōnē vĭrĭdis, green turtle.

Calliper-compasses ; Callipers. Compasses with bowed legs for measuring the diameters of cylinders. (Calibre.)

Callisthenics. Gymnastics, exercises of strength [Gr. $\sigma \theta$ évos], only to develop grace

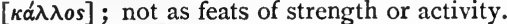

Callisto. (Muses.)

Callosity. [L. callōsǐtā, -tem.] Hardness of skin. (Callidity.)

Callow. [O.E. caluw, colo ; (?) of. L. calvus, bald.] Unfledged, tender, as young birds in the nest.

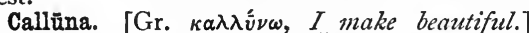
(Bot.) A gen. of plants, ord. Erīceæ, having one spec. Vulgāris, Common heath.

Callus. 1. New bony growth, uniting fractured ends. 2. Sometimes $i . q$. callosity.

Caloric. The (imaginary) principle of heat [L. călor]; it was supposed to be a fluid substance diffused, but unequally, through all bodies, and producing the sensible effect of heat.

Caloriduct. [L. călōrem, heat, dūco, I lead.] A better form than Caliduct (q.v.).

Calorifère. [Fr., L. călor, heat, fĕro, I bring.] A stove.

Caloriměter; Calorimětry. [L. călor, heat, Gr. $\mu \epsilon ́ \tau \rho o \nu$, measure.] An instrument for ascertaining the quantity of heat required to raise a given quantity of a given substance from one specified temperature to another, or to make it change its state, e.g. from ice to water, or from water to steam. Calorimetry is measurement of quantities of heat, which must be distinguished from measurement of temperature.

Calotte. [Fr.] A skull-cap, worn by ecclesiastics.

Calottistes [Fr.], or Régiment de la Calotte. A bold satirical society (temp. Louis XIV.), who sent to any public character who had made himself ridiculous, a calotte or skull-cap for the weak part of his head.

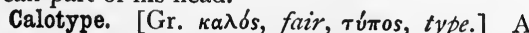
method of photography in which a negative picture is obtained on paper covered with iodide of silver.

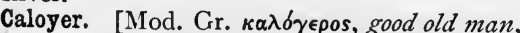
from $\kappa \alpha \lambda \delta \delta$, good, $\boldsymbol{\gamma}^{\prime} \rho \omega \nu$, old man.] A general name for monks of the Greek Church. There are also C. nuns. All follow St. Basil's rule only.

Caltha. [L.] (Bot.) A gen. of plants, ord.
Ranunculācěæ; the marsh marigold (C. palustris) is a well-known British plant, with large yellow cup-shaped flowers, blooming in marshy places in early spring.

Caltrop. [A.S. coltræppa.] 1. (Bot.) A small prostrate plant, Tríbŭlus terrestris. Ord. Zygophyllaceæ. In S. Europe. It has prickly fruit, dangerous to the feet of cattle. 2. (Mil.) An iron instrument, with four points so arranged that, three being in the ground, the fourth projects upwards. Used for harassing the enemy's cavalry, as by Bruce at Bannockburn.

Calumba root. The bitter tonic root, large, fleshy, deep yellow, of the Jateorhiza palmāta of Mozambique. Ord. Menispermaceæ.

Calumet, or Peace-pipe, of N.-American Indians, with long reed stem and marble bowl; smoked, by representatives of both sides, in making a treaty.

Calvary. [L. calvārium, a skull $=\mathrm{Gr}$.

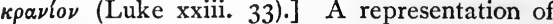
the Passion, with the figures of St. John and the B.V. Mary, generally life-size, in a church or on some eminence.

Calver. To shrink, when cut, not falling in pieces ; said of fish, especially salmon, prepared in a particular way, when fresh and firm.

Calville. A kind of apple. White winter C., grown on the Continent, is a choice variety.

Calvinists. (Eccl.) The followers of Calvin, the head of the Reformed Church in Geneva, in the sixteenth century. (Sublapsarians.)

Calx. [L., quicklime.] A term derived from the alchemists, $=$ the products of calcination, i.e. of the heating or roasting the various metallic ores.

Căly̆cŭlus. [L., dim. of calyx $(q . v)]$.1 . (Bot.) A partial involucre, containing but one or perhaps two flowers. 2. The external bracts of a capitulum, when they form a distinct ring or rings.-Treas. of Botany. Adj., Calyculate.

Calyon. [Fr. caillon.] Flint, pebble stone, used in building houses, walls, churches, e.g. in eastern counties.

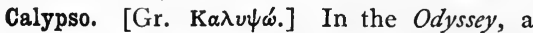
nymph or sea-goddess who detains Odysseus (Ulysses) for seven years on his way home to Ithaca. She is the Venus of the Tanhauiser legend, and the Fairy Queen in that of Thomas of Ercildoune.

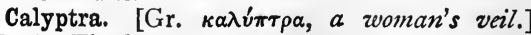
(Bot.) The hood of a moss.

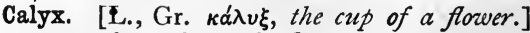
The external envelope of a flower.

Calzoons. [Corr. of Fr. caleçon or It. calzoni.] Drawers.

Cam. [A Gael, word.] 1. Crooked. [Cf. $\kappa a ́ \mu \pi \tau \omega, I$ bend, L. cămŭrus, crooked.] The rivers Cam ; More-cambe, crooked sea, one of which the coast takes many bends. 2. (Mech.) A single tooth which either rotates continuously or oscillates, and drives a sliding or turning-piece either constantly or at intervals.

Camaieu. [Fr.] A painting executed in different shades of one colour only; and thus resembling a cameo (q.v.).

Camail. [Fr., Prov. capmail ; L. caput, 
head, and maille, a mesh, L. măcŭla.] 1. A coat of mail, covering head and shoulders. 2. A clerical short cloak, like in shape, but longer.

Camaldŭlites. Benedictine monks, established at Camaldoli, in the eleventh century.

Camaraderie. [Fr.] Good fellowship.

Camarilla. [Sp., L. căměra, $a$ chamber.] $A$ small room or audience chamber of the king; and so $=$ his secret cabinet.

Cambel and Triamond. Inpersonations of friendship, Spenser's Faëry Queen, bk. iv.

Camber. [Fr. cambré, arched.] The convexity on the upper side of a beam, to prevent its bending under the weight it has to sustain.

Camber, To. [Gr. $\kappa a ́ \mu \pi \tau \omega, I$ bend, L. cămŭrus, crooked.] 1. To curve planks. 2. (Naut.) C. backed keel, one slightly arched, but not enough to constitute actual arching $(q . v$.). . 3. A C., a place for storing and cambering timber.

Cambistry. The science of money exchanges. [L. cambiare, to barter, whence Fr. changer.]

Cambium. [L. cambio, I exchange.] 1. A viscid secretion in spring, between the bark and alburnum (q.v.), the supposed material of new wood and bark. 2. A (supposed) restorative of bodily wear, residing in the blood.

Cambogo. (Gamboge.)

Cambrai, League of. An alliance, I 508, between the pope, the emperor, France, and Spain, against Venice.

Cambrai, Peace of. A treaty between France and the emperor, 1529.

Cambrasine. [Fr. cambrésine.] A kind of fine linen, like cambric (Cambrai, the place of manufacture).

Cambria. Old name of Wales; land of Cymry.

Cambrian, Cumbrian. Professor Sedgewick's term for some of the oldest known fossiliferous rocks, underlying the true Silurian; occurring extensively in Wales (Cambria) and in Cumberland.

Cambuscan. The model king in Chaucer's Squire's Tale. (Canace.)

Camden society. (In honour of Wm. Camden, buried at Westminster, I623.) Publishes early historical and literary remains.

Came. Lead cast into thin rods, used for framing the glass of casements.

Camel. [Gr. кá $\mu \eta \lambda$ os, a Semit. word.] 1. (Zool.) A ruminant. The two spec. of this gen. are the common camel and the Dromedary. 2. (Naut.) A wooden case enclosing a ship, to float it over shallows.

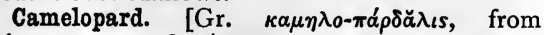

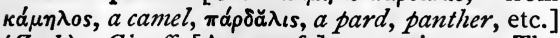
(Zool.) Giraffe [Ar, zurafa]; a ruminant. .The tallest extant quadruped, and the only spec. of its gen. and fam. Nubia and adjacent southwest open country of Africa. Ord. Ungŭlāta. (Wrongly pronounced cameleopard.)

Camelot. The city in which Arthur had his court and his Round Table.

Cămēlus saltat. [L.] The camel is dancing; said of one doing something very unlike his usual habits.
Camēnæ. [L.] Latin deities whose names, as shown by the forms Carmentis and Carmēnæ, were connected with [carmen] song. Hence they were identified with the Greek Muses.

Cameo. [Fr. camaïeu and camée, It. cameo, and L.L. camæus.] Carving, in relief, of shells; and of agate, onyx, sard : opposed to Intaglio, an incising; as for a seal.

Cămĕrā, In. [L.] In a chamber, privately.

Cameralistics. [L. căměra, $a$ chamber.] Science of public finance.

Cămĕra lūcĭda. [L., a bright chamber.] An optical instrument invented by Dr. Wollaston, in 1807. Originally a four-sided prism of glass set in a brass frame ; used by artists for obtaining an accurate outline of a distant object. The faces are inclined at such angles that, when it is placed in a proper position, light from the object after two internal reflexions forms, on-or more strictly behind-the paper, an image which the artist can then trace.

Căměra obscūra. [L.] $A$ darkened chamber or box, in one of the walls of which is placed a convex lens or combination of lenses, by means of which the image of an external object can be formed on a screen placed in a proper position; in the form used by photographers it is often spoken of simply as a Camera.

Camerel, Cambrel. A wooden notched crook, by which large pieces of meat are hung. [Cf. cam (q.v.) and L. cămŭrus, crookea, in E. Ang. croom.]

Camerlengo $=$ Chamberlain. The pope's Minister of Finance, and of civil aftairs generally; temporary head of the Church "sede vacante ;" sole head in things temporal ; assisted by other cardinals in things spiritual.

Cameronians. 1. (Richard Cameron, killed I680.) Resisting Charles II.'s attempts to settle Church government, became a definite sect, after 1688 ; a very small body now. 2. The 26 th Light Infantry; raised from the Cameronians in 1688 .

Camisards, The. (Fr. Hist.) Insurgents in the Cevennes Mountains, at the beginning of the eighteenth century; so called from the white shirt or jacket which they wore to recognize each other by night. (Dragonnades.)

Camlet. [Fr. camelot, from Gr. $\kappa \alpha \mu \eta \lambda \omega \tau \eta \dot{n}, a$ camel's skin.] 1. A fine cloth made of goat's hair. 2. A similar cloth made of wool mixed with linen or cotton.

Camouflet. [Fr. ; origin very uncertain; see Littré (s.v.).] 1. A puff of smoke in the face. 2. An affront. 3. A small mine established from the galleries of a besieged fortress, in the wall of an enemy's gallery, for the purpose of blowing in the latter.

Camous, Camoused, Camoys. [(?) Cf. L.cāmus,

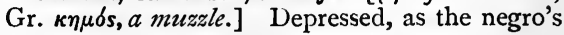
nose.

Campagna, Campagna di Roma. [It.] An undulating, unhealthy, uncultivated plain surrounding Rome, including the larger part of the ancient Latium ; the ground almost entirely volcanic.

Campagnol. [Fr. campagne, country.] (Zool.) A kind of field-mouse, Arvǐcŏla arvāli.j. 
Campanile. The Italian name for a belltower, the structure in Italy being usually or often detached from the church.

Campanology. [L.L. campāna, a bell, and Gr. $\lambda$ oryos, discourse.] Knowledge of bells and of the art of ringing.

Campanulate. (Bot.) Shaped like a bell

[L.L. campanŭla].

Campeachy wood. (Logwood.)

Campeador. [Sp.] A champion.

Camp equipage. Includes the tents, bedding, implements, and utensils used by an army when encamped.

Camp fight. Trial of a cause by duel or combat,

Camphene, Camphilene. An artificial camphor obtained from turpentine.

Camphine. A spirit of turpentine obtained from the Pinus austrālis of the S. States of America. Used for burning in lamps.

Camphire. [Heb. côpher, Gr. кúmpos.] In Song of Sol. i. I4 and iv. I3; a small shrub, Lawsonia inermis, with white and yellow sweetscented flowers; its leaves yielding the henna of the Arabs, used to dye the nails, palms, etc.

Camphor. [Ar. kâfrû.] A solid essential oil, distilled from the wood of the Laurus camphora. Malay, Borneo, Sumatra, or hard $C$., is found in masses in the Dryobălănops arōmatǐca. By some chemists all volatile oils which are concrete at ordinary temperatures are called Camphors.

Campion. (Bot.) The English name for the spec. of the gen. Lychnis, ord. Caryophylläcěæ.

Campo Santo. [It., Holy ficld.] 1. A cemetery ; especially, 2, one for persons of distinction; so called from that of Pisa.

Camus, Camis. A light tunic. [L. cămı̌sia, $a$ night-gown ; whence Fr. chemise.]

Camwood. A red dye-wood, mostly from Sierra Leone; used also in ornamental turnery ; from a leguminous shrub, Baphia nitĭda.

Can, Ken, Kin. [Cf. Gael. cenn, head.] Part of a name, as in Ken-more, Can-tire.

Canaanite. Matt. x. 4 ; a misprint for Cananite ; most likely from Heb. kana, to be zealous, and $=$ Zèlötēs, Luke vi. I5, the Zealot (q.v.).

Canacē. A model woman, daughter of Cambuscan $(q . v$.$) ; owner of the mirror which showed$ the true or false lover, and of the ring which explained the language of birds.

Canada balsam. An oleo-resin from the balm of Gilead fir, Abies balsamea, which grows abundantly in Canada and Northern U.S. It is used for making colourless varnish.

Canada clergy reserves. One-seventh of all lands in Upper C., and of those of the townships in Lower C. ; with which in 1853 , by 16 Vict., the Legislature was empowered absolutely to deal, life-interests being untouched.

Canaille. [Fr., mob, rabble, It. canaglia, lit. a pack of dogs.] The likeness in form and meaning to $\mathrm{L}$. cănălícŏlæ is accidental.

Canakin. [Dim. of can.] A cup, or small can. Canaliculate. (Bot. and Anat.) Channelled, having a small passage or furroze [L. cănālǐcŭlus].

Canard. [Fr., a duck.] A French satirist of the last century told a story of a number of ducks which devoured their companions as each was killed, until one only remained, with the flesh of all in his stomach. This story, made up in ridicule of travellers' tales, was revived more recently for the same purpose in America, and the word has thus come to denote an extravagant tale or hoax.

Canariensis. (Bot.) A common garden name for Canary creeper (Tropæŏlum peregrinum). Ord. Geraniaceæ.

Canaries. A lively dance of former times, in $\frac{3}{8}$ time, imported, it is said, from the Canary Islands; though probably it had been exported thither previously from Normandy by Bethencourt, who invaded them in the fourteenth century (Eng. Cyclop.). To canary is an obsolete verb.

Canary, or Sack. Wine made in the C. Islands.

Canary wood. (From the colour.) A light S.-American wood used for cabinet-work, etc.

Canaster. [Sp. canasta, a basket.] A coarse, dry smoking tobacco, originally brought from $\mathbf{S}$. America in rush baskets.

Can-buoys. (Naut.) Large, cone-shaped buoys over shoals, sunken vessels, etc.

Cancelier. [Fr. chanceler, to stagger, reel.] To waver in flight ; to turn upon the wing; said of a hawk.

Cancellate. [L. cancelli, plu., railings, a lattice.] (Bot.) Consisting of a network of veins.

Cancelled ticket. (Naut.) One with the corner cut off for bad conduct, still valid, as showing the time of a sailor's past services.

Cancelli. [L.] 1. Rails in a basilica separating the court from the audience; whence the Eng. chancel. 2. A gate of rails or lattice-work. (Carceres.)

Candēlābrum. [L.] Candlestick or lampholder.

Candent. [L. candentem, glowing with heat.] In a state of white heat.

Canderos. A clear white Indian resin.

Candidates. [L. candidātus, clothed in zuhite.] Applicants for public offices in Rome ; so called either from their then wearing a white toga or putting white marks on their dress.

Candide. Hero of Voltaire's Candide, a cynical optimist indifferent to accumulated misfortunes.

Candleberry. (Bayberry.)

Candlemas Day. The festival of Purification of B.V. Mary; numerous candles having been used, in reference (?) to Luke ii. 32. (Hypapante.)

Candle-waster. One who keeps late hours, as spendthrift or as student.

Candock. A weed that grows in rivers.Johnson.

Candour, Mrs. In Sheridan's School for Scandal, a slanderous gossip, "with a very gross affectation of good nature and benevolence."

Candroy. A machine used in preparing cotton cloths for printing.

Candy. 1. A weight of 20 maunds, either in Madras or Bombay. 2. A dry measure of $24 \frac{1}{2}$ English bushels.

Canella. [Fr. cannelli, dim. of canne, cant.] (Bot.) White cinnamon, or Whitewood bark, the 
bark of the young branches of C. alba, of W. Indies and S. America; stomachic and stimulant tonic.

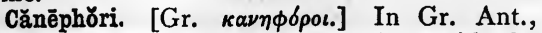
figures bearing on their heads baskets with the materials for sacrifice. (Caryatides.)

Canescent. [L. cānesco, I grow white.] Growing white.

Cano-sugar. The non-fermenting sweet element in cane, maple, beet-root, etc. (Glucose; Sucrose.)

Cano-trash. The dry splinters, used as fuel, into which sugar-canes are turned after their third compression, in sugar-making ; called also Bagasse, from Sp. bagazo, a residuum.

Cangica wood. A yellowish-brown S.-American wood, used for cabinet-work, etc.

Canicular [L. cănīcula, belonging to the $D o g$ star] period; C. Jear. The C: year was the fixed year of the Egyptians, of $365 \frac{1}{4}$ days, reckoned from one heliacal rising of the Dogstar to another, as distinguished from the wandering year of 365 days, by which they regulated their festivals. (For $C$. period, vide Sothic period.)

Canidia. [L.] A sorceress in Horace.

Canister-shot. Cylindical tin cases containing a number of shot which scatter as they are discharged from the gun.

Canker. [L. cancer, crab.] 1. In the horse's foot, a fungoid growth between the hoof and the sensitive part. 2. In the dog's ear, inflammation of the lining membrane. 3. (Bot.) (Bedeguar.)

Canker-worm. [Heb. yeleg.] (Bibl.) Larva of locust.

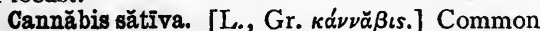
hemp.

Cannel-coal, i.e. candle-coal. Coal of a kind not lustrous, nor soiling the fingers ; compact, breaking conchoidally; burning readily, giving out a clear yellow flame, without melting.

Cannibals. Devourers of human flesh, called by the Greeks Anthrōpŏphăgoi. The origin of the word is uncertain : it may be a corruption of the name Caribbee.

Cannon or Shank of a horse's leg. [L. canna, $a$ reed.] The front and largest bone of the three between the knee and the fetlock, the two smaller and hinder bones being splints.

Cannon-ball tree. Couroupita Guiancensis. A Trop. American tree. Ord. Myrtācěæ; so called from appearance of fruit.

Cannuck, Cunnick, Canuck. [Amer.] Nickname for a Canadian.

Canon. [Gr. $\kappa \alpha \nu \omega \dot{\nu}, a$ rule.] 1. Any rule or principle, as the canons of criticism. 2. Laws and ordinances of ecclesiastical Councils ; whence the C. law made up of them. 3. The C. of Scripture, the authorized catalogue of the sacred books. 4. In cathedral and collegiate churches, one who performs certain services in the church, and is possessed of certain revenues connected with them. 5. In Music, a perpetual fugue, the production of harmony by the parts, each of them taking the same melody, but beginning it at separate times. Tallis's Evening Hymn is a C. of two parts. 6. In Printing, a large type, seldom used except in posting-bills. 7. (Math.) A general rule or formula for the solution of mathe. matical questions. 8. A table of the numerical values of sines and tangents of angles was called the Trigonometrical $C$. 9. The solar table constructed by Hipparchus to show the place of the sun with respect to the fixed stars was called the $\mathrm{C}$.

Cañon. [Sp. ; one of very many words meaning a hollow, or tube-like form; e.g. Gr. кá $\nu \nu \alpha, \mathrm{L}$. canna, cane.] A deep gorge or ravine between high and steep banks worn by a stream of water. The term is in common use in the territories of the U.S. bordering on Mexico.

Canonical hours. The name given to the seven hours for devotion, imposed on the clergy of the Latin Church by Canon law, namely, matins, with lauds, prime, terce, sext, none, vespers, compline. (Breviary.)

Canonization [Eccl. L. cănōn, a list or roll], which succeeds beatification (q.v.), enrols a deceased person among the saints.

Canon Law. Regulates the discipline of the Church of Rome; being made up of various books of Decretals (q.v.), decrees of popes, and Canons of Councils.

Cant, Cantle. [Fr. chanteau, L.L. cantellus.] 1. A corner, an edge. 2. The hind bow of a saddle. 3. Verb, (I) to raise, or rise, on the edge or corner, e.g. to decant ; (2) to cut off the angle of a square building; (3) to edge in, put a border ; $c f$. Ger. kante, corner, border.

Cantab. One who belongs or has belonged to the University of Cambridge [L. Cantabrigiensis].

Cantābit văcuus cōram latrōne viātor. [L.] A traveller with empty pockets will whistle before the highwayman; poor folks have no fear of thieves, burglars, etc.

Cantaliver. (Arch.) A block or bracket supporting a balcony or cornice.

Cantaloupe, or musk-melon. Cultivated at the papal villa of Cantaluppo.

Cantāta. [It., L. canto, $I$ sing.] Properly a short lyric drama, with airs, recitatives, choruses; e.g. Purcell's Mad Bess; but the word is now used indefinitely.

Canteen. [Fr. cantine, from L. quintāna, a camp market (Littré).] 1. Sutler's establishment provided in barracks for the use of the soldiers. 2. A vessel for containing food, attached to a soldier's knapsack. 3. A chest for holding the different table requisites of an officer.

Cantera. (Naut.) A Spanish fishing-boat.

Canterbury. A low wooden stand with divisions for holding music, etc.

Canterbury gallop, or Canter. A slow gallop, like that of the pilgrims, ambling to Canterbury. (Canter, if from cantērius, a gelding, would have appeared in continental languages.)

Canterbury Tales. By Chaucer (died I400); are told, each of them, by some one of a party of pilgrims at the Tabard Inn, Southwark, on their way to the shrine of St. Thomas of Canterbury; and give various pictures of English life of the time. 


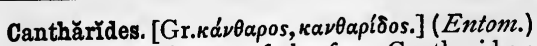
A coleopterous insect, of the fam. Cantharidæ; called also Spanish fly. The blister-fly $(q . v$. of the apothecary.

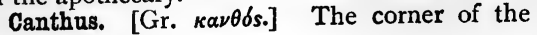
eye.

Canticle. [L. canticŭlum, dim. of cantǐcum, a song.] A name used to denote the songs or psalms introduced into the Order for Morning and Evening Prayers in the Prayer-book. The Song of Solomon is sometimes spoken of as Canticles.

Canting heraldry. A coat of arms or motto, containing a pun on the name of the bearer; as the device of a broken spear for Brakspeare, or the motto "Ver non semper viret" for Vernon.

Cantire. Gael. = headland. (Can.)

Canto fermo. (Cantus firmus.)

Canton. [Fr.] (Her.) A square figure, occupying one-third part of the chief, generally on the dexter side.

Cantonments. [Fr. canton, a district.] (Mil.) Permanent station, where troops of all arms are massed together away from the native inhabitants.

Cantoon. Fustian, with a fine cord visible on one side, and a saling surface of yarns on the other.

Cantōris side. [L., of the chanter.] In a cathedral, that of the precentor ; opposed to that of the dean [Děcāni], who is generally on the south.

Cantor Lectures. (Dr. C., died I861.) Three courses of six each, in connexion with Society of Arts, covering a wide range of subjects.

Cantrap. A Scand. word, denoting a spell or incantation ; hence spiteful mischief.

Cantred, Cantref. [Welsh.] A district of a hundred [cant] villages [tref, a village].

Cantus firmus [L.], Canto fermo [It.]. (Music.) 1. In chanting, the chief melody, the air; which, now taken by the sopranos, was once sung by the tenors. 2. The subject or theme of counterpoint.

Cantus plānus. (Plain song.)

Cantwara. [Cant-, a British tribal name; wara, Teut., host.] Man of Kent.

Cānŭla. [L. cannŭla, dim. of canna, a reed.] In Surgery, a metallic tube; a portion of the surgical instrument trochar and canula. (Aspiration.)

Canzone. [It., L. cantionem, $a$ singing.] A kind of lyric poem, adopted with alterations from the poetry of the troubadours in Italy, in the thirteenth century; divided, like the Greek strophic ode, into stanzas. The dim. canzonet, a kind of $\mathrm{C}$. in short verses, a favourite form with the poets of the fifteenth century. Canzonet also means $a$ short song; sometimes, like the Neapolitan and Sicilian C., a rondeau.

Caoutchouo. [Native S.-Amer. name.] Indiarubber, gum elastic, a vegetable compound found in all plants with a milky juice, especially in the moraceous, euphorbiaceous, arto-carpaceous, and others. Fìcus ělastǐca of India, Siphönia ĕlastǐca of S. America, yield it largely.

Cap. ( $\Lambda^{\top}$ aut.) A strong piece of timber or iron fitted to a masthead (having two holes in it, one round and the other square) to confine an upper mast to a lower.

Capability Brown. A successful landscape gardener of last century; much given to using the word $\mathrm{C}$.

Capacity. [L. capācĭtatem.] The solid contents of a body. The Thermal $C$. of a substance is the number of units of heat required to raise a unit weight of the substance one degree of tem. perature.

Cap-à-pie. [O.Fr. (de) cap a pie, from head to foot.] Said of a man when fully armed.

Caparison. [O.Fr. caparason, from Sp. caparazon, L.L. caparo, hood.] A cloth over the saddle of a horse, often richly ornamented.

Capax dŏli. [L.] Capable of deceit. (Callidity.)

Capel Court. Where the members of the Stock Exchange meet, is, by meton., often used as = Stock Exchange.

Capelmeister, Kapellmeister, Maestro di Capella. [Chapel-master.] Director, often composer, of music, and choir-trainer in a royal or ducal chapel; a post of honour and importance. Palestrina, Handel, Bach, Haydn, Mendelssohn, and other great musicians were $C$.

Capercailzie, Capercali, Caperkally. [Horse of the woods (Pennant).] (Ornith.) Wood-grouse, cock of the wood. Male, three feet long ; wings, from tip to tip, four feet. Female much smaller, and with plainer plumage. N. parts of Europe and Asia. Lately reintroduced into Scotland. Tetrăo ūrŏgallus, fam. Tetrăōnĭdæ, ord. Gallīnæ.

Cape, To. (Naut.) To keep a course; e.g. How does she $C$.? i.q. How is her head? [L. căput].

Capias. [L.] You are to seize; writ of arrest for debt. (Mesne process.)

Capias ad satisfaciendum, commonly called Ca. sa. A writ of execution taken out by a plaintiff after having recovered judgment against the defendant, whom the sheriff is therein directed to keep and bring on a day named to Westminster, that the plaintiff may have satisfac. tion for his demand; "issuable now in a very limited class of cases, viz. where imprisonment for debt or final judgment is still permitted " (Brown, Law Dictionary).

Capillaire. Syrup of maidenhair fern, prepared from Adiantum căpillus Věněris, and also from the fragrant root-stock of an American spec., Adiantum pědātum; and flavoured with orange flowers.

Capillary [L. căpillāris, pertaining to the hair, capillus] action; C. attraction; C. repulsion; C. tubes. Tubes of very fine bore are called $C$.tubes. When a $C$. tube of glass is dipped into water, it is found that the water rises in the tube above the level at which it rests outside; the force of adhesion of water to the glass being greater than the cohesion of the parts of the water to each other. The like is true of other liquids and tubes, provided the liquid can wet the tube. These are instances of $C$. attraction. That term is, however, applied more generally to all cases in which the surface of the liquid is raised above its general level where it is in contact with a 
substance which it can wet. If the cohesion of the parts of the liquid to each other exceeds the force of adhesion of the liquid to the solid-as in the case of mercury and glass-there is depression instead of elevation; and in this case there is said to be $C$. repulsion. The term C. action is $=\mathrm{C}$. attraction or repulsion.

Capillary vessels. 1. (Anat.) A network of minute vessels, connecting the veins and the arteries. 2. C. leaves (Bot.), hair-like; e.g. fennel.

Căpĭta aut nāvim. [L.] With Roman boys, = head or tail; lit. heads of the two-faced Janus on one side of the ās, or ship on the other.

Capital. (Mil.) An imaginary line bisecting the salient angle formed by the two faces of any fortification.

Capite censi. [L., reckoned by the head.] Roman citizens, who from poverty paid no taxes. (Proletarians.)

Capite, Tenure in. (Jeg.) Tenure in chicf, of lands held directly from the Crown; they are now held in common socage.

Capitol. [L. capitollium, the head of the city.] In ancient Rome, the great temple of Jupiter on the Tarpeian Mount.

Capitularies. [L. căpitŭla, little chapters ; articles of instruction from bishops to their clergy.] A term applied to ordinances issued by the Frankish kings, many of them concerned with the government of the Church.

Capitŭlum. [L., a little head.] (Bot.) The head of flowers in a composite ; e.g. the daisy.

Capnomancy. With the ancients, divination

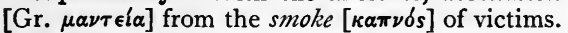
Capoc. Cotton too short and fine to spin, used as cotton wool.

Capoch, Capouch. [Fr. capuce.] 1. A monk's hood. 2. The hood of a clerk.

Capo di Monte China Manufactory. Formerly near Naples. Articles were made in coloured relief (1736-1821). The moulds and marks are now in use at $\mathrm{La}$ Doccia, near Florence.

Caponniere. [Fr., from Sp. caponnera, $a$ fattening-coop.] (Mil.) Covered passage protected by stockade work and earth, sunk across the dry ditch of a fortification, which is also utilized for its defence.

Capote. [Fr.] A long cloak with a hood. [Dim. of Fr. cape, a cape, cloak; this being, according to Littré, the Picard pronunciation of chape, It. cappa, L.L. capa, a cope, from căpere, as containing the whole body.]

Cappadine. The last part of the silk which cannot be wound off the cocoon.

Cappagh brown. (Geol.) A bituminous earth, found at Cappagh, near Cork. It contains oxide of manganese and iron, and is used as a pigment in oil-painting.

Cap-paper. 1. A coarse brown paper, used for making caps to wrap sugar, etc. 2. Foolscap. Capped hock, or elbow. (Spavin.)

Capreolate. [L. caprěŏlus, a tendril.] (Bot.) Having tendrils, or spiral claspers, for support.

Capriccio [It., freak, fancy], or Fantasia. A musical piece, fanciful and unrestrained in subject and treatment.

\section{Capricorn. (Zodiao.)}

Caprification. [L. căprĭfîcatĭo (Pliny).] 1. In the Levant, the maturation of figs, by placing over them branches of the wild fig, caprificus, on which are insects, which, puncturing the fruit, are said to hasten the ripening. 2 . The shakings of male flowers from wild dates over the cultivated palm. (For fertilization, see Herod., i. 193.)

Caprifoils. The honeysuckle family, Caprĭfŏliācěæ, Lonicerěæ.

Caprifole. [O.Fr.] The wild climbing vine.

Capriole. [L. căprěŏlus, $a$ wild goat.] A leap of a horse from all fours at once, upwards only, with a kick of the hind legs ; called by Australians, bucking.

Capstan, Cabestan, Capstern, etc. [Perhaps from L. capistrum, Sp. cabestro, L. capere, to seize, hold.] (Naut.) A machine for lifting the anchor, usually a flat-headed cylinder revolving on an iron pin, with square holes cut in the side of its head, into which bars are inserted, radiating from the centre, and so giving great leverage. Capsule. [L. capsŭla, a small box or chest.] 1. (Bot.) Any dry, many-seeded fruit opening by valves or pores, as foxglove, poppy. 2 . (Physiol.) Any membranous, bag-like expansion, investing a part. 3. (Chem.) A small saucer, used for melting ores, etc. 4. Metallic covering for the corks of bottles.

Captain, Navy. (Rank.)

Captain's cloak. The thirty-sixth Article of War; so called from its sweeping character.

Captation. [L. captātio, -nem, a catching at.] The act or the disposition of courting favour or popularity.

Caption. [L. captio, -nem, a taking.] (Leg.) That part of an instrument which shows its authority.

\section{Capncha. (Capoch.)}

Capuchin Friars. A seceding order of Fran. ciscans, established by Clement VII. ; when the pointed cowl (Capoch) was added to the F, habit.

Capulet. In a horse. (Spavin.)

Capulets and Montagues. In Shakespeare's play of Romeo and Fuliet, rival houses of nobles of Verona.

Caput Jejünii. [L., head of the fast.] A name for Ash Wednesday, and sometimes for the Wednesday preceding.

Caput mortuum. [L., dead head.] 1. In Hist., this word denotes the residuum of a traditional narrative after all the supernatural or extraordinary incidents have been cast aside. What remains may be possible or likely, but rests on no evidence. (Euemerism.) 2. With the old chemists, the inert residue of the distillation and sublimation of different substances : its symbol being a death's-head and cross bones.

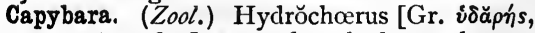
watery, xoîpos, hog], water-hog, the largest known existing rodent; three to four feet long; the water-horse (i.e. D. water-haas, zuater-hare) of Demarara. Banks of rivers in Trop. S. America. Fam. Cavǐldæ, ord. Rōdentia.

Caqueux. (Cagots.) 
Car-. [Cymr., city, fortified post.] Part of names, as in Car-lisle. (Caer-.)

Carabas, The Marquis of. The title assumed by the young miller in Puss in Boots; hence any arrogant, pretentious parvenu.

Carabine. (Carbine.)

Cáracal. [Turk., black-ear.] (Zool.) Spec. of (or (?) gen. allied to) lynx, as large as a bull terrier; reddish brown. S. Asia and Africa. Cáracal mělănōtis, fam. Fēlŭdæ, ord. Carnǐvŏra.

Caracana. (Ornith.) Carrion hawks. Trop. America. Pandion (Cuvier). Gen. Pŏly̆bŏrĭnæ

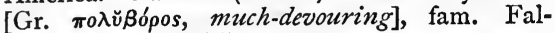
cōnĭdæ, ord. Accǐpitres.

Carack, Carrak, or Carrick. (Galleon.)

Caraool. 1. A half-turn to right or left, of a horseman. 2. A winding staircase. [Sp. carăcol means both of these ; also a snail.]

Caracoli. An alloy of gold, silver, and copper, used for cheap jewellery.

Caracora, or Caracol. (Naut.) Of Borneo and Eastern isles, a kind of prahu (q.v.).

Caractères de civilité. [Fr.] In Printing, the cursive characters used in the sixteenth century, by the printer Granjon, of Lyons.

Carafe. [Fr., from It. caraffa, a decanter.] A water-bottle.

Caragheen. (Carrageen.)

Caraites. A Jewish sect, which adheres to the letter of Scripture, and rejects the rabbinical interpretations and the Cabala.

Carambole. [Fr.] A cannon in billiards; origin unknown.

Caramel. [Sp. caramello.] The brown mass which cane-sugar becomes at $420^{\circ}$ heat ; used to colour sugar, coffee, malt, spirits, etc.

Caramoussal. (Naut.) A Turkish merchant ship, with pink stern. (Pink.)

Carapace. [From Sp. carapacho; another form of the Catal. carabassa, a calabash.] (Zool.) Upper shell of tortoises and turtles, of lobsters, etc., and of certain infūsōria. (Chelonidæ.)

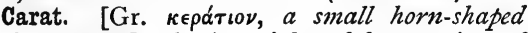
seed, a carat.] 1. A weight of four grains of barley ; the jeweller's C. at Vienna is 0.206085 grammes $=3.19$ grains. In London, for diamonds, the ounce troy is divided into $15 \mathbf{I}_{2}^{\frac{1}{2}}$ carats, making a C. $3 \cdot 17$ grains. 2. As applied to gold, the ounce is divided into $24 \mathrm{C}$., and if of the twenty-four parts by weight, two, three, four, etc., parts are alloy, the gold is said to be twenty-two, twenty-one, twenty, etc., carats fine.

Carăvan. A Persian word, denoting a company of travellers associated for self-defence in crossing deserts or other dangerous regions. Four regular caravans yearly visit $\mathrm{Mecca}$.

Caravansary, properly Caravanserai. An unfurnished public building for the lodgment of a caravan on its journey.

Caravel, Caravela. (Carvel.)

Carbasse, or Karbaty. A Lapland boat.

Carbazotic acid. (Carbon and azote.) (Chem.) Picric acid (q.v.).

Carbine. [Fr. carabine, from It. carabina.] Short musket used by cavalry and artillerymen. One regiment of English cavalry retains the name Carbiniers, but the term has lost its former acceptation.

Carbolio acid. (Chem.) An oily liquid obtained from coal-tar, used as a disinfectant.

Carbon. [L. carbo, a coal.] (Geol.) A nonmetallic element, existing in a pure state as diamond or charcoal.

Carbonaceous rocks. (Geol.) Containing fossil carbon largely; e.g. shales of central Devonshire.

Carbonādo. [Sp., from L. carbōnem, coal, charcoal.] Meat cut across for broiling.

Carbonāri. [It., from L. carbo, -nem, charcoal.] A secret association first instituted amongst the charcoal-burners of Germany, who found it necessary in the vast forests of that country to aid one another against robbers and enemies by conventional signs known only to themselves, their oath being called "The Faith of Charcoalburners." In the early part of the present century the association, having spread to France and the Netherlands, was extended into Italy, where its object was the expulsion of the Austrians and union of the people of the peninsula into one state, an object which has been attained by the establishment of the Italian kingdom.

Carbōne nŏtāre. [L.] To mark with charcoal. (Creta notatus.)

Carbonio acid. (Chem.) Dioxide of carbon ; a suffocating gas. Its salts are called carbonates.

Carboniferous [coal-bearing] system (Geol.) $=$

Palæozoic strata, resting upon the Devonian, and covered by the Permian; a vast series of beds of sandstone, limestone, shale, and coal.

Carboy. A large glass bottle, cased in wicker, for holding vitriol, etc. ; $c f$. Fr. carafe, Sp. carabba, etc. ; probably an Eastern word.

Carburation. The uniting of anything with carbon. (Blistered steel.)

Carburet, Carbide. (Chem.) A compound of carbon with another element.

Carcanet. [Fr. carcan, an iron collar.] A collar of jewels.

Carcass. [Fr. carcasse, from It. carcassa.] (Mil.) Shell filled with a highly inflammable composition, which, on being fired against buildings, speedily ignites them through three holes in the metal.

Carcass of a ship. (Naut.) The keel, stem and stern posts, and the ribs.

Carcelage. [L. carcer, a prison.] Prison fees. - Johnson.

Carcel lamp. (From the inventor.) A lamp in which the oil is raised through tubes by clockwork

Carcĕres. [L. plu. of carcer, prison.] In Roman race-course [circus], stalls with gates [cancelli], whence the chariots started.

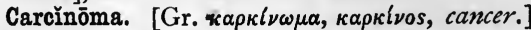
(Med.) A variety of cancer; a form of malignant disease.

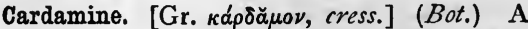
gen. of Crucifêræ. C. prātensis, the cuckoo flower, or ladies' smock, a common spring meadow flower.

Cardămoms. [Gr. к $\alpha \rho \delta \alpha \mu \omega \mu o \nu$.$] (Bot.) The$ aromatic capsules and seeds of several kinds of 
amōmum, especially of Amomum (or Eleltavia) cardamomum, native of the Malabar coast.

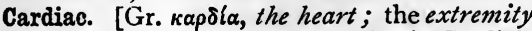
of the stomach, nearest the heart.] 1. Cordial, invigorating. 2. Relating to the heart. 3. (Med.) Plexus, a system of ganglia connected with the heart and great blood-vessels.

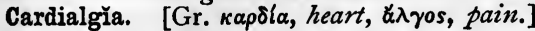
(Med.) Neuralgic affection of heart.

Cardinal. [L. cardinālis, from cardinnem, $a$ hinge.] (Eccl. Hist.) The title of the seven bishops of Rome, and of the clergy of the twenty-eight principal churches of the city, who composed the College of Cardinals. This college now has generally seventy members.

Cardinal bird. (Ornith.) Also called Cardinal grosbeak, a sub-fam. of the Fringillidæ.

Cardinal numbers; C. points; C. signs; C. winds. The numbers which answer the question, "How many ?" i.e. one, two, three, etc., are $C$. numbers. The $C$. points of the horizon are the N., S., E., and W. points ; the two former are the points in which the meridian cuts the horizon near the north and south poles of the heavens respectively; the two latter those in which the prime vertical cuts the horizon near the points where the sun rises and sets respectively. The C. signs of the Zodiac are Aries, Libra, Cancer, and Capricorn. The $C$. winds are those which blow from the $C$. points of the horizon.

Cardinal virtues. Temperance, fortitude, justice, prudence.

Carding. [L. cardŭus, a thistle.] Combing out wool or flax to prepare them for spinning.

Carduus benedictus. (Blessed thistle.)

Careen, To. [L. cărina, keel.] (Naut.) To incline to one side, so as to show the bottom.

Carême. [Fr., O.Fr. Quaresme, L. Quadrāgēsĭma.] The forty days of Lent ; hence Lent.

Carent vate sacro. [L.] They are without a sacred bard (Horace). No poet has sung their praises and made their name live.

Cārex. [L., sedge.] (Bot.) A gen. of grassy, rush-like plants, of which there are many native spec. in Britain ; ord. Cypēracěæ.

Carfax. As at Oxford, a place where four roads meet [L. quatuor furcas].

Cargason. [Sp. cargazon.] Sometimes used as $=$ cargo.

Caribou. [Native name.] An American var. of the reindeer. Tarandus, fam. Cervǐdæ, ord. Ungŭlāta.

Căries. [L.] Destructive softening of bone

Carillon. Chimes played by instruments or finger-keys ; properly on four bells [L.L. quadriliōnem].

Cărina. [L., $a$ keel.] The union in a keellike form of the two oblique front petals of a Papilionaceous flower; e.g. sweet-pea.

Cărīnātæ. [L. cărīna, keel.] (Ornith.) Birds with a keel to their breastbone, flying birds.

Cariole, Carriole. [Fr. carriole, L. carrus, $a$ cart.] A small light open carriage.

Cark. [A.S. carc, care, cearig, anxious, fearful.] Anxious care, worry.

Carline, Caroline. A silver Italian coin, named from Carlo (Charles) VI. of Naples.
Carlines. [Fr. carlingue, It. carlinga.] (Naut.) Small timbers let into the beams, and joining them. On the $C$. and athwart the vessel are placed ledges, to which the deck planking is nailed. Carline knees are what would be beams if a hatchway did not intervene. They support the deck.

Carline thistle. (Bot.) Carlinna vulgāris, ord. Compošrtæ; common in chalky parts of Great Britain. (Cārŏlus, i.e. Charlemagne, to whom an angel is said to have shown the root, as a remedy for plague in his army.)

Carlisle table, or Table of mortality. (Life assurance.)

Carlock. (Charlock.)

Carlovingian kings. (Carolingian kings.)

Carmagnole. (C., in Piedmont, home of the Savoyard players.) 1. A song and dance, popular in the French Revolution; hence, 2, a dress worn by the Jacobins. 3. Turgid and fanatical reports of French successes in the field.

Carmelites, White Friars. Hermits gathered for safety in the twelfth century to Mount C. Albert, Patriarch of Jerusalem, gave them rules, confirmed by Honorius III., A.D. 1224. They left the Holy Land after peace between Frederick II. and the Saracens. (Orders, Mendicant.)

Carminatives. (Med.) Allay, as if by a charm [L. carmen], spasmodic pain in the bowels, and expel flatus.

Carmine. [L.L. carmesinus, from Ar. karmesi the kermes insect.] A red pigment prepared from the cochineal insect, chiefly used in watercolour painting.

Carnation. [L. căro, carnis, flesh.] The flesh tint in painting.

Carneian Apollo. The name for Apollo as worshipped at Sparta, probably connected with that of Ashtaroth Karnaim, or the horned Astarte, of the Phœnician tribes.

Carnelian. (Chalcedony.)

Carnify. To make flesh [L. carnem facěre] by assimilation of food; L. carnifíco being to execute.

Carnival, Carnaval. [In Med. L. carnis lěvāmen, carnělěvāmen, solace of the flesh.] A feast before the fast of Lent.

Carnivŏra. [L. carnem, flesh, voro, $I$ devour.] Flesh-eaters, an ord. of Mammals comprising Pinnǐgrăda (seals and walruses), Plantĭgrằda (as bears), and Diğitı̆grăda (as cats and dogs).

Carnosity. (Med.) A fleshy overgrowth.

Carob. (Algaroba.)

Caroche. [Fr. carrosse, It. carrozza.] A carriage, coach.

Carol, Carolle, was originally a dance [L. chǒrēŏla, dim. of chŏrēa]; then any song of rejoicing, especially a Christmas hymn. Wedgwood prefers cŏrolla, dim. of cŏrōna, $=$ a round dance ; quoting a "karole" of stones, i.e. a circuit, from Robert of Brunne.

Caroline. (Carline.)

Carolingian kings. (Hist.) The dynasty of Frank kings; so called from Charles the Great (Charlemagne), son of Pepin.

Cārŏlus. [L., darling, dim. of cārus, dear; hence Charles.] An old coin worth 23s. 
Caroteel. A large cask, in which dried fruits, etc., are packed.

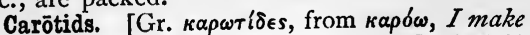
drowesy, as compression of C. does.] (Med.) Two great arteries of the neck, which carry blood to the head.

Carous. (Naut.) A kind of gallery in ancient ships, fitted on a pivot, and raised by ropes and pulleys, so as to be swung out-board, and to render it easier to board another vessel.

Carpal. Pertaining to the wrist [L. carpus].

Carpe diem. [L.] Enjoy the day; use the present time.

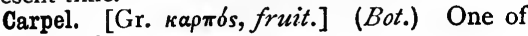
the cells of an ovary.

Carpocratians. In Eccl. Hist., the followers of Carpocrătes, who is called by Eusebius the father of the Gnostic heresy. His system was based on the assertion that men cannot free themselves from the power of evil except by compliance with evil; in other words, that the only road to righteousness is through iniquity.

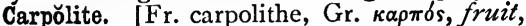
$\lambda$ ioos, stone.] (Geol.) Petrified fruit.

Carpology. That part of botany which relates to fruit $[\kappa \alpha \rho \pi \delta s]$, i.e. to the structure of seeds and seed-vessels.

Carrageen, Carageen, Irish moss. Chondrus crispus, a seaweed-not a moss-on the rocky shores of most parts of Europe, and of Eastern N. America; yielding a nutritious jelly. Ord. Algæ.

Carrara marble. A white saccharine limestone, from Monte Sagro, near Carrara; about sixty miles S.W. of Modena.

Carreau. [Fr.] Heavy square-headed arrow, which, with cour [heart, i.e. courage], pique [pike], and tréfle [trefoil], are the originals of the diamond, heart, spade, and club of playing cards.

Carriage, I Sam. xvii. 22, Gr. $\sigma \kappa \epsilon u ́ \eta$ in LXX.,

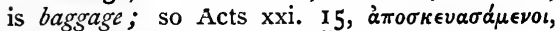
"we took up our carriages."

Carrick. [Erse carraig, crag, rock.] Part of Gadhelic names, as in Carrick-fergus.

Carrière. [Fr.] Career, course.

Carronade. (First made at the Carron Iron Works, Scotland.) (Mil.) Short, light iron gun without trunnions, and having a chamber with slight windage. They are fastened by a loop underneath.

Carron oil, Linseed oil. Equal portions of lime-water and of linseed oil, shaken together ; in use for nearly a century for burns, etc., at the C. Works.

Carrousels. [Fr.] A kind of knightly exercise, common in all countries of Europe till the beginning of the eighteenth century; in imitation of the tournament.

Carrows. In Ireland, needy strolling gamesters.

Carry away, To. (Naut.) To break, as "a rope has carried away," i.e. has broken. To carry on, to carry all sail, even if dangerous.

Carse. [Cymr. kors, fen.] In Scotland, low lands adjoining rivers; sometimes only the level alluvial land; sometimes used to include undulations at a greater distance.
Carstone. A hard ferruginous Cretaceous sandstone in the E. counties.

Carte, $\mathbf{A}$ la. ( $\mathbf{A}$ la carte.)

Carte blanche. [Fr., white card.] 1. A blank paper signed, and given to another to fill up as he likes; and so, 2, unconditional authority.

Carte de visite. [Fr., visiting card.] Commonly used to denote photographic portraits of the size of a visiting card.

Cartel. [Fr. cartel, from It. cartello.] 1. Agreement between hostile forces for the exchange of prisoners. 2. A challenge. 3. A ship bearing a flag of truce, or carrying prisoners of war for exchange.

Cartesian geometry. (Co-ordinates.)

Cartesian philosophy. That of Des Cartes, French philosopher (born 1596, died 1650).

Carthamine. (Chem.) The colouring matter of safflower [L.L. carthămus]. Alkalies change it from red to yellow.

Carthusians. 1. A very rigid monastic order, founded A.D. 1086, by St. Bruno, at Chartreuse, near Grenoble; one of their houses being Charterhouse, in London, a corr. of Chartreuse. 2. A Carthusian, one educated at Charterhouse. Cartilage. [L. cartilāgo.] Gristle, a smooth elastic solid in the body, softer than bone.

Cartilaginous fishes. [L. cartǐlāgĭnōsus, gristly.] (Chondropterygii.)

Cartoon. [It. cartōne, pasteboard, or large paper.] A sketch or drawing for fresco or tapestry. The word is specially applied to the seven well-known compositions of Raphael, at Hampton Court.

Cartouch. [Fr. cartouche, from L. carta, paper.] 1. (Mil.) Wooden case, with holes for the reception of each charge for any firearm. 2. (Arch.) Oval or oblong enclosure in hieroglyphic inscription. (The It. cartoccio, and its derivative Fr. cartouche, have both meanings.)

Cartulary, Chartulary. [L. chartŭlärium.] A collection of charters belonging to a corporation, civil or eccles., or to a family; very common in the twelfth and thirteenth centuries.

Carucate, or Plough-land. [L. carrūca, some sort of four-wheeled carriage.] An ancient division of land, not fixed, but as much as would employ a plough and team during the year; more or less, according to the soil. Where oxen were used, a similar division was an $O x$-gang or Bovate [L. bǒvem, an ox].

Caruncule. [L. căruncŭla, dim. of căro, flesh.] 1. (Med.) A small fleshy growth, natural or morbid. 2. (Bot.) A wart or protuberance round or near the hilum of a seed.

Carvage, Carve. One hundred acres of plough [L.L. carrūca] -land.

Carvel. A light lateen-rigged ressel, undecked. Spain and Portugal. C.-built ship or boat, one the planks of whose sides do not overlap.

Cary̆ătǐdes. [Gr. карuá $ı \delta є s$.$] In Gr. Arch.,$ figures of women employed instead of columns to support entablatures. Male figures so used were called Telămōněs, and sometimes Persians. (Canephori.)

Caryophyllaceous. (Bot.) A nat. ord. of which 
the type is the common pink (Dianthus caryophyllus): the corolla has five petals, with long

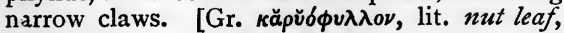
the clove tree.]

Caryopsis. (Bot.) A dry, one-seeded fruit, and so far having the appearance [Gr. o $\psi(s]$ of

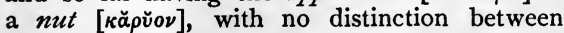
seed-coat and pericarp; e.g. a grain of wheat, barley.

Ca. sa. A writ addressed to sheriff, capias ad satisfaciendum, you are to seize with a view to satisfaction; under which a man was imprisoned until he made satisfaction (for debt).

Cascabel. Reverse end of a cannon; that part which lies behind the base ring.

Cascarilla. An aromatic bark yielded by more than one species of Crŏtōn $(q . v$.$) .$

Case. 1. (Reliquary.) 2. (Naut.) A ship's planking outside; casing ( $\mathrm{I}$ ) the covering of the beams, and (2) a bulkhead round a mast.

Casehardening. The process of converting the outer surface of iron goods into steel, by heating them in charcoal.

Casein, Caseine. The nitrogenous substance contained in milk and cheese [L. casěus]. (Albumen.)

Casemate. [Fr. case-mate, from Sp. casa-mata, casa, a house, mata, to slay.] (Mil.) Vaulted masonry chamber made shell-proof under a rampart for the lodgment of troops and guns.

Caserne. [Fr., barracks, from Sp. caserne.]

Cashew-nut. [Fr. acajou, name of the tree.] The fruit of a tropical tree, Anacardium occidentälě, nat. ord. Anacardiacěæ.

Cashier. 1. [Fr. casser, to annul, L. quassare.] (Mil.) To dismiss an officer from the service with disgrace. 2. [ Fr. caissier, caisse, a case or chest.] A keeper of money.

Cashmere, Cachemere. Textile fabric, made of the downy wool at the roots of the hair of the Thibet goat ; first made in the valley of $\mathrm{C}$., in $\mathrm{N}$. India.

Cask, i.q. Casque. A helmet [probably L. cădiscus, dim. of cădus, an earthen vessel].

Caskets. (Naut.) (Gaskets.)

Cassandra's prophecies. Prophecies which are justified by events, but which no one believes when uttered. The story was that Phœbus Apollo sought to win the love of Cassandra, daughter of Priam, and gave her the gift of prophecy, but, when she resisted him, laid on her the doom that her predictions should be always verified, but never credited. (Paris, Judgment of.)

Cassareep. A condiment made from the juice of the manioc plant. (Cassava.)

Cassation. Reversal of judicial sentence [L. cassāre in Cod. . Fust. being = cassum redděre, to render null and voia].

Cassava, or Manioc. (Bot.) Manihot utilissima; Trop. American plant, ord. Euphorbia. From its large roots, when dried and powdered, a very nourishing food is obtained, of whicn tapioca is a preparation.

Casse paper. [Fr. casser, to break into frag. ments, L. quassāre, to shatter.] In Printing, broken paper, the two outside quires of a ream.
Cassia. Exod. xxx. 24; an ingredient in the anointing oil, aromatic bark of more than one kind of cinnamomum.

Cassimere. [Fr. casimir.] A thin twilled woollen cloth.

Cassinette. [Sp. casinete.] A stuff made of cotton warp and woollen woof.

Cassitěrïěs. [Gr.] Islands which produce tin. Supposed by some to be the Scilly Islands, by others the Isle of Wight, or the coasts of Cornwall.

Cassius, Purple of. (From Cassius, a German of the seventeenth century.) A stannate of gold and tin, used for painting china.

Cassolette. [Fr.] A box with a perforated lid to emit perfumes.

Cassonade. [Fr., from O.Fr. casson, a large chest.] Unrefined sugar (imported in chests).

Cassowary. [Malay kassuwaris.] An ostrichlike bird of the gen. Casuarius. It is a native of Malacca, Java, and the neighbouring islands.

Cast. A tube for conveying metal into a mould.

"Castagnac Capt." Said of states in Turkey ; all patched together.

\section{Castalian spring. (Parnassus.)}

Caste. [Sp. and Port. casta, perhaps from L. castus, pure.] A name denoting the hereditary classes into which the population of Hindustan is divided. According to the book containing the ordinances of Menu, the four castes sprang severally from the mouth, arm, thigh, and foot of Brahma. These are (I) the Brahmans ; (2) the Kshatryas, or warriors ; (3) the Vaisyas, or merchants ; and (4) the Sudras, or tillers of the soil. But the Sudras were properly outcasts, the Aryan conquerors of India belonging to the three castes only.

Castellan, Châtelain. In the Middle Ages, the keeper, warden of a castle [L. castellum, Fr. château].

Castellany. The lordship attached to a castle ; its authority and extent of jurisdiction.

-caster. [L. castra, fortified camp.] Pairt of names of towns in England, as in Don-caster.

Casteth. The steamy air rising from a shaft on winter mornings.

Cast-horse. One which has been pronounced unfit for further retention in the military service.

Castigatory. [L. castigo, I chastise.] (Cucking-stool.)

Castile. Old kingdom of Spain, all except Navarre, Aragon, and Granada, afterwards New C., Old C., two provinces.

Casting. The warping of wood by weather, etc.

Casting accounts. (Naut.) Sea-sickness.

Castle of Indolence. A poem by Thomson; an enchanter entices the unwary into the C. of I., where they lose all strength and good aspirations.

Cast-offs. Landsmen's clothes.

Cast of the lead, To get. (Naut.) (Heave.)

Castor. Beaver; slang for hat; made of fur, before the invention of silk hats.

Castor and Pollux. [Gr. $\kappa \alpha ́ \sigma \tau \omega \rho$ and $\pi 0 \lambda v$ :

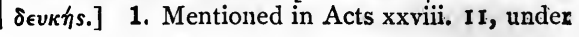


the title Dioskouroi, or the twin sons of Zeus, as the figure-head of a ship. In the heavens, they reappear as the constellation Gemini. In Gr. Myth., they are brothers of Helen. (Paris, Judgment of.) 2. A pair of electric flames seen on the mastheads of vessels, etc., at sea, as being twin lights.

Castor-oil plant. (Bot.) Rĭcinus commūnis (ord. Euphorbiacěæ), much grown lately for its ornamental foliage. The well-known oil is made from the crushed seeds.

Castor ware. Roman pottery made near Castor, Northamptonshire ; ornamented with reliefs usually of a different colour from the ground.

Castrametation. [L. castra, plu., a camp, mētātio, a measuring.] (Mil.) The art of laying out an encampment for troops, on the principle that they may occupy the same frontage as when drawn up in order of battle.

Casual poor. Vagrants and travellers wanting casual shelter and relief.

Casual suffix. (Gram.) Terminations forming cases [L. cāsūs] of nouns.

Casuist. [L. casus, a falling, a condition.] (Theol.) One charged with the decision of cases of conscience.

Casuistry. The science of the treatment of conscience, with its rules and principles in practice. (Cf. Jeremy Taylor, Ductor Dubitantium; Bishop Sanderson, Cases of Conscience.)

Casŭla. (Chasuble.)

Cāsus belli. [L.] $A$ case for war; a sufficient ground for going to war.

Cäsus omissus. [L., omitted case.] (Leg.) Point unprovided for by statute.

Cat. (Naut.) A strong vessel of about 600 tons (usually a collier or timber-ship), built on the lines of a Norwegian, but having a deep waist, narrow stern, projecting quarters, and no ornamental figure-head.

Catabaptists. A word formed on a false analogy [from Gr. $\kappa \alpha \tau \alpha^{\prime}$, against, and $\beta \alpha \pi \tau l \zeta \omega, I$ baptize], and applied to all who deny the necessity of baptism, or oppose that of infants.

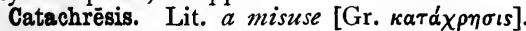
1. In Etym., as alegar, Peterloo, in imitation of vinegar, Waterloo; and oftener, 2, in Rhet., a strained use of words ; as in Hamlet, act iii., " or to take arms against a sea of troubles."

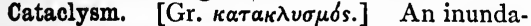
tion; a sudden bursting of waters.

Catacombs. [L.L. catacumbæ ; but the origin of the word is doubtful.] (Arch.) Passages excavated in the soil, with recesses or chambers for graves or bone-houses. At Rome, the catacombs were also used as places for worship during the times of persecution.

Catacoustics. [Coined from Gr. $\kappa a \tau a ́, b a c k$, in

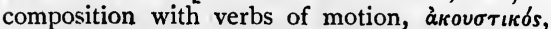
relating to hearing.] The science of reflected sounds, a branch of acoustics (q.v.).

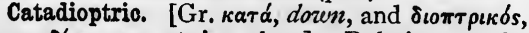

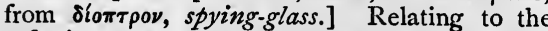
reflexion and refraction of light, as a $\mathrm{C}$. telescope, i.e. a reflecting telescope.

Catafalque. A decorated temporary structure used in funerals; originally a place from which to see a show. [L.L. scadafaltum, from which come also échafaud, and its Eng. equivalent scaffold.] (See Brachet, s.v. "Échafaud.")

Catalan. Belonging to Catalonia. (Naut.) A Spanish fishing-boat.

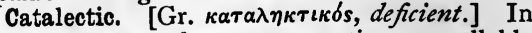
Gr. and L. Prosody, a verse wanting one syllable of its proper length; if wanting two syllables, it was Brachycatalectic. (Acatalectic.)

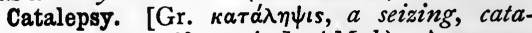
lepsy, a variety of hysteria.] (Med.) A suspension of sensation and volition; the limbs and body remaining as they are placed; a condition of the body resembling death.

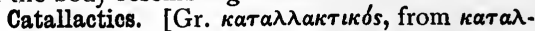
$\lambda \alpha$ a $\sigma \omega, I$ exchange.] The science of exchanges ; political economy.

Catalogue raisonné. [Fr.] List of books, with a short account of the character of their contents.

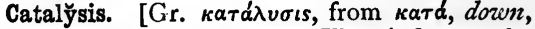
$\lambda v^{\prime} \in \nu$, to loose.] (Chem.) The influence by which (as some chemists have thought) substances are decomposed and recomposed, by the contact of substances which do not enter into actual composition with the original elements, as in the formation of ether from alcohol through sulphuric acid.-Webster.

Catamărán. 1. A kind of raft, of three planks lashed together, the middle serving as a keel, used on the Coromandel Coast, Brazil, W. Indies. 2. Bonaparte's floating batteries, for invading England, were so called. 3. An old hag.

Cat-a-mountain. [Sp. gato montes.] . (Zool.) One of the wild Felidæ, not accurately defined; with Ray, the N.-American lynx.

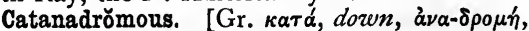
a running $u p$.] A term which has been applied to fish which descend and ascend rivers to and from the sea, as the salmon.

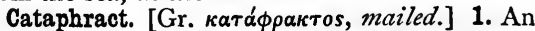
armed horseman. 2. A coat of mail ; armour. Cataphrygians. (Montanists.)

Cataplasm. [Gr. $\kappa \alpha \tau a ́ \pi \lambda \alpha \sigma \mu \alpha$.$] A poultice.$

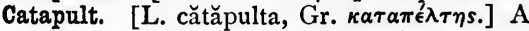
kind of huge cross-bow for throwing stones, javelins, etc. (Ballista.)

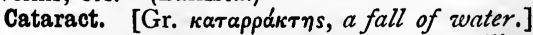
In the eye, an opaque condition of the crystalline lens or its capsule.

Catarrh. [Gr. katáppoos, a flowing down, a catarrh.] A cold, with running from the head.

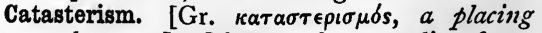
among the stars.] Of Eratosthenes, a list of 475 principal stars according to their constellations ; published about sixty years before the time of Hipparchus.

Catastrŏphē. [Gr., a sudden turn or end.] 1. The change or final event of whatever kind, in a drama or romance. 2. A calamitous change, more or less sudden.

Catastrophic changes. (Geol.)' Those brought about by abrupt, sudden action; opposed to Uniformitarian, the result of steady, continuous action. 


\section{Catastrophist. (Uniformitarian.)}

Catawba. A light, sparkling wine, made near Cincinnati, U.S., from a native grape.

Catch a crab, To. (Naut.) 'lo be knocked backwards by one's oar catching water too much when rowing.

Catchpole. A bailiff, to catch, if necessary, the poll or head [ $c f$. Fr. happe-chaire, catch-flesh].

Catch-work. $(A g r$.$) A series of nearly$ parallel channels on a slope to be irrigated, catching and redistributing the water successively.

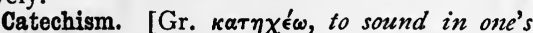
cars.] Instruction by word of mouth, specially by question and answer. In Eccl. Hist., the C. of Nowell, Dean of St. Paul's, taken mainly from that of Poynet, Bishop of Winchester, was approved by Convocation in 1563 . Overall's C. added the questions and answers on the sacraments. The C. known as the Assembly's Larger C., drawn up by the Westminster divines, was approved by the Church of Scotland in 1648 . A shorter form of this $C$. was prepared at the same time.

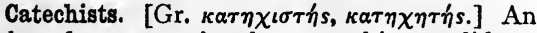
order of men appointed to catechize candidates for baptism in the primitive Christian Church. The catechetical school of Alexandria, to which Origen belonged, was widely celebrated.

Catechu. (Bot.) A watery extract of the bark of Acacia catechu and A. suma, of E. Indies, ord. Legum. containing large quantities of tannin.

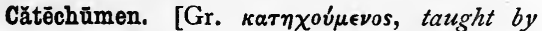
word of mouth.] 1. One who is being instructed in the rudiments of the faith, before baptism; a neophyte. 2. A beginner in any kind of knowledge.

Categorematic. [Gr. $\kappa \alpha \tau \eta \gamma \delta \rho \eta \mu \alpha$, a predicate.] In Logic, any word capable of being employed by itself as a Predicate. Such are all common nouns. (Syncategorematic.)

Categorical proposition. In Logic, a proposition which affirms or denies absolutely the agreement of the Subject with the Predicate, as distinguished from one which does so conditionally or hypothetically.

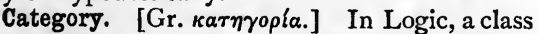
under which a family of predicables may be ranged. The complete number of categories would thus embrace the whole range of human thought and knowledge. Aristotle framed ten categories which may be reduced to four-substance, quality, quantity, relation; but many other schemes have been put forth, none of which, perhaps, can be regarded as final.

Catelectrode. [Gr. $\kappa a \tau \alpha ́$, down, and electrode.] The negative pole of a galvanic battery.

Cătēna. [L., a chain.] A regular uninterrupted succession.

Cătēna Patrum [L., a chain of the Fathers], i.e. a series of passages from the F., elucidating some portion of Scripture, as the Catena Aurea of 'Thomas Aquinas.

Catenary curve. (Geom.) The curve formed by a cord hanging between two points of suspension not in the same vertical line.
Cateran, Caterran [Gael.] = robbers, banditti ; so Loch Katrine, originally Loch Cateran.

Cater-cousin. Cousin in the fourth $[\mathrm{Fr}$. quatre] degree.

Caterpiller. [Heb. khosîl ; I Kings viii. 37, etc.] (Bibl.) Probably locust or its larva.

Caterwauling. [Probably onomatop.] To make a noise like cats, or any other offensive or quarrelsome noise.

Cates. Provisions, delicacies. [Said to be a corr. of delicates, or dainty meats ; more probably from Fr. acheter, to buy, formerly acater, L. ac-capitāre, originally to receive as rent.]

Catfall. (Naut.) A rope used in hoisting the anchor to the cathead.

Cat-fish. (Ichth.) Sea-cat, Wolf-fish, Anarrhichas lupus; carnivorous, naked fish living at the bottom of shallow seas and tidal waters. W. Indies. Gen. Ånarrhichas, fam. Blennĭdæ, ord. Acanthoptěry̆gŭi, sub-class Tělěostěì.

Catgut is made from the intestines of sheep. [ (?) Corr. of cord-gut, or of gut-cord.]

Cathäri. [Gr. katapol, pure.] (Eccl. Hist.) An Eastern sect, probably the same as the Paulicians. (Novatians.)

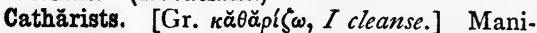
chæans $(q . v$.$) who professed especial purity;$ holding matter to be the source of evil, renouncing marriage, animal food, wine.

Cat-harpings. (Naut.) Ropes keeping the top of the shrouds taut.

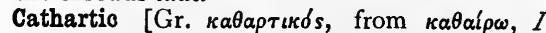
cleanse, purge] remedies purge more mildly;

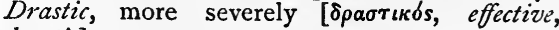
drastic].

Cathay. An old name for China ; Cathay or Khitai being the Mongolian and Russian name for North China; as Chin was the Indian and Portuguese name for South China.

Cathead. (Naut.) A curved timber, which passes through the bulwark forward, and from which the anchor is suspended (when being hauled up) clear of the vessel's bows.

Cathedrals of the New Foundation. The cathedral churches of sees founded by Henry VIII., from funds obtained by the suppression of the monasteries, the cathedrals of the sees already established being called henceforth the C. of the Old Foundation. The new sees were those of Westminster, Oxford, Peterborough, Bristol, Gloucester, and Chester.

Cathedrals of the Old Foundation. (Cathedrals of the New Foundation.)

Catherine wheel, or Rose window (q.v.). St. C., an Alexandrian of royal descent, confessing Christ at a feast appointed by the Emperor Maximinus, was tortured on a wheel, and put to death, A.D. 307 .

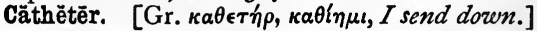
A surgical instrument for emptying the bladder.

Cathetometer. [Gr. ká $\theta \epsilon \tau o s$, adj., let dozen or in, subst. a plumbline, $\mu$ érpov, a measure.] An instrument used for the accurate determination of differences of level, e.g. the height to which a fluid rises in a capillary tube above the exterior free surface. It consists of an accurately divided metallic stem which can be made vertical 
by means of three levelling screws on which the instrument stands. On the stem slides a metallic piece carrying a telescope-like the telescope of a theodolite-whose axis can be made horizontal by a level. The telescope is first directed to one object, and moved by a delicate screw till a horizontal wire in the focus of the eye-piece coincides with the image of the object; the stem is then read. The process is repeated for the second object. The difference of the readings is, of course, the difference of the levels of the objects.

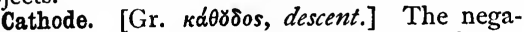
tive pole, or path by which the current leaves a body which is being decomposed by electricity.

Catholes. (Nant.) Two holes astern, above the gun-room ports, through which hawsers may be passed.

Catholio emancipation removed all civil disabilities from Dissenters, 1829 .

Catholio Majesty, Most. Title of the kings of Spain.

Cat-in-pan, (?) To turn. "A cunning which lays that which a man says to another as if another had said it to him" (Bacon, quoted by Johnson); to be a turncoat, to change sides unscrupulously.

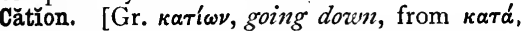
down, iéval, to go.] The element which goes to the negative pole when the substance is decomposed by electricity. (Cathode.)

Catlings. Catgut strings.

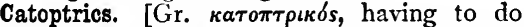

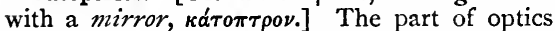
which treats of the formation of images by mirrors and other reflecting surfaces, and of vision by means of them.

Cato Street Conspiracy. A conspiracy formed in 1820 by Thistlewood and others, for murdering the ministers, seizing the Bank, and setting fire to London.

Catraia. (Naut.) Pilot surf-boats of Lisbon and Oporto, about fifty-six feet long by fifteen feet broad, propelled by sixteen oars.

Cat-rig. (Naut.) Vessels rigged with a large fore-and-aft mainsail only, set on a boom and gaff, and having the mast stepped near the stem. Suitable for light winds only.

Catsalt. A fine granulated salt.

Cat's-eye. (Min.) A variety of quartz, translucent, yellowish, greenish, and greyish-brown. Found in Malabar, Ceylon, etc.

Cats'-paw. A dupe who does perilous work for another, as in the fable the cat's paw was used by the monkey to pull the chestnuts out of the fire.

Caucasian races. An incorrect term, $=$ what is now divided into Aryan, or Indo-European, and Semitic ; most of the Caucasian tribes being Turanian $(q . v$.$) .$

Caucus meeting. 1. A general meeting of party. In 1770 , a fray between some British soldiers and Boston ropemakers resulted in democratic meetings of ropemakers and caulkers; called by the Tories caucus meetings. 2. In England now-sometimes called the Birmingham syscem-the management of all electioneering business by a representative committee of voters.
Candate. (Bot.) Prolonged into a kind of tail [L. cauda].

Caudle, Mrs. A nagging wife, who delivers Curtain Lectures; by Douglas Jerrold.

Caul. (Perhaps a modification of corvl.) 1. Membrane sometimes covering the face of a child, at birth. 2. The omentum, or fatty network in which the bowels are wrapped. 3 . Small net for the hair.

Caulk, To. [Akin to L. calcare, to ram in with the heel, Gael. calc, to drive, ram.] (Naut.) 1. To go to sleep in your clothes, lying on deck. 2. To fill in cracks or seams with oakum or other material driven in tight.

Caulker. 1. One who caulks, or pays the seams. 2. A morning dram. Caulker's seat, a box slung over the ship's side, in which a caulker sits and works. (Pay.)

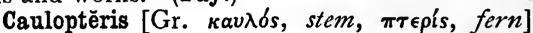
$($ Geol. $)=$ fossil tree-fern stems ; Carboniferous system.

Causa (I) cognoscendi [L.], the cause of our knowing a fact ; (2) essendi, the cause of the fact itself ; e.g. (2) " the ground is wet, because it has rained ;" but (I) "it has rained, because the ground is wet," i.e. this is how we know it.

Causa lătet, vis est nōtissima. [L.] The cause does not appear, the effect is most evident (Ovid).

Cause celèbre. [Fr.] An important or inte. resting trial, which has become historical.

Causerie. [Fr.] Chat, gossip.

Causes. With Aristotle and the logicians, are four: Material, that out of which the effect is produced; Efficient, that by which, as the agent; Formal, that according to which, as the regulating idea; Final, that for which, as the purpose. Thus, of a cup, cause $I$ is the clay; 2, the maker; 3 , the design intended; 4 , drinking.

Causeuse. [Fr. causer, to talk, chat, L. causari, to defend a cause, discuss.] A small sofa.

Canseway, Causey. [Fr. chaussée.] A raised pathway or road for crossing wet land.

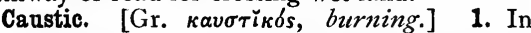
Optics, the curve (or surface) formed by the intersection of consecutive rays reflected from a mirror or other reflecting surface. The bright curve seen by lamplight on the surface of a cup of milk is the caustic formed by the intersection of the rays of light reflected from the inside of the cup. A C. is also formed by the intersection of consecutive rays refracted through a lens or other refracting substance. 2. Lunar. (Lunar caustic.) 3. Any medicament producing an eschar $(q . \tau \%)$.

Cantel. [L. cautēla.] Caution, proviso.

Cautēlā, Ex ăbundanti, or pro majōre. [L.] In Law, out of greater caution; to make certainty more certain; as when, in a legal instrument, some provision is inserted, which the law would itself imply as being just and equitable under the circumstance.-Brown's Law Dictionary.

Cautery. Searing by hot iron [L. cautêrium,

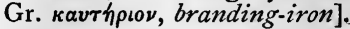

Cantio. [L.] Security, in law or contracts.

Cautionary. Given as a security ; so caution money paid at matriculation. 
Cavalier. [Fr. cavalier, from It. cavaliere.] 1. (Fortif.) A raised work placed in the interior of and corresponding in shape with a bastion.

2. A mounted knight.

Cavaliere servente. [It.] A man who displays devotion to a married lady.

Ca va sans dire. [Fr.] That is taken for granted ; lit. that goes without saying.

Cavatina. [It., short air.] Properly an air of simple, gentle character, having one movement; sometimes preceded by a recitative.

Căvĕa. [L.] The semicircular space for spectators in a Roman theatre.

Caverat emptor. [L.] Let the purchaser beware; e.g. let him take reasonable care that his purchase is really what he expects.

Căvë cănem. [L.] Bezvare of the dog; frequently inscribed on Roman vestibules.

Cavendish. Tobacco mixed with molasses and pressed into cakes.

Cavē ne littěras Bellĕrŏphontis adfĕras. [L.]

Take care you do not bring Bellerophon's letters.

Cavers. Persons stealing ore from Derbyshire mines.

Caves. As spoken of in Geol., are generally excavations made by water along the fissures of limestones; in France, Switzerland, Bavaria, Belgium, S. Wales, Devon, Derbyshire, Yorkshire, etc. ; sometimes containing relics of animals and men inhabiting them in long-past ages.

Caveson. [Fr. caveçon, Sp. cabeza, L.L. căpĭtium.] A kind of bridle or noseband, used in breaking in a horse.

Caviar. [Fr. and Port.] Salted roe of sturgeon and other fish; a Russian luxury.

Cavity. (Naut.) The displacement of water caused by a vessel floating in it. Centre of $C$., Displacement, Immersion, or Buoyancy is the mean centre of such part of a ship as is under water, i.e. considering the whole as homogeneous.

Cavo-relievo. [It.] A kind of carving in relief, where the highest surface is level with the plane of the original stone, giving an effect like the impression of a seal in wax. (Alto-relievo.)

Cavy, Cavia, Cobaia. [Brazilian name.] (Zool.) Aperea. Gen. of fam. Cavı̌dd ; as the guineapig, Restless cavy. S. America. Ord. Rōdentǐa. Cawker. (Caulker.)

Cazique. (Cacique.)

Cecity. Blindiness [L. cæcĭtātem].

Cecropian. Anything relating to Cecrops, Kekrops, a mythical king or founder of $\Lambda$ thens. Sometimes applied to the bees of Hymettus, with the general meaning of Attic or Athenian.

Cecutiency. [L. cæcūtio, I am blind or nearly blind.] A tendency to blindness.

Cëdant arma tŏgæ. [L.] Let arms gize way to peace; the military to the civil.

Cedilla [It. zediglia, dim. of zeta] $\zeta$ in Fr. before $a, o, u$; showing that $c$ is pronounced soft ; as soupçon.

Celadon. 1. In 'Thomson's Summer, lover of Amelia, who is killed in his arms by lightning. 2. Sea-green porcelain.

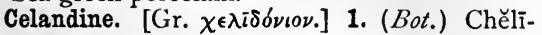
donnium majus, the only spec. of the gen. C., ord. Păpāvěraceæ ; a glaucous annual, with smali yellow flowers and orange-coloured juice; not uncommon; its flowering once thought to be connected with the coming of the swallow $\left[\chi \in \lambda \iota \delta \omega^{\prime} \nu\right]$. 2. C. of Wordsworth and other poets, as also of Theophrastus, Dioscŏrídes, and Pliny, is the Ranunculus ficaria or pilewort, allied to buttercup.

Celature. [L. cælatūra, carving.] Embossing, or the thing embossed.

-cele. [Gr. $\kappa \dot{\eta} \lambda \eta$, a tumour:] ( $\mathrm{Med}$.)

Cělěres. [L.] In old Roman tradition, a body of cavalry instituted by Romulus, divided into the three centurions of Ramnes, Titienses, and Lucěres.

Celestial Empire. A name often used in speaking of the Chinese empire.

Celestines. An almost extinct order, founded in the thirteenth century by Pietro di Morone afterwards Celestine V. ; a branch of the Benedictine.

Celibacy. [L. cælebs, unmarried; probably from ca-, a particle of separation, and the root which has given the Teut. leib, the body, as in Life-guards ; similar formations being seen in the L. cæcus, cocles, blind or one-eycd, from ca- and ac, oc, the root of oculus, Ger. auge, the eye, and in the Eng. ceorl = ca-eorl, churl, halt = ha-lith, deprived of or maimed in a lith or limb, and half $=$ ha-leib, with divided or separated body. The L. cælebs would therefore closely represent the Eng. half (Bopp, Comparative Grammar).] (Eccl.) The condition of unmarried life, imposed as a necessary obligation on all the clergy of the Latin Church, and by the Greek Church on all who are not married before receiving holy orders.

Cell. [L. cella.] 1. Of an ancient temple, the náos or enclosed space within the walls hence a room in a monastery, prison. 2. (Biol.) A definite portion of sarcode, or protoplasm, containing a nucleus [L., a kernel]; whether or not assuming the form popularly called a cell.

Cellarer, Cellarist. In a monastery, i.q. a bursar.

Cellŭläres. (Bot.) The simplest plants, formed of cellulose $(q . v.) ; e . g$. fungi.

Cellular tissue. 1. (Bot.) Coherent cells, not united into continuous tubes or vessels. 2 . (Med.) (Areolar tissue.)

Cellulose. (Chem.) 1. A compound of carbon, hydrogen, and oxygen-C. 24, H. 29, O. 10; the basis of vegetable tissue. 2. The colourless material of the woody fibre of young plants, which forms the walls of the cells [L. cellullæ].

Celts. Weapons of stone or bronze, wedgeshaped or socketed, used by the early inhabitants of Europe (? connected with the name Celts; or (?) with a supposed L. celtis or celtes, $a$ chisel; $c f$. Welsh cellt, a flint.-Evans's Stone Implements).

Cementation. [Eng. cement.] The process of heating a solid body surrounded by the powder of other substances, so that without fusion its nature is changed by chemical combination. (For an instance, vide Blistered steel.)
Cénacle. [Fr.] 1. A guest-chamber [L. 
cœnaculum]. 2. A picture of the Last Supper ; and, especially, Leonardo da Vinci's is so called. 3. Réunion of literary men, intimate, and with some degree of mutual admiration.

Cēna, Cœna. [L.] The chief meal of the Romans, dinner rather than supper. The fashionable hour in the Augustan age was from I.30 to $2.30 \mathrm{p} . \mathrm{m}$.

Cenci, Beatrice. Heroine of Shelley's The Cenci, executed at Rome for conspiring against her unnaturally brutal father's life.

Cendres, Jour de. [Fr., L. dies ciněrum, day of ashes.] French name of Ash Wednesday.

Ce n'est que le premier pas qui coûte. [Fr.] Lit. it is but the first step which costs; the first effort, the first outlay, is the chief difficulty.

Cenobites. (Cœnobites.)

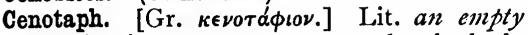

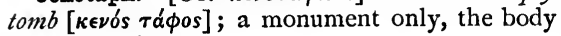
being elsewhere.

Censors. [L. censōres.] In Rom. Hist., two magistrates appointed for eighteen months out of each lustrum, or period of five years, for the purpose of taking the register of the citizens. (Lustration.)

Cent. 1. A hundred [L. centum], as five per cent., i.e. five in the hundred. 2. A coin used in the U.S., made of copper or copper and nickel $=\frac{1}{2} \frac{1}{0}$ of a dollar, or about a halfpenny.

Cental. $\stackrel{ }{\mathrm{A}}$ new English weight $=100 \mathrm{lbs}$. avoirdupois.

Centaurs. [Gr. к'́ (Myth.) Beings, half man, half horse, who are said to have lived in Thessaly.

Centaury. (Bot.) Erythraa Centautrium; ord. Gentianaceæ. A British plant, with numerous smail bright pink flowers, frequent in dry places, and collected for use as a tonic.

Centēnary. [L. centēnārius.] 1. A hundred of anything; as a C. of years. 2. The hundredth anniversary.

Centesimation. The picking out of every hundredth [L. centēsimus) person; $c f$. Decimation.

Centiare; Centigramme; Centilitre; Centimètre. [Fr.] Measures of the hundredth part of an are, gramme, litre, mètre respectively. (Are; Gramme; Litre; Mètre.)

Centigrade. (Thermometer.)

Centime. The hundredth [L. centēsimus] part of a franc $(q . v$.$) .$

Centimètre. The hundredth part of a mètre, i.e. of $39 \frac{1}{3}$ inches ; about $=\frac{2}{5}$ of inch, nearly.

Centner. 1. In Prussia, I Io lbs. or 220 marks, equal to about $113.4 \mathrm{lbs}$. avoirdupois. 2. The Zollverein C. is 50 kilogrammes, or 110 lbs. avoirdupois.

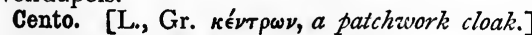
1. Patchwork. 2. A collection of verses from one or more poets, so arranged as to form a distinct poem.

Central force. An attractive or repulsive force which originates in a determinate point of space, and acts round that point in such a manner that its intensity at any point of space depends on the distance only and not on the direction; thus, gravity is a C. F.
Centre [L. centrum, Gr. Kévtpov]; C. of a curve; C. of gravity; C. of gyration; C. of inertia; C. of a lens; C. of mass; C. of oscillation; C. of percussion; C. of position; C. of pressure; C. of a surface. A term used vaguely to mean the middle point or part of anything. The $C$. of a curved line or surface is the point (if there be one) which bisects all straight lines that are drawn through it and are terminated at both ends by the line or surface, such as the $\mathrm{C}$. of a circle, ellipse, sphere, spheroid, etc. The C. of gravity is that point of a body through which the force of gravity on the body will act, in whatever position it may be placed; consequently, if that point is supported the body will rest in any position. It must be remembered, however, that this definition presupposes that the forces exerted by gravity on the parts of the body act along parallel lines. The C. of gravity is called also the $C$. of inertia, and sometimes the $C$. of mass and the $C$. of position. The $C$. of gyration is a point into which, if all the particles of a rotating body were condensed, its moment of inertia, with reference to the axis of rotation, would continue unchanged. The $C$. of oscillation is that point of an oscillating body at which, if all the particles of the body were condensed, the small oscillations would be performed in the same time as the actual small oscillations of the body. The $C$. of percussion is the point of a rotating body at which it must strike an obstacle, so that there may be no jar on the axle or hinges. It coincides in position with the C. of oscillation. The $C$. of pressure of a plane surface immersed in a fluid is the point in which the resultant of the pressures of the fluid meets the surface. This term is sometimes used to denote the metacentre (q.v.). The $C$. of a lens is a point fixed with reference to the lens having this property: if the part of a ray of light within the lens tends towards the centre, the parts outside of the lens are parallel. In the case of an ordinary double convex lens, the centre is within it.

Centrebit. A tool for boring circular holes.

Centrifugal force. [L. centrum, centre, fügio, I fly from.] When a body moves in a circle there is a second body, which may be called the guiding body, and whose place is commonly the centre, by whose action the moving body is deflected from its rectilinear course and caused to move in the circle; the reaction which it exerts against the guiding body is the C. F. of the moving body. When a stone is whirled round in a sling it endeavours to leave the hand that guides it ; and by that endeavour stretches the sling, and stretches it more the faster it moves. The stretching of the sling is due to two forces, the action of the hand and the reaction of the stone; the latter is the C. F. of the stone.

Centring. A temporary wooden support for vaults, arches, etc., while building.

Centring, Error of. In astronomical instruments it commonly happens that the centre of the divisions of the divided circle is not exactly coincident with the centre on which the circle itself turns-although great pains are taken to 
attain coincidence. This being so, the reading taken at a fixed point past which the divided circle turns will differ from the true reading by the E. of C. When this error is small, its effects are completely avoided by taking the arithmetical mean of two readings made with reference to two fixed points at opposite ends of a diameter. Called also Error of Eccentricity.

Centripĕtal force [L. centrum, centre, pěto, 1 seek] is the force by which bodies are everywhere drawn, impelled, or at all events tend, towards some point as to a centre. Such a force is gravity, in virtue of which bodies tend towards the centre of the earth ; or the force of magnetism, by which iron is drawn towards a magnet. The term is used by Newton for what is now more commonly called a Central force.

Centrobaric. [Gr. אé $\nu \tau \rho o \nu, \mathrm{L}$. centrum, centre, Bápos, weight.] Appertaining to the centre of gravity. There are cases in which the attraction exerted by a body (A) according to the law of gravity on another body (B) is reducible to a single force in a line which always passes through a point fixed relatively to the second body. In this case the second body (B) is said to be $C$. relatively to the first (A). When this is the case, the second body (B) is also C. relatively to every attracting mass, and it attracts all matter external to itself as if its own mass were collected in that point. It has been proposed to call this fixed point the Centre of gravity of the body (B), and to distinguish by the name $C$. of mass or $C$. of inertia the point which is usually called the $C$. of gravity.

Centroclinal, or Cycloclinal, strata. [L.

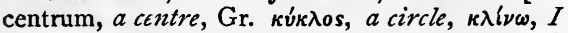
make to slant.] (Geol.) Strata dipping inward concentrically, like basins one within another; e.g. Forest of Dean coal-field.

Centrolinead. [L. centrum, centre, liněa, a line.] An instrument for drawing lines converging to a centre which is outside of the paper on which the lines are to be drawn.

Centumvir. [L.] Hundred-man; member of a committee or court of a hundred.

Centuriators of Magdeburg. (Magdeburg, Centuriators of.)

Centuries. [L. centŭriæ.] In Rom. Hist., the divisions, supposed to be each of 100, in which the people voted in the Comitia, or meeting of Centuries. In the Legion the $C$. was one-half of the Maniple, and the one-thirtieth part of the Legion.

Cepaceous. (Bot.) Having the character of an onion [L. cæpa] in shape or smell.

Cephalalgio remedies are for bain [Gr. à $\lambda$ ros]

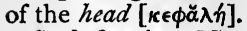

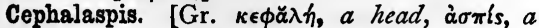
shield.] (Geol.) A fossil fish, with bony bodyshield shaped like a cheese-knife; found by Hugh Miller in the Old Red Sandstone.

Cephălic. Relating to the head; generally medicines for affections of the head.

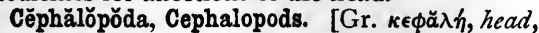

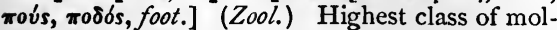
luscs. They have eight or more arms ranged round the head and provided with suckers; most are naked, as the cuttlefish, but nautili have shells.

Ceramic. [Gr. кєрацікбs, of pottery.] Relating to pottery.

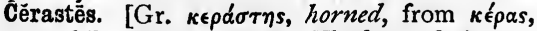
horn ; $c f$. L. cornu.] (Zool.) The horned viper, a venomous viperine snake. Egypt and adjacent parts. About two feet long ; greyish colour.

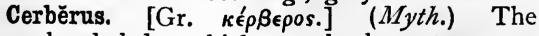
three-headed dog which guards the entrance to the kingdom of Hades, the fellow-monster being Orthros. These two names are found as Çarvara and Vritra in the Rig Veda.

Cerdonians. The followers of Cerdon [Gr. Ké $\rho \delta \omega \nu]$, who in the second century maintained a system of Dualism, combining with it the opinions of the Docetæ. (Ahriman.)

Cere. [L. cēra.] 1. Wax. Cered, waxed. Cere-cloth, one smeared with wax, or similar matter; unless this is A.S. sore-cloth, a cloth for sores. Cerement [L.L. cerementum], a waxed winding-sheet. 2. (Ornith.) The naked space at the base of the bill of some birds.

Cereals. [L. cěrěãlis, relating to Cěrēs, goddess of agriculture.] (Bot.) Grasses cultivated for their edible seed: wheat, barley, oats, rye, maize or Indian corn, rice, millet.

Cerĕbel, Cerebellum. [L. dim. of cěrě̀brum, the brain.] The under and posterior portion of the brain.

Cerebration, Onconscious. The non-voluntary working out and reproduction of ideas, under certain nerve conditions.

Cërës. [L.] (Myth.) The Latin goddess answering to the Greek Demeter. (Eleusinian Mysteries.)

Cerevisia. [L., a Gallic word.] In old legal statutes and elsewhere, beer.

Cerinthians. (Eccl. Hist.) The followers of Cerinthus, who in the first century propounded opinions agreeing essentially with those which were set forth by the Cerdonians in the second.

Cerium. A rare greyish-white metal, named after the planet Ceres.

Cernuous. [L. cernŭŭs, looking downwards, probably from an old cer = Gr. кápa, the head (as in cer-vix, the neck, which carries, vehit, the head) and nuo, nutus, nod.] (Bot.) Hanging down at the top, drooping; e.g. a snowdrop.

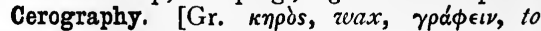
zorite.] Engraving on a copper plate coated with wax, from which a stereotype plate is taken.

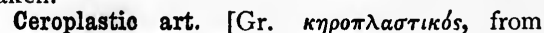
$\kappa \eta \rho o ́ s, ~ w a x, \pi \lambda \alpha \dot{\sigma} \sigma \epsilon \iota \nu$, to mould.] The art of modelling in wax.

Certent et cygnis ŭlŭlæ. [L.] Let ozvls too vic with swans; i.e. if bad authors vie with good ones.

Certification. [L. certus, sure, facĕre, to make.] (Scot. Law.) Assurance to a part of the consequences of non-appearance in court or neglect of a court order.

Certiorāri. [L., to be more fully informed.] (Leg.) Name of a writ commanding an inferior court to return the records of a case before it, so that such case may be removed into a court of equity. 
Certōsa. [It., corr. of Carthus-ia.] 1. A Carthusian monastery. 2. A burying-ground.

Cërümen. [L. cēra, wax.] A secretion of the ear.

Ceruse. 1. Carbonate of lead, commonly called white lead. 2. A white-lead cosmetic preparation. [Fr. ceruse, L. cērussa, with same two meanings.]

Cervical. Belonging to the neck [L. cervīcem]. (Cernuous.)

Cervine. [L. cervinus, from cervus, deer, the horned beast.] Relating to deer.

Cespititious. Made of turf [L. cæspes, cæspütis].

Cespitose. [L. cæspitem, a sod, a knob.] (Bot.) Growing in tufts.

Cess. [L. census, rating.] Assessment or tax.

Cessante causã, cessat et effectus. [L.] The cause ceasing; the effect also ceases; a saying of the scholastic logicians, "cause" being used in its fullest sense; e.g. the flatness of the metal does not cease when the hammering ceases : but cause includes the ductility of the metal, as well as the blow of the hammer.

Cessante ratiōne lēgis, cessat ipsa lex. [L.] On the reason for a law ceasing, the law itsclf ceases (to exist).

Cessävit. [L., he has ceased.] In Law, a writ issued when a tenant has ceased to perform the conditions of his tenure.

Cesser. [L. cessare, to cease.] (Leg.) 1. Neglect of service. 2. As in proviso for $C$., termination of trusts.

Cession. [L. cessiō, -nem, a giving up.] (Eccl.) Of a living, the giving it up, upon appointment to some dignity which cannot be held with it.

-cester, -chester. [L. castra, fortified camp.] Part of Saxon names, as in Wor-cester, Dorchester, Chester, Chester-field.

C'est fait de lui. [Fr.] It is all over with him.

C'est le crime qui fait la honte, et non pas l'échafaud. [Fr.] It is the crime that makes the disgrace, and not the scaffold.

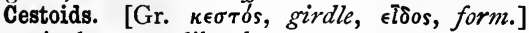
Intestinal worms, like the tapeworm.

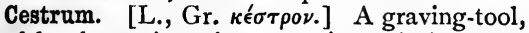
used by the ancients in encausting painting.

C'est tout égal. [Fr.] It is all the same.

Cestui-que trust. [Norm. Fr.] (Leg.) Equitable owner of estate legally vested in a trustee.

Cestui-que use. [Norm. Fr.] The enjoyer of equitable or beneficial interest in estate legally held by the feoffee to uses (q.v.).

C'est une autre chose. [Fr.] That is another thing.

Cestus. (Cæstus.)

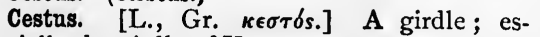
pecially the girdle of Venus.

Cestvaen, Cistvaen, Kistvaen. An enclosure, like three sides of a box, with a stone cover, often found in barrows, generally at the east end ; for burial, generally, and covered with earth; perhaps in some instances made for other purposes. [A hybrid word ; $\kappa i \sigma \tau \eta$, chest, Welsh maen, stone (Latham).]

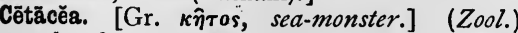
An ord. of mammak without posterior feet, adapted to an aquatic life, warm-blooded, with horizontal tail; including whales, narwhals, dolphins, porpoises.

Ceterach. (Bot.) A gen. of polypodiāceous ferns, of the group Aspleniæ ; to which belongs the common Scale-fern.

Cevenol. An inhabitant of the district of the Cevennes Mountains, France.

C. G. s. unit. (Dyne.)

Chace. The extreme length of a cannon.

Chaconne [Fr.], Chacona [Sp., from Basque chocuna, pretty]. A slow, graceful dance in triple time, Spanish; generally in a major key. Passacaglia, a similar dance, being generally in a minor. P. has been treated classically, by Bach.

Chacun à son goût. [Fr.] Every one according to his own taste.

Chadband, Rev. Mr. In Dickens's Bleak House, a hypocrite.

Chæronean, Cheronean, sage. Plutarch, born at Chærŏneia, in Bœōtia, where he spent most of his life.

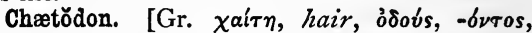
tooth, = having rows of bristle-like teeth.] (Ichth.) Gen. of fish, with deep, compressed bodies and strongly marked colouring. The beaked C. catches flies by squirting water at them. Trop. seas. Fam. Squāmipennes, ord. Acanthoptěry̆gŭi, sub-class Tělěostěĩ.

Chafery. [Fr. chaufferie, from chauffer, to neat.] A forge where iron is wrought into bars. Chafing-dish. [Fr. échauffer, to chafe.] A portable vessel of hot coals, for heating anything.

Chafing-gear. (Naut.) Anything put on rigging or spars, to prevent them from being rubbed or worn.

Chafron. [Fr. chanfrein, from L. cāmus, Gr. $\kappa \eta \mu \delta s, ~ a ~ m u z z l e$, and Fr. frein, a bit, curb; a reduplication by which a rare word is explained by a commoner one (see Littré, s.v.).] Iron mask, frequently with a spike on the forehead, worn by a war-horse.

Chagigah. [Heb., festivity.] A voluntary peace offering made by private individuals, at the Passover, from the flock or the herd.

Chain, Gunter's. (Gunter's chain.)

Chain-moulding. In the Norman style, a moulding resembling a chain, common on Norman window and doorway arches.

Chain-pump. A machine for raising water. It consists of an endless chain passing over two wheels, one above and the other below the water, the former being worked by a winch; to the chain discs or buckets are attached; the chain with the buckets is made to pass upward through a tube, and thereby brings the water up when the winch is turned. (Chain-wheel.)

Chain-rule. A rule in arithmetic for working a sum in compound proportion = double rule of three.

Chains, Chain-wales, or Channels. (Naut.) Blocks of wood fastened to the outside of a ship a little aft of the masts, to which the Chain-plates (iron plates, the lower end fastened to the ship's side, the upper provided with fixed dead-eyes) are attached, by which they are kept 
off so as to carry the shrouds clear of the bulwark. In the chains, stationed between two shrouds to cast the lead.

Chain-wheel. A machine the reverse of the chain-pump. In it, the water falling down the tube communicates motion by means of the brackets to the upper wheel, which therefore becomes a prime mover; in much the same way that a water-wheel, or turbine, is a prime mover.

Chalaza. [Gr. $\chi a ́ \lambda \alpha \zeta \alpha$, hail.] (Bot.) The point of union, at the base of an ovule, between the nucleus and integuments.

Chalcedŏny (abundant near Chalcēdon, on the Asiatic side of the Bosphorus). (Geol.) A beautiful variety of silica, sub-translucent, milk-white or coloured. Agate is laminated C. ; C. red, yellow, white,'is Carnelian, called from the red kind [It. carniola, carne, flesh] ; rich red is Sard; C., in layers, is Onyx. C. of Rev. xxi. 19 $=$ carbuncle; but includes also Chrysocolla, or Native verdigris, an ore of copper, sometimes called copper emerald.-King, Precious Stones.

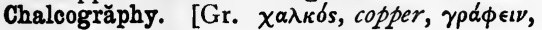
to write.] Engraving on copper.

Chaldee language. The language of the Jews after the Babylonish captivity, being a Hebrew dialect, differing little from the Syriac, or old Assyrian. (Aramaic languages.)

Chaldee Paraphrases. Running commentaries on the Old Testament, called Targums. (Talmud.)

Chaldron, or Chalder. [L. caldārium, a vessel for hot water.] An old dry measure, latterly used as a measure for coals and coke. A chaldron of coals was 36 heaped bushels, or about 27 cwts.

Chalet. [Fr.] Summer hut for Swiss herdsmen ; also Swiss wooden houses generally.

Chalk. [A.S. cealc, L. calx, calcem, limestone.] A white earthy limestone, largely com. posed of coccoliths and glŏbĭgěrinna ; the uppermost Secondary formation in England and in France; rooo feet thick ; represented in Germany by sandstones, etc. (Foraminifera.)

Challenge. Exod. xxii. 9 ; claim. [O.Fr. chalonge, L. calumnia.]

Challenge of jurors. An exception or objection against those empannelled; (I) a challenge to the array being against the whole number, on account of partiality, or for some other reason ; (2) a challenge to the polls being against one or more individuals.

Challis. A fine twilled woollen fabric.

Chalumeau, Chalameau. [Fr., whence Eng. shazom ; L. călămellus, dim. of călămus, a reed.] Pastoral reed-pipe; the lower notes of the clarionet are said to have a $\mathrm{C}$. tone.

Chalybean steel = steel of the best make ; the Chăly̌bes of Asia Minor having been famed as workers in iron.

Chalpbeate waters. [Gr. $\chi a ́ \lambda \nu \psi, \chi a ́ \lambda v \beta o s$, hardened iron.] Mineral waters in which the iron predominates.

Cham. (Khan.)

Chāma. [Gr. $\chi \chi^{\prime} \mu \eta$, a cockle, a gaping shell.] (Zool.) Giant clams, fam. of Conchǐfěra, Bivalve molluscs. Tropics.

Chamade. [Fr., It. chiamāre, L. clamāre, to cry out.] The beat of a drum, or the sound of a trumpet summoning the enemy to a parley. Chamæleon. (Chameleon.)

Chamber. [L. camĕra.] The cell in a mine or gun, where the powder is deposited.

Chamberlain, Lord, or King's C. An officer of very high standing in the royal household (formerly an influential member of the Government), a member of the Privy Council. He has also to do with the licensing of certain theatres and new plays; inquires into the status of persons desiring to be presented; issues the queen's invitations, etc.

Chamberlain, The Lord Great. Holds a hereditary office, very ancient, and once very important. He has the government of the palace at Westminster, receives upon solemn occasions the keys of W. Hall; prepares the Hall for coronations, State trials, etc.; has charge of the House of Lords during the session.

Chambers, Judges'. Rooms where judges sit for despatch of business which does not require a court.

Chambre ardente. [Fr., burning-chamber.] (Hist.) The court instituted by Francis I. for trying and burning heretics.

Chambre des Comptes. [Fr.] A French court, before the Revolution, for the registration of edicts, treaties of peace, etc.

Chameleon. [Gr. $\chi \alpha \mu \alpha \iota \lambda \epsilon \omega \nu$, ground-lion, a lizard which was supposed to change its colour.] 1. (Min.) Manganate of potassium, the solution of which changes colour from green to purple. 2. (Zool.) A gen. of saurian reptiles, popularly supposed to live on air, and to change its colour at will. It lives on insects, and the modifications of colour are produced by the varying proportions in the pigments contained under the rete mucosum, or coloured layer of the skin.

Chamfer. [Fr. chanfrein.] (Arch.) The edge of any right-angled object cut a-slope or on the bevel. (Chafron.)

Chamois. [Heb. zomer.] (Bibl.) Probably Moufflon (q.v.).

Chamomile, Camomile. [Gr. $\chi \alpha \mu \alpha i \mu \eta \lambda o \nu, e a r t h$ apple.] (Bot.) Anthèmis nobīlis (ord. Compositæ), a herb with finely divided leaves and daisylike flowers, the latter used in fomentations, etc.

Champarty, Champerty. [L. campus, field, partem, part or share.] (Leg.) A bargain between $A$, a party to a suit, and B, a third party, that $B$ maintain the suit on condition of a share of the object of the suit if $\mathrm{A}$ win.

Champ clos, Au. [Fr.] Lit. in closed field, = in judicial combat or in tournament.

Champ de Mai. [Fr.] (Hist.) The assembly of the Champ de Mars was, under Pepin and some of his successors, held in May, and so called.

Champ de Mars. [Fr.] (Hist.) A public assembly of the Franks, held in the open air yearly in March. The name of the open space in Paris of this name was probably suggested by the Campus Martius at Rome.

Champignon. [L. campinivicun, as growing in the campus, or open field.] (Bot.) A small kind of Agărǐcus, or mushroom (Agarǐcus orēàdes). 
Champion. [Fr., Sp. campeon.] (Feud.) One who appeared in the wager of battle to fight in behalf of another. In Eng. coronations the king's champion appeared to defend his right against all assailants. For this service he held the manor of Scrivelsby in grand serjeanty.

Champ levé. [Fr., raised field.] A process of cutting down a metal plate, so that the pattern is left raised, and the interstices afterwards filled with enamel.

Chancel. (Arch.) Literally, a place enclosed within cross-bars [L. cancelli]. Hence the sanctuary of a church.

Chancellor. [L. cancellārǔus.] 1. (Hist.) Under the Roman emperors, a notary, or scribe ; so called from the cancelli, or rails, within which he sat. 2. (Eccl.) The principal judge of the consistory court of a diocese. 3. The Lord High C. of England, the highest judicial officer of the kingdom (Seal, Great; Speaker). 4. Anciently, ecclesi-ecdicus, Church lazeyer, an ecclesiastical officer, learned in Canon law, who holds courts for the bishop; advises and assists him in questions of ecclesiastical law. 5. C. of a cathedral, generally a canon, has general care of the literature and schools belonging to it ; sometimes also lectures in theology. 6. C. of university, the supreme authority of a British university, generally a nobleman or statesman.

Chance-medley. [Fr. chaude, hot, mêlée, fray.] (Leg.) A casual affray ; also the slaying an assailant in sudden self-defence, or hasty slaying of one committing an unlawful act.

Chancery. [Cf. Fr. chancellerie, from chanceller, chancellor.] Original seat of chancellor, royal chaplain and amanuensis, keeper of the royal conscience. Under Edward I. arose the extraordinary intervention, between private parties, of the king as the sole source of equity. By Lord Selborne's Judicature Act, 1873, the Court of $C$. became the $C$. Division of the Supreme Court of Judicature, while equity rules are to override common law when they are at variance, so that a fusion of law and equity is attempted. (Cancelli.)

\section{Chances. (Probability.)}

Chandoo. An extract of opium, for smoking.

Changeling. 1. Something left, especially a child, in the place of another. 2. A fool, simpleton. 3. One given to changing sides, wanting in fixity.

Change-ratio, C.-wheels. If $A$ and $B$ are two parallel axes connected by toothed wheels which work with each other, then A's velocity of rotation will bear to B's a ratio depending on the number of teeth in the wheels. Now, if it be required to change this ratio from time to time into some other assigned ratio, this can be done by furnishing the axes $A$ and $B$ with wheels, the sums of whose pitch radii are equal, and on whose circumferences are cut a proper number of teeth ; the wheels are placed on the axles in such a manner that when $\mathrm{A}$ is shifted to the right or left on its bearings by one definite distance, one pair of wheels is brought into action; by shifting it through another distance a second pair of wheels is brought into action, and so on. These wheels

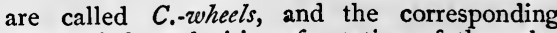
ratios of the velocities of rotation of the axles the C.-ratios. Suppose the wheels on A have 60,36 , and 72 teeth respectively, and those on B, 120, 144, and 108 ; when the first pair is brought into play, A's velocity has to B's the ratio of $2: 1$; when the second pair, $4: 1$; when the third, $3: 2$. These ratios are the C.-ratios.

Chanks. Conch-shells.

Channel-gropers. (Naut.) Vessels kept on service in the Channel. Applied formerly to those on the look out for smugglers.

Chansons. [Fr., song.] Short lyrical compositions sung by the Troubadours.

Chanticleer. The cock [Fr. chante-clair, sing clear], in Reinecke the Fox (q.v.).

Chantry. [Fr. chanter, L. cantāre, to sing.] A chapel or altar, with endowment for a priest to offer Masses for the soul of the founder or others.

Chap-books. Various old and now scarce tracts, miscellaneous, of inferior manufacture, sold by chapmen; at one time the only popular literature ; treating of religion, historical personages, weather, dreams, ghost stories, etc. ; dating from early part of the seventeenth century, and succeeded by the still inferior Penny $C$. $B$., which included stories of humour and roguery. (Cheap-jack.)

Chapeau bras. [Fr.] A kind of cocked hat, which could be flattened and carried under the arm [bras]; worn by regimental officers till about 1812 .

Chapelle ardente. [Fr.] A chapel, lit with many candles placed round a catafalque, or bier, in the funeral rites of the Latin Church.

Chapelle de fer. [Fr., L.L. capa or cappa, a cape.] Close-fitting iron skull-cap; formerly the head-piece for both infantry and light horse.

Chapellet. [Fr. chapelet.] A pair of stirrup leathers with stirrups.

Chaperon. [Fr. chape, I. cappa, a hooded cloak, whence, by meton., its usual meaning.] 1. A hood. 2. A hood or cap worn by knights of the Garter.

Chapiter, Chaptrel. [Fr. chapitre, O.Fr. chapitle, L. căpritŭlum.] The capital of a column, as in Exod. xxxvi. $3^{8}$ and elsewhere.

Chaplet. [Fr. chapelet.] In the Latin Church, a string of Beads on which prayers are counted. (Rosary.)

Chapman. [A.S. .ceapan, to buy; cf. Ger. kaufmann.] A trafficker, especially a buyer.

Chapt. Jer. xiv. 4 ; cracked, gaping open, from the heat; to chap (probably the same word as chip, chop, etc.) being to cleave, to crack.

Chapter. [L. capitŭlum, from caput, head.] The assembly of the dean and canons, forming the council of the bishop, in a cathedral church; or of a superior abbot and his monks in conventual houses.

Chapter House. (Arch.) The room in which the Chapter holds its meetings.

Char. [Celt. cear, red.] (Ichth.). Spec. of salmon, about twelve inches long, back brown, belly yellow. European lakes. Salmo salvělinus, S. umbla, Ombre chevalier of Lake of Geneva. 
Char, Chare. 1. [A.S. cyre, $a$ turn.] An occasional job or turn at work, a separate employment. 2. To hew, work. Charred stone [Fr. carré, L. quadrātus], hewn stone. (See Parker's Glossary of Architecture.)

Char-à-bancs. [Fr.] Pleasure-van.

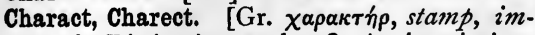
press.] 1. Distinctive mark. 2. An inscription. Characteristio of a logarithm. (Index.)

Charade. [Fr., Prov. charada, L.L. carrāta, cart-load.] An enigma consisting of equivocal descriptions of the idea conveyed by the parts and the whole of a word which is to be guessed. The description may be verbal or dramatic.

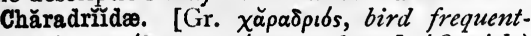

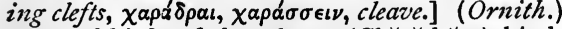
Fam. of birds of the plover (Chărădrius) kind. Cosmopolitan. Ord. Grallæ.

Charah. An Afghan knife or sword.

Charbon. [Fr., coal, charcoal; cf. carbuncle, from L. carbuncŭlus.] (Vet. Surg.) A malignant pustule.

Chard. 1. A kind of white beet. 2. The foot-stalk and midrib of white beet, and some other plants, blanched.

Charegites. [Ar., rebel.] A name given to the sect by one of whom the Caliph Ali was murdered, A.D. 66r. (Assassin.)

Charge. 1. (Her.) Any figure borne on an escutcheon. 2. (Eccl.) Bishop's or archdeacon's address to clergy. 3. A vigorous military attack; the explosive materials in a mine or gun.

Chargé d'affaires. [Fr.] A foreign minister of the third grade.

Charge de Marseille. An old French corn measure, still used; equal to about 4.4 English bushels.

Chariness. [A.S. cearig, chary, careful.] Scrupulous carefulness, circumspectness.

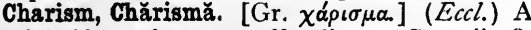
special gift or talent, e.g. of healing; I Cor. xii. 28 .

Charitěs. [Gr.] (Graces.)

Charity-sloops. The ten-gun brigs built at the beginning of this century. Said to have been intended to give employment to officers; hence their name.

Charivari (?). 1. In France, formerly, a mock serenade, with pans, kettles, etc., rough music. 2. Any uproar expressive of dislike. 3. Satirical political papers, as the $C$. of Paris.

Charlatan. [It. ciarlatāno, ciarlāre, to prattle.] A quack; one who pretends to knowledge.

Charles's Wain. The constellation of the Greater Bear; the term is, however, generally limited to the seven stars which are most conspicuous in that constellation. (Rishis.)

Charlock. (Bot.) A wild mustard, Sinnāpis arvensis, ord. Crucifüræ.

Chărōn. [Gr.] (Myth.) The ferryman who rows the dead across the Stygian lake in the under world. (Styx.)

Charpie. [Fr., lint, past part. of O.Fr. charpir, L. carpěre, to pluck.] A substitute for lint, made of small pieces of old linen.

Charpoy. [Hind.] A pallet-bed.

Charqui. [L. caro cocta, cooked flesh.] Lean beef dried in the sun; corr. into Eng. jerked beef.

Chart. [L. charta, paper, that which is written upon paper.] There is no clear distinction between a map and a chart. Either is the delineation on a plane surface of the relative positions of a number of points on the surface of the terrestrial or of the celestial globe. Thus we speak of a chart of a coast or of a celestial chart.

Chart, or Sea-chart. (Naut.) A sea-map, i.e. a projection of some part of the sea and neighbouring coast, with the harbours, bearings, lights, known depths, currents, and kinds of bottom, etc., carefully marked. The coast-line is shaded seaward in maps, and landward in sea-charts.

Charta, Magna. [L.] The Great Charter of the realm, signed by King John, 1215, renewed by Henry III., providing against the unlawful imprisonment of the subject and the imposition of taxes without the consent of the Council of the kingdom.

Charta de ūnā parte. [L.] (Leg.) A deedpoll (q.v.).

Chartæ Lỉbertātum. [L.] Magna Charta and Charta de Foresta, the latter consisting of forest laws confirmed by Edward I.

Charte. [Fr.] 1. A document containing a statement of constitutional law; and especially, 2, that of Louis XVIII., 1814, acknowledging the rights of the nation.

Charter, To. (Naut.) To hire a vessel under a Charter-party, i.e. a deed, or written agreement. A general ship is one which ships goods from others than charterers.

Charterhouse. [Fr. Chartreux.] A college in London, founded by Thomas Sutton; once a monastery. (Carthusians.)

Charter-land. (Bocland.)

Charter-party. A written agreement by which a shipowner lets the whole or a part of a ship to a merchant for the conveyance of goods, and the merchant pays an agreed sum by way of freight for their carriage.

Chartists. In Mod. Eng. Hist., those who maintain what is called the People's Charter, of six points : universal suffrage, vote by ballot, yearly Parliaments, payment of members, abolition of property qualification, and equal electoral districts. Of these the second and the sixth have become law.

Chartulary. (Cartulary.)

Charybdis. (Scylla; Incidit.)

Chase. [Fr. châsse, a reliquary, L. capsa.] An iron frame in which type is wedged, before being placed in the press for printing.

Chase-ports. (Naut.) The gun-ports in the bow and stern.

Chasidim. (Assideans.)

Chasing. [Fr. enchâsser.] Working raised figures on metal.

Chasse marees. French coasters of the Channel. Bluffly built, and generally lugger-rigged, with two or three masts and a topsail.

Chassepot. A rifle introduced into the French army before the Franco-German war. 
Chasseur. [Fr., from chasser, to hunt, L. captare.] Light infantry soldier in the French army; Chasseur à cheval being the name for light cavalry.

Chasǔble, Chasĭble, Chesĭble. [L. casǔla, casubŭla.] (Eccl.) A vestment representing the Roman pænula, which was circular, with a hole to admit the head in the centre. Modern use has left it oblong, so as to expose the arms. It is prescribed as the vestment in the rubric of the first Prayer-book of Edward VI.

Château. [Fr., L. castellum.] In France, a gentleman's country seat, which in feudal times was generally fortified as a castle.

Châteaux en Espagne. [Fr., castles in Spain.]

Romance castles, castles in the air.

Chatelaine. [Fr.] 1. The mistress of a mansion. 2. An ornament with chains for hanging useful articles to a lady's waist.

Chatelains. (Vavassors.)

Chatoyant. [Part. of Fr. chatoyer, to have a play of colours.] Having an undulating lustre, like the eye of a cat [Fr. chat]. (Cat's-eye; Nacreous.)

Chats, Chit. Twigs, young shoots. Chatwood, little sticks fit for fuel.

Chattah. [Hind.] An umbrella.

Chattels. [L.L. catalla, cattle, O.Fr. chaptal, from căpĭta, heads.] (Leg.) Goods not in the nature of freehold or part and parcel thereof. Personal $C$. belong immediately to the owner's person, as most movable goods. Real $C$. also appertain to some lands or tenements in which the holder has use or interest, as a box with writings of land or issue out of some immovable thing, as a lease.

Chatterer, Bohemian. (Ornith.) Bohemian waxwing, European representative of fam. Ampělidæ [Gr. ă $\mu \pi \epsilon \lambda o s$, vine]; about the size of a starling, with chestnut-coloured crest, and horny appendages to the wings, like red sealingwax. Or . Passĕres.

Chatterers. (Ornith.) Cotingidde; an extensive fam. of birds, characeristic of Trop. America, as the umbrelia bird. Ord. Passěres.

Chauffer. [Fr. chauffer, to heat.] An iron stove.

Chansses. [Fr., drawers.] Close-fitting chainmail for legs and feet.

Chauvinism. (From Chauvin, the veteran of the First Empire, in Scribe's Soldat Laboreur.) Idolatry of French military prestige of the Napoleonic idea.

Chavender, Chevin. [L. căp̌rtōnem, a big-head fish.] (Ichth.) Chub, spec. of fresh-water fish,

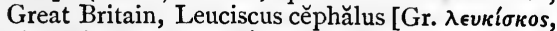

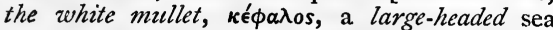
fish (? a mullet)], fam. Cyprinı̌dæ, ord. Phȳsostŏmi, sub-class Tělěostěĩ.

Chay-root. [Sp. chaya.] An Indian root used as a red dye.

Cheap, -cheap. Purchase market ; Saxon name or part name, as in Cheap-side, West-cheap, Chipping Norton, Chippen-ham, Copen-hagen.

Cheap-jack. Popular name for a Chapman.

Cheaters, Escheators. Collectors of Crown escheats $\left(q . v_{0}\right)$, often oppressive and fraudulent; hence the verb to cheat is said to come; but $c f$. A. S. ceat, L. captio, deception.

Checky. (Her.) Covered with alternate squares of two different tinctures, like a chess-board.

Cheek. (Fortif.) The side of an embrasure.

Cheeks. 1. The two solid parts upon the sides of a mortise. 2. The side walls of a lode.

Cheer, Be of good. In Gospels and Acts; be of good countenance. [Fr. chère, Gr. кápa, $a$ head or face.] Spenser, Faëry Queen, pt. ii. 42.

Cheetah. (Zool.) Huntingleopard, Felis jŭbāta (maned) or Cy̆nælūrus, dog-cat, as being in form and habit a sort of connecting link, though a true feline; long domesticated, and employed in the chase. Africa and S. Asia ; in Persia called Youze.

Chef. [Fr.] Chief, head-cook; i.e. chef de cuisine.

Chef d'œurre. [Fr.] Master-piece; lit. head of work.

Cheirŏmys. (Aye-aye.)

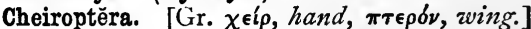
(Zool.) Bats; an order of mammals with a

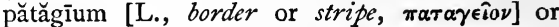
membrane, which enables them to fly, connecting the fingers and toes, and the fore and hind limbs on each side, and sometimes the hind limbs and tail. They are insectivorous, carnivorous, or frugivorous. Universally distributed.

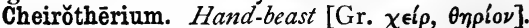
(Geol.) A wild beast, whose hand-like footprints appear on Red Sandstone, probably a Labyrinthodont reptile [Gr. $\lambda \breve{a} \beta \breve{v} \rho \iota \nu \theta o s, a$ labyrinth, óoús, a tooth, from the peculiar internal structure of the teeth].

Chelate. (Nat. Hist.) In shape like a claw [Gr. $\chi \eta \lambda \dot{\eta}]$.

Chēlōnia. [Gr. $\chi \in \lambda \omega ́ \nu \eta$, tortoise.] (Zool.) The fifth ord. of reptiles; tortoises and turtles.

Chĕlönĭdæ. (Chelonia.) (Zool.) Sea-turtles. Chělōnē vĭrĭdis, Green T. (Atlantic), supplies soups, etc.; Hawk's-bill T. (Indian and Pacific), tortoiseshell.

Chelsea china. China ware made at C., I745I 784 ; leading marks, anchor or triangle; moulds transferred to Derby.

Chemic. A solution of chloride of lime for bleaching.

Chemin des rondes. [Fr.] In old fortifications, a broad pathway concealed by a hedge or wall formed outside the parapet, to enable officers to go their rounds.

Cheng. A Chinese musical instrument, a kind of small organ; a bundle of tubes held in the hand and blown by the mouth.

\section{Cherem. (Niddin.)}

Cheroot. A kind of cigar, made in Manila and elsewhere.

Cherry-laurel. (Bot.) Prūnus laurocěrăsus. A common shrubbery plant, in no way connected with the true laurel (Laurus nōbillis). Water distilled from the leaves is used in flavouring, and cases of poisoning have resulted from its employment.

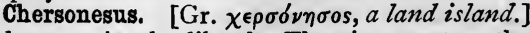
A long peninsula, like the Thracian coast on the N. side of the Hellespont. 
Chert (formerly Chertz; cf. Ger. quarze). (Geol.) A granular siliceous rock ; either of (I) pseudo-morphosed granular limestone, as in the Carboniferous limestone ; or (2) cemented spongespicules and sand, as in the Upper and Lower Greensands.

Cherubic hymn, or Seraphic hymn. (TerSanctus.)

Cherŭbim. [Heb.] 1. An order of angels, with attributes resembling those of the Seraphim. 2. Two symbolical figures placed on the mercyseat of the ark, in the tabernacle and temple.

Chervil. A culinary vegetable, used in soups and as a garnish, especially in some parts of the Continent. Anthriscus cærĕforlǐum (Pliny, for

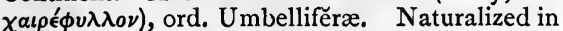
England.

Che sara, sara. [It.] What will be, will be. Chesil Bank. (Beaches.)

Chess. Plank laid on the platform of a pontoon bridge to form the roadway.

Chessel. The wooden vat in which cheese is pressed.

Chessom earth $=$ "mere mould, between the two extremes of clay and sand." -Bacon, quoted by Johnson.

Chess-tree. (Naut.) A piece of oak with a hole in it, or an iron plate with thimble-eyes, fastened to the top sides of a vessel for passing the maintack through, so as to extend the clue of the mainsail to windward.

Chester, -chester. (-cester.)

Chest of Chatham. An ancient institution for wounded and injured seamen of Royal Navy. Re-established by Queen Elizabeth in 1590 , maintained by a proportioned contribution from the pay of each seaman and apprentice, called Smart money.

Chovage, Chiefage. [From Fr. chef, head, L.L. chevagium.] A kind of poll tribute formerly paid by villeins to the lord of the manor.

Cheval glass. [Fr. chevalet, an easel.] A large mirror swinging in a frame.

Chevalier, Bas. [Fr.] A knight of the lowest grade, or a young knight, knight bachelor. (Bachelor.)

Chevalier d'industrie. [Fr.] One of the swell mob, a swindler.

Chevaux de frise. [Fr., first used in defensive warfare in Friesland.] Beams of wood transfixed by pointed stakes or sword-blades, as temporary barriers to a passage.

Chevelure. [Fr.] Head of hair.

Cheveril. [Fr. chèvre, a goat.] Kid leather; adj., pliable, yielding, in a bad sense.

Chevisance. [O.Fr.] (Leg.) 1. An unlawful bargain or contract. 2. An indirect gain in point of usury. 3. An agreement or composition, especially between debtor and creditor.

Chevron. [Fr., L.L. capriōnem, a goat.] 1. A rafter. 2. 'Ligzag moulding, Norman, like a pair of rafters. 3. (Her.) An ordinary in the form of a pair of rafters. 4. (Mil.) Distinguishing stripe;, denoting rank, on the sleeve of a non-commissioned officer's coat.

Chevy Chase. Old ballad founded on the battle of Otterburn, Northumberland, 1388, in which the Earl of Douglas was killed, and Henry Percy (Hotspur), son of the Earl of Northumberland, taken prisoner.

Chewing of oakum, or pitch. (Naut.) Expressive of leakage caused from insufficient caulking.

Chi. The Gr. $\chi$, a mark used anciently by the Greeks, in reading, to note passages as spurious; but $\cdot \chi \cdot, \chi$ with points on each side, noted excellent [Gr. $\chi \rho \eta \sigma \tau \delta s]$ passages. (Chrestomathy.)

Chiāro-scūro. [It., clear-obscure.] In Painting, the proper disposition of lights and shadows.

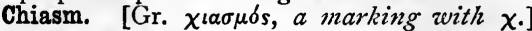
1. (Chi.) 2. A crosswise arrangement of words or clauses, as " Begot by butchers, but by bishops bred."

Chiasma. [Gr. $\chi$ เá $\sigma \mu \alpha$, the mark of $\chi$.] The crossing of the fibres of the optic nerve.

Chibbal. [Fr. ciboule, L. cæpulla.] A kind of small onion.

Chibouque. [Turk.] A Turkish pipe.

Chic. [Fr.] In Mod. Eng. slang, = style, the correct thing. In Fr. (I) originally sharpness in practice; now (2) a term of the workshop = rapid, easy execution, e.g. in painting. Littre inclines to think (I) an abbrev. of Chicane; and (2) a distinct word, the Ger. schick, arrangement, despatch.

Chica. [Sp.] 1. A popular Spanish and S.American dance; said to be Moorish; hence jig (?). 2. A fermented liquor made from maize. 3. Red colouring matter, used by the Indians, from the wood of the climbing Bignonia $C$. of the Orinoco.

Chicanery. Sophistry, sharp practice ; originally, dispute over the game of mall [Byz. $\tau$ Svкavıov]; then, over lawsuits.

Chicard. The harlequin of the modern French carnival.

Chiches. [Fr. chiche, L. cicer.] Chick-pease. Chichevache and Bycorne. Two fabled monsters, of whom B. feeds on obedient husbands and is very fat, $C$. on patient wives and is almost starved.

Chicks. [Hind.] Venetian blinds in India.

Chicory, succory, Common. (Bot.) Cĭchŏrǐum inty̌bus, ord. Compošrtæ; a perennial plant, wild in England and most parts of Europe, having long carrot-like roots, for the sake of which it is cultivated.

Chief. [Fr. chef, L. caput, head.] (Her.) An ordinary occupying the upper part of an escutcheon, and containing one-third part of the field. (Escutcheon.)

Chief, Examination in. (Leg.) First questioning of a witness in the interest of self of the party who calls said witness; opposed to cross-examination and re-examination.

Chief Baron. (Leg.) Presiding judge in Court of Exchequer (q.v.) of Pleas at Westminster.

Chief-rents. (Quit-rents.)

Chiefrie. A small rent paid to a lord paramount.

Chievance. [(?) Fr. achevance, a finishing, bringing to an end, L. caput, O.Fr., chief.] The extortion of unfair discount in a bargain. 
Chiffonier. [Fr.] 1. A collector of rags and odds and ends. 2. A wooden stand, furnished with shelves for odds and ends or bric-d-brac. 3. An ornamental sideboard with drawers.

Chignon. [Fr.] The nape of the neck; hence a mass of hair, often chiefly false, worn at the back of the head.

Chigoe. (Entom.) Figger, Sand-flea; wingless insect breeding under the human skin (Pülex pěnĕtrans).

Child, Childe. 1. Old title of an eldest son while heir-apparent or while candidate for knighthood, as Childe Rowland. 2. A young man ; e.g. Song of the Three Children. 3. In Elementary Education Act, 1876, one between five and fourteen.

Childermas. [A.S. childa-maesse daeg.] Innocents' Day, December 28.

Child-wife. 1. Formerly, a wife who has borne a child; now, 2 , a very young wife.

Chiliad. [Gr. $\chi^{\bar{i} \lambda \iota \alpha ́ s .] ~ A ~ t h o u s a n d ~ i n ~ n u m-~}$ ber; a cycle of a thousand years.

Chiliarch. Commander [Gr. àpxos] of a thousand $\left[\chi^{\left.\frac{1}{\imath} \lambda \iota \circ \iota\right]}\right.$ men.

Chiliasts. [Gr. $\chi \iota \lambda \iota a \sigma \tau \alpha \ell$, from $\chi^{\frac{i}{\imath} \lambda \iota 0 \iota, a}$ thousand.] Believers in a millennium, or blissful reign of the saints on the earth for a thousand years after the final judgment. Papias, Bishop of Hierapolis, in the second century, is said to have been the first who held this opinion.

Chill; Chilled shot; Chilled wheel. When castings of iron are rapidly cooled, they become extremely hard; the iron is then said to be chilled, and the mould in which such iron is cast is called a chill. Chilled shot is shot for heavy ordnance, made of chilled iron. A Chilled wheel is a whee of a railway carriage whose tire is hardened by chilling; such wheels are extensively used in U.S.

Chilled. 1. Varnish is said to be chilled, when through dampness a bloom (q.v.) appears on a picture. 2. (Casehardening.)

Chilli. [Sp. chili.] The pod of the cayenne pepper.

Chiltern Hundreds. A tract extending through part of Bucks. and of Oxford. The steward was an officer appointed by the Crown to preserve order there. A member of Parliament, as he cannot strictly resign, vacates his seat by accepting a nominal office under the Crowen, such as this stewardship. The hundreds are Burnham, Desborough, and Stoke, once forest-land infested by robbers.

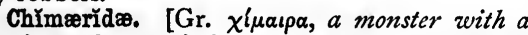
lion's head, a goat's body with second head, and a serpent for a tail; hence a monster gcnerally.] (Ichth.) Fam. of shark-like fishes; $\mathrm{N}$. and S. Temperate latitudes. British spec., Chĭmæra monstrōsa, Rabbit-fish, King of the herrings, Sea-cat; three feet long, white with golden-brown markings, large head, whip-like tail. Ord. Hŏlŏcěphăla, sub-class Chondroptery̆gìi.

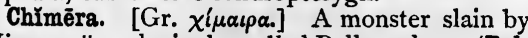
Hipponoös, who is also called Bellerophon. (Bellerophon's letters.) The word meant simply goats of a year old, strictly winterlings; and as the sun slays the winter, the creature slain would be a chimera. It now means commonly a wild fancy or an object impossible of attainment. Adj., Chimerical.

Chimere. [Fr. cimarre, It. zimarra.] The upper robe of satin, black or red, with lawn sleeves attached to it, worn by bishops of the English Church.

Chimin. [Fr. chemin, L.L. caminus, way, road.] (Leg.) A way. Private roads are either $C$. in gross, when a person holds the road as property; or $C$. appendant, as when a person covenants for right of way over another's land to his own.

Chiminage. [Fr. chimin (q.v.).] (Leg.) Toll due by custom for way through a forest.

Chimming. [Ger. kimme, the edye of a cask.] Dressing ore in a tub or keeve.

Chimney money, or Hearth tax. An impost levied in the reign of Charles II., and abolished in that of William III. and Mary.

China clay. $A$ clay found in the west of England, used for making china. China stone is a kind of granite used for glazing fine pottery.

China grass. Grass cloth, a fine glossy fabric, made from the fibre of the Bœhmeria nivea of Assam; not a grass, but allied to the nettle ; ord. Urtīcaceæ.

Chinampas. (Floating islands.)

Chinche. [L. cimícem.] 1. (Entom.) A bug. 2. (Zool.) Chinchilla, burrowing gregarious rodents of the high Andes of Chili and Peru; of about fourteen inches in length, with long hind legs, valued for their soft grey fur. Fam. Chinchillirlæ, ord. Rodentia.

Chincough. [(?) Onomatop. similar names occurring in other languages.] Whoopingcough.

Chine and chine. Casks stowed endways.

Chinese white. Oxide of zinc, used as a pigment.

Chinse, To. To caulk slightly or temporarily, by working in oakum with a knife.

Chintz. [Hind. chhînt.] A cotton cloth, printed in five or six colours.

Chioppine. [O.Fr. escapin, It. scapino, sock.] A kind of clog or patten, once worn by ladies.

Chippendale. Furniture inlaid with coloured woods (made by Chippendale, in the last century).

Chippers. Women who dress the best ore in lead-mines.

Chipping. (Cheap.) A market-place; part of A.S. names, as in Chipping Norton, Chippenham, Copen-hagen

Chîragra. (Med.) Gout in the hand [Gr. $\chi \in \iota p-c^{\prime} \gamma \rho a$, as $\pi \circ \delta-a^{\prime} \gamma \rho a$, gout in (iit. a trap for) the feet].

Chirk. [Cf. Prov. Ger. schirken, to chirp.] To chirp; Loc. Amer. adj., cheerful. Onomatop. of various sounds of birds and insects.

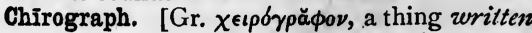
with the hand, a bond.] A diplomatic document, in two copies, on one sheet, between which was written chïrogrăphum, or some such word, so that through this word cut lengthwise the parchment might be divided into authentic duplicates. Chirographist. [Gr. $\chi \in l \rho, a$ hand, $\gamma \rho \alpha \dot{\phi} \omega, 1$ 
write.] One who tells fortunes by palmistry, i.e. by inspecting or reading the lines of the palm.

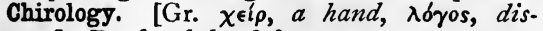
course.] Deaf-and-dumb language.

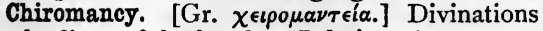
by the lines of the hand. (Palmistry.)

Chiropordist. [Coined from $\chi \in i \rho$, hand, roús, $\pi o \delta$ ss, foot.] One who cuts nails and treats corns, etc.

\section{Chiroptĕra. (Cheiroptera.)}

Chirurgeon, now abbrev. into Surgeon. [Gr. $\chi \in i \rho o v \rho \gamma \delta$ s, working by the hand, a surgeon.]

Chislen. Ninth month of the sacred, the third of the civil, Jewish year; November-December.

Chit. [Hind., a written document of any kind.] (Naut.) A note. Formerly one given by a divisional officer, authorizing the purser to supply "slops ;" has to be presented to the purser.

Chitine. [Gr. $\chi \alpha i \tau \eta$, hair, mane.] A substance allied to horn, of which the skeletons of insects and crustaceans are formed ; in insects it forms the ěly̆tra also, and some internal organs; and in some annelids the loco-motor bristles.

Chiton. [Gr. $\chi \check{\imath} \tau \omega \dot{\nu}$.] A tunic, with or without sleeves, fastened with a girdle or zone [Gr. $\zeta \omega \nu \eta]$. The Ionic C. reached to the feet.

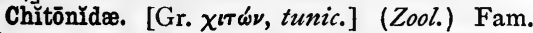
of gasteropodous molluscs, the only known instance of a protecting shell of many portionsnot valves, but overlapping plates.

Chitterling. 1. A short frill. 2. The frill-like small intestines of the hog.

Chittim, Kittim. The Island of Cyprus was known to the Phœnicians and Jews by this name. Its chief town, Kition, was a great emporium for the Phœnician slave-traders. Numb. xxiv. 24, and elsewhere.

Chitty face. [Fr. chiche-face.] A meanfaced fellow.

Chiun. Amos v. 26; generally regarded as the name of an idol. The word may also mean the pedestal or support of an image.

Chive, or Cive. [L. cæpa, an onion.] (Bot.)

Allium Schœenǒprăsum, ord. Liliaceæ.

Chivey. (Naut.) A knife.

Chladni's figures. (Nodal figures.)

Chlamyphore. [As if Gr. $\chi \lambda \breve{\alpha} \mu \breve{v \delta o \phi \delta \rho o s, ~} \chi \lambda \bar{a}$ -

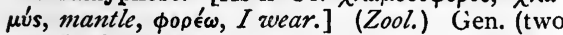
spec.) of armadillo; small. La Plata and Bolivia. Chlămy̆dŏphŏrus, fam. Dăsy̆pŏdǐdæ, ord. Édentāta.

Chlămys. [Gr. $\chi \lambda$ ăuús.] An oblong outer garment, a mantle.

Chloral. (Chem.) A colourless, pungent liquid, obtained by the action of chlorine upon alcohol.

Chlorio acid. (Chem.) An acid obtained from chlorine. Its salts are called Chlorates.

Chlorine. (Chem.) A greenish-yellow [Gr. $\chi \lambda \omega$ ooss] gas; one of the elements.

Chloroform. (Chlorine and formyl, it being a terchloride of formyl.) A powerful anæsthetic, composed of oxygen, hydrogen and chlorine.

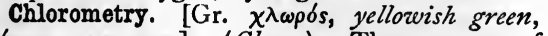

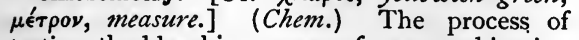
testing the bleaching power of any combination of chlorine.

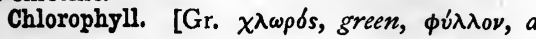

leaf.] (Chem.) A substance to which green leaves owe their colour; minute, somewhat waxy granules floating in the fluid of the cells. Chlōrōsis. [Gr. $\left.\chi^{\lambda \omega \rho} \omega \dot{s}.\right]$ 1. (Bot.) I.q. Etiolation (q.v.). 2. ( $\mathrm{Med}$.$) Green sickness, a$ disease arising from deficiency of red corpuscles in the blood.

Chlorous acid. (Chem.) An acid containing equal parts of oxygen and chlorine.

Chocolate gale. (Naut.) A smart wind from N.W. of Spanish Main and W. Indies.

\section{Choir organ. (Organ.) \\ Choke-damp. (Fire-damp.)}

Choke-pear, Choke-plum. A harsh pear, scarcely eatable; and so, metaphorically, a silencing, sarcastic speech.

Choke the luff. (Naut.) To get the fall of a tackle between the block and the leading part, so as to prevent it from running through the block. Slang for to be silenced, and to get a meal to stay hunger.

Chokí. [Hind. chaukî, guard-house.] A custom-house or police-station in India; hence choki-dar, an officer of customs or police.

Cholagogne. [Gr. $\chi 0 \lambda x \gamma \omega \gamma \delta s^{\prime}$ ] (Med.) A medicine which increases the flow of bile.

Chŏlesterine. [Gr. $\sigma \tau \epsilon \rho \epsilon \delta$ s, solid.] A fatty constituent in bile [ $\chi \circ \lambda \eta]^{\prime}$, the basis of biliary calculus.

Choliambic. [Gr. $\chi \omega \lambda i a \mu \beta o s, a$ halting iambus.] An iambic trimeter, acatalectic verse [sēnārius]; the fifth foot always being an iambus, the sixth a spondee. Also called Scazōnic (q.v.). Chondro-. [Gr. $\chi^{\delta \nu \delta \rho o s, ~ c a r t i l a g e .] ~(A n a t .) ~}$ Chondroptëry̆gii. [Gr. $\chi 6 \nu \delta \rho o s$, gristle, $\pi \tau$ '́ $\rho v \xi$, fin.] (Ichth.) Sub-class of fish, with cartilaginous skeletons, comprising chimæras, sharks, and rays.

\section{Chopine. (Chioppine.)}

Chorägio monument. (Gr. Arch.) A monument in which the tripod bestowed on the Chŏrāgus who best performed his office was publicly exhibited, as those of Lysicrates and Thrasyllos at Athens.

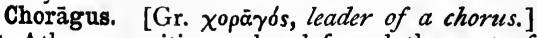
At Athens, a citizen who defrayed the cost of the public choruses in the great yearly dramatic exhibitions. The office was a Liturgy.

Chord. [L. chorda, Gr. $\chi \propto \rho \delta \eta^{\prime}$, cord.] The straight line joining two points of a curve, as a chord of a circle, of an ellipse, etc.

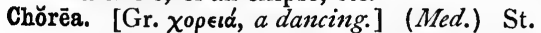
Vitus's dance; a nervous affection characterized by irregular and involuntary muscular movements.

Chörĕpiscŏpus. [Gr. $\chi \omega \rho-\epsilon \pi i \sigma \kappa o \pi o s, ~ c o u n t r y$ bishop.] In the early and mediæval times, most likely = suffragan bishop, having delegated authority only, like present Bishops of Nottingham or Dover; but doing the work also now done by archdeacons, rural deans, and vicars-general.

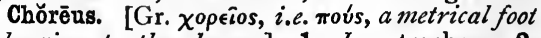
belonging to the chorus.] 1. I.q. trochee. 2. With later metrists, i.q. tribrach.

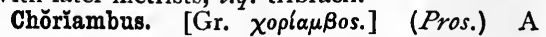
foot, $=$ a trochee + an iambus, $-\cup v-$; as ānxǔětās, HIēlǐgŏlānd. 
Chŏrion. [Gr. xóptov, a caul.] (Physiol.) Outer envelope of the ovum; the membrane enveloping the fotus.

Chŏröid. Like a chorion, in the multiplicity of its vessels; e.g. the choroid coat, one of the internal tunics of the eye.

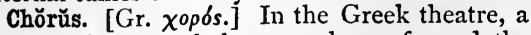
band of singers and dancers who performed the odes introduced into each drama.

Chouans, Chouanerie. 1. A name given, in 1830 , to certain insurgent royalists of the west of France during the Revolution of 1793 ; and used again in 1832. 2. Applied also to the adherents of the elder branch of the Bourbons. [(?) Chouan, a screech-owl, as if describing nocturnal predatory habits; or as being the nickname of Cottereau, one of their leaders. Chouan has been corr. into chat-huant (Littré, s.v.).]

Chough. Cornish chough, red-legged crow.

Choule. I.q. jowl. [(?) A.S. ceole, the jaw ; or Fr. gueule, L. gŭla.]

Chow-chow. [Chin.] A kind of Indian mixed pickle.

Chowder. A stew of fresh fish, pork, onions, etc. C. beer, a fermented liquor; an infusion of black-spruce and molasses.

Chowry. [Hind. chaunry.] A fly-flapper.

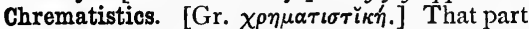
of political economy which has to do simply with money [ $\chi \rho \dot{\eta} \mu \alpha \tau a]$.

Chrēstomăthy. [Gr. $\chi \rho \eta \sigma \tau o \mu a ́ \theta \epsilon ı \alpha$.$] A collec-$ tion of choice passages, excellent $[\chi \rho \eta \sigma \tau \delta s]$ for any one to learn $[\mu \alpha \theta \epsilon i \nu]$ in acquiring a language.

Chriemhild, Kriemhild. [Ger.] Heroine of the Nibelungen Lied; changes from a type of gentle womanhood to a revengeful fury on her beloved husband's murder.

Chrism. [Gr. $\chi \rho \hat{\imath} \sigma \mu \alpha$, unguent.] Consecrated oil used at baptism, confirmation, ordination, orders, and extreme unction, in the Roman and Greek Churches. Chrismatory, a small vessel for C.

Chrisome. A white vesture, in token of innocence, placed at baptism on the child, to keep the oil [Gr. $\chi \rho \hat{\imath} \sigma \mu \alpha$, an unction, New Testament] from running off. Chrisome-child, one shrouded in its C., because dying between its baptism and the churching of the mother; sometimes incorrectly used to mean one dying before baptism.

Christ-cross row. Cris-cross row, the alphabet arranged in the form of $\mathrm{a}+$, with $\mathrm{A}$ at the top and $Z$ at the foot ; in old primers.

Christians of St. John. (Sabians.)

Christmas tree. Among the Teutonic nations, the stem of a tree, generally fir, lit up with candles, and bearing gifts which are tied on to the branches. It represents, in all likelihood, the world-tree Yggdrasil.

Christmas rose. Common in gardens, blooming in winter and early spring. Hellěbǒrus nigger, ord. Ranunculaceæ.

Christology. Discourse respecting the nature and work of Christ; the doctrine of the Person of Christ.

Christopher North. Nom de plume of Jonathan Wilson, Professor of Moral Philosophy at Edin- burgh, I820, and writer in Blackwood; author of Noctes Ambrosiance.

Christ's thorn. (Bot.) Păliūrus ăcūleatus, ord. Rhamnaceæ; of S. Europe and W. Asia; a deciduous thorny shrub. Another Paliurus bears the name of C. T. also, i.e. Zizyphus Spina Christi, used for hedges; a native of countries bordering on the Mediterranean and of W. Asia. Opinions differ as to the identification of the "thorns" of Matt. xxvii. 29.

Chromate. (Chromium.)

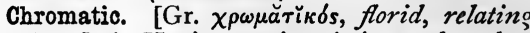
to colour.] 1. Having semi-tonic intervals, other than those of the diatonic scale. C. scale, one of successive semi-tones throughout. 2. In Gr.

Music. (Diatonic.)

Chromatic dispersion. (Dispersion of light.)

Chromatrope. [Gr. $\chi \rho \hat{\omega} \mu \alpha$, colour, троли́, $a$ turning.] An optical toy, consisting of a revolving disc, painted with circles of various colours.

Chromatype. [Gr. $\chi \rho \hat{\omega} \mu \alpha, a$ colour, túnos, type.] A photographic process in which the picture is obtained on paper treated with bichromate of potash.

Chrome (i.e. Chromium) green. Oxide of chromium. C. orange and yellow are chromates of lead. C. red is generally made of red lead.

Chromium, Chrome. [Gr. $\chi \rho \hat{\omega} \mu \alpha$, colour.] A whitish brittle metal, very difficult to fuse ; producing many compounds, from which colours are obtained. Chromic acid is derived from it, the salts of which are called Chromates.

Chromo-lithograph. [Gr. $\chi \rho \hat{\omega} \mu \alpha$, colour, $\lambda i \theta$ os, a stone, $\gamma \rho a ́ \phi \omega, I$ draw.] Reproduction of pictures by the use of coloured inks in lithography.

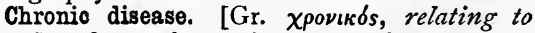
time.] One of continuance, of permanent recurrence; as opposed to Acute, i.e. more severe, rapid in progress, and short in duration.

Chroniclers, Rhyming, more properly Riming. A series of early English verse writers, which became conspicuous at the end of the thirteenth century.

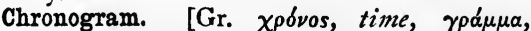
writing, from $\gamma \rho \alpha \dot{\phi} \omega, I$ zurite.] An inscription of which such letters as are Koman numerals, if added, make up a specific date; as on a medal of Gustavus Adolphus, struck 1632: "ChrIstVs DVX ; ergo trIVMphVs;" whereof the capitals make MDCXVVVVII., i.e. MDCXXXII.

Chronograph. [Gr. xpóvos, time, $\gamma \rho a ́ \phi \epsilon \iota v$, to write.] A watch so contrived that the second hand marks the dial when required, as at the beginning or end of a race.

Chronograph, Electro-chronograph. [Gr.

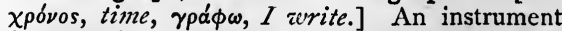
for showing instants and intervals of time graphically. It consists of an electro-magnetic recording apparatus put into communication with the pendulum of an astronomical clock in such a manner that the circuit is broken at a certain point of each oscillation, and in consequence the seconds' beats of the pendulum are indicated by a series of equidistant breaks or points in a continuous line described on a roll of paper to which a uniform motion is given by 
machinery. The instant of the occurrence of a phenomenon-such as the passage of a star across one of the wires of a transit instrumentcan then be indicated "by a dot made by similar means amongst the equidistant dots which denote the seconds. There are other Electrochronographs or Chronoscopes used in researches on the velocities of shot, etc.

Chronometer. [Gr. xpóvos, time, $\mu$ étpov, measure.] A very accurate portable time-keeper. A ship's C. is a large $C$. hung on gimbals, and designed to show the Greenwich mean time wherever the ship may be.

Chrononhotonthologos. A pompous character in $\mathrm{H}$. Carey's burlesque of the same name.

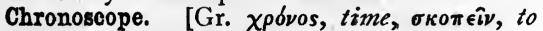
observe.] 1. An instrument to measure the duration of luminous impressions on the retina. 2. An instrument for determining with great accuracy short intervals of time. The chronograph is also called a $\mathrm{C}$.

Chrysaor. (Pegasus.)

Chryselephantine. Made of gold [Gr. $\chi \rho \bar{v} \sigma o ́ s]$ and ivory ['ं $\lambda \epsilon$ '́ $\phi$ as] ; like the celebrated statue of Zeus at Olympia by Pheidias.

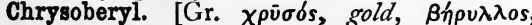
beryl.] (Min.) A hard green or yellowish-green semi-transparent gem, of which nearly 80 per cent. is alumina, and nearly 20 per cent. is the rare earth glucina. Found in Ireland, Brazil, Ceylon, etc.

Chrysolite. Gold-stone [Gr. $\chi \rho \bar{u} \sigma o ́ s$ iĺos.] (Geol.) A name applied to the paler and more transparent crystalline variety of olivine, silicate of magnesia and iron. In volcanic rocks, $\mathrm{Au}$ vergne, Vesuvius, Mexico, Egypt, etc. (Topaz.)

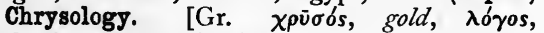
reckoning.] Branch of political economy which concerns the production of wealth and money.

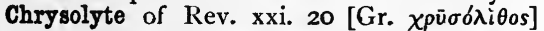
is probably the Oriental topaz, a yellow variety of the true sapphire.-King, Precious Stones, etc. (Topaz.)

Chrysoprase, Chrȳsŏprăsus [Gr. $\chi \rho \bar{v} \sigma o ́ s$, go'd, $\pi \rho a ́ \sigma o \nu, ~ a l e e k]$, i.e. yellowish-leek-green or apple-green variety of Chalcedony. In Lower Silesia and Vermont. C. of the ancients, uncertain. C. of Rev. xxi. 20 is probably the Indian chrysolite (q.v.).-King, Precious Stones.

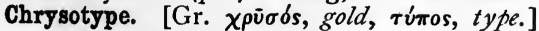
A photograph taken on paper prepared with chloride of gold.

Chuck. The piece fixed to the mandrel of a turning-lathe for holding the material that is to be shaped in the lathe ; there are fork chucks, eccentric chucks, oval chucks, etc.

Chuett, Chewett. Pie or pudding made of small pieces of meat ; to chew $=$ to compress, to crush, to break up.

Chuff. A coarse clown. Chuffy, blunt, surly.

Chukra. Iron quoit with sharp edge, six or eight inches in diameter, used as a weapon of offence in India.

Chunam. The Indian name for lime.

Chupkun. [Hind.] A native's vest in India.

Church-ales. Annual festivals formerly held in churchyards or near a church, on the anniversary of its dedication, or at Easter, or Whitsuntide as Easter-ales, Whitsun-ales, Churchwardens' brewed ale; the profits were appropriated to church repairs. Church-ales grew into fairs, often noisy and riotous. Long discontinued, they are now represented by village fairs, wakes, etc.

Churchdom. Institution, government of a church.

Churches, Robbers of. Acts xix. 37 [Gr. ieporúnous]; retains an earlier use of the word church as applied to any kind of temple.

Churl. (Earl.)

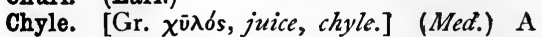
milky fluid into which chyme is converted, and which is absorbed into the lacteals. Adj., Chylaceous. Chyla-poietic organs, those which have to do with making [Gr. moเnтıкós] chyle.

Chyme. [Gr. $\chi \bar{u} \mu o ́ s$, juice, chyme, or chyle.] (Med.) The pulpy mass into which food is converted by the action of the stomach.

Cübörium [Gr. к̌ $\beta \omega ́ \rho เ o \nu, ~ a c u p]$, corr. into Severey. (Arch.) 1. A bay or compartment of a vaulted ceiling. 2. A vaulted canopy over an altar.

Cĭcāda. [L., id.] (Entom.) Tree cxicket. Gen. of Hemipterous insects ; of which the male has a remarkable musical apparatus at the base of the abdomen. Hot countries mostly. Sub-ord. Hŏmoptĕra.

Cicala, i.q. Cicada.

Cicatrice. [L. č̆cātrix, -cem.] (Med.) A scar. Cicātricula. [L., a little scar.] 1. The point of germination in an egg. 2. The same as the scar, in a seed.

Cicerone. (From the orator Cicero.) So called from his garrulity, a guide to art treasures in Italy ; and, generally, a guide of the same kind anywhere.

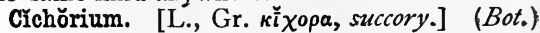
A gen. of Compositæ, including the chicory and endive; having ligulate florets and a milky juice.

Cicisbeo. [It.] A term applied to a knot of ribbons attached to a fan or a sword-hilt; and so to a cavaliere servente, one of a class of persons who dangled at the side of married ladies with the devotion of lovers. The practice, supposed to be drawn from ages of chivalry, is now nearly extinct.

Cicōnǐa. [L., stork.] (Ornith.) A widely spread gen. of the stork family, to which it gives the name of Cúconnŭdæ. Two spec., the Black S. (C. nigra) and the White S. (C. alba) occasionally visit Britain. Ord. Grallæ.

Cicurate. [L. cĭcŭro, I make tame.] To tame an animal, to render harmless, e.g. something poisonous.

Cícūta. [L.] (Bot.) A deadly gen. of Umbelliferæ; C. virōsa, the Cowfane, or Water hemlock, dangerously poisonous, occasionally found wild in England by the side of ditches and ponds.

Cid, Romance of the. A Spanish epic poem, relating the exploits of Cid [Ar. seid, a lord] Roderigo, or Ruy Diaz, known also as El Campeador, the Champion, in the eleventh century.

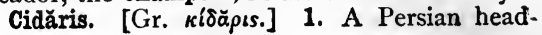


dress, or turban. 2. The mitre of bishops. 3. The triple tiara of the pope.

-cide = slayer, as in regicide, parricide [L. cædo, I slay ; in comp. -cido].

Cider originally meant strong liquor, i.q. Gr. $\sigma i \kappa \in \rho \alpha$, in LXX. and New Testament ; so translated by Wiclif in Luke i. 15. [Grecized from Heb. shâkar, to be intoxicated.]

Ci-devant. [Fr.] Hitherto, formerly ; ci being ici, here, and devant, before [L. de abante].

Cǔlǐa. [L. cǔlium, an eyelash.] (Bot. and Zool.) Hairs, hair-like, fringe-like processes.

Ciliary motion. [L. cillia, eyelashes.] (Zool.) A rapid, vibratile motion of a multitude of minute hair-like processes of the ěputhēlium, even when detached, in all animals, except the Artǐcŭlāta. Its mechanism and source unknown; independent both of the vascular and the nervous systems.

Cilicious. Of cilicium [L.], i.e. cloth made of the soft under-hair of the Cilician goat, or of similar material. (Tentmakers.)

Cimmerian darkness. Like that of the fabled Cimmerii, who lived beyond the ocean in perpetual gloom, "enveloped in mist and cloud" (Odyssey, xi. 14). Another mythical tribe of Cimmerii dwelt in caves between Baiæ and Cumæ. Cf. Cymry, Cimbri, Cumbri.

Cinchona tree. (Bot.) Of S. America, ord. Rubiaceæ; an important gen., native of the tropical valleys of the Andes, and now much cultivated in India; yielding the medicinal bark known as Peruvian bark, Fesuits' B., Quinquina, etc.

Cinchonine. An alkaloid obtained from $\mathrm{Cin}$ chona bark.

Cincture. [L. cinctūra, a girdle.] 1. (Eiccl.) A band or cord by which the Alb of the priest is tied round the body. 2. (Arch.) The fillet which separates the shaft of a column from the capital or the base.

Cinderella. In popular stories, the girl who, like Boots, sits among the ashes, but is the future bride of the king.

Cinematics. (Rinematics.)

Cinereous, Cineritious. [L. cĭnĕreus, cinněrǐcius.] Resembling ashes in form or in colour. Cingalese. Of or belonging to Ceylon.

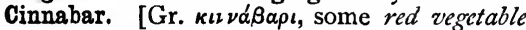
dye.] The native red sulphide of mercury, from which the pigment vermilion is obtained.

Cinnamon-stone. A variety of lime-garnet; the finer specimens valuable. In Scotland, Ireland, Ceylon, N. America, etc. (Garnet.)

Cinque-cento. [It. for five hundred.] The style of art which arose in Italy after the year 1500.

Cinque-pace. [Fr.] A lively dance, i.q. galliard.

Cinque ports. Sandwich, Dover, Hythe, Romney, Hastings, to which afterwards, before the reign of Henry III., were added Winchelsea and Rye ; a separate jurisdiction in some respects from the counties of Kent and Sussex ; originally after the battle of Hastings, erected into a kind of county palatine, under a Warden at Dover Castle.

Cion, i.q. Scion. [Fr. scion, from scier, to saw, L. sěcāre.]

Cipango, Zipangri. A marvellous island in the Eastern seas, described by Marco Polo; sought for by Columbus, etc.

Oipherhood. [Ar. sifr, empty; $c f$. ciffro, L. zephyrus, a gentle wind.] The condition of a cipher, worthlessness.

Ciphering. The continued sounding of an organ pipe when no note is down, from derangement of the mechanism.

Cippus. [L.] A small low pillar, used as a milestone, landmark, or gravestone.

Circean. Belonging to Circe, one of the moon-goddesses of the Odyssey, who can turn men into swine. She is thus the magician or sorceress.

\section{Circensian games. (Circus.)}

Circinate. [L. circìnātus.] In Bot., rolled together downward, as in the foliation of ferns.

Circle; Antarctio C.; Arctic C.; C. of declination ; Galactic C. ; Great C. ; Horary C. ; Hour C. ; Meridian C. ; Mural C. ; Reflecting C.; Repeating C. ; Small C.; Transit C.; Vertical C. 1. The line traced out by a point moving in one plane at a constant distance from a fixed point. 2. The figure enclosed by this line. Of circles on a sphere those whose planes pass through the centre of the sphere are Great $C$. ; those whose planes do not pass through the centre are Small $C$. The Arctic and Antarctic $C$. are parallels of latitude as distant from the north and south poles respectively as the tropics are from the equator, i.e. about $23^{\circ} 28^{\prime}$. Vertical $C$. are great circles passing through the zenith and nadir; they are therefore at right angles to the horizon. Hour $C$., or $C$. of declination, are circles on the great sphere passing through the poles of the heavens. The Galactic $C$. is the great circle of the heavens to which the course

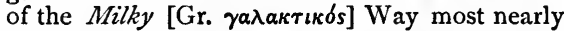
conforms. A Meridian $C_{\text {., }}$ or Transit $C_{\text {., }}$ is a metal circle with its circumference or limb divided into degrees, minutes, etc., fastened to an astronomical telescope whose axis coincides with one of its diameters. It is adjusted so as to move round its axle in the plane of the meridian. It serves for the simultaneous determination of the right ascensions and polar distances of heavenly bodies. A Mural $C$. (q.v.) [L. mūrālis, belonging to a wall] resembles a transit circle, but is mounted in such a manner as to serve only for the determination of the polar distances of heavenly bodies. A Reflect. ing $C$. is an instrument constructed on the same principle and destined for the same uses as a sextant, but it is more complete, as the graduated circle is entire and the divisions are carried all round it. A Repeating $C$. is an instrument designed for the accurate measurement of angles. By a certain mechanical contrivance the observation of the angle is repeated many (say ten) times, and then the arc that is read off is ten times the required angle. The errors in the final result are of two kinds : (I) errors of observation,-these tend to neutralize each other when the observations are numerous; (2) the error in the final reading,-this is divided by the number of observations, i.e. by ro in the case supposed. It might, therefore, be expected that 
an angle would be determined by this instrument with extreme accuracy; but practically the repeating circle has not been found to answer the expectation that was formed of it. The Horary C., or Hour C., on a sun-dial, are the lines which show the hours.

Circle of Ulloa. (Ulloa.)

Circuit. [L. circuitus, a going round.] The continuous path of an electrical current.

Circuits. [L. circuǐtus, from circum, about, eo, $I$ go.] (Leg.). Eight districts visited by judges twice or thrice a year for assize, by commissions of the peace, of oyer and terminer, of general gaol delivery, and of nisi prius. The $C$. are the Northern, Home, Western, Oxford, Midland, Norfolk, North Wales, South Wales. The Scotch $C$. are Southern, Western, Northern.

Circular argument. In Logic, an argument which arrives at a conclusion stated or involved in the major premiss of the syllogism.

Circular notes. Drafts issued by bankers to an intending traveller, and accompanied by a printed letter of indication, bearing his signature and introducing him to certain foreign bankers who will cash a $C$. $N$. if signed in their presence and upon production of the letter.

Circular poets. (Cyclic poets.)

Circum-. [L., around, about.] Often used as prefix.

Circumambient. [L. circum, around, ambio, $I$ encompass.] Encompassing on all sides; as e.g. air.

Circumcelliōnes. [L., from circum, around, cella, hut, cottage.] Donatist Christians of the fourth century, fanatics who went from town to town, professing to reform manners, redress grievances, liberate slaves. Given to violence, and, in desire of martyrdom, to self-destruction.

Circumcursation. [L. circumcurso, $I$ run about.] A running about; a rambling, incoherent method.

Circumferentor. [L. circumfẽro, I carry round.] A particular form of surveyor's compass.

Circumforaneous. [L. circumforrāneus.] Strolling about in the market-place [L. forrum]; attending fairs, etc.

Circumgyration. [L. circumgy̆ro, I turn round, gÿrus, a circle.] The act of turning round and round.

Circumlocution Office. In Dickens's Little Dorrit, a fictitious public office ; a satire upon the delays and roundabout ways of $\operatorname{Red}$ tape $(q . v$.$) .$

Circumstantial evidence. (Leg.) Evidence not of the fact to be proved, but of circumstances from which, when proved, the fact may be more or less satisfactorily inferred or presumed.

Circumvallation. [L. circumvallo, I surround with a wall.] In ancient sieges, an earthen embankment thrown up round a town to prevent succour from without. An inner bank, or Contravallation, was also raised to guard against sorties from the place.

Circus. [L.] (Arch.) A long building at Rome, semicircular at one end, in which the races, called Ludi Circenses, were held. By the Greeks such buildings were termed Hippodromes. Cirque [Fr.], i.q. Circus.
Cirrřpědĭa, Cirripeds, Cirrŏpŏda. [L. cirrus, a filament, pědem, a foot.] (Zool.) Filamentfooted; the lowest class of Crustaceans, as the barnacle.

Cirrus. [L. cirrus, $a$ curl.] Long streaks of white cloud, spreading in all directions. Cirrocumulus and cirro-stratus are combinations of this cloud with cumulus and stratus $(q q . v$.).

Cisalpine Republic, A.D. 1797 to 1802. A state formed in $\mathrm{N}$. Italy west of the Apennines, under the protection of Napoleon I. It merged into the Italian Rep., which in A.D. 1805 become Napoleon's Kingdom of Italy.

Ciselure. [Fr.] The chasing of metals.

Cist. [Gr. $\kappa i \sigma \tau \eta$.] Mystic chest. Like the baskets carried in the Eleusinian Mysteries.

Cistercians. A monastic order, founded at Citeaux (Cistercium), in Burgundy, towards the end of the eleventh century, as a reformed and stricter branch of the Benedictines.

\section{Cistus. (Rock-rose.)}

Cital, i.q. Recital.

Citation. [L. cĭtātio, -nem, a calling out.] 1. Summons to appear at a court of visitation of clergy. 2. Quotation of something said or written.

Cithăra. [L.] Ancient lute, something like a guitar, which is the same word.

Cithărista. [L.] played the cithara only; Cithăradus sang while playing.

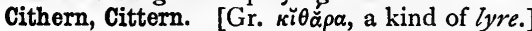

A kind of guitar with eight wires.

Cities of the Plain. Sodom, Gomorrah, Admah, Zeboim, and Bela or Zoar.

Citizen-King. Louis Philippe, elected, A.D. I830, constitutional monarch of France.

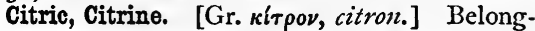
ing to lemons, limes, etc.

Citric acid. [L. citrus, the citron tree.] An acid formed from lemon or lime-juice.

City. [Fr. cité, L.L. cr̆tatem, i.q. cīvitatem.] A town incorporated, which is or has been the see of a bishop ; as London, Bath, Westminster.

City of the Sun, transl. of the Syrian name, Baal-bec. A ruined city in Cole-Syria; with the Greeks and Romans, Hēliŏpǒlis, which also means City of the Sun.

Ciudad. [Sp., i.q. It. civita.]

Cives, i.q. Chives.

Civet. [Pers. zabād.] The brown, musky secretion of the civet cat.

Civet cat. (Zool.). A long-tailed African carnivore (not a cat), black and white, three feet and a half long, secreting "civet" in a pouch beneath the arms. Viverra civetta, fam. Viverridæ. Other spec. secrete a similar scent.

Civic crown. [L. cŏrōna cīvǐca.] Of oak leaves, for saving a Roman citizen's life ; called also quercus civinlis.

Civil Bill Court. (Leg.) In Ireland, analogous to County Court.

Civil death. The being dead in law was the result once of entrance into a monastery, or of abjuration of the realm; now, of outlawry for treason, or felony, or other cause. Hence the use, in conveyance, of the term natural death.

Civilian. 1. Properly, one learned in the civil 
or Roman law. Hence a member of the College of Doctors of Law in the English Ecclesiastical and Admiralty Courts. 2. Popularly, one not belonging to the army or the navy.

Civil law. 1. The law of particular states or cities, municipal law. 2. I.q. Roman law, especially as consolidated by Justinian. (Corpns Juris Civilis.)

Civil list. Annual sum of $£ 385,000$, granted by Parliament at the sovereign's accession, for maintenance of royal household and establishment, together with $£_{1200}$ per annum for pensions to such as have a special claim on the country, as men distinguished in literature and science, or their relations. The sovereign, on accession, surrenders the hereditary revenues of the Crown, and is freed from all obligations in reference to expenses for war or the civil administration of the country.

Civil Service is = all duties performed for and by the State, not being naval or military. $C$. $S$. estimates are all State expenses not in the Army and Navy E.

Civism. Citizenship; citizen-like conduct.

Clack-valve. (Valve.)

Clairvoyance. [Fr., from clair, clear, voir, to see.] An extraordinary power of sight, said to exist in the mesmerized, in other parts of the body than the eye.

Clam, Clom. In the dialect of Lancashire, hungry.

Clamp. [D. klampen, to fasten together.] A mass of bricks heaped up for burning, or of ore for smelting, etc.

Clamp, Clamping-screw. (Astron.) To clamp is to fasten the movable arm of an astronomical instrument; this is done by pressing a piece of metal against the fixed part of the instrument by means of a clamping-screw. It is usual to set the instrument very nearly in the position it is finally to take, and then to clamp it ; the final adjustment is given by means of the tangent, or small motion screw, which generally forms part of the clamping apparatus.

Clancular. [L. clanculārius.] Conducted with secrecy [clam, secretly].

Clapboard. A stave for making casks.

Clapdish. A wooden bowl or dish, with noisy lid, used by beggars to attract attention.

Clapper. [Fr. clapier.] A burrow for rabbits.

Clapperclaw. To scold [from clap and claw].

Claque. [Fr. claquer, to clap.] Preconcerted applause to gain success for a public performance. In Paris, claqueurs have been organized and trained for the last fifty years.

Clarence. (Called after the Duke of Clarence.) A close four-wheeled carriage with a single seat.

Clarencieux. (Originally herald to the Duke of Clarence.) The second king-at-arms in the Heralds' College.

Clarendon, Constitutions of. A statement of the relations between the civil and the temporal powers, subscribed at Clarendon, near Salisbury, by the bishops, Ir64; Becket, the Archbishop of Canterbury, alone refusing.

Clarendon Press. The printing-press of the University of Oxford.
Clare, St., Order of. An order of women instituted by St. Francis, in 1213 , and so called from the first abbess, Clara of Assisi. The nuns are called Minoresses and Poor Clares.

Clarichord. (?) A corr. of clavichord (q.v.); or (?) some kind of harp.

Clarum et věněräbĭle nömen gentǐbus. [L.] $A$ renowned name, and one reverenced by (distant) peoples.

Clary water. A cordial made with flowers of Clary (Salvia sclarea), a plant of the same gen. with sage ; a native of S. Europe.

Clasper. (Bot.) A tendril.

Claudication. [L. claudjco, I limp.] Lameness; inequality of muscular power in the two legs.

Claustral. Relating to a Cloister.

Clausum frëgit. [L., he broke the close.] In Law, = he committed a trespass $;$ he made, in whatever way, an unwarrantable entry on another's soil.

Clavam Hercŭle extorquēre. [L.] To wrest the club from Hercules; to attempt impossibilities.

Clavate. (Clovate.)

Clavated. [L. clava, $a$ club.] Club-shaped ; growing thicker towards the top.

Claveçin. [Fr.] A harpsichord. Claveçinist, a performer on it. C. is clavi-cimbalo, or keyed dulcimer ; cimbalo (denoting, perhaps, a cymballike ring) having once in It. been $=$ dulcimer.

Clavichord. [L. clāvis, a key for tuning; chorda, a string.] A musical keyed instrument, mediæval, used till middle of the eighteenth century, soft-toned, with muffled strings pressed by brass pins projecting from the keys; the origin of the spinet.

Clavicle. [L. clāvǐcŭla, a small key.] (Anat.) The collar-bone, somewhat like an ancient key.

Clavier. [L.L. clāviarius, clāvis, a key.] (Music.) A key-board, whether manual or pedal. Claviform, Clavate. Shaped like a club [L. clāva].

Clavigerons. [L. claviger.] Bearing a club [clava] or a key [clavis].

Clāvus hystěrǐcus. [L.] (Med.) An acute pain of the head, as if a nail [L. clāvus] were being driven in.

Claw. (Bot.) The narrow end of a petal.

Claw, or Claw off. (Naut.) To beat slowly and with difficulty off a lee shore to avoid shipwreck.

Claymore. [Gael. glai-mor, great sword; $c f$. L. gladius major.] Long, straight, double-edged sword with a basket-hilt; at one time much used by the Highlanders of Scotland; about three feet and a half long, and weighing six or seven pounds.

Clean ship. (Naut.) A whaler without either fish or oil.

Clearance. (Naut.) The written permit of the custom-house to allow a vessel to clear ont, or sail.

Clearers. Spectacles whose glasses are weak convex lenses.

Clearing House, City. The place (at corner of Post Office Court, Lombard Street) where 
each London banker (for himself or as correspondent of country banks) sends daily bills and drafts drawn on other bankers. The C. clerks strike balances at the end of each day, make out each banker's account, and settle differences by transfer to and from accounts kept for the purpose by $C$. and bankers with the Bank of England. Thus transactions amounting to millions are settled without employing money.

Clearing House, Railway. The place where railway companies, which do business in common, have their shares of expenses and receipts adjusted on the principle of the City $C$. (q.v.).

\section{Clear-story. (Clerestory.)}

Cleats, Cleets. (Naut.) Pieces of wood to which ropes are fastened. Fixed pegs or pieces of wood, to fasten ropes upon, or prevent their slipping.

Cleavage. (Geol.) Planes of natural division, (I) in minerals, due to original constitution ; (2) in slate, to a superinduced structure, lateral pressure having squeezed all the unmixed particles into parallel position (Sorby). Schist has imperfect cleavage.

Cleavage-plane. (Geol.) Crystals have a tendency to separate along certain planes whose directions are determinate; any one of these planes drawn through an assigned point is a Cleavage-plane.

Cleavers. [Ger. klebkraut.] (Bot.) Goosegrass, catchweed.

Cleche. [Fr. cléché.] (Her.) A cross voided.

Clef. [L. clāvis, a key.] A sign giving the name and pitch of the notes, as, $\mathrm{G}$ or treble clef, $\mathrm{C}$ or tenor, $\mathrm{F}$ or bass.

Cleg. A common name, in some parts, for horse-fly.

Cleishbotham, Jedediah. Sir W. Scott's fictitious editor of Tales of My Landlord, the flogging schoolmaster.

Cleistogamous flowers. [Gr. $\kappa \lambda \in \iota \sigma \tau \delta$ s, closed, qámos, marriage.] Those which do not open, and are consequently necessarily self-fertilized.

Clemătis. [Gr. $\kappa \lambda \eta u \alpha ̆ \tau^{\prime}$ s, dim. of $\kappa \lambda \hat{r} \mu \alpha, a$ twig.] (Bot.) Common Traveller's joy, Old man's beard, a native climbing hedge shrub, with sweet white flowers. C. vitalba, ord. Ranunculācěæ.

Clementines. A collection of Decretals (q.v.) and Constitutions published by Pope Clement V., in the Council of Vienna, A.D. 1308, followed in I3I 7 by the Extravagantes of John XXII.

Clepsy̌dra. [Gr. from $\kappa \lambda \epsilon \in \pi \tau \omega, I$ steal, $\varepsilon \delta \omega \rho$, water.] A water-clock, the principle being that of the hour-glass of sand; used to time speakers in law courts.

Cleptomanĭa. [Gr. $\kappa \lambda \epsilon ́ \pi \tau \omega, I$ stcal, $\mu \alpha \nu i \alpha$, madness.] A mania for stealing, without motive or purpose.

Clerestory, perhaps Clear-story. (Arch.) The range of windows in Gothic churches or buildings, interposed between the main roof and the roof of the aisles.

Clergy, Benefit of. (Benefit of clergy.)

Clerical error. A mistake in copying.

Clericis laicos. [L.] Title of the famous bull of Pope Boniface VIII., I295; severing Church property from all secular obligation, and declaring himself the one trustee of all the property held by clergy, by monastic bodies, and by universities. - Milman's Hist. of Latin Christianity, vii. 60.

Clerks to the Signet. (Signet.)

Cleromancy. [Gr. $\kappa \lambda \hat{n} \rho o s$, a lot, $\mu \alpha \nu \tau \epsilon i ́ a, d i v i n a-$ tion.] Divination by throwing dice and seeing how they turn up.

Clevy. A cross-piece at the end of the tongue of a waggon, etc.

Clew. (Naut.) Of a sail. (Clue.)

Cliché. [Fr., stercotype; clicher being another form of cliquer; $c f$. Ger. klinke, latchet.] 1. The impression of a die in melted metal. 2. Stereotype.

Click. 1. (Ratchet.) 2. Consonants occurring in African languages, as Hottentot and Zulu, formed by separating the articulatory organs after or with sucking in of breath, all other consonants involving cmission of breath. The varieties are guttural, palatal, and dental, of which the two last sound not very unlike English $t c h$.

Client. (Patron.)

Clientèle. [Fr.] 1. The condition of a client. 2. The body of clients with whom a lawyer, banker, broker, etc., have to do.

Clifford, Paul. Hero of Lytton's novel, $P . C$., a romantic highwayman, who marries a lady and reforms.

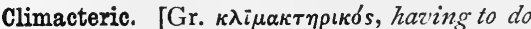
with a critical time, from $\kappa \lambda \bar{i} \mu \alpha \kappa \tau \eta \rho$, , the round of a ladder, a climacteric.] 1. A critical time in life, supposed to be every seventh year; the sixty-third year being the Grand C. 2. The period of cessation of menstrual life.

Climatology. The science which deals with the conditions determining climate.

Climature. An obsolete word for climate.

Climax. [Gr., a ladder.] (Rhct.) The placing of a series of propositions before a hearer in such an order that the impression shall increase in intensity, until it reaches the $\mathbf{A c m e}$. The opposite process is called Anti-climax. (Bathos.)

Clinch. [Cf. Ger. klinke, latch, from a Teut. word comes Fr. clinche.] Lit. a holdfast; metaph. a pun or double entendre.

Clincher, or Clinker built. A ship or boat, the planks of whose sides overlap. Iron ships thus built are called lap-jointed.

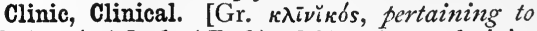

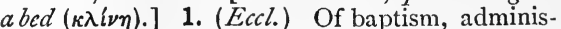
tered to one on a sick-bed. 2. ( $\mathrm{Med}$.) Confined to the bed by illness; of lectures, delivered at patients' bedsides.

Clinker, Humphry. Hero of Smollett's novel of the same name.

Clinkers. [Ger. klinker.] 1. Bricks run together and glazed by great heat. 2. Lumps of slag.

Clinkstone (i.e. ringing musically when struck), or Phonolite. [Gr. $\phi \omega \nu \eta$, sound, $\lambda$ ítos, a stone.] A compact fissile rock of the trachyte family, usually bluish-grey or brownish; composed almost entirely of felspar.

Clinometer. [Gr. $\kappa \lambda i n \omega, I$ make to slant, 


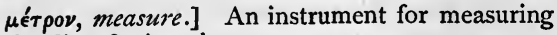
the dip of mineral strata.

Clio. [Gr. $\kappa \lambda \in i \omega$.$] (Myth.) The Muse of$ history.

Clip. To fly or move more rapidly; a term in falconry.

Clipper. A fast sailer. C.-built, i.e. on the model of the sharp-built, low-lying, rakish (q.v.) American schooner.

Clique. [Fr.] A knot of exclusive persons, a small party.

Clōāca. [L., a sezver.] 1. C. Maxima, ascribed to Tarquinius Priscus, the most famous of many Roman drains and sewers, which carried rain and foul water into the Tiber. 2. (Zool.) In birds, reptiles, many fishes, and some mammals, a pouch for the excretions of the intestinal canal and of the generative and urinary organs.

Clock. [A word common to Teut. and Scand. dialects.] 1. The C. in ordinary use, supposed to be perfectly adjusted, shows local mean time ; the astronomical C., used in observatories, shows local sidereal time. (Time.) 2. In a stocking, figured work at the ankle. 3. Proper name for beetle.

Clockard. (Belfry.)

Clock-calm. (Naut.) Dead calm.

Clog almanack, Rim stock, or Prime staff. A primitive kind of calendar; a square piece of wood, containing three months on each of the four edges; the days are shown by notches, every seventh large sized; certain marks and symbols denote the golden number or the cycle of the moon ; saints' days are marked by symbols of the several saints. Used till end of the seventeenth century; some perfect, as at Oxford. [(?) A.S. ge-logian, to place, regulate.]

Cloisonné. [Fr., partitioned, L.L. clōsiōnem, a partition.] Enamel inlaid between narrow partitions of metal.

Cloister. [L. claustrum, from claudo, I shut.] A covered walk in conventual or other buildings. The members of monastic houses are said to be cloistered.

Clonic. [Gr. $\kappa \lambda \delta b \nu$ s, disturbance.]

(Med.) Having a quick, convulsive motion.

Close. (Her.) Having the wings folded or closed.

Closed works. (Mil.) Those in field Fortif., which are entirely surrounded by earthworks, affording an equal cover in all directions from the fire of artillery.

\section{Close harmony. (Open harmony.)}

Close-hauled. (Naut.) Sailing as nearly as possible in the direction from which the wind blows. To do this, the sails are $C$., i.e. brought nearly in a line with the ship's course. Called also on a taut bowline, and on a wind.

Close-reefed. (Naut.) With all the reefs of the sails, which are set, taken in.

Close time. A portion of the year during which it is forbidden to kill game or fish, while breeding.

Closet. (Her.) A diminutive of the bar, being one-half its size.

Closet play. A drama to be read, not performed.
Closh. [Fr. clocher.] Skittles or ninepins.

Cloth in the wind. (Naut.) 1. Sailing so near the wind that the sails shake. 2. Tipsy.

Clot-poll, Clod-poll. A blockhead.

Clôture. [Fr., from an assumed L. clausĭtüra, an enclosing.] With other meanings, has that of summary termination, definite closing of a subject ; especially the termination of discussion by enforced silence, by shutting $u p$ an obnoxious speaker.

Cloud, Palace of St. Built in 1572, by Jerome de Gondy; purchased by Louis XIV., I058; purchased again from the Orleans family by Louis XVI., 1782, as a residence for Marie Antoinette.

Clough, Clangh, Cleugh. [Cf. A.S. cleofan, to cleave, cleft, O.N. kljûfa, Gr. $\gamma \lambda \alpha a \phi \omega, \gamma \lambda \dot{v} \phi \omega$, L. glübo, scalpo, sculpo, $I$ hollow out ; cf. $\mathrm{D}$. kloof, narrow valley.] 1. Part of A.S. names, as in Claugh-ton, Buc-cleugh. 2. A sluice for letting water gently off warped lands. (Warp.) 3. A hollow in a hill-side.

Clout. [O.E. clût, a little cloth.] An iron guard-plate on an axle-tree.

Clout, Colin. 1. Spenser's name for himself. 2. Character in Gay's Pastorals.

Clovate. Like a clove or nail [L. clāvus] in shape ; of a shell.

Clove. Of wool, half a stone, or seven pounds. Cloy. (Spike.)

Clubbing. (Naut.) Drifting down a current with an anchor out, so as to be able to steer. $C$. a fleet, manœuvring it so as to get the first division to windward.

Club-haul, To. (Naut.) In tacking, as soon as the wind is out of the sails, to let go the lee anchor, which brings the vessel's head to the wind; then, as she pays off on the other tack, the cable is cut, and the sails trimmed for that tack: done only in extreme cases, and when otherwise the ship is expected to miss stays.

Club law. Law of force majeure (q.v.).

Club-moss. (Lycopodium.)

Cluck. (Click.)

Clue. [A Teut. and Scand. word, akin perhaps to L. globus and glomus.] (Naut.) The lower corner of a squaresail. C. garnets, $C$. lines, tackle for hauling up the $C$. to the yards in lower and upper sails respectively. From $C$. to earing, i.e. from one extremity to the other; thoroughly.

Clugniacs. A reformed order of Benedictines ; so called from the Abbey of Clugny, on the Saône.-Milman, Hist. of Latin Christianity, bk. viii. ch. 4 .

Clunch. Popularly, stiff indurated clay ; more strictly, the harder chalk, such as is used for stonework in chimney-places, in the inside of churches, etc.

Clutch. 1. In machinery, a projecting piece, whereby one shaft can be rapidly connected or disconnected at pleasure with another shaft. 2. The number of eggs for a hen to hatch at a time.

Clydo, Clwyd, Cloyd, Clydach. [Celt.] River names; $c f$. Gael. clith, strong.

Clydesdale. Old name of Lanark County, from the Norman to the Stuart period. 
Clypeate. (Bot.) Like a round shield [L. cly̆peus].

Clyster. [Gr, $\kappa \lambda v \sigma \tau \eta ́ p$.$] A liquid injected$ into the lower intestines.

Co-. 1. (Math.) Frequently an abbrev. of Complement (q.v.), as in co-sine, co-latitude. 2. [L., together.] Frequent prefix to words, especially of $\mathrm{L}$. origin.

Coacervate. [L. coăcervātus, heaped up, from con-, together, acervus, a heap.] 1. To pile, to heap. 2. Piled, heaped.

Coadjūtor. [L. co-, and adjūtor, a helper.] (Eccl.) The assistant of a bishop or prelate. In the Latin Church, such assistants are generally bishops of sees in partibus infidelium. (Titular bishops.)

Coägŭlum. [L.] A curd, $a$ clot.

Coak. The round piece forming the middle of a wheel.

Coal-whipper. Labourer who unloads coal from the hold of a ship.

Coamings, or Combings, of hatches. A raised wooden ledge, preventing water on deck from getting into the hold.

Coän of Cos. Fine and transparent like the ancient textures woven in $\mathrm{Cos}$ (Kos).

Coarctation. [L. coarctatǐō, -nem, from coarcto, I confine, from co- $(q . v$.$) , arctus, close,$ narrous.] 1. Contraction of the dimensions of anything. 2. Restraint of liberty. 3. (Physiol.) The encasing and complete concealing of parts.

Coat-card. Playing-card with a coated figure on it, king, queen, or knave ; corr. into Court-card.

Cob. [A.S. cop, cob, Ger. kopf, head; borrowed from Celt. ; $c f$. Cymr. cop, cob, top.] 1. A lump. 2. Clay and straw for making walls. 3. A stout, short-legged weight-carrying horse. 4. [Amer.] The receptacle on which the grains of maize grow. 5. The spider cobweb = spider's web

Cobalt. [Ger. kobalt.] (Min.) A brittle, reddish-grey metal. Cobalt bloom is the native arsenate. Cobalt glance, the sulpharsenate. Cobalt blue is a pigment compounded of alumina and cobalt. Cobalt green is a pigment containing iron and cobalt.

Cobb, Cobble. [A.S. cuople, Ger. kübel, tub.] A fishing-boat.

Cobbing. (Naut.) Beating with a flat piece of wood, called the cobbing-board; an old punishment.

Cobbles. Large pebbles or round stones, used for paving.

Cobcal. A sandal worn by ladies in the East.

Cob-loaf. (Cob.) A loaf rounded at the top, not baked in a tin.

Cob-rake. An instrument used in washing crushed lead-ore from mud.

Cob-wall. Wall made of clay and straw.

Coca. (Bot.) The dried leaf of a wild Peruvian tree, Ěry̆throxy̆lon (red wood). Coca, a stimulating narcotic, very pernicious to mind and body. Its cultivation extensive and very lucrative.

Cocagne. [Fr.] Pays de C., Country of Cockayne, an imaginary place or condition, in which every one has an abundance for eating and drinking, without the trouble of getting it. [L. coquĕre, to cook; Picard. couque, a kitihcn.]
Coccŭlus Indicus. [L., little Indian berry.] (Bot.) The black, kidney-shaped, intoxicating, poisonous berry of a climbing shrub, gen. Anamirta, otd. Mēnispermācěæ, used in adulterating beer.

Cochineal. [Fr. chounille, Sp. cochinilla, dim. from L. coccus, scarlet.] A scarlet dyestuff, consisting of the dried bodies of insects found on several kinds of cactus in Mexico.

Cochin leg. One affected with elephantiasis ; common at Cochin, Malabar Coast.

Cǒchlěa. [L., a snail, snail's shell.] (Anat.) Spiral structure in the bones of the ear.

Cochleariform. Of the shape of a spoon [L. cŏchlěar], pointed at one end for drawing out the snail [cochlea], and bowl-shaped at the other.

Cochleary, Cochleated. Screw-shaped.

Cochleate. (Bot.) Like the bowl of a spoon [L. cŏchlěar] ; e.g. pods of Medicāgo maculāta. Cochon de lait. [Fr.] Sucking-pig; man of a pink-and-white complexion.

Cock-and-bull story. A highly exaggerated account of a trifle, or a long story invented merely to suggest an idea; so called from a particular tale of the kind.

Cockatrice. Isa. xi. 8, and elsewhere ; crested serpent, basilisk. Imaginary; a device in Heraldry.

Cockayne. (Cocagne.)

Cock-bill. (Naut.) Anchors perpendicular to the cat-head, cables hanging perpendicular, and yards set slantwise to the deck (a sign of mourning) are a-cock-bill.

Cock-boat, or Cogge. (Naut.) A small river or in-shore boat. A yawl.

Cocker. [(?) Akin to cook, as coddle, origin. ally $=$ parboil. $] \quad$ To fondle, coddle.

Cocker, According to. Edward C., arithme. tician of the time of Charles II.

Cockets, or Coquets. [From quo quietus, words of the old L. form.] (Naut.) 1. A customhouse warrant, allowing shipment of certain goods. 2. Slang name for fictitious ship's papers.

Cocket-bread, i.q. Sea-biscuit.

Cock-feather. Of an arrow, the $F$. at right angles to the direction of the notch.

Cock Lane ghost. (C. L., Smithfield.) The work of "a naughty girl of eleven," to which Dr. Johnson was "weak enough to pay serious attention," going "with some friends at one in the morning to St. John's Church, Clerkenwell, in the hope of receiving a communication from the perturbed spirit."'-Macaulay's Biography.

Cockle. 1. A stove for drying hops. 2. [A.S. coccel.] Popular name for Lychnis githago. 3. In Job xxxi. 40, Bao shah, translated " wild grapes" in Isa. v. 2 ; some foetid weed, perhaps some kind of arum.

Cockney. This name for a citizen of London is as old as the twelfth century, being found in some verses attributed to Hugh Bagot, Earl of Norfolk, in the reign of Henry II. (Cocagne.) C. school, a nickname which J. G. Lockhart hoped to give to a school of writers, including Shelley, Keats, Hazlitt, and Leigh IIunt, whom he thought vulgar.

Cockpit. (Naut.) The part of a man-of-war 
inhabited by the midshipmen, under the lower gun-deck, and near the after hatchway. Fore $C$. , where, in large ships and during war, the boatswain and carpenter have their cabins leading to their storerooms and the magazine.

Cooktail. 1. An American kind of drink, chiefly spirit or wine. 2. (?) For cocked tail, like a sorry nag; poor, worthless.

Cock to Essculapius, To sacrifice a. The dying Socrates bade a pupil do this on his behalf, probably to signify his belief in the continuance of life after death, the cock being the bird of the morning, and Esculapius being the great healer.

Cooor. (Cacao.)

Cocoon. [Fr. cocon, id., from coque $=\mathbf{L}$. concha, $a$ shell.] 1. The silky covering of the pupa of many insects, and of the eggs of spiders. 2. The chitinous capsules containing the eggs of leeches and earthworms. (Chitine.)

Cocote. [Fr.] Fast woman.

Cocus-wood. The wood of the cocoa palm.

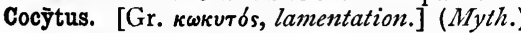
One of the rivers of the infernal regions, denoting deep and clamorous grief.

Coda. [It., tail.] 1. The tail of a note. 2. A few chords or bars added to show the conclusion of a piece, generally of contrapuntal; of music. Dim. Codetta.

Codeine. [Gr. $\kappa \omega ́ \delta \in \iota \alpha, a p o p p y$ head.] One of the alkaline substances found in opium.

Codex. [L.] 1. A manuscript, originally as being written on the bark of a tree ; $c f$. L. liber, Eng. book $=$ beech. The most ancient MSS. containing parts of the Old and the New Testaments are : The C.Alexandrinus, sent to Charles I. by Cyrillus Lucaris, Patriarch of Constantinople, and now in the British Museum; the Vatican $M S_{0}$; both belonging probably to the fifth century. The $C$. Sinatiticus, discovered by Tischendorf, in 1844, in the library of St. Catherine's Monastery on Mount Sinai, may, perhaps, be somewhat older, if its genuineness, which there seems no reason to doubt, may be admitted. The C. Cottoniannus, also in the British Museum, and containing portions of the first and the fourth Gospels, may belong to the end of the fourth century. The C. Beza, in the University Library at Cambridge, has been supposed by some to be the oldest of all known MSS. of the New Testament, and contains the Gospels and Acts with some omissions. (Abbreviations.) 2. (Leg.) A code of laws, as the C. Gregoriannus, Theodosiānus, Justīniānus. (Corpus Juris Civilis.)

Codex Alexandrinus. (Codex.)

Codex Argentěus. [L., Silver Volume.] The MS. containing the Gothic translation of the Gospels by Ulphilas. Formerly at Stockholm, now at Upsala.

Codex Aurěus. [L., Golden Volume.] An important Latin MS. of the Gospels, in the Town Library at Trèves ; (?) eighth century.

Codex Bezæ. (Codex.)

Codex Cottoniänus. (Codex.)

Codex sinařticus. (Codex.)

Codex Vaticānus. (Codex.)

Codices of New Testament.

(Abbreviations.)
Codicil. [L. cōdĭcilli, small tablets, short writing; dim. of cōdex.] A supplement to a will, adding to, explaining, or revoking its provisions.

Codilla. [L. caudicŭla, a little tail.] The coarsest part of flax.

Coefficient, Literal; Numerical c. [L. con-, together, efficio, effect.] The number prefixed to an algebraical symbol to show how many times the number denoted by that symbol is to be taken. Thus, if $x$ denotes any number, known or unknown, rox signifies a number that is ten times $x$, and 10 is said to be the coefficient of $x$ in the expression rox. A coefficient is not necessarily a whole number; it may be a fractional or incomnensurable number, or even a number which is a combination of algebraical symbols, so that there are literal coefficients as well as mumerical coefficients.

Coehorn. 1. Distinguished Dutch engineer, contemporary of Vauban, 1632 to 1704 A.D. 2. Small mortar invented by him, throwing an eight-pound shell.

Cœlatūra. [L., chasing.] The Roman term for working raised or half-raised figures in metal.

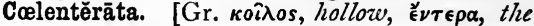
bowvels.] (Zool.) Sub-kingd. of Invertebrates, comprising part of Cuvier's Rădīāta, as corals and sea-anemones. In $\mathrm{C}$. the mouth opens into the body-cavity, which may, perhaps, be considered as an intestinal canal.

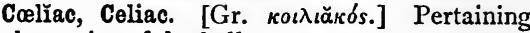
to the cavity of the belly.

Cœlum, nōn ănĭmum, mūtant qū trans măre currunt. [L.] They change their climate not their mind who wend across the sea (Horace).

Coemption. [L. coemtio, -nem, from coĕmo, $I b u y u p$.$] Purchase of an entire estate or quan-$ tity of goods.

Cœnăcŭlum. [L.] Dining-room, usually an upper chamber among Romans. (Cenacle.)

Cœna Domini, In. [L., in the Supper of the Lord.] (Eccl. Hist.) The name of a papal bull, setting forth the rights claimed by the popes over kings and their subjects, and anathematizing all who impugn them. It was so called as being read annually on Holy Thursday.

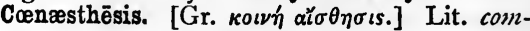
mon feeling.

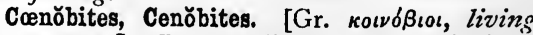
in common.] Persons living under rule in a community, as opposed to solitaries, Anchorets, or hermits.

Coercive, Coercitive, force. [L. coercēre, to compel.] The force which renders a body slow to acquire and part with magnetism.

Coercion Act. Of Lord Grey, 1833, gave the Lord-Lieutenant of Ireland power to suppress any meeting or association which he thought dangerous to peace, to declare any district disturbed, and to suspend the Habeas Corpus Act, with other powers. A Coercion Act was passed in the session of $188 \mathrm{r}$.

Coeval. [L. coævus, from con-, with, ævum, age.] Of the same age.

Coexistent vibrations. The simple harmonic vibrations of different periods, by whose coexist- 
ence any complex vibratory motion of a body can be rep: esented.

Cofering. [D. koffer, $a b o x$.] Putting a ridge of clay round a mining shaft to keep out water.

Coffer. [Fr. coffre.] (Arch.) A sunk panel in vaults or domes.

Cofferdam. [D. koffer, $a$ box, dam, $a$ drain.] A water-tight enclosure formed of timber erected on the bed of a river; from the space thus enclosed the water is pumped out, leaving it clear for the erection of a pier, an abutment, a wharf, or other such work.

Coffin-bone. [L. os pĕdis, bone of the foot.] In a horse, a small spongy bone in the middle of the hoof, very liable to disease.

Coffle. [Ar. kafala, caravan.] A gang of slaves on the way to market.

Cog ; Cog-wheel. [Welsh cog, a short piece of wood.] 1. When the teeth of whecls are separate pieces let into mortises, they are called Cogs; and the wheels are Cog-wheels. 2. A rough square pillar left to support the roof of a mine.

Cog a die. To cheat [Welsh coeglaw, to deceive] with dice.

Cogge, Coggle, or Cog. (Cock-boat.)

Cogito, ergo sum. [L.] I think, therefore I exist ; Descartes's famous reason for asserting the fact of self-existence.

Cognate. (Agnate.)

Cognition. [L. cognitiō, -nem, the becoming acquainted with.] In Moral Phil., one of the three phenomena of Consciousness, and $=$ the faculties of knowledge ; the others being Feeling $=$ capacities of pleasure and pain ; and Desiring and Willing = effort in action; according to Kant, and, after him, Sir W. Hamilton.

Cognizance, Cognisance. [O.Fr., from L. cognoscentia, knowledge.] (Leg.) 1. The judicial hearing of a cause, judicial knowledge. 2. acknowledgment of a fine. 3. The pleading of bailiff or agent as defendant in Replevin. 4. (Her.) An heraldic badge, worn by a retainer (whereby his lord was known).

Cognizee, Cognisee. [L. cognosco, I acknowledge; $c f$. connoiseur.] (Leg.) One to whom a fine of land is acknowledged, the acknowledger thereof being the cognizor.

Cognizor, Cognisor. (Cognizee.)

Cognomen. (Prænomen.)

Cognoscenti. [It.] Well-informed (plu.); knowing ones.

Cognôvit. [Leg. L. C. actionem, he hath admitted (the justice of) the action.] A defendant's written confession that he has no available defence.

Cohobate. [L.L. cohobāre, cohobātum.] To distil over again.

Cohorts. (Centuries; Legion.)

Coif. [Fr. coiffe, L.L. cofea, cuphia, kuppa, kuppha, mitre; cf. A.S. cop, top, head.] A kind of cap, the badge of serjeants-at-law.

Coign, Coigne, Coin, Quoin. [ $C f$. L. cŭněus, zvedge.] A jutting point, an external angle.

Coin. (Mil.) Wedore [L. cŭněus] used for elevating or depressing heavy guns.

Coir. The fibrous covering of the cocoa-nut.
Coistril. [O.Fr. coustillier, groom, lad.] 1. An esquire's attendant. 2. A young fellow.

Col. [Fr.] Lit. neck; a high pass over a shoulder of a mountain or between two ridges.

Colander. [L. cōlo, I strain.] A strainer, often a tin vessel with the bottom and lower part of the sides perforated.

Colbertine. (Named after M. Colbert.) A kind of net lace.

Colcothar. (Word invented by Paracelsus.) Sesquioxide of iron, used as jewellers' rouge.

Colder. (Agr.) Short broken ears or pieces of straw thrown off in threshing; eaten by cattle. Coldshort. Brittle when cold.

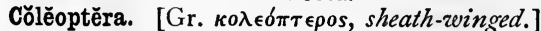
(Entom.) Beetles; ord. of insects with many thousand spec.; four-winged, the first pair converted into elytra, and the second, when not in use, folded crosswise under the first. They are divided into four sections, according to the number of joints in the so-called tarsus, heel-Trímĕra, Tetrămĕra, Pentămĕra, and Hĕtěrŏmĕra ; as ladybirds, weevils, cockchafers, and blisterbeetles, respectively.

Coleraine Co., i.q. Londonderry.

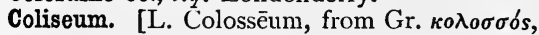
a huge figure; cf. col, hill.] The Amphitheatre of Vespasian, at Rome

Collaborāteur, fem. -trice. [Fr.] Fellowe worker, assistant.

Collar. [L. collum, the neck.] 1. (Arch.) A horizontal piece of timber connecting two rafters. 2. In machinery, a circular projection on a shaft, made to give it a bearing, so that it may not be shifted by a force applied in the direction of its length.

Collate. [L. collātus, part. of confěro, I compare.] 70 compare, especially diplomatically to set down the various readings of different MSS.

Collation. [L. collātio, -nem.] (Eccl.) Appointment to a benefice by a bishop as patron or by lapse. (Institution.)

Collectanea. [L. collectāněus, belonging to a collection.] A collection of excerpts, an anthology, miscellany.

Collects. [L.L. collecta, from colligerre, to bring together.] Short and comprehensive prayers, found in the Liturgies of all Churches.

College. [L. collēgrum.] (Hist.) Any society bound by the same laws or customs. In Europ. Hist., the term is applied especially to societies of persons belonging to universities. These are generally independent foundations, under the superintendence of a visitor.

College of Cardinals. (Cardinal.)

College of Electors. The society of princes who had a voice in the election of the emperor. (Electors.)

College of Heralds. A society dating from the time of Edward III., and consisting of three kings-at-arms, Garter, Clarencieux, and Norroy ; six heralds, and four pursuivants.

Collegiates. (Meunonites.)

Collet. [Fr.] That part of a ring in which the stone is set.

Colletic. Of the nature of glue [Gr. $\kappa \delta \lambda \lambda \alpha]$.

Collibert. (Cagots.) 
Collimating eye-piece; Collimation, Error of ; Line of C.; Collimator. The Line of collimation is the imaginary line joining the optical centre of the object-glass to the intersection of the wires in the field of view of an astronomical telescope. When the axis on which the telescope turns is not exactly at right angles to the line of collimation, the defect from the right angle is called the Error of $C$. This error is corrected by viewing a distant object, first when the telescope is in a certain position, and again when the axis of rotation has been reversed on its bearings. It may also be corrected by means of an eye-piece so constructed that the observer can see at the same time the wires in the field of view, and their image formed by reflexion in a basin of mercury; this is called a Collimating eye-piece. The error can also be corrected by the use of a small telescope floated on mercury, the wires in whose field of view serve as a distant object ; this instrument is called a Collimator. (Collimation should have been written from the first, Collineation; a false reading of collimare, in a passage of Cicero, for collineare -con, together, liněa, a line-having caused the error. See Littré, s.v.)

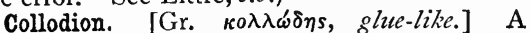
solution of gun-cotton in a mixture of ether and alcohol. It is used in photography.

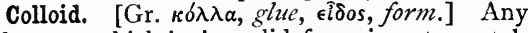
substance which in its solid form is not crystalline; as gelatine, glass, etc.

Collŭviēs. [L.] Refuse, filth.

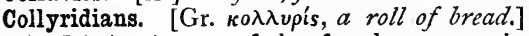
(Eccl. Hist.) A sect of the fourth century, in Arabia and Thrace ; so called from their offering cakes in honour of the Virgin.

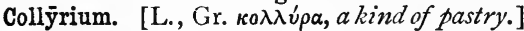
Eye-salve, eye-lotion.

-coln. [L. cŏlōnia, a Roman colony.] Part of names, as in Lin-coln, Coln-ey Hatch, Col(n)chester.

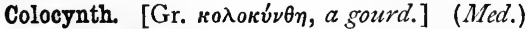
A purgative; dried powdered pulp of the C. gourd, Bitter apple, or Coloquintida. Common in Asia, Africa, Spain. Gen. Cucŭmis, ord. Cucurbitacěæ.

Cologne, Three Kings of. The three Magi, whose bodies were said to have been taken to Constantinople; thence to Milan; thence, A.D. I 64, to Cologne ; and who are popularly known as Gaspar, Balthasar, and Melchior.

Cologne earth. (From Cologne, in Germany.) A violet-brown bituminous earth, used as a watercolour.

Colon. [Gr. $\kappa \delta \lambda \sigma \nu$, misspelt $\kappa \hat{\omega} \lambda o \nu$.$] 1. Part$ of the great intestine, from the cœcum to the rectum. 2. A stop in punctuation, marked thus $[:]$; showing a pause longer than the semicolon, marked [;], and shorter than the period, or full stop, marked [.].

Colony. Acts xvi. 12; a cŏlōnia [L.]; a foreign town, to which had been granted the rights and privileges of Roman citizenship.

Corlöphōn. [Gr., top, finishing stroke.] In MSS. and old books, usually at the end, the scribe's or publisher's notice of the title of a work, his own name, date, and place of issue ; now given on the title-page.

Colophony. (From Colophon, a town in Ionia.) The dark resin obtained by distilling turpentine.

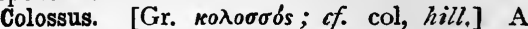
statue larger than life. In Hist., the most celebrated of these statues were the Colossus at Rhodes, absurdly supposed to have bestridden the harbour ; and the Colossus of the Sun, set up at Rome by Nero before the Golden House. The Flavian Amphitheatre, known as the Colosseum, is said to have been so called, as being built on the site where this figure had stood.

Colostrum. [L.] First milk secreted after confinement.

Colour ; Colour-blindness ; Colours, Complementary; C. of thin plates; Primary C.; scale of $\mathbf{C}$. The sensations produced by diferent kinds of light are Colowrs. The Primary $C$. are red, green, and violet (or blue). Sometimes red, yellow, and blue are (erroneously) called the three primary colours; and sometimes there are said to be seven primary colours, but in that case certain compound colours are called primary. "When any two colours mixed in proper proportions produce white, they are Complementary; as, red and green, or blue and yellow. Colour-blindness is insensibility to one or more of the primary colours, The commonest form is "red-blindness," or insensibility to red, whether as a separate colour or as mixed with others. To a person who is red-blind, all colours are blue or green, or combinations of them. The $\boldsymbol{C}$. of thin plates are produced by the interference of light reflected from the upper and under surfaces of the plate; such are those seen in soap-bubbles. Nezuton's scale of colours is the succession of colours due to successive variations in the thickness of these plates, and is exhibited in the coloured rings formed when two lenses are pressed together.

Colourable. [L. cŏlor, colour; in Rhet., pretext, a plea which primâ facie implies some right in an opposite party.] Specious, evasive.

Colportage. [Fr.] Hawking; distribution by colporteurs, hawkers especially of religious publications.

Colstaff. [Fr. col, the neck.] A staff for carrying burdens on the shoulders of two persons.

Colt's-foot. (From the shape of the leaves.) (Bot.) A native plant, in clayey and moist chalky places throughout Europe. Tussīlāgo farfăra; ord. Compositæ [L. tussis, a cough, the leaves being used to relieve asthma and cough, either by smoking or by decoction].

Cŏlumbæ. [L.] (Ornith.) Ord. of birds, comprising the pigeons and doves (Cólumbirdæ) and the three spec. of dodo (Dìdìdæ), all of which latter are extinct. Some authorities class the Cólumbæ and Gallinæ together, under the name of Rāsōrēs, Scratchers.

Cŏlumbārium. . [L., lit. pigeon-cote.] 1. A dovecote. 2. A tomb, with niches in the sides for sepulchral urns.

\section{Columbary. (Columbarium.)}

Columbia, Federal Republic of. Name some- 
times applied to the United States of America; from Columbia, the district containing Washington.

Columbier. Drawing-paper thirty-four and a half inches by twenty-three and a half.

Columbine. (Aquilegia.)

Columbium, Tantalum. First found in N. America.

Column. [L. cŏlumna, a pillar.] 1. (Bot.)

The combined stamens and styles forming a solid central body, as in orchids. 2. (Mil.) Massed formation of troops, showing a small front. 3. (Order.)

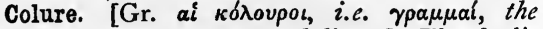
colures, the docked, truncated; lines.] The declination circles on the great sphere which pass through the equinoctial and solstitial points are called the equinoctial colure and the solstitial colure; they divide both the celestial equator and the ecliptic into four equal parts.

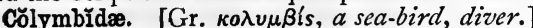
(Ornith.) Divers; fam. and gen. of sea-birds. Northern regions. Ord. Ansěres.

Colza. [Sp.] A kind of cabbage whose seeds yield oil for lamps.

Colza oil. (Colza.)

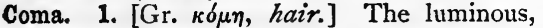
nebulous substance surrounding the nucleus of a comet. The nucleus, with the coma, forms the

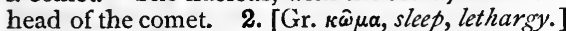
A profound insensibility, resulting from cerebral compression, or some narcotics, as opium.

Comatose. More or less in a state of Cōma.

Cŏmātŭla rŏsäcěa. [L. cŏmātǔlus, having the hair delicately curled, rŏsäcĕus, rose fashion.] (Bot.) Feather star. A small and very beautiful, and the only British spec. of the fam. of

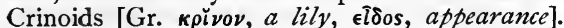
Radiated Ěchīnŏdermăta; free when mature; stalked when young, in which state it has been described as an independent spec., Pentacrīnus

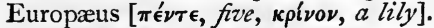

Comazants. St. Elmo's fires.

Comb. A toothed instrument for separating and cleansing flax, etc.

Combe, Comb, Coombe. [Cf. Welsh cym, hollow, ravine.] A dry ravine or gully at the head of a valley.

Combers, Grass. (Naut.) Farm labourers who have volunteered as seamen.

Combination. In Crystallog., a figure bounded by the faces of any number of forms.

Combination-room. The common room in which the fellows of a college meet.

Combinations. (Math.) Of different things, are the different collections that can be made of them without reference to the order in which they are arranged. If there were ten balls marked I, 2, etc., it would be possible to select three of them $(e . g .2,7,8 ; 5,4$, 9, etc. $)$ in 120 different ways; there are, therefore, 120 combinations of ten things taken three and three together.

Combings. (Coamings.)

Combing sea. A rolling wave ready to turn over.

Combining weight. (Atomio theory.)
Comessation. [L. L. cōmessātio, L. comissatiō, -nem, Gr. $\kappa \omega \mu \alpha ́ \delta \omega, 1$ revel.] A revelling.

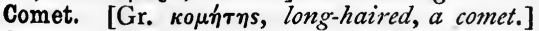
A body having a nebulous appearance, moving in the planetary regions under the influence of the sun's attraction.

Comfit. [Fr. confit, from L. confectum.] A dry sweetmeat.

Comfrey [L.L. confirma, = a strengthener], in O.E. Boneset. (Bot.) A gen. of plants, Symphy̆tum, ord. Borageaceæ; natives of Europe and N. Asia ; formerly esteemed as a vulnerary (q.v.). Prickly $C$. (S. asperrimum), a native of the Caucasus, a tall rough plant, is much spoken of as food for cattle.

Comítia. (Centuries; Plebiscite.)

Comitia of tribes. (Plebiscite.)

Comity of nations. [L. cōmìt, -ātem, courteousness.] The mutual recognition of each other's laws, wherever they are applicable; e.g. extradition $(q . v)$.

Comma. [L., from Gr. ко́ $\mu \mu a$, clause, a thing cut off.] 1. The smallest stop in punctuation, dividing clauses; its sign is $[$,$] . 2. A short$ clause. 3. In Music, a very small interval, about the ninth of a tone. 4. Pros., = Cæsūra (q.v.).

Commandant. (Mil.) The chief executive officer commanding a garrison or combined detachments of troops.

Commandary. A manor or chief messuage with land and tenements thereto pertaining, belonging to the Priory of St. John of Jerusalem, governed for the use of the society by a commander.

Commander. (Navy.) (Rank.)

Commander of the Faithful. [Ar. Emir al Mumenin.] A title of the caliphs, assumed by Omar. (Miramamolin.)

Commandery, Commandry. (Preceptories.)

Command of a work. (Mil.) Relative, the height above a work, in front of it; Absolute, the height above the level of the ground. $C$. of fire, when an effective fire can be delivered over the heads of the defenders of a work without injury to them ; $C$. of observation, when not.

Commëdia, La Divina. (Divine Comedy.)

Commëdia dell' Arte. [Itt.] The Italian popu. lar comedy.

Comme il faut. [Fr., as it should be.] Proper, appropriate.

Commemoration. At Oxford, the annual festival in honour of the benefactors of the university. (Encænia.)

Commemorative symptoms. [L. commĕmŏro, I remind of.] (Med.) Indicate some previous condition of the patient.

Commencement. At the University of Cambridge, the day from which all degrees conferred for a year preceding date, and on which they are confirmed by recitation before the congregation of the Senate.

Commendam, In. [L.L.] In Canon law, one to whom the custody, without profits, of a void benefice was for a time committed, held it for a trust; but by various devices the holding of a living thus became the means of enjoying 
pluralities, with their revenues. Sometimes bishoprics insufficiently endowed were thus assisted. Commendams abolished 6 and 7 William IV.

\section{Commendatory letters: (Literæ formatæ.)}

Commensurable. [L. commensūrābilis, that can be measured with another.] Two magnitudes are said to be commensurable when a third magnitude (called their common measure) can be found of which the two are exact multiples. The ratio of two C. magnitudes is expressed by a vulgar fraction. Thus, I $\frac{1}{4}$ foot is C. with $\mathrm{I} \frac{1}{3}$ yard, their common measure being $\frac{1}{4}$ foot, and their ratio being expressed by $\frac{5}{16^{\circ}}$

Comme sur des roulettes. [Fr.] As though on wheels; metaph. of matters which proceed smoothly and quickly.

Comminuted fracture. (Med.) Said of a bone broken into several pieces [L. comminnūtus, part. of verb comminuo].

Comminution. [L. con, thoroughly, minnuọ, I make (minor) less.] 1. Reducing to very small particles. 2. Continuous removal of small particles.

Commissariat. (Mil.) Department in charge of Government stores and arrangements for supplying provisions and transport. The officers are Commissaries.

Commissary. [L.L. commissārius, commissum, a trust.] 1. One who, under the bishop's commission, exercises ecclesiastical jurisdiction in particular causes and in parts of a diocese inconveniently distant from the B.'s principal Consistory Court. In the Clementine Constitutions, "officialis forrāneus." 2. (Commissariat.)

Commissary of Musters. (Arrayer.)

Commission. [L. commissum, a thing entrusted.] Authority from the sovereign, contained in a document, for the exercise of certain specified powers. Military commissions were until lately under the sign manual.

Commission, Putting a ship in. In the Navy, hoisting the pennant; after which the crew are under martial law. Generally used to mean fitting her out for a voyage after she has been laid up.

Commissioned officers. (Navy.) Lieutenants, and upwards.

Commissure. [L. commissüra, a joining together.] Place of union of two parts, a closure, seam.

Commis vöyageur. [Fr.] A commercial traveller.

Committee of the House of Commons. One to which a Bill, after the second reading, is referred. It may be either a selected one or a $C$. of the whole House, i.e. one formed of every member, the Speaker quitting the chair, sitting and debating as the rest, another member being appointed chairman.

Commode. [Fr.] 1. Head-dress of women. 2. Chest of drawers, bureau, night-stool.

Commodore. [Probably contr. from It. commandatore, a commander.] 1. (Rank.) 2. The convoy-ship, carrying a light in her top.

Commonage. A joint right on common land or water. The most important of these rights is that of pasturage. Among other similar rights is that of cutting turf, called C. of turbary; of cutting wood, called C. of estoners; and of fishing, called C. of piscary.

Commoner, The Great. William Pitt, afterwards Earl of Chatham, Secretary of State, 1756.

Commoners. (Pensioners.)

Common law. (Leg.) Sometimes opposed to Statute law, and = unwritten law, sometimes to Civil and Canon law, often to Equity, sometimes to Lex mercātōria. Unwritten law includes general and particular customs, and rules and principles not expressly and specially authorized by the Legislature.

Common measure. (Commensurable.)

Common Prayer, Book of. The first English Prayer-book, known as the first Prayer-book of Edward VI., was put forth in I549, with the approval of Convocation and Parliament. His second Prayer-book was issued in 1552, without the sanction of Convocation. A third book, differing little from the second, was put forth in I 559 by Elizabeth, who in 1560 issued a book in Latin for the use of the universities. The last revision took place in 1661 , after the Savoy Conference. A Prayer-book for use in Scotland was issued in 1635 .

Common purple, or Purpura. [L.] (Conch.) Purpǔra lăpillus; like a small whelk, white with reddish-brown bands. One of the molluscs secreting that which furnished the Tyrian purple. Common and widely distributed. Fam. Buccinidæ, ord. Prǒsōbranchīāta, class Gastěrŏpŏda.

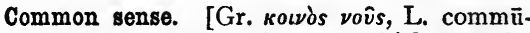
nis sensus.] A supposed sense, which was the common bond of all others; a judge and controller, to which they referred the sensations which they themselves received indifferently and unintelligently.

Commonwealth of England. (Hist.) The name given to the form of government established in England on the death of Charles I.

Commorant. [L. commŏran, -tem, p. part. of com-, mŏror, I tarry.] Abiding, dwelling in a certain place.

Commune. [Fr. commun, L. commūnis, common.] 1. One of the small districts into which France is divided. 2 The name given to the insurgent socialists of Paris, I87I.

Communication. In strategy, a line of C. is any practicable route between the different portions of the same army.

Commutation Acts, Tithe, i.e. 6 and 7 William IV. and others. By these there has been substituted for tithe a rent-charge payable in money, but varying on a scale regulated by averages of the price of corn-wheat, barley, and oats-for the seven years preceding.

Commutator. [L. commutātio, -nem, an interchanging.] A contrivance for reversing or stopping an electric current.

Compaginate. [From p. part. of L. compāgino, $I$ join together, from pāgina, page, leaf.] Unite, hold together, connect.

Companion. (Naut.) 1. The framing and 
sashlights on the quarter-deck, or round-house. 2. In small merchantmen, the hood over the cabin staircase. $C$. ladder, that by which the officers ascend to, and descend from, the quarterdeck. C. way, the stairs, etc., leading to the cabins.

Company. [Fr. compagnie, one of the same district (L. pagus).] (Mil.) Separate body of infantry, commanded by a captain, and possessing its own interior economy.

Company, John. Nickname of the East India Company.

Comparative grammar. The science which determines the relations of kindred languages by examining and comparing their grammatical torms. It could scarcely be said to exist until European grammarians became acquainted with Sanskrit, the ancient language of the Aryans of India.

Comparative mythology. The science which compares the popular traditions and beliefs of different countries, for the purpose of classifying them and determining their origin and the mode of their growth. This science has come into existence since the discovery of the Sanskrit language and literature by European scholars, and without it it would perhaps have been impossible.

Comparative science. Short for comparative study of a particular science, i.e. its study with a view to the comparison of genera and species and the registration of points of similarity and difference, whence general conclusions may be drawn by induction. It is opposed to descriptive or mere analytical science.

Comparison, or simile. (Rhet.) The comparing of one thing with another in some point common to both. It differs from Metaphor only in form, the latter only implying, while the former states the likeness.

Compartment bulkheads. (Bulkheads.)

Compass, Avimuth ; Mariner's C. ; Prismatic C. ; surveying C. The Azimuth $C$. is a magnet, to which a properly divided circular card is attached, mounted by means of a double suspension by gimbals; it is furnished with a line of sights, or some equivalent contrivance, which, being directed to the sun, enables the observer to determine its bearing from the magnetic north ; by means of an observed altitude of the sun and a calculation based thereon, its bearing from the true north at the same instant can be found ; by comparing these two results, the bearing of the magnetic north from the true north can be inferred, i.e. the direction of the magnetic meridian at that time and place can be found. In the Mariner's $C$., the Prismatic $C$., and the Surveying $C$., which are modifications of the same instrument, the approximate constancy of the direction of the magnetic needle over a considerable tract of sea or land is applied to the determination of directions with sufficient accuracy for many purposes of navigation and surveying. In the prismatic $\mathrm{C}$., a prismatic lens is used to show the wire and graduation lines below it in the same field of view, so that the observer obtains the reading without losing the coincidence of the wire with the distant object.

Compassionate allowance. Pensions given since the Crimean war to the children of deceased officers left in reduced circumstances, till they attain a certain age.

Compass-roof. (Arch.) An open-timbered roof, also called Span-roof.

Compass-timbers. (Naut.) Those which are carved or shaped.

Compellation. [L. compellātio, -nem, an accosting.] Appellation used in addressing a person or persons.

Compensate; Compensation balance; C. bar; C. pendulum. An instrument designed for exact measurement is said to be compensated for temperature, or simply to be compensated, when its parts are combined in such a manner that the points on which the measurement depends continue fixed relatively to each other, although the parts severally expand or contract with the ordinary changes of temperature. For the exact measurement of distance, a brass and a steel bar, of precisely the same length at $0^{\circ} \mathrm{C}$., are riveted together at the middle ; at each end a metal tongue, a few inches long, is loosely riveted to both, and projects at right angles to the bars. In consequence of the unequal rates of expansion of brass and steel, points properly chosen on the tongues will remain fixed at a constant distance apart, though the temperature vary. The measurement is effected by means of the fixed points. The instrument is a Compensation bar. The compensation of the balance-wheel of a chronometer is effected by an application of the same principle. (For $C$. pendulum, vide Pendulum.)

Compensation. [L.compensātio,-nem.] (Gram.) The lengthening of a vowel to make up for the loss of part of a consonantal group (and, as some hold, also to make up for the loss of a syllable);

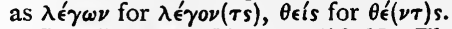

Compertentes. [L., qualified.] Those of the cătēchümens $(q . v$.$) who were immediate candi-$ dates for baptism.

Competition Wallah. A candidate for an examination for a Government office in India.

Compītālia, Iũdi compĭtālǐcii. [L.] A yearly Roman festival in honour of the Lăres compítāles, celebrated in the winter.

Oomplacence. [L. complăceo, I am very pleasing.] In Moral Phil., = moral esteem ; a love for that which is itself benevolent.

Complain, To. (Naut.) To creak, as masts, etc.

Complement; Arithmetical C. [L. complēmentum, that which completes.] When two angles together make up a right angle (or $90^{\circ}$ ), the one is said to be the $C$. of the other. When the sum of two numbers is 10 , the one is the Arithmetical $C$. of the other.

Complement, Moon in her. (Her.) The full moon.

\section{Complementary colours. (Colour.)}

Complete Angler. A treatise on fishing with descriptions of river scenery; reflexions on God's goodness; and charming dialogue. 
A book unique in its way; by Izaak Walton (15)3-1683).

complete-book. . (Naut.) A book containing full information concerning every one on board serving for wages; as to name, age, place of birth, rating, time of entry, etc.

Compline. (Breviary; Canonical honrs.)

Complatensian Polyglot Bible. Printed at Alcala, in Spain (Complutum), A.D. 1514 and 1515; the work of Cardinal Ximenes.

Complŭvium. [L.] A square open space in the middle of a Roman atrium (q.v.), towards which the roof sloped so that the rain [plüvia] fell into a tank [implŭvium] below.

Compo. (Naut.) The portion of wages paid monthly to a crew.

Component. (Composition.)

Compony. [Fr. componé.] (Her.) Composed of a row of squares alternately of two tinctures.

Composing. Placing types in proper order for printing.

Composing-stick. A small frame, held in the hand, wherein the compositor sets up the lines of type.

Compǒsǐtæ. [L.] (Bot.) The largest known nat. ord. of plants, having several florets collected into $\mathbf{a}$ head or a common receptacle ; e.g. dahlia, daisy, aster.

Composite ship. (Naut.) One built partly of wood and partly of iron; having an iron frame and wooden planking.

Composition. [L. compǒsťtio, -nem, from p. part. of compōno, I arrange.] (Leg.) 1. An amicable arrangement of a lawsuit. 2. An agreement for the remission of tithes on some consideration in lieu thereof. 3. A private arrangement with creditors, they agreeing to accept part payment in satisfaction of their claims. (Tithes.)

Composition of forces; C. of proportion; C. of ratios; C. of velocities. The determination in magnitude and direction of the single force equivalent to two or more given forces is the $C$. of those forces; the single force thus found is their resultant; and they are the components of the resultant. The terms Composition, Component, and Resultant are similarly applied to velocities. When two or more ratios are expressed numerically, the ratio which the product of their antecedents bears to the product of their consequents is said to be the ratio which is compounded of those ratios. When four magnitudes are proportional, it may be inferred that the first and second together are to the second as the third and fourth together are to the fourth; this inference is said to be drawn by composition or simply componendo.

Compos mentis. [L.] In full possession of mental powers.

Compost. [L. com-pǒsitus, placed together.] Manure made by mixing dung and urine, especially the latter, with leaves and earths of various kinds, according to the use which is to be made of it.

Compostella, The Order of. (Hist.) An order of Spanish knighthood, founded in the twelfth century, for the purpose of protecting the road to the shrine of St. James at Compostella.
Compos vōti. [L.] Having obtained (or gratified) a wish.

Compotier. [Fr. compote, L. compǒsĭta.] A dish for preserved or stewed fruits.

Compound. In India, the precincts of an English residency.

Compounder. (Univ.) A master of arts who pays down a sum in lieu of all annual college and university fees, for keeping his name registered as a member of the college and Senate.

Compound flowers, i.q. Composite. (Bot.) C. leaf, one divided into separate leaflets; e.g. ash. Compound householder. One who is occupier of a ratable tenement in common with others.

Compressor muscles. Such as compress the parts on which they act.

Compte rendu. [Fr.] A report of an officer or agent.

Comptoir. [Fr.] Counter, counting-house.

Comptroller. [Fr. contrôleur, from contrerôle, L. contra-rŏtŭlus, counter-register.] An examiner of accounts, or reports, or returns.

Compurgation. [From L. compurgäre, to purify.] In Eng. Hist., an ancient mode of trial in civil and criminal cases, which allowed the accused to clear himself by his own oath confirmed by the oaths of eleven of his neighbours. (Jury, Trial by.)

Comtist. In Philosophy, a follower of Auguste Comte. (Positivists.)

Cömus. [L., Gr. $\kappa \hat{\omega} \mu o s, b$ and of revellers, song of ditto.] 1. The chorus which sang a triumphal or complimentary ode in Greece, and the friend who accompanied it. 2. (Myth.) A winged youth, god of festivity. Milton, in Comus a Masque, makes him a vile enchanter. 3. (Naut.) Class of ships (like C. and five others, beginning with letter $\mathrm{C}$, now, or lately, in construction); steel-clad battle-ships; steel replacing the stout iron plates hitherto used.

Conacre. In Irish usage, the subletting by a tenant of a portion of his farm for a single crop.

Con amore. [It.] Lit. with love; with enthusiasm, zeal.

Concave, Double; Concavo-plane; Concaroconvex. (Lens.)

Concentric. [L. con-, together, centrum, $a$ centre.] Curves and surfaces which have a common centre are C. (Centre.)

Concept. [L. conceptus, conceived.] (Log.) The result of the act or the process of mental representation, as distinguished from the process. Conception. [L. conceptio, -nem, a conceiving.] (Log.) The mental act by which we combine a number of individuals together by means of some mark or character common to them all.

Conceptualists. (Nominalists.)

Concession. [L. concessio, -nem, from con-, cēdo, I grant, give up.] (Finance.) Permission conceded by a government to a person or company to undertake enterprises, such as mining, making canals or railways; generally subject to fixed conditions and limitations.

Concetti. [It., conceits.] Ingenuities of thought or expression, jeux d'esprit, etc., introduced in serious composition; the production mostly of 
the sixteenth century; generally in false taste. It., Sp., and Fr., and, e.g. Donne and Cowley, Eng.

Conchoïd. [Gr. кó $\gamma \chi \eta$, a muscle-shell, eíos, form.] Shell-shaped.

Conchs. (Naut.) The wreckers of the Bahama reefs.

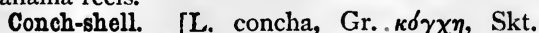
gankha, shell-fish.] (Zool.) Sea-trumpet (Triton variegātus); twelve inches or more long; white, mottled with brown and yellow ; inside, white, streaked with black. Used as trumpet by South Sea Islanders and Australians, who bore a hole about one-fourth the distance from the tip, and blow it as a flute. Warm seas. Fam. Mürícĭdæ, ord. Prŏsōbranchiāta, class Gastěrŏpŏda.

Conciator. [It. conciatore.] The person who dispenses and mixes the materials in glass-making. Concierge. (Ostiarius.)

Conciliation Act. Lord North's, I777, after Burgoyne's surrender at Saratoga, granted all American demands short of independence.

Concĭlinm Rĕgiōnäle. [L.] $A$ district court. Concinnity. [L. concinnitas, from concinnus, neat, well-arranged, from con-, with, cinnus, lock of hair.] Internal harmony, proper adjustment and proportion of parts.

Concision. [L. concīsio, -nem.] Phil. iii. 2

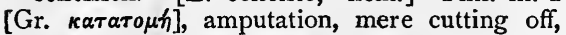

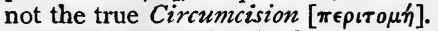

Conclämätum est. [L.] Lit. the (dead man's) name has been called; as the Romans did when a death was ascertained; all is over.

Conclave. [L., from con-, with, and clavis, $a$ key.] (Eccl. Hist.) The name given to the College of Cardinals, especially when shut up in the Vatican for the purpose of electing a pope. (Cardinal.)

Conclusion. [L. conclūisio, -nem.] (Log.) The proposition inferred from two former propositions, termed the premisses of the argument, or Syllogism.

Concordat. [L. concordāre, to agree together.] An agreement (I) originally as to mutual rights of bishops, abbots, priors, etc. ; (2) between the pope and some temporal sovereign, regulating things ecclesiastical in the dominions of the latter.

Concordia discors. [L.] A discordant concord; harmony between things naturally at variance.

Concrete. [L. concrètus, solidified.] A mixture of lime, sand, and gravel, which dries into a solid mass.

Concrete number. [L. concrëtus, growen together, hardened.] Numbers are said to be concrete when the units of which they are composed have a particular name ; as seventeen men, twenty-five apples, etc.

Concrete term. (Log.) A term used when the notion of a quality is regarded in conjunction with the object that furnished the notion, as wise. The quality regarded in itself is denoted by an Abstract term, as wistom.

Condensation; Condense; Condenser. [L. condensātio, -nem, from densus, thick, close.] To condense, (I) to make (or become) closer or more compact; as when we speak of condensed air.
In this sense, Condensation is opposed to Rarefaction. But (2) frequently it implies that the substance condensed undergoes a change of state, as when gases or vapours are condensed into the liquid or solid form. The Condenser of a steam-engine is the vessel into which the steam is withdrawn from the cylinder, and in which it is condensed by the injection of cold water.

Condenser. 1. An instrument for reducing an elastic fluid into a smaller volume. 2. An instrument for concentrating electricity.

Condensing engine. (Steam-engine.)

Conder. (Balcar.)

Condictio. In Rom. Law, a personal action; $V$ indicatio being a real action.

Condignity. [L. con-, with, dignus, worthy.] (Theol.) A scholastic term of the Thomists, denoting that men by divine grace may become worthy of eternal life as a reward for their holiness. (Congruity.)

Conditional proposition. (Log.) A proposition asserting the dependence of one categorical or positive statement on another, the former statement being called the antecedent, the resulting proposition the conscquent.

Conditioned, The philosophy of the. Sir W. Hamilton's expression in reference to the inability of the mind to apprehend or to reason about the abstract and the infinite.

Condottieri. [It., leaders.] In It. Hist., mercenary adventurers of the fourteenth and fifteenth centuries, who commanded bands, or even small armies, whose services they sold.

Conduct. 1. As at Eton, etc., a chaplain; as being, 2, an imperfect member of a corporate body [L. conductus, i.e. hired, salaried], for certain services, but not taking part in the general management.

Conduction of heat. The flow of heat from the hotter to the colder parts of a body, or from the hotter to the colder of two bodies in contact.

Conductivity, Thermal. The quantity of heat which passes in a unit of time through a unit of area of a wall of a given substance; the wall being a unit thick, and its opposite sides having temperatures which differ by a unit. As thus defined, the T. C. of silver is about four times that of brass, and ten times that of iron.

Conductor. [L.] 1. (Mil.) Warrant officer of the Army Service Corps. 2. (Phys.) A substance that transmits heat, electricity, etc.

Conduit. [Fr., from L. conductus, part. of condūco, I lead together.] (Arch.) Properly a passage giving secret communication between apartments. Also a pipe or passage for distributing water.

Condyle. [Gr. $\kappa \delta \nu \delta \breve{v} \lambda o s$, the knuckle, or similar knob of any joint.] (Anat.) The rounded head of a bone.

Condy's fluid. (From inventor.) A mixture of manganate and permanganate of potash.

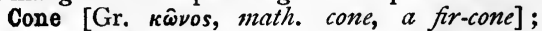
Conical surface. 1. (Math.) (I) The solid generated by the revolution of a right-angled triangle round its perpendicular; (2) more generally, a solid whose surface is generated by a straight line which moves so as always to 
pass through a fixed point, and to conform to some other condition, such as to pass through a given curve whose plane does not contain the point. The surfaces of these solids are often called Concs, though, strictly speaking, they are Conical surfaces. 2. (Bot.) A dense spike of female flowers,-covered with woody scales; $\epsilon . g$. fir.

Coney. [O.Fr. conil, L. cŭnīculus ; said to bë originally Sp.] (Zool.) 1. The rabbit (Lëpus cŭnīcŭlus). 2. In the Bible, the Shāphān, or Aschkôkô (Hy̆rax Sy̆răcus) ; gregarious pachyderm, like the marmot in appearance and size ; spec. of a single gen. forming fam. Hy̆răcŏìděa ; in some points apparently resembling the gen. Rhinoceros. Syria and Africa.

Confarreation. [L. confarreātio, -nem.] An ancient solemn form of marriage with the Romans, bread [far] being sacrificially offered in the presence of the Pontifex Maximus, or Flamen Diālis, and ten witnesses ; its dissolution being Diffarreätio.

Confederation, Germanio. (Hist.) An alliance of German states, formed at the Congress of Vienna, 1815, and designed to supply the want of the ancient imperial government dissolved in $\mathbf{1} 806$.

Confederation of the Rhine. A league of several German states, formed in 1806 , by Napoleon, who made them declare themselves separated for ever from Germany, and united by offensive and defensive alliance with France. Dissolved in 1813 .

Conference. (Hist.) A name applied sometimes to meetings for theological discussion, as the Hampton Court Conference, 1604; the Savoy Conference, I66o.

Confervæ, Confervāceæ. [L. conferva, a waterplant supposed to have healing power.] (Bot.) Simple tubular jointed spec. of algæ, inhabiting fresh water.

Confession, Auricular. (Auricular confession.)

Confession and Avoidance. In Law, an admission of the truth of the allegation, in part at least; followed by reasons against drawing the legal consequence drawn by the opposite side.

Confession of Faith. (Eccl. Hist.) A formulary setting forth the opinions of a religious community, as the Nicene Creed. The word is applied especially to the Lutheran and other Protestant expositions of belief, as the Augsburg Confession, I530; the General Confession of the Scotch Church, I581; the Westminster Confession, 1643 .

Confessor. [Eccl. L.] 1. One persecuted, and ready to lay down his life for the gospel, but not actually martyred. 2. One authorized to hear confessions.

Confirmation of a bishop. The election of a B. by congé d'élire having been certified to the king, the royal assent goes to the archbishop, with direction to confirm and consecrate. He subscribes fat confirmatio; and the vicargeneral then cites to Bow Church all opposers ; and thus, after certain details, the election is ratified.

Confluence; Confluent. [L. confluens, flowing into another river; hence, Coblenz = confluentes.] The point of junction where two rivers meet; the smaller is then a confuent of the larger river.

Conformable strata (Geol.) = lying one upon another in parallel order. Unconformable $=$ overlying another set at a different angle; the latter condition indicating lapse of time.

Conformity, Declaration of, i.e. to the Liturgy of the Church of England. Required of all persons who are to be licensed or instituted to an ecclesiastical charge.

Confrère. [Fr.] Fellozu-member of a fraternity ; intimate associate.

Confucianism. The system of the Chinese philosopher, Kong-fu-tzee, Confucius (about B.C. 550). It was confined to Ethics, to the exclusion of all religion. (Taouism.)

Congé. [Fr., leave.] Permission, leave of absence, discharge. Four de C., holiday. [L. commeātus, authorization, permission.]

Congé d'élire, or eslire. [Fr.] Leave to choose, especially the sovereign's licence to a dean and chapter to elect a bishop to a vacant see.

Congĕner. [L., from con-, with, genus, genĕris, kind.] One of the same genus or kind.

Congenital. [L. congěnǔtus, born with.] $\mathrm{Be}$ longing to a person from birth.

Congeries. [L., from con-, together, gero, I carry.] A collection into one mass, a heap.

Congestion. [L. congestio, -nem, a crowding.] An undue determination of blood, or other fluid, to an organ.

Congiary. [L. congiārium.] A present of corn made by Roman emperors to the people, measured by the gallon [congius].

Conglomerate. (Breccia.)

Congou. [Chin. kung-foo.] A superior black tea, having large leaves.

Congregation. [L. congregātio, -nem, from con-, and grex, a flock.] 1. At Oxford and Cambridge, the assembly of masters and doctors, for transacting the ordinary business of the university ; and at which degrees are given. 2. In the Latin Church, any company of religious persons forming subdivisions of monastic orders ; a committee of cardinals for transaction of the business of the see of Rome.

Congregationalists differ little from Independents, except in admitting a communion of Churches.

Congress. [L. congressus, a stepping together.] (Hist.) 1. A meeting of the sovereigns of states, or their representatives, to arrange international matters. 2. The title of the national legislature of the United States of America.

Congruity. [L. congruita, -tem, agreement.] (Theol.) A term used by the scotists to denote the necessary bestowal of divine grace on those who so live in their natural state as to be fit recipients of it. (Condignity.)

Conic sections. The curves formed by the intersection of a cone with a plane. They are of three kinds-Ellipses, Hyperbolas, and Parabolas, according to the direction of the cutting plane. A point traces out a conic section when 
it moves in such a manner that its distance from a fixed point bears a constant ratio to its perpendicular distance from a fixed line. The fixed point is called the focus, the fixed line the directrix of the conic section.

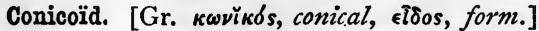
A surface of the second degree, i.e. one of the class of surfaces which correspond to the conic sections in plane geometry.

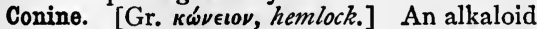
obtained from hemlock.

Conirostrals, Conirostres. [L. cōnus, cone, rostrum, bill.] (Ornith.) Conical-billed birds. A large tribe or fam. of Passerres, or Insessorēs, in those systems which characterize birds by the form of their bills. It includes larks, crows, starlings, hornbills.

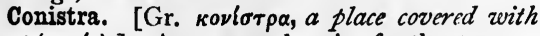
dust (кovis).] An arena, the pit of a theatre.

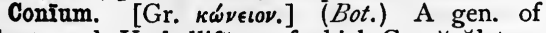
plants, ord. Umbellifěræ, of which C. măcŭlatum (spotted in stem) is common hemlock. Found in Britain and in Europe generally, in waste places, by the sides of ditches, etc.

Conjee. (Naut.) Rice-gruel.

Conjugate; C. diameters; C. foci. [L. conjŭgātus, joined together in pairs, jŭgum, a pair.] 1. (Math. and Phys.) When points, lines, planes, etc., in pairs, are related in such a manner that the first stands to the second in a relation precisely similar to that in which the second stands to the first, they are often said to be Conjugate. $C$. foci of a lens are two points such that light diverging from the first is concentrated by the lens at the second; they are conjugate, because light diverging from the second will be concentrated by the lens at the first. If there be two diameters to an ellipse or hyperbola such that the first is parallel to the tangents drawn through the extremities of the second, then it follows that the second will be parallel to the tangents drawn through the extremities of the first, and the diameters are called $C$. diameters. 2. (Bot.) Growing in pairs.

Conjunction ; Inferior C. ; Superior C. [L. conjunctio, -nem, a joining together.] 1. (Astron.) When two planets have the same heliocentric longitude, they are in Conjunction; but when the earth is one of the planets, the other planet is said to be in C. when it passes behind the sun, i.e. when its geocentric longitude equals that of the sun. If, however, the planet is an inferior planet (Venus or Mercury), this conjunction is distinguished as a Superior $C$. ; and when either of these planets passes between the sun and the earth, they are at Inferior C. 2. (Gram.) A part of speech expressing the relation of propositions to each other.

Conjunctiva [L.], i.e. membrāna. The mucous membrane which, lining the eyelids, is continued over the eyeball.

Conjunctive mood. (Gram.) The modification of the verb which expresses the dependence of the event intended on certain conditions.

Conn, Con, or Cun, To. (Naut.) To direct the steersman. Connings are reckonings.
Connate leaves. [L. connātus, born at the same time with.] (Bot.) United at the base by adhesion, e.g. the leaves of the yellow-wort (Chlōra perfóliāta), the stalk of which is therefore perfoliate $(q . v$.$) .$

Connecting-rod. (Crank.)

Connivent. [L. conniveo, I close together, wink.] 1. Inattentive. 2. (Anat. and Bot.) Lying close together, converging; e.g. the anthers of a borage blossom C. around the style.

Connoisseur. [Fr.] A person thoroughly acquainted with a subject, especially with an art; a skilled critic.

Connusance, Conusance. [Fr. connoissance.] 1. (Leg.) Cognizance. 2. (Cognizance.)

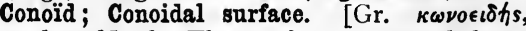
cone-shaped.] 1. The surface generated by a straight line which passes at right angles through a fixed straight line, and is guided in its motion by a given curve is a $C$. surface or a Conoid. 2. Formerly, any one of the surfaces formed by the revolution of the conic sections round a principal axis, i.e. round a line drawn through the focus at right angles to the directrix. (Conic sections.)

Conquistador. [Sp.] One of the Spanish conquerors of Peru and Mexico.

Conscia mens recti. [L.] $A$ mind conscious of rectitude; a good conscience.

Conscience clause. A clause introduced into the Revised Code for national edication in 1860 , for parishes where only one school is needed. It provided for the admission of Dissenters, and exempted them from the religious teaching of the school.

Conscript. [L. conscriptus, enrolled.] (Mil.) One taken by lot to serve in the army under a Consoription.

Conscript Fathers. [L. Patres Conscripti.] (Hist.) The senators of ancient Rome.

Conscription. [L. conscriptio, -nem, a written list.] (Hist.) Compulsory enrolment for military service by land or sea. In ancient Rome the conscription was made by the will of the consuls, who selected as they pleased. In France it is determined by lot.

Consectary. [L. consectārius.] Consequent deducible, to be inferred.

Consecutive intervals. (Music.) Similar intervals in sequence, as $C$. fifths, octaves; forbidden generally when between the same two parts.

Consecutive symptoms, or Sěquēlæ, occur after or during the decline of a disease without being directly connected with it. (Sequela.)

Conseil d'Etat. [Fr., Council of State.] The French House of Commons.

Consenescence. [L. consènesco, $I$ grow old.] Growing old, decay from age.

Consensual. [L. consensus, consent.] Resting on mutual consent as a C. contract ; e.g. marriage.

Consensual actions. Instinctive reflex actions of animals, the result of impressions made on the sensory ganglia, as distinguished from the cerebrum.-Carpenter's Ment. Phys., p. 8I.

Consentes, Dii. [L.] The name by which the Romans spoke of their twelve great deities-Juno, Minerva, Ceres, Vesta, Diana, Mars, Venus, 
Mercury, Neptune, Vulcan, Apollo, and Jupiter the father of all. Also called Dii complices.

Consequent. (Conditional proposition; Ratio.)

Conservancy. [L. conservo, I take care of.] A board which takes care of a river and regulates the traffic.

Conservation of areas; C. of energy; C. of force; C. of momentum; C. of motion of centre of gravity; C. of motion of rotation; C. of motion of translation; C. of vis viva. It is a fundamental principle of Physics that the total energy of any bodly or system of bodies is a quantity which can neither be increased nor diminished by any mutual action of these bodies, though it may be transformed into any of the forms of which energy is susceptible. Thus some of the mechanical or kinetic energy of the system may disappear, to be replaced by an exact equivalent of heat. This principle is termed that of the $C$. of energy. The term $C$. of force is sometimes used as equivalent to the C. of momentum; but more commonly it is used (though inaccurately) as equivalent to the C. of energy. The term C. is used in several connexions in the science of dynamics. Thus it is proved that, in the case of a body acted on by any forces, the motion of the centre of gravity is the same as if all the mass were collected at the centre of gravity and all the forces applied to it unchanged in magnitude and direction, while the motion of rotation round the centre of gravity is the same as if that point were fixed and the forces unchanged. These theorems are called the principles of the $C$. of the motion of the centre of gravity, and of the motion of rotation. The $C$. of momentum is the theorem that, if the particles of a system are acted on only by their mutual attractions and repulsions, the sum of the momenta estimated in a given direction is constant. The $C$. of areas is the theorem that, in the last case, if the mass of each particle is multiplied by the area (referred to any given plane) which it describes round a fixed point, the sum of these products will be proportional to the time of description. Kepler's second law is a particular case of the $C$. of areas. The term $C$. of vis viva is also used.

Conservatoire. [Fr.] A school especially of music, a museum.

Consignee. [Fr. consigné, L. consignātus, signed.] One to whom goods (a consignment) are sent, the sender being the consignor, who consigns or delivers them on trust to the carrier.

Consistentes. [L.] In the ancient Church, the last order of penitents, standing with the faithful after dismissal of the rest, joining in common prayer, and seeing the oblation offered, but not offering nor communicating.

Consistory Courts. (Court, Christian.)

Consolato del mare. [Sp.] A code of maritime laws compiled for the old kings of Aragon.

Console. [Fr.] (Arch.) C. table, a table or slab supported by brackets.

Consols. Stock in the English Funds, consisting of different kinds of annuities severally consolidated into capital, bearing interest at three and three and a half per cent. for ever.
Consommé. [Fr.] Gravy or jelly-soup.

Consonant. [L. consonantes, from con-, with, sono, I sound.] (Gram.) A sound in speech produced by an opening action of the articulatory organs, and which must be sounded with a vowel (q.v.). As adj., in harmony with, agreeing with.

Constable. [Fr. connétable, from L. cŏmes stabŭli, count of the stable.] (Hist.) A title which is supposed to have originated in the Lower Empire. The Constable of France was the first dignitary under the Crown. In Eng. land, the permanent office of Lord High Constable was forfeited by the attainder of the Duke of Buckingham, in 1522 .

Constable of the Tower. Governor of the Tower of London, who is one of the senior generals in the army; the appointment having been anciently one of high importance and trust.

Constans, Type of. (Type of Constans.)

Constant. [L. constan, -tem, part. of constare, to stand together.] In Math., a quantity or number whose value in regard to any question or class of questions is fixed. Constants generally serve to define the relations existing between variable magnitudes. Thus, if $s$ denotes the number of feet through which a body will fall in $t$ seconds, it is known that $s=16 t^{2}$ (approximately); here the constants, 16 and 2, serve to define the relation existing between the variable magnitudes $s$ and $t$.

Constantia. A red wine made at the place so called, near Capetown.

Constantine, Donation of. An alleged gift to the pope by the Emperor Constantine after his conversion, conveying to him the city of Rome and the whole Western Empire. The document is supposed to be a forgery of the eighth century.Milman, Hist. of Latin Christianity, bk. i. ch. 2.

Constellation. [L. constellatio, -nem.] (Astron.) A group of stars. The division of stars into constellations is purely arbitrary. The large stars within the group are distinguished as $\alpha, \beta$, etc. ; as, $\boldsymbol{\alpha}$ Leonis, $\boldsymbol{\beta}$ Aquilæ, $\delta$ Ursæ Majoris, etc.

Constituent Assembly. In Fr. Hist., the first of the national assemblies of the Revolution. Dissolved in 1791. (Assembly.)

Constrictive. [L. constrictivus, constringo, I draw together.] Able to bind together, astringent.

Construct ; Construction. [L. constructus, part. of construěre, to put together.]. To draw by geometrical rules; as " to construct a figure similar to a given rectilineal figure." Mathematical problems are in many cases solved by algebraical processes; but it frequently happens that the steps of the process correspond to the drawing of certain lines on paper, by means of which a line or other magnitude can be determined which serves as a solution of the problem. Under these circumstances the problem is said to be solved by $\mathrm{C}$.

Constructive. (Marine Insur.) Taken for certain. A constructive total loss is reckoned when salvage is highly improbable, and, on abandonment of all claim to salvage, owners recover against underwriters as for total loss. 
It also occurs when it would cost more than a ship's value to repair her. (Abandonment.)

Consuālia. (Ludi circenses.)

Consubstantial. [L. con-, with, substantia, substance.] (Theol.) This word translates the Greek homoiousios, used in the Nicene Creed to denote the oneness of substance between the Father and the Son. (Homoiousian.)

Consubstantiation. (Theol.) The name given to the Lutheran doctrine that, while the bread and wine in the Eucharist retain their natural substance, the body and blood of Christ are at the same time transfused into them, and thus that both substances are partaken of together. (Transubstantiation.)

Consul. [L.] 1. The two supreme magistrates of Rome after the expulsion of the kings were called Consuls. They held office for one year. (Autocrat.) 2. In France, the title was conferred in I 799 on the persons entrusted with the provisional government of the country after the dissolution of the Directory. 3. It is also given generally to public officers who act on behalf of foreign states partly in a diplomatic and partly in a commercial character.

Consulars. [L. consulāres.] Roman citizens were so called after having served as consuls.

Consultation, Writ of. In Law, a writ by which a cause, rẹmoved into the King's Court by Prohibition out of the ecclesiastical court, is returned thither again.

Contadino. [It.] Peasant, countryman.

Contāgium ănĭmātum, or vīum. $A$ living disease germ; a mediæval expression, anticipatory of the modern germ-theory of contagion.

Contango. (Stockbrok.) The commission charged to bulls for carrying over a bargain from one settling day to the next, if stock has fallen in price since he bought. (Continuations.)

Contempŏrānea expositio est optǐma et fortissima in lege. [L.] An exposition delivered at or near the date (of a law or deed) is the best and most powerful in law.

Contents. (Naut.) A document containing a merchantman's destination, cargo, etc., which must be delivered to the custom-house before sailing.

Conterminous. [L. conterminus, from con-, together, terminus, boundary.] Having the same bounds, bordering upon, contiguous.

Contestation. [L. contestātio, -nem, a calling to witness.] 1. A contesting, a controversy. 2. Attestation.

Continental system. (Hist.) The name given to the plan of the first Napoleon Bonaparte, for excluding English merchandise from all parts of the Continent.

Contingent. [L. contingens, -tem, part. of contingere, to concern.] (Mil.) 1. Allowance made to captains for repair of arms, pay of clerk, purchase of documents, the keeping each soldier efficient in kit, and as compensation for risk of taking charge of public money. 2. Establish. ment of troops organized, equipped, and kept in efficiency, at the disposal of a neighbouring superior state.

Continual proportion. If there are any mag- nitudes such that the first bears to the second the same ratio that the second bears to the third, and the second to the third the same ratio that the third bears to the fourth, and so on, the magnitudes are said to be in a Continual or Continued $P$.

Continuations. (Stockbrok.) The carrying over of a time bargain from one fortnightly settling day to another, for which a commission is charged, called contango if a buyer defer settlement, backwardation if a seller defer.

Continued fever. Abating, but never entirely intermitted. (Intermittent fever.)

Continued fraction. A fraction whose numerator is unity and denominator a whole number plus a fraction; this fraction has for its numerator unity and its denominator a whole number plus a second fraction of the same form as the preceding,

$$
\text { and so on; as } \frac{1}{7+\frac{1}{3+\frac{1}{8}} \text { which equals } \frac{25}{183}}
$$

Continued product of three or more numbers is obtained by multiplying the first by the second, their product by the third, and so on. Thus the continued product of 7,12 , and 15 , is I 260.

Continuity; Equation of C. ; Law of C. ; Continnous. A variable magnitude is said to change continuously when it passes from one assigned value to another without breaks or jumps. If we suppose the magnitude to be always on the increase or decrease between the assigned values, it changes continuously when it passes successively through every intermediate value. The Law of $C$. is the doctrine that no change in a natural phenomenon takes place with perfect suddenness or abruptness ; thus the gaseous and liquid states of matter may be made to pass one into the other without any interruption or breach of Continuity. The Equation of $C$. in hydro-dynamics is an algebraical or symbolical statement of the fact that at any point of a fluid in motion the rate of diminution of the density bears to the density the same ratio that the rate of increase of the volume of an infinitely small portion bears to the volume of the portion at the same instant.

Continuous lines. (Mil.) Any series of field works without break or interval.

Continuous style. (Arch.) More commonly called Perpendicular. (Geometrical style.)

Contorted. [L. contortus, part. of contorqueo, I whirl round.] (Bot.) Twisted so that all the parts have a similar direction; as the segments of an oleander flower.

Contour line. [Fr. contour, contour.] 1. (Geog.) A line on a map showing all those points on the surface of the ground which are at an assigned height (say 100 feet or 200 feet) above the sealevel. 2. (Mil.) Represents the intersection of a horizontal plane with the surface of a hill.

Contra audentior ito. (Ne cede malis.)

Contraband. [L. contra, against, bannum, public prohibition.] Goods, such as munitions of war, belligerents' property, which neutrals are 
prohibited from importing or exporting to or from a belligerent's ports.

Contrā bonos mōres. [L.] Against good conduct, against morality.

Contradictory propositions. (Log.) Propositions which have the same term differing in quantity and quality, Contrary propositions being two universals with the same terms-the one negative, the other affirmative.

Contranitency. [L. contra, against, nittor, $I$ strive.] Resistance to force employed.

Contrary motion. (Music.) (Motion.)

Contrary propositions. (Contradictory propositions.)

Contrate-wheel. A Crown-wheel.

Contravallation. (Circumvallation.)

Contrectatio rei ăliēnæ ănìmo fŭrandi est

furtum. [L.] The touching of another's property with intention of stealing is theft.

Contredanse. [Fr., corr. into country-dance.]

An English dance; the performers being in two lines opposite to [L. contra] each other.

Contretemps. [Fr.] Lit. against time; an unexpected accident.

Control. [Fr. contrôle, O.Fr. contre-rôle, a counter-roll, a duplicate, for verification.] (Mil.) Department having entire charge of all payments, stores, quarters, and equipage of an army.

Contumacy. [L. contūmācia.] Obstinate disobedience to the rules and orders of a court, or neglect of a legal summons.

Contusion. [L. contušro, -nem, from contundo, $I$ bruise, crush.] (Med.) An injury without apparent wound, caused by a fall, blunt weapon, etc.

Conundrum. A kind of riddle involving an absurd comparison, by means of a punning answer, between unlike things.

Conusee. (Cognizee.)

Convection; Convective. [L. convectio, $a$ bringing together.] When a heated body is placed in or near a fluid, the neighbouring part of the fluid has its density diminished, and, ascending, is replaced by some of the colder part of the fluid, which in its turn grows warm and ascends; a current is thus set up which is called a C. current, and the heat is said to be diffused by $\mathrm{C}$. C. currents may be set up by other means, as when electricity is the thing carried, e.g. when a conductor ending in a fine point is strongly electrified, the particles of air near the point will be charged with electricity, and then carried towards any surface oppositely electrified. This constitutes a Convective discharge of electricity.

Convener. [L. con-, together, věnio, I come.] A Scotch county official.

Conventicle Act, First, 1664, made liable to fine and imprisonment any over sixteen years of age present at any exercise of religion not allowed by the Church of England, where there were five persons more than the household. C. A., Second, 1670, modified these penalties, but gave part of the fine to informers. (Declaration of Indulgence.)

Convention. [L. conventio, -nem, a coming together.] (Hist.) 1. An assembly of national representatives meeting under extraordinary circumstances, without being convoked by legal authority. Such was the Parliament which restored Charles II. in I66r, and the Parliament which, in 1688 , declared that James II. had abdicated the crown. 2. In Fr. Hist., the assembly which proclaimed the republic in 1792. (Assembly.)

Convergent series. [L. con-, together, vergo, $I$ incline.] A series such that the sum of its first $n$ terms cannot be made to exceed a certain assigned number, however large $n$ may be ; e.g. $1+\frac{1}{2}+\frac{1}{4}+\frac{1}{8}+\frac{1}{16}+$ etc., cannot be made to exceed 2, however many terms may be taken.

Conversazione. [It.] A social gathering for conversation, especially one at which experts and amateurs in literature, art, or science meet.

Convex, Double; Convexo-concave; Convexoplane. (Lens.)

Conveyance. [L. convěho, I convey.] (Leg.)

An instrument which assumes the transfer of property to a living person.

Conveyancing. (Leg.) The art or science of the alienation of property.

Convocation. [L. convocātio, -nem, a callıng together.] (Eccl. Hist.) The Council of the Church, consisting of the clergy of a province summoned by the archbishop. Edward I. first summoned convocations in England for the purpose of obtaining subsidies from them. The power of taxing their own body was taken from them in 1664, when the clergy were allowed to vote in elections of knights of the shire. The House of Convocation in the University of Oxford is the assembly which ratifies decrees and statutes.

Convoy. [Fr. convoi, L.L. conviare, to escort.] 1. (Mil.) Guard accompanying stores and baggage for their protection. 2. (Naut.) A merchant fleet under the protection of armed vessels. 3. The armed vessels themselves. 4. A drag to check carriage-wheels in descending a hill.

Convulsionists, Convulsionaires. [Fr.] Fanatical Jansenists, in France, early in the eighteenth century, exhibiting contortions resembling the movements of all kinds of animals. (Dancing mania.)

Coolies, Coulies. Originally the name of one of the hill tribes of Hindustan; many of these being employed as labourers and porters in Bom. bay, etc. The word C. became = porter; but it is used now to denote emigrant labourers from India and China to other countries.

Coom. [Ger. kahm, mildew.] Suot or coaldust.

Coomb. [(?) Cf. L. cŭmŭlus, a heap.] A dry measure of four bushels, or half a quarter.

Coomings. (Coamings.)

Coöptation. [L. cooptātio, -nem, from con-, together, opto, I choose.] Election of fresh members to a board or college by the existing members.

Co-ordinate axes; C. geometry; C. planes. Co-ordinates ; Origin of C.; Oblique C.; Rectan. gular C.; spherical C. If a point in a plane is taken and through it are drawn two lines or axes which are then produced indefinitely both ways, 
the plane is evidently divided into four portions. Suppose a point taken anywhere in the plane, its position relatively to the two straight lines or axes can be defined thus: Through the point draw a line parallel to the one axis to cut the other; the line thus drawn is called the ordinate, and the intercept the abscissa. If the lengths of the abscissa and ordinate are known, the position of the point is known, provided it be known in which of the four portions of the plane it is situated. If, however, the signs + or - prefixed to the abscissa indicate that it is measured to the right or left of the fixed point, and the same signs prefixed to the ordinate indicate that it is to be measured up or down, it is plain that, the signs and magnitudes of the ordinate and abscissa being known, the position of the point is determined without ambiguity relatively to the axes. The ordinate and abscissa are called the C. of the point, the axes or lines of reference are called $C$. axes, and the point through which they both pass is called the Origin of $C$. ; when the axes are at right angles to each other the $C$. are rectangular, when otherwise the $C$. are oblique. The position of a point in space may be defined by an extension of the same method with reference to three $C$. planes. The position of a point on the surface of a sphere may be similarly defined by arcs of two great circles which are called its Spherical C., e.g. the latitude and longitude of a place on the earth's surface (as commonly defined) are the spherical coordinates which fix its position. $C$. geometry is an application of algebra to geometry, based on the determination of the position of a point by means of its co-ordinates. It is sometimes called Cartesian geometry, from the name of its inventor, Des Cartes. (For Polar co-ordinates, vide Radius-Vector.)

Co-ordinating power of the brain brings mus cular movements into harmony; it is absent, e.g., in intoxication.

Copaiba, Copaiva, Capivi. [Braz. cupauba.] An oleo-resin from a Brazilian tree of this name. It is used medicinally and in oil-painting.

Cupal. An Indian resin (Mexican, copalli), much used for artists' varnish.

Coparcenary. [L. co-, with, O.Fr. parçonnère, from L. partior, I share.] (Leg.) Jointownership of an inheritable estate without partition, by two or more persons possessing equal title, their several claims descending to their respective heirs. C. differs from joint-tenancy $(q . v$.$) and tenancy in common (q.v.), inter alia,$ in origin, kind of seising, and methods of dissolution; also from joint-tenancy in not involving benefit of survivorship (jus accrescendi).

Coparcener. Co-tenant by descent.

Cope. [L.L. cappa, a cape.] 1. (Eccl.) A semicircular vestment worn by the clergy in processions. The rubric of the first Prayer-book of Edward VI. enjoins its use by priests administering the Holy Communion as an alternative with the vestment. 2. The top of a founder's flask.

Copeck. (Rouble.)

Cophetua, King. A legendary king in Africa, in Percy's Reliques, who married a beggar-maid.
Coping of a wall. (Arch.) The covering course, often sloping on the upper surface to throw off water.

Coppel. (Cupel.)

Copperas. [It. copparosa, from L. cupri rosa, rose of copper.] Sulphate of copper, iron, or zinc, accordingly as its colour is blue, green, or white, respectively.

Coppice, Copse. [O.Fr. coupeiz, from couper, to cut.] Wood grown to be cut every few years.

Coprolite. [Gr. $\kappa \delta \pi \rho o s$, dung, $\lambda i \theta$ os, stone.] Fossilized excrements, chiefly of saurians and sauroids ; popularly misapplied to all the phosphatic nodules dug up for artificial manures.

Copts. Properly the people from whom the country of Egypt received its name. More particularly the Monophysite or Jacobite Christians of Egypt, who use the Liturgies of Basil, Cyril, and Gregory.

Copŭla. [L., a band.] (Log.) The part of a proposition which affirms or denies the predicate of the subject. In strictness, the only copula is the present tense of the verb to be, with or without the negative sign.

Copy. Paper twenty inches by sixteen. In Printing, a technical term for an author's manuscript.

Copyhold. (Leg.) A lease tenure nominally at the lord's will but really free by custom. C. is a parcel of a manor which has a court, and must have been demisable by copy of court-roll from time immemorial. The manor court as relating to copyholders is a customary court.

Coq-à-l'âne. [Fr., a cock on an ass.] A story without any connected transition; $d$ 'un sujet $a$ un autre (Littré) ; probably the original meaning of cock-and-bull story.

Coquecigrue. [Fr.] As explained by Littré, an imaginary animal, sometimes $C$. de mer; the word being variously used : e.g. the coming of the $C$. (Rabelais) is = never; He is a $C$. $=$ one who romances; It is a $C$. = nonsense, falsehood ; originally meaning a kind of rest-harrow, a sticky troublesome weed.

Coquilla nut. [Sp. coquillo, dim. of coco, $a$ cocoa-nut.] A Brazilian fruit, with a hard brown shell used in ornamental turning.

Coracle. [Welsh corwgh, from cwrwg, round body.] A very light boat of leather or oil-cloth stretched over wicker-work; used by a single person.

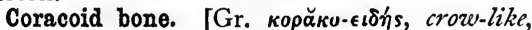
as resembling a crow's bill.] A bone in birds, answering to the coracoid process of the scăpŭla in mammals.

Coracora. (Koracora.)

Coralan. (Naut.) A small open boat of the Mediterranean, used for coral-fishing.

Coral wood. (From the colour.) A fine red wood, used in cabinet-making.

Cōram nōn jūdǐce. [L.] Before one who is not a judge; i.e. in a court not having jurisdiction.

Coram popŭlo. [L.] Before the people.

Coran. (Alcoran.) 
Cor Anglais, English horn. [L. cornu, $a$ horn.] (Music.) 1. The tenor hautboy. 2. A reed-stop in an organ.

Coranto. [It. correre, to run, Fr. courante, courir.] 1. A kind of country-dance, quick, in triple time; Italian. 2. In Handel's and other lessons for the harpsichord, a courante is generally introduced as one of the movements.

Corban. [Heb., an offering or gift.] Among the Jews, anything offered to God, especially in fulfilment of a vow. Any one might thus interdict himself from assisting any one, even parents in distress (Matt. xv. 5).

Corbel. [Fr. corbeau.] (Arch.) A projecting bracket, supporting a superincumbent object, or receiving the spring of an arch. A corbeltable is a parapet or cornice resting on a series of corbels.

\section{Corbel-table. (Corbel.)}

Corbie steps. (Arch.) Small battlements running up the sides of gables.

Cord. A pile of wood eight feet long, four high, and four broad, containing 128 cubic feet. (From the cord with which it is measured.)

Cordate. (Bot.) Shaped like a heart [L. cor, cordis] ; e.g. leaf of violet.

Cordeliers. The Friars Minor, or Minorites, of the order of St. Francis ; so called from the cord tied round the waist. The name was also assumed by a Parisian revolutionary club, of which Danton and Marat were prominent members.

Cordon. [Fr., from corde, a string, L. chorda.] (Mil.) 1. Line of troops spread out for observation. 2. A band of stonework placed along the top of a revetement. 3. Ribbon, twist.

Cordon blea. [Fr.] Lit. blue ribbon, a firstrate cook.

Cordovan. Goatskin leather from Cordova, in Spain.

Corduroy. [(?) Fr., corde du roi, king's cord.] A thick cotton stuff with corded or ribbed surface.

Cordwainer. [Fr. cordonnier.] A shoemaker, originally a worker in Cordovan leather.

Cores. Baked earth placed in the centre of a mould to form a cavity in the casting.

Corf. [Ger. korb, (?) L. corbis, large basket.] A large basket used for coals in mines.

Coriaceons. Like skin or leather [L. cŏrium] in texture.

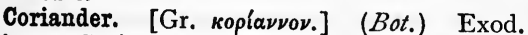
xvi. 31 ; Coriandrum sătīvum, ord. Umbellifěræ; yielding round aromatic fruits; wild in Egypt and Palestine; but much cultivated also.

Corinne. Heroine of Mad. de Staël's novel Corinne, who pines away on being deserted by her lover.

Cŏrǐum. [L., skin, leather.] (Physiol.) The part of a mucous membrane which is below the ěpithēlium.

Corm. (Bot.) A fleshy underground stem, resembling a Bulb, but not scaly; e.g. crocus.

Cormontaigne. French engineer who invented a system of fortification at the beginning of the eighteenth century.

Cornbrash. (Geol.) A coarse shelly limestone,
Oolitic; a brash [cf. breccia], i.e rock broken up by frost, etc., and good for corn-fields.

Corněa. [L.] (Anat.) The transparent disc forming the anterior of the eye, set in the sclerotic ; somewhat horny [corneus] in texture.

Cornel, or Dogwood. (Bot.) A bushy shrub in hedges and thickets (Cornus sanguinea); type of ord. Corneæ.

Corner. [L.L. cornerium, from L. cornu, $a$ horn, an end.] (Stockbrok.) A combination of speculators with a view to influencing prices by getting all available supply of a stock or commodity into a few hands.

Cornet. [L. cornu, a horn.] 1. A kind of horn or trumpet with keys, formerly much used in Church service ; in the King's Chapel especially, and in several cathedrals. 2. (Mil.) Formerly, a commissioned officer of the cavalry, who carried the standard.

Cornice. (Order.)

Corniche, The [Fr.], or Corniche Road. From Genoa to Nice, along the Riviera di Ponente; narrow, like a ledge or cornice; very beautiful, and, in places, 1600 feet above the sea.

Corniculated. [L. cornicŭlum, a little horn, dim. of cornu.] 1. (Anat.) Having processes like small horns. 2. (Bot.) Shaped like a small horn.

Coring. The process of forming gunpowder into grains.

Cornings. [Eng. corn.] The small shoots in malt.

Cornish, or China stone. (Geol.) Disintegrated rock, consisting of quartz, felspar, and a talcose mineral. Cornish, or China clay, artificially prepared kaolin (q.v.) from Cornwall. (Pehtun-tze.)

Corn laws. Laws for the supposed protection (?) of British agriculturists, prohibiting importation of foreign corn for home use unless prices rose above a fixed rate; abol. 1846 . (Anti-Corn-Law League.)

Cornopean, or Cornet-à-piston. A small brass instrument, modern, like a trumpet, but shorter, with valves or pistons, to produce a complete chromatic scale.

Cornstones. (Geol.) Calcareous concretions in the Old Red Sandstone of Herefordshire and Scotland, often containing fossil fishes (pterichthys, etc.), and yielding lime for agriculture ; hence the name.

Cornncopiæ, incorrectly Cornucopia. [L., horn of plenty.] A representation of a horn full of fruit and flowers, an emblem of abundance.

Cornwall, Barry. Nom de plume of Bryan Waller Procter, poet, of whose name Barry Peter Cornwall is an anagram.

Cornwall, Duchy of. Hereditary title and estate of the eldest son of the reigning sovereign of the British empire.

Corody, Corrody. [L.L. corrodium, corredium, It. corredare, to fit out, furnish.] (Eccl.) 1. A defalcation from a salary, for some other than the original purpose; e.g. an allowance given to a servant by the king, from a monastery which he had founded; and generally, 2, allowance of food, clothing, lodging. 
Corolla. [L., a small wreath, or crown, dim. of cŏrōna.] (Bot.) The inner whorl or envelope (composed of petals) surrounding the organs of fructification; popularly called the flozver.

Coromandel wood. A red, hazel-brown variegated wood, from the Coromandel or eastern coast of India, used for making furniture.

Cŏröna. [L., a zoreath, crown.] 1. A luminous appearance of concentric coloured rings sometimes seen round the sun and moon; probably caused by diffraction of light due to the moisture in the atmosphere. 2. The circle of light which appears to surround the dark body of the moon during a total eclipse of the sun.

3. An aurora borealis in the form of a circle round the magnetic pole.

Cŏrōna castrensis, or vallāris. [L.] Crown given to the first scaler of the rampart [vallum] of a foe's camp [castra].

Coronach, Cronach. [Gael., akin to Eng. croon, etc.] Funeral dirge among the Irish and Scottish Celts.

Cŏrōnæ, 0s. [L.] (Anat.), Bone of the shape of a coronet, in the horse ; one of the phalangeal bones of the foot; below the os suffräginnis $(q . v$.$) .$

Coronal. [L. cŏrōnālis, from cŏrōna, crown.] 1. A crown, wreath. 2. Adj., pertaining to a crown.

Coronary substance. In a horse, a fibrocartilaginous band between the skin of the leg and the hoof, liberally supplied with blood; necessary to the formation of horn; attached to the upper part of the coffin-bone.

Coroner. [L. corōnātor.] (Hist.) The title of an office established before the Norman Conquest, the holder, as his name shows, being especially the officer of the Crown. His functions, which extended to property generally as affected by the rights of the Crown, are now practically confined to the holding of inquests on those who die or are supposed to die a violent death. $\mathrm{He}$ is also the sheriff's substitute when the sheriff is interested in a suit.

Coronet. In a horse. (Coronæ, 0s.)

Corozo. Nut of a kind of palm, whose contents harden into a white, close-grained substance known as vegetable ivory.

Corporal. [L. corporālis, relating to the body.] 1. (Eccl.) A linen cloth used for covering the consecrated element of bread after communion. 2. (Mil.) A non-commissioned officer, the lowest whose rank is defined, and distinguished by two stripes on the sleeve above the elbow. A soldier acting as C. has one stripe, and is called a Lance- $C$.

Corporation. [L. corpus, $\boldsymbol{a}$ body.] (Hist.) A body of persons capable of receiving and granting for themselves and their successors. Corporations may be either sole, as a king, a bishop, a parson; or aggregate, as colleges in the universities, the municipalities of towns, etc.

Corporation Acts. 1. Acts regulating municipal corporations. The Corporation and Test Act, passed I66r, was repealed 1828. 2. The popular name of the statute 25 Charles II., c. 2, which ordained that all persons holding any office, military or civil, should have taken the oath of allegiance, and should in the previous year have received the Eucharist according to the rites of the Church of England.

Corporeal hereditament. Any subject or item of real property.

Corposant, or Compsant. [It. corps santo, holy body.] (Naut.) (Castor and Pollux.)

Corps. [Fr., L. corpus, a body.] (Mil.) A body of troops; is now used as = an army complete in itself, under separate commander, an army C.

Corps diplomatique. [Fr., diplomatic body.] The assemblage of ambassadors and diplomatic persons at a court.

Corpse. (Naut.) Slang for a party of marines on board ship.

Corpse candle. A light seen in churchyards, etc., caused by gas evolved from the decaying bodies.

Corpus Christi. [L., the Body of Christ.] (Eccl.) In the Latin Church, a festival in honour of the Eucharist, instituted by Urban IV., in 1264 , and celebrated on the first Sunday after Trinity Sunday.

Corpuscle; Corpuscular. [L. corpuscŭlum, $a$ little body.] The ultimate particles by the aggregation of which the ordinary forms of matter are supposed to be composed are called Corpuscles. The mutual forces which the corpuscles exert on each other and to which their aggregation is due are called Corpuscular forces.

Corpus delicti. [L., the body of the crime.] The subject of a crime which forms an essential part of the proof of most crimes.

Corpus Jūris Cīvilis. [L.] The imperial or civil Roman law consolidated by Justinian. Its four parts are-Instĭtūtiōnes, Digesta or Pandecta, Cōdex Rĕpětīæ Prælectiōnis (nine books, together with Jūs Publicum, three books), and Novellæe.

Corral. [Sp.] In S. America and colonies, a yard or stockade for cattle.

Correi. [Scot.] A hollow on a hillside.

Correlation. [L. con-, with, rělātio, relation.] Reciprocal relation. Correlative terms, in Logic, are such naturally and expressly, as parent offspring. Such terms as white and black are relative only.

Corrigendum, plu. corrigenda. [L.] A thing or things to be corrected.

Corrosive sublimate. (Sublimate.)

Corrugated. [L. corrūgātus, wrinkled.] Bent into parallel furrows and ridges.

Corruption of blood. An immediate consequence of attainder, both upward and downward ; so that neither inheritance nor transmission of land was any longer possible. By 3 and 4 William IV. abolished as to all descents happening after January 1, 1834.-Brown's Law Dictionary.

Corruptio optimi pessima. [L.] The corruption of that which is best is the worst of all corruption; the greater the height, the lower the fall.

Corsair. [L.L. corsarius, from L. currĕre, cursum, to run.] (Naut.) A pirate, especially of Barbary. 
Corsnedd. [A.S.] The morsel of execration, a form of ordeal among the English before the Norman Conquest. A piece of bread or cheese was supposed to cause convulsions to the guilty who tried to swallow it. ( $C f$. the story told of the death of Earl Godwine, father of King Harold.)

Cortege. [Fr.] A train of attendants, a procession.

Cortes. [Sp.] (Hist.) The old assembly of the states in Leon, Aragon, Castile, and Portugal ; the Spanish Parliament.

Cortical. 1. Having the nature of bark [L. corticem]. 2. Acting as an external covering, as the C. layer of the cerebrum.

Cortile. [L.L.] (Arch.) A quadrangular area, open or covered, surrounded by domestic buildings or offices.

Corundum. [Hind. korund.] (Min.) Sometimes termed Adamantine spar; a mineral, crystallized or massive, of alumina, nearly pure ; the hardest known substance next to the diamond. Tinted varieties of precious C. are sapphire and ruby. China, India, America, etc.

Coruscation. [L. cŏruscātio, -nem.] A flash, a flashing.

Corvée. [Fr.] (Hist.) The obligation of the inhabitants of a district to perform certain services, as the repairing of roads, etc., for the sovereign or the feudal lord. (Trinoda necessitas.)

Corvette. (Naut.) A flush-decked war-ship with one tier of guns.

Corybantes. (Cybele.)

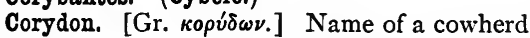
in Theocritus' fourth idyll, borrowed by Virgil, representing a rustic swain generally.

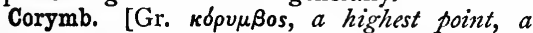
cluster of flowers.] (Bot.) An inflorescence, of which the axis develops lateral pedicels, elongated so as to make the flowers level, or nearly so ; e.g. centaury. Compound $C$., if the pedicels are branched. (Cyme.)

Coryphæus. [Gr. kopv̌paîos.] A leader in the dance, or a conductor of a chorus.

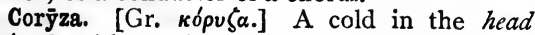
[kópvs], with running at the nose; e.g. catarrh.

Cosas de España. [Sp.] Customs or ways of Spain, e.g. a bull-fight. The phrase has not the meaning of the French Chateaux en Espagne.

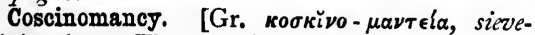
divination. The practice of divination by observing the rest or motion of a suspended sieve.

Cosecant; Cosine; Cotangent. (Trigonometrical function.)

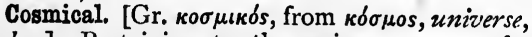
order.] Pertaining to the universe, or to the solar system as a whole.

Cosmical rising and setting. (Acronychal.)

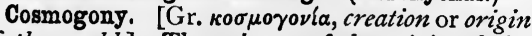
of the world.] The science of the origin of the universe.

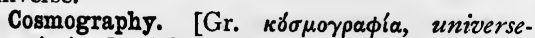
description.] The science of describing the constitution of the universe and the mutual relation of its parts, or a description of the universe.

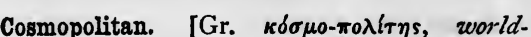
citizen.] Pertaining to a citizen of the world, free from ties or prejudices due to a special home or country.

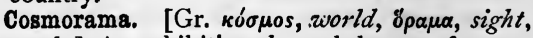
spectacle.] An exhibition through lenses of scenes in various parts of the world, with arrangements for making the pictures look natural.

Cosmos. [Gr. $\delta \delta \sigma \mu o s$, order, harmony, used by Pythagoreans first for the unizjerse.] The universe, or the essential principle of order in the system of the universe.

Cossack. Tartar irregular horseman.

Cosset. [A.S. cote, house, sittan, to sit.] 1. A lamb reared by hand in the house. 2. A pet. 3. To C., to pet, to fondle.

leaf.

Costa. [L., $a$ rib.] (Bot.) The midrib of a Costal. [L. costa, a rib.] Pertaining to the ribs.

Costeaning. [Cornish cottas stean, dropped tin.] The discovery of lodes by sinking pits in their vicinity transversely to their supposed direction.

Costermonger. [Costard, a kind of apple, for O.Fr. custard, custard ; cf. Welsh caws, curd, and A.S. mangere, dealer, from mangian, to trade; $c f$. L. mango, dealer, slave-clealer.] Huckster of fruit.

Costrel. [Welsh costrel, L.L. costrellus, (?) from costa, side, or canistra, basket.] An earthen or wooden bottle with ears for slinging it at the side.

Coterie. [Fr.] A set of persons connected by common interests, who often enjoy each other's society, and are more or less exclusive.

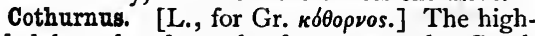
soled boot laced up the front, worn by Greek tragic actors ; originally a hunting-boot, a buskin.

Coticular. [L. cōtícŭla, small whetstone (cōs, cōtis).] Belonging to or fit for whetstones.

Co-tidal lines. Lines drawn across a map of the ocean, to show at what places the times of high tide are the same.

Cotillon. [Fr. cotte, cotille, a petticoat.] A lively dance, something like a country-dance ; name and special character given to it in France.

Cotswold. [A.S. cote, mud hut, weald, forest.] A range of low hills, mostly in Gloucester, in which the Thames rises; noted for a breed of sheep.

Cottăbos. [Gr.] A Greek game, in which liquid was tossed out of a cup into a metal dish so as to make a peculiar sound.

Cotter. A wedge used for connecting certain parts of machinery. If a shaft have one end enlarged and formed into a socket which the end of a second shaft fits, the two may be firmly held together by a wedge driven into a properly formed hole passing through both, and then they will act as a single shaft. The wedge is a C.

Cottier. [Leg. L. cotārnis, from A.S. cote or a like Teut. word.] A cottager who holds in free socage $(q . v$.$) for a certain rent and occasional$ personal service [metayer]; the rent is often a fixed proportion of the yield of the land. 
Cottise. [Fr. côte, a rib, L. costa.] (Her.) A diminutive of the bend, being one-fourth its size. A bend between two cottises is said to be cottised.

Cottonade. A stout, thick cotton fabric.

Cotton Famine. The cessation of work in the mills of Lancashire; no cotton arriving whilst the American ports were closed, I86 I -65 .

Cotton-gin. A machine for separating the cotton fibre from the seed.

Cottonian Library. The remains of the library, containing records, charters, and other MSS., founded by Sir Robert Bruce Cotton (1 570-1631), given to the nation 1700 , placed in the British Museum 1757.

Coty̆la. [L., for Gr. котú $\lambda \eta$.] Originally a cup, then a liquid measure $=$ half a pint nearly.

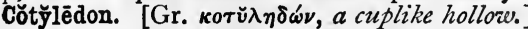
(Bot.) The seed-leaves or seed-lobes of the embryo.

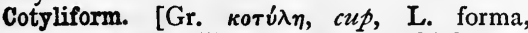
form.] Hollowed like a cup, as the thigh-bone socket.

Couac. [Onomatop.] The quack of inartistic blowing of the clarionet or hautboy.

Couch. 1. A preliminary layer of size, etc., in painting or gilding. 2. A layer of barley for malting, when spread out after steeping.

Couchant. [Fr.] (Her.) Lying down with the head erect.

Couching. [Fr. coucher, to put to bed.] ( $\mathrm{Med}$.) Pushing downwards, by a needle, of the cataractous lens into the vitreous humour.

Couguar. Puma, or American lion, not a lion (Fēlis concŏlor); the " painter," i.e. panther of N.-American farmers.

Coulisse. [Fr.] A side scene in a theatre, a space between the side scenes.

Coulter. [O.E. culter, a knife, from L., id.] Knife-like iron of the plough, cutting the soil in a vertical plane.

Coumarin. (Bot.) A camphor-like sweet substance, the cause of perfume in the tonquin-bean of perfumers, the Coumarou of French Guiana, the woodruff, the sweet vernal grass, and other plants.

Council, Privy. The chief council of the English sovereign. Its jurisdiction is mainly appellate; appeals from all parts of the empire being made to it in the last resort. The Star Chamber and the Court of Requests were formerly committees of the P. C.

Counsels of perfection. (Theol.) In the Latin Church, counsels of holiness not applicable to all, but binding on those who undertake to follow them. These are poverty, chastity, and obedience.

Count. [L. cŏmes, a companion.] (Hist.) In most of the European states, a title corresponding to that of the British earl. Under the Byzantine empire, the ten highest of the forty-three duces, dukes, or great military commanders, were called comites, counts, or companions of the emperor.

Counter-approach. (Mil.) Trench made by the garrison of a besieged place beyond their fortifications, to check advance of the besiegers.
Counter-battery. (Mil.) Guns employed by besiegers to silence the guns of a fortress.

Counter-drawing. [Fr. contre, over against.] Copying by means of transparent paper.

Counterfort. (Mil.) Buttress of masonry placed behind a revetement as a support.

Counter-guard. (Fortif.) Work constructed in front of and parallel to a bastion or ravelin, covering its faces.

Counter of ship. (Naut.) That part abaft the stern-post.

Counterparts. (Original.)

Counterpoint. [It. contrappunto.] The art of composing music in parts.

Counter-proof. An impression of an engraving obtained by pressing plain paper on a freshly printed proof, so as to give a reversed copy.

Counterscarp. (Mil.) Outer side of the ditch of a fortification. (Escarp.)

Countersign. (Mil.) Secret word or sentence entrusted to sentries for preventing any but authorized persons passing their posts. (Parole, 2.)

Countersink. A bit for widening the upper part of a hole, so as to receive the head of a screw.

Countervail. [L. contra valeo, I am worth on the other hand.] Esth. vii. 4 ; to compensate for.

Count of the Saxon shore. [L. comes littŏris Saxonlci.] During the Roman occupation of Britain, an officer whose jurisdiction extended from what are now the coasts of Norfolk to those of Sussex. According to some, he had to guard the country from the invasion of Saxons; others hold that he had the government of Teutonic inhabitants already settled in this country.

Count Palatine (Hist.) represents the comes palatii of the empire, who originally held office in the court, but afterwards obtained within his own district the jurisdiction which the comes palatii had in the palace. Hence the German title pfalzgraf, English palsorave. (Paladins.)

Count-wheel. The wheel which causes a clock to strike the hours correctly.

Coup. [Fr., blow, stroke.] $C$. de bonheur, a piece of good luck; $C$. $d u$ ciel, a special providence ; $C$. d'essai, a first attempt ; $C$. d'état, a stroke of policy, an unexpected State measure more or less violent; $C$. de grâce, stroke of mercy, finishing stroke; $C$. de main, bold sudden

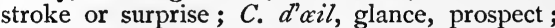
$C$. de théatre, an unexpected sensational event, something done for effect ; $C$. de pied de l'âne, the kick of the ass, given to the dying lion, - a contemptible insulting of fallen greatness; $C$. de vent, sudden squall. [Coup is L. colpus, a later form of cŏlăpus, or cŏlăphus, a blow with

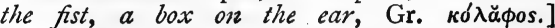
(Jarnac.)

Coup d'œil. [Fr.] View taken in at a glance.

Coup de soleil. [Fr.] A sun-stroke.

Coup de theâtre. [Fr.] Theatrical stroke: an unexpected event or manœuvre, a piece of claptrap.

Coupé. [Fr. for cut off.] 1. The front compartment in a French diligence; also in some railway carriages. 2. (Her.) Cut off short. 
Couple. [L. copŭla.] 1. Two equal forces, acting on a body in opposite directions along parallel lines. A C. tends merely to cause rotation in the body on which it acts. 2. One of the pairs of plates of two metals which compose a voltaic battery.

Conple-close. (Her.) A dim. of the chevron, being one-fourth its size.

Coupler. In an organ, mechanical appliance for connecting manuals with each other or with pedals.

Coupling-box. A hollow cylinder, into which the ends of two shafts fit and are fastened, for the purpose of connecting them in a line.

Coup manqué. [Fr.] $A$ miss; a wrong move.

Coupon. [Fr.] An interest or dividend warrant.

Coupure. [Fr., a cutting, couper, to cut.] (Mil.) Retrenchment made across the terreplein of a fortification, to prevent the enemy, when in possession of one end of a rampart, from having access along the whole face.

Courant. [Fr.] (Her.) Running.

Courbaril. [Native name.] A S.-American resin used for varnish.

Courean. [Fr.] (Naut.) 1. A yawl of the Garonne. 2. A narrow channel.

Course, A ship's. (Naut.) The C. is estimated by the angle which it makes with the meridian, and is reckoned either in points of the compass or degrees; e.g. if she sails N.E., her C. is four points or forty-five degrees.

Courses. (Naut.) The sails hanging from the lower yards. Trysails are, and lower staysails may be, included in the courses.

Court, Christian, Cüria Christianitātis, = the ecclesiastical courts as a whole, distinguished from civil; these being in the Church of England theoretically six in number. 1. The Arch deacon's C., the lowest, held wherever the archdeacon, either by prescription"or by composition, has jurisdiction, the judge being called the official of the archdeaconry. 2. The Consistory C. of each bishop, held in his cathedral, for trial of all ecclesiastical causes within the diocese; the bishop's chancellor or commissary being judge. 3. The Prerogative C., at Doctors' Commons, for proving wills, granting administrations upon the estates of intestates in certain cases. 4. The Arches C. (held anciently, till about $\mathbf{1 5 6 7}$, in the Church of St. Mary de Arcŭbus, or Le-Bow), the supreme court of appeal of the archbishopric of Canterbury in all ecclesiastical causes except those of the Prerogative C., the judge being the official principal of the archbishop. 5. The C. of Peculiars, of Archbishop of Canterbury, subservient to and in connexion with that of Arches. 6. C. of Delegates, the judges being delegated, under the great seal, to sit pro hac vice, upon appeals to the king. But its powers now, in England, are transferred to the Judicial Committee of the Privy Council; and those of the others, in a great degree, to the Courts of Probate, Divorce, and Matrimonial Causes. (See Hook's Church Dictionary.)

Court-baron. [L. curia baronnis.] 1. The court in which the barons who held of the king in grand serjeanty exercised both civil and criminal jurisdiction. 2. (Leg.) A manorial court, not of record, for the maintenance of services and duties of tenure, and determining petty civil cases not concerning more than forty shillings debt or damage.

Court-card. (Coat-card.)

Court-leet. [A.S. leod, Ger. leute, people.] (Leg.) A court of record held once a year by the lord of a hundred or manor, on grant by charter for the viewing of Frankpledges, and presentment and punishment of trivial misdemeanours.

Couscous. An African dish, chiefly consisting of meat and millet-flour.

Coute que coute. [Fr.] Cost what it may cost; at all hazards.

Convade. [Fr. couver, to brood.] A custom practised among negroes, American Indians, and in the Basque country, which compels the husband to take to his bed when his wife bears a child, lest harm happening to him should extend to the infant also.

Covenanters. [From L. convenio, through Fr. convenant.] (Hist.) Those of the Scottish people who signed or expressed their adherence to the covenant of 1638 .

Covenants, Scottish. These were chiefly two. 1. National C., subscribed at Edinburgh, A.D. 1638 , embodying the Confession of Faith of 1580 and 1581 ; caused by Charles I.'s attempt to enforce Episcopacy. 2. Solemn League and C., ratified by General Assembly at Edinburgh, A.D. 1643; an endeavour to enforce Presbyterian uniformity in the three kingdoms, an army being sent into England against Charles. Subscribers bound themselves to mutual defence, and to the extirpation of popery, prelacy, superstition, heresy, schism, and profaneness.

Coventry, Peeping Tom of. (Peeping Tom.)

Coventry, Sending to, Putting into. Excluding from all social intercourse ; said to be derived from the Cavaliers forcing inoffensive Puritans to go to the Puritan stronghold, Coventry.

Cover. [L. coǒpěrio, I cover.] (Mil.) Any screen from direct observation, concealing from an enemy's fire.

Covered way. (Mil.) Road on the immediate exterior of the ditch in a regular fortification, following its course, and covered by the glacis.

Covering party. (Mil.) Detachment of armed troops placed in front of the trenches for the protection of the working party.

Coverley, sir Roger de. A genuine English country gentleman in the Spectator, by Addison and Steele, full of ingenuous weaknesses and unobtrusive virtues.

Covert-baron. (Leg.) Married, under the protection of a husband [L.L. baron].

Coverture. [O.Fr., from couvir, Eng. cover, It. coprire, from L. cǒŏpěrīre, to cover.] (Leg.) The state of a married woman, as she and her property are under the power and protection of her husband, except in so far as his common law rights are limited by marriage settlement or the Married Woman's Property Act (1870). 
Covin. [O.Fr. covine, from convenir, L. convěnire, to come together, agree.] A collusive agreement between two or more persons for the injury of another.

Cow-pox, Vaccinia. [L. vaccinus, of or from a cow (vacca).] (Med.) An eruptive vesicular disease, of which the morbific matter was first obtained from the cow ; caused by vaccination; a prophylactic of small-pox.

Cowrie, Cowry, Gowry. [Hind. kauri.] Cypræǐdæ, fam. of gasteropodous molluscs. All seas. C. mŏnēta, money C., is used in parts of India and Africa as coin.

Coxarian. Relating to the hip-joint [L. coxa].

Coxendix. [L.] The hip, the hip-bone.

Coxwain, Cockswain. (Naut.) One who steers, or pulls the after oar in a boat, and, in the absence of an officer, commands it. (Boatswain.)

Crab. A kind of crane (q.v.).

Crab, or Crab-capstan. (Naut.) 1. A wooden cylinder, the lower end passing through the deck and resting on a socket, the upper end having four holes through it at different heights for the reception of long oars; used to wind in a cable or any weight. 2. A portable winch for loading and unloading timber-ships, etc.

Crabbed. [From crab, sour, rough, as in crabapple, crab-faced; akin to cramp, as in crampbark.] Sour, harsh, rough, difficult, vexatious.

Crabbing to it. (Naut.) Carrying too much sail in a breeze, so as to crab, i.e. drift to leeward.

Crabbler. (Krabla.)

Crackle, Cracklin (i.e. crackling) china. A kind of china covered with a network of veins or fine cracks, artificially caused by unequal expansion of body and glaze. (Body.)

Cradle. [O.E. cradel.] A steel instrument used in preparing the ground of a mezzotint plate.

Cradlings. (Arch.) The timber ribs in arched ceilings or coves to which the laths are nailed in order to receive the plastering.

Craig and tail. (Geol.) A conformation of hill, which has a precipitous front on one aspect, the opposite being a gradual slope, as the Castle Rock at Edinburgh.

Craik, or Crake. A diminutive of carrick (q.v.).

Crambē repetita. [L.] Cabbage repeatedly served up (Juvenal); i.e. stale repetitions.

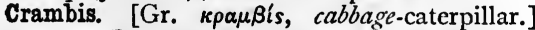
(Entom.) The common grass-moth of meadows in summer, or Veneer. Gen. of Lěpǐdoptěra nocturna, fam. Tǐněĭdæ.

Crambo. "A play at which one gives a word, to which another finds a rhyme" (Johnson). By an easy transition, we get the game of Dumb $C$.

Cramp. [A word common to many Teut. languages.] An instrument consisting of a piece of iron bent at the ends with a screw at one end and a shoulder at the other, used for compressing closely the joints of frameworks, and for other purposes.

Cramper. (Naut.) Yarn or twine fastened round the leg, as a cure for cramp.
Cramp-fish. (Torpedo.)

Crampings. (Naut.) Fetters and bolts for offenders.

Cramp-rings. Rings formerly used on the supposition that they could cure cramp and epilepsy, especially if they were blessed by sovereigns. (Ring's evil.)

Crance. (Naut.) The cap of the bowsprit, through which the jibboom passes.

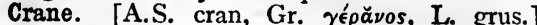
A machine (so called from its likeness to the long-reaching neck of the bird) for raising weights by means of a rope or chain passing from an axle, on which it can be wound up, over a pulley placed at the end of an arm (the $j i b$ ) which is capable of horizontal motion round a vertical axis.

Cranial. Relating to the crānium [L.], or skull [Gr. кpávíov].

Crank [a Teut. and Scand. word]; C.-pin. A piece capable of turning round a centre, connected by a link, called a connecting-rod, with another piece which moves backwards and forwards. A Crank is used to convert an alternating motion into a continuous circular motion, or vice versa. Thus the alternate motion of the piston is converted by the crank into the continuous motion of the driving-wheel of a locomotive engine. The cylindrical piece which joins the crank-arm to the connecting-rod is called the $C$.-pin.

Crank, or Crank-sided. (Naut.) Easy to capsize.

Cranmer's Bible. (Bible, English.)

Crannoge. In Ireland and Scotland, a Lakedwelling.

Cranny. 1. A Portuguese or native office clerk or subordinate employé of the Indian Government. 2. An iron instrument for forming the necks of glasses.

Crantara. [Gael. creantarigh, cross of shame.] The fiery cross which was passed from place to place in the Highlands of Scotland to rally the clans.

Crapaud, Johnny. Lit. Fohnny Toad; nickname of Frenchmen.

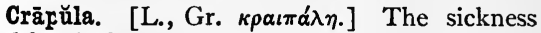
and headache consequent on drunkenness.

Crare, or Crayer. (Naut.) An old name for a heavy merchantman.

Crash. [L. crassus, coarse.] A coarse linen cloth.

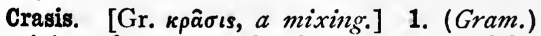
A mixing of two words by the coalescence of the final and initial vowels into one long syllable, as

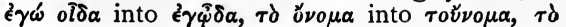

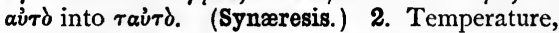
constitution, as if a result of a mixing of various properties.

Crassāmentum. [L. crassus, thick.] The thick, red, clotty part of blood, from which the thin watery part, serrum [L., whey] separates during coagulation.

Crassa Minerva. (Minerva.)

Crassa negligentia. [L.] Gross, criminal negligence.

Crassǔlaceæ. [L. crassus, thick, fat; the leaves 
being fleshy.] (Bot.) Houseleeks, a nat. ord. of polypetalous exogens; succulent, growing in very hot, dry, open places of temperate regions ; many cultivated for their beautiful flowers.

Cratægus. [Gr. крátaılos.] (Bot.) C. oxy̆ăcantha ; hawthorn, may bush. Ord.

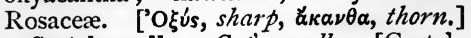

Cratch-cradle, Cat's-cradle. [Cratch $=\mathrm{crib}$, manger; $c f$. Fr. crèche, from Teut. kripya, crib.] A game played by two persons holding an endless string symmetrically in the fingers of the two hands, and taking it off each other's hands so as at once to form a new pattern.

Crater. [L., from Gr. крати́ $\rho$, a mixing-bowl.] 1. A large kind of antique bowl. 2. The mouth of a volcano.

Cratēriform. (Bot.) Shaped like a bowl

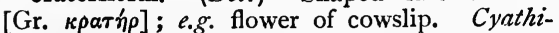
form, more contracted at the orifice, like a

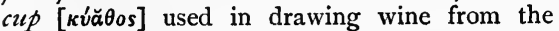

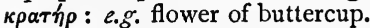

Crau. Between Arles and Marseilles, a singularly stony plain, "Campus lăpǐdeus" of the ancients, of 30,000 acres, covered with rolled houlders and pebbles, once deposited by the Rhône, Durance, etc. ; partly barren, partly irrigated by the Canal de Craponne, and very productive.

Cravat. [Fr. cravate, Croatian.] A neckcloth. The French took this piece of dress (1636) from the regiment le Royal Cravate, which was dressed in the Croat fashion. The Croats (Cravates) are a Sclavonic people in the southeast of Austria.

Craw. [Ger. kragen, neck.] Crop.

Crawl. [Cf. D. kraal, an enclosure.] An enclosure of hurdles or stakes in shallow water for fish.

Crawling off. (Naut.) Slowly working off a lee shore.

Cream of lime. The scum of lime-water. Cream of tartar is purified tartar (from its rising to the top like cream).

Cream ware. Pottery of that colour made by Wedgwood and others. Queen Charlotte gave to Wedgwood's the name of Queen's zuare.

Creance. [Fr. créance, credence.] A small line tied to an untrained hawk when lured.

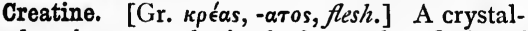
lized substance obtained from the flesh of animals.

Creazes. The tin in the middle part of the buddle.

Crèche. [Fr., Prov. crepcha, O.Sax. cribbia.] Lit. a crib, manger; a public nursery for children.

Crēdat Jūdæus. [L.] Let a Feze believe it; an expression of incredulity, Jews being thought very superstitious by Romans.

Credence table, or Credential. [Perhaps from It. credenzare, to taste meats or drinks before they are offered to another.] (Eccl.) A table or shelf on one side of the altar, for receiving the utensils needed in the celebration of the Eucharist.

Crédit foncier. [Fr.] Credit on land, in
France; a company for lending money on security of landed property.

Cree. A tribe of Indians in Canada, north west of Lake Winnipeg.

Creed of Pius IV. A creed put forth in 1564 , summing up the doctrines laid down by the Canons of the Council of Trent.

Creel. [Gael. craidhleag, basket; cf. $\mathrm{Gr}$.

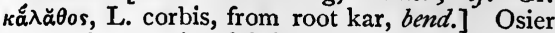
basket for carrying fish in Scotland.

Creoper. (Naut.) A small grapnel for getting things up from the bottom of rivers, harbours, etc.

Creese. Dagger with a wavy blade, used as a weapon by the Malays.

Cremaillere line. [Fr. crémaillère, $a$ pothook, the O.Fr. cremaille being L. cramaculus (Brachet).] (Mil.) Intrenchment composed of alternate long and short faces, to give a certain amount of flanking defence.

Cremation. [L. cremātio, -nem, from crěmc, I burn.] Burning; especially the disposal of dead bodies by fire.

Cremona. Meton. for violin. (Amati.)

Crenate. [L. crēna, a notch.] (Bot.) Having rounded notches, as the margin of the leaf of ground ivy. Serrate [serrātus, serra, a sawe], saw-edged, as a rose leaf. Dentate [dentātus, dens, a tooth], having pointed notches, and concave spaces between them, as the leaves of speedwell.

Créneau. [Fr., from L. crēna, a notch, dim. crēnellum.] Narrow slit made for firing through in old castle walls.

Crenellate. [Fr. créneau.] (Arch.) To furnish a building with battlements; hence to fortify. In the twelfth century, licences to crenellate were permissions to build a castle.

Crenelle. Properly the embrasure of a battlement. Hence the battlement itself.

Crenelled. In Nat. Hist., having notches. (Crenate.)

Creole. [Sp. criollo.] In S. America and $\mathrm{W}$. Indies, generally an individual born in the country, but of a race not native ; more particularly one born in the country, of pure European blood; not an emigrant; not the offspring of mixed blood, such as a Mulatto (white father and negro mother) or a Mestizo (white father and Indian mother).

Creosote. [Gr. кре́as, flesh, $\sigma \dot{\omega} \zeta \epsilon ! \nu$, to preserve.] An antiseptic fluid, obtained from the oil of distilled wood tar.

Creprtus. [L.] In Surg., the grating or crackling of ends of bone against each other, in a case of fracture.

Crepuscular. [L. crěpuscŭlum, twilight, early dawn.] 1. Like to or characterized by the half-light of late evening or early dawn. 2. (Nat. Hist.) Flying only at those times.

Crescent. (Her.) A waxing [L. crescens] moon, with its horns turned upwards. It is borne (I) as a charge, (2) as the difference in the second son's escutcheon.

Crescĭt ămor nummi quantum ipsă pěcūniă crescit. [L.] The love of the shilling gronus as much as the growing hoard of money. 
Crescive. [L. cresco, I grow.] Possessing the active power to grow or increase.

Cresiselle. [Fr. crecelle, a rattle.] (Eccl.) A wooden instrument used in the Latin Church instead of bells before Church services during Passion Week; a temporary return, probably, to primitive custom.

Cresset. [Fr. croisette, little cross, with which tombs were once adorned.] An open burner on a pole to serve as a torch or beacon.

Cresting. (Arch.) An ornamental bordering in stone or metal work, running along the ridge of a roof or a canopy, etc.

Cretaceous system. [L. crētāceus, chalk-like, crēta, chalk.] (Geol.) The uppermost of the Secondary group ; consisting, in England, of the gault, greensand, and chalk.

Crêtā nǒtātus. [L.] Marked with chalk; of a lucky or well-omened day; the unlucky day being marked with charcoal [carbo]. Hence the phrase of Horace, "Creta an carbōne notandus."

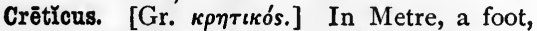
- -, as dïlïgēs, nïghtĭngāle. (Amphimacer.)

Crétin. In Switzerland and other mountainous countries, one in a state of idiocy or semi-idiocy, with more or less of deformity, often goltre. C., probably another form of chrétien, as if = innocent. So Fr. benêt, benedictus, silly, which again is Ger. selig, blessed.

Cretonne. (From the first maker.) A kind of chintz for covering furniture, etc.

Creux. [Fr. for a hollow.] An intaglio (q.v.).

Crevet. [Fr.] A goldsmith's crucible.

Crewel-work. [Crewel is for clewel, from clew; $c f$. Ger. kleuel.] Coarse embroidery worked with worsted.

Cribbage. A game at cards, in which the score is marked on a board, and its four great points are to make fifteens, flushes, flush sequences, and pairs.

Cribble. [Fr. cribbler, to sift, crible, sieve, from L.L. criblus, from L. cribrum, sieve.] To sieve, to sift.

Cribration. [L. cribro, I sift.] A sifting.

Cribriform. Like a sieve [L. cribrum], perforated.

Crichton, The Admirable. James C., a Scotch gentleman of rare learning, wit, beauty, and accomplishments in the sixteenth century. $\mathrm{He}$ took the degree of M.A. at Paris when fourteen years old, and was murdered in his twenty-third year.

Cricoid. (Anat.) Ring-shaped [Gr. крíkos, a ring], lowest cartilage of the larynx; its lower margin parallel to the first ring of the trachea.

Crimen læsæ mājestātis. [L.] Lese-majesty; the crime of injured majesty; high treason.

Criminal letters (Scot. Law) answer to English indictment by a private prosecutor.

Criminate. [L. crīminor, I accuse.] To accuse, to prove guilty.

Crimp. [Cf. Ger. krimmen, to seize with the claws or beak.] One who entrapped persons for impressment into the British navy. The word is also applied to those who get hold of seamen on landing, ply them with liquor, get all they can out of them, and ship them off again penniless.
Crimson. [Kermes, the cochineal insect, Heb. tola, a worm ; Isa. i. 18.] (Bibl.) Cochineal. Homopterous insect, from which the dye is obtained.

Crined. [L. crinis, hair.] (Her.) Having hair different in colour from the body.

Cringle. [A Teut. and Scand. word.] A short piece of rope containing a thimble worked into the bolt-rope.

Crinière. [Fr., from crin, horsehair, L. crinis.] Plate armour worn on the neck of a war-horse.

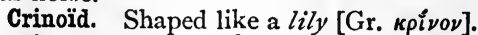

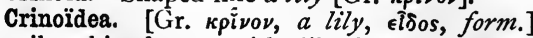
Fossil echinoderms, with lily-shaped radiated disc on a jointed stem (encrinite, pentacrinite, etc.).

Crispin, St. The patron saint of shoemakers.

Criss-cross (Christ-cross). 1. A mark like + . 2. A game played on slate or paper with the figure $¥$, also called Noughts and crosses.

\section{Criss-cross row. (Christ-cross row.)}

Cristate. Having a tuft or crest [L. crista]. Crith. The weight of a litre of hydrogen.

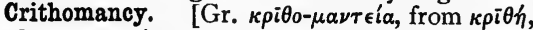
barley, $\mu \alpha \nu \tau \epsilon i \alpha$, divination.] Divination by inspecting barley cakes or barley meal sprinkled on a sacrificial victim.

Critical angle of a transparent medium, one whose sine equals the reciprocal of the refractive index. Thus the refractive index of water is $\frac{4}{3}$, and the angle whose sine is $\frac{3}{4}$ is about $48^{\circ} 36^{\prime}$; this is therefore the critical angle for water. If a ray of light moving in water makes an angle with the vertical exceeding this angle, it cannot get out of the water into air, but is totally reflected internally at the surface. The like is true of all transparent media.

Crizzle. [Ger. grieselig, speckled.] A roughness on the surface of glass which clouds its transparency.

\section{Croat. (Cravat.)}

Crochet. [Fr.] A fancy fabric made by looping wool or thread with a small hook (crochet).

Crockets. (Arch.) Ornaments resembling foliage, running up along the edge of a gable or pinnacle. The word is probably connected with crook, a curve.

Crocking. Blackening with soot or crock.

Crocodile's tears. Hypocritical, forced expressions of grief.

Crocus of antimony. (Chem.) Oxysulphide of antimony, of the colour of saffron [L. crocus]. Crocus of Mars is sesquioxide of iron, known also as jezvellers' rouge (Colcothar).

Croft. [L. crypta, Gr. крú $\pi \tau \eta, c r y p t$.] 1. A covered way, an underground chamber. 2. A small enclosed field.

Croissant, Cross. (Her.) A cross the ends of which terminate in crescents [Fr. croissants].

Crome, Croom. A crook, a hooked staff.

Cromlech. (Archaol.) A horizontal slab resting on two or three or more rude upright stones, once called "Druidical altars," now admitted to be places of sepulture; surrounded by a circle of rough upright stones, and formerly often covered with earth. Found in Britain; in 
France, especially in Brittany, and there called Dolmêns [Gael. daul, table, maen, stone], and elsewhere in Europe; in N. and S. America; Hindustan, etc. [Welsh cromlech, an inclined, an incumbent flagstone (Skeat).]

Crone. [Celt. crion, to zeither.] (Sheep,

Stages of growth of.)

Croodle. To cower down, to lie close.

Crook-rafter. (Bneo-rafter.)

Croon. [Scot.] To hum or murmur in a low tone [cf. Eng. groan]. (Coronach.)

Crop. 1. Ore of the best quality when prepared for smelting. 2. [A.S. crop; $c f$. Gael. crap, $a$ knob.] The receptacle which opens out of a bird's gullet, and in which its food is softened.

Croquet. [Fr.] 1. An almond biscuit, a small portion of some meat encased in a biscuitlike crust. 2. An outdoor game in which wooden balls are knocked through hoops with a wooden mallet on a smooth lawn.

Crore. [Hind.] Ten millions of rupees.

Cross. [L. crux, Ger. kreuz.] 1. (Eccl.) Among the many forms assumed by the cross, the most important are : (I) The Greek cross, with equal limbs. (2) The Latin, with a transverse beam one-third shorter than the vertical. (3) the Maltese, or eight-pointed cross. (4) Cross of Iona, or Irish cross, a Latin cross with a ring over a part of the vertical and transverse limbs. (5) Cross fleury, having fleur-de-lis at the three upper extreme ends. (6) Cross fitché, crossletted on the three upper ends, and pointed at the bottom, representing, it was said, the Crusader's sword. (7) St. Andrew's cross, or the Cross saltire, shaped like the letter X. (8) St. Anthony's, or the Tau cross, shaped like the letter T. (Crux simplex.) 2. (Her.) An ordinary consisting of two broad stripes, one horizontal, the other vertical, crossing each other in the centre of the escutcheon.

Cross-birth. (Med.) A delivery when the child's head is not first presented.

Cross-bow. Short bow fixed horizontally in a stock for shooting arrows. Used as late as the time of Elizabeth by some of the English army.

Cross division. This logical error is when the members into which a class is divided do not exclude each other. Man is divisible, according to race, into Caucasian, Mongolian, Æthiopian ; according to religion, into Christian, Mohammedan, Jew, and Pagan; but a division into Christian, Jew, Mongolian, Ethiopian-even if, as a fact, every man could be ranged under one only of these four classes-would be a C. D., because not dividing "man" upon one principle of division only, whether of religion, race, or any other.

Crosse, Ia, or Lacrosse. A Canadian game, learnt from the N.-American Indians; played with a crosse, or battledore, five or six feet long (across which strips of deer-skin are stretched, but not tightly), and an indiarubber ball, eight or nine inches in circumference; the object being to drive the ball (which is not handled, but picked up by the bent end of the battledore), through a goal, like that used in football.

Crossettes. [Fr.] (Arch.) Small projecting pieces in the stones of an arch, which hang upon the adjacent stones.

Cross-examination. (Leg.) Examination of a witness by or for the side which did not call him or her, generally but not necessarily after examination-in-chief (Voir dire), to make the witness alter or amend or throw discredit on his own evidence or give evidence in favour of the other side. In C. E. leading questions are allowed.

Cross-fertilization. (Fertilization of flowers.)

Cross-fire. In which the range of any firearm sweeps across a space already grazed liy fire.

Cross-hatching. [Fr. hacher, to cut.] Draw. ing a series of lines across each other at regular angles so as to increase the depth of shadow in engraving.

Cross-head. The piece which connects the piston-rod and the connecting-rod of a steamengine. It consists of a socket to which the piston-rod is keyed, and a journal or two journals on which the connecting-rod works. The crosshead is connected with the guiding apparatus which maintains the rectilineal motion of the piston-rod.

Crossjack-yard. (Naut.) Pronounced crojeck. yard. (Yards.)

Crosslet. [Dim. of cross.] (Her.) Having its arms terminated with small crosses.

Cross-trees. (Naut.) The timber laid across the upper ends of the lower and top masts, the former supporting the top, and the latter extending the top-gallant shrouds.

Crǒtōn. [Gr.] (Bot.) A gen. of plants, ord. Euphorbiaceæ ; many having important medical properties. C. tiglium, a small tree of the Moluccas, Ceylon, and other parts of E. Indies ; very actively and dangerously drastic, yielding C. oil.

Crouch ware. Salt-glazed stoneware, made at Burslem and elsewhere, I690-I780. Sometimes called Elizabethan.

Crouds, shrouds. (Arch.) An old name for the crypt of a building, as in Old St. Paul's.

Croupier. [Fr., partner.] At a gaming-table, the dealer or dealer's assistant.

Croupière. [Fr., from croupe, crupper.] Defensive armour covering the haunches of a horse down to the hocks.

Crowdie. (Naut.) Cold meal and milk mixed, or a mixture of oatmeal and boiled water with treacle, or sugar and butter.

Crowfoot tribe. (Bot.) I.q. Ranunculaceæ.

Crown or Demesne lands. (Hist.) Lands, estates, or other real property belonging to the sovereign or the Crown, acquired by purchase, succession, forfeiture, or in other ways. The practice of granting Crown land to subjects in perpetuity was abolished by Parliament, I 702 .

\section{Crowner. (Coroner.)}

Crown-glass. Glass composed of silicates of soda and lime; made by blowing a large bubble and twirling it when reheated till it becomes a flat disc.

Crown-paper. (From the original water-mark.) Paper twenty inches by fifteen. Double crown is thirty inches by twenty. 
Crown-saw. A saw formed by cutting teeth on the edge of a hollow cylinder.

Crown-wheel. A wheel with teeth set at right angles to its plane, and therefore parallel to the axis of rotation.

Crown-work. (Mil.) Large outwork placed beyond the enceinte of a fortress, consisting of two fronts with long branches enclosing the ground in rear. It may broadly be considered as a double hornwork (q.v.).

Crow-quill. A nom de plume of Alfred $\mathrm{H}$. Forrester, the humourist; born 1805.

Crow's-foot. (Mil.) The Roman tribulus or caltrop; an obstacle against cavalry, a small block of wood with four iron spikes inserted, one always projecting upwards as it lies on the ground.

Crow's-nest. (Naut.) A shelter for the lookout man at the top-gallant masthead.

Crucet-house. "A chest short and narrow," and not deep, " with sharp stones," in which a man was placed and crushed. (See Mrs. Armitage's Childhood of the English Nation: Horrors of Stephen's Reign.)

Crucǐble. [L.L. crŭcǐbŭlum, as being formerly marked with a + ; or (?) from crŭcio, I torture, metals having been formerly spoken of as tortured to yield up their virtues.] A vessel for heating and fusing glass, metallic ores, etc.

Cruciffers, or Cabbage tribe, Crŭcĭfĕræ (i.e. bearing flowers like a Maltese cross), Crŭciātæ, Brassǐcaceø [L. brassǐca, cabbage]. (Bot.) A very extensive nat. ord. of plants, including mustard, turnip, cabbage, wallflower, stock, etc., of some 2000 spec. ; absent from parts excessively cold or tropical.

Crude form. (Gram.) Professor Key's name for the Stem of an inflected word.

Crural. [L. crus, crüris, a leg.] Pertaining to or like the thigh or leg.

Crusades. [Fr. croisade, from L. crux, crucis, $a$ cross.] (Hist.) Expeditions undertaken by men who bore on their arms the symbol of the cross, under a vow to wrest the Holy Sepulchre from the unbelievers.

Cruse. [Cf. kroes, akin to crock, Ger. krug, pitcher.] A small vase or bottle.

Cruset. [Fr. creuset.] A goldsmith's crucible.

Crushroom. A hall in a theatre where the occupiers of boxes or stalls can wait for their carriages

Crustäcěa. [L. crustäta, id., crusta, a crust or shell.] (Zool.) Class of Arthrŏpŏda (Annulosa), with external skeleton of chitine, breathing by gills or surface, possessing more than eight legs; as the crab. (Chitine.)

Crutched Friars (or Crouched Friars) = Crossed Friars. [Crouch ; $c f$. O.E. cross, is akin to crotch and crutch, It. croce, L. crux, gen. crŭcis.] Part of a street in the City of London, near Mark Lane.

Cruth, Crwth, Crotta, corr. into Crowed. A kind of harp or violin, six-stringed, anciently introduced into Ireland and thence into Wales. C. or some such instrument was used by the Druids in accompaniment; hence Crowther, Crowder, = a fiddler.
Crux simplex. A single upright piece, without transom. Děcussāta, or St. Andrew's, like a děcussis, i.e. X ; Commissa, or St. Anthony's, T worked on his cope; Immissa, or Latin Cross, +, with place for title specifying the crime. (Cross.)

Cry. [Fr. cri, Prov. crida, from L. quiritäre, freq. of queror.] Afar, a long way. $A C$. of players $=$ company $; \mathrm{a} \mathrm{C}$. originally $=\mathrm{a}$ pack of hounds.

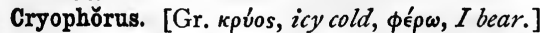
An instrument for showing the cold produced by evaporation. It consists of a glass tube with a short bend at each end, to which are fastened glass bulbs (A and B) which the tube serves to connect. The bulbs can therefore be placed inside two basins or tumblers on a table. One bulb (B) is partly filled with water, and, as the air has been withdrawn and the instrument hermetically sealed, the other bulb (A) and the tube are filled with vapour of water. If the tumbler in which the bulb $A$ is placed be filled with ice, the vapour in $A$ is condensed, and the vacuum thus formed is filled with vapour from the water in B; but this in turn is condensed, and thus a rapid evaporation of the water in $B$ is set up. In this process so much of the heat of the water in $\mathrm{B}$ is rendered latent that its temperature rapidly falls, and at last it is converted into ice.

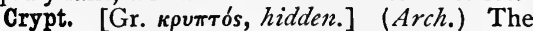
hidden part of a building, that is, the foundation story, supporting the main fabric.

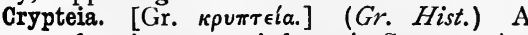
system of espionage carried out in Sparta. According to some its object was to keep down the numbers of the Helots by secret murder; but this is not likely.

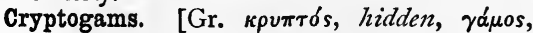
marriage.] (Bot.) Linnæan Class xxiv., flower-

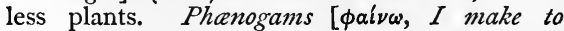

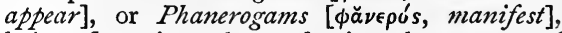
being flowering plants, having the organs of reproduction visible. (-andria.)

Cryptograph. An esoteric style of writing cypher, which beneath the outward form of

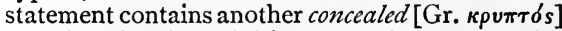
meaning for the uninitiated; so in some stories of the Talmud the rabbis are thought to have inculcated polemical views which could not safely have been given in an undisguised form.

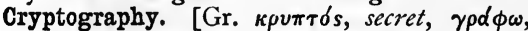
$I$ write.] The art or practice of writing in cypher.

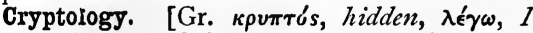
speak.] The art of obscure speech, of enigmatical utterances, as those of the Delphic oracle.

Cryptŏportǐcus. [L.] A covered passage, a vaulted hall.

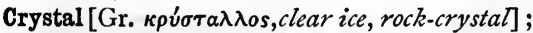
Attractive C. ; Biaxial C.; Negative C. ; Optic axis of C. ; Positive C.; Repulsive C.; Uniaxial C. A solid, which may be either natural or an artificial product of chemical operations, bounded by plane surfaces and exhibiting when broken a tendency to separate along planes which either are parallel to some of the bounding planes or make given angles with them. In a crystal exhibiting double refraction, there will be one or two directions 
along which the refracted ray passes without division (or bifurcation); these are the Optic axes of the $C$. If there are two such directions, as in topaz, the crystal is Biaxial; if only one, as in Iceland spar, it is Uniaxial. Of uniaxial crystals, those are positive or attractive in which the extraordinary ray is more refracted than the ordinary ray; those are negative or repulsive in which the contrary is the case.

Crystalline. Mineral or rock made up of indistinct crystals, sparkling, shining, but not crystallized in one crystal. Sub-crystalline, the same, but in a less degree.

Crystallization, Water of. The water which a salt takes into combination in order to assume a crystalline form.

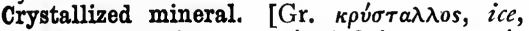
crystal.] Presenting a certain definite geometric form.

Crystallography. The mathematical doctrine of the forms of crystals.

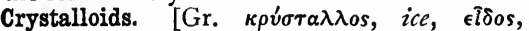
form.] Substances capable of crystallization, as opposed to Colloids.

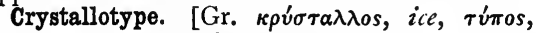
type.] A photograph on glass.

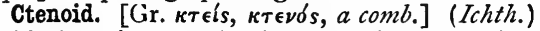
With Agassiz, an ord. of fishes, with scales imbricated and having toothlike pectinations on the hinder margin ; e.g. perch. This mode of classification of fishes, however, is very imperfect. (Ichthyology.)

Cube; C. root; Cubic equation; Cubic foot, yard, etc. A Cube, in Geometry, a solid with six square faces; in Arithmetic, the product of three equal numbers is the cube of one of them ; thus, 64 , or $4 \times 4 \times 4$, is the cube of 4 . The $C$. root of a given number is that number which, when cubed, produces the given number; thus 4 is the cube root of 64. A Cubic foot, yard, etc., is a space whose volume equals that of a cube whose edge is a foot, yard, etc., long. An equation which, after reduction to its simplest form, contains the cube of the unknown number is a Cubic equation; as $x^{3}-3 x=53$.

Cubicular. [L. cŭbǐcŭlārius, from cŭbrcŭlum, bedchamber.] Pertaining to or like to a bedchamber.

Cubilose. [L. cŭbille, bed, lair, nest.] The mucous secretion, in some of the swallow tribe, of which the Chinese edible nests are entirely made.

Cubit. [L. cŭbitus, the elborv as leant upon, a cubit.] An ancient measure of length, in use particularly amongst the Jews. The length of the Common $C$. was 1.817 foot; that of the Sacred $C$. was $2^{\circ} 002$ feet. The Great $C$. was as long as six common cubits.

Cucking-stool (Ducking-stool, or Choking-stool). (Ducking-stool.)

Cuckold. [L. cǔcūlus, $a$ cuckoo.] One whose wife is unfaithful.

Cuckoo. [Used to transl. Heb. shâchaph, to be lean.] (Bibl.) Lev. xi. 16; probably includes gulls and terns, Lărǐdæ.

Cuckoo flower, or Ladies' smock. (Bot.) Cardăminēe prātensis, ord. Cruciferæ; also Lychnis flos curcŭli, as coming with the cuckoo.
Cucullate. [L. cŭcullus, $\boldsymbol{a}$ hood.] (Bot.) Hooded, rolled inwards, so as to conceal any. thing within ; e.g. flower of monkshood.

Cưcullus non facit mŏnăchum. [L.] The cowl does not make the friar. (L'habit.)

Cucurbit. [L. cŭcurbłta, gourd.] A gourdshaped vessel used for distillation.

Cucurbitaceous. (Bot.) 1. Resembling a gourd [L. cŭcurbĭta]. 2. Belonging to ord. Cucurbitaceæ, or gourd tribe.

Cudbear. (Introduced by Dr. Cuthbert Gordon.) A violet powder made from lichens, used as a dye.

Cuddy. (Naut.) 1. The small cabin of a barge, or lighter. 2. In ocean-going vessels, the cabin under the poop-deck. 3. The little cabin of a boat.

Cue. [O.Fr. coue, Fr. queue, from L. cauda, a tail.] 1. A twist of hair like a tail at the back. 2. (Theat.) The last words of an actor's speech, which tell the next speaker when to begin ; hence a part to be played immediately, a hint or prompting. 3. A straight, tapering rod used for playing billiards.

Cuerpo. [Sp., body.] To be walking in C., to be without proper body clothing, to be unprotected.

Cuffey. A nickname or name for negroes.

Cui bono? [L.] Lit. to whom is it for $a$ good? who will be the better for it ?

Cuilǐbet in suā arte pěrìto crēdendum est. [L.] In his own art the skilled man must be trusted; a legal maxim of frequent application in estimating the value of evidence.

Cuirass. [Fr. cuirasse, from It. corazza.] The breast and back plate of armour.

Cuisine. [Fr.] Kitchen department, style of cooking.

Cuissart. [Fr., from cuisse, thigh, L. coxa.] Armour covering the thigh.

Cujusvis hominis est erräre. [L.] Any man may make mistakes.

Culdees. [Probably Gael. gille De, servants of God, words corresponding to the L. cultōres Dei, from which it was mistakenly thought to be derived.] An Irish religious order, said to have been instituted by Columba, who founded the monastery of Iona in the sixth century.

Cul-de-sac. [Fr.] Bottom of the bag; a street, road, or lane which has no egress at one end.

Cŭlex. [L., id.] (Entom.) Gen. of dipterous insects. Male (harmless) has plumed antennæ; female sucks blood.

Culinary. [L. cŭlīnārius, from cŭlīna (colina), a kitchen, from root kak, to cook.] Belonging to the kitchen or to cookery.

Cullet. [From Eng. cull, to pick out.] Broken glass, used as an ingredient in making fresh glass. Culm. 1. [L. culmus, $a$ stalk, especially of grain.] The straw of grasses. 2. [Welsh cwlm.] A hard, slaty coal.

Cult. [L. cultus, tending, worship.] A system of religious belief or worship.

Cultch, Cutch. Rough stones and the like, laid down to form an oyster-bed.

Cultirostrals, Cultirostres. [L. culter, knife, rostrum, bill.] (Ornith.) Knife-billed birds; a 
tribe or fam. in those systems which characterize them by the form of their bills. It includes herons, cranes, storks, etc.

Culverin. [Fr. couleuvrine, couleuvre, $a$ snake, L. cŏlŭber.] (Mil.) The first kind of cannon of great length invented when the system of hooping (q.v.) was discarded.

Cumber (Luke x. 40, $\pi \epsilon \rho \iota \epsilon \pi \hat{\tau} \tau o$, and xiii. 7, $\kappa \alpha \tau \alpha \rho \gamma \in \hat{\imath})$ retains its earlier sense [cf. Ger. kümmern], to cause distress, not simply to be an encumbrance.

Cumbria. Name of the district comprising Cumberland, Westmoreland, and Lancashire, from the Saxon to the Plantagenet period.

Cumbrian. (Cambrian.)

Cum grāno sălis. [L.] With a grain of salt; said of accepting a statement with doubt or reservation.

Cumin, Cummin. The fruits of a small annual umbelliferous plant [L. cŭminum, cy̆minum], native of the East, mentioned in the Old and New Testaments (Isa. xxviii. 25, 27 ; Matt. xxiii. 23) ; used in many places as a carminative, and sometimes mixed with food.

Cum multis aliis. [L.] With many others, or other things.

Cumulātive. [From L. cŭmŭlātus, p. part. of cŭmŭlo, I heap up.] Formed by accretion or addition. A C. argument is a series of considerations of which each suggests some conclusion without proving it, - but which taken together form a proof of more or less validity.

Cumŭlus. [L., $a$ heap.] Thick white clouds, ragged and broad at the base, ascending in the form of peaks. Cumulo-stratus is a compound of this cloud with stratus (q.v.). Cumulo-cirrostratus is the same as nimbus $(q . v$.$) .$

Cūnäbŭla. [L.] Cradle, earliest abode, origin.

Cunctando restituit rem, Unus hŏmo nōbis. [L.] One man restored our power by delaying; said by Ennius of Q. Fabius Maximus, who, by declining to engage, but hanging about Hannibal in the Second Punic War, weakened his force seriously.

Cunctätor. [L.] The Delayer; title of Quintus Fæbiŭs Maximus. (Cunctando.)

Cŭnèi. [L.] The wedge-shaped blocks of seats in a Koman theatre or amphitheatre.

Cuneiform. [L. cŭněus, wedge, forma, shape.] Wedge-shaped. (For C. inscriptions, vide Arrow-headed.)

Cuneiform letters. The name given to the inscriptions found on old Babylonian and Persian monuments, the characters being formed like a wedge [L. cuneus]. This is the oldest form of syllabic writing known.

Cunette. [Fr.] Drain run down the middle of a dry ditch to carry off any water.

Cupel, or Coppel. [L. cüpella, a small cask, dim. of cūpa.] A small flat crucible used in assaying metals; made by pressing moistened bone-ash into circular steel moulds.

Cupellation. The assaying of silver, etc., by melting it with lead in a cupel exposed to the air. The lead, being oxidized, dissolves the impurities, and all but the pure metal is absorbed by the cupel (q.v.).
Cupid. [L. cupīdo, desire.] The Latin name of the god of love, who was called by the Greeks Eros.

Cup-leather. The leather which serves as a packing to the ram of a hydraulic press. It prevents the water from oozing out between the ram and the cylinder when force is applied to the machine.

Cupŏla. [It.] In Arch., a dome.

Cupping. [Fr. couper, to cut, rather than from the shape of the glass used.] Bleeding, by incisions with a scarifier made in a surface towards which blood has been drawn by the exhaustion of the air in a cupping-glass.

Cupric, Cuprous. [L. cuprum, copper.] Containing copper. Cuprous contain a larger proportion of copper than cupric salts.

Cupule. [L. cūpŭla, a little tub.] (Bot.) A small cup, formed by the bracts of an involucre cohering round the base of the fruit; e.g. an acorn.

Curaçoa. A liquor flavoured with orange peel (made in Curaçoa).

Cūrāre cŭtem. [L.] To take care of the skin; to take care of the health, especially by bathing and gymnastic exercises.

Curari, Ourari, Urali, Wourali, Woorara. The arrow-poison of S.-American Indians, which destroys the powers of motion, leaving those of sensation intact. Used by vivisectors for experiments on dogs and other animals, which are thus put to excruciating agonies.

Curate. In Prayer-book, one having the cure [L. cüra, care] of souls.

Cūrätor. [L.] Superintendent, custodian.

Curé. [Fr.] Parish priest.

Curetes. (Cybele.)

Curia. [L.] The name usually applied to the temporal court of the Roman see.

Cüriōsa interprĕtātio reprŏbanda. [L.] A legal maxim, Ingeniously subtle interpretation should be rejected; for the framer of the law, etc., is not likely to have intended it.

Curioso. [It.] $A$ person of great curiosity; sometimes Virtuoso.

Curious. [L. cūriōsus, careful, inquisitive, from cūra, care.] Exhibiting care or skill, abstruse, recondite.

Curmudgeon. A corr. not of corn merchant but of cornmudgin, i.e. corn-mudging, = cornhoarding or corn-withholding. Hence a niggardly, grasping fellow (Skeat).

Currach. [Welsh cwrwg.] A skiff formerly used in Scotland. (Coracle.)

Curra-curra. (Naut.) An extremely fast boat of the Malay Islands.

Currency. [L.L. currentia, from currens, running, current.] 1. Circulation, general estimation. 2. Circulating medium of exchange of publicly recognized value.

Currente calămo. [L.] With flowing pen; of rapid composition.

Current-sailing. Calculating a ship's course as affected by a current.

Curricŭlum. [L.] $A$ course; often used of a course of studies.

Curse of Scotland. A name for the nine of 
diamonds in cards, for the origin of which many reasons have been assigned, no one perhaps being of more value than the rest. One of these assigns it to the nine lozenges on the shield of John Dalrymple, Earl of Stair, concerned in the massacre of Glencoe.-Chambers's Encyclopadia.

Cursitors. [L., from cursus, course.] (Leg.) Clerks of course, clerks of the Court of Chancery, who made out original writs, now done in the Petty Bag Office.

Cursive. [From L. curro, I run.] Running; said of writing in which the letters of a word are all connected and the strokes generally slant; in MSS. opposed to Uncial (q.v.).

Cursörius. [L., pertaining to running.] (Ornith.) A gen. of birds, fam. Glārěŏlìdæ [L. glārea, gravel]. Pratincoles and Coursers. India, Africa, and S. Europe. Ord. Grallæ.

Cursory. [L. cursōrius, from cursor, runner.] Hasty, careless, superficial.

Curtain. [L. cortina, in mediæval sense of an enclosed court, a wall between two bastions.] (Fortif.) The part of a rampart which connects the interior extremities of the flanks of two adjacent bastions.

Curtal friar. A term used by Sir Walter Scott, in Ivanhoe, as equivalent to irregular clerk or hedge priest, and applied by him to Friar Tuck, of Copmanhurst. $\mathrm{He}$ may have coined the phrase to denote a pious monk with a frock shortened for convenience of moving about.

Curtana. [L. curtus, cut short.] The pointless sword of mercy, called the sword of Edzvard the Confessor, borne naked before British sovereigns at their coronation. (Sword of State.)

Curtate distance. [L. curtātus, shortened.] The C. of a planet from the sun or earth is its distance measured along the ecliptic, i.e. the distance from the centre of the sun (or earth) to the point in which the ecliptic is met by a perpendicular drawn to it from the centre of the planet.

\section{Curtein. (Curtana.)}

Curtesy of England. (Leg.) The right of a husband, under certain conditions, to hold during his life the lands of his wife after her death.

Curtilage. [L.L. cortilagium, curtilagium, from L.L. cortile, curtile, dim. from L. cohors, cŏhortis, a yard.] (Leg.) A yard belonging to a dwelling-house.

Curule magistracies. (Hist.) In ancient Rome, the highest offices of the State, the holders being allowed to sit on ivory chairs, sella curiules, when discharging their functions.

Curvature [L. curvātūra, a óending] ; Centro of C. ; Circle of C.; Double C. ; Radius of C.; C. of surfaces. When a moving point traces out a curved line, its direction changes from point to point ; the rate of this change of direction at any point per unit length of the curve is the Curvature at that point. The Circle of $C$. at any point of a curve has the same curvature as that of the curve at that point; the centre and radius of $C$. are the centre and radius of this circle. So far it has been supposed that all the points of rne curve lie in one plane. When this is not the case, the curve is tortuous, and is said to have Double C., or more strictly curvature and tortuosity; the hellix or thread of a screw is a curve of double $C$. The $C$. of a surface at any point will depend on the direction in which the C. is considered; e.g. in the case of a common cylinder there is evidently no curvature parallel to the axis, while at right angles to the axis the C. is the same as that of the circular base of the cylinder.

Curve, Brachistochronous; C. of equal pressure; Tautochronous C. The curve along which a body will descend from one point to another in the shortest possible time is the Brachisto-

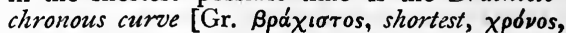
time], or the $C$. of shortest descint. When a curve is such that a body descends along it to the lowest point in the same time from whatever point it starts, it is said to be a Tautochronous $C$. [ $\delta$ auvo's, the same], or a $C$. of equable descent. Curves of equal pressure are such that, when a body descends along them, the pressure against the curve is the same at all points.

Curres, Method of. When one quantity undergoes a series of changes depending on the progress of another quantity, this dependence can be expressed to the eye by means of a curve. Suppose it were required to register the variations in the height of a barometer throughout the twenty-four hours of a day. A sheet of paper can be placed on a cylinder in a vertical position, and made to revolve uniformly by clockwork; if a pencil point pressed against the paper rises and falls with the mercury in the barometer, it will plainly trace out a curve on the paper. Now, suppose the paper to be unwarped, a horizontal line on it, if properly divided, will show the progress of the time throughout the day, and vertical lines drawn from the horizontal line to the curve will show the corresponding heights of the barometer. The variations in the heights of the barometer are thus completely represented by this method, which is one instance of the Method of curves. Indicator curves, adiabatic lines, cotidal lines, etc., are other instances of a method which admits of application in every branch of physics.

Cuseform. (Naut.) A Japanese long open whale-boat.

Cushat. [O.E. cusceat.] The quest, ringdove, or wood-pigeon.

Cushion of a horse's foot. (Frog.)

Cushion capital. (Arch.) Capitals shaped in the form of large cubical masses projecting over the shaft, and rounded off at the lower corners.

Cusp. [L. cuspis, a point.] 1. (Arch.) A projecting point in the foliation of arches or of tracery of any kind. 2. (Geom.) A singular point on a curve, at which two of its branches have a common tangent in such a manner that, if we suppose the curve traced out by a point, it moves up to the cusp along one branch and then moves back along the other. 3. (Astron.) Either point of the horns of a crescent moon or planet. 4. (Anat.) The point or projection on the summit of the crown of a tooth. (Cuspidate.) Cuspidate. [L. cuspis, cuspidis, a spear.] (Bot.) Rounded off, with a projecting point in the middle; e.g. many species of bramhle 
Custard apple. (Anona.)

Customary freehold. (Leg.) (Privileged copyholds.)

Custos mörum. [L.] Guardian of morals.

Custos rótŭlorum. [Leg. L.] Keeper of the rolls; the principal justice of the peace in a county, who has charge of the rolls and records of the sessions of the peace.

Cutch. Catechu $(q . v$.$) .$

Cutchery. A Hindu court of justice.

Cut his painter, To. (Naut.) 1. To die. To go off suddenly or secretly. (Painter.)

Cuticle. [L. cŭtīcŭla, dim. of cŭtis, skin.] (Physiol.) The insensible external layer of the skin; the expldermis, or scarf-skin.

Cǔtis. [L., skin.] (Physiol.) The true skin, condensed areolar tissue. C. ansěriña, Goose-skin, or goose-flesh; a roughness of the skin, produced by cold or fear.

Cut of the jib. (Nraut.) 1. The look of a ship. 2. Metaph. of a person.

Cutter. (Naut.) A small vessel with a single masl and straight, running bowsprit, carrying a large fore-and-aft mainsail and jib; also a gafftopsail, and a stay-foresail. C. brig, a vessel with squaresails, fore-and-aft mainsail, and a iigger-mast. Ship's C., a ship's boat, broader, deeper, and shorter in proportion than the barge, or pinnace, and more fitted for sailing.

Cuttle, Captain. A one-armed retired seacaptain in Dickens's Dombey and Son, ingenuous, eccentric, and kindly; often saying, "When found, make note of."

Cuttle-fish. Sēplădæ, fam. of dibranchiate cephalopods (q.v.), with traces of a shell, and rudiments of internal skeleton. All seas.

Cutty. [Gael. cut, a short tail, Eng. scut; cf. L. cauda, tail.] A short clay pipe.

Cutty-stool. A seat or gallery in a Scotch kirk, painted black, on which offenders against chastity were compelled to sit and make profession of penitence, and to be publicly rebuked.

Cuvette. [Fr.] A large clay pot, in which the materials for plate-glass are melted.

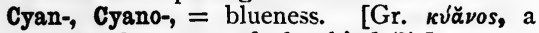
dark blue substance ; of what kind (?).]

Cyanogen. [Gr. kúavos, blue, $\gamma \in \nu \nu \hat{\alpha} \nu$, to beget.] A gas composed of one part of nitrogen and two of carbon.

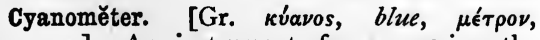
measure.] An instrument for measuring the degree of blueness in the sky.

Cyanotype. [Gr. кúavos, blue, túnos, type.] A photograph of a blue colour, developed by ferrocyanide of potassium.

Cyathiform. Having the shape [L. forma] of a cyăthus. (Crateriform.)

Cyăthus. [L., from Gr. кúă日os, a cup.] A cup especially for drinking.

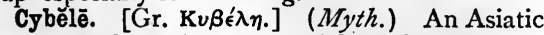
goddess, whose rites were celebrated with great excitement by her priests, who were named Corybantes, Curētes, Galli, etc. Lord Byron makes the penult of the name long, thus making it answer to the Greek form Kybēbē. (Bacchanalian; Dionysian.)
Cycadaceæ, Cycads. (Bot.). The Cycas tribe, a nat. ord. of chlamydeous dicotyledons; small palm-like trees or shrubs, with cylindrical unbranched trunks, pinnate leaves, and diøcious flowers. Natives of tropics and temperate parts of Asia and America.

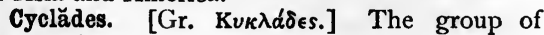
islands in the archipelago east of Eubœa and Attica, round ['́z $\kappa u ́ \kappa \lambda \varphi]$ Delos.

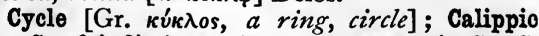
C.; C. of indictions; Iunar C.; Metonic C.; C. of operations; Reversible C.; Solar C. 1. The continual recurrence of a set of events in an assigned order. 2. The period during which the occurrence of one set takes place. The Solar $C$. consists of twenty-eight Julian years, after the lapse of which, on the Julian system, the same days of the week would always return to the same days of each month throughout the year. The Lunar C. consists of 235 lunations, which do not differ from nineteen Julian years by quite an hour and a half. Consequently, if in any one period of nineteen years the days of the occurrence of all the new moons (or full moons) are noted, they will be found to recur on or very near to the same days in the same order in the next period of nineteen years, and so on. These nineteen years constitute a Lunar or Metonic $C_{\text {. }}$, the fact of the recurrence having been discovered by Meton, an Athenian mathematician, circ. 432 B.c. The Golden Number of a year denotes its place in the lunar C. The Calippic C. (Calippus, of Cyzicus, circ. 320 B.C.) was designed as an improvement on the Metonic C., and consists of seventy-six years, or four Metonic C. The adoption of this C. in combination with the Julian calendar brings the succession of new moons back to the same day, and nearly the same hour of the day. $C$. of indictions, a period of fifteen years, used in the courts of law and in the fiscal organization of the Roman Empire under Constantine and his successor; it was thus introduced into legal dates as the Golden Number was introduced into ecclesiastical dates. To find the prime number or year of the solar C., add 9 to the number of the year A.D. and divide by 28 ; to find the Golden Number or year of the lunar C., add $I$ and divide by 19 ; to find the indiction, add 3 and divide by 15 : the remainder, if any, is the required year; if none, the year is the twenty-eighth, nineteenth, and fifteenth of these C. respectively. C. of operations, in thermodynamics, a series of operations by which a substance working in a heat-engine (as steam in a steam-engine) is finally brought to the same state in all respects as at first. When a $\mathrm{C}$. of operations can be gone through first in a given order, and then in the reverse order, the cycle is said to be a Reversible $C$. If a heat-engine were capable of performing a reversible $C$. of operations, it would be dynamically perfect.

Cyclǐca. [Gr. кик入і̌ќ́s, circular.] (Entom.) Section of cŏlěoptěrous insects, Tetrăměrous (Coleoptera), as longicorn, beetles, and weevils.

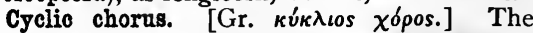
chorus which danced round the altar of Diony- 
sjis (Bacchus) in a circle, in contrast with the square choruses of the tragic drama.

Cyclic poets. (Hist.) The supposed authors of those poems which treated of the heroic and mythoiogical ages of Greece. The Iliad and Odyssey were at first included in this epic cycle, which was arranged at Alexandria in the second century B.C.

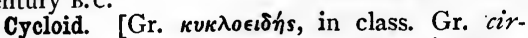
cular.] The curve which is traced out in space by a point on the circumference of a circle, which rolls in a plane along a straight line.

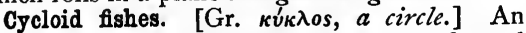
ord. with Agassiz, having C. scales, i.e. formed of concentric layers, not covered with enamel, and with margins not toothed; e.g. herring, trout.

Cyclone. [Gr. кик $\lambda \delta \omega$, I make to whirl round.] A storm which combines a rotatory with a progressive motion.

Cyclopean. (Arch.) Ancient buildings are so termed in which the walls are composed of large stones laid without any mortar, as at Mykēnæ and Tiryns.

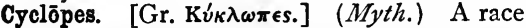
of gigantic beings who are represented in the Odyssey as shepherds, having only one eye in the midst of their forehead. Such was Polyphemus, from whom Ulysses made his escape. They are described also as forging the thunderbolts of Jupiter, and they are supposed to have raised the buildings called Cyclopean.

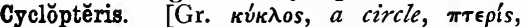
fern.] (Geol.) Applied to two different kinds of fern-like fossil plants, with rounded leaflets, (I) from the coal-measures, (2) Oolite.

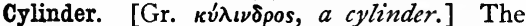
part of a steam-engine in which the piston is driven alternately up and down by the steam.

Cymar, Simar. A light covering, a scarf. (Chimere.)

Cymbiform. (Bot.) -Of the shape of a boat or skiff [L. cymba]; e.g. glumes of canary grass and other grasses.

Cyme. [Gr. $\kappa \hat{v} \mu \alpha$, a youngsprout.] (Bot.) An umbel-like inflorescence ; a panicle, of which the pedicels are unequal in length, and the flowers thereby brought to nearly the same level; e.g. elder.

Cymric, Kymric. [Welsh.] Division of Celtic (Keltic) ; often includes the kindred Cornish and Armorican dialects.

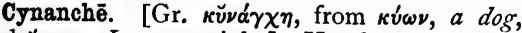
and $a \gamma \chi \omega, I$ squeeze tight.] Has been corr. into Quinsy. C.clericorum, i.g. Dysphonia clericorum.

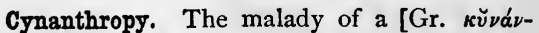
$\theta \rho \omega \pi o s]$ a man [a $\nu \theta \rho \omega \pi o s]$ who fancies himself $a$ $\operatorname{dog}[\kappa v \dot{\omega} \omega]$. Cf. Lycanthropy.

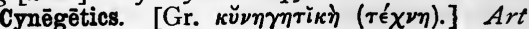
of hunting with dogs.

Cynics. (Hist.) A sect of Greek philosophers : so called, it is said, from their snarling and surly humour, the name being derived from $\kappa \dot{v} \omega \nu, a$ dog. It was founded by Antisthenes, a disciple of Socrates ; and Diogenes belonged to it.

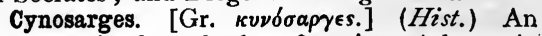
academy in the suburbs of ancient Athens, in which Antisthenes taught (Cynics.)

Cynossure. This word has been supposed to denote a dog's tail, from Gr. кvvórovpa: but the first syllable of this word, as of Cynosarges, has probably nothing to do with $\kappa$ v́ $\omega \nu, a$ dog. It was applied by some philosophers to the constellation of the Lesser Bear, and has hence come to mean any point of special attraction.

Cy pres. [O.Fr.] (Leg.) As near as possible; a rule of approximate construction if strict construction be impossible or involve public harm.

Cyprĭnı̆dæ. [Gr. Kú $\pi \rho \iota s$, name of Aphrǒdīte, from Kúreos, Cyprus.] (Zool.) Fam. of bivalve molluscs. Universally distributed. Class Conchřfĕra.

Cyrenians. '(Hist.) The followers of Aristippus, a disciple of Socrates, who founded a school at Cyrênē, a Greek colony on the north coast of Africa, and whose opinions approached those of Epicuirus.

Cyst. [Gr. $\kappa \dot{v} \sigma \tau t s$, the bladder, a bag.] (Med.) An abnormal development in shape like a pouch, or sac. Cystitis, inflammation of the bladder. Cystoïd, like a C., in appearance.

Cystalgia. Pain [Gr. àjos] in the bladder [ $\kappa \dot{v} \sigma \tau \iota s]$.

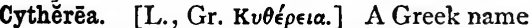
for Aphrodite, Venus, from the island of Cythëra, where she had a well-known temple.

Cy̆tǐsus. [In L., a kind of clover.] (Bot.) Broom; one of many allied gen. Ord. Leguminōsæ, sub-ord. Pāpllĭonaceæ. Common Broom, C. scōparius, from L. scōpæ, plu., twigs, a broom.

Czar, Zar, or Tsar. A title given by many Slavonic tribes to their chiefs. Ivan II. adopted, in 1 579, the title of Czar of Moscow. The wife of the czar is called the Czarina, and the eldest son of the emperor is the Czarowitch.

Czarina. (Czar.)

Czarowena. Wife of the czarowitch, Princess Imperial of Russia.

Czarowitch, Czarowitz. (Czar.) 
D. 1. As a Roman numeral, signifies 500 ; and among Roman writers, stands for Divus, Decimus, etc. D.M., in Roman epitaphs, is for Diis Manibus. 2. In naval affairs. (Abbreviations.)

Da capo. [It.] (Music.) From the beginning, $=$ revert to the commencement of a subject.

D'accord. [Fr.] Agreed, in harmony.

Dacoits, Dacoos. In India, thieves who go about the country in gangs. They prefer generally to rob without violence, being thus chiefly distinguished from the Thugs.

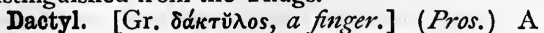
metrical foot, of a long syllable followed by two short ones. (Spondee.)

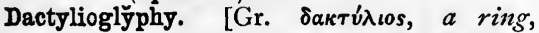
$\gamma \lambda \hat{u} \phi \epsilon i \nu$, to engrave.] The art of engraving gems.

Dactyliomancy. [Gr. $\delta \alpha \kappa \tau v \lambda \iota 0-\mu \alpha \nu \tau \epsilon\{\alpha$.$] Fin-$ ger-ring-divination.

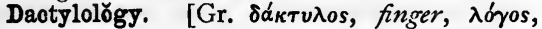
speech.] The art of talking on the fingers by means of a manual alphabet, chiefly practised by the deaf and dumb.

Dā dextram misěris. [L.] Offer your right hand to the zuretched.

Dado. [It.] (Arch.) 1. The part of a pedestal, called the die, in the middle between the base and the cornice. 2. The wainscoting of a wall, which would be supposed to represent the dado of the pilasters arranged round it.

Dædalean. [Gr. $\delta a เ \delta a ́ \lambda \epsilon a$.$] An epithet ap-$ plied to works of art cunningly wrought; from the mythical Dædălus, whose name describes him as the skilful worker. Dædalus is said to have built the labyrinth in Crete for the Minotaur. He escaped from the island on wings which he had made; his son Icarus, flying with him, fell into the sea and was drowned.

Dæmŏna dæmŏne pellit. [L.] He drives out one devil by another.

Dagh. [Turk.] Hill, mountain.

Daguerreotype. (M. Daguerre, inventor, 1839.) One of the earliest successful forms of photography. A copper plate is silvered and polished, and by the action of vapour of iodine covered with a film of iodide of silver. A picture of the object is then formed on the surface by means of a camera obscura. As iodide of silver is decomposed by sunlight, the silver surface will be restored where the lights of the picture fall, but the film of iodide of silver will remain where the shadows fall. The result thus obtained is rendered visible and permanent by vapour of mercury, which easily combines with and tarnishes the plate where the silver is exposed to its action.

Dahm. (Naut.) A decked Indian or Arabian boat.

Daily progress. (Naut.) A return made daily by a vessel as to progress of equipment while in port.
Daimio. When the Shogunate, or authority of the Tycoon, was abolished by the Mikado of Japan, the daimios (or barons) resigned their fiefs into the hands of the latter, with whom the whole power of the state has rested since 1871 .

Daireh. [Turk.] The Khedive of Egypt's private landed estate.

Dais. [Fr.] 1. The raised platform at the upper end of a dining-hall. 2. The upper table on its platform. 3. The seat, sometimes with canopy, for guests at this table. 4. The canopy over the seat of a person of dignity.

Daker, Dakir, Dicker. [L.L. dacra, decara, L. děcūria.] 1. A number of ten units. 2. A score. Daker-hen. The moor-hen.

Dakoity. The system of Dacoit robbery.

-dale, -dell. [Cf. Ger. thal, valley, O.H.G.

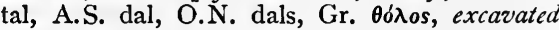
chamber, Skt. dhâras, deep place.] Part of Saxon names, meaning valley, as in Annan-dale, Arun-del.

D'Alembert's principle (French mathematician, 1717-1783) in Dynamics asserts that when a system of rigidly connected particles moves under the action of any forces impressed on it from without, forces equal to the effective forces, but acting in exactly opposite directions, applied at each point of the system, would be in equilibrium with the impressed forces.

Dalesman. Inhabitant of a valley, especially of the dales of the north of England.

Dalgetty, Dugald. A mercenary soldier in Scott's Legend of Montrose, bold, shrewd, unscrupulous, and pedantic.

Dalmatic. A gown or robe with sleeves, worn by deacons in the Latin Church over the alb. It represents a dress imported into Rome from Dalmatia by the Emperor Commodus.

Dā lǒcum mĕliōribus. [L.] Give place to your betters.

Dalriadic. (Dalriada, old name of Antrim.) Pertaining to Antrim.

Daltonism. Colour-blindness (q.v.); so called from Dalton, the chemist, who was colour-blind.

Dalton's theory. The atomic theory. (Atomio philosophy.)

Damage feasant. [O.Fr. damage faisant, doing damage, L.L. damnaticum faciens, from damnum, damage.] (Leg.) Doing injury, trespassing.

Damara, Dammar gum. [Malay dâmar.] A resin from the Indian Archipelago, used for making varnish.

Damask. A stuff woven with raised figures (originally made at Damascus).

Damaskeen. (Damascus, where first made.) Iron or steel inlaid with gold or silver.

Damasse. [Fr.] A Flemish linen in imitation of damask.

Damassin. [Fr.] A kind of damask worked with gold and silver patterns in the warp.

Dame. (Madam.) 
Damelopre. [D. damloper $=$ bilander $(q . v$.$) ,$ from dam, dam, loopen, to run ; cf. Ger. laufen.] (Naut.) A flat-floored Dutch vessel, formerly used for carrying heavy cargoes over shallows.

Damenisation. (Solmisation.)

Damna minus consuēta mŏvent. [L.] Loss to which one is unaccustomed affects one (especially).

Damnant quod non intelligunt. [L.] They condemn what they do not understand.

Damnonia. Name of Cornwall and Devon in the time of the Roman occupation.

Damnōsa hērēdĭtas. [L.] $A n$ inheritance or legacy which entails loss.

Damŏcles. A courtier whom Dionysius I., Tyrant of Syracuse (B.c. 405-367), allowed to take his place and state at a banquet, but had a sword hung over him by a hair, to illustrate the dangers incident to wealth and power.

Dāmōn and Pythras. 1. Two Pythagoreans of Syracuse, in the time of Dionysius I., famous for their close friendship, which made them each willing to die for the other. 2. Damon, shepherd in Virgil's eighth Eclogue; hence any rustic swain. The Damon of $\mathrm{Ecl}$. iii. is the master of a goatherd Tìty̆rus.

Damosel. (Ambisexual words.)

Dampers. In a piano, pieces of wood covered with cloth, and (when the loud pedal is not used) checking the vibrations of the wires when struck.

Dan. [O.Fr. don, Sp. don, It. donno, from L. dŏminus, master.] An old title of respect, like sir, as Dan Geoffrey (Chaucer) in Spenser.

Dance Macabre. (Dance of Death.)

Dance of Death. In a series of woodcuts, said to be by Hans Holbein. Death is represented as dancing with persons of all kinds from Adam downwards. This dance is sometimes called the Dance Macabre, perhaps from St. Macarius. It was painted on the north end of the cloisters of Old St. Paul's, London.

Dancette. (Her.) Zigzagged, generally with three projections.

Dancing mania, which spread through a large part of Middle Europe in the thirteenth and fourteenth centuries, a wild delirium, with religious delusions. Similar were the tarantism of S. Italy, the leaping ague of Scotland, the dance of St. Weit (St. Vitus), and many other phenomena.

Dandie. [Hind.] A boatman.

Dandies. (Naut.) The rowers of the Ganges budgerows (q.v.).

Dandin, George. The hero of Molière's play $G$. $D$., a rich French bourgeois, whose marriage into a noble family brings him endless disagreeables, whereupon he continually exclaims, " $\mathrm{Tu}$ l'as voulu, George Dandin!" ("You would have it so; George Dandin!").

Dandiprat. Child, little fellow, dwarf.

Dandy. (Naut.) A sloop or cutter having a jigger-mast, which carries a lugsail.

Dandy Dinmont. A Liddesdale farmer in Scott's Guy Mannering, who has given a name to a celebrated breed of long-backed Scotch terriers.

Danegelt. In Eng. Hist., a tribute of twelve- pence laid by the Danes upon the Anglo-Saxons for every hide of land throughout the country.

Danelagh, Danelaw. [A.S. Dene-lage.] (Hist.) A name applied to the part of England beyond Watling Street, as the region in which the Danish law remained in force after the peace of Wedmore, by which the Northmen evacuated Wessex and the part of Mercia south-west of Watling Street, A.D. 878-880. - Freeman, Norm. Conquest, vol. i. ch. 2.

Daphne. The Greek word for laurel. The nymph who fled from Apollo was said to be so called, because she was changed into a laurel bush.

Darby and Joan. Representatives of a happy old married couple, hero and heroine of a ballad of the end of the eighteenth century. The originals were claimed by Healaugh, a village in the West Riding of Yorkshire.

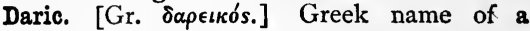
Persian gold coin.

Darien scheme. A disastrous speculation for forming an entrepôt between the Eastern and Western hemispheres (1695-1701), put forth by W. Paterson, founder of the Bank of England, who was fully convinced of its practicability.Macaulay, Hist. of England.

Darks. (Naut.) Moonless nights.

Darning the water. (Naut.) Blockading a port by cruising off it.

Darogah. [Hind.] A superintendent, overseer.

Darraign, Darrain. [O.Fr. desrener, L.L. dērătiōnare, from ratǐo, -nem, reason.] (Leg.) To clear an account, to settle a controversy.

Darrein. [Cf. Fr. dernier.] Last.

Darsena. [It., from Ar. dâr-çana, a place of construction.] (Naut.) An inner harbour. A wet dock (Mediterranean).

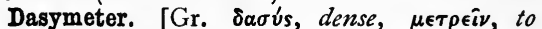
measure.] An instrument for measuring the density of gases.

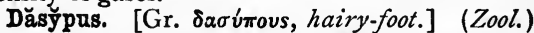
Originally the hare; it now gives a name to the armadillo family, Dăsy̆pŏdı̌dæ. Central and S. America. Ord. Ėdentāta.

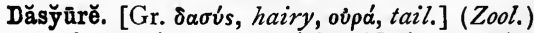
Fam. of rapacious marsupials, Native cats (as the Tasmanian devil, Dăsȳürus ursīnus), ranging in size from a mouse to a shepherd's dog. Australasia.

Datary. [It. datario.] In the pope's court, an officer-a prelate, sometimes a cardinal who receives petitions concerning the provision of benefices. He dates a petition, if registered, writing "Datum Romæ," etc. ("Given at Rome," etc.).

Data tempŏro prosunt. [L.] Timely gifts are beneficial.

Datisoa yellow. A permanent vegetable dye, used in Cashmere.

Datoo. 1. West wind in Straits of Gibraltar. 2. A Malay mark of rank.

Dătum, plu. Dătă. ' [L. p. part. neut. of do, $I$ give.] An admitted fact or proposition which forms a ground for an inference or deduction.

Datum-line. [L. dătum, a thing given.] In levelling, the horizontal line drawn on the pic- 
ture of a section of the ground to which the heights of all points on the surface are referred.

Dauk, Dawk. [Hind.] The mail-post.

Dauphin. The title of the heir-apparent of the French crown before the Revolution. It had been borne by the Counts or Lords of Vienne, in Dauphiné, from the twelfth century or earlier, and was probably of heraldic origin.

Da venĭam lacry̆mis. [L.] Grant indulgence to tears.

Davits. [Fr. davier.] (Naut.) Pieces of timber or iron projecting over a ship's side or stern, from which the boats are suspended. Fish-D., that by which the flukes of an anchor are raised clear of the vessel to the top of the bow ; doing this is called fishing the anchor.

Davy lamp. (Invented by Sir Humphry Davy, 1778-1829.) A lamp used by coalminers. Instead of glass a wire netting surrounds the candle. When a stream of sub-carburetted hydrogen (fire-damp) passes through a fine wire netting, it may be ignited on one side without the flame passing back to the other side of the netting. Consequently, when the lamp is in air charged with fire-damp, the flame of the candle ignites only the gas within the lamp; the outside gas does not ignite till the wire becomes white hot. (Geordy lamp.)

Davy's locker, or Davy Jones's locker. A sailor's phrase, denoting the depths of the sea. The name Davy is akin probably to devil [Ger. teufel]. (Old Nick.)

Dawk-boat. (Naut.) A mail-boat (Indian).

Day. (Naut.) Is reckoned from noon to noon, i.e. from one observation to the next. $D$.-book, old name for log-book.

Day, Apparent solar; Astronomical D.; Civil D.; Lunar D.; Mean solar D.; Sidereal D. The Apparent solar $D$. is the interval between two successive transits of the sun's centre across the meridian. The average length of a very large number of apparent solar days is a Mean solar $D$. The Astxonomical solar $D$. is reckoned from noon to noon; the Civil $D$. from midnight to midnight. The interval between two successive (superior) transits of a given star is a Sidereal D. ; it is the interval of time in which the earth makes one revolution on her axis, and is 3 mins. $55^{\circ} 91$ secs. of mean time shorter than a mean.day. The sidereal $\mathrm{D}$. begins when the first point of Aries is on the meridian. The interval between two successive transits of the moon is called a Lunar $D$. Its average length is about 54 mins. of mean time longer than a mean day.

Day-fly. (Ephemeridæ.)

Day-rule. (Leg.) A permission to a prisoner to leave prison for the purpose of transacting necessary business.

Daysman. Umpire, arbiter deciding between two parties after judicial hearing (Job ix. 33). Day at one time $=$ (1) law day, also (2) day for the meeting of an assembly.

Days of grace. (Grace, Days of.)

Day's work. (Naut.) The reduction by trigonometry of the ship's courses and distances from noon to noon, after allowing for currents, leeway, etc., and so determining her latitude and longitude, i.e. by dead-reckoning.

Dead-angle. Space between any two lines of intrenchment not swept by musketry fire.

Dead-colouring. The first layer of colouring, generally grey; so called because not seen when the painting is finished.

Dead-eye, or Dead man's eye. (Naut.) Flat, rounded pieces of wood with one or more holes in them, through which a lanyard (or small rope) is passed, so as to get a purchase.

Dead-freight. (Leg.) Freight paid by a merchant, who does not ship a full cargo, for the part not shipped.

Dead-heat. The result of a contest in which two or more competitors are equally first.

Dead horse. (Naut.) (Advance money.)

Dead-lights. (Naut.) Wooden shutters fitted into cabin windows.

Dead-lock. 1. A lock without a spring or latch, which can only be worked with key. 2. Metaph. a standstill in negociations or operations.

Dead-men. (Naut.) Reef or gasket ends left dangling from a yard, when a sail is furled in a slovenly manner.

Dead-points. Those points of the circle described by the end of a crank at which the crank and connecting-rod are in the same straight line. In this position the driving power has no tendency to turn the crank, which is carried past the dead-points only by the inertia of the machine.

Dead-reckoning. (Day's work.)

Dead-ropes. (Naut.) Ropes not passing through a block.

Dead-set. 1. Attitude of a pointer giving warning of game. 2. A conspiracy to cheat at cards.

Dead-wood. (Naut.) Blocks of timber fayed on to the upper side of the keel, and at the extręme ends, to a considerable height one upon another. Deal-wood knees, the top pieces of dead-wood fore and aft, shaped so as to fasten the keel to the stem and stern.

Dead-works, Opper, or Supernatant works. So much of a laden vessel as is above water.

Deal. [A.S. dælan, to divide.] As in Exod. xxix. 40 ; a portion.

Deal beach, Rolled upon. (Naut.) A pockmarked man; also called Cribbage-faced.

Dē ălǐèno cŏrǐo lỉběrālis. [L.] Liberal at another's expense; lit. from another's skin.

Dean of Christianity. (Decani.)

Dean of Faculty. (Decani; Faculty Court.)

Dean of the Arches. (Decani.)

Dean of the City. (Decani.)

De ăsinni umbra disceptāre. [L.] To dispute about an ass's shadow; to indulge in idle, useless disputations.

Death in the pot. Poison which has accidentally found its way into an ordinary meal (2 Kings iv. 40). (Sodom, Vine of.)

Death-watch. (Entom.) Gen. of small beetle (Ănōbrum), which calls its mate by tapping with its mandibles. Fam. Ptinidæ.

Debâcle. [Fr.] A breaking up of river ice ; 
a sudden violent flood carrying all before it; lit. an unbarring [bâcler, to bar with a wooden bar, băcŭlus].

Debellation. [L. dēbellāre, to utterly overcome in war.] Utter subjugation, the carrying of a war to an utterly successful issue.

Debenture. [From L. dēbeo, $I$ oue.] A deed-poll charging property with repayment of money lent at a given interest. Public companies often raise money by $D$. The interest on D. stock is a primary charge on the company's property.

Debenture stock. (Debenture.)

Déblai. [Fr. déblayer, to clear azvay, L.L. dēblädare, to clear a field.] Excavation from which the materials remblai [Fr. remblayer, to embank] have been obtained for constructing fortifications.

Déboisement. [Fr.] Clearing off of wood [bois].

Debonair. [Fr. débonnaire, de bon air, of good appearance. (For the history of the word air, see Littré and Wedgwood.)] Graceful, gentle, courteous.

Debouch. [Fr. déboucher, to clear, uncork, bouche, a mouth, L. bucca.] To pass through the outlet, or debouchure, of any defile.

Debruised. (Her.) Having an ordinary placed across it.

Débutant, -ante, fem. [Fr.] One who makes a début, or first appearance, especially on the stage.

Decade. [Fr. décade, L.L. decada, from $\delta \epsilon \kappa a ́ s,-a ́ \delta \hat{o s, ~ a ~ n u m b e r ~ o f ~ t e n .] ~ A ~ s u m ~ o r ~ a g g r e-~}$ gate numbering ten, especially a period of ten years.

\section{Decagon. (Polygon.)}

Décagramme; Décalitre; Décamètre. [Gr.

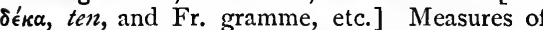
ten grammes, ten litres, and ten mètres respectively. (Gramme; Litre; Mètre.)

Decameron. [Gr. $\delta \epsilon \in k \alpha \mu \epsilon \rho \hat{\omega} \nu$, of ten parts, or $\delta \in \chi\{\mu \epsilon \rho s$, lasting for ten days.] A famous collection of stories by Boccaccio (fourteenth century), supposed to be told in ten days; whence Chaucer, Shakespeare, etc., got material.

Decāni. [L.] (Eccl.) St. Augustine speaks of the chief of ten monks as a Decanus. Hence the dean of a cathedral church is one who is supposed to preside over ten canons or prebendaries at least; and a Decanus Christianitatis, or Dean of Christianity, was so called as having jurisdiction over a district of ten churches. He was also known as Urban Dean, or Dean of the City. Thus, also, the Deans of Faculty in universities presided over their respective faculties, and maintained discipline. The Dean of the Arches is the judge in the metropolitan court of Canterbury, this court having been anciently held in the Church of St. Mary of the Arches, or le-Bow.

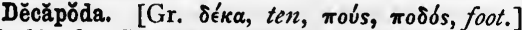
(Zool.) 1. Cephalopods with ten suckers, as cuttlefish. 2. Crustaceans with ten thoracic feet, as crabs.

Decarburation. The freeing of any substance from [L. de] carbon. (Bessemer steel.)

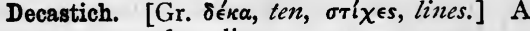
verse or poem of ten lines.

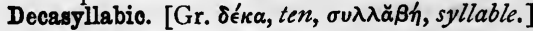
Of ten syllables.

Deccan. A district of high tableland in Central Hindustan, between the Nerbuddah and the Kistnah.

Decemvirs. [L. decemviri, ten men.] (Hist.) This name, applying to any body of ten men, is used especially to denote the commission of ten appointed to revise the laws of Rome in the 302 nd year after the foundation of the city. As the result of their work, they are said to have put forth the laws of the Twelve Tables.

Decennary. [L.L. děcennārium, from děcennium, from děcem, ten, annus, year.] 1. A period of ten years. 2. The day which terminates such a period or begins the next.

Déchéance. The French term for Forfeiture.

Deciduous. [L. de-cřdŭus, that falls down or off.] 1. (Nat. Hist.) Shed during the lifetime of the creature. 2. (Bot.) D. trees, not evergreen.

Děcies rĕpětita plăcēbit. [L.] Though repeated ten times, it will be pleasing.

Décigramme; Décilitre ; Décimètre ; Décistère. [L. decimus, tenth, and Fr. gramme, etc.] Measures of the tenth part of a gramme, litre, mètre, and stère respectively. (Gramme; Litre ; Mètre; Stère.)

Decimal; Circulating D.; D. fraction; D. notation; D. place; Recurring D.; Repeating $\mathbf{D}$. Reckoned by tens. The $D$. notation is that in common use for expressing numbers by units, tens, hundreds, etc. A $D$. is a fraction expressed by an extension of the decimal notation, by tenths, hundredths, etc. ; thus, $2737 \frac{71}{125}$ is expressed by 273.568 , i.e. $200+70+3+\frac{5}{10}+$ $\frac{6}{100}+\frac{8}{1000}$; according as a number stands for so many tenths, hundredths, thousandths, etc., it stands in the first, second, third, etc., $D$. place. It is found that by this notation all numbers can be expressed either exactly or to any assignable degree of approximation. When after any assigned place a decimal consists of a group of digits repeated to infinity in the same order ; as, $2 \cdot 51834834834$, etc., it is a Circulating, or Recurring, or Repeating $D$. ; the group of digits repeated is the Kepetend.

Decimation. [L. děcimäre, to decimate.] 1. The selection of every tenth man for punishment, as after mutiny of Roman soldiers under the empire. 2. A destruction of one in ten, or ten per cent.

Deck-, or Round- house. A cabin on the deck, with gangways on each side.

Decks. In a line-of-battle ship (three-decker) : Poop-D., that which reaches from the mizzenmast to the taffrail. The Upper or Spar D., from stem to stern, divided into Quarter-D., that part abaft the mainmast; Waist or Booms, between the fore and main masts. Forecastle, from the foreshrouds to bows. Main-D., or Gun-D., the whole length of ship below the spar-D.; then the Middle-D., succeeded by Lower-D. and Orlop-D. In a two-decker, the Middle-D. is omitted. Flush-D. is one continued the whole length of a vessel. 
Declaration for liberty of conscience. (Seven bishops.)

Declaration of Indulgence, The, by Charles II., March 15, 1672, suspended all penalties against Dissenters. (Conventicle Acts; Five-Mile Act.)

Declension. [L. dēclīnātio, -nem, Gr. $\pi \tau \hat{\omega} \sigma \iota s$, slanting, inflexion.] (Gram.) The indication by change of form or auxiliary words (prepositions) of the relation of the idea of a noun to other ideas expressed in a sentence. (Aptote.)

Declination; D. circle; Magnetic D.; Parallel of D. [L. declinatio, -nem, a bending aside.] The circle drawn through the poles of the great sphere which passes through the centre of a heavenly body is its $D$. circle; its $D$. is its angular distance north or south of the celestial equator measured on its declination circle ; its Parallel of $D$. is the small circle drawn through it parallel to the celestial equator. The Magnetic $D$. at any place is the angle between the direction of the magnetic north and the meridian; i.e. the bearing of the magnetic north east or west of true north.

Declinometer. [Eng. decline, Gr. $\mu$ é $\rho \rho \nu, a$ measure.] An instrument for measuring the declination (q.v.) of the needle.

Decollation. [From L. dēcollare, to take off from the neck (collum).] Beheading ; especially used of the martyrdom of St. John Baptist.

Děcor inemptus. [L.] Unbonght grace.

Decree nisi. A decree in the first instance of divorce or nullity; to be made absolute in six months, unless cause to the contrary be shown in the mean time.

Decreet. [L. dēcrētum, p. part. of dēcerno, I decree.] (Scot. Law.) Final decision of a court. Decrement. [L. dēcrēmentum, decrease.] (Her.) The wane of the moon.

Decrements. [L. dēcrēmenta, diminutions.] Charges in battels at Oxford for wear and tear of table furniture, etc.

Decrepitating salts. [L. de, and crěpřtāre, to crackle.] Salts which crackle when heated.

Decrescent, Moon. (Her.) A waning [L. decrescentem] moon, having its horns turned to the sinister side.

Decrētals. [L. decrētālis, decretum, $a$ decree.] 1. A portion of Canon law, the decrees or written answers of early popes upon disputed questions. So the Romans had regarded the responsa prudentum when unanimous, as law ; and the emperor's opinion, afterwards, when all legislative power became centred in him. 2. (Hist.) This name is specially used to denote the collection of letters and decrees of the twenty popes from Clement to Melchiades, published during the pontificate of Nicholas I., 858-867. These spurious decretals, which were certainly completed after 829 , assert the papal supremacy, and contain the whole Roman system of dogma and discipline. -Milman, Hist. of Latin Christianity.

Děcŭs et tūtāmĕn in armis. [L.] An ornament and protection in battle (Virgil); of a breast-plate.

Decussate. [L. děcusso, $I$ divide by $\times$, the sign of děcussis, ten.] (Bot.) Crossing at right angles; e.g. the leaves of Pimelea decussāta.
Decypher, Decipher. [Fr. déchiffrer, It. deciferare.] To interpret secret writing (cipher), or illegible writing, or unknown language, as that of Etruscan or cuneiform inscriptions.

Dēděcŏrant běně näta culpæ. [L.] Faults disfigure natural advantages.

Dedication, Feast of. The annual feasts, commemorating the dedication of churches, were in this country called rvakes, i.e. vigils or eves. In his instructions to Augustine, Gregory the Great allows the yearly celebration of these feasts in churches made out of the heathen temples. The custom was kept up to the seventeenth century, when the Puritans raised their voices against it ; and although it has fallen into disuse in some counties, it is still observed generally in the north.

De die in diem. [L.] From day to day.

Dědǐmus pǒtestätem. [L.] (Leg.) We have given the power; a writ or commission to a private person or private persons to forward some act pertaining to a judge or court.

Deduction. [L. deductio, -nem, a bringing down.] A proposition in geometry, the proof of which can be deduced from Euclid's propositions.

Deed-poll. (Leg.) A deed (with a polled edge as opposed to an indenture; $q . v$.), executed by one party only, manifesting the grantor's act and intention, when he undertakes certain obligations without any being imposed in return on the grantee.

Deemster, Doomster. [A.S. dom, doom.] The title of judges in Jersey and in the Isle of Man. In Scotland, an officer so named reads out the sentence awarded by the court.

Deep. (Naut.) More than twenty fathoms.

Deep-sea line. A sounding apparatus for use in the deep sea.

Deer, Stages of growth of. [O.E. deor ; $c f$. Ger. thier, Gr. $\theta \dot{\eta} \rho$, L. ferra.] The young of the ked deer (Cervus élăphus) is termed a calf, and becomes in successive years a Brocket, a Spade or Spayed, a Staggard, a Stag, and a Hart. The corresponding terms in the Fallowe deer (Dāma vulgāris) are Fawn, Pricket, Sorrel, Soare, Buck of the first head, Complete buck. The young of the Roe (Caprěŏlus capræa) is termed a Kid, and becomes successively a Gird and a Hemure. (Antlers.)

De facto. [L.] A legal phrase, denoting possession without reference to title; de jure denoting right of title without reference to possession.

Defalcation. [L. dēfalcātio, -nem, dēfalcāre, from falx, falcis, sickle.] A cutting off or deduction, especially unlawful abstraction by an employé or officer of money entrusted to him.

Defeasance. [From O.Fr. défesant, Fr, défaisant, pres. part. of défaire, to undo.] 1. A defeat. 2. A rendering null and void. 3. (Ltg.)

Defecate. [L. dēfæcāre, to cleanse from dregs (fæces).] To purify, make clear, clarify.

Defender of the Faith. This title (in L., Fidei Defensor) was bestowed by Pope Leo X. (I52I) on Henry VIII., for the publication of his book against Luther. On the suppression of the monasteries, the pope withdrew the title, which 
was afterwards bestowed on the king by Parliament (1544).

Dëfensio Pŏpŭli Anglicäni. [L., Defence of the English People.] Milton's pamphlet, written in justification of the execution of Charles I., in answer to Salmasius, i.e. De Saumaise, a very learned man, employed by Christina of Sweden to write an invocation of divine vengeance upon the Parliament.

Deferent. (Epicyle.)

Deferred stock. Stock on which no interest is paid until the holders of preference and ordinary stock have received interest at the rate of so much per cent.

Defervescence. [L. defervesco, I cease boiling.] A growing cool, a subsiding from a state of ebullition or agitation.

De fide. [L., of the faith.] (Eccl.) Essential. Defilade. [Fr. défiler, to file off.] (Mil.) To arrange the heights of the earthworks of fortification so as to conceal the interior from the fire of an enemy.

Deflagrate, To. [L. deflagrāre, to be burned up.] To cause to burn with sudden and sparkling combustion.

Deflagrator. [L. deflāgrāre, to be burned up.] A kind of voltaic battery used for producing great light and heat.

Defluvium. [L.] A flowing or falling off, as of the hair.

Defterdar. [Turk., book-keeper.] The Turkish Chancellor of the Exchequer.

Dégagé. [Fr.] Unembarrassed, at ease.

Deglutinnate. [L. dēglūtǐnāre, to unglue, from glūten. To separate by moistening or warming, to unglue.

Deglutition. [From L. degluttio, I swallow down.] 1. The act of swallowing down. 2. The power of swallowing.

Degradātion. 1. (Geol.) Gradual waste and removal, as of hill, rock, etc. 2. (Phys.) D. of force or energy, the change of a small quantity of force of a higher intensity into a larger quantity of lower intensity.

Degrade. [L.L. dēgrădāre, to make to step (gradi) down (dē).] 1. In the University of Cambridge, to put off competition in an examination for a degree with honours for a year or more, on some plea to be approved by the authorities. 2 (Her.) To terminate in steps.

Degree [L.L. degrădus, a step, degree] ; D. of an equation; D. of latitude; $\mathbf{D}$. of the meridian. 1. The 360 th part of the circumference of a circle. 2. The angle subtended at the centre by that part. If two stations are taken on the same meridian such that the directions of the plumb-lines at them, when produced, contain an angle of $1^{\circ}$, they are said to be a $D$. of latitude apart; the length of the arc of the meridian between them is a $D$. of the meridian; the length of a degree of the meridian is greater near the poles than near the equator. The $D$. of an equation is the highest power of the unknown quantity, e.g. $x^{3}-7 x+6=0$ is an equation of the third degree.

Degree in University. (Faculty; Regent
Degrees. Fifteen songs of, or psalms of, Ps. cxx.-cxxxiv. inclusive. A very obscure term. (?) Chanted on the return from Babylon; (?) written for pilgrims going up to feasts at Jerusalem ; (?) chanted upon the fifteen steps leading from the court of the women, in the temple, to the court of the men of Israel ; so LXX., "' $\Omega \delta \eta$ $\tau \hat{\omega} \nu \stackrel{\alpha}{\nu} \alpha \beta \alpha \theta \mu \hat{\omega} \nu . "$

De gustibns non est disputandum. [L., we must not dispute about tastes.] There is no accounting for tastes.

Dehiscent fruits. [L. děhisco, I part asunder.] (Bot.' Opening by a suture, which allows the seeds to escape ; e.g. legumes. Indehiscent, when the sutures do not give way at the ripening ; e.g. nut, wheat.

Dehors. [Fr.] Foreign to, outside.

Deianeira. (Nessus, shirt of.)

Dei gratia. [L., by the grace of God.] A formula commonly used in describing the title of a sovereign ; first used by the clergy.

Deľpara. [L.] Translates the Greek Theŏtŏkos, mother of God; the title of the Virgin Mary in the Eastern Church.

Deipnosophists. [Gr. $\Delta \epsilon \iota \pi \nu 0-\sigma o \phi ı \sigma \tau \alpha l$, supper. philosophers.] The characters in Athenæus's (third century) work of the name, in which he professes to record the learned table-talk of Galen, Ulpian, and others.

Deira. A large district of Northumbria in early Eng. Hist.

Déjeuner. [Fr., from L. de, from, jejunium, a fast.] A morning meal, breakfast.

De jüre. (De facto.)

Dekoyts. (Dacoits.)

Delai Lama. (Lama.)

Delation. [L. dëlätio, -nem, an informing against.] An information, a charging with a crime.

Del credere. [It.] Guaranty or warranty by a factor of the solvency of a purchaser.

Dèlē. [L.] Erase, remove from the text; commonly used (or $d$ only) in correcting proofs or the press.

Delectable Mountains. In Bunyan's Pilgrim's Progress, mountains whence the Celestial City could be descried.

Delegates, Court of. (Court, Christian.)

Dëlenda est Carthāgo. [L.] Carthage must be destroyed; the continual contention of the elder Cato.

Delete. [L. dēlētus, p. part. of dēleo, $I$ destròy, erase.] To blot out, remove from a text.

Delft ware, Delf. Coarse earthenware made at Delft, in Holland.

Delian problem. (Duplication.)

Delibation. [L. dēlībātio, -nem.] $A$ tasting, $a$ slight trial.

Delicately. In its older sense, wantonly [Gr. $\sigma \pi \alpha \tau a \lambda \hat{\omega} \sigma \alpha$, I Tim. v. II]

Delimitation. [L. dē, off, līmitāre, to enclose by boundaries, from limes, limitis, limit.] Settlement of frontiers or boundaries.

Deliquescent salts. [L. dēliquescěre, to melt away.] Salts which melt by attracting moisture from the air.

Dēlirant rēges, plectuntǔr Xchīvi. [L.] The 
chiefs art madly; the Achaan people are punished.

Deliration. [L. dēlīrātio, :nem, madness, delirium, from dēlīräre, to draw aside the furrow (lira).] Delirium, mad delusion.

Delitescence. [L. delítesco, I hide away.] (Med.) Sudden subsiding of a tumour or disease generally.

Delivery. [Fr. délivrer, L.L. dēlīběrare, to deliver, from dē, from, liberare, to make free (liber). ] (Leg.) Of a deed, an actual or implied handing it over.

Della Crusca. [It., of the sieve.] The Academia della Crusca was founded in Florence in 1582 , and is now incorporated with the Ac. Florentina. The dictionary published by this academy established the Tuscan dialect as the standard of the Italian language.

Della Cruscan. Name of a class of silly poetasters at the close of the eighteenth century, borrowed by one of the members as signature, from the Florentine academy, Della Crusca.

Della Robbia ware. (From inventor's name.) Terra-cotta bas-reliefs, thickly enamelled with a tin-glaze ; made at Florence, circ. $1400-1530$; in France, circ. 1530-1567.

Delos. (Ortygian shore.)

Delphi. (Parnassus.)

Delphic. [Gr. $\Delta \in \lambda \phi o l$.$] Oracular, ambiguous.$

Delphic oracle. The oracle Apollo at Delphi, the most celebrated in Greece for the wisdom or the ambiguity of its answers.

Delphin Classics. [L. delphīnus, dolphin. (Dauphin.)] Name of an edition of the classics prepared for the Dauphin of France, afterwards Louis XV.

Delphïnı̌dæ. [Gr. $\delta \in \lambda \phi i s$, dolphin.] (Zool.) Fam. of carnivorous cetaceans, as the porpoise. Universally distributed.

Delta. A triangular tract of alluvial land or mud ; so called from its likeness to the shape of the fourth letter in the Greek alphabet, $\Delta$. The largest deltas are those of the Mississippi, Ganges, Nile, Rhone, Po, and Vanube.

Deltoïd muscle. The triangular-shaped muscle of the shoulder, in shape [€îos] like a delta, $\Delta$.

De mal en pis. [Fr.] From bad to worse.

Demarch. [Gr. $\delta \dot{\eta} \mu \alpha \rho \chi o s$, from $\delta \hat{\eta} \mu o s$, district, a $\rho \chi \epsilon i \nu$, to rule.] The mayor of a Greek township.

\section{Deme. (Demos.)}

De mĕdietāte linguæ, A jury. [L., of a moiety of one's own tongue.] One of which half are foreigners, if they can be found; a privilege of foreigners indicted for felony or misdemeanour.

Dêmentia. [L., madness.] In Path., = diminution, through injury or disease, of mental powers which had been fully developed. (Amentia.)

Demesne. [O.Fr. demaine, Fr. domaine, L. dŏminnium, property.] That part of an estate or manor retained by a lord in his own occupation.

Demi-bastion. (Bastion.)

Demi-gorge. (Fort.) Line from the interior extremities of a face or flank of a work in fortification, to the capital (q.v.).

Demijohn. [Fr. Dame Jeanne, Lady Fane, from Demaghan, a town of Khorassan, renowned for glassware.] A large glass jar or bottle with a small neck, covered with wickerwork.

Demi-lune. [Fr., half-moon.] (Fortif.) In primitive fortification, a semicircular work, now occupied by the ravelin (q.v.).

Demi-monde. [Fr., half-world.] Those on the outskirts of the fashionable world. The word got a disreputable sense during the reign of Napoleon III.

De minnimis non cūrat lex. [L.] The law does not concern itself about trifles; otherwise an undignified use would be made of its courts, and petty litigation encouraged.

Demi-rilievo. [Fr. demi, half, and It. rilievo, relief.] Carving in which the figures are half raised from the background.

Demise. [Fr. démise, from démettre, L. dēmittěre, to lay or let down.] 1. (Leg.) A transfer, grant by lease. 2. Hence the death of a sovereign, upon which the kingdom is at once transferred to the successor, as signified by the phrase, "The king never dies."

Demission. [L. dēmissio, -nem, a letting down.] A lowering, abatement, depression.

Demi-tint. Half-tint, that is, the colour of an object neither in the full light nor full shade.

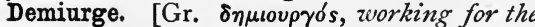

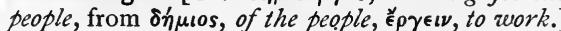

1. The maker of the universe employed by the Supreme Divine Mind according to Plato's Timæus, regarded by Neoplatonists and Gnostics as the source of all evil. In the Zoroastrian system, the Demiurge is Ahriman. 2. A magistrate in some Peloponnesian states, as Mantinea and the Achæan League.

Demi-vill. [Fr. demi, half, vill, Fr. ville, It. villa, township.] A township containing only five freemen. (Frankpledge.)

Demivolt. [Fr. demi, half, volte, It. volta, from vŏlüto, I turn.] An artificial motion of a horse, in which he gives a half-turn with the fore legs raised.

Democrats. (Amer. Polit.) One of the two great political parties in the U.S. (Republicans.)

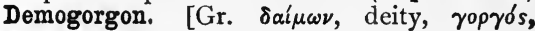
terrible to behold.] A terrible embodiment of supreme power in the superstitions of the first centuries of our era ; mentioned by Milton in Paradise Lost.

Demoiselle. [Fr.] (Damosel.)

Demon. A word now used to denote evil spirits. The Greek word which it represents is supposed to mean simply wise or intelligent; and in the Iliad and Odyssey there is practically no distinction between gods and demons. In the Hesiodic Theogony, the men of the Golden Age become after their death guardian demons of the earth. Demons afterwards were classified as good and bad, and ultimately were regarded only as evil. The Latin genii answered in some respects to the Greek demons ; but the Genius or guardian of each man was as mortal as himself.

Demonetize. To withdraw money from currency, or in any way deprive it of current value.

\section{Demonology. (Angelology.)}


Demonstrator. [L., one who points out.] An exhibitor of dissected parts; a teacher of anatomy.

Dë mortuis nĩl nǐsı̆ bŏnum. [L.] Nothing but good (should be said) about the dead.

Demos. [Gr.] 1. The people, especially the sovereign people of ancient Athens; often treated as a person by the comic poets. 2. The Demoi of Attica were districts or boroughs, into which the members of the tribes were divided. Commonly called Demes by English writers.

Demosthenic. Pertaining to or like Demosthenes, of exalted eloquence or patriotism.

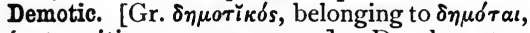
private citizens, commoners.] D. character, a simplified form of the hieratic character of Egyptian writing. (Enchorial.)

Dè mötũ proprǐo. [L.] At his ozen instance; of one who is the real as well as the technical promoter of a suit or measure.

Dempster. [A.S. dêman, to judgre, deem, and -ster, suffix denoting agent.] (Old Scot. Lazv.) The officer whose duty it was to pronounce the sentence or judgment of the court. (Deemster.)

Demulcent medicines, etc. [L. děmulceo, $I$ caress.] Soothing, diminishing irritation.

Demurrage. [O.Fr. demourer, Fr. demeurer, L. dēmŏrāre, to delay.] (Naut.) An allowance made by a freighter to owners of a ship detained in port longer than agreed upon in the contract of affreightment.

Demurrer. 1. (Demurrage.) 2. (Leg.) A pleading by a defendant (generally in a civil suit), which, admitting the facts of the opponent's case, takes exception to the indictment, information, or evidence, and asks the court to decide if such case stands in law. The chief heads of exception are to the jurisdiction of the court, to the person of the plaintiff, to the substance or form of the bill.

Demy. [L. dimidius, half.] 1. A scholar (half a fellow) of Magdalen College, Oxford. 2. A kind of paper about twenty-two inches by seventeen.

-den. [(?) Celt.] Part of names, as in Arden, meaning deep, wooded valley in a forest.

Dēnārii de cārítate. [L.] Pence of charity; oblations made anciently to cathedral churches, by parish priests, going with some of their parishioners to visit them ; these became, in time, a settled charge.

Dēnärius. [L.] A Roman silver coin containing ten, afterwards sixteen, asses, = eightpence or nearly thirteen-pence. The aureus D. $=$ twenty-five silver $D$.

Dendrite, Dendritic. [Gr. $\delta \in \nu \delta \rho i \tau \eta s$, of or

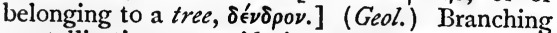
crystallization or oxidation on the surfaces of fissures and joints in rocks; mistaken, sometimes, for fossil plants.

\section{Denier. (Livre.)}

Denis, Abbey of St. The burial-place for the French kings from A.D. 775 .

Denizen. [O.Fr. deinzein, from deinz, = L.L. de intus, from within (Skeat).] 1. An adopted citizen or subject. 2. A resident in a foreign country. 3. Dwellers in, inhabitants.
Denominations, The Three. An association of Dissenting ministers of London and Westminster, A.D. 1727 ; Presbyterian (now Socinian), Independent, and Baptist.

Denominator. (Fraction.)

Dénoûment. [Fr. dénouer, to untie, L. de, and nōdare, to knot.] The discovery, the catastrophe of a drama or plot, a scene of discovery or detection in real life.

Denshiring. Dressing land with ashes of burnt stubble, turf, or parings of top soil.

Density [L. densitā, -tem]; Specific D. The Density of a substance is the quantity of matter in a unit of its volume. Specific D., or Specific gravity, of a substance is the ratio which the weight of any volume of it bears to the weight of an equal volume of some standard substance ; which for solids and liquids is commonly dis. tilled water at some specified temperature, e.g. $60^{\circ} \mathrm{F}$. or $3{ }^{\circ} 94^{\circ} \mathrm{C}$.

Dentation. [L. dens, dentis, tooth.] Formation of the teeth.

Dentirostrals, Dentirostres. [L. dentem, tooth, rostrum, bill.] (Ornith.) Tooth-billed birds, a tribe or fam. in those systems which characterize them by their bills. It includes shrikes 'and thrushes.

Dentition. [L. dentitio, -nem.] The time, the symptoms, of cutting teeth.

Deobstruent. [L. de, from, obstruo, I stop $u p$.] Medicines removing obstruction.

Deodand. [L. Deo dandum, to be given to God.] In English jurisprudence, a practice, now abolished, of inflicting a fine in cases of homicide on the chattel which was declared to be the cause of the death.

Dē omnibus rēbus et quĭbusdam ăliis. [L.] $O n$ all things and some others.

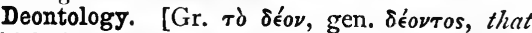
which is binding, right.] J. Bentham's name (1747-1832) for his system of morality, based upon what Dr. Priestley had defined as the object of government, "the greatest happiness of the greatest number."

Deorum cĭbus. [L.] Food for the gods.

Department. [Fr. departement.] In Fr. Hist., the name given by the Constituent Assembly to the eighty-three new divisions into which the whole French territory was divided (1787-90).

Departure. (Naut.) 1. The difference in longitude made good by a ship from the meridian from which she departed. 2. The bearing of an object from which a voyage commences.

Depectible. [L. dē, and pecto, $I$ comb off.] Of tenacious cohesion, viscous.

Depǐlatory. [L. dēpllo, I pull out hairs (pili).] Of use for removing superfluous hair.

Depletion [L. depleo, I empty out] = bloodletting.

Deploy. [Fr. déployer, to unroll.] (Mil.) When troops from a close formation are extended into line.

Depolarization; Depolarize. A ray of polarized light falling at a certain angle on a plate of glass is found not to be reflected; but if a double refracting substance is interposed before the ray reaches the glass, it is now reflected, and is said 
to be Depolarized ; this result is due to the combination of the first polarization with a second. If the interposed substance be a very thin plate, the light, if originally white, becomes coloured, the colour varying with the thickness and position of the plate.

Deponent. [L. dēpōno, I lay down, depose.] 1. (Leg.) One who makes an affidavit, a witness. 2. (Gram.) D.verb, one which has a passive form but an active or intransitive sense, as sěquor, I follow ; mŏror, I tarry.

Depositary. [L. dēpǒsǐtārius.] One with whom any property is deposited in trust. $D e$ pository, the place in which it is so deposited.

Depôt. [Fr. dépôt, deposit, L. depǒsĭtum.] (Mil.) 1. A storehouse. 2. Establishment for the collection of war material. 3. A reserve for the training of officers and men for the service companies.

Deprecations. [L. deprěcātĭo, -nem, from precor, $I$ pray.]' In the Litany, the sentences which begin with the word "From."

Depreseivin of a heavenly body. Its angular distance below the horizon measured on a vertical circle.

Depression of the dew-point. The number of degrees that the dew-point is below the temperature of the atmosphere.

De principatibus. (Machiavellian.)

Depurate. [L. dë, thoroughly, pūrātus, p. part. of pūro, $I$ cleanse.] To free from impurities or alien matter.

Deputies, Chamber of. [Fr. Chambre des Députés.] In Fr. Hist., the lower of the two legislative chambers under the monarchy, from 1814 to 1848 .

Deputy-lieutenant. The deputy of the lordlieutenant of a county. There are several in each county. A uniform attaches to the office.

Deracinate. [Fr. déraciner, from racine, root.] To pluck or dig up by the roots.

Deraign, Derain, Dereyn. (Darraign.)

Derbyshire neck. (Goître.)

Derbyshire spar, i.e. abundant in D. limestone. (Fluor-spar.)

Derelict. [L. dē, and rělictus, utterly abandoned.] 1. (Naut.) A vessel forsaken at sea. 2. Of lands, suddenly left bare by retirement of the sea, i.e. generally by raising of the coast-line.

De rigeur. [Fr.] Necessary according to etiquette.

Deringer. [Amer.] A kind of pistol named from the original maker.

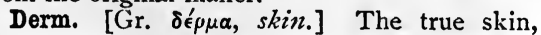
lying under the rētě mūcōsum, which is covered by the epiderm.

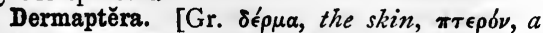
wing.] (Entoin.) Earwigs, Forficŭlidæe. Insects having leathery elytra. Ord. Orthoptěra.

Dermatology. (Dermis.)

Dermis. The vascular layer of the skin [Gr. $\delta$ '́p $\mu \alpha]$; the cŭtis vēra, or true skin. Dermal, relating to the $\mathrm{D}$., or equivalent outer covering. Dermatology, an account of the skin, its functions, diseases, etc.

Dernier resort. [Fr.] Last resource, last resort.

Derogatory. [L. dērŏgātōrius, detracting from.] (Leg.) D. clause in a will, a secret clause known only to the testator, with a condition that no future will not containing this clause word for word shall be valid.

Derrick. A crane on which the jib can be set at different angles with the crane-post.

Dervise, Dervish. This Persian word, signifying poor, denotes certain classes of so-called religious persons among the Mohammedans, some living in monasteries, others as hermits, and belonging to many orders.

Descant. In mediæval times the addition, at first improvised, afterwards written, of parts to a subject; the tentative beginning of modern harmony.

Descensum, Per. [L. for by descent.] By distillation through a pipe from the bottom of a crucible, so that the vapour descends.

Description-book. (Naut.) Contains age, place of birth, and description of each of crew.

Descriptive geometry. A part of practical geometry, treating of the representation of points and lines in space by means of their orthographic projections on two planes at right angles to each other.

Déshabille. [For Fr. déshabillé, undress, morning dress.] A careless light toilet, undress.

Desiccation. [L. desicco, I dry up.] A thorough drying up.

Desired. [Fr. désirer, L. dēsīdĕrare, to regret the loss of.] Mourned for, regretted, missed (2 Chron. xxi. 20).

Desmidīäcěæ. [Gr. $\delta \in \sigma \mu i s,-i \delta o s, a$ bundle, $\delta \epsilon^{\prime} \omega, I$ bind.] One of the lowest groups of organic life, propagated by budding and subsequent fission, distinguished by their green colour, and non-siliceous conıposition from the Diătŏmäcěce, which contain much silex. Found in ponds and streams. It is disputed whether they are animal or vegetable.

Desmology. [Gr. $\delta \in \sigma \mu \delta s, ~ a ~ b a n d, b o n d$.$] That$ part of Anatomy which has to do with ligaments.

De son tort. [Fr.] Of his own wrong; said of a stranger who ventures to act as executor.

Des Poblados. [Sp.] (Poblados.)

Desponsation. [L. dēsponsātio, -nem, from dësponsare, intens. of despondēre, to betroth.] Act or ceremony of betrothal.

Despumation. [L. despūmāre, to take froth off, from spüma, froth, foam.] The act or process of skimming off scum or froth.

Desquamation. [L. de-squāmo, I make to scale off.] A separation of the cuticle in small scales, e.g. after scarlatina.

Desstrictōrium. [L.] A chamber in the Roman thermæ for the rubbing and scraping down after the perspiration.

Desudation. [L. dēsūdātio, -nem.] A violent. sweating.

Desuetude. [L. dēsǔētūdo, disuse.] Disuse, discontinuance of custom or practice.

Dēsultōres. [L., vaulters.] Men who leapt from one horse to another when riding, especially equestrian performers in the circus.

Desynonymize. Words at first synonymous must in time shade off into somewhat different meanings, and are said to D. (Synonym.) 
Detached work. (Mil.) Such fortifications as, being beyond the body of the place, have to depend on their own garrison for protection.

Detachment. Small body of troops sent to garrison a post away from their regiment.

Detail of duty. (Mil.) Roster (q.v.) of the numbers of each rank with the names in turn for military duty.

Detent. (Ratchet.)

Detenn, ne. [Fr.] Prisoner.

Detergent medicines [L. dētergeo, $I$ wipe away] cleanse ulcers, wounds, etc.

Determinable freeholds. (Determine.)

Determinant. (Math.) When $n-1$ numbers satisfy $n$ linear equations, the algebraical expression obtained by their elimination is the D. of that set of equations. The properties of determinants form an important branch of modern algebra.

Determine. [L. dētermino, I put bounds (termini) to.] (Leg.) To bring to a conclusion ; $e . g$. if a widow have an estate granted to her during widowhood, her marriage determines the estate. Estates held for life only subject to a determining contingency are determinable freeholds.

Determining bachelor. A bachelor who will be entitled to the degree of master at the end of the current term.

Determinism. The theory, in its extreme form, of heredity ; that every organism is mainly determined -is what it is-by aggregation of inherited qualities and tendencies, influenced by circumstances. Experientialism, less absolutely, holds experience to be the foundation of all knowledge ; and all primary beliefs (e.g. personal identity, uniformity of nature, etc.) to be generalizations of our own or others' experience. Intuitionalism holds them to be instinctive, naturally implanted, and spontaneously developed. (As to Exp. and Int., vide Carpenter's Ment. Phys., pp. 226, 227.)

Detonating tube. [L. dētǒnāre, to thunder.] A stout glass tube used for exploding gaseous mixtures by electricity.

Detractor muscle. [L. detrăho, I drazv azvay.] (Anat.) One which draws the part to which it is attached away from some other part.

Detriment, Moon in her. [L. dētrīmentum, loss.] (Her.) An eclipsed moon.

Detriments. [L. dētrimenta, plu., rubbing off, damages, from dētěro, I rub off.] College charges at Cambridge, for wear of table linen, etc.

Detritus. [L., part. of dētěro, I rub or wear azeay.] (Geol.) Accumulations of wasted rocksurfaces.

De trop. [Fr.] Lit. too much; and so, in the way, not wanted.

Detumescence. [L. dētŭmescĕre, to cease swelling.] Diminution of swelling, subsidence.

Detur digniōri. [L.] Let it be given to one more worthy.

Deus ex māchina. [L.] A scholastic phrase, borrowed from the stage, where gods might be represented as flying in the air. It was applied to philosophers who, when unable to solve a difficulty by ordinary means, resorted to the aid of a supernatural power.

Deus nöbis hæo ötia fëcit. provided this ease for us (Virgil, Ecl. i.) ; motto of the Chelsea pensioners.

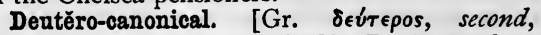

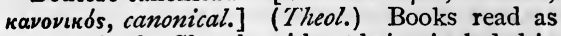
lectures in the Church, without being included in the canon of Scripture. The term was also applied to those books of the New Testament which were not at first generally received. (Antilegomena.)

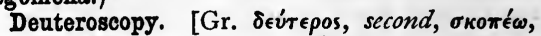
$I$ see.] 1. Second sight. 2. A second, less obvious meaning not seen at first.

Devastavit. [L.] (Leg.) Lit. he has wasted; a waste of property by an executor or administrator.

Developable surface. One described by the motion of a straight line in such a manner that it could be unrolled and laid flat without tearing or stretching; a cone is a developable surface.

Devexity. [L. devexitā, -tem, from dēvěho, $I$ carry down.] A bending down, a sloping, a curving downwards.

Deviation of the plumb-line. The angle at any station between the actual direction of the plumb-line and the perpendicular drawn at that place to the mean surface of the earth assumed to be an ellipsoid.

Devil. (Naut.) The seam next to the waterways. D. to pay, and no pitch hot (Naut.) = the troublesome water-seam to fill in with pitch, and none ready ; a troublesome job, and no one ready to undertake it. [D., a nickname for the water-seam; pay being the O.Fr. empoier, to daub with pitch.] (Pay.)

Devil and bag o' nails. Sign of an inn; i.e. Pan and the Bacchanals.

Devil-cart. One with a pair of large wheels and a long trail $(q . v$.$) , for the purpose of con-$ veying logs of timber.

Devil's advocate. (Advocatus diaboli.)

Devil's coach-horse. (Entom.) Black cocktail, Stăphy̆linus ŏleus, of same fam. as the small one which gets into the eyes, ord. Cólěoptera.

Devil's Wall. A huge Roman wall about 368 miles long, begun in Adrian's time, extending from Ratisbon on the Danube to below Cologne on the right bank of the Rhine, and completing the northern frontier of the empire.

Devil-worshippers. (Jerids.)

Devise. [Fr. déviser, from divĭdo, divide, p. part. divisus, to sort into parcels.] (Leg.) Properly to transmit real property by will, as bequeath is used of personal property; but $\mathrm{D}$. also $=$ bequeath

Devoir. [Fr.] Duty, respects, becoming act of civility.

Devolution. [L.L. dēvǒlūtio, -nem, act of rolling down, from L. dēvolvo, act. and neut., I roll off, away.] 1. A power claimed by the pope of appointing to a see, if the chapter appoint an unworthy person, or neglect to appoint. 2. Act of rolling down. 3. A passing on to a successor.

Devonian. (Geol.) The marine equivalent of the Old Red Sandstone, typically developed in Devonshire; often applied also to the Old Red Sandstone, and to both together. 
Dewel, Dole, Dool, Dowel. [O.E. dél, a portion, dǽlan, to divide; cf. Ger. theilen, D. deelen, $i d$.$] A post, stone, or strip of un-$ ploughed land marking a boundary.

Dewlap. Loose flesh which hangs from the throats of oxen.

Dew-point. When a body is in process of cooling, its temperature, at the instant when dew begins to be deposited on it, is the dewpoint in that particular state of the atmosphere.

Dexter. [L., right.] (Her.) The right-hand side of an escutcheon, which is, of course, to the left hand of a person facing it.

Dextrine. 1. British gum. 2. (Bot.) Starch, in its soluble condition, during its conversion into sugar for the nourishment of plants ; e.g. in germinating barley. At $400^{\circ} \mathrm{F}$., viewed by polarized light, starch has the property of turning the plane of polarization to the right [L. dextra].

Dextrose. [L. dextra, right.] Grape-sugar, which turns the plane of polarization towards the right. (Polarization.)

Dey. 1. [From Turk. dâi, maternal uncle.] Title (misnomer) of the ruler of Algiers ; properly, title of the commander of the Janizaries. 2. Scotch for dairy-maid. [Cf. Prov. Eng. day-house, day-zeoman, O.Swed. döggja, Gr. $\theta \hat{\eta}-\sigma \theta a l$, Goth. daldjan, to suck.]

Dhirzee, Dirzee. [Hind.] $A$ tailor.

Dhobee, Dobee. [Hind.] A washerman.

Dhole, Red dog, Kholsun. (Zool.) Spec. of wild dog, light bay colour, the size of a small greyhound; hunts almost silently, in packs. Western Ghauts, and other mountainous parts of India. Cuōn dükhuensis, gen. Cuōn, fam. Canı̆dæ, ord. Mammalia.

Dhouy, or Dhouey. (Douey.)

Dhotee. [Hind.] A native's waist-cloth in India.

Dhow. An Arabian vessel (of from 150 to 250 tons burden), about 85 feet long by 20 feet 9 inches in beam and 11 feet 6 inches deep, carrying small cargoes, fitted for defence, and rigged with a single mast forward, carrying a large lateen, whose yard is the length of the vessel, the tack fastened to the stem, the halyards leading to the taffrail.

Di-. (Chemr.) (Bi-.)

Di-, Dis-. 1. L. prefix, = in twain, in different directions; also used as a negative, as in displease. 2. Gr. prefix $[\delta i s$, twice $]$, = containing two chemical equivalents.

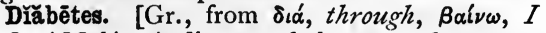
go.] (Med.) A disease of the general system, characterized by excessive hunger and thirst, with great increase of urine containing almost always more or less of sugar ; its true antecedents still obscure.

Diachylon, commonly pron. Diaculum. [Neut.

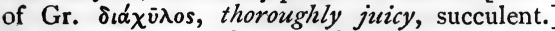
Common healing plaster, of red oxide of lead and olive oil.

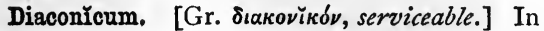
Greek Church, a vestry, sacristy, or credence table.

Diacoustics. [Gr. $\delta_{\iota}\left(\alpha^{\prime}\right)$, through, àkov́w, I hear.] The branch of acoustics which treats of the passage of sounds through different media and of consequent refraction; also called Diaphonics.

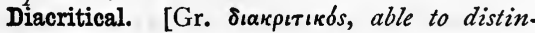
guish.] D. marks, marks in type or writing, added to letters or combinations of letters to give them a special pronunciation, as the cedilla under $c$ in French, to show it is to be sounded as s., e.g. façade ; and the hyphen or dots (marks of diæresis) in proëm, pro-em.

Diaculum. Corr. of Diachylon (q.v.).

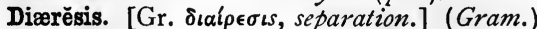
The resolution of a diphthong or a contracted syllable into two syllables.

Diaglyptic. [Gr. $\delta\llcorner\alpha$, through, $\gamma \lambda \check{v} \phi \omega, I$ chisel.] Pertaining to carving in intaglio; opposed to Anaglyphic, or carving in relief.

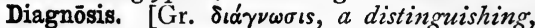
discerning.] ( $\mathrm{Med}$.) Distinction of the characteristics of different diseases, especially the discriminating knowledge of a particular case, from a study of all particular circumstances taken together.

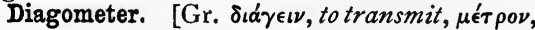
a measure.] An instrument for measuring the power of bodies to conduct electricity.

Diagonal scale. [Gr. $\delta เ \alpha \gamma \omega \dot{\nu} \iota s$, diagonal.] A scale on which, by means of lines drawn obliquely, distances can be read off true to the hundredth of an inch (or other unit) by means of subdivisions a tenth of an inch long. It is to be found engraved on most ivory protractors.

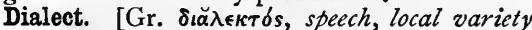
of speech.] Variety of speech. There is no fixed distinction between a D. and a language, but generally $\mathrm{D}$. is preferred for varieties of speech which are comparatively limited in area or literary importance, or for the form of speech of a member of an ethnological family descended from a mother language.

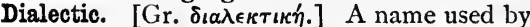
Plato as synonymous with metaphysics, or the highest philosophy. It is applied in a narrower sense to that portion of logic which treats of modes and rules of reasoning.

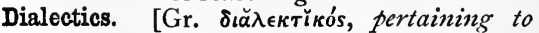
discourse.] 1. Platonic, though invented by Zeno, the method of scientific investigation by question and answer, involving the classification of particulars under generals and generals under universals, and the reverse process of division. 2. Aristotelian, the art of maintaining a tenet in conversation. 3. Kantian, the science of illusory phenomena.

Diallăgē. [Gr., intcrchange.] (Rhet.) A figure of thought under which several arguments are brought to establish one point, the L. consummātio.

Dialogism. (Khet.) The reporting, in the third person, of a dialogue between two or more speakers.

Dialy̆sis. [Gr. $\delta เ \alpha ́-\lambda v ̌ \sigma \iota s$, dissolution.] 1. (Gram.) Diærěsis. 2. (Rhet.) Asyndeton. 3. The separation of the crystalloids from the colloids in a solution containing both, by the diffusion of the former into water through paper parchment. (See Graham's Chemistry.) 
Diamagnetic. (Paramagnetic.)

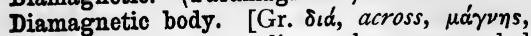
magnet.] A body tending, when suspended between the poles of a magnet, to place itself at right angles to the line joining those poles.

Diameter; Apparent D. [Gr. $\delta ı \alpha ́ \mu \epsilon \tau \rho o s$.$] Any$ chord drawn through the centre of a central curve or surface, as a diameter of a sphere. The angle subtended at the eye of the observer by the diameter-supposed not to be foreshortened - of a heavenly body is its Apparent $D$.

Diamond necklace, The affair of the. A plot by which the name of Marie Antoinette, wife of Louis XVI., King of France, was tarnished, on the supposition that she was privy to the intrigue by which the Countess of Lamotte Valois obtained possession of a diamond necklace bespoken for Mad. du Barry by Louis XV., and at that time in the hands of the queen's jewellers.

Diamond type. [Fr. diamant, (?) from Gr.

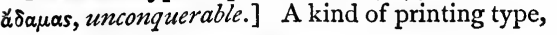
as-

Comparative.

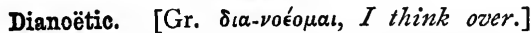
Pertaining to the discursive comparative analogical faculty.

Dianthus. [Gr. $\delta\llcorner\alpha \theta \eta \eta s$, double-flowering, variegated.] (Bot.) A gen. of plants, ord. Caryophyllaceæ, of many spec., annual and perennial, as pink, carnation, sweet william, etc.

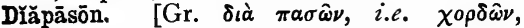
through all the strings.] (Gr. Music.) 1. An octave. 2. In an organ, D. or principal, certain important stops extending usually through the whole compass. (Open diapason.)

Diaper. Figured linen cloth. [Mr. Skeat traces the word to the O.Fr. diaspre, O.It. diaspro, jasper, rejecting the derivation from d'Ypres, of Ypres, the clothworking Flemish city.]

Diapering. [Fr. diaprer, to diaper.] Ornamenting with flowers or arabesques, repeated in squares or other regular patterns.

Diaphănous. [Gr. $\delta\left\llcorner\alpha \phi \alpha \nu \eta^{\prime} s.\right]$ Transparent.

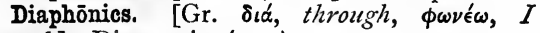
sound.] Diacoustics (q.v.).

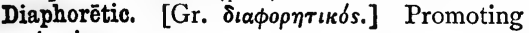
perspiration.

Diaphragm [Gr. $\delta\llcorner\alpha ́ \phi \rho \alpha \gamma \mu \alpha, \delta \iota \alpha \phi \rho \alpha \gamma \nu \bar{v} \mu \iota, I$ barricade], or Midriff [A.S. midrife, hrife, intes. tine]. (Anat.) The transverse muscle in mammalia generally, separating the cavity of the thorax or chest from that of the abdomen or belly.

Diastase. [Gr. $\delta\llcorner\alpha \sigma \tau \alpha \sigma \iota s$, separation.] (Chem.) A nitrogenous substance formed in germinating seeds, which by fermentation converts starch into sugar.

Diastēm-, Diastēmato-, = longitudinal division,

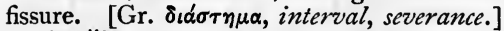

Diastǒlē. [Gr.] 1. (Gram.) The lengthening of a short syllable, opposed to Systole. 2. (Physiol.) Dilatation of the heart and arteries on the entrance of blood; opposed to Systole

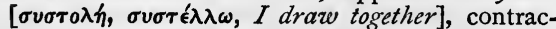
tion, or Systaltic action: these being the first and second heart-sounds, and both together making one rhythm.
Diatessăron. [Gr., through four.] (Eccl. Hist.) A name given to harmonies of the Gospels. The earliest, now lost, was the work of Tatian in the second century.

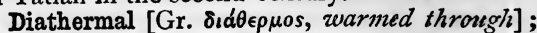
Diathermanous [Gr. $\delta\llcorner\alpha \theta \in \rho \mu \alpha i \nu \omega, I$ warm through]. Capable of transmitting radiant heat ; thus, rock-salt is diathermanous.

Diăthěsis. [Gr., disposition.] ( $\mathrm{Med}$.) Condition of the system generally, with the idea of predisposition to some kind of disease.

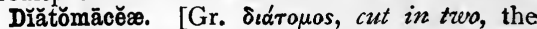
individual consisting of a double frustule, and easily separable from the rest of the series.] Simple organism of protoplasm, with delicate siliceous crust, developed in long linked strings. (Desmidiaceæ.)

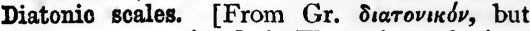
with different meaning.] 1. The major and minor of modern music. $\mathrm{D}$. melody $=$ using no notes not found in the D. scale. Opposed to Chromatic.

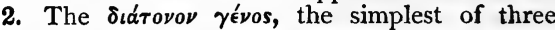
genera of music with the Greeks. (For explanation, see Dict. of Greek and Roman Antiquities.)

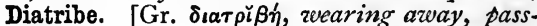
ing of time, discussion.] A continuous discourse ; especially a sustained flow of invective, an elaborate attack. Usually pronounced as a word of three syll. in English.

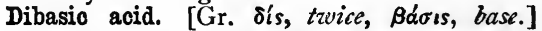
(Chem.) Any acid containing two atoms of hydrogen in its composition.

Dibbs. 1. Slang for ready money. 2. A small pool. 3. An old game, Greek and English, of throwing up the small bones of the legs of sheep and catching them on the palm, then on the back of the hand.

Di běně vertant.

good turn to affairs.

[L.] May the god give a

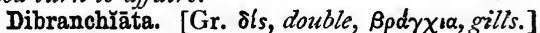
(Ichth.) 1. Cephalopods with one pair of gills, as cuttle-fish. 2. Cirripeds with one pair of gills.

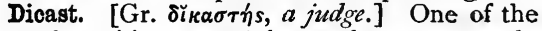
5000 free citizens at Athens who were yearly balloted for and sworn in to serve as judges in the law courts. A judicial panel consisted of many dicasts, often of 500 or more ; they voted by ballot on the verdict, which the majority decided.

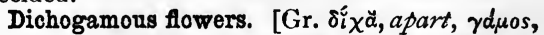
marriage.] Those in which the anthers are developed before the pistil, and vice versâ.

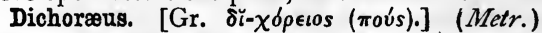
A double choræus or trochee; thus, $-v-v$, as willy-nilly, ēminnērĕ.

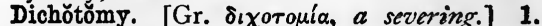
(Astron.) The moon's dichotomy is when she is at half-moon at the end of her first and third quarters. 2. (Log.) The division of a class into two sub-classes, opposed to each other by contradiction, as Earl and Churl, male and female, living and dead, fire and not fire. 3. A division of the more general into two more particular subdivisions; a Pythagorean method adopted by Plato; thus the political is divided into the legislative and the judicial (i.e. so far as theory is concerned). 
Dicker. 1. [ $C f$. L.L. dacra, dicora, probably from a Celt. form, the number ten.] Half a score, especially of hides. 2. [Amer.] A petty bartering.

Dicotyledonous plants. (Bot.) Those of which the embryo is furnished with two cŏtyledons opposite to one another; corresponding to Exogens (q.v.).

Dictātor. [L.] In Rom. Hist., an extraordinary magistrate invested with absolute power for six months.

Dictum. [L.] Expressed opinion or command. (Obiter dictum.)

Dictum de omni et nullo. [L.] In the Aristotelian logic, the assignment of an object to its class, or the placing of one class under another class, so that whatever is true of the class shall be true of every member included in the class.

Didactic. [Gr. $\delta \iota \delta a \kappa \tau \iota \kappa \delta s$, from $\delta\llcorner\delta \alpha \sigma \kappa \omega, I$ teach.] A name applied to any writings which treat of the rules or principles of any science or art, but more especially to poetry of an ethical or reflective character, and to poems embodying a scientific treatise, as the Phanomena of Aratus, De Rerum Natura of Lucretius.

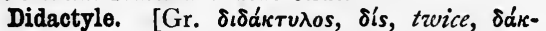
$\tau$ v̌̀os, finger, toe.] (Zool.) Two-toed.

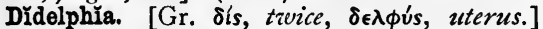
Having a double uterus. The second sub-class of mammals, containing the marsupials, as the kangaroos and opossums.

Didelphy̆ĭdæ. (Didelphia.) The true opossums. Trop. America. Ord. Marsūp̌̄ālĭ (q.v.).

Die. (Dado.)

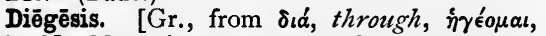
$I$ lead.] Narration, statement of a case.

Dielectric. [Gr. $\delta \iota d$, through, and electric.] A non-conducting body.

Diem perdidi! [L.] I have lost a day! exclamation of the Roman emperor Titus, after passing one day without doing anything for his subjects' good.

Dies ciněrum. [L., day of ashes.] Ash Wednesday.

Dies dŏlōrem minuit. [L.] Time abates grief.

Die-sinking. Engraving a steel die for the stamping of coins or medals.

Diěsis. [Gr.] In Gr. Music, at first a semitone, afterwards came to mean a quarter-tone, or a third of a tone ; (?) from a sense of dissolving the note [ $\delta i t \eta \mu l]$.

Dies non. [L. (sc. juricus).] Not a courtday; a day on which no legal proceedings go on and no business transactions are completed, or if so are invalid.

Die-stock. A contrivance to hold the dies for cutting screws.

Diet. [L.L. diēta, from dies, a day, Ger. Reichstag.] The chief national assembly of the Empire, summoned twice each year by the Emperor; also of other states, as Hungary, Switzerland, etc.

Dien et mon droit. [Fr., God and my right.] The motto of the royal family of England. First assumed by Richard I.

Dieu et son acte. [Fr., God and His act.] The act of God ; said of an inevitable accident. Diffarreātio. (Confarreation.)
Iifference. [L. differentia.] 1. (Her.) A mark added to a coat of arms to distinguish different branches of a family or different sons of one house. 2. In Logic, the predicable, which distinguishes the subject from all others from the point of view in which it is then regarded. The genus, with this difference, is said logically to make up the species. (Predicable.)

Differences. (Stockbrok.) The sums lost and won in speculative time-bargains, being the difference between the price of the stock or shares concerned agreed to on the day of purchase and the available price on settling day.

Differentia. (Differentiation.)

Differential; D. calculus; $\mathbf{D}$. coefficient; $\mathbf{D}$. motion; D. screw; D. thermometer; D. windlass. If the magnitude of one quantity depends on that of a second quantity (as the volume of a sphere on its radius), so that if the second quantity is increased that of the first will be increased (or diminished); the ratio which the increment of the first bears to that of the second when they are indefinitely small is the $D$. coefficient of the first quantity with respect to the second. The indefinitely small increments, considered as separate magnitudes, are Differentials. (For $D$. calculus, vide Calculus.) When a comparatively quick motion is made to communicate a slow motion by means of the difference of the velocities of two pieces, it is said to communicate a $D$. motion. Thus, in the $D$. windlass, the barrel consists of two cylinders of nearly equal radii, the weight is fastened to a pulley in the loop of a rope whose ends are fastened to the cylinders and wound round them in opposite directions; on turning the winch the rope is wound on to one and off the other cylinder ; so that the rope in the hanging loop is shortened (or lengthened) by the difference between the lengths wound on and off. A heavy weight attached to the pulley is thus slowly raised without unduly weakening the barrel. The same principle is applied in the $D$. screw. The $D$. thermometer is an air thermometer with two bulbs, for ascertaining the difference between the temperatures of two substances or places, when the actual temperature of each is not required.

Differentiation. [From L. differentia, difference.] 1. (Log.) Exact definition by the differentia, or characteristic peculiarity essential to classification, of a species. 2. (Biol.) The development in evolution of specific distinctions. 3. Resolution of a homogeneous aggregate into its heterogeneous constituents. 4. (Math.) The process of finding differential coefficients.

Diffraction of light. When a small opaque body is placed in light radiating from a point, its shadow is found not to be its true geometrical projection, but to be surrounded by iris-coloured fringes. The light, therefore, does not proceed in accurately straight lines past the edges of the body, and is said to be diffracted by them. Diffraction is one kind of interference of light.

Diffusion. [I. diffusio, -nem, diffunděre, to shed abroad.] The action by which gases or fluids become intermixed when in contact.

Diffusion of gases. The tendency of two or 
more gases in contact to intermingle with each other.

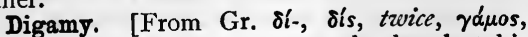
marriage.] Marriage by one who has lost his first wife.

Digest. [L. dīgesta, neut. plu. p. part. of dīgĕro, I arrange.] A systematically arranged work on law ; especially Justinian's fifty books.

Digester. A strong closed vessel for heating water above boiling point.

Digesting. Softening by heat and moisture.

Digests. [L. digestus, brought into order.] (Hist.) Compilations of the Roman law; the best known being that of Justinian, which is also called the Pandects, or general collection, from the Greek words $\pi \hat{a} \nu$, all, and $\delta \in \dot{\chi} \chi \sigma \theta a l$, to receive.

Digit. [L. digltus, a finger.] 1. Any one of the ten numerals. 2. The twelfth part of the diameter of sun or moon. The term is used in estimating the extent of an eclipse, e.g. when three quarters of the diameter of the sun are hidden by the moon, nine digits are eclipsed.

Digntălis, Foxglove (Folks' glove, i.e. Fairies' glove). (Bot.) A gen. of plants, ord. Scrophulariaceæ. D. purpưrea, Common F., native of Britain, is much valued in medicine, and grown as an ornamental plant.

Digitate leaf. (Palmate.)

Digitĭgrăda, Digitigrade. [L. diğitus, finger, toe, grădior, I walk.] (Zool.) Carnivorous quadrupeds which walk upon their toes, as the cat.

Digladiation. [From digglădiāri, to fight handto-hand, from dis-, apart, glădius, sword.] Sharp contention.

Digna cănis pābŭlo. [L.] $A$ dog deserves food; it is a poor dog that does not deserve a crust.

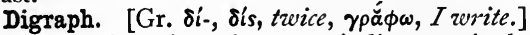
A combination of two letters to indicate a single articulate sound, as 00 in book, $c h$ and $i e$ in chief.

Digression. (Parecbasis.)

Dihedral angle. (Anǵle.)

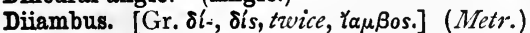

A double iambus; thus, $v_{-} v_{-}$, as ămænĭtās.

Dii consentes. (Consentes, Dii.)

Dikast. (Dicast.)

Dike, Dyke. [O.E. dic, (1) a mound, (2) a trench, something dug ; $c f$. D. dijk, Fr. digue, an embankment.] In the south of England, a ditch, with or without a bank; in the north, a stone fence.

Dī lāneos pĕdēs hăbent. [L.] The gods have feet of wool; i.e. the approach of their vengeance is unheard.

Dilaniation. [From L. dīlăniāre, to tear in pieces.] The act of tearing to pieces.

Dilapidation. [L. dīlăpĩdātro, -nem, a wasting, lavishing.] The result of neglect, on the part of an incumbent, to repair the chancel, glebe house, or any other edifices of his living; or of wilful waste, committed or suffered to be committed upon glebe, woods, or any other inheritance of the Church.

Dilettante. [It.] An amateur devotee of fine art and antiquities.

ligønos. [Fr., L. diligentia.] 1. A heavy stage-coach, used in France. 2. (Scot. Law.) Process of arrest or seizure for debt, or compulsory production of evidence.

Dilligrout. Pottage formerly made for the sovereign on the day of coronation.

Dill-water. For relief of flatulence and griping in children, in which oil of dill is used, which is obtained from the seeds of the common dill (Anēthum grăvěŏlens).

Diluvial agency. [L. dīlŭvium, an inundation.] (Geol.) Powerful exceptional agency of water; opposed to Alluvial.

Dilving. Washing tin ore in a canvas sieve in a tub of water, so that the waste runs over the edge of the sieve.

Dimanche. The French form of the Latin Dominica [sc. dies], the Lord's day.

Dime. A silver coin used in the U.S., a tenth [Fr. dîme, L. děcĭma] of a dollar.

Di mèlius- [L.] May the gods grant it (sc. dent) better; Ovid goes on -quam nôs mŏneāmus tālia quenquam, than that I should give such advice to any one.

Dimension. 1. In Geom., length, breadth, and thickness are the three dimensions of space. 2. In Algebra, each of the letters which occur in a product is a dimension of the product; e.g. $x^{2} y^{3}$ is a product of five dimensions, or of the fifth a'egree.

Dimèter. A verse having two metres [Gr.

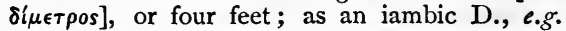
Horace, Epod. i.- -x.

Dimetric system. [Gr. $\delta$ í $\mu \in \tau \rho o s$, of two measures.] In Crystallog., the pyramidal system (q.v.).

Dimidiated. [L. dimidiātus.] Halved.

Dimidium facti qui cœpit habet. [L.] He who begins has half his task (done); well begun, half done (Horace).

Dìmídium plūs tōto. [L.] The half is more than the whole; the golden mean is best, a Latin

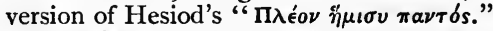

Diminished. (Music.) Made less than minor; e.g. $\mathrm{C}$ natural to $\mathrm{B}$ flat above being a minor seventh, the $\mathrm{C}$ sharpened would make a diminished seventh, i.e. by a semi-tone.

Dimissory letters. In the ancient Church : 1. L. to clergy about to leave one diocese and settle in another, granting the bishop's leave to depart. 2. In the Church of England now, D. L. are a licence from a bishop in whose diocese a candidate for holy orders has a title to another bishop, granting leave to ordain. (Literæ formatæ.) Dìmissōria (sc. lìtěræ), Roman law, a written notice, remitting a case to a superior judge.

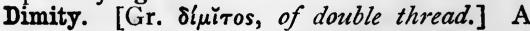
stout white cotton cloth ribbed or figured.

Dimorphism. [Gr. Simopфos, two-formed.] Crystallization of a substance in two different systems; thus carbonate of lime in some forms crystallizes as Iceland spar in the rhombohedral system, and as aragonite in the prismatic system.

Dimsel. (Naut.) A standing water, too large for a pond and too small for a lake.

Dinar. A modern Eastern corr. of the $\mathrm{L}$. 
Denārius, a coin originally worth ten asses, and answering to the Gr. Drachma, the value being about that of the modern franc-piece. In the English New Testament, the Gr. $\delta \eta \nu$ ápiov is translated by the word penny.

Dinghey, or Dingy. 1. A small Bombay boat with sail and paddles. 2. The boats of the Hooghly. 3. A small extra ship's boat.

Dingo. (Native name.) Variety of dog, about two feet high, reddish brown, wild, savage, hunts in packs. Australia. Believed to be an importation.

Dinmont. (Sheep, Stages of growth of.)

Dinmont, Dandy. (Dandy.) A store farmer, in Scott's Guy Mannering, whose name attaches to a valuable breed of long-backed Scotch terriers.

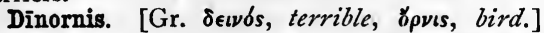
(Ornith.) A gen. of very large birds, tribe Brěvipennes, of New Zealand; local name, moa; extinct since seventeenth century (?).

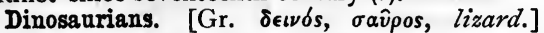
(Geol.) A group of gigantic reptiles, chiefly of the saurian type and of high-class organization. From the Lias to Cretaceous. Iguanodon, megalosaurus, etc.

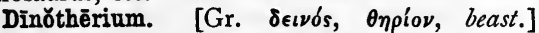
(Geol.) Huge pachyderm, with tusk-like incisors and proboscis; found in the Miocene of France, Germany, etc.; its true zoological position uncertain.

Diocletian æra, or Fra of martyrs, is counted from the beginning of the reign of Diocletian, A.D. 284 .

\section{Dǐœcēsis. (Paroikia.)}

Diœcious. (Monœcious.)

Dionȳsia. [Gr. $\Delta \iota \nu \bar{v} \sigma \iota a$.$] Festivals of Diony-$ sus. There were four in the four shortest months : (I) The Lesser, or Rural ; (2) Lēnæa ; (3) Anthesteria ; (4) City, or Great, D. Comedies and tragedies were performed at these festivals.

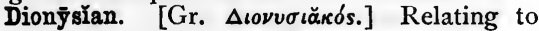
Dionȳsus, son of Zeus (Jupiter) and Sěmělē daughter of Cadmus of Thebes. $\mathrm{He}$ is said to have brought from the East the orgiastic worship with which he was honoured. $\mathrm{He}$ is known also as Bacchus. (Bacchanalian.)

Diophantine analysis or problems. (Diophantus, mathematician, of Alexandria.) Question in indeterminate equations, involving squares or cubes of the unknown quantities, as to divide a given square number into two other square numbers; thus, $17^{2}=8^{2}+15^{2}$.

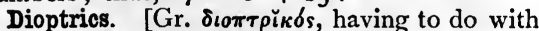

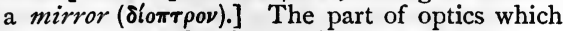
treats of the refraction of light; it includes the formation of images by lenses and combinations of lenses.

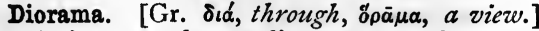
A painting seen from a distance through a large opening, and having the effect heightened by light directed on its surface or shining from behind through the transparent portions.

Diorite. [Gr. $\delta$ sopi $\zeta \omega, I$ distinguish.] (Geol.) An igneous rock (greenstone, etc.), composed of felspar and hornblende.

Diorthōtic. [Gr. $\delta \iota \rho \rho \theta \omega \tau \iota k \delta s$, from Gr. $\delta \iota \rho \rho \delta \delta \omega$,
I correct, from $\delta ı$ d. through, ỏ $\theta \delta$ s, upright.] Pertaining to correction or emendation.

Dioscuri, Dioskouroi. [Gr.] Sons of Zeus. (Castor and Pollux.)

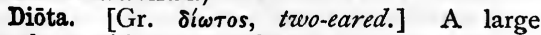
amphora with two handles.

Dip. 1. The inclination of the magnetic needle to the horizon. (Dip of the horizon.) 2. (Geol.) The inclination of strata from the horizon, measured by the angle it makes with the plane of the horizon; the strike [Ger. streich, stroke] being the line of outcrop of a stratum, and at right angles to its $\mathrm{D}$.

Dip, Dipt ware. Pottery ornamented by expressing coloured clays, in arborescent or other forms, upon the article as it turns slowly on a lathe.

Diphthĕria, Diphthĕrïtis. [Gr. $\delta \iota \phi \theta \in ́ \rho \alpha$, prepared leather.] A form of very fatal sore throat, occurring epidemically, with low dangerous fever and formation of a false membrane upon the surface of the mucous membrane of the fauces.

Diplōma. [Gr., lit. a letter folded double.] In Rome, formerly a State letter of introduction for travellers, a magistrate's grant of some privilege; now any document conferring authority, and especially a licence to practise physic or surgery.

Diplomatics. [Gr. Si $\pi \lambda \omega \mu a$, anything folded double.] The science which deciphers and determines the dates of ancient writings. Its principles were fully developed in the great work of Mabillon, De Re Diplomatica, I68I. (Palæography.)

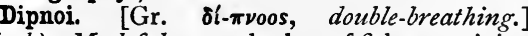
(Zool.) Mud-fishes, a sub-class of fish, containing three gen. of one spec. each, by some reckoned amphibia. Cěrātodus [képas, -âtos, a horn, óbous, a tooth], an Australian spec., presents characteristics suggesting the combination of the sub-classes Tělěostěì, Dipnoi, and Gănŏïděi under the last name.

Dip of the horizon; Magnetio D. The angle at the eye of the observer between a plane at right angles to the plumb-line, and a line drawn to a point on the visible horizon or line which seems to bound the ocean. When a magnet is suspended so as to swing freely round a horizontal axis at right angles to the magnetic meridian, it comes to rest at a certain definite inclination to the horizon; this angle (which is different at different places) is the Magnetic $D$.

Dipolarization. (Depolarization.)

Dipping needle. A magnetic needle so suspended as to show the magnetic dip.

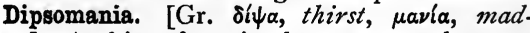
ness.] A thirst for stimulants not to be controlled.

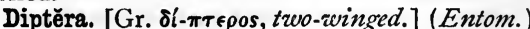
Ord. of insects with two wings, the hind pair represented by short haltērěs, balancers, as houseflies and gnats.

Diptěros. [Gr. $\delta i \pi \tau \epsilon \rho o s$, from $\delta$ l for $\delta i s$, twice, $\pi \tau \epsilon \rho \delta$, wing.] (Arch.) A rectangular temple or building with a double row of supporting columns on all sides. (Peripteral.) 


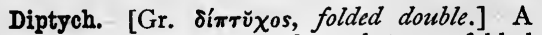
tablet of wood, metal, or other substance, folded like a book of two leaves. Used at first for registers. The diptychs of the Greek Church contain on one side the names of the living, on the other those of the dead, which are to be rehearsed during the office.

Direct motion. (Music.) (Motion.)

Direct motion of a planet. (Proper motion.)

Directōrium. [L.] (Eccl.) A book of rules for the performance of the sacred offices, as Directorium Anglicanum.

Directory. 1. A book of regulations for divine worship, drawn up in 1644 by the Assembly of Divines in England, and set forth by the Lords and Commons to be used instead of the Prayer-book. 2. The name given in 1795 to the executive body of the French republic, overthrown four years later by Bonaparte. (Assembly.)

Directrix. 1. (Conic sections.) 2. In Solid Geom., when a surface is described by a moving line which slides on one or more fixed guiding lines, any one of the fixed lines is called a Directrix.

Direct taxation. (Indirect taxation.)

Dirge. A contraction of L. diř̆ge, direct, which occurs in the first nocturn of the Office for the Dead. Hence (I) music for that office, (2) any mournful tune.

Diř̆gě. (Dirge.)

Diriment. [L. dĭrimo, I take away, annul.] D. impediments to a marriage are absolute bars which would make it void $a b$ initio.

Dirt-beds. (Geol.) Layers of black dirt, old vegetable soil, in the Lower Purbeck beds, with numerous fossil cycadeous stems standing upright, and coniferous trunks lying down.

Diruit, ædíficat, mūtat quadrāta rotundis. [L.] He pulls down, builds up, changes square for round.

Dis. (Pluto.)

Dis-, Di-. [L.] Prefix denoting separation, hence used with privative and negative force.

Disabling Statutes. Acts of Parliament restraining and limiting rights and powers.

Disafforest. To throw open forest ground to the public, or to enclose it for cultivation.

Disaggregation. [L. dis-, prefix of separation, and aggrĕgo, 1 bring to the flock (grex, grĕgis).] Distinction of an aggregate into component parts.

Dis ălïter visum. [L.] The gods determined otherwise.

Disbar. To expel from the bar, a power vested in benchers of the four inns of court, subject to appeal.

Disbench. To expel from the position of a bencher, a power vested in the benchers of an inn of court.

Disboscation. [L. dis-, priv. prefix, and L.L. boscus ; $c f$. Fr. bosquet, thicket, from Teut. bosk, Eng. bush.] The bringing woodland into cultivation or pasturage.

Discalced clerks of the passion. (Passionists.) Disce aut discēde. [L.] Learn or go.
Disceptation. [L. disceptātio.] Debate, discussion.

Discharged living. (Eccl.) One released under 6 Anne from payment of firstfruits.

Discharger. An instrument for discharging a Leyden jar.

Disciplina, Arcani. (Arcani Disciplina.)

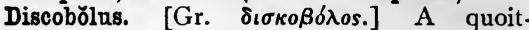
thrower. A celebrated bronze statue of Myron, fifth century B.C., of which several marble copies exist.

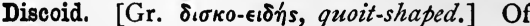
the form of a disc.

Discommon. 1. (Univ.) Of a townsman, to make it punishable for persons in statu pupillari to have any dealings with him, a power of the collective heads of houses. 2. ( $L c g$.$) To make$ no longer common or commonable, as of land by enclosure.

Discontinuous. Not continuous. (Continuity.)

Discovert. (Leg.) A widow, a woman not in coverture.

Discovery. [L. dis-, neg. prefix, and cǒŏpěrīre, to cover.] (Leg.) A bill of $\mathrm{D}$. in equity prays that the court compel the defendant to disclose facts or discover (give access to) documents material to the plaintiff's case, provided such discovery be not perilous to the defendant.

Discrepancy. [L. discrěpantia, discordance.] Disagreement, variance.

Disembody. To deprive a military force of its arms and accoutrements, and release them from service for a limited period.

Disembogne. To discharge.

Disesteem. To feel no esteem for, to deprive of esteem.

Disherison. [L. dis-, neg. prefix, and Fr. hériter, from L. hæres, heir.] The act of debarring from inheritance.

Disintĕgrate. To break up a whole into component parts, to deprive of cohesion, of unity.

Disjecti membra poētæ. [L.] The limbs of the dismembered poet (Horace)

Disjunctive. '[L. disjunctivus, from dis-, neg. prefix, and jungo, I join.] 1. (Gram.) Expressing an opposition or separation of ideas, as the D. conjunctions : but, else, although, unless, lest, either-or, neither-nor. 2. (Log.) Involving opposition or separation of ideas, as the D. syllogism : "It is either good or bad, or both ; but it is not bad, therefore it is not both, therefore it is good."

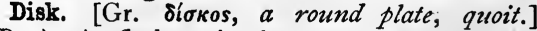
(Bot.) A fleshy circular organ enlargement between the stamens and ovary, as in spindletree (Euonymus).

Dislocation of memory. (Path.) The curious effects upon it of injury, disease, or decay.

Dislocations, Slips. (Geol.) Displacements of stratified rocks from their original sedimentary position by fracture. (Fault.)

Dismal Swamp. About thirty miles north to south by ten miles of country around Lake Drummond, $\cdot$ chietly in Virginia, partly in Carolina, U.S.

Dispark. To throw or lay open, as a Park.

Dispart. [(?) Fr. disparité, disparity.] The 
excess of half the diameter of the base ring of a gun over half the diameter of the muzzle.

Dispauper. To disqualify from suing in form $\bar{a}$ pauperis one who has been admitted to sue thus, either because he has subsequently acquired property or for any other sufficient cause.

Dispensatory, i.q. Pharmacopaia (q.v.).

Dispensing power. (Hist.) The power of the English sovereign to dispense with penalties on things forbidden by law but not by moral obligation. James II. regarded this power as authorizing him to dispense with tests against Roman Catholics and Dissenters.

Dispersion of light, or Chromatic D. of light. The separation of a pencil of rays of white light into rays of coloured light by means of a prism or other refracting medium.

Displacement. (Naut.) (Cavity.)

Displayed. [Fr. déployér.] (Her.) Having its legs spread and wings expanded.

Dispondēus. [L.] A double spondee; thus, - - - , as dēsōlātæ.

Disseisin. [Fr. dissaisin.] A deprivation of actual seisin (q.v.) by force or fraud, a turning out of an owner in actual possession of a freehold.

Dissepiment [L. dissēpimentum, dissēpio, $I$ hedge off], or Septum [L., an enclosure]. (Bot.) A vertical partition, division into cells, of compound fruit ; $e . g$. wallflower. (Loculus.)

Dissǐdents. [L. disš̌dentes, sitting apart.] (Hist.) Dissenters in Poland from the Roman Catholic or established religion, who were allowed the free exercise of their faith. After the partition of the country, they were placed on the same footing with the members of the Latin Church.

Dissilient. [L. dissǐlio, I start asunder.] Starting open, opening with elastic force.

Dissimilation. [L. dis-šmı̌lis, unlike.] (Gram.) Change of one of two contiguous similar or identical sounds, or avoidance of the juxtaposition of such sounds, as $\tau i \theta \eta \mu \iota$ for $\theta i \theta \eta \mu \iota$, equester for equetter, văriětas not văriitas.

Dissĭpat ēvius cūras ědāces. [L.] Wine disperses gnawing cares (Horace).

Distaff. [O.E. distaef.] A cleft stick for holding the bunch of flax, etc., from which the thread was drawn in hand-spinning.

Distemper. [Cf. dis-ease, dis-order.] 1. In dogs, an affection, typhoid, contagious, of the upper air-passages; somewhat like strangles in horses, and scarlatina in children. 2. In horses, $D$. means influenza, an epidemic catarrh, severe, attended with great weakness. 3. In cattle, sometimes, epizoötic (q.v.), pleuro-pneumŏnia (q.v.). 4. [It. tempera.] Painting on a dry surface of plaster, etc., with colours mixed in some aqueous vehicle, such as size.

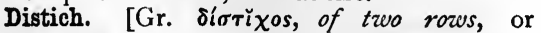
verses.] In poetry, a rhymed couplet.

Distillation. [L. distillatio, -nem, distillāre, to drip down.] The process of heating a substance so that it gives off a vapour afterwards condensed by cold.

Distinguishing pendant. A special flag to distinguish signalling-ships in a fleet or squadron.

Distrait. [Fr.] Preoccupied, absent.
Distress. [O.Fr. destresse, from districtus, p. part. of distringo (distrain).] The act or fact of distraining.

District. [L.L. districtus, a crossing over.] (Mil.) Province occupied by troops commanded by one general officer. England is divided into nine, Scotland one, Ireland three, Channel Islands two.

Distringas. [L., that you distrain.] (Leg.) A special writ of execution addressed to a sheriff, issued against a corporation aggregate; or to restrain transfer of stock or payment of dividends by the Bank of England.

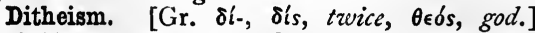
Belief in two gods. (Dualism.)

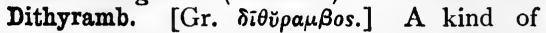
lyric poetry, in honour of Dionysus Bacchus, then of the other gods also ; cultivated especially at Athens; degenerating from its wild lofty style, $D$. became $=$ bombast (origin of the word unknown, but perhaps akin to Gr. $\theta$ pía $\mu$ Bos, L. triumphus).

Dī tǐbǐ dent annos. [L.] May the gods give thee years.

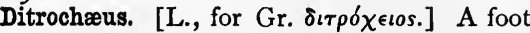
consisting of two trochees. (Dichoræus.)

Dittany, Common or Bastard, or Fraxinella. (Bot.) Native perennial of S. Europe, cultivated in England; Dictamnus fraxinella, ord. Rūtāceæ; containing a quantity of lemon-scented oil, and giving off enough from its erect, rose-coloured, sometimes white, raceme, to take fire from a

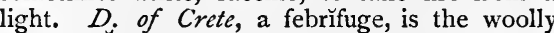
labiate Orīgănum dictamnus, growing abundantly on Mount Dictē.

Dittay. [From L. dictāre, to assert, freq. of dicerre, to say.] The matter of a charge or indictment against an accused person, in Scotland. Taking up $D$., collecting the information necessary for trial.

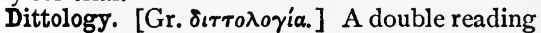
or interpretation of a text.

Ditty-bag. A sailor's bag, to hold smaller necessaries. D.-box, that in which he keeps his valuables.

Diurnal motion; D. circle; D. aberration. The apparent daily motion of the heavenly bodies, which is due to the rotation of the earth on its axis. Consequently each star seems to describe a circle-its $D$. circle-in the course of a day. (For $D$. aberration, vide Aberration.)

Divan. [Pers. dîwân, a book of many leaves, a council.] 1. A council. 2. A council-chamber. 3. A salon with cushioned seats. 4. A cushioned seat or sofa along a wall.

Divaricate. [L. divārĭcătus, splayed, spread asunder, from di- for dis-, apart, and vārus, azory, grown apart.] 1. Widely divergent. 2. To diverge widely.

Divellent. [L. divellens, -entis, p. part. of divello, I pluck asunder.] Drawing asunder, pulling apart, tending to separate.

Divergent series. (Math.) A series such that the sum of its first $n$ terms can be made to exceed any assigned number, however great, by taking $n$ large enough; e.g. $1+\frac{1}{2}+\frac{1}{3}+\frac{1}{4}$, etc., is a divergent series. 
Di Vernon. The heroine of Scott's Rob Roy, in whom beauty, courage, straightforwardness, and purity of heart are singularly blended.

Diversions of Purley. Written by HorneTooke, 1786, et seqq. A series of dialogues on language.

Dīversum vǐtio vĭtǐum prŏpĕ mājus. [L.] The opposite of a vice is almost a greater vice; e.g. asceticism is often as selfish as self-indulgence.

Divěs agris, dīes pŏsĭtīs in fēnŏre nummis. [L.] Rich in lands, rich in money laid out at interest (Horace)

Divide. (Math.) To mark with graduation line, as to divide the arc of a sextant. Dividers, compasses used in mechanical drawing.

Dīṽ̆dĕ et impěrā. [L.] Divide and rule; if you can bring about disunion and disintegration in a people, you can easily keep it in subjection.

Dividend. [L. dividendum, sum to be disided.] (Finance.) 1. Amount available to be paid to creditors or share or stock holders, by pro rata division. 2. The sum paid to each, the share determined by such division. 3. The percentage on the debt or capital so divided.

Divi divi. A Central-American plant, the pods of which are used in tanning and as a mordant.

Divine Comedy, La Divina Commédia. The immortal work of Dante, or Durante Alighiéri (1265-1321); divided into Inferno, Purgatorio, Paradiso; a vision of Torment, Expiation, Bliss; with powerful invective against existing corruptions in Church and State; entitled by Dante La Commédia, because ending cheerfully, Divina being an addition of after-times.

Divine Doctor, The. Title of Jean Ruysbroek ( I 294-1 38I), a celebrated mystic and schoolman.

Divine Legation of Moses. Bishop Warburton's work, in answer to the deistical works of Shaftesbury, Tindal, and others.

Divining-rod. A rod, usually hazel, forked at the top, used by those who pretend to find water or metals by occult means.

Division. (Mil.) Two or more brigades (q.v.) of an army.

Divot. [Scot.] (Feal and dust.) turf used for roofing cottages.

Dixie, Dixie's Land. An ideal paradise in the Southern states. In the popular mythology of New York City, Dixie was the negro's paradise on earth in times when slavery and the slavetrade were flourishing in that quarter. Dixie owned a tract of land on Manhattan Island, and also a large number of slaves; and his slaves increasing faster than his land, an emigration ensued, such as has taken place in Virginia and other states. Naturally, the negroes who left it for distant parts looked to it as a place of unalloyed happiness, and it was the "Old Virginny" of the negroes of that day. Hence Dixie became synonymous with an ideal locality, combining ineffable happiness and every imaginable requisite of earthly beatitude. - Bartlett's Americanisms.

Djerrah. A Turkish barber-surgeon.
Doa. (Naut.) A Persian trading-ship.

Doab. 1. Two rivers; the Skt. equivalent to the Gr. Mesopotamia, L. Interamna. 2. Applied particularly to the district between the Jumna and the Ganges.

Doccia. A pottery and porcelain manufactory near Florence, established 1735 ; where Capo di Monte and Della Robbia ware are largely imitated.

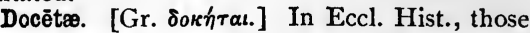
who maintained that Christ suffered in appearance only. (Cerdonians; Cerinthians.)

Dochmiac. [Gr. $\delta \delta$ ó $\mu$ os, athwart, name of a foot in prosody.] (Pros.) A measure of which the type is an iambus followed by a cretic; thris,

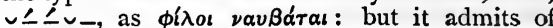
about thirty variations.

Docimastic art. [Gr. art of assaying metals.

Docket, Docquet. 1. A small piece of paper or parchment containing a summary or abridgment of a greater writing. 2. A register of cases in a court. 3. A label tied to goods, containing the name of owner or consignee or the name of place of delivery.

Dock herself, To. (Naut.) To settle in the mud.

Dock-warrant. Certificate of the possession of goods stored in a dock; they are negotiable, so that the rightful holder is owner of the goods specified.

Doctissĭmus Rōmānōrum. [L.] Most learned of the Romans; title of the grammarian Varro.

Doctor. [L., a teacher.] A word first used as a title of learned distinction in the twelfth century. With some further epithet it has been applied to many of the schoolmen and divines of the Middle Ages. Thus, Thomas Aquinas is the Angelic or Universal Doctor; William of Ockham, the Invincible; Alexander of Hales, the Irrefragable; St. Bernard is the Mellifuous; Roger Bacon, Mirabilis or Wonderful; Thomas Bradwardine, the Profound; Bonaventura, the $\mathrm{Se}$ raphic; and Duns Scotus, the Subtle Doctor. The four Greek doctors are-Athanasius, Basil, Gregory Nazianzen, and Chrysostom. The four Latin are-Jerome, Ambrose, Augustine of Hippo, and Gregory the Great.

Doctrinaire. [Fr.] Given to applying favourite doctrines in practice; one who applies abstract principles of a special study in practical matters, regardless of the logic of facts.

Doddrat. [Cf. dodipoll, stupid person.] 1. A sort of hockey-stick. 2. A stupid fellow.

Dodder. (Bot.) A plant parasitic on furze, heath, thyme, etc., with red thread-like stems, somewhat resembling catgut. Cuscŭta épŭthy̆mum, ord. Convolvulaceæ.

Dodecahedron. (Polyhedron.)

Dodecasyllabic. Consisting of twelve [Gr. $\delta \omega \delta \in \kappa \alpha]$ syllables $[\sigma v \lambda \lambda \alpha \beta a i]$.

Dodo. A recently extinct bird of the pigeon kind, weighing forty or fifty pounds. Plumage grey and brown, wings aborted. Mauritius. Dỉdus Ineptus, fam. and gen. Dỉdǐdx, ord. Cŏlumbx.

Doe, John. The fictitious plaintiff in an eject- 
ment, abolished, with equally fictitious defendant Richard Koe, in 1852 , by the Common Law Procedure Act.

Doeskin. A close, twilled cloth.

Doff. [From do, in old sense "put," and off.] To put off, either of a dress or a suitor or claimant. (Don.)

Dog. The carrier of a lathe.

Doge. [L. dux, ducis, a leader.] The supreme magistrate of the Venetian republic. The office had its origin towards the end of the seventh century. The same title was also given to the chief magistrates of Genoa. (Bucentaur.)

Dogfish. (Ichth.) Small sharks. Several British spec. Eighteen to thirty-six inches long ; horny eggs ; familiar as Mermaids' purses, Seapurses. Scyllium and Pristiūrus, fam. Scyllı̌̆dæ, ord. Plăgǐostŏmăta, sub-class Chondroptěry̆gĭi.

Dogger. [D., codfish.] Dutch fishing-smack about I 50 tons, generally two-masted, used in the Dogger Bank fishery.

Doggy. A colliery superintendent, under a butty.

Dog-star. The star $\alpha$ Canis majoris, or Sirius ; the brightest of the fixed stars; it is due south at midnight at Greenwich about the Ist of January, and at an altitude of about $22^{\circ}$.

Dog-tooth moulding. (Arih.) An ornament in the form of four leaves arranged pyramidally and placed in a hollow moulding. Frequently seen in late Romanesque and Early English or lancet-work.

Dog-vane. (Vane.)

Dog-watch. (Watch.)

Dogwood. A small kind of underwood, used for butchers' skewers, etc.

Doit. [D. duit.] A small Dutch coin.

Dolabriform. (Bot.) Of the shape of a hatchet [L. dŏlābra]; e.g. leaves of some mesembryanthemums.

Dolce far niente. [It.] A phrase denoting the pleasure of doing nothing, with reference generally to previous strain of work.

Doldrums. 1. Sailor's name for the region of calms near the equator. 2. Ennui, listlessness.

Dole. [A.S. doel, division, Ger. theil, Goth. dailis.] 1. A distribution, or dealing out. 2 A portion given. 3. A boundary mark.

Dolerite. [Gr. $\delta 0 \lambda \epsilon \rho \delta s$, deceitful.] An igneous rock (lava, etc.) composed of felspar and augite.

Dŏli căpax. [L.] (Leg.) Capable of crime.

Dolichocephălic. (Brachycephalic.)

Dōlium. [L., a very large jar.] (Zool.) Gen. of whelk, Apple tun-shell, barrel-shaped and with short spire. Mediterranean and Pacific.

Dollar, i.q. Thaler. (Joachims-thaler.) A silver coin, having different values in different countries. In the U.S. its full weight is $4 \mathrm{I} 6$ grains, of which $371 \frac{1}{4}$ grains are pure silver. It is the unit of money value in the U.S., and is worth about $4 s .2 d$. The Spanish duro, or hard dollar, has about the same value. The Prussian thaler is worth about $2 s$. II $d$. ; the rix-dollar of Bremen, about $3 s$. $4 d$., etc.

Dolmen. [Turk. dôlâmân.] A long gown worn by Turks.

Dolmen. (Cromlech.)
Dolomite. (M. Dolomieu.) (Geol.) A crystalline variety of magnesian limestone.

Dolphin. (Naut.) A buoy, or a post on a quay or beach, to make fast to. $D$. of the mast, a strap of plaited cordage fastened round the lower yards. D.-striker, a short gaff spar under the bowsprit-end, suspended perpendicularly for guying down the jibboom.

Dolus an virtus, quis in hoste requirat? [L.] Whether craft or valour, who asks in the case of a foe? (Virgil).

Dŏlus mălus. [L., evil craft.] (Leg.) Fraud; opposed to dolus bonus, honest stratagem.

-dom. [From A.S. dôm, judgment, state; $c f$.

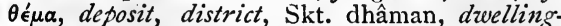
place, law, condition, from root dhâ, to place, lay, do.] Termination of words, meaning state condition; answering to -thum in German.

Dom. [L. dominus, master.] 1. In the Middle Ages, a title of the pope, and afterwards of dignitaries of the Latin Church and of certain monastic orders. 2. The German word for cathedral [L. domus].

Domdaniel's cave. A cave sometimes supposed to be near Babylon; the imaginary abode of evil spirits, genii, and enchanters.

Dome-book. (-dom.) A book of local customs as to judicial proceedings, Līber Füdíciālis; composed under King Alfred; lost since Edward IV.

Domesday-book. This book, called Liber Fudiciārius or Censuālis Anglia, and drawn up by order of William the Conqueror, contains a general survey of English lands, describing the amounts under the several forms of culture, and giving, in many cases, the number of the inhabitants, free or bond.

Domett. A mixed woollen and cotton cloth.

Domicile. The place which the law regards as that of a man's abode [L. domicilium].

Domiciliary. [L. dŏmícilium, private residence, regular abode.] A $D$. visit, a visit of officers by authority to search a private dwelling.

Dominant. [L. dŏminans, -tis, governing.] (Music.) 1. The fifth above the key-note. 2. In Greg. Music, the prevailing note in the recitation.

Dominant tenement. ( $L e g$.$) In relation to$ servitudes, the tenement in favour of which the service is constituted.

Dominica. (Dimanche.)

Dominica in Albis. (Albis, Dominica in; Quasimodo.)

Dominical letter [L. Dominica, sc. dies, the Lord's day], or Sunday letter. The days of the year are marked in the calendar by the letters $A, B, C, D, E, F, G$, repeated in order, the Ist of January being marked A. The letter written against the first Sunday in any year is the Dominical letter of that year. The 29th of February has no letter.

Dominicans. Friars of the order of St. Dominic, instituted in the thirteenth century. (Orders, Mendicant.)

Dominie Sampson. The awkward but devoted tutor, who has failed to pass his ordeal as a preacher ; a well-known character in Scott's Guy Mannering. 
Dominion of Canada, $=$ all British N. America except Newfoundland. In February, I867, upon the combined principles of federation and local self-government, Ontario and Quebec, i.e. Upper and Lower C., with New Brunswick, were formed into one dominion, under a governor-general, Senate, and House of Commons. Afterwards were added Manitoba, British Columbia, Prince Edward's Island.

Domino. [It.] 1. A long cloak with a hood, worn at masquerades. 2. A kind of mask.

Dominus. [L.] (Univ.) Title attached to the degree of bachelor.

-don. [Celt. dun, a hill fort.] 1. Part of names, as in Lon-don, Dun-mow. 2. Name or part name of rivers, as the Don and the Bandon.

Don. [Sp., from L. dŏmĭnus, lord, master.] 1. The Spanish form of Dom, sir, mister. 2 . (Univ.) A fellow of a college or a professor in the university. 3. To $D$. [from $d o$, in old sense of "put," and on], to put on, assume. (Doff.)

Donation of Charlemagne. (Hist.) A gift made to the pope, A.D. 774, by Charles the Great, of the powers which he had by conquest over the Lombard kingdom and the exarchate of Ravenna. It confirmed the Donation of Pepin; but the extent and conditions of the gift are not known.-Milman, Hist. of Latin Christianity, bk. iv. ch. 12.

Donation of Pepin. (Hist.) The presentation, by the Frank king Pepin to the pope, in A.D. 755 , of the keys of the chief towns in the exarchate of Ravenna, which he had wrested from the Lombards.

Donations of Constantine. A clumsy and audacious forgery, circ. A.D. 760 , granting from C. to the pope and his successors "palatium nostrum, et urbem Romam, et totius Italiæe et occidentalium regionum provincias, loca, civitates," etc.; when the seat of empire was transferred to Constantinople. (See Milman, Hist. of Latin Christianity, bk. i. 72.)

Donatists. (Eccl. Hist.) A religious faction, raised in Africa early in the fourth century by the Numidian bishops opposed to Cecilianus, Bishop of Carthage. Two persons named Donatus are mentioned as leaders of this party. The name Circumcelliones was given to the bands of country. people who took up arms in their cause.

Donative. [L. dōnātīvum, a largess.] 1. Largess given by a Roman emperor to his soldiers. 2. A kind of advowson; when the king, or a subject by his licence, founds a church or chapel, which shall be in the gift or disposal of the patron, and vested absolutely in the clerk by mere donation, without presentation, institution, or induction.

Dōnātory. [From L. dōnātor, $a$ donor, or for donatary, L.L. dōnātārius, from p. part. of dōnāre, to give.] (Scot.Law.) A donee of the Crown and recipient of escheated property.

Dŏnax. (Arundo.)

Donee. [Fr. donné, L. dōnātus.] The object of a gift or donation.

Donga. A ravine with steep sides (S. Africa)

Donkey-engine. A small steam-engine used as subsidiary to a large engine, pumping water into its boilers, etc.

Donkey frigate. One carrying twenty-eight guns, and having an upper deck.

Donna. [It., L. domina.] Title of ladies.

Dono dedít. [L.] He gave as a gift.

Don Quixote. (Quixotism.)

Donzel. [It. donzello, O.Fr. donzel, from L. dŏmǐnǐcellus, dim. of dŏminus.] A young squire or knight's attendant.

Doolah. A passage-boat of Canton river.

Dooley, Dhoolie. Covered Indian litter, carried by a pole on men's shoulders, for the sick and wounded.

Dop. The copper cup which holds diamonds while being polished.

Dorax. A renegade Portuguese in Dryden's play Don Sebastian.

Dorcas. (Dragon.)

Dorcas Societies make or collect and distribute clothing to the poor (Acts ix. 39).

Dorey. A flat-floored, W.-Indian boat of burden.

Dorian mode. (Greek modes.)

Dormant. [Fr.] (Her.) Lying down with the head resting on the fore paws, as if asleep.

Dormer window. (Arch.) A window placed in a gable projecting from a sloping roof.

Dornock. A stout figured linen (made at Dornock, in Scotland).

Dorsal. [L. dorsum, back.] Of or belonging to the back, as dorsal fin in fishes.

D'Orsay, Count. A celebrated French beau and politician, friend of Napoleon III.

Dorsibranchiate [L. dorsum, the back, Gr.

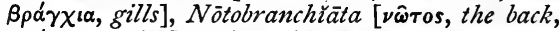

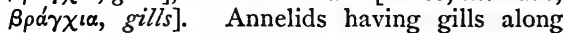
their backs, as the sea-mouse (Aphrŏditēe).

Dort, synod of. An assembly of Protestant divines, who, at D., near Rotterdam (A.D. 161819), decided in favour of absolute decrees, and excommunicated the Arminians.

Dorture. [From L. dormio, I sleep.] A dormitory of a convent.

Dos à dos. [Fr.] Back to back.

Dosithěans. (Eccl. Hist.) The followers of Dosithěus, who, in the first century, seems to have given himself out as the Messiah.

Dossal, Dorsal. [L. dorsuālis, on the back.] That which hangs on the back of anything. The cloth or hanging behind an altar. (Reredos.)

Dot. [Fr.] Dowry, tocher, heiress's property.

Dotation. [From L. dōtāre, to endow, give $a$ marriage portion (dōs, dōtis) to.] 1. Act of bestowing a dowry. 2. Endowment.

Dotheboys' Hall. The "Yorkshire school" kept by Squeers, in Dickens's Nicholas Nickleby, where boys were beaten, made drudges of, and starved.

Dotted Bible. A folio edition of the Bible, published in London, 1578.

Douane. [Fr.] Custom-house.

Douanier. French custom-house officer.

Douay Bible. (Bible, English.)

Double a ship, To. (Naut.) To line or case her with planking not less than two inches thick. 
Double-banked. (Naut.) A boat where two men sit on one thwart, either each to an oar or both to one. Double-bankers, sixty-gun frigates, with guns along the gangway.

Double Cabinet. (King's Men.)

Double conscionsness. A morbid condition, in which the patient imagines himself, at times, more than one person ; or, without knowing it, has two independent sets of observation and recollection; thought to be connected with unconscious cerebration (q.v.), but not yet explained.

Double entendre. [Fr.] Double meaning; a speech capable of a questionable construction as well as an innocent one.

Double entry. A system of book-keeping, in which the cost price of each article or item sold is entered by the selling price, or whereby the debit and credit of each transaction is exhibited.

\section{Double quarrel. (Duplex querela.)}

Double star. Two stars which appear as one to the naked eye, and are seen as two only when looked at through a telescope of some power. The brightest star of the Twins ( $\alpha$ Geminorum) is a double star. There are many others.

Doublet. [O.Fr. doublet, dim. of double, double, pair, from L. dūplus.] 1. A throw of two identical numbers with dice. 2. Doublets, a game in which a list of words is formed, containing the same number of letters, each of which only differs in one letter from the next, the first and last being given : thus, turn cat into dog-cat, can, tan, ton, don, dog. 3. A pair of words arising out of the same root, but differing somewhat in form and meaning; so from $L$. abbreviäre (through the Fr.), abbreviate and abridge; Fr. Noël and natal; endroit and indirect. (Variants.) 4. A waistcoat. 5. A counterfeit gem, formed of two pieces of crystal with a colour between them. 6. A word or phrase accidentally repeated in printing.

Doubling. The lining of the mantle borne about an escutcheon.

Doubloon. A Spanish coin, worth about $£ 35$ s. Spelt also Doblon. The modern doblon is, however, worth five hard dollars, or about $20 s$. 1od.

Doubly oblique prismatic system. In Crystallog., consists of those crystals whose axes contain unequal angles, and whose parameters are unequal ; when transparent, they are optically biaxial, as blue vitriol.

Douce pere. [Fr.] One of the twelve peers [douze, pairs] of French romance.

Douceur. [Fr., sweetness.] $A$ present, especially one intended to mollify or corrupt.

Douche. [Fr.] $A$ jet of water used in bathing.

Douey. (Naut.) A one-masted, flat-bottomed vessel, of the Coromandel coast.

Dough-boys. (Naut.) Hard dumplings boiled in sea-water.

Dough-faces. A contemptuous nickname applied to the Northern abettors of negro slavery. The term generally means a pliable politician, one who is accessible to personal influences and considerations.-Bartlett's Americanisms.

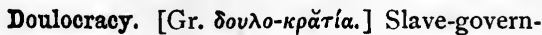
ment, government by slaves.

Dove's dung. Chiryônim, 2 Kings vi. 25 ; some kind of pulse, called in Arabic dove's dung or sparrow's dung ; or perhaps the root of Orinthŏgălum umbellatum ; or (?) some kind of fuel ; or (?) to be understood literally.

Dovetail. When two boards are to be joined neatly and securely with their faces at right angles to each other, wedge-shaped projections are cut on the one piece which exactly fit notches cut in the other. The joint thus formed is called a dovetail, from the shape of the notches and projections.

Dowel (corr. of Dovetail). [Fr. douille, socket.] A small wedge or piece of wood driven into the joints of brickwork, to which other pieces of wood may be fastened by nails; a vertical iron rod fixed into a wall and also into a body which is to be attached securely thereto, as a cross on the wall of a church. (Coak.)

Dowlas. [(?) O.H.G. dwahilja, towel (q.v.).] Coarse linen cloth.

Down-haul tackles. Those used to prevent lower yards from swaying while being struck.

Downs, The. A road for ships, six miles long, off Kent, between N. and S. Forelands.

Down with the helm. (Naut.) Put the tiller to leeward.

Dow-purse. A sum of money presented by the bridegroom to the bride, in some parts, on the wedding night.

Doyen. [Fr., L. děcānus.] Meaning a dean, is often colloquially $=$ the senior member of an associated body.

Dozen; Baker's D.; Devil's D. ; Long D. [Fr. douzaine, L. duodecim.] Twelve. A Baker's $D$., a Devil's $D$., or a Long $D .,=$ thirteen.

Drab. [O.E. drabbe, dregs.] A wooden box for holding salt when taken out of the boiling-pan.

Drabler. Extra canvas to deepen a Bonnet.

Drachma. (Dinar.)

Dracōnic. Exceedingly severe ; said of laws, regulations. Draco is said to have been author, or perhaps compiler, of the first written laws $\left[\theta \epsilon \sigma \mu o^{\prime}\right]$ of Athens, which made death the penalty of almost all crimes. But the word is unfair ; the legislation of D., as far as we know it, being a mitigation of existing law.

Draft. 1. (Leg.) A rough copy of a document. 2. (Com.) A. written order for the payment of money, i.q. a bill of exchange.

Dragoman. [L.L. dragomannus, drogamendus, from Ar. tardjumân (Targum), more rarely truchman and trudgman.] An interpreter in Turkey and the Levant.

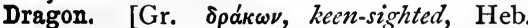
tan, Job xxx. 29, etc., tanan, to extend.] (Bibl.) 1. A beast of the desert, most probably the jackal. 2. [Tannîn, Ps. cxlviii. 7, has same root as, but is different word from, tan, as above.] (Bibl.) An aquatic animal. (Leviathan and Whale.) 3. With the Greeks, any creature with keen sight, the gazelle being called from the same verb Dorcas. 4. A noxious serpent, especially in Myth., those which cause drought. (Sphinx.) 
Dragonet, Skulpin. Name of two British spec. of fish, Gemmeous D. (Calliōny̆mus lyra)

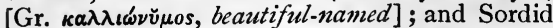
D. (C. Drăcunculus), nine to ten inches long, with large pectoral and ventral fins. Fam. Gobiidæ, ord. Acanthopterygii, sub-class Teleosteī.

Dragonnades. Persecutions of the French Protestants by Louis XIV. and Louis XV. ; so called because dragoons were employed in them against the people.

Dragon's-blood. A resin which exudes from the fruit of a palm (Călămus drăco), native of Malaya, used in varnish.

Dragon's teeth. (Cadmeian victory.)

Drag-ropes are attached to guns to assist in moving them on an emergency. D. issued to our cavalry are lassoes.

Drakkar. (Naut.) A pirate boat formerly used by the Normans.

Drämătis persōnæ. [L.] The actors in a play. (Person.)

Drapier's Letters. Those of Dean Swift, writing under this pseudonym in an Irish paper, to warn the Irish against giving gold and silver for Wood's halfpence, i.e. £iso,ooo worth of bad copper, which W. Wood was by patent empowered to coin.

Drastic medicines. Especially purgatives;

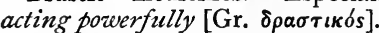

Draught. 1. (Mil.) Detachment of soldiers from the depôt reinforcing the main body. 2 . (Naut.) Of a vessel, her depth in the water.

Dranght-house. 2 Kings x. 27 ; cesspool. So draught, Matt. xv. I7 [Gr. à $\phi \in \delta \rho \hat{\omega} \nu a]$.

Dravidian. Name of a family of agglutinative non-Aryan languages, in Central India, such as Tamil and Telegu.

Draw, To (as a sail). To fill.

Drawback. A term used to signify the paying back of duties previously levied on goods upon their exportation.

Draw-bar; D.-hook; D.-spring. The hooks which carry the coupling connecting one railway carriage with another are Draw-hooks. The D.-bar is the prolongation of the hook by which it is fastened to the buffer spring, when only one spring is used for buffers and drawhook ; or to the $D$.-spring, when each buffer and draw-hook has its own spring.

Drawcansir. The braggart in Villiers's The Rehearsal.

Drawer. The person who creates a draft or bill of exchange.

\section{Drawing-room. (Levée.)}

Draw-plate, or Wire-drawer's plate. A steel plate furnished with a graduated series of conical holes, through which wire can be drawn successively till its thickness has been reduced to the required amount, without subjecting it to a force that would break it.

Dresden china. A delicate, semi-transparent, highly finished china.

Dreykönigstag. With the Germans, Twelfth Night ; Three Kings' Day, i.e. the three Magi of tradition-Gaspar, Melchior, and Balthasar.

Drift, Northern D. (Boulder-clay.)
Driftland, Drofland, Dryfland. (Leg.) Yearly rent paid by tenant for the right of driving cattle through a manor.

Driftsail. A sail allowed to drag in the water to check drifting.

Driftway. A passage between two shafts in a mine.

Drill. [Ger. drillich.] 1. A coarse linen or cotton cloth. 2. A borer. 3. An agricultural implement.

Dripstone. (Arch.) The Moulding placed over doors, windows, archways, etc., to carry off rain. It is also called weather-moulding, water-table, label, and Hood-moulding.

Driver. 1. (Mech.) A piece which communicates motion to another piece; e.g. when two toothed wheels work together, the one which communicates motion is the $D$. , and the one which receives the motion is the Follower. 2. (Sails.)

Driving notes. (Music.) In syncopated passages, the notes which send on the accent to that part of the bar which is not generally accented.

Driving-wheels of a locomotive engine. The wheels which are connected by means of a crank, etc., to the pistons, and communicate motion to the train.

\section{Drofland. (Driftland.)}

\section{Drogheda, Statute of. (Poyning's Law.)}

Drogher. (Naut.) A small vessel of the W. Indies, to take off sugar, rum, etc., to ships. Lumber- $D$. is a W.-Indian coaster.

Droit d'aubaine. (Fir. Law.) Right of the king to the property of an alien at his death.

Dromio. Name of twin brothers exactly like each other, in Shakespeare's Comedy of Errors.

Dromoes, Dromos, Dromonds. Vessels of large burden, ships of war.

Drop-scene. The painted sheet let down in front of the stage of a theatre, between scenes and acts of a play.

Drŏsĕra [Gr., dezvy], sundew. A gen of. curious little plants, Exogens, ord. Droseraceæ, natives of Britain, having leaves covered with viscid red glandular hairs, in which insects are caught, the plant being thus nourished. Mr. Darwin's researches upon the sundew are well known.

Drosky. [Russ. drozhki.] A low, open, fourwheeled carriage.

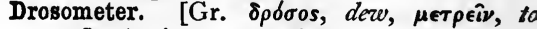
measure.] An instrument for measuring the fall of dew.

Drown the miller, To. (Naut.) To put too much water into wine, etc.

Druggers. (Naut.) Small French vessels of the Channel ports, which carried fish to the Levant, and brought back spices, etc.

Drugget. [Fr. droguet.] A coarse, thick woollen cloth, stamped on one side with figures.

\section{Druidical altars. (Cromlech.)}

Drum. 1. A cylinder revolving on its axis, on to which (or off from which) ropes are wound. 2. (Arch.) The upright part of a cupola, above or below a dome; generally the part below it. 3. A large social gathering at a private house; 
(?) from the phrase, "John Drum's entertainment" (Shakespeare).

Drum, Sacred. Among Laplanders, formerly, a kind of necessary household god in every family; a hollowed section of fir or beech, covered with skins on one side, hung with rings, beaten with a reindeer's horn; divination was by the movement of the rings.

Drum-Alban. Formerly name of the Grampian Mountains.

Drum-head court-martial (the D. serving as an impromptu writing-table). One held in the field, for treachery, plundering, killing the wounded, or other gross offence; the sentence is carried out on the spot.

Drum-major. The non-commissioned officer in charge of drummers and their instruction.

Drumming. In mercantile phrase, means the soliciting of customers. It is chiefly used in reference to country merchants, or those supposed to be such. - Bartlett's Americanisms.

Drummond light. A light produced by heating a piece of lime in the flame of a jet of oxygen and hydrogen (invented by Captain Drummond).

Druses. A people of the Lebanon, reaching as far as Baalbec, Regarded by the Maronites as atheists. Some, styling themselves Okkals, or Spiritualists, make great claims to purity.

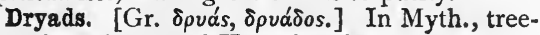
nymphs ; also called Hamadryads.

Dryasdust, The Rev. Dr. Representative of dry, dull learning, in some of Scott's prefatory letters before his novels.

Dry ducking. Suspending a person a short distance above the water. $D$. flosging, flogging with clothes on.

Dryfland. (Driftland.)

Dry goods. Cloths, stuffs, laces, etc., as distinguished from groceries.

Dry light. [L. siccum lümen.] The clear, bright light of the intellect, not heated by passion nor clouded by prejudice.

Dry pile. A voltaic pile, in which the liquid is replaced by leather or paper, and which is chiefly used for electroscopes.

Dry point. Etching with a sharp needle without the use of acid.

Drysalter. 1. A dealer in drugs and chemicals. 2. Originally a dealer in cured meats, pickles, etc.

\section{S. Q. (Naut.) (Abbreviations.)}

Dualism. The (I) concurrent or (2) antagonistic working of two principles in the same object-matter ; as (I) matter and spirit, or (2) the Manichæan idea of good and evil in outward nature. (Ahriman.)

Dub. To strike, as with the flat sword, in making a knight ; (?) the last affront he was to endure, like the blow of liberation from a Roman master in the manumission of a slave. [Dub and the Fr. adouber, with It., Sp., L.L., and other forms, probably from Ger. dubban, to strike (Littré).]

Du Barri. (Pompadour.)

Dubber. [Hind. dabbah.] A bottle of leather. Dubbing. [O.E. dubban, to strike.] A greasy dressing for leather.

Ducat. The Dutch and Austrian ducats are gold coins worth about $9 s .4 d$. ; the Neapolitan $\mathrm{D}$. is a silver coin worth about $3 s .4 d$. The first coined ducats were Sicilian, in the twelfth century, bearing the inscription, "Sit tibi, Christe, datus, quem Tu regis, iste Ducatus," i.e. Duchy.

Ducatoon. A half-ducat, worth about $5 s$.

Duces tecum. [L.] You shall bring with you; name of a subpœena requiring a person to bring into court as evidence any written instrument, etc.

Duck. [Ger. tuch, cloth.] A light canvas, used for sails, etc.

Duck at the yardarm, To. An old punishment in the French navy. A rope is passed through a block at the yardarm, to one end a cross-piece of wood is fastened, and the prisoner sits lashed on it; he is then hauled up to the yardarm, and dropped into the sea as often as ordered. $D$. $u p$, haul up a sail when it hinders seeing how to aim a gun, or to steer.

\section{Duck-billed plăty̆pus. (Ornithorhynchus.)}

Ducking-stool, or Cucking-stool, Coke-stool, Gogin-stool, Castigatory, Trebucket. A stool in which common scolds were tied and soused in water; from the fifteenth to the eighteenth century.

Ductor Dŭbǐtantium. A treatise on questions of casuistry, by Bishop Jeremy Taylor (1613-1667).

Ducts. [L. ductus, a leading.] (Bot.) Tubular vessels marked by transverse lines or dots.

Duddeen. [Ir.] A very short clay pipe.

Dudder. A hawker of cheap goods (duds).

Duds. (Naut.) Clothes or personal property.

Duenna. [Sp.] 1. The chief lady-in-waiting of the Queen of Spain. 2. An elderly chaperone or governess.

Duessa, or Fidessa. In the Faëry Queen, "clad in scarlet red," Falsehood ; signifying the faith of Rome, not without reference to Mary Queen of Scots, as representing Romish hostility to Elizabeth. D. is the double one, Truth being Una (q.v.).

Duff. [Eng., dough.] A stiff flour pudding.

Duffle. [D. duffel.] A coarse woollen cloth, with a thick nap.

Dugong. [Malay dúyóng.] Sea-cow, an aquatic herbivorous mammal, similar to, but three times as long as, the manatee. (Manatǐdæ.) Indian Ocean, including the Red Sea.

Dug-out. A canoe made of a hollowed tree.

Duke Humphrey, To dine with. To get no dinner at all ; said to refer to D. H.'s walk in Old St. Paul's, a promenade for the dinnerless. D. H., son of Henry IV., was reporied to have been starved to death.

Duke of York's School, or Royal Military Asylum, Chelsea, opened 1803 , for 700 boys and 300 girls, children of deceased soldiers. The girls' scliool has been discontinued.

Dukes. Gen. xxxvi. ; leaders of the people [L. dŭces]; so Solinus is D. of Ephesus, in Comedy of Errors; Theseus D. of Athens, in Midsummer Night's Dream.

Dulcarnon. Name for "The Asses' Bridge," the fifth proposition of the first book of Euclid.

Dulce est deš̄pĕre in löco. [L.] ' $T$ is sweet to play the fool in season (Horace). 
Dulce et děcōrum est prō patriā mŏri. [L.] It is sweet and honourable to die for one's country (Horace).

Dulcimer. [It. dolcimela, as if dolce, sweet,

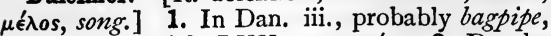
Heb. sumphoniah, LXX. $\sigma v \mu \phi \omega \nu i a .2$. D., the origin of the piano ; an ancient instrument, found in some form almost everywhere; is at first a flat piece of wood over which, on raised converging strips, strings are stretched, which are struck by hammers held in the hand.

Dulcinea. The rustic love of Don Quixote.

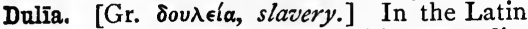
Church, three degrees of worship are distinguished: D., the reverence paid to angels and saints in general; Hyperdulia, the special veneration paid to the Virgin Mary; and Latria, the service of God only.

Dulocracy. (Doulocracy.)

Dumb-craft. (Naut.) 1. Lighters, lumps, etc., without sails. 2. The screws used in lifting a ship.

Dum běnĕ sē gessěrit. [L.] While he shall behave himself well, during good conduct.

Dumb-waiter. A set of circular shelves turning on a pivot, on which dishes and table necessaries are placed, and brought within reach by turning it.

Dum lợuimur fugit ætas. [L.] While we are speaking time is flying.

Dumose. [L. dümus, a thorn or bush.] (Bot.) Of compact, bushy shape.

Dumous. [L. dūmōsus.] Full of brushwood.

Dump. An old dance, somewhat slow ; named (?) from a trick of the players striking the lute with the fist at intervals.

Dumpage. 1. Fee paid for dumping rubbish from carts. 2. The right of dumping, i.e. unloading a cart by tilting.

Dumpy level. A short instrument fitted with a telescope, for taking levels.

Dum spiro, spēro. [L.] While I breathe I hope.

Dunce. A word said to be derived from Duns Scotus Erigena, the Subtle Doctor (Doctor) ; on the principle by which a bully is called Hector, and a blockhead Solomon, that is, from the rule of contraries.

Dunciad, The. Pope's satire on "dunces," i.e. on his critics ( $c f$. Byron's English Bards and Scotch Reviewers).

Dunder. The lees of sugar from which rum is made.

Dunderhead. (Naut.) 1. The devil. 2. A stupid fellow.

Dune. [Gael. dun, hill.] (Geol.) A hillock of drifted sand.

Dun-Edin. Name for Edinburgh in Scotch poetry.

Dunes. [Akin to A.S. dun, downs.] Low hills of blown sand, which skirt the shore in Holland, Spain, and other countries.

Dunging. Immersing calico in a bath of cowdung and hot water.

Dungiyah. (Naut.) An Arabian coaster, with great beam and a flat bottom, trading between the Red Sea, Persian Gulf, and Malabar.
Dun-head. (Naut.) The after-planking of E. -country barges, making the cabin.

Dunkers. (Urigin of name unknown.) A sect of Baptists, formed under peculiar rules in Pennsylvania, in 1724 .

Dunkirks. Dunkirk pirates

Dunmow flitch. A prize for any married couple who will swear that they have not quarrelled or repented of their marriage within a year and a day of its celebration; instituted at D., in Essex, 1244, by Robert Fitzwalter.

Dunnage. Anything packed amongst the cargo to keep it from shifting, or placed below a dry cargo to keep it from bilge-water. $D$. battens, a second floor, slightly above the other, to keep the cargo, etc., dry in case of a leakage.

Duodecimals ; Duodenary. In Duodenary arithmetic the base is 12, just as in ordinary decimal arithmetic the base is $10 ; e . g$. in the former, $257 \cdot 81$ stands for $2 \times 12^{2}+5 \times 12+7$ $+\frac{8}{12}+\frac{1}{12}$; just as in the latter it stands for $2 \times 10^{2}+5 \times 10+7+\frac{8}{10}+\frac{1}{10^{2}}$. Practically, a partial use of the system is made in Duodecimals, where the subdivisions of the foot are reckoned by twelfths: I foot $=12$ primes, 1 prime $=12$ seconds, etc.

Duodēnum. [L. duǒdēni, twelve each.] (Anat.) The first of the small intestines in immediate connexion with the stomach; about twelve inches in length.

Duos qui sĕquĭtur lěpŏres neutram capit. [L.] He who follows two hares catches neither.

Dŭplex quěrēla. [L.] A process, by which an appeal from an ordinary who refuses institution to a benefice is made to his next immediate superior; who may grant it if the grounds of refusal seem insufficient.

\section{Duplicate. (Original.)}

Duplicate of a ratio. If three magnitudes are in continued proportion, the ratio of the first to the third is the duplicate or double of the ratio of the first to the second. The duplicate of the ratio of two numbers is the ratio of their squares; thus, $16: 25$ is the duplicate of the ratio of $4: 5$

Duplication. [L. duplicātio, -nem, from duplico, I make double.] (Lang.) The process by which one word or form develops into two different meanings becoming attached to different pronunciations (or spellings), as custom and costume from O.Fr. coustume.

Duplication of the cube. The Delian problem, viz. to find by elementary geometry the edge of a cube whose volume is double that of a given cube. Under the conditions the problem is insoluble. It can be solved to any degree of nearness by extracting the cube root of 2 . It is a particular case of the problem of inserting two mean proportionals between two given magnitudes; i.e. given $a$ and $b$ find $x$ and $y$ such that $a: x:: x: y$ and $x: y:: y: b$.

Düra mater. [L.] The outermost, as Pia $M$. is the innermost, covering enveloping the general nervous mass of the brain. Matres, because once imagined to give rise to the other membranes of the body. 


\section{Dürämen. (Alburnum.)}

Durandal. The marvellous sword of Orlando or Roland in romance. (Excalibur.)

Durante bene placíto. [L.] (Leg.) During the sovereign's good pleasure.

Durbar. [Hind. darbâr, audience-hall.] A levée held by a chief or a representative of the British empire in India.

Durden, Dame. A notable housewife of an English popular song.

Duress. [O.Fr. duresse, from L. dūrĭtia, hardness.] 1. Restraint of liberty. 2. (Leg.) State of compulsion by wrongful imprisonment or threats of confinement, murder, mutilation, or mayhem, which makes a contract voidable.

Durmast. (Bot.) The sessile-cupped, or shortstalked oak, Quercus sessilliflora; this and the common O., pědunchllata, having stalks, being two spec., or varieties of the same spec. Common throughout Europe.

Dustooree. [Hind.] Custom, duty on goods.

Dutch auction. A sale in which goods are put up at a price higher than their value, lower prices being gradually named till some one buys.

Dutch caper. A light-armed D. privateer of the seventeenth century.

Dutch clinker. [Ger. klinker.] A hard brimstone-coloured brick, made in Holland. Dutch pink is chalk or whiting dyed yellow, used for paper-staining. Dutch rush, a rough kind of rush used for scouring and polishing. Dutch gold, leaf, foil, mineral, or metal, is an alloy of eleven parts of copper and two of zinc, rolled or beaten into thin sheets.

Dutch eel-skuyt. (Naut.) A flat-bottomed sea-boat with lee boards, cutter-rigged and roundlooking, with two water-tight bulkheads for keeping live fish.

Dutchify, To. (Naut.) To turn a square stern into a round one.

Dutch pump. The punishment of drowning, for one who did not pump hard. D. reckoning, a bad day's work, everything wrong.

Dutch school. A school of painting, characterized by accuracy of representation and coarse homeliness of subject. Its chief painter was Rembrandt.

Duty of a steam-engine. The number of footpounds of work done by a steam-engine in consequence of the consumption of an assigned quantity of coal, generally a bushel (eighty-four or ninety-four pounds) or a hundredweight.

Duumviri. [L.] A body of two persons who fill an office. $D$. sacrorum, the two keepers of the Sibylline books in ancient Rome.

Duvet. [Fr.] Down, wool, nap.

Dux fĕmina facti. [L.] $A$ woman the author of the achievement (Virgil, of Dido).

Dyad. [Gr. Suás, the number two.] A metal one atom of which replaces two of hydrogen in a compound.

Dyas. (Permian system.)

Dying Gladiator. A celebrated statue in the Capitoline Museum ; the figure of a Gaul, with Celtic torques or necklace. (See Byron, Childe Itarold, canto iv. 140.)
Dying man's dinner. (Naut.) Food hurriedly eaten when a vessel is in great danger.

Dyke. [A.S. dîc, D. dijk ; of. Gr. $\tau \in \hat{\imath} \chi \chi o s$, wall, Skt. dêhi, rampart, mound.] A mound or wall of earth, as the Devil's Dyke, near Newmarket. (Dike.)

Dykes. [An older form of ditch, from A.S. dician, to dig.] (Geol.) Solidified walls of molten material filling up, from below, fissures in stratified rocks; $\mathrm{D}$. meaning walls or fences, in Scotland.

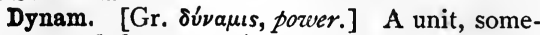
times used for measuring the rate at which an agent does work, viz. the work done when a kilogramme is moved against gravity through one mètre in a second of time. 76 dynams $=1$ horse-power.

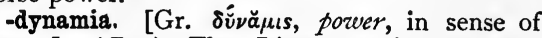
excess.] (Bot.) The Linnæan xiv. and xv. classes are Di-dynamia, having four stamens, two longer than the others. Tetra-dynamia, having six stamens, four being longer than the others. (-andria.)

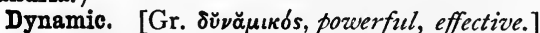
(Lang.) Intended to express change of meaning or the reduplication $(q . v$.$) of the root in forms$ which express completed action.

Dynamics. 1. The science which determines the motion of a body when the forces applied to it are not in equilibrium (Poisson). 2. The science which treats of the action of force, comprising two divisions: Statics when the forces maintain relative rest, and Kinetics when force produces acceleration of relative motion (Thompson and Tait). In the former sense $D$. is exactly equivalent to the subdivision Kinetics, when D. is used in the latter sense.

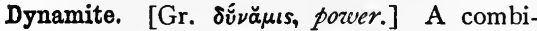
nation of three-fourths of nitro-glycerine with one-fourth of powdered silica ; of a pasty consistency; exploded by a percussion cap, which brings both percussion and fire to bear.

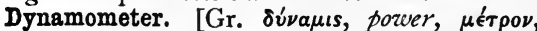
measure.] An instrument for measuring ( $\mathrm{I}$ ) force, as a spring-balance; (2) force and motion and therefore work, as the steam-indicator.

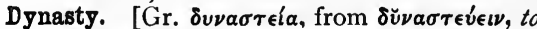

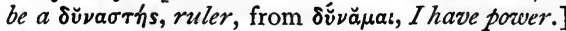
A succession of rulers of the same race or line, as the Athiopian D. in ancient Egypt, the Bourbon D. in France.

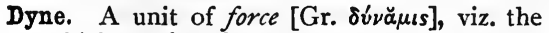
force which, acting for one second on a mass of one gramme, produces a velocity of one centimètre a second. It is called a $C . G$. S. unit.

Dynevor. The southern division of Wales in the Saxon period.

Dys-. [Gr. $\delta v \sigma-$.$] A prefix in some compound$ words, with a general notion of badness, harshness, unfavourableness; the opposite being $\epsilon \hat{\bar{v}}$, well.

Dyschromatopsy. [Gr. $\delta v \sigma-$, with difficulty, $\chi \rho \hat{\omega} \mu \alpha,-\tau o s$, colour, ö $\psi \mathrm{s}$, appearance.] Colourblindness.

Dysentery. [Gr. $\delta v \sigma \in \nu \tau \epsilon \rho / a$, from $\delta v \sigma$-, દ̌ $\nu \tau \in \rho \alpha$, bozvels.] A disease of the mucous membrane of the colon; with marked fever, great pain, bloody stools, etc. 
Dyspepsia. [Gr. $\delta v \sigma \pi \epsilon \psi(a$, from $\delta v \sigma-, \pi \epsilon ́ \sigma \sigma \omega, I$ cook, digest.] Impaired or difficult digestion.

Dysphōnia clerìcorum [Gr. $\delta v \sigma \phi \omega \nu i a$, rough ness of sound], Clergyman's sorethroat. A general name for those various affections of the throat to which public speakers and singers are liable. (Cynanche.)

Dyspnœa. [Gr. $\delta \dot{v} \sigma \pi \nu 0 เ \alpha$, from $\delta v \sigma-, \pi \nu \boldsymbol{c}^{\prime} \omega, I$ breathe.] Difficulty of breathing.

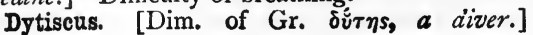

Water-beetle, Pentămĕrous (i.e. five-jointed) aquatic cŏlěoptěra.

Dyvnorint. An old name for the north of Devonshire.

Dyvour. (Scot. Law.) Bankrupt.

Dwarf incarnation. (Myth.) The Avatar of Vishnu as Hari, the new-born sun, who in two strides becomes a giant, and in three accomplishes his course.

Dwergar. (Pygmy.)
E. The fifth letter in the Greek and other allied alphabets; denotes, as a Latin number, 250. In Music, it marks a note of the scale corresponding to the $m i$ of the French and Italians.

-ea, -ey. [Cf. ay, a, oe; A.S.] Part of names, meaning island, as Chels-ea, Cherts-ey.

Eagle. 1. [Fr. aigle, L. ăquĭla.] A gold coin of the U.S., of the value of ten dollars; so called from its bearing on the reverse the figure of the American eagle. There are also double-eagles of twenty dollars, as well as half and quarter eagles. -Bartlett's Americanisms. 2. [Nesher, Micah i. I6, etc.] (Bibl.) Spec. of vulture, great griffon V. (Gyps fulvus), four feet long, plumage yellowish brown, with nearly black quill feathers and white frill.

Eagle, or Spread eagle. (Naut.) A man fastened to the shrouds by his extended arms and legs ; an old punishment.

Eagle-stone. (Nodule.)

Eagle-wood (eagle being the Malayan name agila). Agallochum aloexy̆lon, a very fragrant wood, yielding incense, burnt from very early times in India and in China.

Eagre, Eager, or Hygre.

Ealdorman. (Alderman.)

Eame. [A.S. eam, Ger. oheim.] Uncle.

Ean. (Yean.)

Eanling. (Yeanling.)

Ear, Earing. [L. ăro, Gr. à ós, I plough.] Gen. xlv., I Sam. viii., etc. ; ploughing, any manner of preparing ground for seed.

Earings. (Naut.) Small ropes by which the upper corners of sails are fastened to the yard.

Earl. [Norse jarl.] At first any person- of noble race, eorl ; all others being included in the class ceorl, or churl. (Celibacy ; Ealdorman.)

Earles-money, [Earles, from Fr. arrhes, L. arrha, security, from a Phœnician word.] Earnest money.

Earles-penny. The same as Earles-money. Earl-marshal. (Marshal.) The hereditary head of the Heralds' College.

Early English style. (Geometrical style.)

Ear-mark. The mark made on the ear of a horse, cow, pig, or sheep by its owner; and hence the token or signal by which a thing is known. So used also in the north of England. The laws of several of the states require the ear- mark of every proprietor to be recorded with the town clerk, as evidence for reclaiming strays, etc. - Bartlett's Americanisms.

Earnest. In commercial transactions, the paying down any part of the price of goods, if it be but a penny, on the delivery of any portion of the goods; which, according to Blackstone, is called in the civil law, arrha [L., earnest], and interpreted to be "emptionis, venditionis, contractæ argumentum," a proof of a real buying and selling.

Earsh. (Earing.) Grass that grows after ploughing.

Ears of a boat. (Naut.) The pieces of timber forward at the same height as and outside of the gunwale of a boat.

Earthshine, Earthlight. The faint light on the dark part of the disc of the moon in her first or fourth quarter, due to the sunlight scattered from the earth, which would render the earth visible to a spectator in the moon.

Easel. [Ger. esel, donkey.] An artist's frame for holding the canvas on which he is painting.

Easement. [Fr. aisement.] In Law, accord. ing to the old writers, "a service or convenience which one neighbour hath of another by charter or prescription without profit ; " having reference to rights of way, watercourses, ancient lights, etc. ; e.g. a right to divert or pen back a stream, or to pollute it, or the air, to a certain extent Similar are the Servituites of Roman, and the Servitudes of French and Scotch laws. (See an exhaustive account in Brown's Law Dictionary.)

Ease the helm. (Naut.) Put it a little down.

Eassel and Wessell. Lowland Scotch for east and west. (See Scott's Guy Mannering, ch. i.)

East Anglia. Name of Norfolk, Suffolk, and Cambridgeshire in early English history.

East Country. (Naut.) Countries bordering on the Baltic.

\section{Easter eggs. (Eufs de Pâque.)}

Easterling. (Sterling.)

Eastern Empire. The Greek or Byzantine empire, 395-1453.

Eastern States. The six states of New England, in America-Maine, New Hampshire, Vermont, Massachusetts, Rhode Island, and Connecticut.

East India Company. A chartered English company, originally founded in 1600 for trading 
with India. Since $\mathbf{1 7 4 8}$ it acquired great political power, and at the time of its political annihilation $\left(185^{8}\right)$ it governed as subject or tributary the vast empire of India, which then passed to the Crown.

Eastminster. Original name of the cathedral church of St. Paul's, London.

East Sea. Old name of the Baltic.

Eat the wind ont of a vessel, To. To steal to windward of an opponent by very smart seamanship.

Eau de Lnce. [Fr.] A compound solution of ammonia, mastic, and oil of amber, used as a remedy for snake-bites (invented by Luce).

Ebb; Ebb-tide. The reflux of the tide towards the sea.

Ebbsfleet. The channel between the Isle of Thanet and Kent in the Saxon period.

Ebenaceous. [From L. ěběnus, ebony.] Consisting of or like ebony.

Ebionites. (Eccl. Hist.) A sect of the first century, who, holding opinions resembling those afterwards maintained by the Arians, insisted on the observance of the Mosaic Law and rejected the authority of St. Paul.

Eblis. Arabic name of the prince of the rebel angels exiled to the infernal regions for refusing to worship Adam.

Ebonite. [Eng., ebony.] A hard, black, elastic compound of indiarubber and sulphur, also called vulcanite.

Ebony. 1. A punning name given to W. Blackwood, original publisher of Blackwood's Magazine, by James Hogg, the "Ettrick Shepherd." 2. Nickname for Blackzwood's Magazine.

Ebridæ Insulø. Name of the Hebrides under the Romans.

Ebullition. [L. ebullire, to boil ozer.] Boiling or effervescence.

Écarté. [Fr.] A game at cards, generally played by two, in many respects like whist, but if the hands dealt contain bad cards the players may throw out [écarter] cards and take others in their place from the pack till one is satisfied.

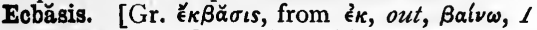
go.] (Rhet.) A figure by which a necessary consequence from a proposition concerning the matter in hand is exhibited; e.g. "Education lessens crime, therefore excess of crime shows defective education."

Ecbatic. (Ecbasis.) (Gram.) Relating to or indicating a result or consequence.

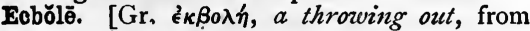
'́ $\kappa$, from, $\beta \dot{\alpha} \lambda \lambda \epsilon \iota \nu$, to throw.] (Rhet.) A digression in which a person is introduced speaking in his very words.

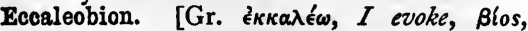
lite.] A hatching-machine.

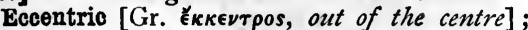
E. chuck; E. gear; E. strap; E. rod. 1. The apparent proper motion of the sun is nearly accounted for by supposing him to move uniformly in a circle whose centre does not coincide with that of the earth. Such an orbitwhose centre does not coincide with the centre of motion-was called an $E$. in the old astronomy. 2. (Mech.) A modified crank convert- ing the circular motion of the main shaft into an alternating rectilinear motion for working the slide-valves of a steam-engine. It consists of a circular disc or. sheave keyed on to the shaft, with whose axis the centre does not coincide; this disc is embraced by a hoop, the $E$. strap, furnished with an arm, the $E$. rod; the disc can slide within the hoop, and consequently, if the arm is properly guided, its end moves backwards and forwards when the shaft is turned. The $E$. gear is the whole of the E. apparatus. An $E$. chuck holds a piece in a lathe in such a manner that the tool cuts on it E. circles.

Eccentricity. 1. Of an eccentric circle, the distance from the centre of the orb to the centre of motion. 2. Of an ellipse, the distance from focus to centre, or ratio of that distance to semimajor axis.

\section{Eccentricity, Error of. (Centring, Error of.)}

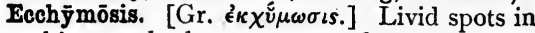
the skin, made by extravasated blood in or under the skin ; e.g. a black eye.

Ecclesiastical Polity, Laws of. Richard Hooker's great work, 1594, in defence of the Church against Puritans.

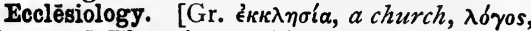
discourse.] The science which studies all matters relating to the fabrics of ecclesiastical buildingstheir furniture, decorations, etc.

Ecdy̆sis. [Gr. Ĕ $\kappa-\delta \check{v} \sigma ı s$, a stripping off.] Putting off the skin, as is done by snakes.

Échelle. [Fr., L. scāla.] Musical scale.

Echelon. [Fr., the step of a ladder, échelle, L. scāla.] (Mil.) Tactical movement by which a battalion moves either directly or obliquely to its front, by each company marching in a parallel direction to, but not following the one preceding it.

Echidna. [Gr., the throttler, properly of constrictors.] (Zool.) Australian hedgehog, Porcupine ant-eater. One of the two gen. of the ord. Mŏnŏtrēmăta (the other being the Ornithōrhyncus) containing two spec., E. hystrix and E. sētōsa. Australia.

Echinite. [Gr. ÉXî̀os, sea-urchin.] (Geol.) Any fossil echinoderm, related to ěchinus.

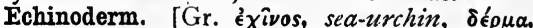
skin, shell.] (Zool.) A class of Annuloöda, having an integument firm, coriaceous, or crustaceous, and very generally spinous, like the sea-urchin.

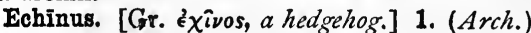
A kind of moulding under the capital of an Ionic column, of which the chief feature is a row of egg-shaped ornaments in relief. 2. (Zool.) Seaurchin, sea-hedgehog. Gen. of class Echinŏdermătă, having its rays connected, and their tips turned in, so as to form a hemispheroidal envelope of its leathery integument, which becomes a shell with upper and under orifices.

Eckhardt, The faithful. An old man of German legend, who drives folk indoors on Maunday Thursday, to save them from the terrors of a procession of the dead. Tieck made E. a faithful servant who perished to save his master's children from the temptations of fiends.

Éclaircissement. [Fr.] A clearing up, a discovery. 
Éclat. [Fr.] Brilliant effect.

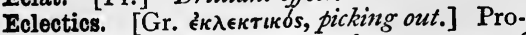
perly, any who borrow from other systems of thought to complete their own. In this sense Plato and Aristotle, and perhaps all thinkers, are eclectics. But the name was specially applied in the second century to the New Platonists of Alexandria. (Neoplatonism.)

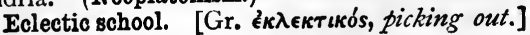
(Bolognese school.)

Eclipse [Gr. డ̌ $\kappa \lambda \in \iota \psi \iota s$, a forsaking, an eclipse] ; Annular E.; Iunar E.; Partial E.; Solar E.; Total E. A Solar $E$. is the obscuration of the sun caused by the moon passing between the sun and the spectator, and is partial or total according as the sun is partially or totally obscured at the place where the c.sscuration is greatest. If at any place the whole disc of the moon is seen against the sun, so as to appear surrounded by a ring of light, the E. is annular. A Lunar $E$. is the partial or total obscuration of the moon caused by her partial or total immersion in the earth's shadow.

Ecliptic. The circle on the great sphere along which the sun appears to move round the sphere in the course of a year ; its position is marked out in the heavens by the signs of the Zodiac. The earth's actual motion in her orbit-to which the sun's (apparent) proper motion is due-takes place in the plane of the $\mathrm{E}$.

Ecliptic limit. The angular distance from a node, or the point of intersection of her orbit with the sun's orbit, within which the moon must be at conjunction with the sun for an eclipse to be possible. As these orbits are inclined, it follows that when the new moon is more than a certain distance $\left(17^{\circ}\right)$ from a node, she passes above or below the sun, and there is no solar eclipse visible anywhere on the earth ; and when the full moon is more than a certain distance (II ${ }^{\mathcal{C}}$ ) from a node, she does not dip into the earth's shadow, and there is no lunar eclipse.

Eclŏgē, Eclŏgă. A choice collection [Gr.

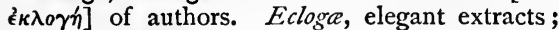
and by the grammarians the Bucolics of Virgil are also called Ecloge, Eclogues, or Bucolicón E., collections of Bucolics.

École Polytechnique. (Polytechnic School.)

Economic botany. [Gr. oikovoría, managcment of a household.] B. as concerned with all arts which supply human needs or comforts.

Economy. (Reserve.)

Eoonomy, The. (Arcani Disciplina.)

E converso. [L.] (Log.) Conversely; said of a proposition formed from another proposition with transposition of the subject and predicate, as "Queen Victoria is the Queen of England."

Écorché. [Fr., flayed.] A representation of an animal flayed so as to show the muscles, etc. Écossais. [Fr.] Scotch.

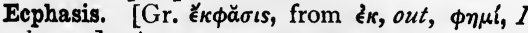
speak, say.] An open statement.

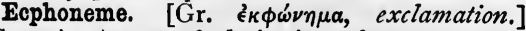
(Gram.) A note of admiration, thus-!

Ectăsis. [Gr., a stretching out, from é $\kappa$, out, $\tau \in i \nu \omega, I$ stretch.] (Pros.) Lengthening of a short syllable; which was generally, however, the going back for once to the original length of a vowel which had become short in course of time.

Ecthĕsis. [Gr. Е̌k $\theta \epsilon \sigma \iota s$, an exposition.] (Hist.) A decree of the Emperor Heraclius, A.1. 639 , drawn up to put an end to the Monothelite controversy. Withdrawn by the Emperor Constans, who in 648 issued his Type, by which he imposed silence on both sides.

Ecthlipsis. [Gr. ék $\theta \lambda \hat{i} \psi(s, a$ squeezing out, from 'e $\kappa$, out, and $\theta \lambda i \beta \epsilon \iota \nu$, to press.] (Pros.) The elision in Latin of a syllable consisting of a vowel followed by $m$, as, " $\bar{O}$ èt præsídi(um) ct dulce decus meum " (Horace, Od. i. 2).

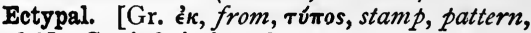
model.] Copied, imitated.

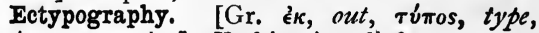
$\gamma \rho a ́ \phi \epsilon \iota \nu$, to write.] Etching in relief.

Ecurie. [Fr.] A stable.

Eczèma. [Gr. ё $\kappa \zeta \epsilon \mu \alpha$, from $\epsilon^{\prime} \kappa \zeta \zeta^{\prime} \omega, I$ boil out or over.] An eruption of small aggregated vesicles on various parts of the skin.

Edda. This Norse word, signifying Grandmother, denotes the collection of the most ancient Scandinavian poetry. Of the two Eddas the Older, ascribed to Sæmund Sigfusson, is supposed to have been reduced to writing about the end of the eleventh century. The New Edda, bearing the name of Snorri Stirluson, about two centuries later, is an aloridgment of the Older Edda, the parts being also rearranged. - Thorpe.

Eddish, Earsh. [A.S. edisc, from ed, again; cf. L. at, yet, Gr. 'ย $\tau$, yet, still.] Grass which grows again after mowing or reaping, aftermath.

Edelweiss of the Alps. Leontopodium alpinum, ord. Compositæ.

Edēma. [Gr. oł $\eta \mu \alpha$.$] A swelling; adj.,$ Edematous.

Edentāta. [L. e-dentātus, having the teeth knocked out.] (Zool.) An ord. of mammals, some entirely toothless, as the great ant-eater (Myrmēcŏphăga jŭbāta); all destitute of incisors, as the sloth (Brădy̆pus).

Edessa. A principality on the Euphrates, north and north-east of Aleppo, in the time of the Crusades.

Edible nests. (Cubilose.)

Edict. [L. edictum, that which is spoken out.] In Rom. Hist., the ordinances of the Prætors, who on taking office laid down their rules for regulating the practice of their courts.

Edict of Milan. A proclamation issued by Constantine, A.D. 313 , securing the civil and religious rights of Christians.

Edict of Nantes. A proclamation issued by Henry IV. of France, I 578, securing to Protestants the free exercise of their religion. Revoked by Louis XIV., 1685 .

Edition do luxe. [Fr.] A very beautifully got up edition of a work.

Editio princeps. [L.] The original printed edition of ancient works, often of great value to critical scholars, as being records of readings of manuscripts since lost.

Édredon [Fr.], i.q. eider-down; formerly ederilon, from Ger. eider-dune.

Edrisites. A dynasty ruling in $\mathrm{Fez}$ in the ninth century. 
Educt. [L. ēductum, p. part. of e-dūco, $I$ bring out.] That which is educed or brought to light.

Edulcŏration. [L. e, out of, dulcŏrāre, to sweeten.] The act of cleansing by repeated affusion of water.

Edward VI.'s first Prayer-book. (Common Prayer, Book of.)

Edward VI.'s second Prayer-book. (Common Prayer, Book of.)

Eerie. [Scot.] Wild, weird.

E, Ex. L. prefix, = from, out of, and with intens. force; added to official titles, it denotes one who used to hold the office indicated, as ex-premier.

Effectivo. [L. effectivus, from effrciǒ, $I$ effect.] (Com.) Specie or hard cash, opposed to bills or paper money.

Effective force. (Dyn.) The force that must be applied to a detached particle to make it move in precisely the same manner as that in which it actually moves when forming part of a moving system.

Effendi. A Turkish corr. of the Greek word

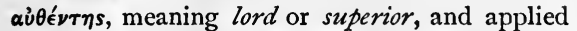
to civil functionaries as opposed to military, who are called Agas.

\section{- Efferent. (Afferent.)}

Efflörescence. [L. efflöresco, I blossom forth.] (Min.) The appearance of a whitish saline crust on material changed by the atmosphere from a crystalline to a powdery state; e.g. alum in caves, sulphate of iron on pyrites, etc.

Effŏdiuntur ŏpēs irrītāmenta mălörum. [L.] Riches the incentives to evils are dug out of the ground.

Égalité. [Fr., equality.] Name taken (1792) by Louis Philippe Joseph, Duke of Orleans.

Egestă. [Things carried off or out (L. ëgestus).] Excretions; matters thrown from or out of the bodies of animals.

Egger. (Eggs.) (Entom.) Lasiocampa, gen. of moth, spec. L. quercǐfólia, pōpŭlǐfŏlia, etc., according to the trees, etc., which it affects. Sub-fam. Bombȳcĭdæ, ord. Lěpüdoptěra.

Eggs, Easter. (Eufs de Pâque.)

Eggs, Mundane. (Eufs de Pâque.)

Eggshell china. China turned down in a lathe till little but the glaze is left.

Ego. (Subjective and objective.)

Egoïsm. [Coined from L. ěgo, I, Fr. égoisme.] 1. (Metaph.) Subjective ideality; the tenet which limits knowledge to personal experience and existence to its phenomena. 2. Selflove, habitual reference to self.

Egress. [L. ēgressus, a going out.] (Astron.) The end of a transit of Venus or Mercury when it is seen to pass off from the sun's disc.

Egret. [Fr. aigrette, id., O.H.G. heigro, L.L. aigronem, O.Fr. hairon, Fr. héron.] The white heron; found in both hemispheres. Two spec., the Great E. (Ardea alba) and the Little E. (A. garzetta), occasionally found in Britain. Fam. Arděĭdæ, ord. Grallæ.

Egrette. (Aigrette.)

Egyptology. The scientific study of Egyptian antiquities and language.

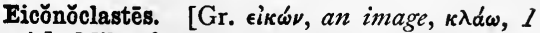
break.] Milton's answer to Eikōn Băsillikē (q.v.).

Eider-down. The down of the eider-duck [Sw. ejder].

Eidograph. [Gr. єi்os, form, $\gamma \rho a ́ \phi \epsilon \iota \nu$, to write.] An instrument for copying drawings.

Eidōlŏn. [Gr., an image.] 1. A form, phantom. 2. (Scient.) A baseless theory.

Eigné. (Bastard eigné.)

Eikōn Băsŭlǐkē. [Gr., image of the king.] (Hist.) A Portraiture of His Sacred Majesty in His Solitude and Sufferings, ascribed to Charles I., but probably written by Gauden, Bishop of Exeter. The recent discovery in the Record Office of a prayer in Charles I.'s writing, identical with one in E. B., has reopened the question. The Daily News, April 24, 1880, argues in favour of the authorship of W. Dugard, High Master of St. Paul's, but more recent criticism tends to confirm the authorship of Gauden.

Eire. (Eyre.)

Eirēnǐkon. [Gr., peaceful.] A name for works designed to reconcile opposite schools in politics or theology, by showing that the points on which they agree are more in number than those on which they differ, or that their differences are not fundamental.

Eisteddfod. [Welsh eistedd, to sit.] 1. An assembly or session of Welsh bards, with competition in native poetry and music; the judges commissioned by Welsh princes, and, after the conquest, by English kings. The last commission was issued in 1568. 2. By a late revival, meetings held in Wales for recitation of prize poems, performances on the harp, etc.

Ejectment. [From L. èjĭcio, $I$ eject.] A mixed action to recover possession of real estate and damages and costs for wrongful withholding, the best method of trying a title to landed estate. The action lies against a tenant, the plaintiff being either a claimant to the estate or his legal representative (as trustee or guardian), or the landlord for forfeiture by nonpayment of rent.

Eke; also A.S. éc, écan, akin to L. aug-ere, to increase, prolong.

Élan. [Fr.] Vehemerit impulse, such as is supposed to characterize French soldiers when entering into action, as contrasted with the quieter but more steady endurance of the English.

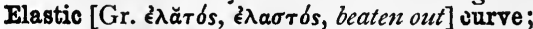
E. fluid; E. limits. The $E$. curve is the figure assumed by the longitudinal axis of a slender flat spring of uniform section under the action of two equal and opposite forces. Air and other gases are called $E$. fluids, because when a portion of gas is enclosed it expands or contracts freely when the containing space is enlarged or diminished. The E. limits of a given substance are the extreme amount of the strain (elongation, compression, etc.) that the substance can undergo without permanently altering its form.

Elasticity; Modulus of E.; Perfect E.; etc. The tendency of a strained (elongated, compressed, distorted) body to return to its original volume and form when the straining forces cease 
to act. The E. is perfect when the body, having been brought into a certain state of strain by the action of certain forces, requires the continued action of those forces to keep it in that state of strain. The Modulus of $E$. of any substance is a column of the same substance capable of producing a pressure on its base, which is to the weight causing a certain degree of compression as the length of the substance is to the diminution of its length. The modulus of $\mathrm{E}$. is frequently given in pounds per square inch of the cross-section of the compressed prism.

Elder Brethren. Name of the Masters of the Trinity House.

Eldest Son of the Church. A title of the Kings of France.

El-Doraido. [Sp., the golden region.] The name given by the Spaniards in the sixteenth century to a country supposed to lie between the Orinoco and Amazon rivers in S. America. It is now applied to any fabulous lands of boundless wealth.

Eldritch. [Scot.] Ghastly, weird, fiendish.

Eleanor crosses. Memorial crosses erected on the spots where the bier of Eleanor, wife of Edward I., rested on its way to Westminster, the last of these halting-places being at Charing Cross.

Eleatic philosophy. (Hist.) The philosophic system of Xenophănes, in the sixth century B.C. It was confined to what he regarded as the only objects of real knowledge, namely, the ideas of God, or of being as it is in itself and as contrasted with the world of changing phenomena.

Elecampane. (Bot.) Large-leaved yellow-

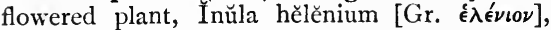
ord. Compositæ. Native of damp meadows in Mid. and S. Europe; rare in Eritain. Its root once much used in medicine.

\section{Election. (Theol.) (Arminians.)}

Electors [L. electōres, choosers], under the Empire, were princes having a voice in the election of the Emperor. The Elector of HesseCassel is the only one who still retains the title, the rest having become kings, grand-dukes, etc. (Emperor ; Empire.)

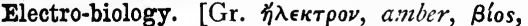

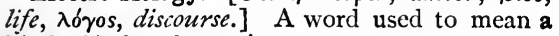
kind of induced reverie.

\section{Electro-chronograph. (Chronograph.)}

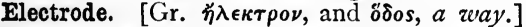
The surface through which the electric current enters the substance to be decomposed, in electrolysis.

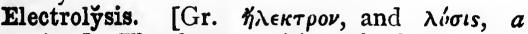
loosening.] The decomposition of a body by an electric current. Electrolyte, a body capable of being thus decomposed.

Elestro-magnet. A mass of soft iron temporarily magnetized by being placed within a coil of wire through which an electric current passes.

Electro-plating. Precipitating a coating of silver, etc., on some other metal by voltaic agency.

Blectuary. [L.L. electārium, elingo, I lick out.] A medicinal compound of the consistency of honey, into which honey, sugar, etc., enter.
Eleemosynary. [L.L ělěēmǒsŭnārius, adj., from Gr. $\epsilon_{\lambda \epsilon \eta \mu \sigma \sigma u ́} \eta$, alms.] 1. Relating to alms. 2. Subsisting on alms.

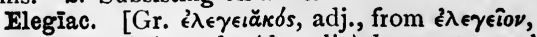
a distich consisting of a (dactylic) hexameter and a pentameter, the commonest metre of é $\lambda \epsilon \gamma o l$, songs of mourning.] 1. Plaintive, expressing sorrow or complaint. 2. (Metr.) Consisting of é $\lambda \in \boldsymbol{\gamma} \in \hat{\imath} \alpha$ (see above).

Elëgit. [L., he has chosen.] Name of a writ bidding the sheriff give the judgment-creditor the lands and tenements belonging to or occupied by the debtor, to be held and enjoyed until the debt is paid. The property is said to be extended on an $E$. (Extend.) Before the right of entry is given, the sheriff empannels a jury to value the debtor's goods and chattels in case they may satisfy the debt.

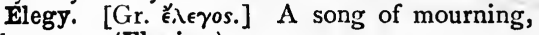
a lament. (Elegiac.)

Element. [L. ělěmenta, plu., first principles.] 1. A substance which cannot by any known means be split up into any simpler form of matter. (Abbreviations, Ch:mistry.) 2. (Math.) An indefinitely small portion of a curved line, of a surface, or of a solid.

Elementary mathematics. A term frequently used to denote those parts of mathematics which can be treated without systematic reference to infinitesimals or limits.

Elemi. A resin used for varnish.

Elenchus. [Gr. É $\lambda \in \gamma \chi 0 s$.$] (Log.) 1. Con$ vincing argument in refutation, especially re. ductio ad.absurdum or ad impossibille. 2. Disproof, refutation.

Elephant. Drawing-paper measuring twentyeight inches by twenty-three (from its size).

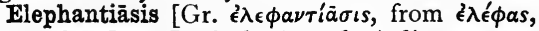
an elephant], or Barbados leg. 1. A disease common in hot countries, the skin becoming livid, rugous, tumid, especially in the leg, which becomes an elephant's leg, i.e. large, misshapen. 2. $E$. Grecorum, a blood disease, in which the skin becomes thick, rugous, and insensible, with falling off of all hair except from the scalp, hoarseness of voice, and disfiguration of the countenance; giving rise to the term Satyriasis

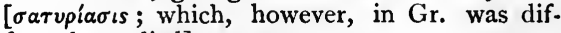
ferently applied].

Eleusinian Mysteries. (Gr. Hist.) A festival held yearly at Eleusis, near Athens, in honour of Dêmêtêr, or Mother Earth. The ceremonial set forth the revival of nature in the spring-time, as the return of the maiden (Kŏrê) Persěphŏnē (Proserpine) from the kingdom of Hades, who had stolen her away from the plain of Enna in the late autumn.

Elevation. [L. elěvāre, to raise up.] 1. Of a gun, the angle made by the axis of its bore with the horizontal plane. 2. The representation of a building or other body on a vertical plane, by means of perspective or some other ordinary projection.

Elevation, Angle of ; $\mathbf{I}$. of the pole. The Angle of $E$. of a point is the angle, in the vertical plane passing through the point and the eye, between a horizontal line and a line drawn 
from the eye to the point. The $E$. of the pole at any station is the arc of the meridian between the (elevated) pole and the (rational) horizon. It measures the latitude of the station.

Elevator. 1. A mechanical contrivance for lifting grain, etc., to an upper floor ; also a building containing one or more elevators. 2. A mechanical contrivance now in use at large hotels for carrying guests to the upper stories. - Bartlett's Americanisms.

Eléve. [Fr.] Pupil.

Elgin marbles. A collection of statues and other works, derived chiefly from the ruins of the Parthěnon at Athens, brought to England by Lord Elgin, I814, and now deposited in the British Museum. (Parthenon; Arundelian marbles.)

Elia. Nom de plume of Charles Lamb.

Elia, Essays of. Chief literary work of Charles Lamb (died ז835).

Elimination. [L. e-limino, I take out of doors.] (Math.) The process of finding the equation which connects certain numbers, when two equations are given connecting those numbers and one more number which is commonly unknown. By an extension of the process, $n$ unknown numbers can be eliminated from $n+$ equations.

Eliot, George. Nom de plume of Mrs. Cross, née (Marian) Evans, author of " Adam Bede," etc. (died December, I880).

Eliquation. [L. èliquäre, to strain.] The separation of silver from copper by adding lead, and then melting out the silver and lead together.

Elision. [L. elīsiōnem.] (Gram.) The cutting off or the suppression of a vowel at the end of a word, as in Greek, Latin, and Italian poetry.

Elisors. [Fr. éliseurs, choosers.] Two clerks of the court or two other persons of the county, sworn to choose a jury if the sheriff and coroners are challenged as partial, etc. Their choice cannot be challenged.

Elite. [Fr.] The select few, the pick.

Elixation. [L. ēlixo, I thoroughly boil.] Decoction.

Elixir. [Ar. el-ikser.] 1. The philosopher's stone, for transmuting metals into gold. 2. A tincture for prolonging life.

Elizabethan ware. (Crouch ware.)

Elizabeth's Prayer-book. (Common Prayer, Book of.)

Ell. [D. eln, O.Fr. alne ; $c f$. L. ulna, Gr.

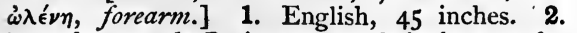
French, aune de Paris, 44 French inches or 46.9 English inches.

Ellandonan. District near Kintail, in Rossshire, in the Tudor period.

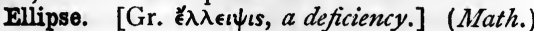
The plane curve described by a point which moves in such a manner that the sum of its distances from two fixed points (the foci) remains the same in all its positions. It is a central curve, and its greatest and least diameters are called its major and minor axes. (Conic sections.)

Fllipsis, Ellipse. (Gramt) An omission of words the meaning of which is implied, as, "He struck me, not I him."

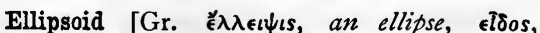
form ] ; $\mathbf{E}$. of revolution. A solid (resembling an egg) all whose plane sections are ellipses or circles. An $E$. of revolution is formed by the revolution of an ellipse round its greatest or least diameter; it is often called a Spheroid, which in the former case is said to be prolate, and in the latter oblate.

Elliptic compasses are made for the description of ellipses, as ordinary compasses for the description of circles.

Ellipticity of the earth. The figure of the earth is very nearly that of an oblate spheroid; the equatorial being the greatest diameter, the polar the least. The ratio which the excess of the equatorial above the polar diameter bears to the equatorial diameter is called the $E$. of the earth, and is very nearly $I: 300$.

Elmo, Fire of St. A name of the electric glow known as Castor and Pollux.

Éloge. [Fr.] A funeral oration.

Eloigne, Eloine, Eloign. [Fr. éloigner, from L. èlongare.] To remove to a distance.

Elongation. The angular distance of a planet from the sun.

Eloquent Doctor, The. Doctor Fācundus, Peter Aureōlus, Archbishop of Aix, fourteenth century.

Elul. The twelfth month of civil, sixth of ecclesiastical, Jewish year ; August-September.

Elutriate. [L. elutriāre, to wash off, from èluo, as Pliny uses it.] To cleanse or free from alien matter by washing, especially of an aggregate of heavy particles, from which lighter particles are to be disengaged.

Eluxation. [L. e, out, luxātǐo, -nem, dislocation.] Dislocation of a joint.

Elvan. A name for felspathic dykes or veins in Cornwall.

Elves. (Myth.) An old English word, denoting probably beings inhabiting the waters. (Demons ; Fairies; Nymphs.)

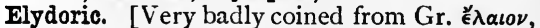
oil, $\delta \delta \omega \rho$, water.] A mixture of oil and watercolour painting.

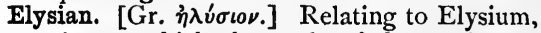
the region to which the souls of the good were carried after death. It was supposed to be in the west, beyond the columns of Herăkles (Hercŭles).

Elytrum. [Gr. Ě $\lambda \nu \tau \rho \rho \nu, a$ cover, é $\lambda \dot{\nu} \omega$, to cover.] (Entom.) The anterior wing of a beetle, etc., converted into a horny (chitinous) sheath for the hinder one.

Elzĕvirs. Books beautifully printed are sometimes compared to Elzevirs, that is, to works published by the family of Elzevir, properly Elzevier, at Amsterdam and other places, in the seventeenth century. (Aldine editions.)

Em (M). The portion of space occupied by the letter $M$; used as a unit in measuring printed matter.

Embargo. [Sp., from embargar, to arrest, detain.] An order preventing vessels leaving port, a detention in port.

Embarras de richesse. [Fr.] A perplexing superabundance of riches. 
Embattled. (Her.) Having an outline like the battlements of a tower. Embattled grady, or battled embattled, signifies that each side of each battlement rises by degrees, like a flight of steps [L. gradus].

Ember days. [L. quatŭor tempora, four times, passing into ember through the form zuatember, D. temper, Sw. tamperdagar, ymberdagar.] Fast-days, occurring at the times in the year appointed for ordinations, being the Wednesday, Friday, and Saturday after the first Sunday in Lent, Whit Sunday, September 14, and December 13 .

Emblements. [O.Fr. embléer, It. imbiadare, to sow with corn (Fr. blé, It. biado) ; cf. A.S. blaed, short, leaf, fruit, Ger. blatt, leaf, remotely akin to L. flōs, flower, bloom, Gr. $\phi^{\lambda} \boldsymbol{\lambda}_{\epsilon} \in \nu$, to teem.] Growing crops of vegetable productions which are planted or sown with a view to speedy return, as grain, root crops, or vegetables, not trees, shrubs, or grass.

Embless de gentz. . [O.Fr.] Old Parliamentary rolls, stealings from the people.

Embody. (Mil.) To incorporate for service troops previously enrolled.

Embolism. [Gr. $\epsilon \mu \beta o \lambda \iota \sigma \mu \delta s$, insertion, or ${ }_{\epsilon}^{\prime} \mu \beta \delta \lambda_{\iota} \sigma \mu \alpha$, a thing inserted; $c f$. Fr. embolisme.] 1. Intercalation, insertion of days, or months, or years between consecutive corresponding divisions of the ordinary modes of reckoning.

2. The time inserted as above.

Embonpoint. [Fr., in good case.] Plumpness, fulness of figure.

Embossing. [Prefix em, $=$ L. in, and Ger. butz, point.] Working figures in relief, whether by casting, cutting, or stamping.

Embouchure. [Fr.] $A$ mouth, an opening, as of a defile, a river, etc.

Embowed. (Her.) Curved like a bow.

Embracery. [Norm. Fr. embraserie.] attempt to bribe or corrupt a jury.

Embrail. To use the Brails.

Embrasure. [Fr., of doubtful origin (Littré).] Opening cut in a parapet through which a gun can be fired whilst the gunners are protected. (Crenelle.)

Embrocation. [Gr. é $\mu \beta \rho \in ́ \chi \omega, I$ make to soak in.] (Med.) 1. The rubbing of a diseased part with medicated liquid. 2. The liquid itself.

Embryology (Anat.) traces the development of life in the foetus, or embryo [Gr. $\tilde{\epsilon}_{\mu} \mu \rho \rho v \nu$, from 'ं $\nu$, within, $\beta$ púw, I grow in fulness] from the first to the time of birth.

Emerald. A kind of type, as-

\section{Christmas.}

Emerald green. Arsenite of copper, a pigment of this colour, very poisonous.

Emerald Isle. Name of Ireland, from the exceeding greenness of the vegetation, caused by the damp climate.

Emeril. [Fr., from Gr. $\sigma \mu u ́ p i s$, emery.] A glazier's diainond.

Emeritus. [L.] 1. A Roman soldier was so called after serving his full time. 2. Hence any one who has reached the end of his term of office.
Emerods. Deut. xxviii. 27; I Sam. v. ; corr. of Hæmorrhoids.

Emery. [Fr. émeri, It. smeriglio, Gr. $\sigma \mu u ́ p$ ss.] A granular variety of Corundum (q.v.), generally mixed with iron ore; chiefly imported from Naxos ; found also in several parts of Europe, Asia Minor, America, and India ; crushed and sifted to various degrees of fineness.

Émeute. [Fr., of doubtful origin (Littré).] Disturbance, riot.

Emication. [L. ēmǐcātio, -nem, a springing forth.] A flying off in drops, sparks, or any small particles, a sputtering.

Émigré. [Fr., an emigrant.] A political refuggee.

Émile. J. J. Rousseau's ideal of a perfectly trained youth.

Emilia. 1. Heroine of Chaucer's Knight's Tale. 2. Iago's wife, in Shakespeare's Othello.

Emilian Provinces = the Romagna $(q . v$.$) , to-$ gether with the duchies of Parma and Modena; through which the ancient Via Amilia, a continuation of the Via Flaminia, or great northern road, passed ; formally annexed to Sardinia, I860.

Eminent domain. (Leg.) The right of a government to take the land of private persons into public use.

Emir, Amir, Ameer. [Ar., commander.] 1. An Arabian ruler. 2. One of Mohammed's descendants. The khalifs took the title of Emir-alMumemin, Chief of the Faithful, corr. in the West into Miramamolin.

Emmett's Rebellion. Napoleon having by his agents excited discontent in Ireland against the Government, E., son of a Dublin physician, after interviews with the first consul at Paris, planned a general rising, July 23, 1803 . It ended in little more than a city riot.

Empalement. [Fr.] (Her.) Conjunction of two coats of arms in one escutcheon, parted by a vertical line down the middle. (Pale.)

Empannel. (Leg.) The writing on a parchment schedule by the sheriff the names of jurors summoned by him.

Empawn. To pawn (q.v.), to pledge.

Imperor. (Hist.) This word, which represents L. imperātor, denoted the military authority of the consuls. On the fall of the republic, the title was conferred first for a term of years, then for life on Octavius (Augustus); and by it his successors were known. Hence the emperor is properly the head of the Roman world. The imperial power conferred, A.D. 800 , by Leo III. on Charles the Great (Charlemagne) was only a revival or extension of the Western Empire. As assumed by some sovereigns in modern times, it is a mere arbitrary title. (Aulic Council.)

Emphȳsēma [Gr. é $\mu \phi \dot{\sigma} \sigma \eta \mu \alpha$, an inflation], or Pneumătōsis [Gr., inflation]. (Med.) A collection of air in the cellular membrane, arising sometimes spontaneously, but generally from some wound which affects the lungs; rarely, the effects of certain poisons.

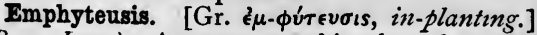
(Rom. Lazv.) A new ownership planted on the real dominion, when lands or buildings are let 
for yearly rent for a long term or even in perpetuity. E. included the letting of agri vectignales. The tenant was Emphyteuta.

Empire, The. This phrase denotes strictly the Roman Empire, afterwards called the Holy Roman Enpire. (Emperor.) But it is also applied to any widely extended dominions of a single power, as the British empire.

Empiricism. 1. Knowledge which is nonscientific, and founded upon experience [Gr. $\left.\epsilon^{\prime} \mu \pi \epsilon \iota p^{\prime} \alpha\right]$ only. 2. In a bad sense, = quackery.

Emplastic. [Gr. '̇ $\mu-\pi \lambda \alpha \sigma \tau \iota k o ́ s$, pertaining to plastering.] Adhesive, suitable for a plaster.

Emplastrum. [Gr. $\epsilon^{2} \mu \pi \lambda \alpha \sigma \tau \delta \nu, a$ thing smeared

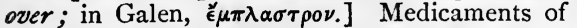
an adhesive character spread upon leather or other texture and applied to the body.

Emplead. [O.Fr. emplaider.] To indict, to accuse.

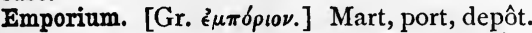
Empressement. [Fr.] Impressive exhibition of anxiety, eagerness, heartiness.

Emprise. [O.Fr. ; $c f$. It. impresa, undertaking, from in (Fr. en, em) and prenděre (Fr. prendre), to take.] Enterprise.

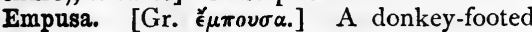
['óó $\kappa \omega \lambda o s, \dot{o \nu o \sigma \kappa \in \lambda i s] ~ h o b g o b l i n ~ s e n t ~ b y ~ H e c a t e, ~}$ or identified with Hecate ; a horrible phantom.

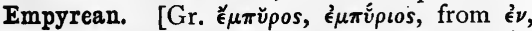
in, $\pi \hat{v} \rho$, fire.] A sphere of fire, supposed to exist above the sphere of air, because the element of fire being lighter than that of air, it would naturally occupy the highest place.

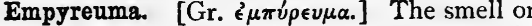
taste of animal or vegetable substances burnt in a close vessel.

Empyreumatic. [Gr. $̇ \mu \pi \dot{u} \rho \in v \mu \alpha$, thing set on ('́) fire $(\pi \hat{v} \rho-)$.] Like burnt animal or vegetable substances in taste or smell.

Emulsion, Mulching. As used by gardeners $=$ manuring.

Emunctories. [L. ēmungo, I blow the nose.] Parts of the body where things excrementitious are collected for ejection.

En-. Prefix : 1. Fr. en-, from L. in, in, on, into, against (and with intens. force), as in entreat; with Teut. words, as in en-thrall. 2. $\epsilon^{2} \nu$, in, on (and with intens. force), as in en-tonic. 3. Teut. for A.S. on, $c f$. à $\nu \alpha^{\prime}, u p$, as in en-lighten.

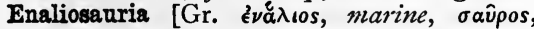
lizard] $($ Geol. $)=$ great fossil aquatic lizards, as ichthyosaurus, plesiosaurus, etc.

Enallăgē. [Gr., interchange.] (Gram.) Interchange of words or of modes of inflexion between words of a sentence, as [L.] Virtīs est vǐtium fügĕre, to flee vice is virtue, for Virtūtis est vĭtium fŭgĕre, or Virtūs est füga vǐtiörum.

Enamel. [Fr. émail.] An opaque or semitransparent glaze.

\section{Enarmed. (Her.) Armed.}

En arrière. [Fr.] In the background.

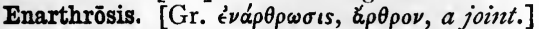
(Anat.) A ball-and-socket joint, the head of one bone being received into the concavity of another, as in the hip and shoulder joints, admitting an extensive range of motion. Gingly.

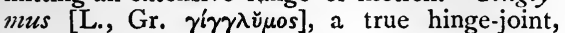

two or more prominences fitting into corresponding concavities, as the ankle-joint, and giving no lateral motion.

En attendant. [Fr.] While waiting.

En avant. [Fr.] Onwards, in advance.

En bloc. [Hr.] In a mass, collectively. Resolutions a: a meeting are sometimes carried en bloc, instead of being discussed one by one.

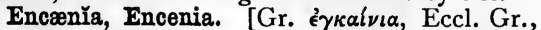
feast of dedication.] At Oxford University, a Commemoration of benefactors. (Dedication,

\section{Feast of.)}

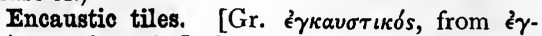
$\kappa a i \epsilon \iota \nu$, to burn in.] Ornamental tiles, the colours of which are fixed by burning them in.

Enceinte. [Fr.] 1. (Mil.) (Body of the place.) 2. Pregnant, with child.

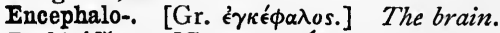

Enchiridion. [Gr. É $\gamma \chi \in \iota \rho і \delta\llcorner o \nu, ~ m a n u a l$, from $\epsilon^{\prime} \nu$, in, $\chi \epsilon i \rho$, hand.] 1. Manual, handbook. 2. A dagger.

Enchorial. (Rosetta store.)

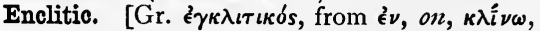
I lean.] (Gram.) A word, generally a particle or pronoun, which cannot be used without a preceding word, the accentuation of which it often alters, as the L. interrogative -ne: audîsne? do you hear? but aúdis, you hear.

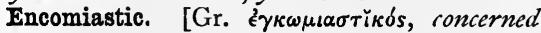
in praise, from é $\gamma \kappa \omega \mu \iota \nu$, encomium.] Laudatory, panegyrical, full of praise.

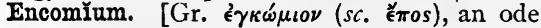
sung by a $\kappa \hat{\omega} \mu o s$, band of revellers, in praise of a victor or distinguished man.] Elaborate praise, panegyric, laudation, eulogy.

Encore. [Fr., from L. hanc horam, this hour.] A word used in demanding repetition of music.

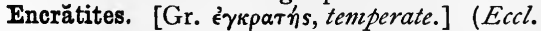
Hist.) A Gnostic sect, which condemned marriage.

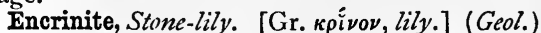
A crinoid (q.v.), with cylindrical stem; abundant in the Muschelkelk. Allied forms abound in many Palæozoic limestones, and some also in Secondary rocks.

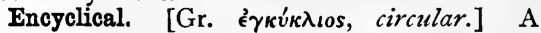
circular letter, whether from a Council, pope, or bishop (see Acts xv. 23).

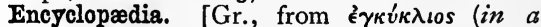

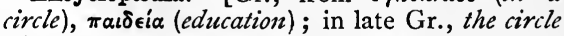
of arts and sciences.] A work containing a general survey of all branches of knowledge in general articles on arts and sciences and special articles on particular objects.

Encyclopædists. (Hist.) The French writers whose works prepared the way for the Revolution are sometimes so called.

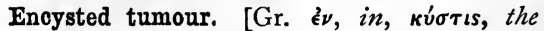
bladder.] Enclosed in a sac or cyst.

Endeavour. [Fr. en devoir, in the phrase, Se mettre en devoir de faire, lit. to place one's self in the task of doing, to set one's self to do; O.E.] To cause or make to try, originally with reflexive pron., as in "E. ourselves," in the Ordinal and elsewhere in Common Prayer-book.

Endeavour one's self. (Endeavour.)

Endemic, Endemial. Disease peculiar to the 
people [Gr. $\delta \hat{\eta} \mu o s]$ or country; naturalized and always existing there.

Endermic, Endermatic. Remedies rubbed into the skin [Gr. $\left.\delta \epsilon^{\prime} \rho \mu \alpha\right]$ or applied after the removal of the cuticle.

End for end. (Naut.) Reversing logs, spars, etc., e.g. if you shift a rope end for end in a tackle, the fall becomes the standing part, and vice vers $\hat{a}$; also if a running rope runs out through a block, or a cable runs entirely out, it is end for end.

Endless band; E. screw. A band, strap, or belt with its ends fastened together, placed over two pulleys so as to embrace a part of the circumference of each and stretched tightly enough to enable it to take hold of them and communicate motion from one to the other An $E$. screw is a screw mounted so as to be capable of rotation only, which gives motion to a revolving follower, or wheel furnished with properly shaped teeth cut on its circumference, which work with the thread of the screw.

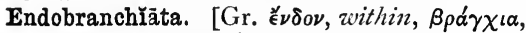
gills.] (?) Tectibranchiate, as tornātella.

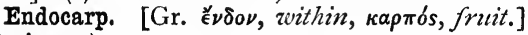
(Pericarp.)

Endogenite. (Geol.) Fossil stem of endogenous structure. Endogenites, a special fossil plant of the Wealden strata.

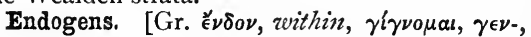
$I$ am produced.] (Bot.) Growing by additions to the inside, the outside being the oldest and hardest part; as grasses, lilies, palms. Exogens, by additions to the outside [ُ $\left.\xi^{\prime} \xi \omega\right]$, with separable bark and concentric heart-wood; as forest trees.

Endorse. (Her.) A diminutive of the pale, being one-fourth its size.

Endorsement. (Indorsement.)

Endosmōsis; Exosmōsis. [Gr. ๕̌ $\nu \delta o \nu$, within, ${ }^{\prime} \xi \omega$, without, $\dot{\omega} \sigma \mu o ́ s$, a thrusting.] In the passage of fluids of different densities through animal or vegetable membranes or porous solids; Endosmosis is from the outside to the inside, Exosmosis from the inside to the outside.

Endrŏmis. [Gr.] 1. A strong hunting-shoe. 2. A thick rug worn after running [ $\left.\delta \rho \delta \mu_{\mu} s\right]$.

Endy̆mion, sleep of. Deep and dreamless sleep. The phrase refers to the Greek myth of Endymion, the darling of Selēne (the moon).

En effet. [Fr.] In effect.

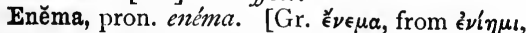
$I$ send in.] An injection, clyster.

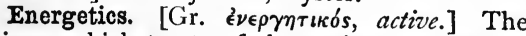
science which treats of the various transformations of Energy.

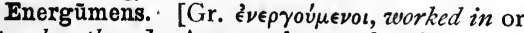
upon by others.] A general name for all persons under demoniac influence. In the primitive Church they formed a distinct class, and were under the direction of exorcists.

Energy [Gr. é $\nu \in \rho \gamma \epsilon \iota \alpha, a c t i o n]$; Actual E.; Intrinsic E.; Kinetic E.; Potential E. Capacity for doing work. Actual or Kinetic $E$. is the capacity of a body for doing work in virtue of its velocity, and is proportional to its mass multiplied by the square of its velocity. The Intrinsic $E$. of a body is the work it can do in virtue of its actual condition, without receiving energy from without. Potential $E$. is the capacity of a body for doing work in virtue of its position relative to other bodies, or of its parts to each other; e.g. when the weight of a clock has been wound up it has potential energy due to its position; so the mainspring of a watch, when wound up, has potential energy due to its configuration.

En famille. [Fr., in family.] Without ceremony.

Enfant gaté. [Fr.] A spoiid child.

Enfants perdus. [Fr., lost children.] A forlorn hope (q.v.).

Enfant terrible. [Fr.] Lit. terrible child; one given to making inconvenient remarks, more or less clever, and mostly personal, to the confusion of present company.

Enfant trouvé. [Fr.] A foundling.

Enfeoffment. [From L.L. infeoffare, to invest with a feud or fee.] The act of or instrument of investment with a feud or fee $(q . v$.).

Enfilade. [Fr., from enfiler, to thread.] (Mil.) Fire from a gun or musket raking a line of troops or the interior of the parapet, and at the same time grazing its whole length.

En fin. [Fr., at the end.] Finally.

Enfranchise. To make free, to invest with a franchise.

Engaged columns. (Arch.) Columns, or shafts, of which a portion is attached to or concealed by the wall. They never stand out less than half their diameter.

Engaged wheels. Toothed wheels working with each other.

Engagement, The, substituted by Cromwell's Parliament for subscription to the Covenant, bound all who ministered to swear " to be true and faithful to the Government established, without king and House of Peers."

En garçon. [Fr.] In bachelor fashion.

Engineer [from L. ingenurum, native talent or power, through Fr. ingenieur]; Civil E.; M echanical E.; Military E.; Royal E. Originally one who manages engines, but now used in several connexions. A constructor or designer of the larger kinds of machines and engines is a Mechanical $E$. One who designs and erects structures subservient to the use of engines is also an Engineer; a Civil E., if the engines are for civil us es, as locomotive engines ; a Military $E$., if the engines are for warlike uses, as heavy guns. Hence nearly every kind of structure, roads, bridges, canals, fortifications, are raised by engineers, and works preliminary to their construction are performed by E. Military engineers in England are called Royal $E$., because their works are carried on under royal authority. There are also Gas E., Marine E., Mining E., Sanitary E., Telegraphic E., etc. ; but in some of these cases the word engineer has no meaning, and is merely a name by which some men choose to call themselves.

\section{England, Now. (New England.)}

English. A kind of type, as-

Irish. 
English pale. The portion of Ireland to which, for some centuries after its invasion by the English under Henry II., the dominion of the latter was confined.

Englishry. William the Conqueror, to check the assassination of his unpopular Normans, laid under a heavy amercement the hundred in which an assassinated person was found; and he was presumed to be Norman, unless four nearest relations proved his $\mathrm{E}$.

Engobe. [Fr., from verb engober; Littré compares s'engober, to stuff one's self with food, in Normandy.] A layer of Slip (q.v.), for semiliquid paste, applied to the surface of pottery.

Engoulée. [Fr., from en, in, and gueule, mouth.] (Her.) Having the end in the throat of an animal.

Engrail. [Fr. engrêler, from grêle, hail.] 1. To spot as with hail, to indent or make jagged at the edges. 2. (Her.) To border by a line formed of small semicircles with the points turned outwards.

En grand seigneur. [Fr.] In the style of a grandee, in great state.

En gros. [Fr.] Wholesale.

Engross. [L.L. ingrossare, to make large.] 1. To increase in bulk. 2. (Leg.) To write out fair, in large hand (a deed or instrument). 3. (Com.) To buy up as much as possible of anything, in order to sell at advanced rates; to forestall. 4. Hence to occupy wholly, to take up all one's attention.

Enhanced. [O.Fr. enhausser, to exalt.] (Her.) Placed higher than usual on an escutcheon.

Enharmonic. [From the E. scale in Gr. Music,

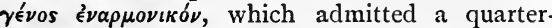
tone between $\mathrm{E}$ and $\mathrm{F}$.] 1. Having intervals less than semi-tones; thus, an $E$. scale would have more than the twelve piano-divisions of the octave, and give separate sounds for $\mathrm{G}$ \# and A b. But, 2; $E$. modulation or change, is a change of the name only of the note, i.e. a treatment of notes theoretically different as if really the same; e.g. of $A b$ as if it were $G$ *. 3. For E. Gr. Music-a short statement of which would probably mislead-reference must be made to such works as Stainer and Barrett's Dictionary of Music.

Enlarge, To. (Naut.) Said of the wind when it gets more astern.

Enlarger l'estate. ( $\left.L c_{g}.\right)$ A kind of release by which ulterior interest in an estate is conveyed to a particular tenant.

Enlightened or Illuminated Doctor. Raymond Lully (1235-1315), a very distinguished schoolman, whose system, Ars Lulliana, undertook to show that the mysteries of faith were not contrary to reason.

Enmanché. [Fr. manche, sleeve.] (Her.) Covered with a sleeve; said of the chief when lines are drawn from the middle point of the top to the lower corners.

Ennui. [Fr., perhaps from L. in odio, in hate, $=$ hateful.] Listlessness, from lack of employment, want of interests, or satiety, indifference to pleasures and excitements. (Tedium vitæ.)
Ennnyé, fern. ée. [Fr.] One suffering from ennui (q.v.).

Enoch, Book of. A book written probably in the century preceding the Christian era. It was lost after the time of Jerome, who mentions it ; but two Ethiopic copies were discovered by Bruce, the African explorer. A passage from this book is quoted in the Epistle of St. Jucle.

Enodātion. [L. ēnōdātio, -nem, from ênōdāre, to free from knots (nōdi).] Clearing fron knots, solution, untying

En petit comité. [Fr., in a small company.] In a snug little party.

En plein jour. [Fr.] In open day.

En rapport. [Fr.] In agreement with, in harmony with, especially of connexion by mesmeric influence, secret sympathy or private understanding.

En revanche. [Fr., in return.] To make amends.

Enrollment, Enrolment. [From en- and roll.] Recording, registration, record, register. Differs from enlistment, as not necessarily implying consent to military service.

Ensanguine. [ $E_{n}$ - and sanguine (verb or subst.).] To stain deeply or widely with blool.

Ensconce. To cover by a Sconce, to hide securely.

Ensemble. [Fr.] A whole, a complete collection of parts taken [L. in šmŭl] together.

Ensient, Enseint. (Leg.) Enceinte (q.v.), with child.

Ensiform. [L. ensis, a sword, forma, form.] (Bot.) Like a straight, narrow sword-blade; e.g. iris-flag.

Ensign. [Fr. enseign, one carrying military decorations, L. insignia.] (Mil.) The title, until lately, of an officer of infantry upon receiving his first commission.

Ensigned. [L. insigne, a badge.] Adorned.

Ensilage. [Fr.] The name given to the method of preserving Indian corn or other fodder in a green state for winter feeding.

Ensue. [O.Fr. ensuer, L. in-sěquor.] To follow after.

\section{Entablature. (Order.)}

Entail. 1. (Arch.) The O.E. form of the It. intaglio, denoting any kind of carved or moulded decoration. 2. An estate or fee limited to particular heirs or descendants. (Tail.)

Entanglement. A military obstacle, stems of trees half cut through and the upper parts picketed down to the ground, or strong wire twisted round top of pickets a foot in length.

Entasis. [Gr.] (Arch.) The almost imperceptible swelling of the shaft of a column in the Greek orders.

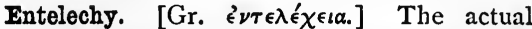
being of a thing, as opposed to simple capability or potentiality.

Entente cordiale. [Fr.] (Dipl.) Corä̈al understanding, generally between countries and statesmen.

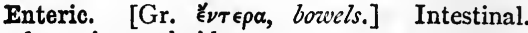
E. fever, i.q. typhoid.

Enter short. (Bank.) To note down particulars of bills paid in to customers but not due 
on a previous column, not putting the amounts into the cash column until paid. If the banker becomes bankrupt, the customers are entitled to their bills so entered or to the proceeds if paid.

Entêté. [Fr.] Wrong in the head [tête], obstinate, vain, captivated.

Enthymeme. [Gr. és $\nu \dot{u} \mu \eta \mu \alpha$.$] (Rhet.) 1. A$ syllogism of which the premisses relate to the contingent in the sphere of human action. 2 . Often wrongly used for an incomplete syllogism, i.e. with one premiss suppressed.

Entire. [Fr. entier, L. intěger, whole.] Among brewers, beer combining the qualities of different sorts, so that it can be drawn at once without after-mixture.

Entire contract. (Leg.) A contract wherein everything stipulated for on one side must be performed as condition of everything being performed on the other side.

Entireties, Tenancy by. (Leg.) Tenancy of a man and wife to whom an estate is conveyed or devised during coverture, and who are seised per tout, each of the whole estate.

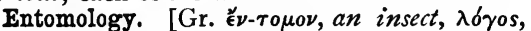
an account.] The science of insects, including other articulated animals, though possessing more than six legs, undergoing no proper metamorphosis, and not having compound eyes.

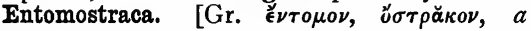
shell.] Small crustacea, of low type, some bivalved, such as $C_{y}$ pris, $C_{y}$ there, Estheria, etc., others provided with a carapace. Common in very many formations; e.g. Cypridiferous Wealden clay.

Entourage. [Fr.] Surroundings, associates.

Entr' acte. [Fr.] 1. The interval between the acts of a play. 2. Any entertainment provided at such times.

Entrance. (Naut.) The shape of the bow below water where it meets the sea. Also the fore foot : it is opposed to the run.

Entrechat. [Fr., caper.] Rapid piece of execution in dancing.

Entre chien et loup. [Fr., between dog and zolf.] Said of twilight.

Entrée. [Fr.] 1. Right of entering, privilege of visiting. La grande E., admission on a formal footing; la petite $\mathrm{E}$., on a footing of intimacy. 2. A made dish of the course before the joint or pièce de resistance.

Entre les deux vins. [Fr., between the two wines.] Neither quite sober nor quite in. toxicated.

Entremets. [Fr. entre, between, mets, $a$ dish.] 1. Side dish, the chief dishes being entrées, the joints being known as pièces de resistance; but originally, 2, short allegorical or dramatic entertainments held during feasts. (For their connexion with the Crusades and the modern opera, vide Stainer and Barrett, Dictionary of Music.)

Entre nous [Fr.], Inter nos [L.]. Between ourselves, in confidence.

Entrepôt. [Fr., warehouse.] Magazine for goods meant for exportation.

Entrepreneur. [Fr., contractor.] Especially, one who brings out musical and theatrical performers.
Entresol. [Fr., between the floors.] A part of a building on a level between those of two floors, especially the ground and first floors; a suite of rooms approached from a landing on a flight of stairs. (Mezzanine.)

Inucleate. [L. ēnuclěo, I take out (e) the kernels (nuclěi).] To explain, clear up, solve.

Enure. (Inure.) 1. To habituate, to accustom. 2. (Leg.) To take place, to be available.

Envelop. (Math.) The line or surface which touches each of a family of lines or surfaces ; thus, if a great number of equal circles are drawn with their centres on the circumference of a given circle, the envelop is two circles concentric with the given circle.

Envelope. [Fr. enveloppe, envelopper, to wrap up.] (Fortif.) Earthwork constructed to shelter some weak point in the ground before a fortification, without being brought into the general scheme of defence.

In vérité. [Fr.] In truth, really.

Envermeil. [Fr. en- and vermeil, vermil, vermilion.] To dye red.

Environment. [Fr. environner, from en- and viron, circuit, from L.L. virare, to turn about.] Of any organic being, the aggregate of circumstances by which it is surrounded.

Envoi, Envoy. [Fr. envoyé, sent.] An address to readers or to the work itself, at the end of a literary work.

Eocene. [Gr. ’’ $\omega s$, morn, kaıvós, new.] (Geol.) That on which the dawn of life appears, i.e. the lowest group of the Tertiary. Miocene $[\mu \in \hat{i} o \nu$, less $]=$ Middle Tertiaries, as having a smaller percentage of recent species than Pliocene $[\pi \lambda \epsilon \hat{o}$, more $]=$ Upper Tertiary group. Pleistocene $[\pi \lambda \epsilon \hat{\imath} \sigma \tau o s$, most $]$ being $=$ post-Tertiary; its organic remains belonging almost wholly to existing species.

Eölian accumulations. (Geol.) Formed by the drifting of winds [Eolus, god of winds]; called also Sub-aërial.

Eolian mode. (Gregorian modes.)

Eos, Tears of. Eos was, in Gr. Myth., the dawn. When her son Memnon was killed, her tears are said to have fallen from the sky in the form of morning dew.

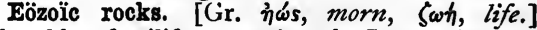
The oldest fossiliferous rocks; the Laurentian and Huronian of Canada, Bohemia, etc.

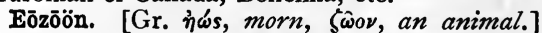
A foraminiferal organism of the Eocene rocks, E. Canadense.

Ep-, Eph-, Epi-. Gr. prefix, $\dot{\epsilon} \pi \boldsymbol{\imath},=$ to, on, over, in addition to, against, and with intens. force.

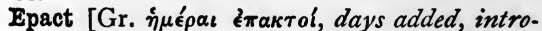
duced]; Monthly E.; Annual E. The Monthly $E$. is the excess of the calendar month above the lunar month. The Annual $E$., the excess of the solar year above the lunar year of twelve synodical months. The $\mathrm{E}$. of any given year in the lunar cycle is the number of days of the moon's age on the Ist of January; thus, during the present century, when the golden number is 5 the epact is 14 ; in the year 1847 , the golden number was 5, and it appears from the nautical 
almanacs for that year that the age of the moon at noon on January I was fourteen days.

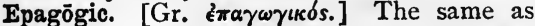
Inductive.

Epănădĭplōsis. [Gr., added repetition.] (Rhet.) The repetition of the first word of a sentence at the end, as, "Oh, Sophonisba! Sophonisba, oh!"

Epănălëpsis. [Gr.] (Rhet.) Recurrence to the same word or phrase.

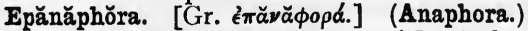

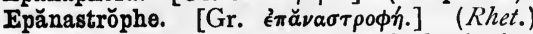
Repetition of the end of a clause at the beginning of the next, as, "The public blame the butchers, the butchers try to shift the responsibility on to the farmers;" or as, "The mouse ran up the clock, the clock struck 'one,"' etc.

Epănŏdos. [Gr., return.] (Rhet.) 1. Repetition of a clause of a sentence with its parts (which may be slightly altered) in inverted order. 2. A return to subjects already mentioned together for separate treatment.

Epănorthōsis. [Gr. ¿̇ $\pi \check{\nu} \nu \rho \theta \omega \sigma \iota s$, correction.] (Rhet.) An effective correction of something just said, as, "His fault, perhaps I should rather say, crime," etc.

Epăphos. (Apis.)

Epaulement. [Fr. épaulement, épaule, $a$ shoulder.] (Mil.) Open, covering parapet, thrown up merely for the concealment of troops.

Epaulette. [Fr., from épaule, shoulder, L. spătŭla.] Bullion ornament worn on the top of the shoulders by commissioned officers. Abolished for the English army in A.D. 1854, and now replaced by a bullion cord.

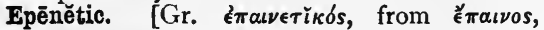
praise.] (Rhet.) Laudatory or encomiastic oratory.

Epenthěsis. [Gr., an insertion.] In Gram., the insertion or doubling of a letter in a word. (Metaplasm.)

Épergne. [Fr.] An ornamental stand for the centre of a dinner-table; the centre-piece of a dinner or dessert service.

Epexëgēsis. [Gr.] Explanation. (Exegesis.) Ephah. (Omer.)

Ephēmĕrĭdæ. [Gr. $\dot{\epsilon} \phi-\eta \mu \mu \epsilon \rho \nu$, an insect living for $a$ day.] Neuropterous insects, of which the may-fly or day-fly is the type.

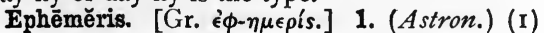
A statement, in the form of a table, of the position of a planet on each day of the year; as the ephemeris of Mars. (2) A collection of these and similar tables, published from year to year, as The Nautical Almanac and Astronomical Ephemeris. 2. A journal, diary. 3. A record of events arranged according to the day of the year on which they have occurred.

Ephod. A sacred robe of the Jewish high priests, afterwards worn by ordinary priests. On the part of the ephod which covered the shoulders of the high priest were two large gems, each bearing the names of six of the tribes. The ephods of the ordinary priests were of fine linen.

Ephors. [Gr. Ёфopo, overseers.] (Hist.) Chief magistrates in many Dorian states of ancient
Greece. Those of Sparta are the most prominent.

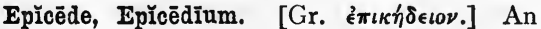
elegiac funeral song.

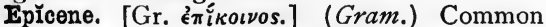
to both genders of a word, which does not change its masc. or fem. grammatical gender whether it stands for male or female, as L. aquila, fem., eagle.

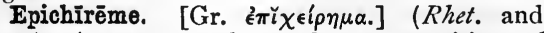
Log.) An attempted proof, a proposition of which the premisses need proof, and to which a reason for their adoption is appended.

Epic poems. [Gr. Еँ Popular poems relating events belonging to national tradition or mythology. Such are the Iliad and Odyssey of the Greeks, the Mahabharata and Ramayana of the Hindus, the Shah. nameh of Firdusi, the Nibelungen Lied of the Germans, etc. (स्neid.)

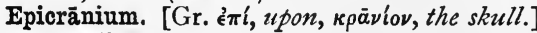
(Anat.) The scalp.

Epicurean. Anything supposed to resemble or to belong to the philosophy of Epicurus, who taught at Athens in the third century B.C., and whose system is popularly regarded as making pleasure of a sensual sort the main end of life.

Epicuri de grege porcus. [L.] $A$ hog of Epicurus's herd.

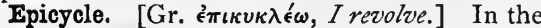
ancient astronomy, a mode of representing the apparent motion of a planet was that of supposing it carried round by the revolution of a small circle-called the E. - whose centre moved uniformly along the circumference of a large circle - the deferent-which was supposed to have the earth in its centre. If necessary, a second $\mathrm{E}$. was imagined to which the first was a deferent.

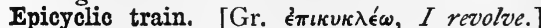
A train of mechanism the axes of which are carried by a revolving arm or frame. Such trains are used in various orreries, in the bobbin and fly-frame, etc.

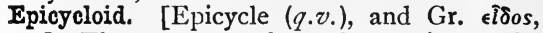
form.] The curve traced out by a point on the circumference of a circle which rolls without sliding on a fixed circle with which it is in exterior contact-the two circles being in the same plane. If the circles are in interior contact, the curve is a Hypocycloid.

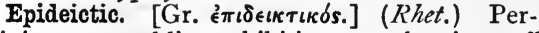
taining to public exhibition or showing off

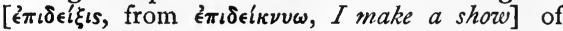
speeches neither forensic nor deliberative, such as panegyries, funeral orations, etc.

Epidemic disease. [Gr. $\dot{\epsilon} \pi \dot{\imath}, u p o n, \delta \hat{\eta} \mu o s$, the people.] One attacking many persons at the same time and in the same place; opposed to Sporadic (q.v.).

Epidermis. [Gr. $\dot{\epsilon} \pi \delta \epsilon \rho \mu i ́ s$, from $\dot{\epsilon} \pi \dot{\imath}, u p o n$, $\delta \epsilon ́ \rho \mu \alpha$, skin.] Cuticle.

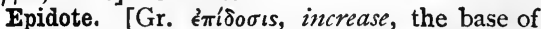
the primary form exhibiting an increase in some secondary forms.] A green mineral ; silicate of alumina with lime, iron, and manganese.

Epigastrium. [Gr. '̇ $\pi \iota \gamma a ́ \sigma \tau \rho \iota \nu \nu$, from $\dot{\epsilon} \pi \dot{l}$, upon, $\gamma \alpha \sigma \tau \eta \dot{\rho}$, the belly.] (Med.) The upper 
part of the abdomen; popularly the pit of the stomach.

Epiglottis. [Gr. é $\pi \dot{i} \gamma \lambda \omega \tau \tau \iota s$, from $\dot{\epsilon} \pi \dot{i}, u p o n$, $\gamma \lambda \omega \tau \tau$ is, the glottis, mouth of the windpipe.] (Med.) Cartilage covering the opening of the windpipe in deglutition.

Epigonotǐkon, Epigonation. [Gr.] (Eccl.) A lozenge-shaped ornament hanging from the right side of the girdles of Eastern bishops and other dignitaries; in the West, used by the pope only.

Epigram. [Gr. émi $\gamma \rho \alpha \mu \mu \alpha$, in-scription, from

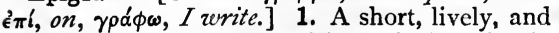
pointed poem, generally satirical. 2. A saying in the style of such poems. 3. A Greek inscription.

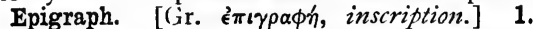
An inscription. 2. A quotation placed before a book or chapter as a motto.

Epigraphy, Epigraphê. [Gr. ė $\pi \iota \gamma \rho a ̆ \phi \dot{n}$, inscription.] The study of inscriptions.

Epilogue. [Gr. émínoyos.] An address to the audience at the end of the play. (Prologue.)

Epimetheus. (Prometheus.)

Epinglette. [Fr., from épingle, $a$ pin, L. spinŭla.] (Mil.) Iron pricker for piercing the canvas covering of the charge for a cannon.

Epǐphŏra. [Gr. émıфopá, a defluxion.] Involuntary constant trickling of tears. (Stillicide.)

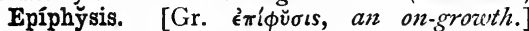
(Anat.) At the end of the long bones; an ossification from a separate supplementary centre.

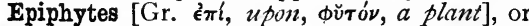
Aerophytes [án $\rho, a i r]$. (Bot.) Air-plants ; generally orchidaceous, attached to trees, but nourished almost entirely by the air. Parasites

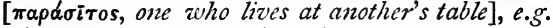
mistletoe, feed upon other plants.

Epiplēxis. [Gr., striking at.] (Rhet.) Persuasive upbraiding.

Epiplocē. [Gr. é $\pi \iota \pi \dot{\lambda} \circ \kappa \dot{n}$, a plaiting on to.] (Rhet.) Statement of several particulars in a gradation of importance.

Episode. (Episodical.)

Episodical. [Gr. é $\pi \epsilon \iota \sigma \delta \delta\llcorner o \nu$.$] Anything of$ the nature of a digression or incidental narrative not essential to the main plot of a poem, the episode of the Greek drama being originally the portion of dialogue between the songs of the chorus.

Epistaxis. [Gr., from é $\pi \iota \sigma \tau \alpha \zeta \omega$, I bleed at the nose.] (Med.) Hemorrhage from the nose.

Epistŏla non ērŭbescit. [L., a letter does not blush.] You can write things, especially in asking favours, which you cannot so easily say.

Epistŏler. The reader of the Episile in the Communion Office.

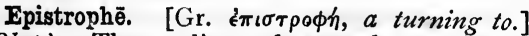
(Rhet.) The ending of several consecutive clauses or sentences with the same emphatic word or phrase.

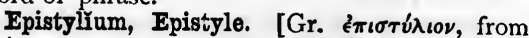
$\epsilon \pi \boldsymbol{\epsilon}$, on, $\sigma \tau \hat{v} \lambda$ ol, pillars.] The lintel resting on pillars of a building, the architrave.

Epităsis. [Gr., a stretching.] 1. The tightening of the strings and raising of the pitch, of instrument and voice, $\boldsymbol{t}_{\nu \in \sigma} \mathrm{s}^{\mathrm{s}}$ being the slackening. 2. The thickening of the plot of a play; the tension, as it were, of the main thought.

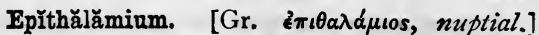
A nuptial song or ode, such as those of Theocritus and Catullus.

Epithēlium. [Gr. $\dot{\epsilon} \boldsymbol{i} \dot{i}$, and $\theta \eta \lambda \hat{\eta}$, the nipple.] (Anat.) The thin cell-tissue investing the nipple, lips, mucous membranes, etc., investing the closed cavities also, e.g. the great serous membranes, the ventricles of the brain, the interior of the heart.

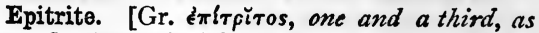
4 to 3.] A metrical foot of four syll., any one of them being short; a combination of spondee = four beats with trochee or iambus $=$ three.

Epitrochoid differs from an Epicycloid (q.v.) in this, that the describing point is within (not on) the circumference of the rolling [Gr. tpoxos] circle.

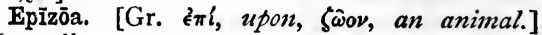
Haustellāta, crustacean parasites attaching themselves to the bodies of fish.

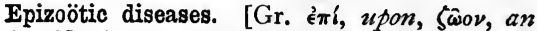
animal.] (Med.) Attacking brute animals at the same time. (Epidemic disease.)

E plürǐbus ūnum. [L.] $A$ unit formed out of many ; motto of the United States.

Epoch. [Gr. ė $\pi 0 \chi \dot{\eta}$, a check, a point of time.] In Phys. Astron., the moment of time when a planet is at some precisely determined point of its orbit.

Epode. [Gr. $\epsilon \pi \omega \delta \delta s$.$] 1. In the strophic$ choruses of the Greek drama, the strain following the strŏphē. 2. Horace's E. are = ad'ded to the Odes. (Strophe.)

Epony̆mous, Eponym. [Gr. é $\pi \omega \dot{\nu} \nu \mu o s$, gizing a name.] In Gr. Hist., the gods or heroes were so called whose names were borne by Greek cities. Thus Athene was the eponym or namegiver of Athens. (Archons.)

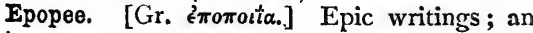
epic poem.

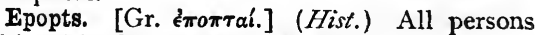
initiated in the Eleusinian Mysteries.

Epsom salts. Sulphate of magnesia.

E' pur si muove. [It., yet it moves.] Words said to have been whispered by Galileo, when abjuring the Heliocentric theory of astronomy.

Equal temperament. (Music.) (Temperament.)

Iquant. [L. part. of æquans, making even.] In order to represent the observed motions of the planets, Ptolemy supposed that in certain cases the deferent was eccentric, and the motion in it uniform, not about the centre, but about another point, the Equant. (Epicycle.)

Equation [L. æquātio, -nem, an equalizing ]; $\mathbf{E}$. of centre; $\mathbf{E}$. of a curve; $\mathbf{E}$. of payments ; $\mathbf{E}$. of time; Personal E. (Math.) When two algebraical expressions are connected by the sign of equality, the whole is called an $\mathrm{E}$. The $E$. of a curve (or curved surface) is the algebraical relation between the co-ordinates of any of its points. $E$. of payments is a rule for answering such questions as the following :-A owes B several sums of money falling due at different dates, and bearing interest from those dates; at what time must the whole be paid in a lump, that neither party may sustain loss ? In Astronomy, E. often means the quantity by which the actual value at 
any instant of a variable magnitude must be increased or decreased to make it equal to its mean value at that instant. The $E$. of time is the number of minutes and seconds to be added to or taken from the apparent solar time at an instant to make it equal to the mean solar time at that instant. The $E$. of the centre is the difference between the true and the mean longitude of a planet at any instant. The Personal $E$. of an observer is the constant error of his observations, due to the individual peculiarities of his organs of perception.

Equator; Celestial E.; Magnetic E. 1. (Geog.) The great circle on the earth's surface which is equidistant from the poles, and divides the earth into a northern and a southern hemisphere. Strictly speaking, the equator is an irregular line which is very nearly a circle and still more nearly an ellipse. 2. (Astron.) The great circle of the great sphere, which is at every point $90^{\circ}$ distant from either pole of the heavens; called also the Equinoctial and the Celestial E.; its plane coincides with that of the equator of the earth, supposed to be a sphere or spheroid. The Magnetic $E$., the line joining a series of points near the equator at which there is no magnetic dip.

Equatorial. If a telescope can turn freely round a fixed axis (A) at right angles to its direction, it will plainly sweep over a single great circle of the heavens-or, at least, so much of it as is above the horizon. Now suppose this axis (A) to be firmly fixed at right angles to a second axis (B) which can turn on fixed pivots at its ends. The telescope can now be made to sweep over the whole heavens in successive great circles, which will all pass through a point in the prolongation of the axis $B$. Now suppose that this axis (B) is fixed in a direction parallel to the earth's axis; the telescope will now be able to sweep over the whole heavens along great circles passing through the poles (declination circles). Such a telescope is said to be equatorially mounted, and, if supplied with properly graduated circles, is called an E. The axis $(\mathrm{B})$ can be turned on its pivots by clockwork, so that when the telescope is set on a particular star, its motion is the same as that of the star, which will therefore remain as if fixed in the field of view as long as it is above the horizon.

Equatorially mounted. (Equatorial.)

Equerry. [Fr. écuyer, from L.L. scutärius, shield-bearer.] 1. An officer of State, under the Master of the Horse. 2. A personal attendant of royal or princely personages.

Equinoctial; E. colure; E. gales; E. points. The celestial equator. The $E$. points are the points in which the celestial equator cuts the ecliptic. The $E$. gales are the winds which are believed to be prevalent about the time when the sun, in virtue of his proper motion, passes through the equinoctial points, in the spring and autumn. (For E. colure, vide Colure.)

Equinox [L. æquinoctium, the time of equal days and nights], Autumnal; Vernal E. That equinoctial point through which the sun passes from the southern to the northern hemisphere is the Vernal E.; so called because it takes place about the 2Ist of March, in the (northern) spring; that through which the sun passes from the northern to the southern hemisphere is called the Autumnal E., because it takes place about the 23 rd of September, in the (northern) autumn.

Equipage. [Fr. équiper, O.Fr. esquiper, to fit out, properly to rig a ship, Goth. skip.] (Mil.) Different requisites for enabling an army to move from one place to another.

Equipollent. [L. æquipolleo, to have like value.] In Log., propositions equivalent in substance, though differing in expression.

Equites. [L., horsemen.] In ancient Rome, a class of citizens who served on horseback in the army.

Equity follows law, Aqquĭtas sĕquǐtur lëgem [L.], i.e. the courts of equity follow, in construing documents and determining rights, the same principles as the courts of common law, but with some important exceptions.

Equivalent. [L. æquus, equal, vălēre, to avail.] (Chem.) The weight of a substance that in a compound will replace one atom of hydrogen.

Equivocal chords. (Music.) Common to two or more keys, the resolution of them being therefore uncertain.

Equivocal generation. Apparently spontaneous. $E$. symptoms, belonging to several diseases.

Equivoque. [Fr.] An ambiguity.

Equŭleus. [L.] A sharp-edged plank, on which the victim is placed astride as on a horse.

Era. (Gelalæan era; Nabonassar, Era of; Sothic period ; Yezdigard, Era of; Yugs.)

Eranian, Iranian. Name of the family of languages comprising Zend, Old Persian, and Armenian.

Erased. [L. ērāsus, scraped off.] (Her.) Torn off so as to leave a jagged edge.

Erasmus's Paraphrase. (Bible, English.)

Erastianism. The undue or disproportionatc exercise of secular authority in things spiritual. (Erastus, physician to Elector Palatine Frederick III.-died at Bâle, I583-writing against excessive use of censures, has been supposed to hold that all ecclesiastical authority should be subordinate to civil.)

Erăto. [Gr.] The Muse who presided over love poetry.

\section{Erbium. (Yttrium.}

Erd-kunde [Ger., earth-lore] = "Knowledge of the face of the earth and its products," for which the only "English name" is "physical geography."-Kingsley's Health and Education.

Erěbus. [Gr. 'E $\rho \in \beta$ Bos.] Popularly any place of darkness, a hell. In Gr. Myth., E. was a son of Chaos and Darkness.

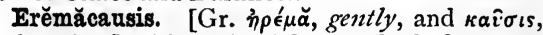
a burning.] (Chem.) The gradual decay of organic compounds ; that of slow combustion, or oxidation, at ordinary temperatures.

Ergot. [Fr., the spur of a bird; origin unknown.] 1. The soft horny stub behind a horse's pastern. 2. Ergot of rye and other grains; a morbid condition of the ovary, which becomes dark and like a long spur; caused by a minute fungus ; sometimes administered as a medicine. 
Eric, Eriach. [Ir. eiric.] (Ir. Law.) A fine paid to the relatives of a murdered person.

Erin. Early and poetic name of Ireland, in its Latin form Ierne.

\section{Erin-go-bragh! Ireland for ever!}

Erinyes, The avenging. In Gr. Myth., the beings who exact vengeance for bloodshed are so called. Thus the Erinyes of Clytemnestra haunt her son Orestes. The Erinys is the Skt. Saranyu (the morning, whose light reveals the hidden things of darkness).

Erl-king. [Ger. erl-könig.] A destructive goblin of the Black Forest, especially fatal to children; subject of a poem by Goethe. The legend is borrowed from Norse sagas.

Ermine. [L. pellis Armenia, the fur of the Armenian rat.] (Her.) A white fur with black tufts. Ermines is a black fur with white tufts. Erminois is a golden fur with black tufts. Erminites is a white fur, with black tufts having a red hair on each side.

Erminia. Heroine of Tasso's ferusalem Delivered.

Ermin Street. The Roman street or road from London to Lincoln.

Erosion. [L. ērōsio, -nem, a gnawing away.] (Geol.) A wearing away; e.g. a valley formed gradually by water-erosion.

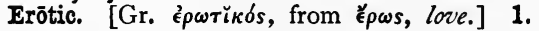
Anything relating to love. 2. The works of poets and others who write of love, as of Sappho, Anacreon, Ovid, etc. In Gr. Myth., Eros is one of the great cosmogonic powers. The name reproduces that of the Vedia Arŭsha, the newborn sun, described as a child with wings.

Erpetology. (Herpetology.)

Erratic. [L. errätīcus, roving.] (Geol.) Carried from its original site by water, ice, etc.; said of blocks, gravel.

Erse. Irish ; Erse language, a division of the Gadhelic branch of Celtic.

Erst. [A.S. ærest, superl. of ær, ere ; $c f$. Ger. erst, first.] First, at first, long ago.

Eructation. [L. eructatǐo, -nem.] A belching; loud, sudden ejection of wind from the stomach.

Erudition of any Christian Man, The Necessary. (King's Book.)

Erysipelas. [Gr. '́ $\rho$ v̌ $\sigma i \pi \in \lambda a s$, usually derived

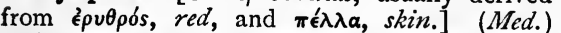
Inflammatory and febrile disease of the skin, with diffused redness and swelling, largely affecting face and head; sometimes epidemic. Called also Ignis sacer, the Rose, St. Anthony's fire.

Escalade. [Fr., from It. scalata.] (Mil.) To climb the walls of a fortress by means of ladders.

Escalloped. Edged or covered with curves in the form of a scallop-shell.

Escapade. [Fr.] $A$ breach of propriety, $a$ freak.

Escapement; E.-wheel. The part of a clock or watch which oscillates with the pendulum or balance and enables it to escape at each beat from the action of the wheelwork, the motion of which-produced by the weight or mainspring-it thus regulates, is the $\mathrm{E}$. The $E$.- wheel is the wheel on which the pendulum acts directly, and which is under the continuous action of the weight or mainspring. Called also Scapement and Scape-wheel.

Escargatoire. [Fr. escargotière.] A nursery of snails [escargots].

Escarp. [Fr. escarpe, from. It. scarpa.] (Fortif.) Slope beyond a parapet or rampart, forming the inner side of the ditch.

Escarpment. [Fr. escarpe, the outzuard slope of a fortification.] The abrupt steep face of a hill.

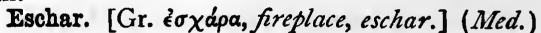
Dry slough caused by burning or by caustic. Escharotic, producing eschar.

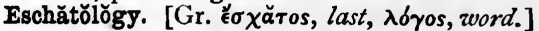
1. (Theol.) The general body of opinions set forth respecting the last things leading to the consummation of the divine kingdom. 2. =

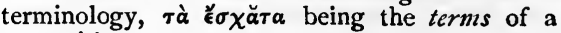
proposition.

Escheat. [O.Fr. eschet ; $c f$. Fr. échéance, escheat.] Corruption of blood. It differed from forfeiture in operating on inheritance, not merely on rents and profits.

Escheator. (Escheat.) (Old Lazo.) A county officer appointed by the Lord Treasurer to make inquest of titles by escheat.

Eschevin. The head man of an ancient guild.

Eschew. [O.Fr. eschever, eschiver, Fr. esquiver, from Teut. form akin to O.H.G. skiuhan, Ger. scheuen, avoid, shun, Eng. shy.] Flee from, shun, avoid, escape.

Escobar. A great Spanish writer on casuistry.

Escot. (Scot.) An old tax in boroughs and corporations, paid towards the common maintenance.

Esoritoire. [O.Fr. ; cf. Fr. écritoire, from L. scriptorius, pertaining to writing.] A writingdesk.

Escrow. [O.Fr. escroue, escrowe, scroll (q.v.).] A sealed writing delivered by $\mathrm{A}$ to $\mathrm{C}$, to be held until B performs some condition, upon which it becomes an absolute deed, and $\mathrm{C}$ hands it over to $\mathrm{B}$, for whose benefit it purports to be drawn.

Escuage. [O.Fr.] Scutage (q.v.).

Escurial, or Escorial. A royal palace in Spain, about twenty-two miles from Madrid, begun by Philip II., in 1563 .

Escutcheon. [Fr. écusson, L. scūtionem, dim. ( A B C shield on which armorial bearings D are painted. If it be divided into F. three equal parts by horizontal lines, G I the upper part is called the chief, the lower part the base, and the middle part the fess. A is called the dexter chief, $\mathbf{B}$ the middle chief, $\mathbf{C}$ the sinister chief, $\mathbf{D}$ the honour point, $\mathrm{E}$ the fess point, $F$ the nombril [Fr., L. umbiliculus] or navel point, $G$ the dexter base, $H$ the middle base, I the sinister base. An $E$. of pretence is the small shield in the centre of his own, on which a man bears the coat of arms of his wife, if she is an heiress (to show his pretension to her lands). 2. (Naut.) The place in a ship's stern where her name is. 
Esk. Celt. name of rivers [cf. Gael. and Erse uisge, water, as in whisky; Welsh wysg, R. Usk; also Ex, Exe, Axios, Axe, Ux-, Wash, Wis-].

Eskdale. Name of the north-east part of Dumfriesshire in the Stuart period, formerly part of Annandale.

Esmarch bandage. Brought out by Professor E., German, in the Franco-German war; used by Ambulance classes (q.v.); simple, and most valuable as first aid to the injured, pending the arrival of a doctor; may be used in thirty-two different ways. A yard of calico, cut diagonally, makes two E. B.

Esmond, Henry. Hero of Thackeray's novel Esmond, a chivalrous Jacobite of Queen Anne's reign.

Esnecca. Royal yacht, or perhaps transport, of the twelfth century.

Esnecy. [From O.Fr. aisné.] (Leg.) The right of the eldest coparcener to choose first in the division of the inheritance.

Esoteric. (Exoteric.)

Espalier. [Fr., from It. spalla, shoulder.] A tree, trained to spread on stakes or poles, or along a wall.

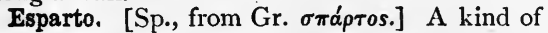
Spanish rush, used for making cordage, paper, etc.

Espials. (Naut.) Night watches in dockyards and harbours; usually a boat told off for the purpose.

Espiêglerie. [Fr.] Roguishness, archness. (Calembonr.)

Espionage. [Fr.] Employment of spies, observation by spies.

Esplanade. [Fr., from It. splanāta.] (Mil.) Open spaces left between glacis of citadel and town, to prevent latter from being used as cover in attacking former.

Espousals. [L. sponsālĭa, from spondeo, I pledge.] Contract of marriage, betrothal. In the Eastern Church, betrothals precede marriage, and are binding, as they are in Germany.

Esprit de corps. [Fr.] Loyal attachment to a body of which one is a member, zeal for one's order.

Esprit fort. [Fr.] Advanced thinker, bold spirit.

Esqurline. [L. Esquillinus (collis).] The Esquiline Hill on the east of Rome.

Esquire. [Fr. écuyer, escuyer, L. scūtarius, one who carries a knight's shield (scūtum).] A gentleman bearing arms under the rank of knight. A captain's commission confers the title.

Esquisse. [Fr.] The first sketch of a picture or model of a statue.

Essay on Education. That of John Locke (1632-1704); important, as having mainly contributed to the change. by which a more enlarged and liberal education replaced the universal and excessive attention to mere philology; and by which the appeal to a pupil's conscientiousness replaced tyrannical authority.

Essay on the Human Understanding. The most celebrated and most important work of John Locke (1632-1704); the first application of the inductive method to the consideration of mental phenomena; which are traced to sensation and reflexion only; in opposition to the doctrine of innate ideas.

Essenes. A sect of Jews, mentioned by Philo and Josephus as leading a life of solitude and contemplation, as believing in the life to come, and interpreting all the Scriptures allegorically.

Essential notes. (Music.) The key-note, third, and fifth.

Essential oil. [L. essentia, the very being.] A volatile oil to which a plant owes its characteristic odour.

Essoin, Essoign, Assoign. [O.Fr. essoine, L.L. sonia, excuse, exoniare, essoniare, toexcuse.] ( $\mathrm{Leg}$.) Excuse for non-appearance to answer an action, etc., by reason of illness or other just cause.

Essorant. [Fr. s'essorer, to soar, L. ex-aurare.] (Her.) With outspread wings in act to fly.

Estafette. [Fr.] A courier who takes messages, etc., as one of a system of relays, an express messenger.

Estaminet. [Fr. ; "origin unknown," Littré, who gives, as conjectures, étamine, stuff, of the tablecloth; Ger. stramm, in sense of fatigued; Flem. stamenay, from stamm, family stock, as if = familiar gathering.] A tap, smoking-room. Estanques. Weirs or kiddles in rivers.

Estates of the realm, Three. Clergy, nobles, and commons.

Est modus in rebus. [L.] There is a medium in all things.

Estoilee. [O.Fr. estoile, star.] Having the form of a star, generally four-rayed.

Estoliland. Name given to a great tract of Arctic N. America by imaginative persons in the fifteenth and sixteenth centuries.

Est opěræ pretium. [L.] It is worth while.

Esto perpetura. [L.] Be thou everlasting; addressed to Venice by Paul Sarpi.

Estopilla. [Sp.] A long lawn or mixed linen fabric made in Silesia.

Estoppel. [From O.Fr. estoper, L.L. stuppare, to stop up with tow (L. stuppa).] (Leg.) A conclusive admission which bars further pleading on the point or points concerned, as that one who disputes a title is the possessor's tenant, and therefore debarred from disputing the title.

Estovers. [From O.Fr. estoffe, Fr. étoffe, stuff; cf. Ger. stoff, material.] (Leg.) Necessaries of life, sustenance, alimony.

Estrade. [Fr. estrade, Sp. estrado, It. strato, L. strātum, a parchment, a coverlet, from root of sterno; I spread out.] A level space, a level daïs in a room.

Estreat. [O.Fr. estrait, from L. extractum, extract.] ( $L$ eg.) The true extract, copy, or note of a writing or record, especially of recognizances, fines, amercements, etc., entered on the rolls ot a court.

Estrich, Estridge. (Ostrich.)

Estuary. [L. æstuārium, a part of the coast covered at flood-tide only.]. (Geog.) An inlet at the mouth of a river into which the tides of the sea enter; as the estuary of the Severn.

Estuation. (Restuation.) 
Établissement. [Fr.] Establishment, institution, shop.

Etagère. [Fr.] A whatnot, a piece of furniture with several shelves or stages.

Etappen. [Fr. étape, rations, formerly estaple, i. stapŭla.] The arrangements for establishing depôts and forwarding supplies along the communications of an advancing army.

État major. [Fr.] Staff, staff office.

Etching. [Ger. ätzen, to eat or corrode.] Producing designs on metal or glass by corroding it with strong acid, the rest of the surface being protected by a coating of wax called the etching-ground.

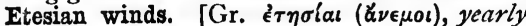
winds.] Monsoons, especially north-west winds which blow in the Agean Sea for forty days after the rising of the Dog-star.

Ethanim (1 Kings viii.), or Tisri (q.v.). First month of civil, seventh of ecclesiastical, Jewish year, September-October.

Ethĕlo-proxĕnos. (Proxenos.)

Ether. [L. æthēr, Gr. aitin 1. (Phys.) A medium of perfect elasticity and extreme tenuity, supposed to pervade space, and to propagate undulatory movements which affect us with the sensation of light and radiant heat. 2. (Chem.) A light volatile liquid obtained by distilling alcohol.

Ethics. [Gr. $\dot{\eta} \theta i \kappa \delta s$, from $\hat{\eta} \theta 0 s$, moral temper.] The science which treats of the nature and laws of voluntary actions in man, and so seeks to determine his moral duty. Fithics therefore and morals denote the same thing.

Ethiopian language. (Enoch, Book of.)

Ethiops mineral. (Ethiops mineral.)

Ethnography. [Gr. ${ }^{\prime} \theta \nu 0 s$, race, $\gamma \rho \alpha \dot{\phi} \phi \omega, I$ write.] The descriptive branch or view of ethnclogy $(q . v$.$) .$

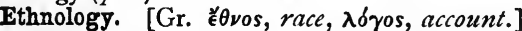
The study of the characteristics, relations, and origin of the various races of mankind.

Etiam periēre ruiñ. [L.] Even the ruins have perished.

Etiolation. [Fr. étioler, L. stipŭlare, from stǐpŭla, $a$ stalk.] (Bot.) Blanching, natural or artificial.

\section{Etř̌logy. (政tiology.)}

Et mŏnēre et mŏnēri. [L., to warn and to be warned.] Both to give and to receive advice, reproof; with Cicero, one of the essential marks of friendship.

Etrennes. [Fr.] New Year's gift, Christmas-box.

Etruria, Kingdom of. 1. Constituted under the ancient name out of the territory of Tuscany, from 1801 to 1814 . 2. Name of the chief pottery district in Staffordshire; so called owing to the celebrity of the ware of ancient Etruria

Etruscan language. The speech of the people of ancient Etruria. It is probably a Turanian dialect.-Taylor, Etruscan Researches.

Itsbā. [Heb.] A Jewish measure of length, $=a$ finger's breadth.

Ittrick shepherd, The. Name given to the Scotch poet, James Hogg (1772-1835), a shepherd in the forest of Ettrick, Selkirkshire.
Et tu, Brute! [L.] You too, Brutus! said by Cæsar on seeing his friend Brutus among his assassins.

Etymologicum Magnum, Etym. Mas. A large Greek etymological lexicon, compiled in the eleventh century, useful, but necessarily quite untrustworthy as to derivations.

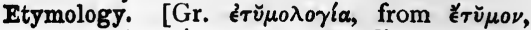

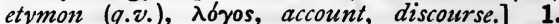
(Lang.) The branch of philology, or of the science of language, which traces the history of special words and inquires into their early forms, meanings, and elements. 2. (Gram.) Classification of the inflexional changes exhibited by the words of a language, and of phonetic changes from the earliest recorded forms of the language.

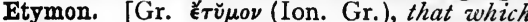
is real.] (Lang.) 1. The original sense of a word determined by tracing its derivation. 2. The original form of a word as restored approximately by the comparative method. 3. A primitive item of speech, a radical.

Eu- [Gr. $\epsilon \bar{u}$, zuell.]

Eucalyptus. (Bot.) A large gen. of Austra. lian trees, known as gum-trees. E. globŭlus is much planted in S. Europe as a preventive of malaria and fever. Ord. Myrtaceæ.

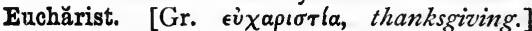
(Theol.) The sacrament of the Lord's Supper. (Consubstantiation; Sacrament; Transubstantiation.)

Euchĕlaion. [Gr., oil used with prayer.] In the Eastern Church, penitents conscious of grievous sins are anointed with oil which is consecrated once a year by the bishop. (Extreme Unction.)

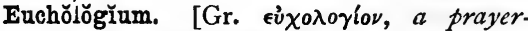
book.] (Eiccl.) The clief liturgical book of the Greek Church, containing everything relating to religious ceremonial. Euchologium sometimes $=($ Rom. $)$ Missal or Breviary.

Euchre. A German and American game of cards, in which the knave of trumps, the right bower [Ger. baur, knave], is the highest card.

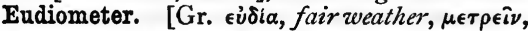
to measure.] An instrument invented for analyzing air, or determining the proportion of oxygen present. Its use is now extended to the analysis of various gases.

Eudoxians. (Eccl. Hist.) A branch of the Arians, who adopted the opinions of Eudoxius, Bishop of Antioch, in the fourth century.

Euergětēs. [Gr., a benefactor.] A title bestowed by the Greeks on some who deserved well of the State, and applied especially to some of the Egyptian Ptolemies; Luke xxii. 25. A title common on the coins of the Syrian kings.

Euemerism, Euhemerism. The system by which Euemeros, a Sicilian author of the time of Alexander the Great, converted mythology into plausible historical narrative by setting aside all unlikely, or impossible, or extraordinary incidents recorded in ancient traditions. Thus Zeus, or Jupiter, became a mortal man who, for benefits done to his fellows, was after his death worshipped as a god. We find the germs of this system both in Herodotus and in Thucydides. (Caput mortunm.) 
Eugubine, Euguvine, Tables. Seven tablets inscribed with prayers and formulæ in Umbrian, the ancient dialect of N.E. Italy ; probable date as early as the third century B.c. Found at La Schieggia, near Ugubio, the ancient Eugubium, 1444.

Eulenspiegel, Tyll. [Ger., Tyll Owl-glass.] Hero of a popular comic German tale of the fifteenth or sixteenth century, a mechanic of Kneittingen, in Brunswick.

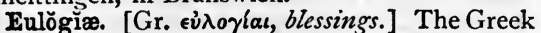
name for the Panis benedictus, pain beni, or bread over which a blessing is pronounced in the Latin Church, and distributed to those who are not qualified to communicate.

Euměnĭděs. (Myth.) This Greek word, meaning gentle, was a name given to the Erinyes, as it was supposed, by the figure of speech called Euphemism. In later times it denoted the three Furies-Allecto, Megæra, and Tisiphine. (Erinyes.)

Eunomians. (Eccl. Hist.) The followers of Eunomius, who maintained an Arianism more extreme than that of his friend Eudoxius. (Eudoxians.)

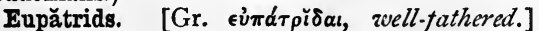
(Hist.) The dominant class in ancient Athens, answering to the Patricians at Rome.

Euphëmism. [Gr. $\epsilon \dot{u} \phi \eta \mu \iota \sigma \mu \delta s_{s}$.] (Rhet.) The substitution of a word or phrase for another which may give offence. Thus the Furies, it was said, were called Eumenides, and the Black Sea Euxine [Gr. $\epsilon \tilde{u} \xi \epsilon \iota \nu \circ s]$, or hospitable.

Euphony. [Gr. €ì $\phi \omega \nu i ́ a$, good sound, from $\epsilon \hat{v}$, well, $\phi \omega v \eta \dot{n}$, sound.] (Gram.) Agreeable sound, the avoidance of disagreeable combinations of articulate sound in speech.

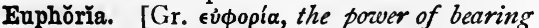
easily.] A feeling of bodily well-being.

Euphrosynē. [Gr.] One of the Graces.

Euphuism. (Hist.) An affected style of speaking and writing in vogue in the time of Queen Elizabeth, and carried to its height by John Lilly in his work called Euphuies [Gr., graceful].

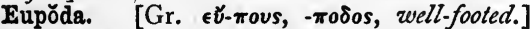
(Entom.) Fam. of tetrămĕrous beetles.

Eurasian. A half-breed between a European and an Asiatic parent.

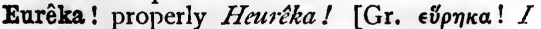
have found! Said by Archimedes when he discovered the principle of specific gravity; hence used in connexion with any discovery.

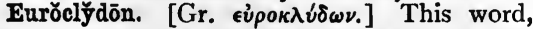
probably denoting a storm from the east, is mentioned in Acts xxvii. I4; but there are many readings, one of them being Eurakylon, the north-east wind [L. Euraquilo].

Eurōpa. [Gr. єù $\omega \pi_{\pi \eta}$.] (Myth.) The daughter of the Athenian Agenōr, and sister of Cadmus. She was carried over the sea to Crete by Zeus in the form of a white bull, and there became the mother of Minos, Rhadamanthys, and Eăcus.

Eurus. (Wind.) hold.

Eury. The linen-room in the royal house.
Eury̆dicē. (Myth.) (Orpheus.)

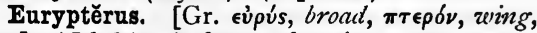
fin.] (Ichth.) A fam. of extinct crustaceans, with broad swimming feet; ranging from the Upper Silurians to the coal-measures.

Euskarian. Dialect of the Basques, nonAryan inhabitants of the Pyrenees.

Eustachian tube leads from the tympanic cavity of the ear to the pharynx. (Eustăchius, its discoverer, Italian anatomist, died 1574.)

Eustathians. (Eccl. Hist.) 'The followers of the monk Eustathius, whose opinions were condemned by the Council of Gangra in the fourth century.

Euterpē. (Muses.)

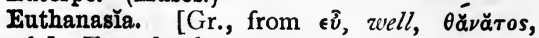
death.] Easy death.

Eutychians. (Eccl. hist.) The followers of Eutyches, abbot of a monastery at Constantinople, a vehement opponent of Nestorius. The latter asserted that there were two distinct natures in Christ, the former that His human nature was merged in the divine. (Nestorians.)

Evacuation Day. The day on which the British army evacuated the city of New York (November 25, I783), the annual return of which has been celebrated in that city for nearly a century.-Bartlett's Americanisms.

Evangelical Prophet, The. Isaiah. (Protevangelion.)

Evangelic Doctor, The. Wyclif, the Reformer.

Evaniadæ (so termed by Dr. Leach ; etym. ?).

(Entom.) Gen. of hyměnopterous insects, parasitical in cockroaches, blattĭdæ.

Evaporatometer. (Atmometer.)

Evection. [L. ëvectio, -nem, a carrying out or forth.] (Astron.) The greatest of all the inequalities of the moon's motion, due to the disturbing influence of the sun, which causes a variation in the form and position of her orbit considered as an ellipse; so that she is sometimes as much as $1^{\circ} 20^{\prime} 30^{\prime \prime}$ before or behind her position as it would have been had her elliptic motion been undisturbed

Evelyn's Memoirs. Published 1818; a Diary of events carefully observed from I64I to 1706 ; with much other curious and valuable matter; by John Evelyn, of Wotton, scholar, author, and a very perfect country gentleman, of the highest Christian character. Sir Walter Scott "had never seen a mine so rich." (Sylva.)

Evening gun, The. (Naut.) Fired in summer at nine, in winter at eight o'clock.

Evening star. The planet Venus when she sets after the sun.

Even keel, On an. (Naut.) Said of a vessel drawing the same depth of water at the stem and stern.

Evens, or Vigils. The evenings or nights before certain holy days of the Church, the word Vigil being used when the evening is a fast.

Every inch of that. (Naut.) Belay without easing the rope. Every rope an end, coil down running rigging, etc. ; also, see every rope clear for running.

Eviction. [L. ēvictio, -nem, from ē, out of, vinco, I conquer.] (Leg.) 1. Recovery of pro- 
perty by a judicial process. 2. Expulsion from a tenement by the landlord.

Evil eye. According to an ancient and widely spread superstition, some persons have the power of injuring those upon whom they look.

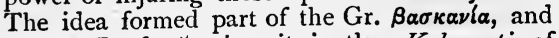
of the L. fascinatio; it is the Kakomati of modern Greece, the Malocchio of Italy ; and the belief exists in Turkey, Egypt, Ireland, Scotland, and some parts of England. (See Virg., Ecl. iii. 103.)

Eviscerate. [L. èviscĕräre.] 1. To take out [ē] the bowels [viscěră], to disembowel.

(Metaph.) To deprive of matter or strength.

Evolute. (Involute of a curve.)

Evolution. [L. èvŏlutio, -nem, an unrolling.] 1. (Arith.) The process of extracting the roots - square root, cube root, etc.-of numbers. 2. (Biol.) A development of more complex from more simple organization. In Darwin's theory, which ascribes physical and moral phenomena to continuous E., breaches of continuity are explained by the hypothesis of natural selection. 3. (Mil.) Execution of a tactical movement.

Evovæ. A word used $=$ the ending of a Gregorian tone ; e, u, o, u, a, e, being the vowels of "sEcUlOrUm, AmEn."

Ewo-necked horse. Having the neck not arched, but somewhat hollowed out; as seen in the sheep, goat, etc.

Ewrar, Ewary. An officer in the royal household, who attended with ewer for the washing of hands after meals. Forks were not used till at least as late as Elizabeth's time.

Ex-. 1. L. prefix =out, out of, from, thoroughly. 2. Celt. name of rivers; Rom. Isca (cf. Esk).

Ex ăbundanti cautēla. [L.] From excessive caution.

Exacerbate. [L. exăcerbāre, from ex-, intens. ăcerbus, sour.] To irritate, exasperate.

Exacerbation. [L. exăcerbo, I exasperate.] 1. Bitterness of spirit. 2. (Med.) Aggravation of the symptoms of disease.

Ex æquo et bŏno. [L.] In equity and good conscience.

Exaltädos. [Sp., exalted.] In Sp. Hist., the liberal party in politics.

Exaltation. [L. exaltatio, -nem.] (Med.) Morbid activity of the brain.

Exanimation. [L. ex, out of, anima, breath, life.] Want of life, real or apparent.

Exanthematous diseases. [Gr. '̇' $\alpha^{\prime} \alpha \theta \eta \mu \alpha$, (I) efflorescence; (2) cutaneons eruption.] (Mid.) Eruptive.

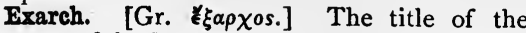
viceroys of the Byzantine emperors in the Italian and African provinces. The E. for Italy was known as the E. of Ravenna. (Donation of Pepin; Donation of Charlemagne.)

Excalibur. In the Arthir legend, the sword which Arthur alone is able to draw from the stone into which it had been fixed, thus proving his title to the kingdom. It answers to Gram, the sword of Odin ; to Durandal, the sword of Roland; to the Glaive of Light in the Scottish stroy of Esaidh Ruadh (Campbell, Tales of the
West Highlands); the sword of Apollo, Chrysaor, and many others.

Ex căthĕdrâ. [L.] From the chair of professor or bishop; i.e. spoken with authority.

Exceptio prőbat regŭlam de rebus non exceptis. [L.] A special exception to a rule proves it (to hold) concerning things not (specially) excepled. A legal maxim, of which the first three words are often misapplied as meaning "the fact of there being an exception proves the existence of a rule," or "an exception is essential to every rule."

Excerpt. [L. excerptum, thing plucked out.] An extract, a selected passage.

Exchanges, Theory of. In Heat, the doctrine that when bodies are in the same region all radiate heat, the hotter bodies radiating more heat, the less hot less heat ; so that an exchange of heat takes place between them.

Exchequer. [O.Fr. exchequier, L.L. scaccarius, chess-board.] 1. Court of $E$. Chamber, a superior court of revenue ; so called from a checked cloth originally on the table. 2. The public treasury. 3. A treasury generally, possessions in money.

Exchequer bills. Bills of credit issued by authority of Parliament, bearing interest per diem according to the usual rate at the time. First issued, 1696.

Exchequered. (Naut.) Seized as contraband. Marked with broad arrow.

Excise. [O.E. accise, L.L. accisia.] 1. A charge or impost on certain articles of home production and consumption, as malt, alcohol, hops, or on trade licences. 2. Revenue raised by taxing inland commodities or traders, i.e. by indirect taxation.

Exciting cause of disease; its immediately preceding cause, as distinguished from predisposing cause.

Exclusion, Bill of. (Hist.) The bill introduced into Parliament during the reign of Charles II., for the purpose of excluding the Duke of York, as a papist, from the succession.

Excommunication. [Eccl. L. excommunicatio, -nem.] A censure, casting the offender out of the communion of the Church ; the Lesser E. depriving of sacraments and public worship, the Greater, of all society of the faithful also.

Ex concesso. [L.] From what is admitted.

Excŏriate. [L. excŏriāre, from ex, off, cŏrium, skin.] To wear off the skin, to remove skin by striking, rubbing, or the use of acrid substances.

Excursus. [L., a running forth.] An essay on a special point appended to a section of a book.

Exeat. [L., let him depart.] A permission or order without which no person in statu pupillari may go out of residence at a university or college, or from a religious house.

Executive City, The. Washington.-Bartlett's Americanisms.

Exědra. [Gr.] (Eccl. Ant.) A building distinct from the main body of the church, as a cloister, baptistery, sacristy, etc.

Exēgēsis. [Gr., a narrative, explanation,

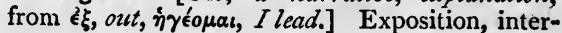


pretation, especially of sacred or classical works.

Exĕquātur. [L., let him execute (the duties of the office).] Instrument recognizing one as consul or commercial agent for Government, and conferring his authority.

Exequies. (Exsequies.)

Exergue. [Fr.] In Numismatics, the lower limb of a coin or medal, marked off by a straight line from the rest of the surface, where the date is placed.

Exfoliation. [L. exfŏlio, I strip of leaves.] A throwing off of dead from living tissue ; e.g. a separation of a dead portion of bone.

Exhaustion, Method of. 1. (Math.) A geometrical method used by the ancient geometers for proving indirectly the equality of certain magnitudes and ratios. Suppose it can be proved that $\mathrm{A}+x$ is greater than $\mathrm{B}$, and that $\mathrm{A}-y$ is less than B ; and suppose that, consistently with this, it can be shown that $x$ and $y$ can be diminished till their magnitude is exhausted, and they at length become less than any magnitude that can be assigned; then it can be inferred that A must equal B. 2. ( $\log$.) When it is known that $A$, or $B$, or $C$, or $D$, or $E$ was the doer, and it has been proved that not $\mathrm{A}, \mathrm{B}, \mathrm{C}$, or $\mathrm{E}$ did it, it follows that $\mathrm{D}$ did it.

Exhibit. [L. exhřbitum, n. p. part. of exhibeo, I exhibit.] Something shown to a witness when giving evidence which is referred to by him in his evidence.

Exhibition. [Leg. L. exhǐbrtio, -nem, maintenance.] (Univ.) Yearly allowance for maintenance given to students who do not thereby become scholars on the foundation of the college.

Exigant. [L., let them demand.] (Leg.) Name of a writ calling on the sheriff to have-a defendant, who non est inventus, demanded at five county courts or five London hustings, after which, unless he appear, he is outlawed.

Exigeant, -ante. [Fr.] Exacting.

Exigi făcias. [L., do thou cause to be demanded.] (Leg.) I.q. exigant.

Exinanition. [L. exǐnānītio, -nem, from exinānire, to emply.] 1. Privation, emptiness, humiliation. 2. (Med.) Bodily emptiness and exhaustion.

Exit. [L.] He, or she, goes out.

Ex mĕro mōtu. [L., on mere impulse.] Of one's own will.

Exŏdǐa. [Gr.] In ancient Rome, burlesques acted after other plays. With the Greeks the Exodion was the final chorus in a tragic drama.

Ex officio. [L.] By virtue of office.

Exogens. (Endogens.)

Exömis. [Gr.] A sleeveless tunic hanging

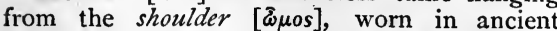
Greece by women, slaves, and poor men.

Exon. An officer of the yeomen of the Royal Guard.

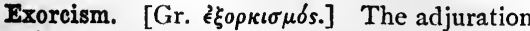
by which evil spirits were bidden to depart from the Energumens.

Exordium. [L.] A beginning, introduction of a work; its first meaning being the warp of $a$ web; from ordior, $I$ weave [ $c f$. Gr. o’ $\rho \delta \epsilon^{\prime} \omega, 1$ begin a web, ó $\delta \eta \mu \alpha, a$ ball of worsted].

Exŏriare aliquis (nostris ex ossibus nltor) [L. $]=$ Oh for some deliverer! lit. Oh, mayest thou rise up, some one or other, out of our bones, i.e. descendants, as an avenger! (Virgil).

Exosmose. (Osmose.)

Exostōsis. [Gr. $\dot{\epsilon} \xi \delta \sigma \tau \omega \sigma \iota s$.$] A morbid$ growth of bone; $e . g$. splint, in a horse.

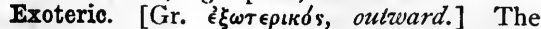
published writings of Aristotle were called E., that is, designed for the people. These had the form of dialogues. The treatises which he prepared for his pupils were termed Esoteric; but the notion that these conveyed mysterious doctrines not to be found in the others has no foundation.

Expansion. [L. expansio, -nem, an extending.] 1. In Algebra, when a succession of terms of which one does not contain $x$, and the others are multiples of $x, x^{2}, x^{3}$, etc., is found whose sum equals an assigned function of $x$, that function is said to be expanded in ascending powers of $x$. Thus, if the function is $(1+x)^{10}$, the expansion is $1+10 x+45 x^{2}+120 x^{3}+$, etc. 2. In the steam-engine, if the connexion between the steam in the cylinder with that in the boiler is cut off when a portion only of the stroke is completed, the engine is said to work by E., because through the remainder of the stroke the piston is urged forward by the force which the steam exerts in the act of expanding.

Ex parte. [L.] On one side.

Expectation of life. 1. The mean or average duration of life (q.v.). 2. More exactly, the probable life, or the number of years more which a person of given age has an even chance of living. According to the Carlisle Table, a person twenty years old has an even chance of living $44^{\circ} 8$ years more.

Expectation Week. (Eccl.) The interval between Ascension Day and Whit Sunday; at which time the apostles waited for the promise of the Comforter.

Ex pĕde Hercŭlem. [L.] (You can judge of) Hercules from his foot; as Pythagoras is said to have calculated Hercules' height from the length of the Olympic foot. The saying implies that you can judge of the whole by the part. (Ex ungue leonem.)

Expense magazine. (Mil.) Contains the immediate supply of ammunition for the batteries of a siege, and is formed under the parapet.

Experimentalism. (Determinism.)

Expĕrīmentum crŭcis. [L.] A decisive $e x$ periment; so called, according to Lord Bacon, because, like a cross or finger-post, it shows men which of two ways they are to go along.

Expert. [L. expertus, experienced.] One who has scientific knowledge of a subject ; said especially of witnesses on matters of science, handwriting, etc.

Experto crēde. [L.] Believe one who has tried. Expīlation. [L. expīlātio, -nem, from expīlo, $I$ plunder.] A plundering, ravaging, pillaging. Expiration. [L. exspirāre, to breathe out, to die.] (Leg.) Reversion of a fee to the lord on 
the failure of the intestate tenant's family, or formerly when a tenant had been attainted of treason or murder. In England, estates escheat to the Crown if heirs fail one who holds of the Crown, by E.

Explētive. [L. explētivus, from expleo, I fill out.] 1. A word or phrase inserted in a sentence, which has no meaning, but often serves the function of emphasis; e.g. the old certes. 2. Hence euphemistic for an oath or coarse expression.

Explǐcit. [For L. explǐcítus est liber, the book is finished.] A word formerly put at the end of books, as Finis is now. (Colophon.)

Exploitation. [Fr., from exploit, exploit, product, from L. explicǐtus, unfolded, exhibited.] A turning to account, exhibiting, etc.

Explosive. [L. explōsus, p. part. of explōdo, $I$ drive out by clapping.] In Lang., relating to or produced by explosion; as $E$. sounds, $E$. consonants, of which the commonest are $k(q), c h, t, p, g, j, d, b$, with their aspirated forms and the spiritus lènis. They are also called momentary or shut sounds, being incap. able of prolongation, and produced by the opening action of the articulatory organs which are previously in contact so as to stop the emission of breath.

Exponent. In Algebra, the index of a power; thus, $x$ is the exponent of $a^{x}$. Exponential series, the expansion of $a^{x}$ in ascending powers of $x$.

Exposition of the Blessed Sacrament. In the Latin Church, when the Host is exposed for the devotion of the people, it is watched night and day with prayers.

Ex post facto. [L.] By an after act.

Expression. In Algebra, a collection of algebraical symbols; as, $5 a^{2} b+3 c$.

Exprobrātion. [L. exprobrātio, -nem, from exprobro, I consider a shameful act (probrum).] Severe reproach, condemnatory censure.

Exsequies. [L. exsěquræ, from ex, out, root of sĕquor, $I$ follow.] Funeral procession, ceremonies of burial.

Exstipulate leaves. (Bot.) Leaves from which stipules are absent.

Ex tempore. [L., from the occasion (time).] Off-hand; said of speaking or preaching impromptu, without book or paper to refer to.

Extend. (Mil.) A light infantry movement, in which skirmishers take up stated intervals.

Extension. [L. extensio, -nem.] 1. ( $\mathrm{Med}$.) Of a fractured or dislocated limb, pulling it strongly in order to reduce it. 2. (Mech.) The property of a body in virtue of which it occupies a portion of space.

Extensor muscle. [L. extendo, I stretch out.] It extends the part on which it acts. (Flexor muscle.)

Extensum. [N. p. part. of extendo, I stretch out.] (Eccl.) The full written text from which a brief is drawn up. Hence in extenso, as opposed to an abstract.

Exterminate. In Algebra, to eliminate.

Extillation. [L. ex, out, stillare, to drop.] (Distillation.)

Extispicious. [L. extispicium, from exti-spex, entrail inspector.] Pertaining to divination by inspection of entrails [exta].

Extradition. [L., from ex, out, and trädĭtio, -nem, a giving $u p$, from trans, over, do, I give.] Delivering up, in a foreign country, a person accused of non-political crime to the authorities of his own country for trial, usually according to an international convention.

Extrādos. [Fr., from L. extra, beyond, dorsum, the back.] (Arch.) The external curve of the arch. (Intrados; Soffit.)

Extramural. [L. extrā, beyond, mūrus, $a$ wall.] Beyond or outside the walls.

Extravagants. [L. extravagantes.] The decretal epistles of popes after the Clementines, at first ranged without, not included in, Canon law. But the collection called Common Extravagants was embodied in the Canon law, A.D. 1483 .

Extravaganza. [It.] A musical or dramatic piece of great wildness or absurdity.

Extravasated blood. [L. extra, beyond, vas, väsis, $a$ vessel.] (Med.) Forced out of its proper vessels into the surrounding tissues; e.g. in discolouring bruises. (Ecchymosis.)

Extra vires. [L.] Beyond one's powers.

Extreme, or Extreme term. (Proportion.)

Extreme Unction. In the Latin Church, the last of the seven sacraments. Administered to the dying, only when all hope of recovery is given up. The oil is consecrated by a bishop yearly on Maunday Thursday. (Euchelaion.)

Extrinsic. [L. extrinsěcus, from without.] Unessential, not given by nature, adventitious, coming from without; correl. to Intrinsic.

Extrusion. [L. extrūsus, p. part. of extrūdo, I push out.] A thrusting or driving out.

Ex unguo leōnem. [L.] From the claw, a small but characteristic thing, judge of the lion; so Ex pede Herculem, from the foot, or footprint, judge of Hercules.

Ex uno disce omnes. [L.] From one learn the character of all.

Exŭviæ. [L., from exuo, I divest myself of.] Originally the shed skin of the snake; now (Med., Bot., Geol.) the outward parts of animals or plants which are shed, or cast off; skin, shells, slough, etc.

-ey. Part of Anglo-Saxon names, = island, as in Romn-ey. (-ea.)

Eyalet. [Turk.] A Turkish principality, a district under the government of a pasha of the first class.

Eyas. [O.E. nyas, nias, Fr. niais, stupid, silly, L. nīdäcem, fresh from the nest (nidus).] 1. A young hawk just taken from the nest. 2 . An infant.

Eye. (Naut.) The loop of a shroud or stay placed over the mast. A collar generally. Eyes of a ship, or $E$. of her, the foremost part in the bows, the hawse-holes.

Eye-glass, Eye-piece ; Erecting I.; Inverting E.; Negative E. ; Positive $\mathbf{E}$. The eye-piece of a telescope is the combination of lenses to which the eye is applied, and which serves as a microscope for magnifying the image formed by the object-glass or reflector. In astronomical telescopes, an Inverting $E$. (Ramsden's or Huy- 
ghens's) consisting of two lenses is commonly employed; the object is seen through it inverted. When Ramsden's eye-piece is used, the image is actually formed by the object-glass before it is viewed by the eye-piece, and it is called a Positive $E$. The rays converging from the objectglass are intercepted by Huyghens's eye-piece before the image is actually formed, and it is called a Negative $E$. . In terrestrial telescopes the eye-piece commonly consists of four lenses through which the object is seen upright; this is an Erecting $E$. In some telescopes the image formed by the object-glass is seen through a single lens, which is called an Eye-glass.

Eye-teeth. The canine, or two upper cuspi- date, of which the fangs extend far upwards in the direction of the eye.

Eyot, Ait, Eight. [Dim. of -ey.] A small island in a river.

Eyre. [Fr., from L. in, İtinere, on the jour ney.] Court of justices itinerant.

Eyry, more properly Aery. An eagle's nest. [Icel. ara-hreiðr, hreiðr corresponding to our wreath, but used in Icelandic in the special sense of a nest. Akin to Icel. are, an eagle, are the Sw. örn, A.S. earn, heron, Gr. ópvis, all containing the root AR, to raise one's self. The word has, therefore, nothing to do with $\mathrm{egg}$, as if it were an eggerv.-Skeat, Etym. Dict. of Eng. Lang., s.v. "Aery."]
F. With the Romans, was used as an abtreviation of Filius in letters and inscriptions, as M.F. = Marci Filius, son of Marcus. In Eng. usage, it was employed in branding, the letter denoting the word." Felon:" the custom was abolished by law in 1822 .

F's, The three. Of the Irish Land League : Fair rent, Fixity of tenure, Free sale.

Făber quisque fortünæ suæ. [I.] Every one is the architect of his ozen fortune (Sallust).

Fabian policy. (Rom. Hist.) The policy of avoiding engagements, by which $\mathrm{Q}$. Fabius Maximus is said to have foiled Hannibal in the Second Punic War. (Cunctando.)

Fables of Bidpai, or Pilpay. (Hitopadesa.)

Fabliaux. [Fr.] The metrical tales of the Trouvères, or poets of the Langue d'oil, or northern French dialect.

Fābŭla quanta fui! [L.] What a subject for town-talk have I been!

Faburden, i.e. Faux bourdon [Fr.], or Falso burdone [It.]. An early method of harmonizing Plain Song (q.v.). (Bourdon.)

Façade. [Fr. ; cf. It. facciata, from L. făcies, front, face.] The whole front aspect of regular architectural building, the front elevation.

Face. (Mil.) Of a bastion in fortification, means the two ramparts which meet in a salient angle and terminate at the shoulders.

Face of a crystal. Any one of its bounding planes; a cleavage-plane is always parallel to a plane which is or may be a face of a crystal.

Face of workings. The portion of a coalseam which is in process of removal.

Facētiæ. [L.] Witty, humorous sayings or writings, pleasantry, droll phrases.

Facets. [Fr. facette, dim. of face.] 1. Small faces or surfaces into which the surface of a stone is divided by angular cuttings. 2. The faces of a natural crystal.

Facial angle. In Ethn., the angle between a straight line from the opening of the ear to the bottom of the nose, and another straight line from the most forward central point of the forehead to the corresponding point of the upper jaw. The higher the average cerebral develop. ment in man, the larger is the average F. A.

Făcǐes, non uxor, amātur. [L.] Her face, not the wife herself, is loved.

Facĭle est imperrium in bŏnis. [L.] Ruling over good people is easy.

Făcille princeps. [L.] Easily first. Preeminent.

Făcĭlī sævĭtīā něgat. [L.] With goodhumoured cruelty she refuses (Horace).

Facilis descensus Averni. [L.] (Avernus.)

Facing-sand. A compound used for the surfaces of moulds in founding.

Făcĭnus mājōrǐs ăbollø. [L.] $A$ crime of $a$ longer cloak, i.e. of a philosopher.

Făcĭnus pulcherrǐmum. [L.] A most noble deed.

Fack. (Fake.)

Façon de parler. [Fr., a fashion of speaking.] A mere trick of speech.

Fac-simile. [L., lit., make a copy.] An exact copy, especially of handwriting or printed work.

Factă cănam, sĕd ĕrunt quĩ mē finxisse lŏquantur. [L.] I will sing of facts, but there will be some to say I have romanced (Ovid).

Factions. In the ancient games of the Circus, parties distinguished by their colours. To the earliest, the red and the white, were added afterwards the blue and the green; and the four were supposed to represent the four seasons. By others the blue and green were regarded as denoting the conflict of the earth and the sea. These factions were causes of serious disturbances in Constantinople.-Gibbon, Roman Empire, ch. $\mathrm{xl}$.

Factitious. [L. facticius, made by art, from factus, p. part. of făcio, I make, do.] Artificial, unnatural.

Factor; Prime F. [L., a maker.] 1. (Math.) Numbers which when multiplied together produce a number are its factors. When they are prime numbers they are called its Prime $F$. A number may be divided into factors in several ways, but into prime factors in only one way ; e.g. 315 can be divided into $15 \times 21$, or $5 \times 63$, 
or $45 \times 7$; but in prime factors it is $=3 \times 3 \times 5 \times 7$. 2. In Com., an agent or commission merchant, especially in foreign ports. 3. In Scotland, a bailiff or steward to an estate.

Factorial. A product whose factors are in arithmetical progression, as $3 \times 5 \times 7 \times 9$, whose $\mathrm{F}$. is 945 .

Factory. 1. A place where factors, i.e. commercial agents, reside. 2. The collective body of such agents.

Fac-tŏtum. [L., lit. do the whole.] One who performs service of all kinds.

Factum. [L.] (Leg.) 1. A person's act and deed. 2. Anything stated or proved.

Factum ŏbiit, mŏnŭmenta mănent. [L.] The event has passed away, memorials thereof remain (Ovid) ; motto of London Numismatic Suciety.

Făculty. [L. facultas, ability', pozver.] 1. Permission, authority, privilege. 2. A body possessed of authority and privileges; as the graduates in a special department of learning, or the members of a learned profession. 3. A special department of knowledge or a learned profession; as the $\mathbf{F}$. of Divinity, Law, Medicine. In Scotland, the Dean of F. is the president of the F. of advocates, or barristers.

Faculty Court, The. Belongs to the Archbishop of Canterbury; not holding pleas, but granting rights to pews, monuments, etc., and dispensations to marry, to eat flesh on prohibited days, to hold two or more benefices, etc.

Fadaises. [Fr.] Nonsense, rubbish. Brachet derives Fr. fade, insipid, from L. văpĭdus, flat, savourless; Littré from fatuus.

Fadladeen. Grand-chamberlain of the harem in Moore's Lalla Rookh.

Faëry Queene. The title of the celebrated poem of Edmund Spenser, the first part of which was presented to Queen Elizabeth in 1590. It contains a double allegory, illustrating the triumph of Holiness over Sin; and also that of Truth over Falsehood, in the history of the Reformation.

Fæx pŏpuli. [L.] Dregs of the people.

Fafnir. In Northern Myth., the dragon who guards Brynhild and her treasure on the glistening heath. (Python; Volsunga Saga.)

Fag. A lying servant in Sheridan's Rivals.

Faggot votes. Votes obtained by splitting up a property into a number of small holdings just large enough to confer the qualification. When this is done by those who pretend to have an identity of interest with the voters of a constituency, though they have none, only for the temporary purpose of excluding a certain candidate, the practice is considered dishonourable.

Fagin. An old Jew trainer of young thieves in Dickens's Oliver Twist.

\section{Fagotto. (Bassoon.)}

Faience [Fr.], and sometimes Faenza [It.] Glazed and coloured earthenware, called in Italy Majolica; in France, Faience. (From a town in the province of Ravenna, the original place of manufacture.) Known also as Raphael ware, from Raffaelo Ciarla of Urbino, in the sixteenth century.

Faikes, Fakes. (Geol.) In Scot., = shaly sandstone, of irregular composition; bituminous shale being Blaize.

Faillis. [Fr. faillir, to fail.] In Her., a fracture in an ordinary, as if a splinter were taken from it.

Fainéant. [Fr.] Do-nothing.

Faints. The impure spirit which comes over first and last in distilling whisky.

Fairies. [Fr. fée, It. fata, from $L$. fatum, fate; not connected seemingly with the Pers. peri, pronounced by the Arabians feri.] Imaginary beings, belonging chiefly to the mythology of the Celtic tribes of Wales, Scotland, and Ireland. They are small in size, and are sometimes seen by human eyes. Mortals have sometimes been decoyed into fairyland, as in the case of Thomas the Rimer of Ercildoune.

Fairservice, Andrew. A coldly calculating, selfish, but somewhat humorous Scotch gardener in Scott's Rob Roy.

Fairway. (Naut.) The navigable channel of a river or harbour. Pilot's $F$., one requiring a pilot.

Fairy rings. Green circles or segments of circles sometimes seen in grass, caused by agarics growing from a centre and fructifying at the circumference, but popularly ascribed to the dancing of fairies.

Fait accompli. [Fr., accomplished fact.] Something definitively settled or achieved.

Faitour. [Norm. Fr. ; cf. O.Fr. faiteur, from L. factor, doer.] An evil-doer.

Fake, Fack, or Falk. (Naut.) One of the circles forming the coil of a rope.

Faking. The cutting of slits or slices in a dog's ear, altering its configuration, often in a very slight degree indeed; a dishonest attempt to add to the number of points required in estimating the excellence of a dog.

Fakirs. [Ar., poor.] In the East, enthusiasts who renounce the world and give themselves up to religious austerities. (Dervise.)

Falbalas. [Fr.] Finery, frippery, fal-lalls. (Furbelow.)

Falcated. [L. falcātus.] Shaped like a scythe [fal-cem].

Falcon. (Musket.)

Falconet. In fifteenth and sixteenth centuries, the smallest kind of cannon, the ball weighing from one to three pounds, the gun from five to fifteen hundredweight.

Falcŭla. [L., dim. of falx, sickle.] (Ornith.) The compressed curved talon of: a bird of prey.

Faldage. [L.L. falda, a fold.] (Leg.) Anciently, the privilege of setting up folds for sheep in fields within the limits of a manor, for the purpose of manuring them.

Faldistory. [L. faldistorrium.] The bishop's seat or throne, in the chancel; the chair in which he sits to address the candidates at ordinations.

Faldstool. [L.L. faldestolium, perhaps from L.L. falda, $a$ fold.] A small desk at which the Litany is recited. (Fauteuil.)

Faldworth. (Leg.) One of age to be reckoned in a tithing or decennary $(q . v$.$) .$ 
Falernian wine. Of the Falernian district in Campania ; highly prized in ancient Rome.

Falk. (Fake.)

Falkland. Hero of W. Godwin's novel Caleb Williams, driven by passionate love of fame to crimes revolting to his nature.

Falk laws. (Dr. F., minister of justice.) In Prussia, in 1873 , made the sanction of the State necessary for the exercise of all religious functions; and required, before ordination by a bishop, an examination implying previous education at a public university; so as to keep out of the Church foreign or other anti-national tendencies.

Fall. The fall of the leaf; autumn. - Bartlett's Americanism.s.

Fall, a fall! The whaler's cry when a whale is harpooned.

Fallācior undis. [L.] More treacherous than the waves.

Fallacy. [L. fallācia, from fallo, $I$ deceive.] In Log. and Rhet., any argument which professes to settle a question while really it does not. Logical fallacies are strictly those only which are so in dictione, in the words, i.e. in which the conclusion does not follow from the premisses. If the premisses themselves are unsound, the fallacy is said to be extra dictionem, i.e. in the matter, and thus to be beyond the province of logic.

Fal-lalls. Bits of finery.

Falling off. (Naut.) The turning of a ship's head to leeward, especially when sailing near the wind or lying by ; the opposite of Griping, or Coming up to the wind.

Falling sickness. Popular name for epilepsy. Falling star. (Aerolith.)

Fallĭtŭr augŭrĭo spēs bŏna sæpè suo. Fair hope is often cheated by its own augury (Ovid).

Fall of a tackle. (Naut.) The loose end; i.e. the end one hauls upon.

Fallŏr ? an armă sŏnant? [L.] Am I mistaken? or do 1 hear the clash of arms? (Ovid).

Fallow. [A.S. fealu, yellowish; $c f$. pale, L. pallǐdus.] Originally land left for a year without cropping, and without culture beyond one or two ploughings; now generally represented by turnips and clover, or dispensed with. (Rotation of crops.)

False keel. (Naut.) An additional keel below the main one.

False kelson, or Kelson rider. (Naut.) A piece of timber fastened lengthways to and above the main kelson.

False ribs. In Anat., the five inferior, of which the last two are the floating ribs.

False stratification, Drift bedding. In Geol. ; so called when a stratum is made up of smaller beds [L. strātŭla] set oblique to its upper and lower horizontal planes, by the shifting tides and deposition of sand over a bank or beach edge from a higher to a lower level.

Falsi crimen. [L.] (Leg.) Fraudulent subornation or concealment with intent to deceive, as by perjury, false writing, or cheating by false weights and measures.
Falstaff, Sir John. A fat, sensual, cowardly, humorous braggart in Shakespeare's Merry Wives of Winclsor and Henry $I V$.

Falsum In ūno, falsum In omni. [L.] False in one point, false in all.

Fāmā nŭhĭl est cĕlěrĭus. [L.] Nothing is swifter than rumour (Livy).

Fămes optimum condimentum. [L.] Hunger is the best sauce.

Familiar. [L. familiāris, from fămǐlı̆a, family.] An attendant demon or evil spirit.

Familiars of the Inquisition. Officers and assistants of the I., often from the nobility, to whom great privileges were granted for apprehension of accused persons; the king himself being protector of the order.

Familists, Family of Love. Enthusiasts of the latter part of the sixteenth century, an offshoot of Dutch Anabaptists; who denied Christ's Person, the Resurrection, etc., interpreting Scripture mystically.

Family Compact. A treaty, signed at Versailles, August, 176r, between Louis XV. and Charles III. of Spain, as a mutual guarantee of protection; no one external to the house of Bourbon was to be adnitted.

Fan. (Mech.) A leaf of a wheel whose revolution produces a current of air.

Fanal. [Fr., from L.L. fanale, Gr. $\phi \bar{a} \nu \delta s$, bright.] A lighthouse or its light.

Fanatic. [L. fānātǐcus, from fānum, a temple.] A word applied at first to priests of Cybele or other deities, who performed their rites with extravagant wildness. Hence zealots or bigots in religion. (Bacchanalian.)

Fancy stocks. A species of stocks which are bought and sold to a great extent in New York. Unlike articles of merchandise, which may be seen and examined by the dealer, and which always have an intrinsic value in every fluctuation of the market, these stocks are wholly wrapped in mystery. No one knows anything about them except the officers and directors of the companies, who, from their position, are not the most likely men to tell the truth. They serve no other purpose, therefore, than as the representative of value in stock gambling. Nearly all the fluctuations in their prices are artificial. -Bartlett's Americanisms.

Fandango. [Sp.] A lively Spanish dance, in $\frac{3}{8}$ or $\frac{6}{8}$ time, the dancers wearing castanets; probably brought into Europe by the Arabians, to whom it was known in remote ages.

Fanfare. [Fr., from Sp. fanfa, bragging.] A flourish of trumpets. Fanfaronade, bragging.

Fanfaron. [Fr., Sp. fanfarron.] Swaggerer, boaster, bully, blusterer. (Fanfare.)

Fang. 1. A sheriff's officer in Shakespeare's Henry $I V$., pt. ii. 2. A niche in the side of an adit or shaft for ventilation.

Fang, With the. [A.S. fang, a taking or thing taken; $c f$. Ger. fang and v. fangen.] With the stolen property on his person. The phrase was once common, and is still used, in Scotland.

Fanning-machine; F.-mill. A machine for separating chaff from grain. 
Fantasia. [It., fancy, imagination, Gr.

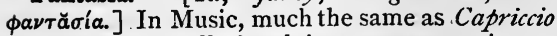
(g.v.), but generally involving more execution.

Fantoccini. [It.] Puppets which move by machinery so as to act dramatic scenes; a set of marionettes.

Fantods. (Naut.) Crotchety orders, fancies, of officers, nicknamed jib-and-staysail-jacks.

Fan vaulting. (Arch.) A form of vaulting, much used in the Perpendicular or Continuous style of English architecture, the ribs radiating like a fan from the spring of the vault. The finest specimens are those of King's College Chapel, Cambridge, and Henry VII.'s Chapel, Westminster.

Faraday's wheel. (Phenakistoscope.)

Farandole. [Fr., from Prov. farandŏlo, from Sp. farandŭla, comic acting.]. A popular dance of Provence and neighbouring parts of Italy; lively, and sometimes associated with great popular excitement.

Farcy, in horses. [L. farcio, 1 cram.] Inflammation, with ulceration of the absorbent glands and vessels of one or both hind limbs ; infectious, and generally an accompaniment of glanders.

Fardel-bag. [Fr. fardeau, burden.] The third stomach of ruminants, in which the food is fully softened.

Farding-deal, i.q. Farthing-deal. [(?) From A.S. feordung, fourth part.] The fourth part of an acre of land; also corr. into Farundel.

Fare-crofts. (Naut.) Vessels formerly plying between England and France.

Farina. [L., flour.] Starch.

Farleu. 1. (Leg.) Money paid in lieu of a heriot (q.v.). 2. Often the best chattel as distinguished from the best head of cattle.

Farmer George. A nickname of George III., from his plain dress, homely manners, and saving habits.

Faro. An old game of cards.

Farouche. [Fr.] Shy, wild.

Farrago. (Olla podrida.)

Farse. [L. farsus, p. of farcio, I stuff up.] Explanations in the vernacular tongue, introduced into various parts of the offices of the Latin Church, as the Kyrie, the Epistle, etc.

Farthingale. [O.Fr. verdugalle, vertugalle, $\mathrm{Sp}$. vertugādo, from verdugo, a rod or shoot of $a$ tree, Sp. verde, L. virídis, green.] A hooped petticoat, a set of hoops to make the petticoat stand out, something like a crinoline.

Farthing-land. (Farding-deal.) A measured portion of land, quantity not known.

Farundel. (Farding-deal.)

Faryndon Inn. An old name of Serjeants' Inn.

Fasces and sěcüres. [L.] (Hist.) Bundles of wooden rods, with an iron axe protruding from them; an ensign of authority of the superior. Roman magistrates, carried before them by officers called Lictors.

Fascet. An iron rod on which glass bottles are carried to the annealing furnace.

Fascia. [L., band, bandage.] In Anat., a tendinous expansion or covering of the muscles. Fasciation, a bandaging. Fasciate (Bot.),
banded.
Fascicled, Fascicular, Fasciculated. [L. fascis, a bundle, dim. fascǐcŭlus.] United or growing in bundles, tufts; e.g. the roots of a dahlia.

Fascícŭlus. [L.] A little bundle; hence any small collection of things which may be thought of as tied together, such as writings, etc.

Fascination. [L. fascǐnātio, fascino, Gr.

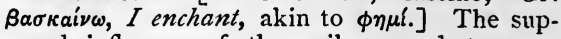
posed influence of the evil eye;. but, more properly, charming through incantations.

Fascine. [Fr., from L. fascis, plu. fasces, $a$ bundle of sticks.] (Mil.) Faggot of brushwood for forming the revetment to support earth.

Fãs est et ab hoste dŏcēri. [L.] It is iazviul to be taught even by a foe.

\section{Fast. (Evens.)}

Fast and loose pulleys. Two pulleys set side by side, one fast and the other loose, on a shaft driven from another shaft by means of a band. When the band is shifted by a fork from the fast to the loose pulley, it no longer turns the shaft; and vice versâ.

Fasten-penny, Fessen-penny. The money, usually a shilling, given by the farmer to fasten the engagement of a servant hired at a Mop (q.v.).

Fastern's Eve. A Scotch name for Shrove Tuesday.

Fasti. [L.] 1. (Hist.) The records of the ancient Roman state. 2. The poem of Ovid, so called, gave an account of the Roman year. 3. Sc. dies, days on which legal business could be transacted. 4. A calendar, almanack.

Fastigiāte. [L. fastīgium, a top, gable.] (Bot.) Narrowing towards the top, as the Irish yew.

Fatal children. In folk-lore, a group of children, often born immediately before the death of their mothers, destined to bring ruin on their parents, and to rise to greatness or sovereignty.

Fata Morgana. [It.] A phenomenon of mirage, supposed to be brought about by the queen of the fairies, the Morgan le Fay of the Arthurian legends and the story of Olger the Dane.

Fata obstant. [L.] The Fates stand in the way.

Fāta vŏlentem dūcunt, nōlentem trăhunt. [L.] The Fates lead the willing, drag the unwilling.

Fates. [L. fatum, the spoken word.] In Myth., the beings who determine the destiny of men. They were supposed to be three-Clotho, the spinner; Lachesis, the allotter; and Atropos, the unchangeable, who cuts the thread of human life. By the Greeks they were called Mœræ; by the Latins, Parcæ, pitiful. (Eumenides; Euphemism; Norns.)

Fătētur făcǐnus is qui judǐcĭum fŭgit. [L.] He acknowledges guilt who flecs from trial.

Father. (Naut.) He who constructs a ship for the navy.

Father of Equity, The. Lord Nottingham. (Chancery.)

- Father of History. Herodotus, Greek historian, born B.C. 484 , at Halicarnassus, in Caria. $\mathrm{He}$ describes the struggle for supremacy between the Persians and the Greeks. 
Fathom. [A.S. fæthm, D. vadem.] A measure of length = two yards.

Fathom, Count Ferdinand. The villain of Smollett's novel of that name.

Fatidǐcal. [L. fātǐdǐcus, from fātum, destiny, and root of dîco, $I$ tell. $]$ Prophetic, foretelling.

Fatigue duty. [L. fătigo, I weary.] (Mil.) Any duty entailing labour, other than military, upon a soldier.

Fatiloquist. [From fātılŏquens, from fătum, fate, and lŏquor, I speak.] A foreteller of destiny, a fortune-teller.

Fatimites. Caliphs reigning in Egypt, claiming descent from Ali, A.D. 9IO-I I I. (Shiahs.)

Fatlute. A mixture of pipe-clay and linseed oil. (Luting.)

Fattöre. [It.] A bailiff or steward to an estate ; the Scottish factor.

Fătuous. [L. fatŭus.] Silly, senseless.

Taubourg. [Fr., suburb.] A corr. of for. bourg [L.L. foris burgum], the part outside the city wall.

Faucal. [From L. fauces, plu., opening of the throat, phärynx.] (Lang.) Articulated in the pharynx, or top of the larynx, above the vocal chords; as the spiritus lēnis, or deep gutturals ; e.g. the Heb. caph.

Fauces. [L.] The opening of the mouth into the pharynx.

Faucet. [Fr. fausset; origin unknown.] A tube for drawing liquor from a cask.

Fault. (Geol.) Any fissure in a rocky crust, accompanied with a raising or a lowering of strata on either side. (Dislocations.)

Fann. (Fauna.)

Fauna. A name derived from the Fauns, ov rural deities of Rom. Myth., and used to denote the animals peculiar to a country.

Fausse-braie. [Fr., false coat, lit. breeches, L. brācæ.] (Fortif.) A work of low relief, with parapet, constructed on exterior of rampart of enceinte of fortress, to give a grazing fire.

Fausse Rivière. [Fr., false river.] A lake of Louisiana, once the bed of the Mississippi, which, about 17 4 , took a shorter course to the sea.

Faust. Goethe's student, who makes a compact with the devil Mephistophèles, to regain a period of youth and sensual gratification.

Fausted. Refuse lead ore reserved for another dressing.

Faustus, Dr. Marlowe's sorcerer, a vulgar Faust, with the addition of a familiar spirit.

Faute de mieux. [Fr., for want of something better.] Failing some better arrangement.

Fauteuil [Fr.], formerly Faudestenil [L.L. faldestolium]. 1. An armchair. 2. A seat in the French Academy. (Faldstool.)

Fautor. [L., from favěo, $I$ favour.] A supporter or abettor.

Fauvette. [Fr. fauve, Ger. falb; its colour being light brown, inclining to olive.] Garden warbler, small olive-brown migratory bird. Currūca hortensis, sub-fam. Silviînæ, fam. Silviădæ, ord. Passěres.

Faux pas. [Fr., L. falsus passus, false step.] A mistake, an ill-bred act or speech.
Favel, To carry, is to curry the chestnut horse; to pay particular attention to one with whom we would stand well; corr. into " currying favour." Fável [Fr.] is = chestnut horse; and curry is the Fr. corroyer, to curry (leather), from Fr. corroi, L.L. conredium, a hybrid word, = cum, with, and redum, arrangement; $c f$. Flem. rêden, to arrange, and A.S. rǽdan, to regulate.

Faveolate, Favose. Honeycombed [L. fãvus, a honeycomb].

Favēte linguis. [L.] Lit. favour with your tongues; i.e. be silent, so as to utter nothing unpropitious during a religious solemnity.

Favour, To curry. (Favel.)

Fawn. [Fr. faon, originally the young of any beast ; formerly féon, $L$. fœetonem, from fœus, brood.] (Deer, Stages of growth of.)

Fay, Fairy. Elf, sprite. (Fairies.)

Fay, To. (Naut.) To join pieces of wood with no perceptible space between them.

Fay-fena. (Naut.) A galley of Japan, carrying thirty oars.

\section{Faytour. (Faitour.)}

Feal and dust (Scot. Lazv), = Eng. right of turbary for fuel, and turf for roofing.

Feal and leal. (Leg.) Faithful and loyal, as tenants by knight's service swore to be to their lords. [Feal is O.Fr., from L. fĩdēlis, faithful.]

Fearn. (Naut.) The windlass of a lighter.

Fearnaught, or Dreadnaught. (Naut.) A stout, woollen felt, used for port linings, etc.

Feast of Fools. (Fools, Feast of.)

\section{Feast of Weeks. (Pentecost.)}

Feateous. [O.Fr. faitice, fetis, well made, from L. facticius, made by art.] Dexterous, skilful, neat.

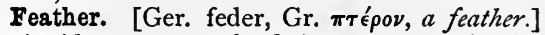
1. A ridge on an axle fitting a groove in the eye of a wheel, to ensure their turning together. 2. (Naut.) A vessel cuts a feather when she makes the water fly $F$. fashion from her bow. To F. an oar, in rowing, is to turn it horizontally when clear of the water.

Feather, White. (White feather.)

Featly. [From O.E. feat, O.Fr. fait, well made, neat, from L. factus, p. part. of făcǐo, $I$ make.] Dexterously, skilfully, gracefully, neatly, prettily.

Feaze, To. (Naut.) To untwist a rope, to make it into oakum.

Febrifuge. [L. febris, fever, and fŭgo, I put to flight.] (Med.) That which drives away or mitigates fever.

Februation. [L. februatio, -nem.] Purifcation.

Fecket. (Naut.) A guernsey.

Fēcŭla. (Bot.) 1. Starchy, nutritious substance of tubers, as potato, arrowroot. [L. fæcŭla, dim. of fæx, sediment, salt of tartar, deposited as a crust and used as a drug (Horace, Sat. II. viii. 9).] 2. Any kind of starch. 3. Chlorophyll, the green colouring matter of plants.

Fẻcundĭ călǐces quem non fēcēre dísertum ? [L.] Whom have not brimming cups made eloquent? (Horace). 
Fedelini. [It.] A small kind of vermicelli. Federal currency. The legal currency of the United States. Its coins are: The gold eagle of ten dollars; the double-eagle, twenty dollars; half and quarter eagles, of proportionate value. The silver dollar, of one hundred cents; its half, quarter, tenth, and twentieth parts. The coin of ten cents in value is called a dîme; that of five cents, a half-dime. The lowest coin in common use was the copper, now supplanted by the nickel, cent. Half-cent coins have been made, but few or none of late years. - Bartlett's Americanisms.

Federal government. [L. fædus, a treaty.] A government by the union of several states, each of which surrenders a portion of its sovereign power to the central authority; as that of the Swiss cantons. - Freeman, Hist. of Fied. Government.

Federals. Name of the loyal Americans in the civil war of North against South, 186I-1 866.

Fee. [O.Fr. fie, fiee, fieu, fief, fied, fief, feu, feod, feud.] (Leg.) 1. Property, possession. 2. A fief, a manor held in possession by some tenant of a superior. 3. An estate of inheritance held ultimately from the Crown. 4. In America, an estate transmissible to heirs held absolutely.

Fee. [A.S. feoh, cattle; $c f$. Goth. faihu, money, O.H.G. vihu, beast, money, L. pěcus, pěcu, head of cattle, pěcŭlium, small private property held by husband's, father's, or master's consent, pěcūnia, money, riches.] 1. Remuneration for professional services, hŏnōrārium. 2. A perquisite, a douceur paid to officers or servants.

Fee-base. (Base-fee.)

Feed; F.-heater; F.-motion ; F.-pipe ; F.pump. In Mech., to feed a machine is to supply it with the material on which it operates. $A F$. or a $F$.-motion is the part of the machine which brings the material up to the working point. In the steam-engine, the $F$-pipe supplies the boiler with water, which is raised by a F.-pump, in most cases from a $F_{\text {. }}$-heater, i.e. a reservoir in which the water is heated by waste steam.

Feeder. (Float.)

Feeding-part of a tackle. (Naut.) The part which runs through the block; opposed to Standing-part.

Feed of grass. (Naut.) Supply of vegetables.

Feo-farm rent. (Leg.) Rent reserved on granting an estate in fee, of at least a fourth of the annual value of the lands at the time of reservation.

Feel the helm, To. (Naut.) Spoken of a ship when she steers quickly; also when she gets enough way on to answer the helm.

Fee-simple. (Leg.) A freehold estate of inheritance absolute and unqualified, enjoyable in all hereditaments as well as in personalty. (Fee.)

Fee-tail. [L.I. feodum talliātum.] A freehold estate limited to a particular line of descent.

Feigned diseases. (Med.) Real, but voluntarily induced or aggravated.
Fel-. (Field.)

Felicitate. [L.L. felīcitare.] To wish a person joy, as one may even wish for a successful rival; to congratulate [congrātūlāri] being to unite cordially in the joy.

Fēlǐdæ. [L. fēlis, cat.] (Zool.) Digitigrade carnivŏra of the cat kind, specially distinguished by retractile claws and lacerating teeth, ranging from the cat to the lion and tiger. Found everywhere, except W. Indies, Madagascar and adjacent islands, Australasia, and Polynesia.

Felix faustumque sit. [L.] May it be happy and blest.

Fell. [Goth. filla, A.S. fel, fell, Ger. fell, L. pellis, Gr. $\pi \epsilon ́ \lambda \lambda \alpha$, from palna.] Skin, hide of a beast.

Fell. [Ger. fels, Dan. fjäld, mountain, rock.] A barren, rocky hill.

-fell. Part of names of hills [of Norw, origin, from a form akin to fjeld, hillside, as in Snaefell].

Fellah, plu. Fellahin, Fellaheen. A peasant in Egypt, a cultivator of Egyptian soil.

Fellmonger, formerly called also a Glover.

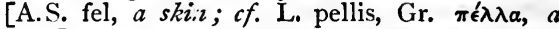
hide.] One who prepared skins for the leatherdresser, by sep rating the wool from the hide.

Fellow. Herhaps O.E. felau, Norse felagi, a partner in soo.ts.] The title of members, or the higher members, of colleges in the universities, who form the governing body of the college, and divide a large portion of its net revenues. Hence, generally, the members of any society.

Fellow-commoner, in Cambridge, or Gentleman commoner, at Oxford. A resident in college, in statu pupillāri, allowed on payment of extra college fees to live at the Masters of Arts', etc., or Fellows' table; now almost extinct in both universities.

Fellowship. In Arith., a rule for dividing profits and losses amongst partners.

Felly. [Ger. felge.] The rim of a wheel.

Fèlo de se. [L., felon concerning himself.] (Leg.) One who commits suicide, being of sound mind.

Felspar. [(?) Ger. feld-spath, field-spar, i.e. found on the ground; or fels-rock, as being common in granite or on mountains.] (Geol.) A very abundant mineral, silicate of alumina with soda, potash, lime; of various colours ; an ingredient of nearly all igneous and of many metamorphic rocks.

Felstone, Felsite. A rock composed wholly or largely of felspar.

Felucca. [Ar.] (Naut.) 1. A narrow-decked vessel of the Mediterranean, with one, two, or three masts, carrying lateen sails. 2. A small Mediterranean craft, with six or eight oars, in which the helm may be shipped at either end.

Femme-couverte [Leg. Fr.], also Femecovert. Married woman. (Covert-baron.)

Femme sole. [Leg. Fr.] Single woman, spinster, or widow.

Femǒra. (Triglyph.)

Femŏral. [L. fĕmur, the thigh.] (Anat.) Relating to the thigh-bone. 
Fence-month. (Leg.) Fawning-month of deer, when they may not be hunted.

Fence-time, or Close-time. The breeding-time of fish or game, when they should not or must not be caught or killed.

Fencible. (Mil.) Soldiers formerly enrolled for a limited time for service in a particular country; e.g. Malta Fencibles.

Fencing. Buying stolen goods much below their value. Fience, one who so buys them.

Fenders. [Abbrev. for defenders.] (Naut.) 1. Planks placed to prevent the chafing of a ship's sides by things being hoisted on board. 2. Pieces of old cable, etc., put over the side to prevent one vessel from touching another, or the side of a dock, etc.

Fend off, To. (Naut.) To keep a vessel from coming into contact with anything, by means of spars, fenders, etc. Fend the boat, keep her off the ship's side.

Feneration. [L. fēněrātio, -nem, from fēněror, Ilend on interest (fenus).] Lending on interest, usury.

Fênestræ. [L., windows.] (Anat.) Of the ear, two holes in the cavity of the tympanum.

Fenestral. [From L. fĕnestra, window.] Of or pertaining to windows or a window.

Fenians. [Perhaps from Finn (Fingal) and his Feni, a militia.] An association of Irishmen formed in America, in 1865, with the professed purpose of separating Ireland from England.

Fenks. The refuse of whale-blubber, used in making Prussian blue.

Fenris. In Myth. (Ioki.)

Fens. [A.S. fen, Goth. fani, O.H.G. fenna, marsh, mud.] Marshy land, especially the reclaimed marsh-land of W. Norfolk, N. Cambridgeshire, S.E. Lincolnshire, intersected by the rivers Cam and Ouse, Nen and Welland.

Feoffee. [Fr. feoffé.] (Fee.) One to whom a corporeal hereditament is "given, granted, and enfeoffed."

Fĕræ natüræ. [L., of wild nature.] Wild animals, as rabbits, hares, deer, game, and savage kinds of beasts; they are not absolute property, but landowners or privileged persons have a qualified property in them while they remain within the limits of their land or liberty.

Feral. [L. fĕrālis, from fëra, wild animal.]

Wild descendants of domesticated spec.

Fërīæ. [L.] 1. (Hist.) Latin for festivals. The most important were the Feriæ Latinæ, celebrated on the Alban Mount by all the Latin states. 2. (Eccl.) In the Latin Church, any days which are not feasts ; ordinary weekdays.

Ferial. [From fériæ, holidays.] In the Latin Church, not festive, of or pertaining to nonfestal days.

Feriation. [L. fëriatus, keeping holiday.] keeping holiday.

Feridun. (Zohak.)

Feringhee. The Oriental name for European : probably from the Varingii, Warings, Norsemen who took service at Constantinople under the Byzantine emperors; or, as some think, from the Franks.

Fernan-bag. (Naut.) 1. A small ditty-bag, used for carrying tobacco, etc. 2. A monkey's pouch.

Ferracute. A pagan giant of chivalric romance, slain by Orlando.

Ferrara. A kind of sword made at F., in Italy ; an Andrew $F$. being one of the make of Andria di F., especially prized.

Ferret. 1. [Heb. anâza, in Lev, xi. 30.] (Bibl.) Unidentified; perhaps a lizard. 2. [Fr. for a tag, dim. of fer, iron.] The iron used to try whether molten glass is fit for working. 3. A narrow kind of tape.

Ferretto. [It. ferretto di Spagna, little iron of Spain.] Copper calcined with brimstone or white vitriol.

Ferric salts. [L. ferrum, iron.] (Chem.) Salts containing iron. Ferrous contain a larger proportion of iron than ferric salts.

Ferrotype. [L. ferrum, iron, Gr. Túmos, type.] A photograph taken with ferrous salts.

Ferruginous. [L. ferrūginněus, from ferrūgo, iron rust.] I.q. chalybeate $(q . v$.$) .$

Fertilization of flowers. (Bot.) This is accomplished by the contact of the pollen with the stigmatic surface. Cross-fertilization, the fertilizing of a blossom by pollen from another blossom on the same plant or on a different plant of the same spec. This is often effected by means of insects, who, in their search for honey, carry the pollen from one blossom to another. Mr. Darwin's researches into the subject are well known.

Fervens diffīcūli bĭle tŭmet jěcur. [L.] $M y$ liver is inflamed and swollen with bile from ill temper (Horace).

Fescennine verses. (Rom. Hist.) Recited extemporaneously by the youth of Latium and Etrüria, first, it is said, at Fescennia, a town of Etrūria, at rustic festivals ; playfully abusive ; out of which grew Satire, the only native poetry of Italy.

Fescue. [L. festūca, a stalk.] An important gen. of grasses ; Meadow F., Festūca prātensis, being one of the most valuable for pasture.

Fess. [L. fascǐa, a girdle.] (Her.) (Escutcheon.)

Fessen-penny. (Fasten-penny.)

Fesiinā lentē. [L., hasten gently.] More haste, worse speed.

Fetch of a bay, or gulf. (Naut.) The line between the points enclosing it.

Fête-champêtre. [Fr.] An outdoor entertainment, a large garden-party.

Fetials. [L. fétiāles.] (Hist.) The heralds of ancient Rome, whose duty it was to declare war and conclude peace. (Fater patrātus.)

Fêtish, Fetishism. [Fr. fétiche, Port. feitiço, charm, from L. facticius.] The worship of material substances-stones, weapons, plants, etc., prevalent amongst barbarous nations, especially those of negro race; tribes, families, individuals, having their special F. "It is, perhaps, not so much a worship of natural objects, ... as a system of incantation by a sorcerer class" (Kingsley, At Last, p. 287) (Obi.)

Fetlock. The lock, tuft of hair, that grow 
behind the pastern-joint $(q . v$.$) on the feet of$ horses.

Fettle. [O.E. feat.] 1. In Athletics, order, condition, preparation. 2. (Naut.) To fit, repair, put in order; also used as a threat.

Fetwah. [Ar.] A written judgment of a Mohammedan mufti on a point of law.

Feu. In Scot. Law, $=$ feud, fee, limited, however, to vassal tenure, wherein the return service is payment of grain, or money.

Feuar. In Scot. Law, one who holds a Feu.

Fendal system. (Hist.) A system in which the sovereign is regarded as the proprietor of all lands, the holders paying him homage and swearing featly or faith. The chief is thus suzerain, and the tenant is his vassal.

Feu-de-joie. [Fr., lit. fire of joy.] (Mil.) Troops in line firing in the air in succession, to commemorate any occasion of rejoicing.

Feu d'enfer. [Fr., fire of hell.] A very hot fire from firearms.

Feuillans. (Eccl. Hist.) A religious order, branching off from the Bernardines, and established at Feuillant, in Languedoc. The Club des Feuillans was a revolutionary society in Paris, in $1791-92$.

Feuillemort. [Fr. feuille morte, dead leaf.] The colour of a dead leaf.

Fouilleton. [Fr., dim. of feuillet.] 1. Part of a newspaper devoted to light literature, criticism, and belles lettres, etc. 2. An article on light literature; a part of a novel published in a journal.

Fez. [Turk.] A brimless cap of cloth or felt.

Fiacre. [Fr.] A kind of hackney coach in France, a four-wheeled cab ; the first carriages for hire in Paris having been stationed at the Hôtel de St. Fiacre, 1640. F., an Irish saint of the sixth century, is in France the patron saint of gardeners.

Fiametta. [It., little flame.] Boccaccio's name for his lady-love.

Fiancé, fem. -ée. [Fr., betrothed.] Intended husband or wife.

Fiar. In Scot. Law, the person in whom the property of an estate is vested, subject to the estate of the life-renter.

Fiars. A term used in Scotland to denote the regulations fixing the price of grain yearly in the different counties.

Fiasco. [It., a flask.] A failure in singing, acting, etc. (See, for an ingenious account of the word, Stainer and Barrett, Musical Dictionary ; and $c f$. ampulla, meaning lit. bottle, meton. bomibast.)

Fiat. [L., let it be done.] An effective command to action; a decisive or operative decree, especially a divine decree which involves its own inmediate realization.

Fibril. [L. fibrilla, a coined dim. of fibra, $a$ fibre, filament.] A minute or terminal fibre.

Fibrine. [L. fibra, a fibre, filament.] In animals and plants, an organic compound, closely resembling albumen and caseine ; distinguished by the very delicate flaments in which it appears when dissolved in fluid. (Albumen.)
Fībŭla. [L.] 1. A brooch, a buckle. 2. (Anat.) The small bone of the leg, attached to the outer side of the tibia, or great bone of the leg; long and slender, and somewhat resembling the pin of a brooch.

Fico. [It., a fig.] An action expressing contempt; the placing of the thumb between two fingers.

Fid. (Naut.) 1. A square bar of wood or iron passed through a hole in the foot of an upper mast, the ends of which rest on the trestle-trees to support the weight of the upper mast. 2. A wooden pin to open the strands of a rope. 3. The piece of oakum placed in a gunvent. 4. Fid of anything; a quid, or small thick piece. When the $\mathrm{F}$. has been inserted in the mast and the mast-rope slackened, the mast is Fidded.

Fiddle. (Naut.) Small cords to prevent things rolling off a table at sea. F-block, one having two sheaves, the lower one being the smaller. Fo-head, one finished by a scroll turning aft, in contradistinction to a Scroll-head, which turns forwards.

Fiddler's Green. A nautical Mohammedan paradise.

Fiddlewood. [Fr. fidèle, trusty.] A hard W.-India wood used for carriage wheels, etc.

Fĭdĕi commissum. [Leg. L.] Property given by testament to one person who is obliged by operative words of request to transfer it to a third person ; trust property.

Fiděi Defensor. (Defender of the Faith.)

Fìde jussōres. In Rom. Law, sureties for any one on bail, came in Eccl. L. to mean sponsors,

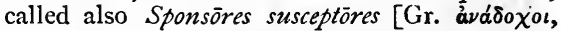
Eng. gossips (i.e. God-sibs, or relations in God), Godparents]. The term Fide jussores is now used for bail sureties in the Instance Court of the Admiralty. - Admiral Smyth's Sailor's Word-Book.

Fidessa. (Duessa.)

Fiduciary. [L. fidūciārius, from fidūeia, trust, from fīdus, trusty.] 1. (Leg.) One who holds property in trust. 2. In Theol., one who denies the necessity of good works, insisting on aith only.

Fĩdŭs Achātes. [I., faithful Achates.] The trusty follower and tried friend of AEnēas (Virgil, Aneid); hence any staunch friend.

Fief. [L.L. feodum, from Goth. faihu, A.S. feoh, cattle; hence other goods, especially money; hence property in general.] An estate in lands held of a feudal superior. (Fee.)

-field, -feld, as part of geographical names, is the A.S. feld, a clearing in forest-land, where trees have been felled; as in Cuck-field, Fel-sted.

Field. [A.S. feld.] (Her.) The whole surface of an escutcheon.

Field fortification. (Mil.) The throwing up of such works as are required for retrenching villages, camps, and posts, in aid of temporary operations in the field.

Field officer. (Mil.) Every officer holding the rank of colonel, lieut.-colonel, or major in the army.

Field of the Cloth of Gold. (Hist.) The name given, from the splendour of the ceremony there 
observed, to the spot, between the French towns of Ardres and Guines, where Henry VIII. with Wolsey met Francis I. (1 520).

Field-piece. (Mil.) Light artillery (drawn by horses) which takes part in the evolutions of troops.

Fieldwork. (Mil.) Any earth or stockade work constructed for the protection of troops in the field.

Fiĕri facias. [L., cause thou to be made.] (Leg.) A judicial writ, commanding a sheriff to levy the amount of debt or damages recovered in the Queen's courts by execution on goods and chattels.

Fi. fa. (Fieri facias.)

Fife-rails. (Naut.) The rails above the bulwark of poop and quarter-deck, and round the mainmast.

Fifth-monarchy men. (Hist.) A faction or sect which regarded the protectorate of Cromwell as the foundation of a fifth monarchy (succeeding those of Assyria, Persia, Greece, and Rome), in which Jesus Christ would reign visibly for a thousand years. (Millennium.)

Figala. (Naut.) An E.-Indian boat, having one mast, and paddles.

Figăro. Beaumarchais's barber of Seville, and in Le Mariage of $F$, a valet de chambre. An adroit, unscrupulous intriguer.

Figger. (Naut.) A Smyrna trader.

Figgie-dowdie. [Figs and dough.]

A kind of plum-pudding.

Fighting-lanterns. (Naut.) Used in night actions, generally one to each gun.

Fighting-sails. (Naut.) In sailing-ships, usually the courses and topsails only.

Fighting-water. (Naut.) Casks of water, dashed with vinegar, placed on the decks, for use in action.

Fights. (Naut.) Wastecloths hung about a ship, to hide men from the enemy. Close-fights, i.g. close quarters.

Figurant, fem. -ante. [Fr.] An inferior operatic dancer; fem., a ballet-girl.

Figurate numbers. (Math.) Such as can be written as fractions in which numerator and denominator are factorials of the same number of factors having unity for a common difference ; the first factor in the denominator is unity, but in the numerator it may be any number whatever; e.g. $\frac{7.8 .9}{1.2 .3}=84$, which is a F. N.

(Factorial.)

Figure. [L. figūra, shape, form.] 1. (Naut.) The principal ornament at a ship's head. $F$. head, a carved bust or figure at the prow. 2 . (Rhet.) An effective mode of expression, which ceviates from the plainest form of utterance. There are $F$. of thought, as a simile; and $F$. of language, as antithesis, chiasmus. Figures affect clauses and sentences, while a Trope affects a single word.

Figured. (Her.) Bearing a human face.

Figured bass. In Music, with numbers above and below, is a kind of musical shorthand, indicating the harmony.

Filacer, Filazer, Filizer. [Fr. filace, from L. filum, thread.] (Leg.) An officer of superior courts, who filed original writs, etc., and issued processes thereon. The office is now abolished. Filadiere. (Naut.) A small, flat-bottomed boat of the Garonne.

Filature. [Fr.] A reel for winding off silk from cocoons.

File. [Fr. file, thread, L. fïlum.] (Mil.) The front and corresponding rear rank man of any double rank of soldiers drawn up in line.

Filiated colleges. Educational institutions, residents at which can proceed to degrees at the filiating (i.e. adopting, as L. filius, a son) university upon examination only.

Filibuster. A freebooter, of which word it is a corr. Hence the Sp. filibote, flibote, a fastsailing vessel. (Buccaneer; Flûte.)

Filiform. (Bot.) Slender and round, like a thread [L. filum]; e.g. stem of dodder.

Filigree. [Fr. filigrane, from It. filigrana, L. fillum, a thread, grānum, a grain, i.e. bead.] Network of silver wire adorned with beads.

\section{Filiōque. (Nicene Creed.)}

Fìlǐus mulierātus. [L.L.] (Leg.) Eldest legitimate child of a woman who cohabited with her husband before marriage.

Filius nullius. [L., son of nobody.] Illegitimate child or son of an obscure person. (Hidalgo.)

Filius pŏpŭli. [L., son of the people.] Illegitimate child.

Filler, Fill-horse. (Thiller, Thill-horse.)

Fillet. [Fr. filet, thread.] (Her.) The diminutive of the chief, being at most one-fourth its size. The chief being divided into four equal horizontal strips, the lowest strip would be the fillet.

Fillibeg, Philabeg. [Scot. Gael. filleadh beag, little plaid (Latham, s.v.).] A kilt, or kind of petticoat reaching only to the knees, worn by the Scotch Highlanders.

Fill the mainyard, To. (Naut.) To fill the main-topsail, after it has been aback.

Filoselle. [Fr., L.L. folasellum, firosellum, It. filugello; corr. of a dim. of L. filum, thread. j A coarse-twisted floss silk.

Fimbria. [L., a fringe.] (Anat. and Bot.) A fringe-like part, or process; e.g. the margin of a pink.

Fimbriated. [L. fimbriātus, fringed.] (Her.) Having a border of a different tincture.

Finality John. Nickname of the late Earl Russell, who thought the Reform Bill of I 83 I final.

Fine. [L. finis, end.] (Leg.) 1. A lump sum paid to a landlord on entrance into tenancy or on renewal of a lease. 2. An assurance by record (often with four terminal proclamations in the Court of Common Pleas) of a transfer of property founded on a fictitious pre-existing right - the transferer being called the deforceant, conusor, or recognizer; the recoverer the plaintiff, conusee, or recognizee.

Fine-drawing. Sewing up a rent so that the seam is not visible.

Fine metal. White cast iron.

Finesse. [Fr.] Artifice, acuteness, nicety, trickery.

Fin-foot. (Zooi.) Water-bird, about thirteen 
inches long, with lobated feet like grebes. America, Africa, and Borneo. Sub-fam.

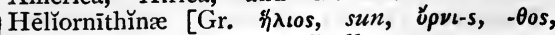
bird], fam. Rallidæ, ord. Grallæ.

\section{Fingers and toes. (Anbury.)}

Finial. [L. finis, an end.] (Arch.) The top or finishing of a seat, pinnacle, or gable. (Crockets.)

Finis corōnat öpus. [L.] The end crowns the work.

Finner. (Zool.) Gen. of whales with dorsal fin and skin furrowed. Temperate and cold latitudes. Ord. Phȳsălus.

Finnic. (Lang.) Name of a northern Turanian or agglutinative group of languages; also called Norse.

Finos. [Sp., fine.] Second best Merino wool.

Fiord. [Norw. form of the word frith or firth.] A narrow inlet of the sea, penetrating far inland.

Fioriture. [It.] (Music.) Florid passages in melody or accompaniment.

Fir-bome, Fire-bare. [(?) Ger. feuer, fire, baum, tree.] Old names for a beacon.

Fire, Greek. (Greek fire.)

Fire and lights. In Naut. slang, the masterat-arms.

Fire-annihilator, Phillips's. A contrivance for extinguishing fire by pouring in streams of carbonic acid, sulphurous acid, and other gases which do not support combustion. Drops of sulphuric acid are made to fall from a bottle, when broken, upon a mixture of chlorate of potash and sugar; and the intense combustion of the sugar fires a surrounding mixture of charcoal, nitre, and gypsum, and dense volumes of the above-mentioned gases are evolved.-Chambers's Encyclopadia.

Fire-ball. 1. A luminous meteor, like a large shooting star. (Elmo, Fire of St.; Castor and Pollux.) 2. (Mil.) Globular framework of iron containing an inflammable composition projected from mortars during the night to discover the positions of the trenches of besiegers.

Fire-bill. (Naut.) The placing of officers and men at fixed stations in case of fire. F.-booms, spars to keep off burning ships, etc. F-screens, pieces of fearnaught put round hatchways in action.

Firebote. (Leg.) Necessary fuel allowed to be taken off the land by tenants.

Fire-box; F.-tubes. The chamber of a locomotive engine in which the fire is placed is the Fire-box; the tubes passing through the boiler which convey the heated air from the fire to the smoke-box are $F$.tubes.

Fire-clay, Fire-brick. A nearly pure silicate of alumina, able to retain its form against a great degree of heat, owing to the absence of lime, etc., which would act as a flux. The clay-bed, or seat-earth, underlying nearly every coal-seam, is good fire-clay; its carbonaceous blackness goes off with burning.

Fire-damp, in mines ; or Marsh gas, as being generated in bogs, etc. Light carburetted hydrogen; After-damp, Choke-damp, or Stythe, being the carbonic acid gas formed by the explosion.
Fire insurance. (Life assurance.)

Fire-raising. In Scotland, arson.

Fire-ship. (Naut.) A ship fitted with grap-. pling irons, and filled with inflammable materials, to set fire to the enemy's ships.

Fire-swab. A mop of rope-yarn, wetted, and used to cool a gun and mop up loose powder.

Fire-water. The name given by some of the Indian tribes to ardent spirits.-Bartlett's Americanisms.

Fire-worshippers. (Guebers.)

Firkin. [Dim. of four; cf. farthing, firlot.] 1. Of ale, nine gallons. 2. Of butter, fifty-six pounds. 3. Of soft soap, sixty-four pounds.

Firlot. [Said to be A.S. feórtha hlot, fourth lot, or part.] An old Scotch dry measure, $=$ a quarter of a boll, which latter varies in quantity according to the locality and the article measured; but in the case of oats is $=\operatorname{six}$ bushels.

Firman, or Fermân. [Pers.] In Persia and the Turkish empire, any mandate of the sovereign, from an ordinary passport to an instrument conveying extraordinary privileges. (Hattisherif.)

\section{First-fruits. (Annates.)}

First intention. (Intention.)

\section{First-pointed style. (Geometrical style.)}

Firth-guild. [A.S. ferd, army, and guild (q.v.).] An association of a hundred men to carry out a deadly feud or avenge manslaughter. Fìscal. [L. fiscālis, from fiscus, moneybasket, emperor's privy purse.] 1. Pertaining to the public treasury. 2. (Scot. Law.) A public prosecutor in petty criminal cases.

Fish, Fish-piece. A long spar, round on one side, hollowed on the other, bound to masts or yards to strengthen them. To $F$., to strengthen them thus. To $F$. the anchor, to turn it upside down for stowing.

Fish-beam; F.-bolt; F.-joint; F.-plate. A Fish-beam is one flat at top and curved below, being thickest in the middle-like a fish's belly - so as to offer at all sections a resistance bearing a uniform ratio to the bending moment; the beam is thus equally strong at all sections. A F.-joint fastens two rails end to end, by means of $F$.plates, which are flat pieces of iron an inch thick placed on each side of the rails and fastened by four screw-nuts and bolts, called $F$.-bolts, two of which pass through the foot of the one rail, and two through the head of the other.

Fisherman's ring, In Latin, Annülus piscātôris. A seal of the pope; its device being St. Peter in a boat casting his net.

Fisherman's walk. (Naut.) A very small space ; "three steps and overboard."

Fish-fag. (Naut.) 1. A woman who carries a fish-basket. 2. A slattern.

Fish-fights, siamese. The Ctĕnops pugnax, a small fresh-water fish, is kept for this purpose; exhibitions of fights between these are licensed, yield considerable revenue, and are connected with desperate gambling.

Fishing hawk. (Osprey.)

Fish-stew. [Low Ger. stauen, to stop, to make 
a dam (stau).] A pond for rearing and fattening fresh-water fish.

Fission. [L. fissiō, -nem, a splitting.] Reproduction by division of the parent, either partial, as in many corals, or complete, as in some hydrōzōa.

Fissiparous. [L. findo, sup. fissum, $I$ cleave, părio, $I$ beget.] Dividing into parts, each of which is a reproduction of the original. (Gemmation.)

Fissiped. [L. fissǐ-pědem.] Cloven-footed, as deer ; a division of Ungǔlāta.

Fissirostrals, Fissirostres. [L. fissus, split, rostrum, bill.] (Ornith.) Wide-billed birds; a tribe or fam. in those systems which characterize birds by their bills. It includes swallows and goat-suckers.

Fissures-of-retreat. (Geol.) 1. In granite and basalt, due to contraction in solidifying from a molten state. 2. In septarian nodules $(q . v$.$) , to$ solidification from a soft wet state; so also mudcracks, i.q. sun-cracks, found fossil, are F.

Fistŭla. [L.] 1. A shepherd's pipe, generally a Pan's pipe. 2. (Med.) A tubular ulcerous channel, with constant discharge.

Fitch. [O.E. fitchew, polecat.] The fur of the polecat.

Fitches. Isa. xxviii. 25; the same word as vetches [L. viciæ].

Fitchett, Fitchew. (Polecat.)

Fitchy. (Her.) Sharpened to a point, so that it might be fixed [Fr. fiché] in the ground.

rits of easy transmission and reflexion. Newton supposed that the molecules of light in their progress through space pass continually into alternate states which recur periodically at equal intervals. In one of these it is disposed to obey the reflective forces of the body which it meets; it is then in a Fit of easy reflexion. In the other state it is disposed to obey the refractive forces of the body, and is then in a Fit of easy transmission. Newton proposed by this means to account for the colours of thin plates.

Fitter. A skilled workman who exactly adjusts the parts of a machine to each other before it is finally put together.

Fitz-. Part of names, $=$ son of [for Norm. Fr. fiz, = Fr. fils, from L. fillius] ; often forming surnames of royal bastards; as Fitz-James, Fitz-William, Fitz-Herbert.

Five-Mile Act, 0xford Act. (Eccl. Hist.) An Act passed, 1665, ordaining that, except in travelling, no Dissenting teacher who had not submitted to the declaration required by the Act of Uniformity should approach within five miles of any corporate town.

Five points. (Eccl. Hist.) Five doctrines debated between Calvinists and Arminians : (I) Particular election; (2) particular redemption; (3) total depravity of human nature; (4) irresistible grace; (5) final perseverance.

Fives. A game in which a small hand-ball is hit by the hands before the second bound against the front or side walls of a three-sided court; played sometimes with one wall only.

Five-share men. (Naut.) Men who enter on whalers, etc., and agree to take a share of the proceeds of the voyage as pay.

Fixed air. An old term for carbonic acid gas, from its existence in a fixed state in limestone, etc.

Flag. [From flag, to droop or flutter (Skeat).] (Naut.) Taking a Flag to be oblong, the Cornet is a swallow-tailed $F$., in signalling called a Burgee; which, otherwise, tapers either to a point (and is then, in signalling, a Pennant) or to a pair of swallow-tails, which latter is the shape of a Broad pennant. In the R.N., a Pennant, Whiff, or Whip is flown at the masthead, and is lengthened according to a ship's Flag-time, i.e. period of foreign service. The leading British nautical flags are as follows:1. The National F., viz. (I) the Union Fack, a combination, heraldically incorrect, of the crosses of St. George, St. Andrew, and St. Patrick, with a broad white border; and (2) the Red Ensign. 2. The Blue E., restricted to the Naval Reserve, certain Government services, and Royal Yacht Clubs. 3. The White $E$. with a red cross, or St. George's $E$., is restricted to the R.N. and the R.Y. squadron. Each E. bears in the upper corner next the mast the U.J., the use of which, undifferenced, is similarly restricted to the R.N., where it is flown in the bows, but by the admiral of the fleet at the main. 4. Admirals, Vice-A., and Rear-A. fly the old English colour, or St. George's Fack, i.e. plain white with plain red cross, at the main, fore, and mizzen, respectively; formerly they flew the R., the W., and the B. E. respectively; rank in each division being further denoted by the mast at which each E. was flown. A commodore flies a Broad pennant at the main or fore, according to his class; all of a lower rank fly the ordinary White E. at the peak or flagstaff. 5. The Pennant, flown by all ships in commission, White for the R.N., and Blue for armed Colonials, etc., bear a St. George's cross next the mast. There are many other British flags appropriated to various services, colonies, and dependencies ; as the Royal Standard, showing that one of the royal family is on board; the Red E. with the Dominion arms in the fly for Canada; the Green, Red, White Tricolour (horizontal), with the U. J. in the upper corner next the mast, for Heligoland. Some foreign merchantmen's flags are subjoined. War and governmental $\mathrm{F}$. vary, sometimes very widely, from merchantmen. France: blue, white, red. Italy: green, white, red. Belyium: black, yellow, red. Portugal: blue, white ; all vertical, and reckoned from the mast outward. Holland: red, white, blue. Russia: white, blue, red. Germany: black, white, red. Spain: yellow, red, yellow, red, yellow. Austria: red, white, with two coats of arms, half red and half green. Greece: five blue, four white, with Jack in corner; all horizontal, and reckoned from the top downward. Denmark: red with white cross. Norway: red with blue cross, and Jack in corner. Sweden: blue with yellow cross, and Jack in corner. $U$. S. A.: red and white horizontal stripes, with white stars on blue ground in corner, 
corresponding in number to the states in the Union. Turkey: green, with white crescent on red central disc. Egypt: red, with white crescent and three stars. The terms Flag and Pennant are sometimes used to denote admiral and commodore respectively.

Flagellants. [L. flagellantes, from flăgello, $I$ whip, scourge.] Fanatics who, first at Perugia, A.D. 1260, and elsewhere through Italy, then, at intervals, in many other parts of Europe till the sixteenth century, found in self-scourging a vent for wild religious feeling.-Milman, Hist. of Latin Christianity, bk. vi. 334 .

Flagelliform. (Bot.) Shaped like the thong of a ivhip [L. flăgellum].

Flăgellum. [L., a scourge, a young shoot.]

(Bot.) A vegetating node, a runner; e.g. strawberry.

Flagrante dēlicto. [L., while the offence is hot.] In the very act.

Flag share. The admiral's share, one-eighth, in prizes.

Flake-white. The purest white lead, in flakes or scales, used in oil-painting.

Flambeau. [Fr., a torch.] A large wax-light for illuminations.

Flamboyant. [Fr.] (Arch.) The French term for the style of architecture answering to the Flowing English, from the flame-like forms of the tracery. (Geometrical style.)

Flämen. The Latin title for the priests of any particular deity, as distinguished from priests in general.

Flamingo. [Sp., from its colour.] (Zool.) A gregarious, wading bird, five or six feet high. Full plumage, red, with black quill feathers. Tropical and Southern countries, but not Australasia ; occasionally S. Europe. Phœnicoptěrus

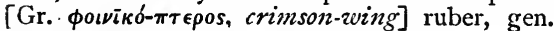
P., fam. Phœnīcoptěrĭdæ, ord. Grallæ.

\section{Flamingo plant. (Anthurium.)}

Flaminian Way, Via Flaminia. Made by C. Flaminius, B.C. 22I ; led from Rome to Ariminum ; continued to Milan, as the Via Emilia. (Emilian Provinces.)

Flanche. (Her.) An ordinary bounded by two circular arcs projecting, one from each side of an escutcheon. A Flasque is of the same shape but wider, and a Voider wider still.

Flancois. [Fr. flanc, flank, L. flaccus, as being the weak, flabby part (Littré).] Covering of armour for the flanks of a horse.

Flâneur. [Fr. flâner, to stroll about.] A lounger, idler, man about town.

Flandrin. [Fr.] 1. A Fleming, or man of Flanders. 2. As a nickname, a lanky, meagre fellow.

Flange; F.-beam; F.-joint； F.-rail ; F.wheel. A projecting edge or rib. A Flange-joint consists of projecting pieces on two shafts or pipes, by which they may be securely bolted together end to end. A $F$.-rail has a projecting edge on the outside, so that a wheel with a flat tire may not slip off it. Railway cars have $F$.-zwheels, the flange being the projecting part, of larger diameter than the rest of the tire, which restrains the wheel from leaving the rail. A
$F$.-beam has along its length a flange at its upper and under side, the part between them being often thin (and called a web), so that the resistance it offers to bending is mainly exerted by the flanges. (Flank.)

Flank, probably from L.' flaccus. (Flancois.) 1. (Mil.) Either extremity of a line of troops. 2. (Fortif.) The rampart at the extremity of a face of a work.

Flanked angle. A salient in fortification, defended by a cross-fire from some other work.

Flash. Burnt sugar and capsicums for colouring spirits.

Flashing signals (Naut.) are effected by dots and dashes as in electric telegraphy. At night a white light is exposed and quickly covered for a dot, and left longer exposed for a dash. In the daytime the dots and dashes are indicated by collapsing cones.

Flask. [Ger. flasche, bottle.] The box in which moulds for castings are made.

Flasket. [Welsh fflasged.] A long shallow basket.

\section{Flasque. (Flanche.)}

Flat aback. (Naut.) Sails so much aback as to give stern-way.

Flat-fish. (Pleuronectidæ.)

Flatting. [Probably Fr. flou, softness of touch (Flou).] 1. A mode of painting, which leaves the work without gloss. 2. A method of gilding, where it is unburnished but covered with size. 3. Rolling out metal into plates.

Flavescent. [L. flāvescentem, p. part. of flāvesco, I grow yellow (flāvus).] Turning yellow.

Fleam. [L.L. flěbŏtŏmum, fletum (Phlebotomy).] (Vet.) A short lancet projecting from the side of a straight piece of steel, used by percussion for bleeding horses and cattle.

Flèche. [Fr., an arrow, M.H.G. flitsch.] 1. (Mil.) A work in the shape of an arrow, at the foot of a glacis, covering the communications with advanced works. 2. (Arch.) A slender spire.

Flecherra. (Naut.) A swift despatch-vessel; S. America.

Flectĕre si nĕqueo sŭpěros, Ăchĕronta mŏvēbo. [L.] If I fail to bend the gods above, I will stir up hell below (Virgil). (Acheron.)

Fleece, Order of the Golden. An order of European knighthood, founded by Philip III., Duke of Burgundy, I430. (Golden fleece.)

Fleet. A.S. name or part name, = channel [Norse fliot; $c f$. A.S. fleotan, to float], as in Fleet Street, Pur-fleet.

Fleet marriages. Until A.D. I754, mutual consent alone sufficed for legal civil inarriage in England; but a full marriage as to Church communion and its important consequences bearing upon baptism, legitimacy, probate of wills, etc., required a priest. Numberless secret marriages had been performed in "lawless churches," i.e. in churches claiming exemption from the ordinary's jurisdiction; amongst them Fleet marriages by clergymen imprisoned in the Fleet. Abolished by Lord Hardwicke's Act, A.D. 1754. (See Eng. Cycl., ii. 1016.)

Flemings. [Cf: O.E. fléem, outlazv, from 
A.S. flean, to slay.] The tribe which gave its name to Flanders; perhaps = outlaws or their descendants.

Flemish. Of or from Flanders.

Flemish account. In Naut. parlance, one showing a deficit.

Flemish school. A school of painting, established by the brothers Van Eyck, at Ghent and Bruges, early in the fifteenth century, and marked by excellence of drawing, colour, and chiāro-scüro. Rubens, Vandyke, and Teniers were the great masters of the second period.

Flensing. [Dan. flensen.] Cutting up the blubber of a whale.

Flesh traffic. (Naut.) Slave-trade.

Fleta, seu Commentārium Jūris Anglicani. [L.] (Leg.)' A treatise on the whole law, after Bracton and Glanville, composed in the reign of Edward I.

Fleur-de-lis. [Fr.] 1. The lily of the royal arms of the French kings, represented in a form more like that of the head of a javelin. 2. In Her., used (I) as a charge, or (2) as difference in the sixth son's escutcheon.

Flexor muscle. [L. flecto, $I$ bend.] It bends the part on which it acts. (Extensor muscle.)

Flexure, contrary, Point of. (Singular point.)

Flight. A Dutch canal-boat.

Flint-glass. Glass composed of silicate of potash and oxide of lead, used for table glass and for optical instruments.

Flint implements. Instruments of various kinds; weapons, arrow-heads, knives, and when fixed to wooden handles-hatchets, etc., used by primitive and by savage man.

Flipper. (Naut.) The fin or paw of seals, etc. ; meton. the hand.

Flitter-mouse. [Ger. fleder-maus.] The bat. (Cheiroptera.)

Float. 1. The channel which distributes water for irrigation. 2. A wooden trowel used in plastering.

Float-board. A board fastened radially to an undershot water-wheel, or to a paddle-wheel of a steamer, to give the water a hold for turning the wheel or propelling the steamer.

Floating anchor. (Anchors.)

Floating coffins. A nickname of the old tengun brigs. Unseaworthy vessels.

Floating islands. In lakes and slow rivers; sometimes a collection of driftwood and alluvial soil, e.g. those carried out fifty to a hundred miles from the mouth of the Ganges ; sometimes, as in Scotland and Ireland, masses of floating peat; others appear and disappear, e.g. one in Derwentwater ; some, as the Floating Gardens of Cashmere, and the Chinampas of Mexico, are artificial, and very ancient. (Rafts.)

\section{Floating ribs. (False ribs.)}

Floccillation. [L. floccillus, coined dim. of floccus, wool.] A delirious picking of the bedclothes before death.

Flock. [L. floccus.] The refuse of cotton and wool, used for stuffing mattresses, etc.

Flogging the glass. (Naut.) Shaking the half-hour glass, by which the bells are regulated, to make the sand run quicker.
Flood anchor. (Naut.) The anchor used during the flood-tide.

Floor. (Naut.) The bottom of a ship; strictly, what rests on the ground when a ship is ashore.

Flora of a country or geological epoch $=$ the plants belonging to it. (F., the goddess of flowers.) (Fauna.)

Flörälia, Flōrāles Lūdi. [L., floral games.] A Roman festival in honour of Flora, from April 28 to May 2, conducted by the Ædiles, and celebrated with theatrical performances, and much general licence.

Floreal. Eighth month of French first Republican calendar, from April ig to May 20.

Florin. A coin having different values in different countries: the Austrian florin (or gulden) is worth about $2 s$. ; the Bavarian F. or G. about is. $8 d$.; the Polish F.about $5^{\frac{1}{2}} d$. (Originally a gold coin struck at Florence, in the thirteenth century, having on one side the head of the Baptist, on the other a lily: called from the city, or from the flower (?).)

Flory. [Fr. fleuri.] (Her.) Adorned with fleurs-de-lis.

Floss. [L. flos, flower.] 1. Untwisted filaments of silk, used in embroidery, etc. 2. A glassy scum floating on iron in the puddling furnace.

Flota. The Spanish word for fleet, applied to the ships sailing under convoy from Cadiz, or other ports, to the Transatlantic possessions of Spain.

Flotant. [Fr. flottant.] (Her.) Floating in the air.

Flotation, Plane of. [Fr. flot, a wave, L. fluctus.] The imaginary section of a body made by a plane coinciding with the surface of the still water in which it floats.

Flotsam, Flotson (i.e. floating). Derelict or shipwrecked goods floating on the sea; as distinguished from Fetsam, or Fetson [L. jactationem, a throwing over], goods thrown over and sunk; Lagan [i.e. lying ; $c f$. Ger. legen, to lay], goods sunk with the wreck, or attached to a buoy, as a mark of ownership.

Flou. [Fr.] A term in painting, meaning softness of touch; formerly flo, the Flem. flaun, or L. fluĭdus (Littré); but are not these connected?

Flower-Girl Brigade. A society of flowergirls in London, founded by Lady Burdett Coutts, 1879, which seeks to improve their condition by regulating the supply of flowers, the conditions, places, etc., of sale, with fixed payment or commission.

Flower of the winds. (Naut.) The compass, as drawn on maps and charts.

Flowers of sulphur; F. of zinc. Sulphur, or white oxide of zinc, condensed from sublimation ; so called from their appearance.

Flowing sheet, With a. (Naut.) With the wind at about right angles to a ship's course.

Flowing style. (Geometrical style.)

Fluctuation. [L. fluctuātǐo, -nem, a wavering motion.] (Med.) Undulation of fluid in any cavity of the body, as distinguished by proper manipulation. 
Fluent. [L. fluentem, p. part. of fluo, I flowv.] (Math.) A quantity whose value changes continuously; thus the length of the path described by a moving point changes continuously with the time. In Newton's language, a $F$. is what is more commonly called an Integral.

Flummery. [Welsh llymry, $a$ kind of oatmeal gruel.] 1. Pap. 2. Metaph. silly talk, finniking ornament.

Fluorescence. If we look through a solution of sulphate of quinine at the end of the solar spectrum which is beyond the violet rays and dark to the naked eye, we see a blue-coloured light, arising from a lessening of the refrangibility of the rays beyond the violet rays; i.e. the solution reduces the rate of the ethereal vibrations to within the limits at which they produce the sensation of light. This phenomenon-which can be exhibited in several forms-is called $F$.

Fluorine. A colourless gas, one of the elements, occurring in fluor-spar.

Fluor-spar [a word coined from L. fluo, 1 flowe ; i.e. useful as a flux in fusing iron ore], or Derbyshirespar (q.v.).] (Min.) Fluoride of calcium, calcium fluorine; a mineral common in some metalliferous lodes.

Flush at cards. A hand in which all the cards are of one suit.

Flush-deck. (Decks.)

Flûte, Armed en. [Fr.] (Naut.) Partly armed, as a flute, fluyt, or fly-boat (q.v.) might be. (Filibuster.)

Fluviatile. [L. flŭvīătı̌lis, belonging to a river (flŭvius).] (Geol.) 1. Produced by river action. 2. Of or belonging to rivers.

Flux. [L. fluxus, a flowing.] Any substance used to promote the fusion of minerals.

Fluxion. [L. fluxio, -nem, a flowing.] (Math.) The rate of change per unit of time of a Fluent, i.e. of a magnitude whose value changes with the time; thus the velocity of a moving point at any instant is the $\mathrm{F}$. of the length of the path described up to that instant. A F. is the name given by Newton to what is now commonly called a differential coefficient.

Fluxions, Method of. A mathematical method invented by Newton, equivalent to the differential and integral calculus subsequently promulgated by Leibnitz.

Fly; Fly-wheel. $A$ Fly consists of two or more vanes set on an axis to prevent the acceleration of the velocity of a falling weight by means of the resistance (which increases very rapidly with the velocity, and soon becomes equal to the weight) offered by the air to their motion. A $F$. -roheel is the heavy wheel keyed to the main shaft of a steam-engine; it serves as a store of energy to keep the angular velocity of the shaft uniform.

Fly-away, Cape. A cloud-bank mistaken for land ; i.q. Dutchman's cape.

Fly-boat. (Flûte; Filibuster.) (Naut.) 1. A Dutch vessel, from 300 to 600 tons burden, flatbottomed and high-sterned. 2. A fast canalboat.

Fly-by-night. (Naut.) 1. An extra sail like a studding-sail, used in sloops when before a wind. 2. A spare jib set from topmast-head to the yardarm of a squaresail.

Flyer. A venture. To take a $\mathrm{F}$. in stocks is the expression used in Wall Street when persons not stockbrokers, .or dealers in stocks, occasionally make a venture.-Bartlett's Americanisms.

Flying buttress. (Arch.) A buttress, shaped like an arch, springing from a mass of masonry on the external wall, and abutting against the springing of another arch. The flying buttresses of Amiens and Cologne Cathedrals are among the finest specimens.

Flying camp. Troops leaving their quarters, with provisions for two or three days and a limited amount of baggage, for the purposes of training under canvas and of constantly moving.

Flying colonrs, With (Mil.), = victorious; to exhibit the colours or flags of a regiment being considered somewhat of a display suited to important occasions. Only certain regiments may march through London with F. C.

Flying Dutchman. (Naut.) 1. Spectre ship supposed to haunt the Cape of Good Hope. 2. Any phantom vessel.

\section{Flying-jib. (Sails.)}

\section{Flying-jibboom. (Bowsprit.)}

Flying-kites. (Naut.) The lofty sails, as skysails, royal studding-sails, and those above them. Flying-light. (Naut.) Crank from insufficient ballast or cargo.

Flying-sap. (Mil.) Intrenchment formed on open ground by placing a row of empty gabions on end touching one another, and filling them as rapidly as possible from the earth immediately behind them.

Flying squirrel. [From Gr. $\sigma$ ki-ovoos, shadow. tailed, through L.L. dim. scīuriŏlus, Fr. écureuil.] (Zool.) Two gen. of squirrels, Sciūuroptěrus (flattailed) and Ptěromys (round-tailed), having the skin of their flanks so modified that, when they extend their legs, it extends correspondingly, enabling them to glide from tree to tree. Some spec. measure nearly three feet across. Sciūropterus is found in E. hemisphere from Lapland to Borneo, and in W. hemisphere from Labrador to California ; Ptěrŏmys in E. hemisphere only, from Himalayas to Borneo.

Flying-to. The ship's head coming up to the wind very quickly.

\section{Fly of a flag. (Hoist.)}

Fo. 1. The Chinese name for Buddha. 2 The dog of Buddha, the lion-like animal often forming the knob of a China vase-cover.

Focal length. 1. Of a lens or mirror, the distance from the surface to the principal focus. 2. Of a telescope, that of the object-glass.

Focus [L., a hearth]; Actual F.; Geometrical F.; Principal F.; Virtual F. 1. In Optics, the point to or from which rays falling on a lens or mirror converge or diverge after refraction or reflexion; in the former case the F. is Actual, as the rays meet in the focus; in the latter Virtual, as the rays proceed as if they diverged from the focus. When the incident rays are parallel to the axis, the point is a Principal $F$. If the surfaces of lens or mirror are spherical, the convergence to a point is accurate only on 
the supposition that their extent is indefinitely small ; the focus is always determined on this supposition, and when it is necessary to draw attention to the approximate character of the determination it is called a Geometrical $F .2$. (For Focus in Geom., vide Ellipse; Hyperbola; Parabola.)

Fœdum inceptu, fœdum exǐtu. [L.] Disgraceful in the outset, disgraceful in the issue (Livy).

Fœnum hăbět in cornu. [L.] Lit. he has hay on his horn; said of a dangerous head of cattle; he is a dangerous character (Horace).

Fœtus. [L.] The unborn child, from the time of quickening.

Fog. [L.L. fogagium, forest winter pasture.] $(A g r$.$) Grass not eaten down in summer. To$ $F$. is to shut pasture early in May, and to feed it from November or December till the next May.

Fogram. [(?) Catachr. from Grogram (Grog).] (Naut.) Indifferent liquor.

Föhn. [Ger.] In Switzerland, the moist south wind of spring; the L. Făvōnius (Horace, Od. I. iv.). (Pan.)

Foil arches. (Arch.)

Folcland. [A.S.] Land of the people, either held in common or parcelled out to individuals for life under the sanction of the freemen in their local meetings (fulc-gemote). It was assignable to freemen and to thegns. (Bocland.)

Fold. [A.S. falod.] Originally an inclosure of felled trees.

Folio. [L. folium, leaf.] A book formed of sheets so folded as to make two leaves each.

Folk-lore. The popular tales, traditions, and superstitions of a country; often of high antiquity.

Folkmote. [A.S. folc-mot.] Any public meeting of the folk of a given place or district, and varying with the latter in importance.

Follicle. [L. follis, $a b a g$, dim. follǐcŭlus.] 1. (Anat.) Small hollow gland of the skin, or mucous membrane. 2. (Bot.) A carpel not having dorsal suture, and dehiscing by the ventral suture.

Follǔcŭlus āĕris. [L., air-bag.] Formed by the duplicated lining membrane at the large end of a bird's egg.

Follower. In Machinery. (Driver.)

Followers. In sea phrase, men allowed to be taken by a captain in the navy when he changes his ship.

Föměs. [L., fuel.] (Med.) Any substance retaining contagious effluvia.

Fonda. [Sp.] $A n$ inn.

Fondus. [Fr. fondre, melted.] A style of printed calico, etc., in which the colours melt or shade into one another.

Fontange. [Fr.] A knot of ribbon on a head-dress, a top-knot (introduced by Mdlle. de F., 1679).-Brachet, Etym. Dict.

Fonticŭlus. [L., little fountain, dim. of fons.] (Med.) An issue.

Fools, Feast of. (Hist.) A feast celebrated anciently in French churches on New Year's Day; a survival, probably, of the Roman Saturnalia.

Foolscap. Paper twenty-seven inches by seventeen.
Fools' paradise. (Limbo.)

Foot-pound. A unit of work-the work done when a pound weight is raised vertically one foot. Foot-ropes. (Naut.) (Horse.)

Foots. Settlings of oil, sugar, etc., at the bottom of a hogshead.

Forage. [Connected with fodder and forray, L.L. foderare, to demand foder-age for man and horse (Wedgwood).] (Mil.) 1. Allowance of oats, hay, and straw, given to horses. 2. The searching for provisions of any kind is called Foraging. 3. The undress head-covering of a soldier is a $F$. -cap.

Fơrāmen. [L. fŏro, I bore, pierce.] 1. An opening, hole. 2. (Bot.) The small orifice in the integument of the ovule.

Fŏrāmǐnŭfĕra. [L. fơrämen, an aperture, fĕro, I carry.] 1. (Zool.) Ord. of Rhizŏpǒda (mouthless Prōtōzōa, capable of emitting pseudŏpŏdǐa, i.e. extensions for prehension and locomotion), with a test, or shell of carbonate of lime or of cemented sand-grains, filled, and sometimes invested, with sarcode. The pseudópŏdia are emitted from the mouth of or through holes [forämina]. in the shell, which is sometimes simple, and sometimes compound like that of the Pearly nautilus. Subkingd. Prōtōzōa. (Amœba.) 2. (Geol.) Their remains are found in the sands and ooze of existing seas, and in very many sedimentary strata, especially Fusulina limestone, chalk, Nummulitic limestone, Miliolite limestone.

Force [L.L. fortia, strength, from fortis, strong]; F. of inertia; Living F. Any cause which changes or tends to change the state of a body as to rest or motion; it is measured by the quantity of motion (i.e. the momentum) which it generates (or would generate if constant) in a unit of time. This word is often used loosely and even inaccurately. $F$. of inertia is the reaction of a body against another body by whose action its velocity is changed in magnitude or direction. (For Living F., vide Vis viva.)

Forced men. (Naut.) Men serving on board a pirate from compulsion.

Force majeure [Fr.] is used as $=$ a power against which one can do nothing. Sauf les cas de F. M., except in the case of impossibilities. (Vis major; Forlorn hope.)

Forceps. [L.] A pair of pincers or tongs.

Forcing-pump. A pump with a solid piston or plunger, and two valves in immediate connexion with the barrel ; one opening upwards at the top of the suction-pipe, the other outwards at the junction of the exit-pipe. On the upstroke water comes up the suction-pipe into the barrel, on the downstroke it is forced out of the barrel into the exit-pipe, and so to the cistern. The one valve keeps the water from returning out of the barrel into the suction-pipe, and the other out of the exit-pipe into the barrel.

Fore-and-after. (Naut.) 1. A cocked hat worn peak in front. 2. A schooner without any squaresails, or with only a crossjack-yard.

Fore-and-aft sails. (Naut.) Any sails not set on a yard.

Forebear. Ancestor, ancestress.

Forecastle. In a man-of-war, the upper deck 
before the after fore-shroud ; in a merchantman, the seamen's cabin forward. Top-gallant $F$., a raised deck extending from the bows to the foremast, which it includes.

Foreclose. [L.L. foris clauderre; to exclude from.] (Leg.) To take over property on which one holds a mortgage upon non-fulfilment of the mortgagor's agreement ; to apply for the extinction of the mortgagor's equity of redemption.

Foreclosure. A closing off or shutting off of a mortgagor from all right or equity of redemption. (Foreclose.)

Forefoot. ( N $^{\top}$ aut.) The curved timber which joins the stem and keel.

Forel, Forril. [O.Fr. forel.] Sheepskin prepared for binding, for drums, etc.

Forelock. (Naut.) An iron wedge driven through a bolt to hold it in its place.

Foremast-man. (Before the mast.)

Forensic. [L. forrensis, belonging to the forum.] Pertaining to courts of justice and law ; e.g. F. medicine (q.v.).

Forensic medicine, i.q. Medical jurisprudence. Medicine as bearing upon questions arising in law courts-of death, or injury, sanity, legitimacy, etc.

Fore-peak. (Naut.) 1. The narrowing part of a vessel's hold. 2. The part under the lower deck, close to the bows.

Fore-sheets of a boat. (Naut.) The part afore the bow oar.

Fore-sight. (Back-sight.)

Forestall. [A.S. foresteallan.] (Leg.) To buy up goods before they get to the market stalls, with intent to push up prices.

Forest courts. Old courts for governing the royal forests. They were: Woodmote, held by verderers every forty days, to try offences against vert or venison; court of regard, every third year, for expeditation of mastiffs; sweinmote, thrice a year before the verderers and a jury of sweins (freeholders) ; justice seat, before the justice in eyre.

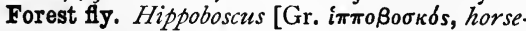
feeding]. (Entom.) Gen. of dipterous insect; round-bodied, producing its young advanced to the pupa stage. Gives name to fam. Hippoboscidæ ; forest flies and sheep-ticks.

Forest-marble and Fuller's-earth Oolite. (Geol.) Thin-bedded Lower Oolitic strata in the west of England, yielding roofing-stone, fuller's earth, etc.

Forfeiture. [L.L. forisfactura, expulsion or outlazory.] (Leg.) Punishment annexed to some illegal act or negligence in the owner of real property, by which his interest in it is transferred to another.

Forgavel. (Leg.) Quit-rent.

Forged Decretals. An imposture of the ninth century, ascribed to Isidore Mercator; a spurious collection of $D$., professedly of above thirty successive popes of the first three centuries. They-make the papal power supreme over bishops, give appeal to Rome in all cases, from all parts of the world, etc. (Decretals.)

Fork. (Fast and loose pulleys.)

Forkers. (Naut.) Thieves or receivers of dockyard stores; or dealers in tiem when stolen.
Forlorn hope. [A.S. for-loren, lost utterly.] (Mil.) Formerly the officers and men who volunteered to lead the way in some specially dangerous assault; a work now carried out by thuse next for duty. [Hope, D. hoop, Ger. haufen, Eng. heap, is body of men.] (Forve majeure; Life Guards.)

Form [L. forma] ; Hemihedral F.; Holohodral F. Form, in Crystallog., consists of a face and of the other faces which by the law of symmetry must coexist with it ; the Holohedral

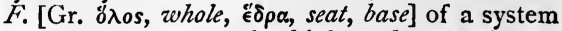
are such as possess the highest degree of symmetry; the Hemihedral $F$. [i $\mu_{i-}$, half $]$ are obtained from the holohedral by the omission in certain ways of half the faces.

Formā pauperris, In. [Leg. L.] In the character of a destitute petitioner.

Formation. [L. formātio, -nem, a shaping.] (Geol.) Strictly, subordinate to Sistem, and = special groups of strata.

Forme. [L. forma.] In Printing, the type from which an impression' is to be taken, arranged and secured in a chase (q.v.).

Formic acid. An acid obtained originally from red ants [L. formicx].

Formication. [L. formica, an ant.] A feeling like that of ants creeping over any part.

Form-line. A line used in surveying to give the outline of the shapes of hills, and to mark the points where the changes in the slopes take place.

Formŭla. [L.] In Math., a rule or theorem expressed by means of algebraical symbols.

Formulary. [L. formŭla, forma, $a$ form.] (Eccl.) 1. Any book containing the ceremonies, rites, or offices of the Church. 2. Any writing containing an official oath.

Forsăn ĕt hæc ölim mĕmǐnisse jŭväbit. [L.] Perhaps it will one day be a pleasure to remember this too (Virgil).

Fortem posce animum. [L.] Pray for a brave spirit (Juvenal).

Fortes creantur fortřbus et bonis. [L.] The brave spring from the brave and good (Horace).

Fort-major.: (Mil.) Performs duties in a garrison for the commandant, analogous to those which an adjutant does in a regiment.

Fortūnø filius. [L.] $A$ (favourite) child of fortune.

Fortūna fortes adjŭvat. [L.] Fortune helps the brave (Terence).

Fortūna multis dat nimium, nulli sătis. [L.] Fortune gives too much to many, enough to none.

Fortūna nōn mütat gĕnus. [L.] Fortune does not change the breed (Horace).

Fortünätus. Hero of a popular German story, who had an inexhaustible purse, and a wishingcap which took the wearer instantly to any part of the world; these two miraculous possessions proved F.'s ruin. (Hermes.)

Forty thieves. (Naut.) Forty line-of-battle ships which were built at the beginning of the century, and turned out badly.

Fŏrum. [L.] In Rom. Ant., any open space in front of buildings, especially before sepulchres. There were fora for merchandise, as well as for 
judicial and civil purposes. Especially the large market-place at Rome, where courts of justice were held, public speeches made, and money transactions carried on.

Fosse. [Fr., from L. fossa, a ditch.] In Fortif., the ancient term for ditch.

Fossil lightning. (Fulgurites.)

Fossils. [L. fossillis, dug up.] A word now applied to petrified organic remains, but formerly these were termed "extraneous fossils," and minerals were the real $\mathrm{F}$.

Fossway. One of the great Roman roads, from the south-west of Cornwall, by Tetbury, Coventry, and Leicester, to Lincoln.

Fothering. (Naut.) Stopping a leak by passing a prepared sail over it; i.q. Thrumming.

Fougass. [Fr. fougasse, L. focus, a fireplace.] (Mil.) Small mine, not more than ten feet underground, ignited from surface; containing merely a bursting charge, loaded shells, or a heap of stones, to destroy a small work or check an assault.

Foul anchor. (Naut.) An anchor is foul, or fouled, (I) when it hooks anything under water, as the cable of another vessel ; (2) when the slack of the cable gets round its stock, or fluke. The Admiralty badge is a $\mathrm{F}$. A. of the second kind.

Foulard. [Fr.] A thin fabric of silk or silkcotton; origin of the word unknown.

Foul berth. (Naut.) When two ships are so anchored that they and their cables cannot swing clear.

\section{Foumart. (Polecat.)}

Fount, Font. [Fr. fonte, from fondre, to cast.] A complete set of printing types of one size.

Four-centred arch. (Arch.)

Fourchée. [Fr.] (Her.) Having the ends forked or branched.

\section{Four-course shift. (Rotation of crops.)}

Fourierism. A system of socialism; so called from Charles Fourier, of Besançon, its promulgator, who died in 1837 .

Fowler's service. (Rowan.)

Fox. [Heb. shu'al.] (Bibl.) Includes the jackal.

Foxing. 1. Turning sour; said of beer. 2. Covering boots, etc., with new front upper-leather. 3. The appearance of spots upon paper.

Fox-tail. (Bot.) An important gen. of grasses, of which Ǎlōpěcūrus prātensis, ord. Gramineæ

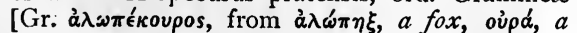
tail], is one of the best for pastures and for lawns.

Foyer. [Fr.] (Theatr.) The green-room. [L.L. fŏcarium, a fireplace.] (I) A fireplace; then (2) a home; then (3) a particular room.

Foying. (N'aut.) Going off to ships, with provisions, or to aid them.

Foyst. (Naut.) Old name for Brigantine (q.v.).

Fracas. [Fr. fracasser, to shatter, It. fracassare.] Noisy interruption, quarrel in public, disturbance.

Frache. In glassworks, a flat iron pan, in which glass vessels are put, to be placed in the oven.

Fracted. [L. fractus, broken.] (Her.) Having a part displaced, as if broken.
Fraction. [L. fractio, -nem, a breaking.] In Arithmetic, one or more aliquot parts of unity. A F. can be expressed only by two whole numbers, one to denote the parts into which the unit is divided, and the other to show how many of these parts are taken to form the $F$. The first of these numbers is called the denominator, and the second the numerator.

Fra Diavŏlo. [It., Brother Devil.] 1. Michele Rezza (1740-1806), Calabrian bandit and guerilla chief against the French. 2. Name of a bandit in Auber's opera of that name.

Fradubǐo. [It. fià, betzveen, dúbbio, doubt.] In Spenser's Faëry Queene, a type of the undecided in that day in the matter of Rome and the Reformation.

Frail. [Norm. fraile.] A rush basket.

Fraise. [Fr., a fringe, from Sp. fresco.] (Mil.) Pointed stake, a row of which, inclined downwards, is placed along the upper edge of a ditch, to increase difficulty of an assault.

Frame of a machine. The part which supports the moving pieces.

Franc. The French unit of money. It is a coin made of nine parts of pure silver and one of copper, and weighs five grammes; = Iod., nearly.

Francesca of Rimini. One of the women whose doom is related by Dante, in his Inferno.

Franciscans. One of the four mendicant orders founded by St. Francis of Assisi, in 1209. (Dominicans ; Orders, Mendicant.)

Franconia. Name of a German province before 1714, now almost included in N.W. Bavaria.

Franc-tireur. [Fr., lit. free-shooter.] Irregular sharp-shooter, generally raised from amongst the dependents of the French country gentry during the late war with Germany; a revival of a kind of soldier common in the Middle Ages.

Frangas non flectes. [L.] You may break, you will not bend (Juvenal).

Frangipanni. [It.] A scent, derived from a W.-Indian flower.

Frank-aleu. In feudal language, land acknowledging no superior; hence not a tenure. (Allodium.)

Frankalmoigne. [Norm. Fr., free alms.] A gift of lands to those who were consecrated to the service of God, upon the condition that Masses and divine service be said for the grantor and his heirs ; the only way, anciently, of alienating without an heir's consent lands which had come by descent; and the tenure by which, mostly, Church lands are held now by corporations sole or aggregate (q.v.).

Frankenstein. Mrs. Shelley's student, who makes a soulless monster, endowed with a kind of human life, but debarred by its hideousness from sympathy. By a series of horrible crimes, it inflicts a terrible vengeance on the author of its wretched being.

Frank-fee. Freehold lands exempt from all services except homage.

Frankfort black. A German pigment obtained from calcined vine branches.

Frankincense. Exod. xxx. 34 ; a constituent 
of incense, the fragrant gum of three spec. of Boswellia (see Speaker's Commentary, and "Boswellia" in Eing. Cycl.).

Frank letters, To. To send them free of postage. Members of either House of Parliament could do this, by signing their names outside. In January, 1840, when the penny post was introduced, the privilege was abolished.

Franklin. [O.E.] A bailiff or steward of an estate.

Frank-marriage. (Leg.) A kind of tenure by which tenements were held when given to a man and his wife, she being daughter or cousin to the donor, for them and the heirs of their body, with no service except fealty.

Frankpledge. (Feud.) A surety given by a lord for his tenants, or by a tything for its members, making the lord or the tything responsible for the were, or money payment of offences committed by those who might abscond. The tythings, as thus pledged, were called Frithborhs, peace-boroughs. 'This word became corrupted into Friborhs, and the Normans hence invented the phrase Frankpledge. (Leet, Court.)

Franks. A Germanic confederacy of tribes, freemen, who established themselves in and gave the name to France.

Frank-tenement. (Leg.) A freehold estate held under tenure of (1) knight-service, (2) of free socage.

Frap. (Naut.) A boat for shipping salt (Mayo, Cape de Verde). To $F$., to brace tightly together. To $F$. a ship, to pass a large rope round her four or five times, so as to strengthen her; also, to snap your fingers, and to beat [Fr. frapper].

Frāter consanguiněus. [L.] A half-brother by the father's side ; F. üterinus, by the mother's.

Fraticelli. [It., brethren.] (Eccl. Hist.) A Franciscan sect founded in Italy in the thirteenth century. At the Reformation they embraced the doctrines of Luther.

Fran. [Ger.] Wife, Mrs.

Fräulein. [Ger.] Young lady, Miss.

Fraunhofer's lines. First examined by F., of Bavaria (died 1826). A great number of very narrow dark lines crossing the solar spectrum at right angles to its length.

Fraxinella. (Dittany.)

Fray. [Fr. effrayer, L. exfrīgĭdāre.] Deut. xxviii. 26 ; to affray, scare.

Freebench. (Leg.) Dower of a widow out of copyholds, to which the custom of some manors entitles her; generally a third for life. The right does not attach till the husband's decease, while the right to dower attaches at marriage.

Free-board. (Naut.) A ship's side from the water-line to the gunwale.

Free-borongh men. (Leg.) The great men, who were exempt from frankpledge.

Free cities, German. Hamburg, Bremen, Lubeck, Franfort-on-the-Maine ; sovereign members of the German confederation.

Freedmen. In Gr. and Rom. Hist., persons set free from slavery. (Libertines.) originally feudal, now the only free lay mode of holding property, only the honorary services of grand serjeanty being retained after the Restoration. 2. An estate in real property held in fee simple, fee tail, or for life.

Free imperial cities. In Europ. Hist., cities which acknowledged no head but the emperor, and were thus virtually independent. Some of these cities formed themselves into leagues. (Hanseatio League.)

Free lance. An independent person; metaph. from the mercenaries of the Middle Ages, who offered their services to any side.

Freeman. (Leg.) 1. One born or made free of certain municipal privileges and immunities. 2. One having a franchise. 3. An allodial proprietor.

Free-martin. A cow-calf, twin with a bull.

Freemason. Properly a guild or fraternity of builders, the word being not improbably a contraction for "freestone" mason. In the Middle Ages this guild was especially patronized by the see of Rome; and to this fraternity we owe probably the stately magnificence of our great churches and cathedrals. In Scotland the Abbey of Kilwinning was built by the freemasons in the thirteenth century; and the Kilwinning and York lodges are the most ancient in Scotland and England. A severe Act was passed against the association by the Parliament of 1425 , but it seems to have remained inoperative; and Henry VII. was succeeded by Cardinal Wolsey as Grand Master of the order. The first grand lodge in London was formed in 1717 ; the first French lodge, in 1725 ; the first American, in 1730; the first German, in 1735.

Free ship. (Naut.) A pirate, in which all share plunder equally.

Free socage. (Leg.) Plough-service, a free tenure of property originally distinct from the military tenures of knight-service or tenure in chivalry, grand serjeanty, and cornage; and comprising petty serjeanty, tenure in burgage, and gavelkind.

Free-warren. (Leg.) Royal franchise granted for the care of beasts and fowls of warren.

Freezing point. (Thermometer.)

Freight. [Ger. fracht.] 1. The sum paid for the use of a vessel, or carrying of goods. 2. The load itself.

Fremden-blatt. [Ger.] List of visitors.

French-berries. Buckthorn berries, which give a green or purple dye.

French-chalk. A kind of hardened talc, used for drawing lines on cloth, etc.

French white. Pulverized talc.

Fresco. [It., fresh, L. frīğdus.] Painting on fresh plaster with water-colours.

Freshen, To. (Naut.) To move anything so as to lessen the strain, to relieve a certain part or to give it a different effect; as to $F$. a hazuse, to $F$. ballast.

Freshet. [From fresh.] A river swollen by rain and rushing to the sea with a current wider and more rapid than usual.

Freshman. (Univ.) An undergraduate student in his first year of residence. 
Fret. 1. (Arch.) An ornament consisting of small fillets cutting each other at right angles. 2. (Her.) An ordinary consisting of two diagonal bands, called laths, interlaced with a mascle. An escutcheon cross-barred with many interlacing laths is called Fretty.

Frets. [Fr. ferrette, an iron clamp.] (Muszc.) Small projections across the finger-board of guitars, etc. ; by pressure of the finger upon them the vibrating length, and therefore the pitch, is regulated.

Fretwork. In woodwork, a pattern sawn out. Freja. (Thor.)

Friar. [Fr. frère, L. frater, brother.] A general name for the members of any religious order, but applied especially to the mendicants. (Orders, Mendicant.)

\section{Friborough, Frithburgh. (Frankpledge.)}

Fricandeau. [Fr.] A ragout or fricassee of veal.

Fricative. [From L. fricātus, a rubbing.] (Lang.) A continuous consonant, for which the articulating organs are approximated during emission of breath just before the separation which completes the consonantal articulation. In English the principal fricatives are $s h, z h$ ( $s$ in pleasure), $y, r, l, n, t h, s, z, f, v, z, m$.

Friction [L. frictiō, -nem, for fricatiō, -nem, a rubbing]; Angle of F.; F. brake; Coefficient of F.; F. cones; F. conpling ; F. rollers ; Rolling F.; F. wheels. Friction is the tangential resistance offered by one body to the sliding of another body over it. Coefficient of $F$., the ratio of the tangential resistance to the normal reaction of a body against another body which is sliding, or on the point of sliding over it. Angle of $F$., an angle so taken that its (trigonometric) tangent equals the coefficient of friction. Rolling $F$., the resistance offered by ene body to the rolling of another over it, due to the mutual compression at the point of contact. $F$. coupling, a mode of connecting two pieces by their friction when liable to sudden changes of force or velocity; e.g. by a turn of a screw a number of metal plates carried by one piece may be pressed against a number of wooden plates, and then the connexion between the pieces is established by a force equal to the friction multiplied by the number of contacts between the plates; another kind is a pair of $F$. cones, viz. a solid cone on one shaft fitting into a hollow cone on the other. $F$. rollers are placed under a heavy body that is to be moved forward, so as to substitute rolling friction for the much greater resistance of ordinary friction. For a like reason an axle is sometimes placed in the angle between each of two pairs of $F$. wheels instead of being placed on two fixed supports. (For F. brake, vide Brake.)

Friends, Society of. More generally known as Quakers (q.v.).

Friends of God. (IIist.) A secret brotherhood, not organized, formed in the fourteenth century, by certain who held that union with God was not to be limited by the observance of particular ordinances. - Milman, Hist. of Latin Christianity, bk. xiv. ch. 7. (Quakers.)

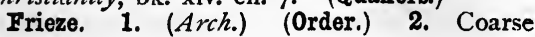

woollen cloth, with a nap on one side, perhaps originally $=$ cloth of Friesland.

Frigate. [Sp. fregāta, a word of uncertain origin.] In the Navy, ranks after a line-ofbattle ship. Formerly built for swift sailing, and carrying from twenty-eight to sixty guns. $F_{\text {.-built, }}$ with raised quarter-deck, and forecastle. Vessels having a flush-deck are galley-built.

Frigate-bird. (Ornith.) Fregetta, gen. and spec. of birds, adult male about three feet long and eight across; black with red pouch. Tropical seas. Fam. Pělěcānı̆dæ, ord. Ansěres.

Frigătoon. (Naut.) 1. A square-sterned Venetian vessel with only main and jigger masts, and a bowsprit. 2. A sloop of war, ship-rigged.

Frigidarium. [L.] The cooling-room in a Roman bath.

Friling, Freoling. A freeman born.

Frimaire. [Fr frimas, hoar-frost. ] Third month of the first French Republican calendar, from November 21 to December 20.

Fringes of shadows. (Diffraction of light.)

Fringillǐdæ. [L. fringilla, finch.] (Ornith.) Finches, an extensive fam. of small, short-billed birds, ord. Passerres. Some authorities class the Emběrīzidæ [Ger. ammer, emberitz], buntings, among them; others exclude the Australian finches, so called.

Friponnerie. [Fr. fripon, a gourmana, then a cheating trickster; friper, to rumple, to gulp down.] Rascality, trickery.

Frisian. Of Friesland, north of Netherlands. F. dialects are Low German.

Frisket. [Fr. frisquette.] 1. A light iron frame which turns down over the sheet to be printed, to hold it firm and keep the margin clean and fresh [Fr. frisque (Littré)]. 2. The paper with which wood-engravers, when taking a proof of their work, cover that portion of the woodcut which is not cut away, but which forms no part of the engraving.

Frit. [Fr. fritte, It. fritta, fried.] 1. Semivitrified earthenware, often pounded and used for glaze. 2. The material for glass, after calcination, but before fusion.

Frith-. [A.S. frithn, O.H.G. fridn, Ger. friede.] Peace. (Frankpledge.)

Frith gilds, i.e. Peace clubs. Voluntary associations of neighbours for purposes of order and self-defence, general throughout Europe in the ninth and tenth centuries; on the Continent roughly met and suppressed; in England recog. nized, as aiding social order.-Green's Hist. of English People, p. 191.

Frithman. Member of an association for the keeping of the peace.

Frithsoke, Frithsoken. [A.S.] (Leg.) The right of liberty of frankpledge.

Fritillary. [L. frítillus, dice-box.] (Bot.) Snake's-head, Frĭtillāria meleāgris, ord. Liliāceæ; a native bulbous plant, with chequered tulip-shaped flower ; in meadows and pastures, throughout Europe.

Friūli, corr. of Forum Fülii. Not marked in modern maps, once capital of Venetia; afterwards a Lombardic duchy; ceded at the fall of 
Venice (1797) to Austria ; in extent = modern province of Udine.

Frog. 1. [Possibly a corr. of tork, which it resembles in shape (Skeat); but the Greeks

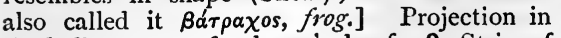
the hollow part of a horse's hoof. 2. Strip of leather attached to the waist-belt for carrying the sword or bayonet. 3. Loops of braid which hang from the undress coats of some officers.

Froglanders. (Naut.) Dutchmen.

Froissart, Chronicle of, i.e. by Sire Jean Froissart. A very valuable, abundant, and lively record of contemporary character and manners, from 1326 to 1400 , i.e. about $=$ reigns of Edward III. and Richard II.; the greater part derived from his own life at the courts of Edward and Philippa, of David Bruce, with the Black Prince in Aquitaine, with the Duke of Clarence in Italy and Amadeus of Savoy (Chaucer and Petrarch being his companions), with the Duke of Brabant, Count of Blois, and Richard II. It is written in Anglo-Norman French.

Frond. [L. frons, frond, -em, a leat.] (Bot.) A combination of leaf and stem, as in many algæ and liverworts; also applied to ferns.

Fronde, War of the. [Fr. fronde, $a$ sling.] In Fr. Hist., the war waged by the partisans of the Parliament against the government of Cardinal Mazarin in the reign of Louis XIV.

Frondeurs. [Fr.] The supporters of the Parliament in the war of the Fronde.

Fronti nulla fides. [L.] (There is) no trustworthiness in outward features (lit. brozv) (Juvenal).

Front of fortification. The part constructed on one side of a polygon, consisting of the face and inner flanks of two collateral bastions with their connecting curtain.

Frou-frou. [Fr.] A rustling; as of leaves, of silk, etc. ; onomatop.

Fructidor. [Fr., a nongrel word, from L. fructus, fruit, and seemingly Gr. $\delta \hat{\omega} \rho \circ \nu, a$ gift.] The twelfth month in the French Republican calendar, August 18 to September 16.

Fructification. In Bot., the parts of the flower; or the fruit and its parts.

Fructuary. [L. fructuārius, productive, enjoy. ing usufruct, from fructus, fruit, enjoyment.] (Leg.) One who has use of the produce of property, one who enjoys the usufruct.

Fruit. [L. fructus.] That part of a plant which consists of the ripened carpels and the parts adhering to them.

Frumenty. [L. frūmentum, wheat.] Food made of wheat boiled in milk and sweetened and spiced.

Frump, To, = to mock; to insult. A very old word, occurring in the dictionaries of Cotgrave and Minshew. "I was abas'd and frumped, sir" (Beaumont and Fletcher). This old word, though long out of use in England, still lingers among the descendants of the first settlers in New England.-Bartlett's American. isms.

Frustum. [L., a piece, bit.] The portion of a solid-in most cases of a pyramid or cone- which is left when the top is cut off by a plane section.

Fucites, Fucoïds. [L. fūcus, rock-lichen, wrongly translated seaweed.] (Geol.) Seaweedlike impressions, occurring in many strata; often due to tracks and burrowings of worms and small crustaceans.

Fucīvŏrous. [L. fūcus, or rather Gr. фûкos, seazveed, vŏro, $I$ devour.] Eating seaweed. Sheep in Iceland are F.

Fud. Woollen waste.

Fuer. [L. fŭgĕre, to flee.] (Leg.) Flight; fuer in fait, actual flight; fuer in ley, non-ap. pearance when called in a county court.

Fueros. [Sp.] (Hist.) The name given to the rights and privileges of certain Spatiish subjects. It corresponds to the O.Fr. for or fors, and may come from the L. forum, or from $\mathrm{Sp}$. fuera, without. These privileges especially dis. tinguish the Basque provinces.

Fu-fu. (Naut.) Barley and treacle made into a kind of pudding.

Fugitation. [From L. fügito, I flee, freq. of fŭgio, I flee.] In Scot. Law, sentence of forfeiture of goods pronounced against one who does not obey a citation to answer a charge in court.

Fŭgit hōra. [L.] Time is flying.

Fŭgit irrěvŏcābille tempus. [L.] Time is fying, not to be recalled (Virgil).

Fugleman. [Ger. fliigelmann, from flïgel, $a$ wing.] (Mil.) 1. Specially well-drilled soldier posted in front of a battalion to give the time to the others in performing the musket exercises. 2. Leader, guide, director in general.

Fugue. [Fr., L. fŭgă, a flying.] (Music.) A contrapuntal composition, not easily defined. The parts, not beginning at once, follow or pursue one another at intervals. A short theme or melody generally begins; then follows the answer, i.e. the same theme a fifth higher or a fourth lower. The third part gives the original subject in the principal key but an octave higher or lower, and is also followed by its answer. The themes are treated with freedom and variety, and recur at diminished intervals of time.

Fuit Illum. [L.] Troy has been, i.e. ceased to be.

Fulcrum. (Lever.)

Fulguration. [L. fulgŭrāțio, -nem, from fulgur, lightning.] The sudden brightening of a metal in assaying as the last impurity is driven off.

Fulgurites. [L. fulgur, lightning.] Vitrified sand-tubes, mostly vertical, twenty feet or more in depth, produced by lightning through sand; called sometimes Fossil lightning.

Full and by. (Naut.) Sailing as near as possible to the wind without letting the sails shake.

Full-bottomed. (Naut.) A ship designed to carry a large cargo.

Full due. (Naut.) 1. For good, for ever, complete. 2. As an order, = belay.

Fuller's earth. A compact, friable, unctuous clay, not plastic, falling to pieces in water ; often greenish ; absorbing grease, and once much used in fulling. In .Oolite (Somerset) and Cretaceous and Neocomian systems (Surrey).

Fuller's Worthies of England and Wales. 
Biographical notices of eminent Englishmen, an abundant treasure of curious stories and observations, by Thomas Fuller, a royalist clergyman, and "a wise and leaıned humourist" (I608166I).

Fulling. [L. fullo, a fuller.] In Manuf., scouring, cleansing, and thickening cloth by beating it with hammers in a mill.

Full man. (Naut.) In coasting vessels, i.q. A.B. (q.v.)

Fulmar. (Ornith.) A gen. of birds, fam. Prŏcellāriŭdæ (petrel kind), ord. Ansěres. A spec. supplying food and oil inhabits St. Kilda, Hebrides; it is about twenty inches long; plumage grey above, white below, white head and neck.

Fulminating [L. fulmǐnāre, fulminătum, to lighten] gold, silver, mercury. Explosive compounds formed of the oxides of these metals combined with ammonia or nitrogen.

Fumage. [L. fümus, smoke.] A chimney tax or hearth money; abolished in the reign of William III.

Fumarole. [It., from L. fumāre, to smoke.] An opening in a volcanic region, from which steam and gaseous vapours escape.

Fumitǒry, Common. (Bot.) A wild plant, Fūmāria offícinalis, ord. Fumariaceæ, exhaling an unpleasant smell like smoke [L. fümus].

Funambulist. [L. fünambŭlus, rope-dancer, from fünis, rope, ambŭlo, $I$ walk.] A ropeJancer, a performer on the rope.

Fund, Sinking. (Sinking fund.)

Fundamental laws. (Organic laws.)

Funds. [L. fundus, bottom, depth.] Originally the taxes or funds appropriated for the discharge of the principle of Government loans upon terminable annuities; now the various stocks constituting the public debt, of which far the largest part consists of three per cent. Consols, i.e. Consolidated annuities, formed from the throwing together of several separate stocks (I75I).

Fungiblyes res. [Leg. L.] Movable goods which can be replaced so that the difference could not be distinguished, they being estimated by weight, number, or measure.

Funicular polygon. [L. fūnǐcŭlus, $a$ slender rope.] The form assumed by a thread supported at both ends when weights are fastened to different points of it.

Fünioŭlus. [L., a little cord.] (Bot.) The stalk by which some seeds are attached to the placenta.

Funny. (Naut.) A long, narrow, clinkerbuilt boat, propelled by one sculler only.

Funny-bone. Not a bone at all ; popular name for the sensation produced by pressing on the ulnar nerve as it passes between the inner condyle of the hŭměrus and the olěcrănon process of the ulna.

Furbelow. [Fr. falballa, a word traced to the time of Louis XIV., of unknown origin; according to Ménage, a word invented in a joke (see Littré, s.v.).] A flounce, a plait, on any part of a dress.

Furcam et flagellum, Per. [Leg. L., by gal- lows and whip.] The lowest servile tenure, when the lord had power of life and limb over the bondman.

Furcifer. [L.] Among the Romans, one who had to bear the furca, a two-pronged instrument in shape like the letter $\mathrm{V}$, for carrying burdens. Hence any low rascal or scoundrel.

Furies. (Erinyes ; Eumenides.)

Furlong. [Corr. of furrow-long.] The eighth part of a mile, or 220 yards.

Furlough. [D, verlof, leave.] (Mil.) Leave of absence granted to a non-commissioned officer or soldier.

Furniture. [Fr. fourniture.] 1. In Printing, wood or metal pieces to place around the type in "locking up," i.e. tightening in the chase, or iron frame, the types when ready for printing. 2. (Naut.) The rigging, sails, spars, etc., provisions, and every article with which a ship is fitted, including boats.

Furor arma ministrat. [L.] Rage supplies zueapons (Virgil).

Fuse. [Fr. fusée, originally a spindleful of thread, L. fūsāta, and so any pipe-shaped hollow.] (Mil.) Funnel-shaped tube of beech wood filled witl a composition of gunpowder, fixed into the side of a shell for the purpose of causing it to explode at a regulated time after leaving the gun.

Fusee. [Fr. fusée, a spindleful of thread, L. fūsāta.] Of a watch, the conical wheel round which the chain passes in a spiral groove to the barrel containing the mainspring. It is designed to equalize the action of the mainspring by enabling it to act at a greater leverage as its force is diminished by its gradual unwinding.

Fusel. [Ger. fusel, bad liquor.] A poisonous alcohol found in new spirits.

Fusible metal. An alloy of one part of bismuth, one of lead, two of tin. It melts at a heat below the boiling point of water.

Fusiform. (Bot.) Of the shape of a spindie [L. füsus], thickest in the middle and tapering upwards and downwards, as the root of a radish.

Fusil. (Her.) An ordinary shaped like a spindle [L. füsus] or elongated lozenge.

Fusil. [Fr. fusil, hammer of a gun.] (Mil.) Short musket formerly carried by sergeants and certain regiments called Fusiliers.

Fust. (Naut.) A low, roomy, armed vessel, fitted with sails and oars, used as a tender to galleys. Also a scampavia (q.v.), barge, or pinnace.

Fustet. [Fr., dim. of O.Fr. fust, fût, forest wood, L. fustis, a long piece of wood.] The wood of a shrub (Sumach) of S. Europe, which yields a fine orange colour.

Fustian. [O.Fr. fustaine, from Fostat, i.e. Cairo, where it was made.] A kind of coarse twilled cotton stuff, including corduroy, velveteen, etc.

Fustic. [Fr. fustoc and -tok.] A W.-Indian wood used in dyeing yellow. Young fustic is another name for Fustet.

Futhoro. Ancient Runic alphabet; its first six letters are $f, u, t h, o, r, c$. -Isaac Taylor, Greeks and Goths. 
Futtocks, or Foot-hooks. (Naut.) The pieces of timber composing a ship's frame. There are four or five in each rib. Those next the keel are Ground $F_{\text {., }}$ or navel-timbers, the others Upper $F$.
Futurition. [Fr.] Future state. Fyrd, Fyrdung. The militia. (Trinōda nĕcessitas.)

Fyrdwite. (Leg.) Fine for neglecting to join the fyrd.
G. Was used by the Romans as an abbrev. for Gens. G.L. stood for Genius loci, and G.P.R. for Gloria populi Romani. As a numeral, it denoted 400.

Gabardine, Gaberdine. [It. gavardina, a word of Celt. origin.] A coarse frock, a smock. (The O.Fr. galleverdine, galvardine, suggest farthingale, q.v.)

Gabarre. (Naut.) French store-ship ; formerly a lighter.

Gabart, Gabbert, or Gabert. (Naut.) A kind of lighter on Scotch rivers and canals.

Gabel. [A.S. gafel, perhaps from gifan, to give.] Any impost or tax. In France the gabelle, when used by itself, came to denote especially the duties on salt; otherwise it was spoken of as the Gabelle de vins, de drape, etc. (Gavel.)

Gabelle. (Gabel.)

Gabion. [Fr., from It. gabbione, and this from gabbia, cage.] (Fortif.) Strong cylindrical basket without top or bottom, three feet high by two feet in diameter. Gabions are filled with earth, and used for supporting earthworks in a steep position.

Gable, or Gabulle. (Naut.) Old name for a cable.

Gad. [O.Fr. gad, goad or sting.] A pointed wedge used by miners.

Gad-fly. [O.E. gad, a point, a goad.] (Breeze-fly.)

Gadhelio. (Lang.) Keltic languages are divided into Cymric and $G_{\text {., }}$ which latter includes Erse, Gaelic, and Manx. (Keltic languages.)

Gad-yang. (Naut.) Cochin-China coaster.

Gaelic (Gaidheal, Gael). The dialect of the Scotch Highlands, a branch of the Gadhelic division of Celtic (Keltic). (Erse.)

Gaff. [Ir. gaf, Welsh caff, a hook, grapple.] (Naut.) The spar which extends the upper end of fore-and-aft sails, other than stay and sprit sails. The end next the mast is the jaw, the other end the peak. The jaw is semicircular and fits on the mast, to which it is secured by the jazwrope, which has wooden balls, called trucks, strung on it to lessen the friction.

Gaffer. [A corr. of gramfer, as gammer is of grammer, the west of England forms of grandfather and grandmother (Halliwell, quoted by Skeat).] Old fellow, once a title of respect.

Gaffoldgild. (Leg.) Payment of custom or tribute (gafol). (Gavel.)

Gaffoldland, Gafol-land. Property subject to Gaffoldgild.

Gafol. (Gavel.)

Gage. [O.Fr. gauger.] (Naut.) The depth to which a ship lies in the water. A ship to windward of another has the Weather-G., to leeward the Lee-G., of her.

Gage. [Fr. gage, L.L. gadium, vadium, from Teut. vadi, akin to $L$. vas, gen. vădis, surety; cf. Ger. wette, bet, A.S. wedd, pledge, from root vadh, carry home; cf. Skt. vadhu, young wife.] Pledge. Estates in G. are held in vivum vadium, vifgage (q.v.), or mortuum vadium, mortage (q.v.).

Gage d'amour. [Fr., pledge of love.] Lovetoken.

Gaillardise. [Fr.] Excessive merriment; in the plu., indecent jokes, from Fr. gaillard, sprightly; cf. Cymr. gall, strength, Gael. galach, courage.

Gained day. (Naut.) In the navy, when the globe is circumnavigated to the eastward (by which a day and night are gained) pay is given for that day.

Gain the wind, To. (Naut.) To get to windward of another vessel when both are going to windward.

Gair-fowl. [Celt. gairan, to call.] (Ornith.) The great auk. (Alca; Ank.)

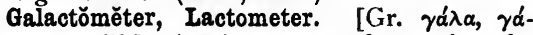

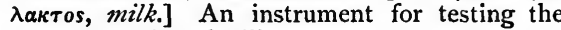
specific gravity of milk.

Galahad, sir. The pure knight of King Arthur's Round Table, who found the Holy Grail. (Sangreal.)

Galanga. [Ar. khalaudjaû.] An aromatic root from India or China, used as a spice.

Galatëa. (Nereids.)

Galaxy. [Gr. $\gamma \alpha \lambda \alpha \xi^{\prime} \alpha s$, from $\gamma a \dot{\lambda} \alpha$, milk.] The Milky Way, a faintly luminous belt surrounding the heavens, which is found on telescopic examination to consist of stars scattered by millions on the black ground of the heavens. Its general direction is that of a great circle whose northern pole is in R.A. 12 hrs. 47 mins. and N.P.D. $63^{\circ}$.

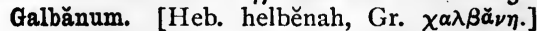
Exod. xxx. 34; the gum-resin yielded by two or more spec. of Ferula, ord. Umbelliferæ, from which was obtained one of the ingredients of the "holy perfume."

Galbŭlus. [L., a cypress cone.] (Bot.) Any small cone with scales all consolidated into a fleshy ball ; as juniper.

Gale. (Leg.) Periodical payment of rent. (Gavel.)

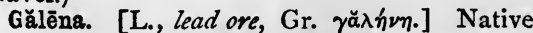
sulphide of lead; the most abundant and productive of lead ores.

Galēnio. Relating to the doctrines or method 
of Galēnus, physician at the court of Rome. He died circ. A.D. 200.

Galënists. 1. (Eccl. Hist.) A subdivision of the Waterlandians. 2. (Med.) The followers of Galen, a physician of the second century, and opposed to the alchemists. (Alchemy.)

\section{Galenites (Mennonites.)}

Gale of wind. (Naut.) Hard or Strong G., number ro in the scale of wind-force. Stiff $G$. , not so strong. Fresh $G$., still less strong, one in which reefed topsails may be carried, when on a wind. Top-gallant $G$., when not too strong to allow these sails to be carried. Gentle $G$., when royals and flying-kites may be carried; number of force, 4. To gale away, i.q. to go free.

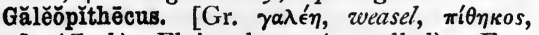
ape.] (Zool.) Flying lemur (so called). Fore and hind legs and tail connected by skin extension. It is doubtful whether it should be placed in fam. Lěmŭrŏïděa, ord. Prìmātēs, or at head of ord. Insectivorra, though a vegetable feeder. They are nocturnal and arboreal, and sleep hanging by their talls. One spec., Malacca, Sumatra, Borneo ; another, Philippines.

Galère. [Fr., a galley.] 1. Vogue la G., = come what will; lit. let the galley or penal-ship row, as the consequence. 2. Que diable allait-il faire dans cette G.? What business had he to get into that mess? from Molière's Fourheries de Scapin; the reiterated question of Géronte, when S. tells him the trumped-up story that his son Léandre has been enticed on board a Turkish galley, and will be carried as a slave to Algiers, unless a ransom of 500 crowns is paid within two hours.

Galette. [Fr. galet, O.Fr. gal, a pebble.] French pastry, biscuit.

Galilee. The cathedrals of Durham, Lincoln, and Ely have appendages called by this name; but beyond their name these buildings have little in common. These Galilees, which may have had some connexion with discipline, were all built in the latter part of the twelfth and the early part of the thirteenth centuries.

Galimatias. [Fr., (?) L.L. ballımatia, cymbals; but see Littré (s.v.).] A confused mixture (of language), gibberish, utter nonsense.

Galipot. [Fr. ; origin of the word unknown.] A white resin from pine or fir trees.

Gălǐum. (Bedstraw.)

Gall. 1. [L. galla, an oak-apple, gall-nut.] A vegetable excrescence on the oak. 2. [A.S

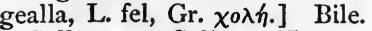

Galleon, or Galion. [L.L. galea, a gallery.] (Naut.) Formerly a war-ship, with three or four batteries; now the largest Spanish ships trading to the W. Indies and Vera Cruz. Portuguese vessels trading to India resemble these, and are called Caragues. The Carracks were galleons fitted for fighting as well as commerce; they had great depth, and were chiefly Spanish and Portuguese.

Galleot, or Galliot. (Naut.) 1. A small (Galleon) galley, carrying one mast and from sixteen to twenty oars. All the men carried muskets, as she was designed for chasing only. 2. A Dutch or Flemish trader, having a mainmast carrying a square mainsail and a mizzen- mast far aft, very round in the ribs, and nearly flat-bottomed. 3. A bomb-ketch. (Retch.)

Gallery. [Fr. galĕrie, from It. galerĭa.] 1. (Mil.) Underground passage of a mine leading from the entrance to the Chamber. 2. (Naut.) A balcony projecting over the stern, from the admiral's or captain's cabin, and extending the breadth of the vessel. Quarter-G., in large ships, a kind of balcony with windows, on the quarters.

Galley. (Galleon.) (Naut.) 1. A low vessel, with one deck, propelled by sails and oars. 2. An open rowing-boat of the Thames, pulling six or eight oars; used by the Thames police, etc. 3. A clinker-built, fast-rowing man-of-war's boat, larger than a gig, and appropriated to the captain. 4. A ship's kitchen. 5. In Printing, a ledged board which receives the types from the conposing-stick.

Galley-nose, etc. (Naut.) The figure-head. Galley-packets, unauthenticated news. Galleypepper, soot or ashes in food. Galley-stoker, an idle skulker.

\section{Galli. (Cybele.)}

Galliard. [Fr.] (Gaillardise.) One full of animal spirits.

Galliard, Gaillard. [Fr., a jovial fellowe (Gaillardise).] An ancient dance in $\frac{3}{4}$ time, by one couple only; the origin of the minuet, but more lively.

Gallias, or Galeas. (Naut.) A heavy, low trading-vessel.

Gallic acid. An acid obtained from gall.

Gallican Church. The distinctive title of the Church in France, which naintains a certain degree of independence in respect of the Roman see. The liberties of this Church, first asserted in the Pragmatic Sanction of 1438 , were defined and confirmed by the Propositions of the Gallican Clergy, promulgated in I682. The Gallican Church suffered a very severe defeat in the early part of the French Revolution, when its leaders sided to a considerable extent with the party of progress, and accepted the "civil constitution" of the clergy. The Concordat made by Napoleon with Rome had no tendency to reconstitute the Gallican Church as it had stood in the eyes of the famous Bossuet, who drew up the Declaration of 1682 . Since the time of the Concordat with Bonaparte, the influence of the Ultramontane party seems to have increased steadily.

\section{Gallican Liturgy. (Liturgy.)}

Gallicism. [From Galli, ancient Celtic inhabitants of France and N. Italy.] A French idiom or mode of expression.

Galligaskins. Large open hose, worn originally by seafaring Gascons. Wedgwood regards the word as a corr. of Greguesques, a Greekish kind of breeches, worn at Venice.

\section{Gallimatias. (Galimatias.)}

Gallimanfry. [Fr. galimafrée; origin unknown.] 1. A hash of various meats. 2. A ridiculous medley. (Farrago; Olla podrida.)

Gallīnæ, Gallināceous birds. [L. gallīna, $a$ hen.] Poultry and game birds (except bustard, woodcock, and snipe), sometimes called Rāsōres [L., scrapers] from their scratching habits, and made to include Cŏlumbřdæ. 
Gallivats. (Naut.) Armed Indian row-boats, generally from fifty to seventy tons.

Gallon. [A word of unknown origin.] A measure of capacity. The English imperial gallon is the volume of ten pounds of distilled water weighed in air at temperature $62^{\circ} \mathrm{Fahr}$., the barometer standing at 30 inches; it contains 277.274 cubic inches (or 277.27 cubic inches). The old wine G., fixed by 5 Queen Anne, contained $23 \mathrm{I}$ cubic inches; the old ale G., 282 cubic inches; the old corn G., 268.8 cubic inches, which was in fact the Winchester $\mathrm{G}$. as fixed by I William and Mary; there was also an old wine $\mathrm{G}$. containing 224 cubic inches.

Galloon. [Fr. galon, from galonner, to lace with gold, silver, silk, etc.] 1. A kind of ornamental ribbon, usually interwoven with gold or silver threads. 2. Cotton or silk tape for binding hats, etc.

Galloway. 1. A S.-Scottish full-sized pony, a clever hack generally, with some Eastern blood; seldom above fourteen hands. The breed lost, and the term obsolete. 2. Applied also to a breed of cattle ; large and black.

Gallows. [A.S. galgo.] (Naut.) Cross-pieces (for stowing booms, etc.) on the bitts by the main and fore hatchway. Called also Calloweses, G.-bitts, G.-stanchions, and G.-tops.

Galoche. [Fr., L. calopedĭa, in mediæval

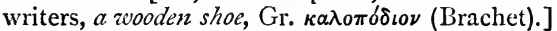
An overshoe, galoshe.

Galore. [Erse gu leor, enough.] In plenty, in abundance. An old word, found in Irish ballads; now obsolescent.

Galvanism. (From Galvani, the discoverer.) Electricity developed by chemical action between different substances without friction.

Galvanized iron. Iron coated with zinc. The best sort receives first a thin coat of tin by $\mathrm{gal}$ vanic action.

Gamba. [It., leg, shank.] (Mussic.) 1. Viol di G., an old instrument, a sort of viol, smaller than the violoncello, six-stringed, held between the knees. 2. An organ stop, somewhat like a violoncello.

Gambe. [O.Fr. gambe, now jambe ; $c f$. Gr. $\kappa \alpha \mu \pi \dot{n}$, a bending.] (Her.) A leg.

Gamběson [etym. uncertain], or Wambeys. Quilted tunic, stuffed with wool, worn under a shirt of mail.

Gambet. [It. gambetta, dim. of gamba, shank.] (Ornith.) Red-shank, with imperfect plumage. Tŏtănus călĭdris, fam. Scŏlōpācĭdæ, ord. Grallæ.

Gambier. (Native name.) An astringent extract from a Malayan plant used in tanning.

Gambit. [Fr. gambit, from It. gambetto = croc-en-jambe, lit. a mean trick (Littré).] In chess, an offered and accepted sacrifice in opening a game, to give the first player a good position.

Gamboge. A yellow gum-resin, from Cambodia, in India, used as a pigment.

Gambrel. [O.Fr. gambe, for jambe, legs.] A crooked stick, used by butchers for suspending slaughtered animals.
Gambroon. [Sp. gambron.] A twill linen cloth for lining.

Game. [A.S. gamen, gomen, sport, O.H.G. and O.N. gaman, joke.] In England (I and 2 William IV., c. 32), includes "hares, pheasants, partridges, grouse, heath or moor game, black-game, and bustards;" and (25 and 26 Vict., c. II4) also "the eggs of game, woodcocks, snipes, rabbits." In Scotland, G. is not so clearly defined; but the difference is trifling, mainly of importance in dealing with each separate Act. In Ireland, G. includes "deer, hares, pheasants, partridges, grouse, landrails, quails, moor-game, heath-game, wild turkeys, or bustards."-Stonehenge's Brit. Rural Sports.

-gamia. (Bot.) (Cryptogams; Polygamia.)

Gamin. [Fr.; etym. unknown.] A street Arab, urchin.

Gammărina. [L. gammărus = cammărus,

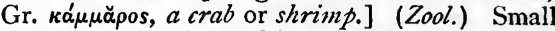
crustaceans, as the sand-hopper (Talitrus loccusta) and f:esh-water shrimp (Gammărus pūlex).

Gammer. [For etym., vide Gaffer.] Old woman, once a title of respect.

Gammer Gurton's Needle. A comedy of rustic life, the earliest English comedy, probably, but one ; circ. 1565 ; (?) by J. Still, afterwards Bishop of Bath and Wells. Humorous, but somewhat coarse (see Shaw's Student's Eng. Lit.).

Gammon, To. [O.Fr. gambon, from gambe, $a$ leg.] (Naut.) To pass a lashing over the bowsprit, and through a hole in the cut-water in a peculiar manner, so as better to support the foremast stays.

Gamp, Mrs. Sarah. A vile nurse in Dickens's Martin Chuzzlewit.

Gamut, Gammut. [O.Fr. gamme.] (Music.) The series of seven sounds which constitute the musical scale, said to be from "gamma" $(\gamma$, third letter of the Greek alphabet), which designated the first of the parallel lines upon which the notes were placed by Guido Aretini ; but vide Sol-fa.

Gang (from the gang, or course, taken; this being the earlier meaning of the word). (Agr.) A party of labourers provided by a middle-man.

Gang-board. (Naut.) 1. (Gangway.) 2. A plank used for getting in and out of boats, where the water is shallow.

Gang-casks. (Naut.) Used for bringing off water in boats, and holding about thirty-two gallons.

Ganger. (Agr.) The middle-man who pro. vides a Gang.

Ganglion. [Gr. $\gamma a$ ar $\gamma \lambda \iota \lambda_{1}$, a tumour under the skin.] (Biol.) A knot or enlargement, sometimes a central mass, of nerve-trunks. Ganglionic system. (Sympathetio.)

Gangue. [Fr., from Ger. gang, mineral vein, Eng. a going or course.] The stony matter in which veins of ore are found.

Gangway. [From M.E. gang, a zvay, with the word way unnecessarily added, after the sense of the word became obscured (Skeat) ; $c f$. Wansbeckwater.] 1. (Naut.) In deep-waisted vessels, the narrow platforms next the sides, which con- 
nect the quarter-deck and forecastle, sometimes called G.-board. 2. The openings in a vessel's side, or bulwarks, by which one enters and leaves. To bring to the $G$., to flog a seaman, lashed to the grating. 3. (Parl.) The passage across the House of Commons, below which junior and independent members sit.

Gannet. [O.E. ganot, sea-fowl; $c f$. gander, Ger. gans, L. anser, Gr. $\chi \not \nu$.$] (Ornith.) Gen.$ of birds, found in all climates. British spec. (Solan goose, Sula alba), about three feet long, nearly all white; young, black, streaked, and spotted with white. Fam. Pĕlěcānı̆dæ, ord. Ansěres.

Gannister. [Local term.] A compact siliceous sandstone, used in the formation of furnaces; found under certain coal-beds in N. England.

Gănǒïdĕi, Ganoids. [Gr. $\gamma \alpha \nu \omega \delta \delta \eta s$, from $\gamma \alpha \dot{\nu} o s$, brightness, eîंos, appearance, of a bright appear. ance.] (Ichth.) Sub-class of fish, mostly with ganoid, i.e. enamel-covered, bony scales, bucklers, or spines, and heterocercal tails, as the sturgeon, and gar-pike. Dr. Günther now combines the sub-classes Tĕlěostěi and Dipnoi with the Gănǒïěi. (Dipnoi.)

\section{Gant-line. (Girt-line.)}

Gantlope, Gauntlope, Gauntlet, and Gantlet, To run the. [Sw. gatlopp, from gata, a street, lane, and lopp, a course; cf. Eng. leap, loafer, Ger. laufen, to run.] To run, stripped to the waist, between two rows of men, each of whom had a knotted cord, knittle, originally a gauntlet, with which he struck the offender as he passed.

Gantois. [Fr.] An inhabitant of Ghent.

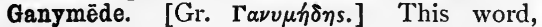
which is sometimes used to denote any beautiful youth, is in the lliad the name of the son of Tros, who is said to have been carried away by an eagle to Olympus, where he became the cupbearer of Zeus, or Jupiter.

Gaol delivery. A commission to judges, etc., to try and deliver (to freedom or punishment) every untried person in gaol, on their arrival at the assize town.

Garancise. [Fr. garance, madder.] An extract of madder for dyeing.

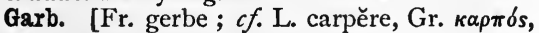
fruit, Ger. herbst, Eng. harvest.] (Her.) A sheaf.

Garble, To. (Naut.) To mix rubbish with a cargo stowed in bulk.

Garbler of spices. [Ar. girbhal, a sieve (Skeat).] An old officer in London city, who may enter places where spices and drugs are sold, and garble (clean) them.

Garboard-strake, or Sandstreak. (Naut.) The planks upon a ship's bottom next the keel, and rebated into it, and into the stern and sternposts.

Garçon. [Fr. ; origin of the word very uncertain.] Lad, waiter; in Irish gossoon.

Gardant. [Fr., guarding.] (Her.) Turning its head to gaze full-faced.

Garden City. Chicago; so called from the number of its gardens.-Bartlett's Americanisms.

Gardiloo! [Corr. of Fr. gare à l'eau! look out for the water!] In Edinburgh, formerly, a cry to passengers to beware of slops about to be thrown out of window.

Gare! [Fr. ; $c$. Eng. beware, O.H.G. waron, to take care.] Look out!

Gar-fish. [O.E. gar, a lance.] (Ichth.) Seapike, Mackerel guide; about two feet long, bluishgreen back, white belly, elongated jaws, homocercal tail. British coast. Bělǒnē vulgāris, fam. Scombrěsŏcĭdæe, ord. Phȳsostŏmi, sub-class Tělěostěĩ.

Gargantua. The giant of Rabelais's romance of that name, with a vast mouth and swallow.

Garish, Gairish. [From gare, to stare, a variant of M.E. gasen, to gaze, by the frequent change of $s$ to $r$ (Skeat).] Excessively bright, staring, flaunting.

Garland. [A word of uncertain origin.] (Naut.) 1. A rope collar round the head of a mast, used to prevent chafing the shrouds, and for other purposes. 2. A wreath, made by crossing three small hoops covered with ribbens, etc., hoisted on the wedding day of any of the crew. 3. A net, with a hoop at top, used for keeping food in.

Garnet. [A corr. of granat, from the colour and shape of the seeds of the pomegranate, L. grānātum.] 1. (Min.) A common mineral in some metamorphic and igneous rocks; the several varieties being (I) lime-G. (Grossular, etc.) ; (2) Magnesia G. ; (3) Iron-G., Precious and Fire-G., Py̆rōpe, Carbuncle, and Common G. ; (4) Manganese G. ; (5) Iron-lime G. ; (6) Lime-chrome G. The best come from Bohemia, Pegu, Ceylon, and Brazil. 2. (Naut.) A purchase fixed to a ship's mainstay, and used for lifting cargo in and out.

Garnish. [A word of O.L.G. origin, seen in A.S. warnian, to bezvare of (Skeat).] (Naut.) 1. A large amount of carving, etc., about a ship. 2. Money, formerly exacted by pressed men from newly pressed men coming on board.

Garnishee. [For etym., vide Garnish.] (Leg.) One warned not to pay a debt to one indebted to a third person.

Garniture. [Fr.] Embellishment, ornament, furniture, decoration. (Garnish.)

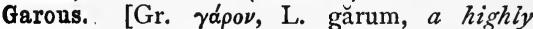
flavoured condiment prepared from fish.] Of the nature of garum.

Gar-pike. [O.E. gar, a lance, pic, a point, of Celtic origin (Brachet); cf. Fr. brochet, pike, from broche.] (Ichth.) Bony pike, gen. of ganoid fish, several feet long, covered with scales, elongated jaws, heterocercal tail. N. America to Mexico and Cuba. Lěpridostěus, fam. Lěpĭdostěi, ord. Hǒlostěi.

Garrooka. (Naut.) Native name for a fishingvessel in the Persian Gulf.

Garrote. [Sp.] 1. A mode of execution by strangling with an iron collar (fixed to a post), which is gradually tightened. 2. To seize by the throat from behind, as robbers frequently do.

Garrŭli. [L., chattering.] (Ornith.) Gen. of jays; sub-fam. Garrŭlinæ, fam. Corvǐdæ, ord. Passĕres. 
Garter. [Fr. jarretière, from jarret, the ham.] (Her.) 1. A diminutive of the bend, being onehalf its size. 2. The principal king-at-arms.

Garter, Order of the. The highest order of English knighthood, said by some to have been founded by Richard I., while others accept the story which assigns it to Edward III. and the dropping of the Countess of Salisbury's garter. The order was, however, either founded or restored by the latter sovereign.

Garter-fish. (Ichth.) Scabbard-fish; various spec. of fish, some five feet long. British spec. silvery colour, gen. Lěpŭdŏpus [Gr. $\lambda \epsilon \pi-i s,-i \delta o s$,

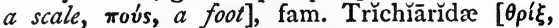
$\tau \rho^{\prime} \chi ð \delta s$, hair], ord. Acanthoptěry̆gĭi, sub-class Tělěostěī.

Garters. (Naut.) Ship's irons, bilboes.

Garth. [From A.S. gyrdan, to surround.] 1. (Leg.) An inclosure round a building, a close. 2. A dam or weir.

Garum. [L., from Gr. rápov.] A dainty sauce of small fish preserved in brine.

Gasconade. [Fr. gasconnade.] Bragging talk; said to have been characteristic of the Gascons, the Vascónes, Basques of Navarre.

Gaskets. (Naut.) Cord, etc., wound round a furled sail.

Gaskin, shortened from Galligaskins. In a horse, the lower thigh of the hind legs, the part just above the hock, corresponding to the forearm of the front legs.

Gas-pipe. In Naut. slang, a breech-loading rifle.

Gassing. Burning off the small fibres of cloth by passing it through gas-jets.

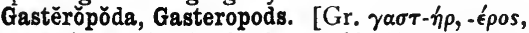

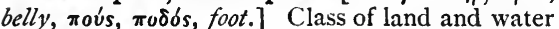
molluscs, with single shell or naked, progressing by ventral disc, by vertical fin, or by tail, as snail, whelk, sea-lemons (Dōris), Cărīnārĭa [L. cărīna, keel].

Gastrülŏquist [a mongrel word, made up of Gr.

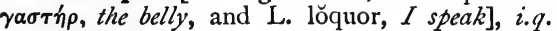
Ventriloquist.

Gastritis. Inflammation of the stomach [Gr.

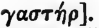

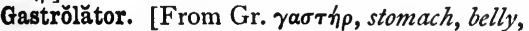
$\lambda \alpha$ '́ $\rho \eta s$, worshipper.] One "whose god is " his "belly."

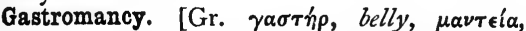
divination.] 1. A kind of divination by sounds from the stomach. 2. Divination by appearances in round transparent vessels.

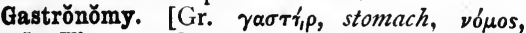
lawe.] The art of promoting the welfare of the stomach, generally confounded with the art of luxurious feeding.

Gas-water. Water which has been used for purifying gas ; called also Gas-liquor.

Gatchers. The after-leavings of tin.

Gate. In founding, the channel leading to the mould from the sprue, or hole into which the metal is poured.

Gate, or Sea-gate, To be in a. (Naut.) Used of two ships thrown one on board the other by a wave.

Gate, To. (Uniz.) To order a person in stătu püpillāri not to leave his college or lodgings after a certain hour of the day for a time, as a punishment.

\section{Gate of Janus. (Janus.)}

Gate of Tears. Straits of Bab-el-mandeb, a transl. of the Arabic name.

Gatling gun. (Mil.) A gun composed of a series of six barrels arranged round a centrai shaft, each being fired almost simultaneously by an independent revolving lock.

Gauch, Gaunch. To kill, as in Turkey, by dropping a man on to hooks, and so leaving him to die.

Gaucherie. [Fr., from gauche, the left hand.] Awkwardness.

Gaudy. [L. gaudium, gladness.] (Oxf. Univ.) A college feast-day.

Gauge [a word of uncertain origin; in L.L. gaugstum] ; Broad G.; Narrow G.; Railway-G.; Rain-G.; Salt-G.; Steam-G.; Tide-G.; Vacuum-G.; Water-G.; Wind-G. To gauge a cask is to ascertain the quantity of liquor it contains or is capable of containing. Gauge, a measure or standard; generally used as part of a compound word. A Railway-G. is the distance between the two rails on which the train runs, viz. 7 feet in Broad-G., and 4 feet $8 \frac{1}{2}$ inches in Narrow-G., lines. A Steam-G measures the pressure of steam in a boiler; a Water-G., the depth of water in a boiler; a Salt-G., the quantity of salt in the water in a boiler. A Vacuum-G. measures the pressure of the air or vapour in the condenser of a steam-engine or the receiver of an air-pump. A Rain-G. measures the quantity of rain that falls at a given place in a given time; a Tide-G., the height of the tide at any instant or the variations of height during any assigned time; a $W$ ind-G., an anemometer, the force of the wind, e.g. in pounds per square foot.

Gauge. [O.Fr.] A lind of plaster used for mouldings on a ceiling.

Gauger. Surveying officer under the Board of Excise.

Gaul. [L. Gallus.] Celtic inhabitant of what is now France.

Gault, Galt. (Geol.) Provincial name for clay; but applied, more strictly, to the cretaceous clay below the chalk at Folkestone and elsewhere.

Gauntlet. [O.Fr. gantelet, from gant, Sw. wante, a glove.] 1. Glove covered with scales, with metal cuff. Running the $G$., formerly a military punishment, the offender being forced to pass between two lines of men facing inwards, each of whoin struck at him as he passed. 7 hrowing down the $G$. was formerly a challenge to fight in the tilting ring. At the coronation of an English sovereign, the hereditary champion thus challenges any one who disputes the right of succession. 2. (Naut.) A rope round a vessel, fastened to the lower yardarms, for drying ham. mocks. (Gantlope.)

Gavel. [O.Fr. gavelle, It. gavella, handful.] A small heap of loose wheat or other cereal. (Gabel; Cabelle.)

Gavel, Gabel. [A.S. gafol, gaful, Fr. gabelle, from L.L. gabella, gabulum, from 
O.H.G. geban, A.S. gifan, to give.] (Leg.) Tribute, toll, tax.

Gavelgeld. (Leg.) Payment of tribute or toll. Gavelkind (kind of land which yields gavel, not military service). [A.S. gafol, tribute (Gabel; Gabelle).] A mode of descent more general before the Conquest, and still retained in Kent, by which the land of the father is at his death divided equally among his sons, or of a brother among his brothers, if he has no sons of his own. (Borough English.)

Gavial. (Zool.) Gen. of crocodile; longsnouted. Ganges, Borneo, and N. Australia.

Gavot, Gavotte. [Fr.] 1. A dance, stately and spirited, popular in the seventeenth and eighteenth centuries; originally a dance of the Gavotes or people of Gap, Hautes Alpes. 2. Tune written for the dance, or whose measure and rhythm were suggested by it; e.g. those of Bach, Handel, etc. A G. properly begins on the second half of the bar.

Gawain, sir. King Arthur's nephew, a knight of the Round Table.

Gay science. (Troubadour.)

Gaze, At. (Her.) Standing still and turning its head to gaze full-faced.

Gazette. [It. gazzetta, a Venetian coin worth about $\frac{3}{4} d$., the price of the first paper at Venice.] A newspaper or journal, especially official. The $G$. is the London Gazette, containing all State proclamations, appointments and promotions of officers, notices of dissolution of partnership and of bankruptcy.

Gear [a Teut. wurd]; Gearing; G.-chain. Gearing, a means of transmitting motion particularly by toothed wheels; two wheels are in $G$. when their teeth are engaged together, and out of $G$. when disengaged so that the one can no longer drive the other; the terms are also applied to any driver and follower, however connected. A G.-chain is an endless chain whose links are adapted to work with the teeth of wheels so as to transmit motion from one to the other. Spelt also Geer, Geering, etc.

Gears. (Jeers.)

Geëz. (Lang.) An early Abyssinian dialect, also called Athiopian.

Gehenna. [Gr. $\gamma^{\prime} \in \nu \nu \alpha$. Means in Hebrew the valley of Hinnom, where the Jew's burnt their children in the fire to Moloch. In the English Authorized Version of the Scriptures, it is translated by hell. By mediæval writers it was used generally in the sense of pain and suffering. Hence the verb gehenner, to torture, which has passed into the Moc!. Fr. gêner, to annoy. In India the word has assumed the form Jehanum.

Geist. [Ger.] Great intellectual gifts, genius, vivacity, spirit.

Gelalæan era. The era, fixed to March 15 , I079, drawn up in the reign of Malek Shah (1072-I092), one of whose titles was Gelaleddin, Glory of the Faith.-Gibbon, Roman Empire, ch. Ivii.

Gellywatte. [Gael. geola, a ship's boat; cf. Dan jolle, a yawl, and the modern corr. into jolly-boat.] (Naut.) An old term for a captain's boat.
Gemăra. (Talmud.)

Gemel. [L. gemelli, twins.] (Her.) Double. Gemini. (Castor and Pollux.)

Gemmation. [L. gemma, a bud.] Reproduction by buds, inside or outside an animal's body, developing into independent beings, attached to or separated from the parent, as in sea-mats (Flustra) or in tapeworm (Tænia). (Fissi. parous.)

Gemote. [A.S.] Meeting.

Gendarme. [Fr.] Formerly a man in armour, and written gent d'arme; but now a policeman of a military character. The gendarmerie of a country is a police force organized and disciplined on military principles.

Gêne. [Fr.] Boredom, annoyance. (Gehenna.) General Assembly. (Assembly, General.)

General average. (Naut.) A claim upon owners and cargo by those whose property has been sacrificed for the general good.

General Confession of the Scotch Church. (Confession of Faith.)

General ship. (Charter, To.)

Generätrix. [L. linea, the line that produces.] The point or line whose regulated motion describes a line or surface.

Genet. [Sp. gineto, a light horseman.] I.q. Fennet. A small breed of horses; Spain.

Genet. [Ar. djerneith.] I.q. Genette. Gen. of sub-fam. Viverrinæ, sharp-nosed, long-tailed, with spotted or striped fur, and with feeble musk-secreting apparatus. S. Europe, Africa, and adjacent parts of Asia. Fam. Viverridæ, ord. Carnivǒra.

Genethlǐac. [L. genethliăcus, from Gr. $\gamma \in \nu \epsilon^{\prime} \theta \lambda \eta, a$ birth.] 1. Belonging to nativities, calculated according to the rules of astrology. 2. A birthday poem.

Genethliacs. In ancient Rome, those who told fortunes by means of the stars presiding over a man's birth. They were sometimes called Mathemătǔci, from the diagrams which they used.

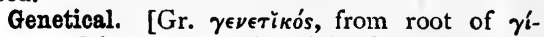

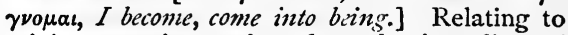
origin, genesis, mole of production, line of descent.

Genette. (Genet.)

Geneva. [Fr. genièvre, juniper, L. jūnǐpĕrus.] A spirit distilled from grain, and flavoured with juniper berries.

Geneva Bible. (Bible, English.)

Gen. fil. [For L. gěněrōsi filius.] Son of a gentleman.

Geniculate stem. [L. gěnǐcŭlum, a little knee.] (Bot.) One which bends suddenly in the middle, like a knee ; e.g. stem of knot-grass.

Genui. The ginn or djinn of Eastern nations, beings created from fire, whose abode is Ginnistan, the Persian Elysium, are sometimes so called. (Genius.)

Gěnista. [L.] A gen. of leguminous plants, Planta genista, Whin, the gen of the Celts, genêt of the French; the badge of a race of English kings, but it is not known what kind is meant-perhaps the common broom.

Genitive case. [L. genitivus, relating to 
genus.] (Gram.) That inflexion of the noun which denotes relation or procession.

Genins. [L.] In the Old It. Myth., a guardian spirit, whose life ceased with that of the person whom he guarded. (Hamadryads.)

Gĕnius löci. [L.] The genius or presiding deity of a place, the pervading spirit, influence of associations, etc., of a place.

Gennet, Order of the. An order of knighthood, founded by Charles Martel after his victory over the Saracens at Tours, in 726 ; so called from the gennet, or wood-martin, to denote the aid supposed to be given by St. Martin of Tours in the battle.

Genoese Republic. The free government of Genoa (N.W. Italy) at various times from 1000 to 1815 , especially from 1000 to 1326 , and 1428 to 1694 .

Genouillère. [Fr., knee-piece, frôm genon, $a$ knee, formerly genouil, L. gěniculum.] (Fortif.) The part of the parapet between the sole of an embrasure and the terreplein of a battery.

Genre. [Fr.] As applied to Painting, is perhaps $=$ a familiar every-day life treatment of a subject, not in itself an important one; as opposed to the sacred, classical, severe, typical. G., not reproducing simple essential characteristics, emphasizes minor details. Similarly, Dickens's treatment of a character, as contrasted with Shakespeare's, may be called G.

Gens de condition. [Fr.] People of quality.

Gens d'église. [Fr.] Churchmen, ecclesiastics. Gens de guerre. [Fr.] Military men.

Gens de lettres. [Fr.] Men of literature.

Gens de robe. [Fr.] Men of the law.

Gentile. [L. gentilis.] With the Latins this word denoted all who belonged to the same gens, or class, in which many families were united. After the rise of Christianity, it came to signify those who adhered to the old religions, as did also the Gr. é $\theta$ vǐós, ethnic, or heathen. (Apaturia.)

Gentleman-at-arms. One of a corps composed of retired officers or those who have formerly served in the army, marines, militia, or yeomanry (although civilians were formerly admitted), forming the sovereign's body-guard on State occasions. Established in A.D. 1509.

Gentleman commoner. (Fellow-commoner.)

Gentoo. [Port. gentio, heathen.] A Hindu or Brahman.

Genus. In Logic. (Difference.)

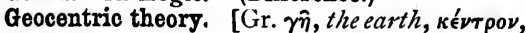
centre.] (Astron.) The theory which makes the earth the centre of the movements of the heavenly bodies, the earth herself being supposed to be at rest. (Heliocentric theory.)

Geode. [Gr. $\gamma \in \omega \dot{\delta} \eta s$, earthy.] (Geol.) A rounded hollow nodule, popularly potato-stone, the interior of which is often lined with crystals. (Nodule.)

Geodesio line; G. survey; Geodesy [Gr. $\gamma \in \omega \delta \alpha \cdot \sigma i a, a$ dividing of the earth, from $\gamma \hat{\eta}$, earth, $\delta a i \omega, I$ divide]. A Geodesic survey is a survey of a large tract of country conducted with extreme exactness, for the purpose of determining the form and dimensions of the earth. Geodesy, a systematic account of the methods of observation and calculation used in a geodesic survey. A Geodesic or Geodetic line is the shortest distance between two points on a given surface, measured along the surface.

Geognosy. [Gr. $\gamma \hat{\eta}$, earth, $\gamma \nu \hat{\omega} \sigma$ เs, knowledge.] 1. Study of the actual condition of the earth's crust, without reference to its causes, history, etc., which latter belongs to Geology. 2. With some, i.q. Geology.

Geograffy. In Naut. slang, a drink made by boiling burnt biscuit.

Geography [Gr. $\gamma \in \omega \gamma \rho \alpha \phi i a$, from $\gamma \hat{\eta}$, the earth, $\gamma \rho a ́ \phi \omega$, I draw or describe]; Astronomical G. ; Physical G. ; Political G. A delineation or description of the earth. Astronomical $G$. treats of the methods by which the relative positions of points on its surface, and its form and magnitude, are determined. Physical G. treats of the forms of continents and seas, rivers and mountains, climates and products; Political G., of the appropriation of the surface of the earth by communities of men.

Geomancy. [From Gr. $\gamma \in \omega$-, stem in composition of $\gamma \hat{\eta}$, the earth, and $\mu a \nu \tau \in$ ia, divination.] Divination by figures and line of points, originally marked on the ground.

Geometrical style. (Arch.) The style in which window and other tracery is composed entirely of pure geometrical figures, as the circle or the spherical triangle. This style succeeded the Early English, or Lancet, or First Pointed style, and is itself also known as the Second Pointed, or Middle Pointed. It was followed by the Flowing style, in which the window tracery is carried up from the mullions to the arch in soft wavy lines; and this in its turn was succeeded by the Continuous, or Perpendicular, known also as the Third Pointed, in which the lines of the tracery are carried up to the window arch in straight lines.

Geometry [Gr. $\boldsymbol{\gamma} \in \omega \mu \in \tau p i ́ a$, land-measuring, seometry]; Algebraical G.; Analytical G.; Coordinate G.; Descriptive G.; Elementary G. ; Higher G.; Modern G.; Plane G.; G. of position; Practical G.; Solid G.; Spherical G.; G. of three dimensions; G. of two dimensions. Geometry is the science of space, or the science which treats of the position, form, and magnitude of bodies or portions of space. If the bodies are on a plane the science is Plane G., or G. of two dimensions; if they are not in a plane, Solid $G$., or $G$. of three dimensions; if they lie on the surface of a sphere, Spherical $G$. The part of the science which can be deduced from the axioms and definitions of Euclid's Geometry, and involve the properties of straight lines and circles only, is Elementary $G$.; all beyond this belongs to the Higher $G$. The division between elementary and higher $G$. is, however, sometimes drawn a little differently from this. For Algebraical, or Co-ordinate, $G$., vide Co-ordinate; this kind of geometry is often called Analytical $G$., because the use of general symbols enables us to prove propositions by an analysis of algebraical expressions that are more general than the propositions. themselves. Modern $G$. is a collection of methods-invented in recent times and in most cases depending on 
a combination of algebra with G.-to facilitate the discovery and proof of geometric truths. $G$. of position is a branch of modern G., relating to the conditions under which three or more defined straight lines will have a common point, three or more defined points will range in a straight line, and the like. Practical $G$. is a body of rules for the actual delineation of the problems of G. ; in its higher branches it furnishes rules for the delineation on paper of constructions in solid space, and then is subdivided into Linear perspective, Descriptive G., Orthographic and other kinds of Projection (q.v.).

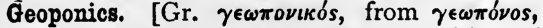
husbandman, from $\gamma \in \omega$-, stem in composition of $\boldsymbol{\gamma} \hat{\eta}$, earth, and $\pi \dot{w} \nu$ s, labour.] Science of tillage, of agriculture.

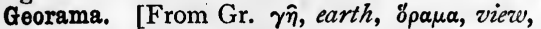
spectacle.] A hollow globe on the interior surface of which the earth's surface is depicted so that one standing near the centre of the sphere gets a comprehensive view of the geography.

Geordy lamp. A lamp, similar to the Davy lamp, invented at the same time by George Stephenson.

George, A. In Her., a figure of St. George on horseback, worn by the knights of the Garter.

George Eliot. Nom de plume of Miss Marian Evans, afterwards Mrs. Cross (died December, I880).

Georgics. [Gr. $\tau \grave{a}$ $\gamma \in \omega \rho \gamma \iota \kappa a ́$, things belonging

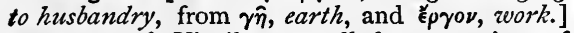
A poem of Virgil; so called as treating of agriculture and farm management generally.

Georgium sidus. [L.] (Planet.)

Geoscopy. [From Gr. $\gamma \in \omega-$, stem in composition of $\gamma \hat{\eta}$, earth, and $\sigma \kappa o \pi \epsilon ́ \omega, I$ look at.] Inspection of the earth, study of the results of such inspection.

Gerbil. (Zool.) Gen. of mouse (Leaping mouse), with long hind legs, like the gerboa, but classed in fam. Mūrìdæ. Several spec. Africa and Asia. (Gerboa.)

Gerboa. [Heb. and Ar. 'akbar, id.] (Zool.) Several spec. Europe, Asia, and Africa ; one spec. N. America. Fam. Dǐpǒdĭdæ, ord. Rōdentǐa. This fam. includes the Spring-haas, or Cape Leaping hare (Hēlămys Căpensis), about the size of the common hare ; it will leap eight or nine yards at a bound. (Gerbil.)

Geri and Freki. In Myth., the wolves of Odin.

German. [L. germänus, -a, having both parents the same, said of brothers and sisters.] Nearly related by blood, closely akin.

Germane. (German.) Closely allied, appropriate, relevant.

German school. Of Painting, a school marked by careful and matter-of-fact truthfulness. Its head was Albert Durer (born 147I).

German silver. An alloy of copper, zinc, and nickel (resembling the product of an ore at Henneburg, in Germany).

Germinal matter $=$ albūmen (q.v.) ; so called from the belief that albumen alone is concerned with generation and nutrition.

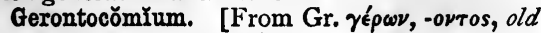

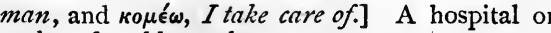
asylum for old people.

Gerund. [L. gěrundium, from gĕro, $I$ bear.] (Gram.) A verbal adjective in Latin, used foi the oblique cases of the infinitive mood, and so bearing the function of case-government, like the verb; stem ending is - $n d$; as, Urbem vĭdendi causa, for the sake of seeing the city.

Gerundive. [1. gĕrundivus, from gĕrundium, gerund.] (Gram.) A verbal adjective, ending in Latin in -ndus, etc., serving as a present participle passive, and as a "participle of necessity," or future participle passive ; as, Urbis videndæ causâ, for the sake of seeing the city; Urbs videnda est, or, urbem videndum est, the city must be (is to be) seen.

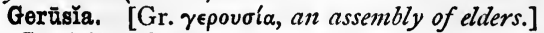
In Gr. Hist., the Spartan senate.

Gesta Romānōrum. [L., deeds of the Romans.] An olla podrida of mythical stories, monkish legends, romances, ciassical tales, ghost stories, etc., gathered from all sources and translated into Latin, some of which furnished themes to Chaucer, Shakespeare, and others ; light reading for monks on winter evenings (see Collier's Eng. Literature). (Panchatantra.)

Gests. (Minstrels.)

Gesture language. A term expressing the communications of savages by gestures which represent not letters but ideas.-Tylor, Primitive Culture.

Geysers. [Icel., raging.] Spouting fountains, boiling, intermittent; produced by rain and snow-water subterraneously heated in the neighbourhood of Mount Hecla.

Ghaut. [Hind. ghât, a mountain pass, gate.] 1. A mountain pass. 2. A range of mountains, especially along the Malabar (W.) coast of India. 3. Steps down to a river.

Gheber. [Pers. ghebr, infidel.] (Gueber.)

Ghee. [Hind. ghi.] A butter made of churned curds, used in India, and used in sacrifice by Brahmans.

Ghetto. [It.] The Jews' quarter in Rome.

Ghibellines. In It. Hist., the party which maintained the supremacy of the Emperor over the Italian states. (Guelfs.)

Ghirdawar, Girdwar. [Hind.] Inspector or superior officer of police.

Ghoul. [Pers.] An evil being of Eastern legend, supposed to prey on corpses.

Ghrime-sail. (Naut.) Old name for a smokesail, i.e. one so hoisted as to prevent the smoke from the galley blowing on to the quarter-deck.

Ghyll. (-gill.) Mountain torrent, gulley, goil. Giallolino. [It., yellow.] (Massicot.)

Giaour. A Turkish word, meaning infidel, and denoting all non-Mohammedans, especially Christians.

Gib. Quasi-personal name of a cat (Chaucer, Romance of Rose, 6204).

Gibberish. [From the old verb gibber, formed as a variant of jabber, and allied to gabble (Skeat).] Utter nonsense, unintelligible jargon.

Gibbous. [L. gibbus, humped, gibbous.] Said of the moon or of Venus when more than half the disc is bright. 
Gibier. [Fr. giboyer, to hunt; origin unknown.] Game, wild-fowl. Gibier de potence, a gallows bird.

Gibraltar. (Pillars of Herakles.)

Gier-eagle. [Heb. racham, the tender one, from its affection to its young.] (Bibl.) Lev. xi. I8; the Egyptian vulture, Nĕophron percnoptěrus. Fam. Vultŭrĭdæ, ord. Accǐpitres.

Giffard injector. A contrivance for introducing water into a boiler without pumping. A pipe comes from the top of the boiler, out of which a jet of steam issues into a vessel containing water, by which part of it is condensed; a partial vacuum is thereby formed near the end of the pipe. As steam (or any air or gas) enters a vacuum with a very great velocity, the uncondensed part of the steam enters the water with a great velocity, and thus sets up a current of water warmed by steam, which, being directed into a second pipe, is injected into the water in the boiler. The velocity of this current is sufficient to keep the water in the boiler from flowing out along the second pipe.

Gift-rope. (Guest-rope.)

Gig. [A word of Scand. origin, the root being perhaps ga, to go, which seems to be reduplicated (Skeat).] (Naut.) A narrow, clinkerbuilt ship's boat, adapted for expeditious rowing or sailing

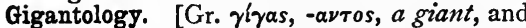
$\lambda \delta$ jos, an account.] An account of giants, study of, or a treatise on, giants.

Gigot. [Fr. gigue, a leg; origin unknown.] Leg of mutton, piece of meat.

Gil Blas. Hero of Lesage's romance of the name.

Gild. [A.S. and Goth. ; cf. Ger. gilde, corporation.] (Leg.) Tax, tribute, contribution. (Guild.) -gill. Norse part of names in Lake district, $=$ ravine, as in Stock.gill; Scottish -goil. (Ghyll.)

Gillie. [Gael. giolla, boy.] A Highland attendant.

Gilpin, John. Hero of a humorous poem by Cowper.

Gilpy. In Naut. parlance, a hobble-de-hoy.

Gimbal, or Gimbol, sometimes Gymbol-rings. [L. gĕmellus, twin.] A mode of suspension by which a chronometer, a compass, etc., remains horizontal in spite of the oscillation of the ship. The chronometer is hung within a ring on an axis coinciding in direction with a diameter; the ring is suspended inside a second ring on an axis coinciding in direction with a diameter at right angles to the former; the second ring (which may be a box or case) is suspended on an axis at right angles to the second and parallel to the first axis. If the third axis is tilted, the second, and with it the first, remains horizontal; if the second axis is also tilted, still the first remains horizontal. Now, any oscillatory movement of the ship whatever is equivalent to movements round two axes at right angles to each other, and therefore cannot do more than tilt both the second and third axes; so that under all ordinary circumstances, the first axis will remain horizontal.
Gimcrack. [O.E. gim, neat, crack, braggart.] A dainty toy, a trivial piece of work.

Gimmer. [Icel. gymbr.] - (Sheep, Stages of growth of.)

Gimp. [O.Fr. guimpe, the pennon of a lance.]

A kind of braiding used in trimming furniture.

Gin [Fr. engin, L. ingěnium, (I) skill, (2) in later L., a war-engine]; Cotton-G.; Whim-G. Gin is a contraction of the word engine, and is used in connexions in which the very general sense of that word has nearly dropped out of sight. Thus, a certain engine of torture is a G. ; a tripod with block, and tackle, and wheel, and axle for lifting cannon is also a G. ; a horsecapstan is a Whim-G., i.e. a turning engine ; an engine for separating the seed from the cotton is a Cotton-G. (Engineer.)

Ginevra. An Italian bride in S. Rogers's poem of the name, who hid in an oaken chest, and, the lid closing on her, was buried alive.

Gingerbread hatches. (Naut.) Sumptuous quarters. G. work, gorgeously carved ship's decorations.

Gingham. [Fr. guingan, said by Littré to be a corr. of Guingamp, the town where such fabrics are made.] Cotton fabric, originally made, it is said, in India.

Gingival. Relating to the gums [L. gingiva, a gum ]

Gingly̆mus. (Enarthrosis.)

Ginseng. [Chin. yansam.] A medicinal root used in China.

Gip, To. (Naut.) To take entrails out of fish. Giraffe. (Camelopard.)

Girandole. [Fr., It. girondola, L. gȳrare, to gyrate.] As commonly used, a branched chandelier; meaning also circular displays of $j c t s$ d'eau, and of fireworks.

\section{Gird. (Deer, Stages of growth of.)}

Girder; G.-bridge. A Girder is a long rectangular structure, consisting of two beams, one above and one below, built up of plates of wrought iron riveted together; the two are connected, not by a continuous web, but by strong bars arranged obliquely and dividing the intervening space into triangles. In a G.-bridge the space between the piers is spanned by two or more parallel girders, which support the roadway.

Girdle of Venus. The magic cestus of Aphroditē, which subdues all to love.

Girdwar. (Ghirdawar.)

Gironde, The. In Fr. Hist., a revolutionary party, the members of which are called Girondists, from the department of La Gironde, which returned three of its chief leaders to the Legislative Assembly of I 791. (Assembly.)

\section{Girrock. (Gar-fish.)}

Girt. In Naut. language, a ship moored so taut by two distant anchors that, when she tries to swing, she is caught by one cable while doing so, is girt, i.e. lies with side or stern to wind or current.

Girt-line, or Gant-line. (Naut.) A rope passed through a single block at the head of a lower mast, by which rigging and riggers are hoisted up. The first rope fitted to a vessel when rigging her. 
Gisement. (Leg.) Cattle taken in to graze at a certain price; also the saịd price. (Agistment.)

Gist. (Giste of action.)

Grste of action. [Fr. giste, L.L. gista, i.e. jăcĭta, from L. jăceo, I lie.] (Leg.) The cause for which an action lies; hence Gist, the main point in some matter; that on which it turns. (Agistment.)

Gitano. [It.] A gypsy.

Gittith, "to the chief musician upon G." Ps. viii., lxxxi., lxxxiv. ; some instrument or strain of music for stirring occasions of praise, but it is not known what. G. perhaps = of Gath (vide Speaker's Commentary).

Gizzard. [Fr. gésier, L. gĭgěria, plu.] (Anat.) The muscular division of the stomach, in birds, below the liver, on the left side of the abdomen, resting on the intestines; in which food is triturated by sand, gravel, etc.

Glabrous. [L. glăber.] (Bot.) Smooth, having no hairs.

Glacé. [Fr. glacer, to glaze, L. glacia, a secondary form of glacies, ice.] Glazed.

Glacial. [L. glaciālis, icy.] Having a crystalline appearance, as glacial acetic acid.

Glacial opoch. (Geol.) A time, succeeding the formation of the Pliocene strata, of arctic condition in the now temperate latitudes of Europe, giving rise to the Glacial drift, or boulder formation. (Boulders.)

Glacier. [Fr., from L. glacies, ice.] A stream of ice [Fr. glace], which moves slowly down a valley below the limit of perpetual snow, and is continually fed from the snow-fields above with snow which is compressed into ice in its descent.

Glacières [Fr. glace, ice], Ice-caves. Caves, chiefly in the Alps, full of ice; not connected with any glacial system, the surface of the earth being much above freezing point.

Glacis. [Fr.] (Fortif.) The outside of a fortress where the superior slope of the parapet of the covered way is gently produced till it meets the level of the surrounding ground with. out giving cover to the assailant.

Glades. Everglades; tracts of land at the south, covered with water and grass. - Bartlett's Americanisms.

Gladiators. [L. gladiātōres.] Swordsmen, employed by the ancient Romans to fight at funerals, and appease by blood the manes of the dead. They were afterwards introduced into the public amphitheatres.

Glădio succinctus. [L., girt with the sword.] So an earl was said to be, as having jurisdiction over his county; of which the sword was the symbol.

Glair. White of egg [L.L. clārium ōvi, clarus, clear] or any similar viscous substance.

\section{Glaive of Light. (Excalibur.)}

Glamour. [Scot.] A bewitching influence on the eyes, making them see things differently from ordinary healthy sight.

Glance. [Ger. glanz, lustre.] (Geol.) A term applied to certain coals and metallic ores which are lustrous; e.g. copper-glance, glance. coal or anthracite $(q . v$.$) .$

Gland. [L. glans, = galans, akin to Gr.

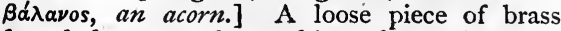
forced down on the packing of a stuffing-box (e.g. the stuffing-box at the top of the cylinder of a steam-engine, through which the piston-rod works) by two or more bolts for compressing the packing so as to prevent leakage.

Glanders. In horse, mule, and ass; an inflammation, often acute and dangerous, of the glandular system, especially of the nasal mucous membrane ; contagious, sometimes, to man, and even fatal.

Glands. [L. glandem, an acorn.] 1. (Physiol.) Various organs, which produce the chief secretions; e.g. lachrymal, mammary, liver, kidneys. 2. Some, being ductless, i.e. with no excretory opening, as the spleen, though called G., are not true G. 3. (Bot.) Elevations of the cuticle, containing generally acrid or resinous substances.

Glass. [One of a vast number of words containing the root gal, to shine.] (Naut.) A halfhour sand-glass, used on board ship to measure time by ; e.g. three glasses $=$ an hour and a half. Half-minute and quarter-minute glasses are used to measure the running out of the log. line.

Glasse, Mrs. Name or nom de plume of the authoress of the first English cookery-book.

Glass-gall. The scum which collects on melted glass.

\section{Glassites. (Sandemanians.)}

Glass-paper. Paper covered with powdered glass, used for polishing.

Glass-soap. Black oxide of manganese, or any other substance used to take away colour from glass.

Glauber's salts. Sulphate of soda (discovered by Glauber).

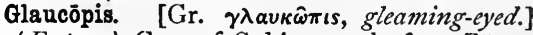
1. (Entom.) Gen. of Sphinx moth, fam. Zy̆gænĭdæ [(víraıva, some kind of shark]. 2. (Ornith.) Brush-bird, about the size of a magpie; plumage, brown with white stripes lengthwise on back; red wattles. Australia. Gen. Anthŏcæra [(?)

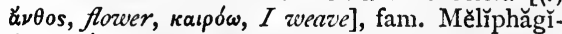
dræ [ $\mu^{\prime} \lambda_{\imath}$, honey, $\phi a \gamma \epsilon \hat{\imath} \nu$, to eat $]$, ord. Passěres.

Glaucous. [L. glaucus, bluish-grey'] (Bot.) Covered with bloom; e.g. a plum.

Glaucus. [Gr. yravkós, gleaming.] (Zool.) Sea-lizard; nudibranchiate mollusc, dark blue back with white stripe, white belly, class Gastĕrŏpŏda.

Glaze. [Akin to Glass.] A substance which, being applied to or deposited on the surface of pottery or porcelain, vitrifies with heat, and unites with the body. Salt, or flint combined with lead or tin, is the chief G.

Glazer. A wheel covered with emery, used for polishing cutlery, etc.

Glazing. Applying a very thin layer of colour over another, to modify its tone.

Glede. [O.E. glida, glidan, to glide.] 1. (Rite.) 2. (Bibl.) Buzzard, Būtěo, fam. Falcōnǐdæ, ord. Accîpitres. 
Gleomen. In Old Eng. Hist., itinerant singers, who after the Norman Conquest were called Minstrels.

Glen. [A.S.; $c f$. Welsh glyn, Gadh. gleann.] Narrow valley, retired hollow between hills or through raised ground.

Glenlivet. A superior Scotch whisky (from the place where it is made).

Glenoï. [Gr. $\gamma \lambda \eta \nu o \epsilon เ \delta \eta \dot{s}$, from $\gamma \lambda \eta \nu \eta$, the (shallow) socket of a joint.] (Anat.) Pertaining to a shallow articular cavity.

Glimmer. (Glass.) The miners' name for mica ; so called from its sparkle.

Glissade. [Fr.] $A$ sliding.

Gloaming. [Akin to gloom.] Twilight, dusk.

Globe-rangers. A Naut. nickname for the Royal Marines.

Globular chart; G. projection. The Globular projection of the circles of a sphere is the same as the stereographic, except that the point of projection is removed from the sphere by a distance equal to the sine of $45^{\circ}$. A chart drawn on this projection is a $G$. chart. The ordinary map, in which the surface of the world is represented on two circles, is-save for a few convenient inaccuracies-a G. chart of the eastern and western hemispheres.

Glomeralls. A name applied at Cambridge University to commissioners appointed to arrange disputes between gownsmen (students) and townsmen.

Gloriana. Spenser's Queen of Fairyland, meant both for Glcry and for Queen Elizabeth, who is also called Belphœbe and Britomart. It was a court fashion to address her as Gloriana, Oriana, Astræa, Cynthia, etc.

Gloss. [Gr. $\gamma \lambda \hat{\omega} \sigma \sigma \alpha$, languagr, word.] 1. In the Rhet. of Aristotle, a word which needs explanation. Hence, 2, an interpretation, comment, generally attached to the text and so marginal or interlinear; especially remnants of old iVelsh and Irish language preserved on Jatin MSS.

Glossary. [L. glossārium, from Gr. $\gamma \lambda \hat{\omega} \sigma \sigma \alpha$, language, word.] 1. A collection of difficult words or terms in a book or author explained. 2. A limited dictionary of special terms and words, as of an author, a science, a dialect.

Glosso-. [Gr. $\gamma \lambda \hat{\omega} \sigma \sigma \alpha$, the tongue.]

Glossology. [Gr. $\gamma \lambda \hat{\omega} \sigma \sigma \alpha$, language, word, $\lambda$ ó os, account.] 1. The science of interpreting words and terms. 2. = Glottology.

Glottis. [Gr. $\gamma \lambda \omega \tau \tau i$ s.] (Physiol.) The chink or aperture in the larynx for breathing and speaking, somewhat like $a$ small tongue in shape.

Glottology. [Gr. $\gamma \lambda \hat{\omega} \tau \tau \alpha$, language, $\lambda \delta$ 'ros, account.] The science of language in the most comprehensive sense.

Glover. (Fellmonger.)

Glubdubdrib. The fictitious island in Swift's Gulliver's Travels, where sorcerers evoked the spirits of the dead.

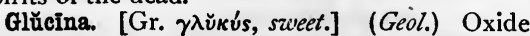
of glucinum, a rare earth, and a constituent of emerald and beryl.

Glucinum. A rare white metal, resembling aluminium in its properties. Its salts have a sweet [Gr. $\gamma \lambda$ ǔkús] taste. It is sometimes called
Beryllium, because it exists in the beryl. Other names are Glycinum, Glycium.

Glucose. [Gr. $\gamma \lambda$ v̌kús, sweet.] Grape-sugar; the fermented product of starch, cane-sugar, and woody fibre.

Glumdalclitch. The little girl of nine years old, only just forty feet high, who took care of (Swift's) Gulliver in Brobdingnag.

Glume. [L. glūma, a husk.] (Bot.) The chaff, bracts, of the grasses.

Glycerine. The sweet [Gr. $\gamma \lambda$ vкe of oils and fats. A clear, viscid liquid, which never dries at ordinary temperatures.

Glyn-. Part of Welsh names, = glen, as in Glyn-neath.

Glyphography. [Gr. $\gamma \lambda \dot{u} \phi \omega$, I engrave, $\gamma \rho a ́ \phi \omega$, $I$ write.] The taking an electrotype cast of an etching, to be used as a block to print from.

Glyptŏdon. [Gr. $\gamma \lambda \nu \pi \tau \delta s$, carved, ósoús,

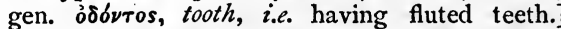
(Zool.) An edentate gen. of fossil animals, allied to the armadillos.

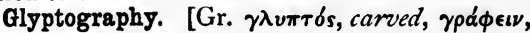
to zerite.] The art of engraving on gems.

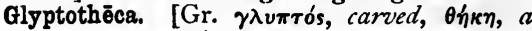
store.] A building in which sculptures are preserved; as the Glyptothek at Munich.

Gnătho-. [Gr. $\gamma \nu a \check{\theta} \theta 0 s$, the jaw.] In Anat.

Gnătho. [Gr. $\gamma \nu \alpha \dot{\theta} \omega \nu$.] A representative parasite in Terence's Eunüchus.

Gneiss. [Ger.] (Geol.) A name for the lowest series of stratified (metamorphosed) Primary rocks ; compounded, like granite, of quartz, felspar, and mica. Some gneiss is a metamorphic rock of much later age.

Gnome. [Gr. $\gamma \nu \omega \mu \eta$, a maxim, wise saying.] A brief and weighty sentence, a maxim, as "Know thyself."

Gnomes (properly Gnomons, from Gr. $\gamma \nu \omega \mu \omega \nu$, knowing). Elemental spirits who, according to the Cabalistic writers, inhabited the earth, and who were regarded as goblin dwarfs.

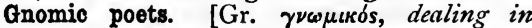
maxims.] Greek poets, whose works consist chiefly of short precepts or reflexions, as those of Theognis and Solon.

Gnomon. [Gr. $\gamma \nu \omega \dot{\mu} \omega \nu$, the gnomon or index of a sun-dial, a carpenter's mule.] 1. (Geom.) Let a parallelogram be divided into four others by lines parallel to the sides and intersecting in a diameter; if one of the parallelograms, across which the diameter passes, be removed, the figure formed by the remaining three is a $G$. 2. (Astron.) A pillar, the length of whose shadow on the level ground was used by the ancient astronomers for finding the altitude of the sun. 3. (Dialling.) The style or pin of a sun-dial, whose shadow marks out the hours.

Gnomonical projection. A representation of the circles of a sphere on a tangent plane, the projecting point being at the centre.

Gnomonics. The art of constructing dials.

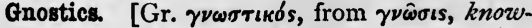
ledge.] (Eccl. Hist.) Properly, persons laying claim to or possessed of knowledge. More particularly, those who in the first centuries of the Christian era manntained doctrines similar in 
their essential features to those of Zoroastrianism. (Ahriman.) Matter to them was simply the product of evil; and this conclusion brought them sometimes to great asceticism, and sometimes to the grossest licence. The Gnostics, as time went on, split into various sects, distinguisherl rather by differences in their cosmogonical systems than by any real divergence of principles. Among these were the Basilidians, Carpocratians, Cerdonians, Cerinthians, Valentinians, and others.

Gnu. [Hottentot gnu or nju (Littré).] (Bot.) A gen. of antelope, with mane, and bull-like head. S. Africa. Gren. Cătōblěpas [Gr. кátw, down, $\beta \lambda \epsilon ́ \pi \omega, I$ look], sub-fam. Alcělăphĭnæ, fam. Bǒvĭdæ, ord. Ungŭlāta.

Goaf. [Welsh gob, a heap.] The waste place or material in a colliery.

Go-ashores. In Naut. slang, a sailor's best clothes.

Goat, Wild. [Heb. ago.] (Bibl.) (Ibex.)

Goat and Compasses. Sign of an inn; i.e. "God encompasses us."

Goat-sucker. (Ornith.) An almost universally distributed fam. of night-flying, insectivorous birds, with enormous gape of beak; plumage, moth-like in colouring, owl-like in texture. The British spec., Night-jar, Night-hawk, Moth-hawk, is between ten and eleven inches long. Gen. Caprĭmulgus, fam. Caprĭmulğ̌dæ [L. caprĭmulgus, goat-milker], ord. Picārǐæ (Cuvier, Fissirostres, ord. Passěres).

Gobelin tapestry. French tapestry; so called after Giles Gobelin, a well-known dyer in the reign of Francis $\mathrm{I}$.

Gobe-mouche, or Gobe-mouches. [Fr. gober, to gulp, mouche, $a f y$.] 1. The fly-catcher, a bird; hence, 2 , a silly gossip, ready to swallow any news.

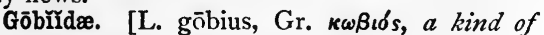
fish, sometimes identified with gobio, the gudgeon, which, however, belongs to ord. Phyेsostŏmi.] (Ichth.) Fam. of carnivorous fresh and salt water fishes-temperate and tropical waters-as Gobies, Dragonets, and Pěriophthalmus [Gr. $\pi \epsilon \rho t-\delta \phi \theta \alpha \lambda \mu o s$, properly round the eye, but here meaning with eyes that look all round]. This last gen. (Africa and the East) hunts its prey on the mud. Ord. Ǎcanthoptěry̆gui, sub-class Tělěostěi.

Godown. A storehouse, E. India.

God's acre. [A.S. æcer, L. ăger, field.] The churchyard.

Goëlettı. [Fr.] (Naut.) 1. A schooner.

2. A war-slocp.

Goffering. [Fr. gaufrer, to figure cloth, gaufre, a honey-comb; $c f$. Eng. wafer-cake.] Plaiting or fluting frills.

Gog and Magog. Two symbolical warriors noticed in some books of the Old Testament. In the Apocalypse they denote the enemies of the Christian faith; and in the Koran the names are in like manner used to mark the opponents of Islam. Two wooden giants in the Guildhall, London, are also known by this name.

Going through the fleet. (Naut.) Being towed in a launch from vessel to vessel (the drummers playing the rogue's march), and receiving a certain number of lashes alongside each.

Goître.] Fr.] Swollen neck; i.q. Bronchocēle (q.v.).

Gold-beater's skin. A delicate membrane, prepared from the peritoneal membrane of the ox ; pieces of gold are interleaved with leaves of $G$. for further beating, after the process of attenuation by vellum leaves.

\section{Golden Age. (Ages, The four.)}

Golden apple. (Paris, Judgment of.)

\section{Golden ass. (Psyche.)}

Golden Bull. [L. aurea bulla, the seal attached having been encased in gold.] 1. In Ger. Hist., the edict by which Charles IV. settled the law of imperial elections, the uncertainty of which had had the effect of placing the decision, mostly, in the hands of the pope ; enacted at Nürnberg and at Metz, 1356. 2. Any papal bull sealed in gold.

Golden fleece. In Myth., the fleece of the golden ram which bore Phrixus and Helle to Colchis. (For Order of G. F., vide Fleece.)

Golden Gardens. The Great and Little Schuitt, about half-way between Vienna and Pesth, islands inclosed by the dividing waters of the Danube. Other large tracts of soil are similarly formed by the D.

Golden Horn. "The harbour of Constantinople ... obtained, in a very remote period, the denomination of the G. H.," expressive of "the curve which it describes," and "the riches which every wind wafted from the most distant countries."-Gibbon, Decline and Fall of the Kom. Empire, ch. xvii.

Golden Iegend. A collection of lives of saints, compiled under the title Aurea Legenda, by Jacobus de Voragine, in the thirteenth century. Golden rose. A rose of beaten gold, blessed by the pope on Mid-Lent Sunday, and usually sent by him as a gift to some female sovereign.

Golden wedding. The fiftieth anniversary of the wedding of a couple, who are both still living in wedlock.

Golf. [Akin to Sw. kolf, a bolt, Ger. kolbe, a club.] 1. A Scotch game, in which a small ball is knocked into a set of holes in the ground, in as few strokes as possible. 2. (Her.) A purple roundlet or disc.

Gomascites. (Eccl. Hist.) The Calvinistic followers of Francis Gomas, in the Dutch Church of the seventeenth century.

Gomashtah. [Hind.] An E.-Indian factor or agent.

Gombron, or Gombroon ware. (From G., otherwise Bunder Abbas, opposite Isle of Ormuz, in the Persian Gulf.) Persian fayence, and, according to some, Chinese porcelain imported viâ $\mathrm{G}$.

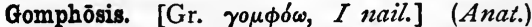
$A$ nailing, an articulation with immobility, or nearly so; as that of teeth in the alveolar processes.

Gomuti. [Malay.] A fibre, resembling black horsehair, obtained from the Gomuti palm.

Gondola. [It.] (Naut.) 1. The well-known 
boat used in Venice. It is about thirty feet long and four wide, nearly flat-bottomed, sharp and high at the stem and stern, always painted black, and usually propelled by one long oar, which is plied by the gondolier, standing. 2 . A six or eight oared boat of other parts of the Italian coast.

Gone. In Naut. phraseology, carried away. Gone-goose, an abandoned ship, or one given up as lost.

Gonfalon. [It. gonfalone.] (Gonfanon.)

Gonfanon. [O.H.G. guntfano, from gundja, combat, fano, banner (Littré).] 1. Small pennon attached to the lance, of the eleventh century; restored to lancer regiments of the Army of Occupation, 1815. 2. The banner of the papal army, shaped like the Labărum.

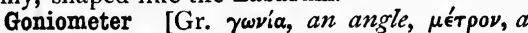
measure]; Reflecting G. An instrument for measuring the angles between the faces of crystals. In the Reflecting $G$. the measurement is effected by observing the angle through which a crystal must be turned in order that the images of a signal A, formed by reflexion on two faces, may successfully coincide with the signal $\mathrm{B}$.

Goniometry. The measurement of angles. The goniometric functions of an angle are its trigonometric functions (q.v.).

Gooroo, Gŭrû. [Hind., Skt. gŭrŭ.] Spiritual teacher.

Goosefoot. Chënǒpǒdium [Gr. $\chi \not \eta \nu$, goose, and

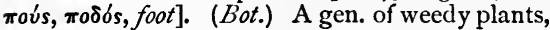
ord. Chenopodium; on dunghills and waste places, known as Fat hen, Good King Henry, etc., to which belongs the Quinoa of Peru (q. $\left.{ }^{\prime}.\right)$.

Gopher. (Zool.) A fam. of rodents (Pouched rats), with food-carrying pouch projecting from each cheek, and some with long hind legs like Gerbils (q.v.). American Rocky Mountain region, mostly. Saccŏmy̆idæ. Not to be confounded with the marsupial Pouched mice (small Dăsy̆ürǐdæ) of Australia.

Gopher wood. Gen. vi. I4 ; untranslated ; the meaning is mere matter of conjecture.

Gor-cock. (Gair-fowl.)

Gor-crow. The common crow ; from gore, in the sense of filth; compare the provincial name midden crow, and vide Middings.

Gordian knot. (Hist.) A knot said to have been made by Gordius, a Phrygian king, and so intricate that no one could untie it. Alexander the Great, it is said, cut it with his sword.

Gordon riots. Anti-popery riots, incited or headed by Lord George Gordon, I760.

Gore. [O.E. gâr, lance.] (Her.) An abatement denoting cowardice. It is bounded by two curved lines meeting in the fess point.

Gorge. [Fr., from L. gurges, a whirlpool, a throat.] 1. (Mil.) The contracted space between the interior extremities of the faces or flanks of a fortification. 2. A narrow passage between two hills.

Gorged. (Her.) Wearing a crown or the like round the throat [Fr. gorge].

Gorget. (Gorge.) (Mil.) A piece of metal armour protecting the neck and throat, after- wards modified into a crescent-shaped ornament suspended on the chest and worn by the officer on duty.

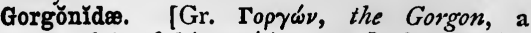

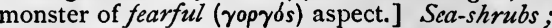
arborescent corals, as Corallium rubrum, Ked coral. Fam. Alcy̆ŏnārǐa, ord. Zōanthāria, class Actīnōzōa, sub-kingd. Cœlentěrāta.

Gorgons. [Gr. Topyoves.] (Myth.) In the Hesiodic theogony, three sisters, of whom one was Medūsa, whose head turned to stone all who looked on it. (EEgis.)

Gos-hawk. [O.E. gós-hafoc, goose-hawk.] (Ornith.) A short-winged British hawk, used mainly for ground game. Male, eighteen inches long, female, twenty-four inches. Plumage, grey-brown above, white dashed with black below; young birds, gentil falcons, are more of a red colour. Astur pălumbārius [L., hawk used for doves (pălumbes)], sub-fam. Accip̌rtrīnæ, fam. Falcōntdæ, ord. Accípĭtres.

Gospeller. The minister who reads the Gospel in the Eucharistic Office.

Gossip. [A.S., from God, and sib, kindred.] This word now denotes only a tattler, or busybody. Anciently it was applied to sponsors, as contracting a spiritual kinship with the baptized child; and in some parts it still retains its original meaning of a godparent. Similarly commère [Fr., a godmother] has acquired the meaning of a gossip.

Goth. In modern phrase, a representative of tasteless barbarism.

Gotham. Three wise men of Gotham; they "went to sea in a bowl," it is said. G. is a village in Nottingham, with a reputation for folly ; said to be due to absurd customary services attached to land tenure there; but the stories told of the men of Gotham are to be found almost everywhere.

Gothamist. Wiseacre, silly blunderer. (Gotham.)

Gothenbarg system. That by which the municipal body is the only proprietor of publichouses in the town, and the only trader in liquor; the publican being their salaried servant, and having no interest in the amount of drink consumed.

Gothic language. A Low German dialect, preserved in the translation of the Bible made by Ulphilas in the fourth century for the Goths of Moesia; preserved in a single MS. (fifth century) now at Upsala, in Sweden.

Gothio styles. (Romanesque styles.)

Gothic version. The version of the Scriptures made for the use of the Goths by Ulphilas in the fourth century. (Gothic language.)

Gouache. (Guazzo.)

Gouge. [Fr.] A chisel with a semi-cylindrical blade.

Gourmand. [Fr., a glutton; origin unknown; (?) onomatop.] One fond of high living, but deficient in taste as to food.

Gourmet. [Fr.] A dainty lover of luxurious food, a fastidious devotee of the pleasures of the table.

Goût. [Fr., L. gustus, taste.] Taste, relish. 
Gouvernante. [Fr., governess.] G. de ménage, housekeeper.

Governor. [L. gubernator, Gr. $\kappa \nu \beta \epsilon \rho \nu \hat{\nu} \nu$, to steer.] 1. (Mil.) An officer placed in supreme authority, both civil and military. 2. (Mech.) A contrivance for regulating the supply of steam to the cylinder, so as to prevent the motion of the piston from exceeding a certain assigned rate. The commonest form (Watt's) consists of two heavy balls at the end of arms fastened by hinges to a vertical spindle turned by the machine; as the speed of the rotation increases, the distance between the balls increases, and motion is given to the end of a lever connected with a valve in the steam-pipe, which is thereby partially closed.

Gowrie Conspiracy. An alleged attempt on the part of the son of the Earl of Gowrie, executed for his share in the Raid of Ruthven, to get possession of the person of James VI. (1600).

Goyenda. [Hind.] Informer, police agent.

Grab. (Naut.) An Indian coasting-vessel of $\mathbf{5} 50$ to 200 tons, generally two-masted.

Grace. Of a university senate, an act or decree of such a deliberative body.

Grace, Days of. (Leg.) Time of indulgence granted to an acceptor for the payment of his bill after it has become due, if not payable at sight or on demand. The number varies in different places, but Sundays are always reckoned.

Grace-cup. The cup passed round after a formal dinner in a college and elsewhere, wherewith the feasters drink, standing, to the opposite and left-hand men, who also stand, and also sometimes to an institution or benefactor's memory.

Grace notes. In singing or playing, ornamental, not necessary, turns, shakes, etc.

Graces. [L. Grātiæ.] In L. Myth., the Gratiæ answered to the Greek Charites, of whom Hesiod names three. They are embodiments of beauty. The name is found in that of the Sanskrit Harits, the horses of the sun; so called as gleaming with ointment or light.

Gradgrind, Thomas. A thoroughly practical utilitarian in Dickens's Hard Times.

Gradient. The rate of ascent or descent of a road ; generally spoken of as a gradient of $\mathbf{I}$ in so many; as, I in Io, i.e. one foot of vertical rise or fall to every ten feet of horizontal distance.

Gradin, Gradine. [Fr.] Seats of a theatre or amphitheatre, arranged one above another.

Grădŭāle, Gradual, Grail, Grayle. 1. In the Rom. Church, a book containing the musical portions of the Mass. 2. An anthem between Epistle and Gospel, sung while the deacon ascends the steps [L. grădūs] of the altar.

Græca fĩdēs. [L., Greek loyalty.] Treachery, duplicity. (Punica fides.)

Grail, The Holy. (Sangreal.)

Grain. [L. grānum, a small seed, corn.] 1. The $\frac{1}{7000}$ th part of a pound avoirdupois. The grain was originally the weight of a grain [grānum] of barley. 2. A red dye made from kermes (kermes).
Graining. 1. Painting in imitation of the grain of wood. 2. A process in leather-dressing, by which the skin is softened and the grain is raised.

Grains of paradise, Meleguetta pepper. Seeds of the Amōmum grana părădisi, one of the ginger family, from Guinea; used to give fictitious strength to spirits and beer. Brewers who possess them, and chemists from whom they buy them, are liable to heavy fines, $£ 500$ and $£ 200$.

Grakle. [L. grācŭlıs, jay or jackdaze.] (Ornith.) A designation given by some to certain birds of the starling kind (Sturnus), peculiar to the eastern hemisphere, as those of the gen. Pastor [L., feeder] and Acrĭdǒthērēs [Gr.

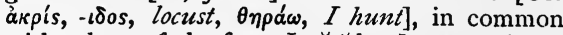

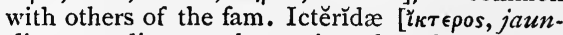
dice, according to the notion that the sick recovered on seeing the bird, and it died].

Grallæ, Grallātōres. [L., stilt-walkers, from grallæ, stilts.] (Ornith.) Wading and running birds, an ord. ranging from the snipes to the bitterns and flamingoes.

Gram. 1. (Excalibur.) 2. An Indian grain on which horses-are fed.

Gramarge. [Fr. grimoire, conjuring-book.] The art of divination.

Gramercy. [Fr. grand' merci.] Great thanks.

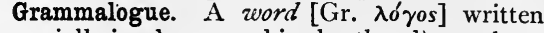
(especially in phonographic shorthand) as a letter $[\gamma \rho \alpha \mu \mu a], i . e$. represented by a single sign, as $\&=$ and. mar.)

Gramme. [Fr.] The weight of a cubic centimètre of distilled water, at a temperature of $4^{\circ} \mathrm{C}$. $\left(39^{\circ} 2^{\circ}\right.$ Fahr. $)$; it equals 15.43235 grains.

Grampus. [Fr. grand (?) or gras (?) poisson, large or fat fish.] (Ichth.) Gen. of dolphin. The Common grampus (sometimes thirty feet long, with black back and white belly); attacks the whale. Ranges from North Sea to Cape of Good Hope. I.q. Thresher or Killer, fam. Delphīnĭdæ, ord. Cētācěa.

Grampus, Blowing the. (Naut.) Sluicing any one with water.

Granadilla. [Sp., dim. of granada, pomegranate.] The fruit of a climbing vine, found in Brazil and W. Indies.

Grand Alliance. (Hist.) A league formed against Louis XIV., by Holland, England, the Emperor, Spain, and Saxony, 1689-1694; renewed between the Emperor, Great Britain, Holland, Prussia, and Hanover, I 7or.

Grand coup. [Fr.] Great stroke, great hit. Grand division. (Mil.) Tactical formation, in which two companies stand abreast.

Grandee. [Sp. grande de España.] The highest title of Spanish nobility. (Hidalgo.)

Grandiloquent. [From L. grandǐ-lŏquus, grandly speaking.] Bombastic in style of speech.

Grandison, Sir Charles. The title of a novel

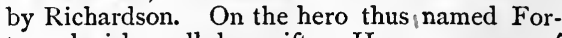
tune lavishes all her gifts. Hence persons of superlative grandeur and good luck are some. times so called. 
Grand jeu. [Fr.] The full play, or strength, of an organ or harmonium.

Grand Lama, Ilama. Buddhist high priest of Thibet, regarded as divine.

Grand larceny. (Petty larceny.)

Grand serjeanty. An old mode of tenure by military service, or an equivalent payment. (Tenure.) It has now become freehold, though some honorary services are retained.

Granite. [It. granito, formed of grains.] (Geol.) Strictly and typically, formed of quartz, felspar, and mica. Most is igneous, but some of metamorphic character : in the latter case passing into gneiss ; in the former, into syenite.

Granitic rocks $($ Geol. $)=$ granite proper, graphic granite, syenite, gneiss, and others, more or less like $\mathrm{G}$. in character and appearance.

Grant: [O.Fr. graanter, craanter, creanter, from L. crēdo, $I$ believe.] (Leg.) Originally a deed transferring incorporeal hereditaments and expectant estates where transfer by livery of seisin was impossible. This conveyance is now the usual mode of transferring real property, and if uses are superadded, it is called $G$. to uses. (Seisin.)

Grantee. (Leg.) One to whom a grant is made.

Granth. The scriptures of the Sikhs, the writings of gurus, beginning with Nanek, in the fifteenth century.

Granular casts. (Path.) Granular matter adhering to kidney tubecasts; found in the urine, denoting chronic disease in the kidneys.

Granulating. [Fr. granŭler.] Forming into small masses or grains.

Granulation. [L.L. grānŭlum, a little grain.] In healing of wounds and ulcers, minute red vascular particles, the materials of new texture.

Grape-shot (general shape of bunch of grapes) (Mil.) Projectile composed of layers of shot, either arranged in a canvas bag round an iron pin on a circular plate or without the canvas bolted between four plates.

Grape-sugar. (Glucose.)

Graphic. [Gr. ypăфıкós, pertaining to writing or delineation.] Clearly and vividly described, expressed, or delineated.

Graphic method. The Method of curves (q.v.). (q.v.)

Graphite. [Gr. $\gamma \rho a ́ \phi \omega, I$ write.] Black-lead

Graphitoid. [Graphite, and Gr. eî́os, form.] Resembling graphite, or black-lead.

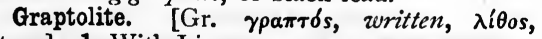
stone.] 1. With Linnæus, appearances on stone, as of drawings, maps, vegetable forms. Now, 2, fossil zoophytes-Silurian-resembling the seapens of our own seas.

Grasseyé. [Fr.] (Iang.) Pronounced with a guttural trill or uvula vibration, as the Fr. $r$.

Grasson, Grassum. [A.S. gearsum.] A fine paid on the transfer of a copyhold estate.

Grätis. [L.] For thanks (only), for nothing.

Grăvāmon. [L.] A grievance, inconvenience; in conversation, the substantial part of a complaint.
Gravel. [Fr. gravier, O.Fr. grave, rough sand mixed with stones.] Irregular, subangular stones of hard rock, left by rivers and lakes. Shingle consists of pebbles.

Graver. An engraving tool.

Graving. (Naut.) Cleaning a ship's bottom, and coating it with tar or the like.

Gravitation. The mutual force by which any two particles of matter in the universe attract or tend to draw each other together. The force is directly proportional to the two masses and inversely to the square of the distance; i.e. it is represented by the formula, $\frac{m m^{\prime}}{r^{2}}$.

Gravity, Centre of. (Centre.)

Gravity, Specific. (Density.)

Great Bear. In Astron. and Myth. (Rishis, The Seven.)

Great Bible. (Bible, English.)

Great Cham, or Khan. The supreme ruler of Tartary.

Great circle. (Circle.)

Great-circle sailing (or Tangent sailing). That method of navigation by which a ship's course is directed along the arc of a Great circle (q.v.), that being the shortest distance between two points on the globe's surface.

Great Commoner, The. William Pitt, afterwards Earl of Chatham.

Great Divide, The. The Rocky Mountains, which constitute the chief watershed of $N$. America.

Greater Bull. (Ausculta fili.)

Greater Excommunication. tion.)

Great Forty Days. Those between the Resurrection and the Ascension.

Great Mogul, The. Title of the Mohammedan emperors of Delhi, of Mongrian race.

Great organ. (Organ.)

Great Seal of England. The seal, in the keeping of the Lord Chancellor, used for giving the royal assent to all charters, commissions, grants of land, letters patent, franchise, liberties, etc. Priz'y Seal, in the keeping of the Lord Privy Seal, that used for sanctioning issues of treasure.

Great tithes. (Tithes.)

Greave. (Mil.) Armour to protect the legs.

Greaves, Graves. The sediment of melted tallow.

Grebe. [Ger. grebe, from Mod. Gr. $\gamma \lambda \lambda^{\prime} \beta$ os, a gull (Littré, Devic's Supp.) ; or Celt. krib, a crest (Skeat's Etym. Dict. ?).] (Ornith.) A universally distributed fam. of diving-birds, with lobated feet set so far back that the bird has a difficulty in walking. The dab-chick is the most familiar British spec. Fam. Pōdǐcǐpǐdæ [L. pōdǐcem, fundament, căput, head], ord. Ansěres.

Grecian. 1. A boy of the head class at Christ's Hospital. 2. A Greek scholar. 3. A Jew who knew Greek (Acts vi. I).

Grecian steps. At Lincoln and elsewhere. A corr. of gresen steps, grese being the O.E. form of Fr. degré, L. gradus, a step. Gresen steps is, therefore, a tautology.

Greek Calends, or Kalends. (Calends.) 
Greek Church. The same as the Eastern or Orthodox Church. (Nicene Creed.)

Greek cross. (Cross.)

Greek fire, i.e. used in defence against the Saracens by the Byzantine G., who, circ. A.D. 673, learnt its use from Callinicus of Heliopolis, as it is said. Its composition supposed to be of nitre, sulphur, naphtha; highly inflammable, and said to burn under water. Its use spread through W. Europe in time. Grecque, through the form Creyke, becomes cracker.

Greek modes, or scales, or divisions of the interval between two octaves, were fifteen, the Principal, or Authentic, being five : viz. Dorian, from $\mathrm{D}$ to $\mathrm{D}$, with us ; Ionian, or Jastian, $\mathrm{E}$ to E b ; Phrygian, E; Álian, F ; Lydian, F From these were constructed all the Church

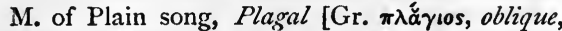
indirect $] M$. being added, formed from Authentic, by taking the fourth below as a new key-note. Thus, Hypo-Dorian is our A. Authentic M. were also distinguished as Hyper- ; e.g. Dorian is i.q. Hyper-Dorian. (But Hyper- has not uniformly this meaning.)

Greenbacks. Legal tender notes. The national paper-money currency of the U.S., first issued on the breaking out of the late civil war. The backs of notes so issued by the Government, and by the national banks, are printed in green, mainly for the purpose of preventing alterations and counterfeits. -Bartlett's Americanisms.

Green Cloth, Court of. A court having jurisdiction over all matters of justice in the king's household; abolished in 1849.

Green-eyed monster. Jealousy.

Greenheart. (Bibiri.)

Green Man and Still. Sign of an inn; i.e. herbalist and distillery.

Greensand $($ Geol. $)=(\mathrm{I})$ Upper greensand, or G. proper, and (2) Lower, or Neocomian (q.v.), which two are divided by the gault. The lower part of the Cretaceous system, of which the chalk is the upper; containing, in some beds, numerous greenish specks of glauconitic silicate of iron.

Green sickness. Popular name for Chlörösis (q.v.).

Greenstone, Diorite. A variety of trap rock, found in masses and dykes, associated with various other rocks.

Grego. [It. Greco, Greek.] A short cloak of coarse cloth, worn by Levantines.

Gregorian Calendar. (Calendar; New Style.)

Gregorian epoch. The epoch of the Gregorian Calendar.

Gregorian modes, or tones (collected and arranged by Gregory the Great, circ. A.D. 600). Certain Church modes, chants, melodies, of Plain song, taken, as is generally held, from the Greek modes (q.v.), or from some diatonic system common to Hebrew and to Greek music, and thence derived to the early Church.

Gregorian telescope. A particular kind of reflecting telescope, named after its inventor, Professor Gregory, and described by him in Optica Promota, I660. (Telescope.)

Grenade. [Sp. granado.] (Mil.) A large shell or bomb. A hand.-G., barely two pounds in weight, used for throwing against storming parties, at a distance of about twenty-five yards. The tallest soldiers, when formed into companies or regiments by themselves, are called Grenadiers, having been raised for this duty by Charles II.

Grenadillo, Granilla. [Sp.] A pale W. Indian cabinet wood.

Grenadine. [Fr.] A thin silk for dresses, shawls, etc.

Grès. [Fr., sandstone, gritstone, O.H.G. gries, gravel.] Stoneware.

Grès de Flandre; so called. Stoneware, apparently German.

Gresham Lectures. Free scientific lectures delivered in the City of London, under the will of Thomas Gresham.

Gretna-Green marriages. Marriages celebrated at Gretna Green, being the first place across the Scottish border that could be reached from Carlisle by persons wishing to avail themselves of the facilities afforded by the Scottish law of marriage. Such marriages are no longer celebrated, a residence of twenty-one days being now required in Scotland as in England.

Grettir Saga. The Icelandic story of a hero whose exploits answer to those of the Greek Herakles. (Berserkers.)

Grex venālium. [L.] $A$ venal throng

(Suetonius).

Greybeard. In Pottery. (Bellarmine.)

Grey Friars. Franciscans; so called from the colour of their habit.

Greyhound. [Heb. zarzir mathnaim, girded of the loins.] (Bibl.) Prov. xxx. 3I ; probably horse (vide margin of Authorized Version).

Grey spectre. (Banshie.)

Greystone. (Trachyte.)

Greywacke. [Ger. grauwacké, grey, coarse rock.] An indurated argillo-arenaceous rock, sometimes gritty; Silurian and Cambrian, chiefly. But the term is not strictly defined.

Grice. [(?) Fr. gris, grey.] A young wild boar, or domestic pig, or badger.

Gridiron. (Naut.) A timber frame, between high and low water marks, for a ship to rest on, to allow an examination of her bottom.

Griffin. 1. [Gr. $\gamma \rho u ́ \psi$.] A fabulous being of mediæval fiction and romance, but answering practically to the dragon of the Gardens of the Hesperides, or of the Glistering Heath in the Volsung tale. (Saga.) 2. [Anglo-Ind.] New. comer to India. 3. An heraldic animal, with a lion's body and an eagle's head and wings.

Grilse. Salmon in second year, returned from sea.

Grimalkin. 1. Quasi-personal name of a (properly she-)cat. 2. Name of a familiar of one of the witches in Macbeth. Graymalkin suggests the idea of a cat such as assists at the orgies of witches, in connexion with a witch-song beginning "Grauwölcken," Grey clouds. Dr. Latham and others say gri-malkin = grey scarecrow. . Richardson quotes, "Grimalkin's a hell-cat; the devil may choke her" (Ballad of Alley Croker). [Mal- 
kin is for Moll-kin, dim. of Moll, Mary, with suffix -kir.]

Grimc's Dyke. Wall of Antōnīnus, from the Forth to the Clyde.

Grimgribber. [(?) Fr. grimoire, a conjuringbook.] The jargon of legal sophistry.

Grimm's law. (Lang.) The generalization of Jacob Grimm, as to the change of early explosive consonants in Teutonic about the first century, and a further partial change, especially in dentals, in O.H.G. Represented as three stages in column, we have-

Early stage : $\mathrm{GH} ; \mathrm{g} ; \mathrm{k}: \mathrm{DH} ; \mathrm{d} ; \mathrm{t}: \mathrm{BH} ; \mathrm{b}$; Teut. ch. : $\mathrm{g} ; \mathrm{k} ; \mathrm{h}(\mathrm{g}): \mathrm{d} ; \mathrm{t} ; \mathrm{th}(\mathrm{d}): \mathrm{b} ; \mathrm{p} ; f(\mathrm{~b})$ O.H.G. ch. : k; ch, hh; $h(\mathrm{~g}): \mathrm{t} ; z, s z ; \mathrm{d}: \mathrm{p} ; f(\mathrm{~b}) ; f(v, \mathrm{~b})$ Small capitals are aspirates, italics are spirants, or breathings. There is scarcely any passage from spirants in O.H.G., except from the dental th, which seems to have been distasteful.

Grindery. Shoemaker's materials.

Griping. (Naut.) (Falling off.)

Griquas. A S.-African race, sprung from Dutch settlers and Hottentot women.

Grisaille, Fn. [Fr.] Ornamented with designs in grey.

Griselda. The very patient wife in Chaucer's Clerke of Oxenford's Tale.

Grisette. [Fr.] 1. A coarse grey dress. 2. A woman who wore it.

Grison, Grisonia, vittāta. [Fr. grison, gris, grey.] (Zool.) An animal of the weasel kind, about two feet long, light grey back, black belly ; playful when tamed, but mischievous. Gălictis, sub-fam. Mustēlīnæ, fam. Mustēlı̆dæ, ord. Carnǐvǒra.

Grist. [O.E.] That which is ground in a mill.

Grit = any stone made up of particles more or less angular (mostly siliceous), cemented together, as shell-grit, which is calcareous ; millstone grit, siliceous.

Groat. [D. grote schware, great $S .=$ five little schware.] Any great or large coin. An old English silver coin, equal to fourpence of our present money.

Groats. [O.E. grôtz, meal of wheat or barley.] Oats deprived of the hulls, or outer coating.

Grocer's itch. A kind of Eczëma (q.v.) on the hand, from the irritation of sugar.

Grog. 1. Rum and water, introduced as a regular navy drink by Admiral Vernon, called "Old Grog," from his grogram cloak. 2. Any mixture of spirits and water.

Grog, 0ld. Admiral Vernon, who took Puerto Bello, New Granada, in 1739; known by his grogram cloak ; originator of grog.

Grogram. [O.Fr. gro-grain, coarse grain.] A coarse stuff, made of silk and mohair.

Groins. [Connected with Icel. grein, Sw. gren, Dan. green, a branch or arm.] (Arch.) The lines formed by the intersection of arches crossing each other at any angle.

Grolier. (From the inventor.) A kind of decoration for bookbinding, consisting of a scroll, embracing curves, semicircles, and angles.

Grommets, or Grummets. (Naut.) Rings of rope, used to fasten the sail to a stay, and for other purposes.
Groningenists. (Eccl. Hist.) . A subdivision of the sect of Anabaptists.

Groom of the Stole. In the royal household, the first lord of the bedchamber ; so called from the long robe, or stole, worn by the sovereign on State occasions.

Gros. [Fr.] Thick, strong; used in many compound words for silk goods, as gros-deNaples, etc.

Groschen. [Ger., dim. of gross, and originally = any somewhat thick or large coin.] A German coin ; 30 silver $\mathrm{G}$. $=24$ good G. $=1$ thaler.

Grossièreté. [Fr.] Coarseness, vulgarity.

Grotesque. [Fr., It. grottesco, in grotto style.] Quaint, irregular, whimsical.

Grotius. Of Delft, Holland, the great publicist of Europe (born 1585 ).

Groundage. Wharfage.

Ground bass. (Music.) A bass passage of four or eight bars, repeated frequently, each time with a variation of melody and harmony.

Ground-tackle. (Naut.) Anything used in anchoring or mooring a ship.

Grow, To. (Naut.) Used of the direction of the cable towards the anchor; thus: "The cable grows on the port bow" means that it inclines to the left side.

Grub Street. Near Moorfields, where many literary hacks lodged in the seventeenth and eighteenth centuries. It is now Milton Street. It supplies an epithet for worthless authors and their works. ful.

Gruesome, Grewsome. [Scot.] Ugly, fright-

Grummet. (Grommets.)

Grumous blood. [L. grūmus, a little heap of earth.] 1. Thick, clotted. 2. (Bot.) Knotted, clubbed.

Grundy, Mrs. A dame often referred to by Dame Ashfield, in Morton's Speed the Plough, as to "What will Mrs. Grundy say ?" Hence the name stands for respectable English society and its censorious propriety.

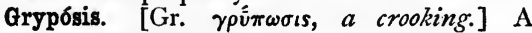
growing inwards of the nails.

Guacharo. [Sp., screamer; $c f$. It. guajare, to yell.] (Steatornithidæ.) $G$. caves, in the valley of Caripe, Venezuela, the haunt of the G., a remarkable nocturnal bird, described by Hum. boldt ; of ord. Insessores, tribe Fissirostres, and referred to Caprimulgidæ ; but widely differing from Insess., as being strong-billed, frugivorous. From the fat of the young a valuable oil or butter is obtained.

Guachos. Half-breed inhabitants of the Pampas of La Plata, of Spanish and native American extraction.

Guanches. The aborigines of the Canary Islands ; now extinct.

Guano deposits. Of Pacific and other tropical islands; the droppings of sea-fowl, with their skeletons and eggs, bodies and bones of fishes, seals, and other animals ; 60 to 120 feet deep; a valuable manure. The word is Spanish.

Guarana. A kind of chocolate made from a Brazilian plant.

Guardacosta. [Sp., coastguard.] (Naut.) 1. 
War-vessels formerly employed in the preventive service on the coasts of S. America. 2. Spanish revenue-vessels are still so called.

Guard-boat. (Naut.) 1. A boat used in harbour to see that officers and crews are on the alert, by rowing amongst the men-of-war. 2. One employed to enforce quarantine.

ctuardian of the spiritualities. The person or persons in whom resides the ecclesiastical jurisdiction of a diocese, when a see is vacant by death or translation.

\section{Guardians of the poor. (Poor laws.)}

Guard-mounting. (Mil.) Form of parade preparatory to guards leaving the inspectionground for their respective posts.

Guardo. [Sp.] (Naut.) A guard-ship, or man belonging to one. $G$., a trick upon a landsman, generally in a guard-ship.

Guard-ship. (Naut.) A man-of-war, stationed in a harbour to superintend marine affairs there, and inspect nightly vessels not in commission. In fleets, each ship takes the guard in turn for twenty-four hours, commencing at 9 a.m., and during her tour of duty hoisting the Union Jack at the mizzen.

Guava. (Bot.) Fruit of the Psidium pōmĭfĕrum and py̆rifĕrum; extensive gen. of Myrtaceæ, of Trop. America only.

Guazzo. [It., gonache.] A very durable kind of distemper painting.

Gubbio ware. Fayence made or finished at Gubbio, in Italy, about 1518-1537. Noted for its ruby and other metallic lustres.

Gudgeon. The iron piece at the end of a wooden shaft on which it turns; as the gudgeon of a water-wheel.

Guebers. This word, meaning infidel (Giaour), is applied by the Mohammedans to the worshippers of fire, who in India are called Parsees, as having come originally from Persia. Their sacred books are the Zendavesta.

Guelfs. (It. Hist.) In the twelfth century, the Welfs, or Guelfs, dukes of Bavaria, were constantly at war with the house of Hohenstauffen, whose chief adversary in Italy was the pope. The popes thus became the heads of the Guelf party, as opposed to the Ghibellines, or supporters of the emperor; and the struggle between the two became a contest between the spiritual and temporal powers.

Guenevere. (Arthur, King.)

Guêridons. [Fr.] Loo-table.

Guerilla. [It., dim. of guerra, O.H.G. werra, war.] One of a hand of men carrying on irregular warfare and subsisting by plunder.

Guerre à la mort. [Fr.] War till death.

Guerre à l'outrance. [Fr.] War to the (bitter) end.

Guest-rope, or Guest-warp. One carried to an object at a distance, either to warp a vessel or make a boat fast. Guest-warp-boom, a swinging spar outrigged from a vessel's side, to fasten boats to.

Guicowar. [Hind.] Lit. cowherd; title of the sovereign of Gwalior. Also written Gaikwar.

Guide-pulley. A pulley used to alter the direction of a belt and enable it to transmit force from one axle to another to which it is not parallel.

Guides, or Guide-bars. The pieces in which the cross-head of the piston-rod slides, and by which the motion of the rod is kept parallel to the cylinder.

Guidon. [Fr., from guider, to guide.] (Mil.) Standard of a regiment of heavy dragoons ; light dragoons not carrying them in the English army.

Guidones, or Guides. Priests established by Charles the Great (Charlemagne), at Rome, to aid pilgrims on their way to Jerusalem.

Guild. [A.S. gildan, to pay.] A brotherhood or society, religious, social, commercial, acting with funds contributed by the members. In the Middle Ages there was a general tendency to the formation of such societies in all trades. Ultimately the guild became coextensive with the corporate body of the town or borough. (Gild.)

Guillemets. [Fr., from name of inventor.] Quotation marks or inverted commas.

Guillemot. [Fr.] (Ornith.) Gen. of rockinhabiting, diving sea-birds. The common guillemot of Great Britain, with black and white breast, is about eighteen inches long. Gen. Ūria [Gr. oủía, water-bird], fam. Alcìdæ, ord. Ansěres.

Guillotine. The French instrument of decapitation, introduced, or improved, by Dr. Guillotin, who died I8I4.

Guimauve, Pâte de. [Fr.] A lozenge made of the root of the marsh-mallow [guimauve].

Guimbarde. [Fr., originally a waggon; etym. unknown.] Jew's-harp.

Guinea-fowl. (Named from locality whence introduced.) An African bird, domesticated in Great Britain, and acclimatized in America and W. Indies. Gen. Nŭmĭdĭnæ [L. Numidian], fam. Phāsīanňlæ [Gr., of the Phasis river], ord. Gallinæ.

Guinea-grains. Grains of paradise (brought from Guinea).

Guinea-pig. [(?) Corr. of Guiana.] The restless cavy. (Cavy.)

Guinea-worm, Fīlāria drăcunciŭlus, or $M e$. dinensis. A parasite. In hot climates, e.g. Arabia, Upper Egypt, Guinea, etc. ; especially affecting the leg; from a few inches to three or four yards long.

Guipure. [Fr.] 1. Originally a thick thread or cord, over which is twisted a thread of silk. gold, or silver; applied, 2, to thread-lace, with G. reliefs ; and so, 3, to all lace without grounds, the various patterns of which are united by brides, i.e. irregular uniting threads.-Mis. Palliser, History of Lace.

Guisards. In Scotland, masquerade actors, answering to morrice-dancers in England. (Morrice-dance.)

Gulden. (Florin.)

Gules. [Fr. gueule, a throat.] (Her.) The red colour in coats of arms, represented in engraving by vertical lines.

Gulf. (Univ.) To give a common pass 
degree to a candidate who has been examined for honours.

Gulf Stream. A warm oceanic current, which originates in the Gulf of Mexico, passes through the Straits of Bahama, skirts the coast of N. America, and then widens out and crosses the Atlantic mainly in a north-easterly direction.

Gulliver's Travels. The title of a romance by Dean Swift, relating the adventures of Gulliver in Lilliput, the land of pygmies; Brobdingnag, the land of giants; Laputa; and the land of the Houyhnhnms, in which horses are the head of creation, while a degraded race of human beings, called Yahoos, are their servants. The last of these narratives seems to be a fierce outburst of scorn for mankind. The first is a satire referring to the court and politics of England, Sir Robert Walpole being represented by the premier Flimnap. The third is levelled at the abuses of philosophical science by pretenders or charla. tans. The second is of a more general character, exhibiting human action and feeling as they might appear to beings of enormous size and of cold reflecting dispositions.

Gum tragacanth. The gummy exudation from the stems of several Eastern spec. of Astrăgălus; used as a demulcent; and for imparting firmness to lozenges and pill-masses.

Gum-tree. (Eucalyptus.)

Gun-boat. (Naut.) A war-vessel, of small draught, and carrying one or more guns in the bow ; now propelled by steam, but formerly by sails and sweeps.

Gan-cotton. Cotton soaked in sulphuric and nitric acids, and then dried; used as gunpowder.

Gunfire. (Naut.) Morning, at daybreak; evening at 8 p.m. winter, 9 p.m. summer. called "the admiral falling down the hatchway."

Gunge. [Hind.] A granary, depot, a wholesale market; as Ranee-gunge, the queen's market.

Gungnir. [From the root of gang, to go, as in Rolf the ganger, or walker.] In Teut. Myth., the spear of Odin.

Gunjah. Dried hemp, from which the resinous juice has not been removed.

Gun-lod. (Naut.) An explosive fire-ship.

Gun-metal. An alloy of about nine parts of copper and one of tin, for making cannon, etc.

\section{Gunnel. (Gunwale.)}

Gunner of a ship. A warrant officer, who has charge of guns and stores belonging to them, and instructs the crew in their use.

Gunny. [Hind. gon, sack.] Coarse sacking, used in India for rice-bags, etc.

Gunroom, The. (Naut.) In large vessels, is situated at the after end of the lower gundeck, and partly occupied by junior officers ; in sma:ones, below the gundeck, and is the lieutenants' messroom. In frigates, stern-ports are cut through the gunroom.

Gunten. (Naut.) A merchant-vessel in the Moluccas.

Gunter's chain; G. line; G. scales. The chain commonly used by surveyors; it is sixty-six feet long, and consists of a hundred links; ten chains make a furlong, ten square chains an acre. When lines are measured in chains and links, areas can be calculated decimally. $G$. scales show the logarithms of numbers, of the sines, tangents, etc., of angles; they are used for finding products and quotients of numbers, and for solving triangles, by measuring distances with a pair of compasses, on the same principle that multiplication of numbers is performed by addition, and division by subtraction, with the aid of a table of logarithms. The scale which gives logarithms of numbers is called $G$. line.

Gunwale, or Gunnel. (Naut.) Strictly speaking, the plank placed horizontally upon the timber-heads, so as to cover them, but often used for plank-sheer, i.e. the uppermost plank in a vessel's side. $G$. of $a$ boat, a binder going round the uppermost plank. G.-to, having the $\mathrm{G}$. level with the water.

Gurgoyle. [Fr. gargouille, a water-shoot.] (Arch.) Spouts for carrying off water, often shaped in the form of human or other heads and bodies. The word is akin to our gargle and gurgle.

Gurjun. A thin Indian halsam or oil.

Gurnard. [O.Fr. gournauld, grougnaut, id. (Cotgrave), Fr. grogner, L. grunnio, I grunt ; of. Fr. grondin, Ger. knurrhahn, id., from grunting when taken.] (Ichth.) Widespread gen. of fish, mostly salt-water, head and cheeks protected by bony plates; one spec. flies. Several British spec. Trigla, fam. Triglĭdæ, ord. Acanthoptěry̆gii.

Gurrah. [Hind. gorhâ.] A plain coarse Indian muslin.

Gusset. [Fr. gousset.] A square patch doubled over the ends of a seam to secure them.

Gustus, Gustatio. [L.] The first part of a recta cœna ; of lettuces, eggs, shell-fish, etc., to whet the appetite.

Gutta căvat lăpĭdem. [L.] The drophollows out the stone (Ovid). Non vi sed sæpe cădendo, not by force but by frequent falling.

Guttapercha. [Malay gutta, gum, percha, the tree from which it is procured.] A concrete juice resembling indiarubber.

Gutta sěrēna. [L.] The drop serene of Milton, i.q. Amaurōsis (q.v.); so called because the cornea remains bright and transparent.

Guttŭral. [L. guttur, throat.] An articulate sound pronounced with the back of the tongue and the back of the palate; also called back palatals. The commonest are $k, g, g h, n g, c h$, as in Ger. nach, $k h(\chi)$.

Gutty. (Her.) Sprinkled with drops [Fr. gouttes].

Gay. [Sp. guia, a guide.] (Naut.) Guy-rope, 1. One used to steady or guide anything. 2. A large rope, slack, and extending from masthead to masthead, to which a tackle is fixed for loading or unloading a vessel.

Guyon, sir. 'Type of temperance, in Spenser's Fä̈ry Queene, bk. ii.

Gure. (Her.) A sanguine (blood-coloured) roundlet or disc.

Gwent, Kingdom of. A Celtic kingdom com- 
prising Monmouthshire and Glamorganshire. G. = champaign land.

Gwynedd. [Welsh.] Uld name of the counties of Carnarvon, Denbigh, and Flint.

Gwyniad. [Welsh gwyn, white.] (Ichth.) Schelly, fresh-water herring, like the herring. Spec. of Coregonus, fam. Salmōnǐdæ, ord. Phȳsostŏmi, sub-class Tělěostěĩ.

Gyall. (Zool.) E.-Indian jungle ox (Bos frontālis) ; supposed original stock of humped breed. Gybe. (Jibe.)

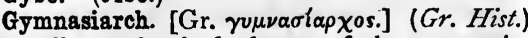
The officer who had charge of the gymnasia. (Liturgies.)

Gymnasium. [L., Gr. $\gamma u \mu \nu d \sigma$ ǒ 0 .] 1. An open space covered with sand, for the purpose of athletic games. 2. Buildings for the general training of the young. The most famous gymnasia at Athens were the Lycæum and the Academy.

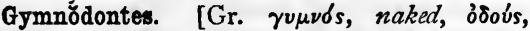
obbvios, a tooth.] (Ichth.) Fam. of fish, Globefishes, Sun-fishes. Temperate and tropical seas, occasionally Great Britain. Ord. Plectŏgnăthi.

Gymnogens, or Gymnospermous plants. [Gr. qupubs, naked.] (Bot.) In Lindley's system, flowering plants, with exogenous stems and naked seeds ; a separate class, of which Coniferæ, Taxaceæ, Cycadaceæ, and Gnetaceæ are orders.

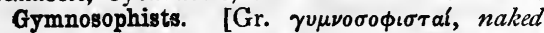
philosophers.] The Greek name for Fakirs and Dervises, from their ascetic habits.

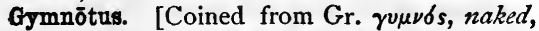
vîros, back.] Gen. and spec. of fish, Electric eel, five to six feet long. Marshes of Trop. S. America. Fam. Gymnōsĭdæ, ord. Phÿsostŏmi, sub-class Tĕlěostēī.

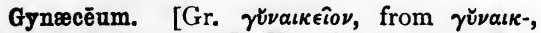
stem of $\gamma v v \dot{\eta}$, woman.] Female apartments.

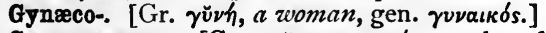

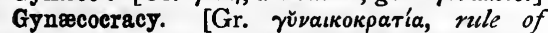

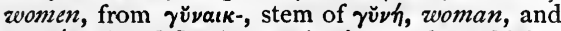
кратє́ $\omega, I$ rule.] A constitution under which a woman is or can be sovereign.

Gynandrous. (Bot.) Having stamens, style, and ovary, all in one body ; e.g. orchids.

-gy̆nia. [Gr. yǔvó, a woman.] (Bot.) Each of the twenty-four Linnæan classes is divided into two or more orders ; in the first thirteen depending on the number of pistils. Monogynia have one pistil ; Di-, 2 ; Tri-, 3 ; Tetra-, 4 ; Penta-, 5 ; Hexa-, 6 ; Hepta-, 7 ; Deca-, Io; Dodeca-, 12 ; Poly-, niany.

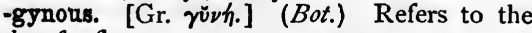
styles of a flower.

Gyp. (Camb. Univ.) A college servant.

Gypsies. [A name which is said to be a corr. of the word Egyptian, but of which the Ger. zigeunes, the Russ. tzigan, the It. zingaro, the Sp. gitano, seem to be cognate forms.] A vagrant people, called by the French Bohemians, who appeared in Western Europe early in the fifteenth century, and who form everywhere a distinct race. Many still live in England, dwelling in camps or carts, and exist by fortunetelling, selling brooms, baskets, etc., and begging. Some are dishonest, but seldom towards those who show them kindness. They call themselves Romany.

Gypsum. [L., Gr. rúuos, chalk.] Sulphate of lime + water, very widely diffused in strata essentially differing. Plaster of Paris is G., the water being driven off by heat.

Gyrate. [L. gȳro, I turn in a circle (Gr. ripus).] To revolve round a (frequently moving) point or axis, to move in a spiral or circle, to rotate.

Gyration [L. gȳro, I make to turn round in a circle] ; Centre of G.; Radius of G. Rotation; the Radius of $G$. is the distance from the axis to the Centre of $G$. (For Centre of $G$., vide Centre.)

Gyres. [L. gȳrus, Gr. $\gamma \hat{v} \rho o s$.$] A revolution,$ a turn of circular motion.

Gyr-falcon. [Ger. geier-falk, haww-falcon.] (Ornith.) Largest of true falcons; plumage, dull brown when young, nearly pure white when mature ; difficult to train. N. Europe and $N$. America. Falco gyrfalco, sub-fam. Falcōnīnæ, fam. Falcōnŭdæ, ord. Accǐpĭtres.

Gyron. [O.Fr.] (Her.) An ordinary bounded by two lines drawn from the fess point, one to an angle of the escutcheon and the other to the middle point of an adjacent side. An escutcheon divided into eight equal triangles by lines drawn through the fess point is called gyronny.

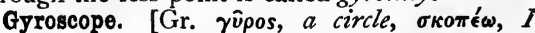
behold.] A machine, made in several forms, to exhibit the composition of rotatory motions.

Gyres, Gives. [Welsh gefyn.] Fetters.
I. Was used by the Latins as an abbrev. of Homô, Hæres, etc. As a numeral, it expressed 200. In music it is used by the Germans to designate our B flat.

Haaf-boat. [Dan. hæv, the sea.] (Naut.) One used in the deep-sea fishery of the Shetlands and Orkneys.

Kăbeas Corpus. [L.] (Leg.) Name of several writs, of which the most famous is $H$. C. ad subjiciendum, addressed to any one who detains a person in custody, commanding him to have the body to answer; i.e. to produce in court, that the rightfulness of such detention may be considered. It is issued by the Lord Chancellor or any vacation judge, unless a due committal of the prisoner be proved. It is the great safeguard of personal liberty. Date of H. C. Act, 1679 .

Hăbēmus confitentem reum. [L.] Iit. we have the accused person confessing ; in argument, 
$=$ here is an important admission on the opposite side.

Hăbendum. [L., to be had, gerundive of haběo, I havee.] (Leg.) That part of a deed which determines the amount of interest conveyed.

Habitants, Habitans. [Fr.] French farmers of Lower Canada.

Hăbitat. [L., he inhabits.] The totality of stations occupied by any given organized being.

Habitué, ée. [Fr.] One accustomed to frequent a place; as an $\mathrm{H}$. of a theatre, publichouse, etc.

Hachish, Haschisch. An intoxicant, made from Indian hemp (Cannăbis), from remote times, in the Levant. (Assassin.)

Hachure lines, or Hatching. [H. in Fr., hatching, hache, a hatchet.] On maps, short broken strokes; the shading of sloping ground.

Hacienda. (Ranch.)

Hackery. [Hind. chhakrâ, cart.] A Bengal street cart, drawn by oxen.

Hackney. [Fr. hacquenée, ambling nag.] 1. A nag. 2. A horse for hire. 3. A H.-coach, a coach and horse for hire ; first used in London, I634.

Hactenus invidiæ respondimus. [L.] Tȟzes far have we made answer to envy (Ovid).

Hadán. (Muezzin.)

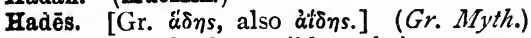
The land of the dead, possibly as being unseen. Hence the king of that land, the husband of Persephone. The name may be compared with that of Hodr, the slayer of Balder. (Eleusinian Mysteries.)

Hades, Helmet of. (Tarnkappe.)

Hading. [Ger. halde, slope.] The angle at which a vein of ore is inclined to the vertical.

Fiadj. The Mohammedan pilgrimage to Mecca and Medina. Those who have performed the pilgrimage are called Hadji.

Hadji. (Hadj.)

Hadrian's Wall, or the Wall of Sevērus, ran from Wallsend (Wall's End), near Newcastle, to Carlisle.

Hæma-, Hæmat-, Hæmato-. [Gr. al $\mu a$, blood, gen. ailuaros.]

Hæmal. Pertaining to the blood [Gr. ai $\mu a]$ in blood-vessels.

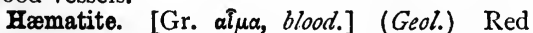
and brown kidney-iron ore ; native peroxide of iron, found in veins and masses; impure, Limonite; earthy, Ruddle ; crystallized, Specular iron ore.

Hæmătūria. (Med.) Bloody urine [Gr. oทิpov].

Hæmŏny. Comus, 629, et seqq., "A small unsightly root," with " bright golden flower ... of sovran use 'gainst all enchantments, mildew, blast, or damp, or furies." (Moly.)

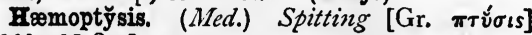
of blood [aina].

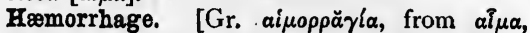
and a root of $\dot{p} \eta \dot{\gamma v u \mu}, I$ break.] (Med.) Flow of blood from a ruptured vessel.

Hæmorrhoids. [Gr. aipoppoti $\epsilon s, s c . \phi \lambda \epsilon \in \in \in$, blood-discharging.veins.] (Med.) Bleeding piles; corr. into Emerods.
IIæmostatio. [Gr. $\sigma \tau$ ăтǐ ós, causing to rest.] (Med.) Stopping hæmorrhage.

Hærétǐco Comburendo. [L.] The title of the writ which handed over the person of the heretic to execution by burning.

Hæret lătěri lëtālis ărundo. [L.]. The deadly, shaft remains fixed in her (his) side (Virgil); of the wounds of passion.

Haffle. To speak unintelligibly, as "a hafflin' callant" (Scott's Guy Mannering); to prevaricate.

Hafiz. The great lyric poet of Persia.

Hag. (Ichth.) Myxine, Borer, etc. ; spec. of worm-like, eyeless fish, twelve to fifteen inches long, which works into the inside of other fish, and eats them away. Gen. Myxinida [Gr. $\mu \nu \xi \hat{\imath} 0 s$, slime-fish], ord. Marsipobranchii, subclass Cyclostomi.

Hagadôth. [Heb., legends, narrations.] A collection of legendary matter, Halachôth [rules], one of traditional customs, belonging to the oral law of the Jews, and eventually reduced to writing. (Talmud.)

Haggis. [Scot.] A pudding of sheep's or lamb's entrails, chopped fine, with suet, herbs, leeks, and spices, boiled in the paunch.

Hagiogrăpha. [Gr.] Sacred writings.

Hagiology. Biography of the saints [Gr. ă $\gamma$ เot].

Ha-ha, Haw-haw. (Haugh.) A sunk fence, a fence in the middle of a depression, so that it cannot be seen at a short distance.

Haigh, Hay. [Cf. D. hang, inclosure, Ger. hägen, to fence.] A place surrounded by a hedge for purposes of chase, as Rothwell Haigh; so Haye Park, Horse-hay.

Hâik. [Ar.] A piece of woollen or cotton cloth worn over the tunic by Arabs.

Hail, To. [A word containing the root of call.] (Naut.) To H. from a place, to belong to it. To H. a vessel, to inquire whence it comes and whither bound.

Hainault. (Geog.) A province of the Netherlands (S.), now partly in France, partly in Belgium.

Hakîm. [Ar.] Wise man, physician.

Halachôth. (Hagadôth.)

Halbert. [Fr. hallebarde, from It. alabarda.] A kind of pike, formerly carried by sergeants, having under the spear-point a hatchet at one side and a hook at the other.

Halcyon days. Fourteen days of winter, when

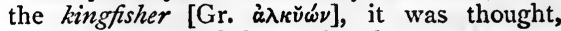
builds its nest, and the sea is calm.

Hale. [Cf. O.H.G. halôn, holôn, Ger. holen, to draze, pull.] To pull, tug, tow.

Haler. (Punt.)

Half-deck. (Naut.) 1. The space immediately below the quarter-deck, between its foremost part and the steerage. 2. The steerage. 3. A H.-decked vessel is one not decked throughout.

Half-press. The work done by one man at a printing-press.

Half-topsails, Onder. (Naut.) When only the upper half of a ship's topsails is visible; i.e. about twelve miles off. 
Halibut. [A.S. hali, holy, but = flat-fish.] (Ichth.) Holibut, one of the largest of flat-fishes, five to seven feet long. British and Northern seas. Hippoglossus [Gr. $i \pi \pi b \gamma \lambda \omega \sigma \sigma o s$, like a horse's tongue] vulgāris, fam. Pleurŏnectĭdæ, ord. Anăcanthĭni, sub-class Tělěostěĩ.

Halǐdom. [A.S. hâligdôm, Ger. heiligthum.] 1. Holiness. 2. The holy or consecrated thing, as a relic. 3. The place where it is preserved. Hence, 4, a sanctuary ; or, 5 , the possessions of a religious house, as the Halidom of the Abbey of Melrose (Scott). 6. An oath sworn by the holy thing or place.

Hallamshire. Sheffield and the neighbouring district.

Hallel [Heb., praise], or Paschal hymn of the Jews, consisted of Ps. cxiii., cxiv., cxv., the first portion sung in the early part of the feast; and Ps. cxvi., cxvii., cxviii., sung at the conclusion of the supper (see Matt. xxvi. 30).

Halliards, Halyards, or Haulyards. [From hale or haul, and yard.] (Naut.) The ropes, or tackles, by which sails are hoisterl and lowered upon their yards, etc.; in lower sails called jeers. The cross-jack and spritsail yards are generally slung.

Hall-mark. The official stamp of the Goldsmiths' Company or other public assayers, on genuine gold and silver articles.

Hallowe'en. The evening of October $3 \mathbf{r}$, being the eve or vigil of All-hallows, or All Saints' Day, November I ; devoted once in England to amusements, in Scotland to customs somewhat superstitious. (See Burns's Hallowe'en.)

Hallncinations. [L. hallūclyor, I wander in mind, dream. ] Morbid conditions, in which, no impression having been made upon the senses, the object is believed to be existing. $H$. are often felt to be $\mathrm{H}$., being different from delusions, and consistent with sanity, as in the case of Bernadotte, Swedenborg, etc.

Hallux, Hallex, Allux, Allex. [L.] (Anat.) The great toe. The class. forms are allex and hallex.

Halm. (Haulm.)

Halo. [Gr. å $\lambda \omega s$, a halo] 1. A coloured circle often seen in the colder months of the year surrounding the sun or moon at distances of about $22^{\circ}$ and $46^{\circ}$ from their centres; such circles are probably caused by refraction of light through elementary crystals of snow in the atmosphere; they are frequently attended by secondary circles. 2. A bright ring surrounding the heads of saints in pictures.

Haloscope. An instrument for exhibiting phenomena resembling halos.

Halsfang. (Healfang.)

Halyards. (Halliards.)

-ham, Ham-. [Cf. Goth. haims, home, Ger. heim, inclosure, geheim, home, Eng. ham-let, Gr. $\kappa \omega \mu \eta$, village, $\kappa \hat{v} \mu \alpha_{l}$, from root $\kappa \iota$, be quiet.] Part of A.S. names, as in Ing-ham.

Hamadryads. [Gr. ¿̊ $\mu \alpha \delta \rho u d \delta \in s$.$] (Myth.)$ Nymphs who were supposed to live and die with the trees which they guarded. (Genii.)

Hamburg white. A pigment composed of two narts of baryta and one of white lead.

\section{Hameln, Piper of. (Orpheus.)}

Hamesucken, Homesoken. [Ct. Goth. sakan, to quarrel.] (Scot. Law.) The offence of wrongfully assaulting a man in his own house.

Hamiltonian system (James Hamilton, mer. chant, died 1831). Reactive against the excessive study of grammar before reading or speaking languages, took the pupil at once to the language itself, which he learnt, if with a teacher, by word. for-word translation, or if alone, by interlinear translation; the grammatical and the practical knowledge being gained sinuultaneously.

Hamitio. (From Ham, son of Noah.) (Lang.) The N.-African family of languages, including Egyptian (Coptic), Berber (Libyan), Ethiopian.

Hammerbeam. (Arch.) A horizontal piece of timber, acting as a tie at the feet of a pair of principal rafters, but not extending so as to connect the opposite sides.

Hammercloth. [Of uncertain origin.] A cloth which covers the coach-box.

Hammerslag. The coating of oxide formed on heated iron, which is removed by hammering the metal when cold.

Hampton Court Conference. Held by James I., A.D. I603, at H. C., first between the king and the representatives of the Episcopalian party, then between these and the representatives of the Puritans, for the settlement of disputes. (Millenary Petition.)

Hamster, Crīcētus frümentārius. [Ger.] (Zool.) A destructive, burrowing rodent, about fifteen inches long, with greyish-fawn back, black belly. N. Europe. Fam. Mürĭdæ.

Hamstring. To cut the tendons of the ham.

Hanaper. [A.S. hnäp, a cup, or boul.] (Leg.) A treasure, = exchequer.

Hanaper, or Hamper, Clerk of the. An officer of the Court of Chancery, who received all money due to the king for the seals of charters, patents, commissions, and writs, and the fees due to the officers for enrolling and examining them.Brown, Law Dictionary.

Handfasting. In the border country formerly, the living as man and wife for a year and a day, after which came either separation or marriage. (See Scott's Monastery.)

Handicap. 1. A game at cards: something like loo, in which the winner of one trick has to hand $i$ the cap, i.e. put in the pool, a double stake, the winner of two tricks a triple stake, and so on. (See Pepys's Diary, September 18, 1660.) 2. A race in which less weight or distance or more time is given to competitors, in presumed proportion to their inferiority, so that, theoreti. cally, the worst has as good a chance as the best.

Handmast-spar. (Naut.) A round mast. H.-M.-piece, a small round mast. H.-spike, a capstan bar, round, with square head.

Handsaw, in phrase, " Not know a hawk from a H.," is for Heronshaw, Hernshaw.

Handsel. 1. Something delivered [A.S. sel. lan, syllan, to hand over] in to the hand, especially a first payment, or gift, or purchase, or use, re. garded as an omen. 2. (Leg.) Earnest money.

Handsomely. In Naut. language, gently.

Handspike. (Mil.) Wooden lever for slight!y 
moving the trail (q.v.) of a gun in taking aim, or for raising any kind of weight.

Hanging Gardens. Of Nebuchadnezzar's palace, at Babylon; raised terraces, supported on piers of brickwork. Said to have been built for his Median queen, Nitocris, to remind her, in the unbroken naked plain, of her native hills and woods.

\section{Hangnail. (Agnail.)}

Hank. [Dan., $a$ handle.] A parcel of two or more skeins of yarn or thread tied together. Hanks, hoops or rings, with which the fore part of a fore-and-aft sail is confined to its stay.

Hankey-pankey. Professional cant, specious talk, properly the chatter of conjurers to divert attention from their doings.

Hank for hank. (Naut.) Used of two ships beating together in racing, etc.

\section{Hannibalian War. (Punio Wars.)}

Hansard. 1. Reports of Parliamentary proceedings (named from the publisher). 2. (From Hanse.) Citizen of a town belonging to the Hanseatic League.

Hanseatic League. (Hist.) A confederacy of the Hanse towns on the coasts of the Baltic, formed in 1239 . It numbered at one time eighty. five cities.

Hanse towns. [O.H.G. hansa, association.] (Geog.) Towns of the Hanseatic League, for defence of commerce, formed in the thirteenth century; the chief being Lubeck, Hamburg, and Brunswick. The two first and Bremen now constitute this league for hansa.

Hansom. (From the inventor.) A light twowheeled carriage, with the driver's seat elevated behind.

Harakiri. The Japanese suicide, especially upon being insulted, which entails the suicide of the insulter.

Haras. [Fr., a stud, from Ar. faras, a horse.] Stud for horses for the use of an army.

Hard. (Naut.) 1. H. a-lee, when the rudder is to windward; or the order so to place it. 2. $H$. a-weather, or $u p$, when the rudder is to leeward ; or the order so to place it. 3. H. a-port, when the rudder is to starboard; or the order so to place it. 4. H. a-starboard, when the rudder is to port; or the order so to place it. 5. A hardy seaman is said to be $H$. a-weather.

Hard dollar. (Amer. Finance.) Silver dollar; opposed to Soft, i.e. paper, dollar. Name of the U.S. party which advocates resumption of specie payments.

Hardle, Hartle. To prepare a dead hare or rabbit for carriage in the hand or on a pole, by cutting the tendon Achillis immediately above the hock in one hind leg, and making between the tendon and the bone in the other an incision through which the first foot is passed beyond the hock, the projection of which prevents the foot from slipping back.

Hard paste. (Paste.)

Hards. Tow.

Hardware. Ware made of metal, as cutlery, fenders etc.

Harem. [Ar. haræm, forbidden, or sacred.] In Eastern houses. the rooms set apart for women.
Hariolation. [L. hărīŏlātio, -nem, from hăriŏlus, diviner (Haruspices).] Divination, soothsaying.

Harits. (Graces.)

Harl. [O.G. harluf, rope.] The threads of hemp or flax.

Harlequin. [It. arlechino.] Originally a droll, greedy rogue of Italian comedy, servant of Pantaleone, and lover of Columbina; now a dancing masked magician of Christmas pantomime. (Scaramouch.)

Harmattan. [Afr.] A dry, hot wind, blowing from the interior of Africa towards the Atlantic,

Harmodius. An Athenian, who, with his friend Aristogeiton, murdered Hipparchos, the son of Peisistratos, and so led to the downfall of the family of the Peisistratidai.

Harmónia. [L., Gr. á $\rho \mu o v i ́ \alpha$.$] (Med.) A$ joining together of bones, e.g. the nasal, by simple apposition.

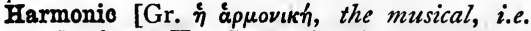
science]; Acrte H.; Grave H. (For Harmonic or Acute H., vide Tono.) The Grave $H$. is heard in certain cases when two perfectly just notes are sounded together depending on the difference of their pitches; thus when the middle $\mathrm{C}$ and its major third (whose pitches are as $4: 5$ ) are sounded together, a very faint $\mathrm{C}$ two octaves lower (whose pitch is as $5-4=1$ ) is heard ; it used to be considered that this note was due to the coalescence of the beats into a continuous sound, but now it is thought to be due to the fact of the vibration having a finite, though very small, extent.

Harmonio function; H. motion; H. progression. If a point moves uniformly in a circle, the foot of the perpendicular let fall from it to a fixed diameter has a simple Harmonic motion; the algebraical expression for such a motion is a Simple $H$. function; the sum of two or more S. H. functions is a Complex H. function. The motions which occasion sound, light, etc., can be represented by $H . F$. (For H. progression, vide Progression.)

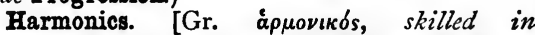
harmony.] Tones of a vibrating body given off in addition to the original tone; e.g. the octave, the fifth above the octave, the double octave, etc., of a note struck on the piano. (Nodes; Tone.)

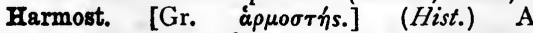
magistrate sent out from Sparta to govern a conquered state. We hear also of Theban harmosts.

Harness. [Harnais, the full fitting out of a knight and his horse, formerly harnas, a Celt. word (Brachet).] I Kings xx. I I, and elsewhere ; body-armour of a soldier.

Haroun-al-Raschid. The caliph of the Arabian Nights' Tales, a despot who used to mingle with his subjects in the streets of Bagdad, in disguise. He was a contemporary of Charles the Great (Charlemagne).

Harpagon. Molière's L'Avare, an utter miser.

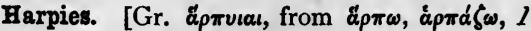
seize.] In Gr. Myth., the storm-winds. In Hesiod they are described as the beautiful 
daughters of Thaumas and Electra. In Virgil they are of repulsive ugliness, and insatiably greedy.

Harpings, or Harpens. (Naut.) 1. That part of the wales which incloses the bow, and is made extra thick. 2. The pieces of oak, bolted to the shape of a vessel, which hold the fore and after cant-bodies together, until planked; but generally applied to those at the bow. Cat-H., ropes crossing from futtuck-staff to futtuck-staff, below the tops.

Harporcrătês. The Greek form of the Egyptian words Har-pi-chruti, or Horus the Child, who is represented as a naked boy sitting on a lotus flower, with his finger in his mouth.

Harpoon. [Fr. harpon.] A long spear with a flat, harbed head, for striking large fish.

Iarpsichord. [Corr. of Fr. harpe-chorde.] A stringed instrument, in shape like a grand piano, sometimes having two manuals-one loud, the other soft; the sound independent of the degree of pressure, and produced by plectra moving the wire ; compass about four octaves.

Harpy. [Gr. "Aprvia.] (Her.) An heraldic animal, with a woman's head and breast and a vulture's body and legs.

Harpy eagle. (Harpies.) (Ornith.) Largest of eagles, three feet and a half and upwards in length. Plumage (adult), back slate-coloured, belly white; it has a frill and two-pointed crest, which it can raise at pleasure. Central and $S$. America. Thrăsāëttus, sub-fam. Acč̌pittrinæ, fam. Falcōnǐdæ, ord. Accǐpĭtres.

Harridan. [Cf. Fr. haridelle, knacker, jade.] Shrewish old hag.

Harry, To. [A.S. herian, to ravage as an army (here, Goth. harjis).] To pillage, ravage, worry. of.)

Hart. [O.E. heort.] (Deer, stages of growth

Hartshorn. An impure carbonate of ammonia obtained by distilling hart's horn or any kind of bone.

Haruspices. (Aruspices.)

Harveian Oration. One annually delivered in London, in honour of Harvey, discoverer of the circulation of the blood.

Harvest-moon. The moon near the full at about the time of the autumnal equinox, when the daily retardation of its rising is partly counterbalanced by its comparatively rapid motion in north declination, so that it rises for several days together at about the time of sunset.

Haschish. (Assassin; Hachish.)

Hassock. [Scot.] Lit. tuft of grass. 1. Hence besom, or piece of turf for a seat. 2. A kneeling cushion for church or chapel.

Hastate leaf. [L. hastātus, bearing a hasta, spear.] (Bot.) Halbert-shaped, like an arrowhead with the barbs at right angles; e.g. Atriplex hastata.

Hastāti. [L., from hasta, a spear.] The first ranks of the Roman legion, consisting of young men armed with spears. Behind these stood the Principes, and behind these the Triarii.

(Antepilani ; Antesignani.)

Hatch. [O.E. haca, the bar of $a$ door.] 1. An opening into a mine, or in search of one; from the hitch-gate, which kept cattle from straying (Taylor, Words and Places). 2. Part of names near old forests, as Colney Hatch.

Hatch-boat. (Naut.) A small pilot-boat, with a deck mainly composed of hatches, i.e. movable coverings of the hold.

Hatchel. [Ger. hechel.] (Heckle.)

Hatchet, To bury the. To forget past quarrels, as the N.-American Indians bury the tomahawk when peace is made.

Hatchet-face. A lean, miserable, ugly face.

Hatching. [Fr. hacher, to chop.] Shading by cross lines with pen or pencil. (Hachure lines.)

Hatchment. [Corr. from achievement.] A square frame bearing the escutcheon of a dead person.

Hatchways. (Naut.) The openings in the decks of a vessel, through which access is gained to the lower decks and hold.

Hâtelettes. [Fr.] Morsels of meat cooked on a spit.

Hatt. Short for Hatti-sherif.

Hatti-sherif. An edict signed by the hand of the sultan himself. (Firman.)

Hatto, Bishop. Devoured by rats in his castle in the Rhine, for hoarding grain and burning a barn full of poor people in a time of scarcity; as told by Southey.

Hauberk. [O.G. halsberge, A.S. healsborg, from hals, the neck, and bergen, to hide.] A jacket of chain-mail, with a hood, and sleeves reaching below the elbow.

Haud ignāra mali, misĕris succurrĕre disco. [L.] Not ignorant of evil, I learn to help the woretched. Words put by Virgil into the mouth of Dido.

Haugh. [Scot. ; $c f$. haw, A.S. haef, inclosure, haga, hedge, Ger. haj, hedge, inclosure, Dan. hauge, garden.] A low-lying meadow.

Haul her wind, To. (Naut.) A vessel coming up to the wind is said to $H$. her wind.

Haul in, To. (Naut.) To sail closer to the wind, so as to approach, to $H$. off; so as to get away from, an object.

Hauling-down vacancy. (Naut.) One caused by the promotion given to a flag midshipman or lieutenant, when an admiral hauls down his flag. Hauling sharp, having only half-rations.

Haulm, Halm. [O.E. healm, haulm, or straze; cf. Ger. halm, Fr. chaume, id., L. călămus, Gr. кă $\lambda a ̆ ́ \mu \eta$, a stalk, straze, or reed.] (Agr.) Stalks left after reaping or after gathering the seeds of culmiform crops

Haulyards. (Halliards.)

Haurient. [L. hauriens, drinking.] (Her.) In a vertical position, with the head upwards.

Hausmannize. To renovate a city with extravagant magnificence, as Hausmann did Paris, under Napoleon III.

Haustellate. (Zool.) Provided with an haustellum (q.v.).

Haustellum. [Dim. from L. haustrum, id., haurio, $I$ draw water, etc.] Apparatus for pumping or sucking, in the mouths of certain crustaceous insects, as Ëpizōa (q.v.).

Haustōrium. [L. haurio, I draw out, draw water.] $A$ sucker. 
Hautboy. [Fr. hautbois, i.e. instrument of wood, bois, having a shrill, hant, sound.] (Oboe.)

Hauteur. [Fr.] Loftiness of manner.

Haut gôut. High seasoning.

Haut mal. With the French, = severe form of epilepsy; distinguished from Petit mal, the ordinary form.

Haversack. [Fr. havre-sac, knapsack, originally a bag for oats (Ger. haber).] (Mil.) Wallet used by soldiers for carrying their day's provisions.

Havildar. [Hind.] Sergeant of Sepoy troops.

Havilee. [Hind.] Superior house in India, of brick or stone; flat-roofed, on one story raised from the ground.

Haw. (Haugh.) 1. Hedge, inclosure.

Berry of the hawthorn, i.e. hedgethorn.

Haw, or Nictitating membrane (q.v.), of horse, dog, etc. A cartilage lying just within the inner corner of the eye, but capable of being thrust outwards, so as partially to cover it when irritated by dust, etc.

Hawk's bell. (Arch.) A name considered by $\mathrm{Mr}$. Parker more appropriate than Ballflower (Glossary of Architecture, vol. i. 53).

Hawse. [From A.S. halse, the neck.] 1. That part of the bow where the H.-holes for the cable to pass through, are. 2. The position of the cables when a vessel rides with both anchors out, one to starboard and the other to port. 3 . The space between a vessel at anchor and the anchor. Bold H., the H.-holes high above the water. H.-full, pitching bows under.

Hawser. [I.e. a raiser, to hawse being to raise, Fr. haulser, hausser, It. alzare.] A cablelaid rope, not so large as a cable, but larger than a tow-line. H.-laid rope, made of three or four strands of yarn, considered proportionately stronger than cable-laid rope, which is made of small ropes more tightly twisted. H.-laid rope is used for rigging, etc. ; cable-laid in water, etc.

Haxo casemate. (Mil.) An earth-covered masonry chamber placed on the terreplein of a work, for the protection of guns firing through embrasures $(q . v$.$) of a parapet, and acting also$ as a traverse $\left(q . v^{2}\right)$.

Hay. (Haigh,)

Haybote. Hedgebote, an allowance of wood to a tenant for repair of fences.

Hayward (i.e. hedge-guard). An officer who has to take care of hedges and impound stray animals.

Headborough. (Leg.) In frankpledge, the chief of the ten pledges or freemen of a tithing, or decennary; also called Borowhead, Borsholder, Tithingman, etc.

Headland. (Agr.) The upper part of land left for the turning of the plough.

Head-quarters. (Mil.) Station of a general commanding.

Headsails. (Naut.) All those set on a foremast, bowsprit, jib, and flying-jibbooms.

Healds. The harness for guiding the warpthreads in the loom.

Iealfang, Halsfang. [A.S., a catching of the neck.] The old English name for the pillory.

Eearth money, Hearth penny. A chimney tax (Fumage) levied from the reign of Charles II. to the Revolution.

Hearth tax. (Chimney money.)

Heart-sound. (Diastole.)

Heart-wood. (Duramen.)

Heat. [A word common to many Aryan languages.] (Racing:) When all competitors cannot walk, run, or row together, they race in divisions, which races are called heats. The various winners then race with each other. The deciding race is the final $\mathrm{H}$. In coursing and wrestling, the term tie is used.

Heat-apoplexy, i.q. popularly Sunstroke. Undue determination of blood to the brain, from exposure to the heat of the sun or other intense heat.

Heath. [Her. avar.] Jer. xvii. 6; xlviii. 6; Jūnǐpĕrus săbīna, a dwarf juniper, in barren, rocky places of the desert.

Heave, To. [Ger. heben, to lift.] (Naut.) To throw overboard, to cast, as to $\mathrm{H}$. the $\log$; to haul, drag, prize, etc., as, to $H$. at the anchor. To $H$. the log, to ascertain a ship's velocity by aid of the log-line and sand-glass. To $H$. the lead, to ascertain the depth of water with the hand lead-line. To get a cast of the lead is to ascertain it with the deep-sea lead and line.

Heave down, To. (Naut.) To careen a ship by purchases on the masts. To heave kcel-out, to careen a vessel so much that the keel shall be out of water.

Heave offering. (Wave offering.)

Heave-to, To. (Naut.) 1. To bring-to (q.v.), 2. In a gale, to set only enough sail to steady the ship.

Heavy marching order. (Mil.) That of a soldier equipped and carrying, besides his arms and ammunition, complete kit, and great-coat, amounting altogether to about sixty pounds; to which are occasionally added a blanket and three days' provisions.

Heavy spar, Hepatile, Bologna spar. (Geol.) Native sulphate of barytes (q.v.), common in many mining districts ; used as a white paint, and in adulterating white lead.

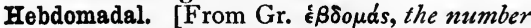
seven, a week.] Weekly, as in Oxf. Univ., the H. Council, the board elected by the Senate to prepare and regulate university business, which meets at least once a week during term.

Hëbë. [Gr., youth.] (Gr. Myth.) The cupbearer who handed round nectar to the gods at their banquets. She answers to the Latin Fuventas.

Hebetation. [L. hěbětātio, -nem, dulness, from hěběs, hebĕtis, blunt, dull.] A making or a being dull. blunt, stupid.

Hebetude. [L. hěbĕtūdo, bluntness.] Insensibility, dulness.

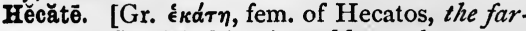
shooter.] (Gr. Myth.) A goddess who represents the moon; not mentioned in the Iliad or Odyssey, but described by later writers as a daughter of Perses and Asterria.

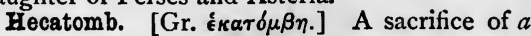

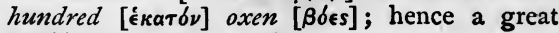
sacrifice to a god or gods. 
Heok. [Akin to hook.] An apparatus by which the threads of warps are separated into sets for the heddles.

Heckle, Hackle, Hatchel. [Ger. hechel, dim. of D. haak, hook.] A comb for separating the coarse parts of flax or hemp from the fine.

Heckling. [Scot.] Worrying, putting questions to a candidate for Parliament.

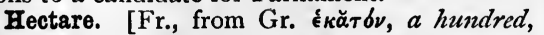
Fr. are, L. ārea.] A French measure, equivalent to 2.47 I I English acres. (Are.)

Hectio fever. [Gr. écrıkós, belonging to the habit ( $\tilde{\epsilon}^{\prime} \xi$ เs).] Constitutional, long-continued, more or less intermittent; often attending the termination of organic disease.

Heotogramme, Hectolitre. [Fr.] Measures of a hundred grammes and litres respectively. (Gramme; Iitre.)

Heddle. (Frealds.)

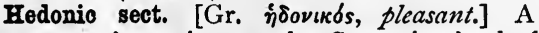
name sometimes given to the Cyrenaic school of philosophy, founded by Aristippus, circ. B.c. 424 . They are said to have despised speculative and

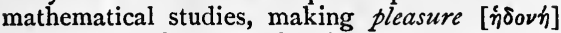
and a general sense of quiet engagement the basis of their ethical system.

Heel. (Naut.) 1. Where the keel and sternpost join. 2. The lower end of a mast, bowsprit, boom, or timber. To $H$., to incline to one side. H.-knee, the shaped timber which connects the keel with the stern-post. H.-rope that which is fastened to the $H$. of spars (other than topmasts) to ship them.

Heelball. A composition of bees-wax, tallow, and lampblack, used for blackening leather.

Heel-tool. A tool used by turners for the first rough shaping of a piece of iron.

Hëgěmony. [Gr. ท́ $\gamma \in \mu o v i ́ a$.$] The presidential$ or guiding power possessed by a state over other states in alliance with it. Such $\mathrm{H}$. was claimed by Athens and Sparta over the members of their respective confederacies.

Hegira. (Hist.) The Mohammedan era, marked by the flight of Mohammed from Mecca to Medina, A. $\Gamma$. 622. It is strictly lunar.

Heights of Abraham, The. Above the city of Quebec; here Wolfe defeated Montcalm, and Quebec fell into the hands of Britain (September, 1759).

Heimskringla. (Saga.)

Heir. [O.Fr., from L. hæres.] (Leg.) One entitled to succeed to an estate of inheritance. In Scotland H. is also applied to successor to personal property. There are eight kinds of $\mathrm{H}$. : 1. H.-apparent, who must succeed if he live long enough. 2. $H$. by custom, by peculiar custom, as Borough English, gavelkind. 3. $H$. by devise, made $\mathrm{H}$. only by will. 4. $H$. general, $H$.at-law, in whom right of inheritance lies after a possessor's death, a term applicable to most heirs on succession. 5. H.-presumptive, who will succeed unless one be born with better right. 6. Hæres sanguinis et herēdřtātřs, $H$. of blood and inheritance, a son who can be disinherited. 7. H. special, e.g. by custom or entail. 8. U1tımus hæres, last heir. (Escheat.)

Heirloom. [From heir, and A.S. geloma, goods.] (Leg.) A movable or personal chattel, as an ornament, weapon, or piece of furniture, which by special custom goes with the inheritance, though an owner while living may dispose of it.

\section{Hektemorians. (Thetes.)}

\section{Heldenbuch. (Minnesingers.)}

Helen. (Paris, Judgment of.)

Hělěna. (Meteorol.) (Castor and Pollux.)

Heliacal. [Gr. ì $\lambda$ เakós, belonging to the sun.] (Astron.) The $H$. rising or setting of a heavenly body takes place at nearly the same time as that of the sun. A star rises heliacally when it is seen to rise before the sun, i.e. just after it emerges from the rays of the neighbouring sun.

Heliæa. [Gr. $\dot{\eta} \lambda_{\iota} \alpha_{i} \boldsymbol{i}_{\text {. }}$ ] In Athenian Hist., the chief of the ten courts among which the Dicasts, or jurymen, were distributed.

Helǐcōn. (Pegasus.)

Heliocentric theory. [Gr. $\eta_{\lambda}$ oss, the sun,

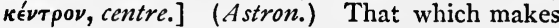
the sun the centre of the motions of the planets, including the earth, and explains the apparent movements of the heavenly bodies by the rotation of the earth on her axis, and her motion round the sun in her orbit; it was propounded by Aristarchus of Samos, in the third century B.C., and established by Copernicus, De Rev. Orb. Calest. (I 543). (Geocentric theory.)

Heliochromy. [Gr. $\eta \lambda_{\imath}$ เos, sun, $\chi \rho \hat{\omega} \mu \alpha$, colour.] A process of photographing objects in their natural colours.

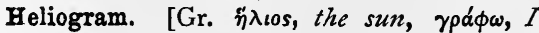
write.] A sunshine message.

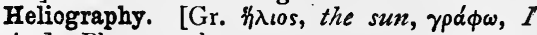
write.] Photography.

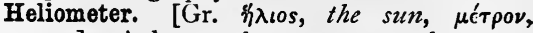
measure.] A large telescope mounted equatorially, whose object-glass is divided along a diameter, the parts being mounted in separate frames capable of relative motion produced and accurately measured by a screw; each half forms its own image; the images are seen side by side through the eye-piece, and can be moved by the screw. It is used for the exact measurement of small astronomical distances, e.g. the diameter of a planet, the distance between the components of a double star, etc.

Heliostat; Heliotrope. An instrument for throwing the reflected light of the sun in any required direction.

Heliotrope (Min.), or Blood-stone. A deepgreen stone ; a jaspery variety of silica, with red spots, caused by oxide of iron. (Heliostat.)

Hělix. [Gr. "̈ $\bar{\lambda} \iota \xi$, adj. and subst., spiral.] 1. (Mech.) A spiral line of the same form as the thread of a screw; right-handed, when it ascends from the right hand to the left hand of a person standing within the coil; lefthanded, when it ascends in the opposite direction. 2. (Anat.) The reflected margin of the outer ear. 3. (Arch.) The curling volutes under the flowers of a Corinthian capital. 4. (Zool.) Gen. of pulmoniferous mollusc. Cosmopolitan; more than $2 \mathrm{cos}$ spec. Gives its name to fam. Hĕlǐčrdæ, snails, with 6000 spec. Class Gastěrŏpŏda. 


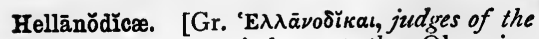
Hellenes.] The two judges at the Olympian games.

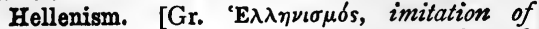

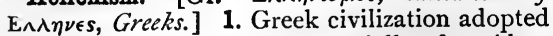
and reacted on by aliens, especially after Alexander the Great's death; adj., Hellenistic. 2. The best civilization of unmixed independent Greece (Hellas), as the word is used by Grote and others ; adj, Hellenic.

Hellenistic Greek. The Greek used by Jewish writers. It differed from other Greek chiefly in its frequent use of Oriental metaphors and idioms.

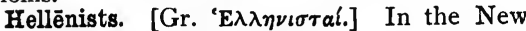
Testament, a body, including not only proselytes of Greek, or foreign, parentage, but also Jews who, settling in foreign countries, adopted the forms of Greek civilization and the use of the common Greek dialect.

Helm. 1. [O.E.] A heavy cloud on the brow of a mountain. Helm wind is the wind attending such a cloud. 2. [A.S. helma.] (Naut.) The tiller, which was always rigged in-board, and in the phrase, "Helm a-lee," etc., is still always so understood. 3. Applied to the rudder, and the wheel or other means used to turn it.

Helmet of Hades. (Tarnkappe.)

Helminthology. [Gr. $\ddot{\epsilon}^{\prime \prime} \lambda \mu \iota \nu s, a$ zvorm, $\lambda \delta$ ros, discourse.] The natural history of worms.

Helots. [Ei $\lambda \omega \omega^{\prime} \alpha_{\iota .}$. (Hist.) The slaves of the Spartans, supposed to be so called from the Laconian town Helos; but the name probably merely denotes captives. They resembled the mediæval serf in being attached to the soil. (Villein.)

Helve. [A.S. hielfa, O.H.G. helbe ; $c f$.

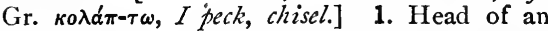
axe or hatchet. 2. Handle of an axe or hatchet.

Helvetic Confession. (Basle, Confession of.)

Hemĕrŏbaptists. An ancient Jewish sect ; so called from their washing daily [Gr. ín $\mu$ é $\rho \alpha, a$ day] as a religious solemnity. Perhaps the same as the Sabians.

Hemǐopsia. [Gr. i் $\mu l$-, half, ช้ $\psi t s$, evesight.] (MTed.) Faulty vision, the patient seeing only half an object.

Hēmīplëgia. [Gr. form $\dot{\eta} \mu \iota \pi \lambda \eta \xi \mathfrak{i}$, from $\dot{\eta} \mu \iota$-, half, and $\pi \lambda \hat{\eta} \xi \iota s$, a striking.] (Med.) Paralysis

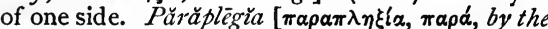
side of], paralysis of the lower half of the body.

Hêmiptěra. [Gr. ínt-, half, $\pi \tau \epsilon \rho o ́ \nu, a$ wing.] (Entom.) Rhyncōta. Ord. of insects, containing three sub-orders: Hŏmoptěra, as aphìdes and ricadas ; Hĕtĕroptěra, as land and water bugs ; Thy̆sănoptěra, the gen. Thrips, destructive in green-houses, etc.

Hemisphere of Bērōsus (Babylonian astronomer). A hollow hemisphere, with its rim horizontal, and having the end of a style as the centre : the shadow of this point on the concave surface would show the zenith distance of the sun. It was used, however, as a sun-dial.

Hemistich. [Gr. $\dot{\eta} \mu \iota \sigma \tau i \chi \chi \iota \nu \nu$.] A half-verse ; e.g. either fralf of a pentameter. The unfinished verses in the AEneid, as bk. i. 534, 636, are called $\mathrm{H}$.
Hemuse. (Deer, Stages of growth of.)

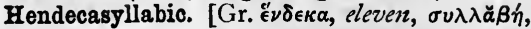
syllable.] A verse of eleven syllables, e.g. that of Catullus, "Passer deliciæ meæ puellæ," or a heroic verse lengthened by a syllable, as in It., Ger., and Eng. verse.

Henna. [Ar. huinâ.] A paste made of pounded leaves, used by Asiatics for dyeing their nails, etc., of an orange hue. (Camphire.)

Henotheism. (Monotheism.)

Henōtǐcŏn. [Gr., capable of uniting. ] (Eccl. Hist.) The Edict of Union, issued A.n. 482, by the Emperor Zeno, with the view of ending the Monophysite controversy by avoiding expressions offensive to either side (Milman, Hist. of Latin Christianity, bk. iii. ch. I).

Henricians. (Eccl. Hist.) The followers of Henry, an Italian monk of the twelfth century, who rejected infant baptism, and declaimed against the vices of the clergy (Milman, Hist. of Latin Christianity, bk. ix. ch. 8).

Henri Deux ware (Henri II. of France). A peculiar ware of fine pipe-clay, inlaid with coloured pastes, in arabesques, interlaced letters, and other devices, and enriched with reliefs of lizards, masks, etc. It appears to have been made temp. Francis I. and Henri II., in Touraine, at the château of Oiron, the chapel of which is paved with tiles of identical composition. Only tifty-three pieces are known.

Hepar. [Gr. $\hat{\eta} \pi \alpha \rho$, liver.] (Chem.) Liver of sulphur.

Hepatic. Belonging to the liver [Gr. $\bar{\eta} \pi \alpha \rho$,

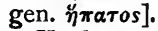

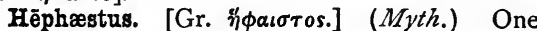
of the Greek gods of fire.

Hephthemimeral. [Gr. $\dot{\epsilon} \phi \eta \eta \mu \iota \epsilon \rho \eta \dot{s}$, containing seven (é $\left.\pi \tau \alpha^{\prime}\right)$ half- $(\dot{\eta} \mu l-)$ parts $\left.\left(\mu \epsilon^{\prime} \rho \eta\right).\right]$ (Pros.) Of or after three feet and a half.

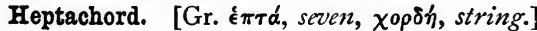
(Music.) 1. A series of seven notes. 2. A seven-stringed instrument.

Heptarchy. [Gr. ė $\pi \tau a ́$, seven, ă $\chi \omega, I$ govern.] (Eng. Hist.) A division of England into seven kingdoms-Kent, Sussex, Wessex, Essex, East Anglia, Mercia, Northumberland, which are supposed to have existed at the same time with and independently of each other. In point of fact, this was never the case.

Hēra, or Hĕrē. (Gr. Myth.) The wife of Zeus, or Jupiter, and Queen of Olympus ; answering to the Latin Funo.

Heracleids. In Gr. Myth. Hist., the descendants of Heracles, or Hercules, who are supposed, after a long series of conflicts, to have divided the Peloponnesus between them.

Hērăcles. (Gr. Myth.) The hero called by the Latins Hercules.

Heralds, College of. (College of Heralds.)

Herbal. [From L. herba, herb, plant.] 1. A book on plants. 2. $=$ Herbarium.

Herbärium. [L.L.] 1. A collection of dried herbs [herbæ], a hortus siccus. 2. A book for dried specimens of plants.

Herculean. Belonging to or like Hercules, who represented the Greek Heracles, a hero of invincible strength, whose life was a series of 
labours, set down by later poets as twelve in number. The Latin Herculles, or Herculus, was properly a god of boundaries and fences, and had nothing to do with the Greek Heracles.

Hereditament. [L.L. hærēdítāmentum, from L. hærēditas, heirship.] Inheritable property or rights of which any property is susceptible. Corporeal hereditaments are lands; incorporeal $H$., rights arising out of lands, of which the chief are advowsons, tithes, commons, ways, offices, dignities, franchises, pensions or corodies, annuities, and rents.

\section{Hereford Use. (Use.)}

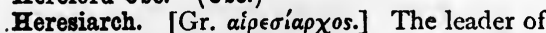
a party, usually of a religious sect.

Heretoch. [A.S., Ger. herzog.] The old Eng. lish name for the persons chosen at the Folkmote to lead the armies of the kingdom.

Heriot. [From A.S. here, army, geatu, supply.] Originally the horse and habiliment of a deceased tenant, given as tribute to the lord ; then the tenant's best beast (averium) or best dead chattel (or money in its stead).

Heritor. (Scot. Law.) A landholder in a parish.

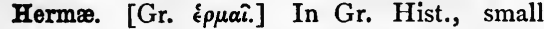
shafts, with the top shaped into a head, perhaps of Hermes, set up on the side and at the crossing of roads.

\section{Hermaion. (Trouvaille.)}

Hermann's Consultation. (Theol.) A treatise drawn up by Hermann, Archbishop of Cologne, for the purpose of bringing about a reformation of doctrine and ceremonies. An English translation of the Latin work was published in 1547.

Hermaphrodite. (Anat. and Bot.) Partaking of the characteristics of both sexes (Hermaphrǒditos, supposed son of Hermes and Aphrŏdîte).

Hermaphrodite, or Brig-schooner. (Naut.)

Two-masted vessel, carrying fore-and-aft sails only on mainmast, and square-rigged, but without a top, on foremast.

Hermëneutæ. [Gr. é $\rho \eta \eta \nu \in v \tau \alpha i ́$, interpreters.] In the public worship of the ancient Church, translated one language into another ; the ministrant and the people being often unacquainted with each other's tongue.

\section{Hermeneutics. (Hermes.)}

Hermes. (Gr. Myth.) The messenger of the gods, to whom, in Acts xiv. 12, St. Paul was likened, as being "the chief speaker." In the Rig Veda the name occurs in the form of Savarnâ, a word denoting the dawn, with the fresh morning breeze. Hermes is thus the god of the moving air, which can either discourse sweet music or fill the forests with its roar. As messenger of the gods, he is the interpreter of secrets. Hence Hermeneutics, the science of interpretation, especially as applied to the Scriptures. (Caduceus ; Petasus.)

Hermēs Trisměgistus. Neoplatonic name of the Egyptian god Theuth, the inventor of letters and the arts and sciences, to whom many works were ascribed which really belong to the fourth century A.D.

Hermetically sealed. Said of a glass so closely stopped that no exhalation can issue from its contents. The neck of the vessel is heated by a blow-pipe till on the point of melt ing, and then nipped with hot pincers. (Hermetio art.)

Hermetic art, Alchemp. So called from Hermēs Trisměgistus, its supposed discoverer.

Hermit. [Gr. Ép $\mu i \tau \eta s$.$] One who dwells in$ deserts. (Eccl. Hist.) A solitary, as opposed to those who live in common under rule. (Cœnobites; Regulars ; 8eculars.)

Hernia. [Gr. є̌ $\rho \nu o s$, sprout.] Protrusion of an internal organ, or a part of it from its natural cavity, through an abnormal or accidental opening.

Hernshaw. (Handsaw; Heronshaugh.)

Heroic Age. (Ages, The four.)

Heroic treatment, or remedies. [Gr. ípwïkós, belonging to heroes.] (Med.) Violent, as opposed to mild, benignant.

Heron-shaugh, -shaw (Egret.) [Shaugh, or shaw, $a$ wood.] 1. A wood where herons breed. 2. The heron. (Handsaw.)

Herpēs. [Gr. ๕̈ $\rho \pi \eta s$, from $\ddot{\epsilon}_{\rho} \pi \omega, I$ creep.] (Med.) A skin-disease, with clustered vesicles on an inflamed base, ending in desquamation; not contagious.

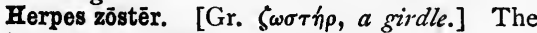
shingles [L. cingŭlum, a girdle], vesicular patches of which usually go about half-way round the waist.

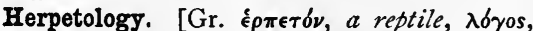
an account.] The science of reptiles, the third class of vertebrates, cold-blooded, with nucleated corpuscles, never provided with gills. Dr. Günther classifies them as follows :-

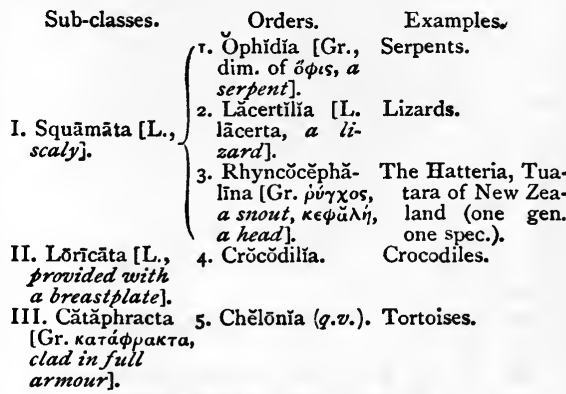

Herring-bone masonry. In Arch., masonry with rows of stones or bricks laid sloping in different directions in alternate rows.

Herschell. (Planet.)

Hership. (Scot. Law.) The crime of forcibly carrying off cattle.

\section{Hervarar Saga. (Saga.)}

Hesperìdes, Gardens of the. (Myth.) A region, much like that of Elysium (Elysian), where the nymphs called by this name keep the golden apples given to Hëra on the day of her marriage. Hessian. 1. A hireling, a mercenary politician, a fighter for pay. Derived from the traditional dislike toward the Hessian soldiers employed by England against her American colonies in the war of the Revolution (Bartlett's Americanisms). 2. A half-boot, with tassels. 
Hesychasts. [Gr. $\dot{\eta} \sigma v \chi \alpha \sigma \tau \alpha$ l.] The Quietists of Mount Athos. (Barlaamites.)

Hetæria. [Gr. éтaıpeía.] A Greek word, denoting any association. In Mod. Hist., it belongs to two societies, which had much to do with the liberation of Greece from the power of the sultan.

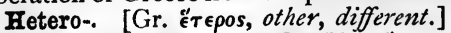

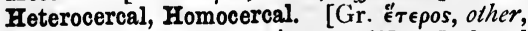

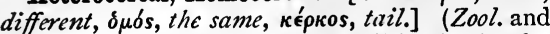
Geol.) In existing fishes, the tail is, 1, simple, e.g. eel; or bifurcate, e.g. rnach ; or rounded, e.g. gilt-head; these all being Hom. Or it is, 2, Het., i.e. unequally bilobate, e.g. shark, ray, sturgeon, i.e. not symmetrical, the vertebræ running along the upper lobe. All strata older than Oolite have Het. only; in and above Oolite are mostly Hom. (Ichthyology.)

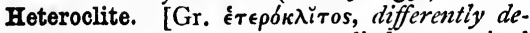
clined.] (Gram.) 1. A term applied to terminal forms which have a different declension from the form to which they are referred, as, L. jūgĕra, neut. plu. (third decl.) of jügerum (second decl.), an acre. 2. A noun variously declined, i.e. having forms of different declensions, as, dŏmus, house, dŏmo, dŏmos (second decl.), domibus, dŏmūs (fourth decl.).

Heterodynamic words. Spelt alike, but $[\mathrm{Gr}$.

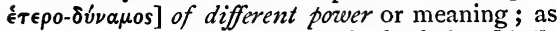
school [L. schŏla], and school of whales [A.S. sceol]; Fr. louer [L. lŏcāre], and louer [L. laudāre].

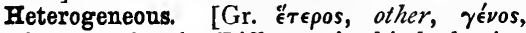
kind, gender.] 1. Different in kind, having elements or component parts of different kinds. 2. (Gram.) Nouns varying in gender, as $\mathbf{L}$. tăpes (masc.), tăpēte (neut.), a carpet.

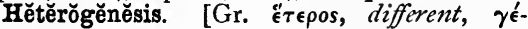
$\nu \in \sigma \iota s$, production.] The production of offspring very unlike to the parent, and showing no tendency to revert to the parental type.

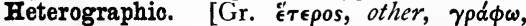
$I$ zurite.] Using the same combinations of written letters to express different sounds, as English spelling does, according to which -ough stands for seven different sounds--e.g. in bough, though, through, thorough, cough, enough, ought.

\section{Hĕtĕroptĕra. (Hemiptera.)}

Hetman. [Russ. ataman, Ger. hetmann.] A Cossack commander or chief.

Heurtoir. [Fr., from heurter, to strike, run counter to.] (Mil.) A piece of timber laid along the head of a platform to prevent the wheels of the gun-carriage from damaging the interior slope of the parapet.

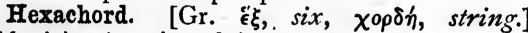
(Music.) A series of six notes.

\section{Hexagon. (Polygon.)}

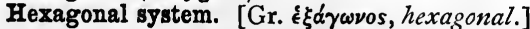
In Crystallog., a name sometimes given to the rhombohedral system (q.v.).

\section{Hexahedron. (Polyhedron.)}

Hexameter. (Pentameter.)

Hexăpla. [Gr., sixfold.] (Theol.) The combination of sir versions of the Old Testament by Origen, viz. the Septuagint, those of Aquila, Theodotion, and Symmachus, one found at Jericho, and one at Nicopolis.

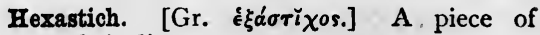
poetry of six lines.

Heybote. (Haybote.)

Heyloed. A burden laid on tenants for repair of fences.

Hiätus. [L., a gaping, a cleft.] 1. (Pros.) A meeting of vowels, concursus vocālium, as in ille amat. 2. In Lit., a missing passage in the MS. of an author.

Hiawatha. The hero of N.-American Indian civilization such as it is or was; his legend is told by Longfellow.

Hibernacle. [L. hībernācŭlum, winter quarters.] A protection or shelter during winter.

Hibernate. [From p. part. of hibernäre, to pass the winter.] 1. To winter. 2. To pass the winter in repose or seclusion, like bears, etc.

Hibernioism. [Hibernia, L. for Ireland.] An Irish mode of expression, an Irish bull.

Hio et ŭbique. [L.] Here and everyzohere.

Hic jăcet. [L.] Here lies; beginning of many Latin epitaphs.

Hickory. [L. jüglans, zvalnut.] (Bot.) The wood of several spec. of H., a gen. of N.-American trees, allied to walnut. Ord. Jüglandaceæ.

Hickory, 0ld. General Jackson, President of U.S.

Hic vēr assĭduum. [L.] Here is perpetual spring (Virgil).

Hic victor cestūs artemque rĕpōno. [L.] Here on mv victory I give up my cestus (q.v.) and my art (Virgil); quoted in reference to retirement from active pursuit of an art or profession.

Hidage. A tax formerly paid to the sovereign on every hide of land.

Hidalgo. [Sp. hijo d'algo, son of somebody.] An obsolete title, which denoted Spanish noblemen of the lower class. (Grandee.)

Hidden fifths; H. octaves. (Music.) A sequence like in character to consecutive fifths, octaves, and giving to the ear almost the impression that they have been actually played, when they have not. (For a full explanation, see examples given in theoretical works on music.)

Hidebound. 1. (Anat.) Morbidly tightened in skin. 2. (Bot.) Barkbound; the bark not swelling enough with the growth of the tree. 3. (Met.) Close, harsh, penurious.

Hide of land. [L.L. hida.] A measure of variable size; (?) 120 acres, or 100 , or even much less ; at first, probably, = enough for one household; A.S. híd, or higid, being another term for hiwisc; $c f$. A.S. híwan, domestics (Skeat, Etym. Dict.).

Hidgild, Hidegild. Money (Gild) paid by a villein or servant to save his hide (skin) a whipping.

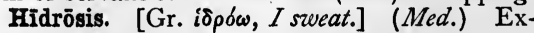
cessive perspiration.

Hiemation. [L. hüĕmatio, -nem, a wintering.] Shelter from the cold of winter.

Hieratic. [Gr. iepāiı́śs, priestly.] The sacerdotal style of Egyptian writing, especially on papȳri, half-way between hieroglyphics and a syllabārium, or alphabet. (Demotic.)

Hierocracy. [Gr. iepós, sacred, крaréw, I rule.] Government by ecclesiastics, as in Jeru. salem after the Captivity. 


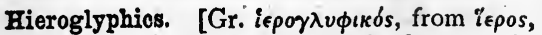
sacred, and $\gamma \lambda \dot{u} \phi \omega, I$ engrave.] Sculpture-writing, or writing by pictures, in which ideas are represented by visible subjects. The likenesses of these objects were in course of time modified, until they assumed the forms of letters in the Phœnician, Greek, and Roman alphabets.

Hierogram. [Gr. ie $\rho \delta ́ s, ~ s a c r e d, ~ \gamma \rho \alpha ́ \mu \mu \alpha$, written letter, from $\gamma \rho \alpha \dot{\phi} \omega, I$ write.] A specimen of hieratic or hieroglyphic writing.

Hierology. [Gr. ie $\delta \delta s, ~ s a c r e d, \lambda \delta \gamma o s$, an account.] The study of sacred writings, especially of Egyptian inscriptions and other writings.

Hieromnemon. [Gr.] In Gr. Hist., the name of one of the two deputies sent to the Amphictyonic Council by each city belonging to the confederacy.

Hierony̆mites. A religious order, with St. Ierome [L. Hierony̆mus] for its patron, and following him in fixing their convents in mountainous and solitary positions.

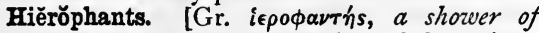
sacred things.] (Hist.) The title of the priests who initiated candidates at the Eleusinian Mysteries.

Higgle. [Cf. haggle, cut in pieces, from hack.] 1. To hawk provisions. 2. To carry on petty discussion over a bargain.

High and Low Dutch. The Teutonic dialects spoken by the German peoples on the upper and lower course of the Rhine. English, as having been brought to this country from Anglia, Friesland, and Jutland, is a Low German dialect.

High-blowing. In some horses, a habit of forcible and rapid expiration; not to be confounded with roaring.

High Celebration. The celebration of the Eucharist with full apparatus of choir and music, known in the Roman Church as High Mass, in distinction to Low Mass, or celebration by the priest alone with a single attendant.

High Commission, Court of. (Hist.) A court erected by Elizabeth, without power to fine or imprison. Under Charles I. it became a court for trying ecclesiastical offences of all kinds, and was abolished by the Long Parliament.

Highfaluten, Highfaluting. [Amer.] Highflown language, bombast. There can be little doubt of its derivation from "highflighting" (Bartlett's Americanisms). It is also used in East Anglia.

Highfliers. A nickname given to the bigoted and extreme maintainers of the doctrine of passive obedience, in the middle of the seventeenth century.

High German. [Ger. Hoch Deutsch.] (Lang.) The dialects of S. Germany; opposed to Lcw German [Platt Deutsch] of N. Germany, the Netherlands, and England.

High-low. A boot just covering the ankles.

High Mass. (High Celebration.)

High-pressure steam. (Steam.)

Hight. [Pres. tense and pass. part. of A.S. hâtan, to call, name, be named ; ct. Ger. heiszen, to call, name, be said, mean, Goth. haitan, O.N. heita ; the past tense is hote.] Called, named.

Hikenhilde street. Heykenylde Strete, from
St. David's, by Worcester, Wycombe, Birmingham, Lichfield, Derby, Chesterfield, York, to Tynemouth.

Hilary Term. One of the legal English terms, appointed by statute to begin on the IIth and end on the 3Ist of January; so called from January 13 being a black letter day in remem. brance of Hilary, Bishop of Poitiers, circ. 350 A.D.

Hilum. [L.] (Bot.) The scar on a seed when separated from the placenta.

Himyaric inscriptions. Inscriptions found in Arabia, in the oldest form of the language spoken in S. Arabia.

Himyaritic. (Lang.) Name of dialects of S.W. Arabia; not now spoken.

Hinc illø lacrimæ. [L.] Hence those tears.

Hind, Hine. [O.E. hína, a male domestic.] (Agr.) A farm labourer hired by the year. He hires at the yearly fair one or more bondagers (females), who keep house for him, and whose services he lets to the farmer. Hinds with girls of their own are now preferred, and extra women-workers are hired by the farmer direct.

Hindi. (Lang.) Dialect of the Hindus of the north-west provinces of India, akin to Sanskrit (Indo-European), but much corrupted, and mixed with Persian words.

Hindley's screw. An endless screw, the threads of which are cut on a solid whose sides are terminated by arcs of the same radius as that of the toothed wheel with which it works ; in this machine several teeth are at work at once, and the pressure on each is diminished by being distributed.

Hindustani. (Lang.) Speech of the Hindus, also called Urdu; a variety of Hindî, with an admixture of Arabic and Persian. The modern Aryan dialects of India are roughly classed as Hindi, Mahratti, Bengalee.

Hinny. The offspring of the horse and the ass.

Hipped roof. (Arch.) A roof in which two sides at least must intersect.

Hippo-. [Gr. i $\pi \pi 0-$, horse.] Part of names, as hippo-centaur.

Hippocampus [from resemblance to $\mathrm{Gr}$. $i \pi \pi \delta$. $\kappa \alpha \mu \pi$ os, a sea-horse], Major and Minor. (Anat.) Two long, curved eminences or convolutions of the brain.

Hippocras. Aromatic, medicated wine, vinum Hippǒcrătis. (Hippocrates, a Greek physician, fifth century B.C.)

Hippocratio face; i.e. described by Hippocrates. That seen in death, or after long illness or excessive hunger; pale, sunken, contracted, with pinched nose, hollow temples, eyes sunken.

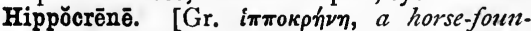
tain.] A fountain at the foot of Mount Helicon, supposed to have been laid bare by the hocf of the horse Pegasus. (Muses.)

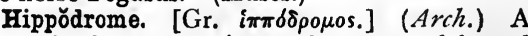
place for horse exercise. The most celebrated hippodromes were those of Olympia and Constantinople. (Circus.)

Hippogryph, Hippogriff. A fabulous animal,

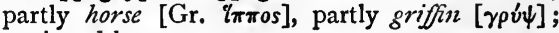
a winged horse. 


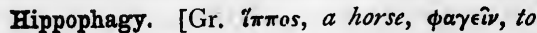
eat.] The eating of horseflesh.

Hippurite. (Geol.) 1. Fossil plant of the coalmeasures, resembling the common Mare's-tail

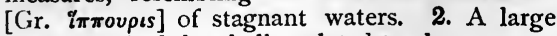
coarse shell of the chalk, related to chema.

Hirst, Hurst. (Geog.) A wood, especially as part of names, as in Chisel-hurst.

Hirsute. [L. hirsutus, hair; $c f$. horreo, 1 bristle, am horrid, Eng. grisly, Ger. grau, horrible.] Hairy, shaggy.

Hispanicism. [L. Hispānus, Spaniard.] A Spanish mode of speech.

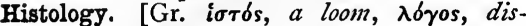
course.] (Anat. and Bot.) The description and classification of tissues.

Histriomastix. A title coined by Prynne, a barrister of Lincoln's Inn [from the L. hister, histrio, an actor, and $\mathrm{Gr} . \mu \alpha ́ \sigma \tau \iota \xi$, a scourge], for a treatise, published in 1634 , against stage-plays, dancing, and public amusements generally.

Histrionic [L. histrio, an actor] affection. A spasmodic affection of the muscles supplied by the facial nerve.

Histrionic art. A name for the dramatic art, from the old Etruscan word hister, an actor.

Hitch. (Naut.) A knot by which ropes are joined together and made fast. There are many kinds. (Rnot.)

Hithe. [A.S. hydh.] Port, landing-place, especially as part of names; as Green-hithe, Lambeth (Lamb-hithe).

Hitopadēsa. [Skt., a friendly instructor.] A collection of fables, commonly called by the name of Bidpai, or Pilpay. Part of this collec. tion, under the title Calila and Dimna, has found its way into Europe.

Hobble-de-hoy. (Hoyden.)

Hobbler. [A.S. hobeler.] 1. A man of Kent, a "hoveller," partly smuggler, partly unlicensed pilot. 2. A man who tows a vessel from shore. 3. One who watches a beacon. 4. (Leg.) A feudal tenant, bound to serve as a light (hobby) horseman or bowman.

Hobby. [Dan. hoppe, a mare, Fris. hoppa ; cf. L. căballus, $a$ nag.] 1. A nag. 2. A horse's head on a stick. 3. A subject or plan which one is always riding, as a child might a toy horse.

Hobiler. [(?) $C f$. hobin, an ambling horse, hobil, a light, quilted surcoat (?), hobby, a small horse (?).] Light cavalry soldier-fourteenth century to sixteenth century-armed with lance, and mounted on a small horse; principally employed on reconnoitring duties. (Hobbler.)

Hobson's choice. A case admitting of no alternative, choice between one thing and nothing. (From Hobson, a Cambridge horseclealer, who would not let out any horse out of its regular turn.)

Höc ăge. [L.] Do this, attend to this, very nearly i.g. "Attention!"

Hoc èrat in vōtis. [L.] This is what he kept wishing for; as, e.g. a busy man might desire, and at length obtain, literary leisure.

Höc jŭvăt et melli est. [L.] This pleases and is as honey.
Hock, Hough. [A.S: hoh, the heel, the ham.] The joint between the knee and the fetlock, in a horse's hind leg. Hock-joint, the hinge formed by tībia and astrăgălus.

Hocketter, Hocqueteur. A knight of the post, a decayed man, a basket-carrier (Cowell).

Hoous. 1. To drug, especially with narcotics; of liquor. 2. To cheat, hoax.

Hocus-pocns. [Said to be corr. of L. hoc est corpus, this is the body, in the Canon of the Mass.] A piece of trickery.

Hodge. [Corr. of Roger.] 1. Gammer Gurton's goodman. 2. Any simple rustic.

Hodgepodge, Hotchpotch. [Fr. hochepot, shake-pot.] A mixture of divers ingredients, a medley, a farrago, olla podrida.

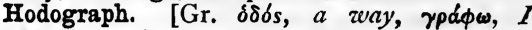
draw.] The diagram of the velocity of a moving point. If a line fixed at one end is always parallel to the direction, and has its length proportional to the velocity of the motion of the point, its moving end traces out the $\mathrm{H}$.

Hog, Hoggaster, Hoggerel, Hogget. (Sheep, Stages of growth of.)

Hogden. (Hoyden.)

Hogging. (Naut.) (Arching.)

Hog-in-armour. (Naut.) An iron-clad.

Hogmanny [Said to be from Norm. Fr. au gui menez, lead to the mistletoe.] 'The Scotch name for the last night of the year.

Hogshead. A measure of capacity. The hogshead of wine is 63 gallons. The word is often used vaguely for any large cask containing wine; thus the $\mathrm{H}$. of hock is 30 gallons; of claret, 46 gallons ; of tent, 52 gallons.

Hog-wallow. [Amer.] On some of the Western prairies, but particularly those in Texas, the ground has every appearance of having been torn up by hogs; hence the name.-Bartlett's Americanisms.

Hoist. (Naut.) The perpendicular height of a sail or flag; in the latter opposed to the $F l y$, i.e. its breadth horizontally from the mast.

Hoisting. (Naut.) Taking up a command, as admiral. $H$. the pendant, commissioning a ship.

Hold. (Naut.) The interior of a vessel, between the floor and lower deck, in a war-ship. That portion of a vessel, below the deck, constructed for carrying cargo, in a merchant-ship.

Hold on the slack. (Naut.) Do nothing.

Hold water, To. (Naut.) In rowing, to hold the oar in the water, as if stopped in the middle of a stroke.

Holibut. (Halibut.)

Holiday. (Naut.) Any part left unpainted, untarred, or the like.

Hollock. A sweet wine used in the sixteenth century.

Holograph. [From Gr. ó $\lambda$ os, whole, all, and $\gamma \rho a ̆ ́ \phi \omega$, I write.] (Scot. Law.) A deed entirely in a grantor's handwriting, held valid without witnesses.

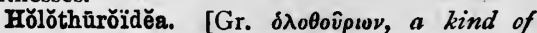

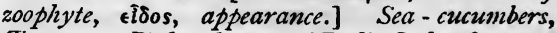
Trepangs, Bèches-de-mer. (Zool.) Ord. of wormlike, leathery-coated Ěchīnŏdermăta. One spec., 
Hŏlŏthūrĭa argus, is a Chinese delicacy. Subkingd. Annŭlöïla.

Holster. [D., O.H.G. hulst, a saddle.] A leathern case for pistols, carried in the front of the saddle.

-holt. [A.S., Ger. holz, a wood.] The ending of the names of many places in England which were originally in the forests. (Hurst.)

Holy Alliance, The. A league of the chief sovereigns of Europe, formed after the defeat of Napoleon at Waterloo. It became practically an engagement to uphold all existing governments.

Holy Coat of Trèves. A coat kept at Trèves, which is said to be the garment worn by Christ at the Crucifixion. Many coats, for which the same claim is made, are kept in other places.

Holy Maid of Kent. (Nun of Kent.)

Holy Rood, or Holy Cross, Feast of the. The commemoration of the exaltation of the cross, September 14, in the calendar of the Latin Church.

Holystone. (Naut.) A kind of sandstone used to clean and whiten the decks.

Holy Thursday. Ascension Day.

Homage. [L.L. homagium, the service of the man or vassal of a feudal chief.] The act acknowledging feudal dependence. Liege homage was rendered to the person of the sovereign, and could not be renounced; simple homage bound the vassal only while he held a fief.

Home Circuit (Leg.), or South-Eastern Circuit, $=$ Norfolk, Suffolk, Essex, Herts, Surrey, Kent, Sussex. (Circuits.)

Home Counties. (Circuits.)

Homëric poems. A title generally used to denote the Iliad and Odyssey, and the hymns in honour of Apollo, Hermes, and other Hellenic deities and heroes.

Homerids. [Gr. $\delta \mu \eta \rho i \delta a$.] A family or guild of poets or rhapsodists of Homeric poetry, in Chios, claiming personal descent from Homer.

Home Rule (vide Fortnightly Review, February, 1880). A scheme which proposes a national Parliament-Queen, Irish Lords, and Irish Commons-legislating for and regulating all internal affairs of Ireland, with full control over Irish resources and revenues; under condition of contributing a just proportion to imperial expenditure; the Imperial Parliament alone dealing with foreign and colonial questions, and the defence of British possessions.

Home Rulers. Those who wish to carry out the scheme of Home Rule.

Homesoken. (Hamesucken.)

Hominy. [N.-Amer. Ind. auhûminea, parched corn.] Crushed maize cooked by boiling.

Homo-. [Gr. osos, the same.] One and the same.

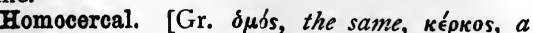
tail.] (Ichth.) Having a tail consisting of symmetrical lobes, as the perch. (Heterocercal.)

Homœ0-. [Gr. "\%oros, like.]

Homœopathy. A system of treatment which professes to remedy by setting up a similar

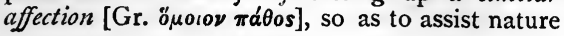

rather than combat disease. Its motto is " $\mathrm{Si}$ milia similibus curantur."

Homogangliate. [Gr. $\delta \mu o$ s, one and the same, ráryicov, a plexus of the nerves.] (Biol.) Having the nervous system arranged symmetrically.

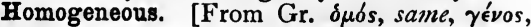
kind.] 1. Having the same nature, similarly constituted. 2. Consisting of identical or similar constituent parts or elements.

Homographic. [From Gr. $\delta \mu \delta s$, same, $\gamma p a \dot{\alpha} \phi \omega$, $I$ write.] Expressing the same sound always by the same distinctive sign; said of certain systems of spelling. Opposed to Theterographic.

Homoioptotōn. [Gr. $\delta \mu o เ \delta \pi \tau \omega \tau o \nu$, with similar (ópotos) cases $(\pi \tau \dot{\omega} \sigma \in t s)$.$] (Rhet.) The ending$ of consecutive clauses with words in the same case or inflexion generally.

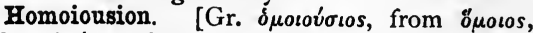
like, où ${ }^{\prime a} \alpha$, substance, essence.] A term asserting the likeness of substance in the Son and the Father, which some Arians wished to substitute

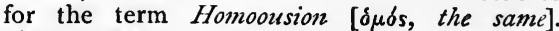
(Anomœans.)

Homoiozoic zones. Belts on the earth's surface, marking similar [Gr. of $\mu \circ$ os] forms of

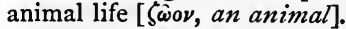

Homologate. [From L.L. hŏmǒlŏgāre, from Gr. $\delta \mu 0 \lambda \sigma \gamma \epsilon i \nu$, to agree.] (Scot. Lavv.) To ratify an act previously void, voidable, or defective.

Homologous. (Math.) In a proportion, the antecedents of the ratios (i.e. first and third terms) are like or H. terms; and so are the consequents (i.e. second and fourth terms). The corresponding sides of similar figures are $\mathrm{H}$. because they would enter the proportions formed between the sides as $\mathrm{H}$. terms, i.e. two similar sides would be both antecedents or both con. sequents.

\section{Homologue. (Analogue.)}

Homology. (Comp. Anat. and Bot.) Correspondence or equivalence of certain parts with reference to an ideal type or to similar parts, homologues, in other organisms ; e.g. arm, wing, seal's fore foot. (Analogue.)

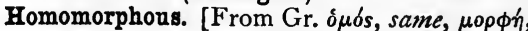
shape.] Similar or identical in shape.

Homonymous. [Gr. $\delta \mu \omega ́ \nu v \mu o s$, from $\delta \mu \delta s$, same, ช̌ $\nu \mu \alpha$, name.] Having different meanings; said of a word used more than once, or of either of two words identical in sound but differing in sense, as "the being of a being;" fee = remuneration, for faihu, head of cattle; fee=estate, for feodum.

Homonymy. (Metaphor.)

Homoousion. [Gr.] The term in the Nicene Creed, asserting the consubstantiality of the Son with the Father. (Homoiousion.)

Homophagy. Misspelling for Omophagy

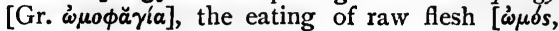
raze, and $\phi a \gamma \in i \nu$, to eat].

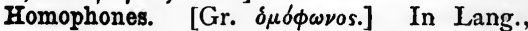
words or syllables having the same sound, although written with various combinations of letters. Such words abound especially in some monosyllabic languages of Asia.

Hŏmoptěra. [Gr. \& $\mu \delta$ s, one and the same, $\pi \tau \epsilon \rho \delta \nu, a$ wing.] (Hemiptera.) 
Hŏmo sum; hūmäni nǔhŭl ā mē ăliēnum pŭto. [L.] I am a man; I think nothing human void of interest to myself.

Homo trium lîtĕrärum. [L.] $A$ man of three letters, i.e. fur [L.], a thief.

Hŏmo ūnŭus libri. [L.] $A$ man y one book.

Hŏmuncŭlus. [L.] A little man; dim. of hŏmo.

Honey-dew. 1. (Bot.) A clammy, saccharine substance, on the leaves and stems of some trees and herbaceous plants; the sap of the plant, flowing, probably, from the punctures of aphids, etc. ; probably, also, from other causes, as the ruptured tissue; in warm, dry weather. It falls, sometimes, in drops, abundantly. 2. An exudation of aphids themselves, different from but mingling with that of the plant.

Hong. [Chin.] A mercantile house or factory in Canton, for foreign trade, or a national department therein.

Honi soit qui mal y pense. [Fr.] Shame be to him who thinks ill of it; motto of the Order of the Garter.

Hŏnörärium. [L., $a$ fee.] The word is often used delicately, to avoid the actual mention of money (post-class. $=a$ present,$a$ douceur, given by one admitted to some post of honour).

Honorarium jus. (Civ. Lav.) The law of the prætors and the edicts of the ædiles of ancient Rome.

Honour. [L. hŏnōrem.] 1. (Leg.) A seigniory of several manors held under one baron or lord paramount. 2. At Whist, the ace, king, queen, or knave of trumps. 3. (Com.) To H. a bill or cheque, etc., to admit the claim of the drawer, or the drawee.

\section{Honour point. (Escutcheon.)}

Honours of war. (Mil.) Vanquished troops, when permitted to march out, carrying their arms with them, from a besieged town, drums beating and colours flying, are said to have capitulated with $\mathrm{H}$. of W.

Hood-moulding. (Arch.) The moulding which throws off the rain from tracery or protects it from dust. (Dripstone.)

Hookah. [Ar. hukkah.] An Oriental tobaccopipe, with a long flexible stem from the mouthpiece to a closed vessel containing water, into which the stem from the bowl passes, so that the smoke is drawn through the water. It is an elegant form of Hubble-bubble.

Hooker, or Howker. (Naut.) 1. A small fishing or pilot boat. 2. An endearing term for one's ship, as, "My old hooker."

Hooke's law. The fact that, initially, the elongations of elastic bodies are proportional to the forces producing them.

Hookland. Land ploughed and sown every year.

Hooped guns. (Mil.) First system on which large guns were constructed, of staves, hooped together with metal rings like a cask.

Hope. [Perhaps a Celt. word.] A valley.

Hoplites. [Gr. $\delta \pi \lambda i \tau \alpha \iota$, from ő $\pi \lambda \alpha$, arms.] (Hist.) The heavy-armed infantry of the Greek armies. (Phalanx.)
Hoppo. [Chin.] A collector, an overseer of commerce.

Hōræ. [L., Gr. «pa..] (Myth.) The goddesses (I) of the seasons, (2) of the hours of the day.

Horary circle. (Circle.)

Hōras nŭmĕro non nǐsi sĕrēnas. [L.] , count but the sunny hours; a motto for a sundial.

Horde. The Tartar word denoting the encampment of the nomadic tribes.

Horděŏlum. [L. horděŏlus, a stye in the eye, dim. of hordeum, barley.] (Med.) A stye.

Horizon [Gr. $\delta \rho / \zeta \omega \nu$, defining, limiting], $\mathbf{\Delta p}$ parent; Artificial H.; Celestial H.; Dip of the H. ; Rational H. ; Sensible H. ; Visible H. The Rational horizon of a station is the plane drawn through the centre of the great sphere at right angles to the direction of the plumb-line at the station. If the radius of the earth is taken to have sensible magnitude, there is a Sensible $H$. parallel to the former, and passing through the station. The circle in which these planes cut the great sphere is the Celestial $H$., or the Horizon. The circle which bounds the visible part of the earth or ocean is the Visible or Apparent $H$., and is sometimes called the Sensible $H$. (For Dip of the H., vide Dip.) An Artificial $H$. is a little trough of mercury. An observer measures the angle between a star and its image formed by reflexion in the mercury. and thus obtains the double altitude of the star.

Hornbeam. (Bot.) A tree, with a hard white wood, much used by turners, wheelwrights, etc., Carpinus betǔlus, ord. Amentaceæ; attaining great height and beauty in some parts of Europe.

Hornbill. (Ornith.) Isolated fam. of birds, Būcěrōtĭdæ [Gr. Boúke $\rho \omega s$, ox-, i.e. huge-, horned], with huge bills having on the upper mandible a bony excrescence, in some spec. nearly as large as the bill, which in the Rhinoceros $H$. is ten inches long. Ord. Pīcārǐæ.

Hornblende. [Ger. horn, horn, blenden, to dazzle.] (Min.) A silicate of lime, magnesia, iron, and manganese; a dark.green or black, lustrous mineral, frequent in syenitic and dioritic, trappean, and metamorphic rocks; with hornlike cleavage.

Horn-book. A child's first lesson-book was once a thin board, about the size of a slate, on which were the letters of the alphabet, the Arabic numerals, and sometimes the Lord's Prayer; protected by a transparent plate of horn.

Horner, Little Jack. Supposed to have been sent to Henry VIII., by the Abbot of Glastonbury, with a pie full of deeds of manors, one of which, "a plum," he abstracted.

Hornpipe. 1. An old wind instrument, "of the shawm or waits character," the open end or bell of which was sometimes made of horn; but it may have been so called from its curved shape ; called in Wales, Cornwall, Ireland, and Brittany, the Pib-corn, pib or piob being i.q. pipe, and corn being i.q. horn. 2. A dance of English origin; called from the instrument played. Stainer and Barrett, Dictionary of Music. 


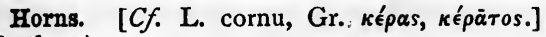
(Antlers.)

Horns of a dilemma. A metaphor for grave practical difficulties when of two or more courses of action both or all appear equally imprudent or dangerous ; borrowed from the argument so called, in Logic [Gr. $\delta\{\lambda \eta \mu \mu \alpha]$, in which an adversary is caught between two difficulties.

Hornstone. (Geol.) A variety of compact quartz; hornlike as to appearance and degree of transparency.

Hornwork. (Fortif.) Outwork consisting of two half-bastions connected by a curtain, with long branches directed for defence on the faces of a work in rear of it.

Horoscope. [From Gr. שpa, a time, a season,

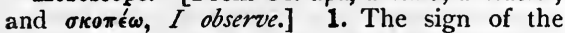
Zodiac rising at the time of a child's birth. 2. A figure of the twelve signs of the Zodiac, wherein was marked the position of the heavens at the time of the child's birth, from which astrologers made predictions as to his fortunes in after life.

Horoscopy. The calculation of nativities.

Horresco referens. [L.] I tremble as 1 relate.

Horror of a vacuum. An imaginary principle by which the action of pumps, siphons, suckers, etc., was thought to be accounted for; the real explanation being the pressure of the xtmosphere. The theory was Aristotle's.

Hors de combat. [Fr.] Out of the combat, disabled from action.

Hors d'œuvres. [Fr.] From a meaning of accessory, not essential, 1. The lesser details in a painting of figures. 2. Sometimes, sidedishes.

Horse-. As a prefix, = large, coarse, of its

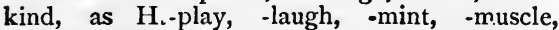
-mackerel, i.e. the scud ; so $O x$-, as $O x$-hunger,

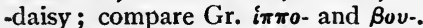

Horse. (Naut.) 1. A foot-rope fastened at both ends of, and hanging below, a yard, for the men to stand on when reefing, etc. 2 . Various large ropes in the running rigging. 3. The iron bar across the deck on which the sheets of a fore-and-aft sail travel. 4. A crosspiece, upon standards, on which booms, boats, etc., are lashed.

Horse-furniture. (Mil.) The caparison of a military horse.

Horse latitudes. Those between the westerly winds and trade-winds, i.e. in the tropics, approximately ; subject to long calms.

Horse-power ; Actual H. ; Indicated H. ; Nominal H. A unit for estimating the rate at which an agent works. It works with one horse-power when it performs 33,000 footpounds of work per minute. The Nominal $H$. of a steam-engine is estimated by its dimensions. The Actual or Indicated $H$. is that of the steam on the piston in the actual working of the engine, and is ascertained by the steam-indicator.

Hortative. [L. hortātivus, from horto, I advise.] (Gram.) Expressive advice or exhortation; term given to what used to be called the imperative use of the Latin subjunctive mood.
Hortus siscus. [L., a dry garden.] A collection of plants or botanical specimens, dried and pressed ; a herbarium.

Horus, Hor Apollo. (Harpocrates.)

Hosanna. [Heb., save, I beseech thee.] A word much used by the Jews in their Hosanna Rabba, or Feast of Tabernacles.

Hose. [A.S. hose.] (Printing.) A case connected by hooks with the platin, for keeping it horizontal and lifting it from the forme.

Hospitaller. [L.L. hospĭtālārius.] One residing in a monastery, to receive strangers and the poor. Knights $H$., a religious order, formerly settled in England, founded circ. A.D. I092, who, to protect and provide for pilgrims, had built a hospital at Jerusalem ; much favoured by Godfrey of Bouillon and Baldwin of Jerusalem; called also $K$. of St. Fohn of Ferusalem, $K$. of Rhodes (1310) after settling there, and after loss of R., $K$. of Malta, where the chief of the order still existing under this title resides. (Orders, Religious.)

Hospǒdar. [Slav.] An officer formerly appointed by the sultan for the government of the Christian principalities of Moldavia and Wallachia.

Host. [L. hostia, a victim.] In the Latin Church, the Eucharistic elements after consecration.

Hostel. [L.L. hospitalis, from hospes, a stranger, or guest.] 1. A place of lodgment for students at the universities. 2. A detached building forming part of a college.

Hostianrius. The title of the second master in some endowed schools, as at Winchester. If the word be another form of L. ostiārius, a door-keeper, the modern usher may be derived from it.

Hotblast. A current of heated air driven by blowers into a furnace.

Hotchpotch. (Hodgepodge.)

Hot-cockles. A game in which one is blindfolded, and guesses who strikes him or touches his hand [ $f f$. Fr. game main chaud, hot hand].

Hôtel de ville. [Fr.] Town hall, city hall.

Hotel Dieu. [Fr., hostel of God.] The principal hospital in a French city.

Hot-pressed. Pressed while heat is applied, so as to receive a glossy surface.

Hound-fish. (Ichth.) Smooth-hound, Raymouthed dog. A small British shark, about eighteen inches long; eatable. Squălus mus-

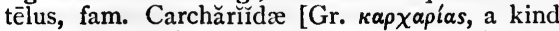

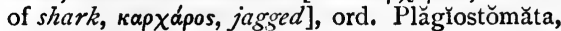
sub-class Chondroptèry̆gì.

Hour-angle; H.-circle; H.-line; H. of longitude; H. of right ascension ; sidereal H. ; Solar H. The twenty-fourth part of a solar day is a Solar hour; of a sidereal day, a Sidereal $H$. The H.-angle of a heavenly body at any instant is the angle at the instant between the meridian and the declination circle of the heavenly body. The H.-lines on a sun-dial indicate the hour of the day when the shadow of the style coincides with them. An $H$. of longitude or of riglit ascension is merely $15^{\circ}$; thus, longitude 2 hrs. 
I 5 mins. E. is the same as longitude $33^{\circ} 45^{\prime} \mathrm{E}$. (For H.-circle, vide Circle.)

Houri. [Ar. hûr al oyûn, black-eyed.] A Mohammedan nymph of paradise; "a higher and purer form" of which idea "we see in the Valkyries of Norse Myth., who guide to the Valhalla the souls of all heroes dying on the battle-field."-Cox's Aryan Mythology.

House. 1. In Astrology, any one of the twelve parts into which the whole circuit of the heavens was divided by astrologers. 2. (Naut.) To enter "within board." To H. an upper mast is to lower it and to secure its heel to the lower mast. To H. a gun is to run it in and secure it. To H. a ship is to cover it with a roof when laid up. Housed in, built too narrow above, "pinched."

House-boat. One fitted with cabins, and suited for towing only.

Housebote. (Leg.) An allowance of wood to a tenant for repairs and fuel ; also called Estovers.

House-carls, or Thinga-men. (Hist.) A force embodied by the Danish Cnut, King of England, receiving regular pay, and forming the germ of a standing army. Under Cnut they may be regarded as a sort of military guild, with the king at their head.-Freeman, Norman Conquest.

Fousehold Troops, or the Guards. Six regiments : three of cavalry-Ist and 2nd Life Guards, and the Horse Guards, or Oxford Blues; and three of infantry-Grenadiers, Coldstream, and Scots Fusiliers.

Housel. [A.S. husul, offering.] The consecrated bread in the Eucharist.

Housemaid's knee. From kneeling on hard, damp stones ; inflammation of the bursa, or sac, hetween the knee-pan and the skin, resulting in the effusion of fluid.

House of Keys. In the Isle of Man, an assembly, composed of twenty-four principal com. moners of the island, having both a legislative and a judicial character.

Housing, or House-line. (Naut.) Line, smaller than rope-yarn, and used for swinging blocks, etc. H. of a lower mast, the part below deck. $H$. of a bozesprit, the part within the knight-heads.

Houyhnhnms. (Gulliver's Travels.)

Hove. 1. (Naut.) H. dozon, or out, i.q. careened. $H$. off, got clear of the ground. $H$. $u p$, hauled up into a slip, etc., on a gridiron. 11. in sight, just come into view. H. in stays, position of a vessel in the act of going about. H. short, when the cable is taut. H. well short, when a vessel is nearly over her anchor. H. to = brought to, etc. 2. $(A g r$. $)$ Used of cattle swollen with eating green food.

Howadji. [Ar.] Traveller, merchant.

Howdah. [Hind. haudah.] A seat for one or 1 more on the back of an elephant or camel.

Howe, How. [ $C f$. haugh, Norse haugr, mound, M.H.G. houc, Ger. hïgel, hill.] A hill.

Howel. [Fr. hoyau, a mattock.] A tool used for smoothing the inside of a cask.

Howitzer. [Ger. haubitze.] (Mil.) Short, light kind of ordnance, with a chamber, used principally for projecting shells nearly horizontally.

Howling dervishes. (Dervise; and see Catherine and Craufurd Tait, p. 5 I6.)

Hoy. [Dan. hoy, Ger. heu.] (Naut.) A vessel carrying goods and passengers from point to point along a coast, or to and from ships.

Hoyden. A clownish, ill-bred girl ; originally applied, and more frequently, to men ; the same word as heathen [D. heyden], lit. dwellers on the heath, rough, wild. (See Trench, Select Glossary.)

Hub. [Ger. hub, heaving.] The central part of a wheel.

Hubble-bubble. (Hookah.)

Hub of the Universe. Wendell Holmes's name for Boston State-House. Hub $=$ protuberance, nave of a wheel.

Huckaback. A kind of linen with raised figures on it, for table-cloths and towels.

Huddock, The. The cabin of a keel, or coalbarge.

Hudibras, Sir. Presbyterian knight ; S. Butler's poem (1663), ridiculing Puritan doctrine and manners

Hue and Cry. 1. An ancient process for the pursuit of felons, which the common law provided, and may still make use of, as it seems, although unnecessary in these days. 2. Gazette published by authority, containing the names of deserters, persons charged with crime, and other particulars of police news.

Hufkyn. [(?) Ger. häuptchen, dim. of haupt, head.] Iron skull-cap formerly worn by archers.

Huggins, Muggins. Names implying pretentious vulgarity.

Huginn and Muninn. In Teut. Myth., the two ravens who sit on the shoulder of Odin as symbols of wisdom [from the words hugr, thought, and munr, mind, as in Menu; Minerva; Minos; and man].

Hubertsburg, Peace of. (Seven Years' War.)

Huguenots. [Perhaps from Ger. eidgenossen, oath-associates, corr. into Eignots.] A distinguishing name of French Protestants from the time of Francis. I.

Huissier. [Fr., from L. ostiārius, doorkeeper.] (Leg.) The usher of a court.

Hulk. [A.S. hulce.] (Naut.) Usually an old vessel unfit to go to sea, used for stores, etc. ; e.g. a Sheer H., one fitted with sheers $(q . v$.$) .$

Hull. [A.S. hule.] (Naut.) The body of a ship, without masts, etc. To $H$., (I) to hit with shot ; (2) to drift without rudder, sail, or oar. To strike $H$., to take in all sails, and lash the helm a-lee ; called also To lie a-hull. Htull-to, situation of a ship lying a-hull. Hull-dowen, said of a ship when.only masts and sails are above the horizon.

Hulsean Lectures. Originally twenty, now eight, sermons delivered yearly at Cambridge, under will of Rev. J. Hulse (A.D. I777).

Hum. A cloudy appearance on well-annealed glass.

Humanitarians. A name for Arians, as be lieving Christ to be a mere man. 
Hūmānum est errāre. [L.] It is human to err. Humble Access, Prayer of. The first prayer in the Canon in the Eucharistic Office.

Humble-bee. (Bombidæ.)

Humectation. [L. hūmectātio, -nem, irrigation.] The steeping of a medicine in water; the application of moistening remedies.

Humeral. Connected with the shoulder [L. hŭměrus].

Humetty. (Her.) Having those parts cut off which would touch the edges of the escutcheon.

Hummelling barley. Removing the awn from the grain after threshing, by a hummeler, a set of blunt knives passing frequently through the grain.

Humming-bird moth, Macroslōssa stellātārum

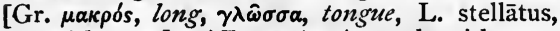
set with stars]. (Entom.) A moth with proboscus long enough to suck the honey from flowers witlout alighting. Fam. Sphingidæ.

Hummums, Hammams. [Ar. hammâm, bath.] Baths, especially Turkish.

Humour. [L. hümōrem.] Galen and later physicians believed the human temperament to be made up of the choleric, the phlegmatic, the sanguine, and the melancholy; and the temperament of the individual to be caused by the prevalence of one or other of these humours over the others.

Humphrey, Duke. (Duke Humphrey.)

Hundred. (Eng. Hist.) A division of a county, for the administration of justice. (Courtbaron; Court-leet; Wapentake.)

Hundred Days, The. In Fr. Hist., the time which elapsed between the return of Napoleon to France from Elba, and his defeat at Waterloo, 1815.

Hundredor. A man of a hundred, fit to serve on a jury, liable for damage caused by felonious rioting.

Hundredweight. One hundred and twelve pounds.

Hundred Years' War. (Salic law.)

Hungary water. A distilled water from rosemary flowers.

Hunger traces. Lines of depression across the nails, the result of want of food, or of deficient nutrition of nail-tissue during some previous disease.

Hunks. A miser, a niggard.

Hunter, Hunting watch. A watch having its glass protected by a metallic cover.

Hunter's screw. A kind of differential screw. (Differential.)

Hunting cog. When two toothed wheels are to work together, the larger wheel is commonly made to have one tooth more than the just number, to prevent the same teeth continually working together; this extra tooth is the H. C.

Huntingdonians. Members of the Countess of Huntingdon's connexion, formed by George Whitefield when, after his separation from the Wesleys, he became her chaplain.

Hunt's up. Noisy music in the early morning, like that which rouses to a hunting expedition. (Aubade.)
Hurdy-gurdy. An old instrument of four gut strings, set vibrating by a resined wheel, to which a handle is attached; two strings forming a drone bass ; the other two, acted upon by kcys pressing them at different lengths, giving the tune.

Hurly-burly. [From O.E. hurl, tumnalt.] Tumult, commotion.

Hurricane. [A Carib. word huracan, whence Sp. huracan, Fr. ouragan, etc.] A storm common in the W. Indies, in which the wind is furious and liable to sudden changes of direction.

Hurricane-deck. A light deck above the others. Hurricane-house, any temporary building on deck.

Hurst, Hirst. A word with the same meaning as Holt in the names of places in England.

Hurtle. [Fr. heurter, to strike.] To clash, to rush noisily.

Husband, or Ship's husband. (Naut.) An agent to receive money, retain claims, make payments, advance, and lend, in matters relating to the vessel ; but not to insure or borrow.

Husgable. (Leg.) House rent (Gabel) or $\operatorname{tax}$.

Hushing. Damming up water and then letting it rush down so as to lay bare new surfaces of ore.

Hush-money. A bribe to prevent the giving of inconvenient information.

Hussites. (Eccl. Hist.) Followers of John Huss, of Bohemia, a very zealous advocate of Wyclif's opinions (A.D. I 407) ; burnt alive (A.D. I4 I 5) by decree of the Council of Constance.

Hussy. [Huswif, housewife.] A pert or worthless girl.

Hustings. (Hus-thing.)

Hus-thing. [A.S., from hus, house, thing, assembly, or council.] (Eng. Hist.) A court held in a house, as distinguished from one held in the open air. Anciently the chief municipal court of the City of London. Hence, incorrectly, the modern Hustings. (Thing.)

Hutchinsonians. The followers of Hutchinson, who, rejecting Newton's theory of gravitation, maintained the existence of a plenum.

Huttonian or Plutonic theory (Dr. H., died I797) accounts, by internal heat, for the elevation of strata, and many other phenomena ; the Wernerian (Werner, of Saxony, died 1817 ) or Neptunian theory supposes a universal dissolution and suspension of mineral substances in water.

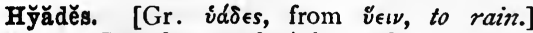
(Myth.) Daughters of Atlas, who wept so violently on the death of their brother Hyas that the gods took them to heaven, where they form a cluster of five stars on the face of Taurus. (Pleiades.)

Hyaline. [Gr. íẳiivos, crystal, of glass.] 1. Crystal, glassy. 2. A crystal surface, as of the sea.

Hy̆ălitis. [Gr. va ${ }^{2} o s$, glass.] (Med.) Inflammation of the vitreous humour of the eye.

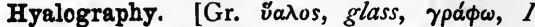
write.] The art of engraving on glass.

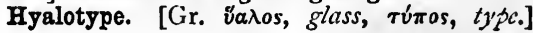


A positive photograph on glass, copied from a negative.

Hybrid. [L. hybrĭda, hibrĭda.] 1. Produced by mixture of species or genera ; mongrel, as a mule. 2. Compounded of elements belonging to different languages ; said of a word, as demigod.

\section{Hycsos. (Shepherd kings.)}

Hyd. (Hide of land.)

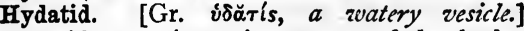
1. Morbid cysts in various parts of the body. 2. Cyst-like entozoa.

Hyde. (Hide of land.) A measure of land. Its contents are uncertain.

Hydr-, Hydro-. [Stem, in composition, of

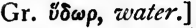

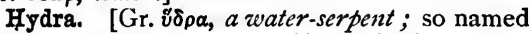
from its reproduction by artificial division, as the Lernæan hydra produced two heads for every one cut off.] 1. (Zool.) Gen. and ord. of fresh-water polypes, consisting of a tube with tentacles at one end. It is reproduced sexually and by budding, and, if artificially divided, every segment becomes a perfect polypite. Sub-kingd. Cœlentěrāta. 2. (Myth.) A monster supposed to infest the marshes of Lerna. As fast as one head was cut off by Heracles (Hercules), two sprang up, until the hero cauterized the necks. The story probably refers to the bubbling up and drying away of springs in marshes.

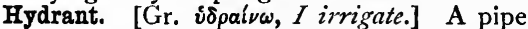
or spout by which water may be drawn from the mains.

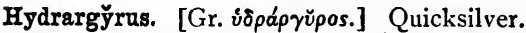

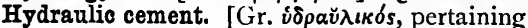
to a water.organ.] A cement, containing silicate of aluminia, and hardening under water.

Hydraulic press; called also the Hydrostatic P. and Bramah's P. A machine in which the force applied to a small piston is transmitted through water to a large piston; as the pressure per unit of area is the same in both cases, the whole pressure on the large piston is to that on the small piston in the ratio of their areas. The principle of the machine was known to Pascal ; it was practically realized by Bramah, who invented a leather collar which enables the pistons to work water-tight.

Hydraulic ram. A machine in which the momentum produced by the fall of a stream from a small height is made to raise a small column of water to a much greater height.

Hydraulics. (Hydraulio cement.) As com. monly used, is the science of the motion of water in pipes, canals, etc., i.e. under the circumstances in which the science subserves the purposes of engineering. (Hydrodynamics.)

Hydro-. (Chem.) (Hydr-.)

Hydro-carbons are naphtha, pětrǒlěum, asphalt, bituminous substances generally ; as being composed of hydrogen and carbon in some proportion or other.

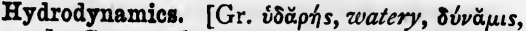
power.] Commonly means the theory of the motion of fluids. Sometimes used as a general term for the science of the effects of force applied to a fluid medium, the subdivisions being
Hydraulics, or Hydrokinetics, when the fluid is in motion, Hydrostatics when it is at rest.

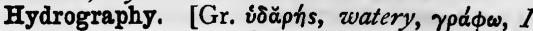
describe.] The branch of geography which relates to the construction of maps of the boundaries of land and water, and of the configuration of land below water as indicated by soundings, whether in the deep sea, in shoal water, or in rivers.

Hydrokinetics. (Hydrodynamics.)

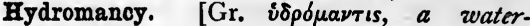
prophet.] Divination by water, of which there seem to have been many modes.

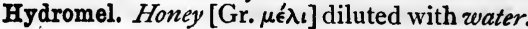

Hydro-metallurgy. [Gr. v $\delta \omega \rho$, water, and metallurgy.] Assaying or reducing ores by liquid reagents.

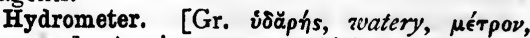
measure.] An instrument which indicates the specific gravity of a liquid by the depth to which it sinks, or by the weight required to sink it to a certain depth, in that liquid.

Hydropathy. Water-cure, = the treatment of disease [Gr. $\pi \dot{a} \theta$ os, affection] by cold water, outwardly and inwardly.

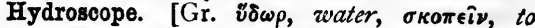
look.] The same as Hygrometer.

Hydrostatic balance; H. paradox; $\mathbf{H}$. press. A balance arranged for ascertaining the weight of a body suspended in liquid, the balance and weights being in the air. $H$. paradox, the illchosen name of an instrument which exhibits the fact that a comparatively light column of water can support a heavy weight in virtue of the fundamental laws of the transmission of pressure through a fluid. (For H. press, vide Hydraulic press.)

Hydrostatics. The science which treats of the equilibrium of fluids under the action of forces, and of the pressures which they exert on or transmit to the sides of the vessels containing them or the surfaces of bodies in them. (Hydrodynamics.)

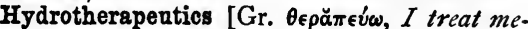
dically], i.q. Hydropathy.

Hydrothermal agency $($ Geol. $)=$ that of heated

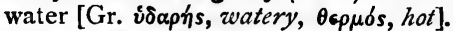

Hydrozōa. [Gr. $\varepsilon \delta \rho \alpha, h y d r a, \zeta \omega \hat{\omega} \nu$, an animal.] (Zool.) Class of Cœlentěrāta, of which the Hydra (q.v.) is the typical form.

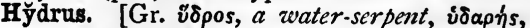
watery.] (Zool.) Gen. of fresh-water snakes (Linnæus).

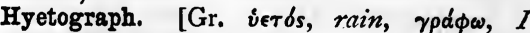
zurite.] The science of the geographical distribution of rain.

Hygieia. [Gr. vifiela, health.] (Myth.) The Greek goddess of health, the daughter of Asklēpios, or Assculapius. Hence Hygiene, the science of matters relating to health; by some used especially of diet, and generally what used to be called non-naturals (q.v.) of the sick.

Hygiene. (Hygieia.)

Hygrometer. [Gr. viypós, wet, $\mu$ érpov, measure.] An instrument for ascertaining the proportionate amount of moisture in the atmosphere. In Daniell's $\mathbf{H}$. the measurement is effected by an observation of the dew-point, on the principle 
of the cryophorus; in De Saussure's H., by the variations in the tension of a hair in different states of the atmosphere.

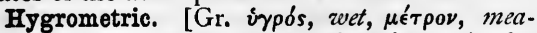
sure.] Showing the degree of moisture in the air ; e.g. the H. property of seaweed, or of the Anastatica (q.v.).

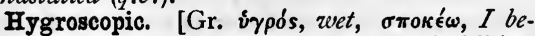
hold.] Having the property of readily imbibing moisture from the atmosphere and thereby serving as an indicator of its state as to dryness or dampness.

Hȳmën. [L., Gr. ' $\Upsilon \mu \eta \dot{\nu}$.] (Myth.) The god of marriage.

Hymenēal. Anything relating to marriage (Hymen), as a song or an ode.

Hyměnium. [Gr. ì $\mu \epsilon^{\prime} \nu t o \nu$, dim. of $\dot{v} \mu \eta \dot{\eta} \nu, a$ membrane.] (Bot.) The membrane of the gills of fungi, where the spores are placed.

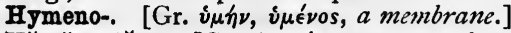

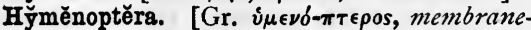
winged.] (Entom.) Ord. of insects with membranous wings, as bees; ovipositor frequently modified into a saw, an awl, or a sting.

Hynden. An association of ten men, from whom, in case of deadly feud, the consacramentals (sworn avengers of blood) were chosen. H. were subdivisions of firth-guilds.

Hyoïd bone. (Anat.) Between the root of the tongue and the larynx; in appearance [Gr. єi $\delta$ os] somewhat like the Greek letter $v$.

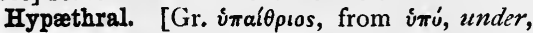
aion $\rho$, air.] (Arch.) A building or temple not covered by a roof.

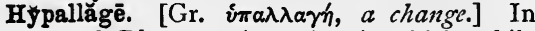
Gram. and Rhet., an inversion in which, while the same sense is conveyed, the predicates are transferred from their proper subject to another as, "Dare classibus austros," to give wind to the Aeets (Virgil), instead of, to give the ships to the wind.

Hypăpantē. The Greek name for the Purification of the B.V. Mary; the meeting [Gr. i $\pi \alpha \pi \alpha \nu \tau \dot{n}$, post-class.] of Simeon and Anna with our Lord.

Hypaspist. [Gr. $\boldsymbol{v} \pi \alpha \sigma \pi ı \sigma \tau \eta \dot{s}$, from $i \pi \delta$, under, à $\sigma \pi i s$, shield.] A shield-bearer.

Hyper-. [Gr. vं $\epsilon^{\prime} \rho$, L. s-ŭper, Skt. upar-i, Goth. ufar, Eng. over, Ger. uber, over, above.] 1. Gr. prefix, denoting over, beyond, or excess, as in hyper-critical, overcritical. 2. (Chem.) (Per-.)

Hyperæmia. (Med.) Superabundance of blood [Gr. $a[\mu \alpha]$ in the capillaries ; congestion.

\section{Hyperæsthēsia. (Anæsthesia.)}

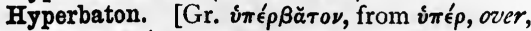
and root of $\beta \alpha i \nu \omega, I$ go.] (Gram.) A reversing of the proper natural order of words so as to separate words or clauses which should be together.

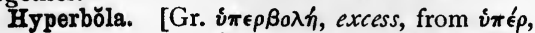
over, and root of $\beta a ́ \lambda \lambda \omega, I$ throw (Ellipse).] 1. (Math.) One of the Conic sections. It is described by a moving point, the difference of whose distance from two fixed points (its foci) is always the same; it consists of two distinct parts contained within the opposite angles formed by two straight lines; it continually approaches but never actually meets these lines, which are called its asymptotes. 2. (Khet.) An exceedingly exaggerated representation of one s meaning, as, "He is able to pierce a corselet with his eye" (Shakespeare).

\section{Hyperbole. (Hyperbola.)}

Hyperboreans. [Gr. oi ' $\Upsilon \pi \in \rho \beta o ́ p \in i o l$.$] (Myth.)$ Literally, those who dwell beyond Boreas, or the North Wind, a region supposed to be much like Elysium, or the Gardens of the Hesperides. Hence Hyperborean comes to mean "happy." (Elysian.)

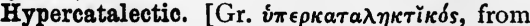

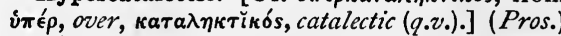
Having a syllable or two beyond the stated metre ; said of verses.

Hyperdulia. (Dulia.)

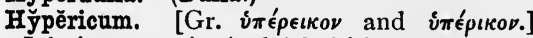
St. John's wort, the (only) British gen. type of ord. Hypericiniæ.

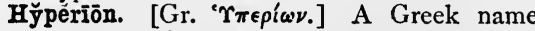
for the sun as he ascends the heavens before noon.

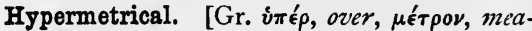
sure.] (Fros.) Having a redundant final syllable, which in Latin ends in a vowel or $m$, and is elided with the initial vowel of the next line.

Hypertrophy. [Gr. $\tau \rho \epsilon ́ \phi \omega, I$ nourish.] 1. A condition arising from greatly increased nutrition. 2. An enlargement of any part, which still retains its natural organization and action.

Hyphen. [Gr. $v \phi^{\prime} \dot{\epsilon} \nu$, in one.] A short line to show that two words or parts of words are to be connected.

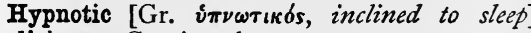
medicines. Causing sleep.

Hypnotism [Gr. $\boldsymbol{v} \pi \nu 6 \hat{\omega}, I$ put to sleep], or Braidism (discovered by Mr. Braid). Artificial somnambulism; induced by gazing for several minutes on a bright object near to and just above the eyes.

Hypo-. [Gr. i $\boldsymbol{\pi} \delta$, under, (I) in point of situation, (2) somewhat in degree.] (Chem.) A prefix denoting that the compound contains less oxygen, as hyponitrous acid, which contains less oxygen than nitrous acid.

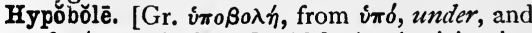
root of $\beta \alpha \dot{\lambda} \lambda \boldsymbol{\lambda}, I$ throw.] (Rhet.) Anticipation of several objections to one's own argument.

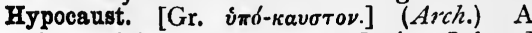

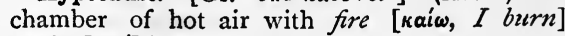
under [ínó] it.

Hypochondria, Hypochondriasis. [Gr. $\tau \delta$

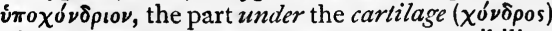
of the breast-bone.] Extreme nervous sensibility, with symptoms of disordered digestion, much gloom and melancholy, and great suffering from imaginary ailments; but there are distinct varieties.

\section{Hypocycloid. (Epicycloid.)}

Hypodermic. [Gr. vimó, beneath, sép $\mu a$, skin.] Existing under the skin, or applied there.

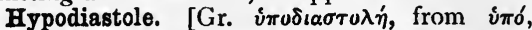

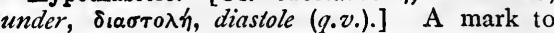
distinguish certain Greek pronouns followed by 
an enclitic, as $\tau \delta, \tau \epsilon, 8, \tau \iota$, from similar com-

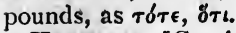

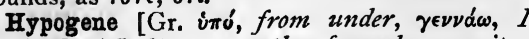
produce $]$ (Geol.) = nether-formed; granite, gneiss, and other crystalline rocks, supposed never to have been formed, or at least to have taken their present aspects at the surface. Obsolete term.

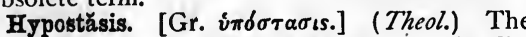
Greek Fathers use this word to denote the distinct personality of the Father, the Son, and the Holy Ghost. The Latin Fathers felt themselves obliged to retain the word, because substantia, which translates it, was used by them to denote the essence or being common to each of the hypostases of the Godhead.

Hypostatic union. The union of Christ's human nature with the divine; constituting two natures in one person.

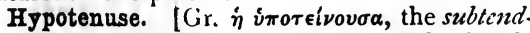
ing line.] The side of a right-angled triangle opposite to the right angle. Spelt incorrectly, Hypothenuse.

Hypothec. [Gr. i $\pi \circ \theta \dot{\eta} \kappa \eta$, pledge, deposit, mortyage, from isí, under, and root of $\tau i \theta \eta \mu \iota, I$ place.] (Siot. Laiv.) Security in favour of one creditor, especially a landlord, over the property of his debtor.

Hypothecation. (Hypothec.) (Leg.) The act of pledging property as security for debt or demand, without transfer of possession of personal property, as by giving bottomry bonds.

Hypothetical baptism. If the priest cannot ascertain, from the answers of those who bring a child to baptism, whether it has been really baptized or not, he is to baptize it hypothetically, or conditionally, saying, "If thou be not already baptized, I baptize thee," etc.

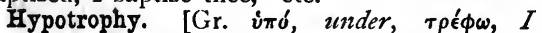
nourish.] State of deficient nourishment.

Hypozoic. (Neozoic.)
Hypsometer; Hypsometry. [Gr. v̈廿os, height,

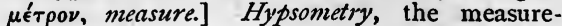
ment of heights; the word generally implies that the measurement is effected not by a triangulation, but by a portable instrument such as an aneroid or mercurial barometer. In an Hypsometer, advantage is taken of the fact that the boiling point of water is lowered when the atmospheric pressure is reduced, to effect the measurement of heights by observing the temperature of the boiling point of water.

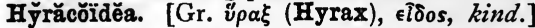
(Zool.) Ord. of mammals, containing but one gen., Hy̆rax. (Coney, 2.)

Hy̆rax. [Gr. ซี $\rho \xi$, L. sŏrex, whence $\mathrm{Fr}$. souris.] (Coney, 2.)

Hyssop. [Heb. ézôb, Gr. ṽ $\sigma \omega \omega \pi$ s.] Exod. xii. 22, and elsewhere; probably the thorny caper, Cappăris spinosa.

Hysteria. [Once supposed to be connected

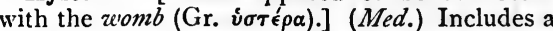
vast number of symptoms known as nervous disordərs, all dependent upon a peculiarly susceptible state of the nervous system. (Hysterical juints.)

Hysterical joints. (Neuro-mimesis.)

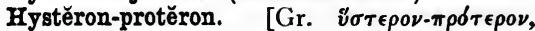
latter-former.] (Rhet.) Inversion of the natural order of ideas or logical propositions; a putting of the cart before the horse.

Hystrix. [Gr. $\left.v^{\sigma} \tau \rho \iota \xi, i d.\right]$ (Zool.) The porcupine, giving its name, Hystricĭdæ, to the fam. of true porcupines, with quills generally long and hollow, and with non-prehensile tails. S. Europe, N. Africa, India, China, and adjacent islands. Ord. Rōdentia. The Cercŏlăbǔdæ, tree porcupines, of America are a closely allied fam., but Cercŏlăbes (S. America) has a prehensile tail.

Hythe. (Naut.) A pier or wharf for loading or unloading at. (Hithe.)
I. As a Roman numeral, denotes $I$; and, if placed before $\mathrm{V}$ or $\mathrm{X}$, it diminishes by a unit the number expressed by those letters.

Iambics. [Gr. Taußos.] Metres in which the feet are chiefly of two syllables, of which the first is short, as ămānt.

Iätro-. [Gr. iāipós.] A physician.

Ibex [L.], Steinbock [Ger.], Rock-goat. (Zool.) Capra ibex, an Alpine and Pyrenean spec., moderately gregarious. The adult male is about two feet eight inches high at the shoulder; reddish brown in summer, grey in winter; the horns are sometimes three feet long. Sub-fam. Caprinæ, fam. Bǒvǐdæ, ord. Ungŭlăta.

Ibidem. [L.] In the same place; written biid. or $i b$., and used in references to a passage or book which has been already quoted.

Ibi omnis effūsus labor. [L.] There all his labour zuas lost (Virgil); of Orpheus when he lost Eurydice.

Ibis. [L., Egypt. phib, Gr. iß $\beta$ s.] (Ornith.) 1. Nūmēnĭus I., Sacred 1. ; spec. of birds, about two feet high, white, with black pendent secondaries. Migratory between Ethiopia and Egypt. Gen. Nūmēnǔus, fam. Scǒlōpācìdæ, ord. Grallæ. 2. Gen. of birds, as Scarlet ibis. Trop. and N. Temp. America. Fam. Plătălěǐdæ, ord. Grallæ.

-ic, -ous. (Chem.) 1. Terminations of the names of the hydrogen salts-as chloric acid, which is chlorate of hydrogen; chlorous acid, which is chlorite of hydrogen. (-ate, -ite.) 2. Terminations distinguishing the salts (-ous) in which the combining power of a metal's atoms is partly expended on uniting them with one another, from those $(-i c)$ where this power is 
wholly employed in combining them with atoms of another body, as ferrous, ferric salts.

Ice-anchor. (Naut.) A curved iron bar, hooked into ice.

Iceberg ; I.-field ; I.-floe ; Ground-I. ; I.-island ; Pack-I. An Ice-floe is a large mass of floating ice; if it is so thick as to rise high above the sea-level, it is an Iceberg. An I.-field is the frozen surface of the sea when it extends on all sides further than the eye can reach, called also Pack-I. ; if its limits are within sight it is an I.-island. Ground-I. is ice formed at the bottom of running water. Icebergs have generally been detached from glaciers; icefields, ice-floes, etc., are merely the frozen seawater.

Ico-blink. A bright appearance, caused by the reflexion of light from ice below the - horizon.

Ice-boat. (Naut.) A sledge-boat fitted with a sail, used on the ice.

Ice-caves. (Glacières.)

Iceland-spar. (Geol.) Finest, most transparent variety of calc-spar ; found in large crystalline masses in I. trap-rock.

Ich dien. [Ger., I serve.] Motto of the Prince of Wales's coat of arms, assumed from that of the King of Bohemia at the battle of Cressy.

Ichnites. [Gr. i $\chi$ vos, a footstep.] (Geol.) A general term for fossil footprints. Ichnology, that part of Geol. which has to do with I. Ornithichnites are such as have been referred to birds

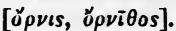

Ichnography. [Gr. ixvos, footstep, $\gamma \rho a ́ \phi \omega$, $I$ describe.] The ground-plan of a building.

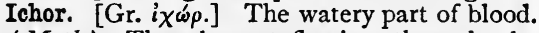
1. (Myth.) The element flowing through the veins of the gods. 2. (Med.) Thin, aqueous, acrid discharge, as distinguished from proper pus

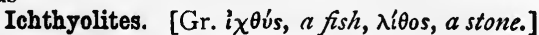
(Geol.) Fossil remains of fishes.

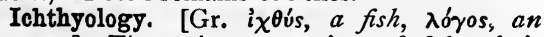
account.] The science treating of fish, their classification, etc. In this work the classification of Dr. Günther's British Museum Catalogue has been adopted (as by Mr. Wallace in his Geographical Distribution, etc.), and not his later arrangement, which fuses the first three subclasses under the name of Gănǒiděi. This is, however, indicated by brackets.

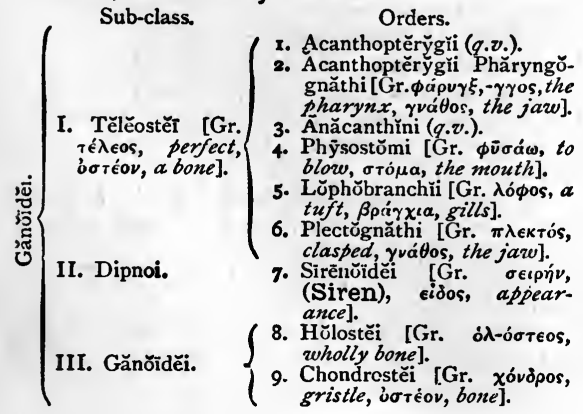

Sub-class.

Orders.

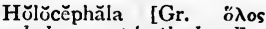
whole, $\kappa \in \phi a \lambda \dot{\eta}$, the head].

I. Plăgǐostŭmăta [Gr. $\pi \lambda \dot{\lambda}$ '́⿴囗十

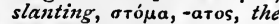

IV. Chondro- $\quad \begin{aligned} & \text { mouth]. } \\ & \text { Sub-ord. Sělăchōiděi [Gr. }\end{aligned}$ ptěry̆gii.

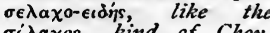

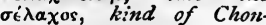
drosteous fish]

Sub-ord. Bătŏìuĕi [Gr. $\beta a \mathrm{a}$ tos, the ray, eidos, $a p$. pearance].

V. Cy̆clostơmăta

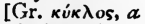
circle, бтóma, the mouth].

VI. Leptǒcardìi [Gr. גertós, slender, кapdia, the heart].

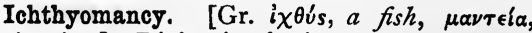
divination.] Divination by inspection of fish.

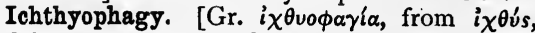
a fish, $\phi a \gamma \epsilon i \nu$, to eat.] The practice of living on a diet of fish.

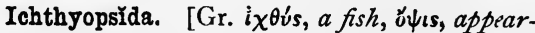
ance.] (Zool.) Fish, and amphibians when classed together as Branchiate vertebrates, i.e. as V. possessing temporary or persistent gills.

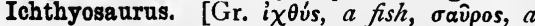
lizard.] (Geol.) A gen. of extinct marine reptiles, resembling saurians, fishes, and, in some respects, cetacea. Triassic to Cretaceous.

Ichthy̆ōsis. [Gr. ix $\theta$ ús, -v́os, a fish.] (Med.) A disease in which the skin assumes somewhat the appearance of fish-scales.

Ichthys. [Gr., a fish.] In Eccl. Art, the emblematic fish, the word exhibiting the initials of the words Iēsous CHristos, THEeu Yios, Sōtēr, Fesus Christ, Son of God, Saviour.

Iconium, or Roum, The kingdom of. A large portion of Asia Minor, contiguous to the Eastern Empire about the time of the Crusades.

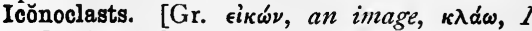
break.] Image-breakers of the eighth century. The I. movement began with the Emperor Leo III.'s edict, A.D. 726, forbidding the honour paid to sacred images. Upon this subject the East and West have been divided ever since.

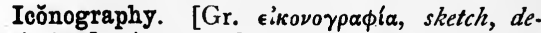
scription.] A name denoting works descriptive of monuments of art, as Didron's Iconographie Chrétienne.

\section{Icosahedron. (Polyhedron.)}

Icteric, Icterical. (Med.) 1. Relating to jaundice [Gr. I $\left._{\kappa \tau \epsilon \rho o s}\right]$, affected with it. 2. Preventing jaundice.

Ictus. [L., stroke.] (Pros.) Stress of voice or a prolongation of a syllable of a word or measure, which coincided with a prominent rhythmic beat, as in the case of the first, third, and fifth arses (Arsis) of a hexameter verse.

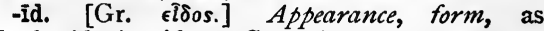
Typho-id, Aro-id-eæ, Cteno-id.

-ide. (Chem.) A termination denoting a compound of two elements, as chloride of iron, a compound of chlorine and iron.

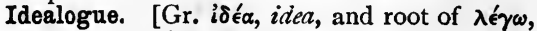
I tell.] A theorist, a speculator.

Ideas. [Gr. ió́al, forms, or shapes.] In the 
Platonic philosophy, the eternal prototypes of being, and the efficient cause of all that is. Of these ideas there is necessarily an indefinite number, for since every generic and specific concept is according to Plato substantial, there must be as many ideas as there are genera and species.-Zeller, Plato and the Older Academy.

I dēmens, et sævas curre pĕr Alpes, ut puéris plăcěas et dëclämātio fias. [L.] Go, madman (i.e. Hannibal), rush over the horrid Alps, that you may delight lads and be made the subject of school themes (Juvenal, Sat., x.).

Idem per Idem. [L.] The same by the same; of an illustration or reference which really adds nothing to the consideration of a case.

Idem velle et Idem nolle. [L.] To have the same likes and the same dislikes, the same tastes and the same aversions; Sallust's account of firm friendship.

Identity, Personal. The sameness of the conscious subject throughout the several stages of existence. The fact which, in strictness of speech, is the only fact absolutely known to each man is that he is a conscious thinker; all other facts being learnt only by inference from this one. This consciousness, which it is impossible to define, constitutes P. I. (Individuality; Monopsychism.)

Ideographic characters. [Gr. iséa, an idea,

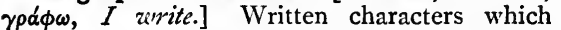
express notions, instead of the arbitrary signs of an alphabet. Such are the Chinese, and such also were the Egyptian, Hieroglyphics.

Ideographic writing. (Phonetic writing.)

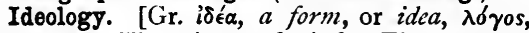
discourse.] The science of mind. The term was first used by the disciples of Condillac, who developed the sensational philosophy of Locke. (Sensational school.)

Ideo-motor movements. Muscular movements arising from simple ideas apart from emotion. (See Carpenter's Mental Physiology, p. 124.)

Ides. [L. idūs.] One of the three divisions of the old Roman month, being near the middle of it. The Ides of March, on which Cæsar was assassinated, has become an expression for an unlucky day.

Id genus omne. [L.] All that class (Horace).

Idio-electrio. [Gr. ' $\delta$ เos, peculiar, and electric.] Naturally possessing electric properties.

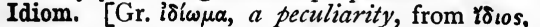
one's ozon, private, peculiar.] 1. A mode of expression peculiar to a language, dialect, or smaller division of speech; e.g. " world without end." 2. The general character or system of expression of a particular language.

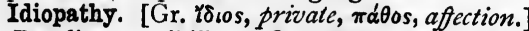
1. Peculiar scnsibility. 2. (Med.) A diseased condition, primary, not symptomatic of or following upon any other.

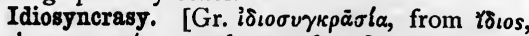

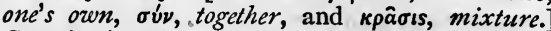
Constitutional peculiarity, e.g. as shown in effects of medicine, food, etc., and of other agents, different from the effects generally produced.

Idiot. (Idiotai.)
Idiōtai. [Gr.] In the primitive Church, a name for laymen as being private persons; also for monks not in holy orders.

Idlers. (Naut.) On a man-of-war, those excused from the night watches; also civil officers.

Idle-wheel. A wheel introduced between a driver and its follower, to make the latter revolve in the same direction as the former without changing the ratio of their velocities.

Idols. [Gr. et $\delta \omega \lambda \alpha$, false appearances.] So Bacon, in the Novum Orgănon, calls the customary sources of error in men's reasoning. They are : 1. I. Tribus, $I$. of the Tribe, errors common to the whole human race. 2. $I$. Spechs, $I$. of the Cave, arising from the circumstances within which the individual is, as it were, inclosed-his nationality, age, religion, etc. 3. I. Fori, $I$. of the Market-place, arising from popular, careless, undefined phrase. 4. I. Theatri, I. of the Theatre, arising from false systems of thought, attractively disguised and presented.

Idrōsis. Should be Hïdrōsis (q.v.).

Ierne. Old name of Ireland.

Igneous [L. ignis, fire], or Pyrogenous [Gr. $\pi \hat{\imath} \rho$, fire], rocks are divided into plutonic, trappean, volcanic, as to general character, not by exact lines of demarcation.

Ignis fatuus. [L., foolish fire.] Light appearing by night over marshy grounds; so called from misleading travellers.

Ignis sacer. (Erysipelas.)

Ignōrämus. [L.] 1. We are ignorant; an ignorant person. 2. (Leg.) We ignore; formerly written on a bill thrown out by a grand jury. Now "not a true bill," or "not found," is used.

Ignōrantia nōn excūsat legem. [L.] (Leg.) Ignorance is no plea against the law.

Ignōrātio ělenchi. [L.] An ignoring (or inability to understand), a refutation, of one's position.

Ignōtum per ignōtius. [L.] What is unknown by what is more unknown; of an explanation or illustration which is more obscure than what is to be explained.

Iguana. (Zool.) Gen. of lizard, with pendulous dewlap. S. America and W. Indies. Some spec. (as I. tūbercǔlāta, four feet to five feet long) much esteemed as food.

Iguanodon (i.e. like iguana, in teeth [Gr. ódoús, a tooth]). (Geol.) Extinct gigantic herbivorous dinosaurian reptiles. Wealden strata

\section{I.H.S. (Abbreviations.)}

\section{Ikenild street. (Hikenhilde Street.)}

Il a la mer a boire. [Fr.] He has the sea to drink; he has undertaken a gigantic enterprise.

Il a le vin manvais. [Fr.] He is quarrelsome in his cups.

Il fant attendre lo boitenx. [Fr.] We must wait for the lame man; we must wait for confirmation of a hasty report.

Iliac. (Med.) Relating to the iliă [L.], or lower bowels.

IlYad. [Gr. 'I lalas.] A Greek poem consisting of twenty-four books, relating to incidents belonging to the war of Troy. 
Ilias mălörum. [L.] $A$ (whole) Iliad of disasters.

IIk. 1. [Scot.] Each; the A.S. ælch, each. 2. [Scot., A.S. ylca, the same.] Of that I. = of that same (named) place, of one whose name is the same as that of his estate.

Illaqueate. [From p. part. of illăqueo, I entangle, from in, in, lăqueus, a noose.] To entangle, ensnare.

Illative conversion. In Logic, a conversion in which the truth of the converse follows from the truth of the proposition given.

Illi rōbŭr et æs triplex circā pectus ěrat, qui frăgìlem trăci commìsit pělăgo rătem primus. [L.] Hc had oak and threefold brass about his breast who first entrusted a frail bark to the remorseless sea (Horace).

Illuminnati. [L., enlightened.] 1. In the early Church, the newly baptized. 2. I., or Allumbrados, a Spanish sect, which spread into France-about A.D. 1675 to 1735 -claiming a special illumination, which needed mental prayer, but not good works or sacraments.

Illuminating. [Fr.] Ornamenting a manuscript with drawings in body colours and gold.

II vino e una mezza corda [It.], wine and an open heart = In vino veritas [L.], wine brings out the truth.

Il y a des réproches qui louent et des louanges qui medisent. [Fr.] There are censures which praise and praises which defame (Rochefoucault).

Image. The figure formed of any object at the focus of a lens or mirror; e.g. the picture in a camera obscura.

Imaginary Conversations. The title of a work of Walter Savage Landor (died I864).

Imaginary quantity or expression. In Algebra, one which involves the square root of a negative number, as $\sqrt{ }(-3)$.

Imam, or Imân. A title (I) of the successors of Mohammed, (2) of the inferior order of ministers in Islam. (Mushtahids.)

Imbibition. [L. imbibo, I drink in.] The interpenetration of a solid by a fluid.

Imbricated. [L. imbricatus, covered with gutter-tiles.] (Bot.) Overlapping, as tiles on a roof; e.g. Araucaria imbrǐcata.

Imbroglio. [Fr.] An entanglement, an intricate plot, a complicated embarrassing state of things.

Imbued. (Her.) Wetted [L. imbūtus] with blood.

Imitatores, servum pěcus. [L.] Imitators, a slavish herd.

Immaculate conception. In the Latin Church, a term which denotes the conception of the Virgin Mary without the taint of original sin.

Immanent acts. [L. immăneo, $I$ remain in.] In Moral Phil., are such as produce no effect outside the mind; as e.g. simple, intellectual operations; Transitive acts being such as pass on, have an effect upon, external objects.

Immersion. [L. immersiō, -nem.] Baptism by the dipping of the whole body under the surface of the water.

Immolation. [L. immǒlātiō, -nem.] (Rom.
Ant.) A ceremony in which some corn or frankincense was thrown on the head of the victim in a sacrifice, together with the mola, or saltcake.

Immovable feasts. Feasts the recurrence of which does not depend on the day on which Easter falls; for instance, Christmas Day, Circumcision, Epiphany.

Impact. [L. impactus, p. part. of impingo, I make to strike against.] A blow; the word is often used in mechanics as an abbreviation of the words impulsive action (q.v.).

Impalement. [Eng., pale.] (Her.) The division of a shield into two by a line passing vertically through the centre, as a pale does.

Impanation. [L. in, and panis, bread.] A word conveying a meaning akin to that of Consubstantiation.

Impannel, Impanel. (Empannel.)

Impar congressus A.chilli. [L.] Unequally matched with Achillcs (Virgil).

Imparl. (Leg.) To get leave from a court to settle a litigation amicably.

Imparlance. (Leg.) 1. Time to plead. 2. Leave to plead at another time, without the assent of the other party.

fice.

Imparsonee. A parson inducted into a bene-

Impartible. A word used by Blackstone in the sense of indivisible, as if from part; by others, as if from impart, with the meaning of "capable of being imparted or communicated."

Impasting. [1t. impasto.] 1. The laying on of colours thickly. 2. An intermixture of lines and points in engraving, to represent thickness of colouring.

Impasto. [It. pasta, paste.] The thickness of the layer of colour on a picture.

Impatronization. [From patron.] Absolute seigniory, full possession, a putting into full possession.

Impeachment. [From L. impětěre, ta prosecute.] A process against persons charged with treason or other public crimes. The House of Commons has the power of exhibiting articles of impeachment against any peer or commoner. The evidence required is that of the ordinary courts of justice. (Attainder.)

Impeachment of waste, Without. In Law, implies, in one to whom an estate is granted for life or a term of years, power to cut timber, etc., and do many things not allowable to ordinary tenants ; abuse of which is preventible by injunction of Court of Chancery.

Impědìmenta. [L.] Baggage, luggage.

Impenetrability. [From L. in, not, and peneträbillis, penetrable.] In Physics, the property of matter in virtue of which one body excludes other bodies from the space it occupies.

Imperatorial. [L. impěrātōrius.] Pertaining to the office of a Roman general, who after a great victory during the republic received the special title imperrātor, which afterwards, from being one title of the Roman emperors, came to be the distinctive title.

Imperial. [Fr. imperiale.] 1. An outside on a diligence. 2. A case for luggage carried on 
the top of a coach. 3. Paper thirty inches by twenty-two.

Imperium. [L., command.] In Rom. Hist., the absolute power conferred by the Comitia, or assembly, of Curies, on the consuls, as commanders-in-chief of the armies of the republic, so long as they were not within one mile of the walls of the city.

Impěrium et lībertas. [L.] Empire and freedom ; misquoted by Earl Beaconsfield, November 9, I879; (?) from Cicero's fourth Philippic, "Cum (D. Brutus) . . . populique R. libertatem imperiumque defenderit;" or (?) "Res olim dissociabiles miscuerit (Nerva), principatum ac libertatem" (Tacitus, Agr., 3).

Impěrium in impĕrio. [L.] $A n$ absolute rule within an absolute rule; power assumed in opposition to constituted authority.

Impermeable. [From L. in, per, through, and meāre, to go.] Not allowing a passage, impenetrable.

Impersonal verbs. (Gram.) Those verbs which are used only in the third person, their subject being the proposition which they serve to introduce.

Impĕtigo. [L., skin eruption, impĕto, I attach.] (Med.) Humid or running tetter, a disease of the skin, in which pustules appear, burst, and dry up in little yellow masses; not accompanied by fever, nor contagious.

Impetration. [L. impetratiōnem.] Obtaining by earnest petition. It was applied especially to the preobtaining from the Roman see of benefices belonging to lay patrons.

Impětus. Mömentum (q.v.).

Impiger, īrăcundus, inexōrăbǐlis, ācer. [L.] Restless, full of fury, pitiless, eager for the fray (Horace, of Achilles).

Implüvium. [L.] The aperture in the centre of the ceiling of the atrium of a Roman house, towards which the roof sloped so as to conduct rain [plüvia] into the reservoir [complŭvium] below.

Imponderable fluids. Hypothetical fliuds without weight ; their existence was imagined in order to render the phenomena of heat, magnetism, electricity, etc., more conceivable.

Imposing-stone. In Printing, the stone on which the pages or columns of types are imposed or made into formes.

Imposthume. Corr. of the word Aposteme (q.v.).

Impound. [From in, and pound.] (Leg.) 1. To place a suspected document in the custody of the law. 2. To place in a pound or safe place of custody, especially stray cattle.

Impresario. [It.] One who gets up and manages concerts and operatic performances.

Imprescriptible. [It. imprescrittibile, from L. in, per, through, scriberre, to write.] 1. Not capable of being lost or impaired by neglect, as certain rights are. 2. Not depending on external authority, self-evidencing, as mathematical axioms.

Impress. To force into the service of a country. It has been more applied to the naval than the military branch.
Impressed force. In Dyn., the forces acting on a body from without ; thus, if a body is hung up from a fixed point and allowed to swing, the impressed forces are its weight (gravity) and the reaction of the fixed points.

\section{Impress-gang. (Press-gang.)}

Impression. 1. Colour which is laid on as a ground. 2. Any coating of a single colour.

Imprimätur. [L., let it be printed.] 1. A licence to print some work, granted by those with whom the censorship of the press rests. 2. Wrongly used as = approval, sanction.

Imprimis. [L.] Among the first, in the first place.

Imprint. Whatever is printed on the titlepage, especially the date, printer's name, etc.

Impromptu. [L. in promptu, in readiness, in sight.] Off-hand, without preparation.

Imprŏperria. [L.] In the Latin Church, the Reproaches, a Good Friday anthem.

\section{Impropriation. (Appropriation.)}

Improvisatōre. [It., from L. improviso, unex pectedly.] A person who is able to recite verses without preparation. After the revival of letters, Italy possessed improvisatores in Latin as well as in Italian.

Impudicity. [L. impudīcitātem, from inneg., pudicus, modest.] Immodesty.

Impulsive action. The mutual action between two bodies, when it is so large as to cause a sensible change in their velocities in an insensibly short time; as that between a hammer and the nail it drives, or a cricket-bat and the ball it strikes. (Impact.)

-in, more commonly -ine (Chem.), = the active principle of ; as achillein, nicotine.

In-, im- before labials, ir- before $r$, il- before $l$. 1. L. prefix $=o n, i n$, into, or intensive [cf. $\dot{\epsilon}^{\prime} \nu$, $\dot{\epsilon} \nu \mathbf{l}^{\prime}$, Teut. in]. 2. L. privative or negative prefix [cf. $\dot{a}, \dot{\alpha} \nu$-, Teut. un-], as in in-grate, un-grateful, im-proper, il-logical, ir-rational.

In-and-in. 1. The name of a gambling game, played by three persons with four dice. 2 . Of cattle, breeding from animals of the same parentage.

Inanition. [It. inanizione, from L. inānis, empty.] Depletion, starvation.

Inappetency. [It. inappetenza, from $L$. inneg., and appetens, desirous of, greedy.] Lack of appetite, indifference.

In ăquâ scrỉbis. [L.] You are writing on water.

Inarticulate. [L. in- neg., artĭcŭlus, $a$ joint.] (Nat. Hist.) Not jointed, or articulated.

In artícŭlo mortis. [L.] At the point of death.

Inauguration. [L. inaugurātiō, -nem.] The ceremony by which the Roman augurs consecrated a person or thing to the service of the gods. It is now commonly, but very wrongly, used to denote the beginning of any undertaking.

In-board. (Naut.) Within the ship; opposed to Out-board.

Inca, or Unce. The title of the ancient kings of Peru, whose empire was overthrown by Pizarro.

Incalescent. [L. incălescentem, from calor, heat.] Growing warm, increasing in heat. 
Incameration. [Fr., from L. in, and caměra, a chamber.] The uniting of lands, revenues, etc., to the pope's domain.

Incandescent. [L. incandesco, $I$ glowe.] White hot, having a more intense degree of heat than if red hot.

In capite. [L.] (Leg.) In chief; said of tenancy immediately from the lord paramount.

Incarnadine. [Fr. incarnadin, It. incarnatino, from L. in, in, caro, carnis, flesh.] 1. Fleshcoloured, of the colour of a carnation. 2. To dye red, raw-flesh-coloured.

Incarnation. (Med.) The making of new flesh [L. carnem] in the healing of wounds. In-

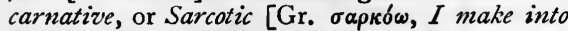
flesh], causing I.

Incessu pătuit dea [L.] The goddess was manifest by her gait.

Inch. [L. uncia.] The twelfth part of a foot, or the thirty-sixth part of a yard; the French inch, which was the twelfth part of the Paris foot, was I 06578 English inches; the French cubic inch was therefore $1 \cdot 2106$ English cubic inches.

Inch-. In Scotland, a prefix to the names of some small islands, as Inch-marnock, Inch-keith; so Inis, in Ireland, to some islands, and to towns on lakes or rivers, as Inis-hark, Inniskilling. [(?) Cf. $\nu \hat{\eta} \sigma o s$, an island, and L. insŭla.]

Inchoate. [L. inchoātus, p. part. of inchŏo, I begin.] Just begun, incipient, incomplete.

Incidence, Angle of. The angle between the direction of a ray of light just before reflexion or refraction, and the perpendicular to the surface of the reflecting or refracting body.

Incĭdit in scyllam cŭpiens vitāre Chărybdim. [L.] He falls upon (the rock) Scylla when eager to avoid (the whirlpool) Charybdis; out of one peril into another as great.

Incineration. The reducing of \& substance into ashes [L. in cĭnerres].

Incisor teeth. [L. incido, I cut into.] Four front teeth in each jaw, for cutting or dividing food.

Incivism. [Fr. incivisme, from L. in- neg., civis, $a$ citizen.] Lack of love for the state of which one is a citizen.

Inclave. [Fr. enclave, a boundary.] (Her.) In a form resembling the parts of a dovetailed joint.

Inclination. [L. inclinatio, -nem, a bending.] In Mag., the angle which the magnetic needle makes with the plane of the horizon; i.e. the dip of the needle.

Inclination of the orbit of a planet. The angle between the plane of the orbit and the plane of the ecliptic.

Inclined plane. A plane inclined at a greater or less angle to the horizon. It is reckoned a mechanical power, because a weight can be raised along it by agents who would be unable to. lift the weight directly.

Inclinometer. [L. inclināre, to incline, Gr.

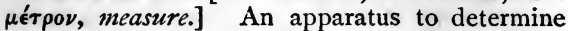
the vertical component of the magnetic force.

Incluse, or Recluse. [L., shut up.] (Eccl. Hist.)
Hermits in single cells, on the doors of which the seal of the bishop or abbot was impressed.

In cœnā Domini. [L., at the Lord's Supper.] The title of a celebrated papal bull, giving extracts from different constitutions of popes, and declaring the rights claimed by the see of Rome from Gregory VII.'s time, with anathema against those who violate them ; read once at least every year in all Roman churches.

In oommendam. (Commendam, In.)

Incommensurable. [L. incommensūrābilis, that cannot be measured with another.] Not having a common measure; e.g. a side and a diagonal of a square are incommensurable, because no line, however small, can be found which, being an aliquot part of the one, is an exact aliquot part of the other.

Incompossible. (Log.) Said of two or more things possible separately, but not conjointly.

Incomprehensible. [L. incomprehensibullis.] That which cannot be confined in space. This is the sense in which it is used in the Athanasian Creed.

Inconcinnity. [L. in- neg., and concinnity (q.v.).] Want of harmony or agreement.

Inconsonancy. [L. in- neg., and consonant, sounding with.] In Music, discordance.

Incorporating languages. (Agglomerative languages ; Polysynthetic.)

Incorporeal. [L. incorpǒreus, from in- neg., corpus, a body.] (Leg.) Not capable of actual, palpable seisin or possession, as rights, dignities, etc. I. chattels, = I. rights incident to chattels, as patent rights, copyrights.

Incremation. (Cremation.)

Increment. [L. incrēmentum, an addition, inerease.] In Rhet., an amplification without a strict climax.

Increment [L. incrēmentum, increase] ; Increments, Method of. (Math.) The amount by which a variable magnitude increases under specified circumstances. The Method of $I$. is the calculus of finite differences. (Calculus of finite differences.)

Increscent, Moon. (Her.) A waxing [L. increscentem] moon, having its horns turned to the dexter side.

Incubation of a disease. [L. incǔbātio, -nem, a brooding.] (Med.) The period between its contraction and the appearance of distinct symptoms. Incubi. (Succubi.)

Incubus. [L., nightmare, from incŭbo, 1 brood.] 1. Fairy demon. 2. Nightmare, a sensation of pressure on the chest and of an impossibility of moving, speaking, or breathing. 3. Meton. a load, weight, discouragement.

Incūnābŭla. [L.] Swaddling clothes, birthplace, origin, beginning.

In cūriā. [L.] (Leg.) In court.

Incus. [L., an anvil.] (Anat.) From its shape, a small bone of the middle ear.

Indefinite proposition. In Log., a proposition with a common term, but without any sign to show whether it is distributed or undistributed, i.e. the universal or particular; as, "Barbarians can be civilized." Here it is in. definite whether all be meant, or some.

Indehiscent. (Dehiscent fruits.) 
Indemnify. [L.L. indemnirĩco, from indemnis, without damage, loss (damnum), and root of fácio, $I$ make.] 1. To secure against loss, harm, or punishment. 2. To compensate for past loss or expense.

Indenizen. To naturalize. (Denizen.)

Indent, sometimes Requisition. (Mil.) Official document demanding the supply of stores for Government consumption. (Indenture.)

Indentation. [L. dentem, a tooth.] In Printing, the act of beginning the first line of a paragraph further in from the margin than the other lines (called a common indentation), or of beginning the second line and those following it further in than the first line (called a hanging indentation.)

Indenture. [From indent, to make notched like teeth (dentes).] (Leg.) A deed recording mutual obligation, of which two or more parties have duplicates; so called from the duplicates having originally been written on one skin, which was divided by a jagged cut, so that the correspondence of the two halves was manifest at once. (Deed-poll.)

Independence, Declaration of A document drawn up by the second Congress of the United States of America, May, 1776, and declaring the colonies absolved from all allegiance to Great Britain.

Independents. In Eccl. Hist., a sect which maintains that every congregation forms a Church or independent religious society in itself, and therefore condemns anything like a national establishment of religion.

Indeterminate analysis; I. coefficients; I. equation; I. problem. If two (or more) unknown quantities enter an equation, for every value of the one there will be generally a corresponding value of the other; such an equation, not serving to determine either, is an Indeterminate equation. A problem whose algebraical statement gives rise to such an equation is an I.problem. It may happen that the solutions of such an equation may be limited by a condition, e.g. that only positive integral values of the unknown quantities are admissible; the rules for finding such values, if any, are the subject of 1 . analysis. The method of $I$. coefficients consists in assuming the form of the expansion of a function, and using the assumption as a means of finding the value of the terms successively.

Index [L., a discoverer, a sign]; I. error; I. of a logarithm; Refractive I. (Math.) The number denoting the power to which a given number is raised; e.g. in $a^{5}$ the number 5 is the Index of the power to which $a$ is raised. The $I$. of a logarithm is its integral part or characteristic. The $I$. error of a sextant is the reading when the planes of the fixed and movable mirrors are parallel; in which case the reading would be zero if the instrument were in perfect adjustment. (For Refractive I., or I. of refraction, vide Refraction.)

Index Expurgatōrius. [L.] A book issued at Rome, specifying erroneous or heretical passages to be expunged from the literature of the day.

Index Prohibitörius. [L.] A book kept at Rome, containing a list of works which, owing to their errors, the faithful are not allowed to read.

Indian ink. (Sepia.)

Indian red. A fine purple ochre.

Indian summer. The short season of pleasant weather usually occurring about the middle of November; so called from the custom of the Indians to avail themselves of this delightful time for harvesting their corn.-Bartlett's Americanisms.

Indian yellow. A golden yellow pigment, used as a water-colour.

Indicative mood. (Gram.) That inflexion of the verb which expresses a simple or unconditional judgment.

Indicator; I.-diagram; Steam-I. The Steamindicator is an instrument for showing the actual pressure of the steam on the piston of a steam-engine at any point of the stroke. It consists of a small cylinder in which a small piston works against a spring of known power. When steam from the cylinder of the steamengine enters the indicator, its pressure and its variations are shown by the compression of the spring. The rod of the indicator's piston is made to carry a pencil, the point of which touches a paper wrapped round a roller, whose motion follows that of the engine; the curve thereby traced out during an up-and-down stroke or revolution is the I.-diagram; it serves as an exact register of the working of the engine during one stroke.

Indicator muscle. [L. indǐco, I point out.] The extensor of the index or forefinger.

Indices of the face of a crystal. If the parts of the axes cut off by the face be multiplied by certain positive or negative whole numbers, lines are obtained proportional to the parameters; the whole numbers are the indices of the face.

Indǐcia, plu. [L.] (Leg.) Discriminating marks, tokens.

Indiction. [L. indictio, -nem, a declaring.] In Chron., a cycle or period of fifteen years, used in the courts of law and in the fiscal organization of the Roman empire under Constantine and his successors, and thence introduced into legal dates. The year of I. corresponding to any year of our era is found by adding 3 to the date, and divid. ing the sum by 15 . The remainder is the year of I. Thus I880 was the eighth year of the I25th I. (Cycle.)

Indictment. [Fr., L. indico, I proclaim, from in, among, dico, I tell.] 1. (Leg.) A written accusation of a crime of a public nature, preferred to and presented by a grand jury. 2. (Scot. Law.) The form of process against criminals' trial at the instance of the Lord Advocate. (Criminal letters.)

Indifferently. In Prayer for Christ's Church militant ; impartially, without distinction [ $\mathrm{J}$. indiffĕrenter].

Indigitate. [L.L. indı̆ğtare, from in, and dígitus, finger.] To point out, indicate.

Indigo. [L. Indicum, the Indian dye.] A vegetable dye-stuff of a deep blue colour, made in the $\mathbf{E}$. and W. Indies.

Indirect taxation. Taxation by duties laid on 
articles of consumption ; direct taxes, as the income tax, being levied on the taxpayer personally.

Indium. A soft grey metal, discovered by two indigo lines which it shows under spectrum analysis.

Individuality. In moral science, the personality of each man. According to Bishop Butler's philosophy, this personality is indivisible, and therefore immortal. (Monopsychism; Identity, Personal.)

Individuate. [L.L. indīvǐduātus, p. part. of indivĭduo, from in-neg., dīvǐduus, divisible.] 1. To distinguish as an individual from other members of a spec., to reduce to single instances. 2. To cause to exist as an individual whole.

Indivisibles, Method of. Nearly the same thing and applicable to the same class of questions as the Method of exhaustion (q.v.).

Indo-European. In Ethn., a term denoting certain nations of Europe and Asia, which have a common origin. The name Aryan is now generally substituted for it.

Indolence. [L. indǒlentia, an invention of Cicero's in transl. à $\pi \alpha ́ \theta \epsilon \iota a$.$] Painlessness.$

Indolent. [L. in-neg., dŏleo, I am in pain.] (Med.) Not suffering pain.

Indorse. (Endorse.)

Indorsement. [L. in, and dorsum, the back.] The writing of a name on the back of an acceptance or bill of exchange. This is done by the holder of a bill on receiving payment, or when he hands it over to another. The word is used, very wrongly, to denote assent or approval generally.

Indra. In the Rig Veda, the sun-god, who, by conquering Vritra, the demon of drought, lets loose the rain. Indra thus speedily became the supreme deity.

Induction. [L. inductio, -nem, a leading into.] 1. (Phys.) The property by which a body, charged with electricity or magnetism, causes or induces it into another body without direct contact. 2. (Eccl.) The act of putting an incumbent, after institution ( $g . v$.), into actual possession of the church and of all temporalities. 3. ( $\log$. The raising of individuals into generals, and of these into still higher generalities. 4. (Math.) A method of proof applicable to cases in which a theorem is to be shown to hold good in an indefinitely great number of cases, which may be arranged .as first, second, third, etc. Suppose that by any means the theorem is shown to hold good in the first case, and further that it can be proved to hold good in any case if it hold good in thn preceding case : this constitutes the proof; for as the theorem is true in the first case, it must also be true in the second case, therefore in the third case, therefore in the fourth, and so on. This form of proof is called a Mathematical $I$.

Inductive. (Log.) Belonging to induction [L. inductio, -nem, a leading in], the process which raises individuals into generals, and these into still higher generalities.

Indulgences. [L. indulgentǐa.] $\mathrm{A}$ power claimed by the Latin Church of granting remission for a certain term, either on earth or in purgatory, of the penalties due to sin. The practice was introduced in the eleventh century, as a recompense to those who incurred the perils of the Crusades. Indulgences are said to be (I) Plenary, or complete ; or (2) Partial.

Indults. [L. indultum, an indulgence.] In the Church of Rome, patronage of benefices granted to certain persons by the pope; e.g. to kings, emperors, the Parliament of Paris.

Indurated [L. indüro, I harden] (Geol.) = hardened by the action of heat or otherwise.

Indüsium. [L., an under-garment.] (Bot.) The membrane overlying the sori of ferns.

Inequality. [L. in-neg., æquālis, equal.] In Astron., any variation in the motion of moon or planet from that which it would have if it moved in strict accordance with Kepler's laws. In the case of a planet, such inequalities are due to the attraction of other planets ; in the case of the moon, to the attraction of the sun.

Inerrancy. [L. in- neg., erräre, to wander.] A word rarely used, denoting freedom from error.

Inertia; Inertiæ, Vis. [L., inactivity.] The indifference of a body to a state either of rest or of motion. The tendency of a body to continue in the same state of rest or of uniform motion in a straight line, except so far as it is compelled to change its state by the action of external forces. The resistance it offers to such change is its $V i$ s inertia.

Inescutcheon. (Her.) A small escutcheon borne as a charge in a man's escutcheon.

In esse. [L.] In actual existence; in posse being said of that which may at some future time be.

In extenso. [L.] In full, without abridgment. In extrēmis. [L.] In desperate circumstances, at the last gasp.

Infair. [A.S. infore, entrance.] The "re: ception" party or entertainment of a newly married couple. West and South.-Bartlett's Americanisms.

Infandum, rēgina, jŭbes rĕnŏvāre dŏlōrem. [L.] Thou biddest me, queen, renew an unspeakable woe (Virgil); said by Aineas when Dido asked him to tell of the fall of Troy.

Infangenthef, Infangthef. [A.S.] The privilege of judging thieves taken on their manors or within their franchises, granted to certain lords.

Infante, Infanta. [Sp.] The title of the younger sons and daughters of a Spanish sovereign; more anciently given to the children of all Hidalgos. The word childe was used in the same way in England.

Infantry of the line [L. infantem, used in the Middle Ages in the sense of boy or servant, who went on foot; hence infanteria became the name of foot-soldiers in general], or Regulars, consist of the foot-soldiers comprised in the regiments numbered I to IOg, with the addition of the Rifle Brigade. These numbers have been lately replaced by territorial titles.

Infeoffment. (Scot. Law.) The act or instrument of feoffment. (Sasine.)

Infĕriæ. [L.] Sacrifices offered by the ancients in honour of the dead.

Inferior planet. (Planet.) 
Infeudation. (Fee.) (Leg.) 1. A placing in possession of a freehold estate. 2. A granting of tithes to a layman.

Infibulation. [L. infībŭlāre, from fibŭla, $a$ buckle.] The act of clasping, or confining as with a padlock, etc.

Infinitesimal. An indefinitely small quantity. The 1 . calculus is equivalent to the differential and integral calculus. (Calculus of finite differences.)

Infinitive mood. In Gram., the inflexion of the verb which expresses the mere conception of the subject, without affirming or denying it.

Inflamed. (Her.) Adorned with flames.

Inflätus. [L.] An inspiration, an access of inspiration.

Inflexion. [L. inflexio, -nem, a bending, from in, and flexum, sup. of flecto, $I$ bend.] (Lang.) 1. A grammatical change of words to express different relations, including declension of nouns and conjugation of verbs, and generally derivation by addition of suffixes and prefixes. 2. A suffix or prefix.

Inflexional languages. (Aryan languages.)

Inflexion of light; Point of $\mathrm{I}$. The change in direction which rays of light seem to experience in passing near the edge of an opaque body. (Diffraction of light.) A Foint of $I$. of a curve is one at which the branches on either side of it are bent in opposite directions, and at which the tangent cuts the curve.

Inflorescence. [L. inflōresco, $I$ begin to blossom.] (Bot.) The flowering of a plant, generally ; the commonest forms being spike, raceme, panicle, corymb, cyme, umbel, capitŭlum (qq.v.).

Influenza. [It., as if from the influence of the stars.] Severe epidemic catarrh, due to some atmospheric peculiarity (?), with serious febrile symptoms and rapid prostration; affecting animals as well as man.

Infoliate. [L. in, folium, $a$ leaf.] To cover with leaves or with forms resembling leaves.

In forro conscientiæ. [L.] (Les.) At the tribunal of conscience.

Infrä. [L.] Below, under, further on in a book.

Infrä dignǐtātem. [L.] Beneath one's dignity, also, infra dig.

Infundǐbŭlum. [L., funnel, from infundo, $I$ pour in.] (Anat. and Bot.) Applied to certain parts having a funnel shape. Adj., Infundibuliform; e.g. convolvulus.

Infüsōrǐa. [L. in-füsus, a pouring in, infusōrium being properly the vessel used.] (Zool.) Minute, mostly microscopic, Prōtōzōa, possessing a mouth and digestive cavity; frequently developed in organic infusions. Some authorities reckon Diătŏmācěæ as I., and not as plants ; some place here the Rŏtĭferra, which are annuloids.

-ing. Teut. patronymic suffix, as in Wok-ing, Birm-ing-ham ; or topographic, as Bromley-ings, men of Bromley.

Ingannation. [It. ingannáre, to deceive, overreach.] A cheat, imposture, deception.

Inge. [A.S. ing.] A meadow, a pasture.

Ingěnuas dĭdǐcisse fidēlǐter artes, Emollit möres nec šnit esse fĕros. [L.] To have dili- gently studied liberal accomplishments refines the manners and does not allow them to be boorish.

Ingesta. [L. ingestus, carried in.] (Med.)

Things introduced by the alimentary canal.

Ingot. [Fr. lingot.] A mass of gold, silver, etc., cast in a mould.

Ingrain. 1. Dyed with grain, or kermes. 2. Dyed in the grain. 3. Ingrain carpet, a double or two-ply carpet. 4. Triple ingrain carpet, a three-ply carpet.

Ingressa. (Introit.)

Ings. (Agr.) Saltings, or tidal salt-water marshes.

Inguinal. Relating to the groin [L. inguen, inguĭnis].

inheritable. [L. in, hæres, an heir.] (Leg.)

1. Capable of being transmitted through blood.

2. Capable of being an heir or conferring heirship.

Inhibition. [L. inhǐbǐtio, from inhǔběo, 1 restrain, from in, in, hăbeo, I hold.] 1. (Leg.) A writ from a higher court, forbidding a judge of an inferior court to proceed with a case. 2 . (Scot. Lazv.) A process to restrain sale of land in prejudice of a debt, or a writ to prohibit giving credit to a wife. 3. A writ from a bishop, prohibiting another bishop or clergyman from undertaking any ecclesiastical duties in his diocese.

Inhoc, Inhoke. A corner of a common field ploughed up and sowed.

Inhumation. [L. in, hŭmus, the gronind.] The act of burying.

Initiated. [L. initiāti.] 1. Persons made acquainted with any mysteries, as with those of the heathen world. 2. In the primitive Christian Church, the baptized.

Injected parts. [L. injicio, $I$ throw in.] (Path.) Having an increased quantity of blood in the vessels.

Injection; I.-cock; I.-pipe. The cold water thrown through a rose at each stroke of the piston into the condenser of a steam-engine, to condense the waste steam and form a vacuum. It is thrown through the I.-pipe from the $I_{\text {. }}$-cock.

Injunction. [L. injunctio, -nem, a command, from injungo, $I$ enjoin.] (Leg.) A writ of an equity court, requiring a party to do or refrain from doing certain acts. A common I. restrains a suitor from prosecuting his legal rights in a court of common law.

Injunctions of Queen Elizabeth. (Advertisements of Elizabeth.)

Injüria [L.] is, in Law, the opposite to jus, and $=$ everything done without a right to do it. Inkle. A kind of broad linen tape.

Inlagation. [L.L. inlāgātio, from A.S. lagu, law.] (Leg.) The restoring an outlaw to legal rights, inlawing.

Inlagh. [O.E.] (Leg.) $A$ person protected by laze; opposed to utlagh, outlaw.

Inland. (Leg.) Demesne land ; opposed to Outland, let to tenants. I. has, as adj., Inlantal.

Inlier. (Geol.) An exposure of a lower stratum through a locally denuded overlying stratum ; often in broken anticlines.

In limine. [L.] At the threshold, by way of preliminary. 
In lŏco părentis. [L.] In the place of $a$ parent.

In mědias rës, Ruere. [L.] To rush into the middle of the subject (Horace).

In mědio tūtissimus ībis. go most safely in the middle.

[L.] Thou wilt

Inner house. (Scot. Law.) Chambers of the first and second divisions of the Court of Session.

Innings. (Leg.) Land recovered from the sea. Innis. [Gadh.] (Inch-.)

Innisfail. An old name of Ireland, $=i$ sland of destiny.

Innis Forda $=$ long island. Celt. name of Lewis and $\mathbf{N}$. and $\mathrm{S}$. Uist.

Inns of Chancery. Institutions consisting chiefly of attorneys, formerly occupied by clerks who studied the framing of writs which belonged to Cursitors. They are appendages of the Inns of Court.

Inns of Court. Four institutions for the enrolment and instruction of law students-the Inner Temple, Middle Temple, Lincoln's Inn, Gray's Inn. The Benchers have the right of admitting persons to practise at the Bar.

In nübibus. [L.] In the clouds.

Innuendo. [L., by nodding.] 1. An indirect hint. 2. (Leg.) Used in pleadings to indicate the application of alleged libels or defamations to certain parties or subjects.

Inoculation. [L. inŏcŭlo, I engraft.] 1. (Med.) Communication of a disease by a specific poison introduced into the blood, especially that of small-pox. 2. (Bot.) Insertion of buds under the bark for propagation. 3. The placing fragments of turf at short distances on prepared ground, to grow together and form a lawn.

Inopercular. Having no covering, or lid [L. ŏpercŭlum].

Inosculation. [L. in, into, osculātio, a kissing, an inosculation.] (Anat.) Generally i.q. Anastomōsis (q.v.), but sometimes A. denotes union of vessels by minute ramifications, I. a direct communication by trunks.

In pări mātěriā. [L.] In similar subjectmatter; where the same rules and method of reasoning apply.

In partibus infidelium. [L., in the parts of the infidels.] In the Latin Church, a phrase applied to those bishops who serve in other dioceses than those of which they bear the title.

Inpeny and Outpeny. (Leg.) Customary payments on alienation of tenants, etc.

In persōnam. [L.] (Leg.) (In rem.)

In petto. [It.] In reserve; lit. in the breast. (Cardinal)

Inpignoration. [L. in, in, pignŏro, I pledge, from pignus, pignŏris, pledoe.] The act of pawning, or depositing as a pledge.

In posse. [L.] (Leg.) In possible being, potential. (In esse.)

In propria persōnâ. [L.] In one's owen person.

In püris nătūrālibus. [L.] In a simple state of nature, naked.

Inquest. [O.Fr. enqueste, from L. inquīsīta, p. part. of inquiro, I inquire.] (Coroner.) Grand I., grand jury. $I$. of office $=$ inquiry by the proper officer into matters affecting Crown or State interests in property.

Inquinate. [L. inquinātus, p. part. of inquino, $I$ defile.] To pollute, befoul.

Inquiry, Writ of. (Leg.) A process addressed to a sheriff, ordering him with aid of a sworn jury to ascertain the quantum of damages after an interlocutory judgment let go by default.

Inquisition. [L. inquīsǐtio, -nem, a seeking for.] In Latin Christendom, a court armed with special powers for inquiry into offences against religion. The first I. was set up in S. France after the conquest of the Albigenses in the thirteenth century.

In rē. [L.] (Leg.) In the matter of.

In rem. [L.] (Leg.) On the subject-matter; said of a civil action as to the status of some particular subject-matter, not for recovery of damages against a person in persōnam.

Insänīre jŭvat. [L.] It is pleasant to play the fool.

Inscribe. [L. inscribo, I write on.] (Geom.) To draw one figure within another, so that their boundaries are in contact at certain points ; e.g. a circle is inscribed in a rectilineal figure when its circumference touches each side of the figure; a rectilineal figure is inscribed in a circle when every. angular point of the figure is on the circumference of the circle.

Insect-fertilization. (Fertilization of flowers.)

Insectivŏra. [L. insecta, insects, vŏro, $I$ devour.] (Zool.) Insect-eating, an ord. of Mammalia (q.v.), also of birds.

Insectivorous plants. (Bot.) Such as Venus's fly-trap, consume and assimilate the insects caught; " their recognized number is greatly on the increase" (Report of British Association, I879, p. 368).

Insessōres.

i.q. Passěres.

In sĭtu. [L.] In the (original) site or position. Insolation. [L. insōlatio, -nem.] Exposure to rays of the sun.

In sŏlǐdo. [L.] (Leg.) In the whole, of a joint contract.

Insomnia. [L.] (Med.) Sleeplessness, restlessness. (Jactation.)

Insouciance. [Fr.] Affectation of carelessness.

Inspeximus. [L., we have inspected.] 1. The first word of an old charter, a royal grant. 2. An exemplification of the enrolment of a charter or of letters patent.

Inspissated. [L. inspissātus, p. part. of inspisso, I thicken.] Thickened, as fluids by evaporation.

Instance Court of Admiralty. (Leg.) The Court of Admiralty when not a prize court. I. = process of a suit.

Instanter. [L.] (Leg.) Instantly, at once.

Instantly. Luke vii. 4 ; Acts xxvi. 7 ; earnestly

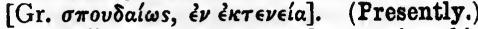

In stătu quo. [L., in the state in which.] In the same condition or state as prevails at any specified time. I. S. Q. ante, in the state or condition which prevailed before a specified cause of modification, as war, negotiations, etc.

Instauration. [L. instaurātio, -nem, from in- 
stauro, I repair, renew.] Renewal, restoration, renovation.

Institute. [L. instǐtūtus, appointed, from in, in, stătuo, I place.] (Scot. Lazw.) A person to whom an estate is first given by destination or limitation.

Institutes. [L. instǐtūtiōnes.] A treatise on the elements of the Roman law, published by order of Justinian, a month before the Pandects, in four vols., containing ninety-eight titles, composed by Trebōniānus Dōrŏtheus and Theǒphĭlus, chiefly from Gaius's Institütiōnes.

Institutes, of Lord Coke, four vols., I628. The first vol., known as Coke upon Littleton, is a comment on a treatise on tenures; the second vol., a comment on old Acts of Parliament ; the third vol., on pleas of the Crown; the fourth vol:, an account of various courts.

Institutes of the Christian Religion. Calvin's great work ; first edition, 1536.

Institution [L. instǐtūtio, from instǐtuo, I ordain, appoint], sometimes called also Investi. ture [investio, $I$ clothe]. Verbal admission of a clerk to a benefice by the bishop. (Collation.)

Institution of a Christian Man, or Bishops Book. A book of instruction in faith and duty, by a committee of the bishops and other divines (May, 1537).

Instrumental case. (Gram.) (Locative case.)

Insucken multures. (Leg.) Quantities of corn paid in by those who are thirled to a mill. (Thirlage.)

Insuetude. [L. insuētüdo, from in-neg., süetus, p. part. of suesco, I become used.] Absence of use, habit, custom.

Insulate. [L. insǔla, an island.] In Thermotics, to protect a hot substance in such a manner that none (or at least very little) of its heat or electricity is transferred to other bodies.

Insulse. [L. insulsus, without salt, from inneg., salsus, p. part. of salo or sallo, $I$ salt.] Insipid, dull, tasteless, lacking salt (metaph.).

Insulsity. The state of being Insulse.

Intaglio. [It., from intagliare, to cut in.] A carving in which the figures sink below the background.

Intakers. (Leg.) Receivers of stolen goods. Integral [L. intěger, whole]; I. calculus; Integration. (Math.) When the differential coefficient of a function is given, the process of finding the function itself is Integration, and when thus found the function is called an $I n$ tegral. (For I. calculus, vide Calculus of finite differences.)

Integument. [L. intěgŭmentum, $a$ covering.] 1. (Anat.) The skin, membrane, shell, which covers any part. 2. (Bot.) The cellular skin of seed, leaf, stem.

Intelligence Department. (Mil.) A branch of the War Office, lately established, for collecting, classifying, and arranging all information with regard to the physical and political geography of our own and of every country with which we are ever likely to be hostilely engaged, together with their resources in men and war material

Intempestâ nocte. [L.] At dead of night.
Intendment of law. [L. intellectio lēgis.] (Leg.) The intention or true meaning of a law or legal instrument.

Intenerate. [L. in, tener, tender.] To make tender. Rare.

\section{Intentio mentis. [L.] Close attention of} mind.

Intention, first and Second. (Log.) A distinction drawn between acts of thought relating to an object out of the mind, as mountain, stream, etc., which are first intentions, and those in which the mind expresses its own states of consciousness, as generalization, abstraction, etc., which are second intentions.

Intention, first, Healing by, is when a wound heals without suppuration. By second, when after suppuration.

Intentio sacerdotis. [L., the meaning of the priest.] In the Latin Church, the validity of the sacraments is made to depend on the condition that the priest, while he confers them, has at least the intention of doing what the Church does.

Intercadence. [L. inter, between, cădo, I fall.] (Med.) An occasional supernumerary beat in the arterial pulsations.

Intercalation. [L. intercălo, I proclaim the inserted days.] The insertion of days out of the ordinary reckoning.

Inter cănem et lŭpum. [L.] 'Twixt dog and wolf, twilight.

Intercept. (Math.) The part of a line included between two points.

Intercessio. [L.] In Rom. Law, the becoming surety. (Fide jussores.)

Interdict. [L. interdictum, a prohibitory decree.] An ecclesiastical censure, forbidding spiritual services of every kind.

Interfacial. [L. inter, facies, $a$ face.] Included between two plane surfaces, an interfacial angle being formed by the meeting of two planes.

Interference. The coexistence of two undulations in which the length of the wave is the same. At certain points of the medium two such undulations may cause the vibrating particles to move with the sum of the movements due to the undulations severally, at other points with their difference. In the case of light, this is equivalent to saying that at some points the light is much stronger, at others much weaker, than that which is due to either undulation separately. Diffraction fringes and many other phenomena of light are explained by $\mathrm{I}$.

Interfretted. [L. inter, between, and fret.] (Her.) Interlaced.

Inter hos vīvendum, et mŏriendum, et, quod est durius, tacendum ! The words of some contemporary of Galileo, quoted by Lacordaire. Such are they amongst zohom one has to live and to die, and, what is harder still, to keep silence!

Intĕrim. [L., in the mean time.] (Hist.) A decree is so called which was issued in 1548 by the Emperor Charles V., for the purpose of reconciling the opinions of the Protestants and the Catholics.

Interior planet. (Planet.) 
Interlacing arches. (Arch.) Arches, usually round ones, intersecting each other. The interlacing of round arches exhibits a succession of highly pointed arches.

Interlocutory. [L. inter, between, lŏquor, I speak.] Decided in the course of an action, but not finally determinate. In common law, judgment by default when only damages are sought is I. before the writ of Inquiry.

Interlude. [L. inter, between, ludo, I play.] Music played between the verses of a hymn or song, the acts of a drama, etc.

Interludes. [L. inter-lūdo, I play in the midst of.] Grotesque, merry performances, which, arising out of the Moralities (q.v.), made an approach towards the regular drama; held during the Reformation controversy in England; each side ridiculing the other; well-known persons, events, corruptions, being ridiculed on the stage.

Interlunar. (Astron.) Belonging to the time when the moon is invisible between old and new moon.

Intermittent fever. [L. intermitto, in neut. sense, I cease for a while.] (Med.) Ceasing for a time and then returning, the patient not suffering in the intervals.

Intermittent springs. An example of the common siphon. If, towards the bottom of a subterranean region, the water which eventually appears as a spring escape by an ascending siphon-like passage, the flow will continue till the reservoir be nearly emptied. Between this time and the rising of the inflowing water to the highest point of the siphon the spring will be intermittent. Examples, the Great Geyser, and the Sabbatic River of Josephus and Pliny, near Tripoli, now the Nebâ el Fûârr (Thomson, The Land and the Book, p. 263).

Internal forces. (Dyn.) Are exerted between the parts of a moving system; thus, if Jupiter and its satellites are regarded as forming a system, e.g. moving together round the sun, the mutual attractions between Jupiter and the satellites would be I. $\vec{F}$. In like manner the cohesive forces which bind together the parts of a solid body are I. F., when the motion of the body as a whole is under consideration.

Internecine. [L. inter, between, něco, I kill.] Mutually destructive, causing mutual slaughter, i.e. between kinsfolk, fellow-citizens, fellowcountrymen.

Internode. [L. internōdium.] (Bot.) The space between two nodes [nōdus, $a$ knot] or points from which normal leaf-buds issue.

Internuncius. [L.] A papal envoy sent to inferior states. (Nuncio.)

Interpellation. [Fr. interpeller, to call upon, to challenge.] In the French Senate, a direct challenge to some particular members to give information, in answer to some question or charge, etc.

Interpleader, Bill of. If the same claim be made on a person by more than one party, he can seek relief by B. of I., praying that the claimants may contest their rights inter se.

Interpolate. [L. interpŏlo, I polish here and there, patch up.] 1. (Astron.) To find values of a function intermediate to values already found; thus, when the sun's right ascension at every Greenwich noon is given, its value at any other time is found by Interpolation. 2. The insertion, in a MS. or any writing or literary work, of spurious words and passages.

In terrörem. [L.] For the purpose of terrifying

Intersect. [L. inter, sěco, I cut.] (Math.) To meet and cut mutually, said of lines, surfaces, etc.

Interstellary. [L. inter, stella, $a$ star.] Lying among the stars, i.e. beyond the solar system.

Interstitial. [L. interstĭtĭum, a space between.] (Anat.) Occurring in the interstices of an organ.

Interstratified. (Geol.) Laid down at the same time with, and among, other strata.

Interval, Intervale. Low or alluvial land on the margins of rivers.-Bartlett's Americanisms.

Intervertebral substance, or cartilage. (Anat.) A layer of elastic, chamois-leather-like cartilage, acting as a buffer, and preventing any jar between the vertebræ. The re-expansion of it adds sometimes half an inch to the height of the body when a good night's rest has succeeded to a day of fatigue ; and its gradual contraction and diminishing moisture shortens the body in old age.

Interview. To question, to obtain informa. tion by questioning, to "pump a person for the purpose of obtaining secrets."-Bartlett's Ameri canisms.

Intestate. [L. in-neg., and testatus, p. part. of testor, I make a will.] (Leg.) Without having left a will, or testament.

In the wind. (Naut.) Said of a vessel thrown nearly head to wind. All in the $W$., with every sail shaking.

Intinction, Communion by. The administering of the consecrated elements in the Eucharist mingled. This is the practice for the laity in the Eastern Church.

Intone. [L. intŏno, I call out loudly.] To recite the prayers on one note-generally $G$-and sing the suffrages and Litany; to monotone being to keep to one note only throughout.

In tŏtĭdem verbis. [L.] In so many wordis.

Inträdos. [Fr., from L. intro, within, and dorsum, the back.] (Arch.) The lower line of an arch. (Extrados; Soffit.)

Intransitive verbs. (Gram.) Verbs denoting actions the effects of which do not pass on to an object.

In transǐtu. [L.] On the passage, often from the owner of goods to the consignee.

Intrinsic. [L. intrinsĕcus, on the inside.] Inward, internal, genuine, inherent, essential. (Extrinsic.)

Introit. [L. introĭtus, entry.] (Eccl.) Verses chanted at the entry of the clergy into the choir for the celebration of the Eucharist. In the Ambrosian ritual, Ingressa.

Intromission. [From L. intro-mitto, I send within (intro).] (Scot. Law.) The assuming possession, etc., of property belonging to another. Introsusception. 1. (Intussusception.) 2. (Path.) The deposition, interstitially, of those 
particles which replace the waste of a living body.

Intrusive rocks. [L. intrüdo, I thrust into.] (Geol.) Igneous rocks which have thrust themselves in sheet-like masses, vertical, oblique, or flat, through or between sedimentary strata, affecting them on both sides, or above and beneath; some igneous rocks are contemporary and interstratified with sedimentary strata, altering only the strata beneath them.

\section{Intuitionalism. (Determinism.)}

Intumescence. [L. intŭmescentem, swelling.] The process of swelling.

Intussusception, Introsusception. [L. intus, intro, within, susceptio, -nem, undertaking.] 1 . When one portion of the bowel is forced into another, either above or below, and is contracted byit; as one part of a glove-finger into an adjacent part, sometimes, in withdrawing the hand. 2. The taking into the system of some foreign matter. In sense (I) sometimes called Invagination [vāgina, a sheath].

Inuline. A substance intermediate between jam and starch, found in many roots, especially elecampane [L. inŭla].

Inure. [Norm. Fr. enurer, from L. inangŭrare, to consecrate, establish, open.] (Leg.) To take effect.

Inusitation. [L. in- neg., usitātum, wonted, commonly used.] Neglect of use. Rare.

Invagination. (Intussusception.)

Invected. [L. invectus, carried in.] (Her.) Bordered by a line formed of small semicircles with the points turned inwards.

Invention of the Cross. [L. inventio Sanctæ Crŭcis.] The day commemorating the discovery of the cross by Helena, mother of Constantine, May 3, 326.

In ventre de sa mëre. A Fr. Law term. Every legitimate child in the womb of its mother is so termed, and is in law, for many purposes, supposed to be born: e.g. it may receive a legacy, a devise of lands, and this equally with children of the same family born before, etc.

Inver-. (Aber-.)

Inversion. [L. inversio, -nem, Rhet., a transposing of words.] (Music.) 1. The various transpositions, having a common root, of the component parts of a chord are called I. 2. Of intervals, is by making the octave below of the upper note into the lower, or the octave above of the lower into the higher; so a fifth becomes a fourth, and a fourth a fifth, etc. 3. Of subjects or phrases. (Per rectè et retrò.)

Invertebrāta, Invertebrates. [L. in- neg., vertebrāta (q.v.).] (Zool.) Animals without a backbone, as the oyster, beetle, starfish, hydra.

Investiture. [L. vestis, a garment.] (Hist.) 1. The delivery of a fief by a lord to his vassal, with certain ceremonies. 2. The endowment of a bishop with the temporalities of his see. (Institution.)

\section{Invincible Doctor. (Doctor.)}

Invincible igmorance. [L. invincỉbǔlis, unconquerable.] Is said, in Moral Phil., to be (I) in itself, e.g. an act of the insane ; (2) in itself, but not in its cause, as an act of the drunken.
In vino vēritas.' [L.] In wine there is truth.

Invitā Mĭnerva. [L.] Against Minerva's will (Horace) ; said of work composed without signs of talent, Minerva being goddess of wisdom.

Invitatory. [L. invītātồius.] Some text chosen for the occasion of the day, used anciently before the Venite, which is also the Invitatory Psalm.

In viriudi observantia. [I.] In fresh obser. vation; seen recently, and by many.

Invoice. [Fr. envois, plu., sendings, things sent; $c f$. lettre d'envoi, letter of advice of goods sent.] (Com.) An account of particulars of goods sent by a seller, with prices and charges annexed.

Involucre. [L. invŏlūcrum, a wrapper.] (Bot.) A whorl of bracts on the outside of a calyx or flower-head, which wraps up the unexpanded flower.

Involute of a curve. The curve described by the end of a thread unwound from that curve, the part of the thread that leaves the curve being kept straight during the unwinding. The curve from which the thread is unwound is the Evolute.

Involution. The squaring or cubing of a number, or raising it to any other power.

Iodine. [Gr. $i \omega \delta \eta n s$, violet-like, from the colour of its vapour.] (Chem.) A bluish-black solid, of metallic lustre; one of the elements.

Ionian mode. (Greek modes.)

Iota. [Gr. $i \hat{\omega} \tau a, i$, Heb. yôd.] The smallest letter of the Phœnician and Greek alphabets; and so, a jot, a smallest part.

Iotacism. (Iota.) (Lang.) A tendency in a language to change other vowels to the sound of iota, It. $i$, as in modern Greek.

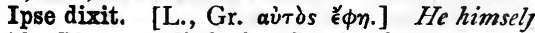
said. Plato applied the Greek phrase to the sayings of Socrates.

Ipsissima verba. [L.] The very identical words.

Ipso facto. [L.] (Leg.) By the very fact.

Iradé. [Ar. irāda, zvill, desire.] In Turkey, an imperial decree.

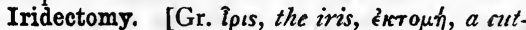
ting out.] The cutting out of the segment of the iris, for an artificial pupil.

Iridescent. Having colours like the raintozo [L. iris, irǐdis].

Iridium. [L. iris, the rainbow.] A rare white metal, generally associated with osmium in connexion with platinum. (From the iridescence of some of its solutions.)

Iris. [Gr. Ipts, rainbone, iris.] 1. (Anat.) A thin flat membranous curtain of the eye hanging in the aqueous humour and before the lens; perforated by the pupil for the transmission of light. 2. (Myth.) The messenger of the Olympian gods, connected especially with the rainbow.

Irish cross. (Cross.)

Irish deer. A large cervine animal, allied to the fallow deer, and now extinct ; found in peatbogs in Ireland and the Isle of Man.

Irish elk. Probably not an elk. (Irish deer.)

Irish pennants. (Naut.) Ropeyarns, loose reef-points, etc., hanging about a ship. 
Irmin Street. (Ermin Street.)

Iron Age. (Ages, Tho four; Prehistorio archæology.)

Iron Cross. A Prussian order of knighthood, instituted by Frederick William III.

Iron crown. The crown of the ancient Longobardian kings; said to have been the gift of Gregory the Great. A plain fillet of iron, said to be a nail of the true cross, encircled by a jewelled hoop of gold, kept in the cathedral of Monza.

Iron Dake. The first Duke of Wellington.

Iron Gate, Demir Kapi, four miles below New Orsova. A broad plateau of rock, I400 yards wide, over which the Danube formerly so rushed as to bar the ascent to all vessels drawing more than two feet and a half. Recent blasting has enabled vessels of eight or nine feet draught to pass at certain seasons of the year.

Iron Mask, Man of the. A prisoner who, having been imprisoned in Ile Ste. Marguerite, afterwards died in the Bastille, I703. M. Taine, L'Homme en Masque de Fer, satisfied himself that this prisoner was Mathioli, minister of the Duke of Mantua; but although his arguments are strong, they have been disputed, and the mystery is scarcely cleared up.

Irons. (Naut.) A ship is in irons when so brought up into the wind that she loses steerage way and will not come round of herself.

Ironstone. (Geol.) 1. Highly ferruginous sandstone, as in the Neocomian greensand of Surrey. 2. Beds and nodules of clay ironstone, or carbonates of iron, more or less argillaceous, abundant in clays associated with vegetable remains, as in the coal-measures, Wealden, etc.

Ironwood, i.e. very hard and very heavy. A name given to several different woods in different countries.

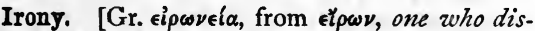
sembles, as saying less than he thinks.] (Rhet.) According to Aristotle, irony was an artful representing of things as less than they really are. The ironical man was thus one who hid his own qualities. The irony of Socrates was employed to lead into contradictions or absurdities those who affected to take for granted the arguments of the speaker. The word now denotes a subtle kind of sarcasm, in which seeming praise really conveys disapprobation.

Irradiation. [L. in, and rădius, a ray.] The apparent enlargement of bright objects seen on a dark ground; it is generally, perhaps always, an affection of vision.

Irrational expression. In Algeb., one of which the root cannot be extracted, a surd.

Irrefragable. [Fr. irréfragable, L.L. irrěfrāgäbilis, from L. in- neg., refrägor, $I$ oppose.] Not to be argued against, unanswerable, incontrovertible.

\section{Irrefragable Doctor. (Doctor.)}

Irremeable. [L. irremeäbı̌lis, from in-neg., re-, back, meāre, to go.] Allowing no return (as he waters of the Styx).

Irresolvable nebula. (Nebula.)

Irritability of plants. (Bot.) A name for the imperfectly understood "sleep of plants," occurring mostly at night; "ciliary motion of the spores of many cryptogams; the action of sensitive plants, and of Venus's fly-trap, etc., and many similar phenomena; more or less found in every plant.

Irritant. [From L. irritus, null, fromin- neg., rătus, established.] (Leg.) Making null and void. (Poison.)

Irvingites. The followers of Edward Irving, of the Scotch Kirk, who in 1830 claimed utterances of unknown tongues. They style themselves The Catholic and Apostolic Church. Their Liturgy, formed in 1842, was enlarged in 1852.

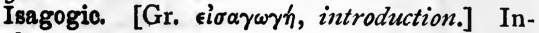
troductory.

Isatine. [Gr. iod́tıs, zvoad.] A yellow crystalline substance obtained by the oxidation of indigo.

Ischial, Ischiatio, Sciatic. [Gr. i $\sigma \chi \iota \alpha \delta \iota \kappa \delta s$.

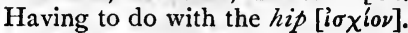

Isfendyar. (Rustem.)

-ish. [Teut. -isk, Gr. $-\iota \sigma \kappa-0,-\iota \sigma \kappa-\eta$.] Dim. suffix, as in redd-ish, rather red.

Ishtar. The Assyrian goddess Ashtaroth. (Astarte.)

Isiac-worship. The worship of the Egyptian goddess Isis, the wife of Osiris and mother of Horus. (Harpocrates.)

Isidorian Decretals. (Forged Decretals.)

Islam. [Ar., submission.] The collective name for all who believe in the mission of Mohammed.

Islands of the Elessed. In Myth., a region corresponding to Elysium (Elysian), the Hyperborean gardens, and the Gardens of the Hesperides. (Hyperboreans.)

Isle of Saints. Name of Ireland in the Middle Ages.

Ismaelians. A Mohammedan sect, formed in the tenth century into a secret association, from which sprang the society of the Assassins.

Iso- [Gr. Ĺos, equal to]; Isobaric; Isochronous ; Isoclinal ; Isodynamic; Isogonic ; Isometrical projection; Isoperimetrical problems; Isothermal. A prefix signifying equality, much used in forming scientific words, especially in the case of lines which represent graphically equality of phenomena; thus, lines drawn on a map to show places where the average barometric pressures are equal, are Isobaric lines; places where the needle has the same dip are shown by Isoclinal lines; places where the magnetic intensity is the same are shown by Isodynamic lines; places where the deviation of the magnet is the same, by Isogonic lines; where the mean annual temperature is the same, by Isothermal lines. Isoperimetrical problems relate to such questions as finding the greatest area inclosed by a given perimeter. The questions are comprised in the calculus of variations. (Calculus of finite differences.) Isochronous [xpóvos, time], performed in equal times; e.g. a cycloid is an isochronous curve because the oscillations of bodies moving in equal cycloids are performed in equal times whether the arcs described be 
long or short. Isometrical projection is a species of perspective, in which the edges of a cube are represented as of equal length, and the measurements of the three visible faces equal in all respects.

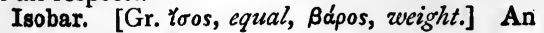
isobaric line. (Iso-.)

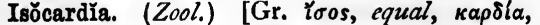
heart.] Heart-shaped molluscs with equal valves, as cockles. Class Conchŭfĕra.

Isochimenal lines, where the average winter [Gr. $\chi \in \hat{i} \mu \alpha]$, and Isotheral lines, where the average summer [ $\theta$ épos], temperatures are equal.

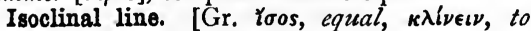
incline.] A line passing through all the places where the magnetic needle has the same inclination, or dip.

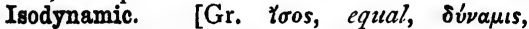
force.] Pertaining to, or showing, equality of forces.

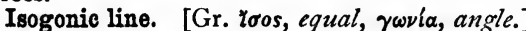
A line passing through all the places where the magnetic needle has the same deviation from the true $\mathrm{N}$.

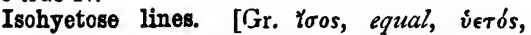
rain.] Lines connecting those places where the mean annual rainfall is the same.

Isomeric. [Gr. ̌̌os, equal, $\mu$ épos, part.] Consisting of the same elements in the same proportion, but differing in physical qualities and in the size of its molecules.

Isometrical perspective. J.q. Isometrical projection. (Iso-.)

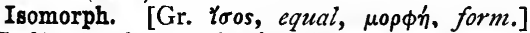
(Geol.) A substance having the same crystalline form as another.

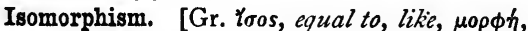
form.] The crystallization in very nearly the same form of substances whose chemical compositions differ by one element, as carbonate of lime and carbonate of magnesia.

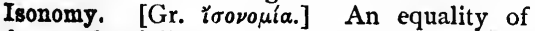
rights and privileges under equal [广\%os] laws [voros].

\section{Isosceles. (Triangle.)}

Isotheral, or Isothermal. (Isochimenal lines.)

Issuable. (Leg.) On or in which issue may be taken, as I. terms, Hilary and Trinity, in which issues (single material points of law or fact) are made up for the assizes.

Issuant. [O.Fr.] (Her.) Rising out of.

Issue, or Fonticŭlus. [L., a small spring.] (Med.) A small ulcer produced and continued artificially, by the insertion of some round body. which shares, bonds, or stock are sold on their first issue above or below the nominal value.

Isthmian games. One of the four Greek national festivals, anciently celebratel on the Isthmus of Corinth every other year, from B.C. 585 probably till about A.D. 312, in honour of Póseidon; said to have been founded by Thēseus, in place of the nocturnal festival of Melikertes $(q . v$.$) . The games were like the$ Olympic, the prizes being garlands of pine leaves, and dried.

Italia irredenta. [It.] Unredeemed Italy; i.e. Trent, Trieste, and whatever else once belonged to Italy, but does not now.

Italian pink. A transparent pigment prepared from the juice of yellow berries or from quercitron bark precipitated upon whiting.

Italio Version. [L. Větŭs İtăla, i.e. Old Italic.] The Latin translation of the Scriptures, generally used until St. Jerome's time, who, dissatisfied with it, made the new translation known as the Vulgate, which by degrees obtained universally in the Latin Church.

Itch, Scăbies, Psōra. (Med.) A contagious vesicular disease of the skin, due to the presence of the itch-mite.

Itchil. Province on east of south coast of Asia Minor about the time of the Reformation.

-ite. (-ate.)

Item. [L., also.] 1. An additional particular. 2. A hint.

Itě, missa est. [L., go, it is sent.] The last words of the Roman Mass. The origin and meaning of the expression is not known.

Iteration. [L. ìterātio, from ìtěro, 1 repeat, from iterum, again.] Repetition.

Itihāsas. The name given to the two great Hindu epics, the Ramayana and Mahâbhârata.

Itinerary. [L. iter, itinĕris, a journey.] A work, naming places and stations to be met with along a particular line of road, as the Latin itineraries, the most important of which is that of Antoninus. The $I$. of Ferusalem describes the journey between Bordeaux and the holy city.

-itis, -iтıs. Termination of Gr. adj., fem.,

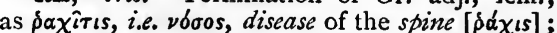
rickets (q.v.).

Ivan Ivanovitch. A fictitious personage, representative of Russian character, as John Bull of English.

Ivory black. A pigment formed of ivory charred in closed vessels.

Iwis-not I wis, as if = I know, but-an

Issue price. (Finance.) The real price at adv., meaning certainly [A.S. gewis, certain]. 
J. The same letter as I. It is only within the last century that any distinction has been made in their forms.

Jacchus. (Zool.) The marmorets, Hăpălĭdæ, a fam. of platyrrhine monkeys, about the size of squirrels. Trop. S. America.

Jachin and Boaz. [Heb., probably He will establish, in strength.] Two brazen pillars "in the porch" of Solomon's temple (r Kings vii. 2) ; or, more likely, isolated columns "at the porch" (see Speaker's Commentary, v. 15).

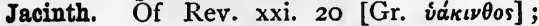
probably the true sapphire.-King, Precious Stones.

Jack. 1. (Ichth.) A pike, Ésox lūcius, under three pounds weight. 2. (Naut.) (Flag.) 3.

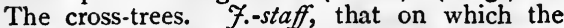
Union Jack is hoisted at the bowsprit cap.

Jack; J.-screw. A portable machine for lifting heavy weights through small distances; when worked with a screw it is a $\mathcal{F}_{\text {. }}$ screw.

Jackasses. (Naut.) Rough and heavy boats of Newfoundland.

Jack-boots. (Mil.) Long cavalry boots, such as are worn by our Life Guards.

Jacket. A covering of a non-conducting substance put over a hot body to keep the heat in.

Jack-in-the-green. The principal character of the mummers who go about in England on May-day.

Jack Ketch. (Ketch, Jack.)

Jack-pudding. A zany, a merry-andrew.

Jack-stones. Bedded masses of clay ironstone in the S.-Welsh coal-fields. Penny-stones are similar, but smaller, in Coalbrookdale, etc.

Jacobin Club. (Fr. Hist.) A society of prominent members of the First Assembly; so styled as holding their meetings in a suppressed Jacobin monastery. Hence the word Facobin came to be synonymous with revolutionary.

Jacobins. In Eccl. Hist., the French Do. minicans were so called, as having their chief convent near the Rue St. Jacques, in Paris.

Jacobites. 1. (Eccl. Hist.) The Monophysite Christians of Syria ; so called from Jacob Baradzi, who revived their belief and ritual in the sixth century. 2. (Eng. Hist.) The partisans of the Stuart dynasty after the Revolution of 1688 .

Jacobus. A gold coin worth 25s., struck in the reign of James I.

Jaconet. [Fr. jaconas.] A thin cotton fabric between cambric and muslin.

Jacque. [Fr. jaque.] English archer's leather tunic, made of overlapping flaps.

Jacquerrie. (Hist.) A revolt of the French peasantry, which occurred during the captivity of their king John in England, in 1356; so called from Facques Bonhomme, a title of derision applied by the nobles to the peasants.

Jactation, Jactitation. [L. jacto, jactîto, I toss about.] (Med.) A tossing about in bed, great restlessness. (Insomnia.)

Jactitation. [L. jactîto, $I$ boast.] In Law, a false boasting. $\mathcal{F}$. of marriage, the giving out that one is married to some other, by which a common reputation of their marriage may ensue. It has been applied also to a false claim to a seat in church; also to a false claim to tithes.

Jade. [Fr. jade.] A term applied to three different minerals having some resemblance in colour; they have been generally termed nephrite (q.v.). 1. Fadeite, allied to the epidotes; China, Mexico. 2. Oriental $\mathcal{F}$., allied to hornblende ; China, Australasia. 3. Oceanic $\mathcal{F}$., allied to pyroxene; New Caledonia and Marquise Isle.

J'adoube. [Fr.] In chess, = I touch this piece, to put it better in place, not to move it. (Dub.)

Jaganath. (Juggernaut.)

Jaggery. [Hind. jâgri.] Dark coarse sugar made of the juice of the cocoa-nut palm.

Jaghir. [Hind.] An assignment of the rent and revenue of an Indian disfrict to a military chief by the English Government. Faghir-dar, the holder of a $\mathrm{J}$.

Jaguar. [Sp.] (Zool.) Fëlis onca, the American leopard, like but larger than that of Asia and Africa.

J'ai jété la manche après la cognée. [Fr.] $I$ have thrown the helve after the hatchet. "We have burnt our ships."

Jail delivery. (Gaol delivery.)

Jalousie. [Fr.] A Venetian blind.

Jambs. [Fr. jambe.] (Arch.) The side pieces of any opening in a wall, supporting the piece that discharges the weight of the wall above them.

Jamdari. A kind of figured Indian muslin.

James, Palace of St. Built by Henry VIII., on the site of a leper hospital founded in 1100 . It became a royal residence after the destruction of Whitehall by fire, 1698 .

James, St., of the Sword. (Hist.) An ancient military order in Spain and Portegal.

Jamma. [Hind.] Rent paid to the Government of India.

Jam proxĭmns ardet రేcălěgon. [L.] Already is neighbour Ucalegon('s house) on fire (Virgil); said of dangers affecting others which we fear will reach ourselves.

Jam rědĭt et Virgo; rĕdeunt Sāturnia régna. [L.] Already too is the virgin returning, the Saturnian rule returns (Virgil); i.e. Astræa, goddess of justice and the Golden Age.

Jam satis! [L.] Ifold, enough!

Janissăries, Janizăries. [Turk. yeni-ischeri, new troops.] The militia of the Ottoman empire, established probably by Orchan in the fourteenth century, and supplied chiefly by the capture of Christian slaves. It was suppressed, after a terrible struggle, in 1826 .

Janitor. [L.] Door-keeper, porter. 
Jansenists. A body of French Roman Catholics, who, following Jansen, Bishop of Ypres, formed a considerable party in the latter part of the seventeenth century. In their opinions they leant to Calvinism. They were defeated in their celebrated controversy with the Jesuits.

Janta. A machine used in India for raising water for the irrigation of land.

Jānuis clausis. [L.] With closed doors; in secrecy.

Jānus. [L.] (Myth.) A god whose name is the masculine form of Diana. The gate bearing his name was open in times of war, and shut only when the Roman republic was at peace.

Japanning. 1. Painting and varnishing wood, metal, etc., after the Fapanese manner. 2. Lacquering.

Jardinière. [Fr., gardener's wife.] A pot or vase for plants.

Jarnac, Coup de. [Fr.] An attack unfair, unexpected, fatal; like the dagger-stab in the leg which $\mathrm{J}$. gave Chateigneraie in the judicial combat fought (1547) before Henri II. ; " manœuvre perfide, déloyale" (Littré).

Jasher, or Jashar, Book of. A book, referred to in the Books of Joshua and Samuel, of which nothing further is known with certainty. - Horne, Introd. to Study of the Bible; Donaldson, Fashar.

Jasper. [Gr. Ł̌ $\alpha \sigma \pi t s$.$] (Min.) An amorphous$ silica ; red, brown, yellow, green, often banded; the result of igneous and hydro-thermal action on clays. (For J. of Rev. xxi. 19, vide Plasma.)

Jasper ware. A compact hard paste, capable of a high polish, and of being tinted throughout by metallic oxides; invented by Josiah Wedgwood.

Jaunting-car. An Irish vehicle, on which the passengers ride sideways, sitting back to back.

Javelin. [Fr. javeline, from It. giavelina.] Short spear or large dart, thrown by the hand.

Javelin-men. Yeomen retained by the sheriff to guard the judge of assize.

Jaw, Jaw-rope of a gaff, or boom. (Gaff.)

Jazail. [Afgh.] Long gun-sometimes ten feet-with narrow stock, used by the natives of Afghanistan.

Jazerant. [O.Fr.] A frock of linked or twisted mail, somewhat lighter than the hauberk.

Jean. (From the town of Genoa.) Twilled cotton cloth.

Jean Jacques. Forenames of the French philosopher Rousseau (1 7 1 2-1 778).

Jean Paul. Nom de plume of the German author J. P. Friedrich Richter (1 763-1825).

Jedburgh justice. (Jeddart justice.)

Jeddart justice. Hanging first and trying afterwards.

Jeers. (Naut.) (Halliards.)

Jehovist. 1. One who holds that the vowel points in the word fehovah are the proper vowels; in opposition to those who insist that they are the vowels of the word Adonai. 2. The supposed writer or writers of those passages in the Pentateuch in which the word Fehovah occurs, as distinguished from the Elohist writer or writers, who use the word Elohim to denote the Deity.

Jehu. By meton. = a fast driver (see 2 Kings ix. 20).

Jëjūnum. [L., fasting, hungcr.] (Med.) The second portion of the small intestine, generally found empty after death.

Jelba, or Jerba. (Naut.) A large coastingboat used in the Red Sea.

Jemadar. [Hind.] (Mil.) Native commissioned officer of Sepoy troops, ranking with lieutenant.

Jemmy Ducks. (Naut.) The ship's poulterer. Je ne sais quoi. [Fr.] I know not what.

Jenkins's Ears, Fable of. Burke's name for a story which excited the English people against Spain, 1739; that of one J., whose sloop had been searched in Jamaica by a Spanish guardacosta, and his ear, as he said, torn off; with an assurance that the king would have been similarly treated.

Jennet. (Genet.)

Jeofail. [For Fr. j'ai failli, $I$ have failed.] (Leg.) An oversight in pleadings or other legal proceedings.

\section{Jerboa. (Gerboa.)}

Jereed. (Jerreed.)

Jeremiad. A name suggested by the Lamentations of Jeremiah, but applied satirically to stories or speeches full of absurd pictures of exaggerated or imaginary evils.

Jerked beef. [Corr. of Fr. charcuit, cooked flesh.] Beef cut in thin stripes and dried in the sun.

Jerkin. [Dim. of the D. jurk, a frock.] A jacket.

Jerquing a ship. (Naut.) The searching on the part of the custom-house for concealed goods in ships professedly unloaded.

Jerreed. Blunted Turkish javelin, darted from horseback with great force and precision.

Jersey. 1. The finest wool. 2. A jacket of coarse wool.

Jerusalem, St. John of, Knights of. (Orders, Religious.)

Jerusalem Itinerary. (Itinerary.)

Jessant. [O.Fr.] (Her.) Springing up.

Jesse window. (Eccl. Arch.) A window exhibiting a Jesse tree, or the genealogy of our Lord from Jesse, father of David. A window in the church of Dorchester, near Oxford, shows this tree worked in stone with the aid of the mullions.

Jester. (Minstrels.)

Jesuits. (Hist.) The Society of Jesus, founded by Ignatius Loyola, in 1534 , on the basis of implicit submission to the commands of the holy see.

Jet. [(?) A.S. geótan, to pour ; cf. Ger. giessen, id.] A large, wooden-handled ladle for taking water out of a pond, and the like.

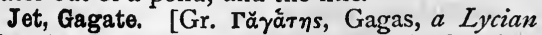
river.] A peculiar form of pitch-coal, electrical when rubbed. Whitby $\%$ is from the Lias.

Jet d'eau. [Fr.] Water-spout.

Jetée. [Fr.] Pier, jetty.

Jetsam, Jetson. (Flotsam.) 
Jettison, or Jetsen. [L. jactātionem.] (Naut.) The act of throwing things overboard.

Jotty. [Fr. jetée.] (Arch.) A projection from a building, overhanging the wall below. Shakespeare, Macbeth, uses the form jutty.

Jeu de main, jeu de vilain. [Fr.] A practical joke is a vulgar joke.

Jeu de mots. [Fr.] A play on words.

Jeu d'esprit. [Fr.] Witticism, a piece of wit ; lit. a sport of the mind.

Jeu de thêatre. [Fr.] A stage trick.

Jeunesse dorée. [Fr.] Gilded youth.

Jewellers' rouge. (Colcothar.)

Jew's-harp. 1. Guimbarde, Fen's-trump. A small lyre-shaped, sweet-toned instrument; the metal tongue is set vibrating by the finger while blown upon with the mouth. Ferw here is only a corr. of Fr. jeu, sport or play. 2. (Naut.) A shackle so shaped, and used to join a chaincable to the anchor.

Jerids, Yedzīdis. A fanatical sect, belonging to the mountainous country near Mosul; their opinions being seemingly a mixture of Mohammedanism, Manichæism, and Zendism. By the Turks they are regarded as devil-worshippers.

Jheel. [Hind.] A shallow lake.

Jhoul. [Hind.] Elephant housings.

Jib. (Naut.) A large triangular sail set on a stay and extending from the outer end of the jibboom towards the fore-topmast head. In cutters and sloops it is set on the bowsprit. A sail jibs when it flies over from one side to the other. (Crane.)

Jib-and-Staysail Jack. (Naut.) An inexperienced and fidgety officer.

Jibber the kibber. (Naut.) To tie a lantern to a horse's neck and check one of his legs, so that the light should move like that of a ship, and decoy vessels on shore.

Jibboom. (Bowsprit.)

Jibe. (Naut.) To shift a sail from one side of the vessel to another.

Jibing, or Gybing. (Naut.) Shifting the boom of a fore-and-aft sail from one side to the other.

Jib-topsail. (Naut.) A fore-and-aft topsail, jib-shaped. F.-traveller, an iron ring which runs on the booms, and to which the tack of the $\mathrm{J}$. and its guys are fastened. $\mathcal{F}_{\text {-tye, the rope }}$ by which the $\mathrm{J}$. is hoisted.

Jig, Gigue [Fr.], Giga [It.]. 1. A lively dance, by one or more dancers, of the same kind as bolero and chica; but varying much in different countries from a somewhat sober to a wild dramatic movement. 2. A movement which grew out of jig.tunes, the origin of the last movement of the sonata. [(?) From jig, gigue, a kind of fiddle, English, mediæval ; or (?) i.q. chica $(q . v$.$) ; or are all these the same$ word ?]

Jigger. (Naut.) 1. A light tackle for holding on the cable when being hove in, and for other purposes. 2. A small sail rigged to a mast and boom over the stern. $\mathcal{F}_{\text {.-mast, }}$ an additional aftermost mast. (Chigoe.)

Jigging. [Ger. schocken, to shake.] Shaking a sieve full of ore in water, whereby the lightest and least metallic pieces are brought to the top.

Jilalo. A large Manila outrigged passageboat.

Jimmart. [Fr.] The imaginary offspring of a bull and a mare.

Jimmy. A short crowbar used by burglars.

Jin, Djin. Demons or spirits in Arabian folklore.

Jingo (in vulgar expletive "By J.;" said to be for by St. Gengulphus). One of the war party, 1877, 1878, among Lord Beaconsfield's supporters ; so called from the phrase "By J.," in one of the music-hall war-songs.

Jinjal. Very small cannon, used in India by the natives.

\section{Jo. [Scot.] Szueetheart.}

Joachims-thaler, or Thaler, whence Low Ger. dahler, Eng. dollar. An excellent coinage of ounce-pieces of silver from the mines of Joachimsthal, coined by the Counts of Schlick about the end of the fifteenth century, and which became a pattern coinage.

Jobber. One who buys or sells for others.

Jobbing-house. [Amer.] A mercantile estab. lishment, which purchases from importers and sells to retailers. - Bartlett's Americanisms.

Jockie. (Minstrels.)

Joco di mano, joco villano. [It.] (Jeu de main.)

Jodeln [Ger.], Jodle [onomatop.]. With the Swiss and Tyrolese, a peculiar manner of singing in harmonic progressions, with natural and falset to voices rapidly alternating.

Joggle-joints. (Arch.) Joints fastened by jogs, or knots, the surfaces of the adjacent stones being mutually indented. (Rabbeting.)

Jogues, Yugs. Mythical eras of immense length in the chronology of the Hindus, answering to the Hesiodic ages in Greek mythology.

John Company. So the Indian natives, unable to realize government by a society, called the E. I. Company, which ceased September I, I 858; the Queen being proclaimed Sovereign of India, with Lord Canning as first Viceroy.

John Doe and Richard Roe. In Law, fictitious personages, plaintiff and defendant, generally in actions of ejectment ; previous to the passing of the Common Law Procedure Act, 1852. They were employed to save certain niceties of law. (See Stephens's Commentaries.)

John Dory. [(?) Fr. jaùne-dorée, yellowgolden, or dorée with John prefixed, or the Gasc. jan, i.e. cock (?).] (Ichth.) Marine fish, with deep compressed body, elongated spines to first dorsal fin, olive brown with yellow tinge.

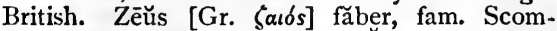
brǐdæ (mackiarel kind), ord. Ăcanthoptěry̆gŭi, sub-class Tělěostěĩ.

John O'Groat's House, more correctly 7ohnny Groat's. (John Grot, chamberlain to the Earl of Caithness, circ. 1500 .) On Dungansby Head, at extreme north-east point of Scotland ; (?) built for travellers to and from the Orkneys ; now a small green knoll. (For its traditions, see Chambers's Encyclopadia.) 
Johnsonese, Johnsonian English. Refer to Johnson's use of long, pompous words from the Latin; the structure of sentences being plain.

Joint-stock. Stock held in company, divided or divisible into shares transferable at the pleasure of any stockholder.

Joint-tenancy. (Leg.) A tenure of the same estate in unity of title, interest, and possession by two or more persons each of which is seised per my et per tout, with accession of the rights and interests of a deceased joint-tenant or jointtenants to the survivors or survivor. J. must subsist $a b$ initio by the estate vesting in the joint-tenants at the same time. (Coparcenary; Jus accrescendi; Tenancy in common.)

Jointure. [Fr., from L. junctūra, a joining, from jungo, $I$ join.] (Leg.) Strictly a joint estate limited to husband and wife, generally a sole estate limited to the wife inuring on the husband's death, vested in herself for her own life at least, expressly in satisfaction of her whole dower.

Joists. (Arch.) The timbers of a floor to which the boards or laths of the ceiling are fastened.

Jolly. (Naut.) A soldier. Royal F., a marine. Tame $\mathcal{F}$., a militiaman. $\mathcal{F}_{\text {.-boat, }}$ clinker-built and tubby, about four feet beam by twelve feet long. $\mathcal{F} \cdot$-jumpers, sails above the moonrakers. $\mathscr{F}$. Koger, the pirate's flag, skull and cross-bones white, on a black ground.

Jonathan, Brother, $=$ the people of the United States. Washington, when in difficulty, often said, "We must consult Brother Jonathan," i.e. J. Trumbull, Governor of Connecticut, in whom he had great confidence, and whose name became a byword. (See Bartlett's Americanisms.)

Jonath-elem-rechokim. In title of Ps. lvi., "the dove of silence of the far ones," "the silent dove among aliens," the name of a tune (?) ; the tune and the circumstances of David being connected.

Jongleur. (Troubadour.)

Jornada. [Sp.] A march or journey performed in a day.-Bartlett's Americanisms.

Joseph. [Fr.] 1. Thin tissue paper. 2. Thin silvered paper.

Joss. [Corr. of Sp. and Port. Dios; God.] A Chinese deity or idol; hence Foss-house, a temple.

Jot or tittle. Matt. v. I8: Fot [Gr. $i \omega \hat{\tau} \tau \alpha]$ is Heb. yod, the smallest letter of the alphabet;

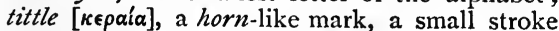
distinguishing, e.g., $\mathrm{E}$ from $\mathrm{F}$.

Jourdain, M. Hero of Molière's comedy, Le Bourgeois Gentilhomme, a rich tradesman who desires to acquire accomplishments and fashionable manners late in life. He talked prose with. out knowing it, not knowing the meaning of the word "prose."

Jour de l'an. [Fr.] New Year's Day.

Journal. [L. diurnus, of a day, daily.] 1. (Naut.) The log-book, or log, i.e. a ship's daily register of winds, weather, course and distance, and of all matters worthy of record. (Mech.) The part of a rotating piece of machinery or of a shaft which is supported by the frame of the machine; it works in a $\mathcal{F} .-b 0 x$. The support of a journal is not necessarily fixed ; thus a crank-pin is a journal.

Journey. [Fr. journée, a day's length, L. diurnus; $c f$. It. giorno.] An agricultural labourer's day's work, especially in ploughing.

Journeyman. [From Fr. journee, a day, $a$ day's work.] 1. A man who works for hire by the day. 2. One who works for hire for any time or by any term.

Jousts. [It. giastrare, Fr. jouster, to tilt.] Popular military games of the Middle Ages.

Jovial. [Fr. joviālis, pertaining to Fupiter (gen. Jǒvis).] 1. (Astrol.) Under the influence of the planet Jupiter. 2. Merry, full of animal spirits, gay. 3. (Alchem.) Pertaining to tin.

Jubé (so called from the form "Jube, domne, benedicere," uttered before the intoning of the Gospel). The French name for the Rood-loft, or rood-screen.

Jubilee year. [L. jübilo, I shout for joy, Heb. yobel, to rejoice.] The grand sabbatical year of the Jews, which was to be celebrated after every seven septenaries of years, as a year of general release of all debtors and slaves. In modern times, the word has been applied to celebrations recurring at intervals of half or of a quarter of a century.

Judaic. [L. Jūdāĭcus, of Jūdæa.] Jewish.

Juddock. (Ornith.) The jack-snipe, Scŏlŏpax gallinula, fam. Scolopacidæ.

Jūdex damnātur cum nǒcens absolvĭtur. [L.] (Leg.) The judge is condemned when a guilty person is acquitted. Motto of the Edinburgh Review.

Judge-Advocate. (Leg.) An officer appointed to attend courts-martial, to provide accommodation for the court, to summon witnesses, to administer oaths to them and the court, to advise the court, to see that the prisoner is properly defended, and to send minutes of proceedings to the $\mathcal{F}$.-A.-General, an officer appointed by letters patent under the Great Seal, who can himself attend courts-martial, all other J.-A. officiating at home being his deputies.

Judge-Advocate-General. The adviser of the Crown in naval and military law.

Judgment. [Fr. jugement, L. jūdǐcium.] $(\log$.$) The mental operation which decides$ whether two notions resulting from simple Apprehension agree or disagree. It must, therefore, be either affirmative or negative.

Judicature, Supreme Court of, consists of (I) the Court of Appeal, and (2) the High Court of Fustice. (I) Sits in two divisions, one at Westminster, the other at Lincoln's Inn; the former takes appeals from the Common Law Division; the latter from the Chancery Divisions, including bankruptcy appeals. (2) Consists of Queen's Bench and Probate-Divorce, and Admiralty Divisions. (See Charles Dickens's Dictionary of London.)

Judicature Act. Lord. Selborne's, I873, unified the various high courts of law into the Supreme Court of Judicature.

Judicial Committee of Privy Council, established 
3 and 4 Will. IV., consists of a Lord President, the Lord Chancellor, and certain judges, being P. Councillors. Under 34 and 35 Vict., and under the Appellate Jurisdiction Act, 39 and 40 Vict., four are paid members. In ecclesiastical appeals, the archbishops and bishops, or some of them, attend, either as members or assessors. The court also receives appeals from the colonies, India included, " and, generally, appeals in all other matters in which the Crown's intervenion is rather executive than judicial."-Brown, Law Dictionary.

Judiciary. [L. jūdǐciārius, from jūdicium, lazw court, from jüdex, gen. ǐcis, judge.] Pertaining to judgments or law courts.

Jüdicium Dei. [L.] In former days, the result of an appeal to the judgment of God, by means of various ordeals, single combat, etc.

Juffs. [Russ. youft.] Tanned ox-hides. Bloomed juffs are red hides, having flower-like spots upon them.

Juggernaut, properly Jaganath. [Skt., lord of the world.]. The name under which Brahma is worshipped, especially at Pooree, in Orissa, the image on the great festival being dragged along in a huge car.

Juggler. (Minstrels.)

Jugular veins. (Anat.) Two on each side of the neck [L. jŭgŭlum] by which the blood is brought from the head.

Julep. [Ar. jelâb, a reddish medicinal drink, made of fruit, etc., from Pers. gul, rose, äp, water.] A sweet, cooling drink.

Julian calendar. (New Style.)

Julian period consists of $7980(=28 \times 19 \times 15)$ Julian years, after which the years of the Solar, Metonic, and Indiction cycles come round again in the same order; the year of each cycle was I on B.C. 4713 ; the J. P. begins on the Ist of January in that year. The use of the J. P. first brought light and order into chronology.

Jump a claim. In Western parlance, is to endeavour to obtain possession of the land, or "claim," which has been taken up and occupied by a settler, or "squatter," in a new country.Bartlett's Americanisms.

Jumper. A long borer, used by one person to prepare a hole for blasting.

Juncate. (Junket.)

Juncite. [L. juncus, a rush.] (Geol.) Fossil stems, rushlike in appearance; their affinities uncertain.

Jungada. (Naut.) A kind of raft, with mast and tilt, used on the coast of Peru.

Jungle. [Hind. jangal, desert, forest.] Land covered with trees and brushwood or coarse vegetation, affording cover to wild beasts.

Jungle fever. [Hind. jungal, wooded swamp.] A kind of intermittent fever, appearing in the jungle districts.

Junior. [L. jünior, younger, comp. of jŭvěnis.] (Leg.) 1. A barrister under the rank of Q.C. or serjeant. 2. The younger in standing of two barristers engaged in a case. 3. An officer of the bar on circuit.

Junius. Pseudonym of the writer of a series of political letters in the Public Advertiser,
1769-1772, attacking royalty and great men connected with the Government. The authorship of these letters, which are believed by Macaulay and others to have been written by Sir Philip Francis, is still a vexed question.

Junk. [L. juncus, a rush, of which ropes were made.] (Naut.) 1. Hard salted beef supplied to ships. 2. Piece of old cables or cordage cut up for various purposes. 3. The flat-bottomed, square-bowed vessels of China, having big sails, water-tight compartments, and a deep rudder.

Junket, Juncate. [L.L. juncāta, a cream-cheese made in a basket of junci, rushes.] 1. A creamcheese. 2. Any dainty. 3. A feasting on the sly.

Junta. A grand Spanish council of State. In England the word J. was used as an equivalent for Cabal, or faction.

Jupe. [Fr.]" Petticoat, skirt.

Jupiter. (Planet.)

Jupon, Juppon. [Fr. jupon.] 1. A tightfitting, sleeveless jacket, reaching to the hips, of silk or velvet over several thicknesses of other stuff, embroidered with the wearer's arms, and ending in a rich border. 2. A petticoat.

Jurassic. In continental Geol., $=$ Lias and Oolite; the rocks of the Jura being analogous to the typical Lias and Oolite series of England, "black" (lowest), "brown" (middle), "white" (uppermost) "Jura."

Jurat. [L., he swears.] (Leg.) 1. Memorandum of time, place, anil person before whom an affidavit is sworn. 2. An officer for the government of some corporation, not unlike an alderman. The bailiff in Jersey has twelve jurats as assistants.

Jūratores sunt jūdices facti. [L.] (Leg.) Furors are the judges of matters of fact.

Juratory caution. (Scot. Law.) A kind of caution (security) offered by a complainer who cannot offer any better.

Jurāvi linguā, mentem injūrātam gero. [L.] $I$ have sworn with my tongue, I have a mind

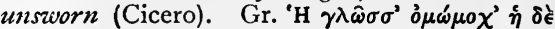

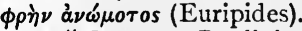

Jürě dīiño. By divine right; as opposed to J. ecclesiastico, J. humāno, J. gentrum. The ministry, sacraments, are J. D.

Juridical. [L. jürĭdǐcus, relating to administration of justice, from jüs, right, lazv, and root of dico, I say.] Pertaining to judges, judgments, or courts of law. $\mathcal{F}$. days, those on which courts can lawfully sit for the administration of justice.

Jürisconsult. [L. jūrisconsultus.] (Leg.) One learned in the law, especially Roman law.

Jurisdiction. [L. jürisdictio, -nem, administration of justice.] (Leg:) 1. The extent of the power of a court to hear and determine causes. 2. The extent of the power and authority of a government or an officer to execute justice.

Jüris et dē jüre. [L.] (Leg.) Of law and from law; of a conclusive presumption.

Jurisprudence. [L. jüris-prüdentia.] The science of law, especially of Roman law.

Jurist. [From L. jus, jūris, lazw.] A civil lawyer, a student of civil law. 
Juror, Withdrawal of a, is, in effect, as if no action had been brought.

Jury, Trial by. Trial by a judge in presence of twelve men, selected for the purpose, to pronounce on the conclusiveness or inconclusiveness of the evidence laid before them. The old compurgators were in strictness nothing more than witnesses to character. (Compurgation.)

Jury-mast (said to be for injury-mast, one put in place of an injured mast). (Naut.) A temporary mast, or substitute for one.

Jury-rudder. (Naut.) Any contrivance for steering a ship when the rudder is disabled.

Jus accrescendi. The right of survivorship, or, as it is called, Accrual, in joint-tenancies.

Jūs albinätus. [L.L.] (Leg.) (Droit d'aubaine.)

Jus Anglörum. [L.] Laws and customs of the West Saxons before the Norman Conquest.

Jūs Cīvile. [L., cizill law.] The whole body of law of any state applying to the citizens [cives]; especially the whole body of Roman law, founded on lëges, enactments of law.

Jus ex injüria non ŏrǐtur. [L.] (Leg.) $A$ right does not arise out of a wrong.

Jūs gentium. [L., law of nations.] The common law of all mankind, founded on nātūrālis rătio, natural reason.

Jus non scriptum. [L.] The unwritten law; of humanity, social interest, public opinion ; introduced by custom, with the tacit consent of the legislator.

Jũs postliminii. [L.] 1. The right of returning home, and resuming former privileges ; the right of a citizen of Rome who, having been made a slave, resumed his rights under a fiction that he had not been in captivity at all. 2 .

"The right of restitution after recapture, as applied in maritime law" now (Brown, Law Dictionary).

Jussi. (Native name.) A delicate fibre obtained from Manila.

Jus summum sæpe summa mălirtia est. [L.] Extreme legality is often extreme wickedness (Terence). (Summum jus.)

Juste milieu. [Fr., the just mean.] The term used to express Louis Philippe's system of government, which began with Casimir Perier after the revolution of 1830 .

Justice Clerk, Lord. The second highest judge in Scotland, and, in the absence of the Lord Justice-General, the presiding judge of the Court of Justiciary.

Justice-General, Lord. The highest judge in Scotland; called also Lord President of the Court of Session.

\section{Justice seat. (Forest courts.)}

Justiciary, High Court of. (Scot. Laze.) The supreme criminal tribunal of Scotland.

Justify. [L. justus, right, facere, to make.] In Printing, to form even or true lines of type by proper spacing.

Justinian, The English. Edward I.

Justinianist. One who studies the civil law codified by order of Justinian.

Justum et tĕnācem prōpǒsǐti vĭrum. [L.] $A n$ upright man and firm in his resolution (Horace).

Jute. A fibrous material like hemp, imported from Bengal.

Juverna. An old name of Ireland.
K. After it had almost entirely disappeared from the Latin orthography, was retained in certain abbreviations ; thus, K. for Cæso, K. or Kal. for Calendæ, KA. for Capitalis, K.S., Carus suis.

Kaaba. The great temple at Mecca ; so called from the black stone worshipped there before the time of Mohammed-probably a large aerolite.

\section{Kadi. (Cadi.)}

Raimakan. In the Ottoman empire, a deputy or governor, of which there are generally twoone residing at Constantinople, the other attending the grand vizier as his lieutenant.

Kaims, Kames. (Geol.) Ridges of postGlacial gravel and sand, at the ends of valleys, like embankments From a few yards to twenty miles long; twenty to sixty feet high. So called in Scotland; known as Eskirs, or Escars, in Ireland.

\section{Kaique. (Caique.)}

Kalani. An Oriental notary public and public weigher.

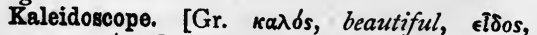
form, $\sigma \kappa o \pi \epsilon ́ \omega, I$ behold.] A well-known toy in- vented by Sir D. Brewster, in which elegant coloured patterns are formed by the symmetrical distribution of the images formed by successive reflexion at two or three mirrors inclined to each other at angles of $60^{\circ}$.

Kalends, Kalendæ. (Calends.)

Kalewāla. The Finnic epic poem, which is ascribed to Wäinämöinen.

Kalmucks, Kali. A tribe of Tartars.

Kami. The Japanese name for the gods who formed their first mythical dynasty.

Kamptulicon. [A word coined from Gr.

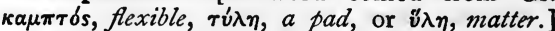
A kind of floor-cloth made by mixing cork, wool, etc., with melted indiarubber, and spreading the mixture on canvas.

Kâneh. [Heb., cane, or reed.] A Jewish measure of length, for measuring on a large scale; as in Ezekiel's vision of the temple and its measurement (ch. xl., et seq.).

Kanjia. (Naut.) A Nile passenger-boat.

Kantian. Relating to the philosophy of Immanuel Kant (1724-1804).

Kaolin. [Chin. word.] Porcelain clay ; a dull opaque clay, of various shades of white; arising 
from decomposition of felspar. A large tract near St. Austell, on rotting granite, supplies Worcester, etc.

Kapellmeister. (Capelmeister.)

Kara. A Tartar word, meaning black; used also in the sense of tributary, as the Kara Kalpacks.

\section{Karaites. (Caraites.)}

Karaman. Province of Asia Minor about the time of the Reformation; north of Itchil.

Karbaty. (Carbasse.)

Karmathians. A Mohammedan sect of the ninth century; so called from its founder, Karmata.

\section{Karmina. (Jpádána.)}

Karroo. Hottentot term for immense undulating plain, about 2000 feet above the sea, north of the Black Mountains of Cape Colony ; of rich clay soil, but unwatered.

Kat. (Cat.)

Katching oil. A very clear oil made of ground-nuts, used in India for cooking.

Kate. [Hind.] A plantation, a field.

Kayak. Fishing-boat of the arctic regions.

Kaxic. A fishing-boat of Shetland.

Kazy. [Hind.] A Mohammedan magistrate in India.

Keblah, Khebli. (Kiblah.)

Keckle, or Cackle. (Naut.) To cover a cable spirally with old rope.

\section{Kedge, or Kedger. (Anchors.)}

Kedgeree. An Indian dish of fish and rice.

Keel. [A.S. ceol.] (Naut.) 1. A low and flatbottomed Tyne boat for carrying coals to colliers. 2. The principal timber quasi-backbone of a ship. To give the $K$., to careen.

Keel-haul, To, or Keel-rake. (Naut.) To drop a man into the sea on one side of a vessel and haul him up on the other; dragging him under the $\mathrm{K}$.

Keelson, or Kelson. (Naut.) An internal keel above the floor timbers, and immediately over the keel.

Reep (that which keeps or protects). The innermost and strongest tower of a castle, in which treasure and prisoners of importance could be most carefully guarded.

Keeping-room. [Prov. Eng.] A common sitting-room, not the parlour, but the second best room. New England.-Bartlett's Americanisms.

Keesh. Flakes of carburet of iron on the surface of pig iron.

Keeve. [O.E. cyf.] A large vat used for fermenting liquor or dressing ores.

Keil, or Red clay. A deep red peroxide of iron, used in marking.

Kelp. [O.Fr. kilpe.] The ashes of burnt seaweed.

Kelpie. [Scot.] A horse-shaped water-sprite, which is supposed to forewarn any one destined to be drowned in the vicinity of the noises and lights which it gives forth.

Kelson rider. (False kelson.)

Kelt. Salmon after spawning.

Kelter. [Celt. celtoir, dress, matter.] 1. Order, condition. 2. (Naut.) In good order; applies to ships and men. (Kilter.)
Keltic languages. 1. Cyinric class : i.e. (I) Welsh; (2) Cornish; (3) Bas-Breton. 2. Gadhelic: (1) Erse, or Irish ; (2) Gaelic, spoken in Scotch Highlands; (3) Manx, in Isle of Man.-Morris, English Accidence.

Kemp, Kempty. Coarse rough hair in wool, injuring its quality.

Kennaquhair. [Scot., ken not where.] A fabricated name of an imaginary locality; of. Ger. weissnichtwo. (Utopia.)

Kent, Holy Maid of. (Holy Maid of Kent.)

Kepler's laws. (Johann K., born near Stuttgart, 1591, died 1630.) Certain laws relating to the motion of the planets, viz.: 1. They describe ellipses round the sun, which is in one of their foci. 2. The line joining a planet and the sun traces out equal areas in equal times. 3. The squares of their periodic times are as the cubes of their major axes.

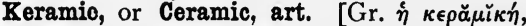
the (art) which has to do with к'́păuos, potter's earth.] Pottery. Kërămeikos, or Cërămīcus, in Athens, the potters' quarter.

Kerlanguishes. [Turk., swallows.] (Naut.) Fast sailing-boats of the Bosphorus.

Kermes. [Ar. for cochineal insect, from Skt. karmi, ziorm.] Dried insects used as a scarlet dye-stuff.

Kermes mineral (from its scarlet colour). An amorphous trisulphide of antimony used in medicine.

Kern. [Erse cearn, warrior.] 1. A footsoldier in Ireland or the Scottish Highlands. 2. (Leg.) Kernes, idlers, vagabonds. 3. In Printing, that part of a type which hangs over the body or shank.

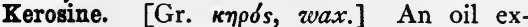
tracted from bituminous coal.

Kerseymere. (Cassimere.)

Ketch. [Fr. caiche, Sp. queche, D. kits.] (Naut.) A galliot-built vessel, with main and mizzen masts, of from 100 to 150 tons burden. $K$. bomb, one built very strongly, and carrying a master.

Ketch, Jack. Common name for the hangman in England; said to have been the name of that officer in the reign of James II., or a corr. of Jacquett's, from the name of the lord of the manor of Tyburn.

Kettle-boiling sound. (Med.) One of the chest-sounds heard at the beginning of phthissis.

Kettle-bottomed. (Naut.) Flat-bottomed.

Kettle-drums. Basins of copper or brass, with parchment stretched over the top.

Keuper of Germany [Ger. kupfer, copper] = uppermost division, red sandstones and marls, with salt and alabaster ; of the Triassic period.

Kevels, or Cavils. (Naut.) Large cleats, or pieces of timber above the rail, for belaying ropes to, etc. Kevel-heads, ends of top timbers, rising above the gunwale, and used as kevels.

Key; K.-seat. (Mech.) A small wedge for fixing wheels, pulleys, etc., to their shafts. The recess into which the key is driven is the $K$.-seat, called also $K$.-bed and $K$.-way.

Key-stone. The middle or uppermost vc ussoir of an arch. 
Khalif. (Caliph.)

Khamseen. [Âr., fifty.] A hot southerly wind in Egypt, because it blows for fifty days after Easter.

Khan. [Turk.] 1. King, chief. 2. An Oriental inn or caravanserai.

Khansaman-jee. [Hind.] Head-butler in India.

Khedive. 1. [Turk.] Title of the Porte's viceroy in Egypt. 2. [Pers.] Khediv, prince, sovereign.

Khidmut-gar. [Hind.] A footman in India. Khi-lin. (Kylin.)

Khotbah. [Ar.] A Mohammedan form of prayer, used in the great mosques on Fridlay at noon.

Kiabooca wood. Amboyna wood.

Kibble. [Ger. kuible.] A bucket in which ore is raised from a mine.

Kibe. [Cf. Skt. root jambh, from gabh, to snap, bite, said to be Welsh cibwst, from cib, cup, gwst, malady, as if rounded, swelling malady (Skeat, Etym. Dict.).] Chilblain, as if frost-bite.

Kibitka. [Russ.] A rude kind of waggon without springs, used by the Tartars; also used as a hut.

Kiblah. The point to which Mohammedans turn when praying. This point was at first Jerusalem; but Mohammed afterwards changed it to the Kaabah at Mecca.-Muir, Life of Mahomet, ch. x.

Kickshaw. [For Fr. quelque chose, anything whatever.] 1. Some fancy thing, hard to give a name to. 2. A fancy dish.

Kicksywicksy. A gibberish word, first used by Shakespeare, seemingly to denote restlessness, and applied contemptuously to a wife.

Kid. 1. A faggot or bundle of heath and furze. 2. (Deer, Stages of growth of.)

\section{Kiddow. (Guillemot.)}

Kieve. [Ger. kufe.] A large tub for washing ores

Riftis. (Naut.) A large Indian boat fitted with cabins on either side.

-kil-. Erse part of names, meaning hermit's cell or church, as in Kil-kerran, Church of St. Ciarran; Icolm-kill, Church of Island of St. Columba.

Kilhamites. (New Connexion Methodists.)

Killas. Local name for a Cornish group of schistose Devonian rocks, much altered near the granite, the elvan, and other dykes; in which lies a great part of the mineral wealth of Cornwall.

Kilogramme; Kilolitre; Kilomètre. Measures

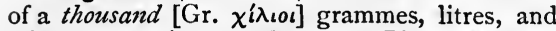
mètres respectively. (Gramme; Litre; Mètre.)

Kilter. (Used still in Suffolk.) Out of kilter, in a bad condition; out of shape. Halliwell notices the word kelter as provincial in England; and Barrow uses it with the prefixed "out of:" "If the organs of prayer are out of kelter, or out of tune, how can we pray?" (Barrow's Sermons).-Bartlett's Americanisms. (Kelter.)

Kimeridge clay. (K., near Weymouth, where the beds terminate.) (Geol.) A fossiliferous clay of the Upper Oolite, containing a bituminous shale, called Kim-coal.

Kindergarten. [Ger., lit. children's garden.] In Germany, a kind of infant school, where children of all classes of society, not yet old enough for school, are taken care of, generally from nine o'clock to one; with systematically arranged amusements, more or less instructive.

Kindfest. [Ger., child-feast.] 1. The Feast of Holy Innocents. 2. In N. Germany, a day once kept in memory of the invention of the child Jesus in the Temple.

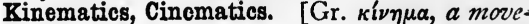
ment given.] The science of motion in its purely geometrical relations, without reference to the forces producing it.

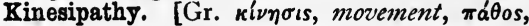
affection.] Treatment of disease by appropriate movements, exercises of the limbs.

Kinēsis. Any kind of morbid affections of movement [Gr. kivnoเs].

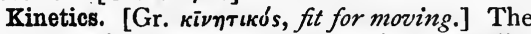
science which determines the motion of bodies due to the action of forces.

Kineton, Battle of. Now always spoken of as B. of Edgehill, October 23, 1642 (see Clarendon's Hist. of Kebellion).

King-at-arms. (Her.) An heraldic officer whose business it is to declare war, arrange coronations, etc. ; the chief of the three Garter kings-at-arms. Clarencieux and Norroy superintend the provinces south and north of the Trent respectively.

King-bird. (Ornith.) Spec. of shrike, eight inches long, black and grey, with red crest. America. Ty̆rannus intrěpĭdus [L., intrepid tyrant], sub-fam. Ty̆rannīnæ, fam. Ty̆rannĭdæ, ord. Passěres.

King James's Bible. -(Bible, English.)

King Iog. The log sent to the frogs in Assop's fable, when they asked Jupiter for a king.

King-post. (Arch.) The middle post of a roof, supported by the tie-beam and reaching to the ridge. (Strut.)

King's Book. 1. (Liber Regis.) 2. A Necessary Erudition of any Christian Man, A.D. 1543, put forth under sanction of King (Henry VIII.) and Convocation ; a revision of the Institution, etc., or Bishops' Book (q.v.).

King's evidence (or Queen's). One who, having been an accomplice in some crime, confesses, offering all the evidence he has to give; generally pardoned, but not absolutely entitled to pardon ; admissible by the judge as a witness in the trial of fellow-criminals.

King's evil. Popular name for scrōfula, once believed to be curable by a royal touch. Clovis touched, A.D. 48I ; and English sovereignsEdward the Confessor to Anne-and Prince Charles Edward at Holyrood, 1745. An Office for the ceremony appears in our Liturgy as late as 1719.

King's Men, King's Friends. A cabal, separating the court (of George III.) from the Administration, controlling the ministry, "intercepting the favour, protection, and confidence of the Crown, ... coming between them and their 
importance in Parliament, ... the whole system called the Double Cabinet," and "throwing everything more and more into the hands of the interior managers." -Burke, Prescn' Discontents.

King's Qnhair, i.e. Quire. A collection of love-verses of great beauty and merit, written by James I. of Scotland (assassinated A.D. 1437), in imitation of Petrarch.

King Stork. The stork sent by Jupiter to rule the frogs, when dissatisfied with King Log $(q . v$.$) . K. S. began at once to gobble up his$ subjects.

King's yellow. Orpiment.

Kingwood. A violet-streaked Brazilian wood used in turnery, etc.

Kino. [E.-Indian word.] An astringent extract obtained from certain tropical trees.

Kiosk. [Turk.] 1. An open Turkish summer-house, consisting of a roof supported on light pillars. 2. Such a structure used as a newspaper stall or flower stall in Paris, etc. [Pers. and Turk. kouchk, a "belvédère" (Littré).]

Kipper. A salmon split open, salted, and dried or smoked.

Kips. The skins of young animals for tanning.

Kirk. The Scottish form of the word Church, connoting also the Presbyterianism of the Establishment.

Kirschwasser. [Ger., cherry-water.] A spirituous liquor made by fermenting the sweet and small black cherry.

Kirtle. [A.S. cyrtel, Dan. kiortel.] A jacket or short gown, a mantle, an outer petticoat.

Kish. A substance like plumbago, which forms in a blast furnace.

Kismet. [Ar., it is decreed.] Mohammedan expression of resignation to what is fated.

Kissing-crust. A projecting piece of upper crust which has touched another loaf in baking.

Kist. [Hind.] An instalment of tax or rent paid by ryots in India to Government.

Kit. 1. (Mil.) The whole of the necessaries carried by a soldier in his knapsack. [For K. in the sense of a collection, a brood, $c f$. D. kudde, $a$ flock, Bav. kïtt, and Ger. kette, a covey of partridges (Wedgwood).] 2. A small violin, about sixteen inches long, used by dancingmasters; (?) carried in the kit or pocket. K. is in Fr. pochette.

Kit-cat. Canvas measuring twenty-nine inches by thirty-six, for portrait-painting.

Kit-Cat Club. Circ. I688; at first simply convivial, afterwards in Queen Anne's reign exclusively political, its members devoted to the Hanoverian succession; among them were Addison, Steele, Walpole, etc. (Christopher Cat supplied the club with mutton pies.) Sir G. Kneller, a member, accommodated a newsized canvas to the height of the walls; hence Kit-cat, $=$ three quarters' length.

Kitchen-middings, Kjokkken-middings (Midden), Shell-mound', of Denmark. Refuse-heaps - Neolithic-containing all kinds of household objects, either thrown away or lost; but not any remains of extinct animals, nor any trace of metal.

Kite. [Welsh cûd, O.E. cyta, (?) from its chiding cry.] 1. (Ornith.) Milvus vulgäris [L., common kite], a bird of the sub-fam. Âquilinææ, twenty to twenty-six inches long ; reddish-brown forked tail. Fam. Falcōnŭdæ, ord. Accipurtres. 2. (Ichth.) Rhombus [Gr., diamond-shape] vulgāris [L., common], the brill, a fish of the fam. Pleurónectǐdæ, smaller than turbot; colour light and dark brown, speckled with white. Ord̆. Ănăcanthǐni, sub-class Tĕlĕostěĩ.

Kiteflying. [Amer.] An expression well known to mercantile men of limited means or who are short of cash. It is a combination between two persons, neither of whom has any funds in bank, to exchange each other's cheques which may be deposited in lieu of money, taking good care to make their bank accounts good before their cheques are presented for payment. - Bartlett's Americanisms.

Kith. [A.C. cyð, Ger. kunde, acquaintance, knowledge, from A.S. cunnan, to ken, know.] Acquaintance, people whom one knows.

Kit's Coty House. A well-known cromlech $(q . v$.$) between Maidstone and Rochester.$

Kittiwake. (So named from its cry.) Spec. of gull, fifteen or sixteen inches long; plumage grey and white, varying with age and season, hind toe rudimentary. Widely distributed. Lărus trĭdacty̆lus [Gr. $\tau \rho \in i s$, three, $\delta \alpha ́ \kappa \tau v \lambda o s$, finger, toe], gen. Lărus [Gr. and L., gull], fam. Lărĭdæ, ord. Ansěres.

Kiwi-kiwi. (Native name.) (Apteryx.)

Klaus, Peter. A German goatherd of Sittendorf, whom a magic draught sent to sleep for twenty years.

Kleptomania. [Coined from Gr. $\kappa \lambda \epsilon \in \pi \tau \omega, I$ steal, $\mu \alpha \nu i \alpha$, madness.] A morbid desire to steal, in persons neither poor nor uneducated.

Kloof. [Boer.] A cleft, or rocky ravine, in S. Africa

Knapsack. [(?) Ger. knappe, a journeyman, sack, bag.] (Mil.) Waterproof receptacle carried on the back or loins of an infantry soldier, to contain spare clothing and necessaries.

Knee. In ship-building, is an angular piece of wood or iron, connecting the deck-beams with the ribs of the vessel.

Knee; K.-timber. A knee. In $K$.-timber, the bend has been produced naturally in the growth of the tree.

Knee-rafter, Crook-rafter. (Arch.) A rafter of which the lower end is crooked downwards to rest more firmly on the wall.

Knife-board. The outside seat along the front of an omnibus, with the driver's box in the middle; so called from the shape of the footboard.

Knight-heads. (Naut.) 1. Two large timbers for supporting the bowsprit, rising above and on each side of the stem, i.q. Bollard timbers. 2. In merchant ships, the bitts supporting the ends of the windlass, on the main-deck. 3. The lower jear-blocks, which were formerly bitts with sheaves in them.

Knight of the shire, $K$. of Parliament. A county M.P. ; town members being Burgesses.

Knight-service. (Leg.) Tenure in chivalry, 
created by investiture with a Knight's fee of twelve plough-lands, i.e. 800 or 680 acres, worth $£ 20$ a year, the tenant giving homage, fealty, and forty days' military service a year, and eventually other harassing services. This tenure did not always imply the amount of land mentioned.

\section{Knight's fee. (Knight-service.)}

Knights Hospitaller, $\mathbf{K}$. of St. John of Jerusalem, $\mathbf{K}$. of Rhodes, $\mathbf{K}$. of Malta. (Hospitaller.)

Knittles. (Naut.) Small lines used as points for reefing, etc.

Knobkiri. A club varying in length from one to six feet, terminated by a knob, and used, the smaller ones as missiles, by the natives of S. Africa.

Knob-stick. A man who does not belong to a trades-union, and who works during a strike.

Knot. [Akin to L. nōdus.] (Naut.) 1. K. to be tied. (Hitch.) 2. K. on the log-line is the $\frac{1}{2} \frac{1}{0}$ th of a Geog. or Naut. mile. Hence the number of knots run per half-minute gives the number of miles per hour, which are consequently termed knots, and $=2025$ yards approximately.

Knott. In names of places, $=$ a small round hill, as in Ling Knott.

Knout. [Russ.] A whip, consisting of a handle two feet long, a leather thong four feet long, with a metal ring at the end to which the striking part is attached, i.e. a flat tongue of hardened hide two feet long. It is used for torturing human beings.

Know-nothings. Founded, 1853 , by an exmidshipman, Ned Buntline. A secret, exclusive, political order; none to be admitted whose grandfathers were not American natives; in answer to every question, they "knew nothing." They maintained-(1) repeal of all naturalization laws ; (2) none but native Americans for office; (3) a pure American common school system; (4) war on Romanism.-Bartlett's Americanisms.

Knubs. W/aste silk formed in winding off the threads from a cocoon.

Knur, Knurl, Knar. [Cf. Ger. knorren.] 1. A knot, a hard lump. 2. A slender club used in the Yorkshire game of $\mathrm{K}$. and spell.

Koala. 1. A name for the jackal in the Marathi language. 2. (Wombat.)

Kobold. A German word denoting a spectre, and answering to the Eng. goblin.

Kobus. (Zool.) A gen. of cervicaprine antelope. Trop. Africa.

Koff. (Naut.) A large Dutch coaster, twomasted, with spritsails.

Koodoo, Kuda. (Zool.) Trăgĕlăphus strepsǐ. cěros, one of the handsomest of bovine antelopes. African highlands, from Abyssinia seawards. Fam. Bǒvǐdæ, ord. Ungŭlāta.

Kookrie. Broad-bladed knife, with concave edge and sharp point, used for all purposes by the Ghoorkas of the Himalayas.

Kopeck, or Copek. [Russ.] The hundredth part of a rouble, and $=I \frac{1}{2}$ farthing of English money.

Koppa. Name of a letter of the oldest Greek alphabets, which fell into disuse. It is preserved in Latin, etc., as $q$; $c f$. Heb. koph. It is written $Q$, and was used by the grammarians to represent the numeral 9o. (8ampi.)

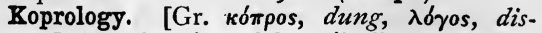
course.] The doctrine of the evil effects of animal or vegetable decomposition of any kind.

Koracora. (Naut.) A Molucca vessel, common in the Malays, broad-beamed, with high stem and stern, and an outrigger.

Kosmos. [Gr. $\kappa \delta \sigma \mu o s$.$] (Cosmos.)$

Koth. A shiny earthy substance, ejected from some $\mathrm{S}$.-American volcanoes.

Koumiss. [Native word.] A spirituous drink distilled from mare's milk, used by the Tartars.

Kowtow, Kootoo, Kotou. [Chin.] A bowing to the earth in deferential self-abasement.

Kraal. [D.] In S. Africa, an inclosure, a collection of huts in a stockade.

Krabla. (Naut.) A Russian vessel, used in the Arctic fishery.

Krang, Kreng. The fleshy part of a whale after the blubber has been removed.

Kremlin, The. A palace at Moscow, begun I367 ; fortified 1492. Burnt during the occupation of Napoleon I., I812 ; rebuilt, 1816.

Krems, Crems, Kremnitz white. A white carbonate of lead (from Crems, in Austria).

Kreosote, Creosote. [Gr. крє́as, flesh, $\sigma \omega \zeta \omega, I$ preserve.] A principle in pyroligneous acid and all the tars, having the property of preserving animal matter; used externally and internally.

Kreutzer. [Ger.] The sixtieth part of a Bavarian and the hundredth part of an Austrian florin; formerly stamped with a cross [Ger. kreuz].

Kriss-Kringle. [Ger. Christ Kindlein, the Infant Christ.] The German for child is kind, of which the diminutive is kindlein or kindchen. This, in some parts of Germany and in Pennsylvania, has been formed into kindel, and the children are promised gifts at Christmas from " Christ-Kindel."-Bartlett's Americanisms.

Kroomen, or Crew-men. (Naut.) Fishmen. An African tribe, British subjects, Cape Palmas; they get in wood and water where the climate is dangerous for Europeans.

Kruller. A curled crisp cake fried in fat.

Kshatrya. (Caste.)

Kūdos. [Gr. кî́os.] Honour, glory.

Kufio letters. The characters of the ancient Arabic alphabet ; so called from Kufa, a town on the Euphrates.

Kulian. [Hind.] A kind of pipe for smoking. Kummerbund. [Hind.] A girdle.

-kund. [Hind.] Part of names, = province, as in Bundel-kund.

Kupfer-schiefer. Copper-slate. (Geol.) A member of the Permian system in Germany; a source of copper from time immemorial ; represented in Engiand by the marl-slate of Durham.

Kutkubala. A mortgage-deed in India.

Kyanizing. (From Kyan, the inventor.) Saturating wood with a solution of corrosive sublimate, to preserve it from dry-rot.

Kyle. A district extending across the middle of Ayr county, from the Norman to the Stuart period. 
Kyley. [Austral.] A boomerang.

Kylin. A Chinese four-footed scaly monster, with dragon-like head and serrated back, supposed to bring good luck.

Kyloes. 1. Ferries between the mainland and western isles of Scotland. 2. The cattle from those districts.

Kärie, The. [Gr. Kúpıє, O Lord!] 1. A term applied to the Lesser, or Short, Litany; and sometimes, 2, applied also to the expanded form of Kyrie eleeson, which forms a responsory to the ten commandments in the Book of Common Prayer. (Litany ; Liturgy.)

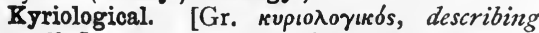
literally.] A term denoting that class of Egyptian hieroglyphics in which a simple picture represents the thing meant ; in contrast with tropical or symbolical representation.

\section{I.}

I. As an abbrev. among the Romans, stood for the prænomen Lucius ; sometimes also for lex, latum, libens, libertus, etc. The form L.L.S. denoted a Sestertium. As a numeral, it stands for 50 .

Laager. [Boer.] A temporary defensive inclosure, formed of waggons, in S. Africa.

Labădists. (Hist.) A sect of the seventeenth century; so called from Jean Labadie. They resembled the Quietists.

Lăbărum (?). The standard of Constantine, made in commemoration of the alleged vision of the cross in the heavens; said to have been a lance, with transverse rod, from which hung a purple veil ; above it, a golden crown encircled the monogram XP, i.e. CHR. The word was also written Laborum, as the Gr. forms are

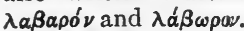

Labdacism. [L. labdăcismus, from $\lambda \alpha ́ \beta \delta \alpha$, $\left.\lambda_{\alpha} \alpha \beta \delta \alpha, \Lambda \lambda, L l.\right]$ (Lang.) 1. Frequent repetition of $L$. 2. A wrong pronunciation of $L$; as when pronounced like $l l, l y, y y$.

Label. [L. lăbellum, a little lip.] 1. (Her.) A Fillet, with three or more pendants, borne as the difference in the eldest son's escutcheon. 2. (Arch.) (Dripstone.)

Labial. [L. lăbia, a lip.] (Lang.) Articulated with the lips; as the vowels $u(o o), o$, and the consonants $p, p-h, b, b-h, m$, the Mod. Gr. $\phi$, Ger. $w$.

Labialization. (Labial.) (Lang.) The tendency to change or the process of changing articulate sounds to labials or labiodentals; as i.e. Skt. katvâr to Goth. fidvor, Eng. four ; Skt. gâus to Boús, bos, ox.

Labiate [L. lăbia, a lip] plants. (Bot.) An ord. of exogens, with corolla divided into upper and lower lips; as rosemary, dead-nettle, snapdragon, etc.

Labiodental. [L. lăbium, a lip, dens, -tem, $a$ tooth.] Pronounced by co-operation of the lips and teeth.

Labiolingual. [L. labiæ, lips, lingua, tongue.] Sounds articulated by rounding or slightly protruding the lips, while the tongue takes some vowel position; w, hw. Perhaps $u, o$, are better called L. than labials.

Lăbor omnia vincit imprŏbus. [L.] Obstinate labour conquers everything (Virgil).

Lăbōrum dulce lěvāmen. [L.] Sweet soothing of $m y$ toils (Horace).
Labouring force. Mechanical work. (Work.) Labrador felspar, Labradorite. (Geol.) A lime-felspar, with beautiful chatoyant play of colours.

Labrador series. (Laurentian.)

Laby̆rinth. [Gr. $\lambda \alpha \beta \hat{p} \rho \iota \nu \theta 0 s$.$] 1. Properly a$ place full of inextricable windings, as the $\mathrm{L}$. of Dædălus. (Dædalean.) 2. (Anat.) The internal ear, the cochlea and semicircular canals; so called from their complexity. 3. A system of canals through which water is transmitted so as to carry off and deposit in certain places the ground ore of a metal.

\section{Labyrinthodon. (Cheirotherium.)}

Lac. [Hind.] One hundred thousand rupees.

Lac. [Pers. lak.] A resinous substance, produced mainly on the banyan tree, the puncture of a small insect. Stick lac is the sub. stance in its natural state, incrusting small twigs. When broken off and boiled in alkali, the residuum is called seed lac. When melted and reduced to a thin crust, it is called shell lac, or shellac. Barbados lac is petroleum from the W. Indies.

Lăcerta. [L., a lizard.] (Zool.) Gen. of lizard, giving name to fam. Lăcertı̌dæ, landlizards, and to ord. Lăcertǐlía.

Lăcertus. [L.] (Anat.) The upper muscular part of the arm.

Laches. [Fr. lâcher, to slacken.] In Law, negligence, delay; e.g. in an heir to enter; a ground for refusing relief in courts of equity. (Vigilantibus.)

Laconism. A short and pithy sentence or adage; so called from the Spartans (Laconians), whose speech was thought to be characterized by such sayings.

Lacquer. A solution of shell lac in spirit, with gamboge, etc., forming a yellow varnish for brass and other metals.

Lacrosse. (Crosse, La.)

Lacryma Christi. [L., tear of Christ.] A dark red Italian wine, much praised.

Lacrymatory. [L.L. lacrymātōrium, from

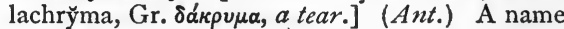
given to small, narrow-necked vessels found in ancient sepulchres, which were supposed to contain the tears of the mourners, with the ashes of the dead.

Lactation. [L. lacto, I suckle.] Suckling; the act or the period. 


\section{Lacteals. (Absorbents.)}

Lactic acid. An acid procured from milk [L. lac].

Lactometer. A hydrometer made specially for finding the specific gravity of milk, and thereby determining its value.

Lactose. [L. lac, lactis, milk.] Sugar obtained by evaporating milk.

Lăcūns. A small opening, gap, hiatus.

Lacustrine. Belonging to a lake [L. lăcus]. (Lake-dwellings.)

Lade. (Naut.) To L. a boat, i.q. to bale it out, or empty it of water. L.-gorn, or L.-pail, a bucket with a long handle, to $\mathrm{L}$. with.

Laden. (Naut.) Having a full cargo. $L$. in bulk, with the cargo not inclosed in casks, bales, etc., but loose in the hold.

Ladia. (Naut.) A clumsy Russian boat, used for inland carrying trade.

Ladino. (Lang.) A mixed Latin dialect of the Upper Engadine, distinct from Romansch.

Ladrone-ship. [It., robber, L. latrōnem.] (Naut.) Strictly a pirate, but used by the Chinese to signify a man-of-war.

Lady. [A.S. hlæfdige.] The wife of the lord, A.S. hlaford, perhaps = hlafweard, warder of bread.-Max Muiller, Lectures on Language, 2nd series.

Lady Bountiful. A benevolent old lady in Farquhar's Beaux's Stratagem, who goes about making all kinds of cures.

Lady chapel. A chapel dedicated to the honow of the Virgin Mary, often placed to the east of the choir or chancel of churches.

Lady Huntingdon's Connexion. (Whitefieldians.)

Lady of the gunroom. (Naut.) The gunner's mate.

Iady's smock, i.e. our Lady's smock. (Cuckoo flower.)

Lagado. In Swift's Gulliver's Travels, a city famous for its academy of projectors, who plan scientific impossibilities.

Lagan. (Flotsam; Ligan.)

Lager beer. [Ger. lager, store, bier, beer.] A German beer, which is kept in store for some months before drinking.

Iagging. The clothing of steam boilers, etc., to prevent radiation of heat.

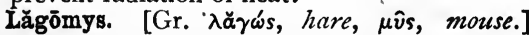
(Zool.) Calling hare, or pika. Gen. of mountain rodent, giving name (Lăgōmy̌ĭdæ) to a fam. of which it is the only gen., ranging from the size of the rat to that of the guinea-pig. Ural Mountains, Himalayas, Siberia, Rocky Mountains.

Lagoon, or Lagune. [L. lăcūna, a natural cavity, $a$ pool.] 1. The sea-water inclosed by the ring of coral land which forms a coral island. 2. The lagoons at Venice are the channels formed by the sea between the marshy places near the city.

La grande nation. [Fr.] The great nation; i.e. the French.

Laid paper. Writing-paper having a surface as it were inlaid with lines. It is called cream. laid or blue-laid from its colour.
Iaid-to. (Naut.) Sometimes used for hoveto; but, when laid-to, the sails are kept full.

Laissez aller. [Fr.] Let go.

Laissez faire. [Fr.] let do.

Iake-dwellings ; Crannoges, Ireland and Scotland; Pfahlbauten, Pile-dwellings, Switzerland. Fortified islands, stockaded villages, built upon piles; stone and bronze ages, and perhaps iron. (See Herodotus, v. 16, an account of Lake Prasias.)

Lakes. [Fr. laque.] Insoluble compounds of animal or vegetable colouring matter, with hydrate of alumina or other metallic oxide.

Iake school. Originally a contemptuous, now a recognized, name for the school of poets of whom Wordsworth, Southey, Coleridge, were the most eminent; they lived chiefly at the English lakes.

Lallation. [L. lallāre, to sing, lullably; cf. Gr. $\lambda a \lambda \epsilon i \nu$, to prattle.] (Lang.) Pronouncing $l$ instead of $r, \lambda$ for $\rho$, as Alcibiades was said to do.

Lama. A Mongol name for priests in general. The Grand Lama, who resides at Lassa, in Thibet, is called the Delai Lama. (Talapoins.)

Lambdacism. (Labdacism.)

Lambeth Articles. Nine Calvinistic statements, drawn up at Lambeth, 1595, by Archbishop Whitgift and others.

Lambeth degrees. Those conferred, in any of the faculties, by the Archbishop of Canterbury.

Lambrequins. [Fr., a Flemish word for a veil or mantle. (Her.) The mantling of an escutcheon.

Iāmellibranchīāta, Lamellibranchiates. [L.

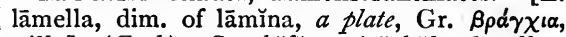
gills.] (Zool.) Conchifëra, Acëphăla, headless bivalve molluscs, with lamellar gills, as oysters. Lamellirostrals, Lamellirostres. [L. lāmella, dim. of lāmina, a plate, rostrum, $a$ bill.] (Ornith.) A tribe or fam. of water-birds (e.g. ducks), viewed as characterized by small lāminæ, or plates, set round the margin of their mandibles.

Lamǐa. [L. and Gr.] Imaginary beings of Gr. and L. Myth., resembling Vampires.

Lamirdæ (from their strange appearance). (Iamia.) (Entom.) Subdivision of Longicorn beetles, living on timber trees.

Lāmina. [L., $a$ thin layer.] (Bot.) The blade of a leaf; the upper part of a clawed petal ; e.g. pink.

Laminated. [L. lāmǐna, a thin 'layer.] Divisible into thin layers or plates.

Lammas Day. August $I$, one of the four cross quarter days, a festival of the Romish Church in memory of St. Peter's imprisonment. (? Lattermath, or Loaf-mass, A.S. hlaf-mæsse, thanksgiving for firstfruits of corn, or from the custom of bringing a lamb alive into the church at High Mass this day, John xxi. 15.)

Iammergeier. [Ger., lamb-vulture.] (Ornith.) Bearded vulture, Gier eagle. (Bibl.) Largest bird of prey of Old World; greyish brown, dashed with white above, nearly white below.

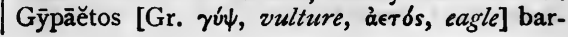


batus [L., bearded], sub-fam. Vultŭrīnæ, fam. Vultŭrĭdæ, ord. Accīprtres.

Lampădēphŏrǐa. [Gr., a torch-hearing.] (Hist.) A celebrated torch-race at Athens. If the torch of the runner, who had to hand it on unextinguished to another, went out, he lost the race.

Lampas. In horses, inflammation of the bars of the mouth, especially in young horses, while shedding teeth or putting up the tushes, sometimes from overmuch corn after a run at grass ; the mucous membrane of the mouth swelling and projecting below the level of the nippers.

Lampoon. [Fr. lampon, a drinking song.] A satire pointed with a strong personal feeling against individuals, as distinguished from the Satire, directed against vice and folly.

Lampshells. (Zool.) Tërebrätülìde [L., dim. of tĕrebra, borer]; fam. of bivalves, having unequal but symmetrical valves, pierced at the beak, and full of minute holes. Earliest known form of animal life. All seas. Class Brāchǐŏpŏda.

Lan-. (Ilan-.)

Lanate, Lanated. [L. lāna, wool.] Having woolly hair.

Lance. (Mil.) Long spear-at one time eighteen feet, now nine feet three inches-sometimes ornamented with a flag ; used by cavalry. Five regiments of light cavalry are at present so armed.

Iance-corporal. (Corporal.)

Iancelot. (Sangreal.)

Lanceolate leaf. [L. lancěŏlātus, having $a$ lancěola, small lance.] Like a lance-head; e.g. the lanceolate pinnate frond of lady-fern.

Lancet style. (Geometrical style.)

Lanchang. A proa of Malay, carrying from twenty-five to thirty men.

Lancinating pains; opposed to dull or aching (wrongly formed from lancea, a lance). (Med.) Piercing as if with a sharp instrument. [Lancination properly means tearing in pieces; L. lancino, I tear, rend.]

Landamman. [Ger. landamtman, country office-man.] 1. The President of the Swiss Federal Diet. 2. The chief magistrate of some Swiss cantons.

Landau (first made at Landau, in Germany). A four-wheeled carriage, whose upper part can be opened and thrown back.

Iandes. [Fr., Ger. lande.] Waste lands, especially the desolate unproductive tracts on the Bay of Biscay, between the Gironde and the Pyrenees.

Iandgrave. [Ger. landgraf.] A title assumed by some German counts in the twelfth century, to distinguish themselves from the inferior counts under their jurisdiction. This was the origin of the Landgraves of Thuringia and Elsas (Alsace)

Landlouper. [Cf. Dan. landlooper, country runner, Ger. laufen, to run.] A vagrant, a vagabond, land-lubber.

Landsman. (Naut.) The old rating for a man who had never been at sea before, now rated second-class ordinary.

\section{Iandsturm. (Levée en masse.)}

Landwehr. [Ger., land-defence.] Militia.

Langued. (Her.) Having a tongue [Fr. langue] different in colour from the body.

Langue d'oc. (Lang.) The dialect of Provence, also called Romance; opposed to the less Roman Lanoue d'oyl of Frankish-Gaul. The former used oc [L. hoc] where the latter used oyl [illud]. (Troubadours.)

\section{Iangue d'oyl. (Langue d'oc ; Trouveres.)}

Laniard, Lannier, or Lanyard. [Fr. lanière, $a$ thong or strap.] (Naut.) Pieces of rope or line made fast to anything as a handle, or to secure it.

Lănǔĭdø. [L. lănius, $a$ butcher.] (Ornith.) Shrikes, butcher-birds. Fam. of Dentirostrals, ord. Passěres.

Lănista. [L.] A trainer of gladiators.

Lansquenet, Lasquenet. [Ger. landsknecht, country boy.] 1. Originally a German camp follower, a German mercenary foot-soldier. 2. A game at cards; called also Lambskinnet.

Iantern. [L. lanterna.] In Eccl. Arch., the central tower of a church is so called when it is open internally to the top, as in Canterbury Cathedral and York Minster.

Iantern, or Lantern-wheel. Consists of two parallel discs with equidistant holes cut in them near their circumferences ; into these holes cylindrical wooden pegs are passed, so that the whole forms a sort of cage; the wheel or cage thus formed serves as a follower to work with an ordinary driving toothed wheel.

Lantern of Aristotle (described by A.). Internal skeleton of globular sea-urchin, carrying five incisor teeth like those of rodents.

Lanthănum, Lantanum, Iantanium, Lanthanium. A metal found with cerium, whereby its properties were at first hidden [Gr. $\lambda \alpha \nu \theta \alpha^{\prime} \nu \in \iota \nu$, to lie hid].

Lanuginous. [L. lānūgĭnōsus, from lānūgInnem, soft down, woolly substance, from lāna, wool.] (Anat. and Bot.) Downy.

Lanx. [L.] A platter, a dish.

Laŏcŏōn. [Gr.] (Myth.) A Trojan priest who tried to dissuade his countrymen from admitting the wooden horse within the walls of Troy, and who was crushed by the folds of an enormous snake which destroyed his two sons with him. The story has gained celebrity from the ancient sculpture representing it, which is now in the Vatican.

Lap. A piece of soft metal used to hold (as in a $l a p$ ) powder for cutting gems or polishing cutlery. It is usually in the form of a revolving wheel.

Iapidary. [L. lapid, -em, a stone.] One who cuts, polishes, and engraves precious stones.

Lapìdes Judaici. [L.] Stones of Fudaa, siliceous accretions, sometimes shaped exactly like little loaves of bread (see Matt. vii. 9; Luke iv. 3).

Iăpis lăzuli, Iăzulite. [It. azzuolo, dark blue.] A mineral, crystalline and massive, of beautifu] azure or ultramarine; much used anciently for engraving, etc. ; found in many parts of the world; (?) the sapphirus of antiquity. (For 
different statements of analysis, see English Cyclopadia.)

Lapithæ. [Gr. $\lambda a \pi i \theta a$. .] A mythical people, who are said to have had many contests with the Centaurs.

Lapping. [O.E. to lap, = to wrap.] Wrapping material used by calico-printers.

Lapsoourse. (Lobscouse.)

Lapse. [L. lapsus, $a$ slip.] (Eccl.) The omission of a patron to present to a benefice within six months of avoidance; the right then devolves to the bishop. If bishop omit, then to archbishop; if archbishop, then to the Crown.

Iapstone. A stone held in the lap, on which shoemakers beat leather.

Iapsus călămi. [L.] $A$ slip of the pen.

Lapsus linguæ. [L.] $A$ slip of the tongue.

Laputa. In Swift's Gulliver's Travels, an aerial island, moved and guided by a huge loadstone, and full of absent-minded philosophers.

Lapwing. [Heb. dukiphath; Lev. xi. I9.] (Bibl.) The hoopoe, Upŭpa ěpops; about thirteen inches long, buff, barred with black and white, buff crest tipped with black. Fam. Upŭpĭdæ, ord. Passěres.

Laquais. [Fr.] Footman, lackey.

Laquais de place. [Fr.] Cicerone, guide.

Lăquear. [L.] (Arch.) A ceiling, with hollowed or depressed compartments divided by spaces or bands, a fretted ceiling ; originally one of the depressed compartments themselves.

Larboard. (A-beam.)

Larbolins. (Starbolins.)

Larceny. [L. latrōcĭnium.] Theft, abstraction and appropriation of personal property belonging to others, a species of felony. $\mathrm{L}$. under the value of $12 d$. used to be called petit; otherwise, grand.

Iarding money. Paid yearly by tenants of Bradford Manor, Wilts., for liberty to feed their hogs with the mast of the lord's wood.

Lărēs. [L.] (Myth.) 1. The Latin household gods, regarded as the spirits of deceased ancestors. 2. Latin gods of the city, the roads, etc., an extension of the same idea to the country generally. (Penates.)

Largess. [Fr. largesse, L. largĭtio, from largus, large.] Bestowal, a gift. Commonly used in the knightly language of the Middle Ages.

Iariat. [Sp. la reata.] A rope made with thongs of raw hide twisted or braided, and sometimes of sea-grass, used for catching and picketing wild horses or cattle. Some writers incorrectly say a riata. It is also called a lasso.Bartlett's Americanisms.

Lărǐdæ. (Larus.) (Ornith.) Gulls and terns ; fam. of shore-birds. Universally distributed. Ord. Ansěres.

Larmier. [Fr.] (Arch.) A dripstone, to carry off the rain [larmes, tears of water]. The same as Lorymer.

La royne le veult. The old Norm. Fr. used by the Clerk of the Parliaments in giving, on behalf of the Queen, her royal assent to Acts is : to Acts granting public money, commonly called Money Bills, "La royne remercie ses bons sujets, accepte leur benevolence, et ainsi le veult," The Queen thanks her good subjects, accepts their aid, and assents; to all other public Acts, and to such private A. as Railway Company A., Acts for towns and gas, water, etc., simply "La royne le veult," The Queen assents; to A. affecting private individuals, their rights, estates, naturalization, etc., "Soit fait comme il est desiré," Be it done as desired; upon a petition demanding a right, whether public or private, "Soit droit (the right) fait comme il est desiré."

I'art pour l'art. [Fr.] Art for art; said of the practice of an art or science for its own sake, without regard to any object or result.

Iắrus. [L., Gr. $\lambda$ ăpos.] (Ormith.) Gull. Large and universally distributed gen. of Lărĭda $(q . v$.$) .$

Iarva. [L., a ghost, a mask.] (Entom.) An insect as it emerges from the egg; e.g. a caterpillar.

Iarvæ. [L.] The name given by the Romans to the spectres of the dead.

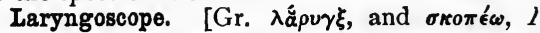
look at.] An instrument, having two mirrors, for viewing the larynx.

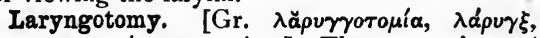

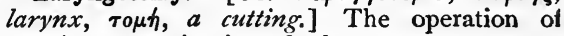
opening or cutting into the larynx.

Larynx. [Gr. $\lambda \dot{x} \rho v \gamma \xi$.] The organ of voiceits parts many and complex-between the trachea, or windpipe, and the base of the tongue.

Iasciate ogni speranza, voi, che 'ntrate. [It.] Abandon all hope, ye who enter; ending of inscription over the gate of hell (Dante's Inferno, canto iii.).

Iaskets. (Naut.) Small lines sewn to the bonnets and drablers, to secure them to each other and the bonnets to the sails.

Lasks. 1. Indian cut stones. 2. Diarrhœea (in old books).

Lassitnde. [L. lassitūdo, from lassus, akin to laxus, loose.] Probably a state of relaxation; hence the sense of heaviness or weariness.

Iasso. [Sp. lazo, from laqueus, a noose.] A rope ending in a noose, used for catching wild horses, etc. (Drag-ropes.)

Iasting. A very durable woollen stuff.

Latakia. A superior kind of tobacco, for cigarettes, etc., from Latakia (Laodicea), in Syria.

Latching keys. (Naut.) Loops on bonnet's head-rope, for lacing it to the sail.

Iăteat scintillula forsan. [L.] Perhaps a tiny spark (of life) may lie concealed; of the apparently drowned. Motto of the Royal Humane Society.

Iateen sail. [Fr. voile latine.] (Naut.) A triangular sail, having its foremost leech bent to a yard, which hoists obliquely to the mast.

Iatent heat [L. lăteo, $I$ lie hid] of a substance is the quantity of heat required to convert a unit of mass of that substance from the solid to the liquid (or from the liquid to the gaseous) state without change of temperature.

Latěran. A church at Rome, originally a palace of the family of the Lateranini, seized by 
Nero and made an imperial residence ; bestowed by Constantine on the popes. Eleven Councils have been held in this basilica.

Lateran Councils. A term especially used of five C. held in the Church of St. John Lateran, at Rome ; the last (1215), under Innocent III., established the Roman doctrine of the Eucharist, using the word "transubstantiation." But ' L. C., with Dr. Hook and others, $="$ all the Councils of the Roman Church."

Lătĕrem lăvas. [L.] You are washing $a$ brick; i.e. an unburnt brick; you are making bad worse.

Laterite. [L. lăter, $a$ brick.] (Geol.) Disintegrated gneiss, generally red; e.g. the indurated, reddish clayish alluvium in many parts of India.

Iătĕt anguis in herba. [L.] $A$ snake lies hidden in the grass.

Lătex. [L., a liquid of any kind.] (Bot.) The fluid of vegetation; the sap.

Lathbrick. A long slender brick like a lath, on which malt is placed in the drying kiln.

Iathe; Engine-L. ; Foot-L. ; Hand-L. ; Power-L. A machine for turning wood or metal. A Foot-L. is worked by the foot acting on a treadle. An Engine-L., or Power-L., is worked by steam-power, and has an automatic feed for bringing the substance to be shaped up to the cutting tool. In a Hand-L. the cutting tool is brought up to the material and guided by the hand.

Lathes. [(?) A.S. geláthian, to assemble. Kent has from an early time been divided into five territorial divisions called L., each of them containing several hundreds : they formerly had distinct courts superior to the hundred courts.

Lathrending. The business of making laths. Iati-. [L. lātus, broad.]

Latin. [L. lătinus, of Lătium.] (Lang.) The language of Rome and Latium.

Latin Church. (Eccl. Hist.) A name given to the Church of Rome and the Churches in communion with it, as distinguished from the Eastern Church, Orthodox, or Greek.

\section{Latin cross. (Cross.)}

Lătĭtat. [L., he keeps hid.] (Leg.) Name of writ by which a person was summoned into King's Bench (abolished in the reign of $W^{\prime}$ illiam IV.) to answer a personal action, he in all cases being supposed to be in hiding, so that he could not be found in Middlesex.

Latitude [L. latitüdo, breadth] ; Astronomical L.; Circle of L.; Geocentric L.; Heliocentric I. 1. (Astron.) The angular distance of a heavenly body from the ecliptic, measured along a great circle - a Circle of $L$. - at right angles to the ecliptic : if the earth is supposed to be at the centre, the latitude is Geocentric; if the sun, Helio centric. 2. (Geog.) The Latitude, or Astronomical $L$., is the angular distance of the zenith from the equinoctial, measured along the meridian; as the earth is not a sphere, this is not the same as the Geocentric $L_{\text {. }}$, or the angle made with the equator by a line joining the station to the earth's centre. Latitudinarians. (Eccl. Hist.) A body of English divines in the reign of Charles II., op- posed both to the high tenets of the ruling party in the Church, and to the extreme notions of the Dissenters. Their position was defended by Fowler, Bishop of Gloucester.

Latria. (Dulia.)

Iatro latruncŭlus. [L.] $A$ draughtsman; a man, a pawn, in chess.

-latry $=$ worship, as in idolatry, Mariolatry

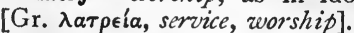

Latten. [Fr. laiton, It. latta, a sheet of tinned iron.] 1. Sheet brass. 2. Thin iron plates coated with tin.

Latter-day Pamphlets. By Thomas Carlyle; a very severe attack upon the political Government of England; written in 1850 , and suggested by the revolutionary events of 1848 .

Iatter-day Saints. Mormons (q.v.); so styled by themselves.-Bartlett's Americanisms.

Iattermath. The same as Aftermath.

Iatus clāvus. [L.] The broad purple stripe down the front of a Roman senator's tunic.

Laudāto ingentia rūra, Exĭguum cǒlǐto. [L.] Commend large estates, cultivate a small one.

Laudātor tempŏris acti. [L.] An admirer of past times (Horace).

Laudātur ăb his, culpātur ăb illis. [L.] He is praised by these, blamed by those.

Laudi spirituali. [It.] The origin of madri gal music, certain motetts, psalms, etc., brought out at Rome by desire of St. Philip Neri, A.D. I 563 .

\section{Iauds. (Canonical hours.)}

Laughing-gas. Protoxide of nitrogen; so called because, when inhaled in small quantities, it causes excitement, often accompanied with laughter. Used as an anæsthetic by dentists.

Launch. (Naut.) 1. The largest boat of a man-of-war, corresponding to the long-boat of a merchantman, but longer, lower, and more flat-bottomed. 2. Steam-L., a swift boat of light draught.

Launders. [Fr. lavandier, a washerman.] 'Tubes, gutters, etc., for the conveyance of water in mines.

Laura. [Gr.] The inclosure or precincts of a monastery in the Eastern Church. 'The ancient lauras of Palestine were collections of cells for hermits, who lived without any common monastic rule (probably connected with $\lambda \alpha \beta \dot{v} \rho\llcorner\nu \theta \omega s$ ).

Laureate. [L. laurěătus, crowned with laurel.] The dignity of poet-laureate, bestowed in the fourteenth century on Petrarch, is said to have been suggested by the tradition of the crowning of Virgil and Horace with laurel wreaths in the Roman Capitol. In England, poets-laureate were sometimes created by the universities as well as by the king.

Iaurel crown. Placed on the brow of a conqueror or hero, as an emblem of victory.

Iaurentian (covering the country north of the St. Lawrence, Laurentius). (Geol.) Highly metamorphosed rocks, crystalline, fossiliferous; gneiss, schist, marble, conglomerate, and graphite, with trap-dykes, metallic ores, etc. Anterior to the oldest Cambrian and Silurian; the oldest known fundamental series of the stratified rocks. Divided theoretically into the Upper 
Laurentian or Labrador series, and the Lower Laurentian.

Iauwine. (Poet.) An avalanche; Ger. Lauwine.

Iava. [It.] Any rock-material which flows, melted, from a volcano ; usually either felspathic (as pumice) or augitic (as black lava).

Lavăcrum. [L.] (Eccl. Arch.) A name for the Piscina.

Lavaret. 1. (Gwyniad.) 2. A name given to Salmo oxyrrhyncus [Gr. ỏ ḱv $\rho$ - $\delta \gamma \chi 0$, sharpsnouted]. North and Baltic Seas.

Lavatory. [L. lăvātŏrium, from lăvo, $I$ wash.] A washing-place.

Laver. [(?) A corr. of ulva, sedge.] (Bot.) Name of some edible seaweeds, especially Porphy̆ra vulgāris and $\mathrm{P}$. lăcǐniata, or Sloke [L. lăcinnia, $a$ lappet], the fronds of which furnish Purple $L$.; and Ulva latissima, Green L. Stewed or pickled, and eaten with various condiments, especially in the Hebrides. Porphyra, because of the purple

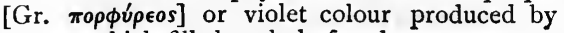
spores, which fill the whole frond.

Laverock [O.E. laferc], abbrev. to Lark. Skylark, Ălauda arvensis [L., lark of the cultivated fields]. Europe, Asia Minor, and N. Africa. Gen. Ălauda, fam. Ălaudĭdæ, ord. Passĕres.

Law, Grimm's. (Grimm's law.)

Law, -law. [A.S. hlaw, an elevation.] (Geog.) Rising ground.

Law; Laws of motion. 1. (Phys.) A general proposition which enunciates any of the unvarying coexistences or sequences observed in natural phenomena; e.g. the law of the reflexion of light is that the angles of incidence and reflexion are in the same plane and are equal. In some cases these laws are known by the names of their discoverers, as Kepler's L., Boyle's L., Hooke's L., etc. 2. (Math.) The L. of $a$ series is the rule in accordance with which its successive terms are derived. The Laws of motion are three fundamental facts concerning motion and the forces which produce it, enunciated by Newton in the Introduction to the Principia, under the head of "Axiōmăta sive Leges Motûs."

Law-calf. A pale buff leather, used for binding laze-books.

Laxative. [L. laxo, I unloose.] Gently aperient.

Lay, To. (Naut.) To come, or go. As to lay out on a yard is to go out towards the yardarms.

Lay brothers. Persons in convents who are under the three vows but not in holy orders.

Lay days. (Naut.) Those allowed for loading or unloading.

Layer. ( $A g r$.) Clover, etc., sown and cut with barley, its aftergrowth supplying green food.

Lay figure. A large wooden doll, having joints, so that it can be placed in any attitude, and used by artists as a model to hang drapery on, etc.

Lay-stall. 1. A place where rubbish is laid. 2. A place in which cows are kept, as sometimes in London.

Lay-to. (Lie-to.)

\section{Iazar. (Lazzaroni.)}

Lazaretto (Lazarus, New Testament). [It.] In foreign seaports, a building for the reception of those suffering from contagious, especially pestilential, disease, and of their goods.

Iazarists. (Eccl. Hist.) A body of missionaries founded by St. Vincent of Paul, I632; so named from occupying the Priory of St. Lazarus, at Paris.

Lazarus, St., Order of. A military religious order, established for the care of lepers in lazarhouses, especially in the Holy Land.

Lazy-bed. (Agr.) System of cultivating potatoes in beds from four to six feet wide, separated by spaces twelve or eighteen inches wide, to supply soil for earthing up the crop.

Lazy-guy. (Naut.) A small tackle which keeps the spanker-boom steady in fine weather, Lazy-painter, a small rope used to secure a boat in fine weather.

Lazzărōni. [It.] The poorer classes at Naples; so called from the Hospital of St. Lazarus, which served as a refuge for the destitute in that city.

Leach. [O.E. leah.] 1. Wood ashes through which water passing imbibes the alkali. 2. The tub in which this process takes place.

Lead. [O.E.] Red lead is a compound of oxide and dioxide of lead, used in glass-making and as a pigment. While lead is carbonate of lead, a common pigment. Sugar of lead is acetate of lead, which has a sweet taste.

Lead or Leads of a rope. The direction or directions in which it is led.

Lead, Sounding. A leaden weight, attached to a line marked in fathoms, used to ascertain depths. (Marks and deeps.)

Leader. (Anat.) A colloquial synonym of tendon.

Leading note. (Music.) (Subtonic.)

Leading-part of a tackle. (Naut.) That leading from block to block.

Leading question. In Law, one which suggests the answer: these may be asked in crossexamination only.

Ieague. Three miles, generally three nautical miles, or $\frac{1}{20}$ of a degree. The length of the L., like that of the mile, is different in different countries; e.g. the old French L. (lieue commune) is 1 of a degree, but the nautical league (lieue marine) was the $\frac{1}{25}$ of a degree, and the postal league (lieue de poste légale) 2000 toises.

Ieague, Hanseatic. (Hanseatic League.)

League, The Holy. (Fr. Hist.) A political association of the Roman Catholic party in the reign of Henri III., I 575, for the overthrow of the Protestant power.

Leagne of Cambrai. (Cambrai, League of.)

League of the Public Weal. In Fr. Hist., an alliance formed by the Duke of Britanny and others against Louis XI., I464. (Public Weal, War of the.)

Leannoth. In the heading of Ps. Ixxxviii., for singing, for humbling, probably = requiring some accompaniment suitable to a psalm of deep affliction (Speaker's Commentary). (Mahalath.)

Leap year. (Year.) 
Lease. [L. laxāre, to loose ; $c f$. Fr. laisser.] To let, to demise for a reserved rent by a grant or contract termed a lease, either for life, for a term, or at will.

Leash. 1. A thong, loose string [Fr. laisse, L. laxa.] 2. A L. of birds, three, a brace and a half.

Leasing. [A.S. leas, empty, false.] Ps. iv. 2; lying.

Leasing. [Ger. lesen, to gather.] Gleaning.

Leatherstocking. " Natty Bumppo, a backwoodsman in Cooper's novel The Pioneers.

Ie bon temps viendra. [Fr.] The good time zill come.

Iecanomancy. [Gr. $\lambda \epsilon \kappa a ́ \nu \eta, b o z v l, \mu \alpha \nu \tau \epsilon i ́ a$, divination.] Divination by throwing three stones into a basin of water, with an invocation.

Lecca gum. (From Lecca, in Calabria.) A gum obtained from the olive tree.

Lectica. [L.] $A$ litter.

Iectionary. In the English Prayer-book, the list of lessons [L. lectiones] from the Old and New Testaments to be read at Morning and Evening Prayer daily.

Lectisternium. [L., from lectus, $a$ bed, and sternĕre, to spread.] (Hist.) An ancient Roman religious ceremony, in which the statues of the gods were, in times of disaster, placed on couches, the gods themselves, it was supposed, taking part in it.

Lectus gěniälis. [L.] The marriage-bed, guarded by the Genius.

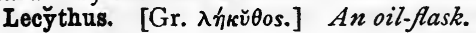

Led-captain. (Naut.) A parasite, a hangeron to a rich or titled personage.

Ledger. [A.S. leger, a bed, a laying down; $c f$. Ger. lager, Boer laager, Goth. ligrs.] (Com.) A book in which accounts are finally entered, summed, and recorded from the journal, wastebook, etc.

Ledger lines. (Music.) Short additional lines above and below the ordinary stave, originally drawn in "light" coloured lines [Fr. léger, light] ; so a ledger is lit. a book with light marginal lines.

Lee. [A word common to many Aryan languages, denoting a sheltered place.] (Naut.) The side away from the wind. $L$. boards, strong frames of plank, fastened one to each side of flat-bottomed sailing-vessels, lowered, when on a wind, and giving a gripe of the water. L. gauge, To have the, to be to leeward of another vessel.

Leech. A physician [A.S. lǽce, a physician, a reliever of pain, from lácnian, to heal]; the medicinal L. being the same word.

Leeches. (Naut.) The edges of a sail. L.lines, ropes fastened to the leeches of the mainsail, foresail, and crossjack, used to truss up those sails. L.-rope, the vertical part of the Bolt-rope (q.v.).

Lee-hatch, Take care of the. (Naut.) Don't let her go to leeward of her course.

Leer. A furnace for annealing glass.

Leet. [A.S. leod, Ger. leute, the people, or the lewd.] A court for preserving the peace by the system of Frankpledge.
Lee tide. (Naut.) One running in the direction in which the wind blows. Opposed to Weather tide.

Leewardly. (Naut.) A vessel inclined to bag to leeward. Opposed to Weatherly.

Lee-way. (Naut.) The drift of a vessel to leeward. Angle of L.-W., the deviation of her true from her apparent course, owing to L.-W.

Left-handed marriage. (Morganatic marriage.)

Leg. (Naut.) 1. The run made upon a single tack. 2. A cringle to a leech-line.

Legacy. [L. lēgāre, to bequeath.] (Leg.) A gift of personal property by will.

Legal memory. Distinguished from living memory, dates from II89, the year of Richard I.'s return from Palestine.

Legates. [L. legāti.] In ancient Rom. Hist., (I) ambassadors : (2) officers who accompanied the proconsuls and prætors into their provinces, or aided the general in the management of his army. (3) Officers exercising powers committed to them by the pope, in foreign countries or courts. (Nuncio.)

Legato. [It.] (Music.) Played or sung slurringly, glidingly, smoothly ; opposed to Staccato Leg-bail, To give, means to escape from custody, to run away.

Legend. [L. lëgenda, things to be read.] 1. Any book is a legend; but the word was applied more especially to, $\mathbf{2}$, the records of saints and martyrs, passages from which were read out in the services of the Church. Such was the Golden $L$., drawn up by Jacobus de Voragine, in the thirteenth century. The term is now often used to denote, 3, fictitious or doubtful narratives of any kind.

Legerdemain. [Fr., lit. light of hand.] Used as subst., $=$ slight of hand, tricks requiring a light, quick hand.

Leghorn. A kind of plait for bonnets, etc., made of the straw of wheat cut while green and dried (first made at Leghorn, Livorno).

Legion. [L. lĕğo, -nem.] The largest division of the Roman army, consisting originally of ten cohorts $=$ thirty maniples $=$ sixty centuries = from 4200 to 6000 infantry ; with 300 cavalry.

Legion of Honour. (Fr. Hist.) An order of merit, both military and civil, instituted by Napoleon Bonaparte, when First Consul.

Iēgis constructio non făcit injüriam. [L.] (Leg.) The construction of the law does injury to no man; i.e. laws are to be interpreted and applied equitably.

Legree. A cruel slave-dealer in Mrs. Stowe's novel Uncle Tom's Cabin.

Legume. [L. legūmen.] (Bot.) A plant having two-valved fruit, dehiscing by sutures on the face and back, like the pod of a pea, bearing its seeds on the ventral suture only. Leguminosa, a very extensive nat. ord., including peas, beans, lupins, clover, acacia, tamarinds, etc.

Légumes. [Fr.] Vegetables.

Leigh. (-ley.)

Le jeu ne vaut pas la chandelle. [Fr.] The game is not worth the candle; the reward of success does not compensate one for the trouble bcstowed on winning it ; the thing doesn't pay. 
I. E. I. Letitia Elizabeth Landon, afterwards Mrs. Maclean, a writer of verses (1802-1838).

Ieman, Iemman. A sweetheart ; formerly leofmon [A.S. léof, beloved, man, a person, a human being]. (Lief.)

Le mieux est l'ennemi du bien. [Fr.] The best is the enemy of the good; in pursuing greater advantages we lose present advantages.

Lemma. [Gr. $\lambda \hat{\eta} \mu \mu a$, (I) a thing taken, as a premiss, L. sumptio ; (2) a summary of contents.] (Math.) A subordinate proposition introduced as a digression into a mathematical book, in explanation of the methods used in proving the propositions which form the subject of the book ; thus the lemnias or lemmăta of the first section of the first book of the Principia explain the method of proof adopted by Newton in the propositions of the second and subsequent sections which make up his subject : he introduces other lemmas as he goes on.

Iemnian earth. A kind of bole from Lemnos; formerly sold in small cakes as a medicine.

Lemniscate. (Math.) The curve traced out by a point moving in such a manner that the product of its distances from two fixed points is constant. Its form nearly resembles that of a figure of eight

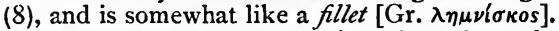

Lemons, salt of. (Chem.) Binoxalate of potash, used for removing ink-stains.

Ie mot d'enigme. [Fr.] The word of the riddle; the key to the puzzle or mystery.

Lemur. [L., a ghost.] (Zool.) A gen. of strepsirrhine [curved-nostril], generally small quadrumanous mammals, giving the name Lemmurŏiděa to a sub-ord. of ord. Prîmātēs, specially characteristic of Madagascar, and apparently indicating a former connexion with India.

Lĕmŭres. [L.] (Myth.) Spirits of the dead, which, in the belief of the Romans, had the power of hurting the living. (Lamia ; Larvæ.)

Lens. [L., a lentil.] (Math.) A piece of glass, such as a common magnifying glass, or other transparent medium, generally of a circular form, bounded by two surfaces of revolution which have a common axis. In most cases these surfaces are portions of spheres, or one of them is plane. A lens has a positive focal length when thinnest, a negative focal length when thickest, in the middle. According to the position of the centres of the spheres, the former lenses may be double-concave, plano-concave (concavo-plane), or convexo-concave ; the latter may be double-convex, plano-convex (convexoplane), or concavo-convex.

Ient. The great fast of the Christian Church; so named from the A.S. lencten, Ger. lenz, spring.

Lenticular. [L. lentǐcŭlāris, like a little lentil.] Having the form of an ordinary magnifying glass, or double-convex lens.

Lentigo. [L. lens, a lentil.] Freckles.

Leonine City, Leonina Civitas. Pope Leo IV., circ. 850 , walled round part of the Vatican Hill and plain beneath, giving the new suburb to some Corsican families as a refuge from the Saracens. In 1146 Eugenius III. began a palace near the Church of St. Peter for the papal residence, which has grown into an immense mass of buildings, known as the Vatican.

Ieonine verse (invented by one of the Popes Leo, or by a monk Leoninus). Latin hexameter or pentameter, riming in the middle, as-

"Dremon languebat, monachus tunc esse volebat : Ast ubi convaluit, mansit ut ante fuit."

Ieonnoys, Lionesse, Lyonnesse. A fabulous country, contiguous to Cornwall, of chivalric romances.

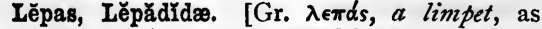
clinging to $\lambda$ émas, a bare rock.] (Zool.) Barnacles, cirropod (i.e. filament-footed) crustaceans, with a stalk or peduncle supporting the rest of the animal in a calcareous shell.

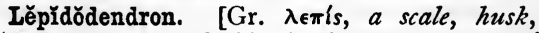
$\delta \in$ é $\delta \rho o \nu$, a tree.] (Geoi.) An important gen. of fossil plants ; arborescent Lycopodiaceæ.

Lěpìdoptěra. [Gr. $\lambda \epsilon \pi i ́ s,-i \delta o s, a$ scale, $\pi \tau \epsilon \rho \delta \nu$, a wing.] (Entom.) Ord. of insects, with four wings, usually covered with microscopic scales. Moths and butterflies.

Lepŏrĭdæ. [L. lĕpŏrem, hare.] (Zool.) Fam. of rodents ; hares and rabbits. Only one gen., many spec. Characteristic of $\mathrm{N}$. hemisphere ; a few in Africa, none (till introduced) in Australia.

Lepto-. [Gr. $\lambda \in \pi \tau$ ds, fine, thin.]

Le roi est mort; vive le roi! [Fr.] The king is dead; long live the king! illustrating the absolute continuity of hereditary government.

Iesbia. Catullus's name for his mistress.

Ièse majesté. [Fr.] High treason. (Leze majesty.)

Les extremes se touchent. [Fr.] Extrcmes meet.

Lesion. [L. læsio, -nem, an injuring.] (Med.) Injury, derangement, structural or functional.

Lessee. (Leg.) One to whom property is let on lease.

Iesser Bull, The. That of Pope Boniface VIII. (1303) to Philip of France, claiming collation to benefices, and asserting the king's subordination in temporals as well as spirituals. Its genuineness doubtful, but rendered probable by the fact of the authenticity of Philip's answer.-Milman, Hist. of Latin Christianity, bk. vii. 113.

Lessor. (Leg.) One who lets property to another on lease.

Let (as used in Collect for Fourth Sunday in Advent, and often in legal conveyances). To impede, keep back [A.S. lettan, to hinder, to make lret, late, slow].

I'état o'est moi. [Fr.] The State is myself.

Iēthē. [Gr., forgetfulness.] (Myth.) The river of Oblivion, of which they who drank, as they entered the land of the dead, forgot their former lives.

Letterpress. Printed words, as distinguished from engravings.

Ietters. Classical and polite literature, arts.

Letters of marque. A commission granted to private persons in time of war to make prize of the enemy's ships and goods; so named as authorizing the capture of property beyond the 
Mark or frontier of the power which grants commission.

Letters of orders. A certificate given by a bishop, that he has ordained a certain person priest or deacon.

Letters of reprisal. I.q. Letters of marque (q.v.).

Letter-wood. The wood of a tree found in Guiana, having black spots in it like letters.

Lettic. (Lang.) Name of a group of IndoEuropean languages, near akin to Sclavonic, including Old Prussian, Lithuanian, and Livonian, or Lettish, all round the bend of the Baltic. They show some of the most ancient Aryan forms.

Lettish. (Lang.) Livonian. (Lettic.)

Iettre de change. [Fr.] Bill of exchange.

Lettres de cachet. [Fr.] Sealed letters, especially of a royal order for the imprisonment, etc., of an obnoxious person.

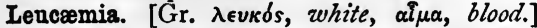
(Med.) A want of colouring matter in the blood; but, according to some, an excess of the white corpuscles.

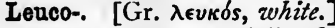

Levant. [Fr., sc. soleil, the rising sun.] A name given to the eastern portion of the Mediterranean, which is bounded by Asia Minor on the north and the Syrian coast on the east.

Levanter. A strong easterly wind of the Mediterranean.

Lěvätor muscle [L. lěvo, I raise] raises that to which it is attached. (Attollent.)

Levée. [Fr., from lever, L. lěvare, to raise.] Ceremonial visits paid to distinguished persons, strictly speaking, at their rising. At present the assemblies at which the sovereign receives gentlemen, the Drawing-room being for both ladies and gentlemen.

Levee en masse. [Fr.] A summons to the whole people to defend the country from invasion ; called by the Germans Landsturm.

Ievel [L. libella, level]; Carpenter's I.; Mason's L. ; Spirit-L.; Surveyor's I. An instrument for finding a horizontal line. A Carpenter's or Mason's L. consists of two pieces set square; one of them is made vertical by a plumb-line, and then the other is horizontal. A Spirit-L. consists of a glass tube sensibly straight, but in reality slightly bent, so that if produced it would form a ring of very large radius. It is nearly filled with spirits of wine, only a bubble being left; when it is held in such a position that the ends of the bubble are equally distant from the middle point, the tube-or more strictly a tangent to the axis of the tube at its middle pointis exactly horizontal. A Surveyor's $L$. consists of a spirit-level attached to a telescope in such a way that the tangent aforesaid is parallel to the axis of the telescope ; the whole is capable of being mounted on a tripod stand.

Levellers. (Eng. Hist.) A party in the army of the Long Parliament, which announced their intention of levelling all ranks. They were put down by Fairfax.

Levelling-staff. A graduated staff used in connexion with a surveyor's level. 'If the level is placed between two points $\mathrm{A}$ and $\mathrm{B}$, and the readings of the staff, held erect first at $A$ then at $\mathrm{B}$, are taken, their difference is the difference in the level of $\mathrm{A}$ and $\mathrm{B}$.

Leven. Name of rivers; from Celt. llevn, smootin.

Lever [L. lěvator, one who lifts] ; Arms of I.; Bent L.; Double L. A rod or bar (e.g. a crowbar or a poker) caused by a power to move round a fixed point (or fulcrum) and thereby overcome a resistance or raise a weight. The distances from the fulcrum to the points of application of power and weight are the arms of the lever. If the arms are not in a straight line it is a Bent $L$. Many simple machines consist of a combination of two levers (e.g. a pair of nut-crackers, a pair of scissors, etc.); these are called Double levers.

Leverage. The mechanical advantage of a lever; it is measured by the ratio which the length of the arm of the power bears to that of the weight.

Ieviathan, published $165 \mathrm{I}$, in favour of monarchical government. The best known work of the metaphysician, Thomas Hobbes. (Oceana.)

Lēviàthān. [Heb.] 1. The crocodile. 2. The grampus, or Mediterranean rorqual. 3. Job iii. 8 ; apparently the astrological dragon, as professedly raised by magicians. In Authorized Version, $\mathrm{L}$. is here rendered "their mourning."

Levigate. [From lēvigare, to make smooth (lēvis).] 1. To smooth, to polish. 2. To grind to powder, to comminute, to pulverize, the process being called Levigation.

Levirate. [L. lěvir, Gr. $\delta \alpha \eta ́ p$, brother-in-law.] A word used to denote the Jewish custom by which the brother of a deceased husband was bound to marry his widow.

Levulose. [L. lævus, left.] (Dextrose ; Polarization.)

Lewdness, Acts xviii. I4 [Gr. $\rho \alpha \delta$ $\alpha v \rho \gamma \eta \mu \alpha]$, retains an earlier sense of ignorant recklessness ; "lewd fellows," in a somewhat stronger sense,

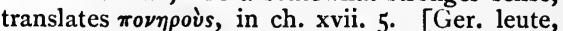
the people; cf. the word "vulgar," from L. vulgus, the common people.]

Lewis, Lewisson (a word said to be first used, temp. Louis XIV.). A contrivance for enabling hold to be taken of a mass of stone that is to be raised by rope or chain. A hole is cut in the stone, which widens downward; into this the L. is put, consisting of two inverted wedges separated by a plug, to which they are fastened by a pin.

Lex appĕtit perfectum. [L.] (Leg.) The law aims at perfection.

Lex lǒci contractūs. [L.] (Leg.) The larc of the place of the contract; meaning some times where the contract is made, sometimes where the contract is fulfilled.

Lex mercātōria. [L.] (Leg.) Mercantile or commercial laze; European.

Lex non scripta. [L.] (Leg.) Unzuritten law ; the common law of England, which originated in custom and rests on precedents.

Iex prospicit non respicit. [L.] ( $L e g$.$) The$ law regards the future, not the past; i.e. as to its operation. 

law.

Lex scripta. [L.] (Leg.) Written or statute

-ley. Part of A.S. names, = pasture in a forest, as in Hors-ley ; also -leigh-, -lea-, -liegh, Belgian -loo [A.S. leah, lying-place], as in Leighton, Had-leigh, Ven-loo.

Leyden jar (invented at Leyden). A glass jar, coated within and without with tinfoil nearly to the top, and used for accumulating electricity. It is furnished with a brass knob at the top, through which it is charged.

Ley gager. (Leg.) A wager of law; one who begins a suit.

Leze majesty. Any crime committed against the sovereign power of the State; from L. crimen lase majestatis, or the charge of injury done to the majesty of the Roman people. (Ièse majesté.)

L'habit ne fait pas le moine. [Fr.] It is not the dress, the cowl, which makes the friar. (Cucullus.)

I'hypocrisie est un hommage que le vice rend à la vertu. [Fr.] Hypocrisy is a homage which vice renders to virtue (Rochefoucault).

Liaison. [Fr., L. lĭgātiō, -nem, a binding.] 1. In Fr. grammar, a tie by which the terminal letter of a word is carried on, so as to form one sound with a vowel following. Thus in the word pied, foot, the $d$ is silent; but in the phrase pied-à-terre the $d$ is joined on, though with a softened sound, to the vowel following. 2. A connexion, acquaintance, generally of a dishonourable kind.

Liane. [Fr., Norm. liaune, the clematis, probably another form of lien; lier, to bind, L. ligare.] A general name for the woody twining or climbing plants which abound in tropical forests.

Lias, i.e. Lyers. (Geol.) A series of argillaceous and calcareous strata, the basis of the Oolitic or Jurassic system.

Libavius, Fuming liquor of. (Chem.) Dichloride of tin, used in dyeing.

Libel. [L. lúbellus, a writing, dim. from lǐber, a book.] (Leg.) 1. A written statement or hint tending to damage, disgrace, or cast ridicule on a person. 2. An immoral, treasonable, or seditious writing. 3. (Scot. Lazu.) The form of a complaint, the ground of a charge.

Iibellers. [L. libellus, a little book, libel.] Authors of the Marprelate libcls (1586-1593). (Martin Marprelate.)

Iiber. [L., (I) bark, and hence (2) book.] (Bot.) The newly formed fibrous layer of bark; the bast-layer.

Iiber Albus. [L., the white book.] The name of an ancient book on the laws and customs of the City of London.

Iiberator, The. A term sometimes applied to Bolivar, also to O'Connell.

IÎbĕrāvi ănimam meam. [L.] (Absolvi animam meam.)

Liber feudōrum. A code of feudal law, published at Milan, II70, by order of the Emperor Frederick Barbarossa.

Irber Rëgis [L.], King's Book, or Vălor Ecclësiasticus. A return made, 26 Henry VIII., of the "firstfruits of all dignities, benefices, and promotions spiritual," and of the "annual pension of the tenth part of all possessions of the Church, spiritual and temporal," due "to the king and his heirs," as supreme heads of the Church of England.

Liber Sententiarum. (Master of the Sentences.)

Liberties. (Leg.) Districts exempt from the sheriff's jurisdiction.

Libertines. 1. Acts vi. 9 ; Libertīnus, in Rome, the son of a freed slave. 2. In Church Hist., a name given in England to the Anabaptists in the sixteenth century.

Lïbertus, In̄berta, fem. [L.] A manumitted slave, in reference to his late master.

Liberty. A privileged district, having certain rights and immunities; very frequently the modern representative of some former ecclesiastical jurisdiction; e.g. the L. of Bury St. Edmund's.

Liberty, Cap of. A symbol suggested seemingly by the representations of the Roman goddess Libertas, who held a cap in one hand. In England Britannia is sometimes represented as bearing such a cap, blue with a white border, on a spear. In France a red cap was chosen as the badge of the Jacobin Club.

Liberty and Necessity, Letter on. A work of the great metaphysician, Thomas Hobbes (I 5881679).

Liberty of Prophesying. By Bishop Jeremy Taylor; the first formal declaration of the duty of toleration; and this in the year 1647 . (Prophesy.)

Liberty Wilkes. John W., brewer : M.P. for Aylesbury, 1757 ; founder of the North Briton, the attacks of which drove Bute from the ministry. Elected several times for Middlesex, but the elections were declared void; an immoral and violent man, but most popular, especially during imprisonment, as the champion of "liberty." Released, and, in I774, lord mayor, and for many years M.P. for Middlesex (born I727, died 1797).

Libidinous. [L. líbídinnōsus, from lǐbīdinnem, pleasure, lust.] Lustful, lecherous.

Iībra, First point of. The autumnal equinox. (Equinox; Aries, First point of.)

Iibration [L. libro, I set swaying, lit. something which is in equilibrium] of the moon. An apparent oscillatory movement of the moon, in virtue of which she docs not always present exactly the same face to the earth; so that on the whole we see a zone a few degrees in breadth on all sides of the border beyond the exact hemisphere; this is partly due to the moon's motion round her axis being uniform while her motion in her orbit is not uniform, and partly to her axis of revolution not being exactly perpendicular to the plane of her orbit.

Licentiate. [L. licentia, licence, from licet, it is lazuful.] One licensed to practise profession. ally any art or faculty.

Iricet. [L.] It is lawful.

Lïchēn, $\mathbf{L}$. trŏpicus. [Gr. $\lambda \epsilon \iota \chi \nvdash \nu$, lichen.] 1. (Bot.) A very extensive ord. of cryptogams, allied to fungi and algæ, growing on the bark of trecs, on rocks, etc. 2. (Mcd.) Prickly heat, a papular eruption of the skin, with itching and stinging. 
Lichenine. A starchy substance extracted from Iceland moss or lichen.

Iich-gate. [A.S. lic, Ger. leich, a corpse.] The covered gate at the entrance to churchyards, beneath which the bearers of the coffin may rest.

\section{Lictors. (Fasces and Secures.)}

Lidford law $=$ Jeddart justice (q.v.).

Iieder ohne wörte. [Ger., songs without words.] Instrumental pieces with marked songlike melody throughout.

Lief. [Ä.S. leof, liof, O.E. lefe, leve, Ger. lieb, Goth. liubs ; $c f$. L. libet, lubet, it is pleasing, Skt. root of lubh, to desire.] 1. Dear, beloved. 2. Adv., gladly, readily.

Liege. [Fr. lige, L.L. ligius, Prov. Fr. litge, Ger. ledig, empty, free, M.H.G. lidig, freed, loosed.] (Leg.) 1. Bound by (originally free) tenure to be feal and loyal to a lord, subject. 2. Sovereign, by misinterpretation of liege lord, i.e. lord of liegemen.

\section{Liege homage. (Homage.)}

Iiege lord. [L.L. ligeus, from L. ligare, to bind, unless it be lord of the leute, leet, lewd, folk or people.] A feudal superior, to whom his liegemen owe vassalage. (Leet; Court-leet.)

Iiegh. (-ley.)

Liën, or Liēnis. [L.] (Anat.) The spleen.

Iien. [Fr. lien, L. lĭgāmen, a tie, from lĭgo, $I$ tie.] (Leg.) Right to retain provisionally another person's property which is in a man's possession until the owner satisfies certain demands of the possessor.

Lie-to, To. (Naut.) In a gale, to keep a vessel nearly head to wind, under little canvas. (Bring-to, To.)

Lie under arms. (Mil.) To rest as a soldier ready accoutred touching his arms, ready for action at a moment's notice.

\section{Iieutenant. (Rank.)}

Life assurance. A bargain or contract essentially such as follows:-A pays B a sum (or premium) annually during the continuance of a certain status (say, the life of C), on condition that $B$ makes $A$ a certain payment (the sum assured) on the determination of the status (say, the death of C, in which case C's life is assured for that sum). For making the bargain a certain rate of interest is fixed on, and the probability must be ascertained of the status existing at the end of the first, second, third, etc., year; when this is done, the probability is also known of the determination of the status in the course of any given year. From these data the present values of the premiums and of the sum assured can be found, and, if the bargain is fair, the two are equal. Practically the office, i.e. the party $\mathrm{B}$, makes a profit by calculating the fair premium at a low rate of interest, as 3 per cent., and by adding a loading, i.e. a certain percentage, as 20 or 25 per cent., to the fair premium. The probability of C's life lasting for one, two, three, etc., years is ascertained by means of tables derived from actual observation, showing the number who die in each successive year of those who were alive and of the same age at a given time; such are the Carlisle Table, the North- ampton Table, the Table of the Twenty Life Assurance Companies, etc. Called also Life insurance. Fire insurance is a similar bargain, except that the status is the existence of a house or some like thing; and it determines by its total or partial destruction by fire.

Life Guards. The body-guard of a sovereign ; in German leib-garde. (Celibacy.)

Iife-lines. (Naut.) Lines stretched from gun to gun, and about a ship, for men to cling to in bad weather. Also from the lifts to the masts, to enable men to stand securely when masining yards.

Iifting. On Easter Monday and Tuesday ; an old custom, still lingering in some counties. A record is preserved in the Tower of fees paid at the lifting of Edward I. in his bed, on an Easter Sunday morning (English Cyclopadia, iii. 262).

Lifts. (Naut.) Ropes from the masthead to the extremities of a yard.

Iigaments. [L. ligāmentum, $a$ bandage.] (Anat.) The bands, or cords, of white fibrous tissue which, in the formation of the joints, connect the bones together.

Ligan, Lagan. [From ligāmen, thing tied; cf. Prov. liam.] Goods thrown overboard, but tied to a buoy or float to mark their position. (Flotsam.)

Iigature. [L. lügātūra, a binding.] 1. (Med.) A cord or thread for tying blood-vessels to prevent hemorrhage. 2. In Printing, two or more letters cast on the same body; as $\Subset, f f i, f f$.

Light, To. (Naut.) To move or lift anything.

Iight-bob. (Light infantry.)

Lighten. In the Te Deum, light, alight ; the Latin is "fiat misericordia Tua super nos."

Iighter. (Naut.) A large flat-bottomed boat, used to carry goods, etc., to and from ships.

light infantry. Soldiers specially instructed for skirmishing movements. In addition to separate regiments so called, each regiment had formerly one company so trained, until it became the duty of the whole army to perfect themselves in every part of tactics. A L. I. soldier was called a Light-bob.

Iight-mill. (Radiometer.)

Lights. Popular name for the lungs, from their light, spongy appearance $[c f:$ the Ger. name, die leichte leber, the light liver].

Iight sails. (Naut.) Those above top-gallant sails, the studding-sails, and flying-jib.

Lign aloes. (Alloes.)

Iignite [L. lignum, wood], Wood-coal, Brown-coal. (Geol.) Wood fossilized; not so far converted into coal as to lose its woody texture ; often earthy, sometimes as bright as coal, burning with a disagreeable odour. In thick beds in Germany, Hungary, and Nebraska; Tertiary and Cretaceous.

Lignum vitæ. [L., zoood of life.] A very hard wood, that of the Guaiacum officinale, of W. Indies and S. America, and perhaps of other spec. ; used for making ships' blocks, and also furnishing gum guaiacum used in medicine.

IIgŭla. [L., i.q. lingŭla, dim. of lingua, the tonguse.] (Entom.) Upper lip of insects. 
Liguorists. (Redemptorist.)

Ligure. [Gr. $\lambda$ irúpiov, (?) from Ligŭria, Heb. leshem.] In the breastplate of Aaron (Exod. xxviii. I9) ; probably amber.

Ligurian = Genoese. The Ligurres were an Italian people in Gallia Cisalpina, Liguria being $=$ modern Piedmont, Genoa, and Lucca.

Lillibullero. A song popular during and after the reign of James II. - Webster.

Lilliput. A country of little people, onetwelfth of the human stature, in Swift's Gulliver's Travels.

Limaceous. [L. limax, slug.] Of the nature of a slug.

Iìmæ lăbŏr et mŏra. [L.] The tedious labour of the file (Horace), i.e. of correcting and revising literary work.

Limation. [L. lìma, a file.] Filing.

Iimax. [L., id.] (Zool.) Slug; gen. of pulmoniferous gasteropod, shell rudimentary or absent ; gives its name to fam. Limācidæ. Not found in S. America or greater part of Africa.

Limb. [L. limbus, A.S. lim, border, edge; whence the idea of extremity or projecting part, as in a limb of the body or of a tree.] (Astron.) 1. The edge of the disc of a heavenly body, as the upper or lower limb of the sun. 2. The graduated arc of an astronomical instrument; as the reading of the limb of a sextant.

Iimbat. A cool north-west wind which blows in Cyprus from 8 a.m. to noon or later.

Iimber. (Mil.) Carriage on two wheels, with the ammunition-boxes, bearing the trail (q.v.) of the gun-carriage, to which the horses are harnessed for the removal of the latter. L. is properly a shaft [cf. Fr. limon].

\section{Limbo. (Limbus.)}

Limbus. [L., a hem.] With the schoolmen, a border-lake flowing around hell, where souls awaited the resurrection; including: $1 . L$. Puerorum, of unbaptized infants. 2. L. Patrum, of the patriarchal Fathers of the Church. 3. Purgatorium, where the better sort are being cleansed; and, with some, 4, L. Fatuorum, of lunatics. (See Milton, Paradise Lost, iii. 495 ; and Faëry Queene, I. bk. ii. 32.)

Lime-juice contains citric acid; that of the Citrus ăč̆da; specific against sea-scurvy.

Limestone. A general term, = all rocks of which the base is carbonate of lime, i.e. lime + carbonic acid. (I) Mostly constituted of the organic calcareous shells and structures of molluscs, crinoids, corals, etc. (2) In some cases, of chemically deposited carbonate lime; as travertine.

Iimit [L. limes, limintis] ; Inferior I. ; Superior I. (Math.) A fixed magnitude to which a variable magnitude can be made to approach so that their difference shall be less than any assigned magnitude, but to which it can never be made exactly equal; e.g. by diminishing the base of an isosceles triangle, either angle at the base continually approaches equality with a right angle, and the difference between it and a right angle can be made less than any assigned angle, but it never actually equals a right angle. A right angle is therefore the limit of this angle.
If the limit is greater than each of the variable magnitudes, it is a Superior L.; if less, an Inferior $L$.

Limitations, Statute of. (I.eg.) Limiting the time within which actions have been brought, e.g. to recover property, to forty years for real property, and six years for debts, damages, and other personal claims (only one or two years against public officers, etc.).

Limited liability. (Com.) The having the liability of the shareholders to discharge the obligations of the public banking or trading to which they belong limited to the full amount of the share or shares which they are respectively registered as holding. Hence in a L. L. company, when all calls are paid, shareholders can only lose their investment.

Limner is the same word as Illuminator, obtained through the Fr. enlumineur. It means usually a portrait or miniature painter.

Limoges. A kind of surface enamelling (perfected at Limoges, in France), adorned by small transparent globules placed over silver tinsel so as to look like gems.

\section{Iimonite. (Hæmatite.)}

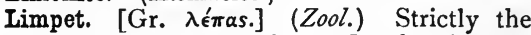
fam. Patellídæ [L. pătella, cup], of which the common tent-shaped limpet is a type. Popularly L. includes also Fissūrellĭdæ [fissūra, fissure], Keyhole L., whose shells have a fissure; Călyptræĭdæ, Bonnet L., whose apex is curved ; and Dentāliădæ [dens, dentis, tooth], Toothshells, shaped like an elephant's tusk. This last is found in N. Atlantic, Mediterranean, E. and W. Indies; the rest inhabit all seas. Ord. Prosobranchiāta, class Gastěrŏpŏda.

Linchpin. [Ger. lïnse.] The small pin put at the end of an axletree to hold on the wheel.

Lincoln, Use of. (Use.)

Iincoln green. A green cloth formerly made at Lincoln.

Linctus. [L., licking, from lingo, I lick.] A thick treacly syrup, for coughs and sore throat.

Iine, The; Equinoctial I.; Meridian I. (Gtog.) The Equinoctial line, often called The line-as when we speak of crossing the line-is the earth's equator. A Meridian $L$. is a line drawn at any station to show the directions of true north and south, i.e. the direction of the meridian of the station.

Line. In measurement, $=$ one-twelfth of an inch.

Linear equation. An equation containing the first powers only of the unknown quantities. When such an equation contains two unknowns, it represents a straight line.

Iinear leaves. [L. līnea, a line.] (Bot.) Long and narrow ; e.g. grasses, pinks.

Iine-of-battle ship. Formerly a vessel of not less than seventy-four guns. Rating by mere number is superseded under the present system of heavy guns.

Line of beauty. The ideal line formed by a graceful figure.

Line of defence. (Mil.) The distance of any point in a fortification from the work that flanks it.

Iine of force. A line whose tangent at each 
point is in the direction of the resultant electrical force at that point.

Lines. (Mil.) 1. Series of fieldworks mutually defending one another. 2. Rows of open barracks are sometimes so called.

ling. [Cf. Norw. laanga, D. leng, id.] (Ichth.) Sea-fish, usually three or four feet long, back grey, belly white. British seas. Lota molva, fam. Gadidæ, ord. Ănacanthǐni, sub-class Tělěostěĩ.

I'ingénu. [Fr.] The frank, ingenuous (character).

Linguadental. (Lang.) Pronounced by the joint use of tongue and teeth [L. lingua, dentes].

Iinguæ centum sunt örăque centum, Ferrea vox. [L.] (Rumour) has a hundred tongues, a hundred mouths, a voice of iron (Virgil).

Iingua Franca. 1. A jargon of the Mediterranean, with an Italian basis, which arose in the galleys of Algiers and the Levant, used for communication between Europeans (Franks) and Mohammedans. 2. Any jargon of mixed speech.

Linguals. [L. lingua, a tongue.] (Lang.) Sounds in the articulation of which the tongue is essentially concerned, including gutturals, palatals, cerebrals, dentals.

Linguistic. [From L. lingua, speech, tongue.] The science of language, glottology.

Liniments. [L. linimentum.] Medicaments of an anodyne or stimulating character, to be rubbed [linire, to besmear] into the skin.

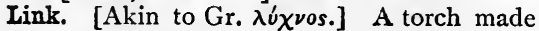
of tow and pitch.

Link [Sw. länk, Ger. gelenk]; L.-motion; L.-work. 1. The $\frac{1}{10}$ part of a Gunter's chain, i.e. $\frac{66}{100}$ of a foot. 2. In Mech., a rigid bar or piece connecting two rotating or oscillating pieces by means of pins, which it keeps at a constant distance during the motion. All such combinations of jointed work, cranks and connecting-rods, parallel motions, etc., are $L$.work. The combination of pieces by which the motion of the slide-valve of a locomotive or other steam-engine can be adjusted or reversed during the motion of the engine, is a L.-motion.

-linn-. [Celt.] Part of names, = still pool, as in Lin-coln, Kil-lin, Lynn.

Linoleum. [L. linum, linen, ŏlěum, oil.] A kind of floor-cloth.

Linseed. The seed of flax (Linum üsǐtātissimum).

Linsey-woolsey. A stuff made of linen and wool, mixed.

Linstock. (Mil.) A staff about three feet in length, for holding a match [Ger. lunte] for firing artillery.

Lint. [O.E. linct, flax.] Linen scraped into a soft substance, used for dressing wounds.

Iinum. [L., flax.] (Bot.) A gen. of plants which gives name to the Linacex, or Lineæ. Flax-worts, a nat. ord. of dicotyledonous plants ; abundant in Europe and N. Africa. The flax of commerce is L. ūsūtātissimum, most in use.

Lionced. (Her.) Adorned with lions' heads. Lioncel. [Fr. lionceau.] (Her.) A young lion.

Lionesse. (Leonnoys.)
Lion's share. An antiphrasis (q.v.) for the whole, being that due as his own private share, + that due to the king of the beasts, + that which he dared the other beasts who joined in the hunt to take.

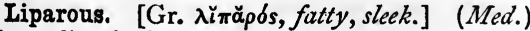
Abounding in fat.

Lip-language. A system of communication by moving the lips without sound, used in prisons, workshops, etc., and, particularly, in communication with deaf-mutes.

Lippǐtūdo. [L., from lippus, blear-eyed, soreeyed.] (Med.) An inflamed condition of the margins of the eyelids.

Liquation. [L. liquäre, to melt.] (Chem.) The process of separating or melting out, by a regulated heat, a more fusible metal from one less fusible.

Liqueur. [Fr.] Preparation of distilled spirit, sweetened and flavoured with herbs, spices, etc.

Iiquidation. [L.L. liquǐdātǐo, -nem, from L. liquîdus, clear.] (Com.) The act of clearing up the affairs of an insolvent company or person.

Liquor. In Brewing, means water.

Liquor of flints. A solution of silicate of potash, called also fusible glass.

Liripipe, or Liripoop. This word, meaning a tippet or stole, is said to be a corr. of the L. cleri ěphippium, the clergy's caparison.

lis-. [Gadh.] Part of names, = earthen fort, as in Lis-more.

Iisbon. A sweet white wine, produced in Estremadura, and shipped from Lisbon.

Lis pendens. [L.] (Leg.) A pending suit.

List. [O.E.] A strip forming the border of cloth or flannel.

List, To have a. (Naut.) To lean on one side, as, She has a list to port, means she lies over on the port side.

Iitany, The Iresser, or The Short. [Gr.

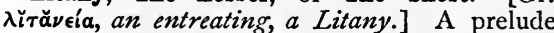
to prayer, as the Doxology is to praise ; a name given from very early times to Kiyrie eleeson, Christe eleēson, $K \bar{y}$ rie eleèson, which, translated Lord, have mercy upon us; Christ, have, etc. occurs in Morning and Evening Prayer soon after the Creed, and in the Litany just before the Lord's Prayer. (Kyrie, The.)

\section{Lit de justice. (Bed of justice.)}

Iiterra cănina. [L.] The dog's letter, i.e. R. Iitëræ formātæ. (Litteræ formatæ.)

Lïtĕræ hūmāniōres. [L.] (Univ.) The more refined, i.e. higher, literature or learning.

Literal contract. (Leg.) A written agreement signed by contracting parties.

Litěra scripta mănet. [L.] The written letter abides; i.e. one cannot avoid the responsibility for what we have committed to writing.

Literates. [L. litĕrāti.] A name usually applied to those who are admitted to holy orders without having obtained a degree at one of the universities.

Lïtĕrātim [L.] Letter by letter. (Verbatim et literatim.)

Litharge. [Gr. $\lambda \iota \theta$ á $\rho \gamma v \rho o s$, from $\lambda(\theta o s$, a stone, a $\rho$ ropos, silver.] (Chem.) A brownish-red oxide of lead. (Massicot.) 
Lithium. [Gr. $\lambda^{\prime}$ ios, a stone.] A white metal, the lightest solid known. It was supposed to exist only in minerals or stones.

Litho-. [Gr. $\lambda i ́$ íos.] 1. A stone. 2. (Med.) Calculus.

Litho-fracteur. [Fr., stone-breaker, a coined word.] (Chem.) A professedly protected form of nitro-glycerine, which is mixed with guncotton, the elements of gunpowder, and other substances ; first made, I87 I, at Cologne.

Iithoglyphic, Iithoglyptic. [Gr. $\lambda$ ítos, a stone, $\gamma \lambda\langle\dot{\phi} \omega, I$ engrave.] Pertaining to the cutting and engraving of gems.

Iithography. [Gr. $\lambda$ íos, stone, $\gamma \rho \alpha \dot{\phi} \phi \omega, I$ write.] The art by which impressions are obtained from designs made with a greasy material on stone, so that they alone take the printer's ink.

Lithological. [Gr. $\lambda$ íos, stone, $\lambda$ óros, dis. course.] (Geol.) Relating to the characteristics of a rock in itself, or of a group of rocks, without reference to relative age, fossil contents, etc.

Iitho-photography. [Gr. $\lambda$ ítos, stone, and photography $(q . v$.$) .] The art of producing$ prints from lithographic stones by means of photographic pictures developed on their surfaces.

Iithotint. [Gr. $\lambda i$ íos, stone, and Eng. tint.] A picture produced in colours from a lithographic stone.

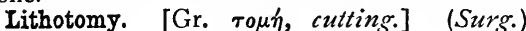
Operation of cutting for stone [ $\lambda_{i}^{i} \theta$ os] in the bladder.

Iithotrity. [L. tĕro, I bruise, sup. trītum.] The operation of breaking a stone $\left[\lambda^{\prime} \theta 0 s\right]$ in the bladder.

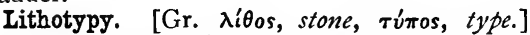
The process of pressing into a mould taken from a page of type, a composition which hardens into a stony substance.

Litmus. [Ger. lackmus.] A deep-blue dye, obtained from the lichen Roccella. Paper stained by it (blue litmus paper) is turned red by acid; and litmus paper thus reddened (red litmus paper) is turned blue by alkali. Hence they are used as tests. Litmus papers are used generally for testing urinary and cutaneous secretions.

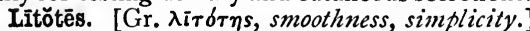
A figure of speech by which a matter is understated, generally more or less sarcastically; as to say of a very ugly man that he is not the bestlooking we have ever seen. It is a species of Irony in the ancient sense of the word. Called

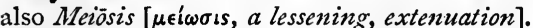

Iitre. [Gr. $\lambda i \tau \rho a$, L. libra.] A cubic décimètre, equal to $I^{\prime} 760773$ pint ; say, a pint and three-quarters English.

Littěræ formātæ. [L.] Letters written in a particular form, and with distinguishing marks, in the ancient Church, were: 1. Commendatory, or Systatic $(q . v$.$) , to persons of quality, or of$ doubted reputation; to travelling clergy. 2. Communicatory, Pacifical, Canonical, to all in communion with the Church. 3. Dimissory (q.v.).

Litterateur. [Fr.] One versed in literature, and at the same time a writer.

Little-endians. (Bigendians.)
Little England. Name given to Barbados by the inhabitants.

Iittle-go. In the Universities of Oxford and Cambridge, the first university examination, which all students must pass ; called officially Responsions, or the Previous Examination.

Iittlo Nell. A type of childish purity, in Dickens's Old Curiosity Shop.

Littleton. (Institutes.)

Littoral deposits, etc. [L. lītŏrālis.] (Geol.)

Belonging to the shore [littus], not to the deep sea. Littus ăma; altum ălii tĕneant. [L.] Hug the shore; let others stand out into the decp.

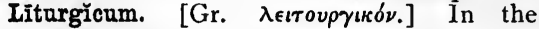
Eastern Church, a book containing the three Liturgies of Basil, Chrysostom, and the Presanctificd.

Iiturgy, Iitnrgies. [Gr. $\lambda \epsilon$ เ zeork.] 1. (Hist.) At Athens, certain public services, exacted of the wealthier citizens, were called liturgies. 2. (Eccl.) The office for the celebration of the Eucharist. The Liturgies of Christendom fall into five classes: (I) Of St. James, or Jerusalem ; (2) St. Mark, or Alexandria ; (3) St. Thaddæus, or the Eastern ; (4) St. Peter, or Rome ; (5) St. John, or Ephesus. For each of these there are further subdivisions. Among them may be mentioned the Ambrosian, or that of Milan; the Ancient British; the Gallican; the Mozarabic, which is still used in one chapel of the Cathedral of Toledo; the Liturgy of Sarum. (Use.)

Iiturgy of St. Peter. (Liturgy.)

Irtŭus. [L.] (Rom. Ant.) 1. The Augur's staff, used in quartering the heavens. 2. A curved trumpet.

Iiver of sulphur. (Chem.) A liver-coloured substance, chiefly composed of trisulphide and sulphate of potash.

Liver of antimony. (Chem.) An impure oxysulphide of antimony.

Livery. [L.L. livrea, from L. lỉběrātio, delivery.] (Leg.) 1. The act of delivering or receiving Seisin. 2. A feudal term for the bestowal of an estate, on his coming of age, upon an heir left a minor at his father's death, the profits during the minority having been taken by the lord, who now gave the land outre-le-main, out of his own hand. 3. Writ by which possession is obtained. 4. (Municip.) A free guild or company in the City of London, the members of which have a peculiar dress, livery [O.Fr. livrée, (clothes) handed over (for a servant)].

Iivery-man. A freeman of the City of London and member of one of the City companies.

Livid sky. (Naut.) The peculiar black-purple hue assumed by the sky before an easterly gale.

Livraison. [Fr., from L.L. liběrātio, -nem.] A part of a book printed and delivered by itself, a number, in a series.

Livre. [Fr., L. libra, a pound.] 1. The old French money of account was 12 deniers $=1$ sou; 20 sous $=1$ livre (tournois). For the conversion of livres into francs, the legal rate was $8 \mathrm{r}$ livres $=80$ francs. 2. The old French pound ; Livre usuelle $=500$ grammes ; Livre poids de Marc $=4^{8} 9^{\circ} 505^{8}$ grammes, or $7554 \frac{1}{2}$ grains troy. 
Lixiviation. [L. lixivius, made into lix, līcis, lye.] The washing of wood ashes in water, so as to extract the saline and soluble particles of cinders, etc.

Ilan- [Cymr.], = inclosure, church ; part of Welsh names, as in Llan-beris. So lan, in Cymric, part of Scotland, as Lan-rick.

Llanos. [Sp., from L. planus.] Vast treeless plains of Texas, New Mexico, S. America.

Iloyd's. (Com.) 1. A society of underwriters (q.v.) ; so called from Lloyd's coffee-house. The rooms are now in the Royal Exchange. This society is the great centre of maritime registration and intelligence. 2. Austrian L., at T'rieste, a general commercial and industrial company. Lloyd's List, the daily gazette edited by a committee of $\mathrm{L}$.

Iloyd's Register of Shipping contains, in addition to the names, class, and other particulars relating to vessels classed by the society, the names, dimensions, etc., of all vessels of one hundred tons and upwards registered in the United Kingdom, and of ships of large tonnage owned abroad. Vessels are classed by the society under the following letters:$A, A$ in red, $A, E, I F$, and $2 F$. The figure I following the class letter shows that the equipment is complete and efficient, while a instead of $I$ shows that it is deficient in quantity or defective in quality. Vessels classed $A$ are new, or continued, or restored to the class. Iron vessels are classed $A$ so long as they are found by survey to be in an efficient condition to carry dry and perishable goods to all parts of the world. Composite vessels are under certain conditions classed $A$ for a term of years; but for all $A$ vessels satisfactory evidence must be first produced of date, build, and place of building. Iron vessels constructed for special purposes may be classed $A$ for such purposes. Numerals prefixed to the letter $A$, thus : Ioo $A$, $90 \mathrm{~A}$, etc., down to $75 \mathrm{~A}$; and also the letter $\mathrm{A}$ cr $B$ within $A$, thus : $\hat{A}$, $\hat{B}$,-relate to iron vessels, and show the rules under or equal to which they were built; as does also * A ; while $\mathrm{A}$ shows an iron vessel of $A$ class, but not built under the rules. $A$ in red denotes wooden vessels, not eligible to be classed $A$, but fit to carry dry and perishable goods to any part of the world. $\mathcal{E}$ denotes wooden vessels fit to carry dry and perishable goods on short voyages, and other goods to any part of the world, and also iron vessels classed $A$ prior to the Ist of July, 1879, and at the expiration of the term of years for which $A$ has been granted. Those classed $E$ are wooden vessels fit to carry cargoes not subject to sea damage on any voyage. Those classed I $F$ and $2 F$ are foreignbuilt vessels classed by the society before the Ist of July, I876: I F, fit to convey dry and perishable cargoes to all parts of the world ; $2 \mathrm{~F}$, to do so on shorter voyages. The character $S$ is no longer used.

Loach. [Cf. Fr. loche, id.] (Ichth.) Freshwater fish, about four inches long, lives under stones, has six barbules to the mouth. Europe,
India, Japan. Gōbītis, fam. Cyprīnĭdæ, ord. Phȳsostǒmi, sub-class Tělěostěĩ.

Load. 1. Of timber, fifty cubic feet. 2. Of hay, thirty-six trusses.

\section{Loading. (Life assurance.)}

Ioad-line. (Naut.) That below which a loaded ship is not to be immersed. Four-fifths of total depth from deck; indicated by a horizontal line through the centre of a disc painted on her side.

Loadmanage, Iodemanage. Hire of a loadman.

Loadstar, Iodestar. Leading star, guiding star ; Pole-star; Cynosuro.

Loafer. [D. loopen, Ger. laufen, to run; $c f$. interloper.] In the middle states of America, a vagabond.

Ioam-moulding. [Eng., loam.] A mould for casting metal, formed by sweeps without a pattern. (Swoep.)

Lobate, Lobated. [Gr. $\lambda o \beta b s$, lobe.] (Ornith.) A term applied to the feet of certain water-birds, as grebes, in which the toes, instead of being connected, are provided on each side with membranes which open in striking and close in retracting.

Lobbs. Underground stairs in a mine.

Lobscouse, or Lapscourse. (Naut.) A seadish, made of salt meat, biscuit, potatoes, onions, spices, etc., minced and stewed.

Iobster-boat. (Naut.) Clinker-built, bluff, and fitted with a well to keep the lobsters alive.

Local attraction. 1. In Mag., an attraction at a given place exerted by objects in the neighbourhood causing a magnet to deviate from the magnetic meridian of the place. 2. A L. A. may be exerted on a plumb-line by the gravitation of a heavy mass, e.g. a mountain, and cause it to deviate from the direction proper to the mean form of the earth in its neighbourhood.

Iocale. [Fr.] Place, locality.

Iocal option. The consent of a community, or stated proportion thereof, to some proposed legislative act, as a prerequisite to the action of the Government.

Locataire. [Fr.] Tenant, lodger, lessee.

Iocative case. In Gram., the case expressive of locality. Such a case existed originally in all Aryan languages, and it survives in Greek and Latin ; but likeness of form has led grammarians to confuse it with other cases, to the great misleading of the learner.

Loch, Lough. [Scot., Cymr. llwch, L. lăcus, lake.] Lake.

Lochaber axe. Large kind of hatchet, used by the Highlanders as a weapon.

Lockout. (Strike.)

Iockram. A sort of coarse linen (from Locronan, in Brittany).

Iockstitch. A kind of sewing in which each stitch is secured, or locked, before the next is made.

Loc-man, or Loco-man. ( $\Lambda^{\top} a u t$.) Old name for a pilot.

Iǒco critāto [L.], Loc. cit. In the passage quoted.

Loco-focos. Name given in $\mathbf{I} 834$ to the U.S. Democratic party, because they relit Tam- 
many Hall with L. matches, after the lights had been extinguished by the other party.

Locomotive engine. (Steam-engine.)

Lŏcŭlus. [L., a little compartment, dim. of loccus.] (Bot.) A cell, especially of the ovary ; adj., bi-, tri-, etc., multi-locular. (Dissepiment.) Locum těnens [L., holding a place.] Any deputy or substitute. From this phrase is derived the Fr. lieutenant.

Lŏcus. [L., place.] (Math.) When all the points in a line (or surface), and no others, satisfy a certain condition, that line (or surface) is the L. of the points; e.g. a circle is the L. of all points that are equidistant from a fixed point.

Locus in quo ante. [L., place in which before.] The position occupied prior to specified operations or negotiations; without ante, the present position.

Lǒcus pœnĭtentīø. [L., a place (or chance) for repentance.] Power of drawing back from a bargain before the performance of any confirmatory act.

Locus sigilli. [L.] The place for the seal; shown by "L. S." in copies of instruments.

Iǒcus standi. [L., a position to stand in.] A tenable ground in argument.

Locutory. [L. locūtor, a speaker.] A synonym of parlour, or the speaking-room, in monasteries.

Lode. [O.E. lâd, course, from lædan, to lead.] 1. A vein of ore. 2. A cut or reach of water.

Lodemanage, or Lodemanship. (Naut.) Hire of pilot; also Pilolage, or Seamanship. L.-ship, a pilot-boat, used also for fishing, temp. Edward III.

Lodesman. A pilot.

Lodestar. (Loadstar.)

Lodged. [Fr. logé.] (Her.) Lying on the ground with head erect.

Iodgment. (Mil.) A permanent footing established in an enemy's works, and artificially protected from his fire.

Lodia. (Naut.) A large White-Sea tradingboat.

Loess, Lehm, Loam, Flood-mud. [Ger. lösen, to loosen.] (Geol.) A loamy fluviatile deposit, yellowish, chiefly argillaceous, with abundant land and fresh-water shells; in the valleys of the Rhine, Danube, Mississippi ; Pleistocene.

Lofty ships. A name formerly given to all square-rigged vessels.

Logarithm [Gr. $\lambda \delta \gamma \omega \nu$ à $\rho \theta \mu \delta s$, the number of the ratios]; Base of I. ; Brigg's I.; Common I. ; Hyperbolio I.; Naperian I.; Table of I. The Logarithm of a number is the index of the power to which a given number (or base) must be raised to equal that number. Thus, to the base 10 , the L. of 1000 is 3 , because $10^{3}=1000$. When logarithms are calculated to the base Io, they are Common L., or Brigg's $L$. The L. of the natural numbers (say, from I to $100, \infty 00$ ), arranged in order, form a Table of $L$. The use of such a table consists in this, that numbers may be multiplied and divided by the addition and subtraction of their logarithms. The invention of $\mathrm{L}_{\text {. }}$ is due to Napier, of Merchison, who used a base $(2 \cdot 71828 \mathrm{r} 8)$ which made the calculation of logarithms less hard. L. calculated to that base are called Naperian $L$., and sometimes Hyperbolic L., because the area of any portion of a hyperbola is expressed by means of them.

Iog-board. (Naut.) Two boards shutting up like a book, on which the mate of the watch writes in chalk the particulars to be copied into the $\log$-book. (Journal.)

Loge. [Fr.] Opera-box.

Ingement garni. [Fr.] Lodgings, furnished. Loggan. (Rocking-stones.)

Loggerhead. An iron ball, fitted with a long handle, used to heat tar, etc.

Ioggia. [It., from L. locus, place.] A gallery or porch adorned with paintings.

Logistic arithmetio; I. logarithms. [Gr.

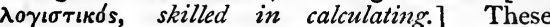
logarithms are adapted for calculating the fourth term of a proportion in which the terms are hours, minutes, and seconds, or degrees, minutes, and seconds ; they are used to shorten the last step in the calculation of a longitude from an observed lunar distance. The term $L$. arithmetic is sometimes used to denote arithmetical operations performed on numbers sexagesimally divided; hence the name $L$. logarithms.

Log-line and Log-ship. A small line, about a hundred fathoms long, divided into sections of forty-two feet (properly forty-seven feet four inches), called knots, and fastened to the $l o g$. ship. Its use is to estimate the rate of a vessel sailing, by observing how many divisions, or knots, run out in a given time after the $\log$-ship has been thrown over, and about fifteen fathoms have run out.

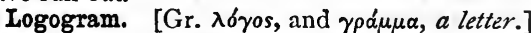
A word-letter, or phonogram, as i.e. for id est.

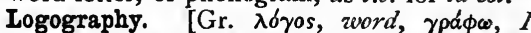
write.] A method of printing, in which each type is a whole word instead of a single letter.

Logogriph. [A word made up of the Gr. $\lambda \sigma^{\prime} \operatorname{os}_{\text {, and }} \gamma \rho \hat{i} \phi o s, a$ fishing-net.] A sort of riddle.

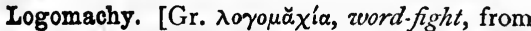

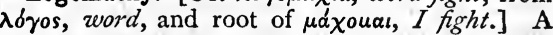
war of words, a contention about nothing more than words.

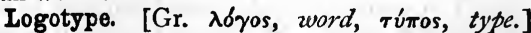
A single type containing two or more letters ; as $f, f l$. (Ligature.)

Logwood. A dark-red dyewood from Central America, imported in logs ; that of the Hæmatoxy̆lon, a leguminous tree, a native of Campeachy Bay.

Lohengrin. In mediæval tradition, a mysterious knight married to a wife who is forbidden to ask his name. The command is disobeyed, and the knight vanishes. The story is counterpart of that of Psyche and Eros.

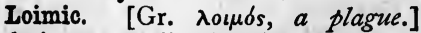

Relating to pestilential disorders.

Iok, or Ioki. In Norse Myth., a deity corresponding to the Persian Ahriman.

Ioligo. [L.] (Cuttle-fish.)

Lollards. A religious sect in Germany, early 
in the fourteenth century, differing in many important points from the Church of Rome. The followers of Wyclif were also called L. [(?) lullen, to sing in a murmuring strain; cf. $\mathrm{L}$. lallare, and lull, with suffix -hard].

Lombard. This word was formerly used in England to denote bankers and money-lenders, Italian merchants from the cities of Lombardy being the great usurers of the Middle Ages. A street in the city of London still bears their name.

Lombard school. (Bolognese school.)

London clay. (Geol.) Brown or dark-blue, tenacious, fossiliferous clay, with occasional nodules of greenish sand, gypsum, etc. ; Tertiary, Eocene ; next below the Bagshot sands.

London Stone. A name given to the stone now embedded in the south wall of St. Swithin's Church, Cannon Street ; supposed to have been a chief milestone of Watling Street, one of the fifteen main Roman roads in England.

London waggon. (Naut.) The tender formerly used to convey pressed men from London to the receiving ship at the Nore.

Lone Star. The state of Texas, whose flag bears a single star in its centre.-Bartlett's Americanisms.

Longa est injūria, longæ ambāges. [L.] Long drawn out are my wrongs, long (will be) the rvindings of the narrative (Virgil).

Ionganimity. [L.L. longanimitas, from longus, long, animus, mind.] Long-sufferance, endurance, patience.

Longbeard. (Bellarmine.)

Long-boat. (Naut.) The principal boat of a merchantman, fitted with masts and spars.

Long-bow. (Mil.) Weapon with which the English archers were first armed, measuring six feet, and shooting a shaft or arrow of three feet. To ensure proficiency, strenuous laws as to its practice were made in England.

Longcloth. Cotton cloth, opposed to Broadcloth.

Longē absit. [L.] Far be it from (me, us).

Longicorn beetles, Longicornia. [L. longus, long, cornu, a horn.] (Entom.) An enormous family of tetrăměrous beetles, containing 1488 gen., 7576 spec., subdivided by English entomologists into Prionidæ, Cerambycidæ, and Lamiidæ. Vegetable feeders.

Longipalpi. [L. longus, long, palpus, $a$ touching sofily, hence the instrument with which this is done.] (Entom.) Brăchèlytrous beetles with maxillary palpi (i.e. filaments attached to the chereing jaws) almost as long as the head.

Longipennate. [L. longæ pennæ, long wings.] (Ornith.) Swimming-birds whose wings reach to or beyond the tip of the tail.

Longirostrals, Iongirostres. [L. longus, long, rostrum, bill.] Wading-birds with long bills ; as woodcocks.

Longitude [L. longitudo, length] ; Geocentric L.; Heliocentric I. 1. (Geog.) The longitude of a place is the arc of the equator intercepted between its meridian and that of a standard station, as Greenwich, Paris, etc. It is generally reckoned east or west from $0^{\circ}$, up to $180^{\circ}$; but it is often reckoned in time, and then I hour of longitude equals $15^{\circ}$. 2. (Astron.) The longitude of a heavenly body is the arc of the ecliptic intercepted between the first point of Aries (Aries, First point of) and its circle of latitude. It is generally reckoned from $0^{\circ}$ up to $360^{\circ}$ in the direction of the sun's proper motion, i.e. from west to east. If the earth is supposed to be at the centre, the longitude is Geocentric; if the sun, Heliocentric.

Long-jawed. (Naut.) Said of a rope when so strained and untwisted that it will coil both ways.

Long note. In ancient musical notation, $=$ two breves. (Breve.)

Long Parliament The last Parliament summoned by Charles I., I640 ; dissolved by Cromwell, I653, having been purged of its Presbyterian members, in 1648 , by Colonel Pride, the members allowed to remain being called the Rump.

Long primer. A kind of type, as-

\section{Large.}

'Long-shore men, or along-. The humbler, rougher men employed about the docks and shipping in the Thames and other rivers.

Long-sighted eye. One wanting in refractive power, and consequently unable to see objects distinctly unless at a distance exceeding the normal least distance of distinct vision, i.e. eight inches. (Presbyopia.)

Long-togs. [L. tŏga.] (Naut.) Landsman's clothes.

Long Vacation. (Leg.) From August io to October 24, Common Law ; October 28, Chancery; Univ., from the end of Easter term to October, more than three months.

Ionicera. (Lonicer, Ger. botanist, died 1586.$)$ (Bot.) A gen. including all honeysuckles; type of ord. Caprifoliaceæ.

Lool. A vessel to receive the washings of ores.

Looming. [O.E. léomian, to shine.] The indistinct magnified appearance of objects as seen in certain states of the atmosphere.

Loom of an oar. (Naut.) The handle.

Loop. [Ger. luppe, an iron lump.] The pasty mass of melted ore taken out of the fire for forging.

Loophole. (Mil.) Narrow rectangular aperture made in masonry or wooden walls for the purpose of firing through with musketry.

Loover ways. Boards placed at an angle like a Venetian blind, so that air is admitted, but not the wet. (Louvre.)

Lorcha. A fast-sailing Chinese vessel, armed.

Lore. [A.S. lâr, from læran, to teach, akin to learn.] That which is learnt, knowledge of any kind. The word is used especially in the phrase folk-lore, or lore of the people, their traditional tales, superstitions, etc.

Loretto cups. Small cups made of clay mixed with dust from the Santa Casa of Loretto, rudely painted with a representation of Christ, or of the Virgin and Child, and inscribed Con pol. di. S. C. (i.e. Con polvere di Santa Casa). 
Loretto, Holy House of. The house in which, according to the tradition, the Virgin Mary was born, and which was conveyed by angels from the Holy Land to Italy in the thirteenth century.

Iorgnette. [Fr.] An opera-glass.

Lörica. [L.] $A$ leather cuirass, a corselet of thongs.

Iổricăta, Loricates. [L., provided with a breastplate.] (Zool.) The fourth ord. of reptiles, protected by bony plates. (Herpetology.)

Iorimer, Loriner. [O.Fr. lormier, L. lōrum, a thong.] A maker of bits, spurs, and otlfer metal work for harness.

Iorry. A waggon with very low sides, for carrying heavy goods.

Lory. [Hind. and Malay.] (Ornith.) Gen. of brush-tongued paroquets, gay-plumaged, mostly scarlet; Austro-Malayan Islands. Lorius, fam. I rĭchŏglossǐdæ [Gr. $\theta \rho \imath \xi, \tau \rho \iota \chi \delta s, ~ h a i r, ~ \gamma \lambda \hat{\omega} \sigma \sigma \alpha$, tongue], ord. Psittăci.

Lory̆mer. (Larmier.)

Losel. [A.S. los, loss, destruction.] A wasteful fellow, scoundrel.

Losenger. [O.Fr. losengier, It. lusinghiere, from L. laudare, to praise, hence to flatter.] A deceiver, a cheat.

Lost day. (Naut.) The day lost when the globe is circumnavigated westward. (Gained day.)

Lothario. A voluptuary in Rowe's Fair Penitent, a representative of those who make love to married women.

Lothian. The part of Scotland containing the counties of Haddington, Edinburgh, and Linlithgow, respectively called the East, Mid, and West Lothian.

Lotman. (Naut.) Old name for a pirate.

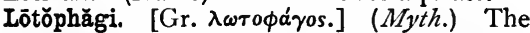
eaters of the lotus, a fruit the taste of which led people to forget their country and friends and to remain idle in the lotus-land.

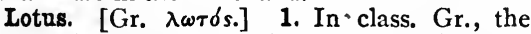
name of several plants (e.g. a kind of trefoil, water-lilies, etc.) quite dissimilar and often confounded. 2. (Bot.) A gen. of plants belonging to the nat. ord. Leguminosæ; L. corniculatus is the common bird's foot trefoil of pastures and dry banks in Great Britain.

Lotus-eaters. (Iotophagi.)

Loud voice. In Prayer-book, = not "sēcrētō," as in the unreformed service, nor with the mystic voice [Gr. $\mu v \sigma \tau \iota k \hat{\omega} s]$ of the Greek Church. Iough. (Loch.)

Louis-d'or. [Fr.] A gold coin, first struck under Louis XIII., I64I, and commonly called a twenty-franc piece.

Iouis Quatorze. This phrase is often used to denote the style of ornamentation for houses, furniture, etc., fashionable in the time of Louis XIV. of France.

Iound. (Naut.) Calm, absence of wind.

Loup-garoux. (Iycanthropy.)

Louvre. [(?) Fr. l'ouvert, the open; but not from the palace known as the Louvre, the origin of which name cannot be determined.] 1. A lantern. 2. A turret for the escape of smoke or for ventilation. 3. The celebrated museum and gallery of Paris, connected with one of the most ancient palaces of France.

Louvre-boarding. (Iuffer-boarding.)

Love, Family of. (Eng. Hist.) A sect of the sixteenth century, holding opinions much like those of the Anabaptists.

Love-feast. (Agapæ.)

Lovelace. A consummate voluptuary and foe to female virtue, in Richardson's History of Clarissa Harlowe.

-low. [A.S. hlaw, a mound, rising ground.] Part of names, as in Mar-low ; $c f$. -law on Scot. Border, as in Hood-law.

Low and aloft. (Naut.) Every sail set.

Iowbote. (Leg.) Recompense for a man killed in a tumult.

Iow Celebration. In the Latin Church, Low Mass, or Mass performed by a single priest, with a server.

Lower-case. In Printing, small letters, types (as distinguished from capitals) kept in the lower case ; abbrev. to l.c.

Lower Empire. A name sometimes applied to the Roman empire in the East, from the establishment of Constantinople as the imperial city to its capture by the Turks in 1453 . (Emperor; Empire.) Lower means later in time ; so Gr. $\kappa a ́ \tau \omega$.

Lowestoft China Manufactory. Established I756, for pottery and soft-paste porcelain. Hard paste introduced about 1775 , and continued till about 1800. It has no distinctive mark, but roses are its most characteristic ornaments.

Low German. (Lang.) Platt Deutsch, name of the dialects of $\mathrm{N}$. and W. Germany, the Netherlands, and Anglo-Saxon.

Low-pressure engine. (Steam-engine.)

Low-pressure steam. (Steam.)

Low Sunday. The first after Easter ; probably a corr. of Laudes, the first word of its Sequence, "Laudes Salvatori," etc. ; because the Introit, from the first word of which the Sunday was commonly named, was on this day the same as on Easter Day, viz. " Resurrexit."

Low wines. The product of the first distillation.

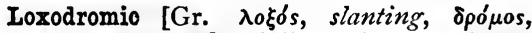
course] curve, or Rhumb-line. A curve drawn on a sphere so as to make a constant angle with all the meridians it cuts. A ship which sails on a given course (e.g. south-west) describes a $L$. curve.

Lozenge. [Fr. losange.] (Her.) A diamondshaped figure, used (I) as an ordinary, (2) as the escutcheon whereon is painted the coat of arms of a maiden or widow. An escutcheon covered with alternate lozenges of two different tinctures is called Lozengy.

I's, Three. In Naut. talk or slang, formerly lead, latitude, look-out; held to be sufficient by those who despised nautical astronomy.-Admiral Smyth's Sailors' Word-Book.

Lubber-land. (Naut.) The happy land of sailors' dreams, where all is play and no work. Lubber's-hole, the space between the head of a mast and the top. Lubber's-point, the mark in the compass-bowl in a line with the ship's 
head. (For Lubber, or Landlubber, vide Landlouper.)

Iūcernam ǒlet. [L.] It smells of the lamp; it bears signs of nightly study.

Iūcifer. [L., lisht-bearing.] 1 . In the classics, the morning star. 2. In Med. Theol., Satan. " Hillel," in Isa. xiv. 12, meaning the morning star, and translated "Lucifer," is from the verb hallal, meaning to shine, but also to be proud. The fall of Hillel, being taken to refer to the fall of some proud angel in connexion with the fall of Babylon, was held to typify Satan and his kingdom. (See note to "proud Lucifera," Faëry Queene, I. bk, iv. 12. Clarendon Press series.) (Phosphorns.)

Luoiferians. (Eccl. Hist.) The followers of Lucifer, Bishop of Cagliari, who in the fourth century refused to hold communion with clergy who had held Arian doctrines.

Iucri causâ. [L.] For the sake of gain.

Iuctation. [L. luctātiōnem, from luctor, I struggle.] Effort to overcome difficulties.

Iǔcŭmo. [Etrusc.] One inspired; and so a priest or prince.

Iūcus a non lūcendo. (Antiphrasis.)

Iud, General. Name of the supposed leader of the artisans who endeavoured (I8II) to stop the introduction of machinery by riot. They were called Luddites.

Ludère par impar. [L.] To play odd and even (Horace).

Lūdi. [L.] Games.

Lūdi Apolliñāres. [L.] Roman games in honour of Apollo, instituted by the advice of the Delphic oracle after the battle of Cannæ, B.C. 212, and held in the Circus Maximus yearly, July 6, conducted by the Prætor Urbanus.

Iūdi Căpĭtōlinni. [L.] A Roman festival to celebrate the departure of the Gauls, B.c. 387 .

In̄di Circenses ; L. Consuāles ; I. Romāni; I. Magni. [L.] The most important Roman games, celebrated yearly, September $4^{-12}$, in honour of Jupiter, Jüno, and Mínerva, or of Consus and Neptūnus Equestris, in the great Circus, superintended by the Curule Ædiles. Races, athletic contests, sham fights, and the cavalry exercise called Lüdus Troia, performed by Roman youths, were carried on. (Consus was supposed to be a deity presiding over counsels and secret plans; but his name is probably connected with that of the Consentes Dii.)

Iūdi In̄běrāles, or Līběrālia. [L.] A Roman festival corresponding to the Greek Dionjysia, celebrated March 17, when Roman youths of sixteen years old received the tŏga virulisis.

Iūdi Sæcŭlăres, Tārentini, Taurii. A Roman festival in honour of the infernal deities during the republic; during the empire, also of the great gods and Vesta, Hercules, Latona, and the Fates (Parcæ); celebrated at first on great public emergencies, afterwards at intervals of many years (especially after the establishment of Augustus's supremacy), in the part of the Campus Martius called Tarentum, and with games, theatrical entertainments, and sacrifices through. out the city.

Iuff, or Loofe. [D. loef, wind, Ger. luft.]
(Naut.) 1. The order to come more into the wind. 2. The air, or wind. 3. Abbrev. for Lieutenant. 4. The fullest part of the bows. 5. The weather leech of a sail. L. and lie = hug the wind, or sail as nearly as possible to it. $L$. and touch her, try how near the wind she will come. $L$. into a harbour, shoot into it, head to wind, gradually. L. round, or L. a-lee, go on to the other tack.

Iuffer-boarding, properly Louvre-boarding. Sloping boards in the apertures of a lourre, belfry, etc., to admit air but to shut out rain.

Lug, Lugg, I.-worm. Sand-worm, Arēnicŏla piscātōrum [L. ărēna, sand, cŏlo, I inhabit, piscātor, a fisherman]. (Zool.) An errant annelid found on the seashore.

Lūgēte Věněres lŭbīdinesque. [L.] Mourn, ye Venuses and Loves ; the first line of the poem of Catullus on the death of Lesbia's sparrow.

Iugger. (Naut.) A boat, or small vessel, rigged with lugsails.

Luggnagg. An island in Swift's Gulliver's Travels, where some of the inhabitants are cursed with an immortality $o_{1}$ old age and decay.

Lugsails. (Sails.)

I'ultima che si perde è la speranza. [It.]

The last thing that is lost is hope.

Iumber. Timber sawed or split for use.

Iumbrīcĭdæ. [L. lumbrīcus, an intestinal or earth-zorm.] (Zool.) Earth-worms. Annelids progressing by means of chitinous bristles. (Chitino.)

Iumbricus. [L.] (Zool.) An intestinal worm; earth-worm.

Iūmen jŭventæ purpŭreum. [L.] The ruddy glow of youth (Virgil).

Iump. (Naut.) A heavy lighter used for carrying anchors, cables, etc., about a harbour.

Iumpers. (Naut.) 1. Men who load and unload ships. 2. In the north, men who furnish a ship with ballast.

Lumpkin, Tony. A representative hobbledehoy, in Goldsmith's comedy She Stoops to Conquer.

Lunar ; I. cycle; I. distance ; $\mathbf{L}$. month ; I. observation; I. table; I. year. A Lunar dis. tance is the distance of a star from the bright limb of the moon. The measurement of this angle is a L. observation, or simply a Lunar ; with appropriate calculations it enables the observer to determine his longitude, and ascertain the error of his chronometer, which is designed to show Greenwich time. A L. month is the interval from new moon to new moon; twelve of them make a $L$. year, which is equal to 354 days 8 hrs. 48 mins. L. tables enable the astronomer to calculate the true position of the moon at any instant past or future. The tables which facilitate the calculation of the Greenwich mean time from an observed $L$. distance are sometimes called L. tables. (For L. cycle, vide Cycle.)

Lunar caustio. [L. luna, moon, the alchemists' name for silver.] (Chem.) Fused nitrate of silver.

Iunation. The interval of time from one new moon to the next, a lunar month or period of 29 days 12 hrs. 44 mins. 
Iune. Name of rivers, from alauna, L. for Celt. al avon, white water.

Iune. (Math.) Any one of the four portions into which the surface of a sphere is divided by two great circles.

Lunette. [Fr., dim of lune, moon.] 1. (Arch.) An opening in a concave ceiling to admit light. 2. (Mil.) Fieldwork of the shape of a bastion, but formerly used also as outworks in permanent fortification. 3. A kind of convexo-concave lens for spectacles (from the shape). In Fr., lunettes means spectacles.

Iuni-solar. Resulting from the joint action of sun and moon, as L.-S. precession, L.-S. tides, etc.

Iuntra. (Felucca.)

Lupercālia. [L.] A Roman festival in honour of Lupercus, an agricultural god, invoked, it is said, as a protector against wolves [lupus, wolf].

Iupuline. [L. lupullus, dim of lupus, the hop.] The bitter extract of hops.

Iŭpum auribus tenēre. [L., to have a wolf by the ears.] To be unable to hold on and afraid to let go; to be in a state of difficulty whichever way one acts.

Iŭpus. [L., wolf.] Once called Nölī me tangëre [L., touch me not]. (Med.) A malignant disease of the skin, closely allied to cancer, and very destructive.

Iŭpus in fäbŭla. [L.] The wolf in the fable, whose appearance deprived speakers of their voice; said of one who appears unexpectedly when he is being talked about.

Iŭpus pilum mütat, non mentem. [L.] The wolf changes his hair, not his disposition.

Iurca. (Naut.) Old name for a coastingvessel of the Mediterranean.

Iurcher. A variety of dog, allied probably to shepherd's dog and to greyhound; used generally by poachers.

Iure. [Fr. leurre, and this from the O.G. luoder (Littré).] In Falconry, a bunch of feathers attached to a cord and tassel, having in the centre of the feathers a split piece of wood, with some meat. The hawk, fed constantly thus, is enticed back after an unsuccessful chase.

Iusiads. [Port. Os Lusiadas.] The great epic poem of Portugal, written by Camoens, published in $157 \mathrm{I}$, the subject being the establishment of the Portuguese power in India.

Inst-huis. [D., pleasure-house.] A little detached room or arbour for summer and autumn evenings, numbers of which overlook public roads and canals in Holland.

Lustration. [L. lustrātio, -nem.] A purification by water, connected with sacrifices and other rites-a Roman ceremony for winning the favour of the gods. A general lustration of the people was held by the Censors at the end of every five years; hence the period itself came to be known as a lustre, lustrum [from luo, the Gr.

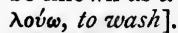

Iustre. [Fr.] A metallic film over the glaze of pottery, so thin as to be iridescent.

Lustre of years. (Lustration.)

Iūsus nätūræ. [L.] A freak of nature.

Iute. A kind of guitar, with from four to six pairs of strings, said to be Sp. laud, Ar. el'ood.

Iutescent. [L. lŭteus, yellowv.] Of a yellowish hue.

Inte-stern. (Pink.)

Iutestring (corr. from Lustring). A plain stout silk for ladies' dresses.

Intetia. Old Latinized name of Paris.

Iutherans. The followers of Martin Luther. (Consubstantiation.)

Luting. [L. lŭtum, mud.] Closing the joints of a vessel submitted to heat by means of a clayey mixture called lute.

Iuxation. [L. luxatio, -nem, from luxo, $I$ dislocate.] (Med.) Dislocation, displacement of a bone or other part.

Iycanthropy. [Gr. $\lambda$

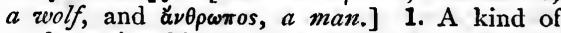
madness, in which a man supposes himself to be a wolf, and acts accordingly. 2. The supposed assumption of the form of wolves by human beings. These human wolves were called by the French loup-garoux, by the old English zere-wolves, by the Germans wehr-wölfe. (Werewolves.)

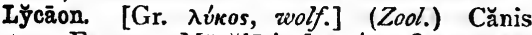

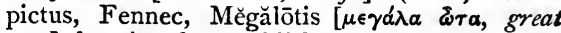
ears], hunting dog, reddish brown patched with black and white; connects hyænas and dogs, having the feet of the former (four toes on each foot), the teeth and bones of the latter. It hunts in packs. S. Africa. Gen. Ly̆cãon, fam. Cănĭdæ, ord Carnǐvŏra.

Iycēum. [L., Gr. $\lambda u^{\prime} \kappa \in t o \nu$, the temple of Apollo Lykeios.] 1. A gymnasium with covered walks in the east suburb of Athens (named after the neighbouring temple of Apollo L.), where Aristotle gave his lectures; hence, 2, any higher school. (Gymnasium.)

Iych-gate. (Lich-gate.)

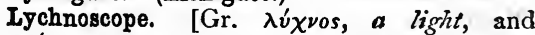
$\sigma \kappa o \pi \epsilon ́ \omega, I$ see.] (Eccl. Arch.) An aperture in the wall of a chancel, through which persons outside might see the priest celebrating at the altar.

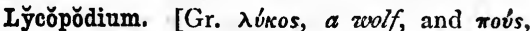

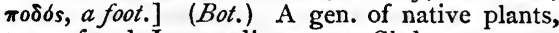
type of ord. Lycopodiaceæ, or Club-mosses, vascular acrogens, plants with creeping stems or corms, and leafy branches resembling moss.

\section{Iydian mode. (Greek modes.)}

Iy̆dĭus lăpis, Lydian-stone. (Basanite.)

Iye, Ley. [O.E. leah.] Water impregnated with alkaline salt imbibed from the ashes of wood.

Iym, Iym-hound. [Fr. limier, a dog held in a leash, O.Fr. liem, L. ligāmen, band.] The bloodhound. (Ban-dog.)

Iymph. [L. lympha, zuater.] (Med.) The fluid contained in the lymphatic vessels; often applied, especially, to the fluid used in vaccination.

Iymphatics. (Absorbents.)

Iynch law. Irregular justice administered by the people ; so called, it is said, from a Virginian farmer named Lynch.

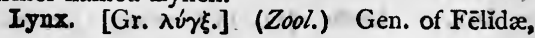


with tufted ears and short tails. N. hemisphere ; except Cáracal (q.v.), which may perhaps be considered a separate gen.

Lyon King-at-arms. Chief heraldic officer for Scotland ; title derived from lion rampant in the royal escutcheon.

\section{Lyonnesse. (Leonnoys.)}

Lyons, Poor Men of. (Hist.) The followers of Peter Waldo, a merchant of Lyons (circ. 1160), commonly known as Waldensians.Milman, Hist. of Latin Christianity, bk. ix. ch. 8.

\section{M.}

M. As an abbrev., stands for the prænomen Marcus; sometimes also for magister, monumentum, municipium. M' stands for the prænomen Manius. A Tuscan symbol like the letter was used to denote 1000 , and was formerly supposed to be the letter itself.

Maash. (Naut.) A large Nile trading-vessel.

Mab. In the mythology of the English poets of the twelfth and following centuries, the queen of the fairies.-Shakespeare, Romeo and Fuliet.

Mabby. A potato spirit used in Barbados.

Mac. A Scotch word signifying son [from the same root with Gr. $\mu$ '́ras, great, Ger. magaths, magd, a maid or grown-up girl, much, muckle, etc.].

Macadamize. To construct roads by forming a crust with layers of stones broken into angular pieces of small size, each layer being consolidated before another is placed on it. This process, which was known long before in Europe, has received its name in England from J. L. Macadam, who died in 1836 .

\section{Macarius, St. (Dance Macabre.)}

Macaroni. [It.] Long slender tubes of a paste, chiefly of wheat flour.

Macaronic. A ludicrous distortion or adaptation of modern words to Greek and Latin inflexions and metre; invented by Theoph. Folengo, in Italy, sixteenth century; with a gross macaroni-like mixture of classical words, as in the schoolbny verses, "Trumpeter unus erat, qui coatum scarlet habebat," etc. The Polemo-Middinia of Drummond is a specimen.

Macassar oil. A kind of hair-oil originally obtained from Macassar, in the island of Celebes.

Macaw. (Ornith.) Gen. of birds like parrots, but with featherless cheeks. America.

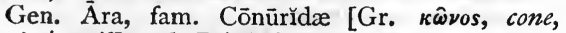
oùá, tail], ord. Psittăci.

Maccaboy. A kind of snuff (from a district in the island of Martinique).

Mace. [It.] The aril-a body which rises up from the placenta and encompasses the seed - of the nutmeg, used as a spice.

Mace. [Fr. masse, a mass, lump, L. massa.] (Mil.) A weapon used by cavalry; a species of club, with large fixed head, or hanging loose by chains. In the first form it is still used as an ensign of authority.

Macedonians. In Eccl. Hist., the followers of Macedonius, who in the fourth century denied the distinct personality of the Holy Ghost.

Maceration. of soft

Machiavellian. Popularly used as $=$ having a character of craft or duplicity in politics.

Machiavellism. The system of government propounded by Machiavelli (1469-1527) in his treatise called The Prince. The term is generally used in a disparaging sense.

Machicolation. [Fr. mâchicoulis, origin unknown, latter part con, with couler, to trickle (Littré).] Projection supported on corbels over the gateway of a castle, through the floor of which stones, scalding water, and molten lead were thrown on the heads of the assailants.

Machine. [L. māchǐna, any military engine.] Name given to any kind of engine used for battering or assisting in the attack of walls, before the invention of gunpowder.

Machine-tool. A machine driven by steam power, capable of adjustment to an automatic feed for shaping metal by cutting.

Mackerel-boat. (Naut.) One clinker-built, with large foresail, spritsail, and mizzen.

Macmillanites. A Scottish sect, representing the Covenanters of the seventeenth century; so called from John Macmillan, who adopted their principles and became their leader and spokesman. They are also known as the Reformed Presbytery, and as Mountain or Hill People.

Macramé. [Fr. Micarême, Mid-Lent, when priests' robes are trimmed with it.] In lace, a kind of work principally applied to ornamenting towels, etc. ; a long fringe is left at each end, for the purpose of being knotted together in geometrical designs. - Mrs. Palliser, History of Lace.

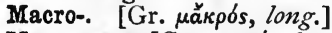

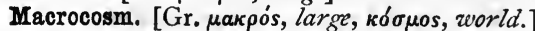

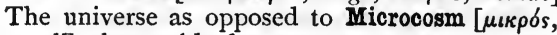
small], the world of man.

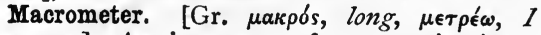
measure.] An instrument for measuring inaccessible objects by means of two reflectors on a common sextant.-Webster.

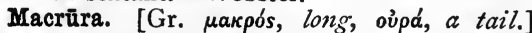
(Zool.) Long-tailed decapod crustaceans; as shrimps and lobsters.

Macte virtūte. [L., happy in thy virtue.] Good luck to you.

Măcŭlæ. [L., spots.] (Med.) Detached dis. coloured spots or patches in the skin, some from textural change, generally pigmentary.

Macule. [L. măcŭla, a spot.] In Printing, a blur, causing part of the impression to appear blur, cauble.
doubli 
Madame; Mademoiselle. The Fr. forms of the L. mea domina, my lady, mea dominicilla, my little lady; the latter being brought by abrasion into the Eng. damsel and miss.

Madder. [O.E. mäddre.] A reddish root, furnishing dyes and pigments.

Madefaction. [L. măděfăcio, I make wet.] (Med.) I.q. humectation (q.v.).

Madeira. A rich wine made in the isle of Madeira.

Madeira nut. A kind of thin-shelled walnut from Madeira.

Madjoun. (Majoun.)

Madge-howlet. [Cf. O.Fr. machette.] An owl.

Madonna. [It. for L. mea domina, my lady.] The Italian term for the Virgin Mary.

Mad Parliament. (Oxford, Provisions of.)

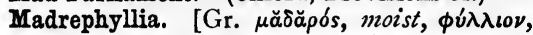
leafage.] Mushroom corals, fungǐæ.

Madrepore. [Fr.] Gen. of coral, giving its name to fam. Madrepŏrĭdæ, and to Madrepǒrārua, the great bulk of recent, coral-making zoophytes, as the Brainstone C. Ord. Zōanthārĭa, class Actīnōzōa, sub-kingd, Cœlentěrāta. (Generally connected with madré, spotted; but Littré gives It. madrepora, from madre, mother, Gr. $\pi \bar{\omega}$ oos, tuft-stone.)

Madrigal. [Fr., from It. madrialè, L.L. matriale, some kind of song (Littré).] 1. Seems to have been originally a theme for the poet improvising; then, 2, the harmonizing of such songs as had become popular; lastly, 3, as perfected in England, part-music, with distinct phrases or melodies, not mere concord of sounds, as a glee may be ; while motett [It. moto, theme, movement], once synonymous with madrigal, came to denote movements intended for the services of the Church, and these became anthems.

Mæcēnas. The friend and patron of Horace and Virgil ; hence any patron of men of letters, as Sir Philip Sidney e.g. was of Edmund Spenser.

Maelstrom. - [Norw., mill-stream.] (Geos.) An eddy or race on the Norwegian coast, exaggerated, like Scylla and Charybdis, into a terrific whirlpool, sucking down everything coming within its reach.

Mæso-Gothic. Belonging to the Mæso-Goths, or Goths settled in Mæsia.

Maestro di Capella. (Capelmeister.)

Magdeburg, Centuriators of. Certain Lutheran writers so styled themselves, who in the sixteenth century compiled, at Magdeburg, a history of the Church down to the Reformation.

Magellanic clouds. (Astron.) Two nebulous or cloudy masses of light, resembling portions of the Milky Way, conspicuously visible to the naked eye between $18^{\circ}$ and $24^{\circ}$ from the South Pole, and covering areas of about forty-two and ten square degrees respectively.

Magenta (from the battle of Magenta, soon after which it was invented). An aniline dye of red colour tinged with violet.

Magged. (Naut.) 1. Worn and stretched rope. 2. Reproved.

Magians. [Gr. $\mu a$ yos, perhaps from the Pehlevi mog, or mag, a priest.] The hereditary priests among the ancient Persians and Medians. Zoroaster is said to have been the great reformer of their order. (Ahriman.)

Magic, Natural; $\mathbf{M}$. square. The art of employing the natural properties of things to produce effects that were thought magical; as the effects produced by the magic lantern. A $M$. square is a square divided into nine, or sixteen, or twenty-five, etc., smaller squares, with a number written in each, such that the sum of the three, or four, or five, etc., numbers in every horizontal, or vertical, or diagonal, row is the same; as-

\begin{tabular}{|c|c|c|}
\hline 4 & 9 & 2 \\
\hline 3 & 5 & 7 \\
\hline 8 & 1 & 6 \\
\hline
\end{tabular}

Magilp. A mixture of linseed oil and mastic varnish, used as a vehicle in oil-painting.

Magister ad Făcultātes. (Master of the Faculties.)

Magister Equrtum. (Master of the Horse.)

Magister Sententiarum. (Master of the Sentences.)

Magistery. A precipitate produced by dilution with water.

Magistrai. [Sp.] Roasted copper pyrites used in reducing silver ores.

Magistral line. [L. măgistrālis, belonging to a master.] (Mil.) The one first traced on the ground, giving the outline of fortification works. If the ditch has a retaining wall, it shows the summit of the escarp; in other cases, the line of crest of the parapet.

Magistral remedy. [L. măgister, master.] (Med.) 1. A sovereign remedy. 2. A remedy according to circumstances for a particular occasion, and so $=$ extemporaneous, not one of the Pharmacopœia.

Magma. [Gr., a kneaded mass.] Any pasty mixture of mineral or organic matters.

\section{Magna Charta. . (Charta, Magna.)}

Magna est verǐtas et prævălēbit. [L.] Truth is great and will prevail.

Magna est vis consuetudinis. [L.] The force of custom is great. (Mos pro lege.)

Magna Græcia. Name given to that part of S. Italy which was thickly planted with Greek colonies-Sybaris, Croton, Tarentum, Rhegium, etc.

Magnas inter ŏpēs inops. [L., poor in the midst of much wealth (Horace).] A miser.

Magnates. [L.L.] In Hungary, and formerly also in Poland, the title of the noble estate in the national representation.

Magnesia. An alkaline earth, the oxide of magnesium (originally found near Magnesia, in Lydia); the medicine being carbonate of M., a white, tasteless, earthy substance, mildly aperient. Epsom salt, i.e. formerly found in springs near $\mathbf{E}$., 
is sulphate of magnesia. Magnesia alba is a mixture of carbonate and hydrate of magnesium.

Magnesian limestone, i.e. having more than twenty per cent. of carbonate of magnesia, is, in Geol., = Permian limestone of Durham, and Zechstein of Germany; the middle member of the Permian system in England and Europe.

Magnesium. A white malleable metal, the base of magnesia.

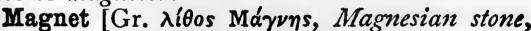
magnet]; Electro-M. A body, commonly a piece of steel, which has the property of attracting pieces of iron to its poles or ends. An Electro- $M$. is a nuagnet formed of a core consisting of a rod, or bundle of rods, of wrought iron round which an electric current circulates. If a bar of steel is used as a core instead of soft wrought iron, it retains its magnetic power after the current has ceased to circulate. In this way magnets are commonly made, though certain kinds of iron ore, called lodestones, are natural magnets; and magnets used to be made by touching steel needles with a lodestone.

Magnetio battery; $\mathbf{M}$. compensator; $\mathbf{M}$. elements; $\mathbf{M}$. field ; M. needle; $\mathbf{M}$. poles; $\mathbf{M}$. storms. A Magnetic battery is a number of magnets joined so that their similar poles come together and strengthen each other. A $M$. compensator is a magnet put in the neighbourhood of the compass of an iron ship, to neutralize the ship's permanent magnetism. The $M$. field is the region surrounding a magnet and so modified by it that another magnet brought within the region is acted on by the force of the magnet. A $M$. needle is a long thin magnet suspended so as to move freely in a horizontal or vertical plane (i.e. as a declination or dipping needle). The north pole of a magnet is that which turns towards the North Pole of the earth; as unlike poles attract each other, the magnetism of the north pole of a magnet is of the same kind as that of the South Pole of the earth. The north and south poles here spoken of are the $M$. poles of the earth, i.e. points at which the earth would exert no directive power on a declination needle; they do not coincide with the geographical poles of the earth. $M$. elements are the infinitesimally small magnets of which magnets are supposed to be made up, in the mathematical theories of magnetism. (For $M$. azimuth, $M$. declination, $M$. storm, etc., vide Azimuth; Declination; Storm, Magnetic ; etc.)

Magnetism; Terrestrial $\mathbf{M}$. The force of attraction or repulsion exerted by a magnet on other magnets. Terrestrial $M$. is the magnetic force exerted by the earth, which is, in fact, a magnet.

Magnetism, Animal, or Mesmerism (q.v.), (once thought to have some analogy to the $M$. of the lodestone). A supposed emanation by which one person can act upon the body and mind of another, controlling both action and thought, the effect being that of "expectant attention" (see Carpenter's Mental Physiology, ch. xvi.).

Magneto-electric induction; M.-E. machine. The phenomenon of a momentary electric current produced in a coil of wire by its motion within a magnetic field. In a M.-E. machine the motion is so arranged that a succession of these momentary currents is made to coalesce into a continuous current in one direction.

Magneto-electricity. Electricity developed by the action of a magnet.

Magnifying-glass. A lens with a negative focal length, in most cases a double-convex lens.

Magni nominis umbra. [L.] The shadow of a great name (Lucan); said of a man who without ability in himself inherits a great name, or of one who has survived or lost his reputation.

Magni rēfert quibuscum vixěris. [L.] It matters much with whom you live. (Noscitur e sociis.) Magnis excridit ausis. [L.] He failed in a great enterprise (Ovid); said of Phaethon.

Magnum bonum. [L., a great good.] The name given to a kind of plum and to a kind of potato.

Magnum est vectigal parsimonia. [L.] Economy is (in itself) a great revenue.

Magnus Apollo. [L.] A great Apollo; said of one distinguished in art or science. (A pollo.)

Magot. (Zool.) The most common gen. of Eastern monkeys, found also in N. Africa and Gibraltar. Some spec. have long tails ; others, as the Gibraltar monkey or Barbary ape, have none. Macacus, fam. Cercōpĭthēcĭdæ.

Mahâbhârăta. [Skt., the great (war of) Bharata.] A long Indian epic poem, relating to the civil war between the Kurus and the Pandus.

Mahâdeva, Mahadeo. [Skt., the great god,

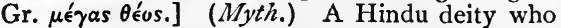
may be identified with Siva in the later Trimurtti or Trinity.

Mahadi. The twelfth Imam.

Mahalath, "to the chief musician upon M. ;" Ps. liii., lxxxviii. ; probably $=$ sickness, i.e. indicating a melancholy tune as appropriate (Speaker's Commentary). (Leannoth.)

Mahaleb. [Ar. mahleb.] A kind of cherry whose fruit affords a violet dye.

Mahlstick. [Ger. malen, to paint, stock, stick.] A stick used to support an artist's hand while painting.

Mahone, Mahonna, or Maon. (Naut.) An obsolete flat-bottomed Turkish ship of burden.

Mahound. A contemptuous name for Mohammed or Mahomet; hence an evil spirit or devil. Often coupled with Termagant.

Maia. A word denoting motherhood (?) or increase [is not May the increasing month, as April is the opening month (aperire)?] ; common to many Aryan languages. In Gr. Myth., M. is the mother of Hermes. In Eng., May.

Maiden. An instrument, resembling the Guillotine, formerly used in Scotland for the beheading of criminals. Hence to kiss the maiden was to be put to death. (Scavenger's daughter.)

Maiden assize. An assize in which there are no prisoners for trial.

Maidenhair. (Bot.) Ădĭantum căpillus Vĕněris, ord. Filices, ferns ; found on moist rocks, old damp walls, etc. Rare in Britain, abundant in S. Europe.

Maid Marian. This term is thought by some to be a corr. of Mad Morion, the boy of the Morrice-dance, so called from the helmet which 
he wore. The corr. of the words led to the change of the sex.

Maid of Kent, Holy. (Barton, Elizabeth.)

Maihem, Mayhem. (Leg.) The offence of injuring another so as in any way to affect his fighting power.

Mails. In Scot. Law, the rents of an estate. Payments made by owners of lands, for protection of their property to the chiefs of marauding clans, were termed black mail.

Maine liquor law. A law first enacted in the state of Maine about 1844 , forbidding the sale of intoxicating drinks except by an agent specially empowered by the local magistrate, or by municipal authority. - Bartlett's Americanisms.

Mainotes. Pirates of the Aggean Sea.

Mainpernor. [Fr. main, hand, pernor = preneur, one who takes.] [L.] A surety for a prisoner's appearance in court at a given time. (Mainprise, Writ of.)

Main Plot. (Bye, or Surprise, Plot.)

Mainprise, Writ of. (Leg.) One of the means of remedying the injury of false imprisonment; directed to the sheriff, commanding him to take sureties for the prisoner's appearance (usually called Mainpernors), and to set him at large. Bail might imprison or surrender before the stipulated day; but M. were simply sureties for appearance on the day. Again, B. were sureties in the special matter only, but $M$. were bound to produce him to meet all charges whatsoever. - Brown, Law Dictionary.

Maintenance. (Leg.) An offence punishable by imprisonment, is, according to Mr. Justice Stephen, "the act of assisting the plaintiff in any legal proceedings in which the person giving the assistance has no valuable interest, or in which he acts from any improper motive."

Maintenance, Cap of. A cap of dignity formed of red velvet lined with ermine.

Mainyard men. In Naut. parlance, those on the doctor's list.

Maison de santé. [Fr., a house of health.] A private hospital.

Maitrank (i.e. May-drink). A popular drink in Germany, prepared by throwing young shoots of woodruiff (Aspěrŭla ŏdōrata) into light white Rhenish wine, and allowing it to stand for a few hours.

Maître d'hôtel. [Fr.] A house-steward.

Maize. (Zea.)

Majesty. [L. mãjestas.] Properly the sovereign dignity of the Roman people. (Leze majesty.)

Majesty, Apostolical. A title bestowed by the pope, A.D. IOOO, on the Duke of Hungary.

Majesty, Catholic. A title bestowed by Alexander VI., I49I, on Ferdinand and Isabella of Spain.

Majesty, Most Christian. A title of the French kings, who were also styled Eldest Sons of the Church.

Majesty, Most Faithful. A title of the kings of Portugal, bestowed by Pope Benedict XIV. on John V.

Majolica. A soft enamelled pottery, introduced into Italy from Majorca, and distin- guished by coarseness of substance and elaborate design.

Majŏrat. [Fr.] In the law of many continental nations, the right of succession to property according to age. (Mayorazo.)

Major-domo. [L. major domûs, the grcater officer of the house.] This title, modified in later times into mord-dom, denotes seemingly three offices: ( 1 ) the chief officer of the prince's table; (2) the mayor of the palace; (3) the count or prefect of the palace, afterwards the Seneschal.

Major o longinquo reverentra. [L.] Respect is greater at a distance; answering to the phrases, "Familiarity breeds contempt ;" "Distance lends enchantment to the view;" and " No man a hero to his own valet."

Majoun, Madjoun. A preparation of hemp, used as an intoxicating drug by Orientals.

Majuscules and Minnscules. [Fr.] In Printing, capital letters and small letters.

Make ready. (Mil.) The old word of command for bringing a soldier's musket to full cock.

Making-iron. A tool like a grooved chisel, used in caulking ships.

Malabric. The language of Malabar, in the presidency of Madras.

Mala causa sǔlenda est. [L.] When your cause is bad you should say nothing (Ovid).

Malacca cane. A brown mottled cane for walking-sticks, from a palm growing in Malacca.

Malachite. [Gr. $\mu a \lambda a^{\prime} \chi \eta$, mallow, the leaf of which has a like colour.] Native green carbonate of copper, used for jewellery, etc.

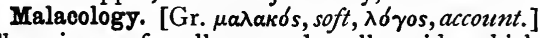
The science of molluscs and molluscoids, which are soft-bodied, unsegmented animals, with one, two, or three nervous ganglia, and (usually) an external skeleton, or shell. They are classified as follows :-

Mollusca Proper, True Molluscs.

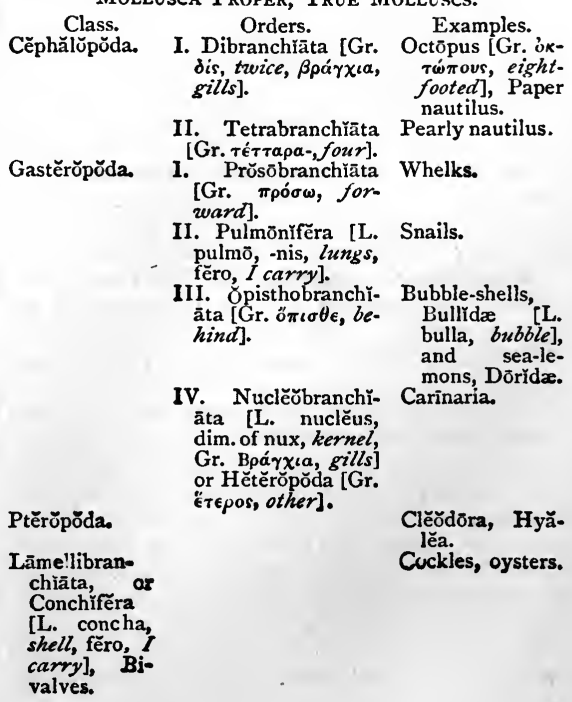




\begin{tabular}{|c|c|}
\hline \multicolumn{2}{|c|}{ MOLLUSCOIDA, MolluscoIDs. } \\
\hline $\begin{array}{l}\text { Class. } \\
\text { Brāchǐoūpŏda. } \\
\text { Tünǐcāta. }\end{array}$ & $\begin{array}{l}\text { Examples. } \\
\text { Lampshells. } \\
\text { Ascidians [Gr. } \\
\text { árós, leather } \\
\text { bag]. }\end{array}$ \\
\hline Pǒlȳző. & $\begin{array}{l}\text { Sea-mats, Flus- } \\
\text { tra. }\end{array}$ \\
\hline
\end{tabular}

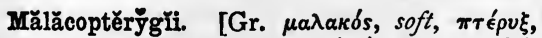
-ryos, fin.] (Ichth.) In Cuvier's system, fish with soft rays in the paired fins; as the carp.

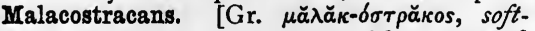
shelled.] (Zool.) Crustaceans with crust soft as compared with those of molluscs, though not so as compared with those of other crustaceans. (With Aristotle, = crustacea generally.)

Malades imaginaires. [L.] Those who fancy themselves ill, hypochondriacs. Le Malade Imaginaire is the title of a comedy by Molière.

Maladie du pays. [Fr.] Home-sickness. (Nostalgia.)

Maladresse. [Fr.] Awkwardness, clumsiness.

Mălā fîdē. [L.] With bad faith. (Bona fide.)

Mala gallina, malum ovum. [L., a bad hen, a bad egg.] Things will produce their like.

Malagash, Malagasy, Madegasse. People of Madagascar; of which island the native name is Madecasse.

Mala mens, malus animus. [L.] $A$ bad head, a bad heart.

Malapert. [O.Fr. apert, L. apertus, open; hence intelligent; hence malapert, unskilful, ill-bred.] Generally denotes pertness, impudence, forwardness.

Malaprop, Mrs. A character in Sheridan's play of the Rivals. She is always using wrong words which resemble the right ones more or less. So named from Fr. mal à propos, not to the purpose.

Mal à propos. [Fr.] Unseasonable, ill-timed.

Malaria. (Miasma.)

Malayala. A dialect of the Malabar language.

Malebolge. [It.] The eighth circle of Dante's Inferno.

Mal-entendu. [Fr., misunderstood.] A misapprehension.

Male-suāda fămēs. [L.] Hunger tempting to evil (Virgil).

Malignants. [L. mălignus, of a bad kind.] (Eng. Hist.) A name applied by the Roundheads or Puritans to those who refused to take the Solemn League and Covenant.

Malignant tumours, etc. (Benign.)

Malingerer. (Naut.) One who shams illness to shirk work.

Malingery. [Fr. malingre, ailing, from mal, and hingre, $\mathrm{O} . \mathrm{Fr} .=\mathrm{L}$. ægrum, sick.] A feigning of illness ; strictly, in shirking military duty.

Mali princīpǐi malus finis. [L.] $A$ bad beginning will have a bad ending.

Malis a vibus. [L.] With bad birds, i.e. with bad omens.

Mălĭtia supplet ætātem. [L.] A maxim of the law, referring to infants between seven and fourteen: malice makes up for want of age; i.e., in the particular case, the premature criminal intelligence of the child shows him to have been fully aware of what he was doing.
On the other hand, the evidence of a child intelligently and religiously brought up, though prima facie not to be received, may be received upon the principle, Săpientia supplet ætātem; generally applied to children of seven and under.

Mall. [L. mallěus, hammer.] A heavy wooden hammer. (Maul.)

Malleable. [L. mallěus, hammer.] Capable of being spread out by hammering.

Mallomaroking. (Naut.) Seamen visiting each other, and carousing on board Greenland ships.

Mallenders, Sallenders. (Vet.) In the horse, scurfy eruptions-M. in the flexure at the back of the knee, S. at the bend of the hock.

Mallěŏlus. [Dim. of L. mallěus, hammer.] (Anat.) The ankle. M. internus, the termination of the tibia; externus, that of the fibula ; forming the outer and inner prominences of the ankle.

Malle-poste. [Fr.] Mail-coach or post, mail.

Malleus. [L., hammer.] (Anat.) The most external of the bones of the ear, attached to the membrāna tympăni; striking upon the incūs [anvil].

Mallum. [L.L.] In the usage of the Teutonic nations, the place for the meeting of the people, each leading state in the empire having its own place of assembly.

Mālm. A yellow kiln-baked brick.

Malmsey. [Fr. malvoisie.] A strong, sweet wine.

Mālo cum Platōne errāre quam cum allis recte sentīre. [L.] I had rather be wrong with Plaic than right with any one else (Cicero).

Malta, Knights of. (Orders, Religious.)

Maltese cross. (Cross.)

Maltha. [Gr. $\mu a ́ \lambda \theta a$.$] A viscid mineral$ pitch.

Malthusian theory. The theory of Malthus, I798, that population would soon outrun the means of subsistence, unless held back by the external checks of vice, misery, and moral restraints; the argument being that population increases in a geometrical, food in an arithmetical, ratio.

Mălum in se. [L.] A thing wrong in itselt, a violation of moral law; as stealing. (Malum prohibitum.)

Mălum prohĭbǐtum. [L.] A law phrase, for things or acts which become wrong only as being prohibited by enactment; as the importation of goods into a country, when so prohibited, becomes smuggling.

Malum vas non frangitur. [L.] Worthless vessels are not broken.

Mălus in üno, mălus in omnibus [L.], or Falsus in uno, etc. (Leg.) A man if bad, if discredited as a witness in one matter, is the same in all matters; a maxim in Law ; a great exaggeration, and not much acted upon, in fact.

Malvaceous. [L. malva, mallowe.] 1. Mucilaginous. 2. Belonging to the ord. Malvaceæ, or mallow tribe.

Malversation. [Fr., from L. male, ill, versāri, to be occupied.] Ill behaviour, especially 
in reference to dishonesty, corruption, and em. bezzlement.

Mameliers. [Fr. mamelière, from mamelles, the breasts.] Metal plates protecting each side of the chest ; fourteenth century.

Maměluke. [Ar. memalik, $\boldsymbol{a}$ slave.] The name of the male slaves imported from Circassia into Egypt. In the thirteenth century they were formed into an armed body of guards, who dethroned the Sultan Touran-Shah, setting up one of their own number in his place. They then governed Egypt for 263 years. They were finally destroyed by Mehemet Ali, I8Ir. (Janissaries.)

Mamertine Prison. Two horrible dungeons were so called, which were set apart for State prisoners in ancient Rome.

Mammālia, Mammals. [L. mamma, breast.] (Zool.) The highest class of vertebrates, briefly characterized by suckling their young, and by having hair upon the whole or part of their skin or hide, at some age or other. In the classification of them we have followed that adopted by Mr. Wallace, Geographical Distribution of Animals.

A.

A. Man

Examples.

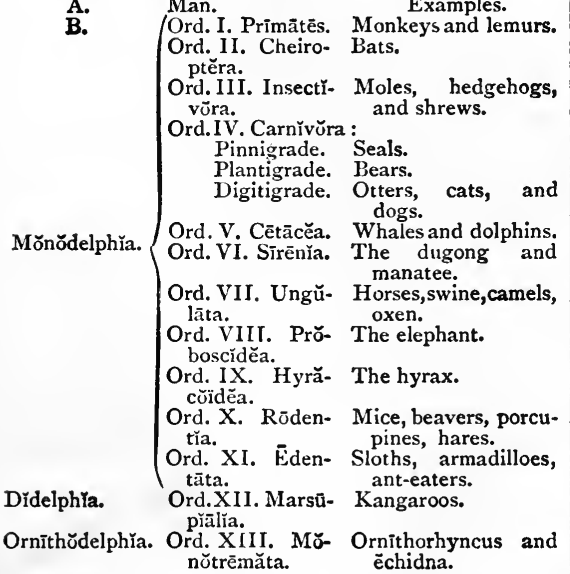

Mammetry. Any false religion, idolatry ; Mammet, an idol, being a corr. of Mahomet, with whose religion the mediæval Church was brought most closely into contact.

Mammillated. Having projections like small nipples [L. mammillæ].

Mammodis. [Hind. mahmudi, praisezvorthy.] Coarse, plain Indian muslins.

Mammoth. (Geol.) Of Siberia and $\mathrm{N}$. Europe, the fossil elephant (Elěphas primige ĕnius), larger than existing elephants and covered with dense, shaggy hair.

Man, Isle of, battery. (Naut.) The battery of three guns mounted on a ship's turret; from the triplicity of the arms of the island.

Manakin. (Ornith.) Fam. of birds, mostly with gay plumage. 'irop. S. America. Fam. Piprǐdæ, ord. Passerres. Some unite these with the Cotingĭdæ, Chatterers, including Rūpicŏla
[L. rūpes, rock, cŏlŏ, I inhabit], Cock of the rock.

Man-at-arms. (Mil.) Designation-fourteenth to sixteenth century-of heavy cavalry soldier fully equipped in armour.

Manatee, Manatus. (Manatidæ.)

Manatĩdæ. (Zool.) Sea-cows; two gen. form. ing ord. Sirēnia-Manatus, the manatee of the Atlantic, and Hălichorē, the dugong of the Indian Ocean; aquatic herbivorous mammals, which may have given rise to the belief in sirens, etc. The dugong is distinguished from the manatee by its forked tail and by its size, being sometimes twenty-six feet long, whereas the manatee is only nine or ten feet in length. Rytina, a third gen. and spec. recently inhabiting the N. Pacific, is believed to be extinct.

Manbote. In O.E. Law, the compensation to be paid for killing a man. (Wergild.)

Manche. [Fr.] 1. An ancient sleeve with long hangings. 2. In Geog., $\mathrm{La} \mathrm{M}$. is the English Channel.

Manché. Of Mangalore, Calicut, etc., a flatbottomed boat for landing cargoes; its planks sewed together with coir-yarn.

Manchester school. That of Mr. Cobden, Mr. Bright, and other leaders of the Anti-Corn-Law League. In $1838 \mathrm{Mr}$. Cobden carried in Manchester a motion to petition Parliament for the repeal of all duties on corn ; the abolition of the corn laws in 1846 was in great part due to $\mathrm{Mr}$. Cobden's lectures, etc., as Sir R. Peel acknowledged.

Manchineel tree. (Bot.) Hippomăne mançanilla, ord. Euphorbiaceæ of W. Indies and Trop. America ; one of the most poisonous of all vegetable productions; a drop of its white juice, used for arrows, will burn the skin. A large handsome tree, its wood valuable.

Manciple. [O.Fr. mancipe, with $l$ inserted, as in participle for participe, from L. manceps.] A steward, especially in colleges in the universities.

Mandāmus. [L., we command.] A writ from the Court of Queen's Bench, directed to any person or corporation within the Queen's dominions, requiring them to perform certain acts.

Mandarin. The Portuguese term [from L. mandāre, to command] for the official order of nobility in China.

Mandarining. Giving an orange colour to silk or woollen goods by the action of dilute nitric acid.

Mandat. [Fr.] A post-office order.

Mandatary. [L. mandatārǔus, from mando, $I$ command.] One to whom a charge is given.

Mandible. [L. mandibŭla, from mando, I chew.] (Anat.) A jaw, the organ of mastication. Mandibulate. [L. mandỉbŭla, a jazv, from mando, I chew.] (Entom.) Insects provided with mandibles [biting jaws] to their last stage as beetles.

Mandoline. [It. mandolina.] An Italian fretted guitar, like an almond [mándola] in shape, of which there are several varieties; played with a plectrum in the right hand, the left being used to stop the strings. 
Mandrake. [Gr. $\mu \alpha \nu \delta \rho a ̆ \gamma o ́ p \alpha s.] ~ G e n . ~ x x x . ~ I 5$; Cant. vii. I3; probably Mandrăgŏra off ǐcinalis, a peculiar plant, with a large dark-coloured fleshy root divided into two or three forks, somewhat like the human body; poisonous (except the orange-coloured, pulpy fruit) and narcotic, so that to have eaten mandrake was, with the ancients, to be stupid. It was said to shriek when torn up, and its fruit was supposed to cure barrenness.

Mandrel, Mandril. [Fr. mandrin ; origin unknown.] The spindle which carries the chuck of a lathe, and the pulleys by which the turning motion is communicated to the chuck.

\section{Mandrill. (Baboon.)}

Mandubi. (Arachis.)

Manducation. [L. manducāre, to cherw.] A term applied to the eating of the element of bread in the Eucharist.

Manége. [Fr., It. maneggīo.] 1. The art of training and managing horses. 2. Riding-school.

Manès. The general name given by the Latins to the spirits of the dead. The word means good or kind. They were commonly identified with the Iares. (Larvæ; Lemures.)

Mangabey. (Zool.) Gen. of monkeys, Whiteeyelid monkeys, with long tails. W. Africa. Cercǒcěbus, fam. Cercōpǐthēcřdæ.

Manganese. (Min.) A metal, greyish-white, brilliant, heavy, very hard, non-magnetic; not known native, on account of its powerful affinity for oxygen.

Mange in horses, dogs, cattle, and Scab in sheep. Diseases resulting from the attacks of minute mites or ăcări ; very similar to itch in the human subject [Fr. manger, to eat, consume; so Fr. démanger, to ilch].

Manger. (Naut.) The front part of the bows, by the hawse-holes, in a man-of-war, separated from the rest of the deck by a high combing, called the manger-board, so that water shipped through the hawse-holes may not come on to the decks.

Mange-tout. [Fr., one who eats all.] A spendthrift.

Mangle-wheel; M.-rack. Mechanical contrivances for converting a continuous circular motion into an alternating circular or rectilinear motion; they are used in mangles. The axis carrying the pinion is capable of a small motion, and, under the guidance of a groove, works alternately on interior and exterior teeth in the case of the wheel, and above and below a set of projecting teeth in the case of the rack.

Mango. (Native name, Mangho.) Asiatic trees, in in some varieties, highly prized.

Mangonel. [It. manganella.] (Mil.) An ancient engine of war, similar to the Trebuchet.

Mangostan, Mangosteen. [Malay manggīstan.] A delicious Eastern fruit, of the size of a small apple ; that of Garcinia mangostana.

Mangrove. [Probably an abbrev. of mangle grove, the Malay name.] A tree of the gen. Rhizophora, inhabiting tropical shores, and known for the dense groves which it forms even down to the water itself.
Manheim gold. Brass, consisting of four parts of copper to one of zinc.

Manübus pedrbusque. [L., with hands and feet.] Tooth and nail.

Manichæans. (Eccl. Hist.) The followers of Manes, who, in the third century, tried to combine Christianity with Eastern systems of philosophy. He thus adopted the system of Dualism (Ahriman), and set forth opinions much like those of the Cerinthians, Cerdonians, Carpocratians, and other Gnostics.

Manichæism. (Manichæans.)

Manifest. [L. mănĭfestus, open.] In commercial navigation, a document delivered to the officer of customs by the captain of a ship, giving a detailed list of the cargo in his charge, with the names of the places where the goods were shipped, and to which they are addressed.

Manilla. [Sp., from L. manus, hand.] 1. A bracelet worn by Africans. 2. A piece of copper shaped like a horseshoe, used as money in W. Africa.

Manioc. (Cassava.)

Maniple. [L. manipŭlus, from manus, $a$ hand.] (Eccl.) Originally a handkerchief, now only a symbolical ornament, attached, in the Latin Church, to the left arm of the celebrant at Mass, and perhaps used at one time for cleaning the sacred vessels.

Maniples. (Centuries; Legion.)

Manitou. [Algonkin manitú or manitó, $a$ spirit, a ghost.] A spirit, god, or devil of the American Indians. - Bartlett's Americanisms.

Manjesty. (Munjeet.)

Manliäna impěrǐa. [L.] Manlian orders ; so called from Titus Manlius, who, being Dictator, is said to have ordered his son to be scourged and beheaded for fighting contrary to his orders.

Manna. A sweetish secretion of several species of ash in S. Europe (supposed to resemble the manna of Scripture).

Mannite. Crystallized sugar obtained from manna.

Manœuvre. [Fr., lit. work of the hand, L.L. mănuŏpěra.] (Mil.) Movement, either tactical or strategical, so disposed as by superior intelligence or practice to surpass the combinations of an adversary.

Man of Ross. So called by Pope, Moral Essays. J. Kyrle, who, with $£ 500$ a year only of his own, and money given by others, built churches and hospitals, largely assisted the poor, sick, aged, orphans (died at Ross, Herefordshire, 1754, aged 90).

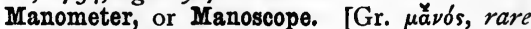

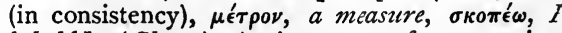
behold.] (Chem.) An instrument for measuring the elastic force of gases and vapours; in most cases either by observing the height of the column of mercury which the force can support, or the degree of compression which it produces in a given quantity of air.

Mansard roof. (Arch.) So called from its inventor, a French architect, who died in 1666. A curb roof sufficiently lofty to admit of an attic being lodged in it. 
Manse. [L.L. mansus, $a$ dwelling.] The Scotch name for a parsonage house.

Man ship, To. (Naut.) To man the yards as a salute.

Mansiaughter. In Law, the killing of a man without malice, express or implied.

Mantelet. [Fr. mantelet, short cloak.] (Mil.) Square metal shield erected on a wheeled stand for protecting sappers from musketry fire.

Mantiger. [Gr. $\mu \alpha \rho \tau \iota \chi \omega ́ \rho \alpha s$, an imaginary beast, the word being a corr. of the Pers. mardkhora, man-eater.] (Zool.) A large monkey or baboon.

Mantilla. [Sp.] A kind of Spanish veil covering the head and shoulders.

Mantis. [Gr., a diviner; also, a kind of locust or grasshopper, with long fore legs in constant motion.] (Entom.) Gen. of orthoptĕrous insects, frequently resembling the twigs and leaves on which they live, called Praying insects, from the way in which they hold "their great raptorial front legs."

Mantissa. [L. mantīsa, mantissa, an addition, a make-zveight.] The decimal part of a logarithm.

Mantle. [L.L. mantellum, Fr. manteau.] (Arch.) The piece lying horizontally between the jambs of the chimney.

Mantling. The drapery or mantle hanging from the helmet around the escutcheon.

Manu. (Menu, Laws of.)

Manual. Of a piano or organ, the key-board for the hands [L. mănūs], distinguished from pedals [pĕdēs, feet].

Manual exercise. (Mil.) Established musket drill of a soldier, exclusive of firing.

Mănübrium. [L., a handle.] (Anat.) The upper bone or portion of the sternum, or breast. bone.

Manumission. [L. manumissio, -nem.] In Rom. Law, the freeing of the slave by the master, who took his hand and said, "I will that this man be free" [Hunc hominem liberum esse volo].

Manx. Belonging to the Isle of Man.

Manzera. (Naut.) A cattle-boat of the Adriatic.

\section{Maon. (Mahone.)}

Map. (Projeotion.)

Maple sugar. Sugar obtained in the woods of the N. United States and Canada by evaporating the juice of some spec. of Acer, more especially $\mathrm{A}$. sacchărinum.

\section{Mapp Fair. (Mop.)}

Marabou. (Native name, Senegal.) (Ornith.) Gigantic African stork, furnishing plumes so termed from under side of tail. Leptoptřlos [Gr.

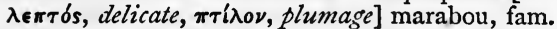
Cĭconǐ̀ææ [L. cǐcōnǐa, stork], ord. Grallæ. Indian spec., the adjutant, L. argála.

Marabout. Mohammedan devotee. (Dervise.) Marabut. (Naut.) A bad-weather sail in use on galleys.

Maran-atha. I Cor. xvi. 22 ; an Aramaic expression, the Lord cometh ; to be separated by a full stop from "Anathema." (Raca.)

Maranta. (Arrow-root.)

Maraschino. [It. marasca, a sour cherry.] A delicate liqueur distilled from cherries.
Mărasmus. [Gr. $\mu a ̆ \rho \alpha \sigma \mu \delta s, ~ \mu \alpha \rho \alpha i \nu \omega, I$ make to wither.] (Med.) Wasting away of the body, atrophy.

Maravedi. A Spanish coin, called after the Marabites (Almoravides), an Arabian dynasty, which ruled in Spain. It was at first made of gold, but is now of copper. It is the thirtyfourth part of a real, and is worth about a twelfth of a penny.

Marble. (Geol.) A limestone (popularly any stone) that will receive a fine polish; usually metamorphic.

Marc. [L.L. emarcus, $a$ kind of vire.] The refuse of pressed grapes.

Marcassin. [Fr.] (Her.) A young wild boar.

Marceline. [Fr.] A thin silk tissue used for lining ladies' dresses.

Marcescent. [L. marcescentem, decaying, withering.] (Bot.) Fading, or withering, without falling off.

March Decrees, of 1880 . By this name the decrees abolishing non-authorized religious communities in France are becoming known.

Marches. [A.S. mearc, mark, boundary.] 1. The borders or frontiers of any district; especially applied to the boundaries between England and Scotland and between England and Wales. Marquis, Markgraf, and other similar titles were $=$ governors of $M$. So Earl of March, i.e. of the Welsh M. ; where, in the Middle Ages, considerable authority was exercised by Marchers, petty kings. Hence to march with. An estate marches with another when they have a common boundary. 2. The eastern provinces of the Papal States (q.v.), from Rimini to the Tronto, about I Io miles along the Adriatic.

Marchpane. [It. marzapane.] A sweet spiced bread.

Marcid. [L. marcĭdus, marceo, I wither.] Lean, wasted away.

Maroionites. (Eccl. Hist.) The followers of Marcion, who, in the second century, adopted the Oriental notion of two opposing principles of good and evil (Ahriman), and imagined that between these existed a third power, neither wholly good nor wholly evil, who was the creator of the world and the author of the Jewish dispensation. (Gnostics.)

Marcle. [O.Fr.] (Her.) A lozenge voided. (Lozenge; Voided.)

Marcosians. A Gnostio sect who are said to have derived their name from an Egyptian magician named Marcus.

Mare clausum. [L.] A sea closed to navigation, from whatever cause.

Maremma [It.], corr. of Maritima. A name given to a vast extent of malarious lowlands on the W. coast of Italy ; especially applied to those of Tuscany and the Papal States (q.v.).

Mare's-tail (from its shape). A long streaky cloud indicating rain.

Marforio. (Pasquinade.)

Margent, like Marge, is a variant of margin, a border or edge [L. marginem].

Marginālia. [L.] Notes on the margin, and elsewhere on the page, made in reading a book. 
Margrave. (Marches.)

Margravine. The wife of a Margrave.

Marie Antoinette. (Diamond necklace.)

Marigold window. (Rose window.)

Marigraph. [L. mare, sea, Gr. $\gamma \rho \alpha ́ \phi \omega, I$ write, or draw.] A machine for registering the height of tides.

Marine acid (because obtained from salt; L. marinus, sea-). (Chem.) Hydrochloric acid. Marine engine. (Steam-engine.)

Marine glue. A mixture of tar and shellac.

Marines. [L. marinus, belonging to the sea.]

In the English army, a body of men enlisted to serve as soldiers, if needed, on board ship. First raised in 1664 . It consists of four divisions of light infantry, and one of artillery.

Marish. Ezek. xlvii. II ; the same word as marsh [Fr. marais, L. L. mariscus].

Maritime law. (Oleron, Laws of; Wisby, Ordinances of; Amalfian Code.)

Mark, or Marc. 1. [A.S. marc.] A sum of I3s. $4 d$. 2. In the new German coinage, which is legal throughout the empire, a mark is a third of a thaler; the twenty-mark gold coin is worth about I9s. 7d. 3. A weight, which in Prussia is 3609 grains troy; it is half a Cologne or Prussian pound, and a little more than an English half-pound avoirdupois. 4. The territory of a primitive Teutonic community, ruled by a king, ealdorman, or soine other elective or hereditary leader. Such are Denmark, Finmark, etc. (Marches.)

Mark, St., Order of. A Venetian order of knighthood, called after St. Mark, the patron of the republic.

Marks and deeps. (Naut.) Marks are the fathoms marked on the hand lead-line, and are placed at two, three, five, seven, ten, thirteen, fifteen, seventeen, and twenty fathoms; Deeps, the fathoms between the marks. In sounding nine fathoms, the leadsman calls, "Deep nine," but at a marked fathom, as ten, he calls, "Mark ten."

Marl. [Marga, Gael. and Latinized by Pliny ; whence L. margŭla, O.Fr. marle.] (Geol.) A mixture of lime and clay in various proportions ; in clay-marl, clay predominates; in marl-clay, lime. Shell-marl contains fresh-water she'ls.

Marl, To. (Naut.) To serve a rope with twine, etc., securing each turn with a peculiar knot, so that, some turns being cut, the others hold.

Marline. (Naut.) A small loosely twisted two-stranded line or string. M.-holes, holes made in sails for marling the bolt-rope to the sail, instead of serving it. M. spike, an iron pin tapering to a point, and used for knotting, splicing, etc. M.-spike hitch, the knot used in marling, with the aid of a M.-spike.

Marmala. [Port. marmélo, a quince.] A scent distilled from the Bengal quince.

Marmorätum. [L.] (Arch.) A cement composed of powdered lime and marble.

Marmot. [Fr. marmotte, óriginally mar montain, L. murem montānum, mountain rat.] (Arctomys.)

Maronites. (Eccl. Hist.) The followers of Maron, an adherent of the Monothelites. They inhabit the mountains of Libănus and Antilibănus, in Syria, and formed a separate sect from the seventh to the twelfth century, when they were reconciled to the see of Rome.

Maroon. 1. [Fr. marron, a chestnut.] Brownish crimson. 2. (Naut.) To put on shore a sailor or passenger on a desert island, and there leave him. Alexander Selkirk was marooned on the island of Juan Fernandez, I704-1708.

Maroons. [Probably a corr. of Sp. cimarron, wild, savage (Littré).] Runaway negroes, such as those who, when Jamaica was conquered by the Spaniards, abandoned by their masters, occupied some of the mountainous parts. The Maroon wars in Jamaica occurred in 1730 and I795.

Marque, Ietters of, and reprisal, which, according to Blackstone, are synonymous-" the latter a taking in return [Fr. reprise, from v. reprendre], the former the passing the frontiers [cf. Eng. the marches; and the words Marquis, Margrave], in order to such taking; may be obtained in order to seize the bodies or goods of the subjects of the offending state, until satisfaction be made, wherever they happen to be found." (Letters of marque.)

Marquee. [(?) Distinguished, part. of Fr. marquer.] Large State tent, generally decorated with flags.

Marqueterie. [Fr. marqueter, to checker, a frequentative of marquer.] Marquetry; inlaid work, of differently coloured pieces of wood, ivory, shell, etc.

\section{Marquetry. (Marqueterie.)}

\section{Marquis, Marquess. (Marches.)}

Marrow Controversy. Arose out of the Marrow of Modern Divinity, the work of a Puritan soldier, temp. Commonwealth; a highly " evangelical" work, condemned by the Assembly, I 720-at that time a very worldly body-but not by the judgment of the people. Substantially the same controversy which led to the expulsion of the Rev. Eben. Erskine, I 733 (who had denounced recent Church legislation), and to the forming of the Secession Church; and to that of the Relief Church also, I758, which asserted the right to elect its own minister. By the amalgamation of S. and R. Churches was formed the United Presbyterian Church, 1847 .

Marry. Indeed, truly. Said to be from the Virgin Mary, owing to the constant invocation of her name.

Mars. 1. The Latin god of war. The word means the crusher or pounder, and the root is found in the names of the Greek Ares, the Indian Maruts, or storm-winds, the Greek Aloadæ and Molionids, and of Thor Miölnir. 2. (Astron.) (Planet.)

Marseillaise (played, when but little known, by a body of troops entering Paris from Mar. seilles). A hymn which has played an important part in French and other revolutions; words and music (almost certainly) by Rouget de Lisle, a French officer quartered in Strasburg in $\mathbf{I 7 9 2 .}$

Marshal. [Ger. marschall, from O.H.G. mara, horse, and scalh, servant, L.L. marescalcus.] A title denoting many high offices in 
European countries. The office of Marshal of England, which stems to have been instituted by William the Conqueror, is now hereditary in the dukes of Norfolk.

Marshalling. [Eng. marshal.] Arranging according to the rules of heraldry, ( $I$ ) persons in a procession, (2) coats of arms of distinct families in one escutcheon.

Marshalsea. [L. sēdem, seat.] In Law, the see or court of a marshal. The King's Bench Prison in Southwark was so called.

Marsh poison, or Marsh miasma. (Miasma.)

Marsúpīālǐa, Marsupials. [L. marsūpŭum,

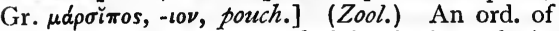
mammals, with an external abdominal pouch, in which the young are nurtured after an exceptionally short period of gestation; e.g. the kangaroo. The opossums of N. America are the only gen. found out of Australia and adjacent islands, where few mammals of other orders are indigenous.

Martagon. [Fr. and Sp., It. martagone.] (Bot.) A kind of lily.

Martel de fer. [Fr.] Iron hammer, carried at the saddle-bow, perhaps replacing the battleaxe; sixteenth century.

Martello towers. [So named probably from It. martello, a hammer.] 1. Towers built on some of the Mediterranean coasts and elsewhere, as a defence against pirates. 2. Towers which have on their summit a gun fixed on a traversing platform.

Martial law. A phrase used to denote arbitrary and absolute power, exercised by a military officer over the lives, persons, and property of individuals, in cases of great emergency.

Martinet. Severe military disciplinarians are so named, it is said, from Colonel Martinet, who, in the reign of Louis XIV., invented a whip for the scourging of soldiers.

Martingale. [Fr. ; said to be from Martignes, in Provence.] 1. A strap fastened to a horse's girth, passing between his fore legs, and ending in two rings through which the reins pass. 2 . (Naut.) A rope extending from the jibboom end to the dolphin-striker, to keep the jibboom down.

Martin Marprelate. The fictitious author of a series of tracts, denouncing episcopal government (1 588).

Martinmas. The festival of St. Martin, Bishop of Tours ; November II ; third of the four crossquarter days.

Martinmas summer. The short period of calm, warm weather often experienced about the time of St. Martin's festival.

Martinus Scriblerus, Memoirs of. Intended satirical treatises on all the abuses of human learning, by Pope, Swift, and Arbuthnot: the project was only partly carried out.

Martlet. [Fr. martinet.] (Her.) A marten without legs, borne (I) as a charge, (2) as a difference in the fourth son's escutcheon.

Martnets. [Fr. martinet.] (Naut.) The leech-lines of a sail, said to be topped, when the leech is hauled up close to its yard.

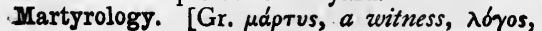

discourse.] Properly, any record relating to the acts and deaths of martyrs. The Martyrology of Eusebius has been lost. Fox's Book of Martyrs relates the sufferings of the English reformers. Gallonius's De Sanctorum Martyrum Cruciātibus is a popular book on the Continent.

Marum, or Marrum. (Ammophila.)

Maruts. (Mars.)

Marver (corr. from Marble). A hollowed plate, for shaping glasswork when blown.

Marzolet. (Naut.) An Indian boat, built of bark, and caulked with moss.

Maschil. A title of Ps. xxxii. and twelve other psalms; meaning uncertain, probably instruction. So LXX. $\sigma v \nu \epsilon \sigma \epsilon ́ \omega s$, and Jerome èrüdĩtio.

Mash. [Ger. maischen, to mash.] A mixture of ground malt and warm water for brewing.

Mashallah! [Ar.] God be praised!

Mask. [Fr. masque, L.L. mascha, a witch.] 1. Masquerade, mummery. 2. Dramatic performance by masked actors, as Comus.

Masked battery. (Mil.) One concealed by woods or otherwise, of which the existence is only disclosed on its opening fire.

Masked troops. (Mil.) Having their powers of offence neutralized by being watched and checked by a superior force.

Maslach. A preparation of opium used by Turks.

Maslin. (Meslin.)

Masǒrah. (Cabala.)

Mass. [L. L. missa.] The Eucharistic Office in the Latin Church; so named, it is said, from the words of dismissal, "Ite missa est ;" but this is doubtful.

Mass. In Physics, the quantity of matter in a given body; it is proportional to the weight. If two bodies exactly counterpoise each other in a perfectly just balance, they have equal masses.

Massētēr. [Gr. $\mu \alpha \sigma \sigma \eta \tau \dot{\eta} \rho, \mu \alpha \sigma \sigma a ́ o \mu \alpha$, I chew.] (Anat.) The muscle which raises the lower jaw.

Massicot. [Fr., from masse, a mass, because obtained in small masses.] (Chem.). Yellow oxide of lead, obtained by heating lead in a current of air. When fused and allowed to crystallize, it forms litharge (q.v.).

Mast. [A.S. mäst.] (Naut.) If made of a single spar, is called a Pole-MT.; if of more than one, a Built-M., or Made-M. The lower masts are as follows :-The Fore-M. is the most forward, and is next in size to the Main-M., which is abaft the F.-M. If there is a third lower M., it is placed abaft the Main-M., and is called the Mizzen-M. Top-masts are those immediately above the fore, main, or mizzen respectively. Top-gallant $M$. are those above Top-M., and Royal M. are those above Topgallant $M$. Top-gallant and Royal M. are often only one. All upper masts are named after their respective lower M. ; as, Main-top M., the one above the Main-M. M.-carlings are the large ones on each side of a lower M. M.-coat, a piece of canvas fastened round a $M$. to prevent water from soaking in between it and the decks.

Master. [A.S. mäster, magester, L. magister.] 
(Naut.) Of a merchantman, the captain; of a man-of-war, an officer ranking with and after lieutenants according to date, but junior in command to all lieutenants. It is his duty to navigate the vessel under the captain, but he reports to the first lieutenant, who gives the necessary orders. $\mathrm{He}$ is also charged with stowing stores, etc. $M$. and commander, former designation of a commander. (Rank.)

Master-gunner. (Mil.) Non-commissioned officer of the highest grade in the artillery, and corresponding with a warrant officer in the navy. He generally has separate charge of the guns and ammunition in a detached fort.

Master of Arts. [L. magister.] In the universities, the highest degree in the faculty of Arts ; the most ancient of all academical titles.

Master of the Faculties, Măgister ad Făcultätes. The archbishop's officer in the Faculty Court (q.v.).

Master of the Horse. 1. In Rom. Hist., an officer, styled in L. Magister Equitum, elected by the Dictator to serve under him during his dictatorship. 2. Nobleman in the sovereign's household in charge of the equerries and horses.

Master of the Sentences, Magister Sententiarum. Peter Lombard, Bishop of Paris, one of the founders of scholastic divinity, author of Liber Senientiarum, i.e. sentences and extracts from the Fathers, illustrating doctrines (died I 164$)$.

Masters. (Leg.) Subordinate officers of the superior courts of law and equity in England. The office of Master in Chancery was abolished in 1853 .

Masters, Iittle. Certain German engravers of the sixteenth century (from the extreme smallness of their prints).

Mastersingers. A class of German poets in the fifteenth and sixteenth centuries, chiefly at Nuirnberg, formed into regular corporations. Hans Sachs belongs to this society.

Master Thief. (Hermes; Rhampsinitos, The Treasures of ; Treasure.)

Mastic. [Gr. $\mu \alpha \sigma \tau i \chi \chi \eta$, from $\mu \alpha \sigma \tau \iota \chi \alpha ́ \omega, I$ chew, because formerly chewed in the East.] 1. A yellow resin obtained from a Levantine tree, ard used for artists' varnish. 2. A cement used for plastering walls.

Mastick (History of Susannah, ver. 54), or Lentisk (Pistācia lentiscus). (Bot.) Evergreen bush, yielding a fragrant gum; in Palestine and other Mediterranean countries.

Mastǒdon. [Gr. $\mu \alpha \sigma \tau \delta s, a$ teat, ỏouv́s, tooth.] (Geol.) An extinct gen. of gigantic proboscidian pachyderms, with large conical mammiform points to the molars, before they are worn down; mostly in Tertiary fresh-water deposits.

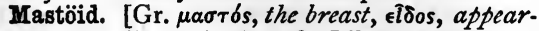
ance.] 1. Like a nipple. 2. Like the structure of the breast.

Mast-rope. (Naut.) That by which an upper mast is hoisted or lowered.

Masulah, or Massolah, boats. Madras boats, from thirty to thirty-five feet long, by ten to eleven feet wide, propelled by twelve oars, double banked, and steered by a man in the stern with a long oar; built of planks sewed together with coir-yarn.

Matador. [Sp., a slayer, probably from L. mactātor, from mactāre, to sacrifice.] The man who gives the death-blow to the bulls wounded in the Spanish bull-fights.

Matamōros. A slayer of Moors, as the Sp. matador is the slayer of the bulls [L. mactâtor tauri] in the arena; hence a swaggerer or braggadocio, like Captain Bobadil in Ben Jonson's play, Every Man in His Humour.

Matchlock. (Mil.) The first kind of musket ; the priming being ignited by a match attached to an iron finger, and brought down to the touch. hole by the thumb of the right hand.

Mate. [A Teut. and Scand. word.] (Naut.) The officers of a merchant-vessel below the captain, viz. first or chief M., second, third, and fourth M.

Maté. (Native name.) Paraguay tea; the dried leaf of the Brazilian holly.

Matelote. [Fr. matelot, a sailor.] A dish composed of many kinds of fish.

Mater artium necessitas. [L.] Necessity the mother of arts, or inventions.

Materfamulias. [L.] The mother, or mistress, of a family.

Mātěrĭa mědioa. [L.] ( $M e d$.$) The science of$ the materials used in alleviation or cure of disease.

Materǐem superäbat ǒpus. [L.] The work was better than the material.

Mathemătici. (Genethliacs.)

Mathematics [Gr. $\mu a \theta \eta \mu \alpha \tau \iota k \delta s$, relating to $\tau \grave{\alpha}$ $\mu \alpha \theta \dot{\eta} \mu \alpha \tau \alpha$, the sciences]; Pure M.; Mixed M. The general term used to denote a body of sciences treating of (I) number; (2) position, size, form ; (3) motion ; (4) force ; i.e. arithmetic, geometry, kinematics, and dynamics (or mechanics). It is usual to apply the term Pure $M$. to arithmetic and geometry, with all their developments, and the term Mixed $M$. to kinematics and dynamics, and the various branches of physical science to which they are applicable, as astronomy, optics, sound, heat, electricity, etc.

\section{Matins. (Canonical hours.)}

Matrass. [Fr. matras.] An egg-shaped vessel, with a tapering neck, used by the old chemists.

Matriculation. [L. matricŭla, $a$ roll or register.] Denotes especially the enrolment of a name on a member's entrance into a university.

Matrix. [L., womb.] 1. The original die used for a coin or medal which has to be represented in relief. 2 . The substance in which metals or gems are found embedded. 3. One of the five simple colours in dyeing-black, white, blue, red, and yellow.

Matt. [Ger., dull.] (Chem.) Crude black copper, reduced but not purified from sulphur, etc.

\section{Mattamore. (Matamoros.)}

Matter, Dead. In Printing, type which has been used in printing, and is ready for distribution. Live matter is type which has been set up, but not yet printed from.

Matthews' Bible. (Bible, English.)

Maud. A shawl wrap, made of undyed wool. 
Maugre. In spite of, notwithstanding [the Fr. malgré, from mal, bad, gré, will, L. grātum].

Maul, or Mall. [L. malleus.] (Naut.) An iron hammer, having one end pointed. Top-M. has an iron handle with an eye, by which it is fastened to the masthead.

Maund. [Hind. man.] An E.-Indian weight. The Madras M. is 25, and the Bombay $M$. 28 pounds avoirdupois; in Bengal, the Factory M. is $74_{3}^{2}$, and the Bazaar M. $82{ }_{15}^{2}$ pounds avoirdupois.

Maundies. The Queen's purses of money, with other gifts, given every Maundy Thursday to poor recipients, equal in number to the years of life to which she has attained.

Maundril. [Fr. mandrin.] A coal-miner's pick, with two points.

Maundy money. Coins of fourpence, threepence, twopence, and one penny in silver; coined for the purpose of being given away by the sovereign on Maundy Thursday.

Maundy Thursday. Thursday before Easter; Dies mandāti, the day of the command, i.e. to "love one another" (John xiii. 34); or from maunds [Fr. mande], baskets of gifts, anciently presented by Christians to one another.

Maunjee. [Hind.] A native boatman of the Hooghly.

Maur, St., Congregation of. (Hist.) A learned body of the Benedictine order ; so called from a village near Paris, where they were established, 1618. It numbered at one time more than a hundred houses.

Mausōlëum. [L.] 1. A tomb built (circ. B.C. 353) in memory of Mausōlus, King of Caria, and reckoned among the seven wonders of the world. 2. Any splendid sepulchre.

Mauvaise honte. [Fr.] Bashfulness, shamefacedness, awkward shyness.

Mauvaise plaisanterie. [Fr.] A sorry joke, a scurvy jest.

Mauvais pas. [Fr., a bad step.] A difficulty, a scrape.

Mauvais quart d'heure. [Fr., a bad quarter of an hour.] A moment of great distress.

Manvais sujet. [Fr., a bad subject.] A worthless fellow, a scoundrel.

Mauvais ton. [Fr., a bad tone.] Want of good breeding, ill manners.

Manve. [Fr., mallow.] A pale lilac colour, obtained from aniline.

Mavis. [Fr. mauvis, id., L.L. malvitius, possibly as doing harm, mălum, to the vine, vitis (Littré).] (Ornith.) Song-thrush, Turdus mūsǐcus, fam. Turdĭdæ, ord. Passěres.

Maw. [A.S. maga, Ger. magen.] (Ornith.) Stomach, the craw of birds.

Mawmetry. (Mammetry.)

Maw-seed. The seed of the opium poppy

(Păpāver somnǐferum), given to birds as medicine

Mawworm. (Tartuffe.)

Maxilla. [L.] Jaw, jawbone.

Maxim. [L. maxĭmus, greatest.] In ancient Music, a note $=$ two long notes or four breves. (Breve.)

Maxíma dēbētar puěro rěvěrentia. [L.] $A$ child should be treated with the greatest reverence (Juvenal).

Maximum. [L., greatest.] When a variable magnitude increases up to a certain value and then decreases, that value is a maximum. A $M$. is not necessarily the greatest value of the variable. (Minimum.)

\section{May. (Maia.)}

\section{Mayflower. (Pilgrim Fathers.)}

Mayor. [L. major, greater.] The chief municipal officer of a borough, after the Norman Conquest, answering to the older Portreeve or borough reeve. In France, the title is now given to the first municipal officer of each commune.

Mayorazo. [Sp., from L. magistrātus.] In Spain, the inheritance of property on condition of its being transmitted unimpaired to the next heirs. In Germany, this kind of entail is known as Majorat.

\section{Mayor of the palace. (Major-domo.)}

Mayor of the staple. (Staples.)

Mazarine. (From Cardinal Mazarin.) A deep blue colour.

Maze. In the herring trade, $=500$ herrings.

Mazurka. A Polish dance, lively, in $\frac{3}{8}$ or $\frac{3}{4}$ time.

Mazzinians. The extreme party of progress in Italy; so called from Joseph Mazzini (1805I\&72), who founded the societies of Young Italy and Young Europe.

Mead. [O.E. medu.] A fermented drink made of water and honey.

Meadow-sweet. (Spiræa.)

Meaking-iron. (Naut.) The tool with which old caulking is taken out of the seams.

Mealie. In S. Africa, Indian corn.

Meal of milk. [A.S. mæ̉l, a fixed portion; cf. Ger. mal, a time.] That given at a single milking.

Meal-Tub Plot. A pretended plot, in connexion with the Popish Plot of Titus Oates; so called from the alleged discovery by Dangerfield of the papers relating to it in a meal-tub (1679).

Mean, or Average, duration of life. The average of the number of years lived by a large number of persons after they have reached a certain age ; thus, according to the Carlisle Table, of people twenty years old the mean duration of life is $4 \mathrm{I} \cdot 5$ years more.

Meander. To wind along ; from the rounding course of the river of this name in Asia Minor.

Mean value; $\mathbf{M}$. term; $\mathbf{M}$. time. The Mean value of two or more numerical quantities is their sum divided by their number; called also the Arithmetical $M$. (For Mean or $M$. term, vide Proportion; for M. time, vide Time.)

Mease. [A word containing the root of measure.] The number of 500 ; as a mease of mackerel $=500$ mackerel.

Meätus. [L.] (Anat.) An opening or passage; e.g. M. auditōrius, the auditory canal.

Mea virtūte me involvo. [L.] I wrap $m y$ self in my virtue (Horace).

Mechanical philosophy; M. powers. The Mechanical powers are the simple machineslever, wheel and axle, pulley, inclined plane, 
screw, and wedge; by which a man is enabled to overcome a resistance greater than the force exerted by himself. They are, of course, sometimes otherwise applied. $M$. philosophy is a doctrine which explains the phenomena of nature by the mutual action of bodies on each other ; the term "body" including minute bodies, i.e. corpuscles or molecules.

Mechanics; Applied M.; Celestial M. Properly the science of machines; but as commonly used it means the science of the motion and rest of bodies as produced by forces, and includes the four divisions of statics, hydrostatics, dynamics, and hydrodynamics. This nomenclature is not universally accepted (vide Dynamics). Applied M. treats of the application of the general doctrine of $M$. to works of human art. Celestial M. treats of the application of the general doctrine of $M$. to the motion of the heavenly bodies under the force of gravity : it is the name given to physical astronomy by Laplace.

Mechanism. The branch of kinematics which treats of the forms of machines considered as modifiers of motion.

Mechanists. [Gr. $\mu \eta \chi \breve{\alpha} \nu \eta$, machine.] Philosophers who refer all changes in the universe to merely mechanical forces; as opposed to the Dynamical philosophers, who assert a living power in nature antecedent to all phenomena.

Mechlin lace (from Mechlin, in Belgium). Lace with hexagon mesh of three threads, in which the pattern is worked.

Mēcōnüum. [L.] 1. Inspissated juice of the poppy. 2. First frees of infants. [Gr. $\mu \eta \kappa \omega \dot{\nu} \iota \nu \nu$, from $\mu$ in $\omega \nu, a p o p p y$, has both meanings.]

Medēa. In Gr. Myth., the daughter of the King of Colchis, by whose aid Jason obtains the Golden Fleece (Argonauts), and who slays her two sons when Jason proves faithless to her.

Mediæval. [From L. medium æuum, the middle age or period.] Belonging to the Middle Ages.

Median line, Mesial line or plane. [Gr.

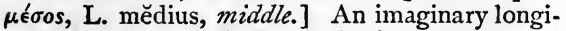
tudinal division of the body into two equal parts.

Mĕdiastinum. [L. mediastīnus, standing in the middle.] (Anat.) (I) A middle partition, especially (2) that formed in the thorax by the approximation of the two pleuræ.

Mediation. [L. mediäre, to halve.] In chanting, that which remains in the former half of a verse, after the reciting note.

Mediatization. The grouping of the smaller German sovereignties with larger neighbouring states after the dissolution of the Empire in 1806. This had often been done before, the word meaning that they were thus made mediately, instead of immediately, dependent on the empire. As the empire was at an end, the term was now used inappropriately.

Medical jurisprudence, i.q. Forensic medicine. The application of the principles of medical science in aid of legislation, or of the administration of justice, as in cases of lunacy, poisoning, etc., or of the preservation of the public health.
Medicine, in the languages of the American aborigines, translates not only medicine proper, but anything the operation of which they do not understand; anything mysterious, supernatural, sacred. Hence, M. man, the doctor and conjurer of the American Indians; $M . b a g$, of remedies and charms; $M$. feast, i.e. religious festival, and $M$. hut, in which it is held, etc. Bartlett's Americanisms.

Medicine chest. In the navy, one containing sufficient for one hundred men for the cruise.

Medietāte linguæ, De. A jury de $M$. $L$. was one consisting one-half of Englishmen, one-half of foreigners, when either plaintiff or defendant was a foreigner; abolished 1870 .

Mediety. A middle state [L. mĕdietātem] between two extremes.

Medio tutissimus ībis. [L.] You will walk most safely in the middle (Ovid), by avoiding extremes. The Aristotelian doctrine was that virtue was a mean [Gr. $\mu \epsilon \sigma \delta \tau \eta s]$.

Medium. [L. medius, middle, mean.] 1. The substance with which the dry colours are ground and mixed for an artist's use; as oil, water, etc. 2. Paper twenty-three inches by eighteen.

Medjidie, Order of the. Instituted in 1852 , by the Sultan Abdul Medjid.

Medoc. Name of a French wine (from Medoc, in the Gironde).

Mĕdulla oblongata. [L.] (Anat.) The prolongation of the spinal cord, or Médulla spinalis, into the cavity of the skull.

Medullary. (Med.) Relating to or consisting of mědulla $=$ (I) marrow, (2) pith.

Medullary rays. (Bot.) Those radiating from the centre of exogenous stems cut transversely. They are cellular plates or processes, connecting pith with bark, and forming the "silver grain."

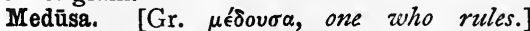
(Myth.) (Gorgons; Pegasus.)

Mědūsæ, Mĕdūsǐdæ. [Gr. $\mu \in ́ \delta o v \sigma \alpha$.$] (Zool.)$ Most of the jelly-fishes, or sea-nettles (Ăcălēphæ), are thus termed; some, however, and perhaps all, are the generative buds of a hydrōzōan.

Meeching, Miching. [Fr. méchant.] Skulking, shirking, mean ; an old Shakespearian word still occasionally heard in New York and New England.-Bartlett's Americanisms.

Meerschanm. [Ger. meer, sea, schaum, foam.] A silicate of magnesia, used for making tobaccopipes.

Meet her. (Naut.) The order to stop a ship from turning more in any direction.

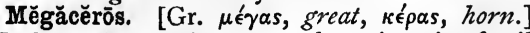
(Geol.) $M$. Hibernicus, the gigantic fossi Irish deer (not elk); in post-Tertiary lacustrine deposits, and in caverns. Ireland, Isle of Man, Scotland, England, European continent.

Megalesian games. Roman games held in the Circus in honour of Cyyberle, the mother of the gods, under the title of $\dot{\eta} \mu \in \gamma \alpha \dot{\lambda} \eta \theta^{\prime}$ 'os, the great goddess. (Mahâdeva.)

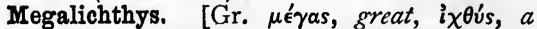
fish.] (Geol.) A gen. of fossil crosso-pterygian 
[Gr., fringe-winged] ganoid fishes; more especially of the Sauro-dipterine [Gr., sauroid-

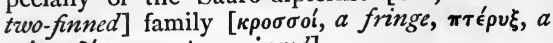

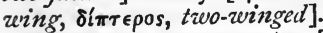

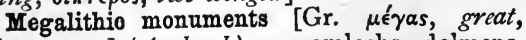
$\lambda($ itos , stone $]$ (Archaol.) $=$ cromlechs, dolmens, and menhirs, or stone pillars, often monoliths.

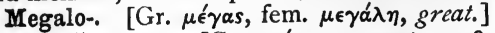

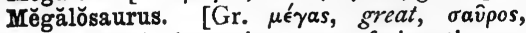
lizard.] (Geol.) An extinct gen. of gigantic reptiles, carnivorous, terrestrial ; in Oolite of Oxon and Normandy; Purbeck and Wealden shales.

Megarian school. The school of philosophy established by the disciples of Socrates at Megara, to which they retreated after his death.

\section{Megass. (Bagasse.)}

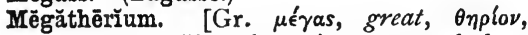
beast.] (Geol.) Gigantic extinct mammal, herbivorous, allied to sloths and ant-eaters. S. America.

Megrim. [Fr. migraine, headache, Gr. ìm-

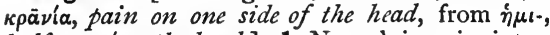
half, $\kappa \rho \bar{\alpha} \nu$ iov, the head.] 1. Neuralgic pain, intermittent, affecting one side of the head. 2. In a horse, vertigo; as when, at work, especially in the hot sun, he reels, and perhaps falls, the circulation through the brain being disturbed, 'dsually by the presence of tumours.

Meiōsis. (Litotes.)

Meistersingers. (Mastersingers; Singers of Germany.)

Melada. [Sp., candied.] Crude undrained sugar, as it comes from the pans.

Mĕlanchŏlia, Melancholy. A form of insanity [Gr. $\mu \in \lambda \alpha \gamma \chi 0 \lambda i a]$, arising, it was thought, from an excess of black bile [ $\mu \epsilon \lambda^{\prime} \alpha \iota \nu \alpha \chi 0 \lambda \hat{n}$ ].

Mĕlanchŏliā, Non est magnum ingěnium sĭne. [L.] An old proverb, quoted by Lacordaire: No great character is free from melancholy.

\section{Melanic. (Xanthous.)}

Mĕlănismus. [Gr. $\mu \in \lambda a ̆ \nu ! \zeta \omega, I$ am black.] Tendency to blackness of skin.

Mělănōsis. [Gr. $\mu \in \lambda$ ă $\nu \omega \sigma \iota s, a$ becoming black.] A malignant disease, with blackish morbid deposition in different parts of the body.

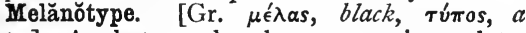
iype.] A photograph taken on an iron plate, coated with collodion.

Melasma. [Gr. $\mu \epsilon^{\prime} \lambda \alpha \sigma \mu \alpha$, black or livid spot.] A cutaneous disease, especially at old age, with dark spots or patches, sometimes ulcerous.

Melchisedekians. (Eccl. Hist.) Several sects have been so named from their opinions respecting the character and office of Melchisedek. Among them were the Theodotians in the third century.

Melchites. (Eccl. Hist.) The Syriac, Egyptian, and other Christians of the Levant were called Melchites, or Royalists [from the Syr. melec, a king], by the Jacobites, or Eutychians, because they submitted to the imperial edicts relating to the Council of Chalcēdon. They are governed by a patriarch resident in Damascus.

Meletians. (Eccl. Hist.) The followers of Meletus, Bishop of Lycopolis, in Egypt, who was deposed by a Synod at Alexandria on the charge of sacrificing to idols during the perecution of Diocletian.

Melikertes. The Greek form of the Syrian Melkarth, the king, a name given to the sungod; also known as Moloch. (Melchites.)

Mellifluous Doctor. (Doctor.)

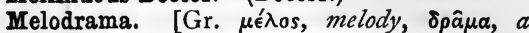
drama.] A sensational dramatic performance, the main story given in speaking, but the striking incidents being accompanied by music, vocal and instrumental.

Melotype. A photographic process, in which the picture need not be at once developed.

Melpŏmĕnē. [Gr., the singer.] One of the Muses, commonly called the Muse of tragedy.

Melusine. In the traditions of S. France, one of the many mysterious beings who undergo a periodical transformation, by which the lower part of the body becomes serpentine. In this state she must not be seen by her husband. If she is so seen, she vanishes for ever. (Lohengrin; Psyche.)

Melwel. (Ichth.) A kind of cod-fish.

Membered. (Her.) Having the beak and legs different in colour from the body.

Memnon's harp. The statue called by the Greeks Memnon, at Thebes, in Upper Egypt, was supposed to emit sounds, like that of a harp, at the rising of the sun. Hence the phrase. (Eos, Tears of.)

Memorābllǐa. [L.] Things noteworthy. The L. title of the memoirs of Socrates by Xenophon, called in Gr. 'A

Memŏrĭa technica. [L.] An artificial system of memory.

Mendicant orders. (Orders, Mendicant.)

Menhir. [Gael. maen, stone, hir, long.] (Arch.) A standing stone or pillar; a memorial, probably of some event; the majority being tombstones. So Gen. xxxi. 5 I ; Exod. xxiv. 4 ; Josh. iv. 21.

Mēningītis. [Gr. $\mu \hat{\eta} \nu เ \gamma \xi$, a membrane.] (Med.) Inflammation of the membranes of the brain.

Mëniscus. [Gr. $\mu \eta \nu$ íкos, a little moon.] A lens convex on one side and concave on the other, but thicker in the middle than at the edges. (Lens.)

Mennonites. The Anabaptist followers of Mennon Simonis, a Frisian, in the sixteenth century. In their objection to oaths and to war they resemble the Quakers. From the M. one offshoot is that of the Galenites, called after Galen, a physician of Amsterdam, and answering to the "Bible Christians" of this country. Another is that of the Collegiates, so called as coming together in meeting-houses, where all had the right of expounding the Word of God.

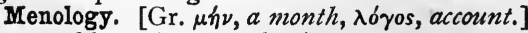
A monthly calendar of saints, martyrs, con. fessors, commemorated.

Mens conscia recti. [L.] A mind conscious of its uprightness.

Mens sāna in corpŏre sāno. [L.] $A$ sound mind in a sound body (Juvenal).

Menstruum. [L. menstruus, monthly, from the belief that the moon had influence on the 
powers of dissolvants.] Any fluid which dissolves a solid body.

Mensuration. [L. mensūratio, -nem, a measuring.] The branch of geometry which gives rules for finding the lengths of lines, areas of surfaces, and volumes of solids.

Mentor. In the Odyssey, a friend and adviser of Tēlěmăchus. Hence any counsellor.

Menu. [Fr.] Bill of fare.

Menu, Laws or Institutes of. The most celebrated code of Hindu law, religious and civil, said to have been revealed by Menu, or Manu, son of Brahma. The name reappears in that of the Cretan lawgiver Minos.

Meo pericǔlo. [L.] At my risk.

Meo sum pauper in ære. [L.] I am poor with my ozen money (Horace); i.e. I am not rich, but I owe nothing. Debt is in L. æsalienum, other persons' money.

Mephistophĕles. The name of the devil in Goethe's Fiust.

Mephitic. Containing měphïtis, pestilential exhalation, destructive of life. Carbonic acid gas is called mephitic air.

Mĕphitis. [L.] Any noxious vapours or smell ; so called from the Latin goddess Mephitis, who was invoked for protection against hurtful odours.

Mercaptan. [Mercury, and L. căpěre, to seize.] A liquid composed of sulphur, carbon, and hydrogen (from its energetic action on mercury).

Mercator's chart or projection. (Named after Gerard Kauffman, which in L. = Mercator, trader.) A map of the world in which the meridians are represented by parallel straight lines, and the equator by a straight line at right angles to them ; the parallels of latitude are, therefore, of the same length as the equator, and the degrees of latitude are lengthened out so as to maintain their due proportion; consequently there is a very great magnification in the areas near the poles. The map is useful to navigators, as the ship's course can be laid down on it in a succession of straight lines.

Mercator's sailing. (Naut.) Calculating a ship's course from Mercator's chart, on which the true proportions of latitude and longitude are intended to be indicated, while their true measurements are sacrificed.

Mercenaries. [L. mercēnārius, from merces, tay.] Soldiers who sell their services for money. By the Greeks they were termed Xenoi, or foreigners. (Condottieri.)

Morchant bars. Finished bars of iron fit for the market.

Mercǔrĭus Aulǐcns, $\mathbf{M}$. Rusticus, and $\mathbf{M}$. Civicus ; i.e. Court Mercury, Country M., Town $M$. Short papers-somewhat like the Tatler and Spectator of later days-" conveying cheap and easy knowledge," published "in the Civil War," to raise and fix the prejudices of the people. -Johnson, Life of Addison.

Mercury. 1. [L. Mercŭrĭus, from merx, mercari, to traffic.] A Latin god of commerce and gain. He had nothing to do with the Creek Hermes, and the Roman Fotials refused to allow their asserted identity. 2. A brilliant white metal, liquid at ordinary temperatures. 3. (Planet.)

Mercy-seat. The golden lid of the ark of the covenant $(q . v$.$) .$

Mere, M. baulk. [O.N. moeri, a boundary.] A boundary, especially the space left unploughed as such in common lands.

Meridian [L. meridies, noon] ; First M. ; Magnetic M. 1. (Astron.) The Meridian of a place is the great circle passing through the poles and the zenith of the place. 2. (Geog.) The line (which is nearly a circle and still more nearly an ellipse) in which the surface of the earth is cut by a plane passing through the poles and the place. The First $M$. is that from which longitudes are reckoned. In English reckoning the first $M$. is that of Greenwich. The Magnetic M. of a place is the direction of the magnetic needle at the place when free to move round a point in a horizontal plane, and uninfluenced by local attraction.

Meridional parts, Table of. Gives the length of the arc of the meridian measured from the equator, corresponding to every degree and minute of latitude on a Mercator's chart. It is used in showing a ship's course on a Mercator's chart.

Merino. A thin twilled fabric of merino wool. Merk. An ancient Scotch coin, i.q. mark.

Merlin. A magician in the story of King Arthur.

Merlon. [Fr. and Sp.] (Mil.) The part of a parapet left standing between two embrasures as cover to the men and guns. [Fr., from a slight resemblance to merle perché, a perched blackbird (Littré).]

Merovingian kings. (Hist.) The dynasty of Frank kings, beginning (48I) with Clovis (Hludwig), grandson of Meroveus (Merwig), and end. ing with Childeric, deposed by Pepin, $75^{2}$. (Rois Fainéants.)

Merry dancers. The Northern lights, from their undulatory movements.

Merry men of May. (Naut.) Currents caused by ebb-tides.

Mesa. [Sp., table, L. mensa.] Throughout the whole region bordering on Mexico, this $\mathrm{Sp}$. word is used for a high plain or table-land. -Bartlett's Americanisms.

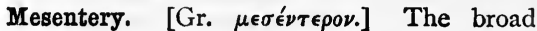
fold of the peritoneum (q.v.).

Mesial line. (Median line.)

Meslin. [O.Fr. mesler $=$ Fr. mêler, to mix, L.L. miscŭläre.] $(A g r$.$) Wheat and rye$ mixed.

Mesmerism. (Mesmer, German physician, died I8I 5.) (Magnetism, Animal.)

Mesne. (Leg.) A word meaning middle, inter. mediate, intervening. So $M$. lord, a lord of a manor, with tenants under him, and a superior lord over him; $M$. process, any writ between the commencement of the action and the final process or execution; $M$. incumbrances, liabilities arising between two given periods, etc.

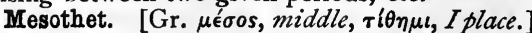
That which placed, as it were, between two 
opposite points, two things apparently contradictory, practically reconciles them; thus action, or duty, is the $M$. of free-will and necessity.

Mesozoic. (Neozoic.)

Mespǐlns. [Gr. $\mu \in \sigma \pi \tilde{i} \lambda \eta$.] (Bot.) The common medlar, M. Germanica, ord. Rosaceæ.

Messenger. (Naut.) An endless rope, or cable, extending from the capstan to the cable, by which the latter is hauled in.

Messidor. [Fr., from L. messis, harvest.] The ridiculous name given to the tenth month in the French Republican calendar. It formed part of June and July. (Vendémiaire.)

Mestino, Mestizo. In Sp. America, the child of a Spaniard or Creole and a native Indian. (Mulatto.)

Meta-. [Gr.] As a prefix, denotes next, after, beyond, reviersely, etc.

Metacentre. [Gr. $\mu \in \tau d$, next afterwards,

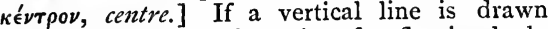
through the centre of gravity of a floating body in its position of rest, and if when the body is slightly displaced a vertical line is drawn through the centre of gravity of the fluid displaced by the body in its new position, the point of intersection of the line at first vertical with the second line is the $M$. If the $M$. is above the centre of gravity, the flotation is stable. The displacement is supposed to take place round a line passing through the centre of gravity of the plane of flotation, and this line must be a principal axis of the plane if there is to be a M.

Metacism. An incorrect form for Mutacism $(q . v$.$) .$

Mëtăgěnĕsis. [Gr. $\mu \epsilon \tau a ́$, in compos. reversely, $\gamma \in \dot{\nu} \in \sigma \iota s$, generation.] Development of the individual, when its parts and organs are not changed into the corresponding parts and organs in the new stage.

Metal. [L. mĕtallum.] 1. In organ pipes, means spotted M. 2. In road-making, stone. 3. In the artillery, gun-metal.

Metallic paper. Paper coated with a solution of lime whiting and size, to be written on with a pezoter pencil.

Metallic tractors. Used thirty or forty years ago, but rejected now ; small pointed metallic bars, drawn over diseased parts, and supposed to cure or relieve by magnetism; invented by Dr. Perkins.

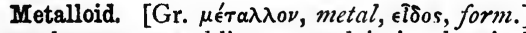
Any element resembling a metal in its chemical properties ; an inflammable non-metallic element, as sulphur.

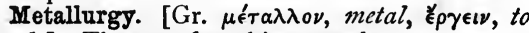
work.] The art of working metals.

Metamorphio rocks. [Gr. $\mu \epsilon \tau \alpha \mu o \rho \phi b \omega, I$ transform.] (Geol.) 1. Altered, whether much or little, from their original form; especially, 2, those exhibiting a change to crystalline structure.

Metamorphosis. [Gr. $\mu \in \tau \alpha-\mu \delta \rho \phi \omega \sigma \iota s, a$ change of form.] (Zool.) A change seriously altering the form and habits of an animal after exclusion from the egg; as that of the caterpillar passing into a chrysalis, or of the chrysalis into a butterfly.

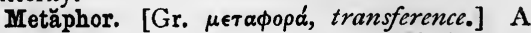
short similitude, sometimes conveyed by one word, and without any sign of comparison. M. is of two kinds: (I) Radical, when, for instance, a root which means to shine is used to furnish names for the fire, the sun, the spring of the year, the brightness of thought, and a hymn of praise ; (2) Poetical, when a noun already made, and assigned to one definite object, is transferred to another, as when the sun's rays are called his hands or fingers. The result of this process would be Homonymy [ $\delta \mu \omega \nu v \mu o s$, of the same

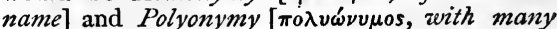
names]; by the former of which objects quite distinct from each other would receive the same name, while the latter would furnish a vast number of names for the same object. These two principles are the chief sources of mythology. Metaphor is said to be broken when a second metaphor, faultily, is introduced; as in Shakespeare's "To take up arms against a sea of troubles."

\section{Metaphysics. (Dialectic.)}

Metăplasm. [Gr. $\mu \in \tau \alpha \pi \lambda \alpha \sigma \mu \mu \delta s$, from $\pi \lambda \alpha \dot{\alpha} \sigma \sigma \omega$, I form.] (Gram.) Any alteration in the letters or syllables of a word. This may take place in three ways-by adding or taking from their number, or by resolving them. (I) Addition at the beginning of a word is called Prosthersis [Gr.]; in the middle, Epenthěsis [Gr.]; at the end, Parăgogo $\bar{e}$ [Gr.]. (2) The taking away of

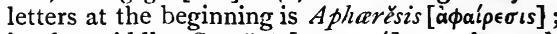
in the middle, Syncŏpe $[\sigma v \gamma \kappa o \pi\}]$; at the end, Aросðреं $[\dot{\alpha} \pi о к о \pi \dot{\eta}]$; by contracting the vowels,

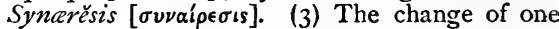
letter for annther is Antrithĕsis [Gr.]; and the transposition of letters is Metăthěsis [Gr.].

Metastăsis. [Gr. $\mu \in \tau \dot{\alpha} \sigma \tau \alpha \breve{\sigma} \iota s, a$ change of place.] (Med.) A change in the seat of a disease.

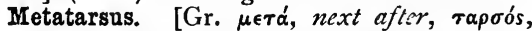
the flat of the foot.] (Anat.) The part of the foot which is between the tarsus and the phalangěs or toes, composed of five bones.

\section{Metăthěsis. (Metaplasm.)}

Metayer. [Fr., L. mediĕtārius.] In the southwest countries of Europe, a form of tenure in which the tenant pays a part of the produce to the landlord. (Thetes.)

Metempsy̆chōsis. [Gr. $\mu \epsilon \tau \epsilon \mu \psi \dot{\chi} \chi \omega \sigma \iota s$.$] The$ migration of the soul through several successive bodies; a special doctrine of the Pythagoreans.

Meteor. [Gr. $\mu \in \tau$ téwpos, high in air.] A body in the sky, of a flowing and transitory nature, such as shooting stars, halos, rainbows, auroras.

Meteorio dust, or Atmospheric dust. Dust, with which the air high above the earth's surface is almost certainly impregnated; mostly iron; often found in snow and on high buildings. Storm-dust is a mixture of fine particles of quartzose and volcanic sand, with diatomaceæ, etc., according to Professor Ehrenberg.

Meteorio iron. Metallic iron, as found in meteorolites.

Meteoric paper. A paper-like substance, found floating in the air, of confervoid origin. 
Meteorio shower. When shooting stars appear in considerable numbers at nearly the same time they form a M. S. They generally do this about August Io and November 13.

Metzorite. (Aerolith.)

Meteorolite. [Gr. $\mu \in \tau$ éwpos, high in air, $\lambda$ íos, stone.] A mass of earthy and metallic matter that has fallen from the sky to the earth.

Meteorology. [Gr. $\mu \in \tau$ éwpos, high in air, $\lambda$ óros, discourse.] The science treating of the various states of the atmosphere as to pressure, temperature, moisture, motion, etc., and their influence on climate, wind, and weather.

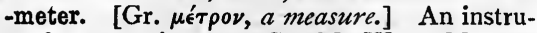
ment for measuring ; as a Gas-M., Water-M., etc.

Metheglin. [Welsh meddyglyn, liquor.] $\operatorname{Mead}(q . v$.$) .$

Methodist New Connexion. A branch of the Wesleyan Methodists, called also Kilhamites, after Alexander Kilham, who asserted, first, the right of the Methodists to have their own hours of worship, and to receive the sacraments from their own ministers ; and, secondly, the right of the laity to share in the government of the body to which they belonged. Apart, therefore, from questions of order, there is no difference between the Old Connexion and the New. The distinction lies only in the degrees of power which each allows to the laity.

Methodists. (Eccl. Hist.) The followers of John Wesley. But many orders so called have withdrawn from this connexion.

donians; Methodist New Connexion.)

Method of curves. (Curves, Method of.)

Method of exhaustion. (Exhanstion, Method of.)

Methylated spirit. Alcohol mixed with ten per cent. of methyl [Gr. $\mu \in \tau a ́$, after, $v^{\prime} \lambda \eta$, wood], or wood-spirit.

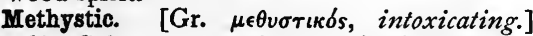
(Med.) Substances causing intoxication or exhilaration.

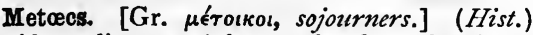
Resident aliens at Athens, who formed a large class of the inhabitants, lying under many disabilities and burdens.

Metonic cycle. A cycle of nineteen solar years, in which the new moons fall on the same days as in the previous cycles. Invented by the Athenian Meton, in the fifth century B.C.

Metonymy. [Gr. $\mu \in \tau \omega \nu v \mu l \alpha$, change of name.] (Rhet.) A figure by which the name of an idea or an object is substituted for that of another to which it has some relation, as sceptre for sway or dominion.

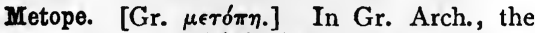
space between the Triglyphs in the frieze of the Doric order.

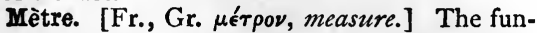
damental unit of length in the metric system; originally designed to be the ten-millionth part of an arc of the meridian, reaching from the pole to the equator. It is, in reality, like the yard, an arbitrary distance, viz. the distance between the two ends of a certain platinum rod at the temperature of melting ice. Its length is $39 \cdot 37079$ inches or $1^{\circ} 09363$ yard.
Metric system. A system of measures having the mètre for its fundamental unit.

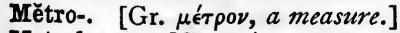

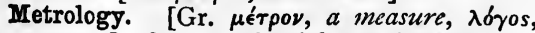
an account.] System of weights and measures.

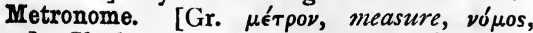
law.] Clockwork, measuring the relative duration of notes by a pendulum, to which a balancerod is attached, on which the various grades of time are measured; a movable weight regulates the speed. The sign $\sigma=13^{2}$, means that that number of crotchets would be played in a minute.

Mëtropolis. [Gr., mother-city.] 1. Originally the parent state from which a colony has sprung. 2. The city in which the archiepiscopal see of a province is established. Thus Canterbury is the metropolis of England. 3. In modern and less correct usage, the chief city or capital of an independent state.

Metropolitan. 1. With the Greeks, one whose see is a civil metropolis. 2. With others, one who, by virtue of his see, presides over other bishops; such sees are Canterbury, Dublin, Calcutta, Capetown, etc. (See "Consecration of Bishops," in Prayer-book.)

Meum et tuum. [L.] Mine and thine.

Mew. [O.E. máw, Ger. mewe, mowe, (?) from its cry.] (Ornith.) Sea-meew, the gull, Lărus cānus [L., grey].

Mew. A cage, or inclosure, especially for trained hawks, or an aggregation of them [Fr. meute, pack, L.L. mōta, troop mobilized, L. mǒvēre, to move].

Mew. [Fr. muer, L. mūtāre, to change.] 1. To moult, as hawks. 2. To shed horns, as stags.

Mew. To inclose, confine. Mew, a prison, place of confinement ; originally, in Falconry, a place for falcons; afterwards for horses, as Mews in London. [Generally derived from O.Fr. mue, a changing, a place for moulting, L. mūtāre, to change. But "in Eng. the sense of cage is the oldest ; whence mew, to inclose" (Skeat, Etym. Dict.). (?) Is the L.L. mūta, a disease, with moulting, possibly, earlier still ?]

Mezzanine. [It. mezzano, middle.] (Arch.) A story of small height introduced between two higher ones. This would answer to the Triforium in the so-called Gothic buildings.

Mezzo-relievo. [It.] Sculptured work, in which the projection is equal to half the true proportions. When more than half, it is Altorelievo; when less, it is Basso-relievo.

Mezzo termino. [It.] $A$ middle term; a stopgap, a compromise.

Mezzotint. [It. mezzo, half, tinto, tint.] A kind of engraving, produced by scratching the whole surface of the plate, and then scraping and burnishing those parts where the lights should come.

Miasma [Gr. $\mu i \alpha \sigma \mu \alpha$, pollution], or Contagion. 1. Efflùvium, noxious emanation, from the bodies of the sick. 2. Marsh M., or Malaria [It., bad air], is from vegetable decomposition, under certain conditions of heat and moisture.

Mica. [L. mǐco, I shine.] (Geol.) A mineral, one of the silicates of alumina, with potash or 
magnesia, a constituent of granite, of gneiss, and mica-schist; metallic in lustre, divisible into flakes, and elastic. Often mechanically mixed in sandstone and shale. Muscovite is a potash mica; Biotite is a magnesian mica.

Michael, St., Order of. A French order of knighthood, instituted by Louis XI., 1469.

Miching. (Meeching.)

Michtam. Title of Ps. xvi., lvi.-lx., = a "golden psalm," as in the margin, and according to the rabbis (Speaker's Commentary).

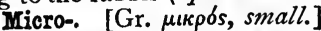

Microcosm. (Macrocosm.)

Microcosmio salts. (Chem.) A triple salt of soda, ammonia, and phosphoric acid, originally obtained from human urine.

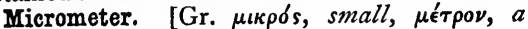
measure.] An instrument for measuring small distances or angles. It consists of a spider line (or wire) placed in the focus of a telescope (or microscope) and moved by a screw with a graduated head. It is first brought into optical contact with a fixed wire, and then with a second point; the difference of the two readings of the screw-head gives the distance from the fixed wire to the point in terms of fractional parts of a turn of the screw. The absolute value of a turn of the screw is found from the number of turns per inch, or by applying the micrometer to an object of known length.

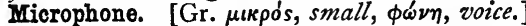
An instrument for magnifying small sounds by means of electricity.

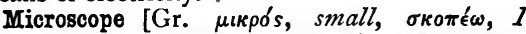
view]; Compound M.; Electro-M.; Oxy-hydrogen M. ; Photo-electric M.; Simple M. ; Solar M. An instrument for rendering minute objects distinctly visible; it may be a single lens or sphere, and in that case is a Simple M. ; but more commonly the term is applied to the Compound $M$. which is a combination of lenses duly mounted, consisting of an achromatic object-glass and an eye-glass (or eye-piece consisting of two lenses) for viewing the image formed by the object-glass. The Electro or Photo-electric, the Oxy-hydrogen, and Solar microscopes are instruments made on the same principle as the magic lantern; they receive their special name from the kind of light employed.

Midas. (Myth.) A Phrygian king whose touch turned everything to gold, and who obtained deliverance by washing in the river Pactolus, which has ever since had a golden hue. The tale points to the illuminating power of the sun, whose light is quenched when he reaches the water-level in the evening. Midas has also the ears of an ass. This is mentioned as a punishment for his preferring Pan, or Marsyas, to Phœbus.

Midden, Mixen. [A.S. midding, id., A.S. meox, mix, dung; "dunghill," Luke xiv. (Wyclif's translation); so myxen.] Dunghill, dustheap.

Middings. (Midden.)

Middle Ages. (Hist.) A vague term, denoting the time of transition from the conditions of the ancient to those of the modern world. They are assumed by Hallam to begin with the sixth and end with the fifteenth centuries.
Middle-latitude sailing. (Naut.) Calculating a ship's course by the mean of the latitudes of the points of departure and arrival respectively.

Middleman. One who goes between the original owner, or producer, and the public; e.g. in trade, taking orders for work, which he then lets out to others; or in agriculture, hiring land in large tracts, and then letting it again in smaller portions.

Middle Pointed style. (Geometrical style.)

Middle term. (Log.) That term in a syllogism with which the two extremes of the conclusion are severally compared.

Middle tint. A mixed tint in which bright colours never predominate.

Middle watch. (Naut.) From 12 (midnight) to 4 a.m. Middle-watcher, the snack taken by the officers of middle watch about 2.30 a.m.

Midgard. In Northern Myth., the middle garden or earth, embraced by the branches of the tree Yggdrasil.

\section{Midlothian. (Lothian.)}

Midrash. (Scribes.)

Midrib. (Bot.) Of a leaf, the central line, a continuation of the footstalk.

Midriff. (Diaphragm.)

Midshipman. (Rank.)

Midwife. [(?) Ger. mühe, labour pains, weib, woman.] One who assists women in childbirth. Mikado. (Tycoon.)

Mile. [In L. mille passuum, a thousand paces; passus being the distance between the place where a foot is set down, and the place where the same foot is set down the next time, about five feet.] The Statute $M$. is 1760 yards. Geographical or Nautical $M .=$ a sixtieth of a degree of longitude measured on the equator, and therefore about 2029 yards. Seamen erroneously call minutes of longitude miles.

Mileage. Allowance for travelling, so much per mile.

Milesian. 1. Properly an inhabitant or native of the ancient Greek city Miletus ; but sometimes, 2, a native or inhabitant of Ireland, descended, according to the tradition, from a Spanish king Milesias, whose sons conquered the island some twenty centuries B.C.

Milliaria, Miliary fever. A disease associated with great heat of the skin and an eruption like the seed of millet [L. millum].

Miliolite limestone. [L. millŭum, millet seed.] (Geol.) The Calcaire grossier of Paris, largely composed at places of Miliola, one of the foraminifera (q.v.).

Military honours. Reception of superiors by troops by lowering flags and saluting. When an officer or soldier is buried with $M$. $H$., the body is attended to the grave by his comrades in military order, either guns or musketry being fired over the grave, according to his rank.

\section{Military law. (Martial law.)}

Military position. A piece of ground so selected as to bring out most advantageously the powers of the different branches of the service of which an army is composed, and which the general has at the time at his command.

Military road. One of superior construction, 
such as those formed by the Romans, accessible in all weathers for troops, with their guns, baggage, and supplies.

Irilitat omnis amans. [L.] Every lover is a soldier (Ovid).

Militia. [L., military service.] In the seventeenth century, before the formation of a standing army, = the entire military force of the nation. The term is now applied to a force raised either by ballot or voluntarily from the population, for home service in the protection of the country; occasionally embodied, for purposes of drill, in time of peace.

Milknippers of a horse; his first, as distinguished from his permanent, teeth; shed at various times between the ages of three and four.

Wilk of lime. A milky mixture of lime and water.

Milkwort, Common. (Bot.) A small perennial plant, Pŏly̆găla vulgāris, ord. Polygaleæ $[\mathrm{Gr}$.

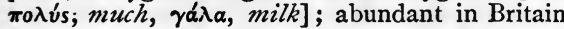
in dry places; its flowers purple, pink, white, sometimes brilliant blue.

\section{Milky Way. (Galaxy.)}

Mill. [O.E. miln.] That part of ironworks where puddled bars are converted into merchant iron.

Millboard. Stout pasteboard.

Mill-dam ; M.-head; M.-race ; M.-tail, etc. A Mill-dam serves to keep back the water of the stream in a sort of reservoir, so that in its descent it may turn a water-wheel, turbine, etc. The stream from the reservoir which acts on the wheel is the $M$.-race; the stream formed by the water that has turned the wheel is the $M$. tail, or Tail-race, or Tail-water. The M.-head is the vertical height through which the water falls in turning the wheel.

\section{Millenarians. (Chiliasts.)}

Millenary Petition. [L. millēnārius, belonging to a thousand.] One presented to James I., A.D. 1603, by (some few hundreds short of) a thousand.Puritan ministers, for relief in certain ceremonies ; and objecting to some parts of the Church service, and to the state of Church discipline.

Millenninm. [L.L.] The space of a thousand years spoken of in Rev. xx. 4.

Millerole de Marseille. [Fr.] A measure of capacity, still used as equal to sixty-four litres, or about fourteen English gallons.

Miller's thumb. (Bullhead.)

Milliard. [Fr.] A thousand million.

Millier. [L. milliārium, a thousand of.] A thousand kilogrammes, nearly equal to a ton weight.

Milligramme; Millilitre; Millimètre. Measures of the thousandth part of a gramme, litre, and mètre respectively.

(Gramme; Litre; Mètre.)

Milling. The grooves on the edge of a coin.

Milling-tool. A roller, with indented surface, for making grooves in metal.

Mill-rind. (Her.) The iron placed in the centre of a millstone to protect the hole from wearing out.
Millstone grit. (Geol.) An English division of the Carboniferous system ; a coarse conglomerate, yielding stone for building, millstones, firestones; N. counties of England and N. and S. Wales.

Milreis. A Portuguese coin, worth about $5 s$. The gold coin of five milreis is worth $£_{1} 3^{s}$. I I $\frac{1}{4} d$.

Mime. [L. mimus, Gr. $\mu \hat{i} \mu o s, a$ mimic.] Anciently, a kind of dramatic entertainment, resembling the modern farce or vaudeville.

Mimir, Well of. In Northern Myth., the well or fountain at which Odin, wishing to drink, was obliged to leave an eye in payment.

Mina. [L., Gr. $\mu \nu \hat{a}$.] An ancient Greek weight and coin, varying in different states. The coin contained 100 drachmas, and was worth about $£ 3$ of our money.

Minaret. [Ar. menarah, a lantern.] In Mohammedan mosques, a turret used for summoning the people to prayers, and thus serving the purpose of a belfry. (Muezzin.)

Minauderie. [Fr.] Mincing, affected manners. Mineral, Mineralogy. [Fr. miner, to mine.] 1. A rock (q.v.), in Geol., is regarded chemically, as resolvable into certain primary elements or minerals. 2. These, in Min., are regarded as being pure or impure, soft or compact, earthy or crystalline, and exhibit certain cleavage, fracture, lustre, optical and other sensible properties.

Minerva. The Latin goddess answering to the Athena of the Greeks. The name denotes intellectual power as well as bodily energy, as is shown by the connexion of the Gr. $\mu$ évos with the L. mens, Skt. manas, Eng. mind. Hence the phrase Sus Minervam, a pig teaches Minerva, the fool instructs the wise. To do a thing tenui or crassā Minervā is to do it poorly or awkwardly.

Minerva Press. In Leadenhall Street, the source from which issued, during the latter part of last century, a great quantity of mawkish weak novels, and which, by means of circulating libraries, gained a factitious popularity.

Minever. [O.Fr. menuver, from menu, small, vair, a kind of fur.] A fine white fur.

Minie-rifle. (Mil.) One carrying a bullet invented by Minie, a French officer, which has a cup inserted in a cavity in its base; on its being projected, the charge expands the bullet into the grooves of the rifle, thus giving great accuracy of flight.

Minims, Order of the. [L. minimi, the least.] Instituted in the fifteenth century by St. Francis of Paul. Their name indicated their lowliness, and their rule was of the strictest kind.

Minrmum. When a variable magnitude decreases down to a certain value and then increases again, that value is a minimum. A $M$. is not necessarily the smallest value of the variable.

Minion. [Fr. mignon, dainty.] A kind cf type, as-

\section{General.}

Minium. [L.] Red lead. (Lead.)

Minnehöfe. [Ger.] This word denoted the courts of love, well known in the history of 
chivalry. These courts, in which ladies acted as judges, were held periodically in Signes, Avignon, Pierrefeu, and Lille.

Minnesingers. Love-singers, the earliest school of German poets, who imitated the Provencal troubadours. Their verses are written in the old Swabian dialect. Among their works is the great national epic, called the Nibelungenlied, and the lays of the Heldenbuch, or book of heroes.

Minorites. Friars belonging to the order of St. Francis. (Franciscans.)

Minorities, Representation of. In Politics, the means for giving effect to the opinion of the minority. The modes generally suggested are twofold: (I) that each elector shall have two votes when three candidates can be returned, or (2) one vote when two are to be elected. To these must be added the suggestion of Mr. Hare, that the elector should be empowered to choose the constituency in which he shall record his vote.

\section{Minoresses. (Clare, St., Order of.)}

Minos. In Gr. Myth., a king of Crete, and one of the judges of the infernal regions. (Menu, Laws of.)

Minot. [Fr., from mine, a corr. of hémine, L. hēmina, Gr. ín $\mu$ ina, which last was about one gallon.] An O.Fr. measure, the forty-eighth part of a muid [L. mŏdius], and a little larger than an English bushel.

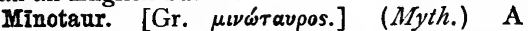
monster, half man, half bull, said to be the offspring of Pasiphăê, wife of Minos. (Labyrinth.)

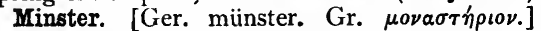
Originally, in this country, an outpost of the Church, maintained by priests living under rule. Thus every station in the advance made by the colleagues of Augustine received the name of monastery or minster, and retained it after secular priests had taken the place of the monks.

Minstrels. [Fr. ménestrel, from O.G. minne, love.] In the Middle Ages, an order of men who seem to have been the successors to the Minnesingers, scalds, and bards. But they soon degenerated. The chanter of the gests [L. gesta, things done, feats], or acts of kings, became a gesticulator or jester; the jongleur of Provence [L. jŏcŭlator] sank into the juggler or jockie. (Gleemen; scald.)

Mint. [Gr. $\mu l \nu \theta \alpha$, L. mentha.] (Bot.) A herb of the nat. ord. Labiatæ, used for flavouring.

Mint. [L. Monēta, a name of Juno, in whose temple money was coined.] A place for coining the national money.

Minuet. [Fr. menuet.] 1. A slow, graceful dance, which had its origin probably in Poitou, and in the seventeenth century ; by two persons, in 3 time; consisting of a coupée, a high step, and a balance, and having short steps [pas menus]; a coupée being when, one leg being a little bent and raised from the ground, a motion forward is made with the other. 2. A musical movement, originally an accompaniment to the dance.

Minute-guns. (Mil. and Naut.) Guns fired at intervals of a minute, as a sign either of distress (as of ships) or of mourning (as at funerals).

Minutǐæ. [L.] Petty details, trifles.

Miocene. (Eocene.)

Miölnir. The crushing or pounding hammer of Thor. (Mars.)

Miquelets. In Sp. Hist., partisan troops raised chiefly in Catalonia ; first heard of in the seventeenth century.

Mirābille dictu. [L.] Wonderful to tell.

Miracle. (Prodigy.)

Miracle-plays. Plays representing events recorded in the Bible. They were common in the Middle Ages. The miracle-play of the Passion is still performed at Ober-Ammergau, in Bavaria, once in every ten years.

Mirage. [Fr. mirage, mirer, to aim at.] A reflected picture of distant objects, seen in peculiar states of the atmosphere. If two transparent media of different densities are in contact, a ray of light in the denser medium, inclined at a small angle to the common surface, will not pass into the rarer medium, but will be reflected internally. It is probable that when the $M$. is seen the atmosphere is arranged in layers of different densities, varying nearly discontinuously, so that light proceeding from objects in the lower strata suffers internal reflexion, and forms for the observer the images which constitute the M.; just as in a long, low room, ceiled with looking-glass, he would see both the end of the room and its inverted image; or in other cases, where the observer and the object are above the heated stratum, he sees it and its image as if formed by reflexion in water.

Miramamolin. (Emir.)

Mirmillōnes. [L.] Among the Roman gladiators, the opponents of the Retiarians; so called from the embossed fish [Gr. $\mu \iota p \mu$ únos] which they wore on their head-piece.

Mirrour for Magistrates, published 1559. A poem, very important in English literature, and very popular in its day, begun by Thomas Sackville, Lord Buckhurst ; completed by .Baldwyne and Ferrers, and others. The first poetical use made of chronicles like Hollinshed's, etc., by which English history, written hitherto in monkish Latin, had recently become known to the people; its plan being to give an account of all the illustrious, but unfortunate, characters, from the Conquest to the end of the fourteenth century ; one of the sources from which Shakespeare drew.

Mirza. This word, a corr. of the Pers. Emir-zadah, sons of the prince, is the common style of honour, when put before the name; coming after it, it signifies prince.

Mischia. (Scagliola.)

Mischna. (Talmud.)

Miscreant. Until lately, often $=$ méscreant [Fr. mécréant], unbeliever;; not morally evil.

Misdemeanour. In Law, any indictable offence not of a felonious character; as libel, seditious acts, etc.

Mise of Lewes. The name given to the treaty between the English barons and the royalists after the battle of Lewes, May, 1264 . 
Miserëre. [L., have mercy.] 1. The fiftyfirst psalm; so called from the first word with which it begins in Latin. 2. (Arch.) The under portion of the seat of a stall, generally richly carved, and often with grotesques, so contrived that it may turn up when wanted as a support in long standing.

Miserricorde. [Fr., pity, either the cry for pity, or (?) ironical.] Dagger worn by knights for stabbing to death those who had fallen.

Misfeasance. [O.Fr. mes, zurong, feasance, doing, from L. facere, to do.] In Law, a trespass or wrong done.

Misnōmer. In Law, a mistake in a name, or the substitution of one name for another; which has no effect, as a general rule, if the subject-matter, or person, is certain or ascertainable notwithstanding.-Brown, Law Dictionary.

Mispickel. [O.G.] (Chem.) A greyish white ore of iron combined with sulphur and arsenic.

Misprision. [From Fr. mépris, negligence, contempt.] In Law, (I) any Misdemeanour which has not a specific name ; (2) contempt, or neglect, in not disclosing crimes, as of treason or felony. (Treason, Misprision of.)

Missal. [L.L. missāle.] The book containing the ritual for the celebration of Mass in the Latin Church.

Missa sicca. [L., dry Mass.] A form of Mass said on days on which there is no consecration.

Missing vessel. (Naut.) One which, not having been heard of for six months in Europe, or twelve elsewhere, is held to be lost.

Missouri Compromise. A name popularly given to an Act of Congress passed in 1820 , and intended to reconcile the two great sections that were struggling, the one to promote, the other to hinder, the extension of slavery. By this Act, it was determined that Missouri should be admitted into the Union as a slave-holding state, but that slavery should never be established in any state to be formed in the future lying north of lat. $36^{\circ} 30^{\prime}$.-Bartlett's Americanisms.

Miss stays, To. (Naut.) Instead of going about, to fall back on the old tack.

Mistico. (Naut.) A small vessel of the Mediterranean, between a felucca and a xebec.

Mistral [as if maestrale, the master wind], Mistraou, Mæstral, the Caurus or Cörus of the Romans, Maestro of Italy. A north-west wind on S. coast of France and up the Rhone as far as Valence ; sudden, violent, bitterly cold, parching, painful to eyes and face, especially prevalent from the end of autumn to the beginning of spring.

Mithriac worship. In Rom. Hist., the worship of the Persian sun-god Mithras, the Mitra of the Rig Veda ; introduced into Rome about the time of the fall of the republic.

Mithridate. An antidote to poison, an alexipharmic. Mithridates Eupător, King of Pontus, succeeding to the throne B.c. I20, when eleven years old, and constantly fearing conspiracy, is said to have invented and constantly taken some very efficacious antidote to poison. A poetical term.

Mitrailleuse. [Fr.] A French gun, the principle of which is much like that of the English Gatling gun.

Mitre, or Mitre-joint; M.-wheels. A joint such as that formed by the skirting-board at the corner of a room; the pieces are cut at a certain angle $\left(e . g .45^{\circ}\right)$ so as to match when put together. Two bevilled wheels with an equal number of teeth, and with axes at right angles to each other, are $M$.-zuheels.

Kitred abbots. (Abbots, Mitred.)

MittImus. [L., we send.] In Law, (I) a writ by which records used to be transferred from one court to another; (2) a document, signed by a magistrate, committing an offender.

Mixed actions. In Law, suits partaking of the nature of real and personal actions. Now abolished except in actions for ejectment.

Mixed chalice. A term used to denote that some water is used with the wine in the celebration of the Eucharist.

Mixtion. [Fr., from mixtio, -nem, a mixing.] A mixture for affixing gold-leaf to wood or distemper pictures.

Mizzen. (Naut.) The spanker or driver, M.-mast. (Mast.)

Mnēmŏsy̌ne. [Gr. $\mu \nu \eta \mu o \sigma u ́ \nu \eta$, memory.] (Myth.) The mother of the Muses.

Moabite Stone. An inscribed stone found among the ruins of Dibon, in 1868 , and unfortunately broken by the natives, owing to the mismanagement of the Europeans, who wished to get possession of it. Almost the whole of the inscription has been recovered from the broken pieces. The stone was set up by Mesha, King of Moab, who rebelled against Jehoram (2 Kings iii. 4, 5), about B.C. 890 .

Mobcap. A cap for women, tied under the chin by a very broad band.

Moccasin. (Native name.) An ornamental deerskin shoe without a sole, used by N.-American Indians.

Mock-heroic. The treatment of a commonplace subject in a pompous and grand style; Burlesque being the treatment of a lofty subject in a low style.

Mocking-bird. (Ornith.) Spec. of thrush, Mīmus pŏly̆glottus [Gr., mimic of many tongues]; nine inches long, ashen brown, with white in wings and tail. America. Fam. Turdřdæ, ord. Passěres.

Mocmain truss. One stuffed with M., a substance growing on the silk-cotton tree.

Modality. In Log., a term denoting propositions in which the meaning of the copula is qualified by some word or phrase.

\section{Modal Trinity. (Sabellians.)}

Moderators, Senior and Junior. In the Universities of Oxford and Cambridge, officers appointed yearly to perform certain duties connected with examinations; so called from having originally moderated or presided in the exercises of undergraduates in the schools for the degree of Bachelor of Arts.

Modes. (Greek modes ; Gregorian modes.)

Modǐcum. [L.] A moderate, sometimes a small, amount of anything.

Modillion. [Fr.] (Arch.) A projecting bracket 
under the Corona of the Corinthian and Composite, and sometimes also of the Roman Ionic orders.

Modiste. [Fr.] Milliner.

Module. [L. modŭlus.] (Arch.) A measure for regulating the proportions of an order, equal to the semi-diameter of a column.

Modulns [L., a measure or standard]; M. of elasticity; $\mathbf{M}$. of logarithms; $\mathbf{M}$. of a machine; Young's M. A measure of comparison. It commonly means the number expressing the ratio of two variable magnitudes which have a constant ratio. The $M$. of a machine is the number expressing the ratio which the mechanical work done usefully at the working point bears to that expended at the driving point of the machine. The $M$. of a system of logarithms is the ratio which the logarithm of any number on that system bears to the hyperbolic logarithm of that number. When a rod of given material is stretched by a force, the elongation bears to the length the same ratio that the force bears to a certain force called the $M$. of elasticity (or Young's M.), which serves to measure, the resistance offered by the material to elongation. Its value is generally estimated in pounds per square inch; thus, in the case of steel, the M. is about thirty million pounds per square inch.

Mŏdus děcimandi, or Modus. (Tithes.)

Modus in rebus. [L.] A medium (or mean) in all things (Horace).

Modus operrandi. [L.] The method of setting to work.

Modus vivendi. (Vivendi modus.)

Mœræ. (Fates.)

Moff. A silk stuff made in Caucasia.

Moghrebins, Mograbians. A name, meaning men of the west, applied formerly to Turkish infantry composed of peasants from N. Africa.

Mogul, Great. The sovereign of the empire founded in India by the Mongol Baber in the fifteenth century. The last titular emperor was banished to Burmah in 1858 , for his share in the mutiny of 1857

Mohair. [Ger. mohr.] A stuff made of the long silky hair of the Angora goat, a native of Asia Minor.

Mohammedanism. The religion of Mohammed. (Islam.)

Mohur. [Pers.] A gold coin worth fifteen rupees; it is of the same weight and fineness as a rupee, i.e. 180 grains, of which 165 are pure gold ; it is therefore worth $29 s, 2 \frac{7}{6} d$.

Moidore. [Port. moeda d'ouro, coin of gold.] A gold coin of Portugal, worth about $£ \mathrm{I} 7 \mathrm{~s}$.

Moire. [Fr.] Moire antique is watered silk. Moire métallique is tinplate to which is given a crystalline appearance by sponging it with dilute nitro-hydrochloric acid.

Molasses. [Sp. melaza, from L. mel, honey.] The brown syrup which drains from sugar in the process of manufacture.

Mole. [Heb.] (Bibl.) 1. Isa. ii. 20 ; Chěphôr-pêrôth, the digger of holes, apparently a blind burrowing rodent; not our mole, but probably the mole-rat (Spalax typhlus). Lev. xi. 30 ; Tinshāměth, probably a lizard.
Molecule. [Scholastic L. mōlëcŭla, dim. of möles, a mass.] One of the finite number of parts into which a given quantity of matter would, it is supposed, be ultimately resolved if the process of division could be carried far enough. Molecules are of different kinds; but it is believed that those of any one kind are all exactly alike, and are unchangeable and indestructible. Each M. is held to be composed of a crowd of atoms moving in a sort of double circulation or vortex.

Moleskin. A soft, shaggy fabric of silk or cotton, like the fur of a mole.

Moline, Cross. [L. mŏlina, a mill.] (Her.) A cross resembling the iron which supports the upper millstone, borne (I) as a charge or (2) as a difference in the eighth son's escutcheon.

Molinism. (Eccl. Hist.) In the Latin Church, a system of opinions respecting grace and predestination not unlike those of the Arminians; so called from the Jesuit Molina, who drew up the propositions on which it rests, in 1588 .

Molinosism. A name given to the doctrine of the Quietists, from the Spanish enthusiast Molinos, in the seventeenth century.

\section{Molionids. (Mars.)}

Mollah. The title of the higher order of judges in the Turkish empire. (Mullah.)

Mollusca. [L. molluscus, soft.] (Malacology.)

Molly Maguires. 1. Members of a secret society in Ireland. 2. A society in Pennsylvania, in character similar to the Ribbon Society of Ireland, so far as they dealt with agrarian troubles; composed almost entirely of Irishmen ; combining against mine-owners and overseers, as they had combined against landlords and agents. Murders were committed, and great quantities of coal and other property destroyed by incendiarism. Ten were executed in June, I877.-Bartlett's Americanisms.

Moloch. The highest deity of the Phœnicians. The word, which means king, occurs in the composition of many Hebrew names, as Melchizedek, Melchishua, and in many forms throughout the Semitic world. (Bacchanalian.) This god was appeased by sacrifices of infants thrown into the fire under his image.

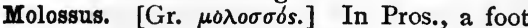
consisting of three long syllables.

Mŏlossus. [Gr., of Mŏlossia, in Ẽpïrus.] 1. The fine Molossian hound from Ëpirus (Virgil, Georg. iii.). 2. The bull-dog, Cănis fämiliăris molossus. 3. The Thibet dog, C. F. M. Thibetānus. 4. The name of three gen. of shortheaded bats, Noctǔliōnĭdæ; Trop. America.

Molten grease. In horses, a kind of dysentery ; the discharge of hard focal matter being brought about by a mucous secretion.

Moly. [Gr. $\mu \hat{\omega} \lambda v_{\text {. }}$ A fabulous herb; so named by the gods; with black root and white blossom; given by Hermes to Ulysses, as a counter-charm to the spells of Circe (Odyssey, bk. x.). (Hæmony.) 2. (Bot.) Allium M., a kind of garlic.

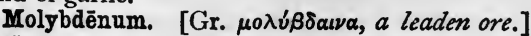
(Min.) A brittle white metal.

Moment [L. mōmentum, movement, a moving 
cause ]; $\mathbf{M}$. of a couple; $\mathbf{M}$. of a force; $\mathbf{M}$. of inertia; Virtual HI. The Moment of a force with respect to a point is the product of the force and the length of the perpendicular let fall from the point on the line along which the force acts. The term M. of a force with respect to a line and a plane is also used. The $M$. of a couple is the moment of either force about a point in the line of action of the other force. The $M$. of inertia of a body with respect to a given axis is the sum of the products formed by multiplying the mass of each particle by the square of its distance from the axis. (For Virtual $M$., vide Virtual.)

Momentum [L.], or Quantity of motion, is the product of the mass of a body and its velocity. The word is often used vaguely for the force or impetus of a moving body.

Momiers. [From Fr. momerie, mummery.] (Hist.) A name applied since 1878 to some sections of the Evangelical party in Switzerland and in parts of France and Germany. On the withdrawal of the penal enactments against them in 1831 , they lost influence and gradually disappeared.

Mömus. [Gr. $\mu \hat{\omega} \mu o s$.$] In the Hesiodic theo-$ gony, a child of night, and the god of raillery and ridicule.

Mon-, Mono-. (Chem.) A prefix, denoting that a salt contains one [Gr. $\mu$ óvos] atom of the element thus marked; as a mono-sulphide, which contains one atom of sulphur in each molecule.

Monad. [Gr. uovás, a unit.] 1. A metal, one atom of which replaces one of hydrogen in a compound. 2. (Bacteria.)

Monarchians. [Gr. $\mu \delta \nu \alpha \rho \chi o s$, ruling alone.] A name applied to those who, in the third century, were charged with ditheism, or the worship of two Gods, or who could not define the subordination of the Son to the Father. Their opponents branded them as Patripassians. -Milman, Hist. of Latin Christianity, bk. i. ch. $\mathbf{r}$.

Moncrieff carriage. (Mil.) By means of which a gun, with a balancing weight, is withdrawn by its own recoil after each discharge below the parapet, thus avoiding the exposure from using embrasures.

Monetization. The act or process of converting bullion into money. So Demonetization, the withdrawal from use, as currency.

Moneyers, Company of. A company which, until 1837 , superintended the manufacture of the money of the realm at the Mint.

Mongolia. A name used to denote a large portion of the Asiatic continent to the north of the Himalayas.

Moniliform. [L. mŏnile, a necklace.] (Bot.) Having many successive swellings, like a string of beads ; e.g. pods of sea-kale.

Monitor. [L., one who warns.] (Naut.) A heavily armoured steamer, of light draught, and small freeboard, carrying her armament in one or two plated revolving turrets, which are situated on her open decks.

Monk. In Printing, a blotch from types which have received too much ink.
Monkey. 1. (Naut.) A small trading-vessel of the sixteenth century. M. -boat, a half-decked boat of the Thames above London Bridge. M.spars, reduced masts, etc., used in training-ships for boys. 2. The weight of a pile-driver.

\section{Monkey-nut. (Arachis.)}

Monkey-wrench. A wrench with parallel jaws, capable of adjustment by a screw.

Monmouth cap. (Naut.) A flat worsted cap, worn formerly by sailors.

Mono-. [Gr. pobvs, ane only.]

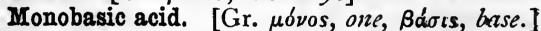
(Chem.) Any acid containing one atom of hydrogen in its composition.

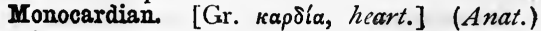
Having a single heart; $c . g$. some reptiles; all mammalia having a double heart.

Monochlamydeous. [Gr. póvos, one only, $\chi \lambda$ ă $\mu$ v́s, a mantle.] (Bot.) Never having both calyx and corolla; e.g. the goose-foots.

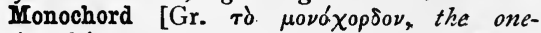
stringed instrument, the monochord], or Sonometer [made up of $\mathrm{L}$. sǒnus, sound, and Gr.

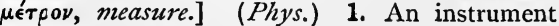
for ascertaining the relation between the various notes of the musical scale, and the rate of vibration by which they are respectively produced. A catgut or wire, placed over a sounding-board and fixed at one end, is carried over a pulley and stretched by a certain weight; it rests on two bridges, one of which is fixed, while the other, sliding to and fro, varies the length of string between the bridges, as shown by a dividing scale. By varying the weight, the tension is increased or diminished. The string can thus be adjusted to yield a given note, and the number of vibrations perceived can be calculated from the stretching weight and the length and weight of the strings between the bridges. 2. With the Pythagoreans, the scale was measured physically and arithmetically by a tuning-string, called the $M$.

Monochromatic lamp. A lamp whose light is of only one [Gr. $\left.\mu a \nu_{0 \nu}\right]$ homogeneous colour $[\chi \rho \hat{\omega} \mu \alpha]$

Monochrome. [Gr. $\mu$ óvos, one, $\chi \rho \hat{\omega} \mu \alpha$, colour.] A painting in various shades of only one colour.

Monoclinal. [Gr. póvos, one only, $\kappa \lambda i \nu \omega, I$ make to bend.] (Geol.) A set of strata dipping in only one direction.

Monoclinic system. [Gr. $\mu \delta$ os, one only, $\kappa \lambda i n \omega$, I make to slant.] (Crystallog.) The oblique prismatic system (q.v.).

Monocotyledonous plants. (Bot.) Having but one cotyledon (q.v.); coextensive with Exogens (q.v.), which term is now more frequently used. (Dicotyledonous plants.)

Monocular. [Gr. póvos, one only, L. ŏcŭlus, eye.] One-eyed; adapted for vision with one eye.

Monodactylous. (Zool.). Having only one finger

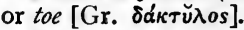

Mŏnŏdelphřa. [Gr. $\mu \delta$ vos, single, $\delta \in \lambda \phi v ́ s$, uterus.] (Zool.) Having a single uterus. The highest sub-class of the class Mammālia, containing all but the Marsupials and Mŏnŏtrēmăta.

Monody. [Gr. $\mu 0 \nu \varphi \delta i ́ a, a$ sola.] A poem in 
which the mourner is supposed to bewail by himself, as opposed to pastoral elegies in dialogue.

Monœcious. [Gr. uóvos, one only, oikos, house, family.] (Bot.) Linnæan class xxi., having stamens and pistils on the same plant, but in different flowers; Diœcious [ $\delta l-$, two] in class xxii., on different flowers, and on separate plants. (-andria.)

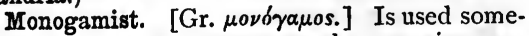
times to denote, not one who marries one husband or wife at a time, but one who objects to all second marriages, like the Vicar of Wakefield.

Monogastrio. Having but one stomach [Gr.

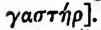

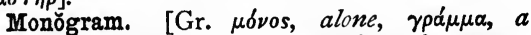
letter.] A cipher, giving the initials of a name, intertwined with each other.

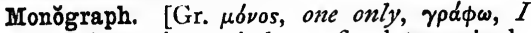
write.] A treatise, strictly confined to a single subject.

Monolith. [Gr. $\mu$ óvos, one only, $\lambda i \theta o s$, stone.] A large single block of stone, artificially or naturally cut out; like many of the old menhirs (q. $\left.v^{\prime}.\right)$ and obelisks.

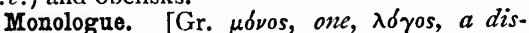
course.] A soliloquy. The word is also used to denote an entertainment in which one performer takes all the parts, after the fashion of C. Mathews, Woodin, etc.

Monometric system. [Gr. $\mu \delta ́$ os, one only,

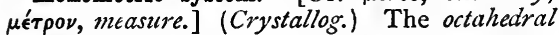
system (q.v.).

Monomial. [As if mono-nomial; vide Binomial theorem.] (Math.) An algebraical expression consisting of a single term, i.e. not of parts connected by the signs plus or minus.

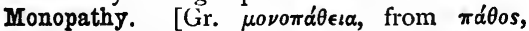
affection.] (Med.) 1. Suffering in some one organ or function only. 2. Sole or individual suffering.

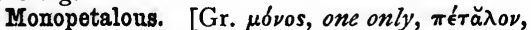
leaf.] (Bot.) Having all the petals united into one body by their edges; e.g. convolvulus, heath, campanula.

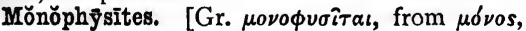
alone, and $\phi \dot{v} \sigma s$, nature.] A name given to all who asserted that there was only one nature in Christ. (Eutychians; Monothelites; Nestorians.)

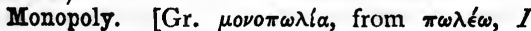
scll.] Interference with free exchange by royal or other enactments assuring the trading in certain articles to privileged persons or to the Crown.

Monopsychism. [Gr. $\mu \delta \nu o s$, alone, $\psi v \chi \eta \dot{\eta}$, life.] The doctrine that the constructive reason is one individual substance, one and the same in all persons; whence it follows that individuality consists only in bodily sensations which are perishable, so that nothing which is individual can be immortal, and nothing that is immortal can be individual. This tenet of the numerical unity of the soul of mankind was the principle of Averroism. (Identity, Personal ; Individuality.)

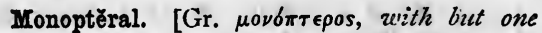
wing.] (Arch.) A temple without a cella.

Monorime, less correctly Monorhyme. A composition in verse, in which all the lines end with the same rime.

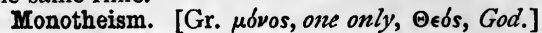
The worship of one God, to the distinct denial of all other gods; Henotheism [eis, gen. ¿ $\boldsymbol{\nu} \delta s$, one in number, a single ohe] being the worship of single gods (or of one at a time), and Polytheism the worship of many deities which together form one divine polity under the control of one supreme god.-Max Müller, Hibbert Lectures, p. 289.

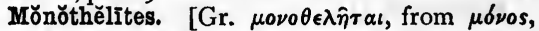
alone, and $\theta$ é $\lambda \omega, I$ will.] A name given to all who, while they allowed the distinction of the two natures in Christ, asserted that the divine will left to His human will no action or efficiency of its own.

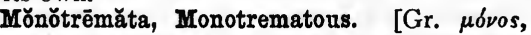
single, $\tau \rho \hat{\eta} \mu \alpha$, hole.] (Zool.) An ord. of mammals, coextensive with the sub-class Ornithŏdelphǐa, having but one outlet for all natural purposes. It is peculiar, both in existing and in extinct animal forms, to Australia, and consists solely of the Ornithorhyncus and the Ëchidnas (qq.v.).

Monotriglyph. (Arch.) In the Doric order, the intercolumniation embracing one triglyph and two Metopes in the Entablature. (Order.)

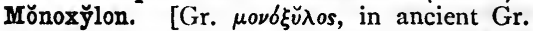
made from a solid trunk.] (Naut.) A boat worked with one oar; Ionian Islands.

Monroe doctrine. That of President $M$. (1823), "the principle, in which the rights and interests of the U.S. were involved, that the American continents, by the free and independent condition which they have assumed and maintained, are henceforth not to be considered as subjects for future colonization by any European power ;" and, further, that the U.S. would consider "any attempt of the Allied Powers to extend their system" (that of the Holy Alliance) "to any portion of this hemisphere as dangerous to our peace and safety." Bartlett's Americanisms.

Monseigneur. [Fr.] A title given in France to dukes, peers, archbishops, etc., the simple monsieur being the title of the eldest brother of the king.

Monsoon. [Fr. mousson, from Malay mosseem, a year.] The wind which blows in the Indian seas in a nearly constant direction, from about N.E. for six months (November to March), and then from about S.W. for the next six months (April to October).

Monstrance. [L. monstro, 1 showe.] In the Latin Church, a vessel in which the host is exhibited to the people through a circle of crystal surrounded by rays of gold and silver.

Montanists. (Eccl. Hist.) The followers of Montānus, who, in the second century, asserted that he had received from the Holy Ghost special knowledge on points not made known to the apostles, refused to communicate with persons guilty of great crimes, and held it unlawful to fly in times of persecution. He also 
condemned second marriages, and enjoined the observance of three Lents. One of his most celebrated adherents was Tertullian. As Montanus was a Phrygian, his followers are sometimes called Phrygians and Cataphrygians.

Mont de Piété. [Fr., hill of piety.] 1. A name for certain benevolent institutions on the Continent for lending money to the poor at low rates of interest. 2. Pawnbroker's office.

Monté. [Sp.] A game of chance, played with cards, of which the Spanish Americans are excessively fond.-Bartlett's Americanisms.

Montem. An old Eton custom; its origin obscure. Every third year the whole school marched in a sort of semi-military array to a mound [L. ad montem] a mile and a half from the college, and money, called salt [(?) sălārium, salt money, allowance], was collected for the captain of the school. Traced by some to the election of the boy-bishop by school-fellows; by others to the solemn initiation of new boys into the Eton mysteries, at the mound still called Salt Hill, by an actual partaking of salt, and a making of epigrams upon them [săles, witticisms]. The last $M$. was in 1844 .

Montgolfier balloon. A fire balloon (first made by the brothers Montgolfier).

Month [L. mensis, Gr. $\mu \eta^{\prime} \nu$; $\mu \eta^{\prime} \nu \eta$, moon, as the measurer of time, Skt. mâ, to measure]; Calendar M. ; Full M.; Hollow M. ; Iunar M. ; Sidereal M. ; Synodic M.; Tropical M. Calendar months are merely artificial parts of the calendar year, January, February, etc. The mean of the intervals from one new moon (i.e. from one conjunction) to the next is the Synodic or Lunar $M$. ; its length is 29 days 12 hrs. 44 mins. 2.8 secs. The Tropical $M$. is the mean interval between her leaving and returning to the first point of Aries; its length is 27 days $7 \mathrm{hrs}$. 43 mins. $4^{\circ} 5$ secs. The Sidereal $M$. is the mean interval between her leaving and returning to a given point in the heavens, i.e. it is the tropical month corrected for precession; its length is about seven seconds longer than the tropical month. A Full $M$. is one of thirty days ; a Hollow $M$., one of twenty-nine days. These terms were used in the distribution of the months throughout the Metonic cycle.

Monton. [Sp. monton, $a$ heap.] A heap of ore.

Montpensier marriages. Two marriages which took place in 1846 , the one between the Queen of Spain and the Duke of Cadiz, the other between the Infanta and the Duke of Montpensier. These marriages had been the subject of much diplomatic action between the courts of England and Spain, and that of Louis Philippe, King of the French, who desired that the husband of the Spanish queen should be a Bourbon, while the English Government urged that he should be a prince of Coburg.

Monumentum ære perennius. [L.] $A$ monument more lasting than brass; spoken by Horace of his fame as a poet.

Mood. [L. modus.] 1. (Gram.) The form of the verb which describes the manner of our conception of an event or fact as certain, con- tingent, possible, etc. 2. ( $\log$.$) The designa$ tion of the three propositions of a syllogism according to their quantity and quality.

Moon-culminating stars come on to the meridian a little before or after the moon, and at nearly the same place. The observation of transits of the moon and of a few of these stars on one night serves to determine the longitude with great exactness.

Moon-rakers. (Naut.) (Sails.)

Moonshee. [Hind. munshi, a zuriter, or secre tary.] A teacher of languages, especially in India.

Moor, To. (Naut.) To fasten a vessel by two cables; sometimes, to fasten her to moorings (q.v.).

Moor-ill. A kind of dropsical ailment in horses, especially when turned out in marshy ground; a swelling of the lower side of the body, after lying down at night, and of the legs during standing.

Moorings. [D. maaren, cable, whence Fr. amarre, amarrer, démarrer.] Heavy anchors and cables placed in harbours, etc., for ships to moor to. Swinging M., when only two M. ; All-fours, when bow and stern M. are used.

Mop, Statute Fair. [L. mappa, a towel, etc., cloth used in cleaning the floor; hence a mop.] Yearly fair for hire of agricultural servants ; now dying out ; formerly called Mapp Fair.

Moplahs. The Mohammedan inhabitants of Malabar.

Mopusses. In Naut. slang, money.

Moraine. [Cf. L.L. morena, a stockade.] (Geol.) Masses of rock and rubbish brought by glaciers down from the mountains. When deposited at the end of a glacier, the mass is a terminal M.; when at the side, a lateral M.; and when along the middle of a glacier formed by the junction of two or more glaciers, a medial M.

Moralities. [L. mōrālis, relating to manners.] A general term for the theatrical exhibitions of the Middle Ages, including Mysteries and Miracle-plays.

Moravians, or United Brethren. These are said to be the followers of Count Zinzendorf, in the last century, and to be so called because the first converts were furnished by some Moravian families. The society itself claims to have had its origin in the days of Methodius and Cyrillus, two Greek monks, by whom Bulgaria and Moravia were converted from heathenism. They profess a general agreement with the Augsburg Confession of Faith.

Morbidezza. [It., delicacy.] The painting of flesh with its natural delicacy and softness of tint.

\section{Morbus pedǐcŭläris. (Pedicularia.)}

Morceau. [Fr., from L.L. morsellum, $a$ mouthful.] (Music.) A somewhat short, simple piece, or extract from longer and more important pieces.

Mordant. [Fr., biting.] Any substance having an affinity for fibrous material and for the colouring matter, and therefore fixing dyes.

Mordred. (Arthur, King.) 
Moreen. [Ger. mohr.] A stout woollen stuff used for curtains, etc.

Mörĕ mäjörum. [L.] After the ways of our forefathers.

Morendo. [It.] (Music.) Dying azway.

Moresque (i.e. Moorish). In Painting or Sculpture, a kind of arabesque ornament, in which fruits and flowers spring out of each other, without the introduction of any animal figures.

Mörě sŭo. [L.] After his own fashion; in a good, or, perhaps oftener, a bad sense ; just like him (her, or them).

Morganatic marriage, also called Left-handed marriage. A marriage between a man of superior and a woman of lower rank, the contract being that the children shall not follow the condition or inherit the possessions of the father. L(?) Goth. morgjan, to shorten.]

Morgan le Fay. In the Arthur legend, a halfsister of Arthur. In the story of Olger the Dane, she is the fairy queen who bears Olger away to her home.

Morgue. [Fr.] In French towns, the place where the bodies of persons found dead are exposed, in order to be recognized by their friends.

Morians' land. In Authorized Version, Ethiopia, = the black-a-moor.

Morigeration. [L. morigerātiōnem, from mos, mōris, manner, custom, behaviour, etc., and gĕro, I bear or carry.] Obedience, obsequiousness.

Morion. [Fr., from Sp. morra, the round of the head.] Musketeer's helmet, with rounded top and turned-up brim, somewhat like a wideawake.

Mormonites. The followers of Joseph Smith, an American of Vermont, settled in the state of New York. The sect receives its name from his religious romance, entitled The Book of Mormon: an Account written by the Hand of Mormon, upon Plates taken from the Plates of Mormon, and printed at Palmyra, New York, in 1830. In I844 the establishment of the Mormons at Nauvoo, in Illinois, was sacked, and Joseph Smith murdered by a mob. In 1848 they established themselves in Great Salt Lake City, in the territory of Utah. They are specially distinguished as upholders of polygamy, which is said to have been authorized by " a revelation on the patriarchal order of matrimony, and plurality of wives," made to Joseph Smith in I843.

\section{Mormons. (Mormonites.)}

Morné. [Fr. mortné, stillborn.] (Her.) rampant lion without teeth, tongue, or claws.

\section{Morning gun. (Gunfire.)}

Morning star. The planet Venus when she rises before the sun.

Morning watch. (Naut.) That from 4 a.m. to $8 \mathrm{a} . \mathrm{m}$.

Morocoo. [Fr. marroquin.] A fine leather made from goat's skin and tanned with shumac.

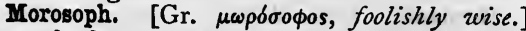
One who has a certain amount of learning without method, or patience, or humility.

Morpheus. [Gr.] (Myth.) The Greek god of sleep; so called as being the shaper [Gr. $\mu о \rho \phi \hat{h}, \mathrm{~L}$. forma] of dreams.

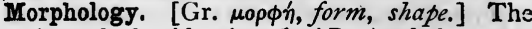
doctrine of the identity, 1, $(B o t$.$) of the same$ organs under different modifications, e.g. of petal, sepal, tendril, etc., with leaf; 2, (Comp. Anat.) of the same organ in different individuals, e.g. phalanges in man, and membranous wing of bat, etc.

Morrice-dance, or Morris-dance. Originally Moresco or Moorish dances ; said to have been introduced into England by Edward III. The performers danced with bells on their feet.

Morse. [L. morsus, from mordeo, I bite.] A clasp. More particularly, the clasp of a cope. (Pectoral.)

Mors jānŭa vītæ. [L.] Death is the gate of life.

Mors ultĭma linĕa rerum. [L.] Death is the limit of (earthly) things or concerns (Horace).

Mortal sins. [L. mortālis, deadly.] With the Church of Rome, "sins gross, knowingly, wilfully, deliberately committed." Venial sins [věniälis, pardonable] are "those of ignorance and negligence, and such as are considered small in their nature."

Mortar. [Fr. mortier, L. mortārium, a mortar.] (Mil.) Thick short gun placed on a bed, for throwing shells at a good elevation; the trunnions (q.v.) are at the breech, and the chamber is shaped as the frustum of a cone.

Mortgage. [Fr., from mort, dead, and gage, pledge.] In Law, an absolute conveyance of an estate from the borrower to the lender, with the condition that, if the loan be repaid within a stipulated time, the estate shall be reconveyed.

Mortier. [Fr.] A cap of State anciently worn by kings of France.

Mortification. In Scot. Law, a term with much the same meaning as Mortmain.

Mortise [Fr. mortaise ; origin unknown] ; M.joint; M.-lock; $\mathbf{M}$. and tenon; M.-wheel. A rectangular hole cut in a piece of timber to receive a tenon or rectangular projection at the end of a second piece. The $M$. and tenon form a $M$.-joint and connect the pieces at right angles. A $M$.-lock fits into a rectangular hole or mortise, cut in the thickness of a door. A M. -wheel is a cast-iron wheel with mortises in its circumference to be fitted with wooden teeth or cogs.

Mortling. [Fr. mort, dead.] Wool taken from a dead sheep.

Mortmain. [O.Fr.] An alienation of real property to any corporation or fraternity; so called because the lands fell into a dead hand, i.e. one incapable of performing the services required of tenants.

\section{Mortŭa mănus. [L.] (Mortmain.)}

Mortuary. [L. mortuārium, money paid at death, soul-shot.] In times preceding the Norman Conquest, a gift left at death to the parish church, as a recompense for personal tithes forgotten or withheld during lifetime, afterwards distinguished into Dead M., as money, etc., and Live $M$., i.e. the best beast, or the second best when the best had gone for a heriot to the lord of the manor. 
Mosaic. [Fr. mosaique, from Gr. $\mu o v ́ \sigma \in \iota o s$, L. musivus, belonging to the Muses; the word being thus another form of music.] Ornamental work, consisting of small pieces of glass, stone, etc., harmoniously inlaid.

Mosaic gold. 1. Bisulphide of tin, a goldcoloured powder ; or, 2, an alloy of equal parts of copper and zinc, used for jewellery.

Moses. (Naut.) A flat-bottomed boat in which hogsheads of sugar are taken off to vessels in the W. Indies. Moses' laze, piratical name for thirty-nine lashes on the bare back.

Moslings. Thin threads of leather shaved off in dressing skins.

Mos pro lēge. [L.] Custom stands for law ; so Gr. $\nu \delta$ ros means (I) custom, (2) law.

Mosque. [Ar. mesjed.] The name for a Mohammedan place of worship. The common form of the mosques has been suggested by Justinian's great church of Santa Sophia at Constantinople, minarets and outer buildings being added at will.

Mosquet. (Musket.)

Moss-troopers. (Hist.) Marauders of the Scottish and English border; so called from the character of the country over which they trooped in bands to plunder.

Most Christian King. A title of the kings of France, given first to Clovis by Pope Anastasius ; most of the Western princes being Arians.

Mötăcilla. [Said to be L. mōto, I keep moving, act.] (Ornith.) Wastail; gen. of birds. W. hemisphere and N.W. America. Fam. Mōtăcillǐdæ, ord. Passěres.

Motazalites. (Separatists.)

Mot d'ordre. [Fr.] Watchword. Bon mot, smart, witty saying. Mot à mot, word for word, a literal saying.

\section{Motes. (Folkmote; Wittenagemote.)}

Motett. (Madrigal.)

Mother Carey's chickens. (Petrel.)

Mothering Sunday, Mid-Lent, or Refreshment $S$. On which day there was once a custom of visiting the cathedral or mother church with offerings ; but Mothering has now come to mean visiting parents. (Simnel bread.)

Mother liquor. [Ger. mutter.] The impure residue of a solution from which crystals have been obtained.

Mother-of-pearl. Shell material of many molluscs, e.g. oysters ; iridescent, owing to the microscopic undulatory alternations of the carbonate of lime and membrane which compose it.

Motif. [Fr.] The leading thought of an artist's work.

Motion. (Music.) 1. Similar or Direct, when two or more parts move in the same direction. 2. Contrary, when towards or away from each other. 3. Oblique, when one part moves while another is stationary.

Motion, Perpetual. That of a machine which would keep itself in motion and do work for ever, if such a thing were possible.

Motion, Quantity of, Momentum (q.v.).

Mot pour rire. [Fr.] A jest, or joke.

Mots a double entente. [Fr.] Properly, words with a double meaning. (Equivoque.)
Mots d'argot. [Fr.] Slang phrases, thieves' language.

Moufflon. [Littré suggests Ger. muffel, $a$ dog or other animal with large hanging lips.] (Zool.) Gen. of large, horned, wild mountain sheep, as the argali of Siberia (A. caprǒvis), four feet high, with horns six inches in diameter at base, and long in proportion ; supposed original of domestic breeds. Corsica, Sardinia, Crete, Asia, Rocky Mountains, and California.

Mould-board. (Agr.) The curved surface in the plough, which throws the soil on one side.

Moulding. In Gr. and Rom. Arch., those members of an Order which are shaped into curved or flat forms. These are eight:.(I) Filet, (2) Astragal, (3) Torus, (4) Scotia, (5) Echinus, (6) Cyma recta, (7) Cyma reversa, (8) Cavetto.

Mouldings. In Goth. Arch., a name for all the various outlines given to the angles of subordinate parts of buildings, as cornices, capitals, bases, etc.

Mound. [L. mundus, world.] (Her.) A globe encircled with a band and surmounted by a cross, held by sovereigns as a mark of dominion.

Mountain, The. [Fr. La Montagne.] In Fr. Hist., a party of Jacobins in the Convention of I793; so called as occupying the highest rows of seats, the muderate men choosing the lower places in the centre, hence called the Plain.

\section{Mountain or Hill People. (Macmillanites.)}

Mountain cork, Mountain leather. (Min.) Felt-like minerals, formerly supposed to be decomposed hornblendic rock, but now known as a distinct mineral-pilolite.

\section{Mountain flax. (Amianthus; Asbestos.)}

Mountain limestone, i.e. appearing in the escarpments of Derby, Yorkshire, Fife, etc., or Carboniferous limestone, i.e. a marked feature in the C. system. (Geol.) A very distinct group of rocks, of the C. series ; British Isles, Europe, Asia, and America ; marked by peculiar corals, encrinites, shells, in great abundance; beds of limestone, with shale, thin seams of coal, and gritty sandstone.

\section{Mountain meal. (Berg-mehl.)}

Mountain train. (Mil.) A battery consisting of peculiarly light field-guns, with carriages easily taken to pieces and broken up into moderate mule burdens, for operating amongst hills or in country devoid of roads.

Mourning. (Naut.) The ensign and pennant half-mast, the yards topped azry or a-peek, or alternately topped an-end, are signs of mourning. The sides painted blue or rubbed with ashes, etc., instead of white, indicates deep mourning. In the navy, a ship is thus painted on the death of her captain, and the flag-ship on that of the admiral; in the merchant service, on that of the owner.

Mouse. 1. [Heb. 'akbâr ; Lev. xi. 29, etc.] (Bibl.) Includes rats and jerboas (q.v.). 2. [Cf. muscle, i.e. musculus, little mouse.] (Naut.) (I) A knot or knob, made of twine, etc. , wrought on to the collars of stays, to prevent the running eye from slipping. (2) A match for firing a mine. (3) A mark upon ropes, to show when squared or brought home. To $M$. a hook, to 
put a turn or so of twine round the pointed neck of a hook to prevent its coming unhooked. 7' raise a $M$., to cause a lump by a blow.

Mousseline de laine. [Fr. for zwool muslin.] A very light woollen fabric.

Movable feasts. Feasts, the recurrence of which is determined by the time when Easter falls.

Movement. 1. The internal parts, springs, wheels, etc., of such machines as clocks, watches, etc. 2. Any mechanism by which the motion of one piece is transferred in some determinate way to another piece.

Mow. A Teut. and Scand. word, denoting a place for storing hay or grain.

Moya. [Sp.] Volcanic effusion of fotid sulphurous mud.

Mozarabic Liturgy. An early Liturgy of Spain, where the Christians were mixed up with Moors and Arabs. (Liturgy.)

Mozarabs, Mozarabes. Christians living under the government of the Moors in Spain.

MS. Abbrev. for L. manu scriptum, written by the hand, manuscript; also for L. memoriæ sacrum, sacred to the memory.

MSS. Abbrev. for L. manu scripta, manuscripts.

\section{Mucilage. (Bassora gum.)}

Mucronate. [L. mūcro, -nem, a dagger.] (Bot.) Having an apex with a small and sharp projection, noticeable apart from the general contour of the margin; as some leaves of plants have, e.g. Lăthy̆rus prātensis.

'Mudian, 'Mujian, or Bermudian. (Naut.) A boat, peculiar to the Bermudas, of from two to twenty tons burden. Its stem and keel form a curved line, so that it draws much water aft; usually decked, and carries lead or iron ballast : rigged with a single mast in the bows, and setting a three-cornered mainsail, the hoist of which is sometimes three times the length of the keel; its only other sail being a small foresail or jib. Unequalled in sailing to windward in smooth water.

Muezzin, Mueddin. [Ar.] General name for the officers of the mosques who sing from the minaret the call, " Hadán," to prayers, "Namaz," at the five canonical hours.

Muffineer. 1. A dish for keeping muffins hot. 2. A salt-box, in the form of a pepper-caster, for salting muffins.

Muffle. [Fr. moufle.] A small earthen oven for heating the alloy, etc., before adding it to the silver and gold in the cupel (q.v.).

Muffle the oars, To. (Naut.) To put matting, etc., round them, so that they should not rattle in the rowlocks.

Mufti. 1. Turkish title of a doctor of the law of the Koran. The M. of Constantinople, the chief functionary of the Turkish Church, represents the sultan in spiritual matters, as the grand vizier does in temporal. 2. With officers in the army, = plain clothes.

Muggletonians. In Eng. Hist., the followers of one Muggleton, a tailor, who, in the seventeenth century, asserted that he and his associate, Reeves, were the two last and greatest prophets of Jesus Christ. A few of their adherents still remain. They were opposed chiefly by the Quakers Fox and Penn.

Muiagros. [Gr.] A god of Elis ; so called as catching or destroying flies, thus answering exactly to the Semitic Baalzebub. (Apomuios Zeus.)

Muid de Paris. [Fr., L. mŏdius, a peck, and in a general sense, measure, amount.] An old French measure of capacity containing about 5I bushels. It was subdivided thus : 1 muid $=$ 12 setiers $=48$ minots $=144$ boisseaux.

Muirburn. In Scotland, setting heath on fire.

Mulada. [Sp.] A drove of mules.-Bartlett's Americanisms.

Mulatto. The offspring of a European and a negro. That of a white and a mulatto is called a Quadroon; of a white and a quadroon, a Mustee; of a white and a mustee, a Mustafina. (Creole.)

Mulching. Dressing tree roots with litter. (Emulsion.)

Mule, M.-jenny. A machine for spinning cotton, invented by Crompton; first completed, I770.

Mull. [Welsh moel, $a$ hill.] A snuff-box made of the small end of a horn.

Mull. A thin soft muslin.

Mullah. The Tartar form of the word Mollah ; but the priests of Tartary so called have not precisely the same rank or office.

Muller. [Ger. mullen, to rub.] A flatbottomed pestle used for grinding artists' colours.

Mullet. [Fr. molette, rowel of $a$ spur.] (Her.) A star with five points, borne (I) as a charge, (2) as the difference in the third son's escutcheon.

Mullion. (Arch.) The upright bar which divides the lights of a window. (Transom.)

Multæ terricŏlis linguæ, cœlestǐbus una. [L.] The in habitants of the earth have many languages, those of heaven only one. In Gr. the line runs, $\Pi o \lambda \lambda a l \mu \dot{\epsilon} \nu \theta \nu \eta \tau o \hat{\imath} \gamma^{\lambda} \hat{\omega} \sigma \sigma \alpha t \mu^{\prime} \alpha \delta^{\prime} \dot{\alpha} \theta x \nu \alpha \tau o \hat{\imath} \sigma t$.

Multiple; Common M.; M. roint; M. star. Any number divisible by a second number is a Multiple of that second number. Any number divisible by each of two or more numbers is their Common $M$. A $M$. star is a group of three or more stars separated from each other by a few seconds, and appearing to the naked eye as one star. (For $M$. point, vide Singular point.)

Multiplicand ; Multiplication; Multiplier. Multiplication (in arithmetic) is the process by which we find the result of adding together a given number of equal numbers; any one of the equal numbers is the Multiplicand; the number of times it is taken is the Multiplier.

Multis ille bŏnis flēbrlis occĭdit. [L.] He died mourned by many good men (Horace).

Multivalve. [L. multus, many, valvæ, folding doors.] (Zool.) Composed of many pieces; as the shell of many cirripeds and of the chiton.

Multoca. The code of laws by which Islam is governed, and which cannot be overruled even by the decrees of the sultan.

Multum. An extract of quassia and liquorice, used for adulterating beer. 
Multum in parvo. [L.] Much in little.

Mum. [Ger. mumme.] 1. A strong kind of beer. 2. [Onomatop.] Slang for silence.

Mummy. [Ar. mumia, from mum, wax.]

In Egypt, a dead body preserved in a dry state from putrefaction. This practice of embalming was much in vogue amongst the early Christians, and seems to have been only gradually abandoned.

Mumps. (Parotitis.)

Mumpsimus. It is said of some priest that he insisted on reading mumpsimus for the $\mathrm{L}$. sumpsimus, we have received, in the prayer after Communion. Hence the word came to denote the obstinacy of ignorance.

Munchhausen, A. Any incredible traveller's story, Baron Munchhausen being the hero of a series of astounding adventures in a tale written by Raspe.

\section{Mundane egg. (Eûfs de Pâque.)}

Mundic. (Chem.) Iron pyrites or arsenic pyrites.

Mundue. (Naut.) A sailor who pulls up the diver and oysters in the pearl fishery.

Mundungus. In Naut. slang, bad, rank, and dirty tobacco.

Mungo. Waste wool, etc., used for making inferior cloth.

Mungo Park, surgeon, of Selkirkshire, traveller, and writer of his travels (I 771-1805).

Municipal corporation. The body of burgesses or freemen of a city, as a self-governing society, constituted by royal charter.

Municipality. [L. munus, an office, and capio, I take.] A society the members of which are capable of holding office. In Rome the name municcps was given to strangers who became incorporated with the Roman people without acquiring the right of citizenship. The word municipal is now often used to mean (I) the local government of a district, (2) the law of particular districts or provinces.

Muniment. [L. mūnīmentum, $a$ defence, $a$ protection.] A document kept by an individual or by a corporate body, in proof of the right to certain property, privileges, etc.

Munjeet. [Hind. manjit.] A kind of madder from the E. Indies.

Muntz's metal. (From the inventor.) An alloy of three parts of copper and two of zinc, used for sheathing vessels.

Mural circle. [L. mürālis, belonging to a wall.] A large graduated circle, to which is fixed an astronomical telescope, the axis of the latter coinciding with a diameter of the former. It moves in the plane of the meridian on a strong horizontal axis let into a massive pier or wall, and secured by screws so as to be capable of adjustment. It is used in connexion with a transit instrument for making the observations which determine the exact position of the heavenly bodies on the great sphere. The transit instrument serves to determine their right ascensions, the M. C. their declinations.

Murexide. [L. murex, the purple fish.] A purple salt of ammonia.

Mürex truncǔlus. [L., and L. dim. of trun- cus, truncated.] (Conch.) One of the dyesecreting molluscs, giving its name to the Tyrian purple. Fam. Mūrǐcǐdæ, ord. Prǒsōbranchǐăta, class Gastěrŏpŏda.

Muriated. Coated with chloride (formerly called muriate) of silver.

Muriatic acid. [L. mưria, brine.] (Chem.) Hydrochloric acid.

Mūrǐdæ. [L. mūrem, mouse.] (Zool.) Fam. of rodents, as rats and mice. None indigenous in the Australasian Islands or Polynesia.

Murrain. [O.Fr. morine, beast's carcase, mourrir, to die.] Exod. ix. 3; Ps. lxxviii.; some kind of cattle plague.

Murrey. (Her.) A mulberry [L. mōrum] colour.

Murrhine vases. [L. Murrhina vasa.] Ancient small vases coming from the East; probably of opalescent glass.

Murzas. The second class of the hereditary nobility among the Tartars, the first class being called Beys. (Mirza.)

Muscæ vŏlítantes. [L., fitting fies.] (Med.) Black spots appearing before the eye.

Muscatel. [Sp. moscalet.] A rich spicy grape.

Muschelkalk. [Ger., shell-lime.] (Geol.) Compact greyish limestone, with abundant remains of molluscs and encrinites; the middle member of the Triassic period, or New Red Sandstone. W. Europe ; absent from England. Muscǐdæ. [L. musca, $a f y$.] (Entom.) Fam. of dipterous insects, including house-flies and blue-bottles.

Muscovado. [Sp. mascabado, spoilt.] Raw sugar.

Muscovy glass = Potash mica, Muscovite; plates of it being still used in some parts of Russia for windows.

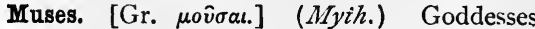
presiding over music, poetry, and art. Later poetry described them as nine in number. (Mnemosyne.)

Musette. 1. A small bagpipe, once much used in different parts of Europe. 2. Melody, like the soft sweet tunes played on a M. 3. A reed-stop on the organ.

Mushtahids. In Persia, high priests who represent the vicegerent of the Imam.

Musk. [Ar.] A fragrant brown substance secreted by the male musk-deer, musk-rat, etc.

Musket. This name for a modern firearm is derived from the mosquet, or sparrow-hawk; so called from its dappled [L. muscatus] plumage. The names of other birds used in falconry were applied, on the disuse of that sport, to firearms. Thus the falcon became the name of a heavier sort of artillery; the Fr. sacre and Eng. saker, $a$ hawk, also denoted a gun; and the It. terzuolo, or hawk, is also a small pistol.-Max Muiller, Lectures on Language.

Mnslin. Fine cotton cloth, with a downy nap, brought originally from the town of Mosul.

Muslin, or Dimity. (Naut.) (Flying-kites.)

Muslinet. [Fr. mousselinette.] A coarse cotton cloth. 
Muspelheim. In Norse Myth., the domain of devouring fire. (Niflheim.)

Musrole. [Fr. muserolle, from museau, muzzle.] The nose-band of a horse's bridle.

Mussel. [L. musculus, a little mouse, used, like Gr. $\mu \hat{v} s$ and Fr. souris, to mean both $a$ muscle of the body and also a shell-fish.] (Conch.) Fam. of bivalve molluscs ; universally distributed. Mȳtǐlĭdæ, class Conchĭfĕra.

Mussel, Pearl. British. (Conch.) Ūnǔo margărītǐfěrus [L. ūnio, a pearl, margărīta (Skt. manjari, pearl), ferro, $I$ carry]; broader than the common M. British rivers. Fam. Ünı̌onı̌dæ, class Conchĭfĕra. There is also a Chinese P. M., Dipsas plǐcatos.

Mussulman. [Ar. muslim, $\boldsymbol{a}$ belicver.] A general name for the followers of Mohammed.

\section{Mustafina. (Mulatto.)}

Mustang. [Sp. mesteño.] The wild horse of the prairies, descended from the stock introduced into America by the first Spanish colonists. $\mathrm{He}$ is of various colours, a cream colour and piebald being quite common. Mustangs are found in the greatest numbers on the rich prairies of S. -W. Texas. -Bartlett's Americanisms.

\section{Mustee. (Mulatto.)}

Mustēlĭdæ. [L. mustēda, weasel.] (Zool.) Fam. of digitigrade carnı̌vora, as weasels, otters, badgers. Absent from Madagascar, Australasia, Polynesia.

Muster. [Fr. monstrer, to shozv.] (Mil.) Monthly parade, at which all officers and men have to appear, as a guarantee that none are entered on the M.-roll who are not entitled to pay.

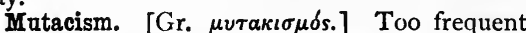
pronunciation of $m$, substituted for other letters. (Iotacism; Lambdacism.)

Mutātis mutandis. [L.] All necessary changes having been madc.

Mutāto nomine, de te fābŭla narrātur. [L.] Change the name, and the tale is told of yourself (Horace).

Muth-labben. In title of Ps. ix. ; an obscure term, probably the name of some well-known melody (Speaker's Commentary).

Mutiny Act. [Fr. mutin, mutinous.] (Mil.) An Act passed annually by Parliament for the raising and keeping a standing army (which otherwise is illegal), and for punishing mutiny, desertion, and other offences against military discipline. (Army Discipline and Regulation Act.)

Mutiny of the "Bounty." A mutiny against Captain Bligh, commander of the Bounty, I789. The crew sent Bligh adrift and took the ship to Pitcairn's Island, which they colonized.

Mutule. [Fr., L. mutŭlus.] (Arch.) A projecting block worked under the corōna of the Doric cornice.

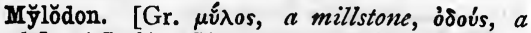
tooth.] (Geol.) Huge tossil ground-sloths, having molars with flat grinding surfaces; Pleistocene. S. America.

Mynchery. The O.E. name for a nunnery, the nuns being called mynchens, the feminine of monk.

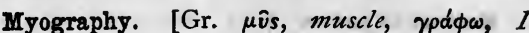
describe.] The describing of the muscles.

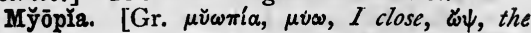
eye.] (Med.) Short-sightedness; the eye discerning objects at less than eight inches.

Myotomy. [Gr. $\mu$ v̂s, a muscle, ro $\mu$, cutting.] (Anat.) The dissection or dividing of a muscle.

Myriad. [Gr. $\mu$ veı́s.] Ten thousand; but the word denotes only a confused mass, like the L. mille, and throws light on the early counting powers of the Greek and Latin tribes.

Myriapoda. [Gr. $\mu v \rho t o-\pi o v s,-o \delta o s$, ten-thousandfooted.] (Zool.) Millipedes, centipedes. Class of Annŭlōsa with not less than eighteen legs, having all their segments nearly alike, the head excepted.

My̆rica, Szueet-gale, Bog-myrtle. (Bot.) Fragrant native plant, type of My̆riaceæ; ord. Amentaceæ. M. of Virgil is tamarisk, Tămărix.

Myrmidons. [Gr. $\mu \nu \rho \mu i \delta \delta \nu \in s$.$] (Myth.) The$ followers of Achilles, who never act except at his bidding. The Greeks, perhaps wrongly, connected the word with $\mu v \dot{\rho} \mu \eta \xi$, an ant, and invented a story to explain it. It is now used much in the same sense as Bravo.

Myrobălănus. [Gr. $\mu$ v้ $\rho-\beta a ́ \lambda a ̆ \nu o s$, from $\mu \dot{v} \rho o \nu$, an unguent, $\beta a ́ \lambda a \nu o s$, an acorn.] A dried Indian fruit like a prune, used in dying and tanning.

Mystagogue. [Fr., from Gr. $\mu v \sigma \tau a \gamma \omega \gamma \delta s$. One who initiates in, or interprets, mysteries.

Mysteries. [Gr. $\mu v^{\prime} \omega, I$ am closed, $\mu v^{\prime} \in \omega, I$ initicte in secrets, $\mu v \sigma \tau \eta s$, one who is initiated, $\mu \nu \sigma \tau \eta \dot{p} \iota \mathbf{\nu}$, that in which he is initiated.] 1. (Hist.) Ritual celebrations connected with secret doctrines. The $M$. of the ancient world differed much in character, some being of a sober, others of a frenzied, type. (Eleusinian Mysteries.) 2. (Eccl. Hist.) This name is given to a species of dramatic composition, with characters and events drawn from sacred history. In all these plays, however solemn might be the treatment of the subject, two persons, the Devil and the Vice, were always held up for the amusement of the people. Among the earliest of Biblical plays is a Greek tragedy on the Passion, by Gregory Nazianzen. A German abbess, named Hroswitha, composed some dramas of this kind in the tenth century. (Miracle-plays; Moralities.)

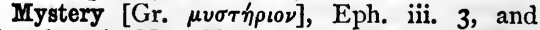
elsewhere in New Testament. Not something above human comprehension, e.g. the origin of evil, but a secret, which, when revealed, is no longer a $\mathrm{M}$.

Mystical tan. The Egyptian T-shaped emblem, which was regarded as the symbol of life.

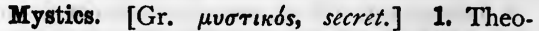
logians who, like Clement of Alexandria and his pupil Origen, deal chiefly with the allegorical and mystical meanings of the Scriptures. 2. Those who aim at tranquil contemplation as an end to be preferred in life to all philosophical or other studies. Those were called also Quietists. Among the most prominent of these were the Spanish priest Molinos (Molinosism), and in 
France, Mme. Guyon and Fénelon, a bishop of Cambrai.

Myth. (Naut.) Land, or anything else by which the course can be directed by sight.

Myth, Mȳthus. [Gr. $\mu \hat{v} \theta o_{\text {s.] }}$ A saying, relating originally to the phenomena of the outward world, be they of sight, or sound, or any other. These sayings, applied to the conditions of human life, grew up gradually into stories, which have furnished materials for the epic poems of the Aryan and other races. Thus the sun was said to see all things, hence to be wise. It was also said that he was compelled to ascend the heaven, and then to come down again. From this sprang the story of Sisyphos, the wise [ $\sigma \delta \phi o s]$ man, condemned to heave to the top of a hill a ball, which immediately rolled down again. Solar myths are myths or sayings re- lating to the sun; Lunar myths relate to the moon, etc., almost all sensible objects giving rise to phrases or sayings which pass into mythical tales. Thus the saying that the moon wanders through the sky amongst the myriad stars grew into the myth or legend of St. Ursula (Horsel, Ursel, being a name for the moongoddess) and her train of eleven thousand virgins. The task of analyzing and comparing these myths belongs to the science of Comparative mythology. Mythology. (Metaphor.)

Mythology, Comparative.

(Comparative mythology.

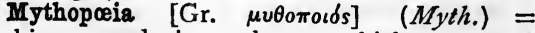
making, producing, phrases which grow up into mythical narratives.

Mȳtǐlus. [Gr. $\mu \bar{v} \tau i ́ \lambda o s$, from $\mu \hat{v} s$, muscle.] (Mussel.)
N. A letter common to all known languages, but in some of them interchangeable with many other letters. As an abbrev., it is used for north, and for the L. numero, number; sometimes also for nātus, něfastus dies, něpos, nōmine. N.B. stands for L. notā bene, mark well; N.L. for L. non liquet, it is not clear; etc.

Nablum. A Jewish musical instrument, of the form of which little is known. Josephus merely says that it was played upon by the fingers.

Nabob. A corr. of the Hind. word Nuwâb, denoting one who has gained wealth in the East and uses it ostentatiously. (Nawâb.)

Nabonassar, Era of. An astronomical era, assigned to the beginning of the reign of Nabonassar, the alleged founder of the Babylonish empire, B.C. 747 .

Naca, or Nacelle. (Naut.) A French boat, without mast or sail, dating from the twelfth century.

Nacarat. [Fr.] 1. A pale orange colour. 2. Fine linen or crape dyed this colour.

Nacodah. (Nakhadah.)

Nacre. [Fr., from Pers. nigar, painting.] The hard lustrous internal layer of shells. (Mother-of-pearl.) Adj., Nacreous.

Nacreous. (Nacre.)

Nadir. [Ar. nazeer, opposite.] (Astron.) The point vertically beneath the observer at any given station, in which the plumb-line produced downward would meet the great sphere.

Nævus [L.], N. mäternus, Mother-spot. A consenital mark or morbid growth on a part of the skin. Some are mere discolorations, others warty, having excrescences; but most of them of excessively vascular tissue, or a dense network of veins raised above the skin.

Nag's Head Consecration. (Eccl. Hist.) A story circulated by Roman Catholic writers that Matthew Parker, Archbishop of Canterbury
I559-1576, was consecrated at the Nag's Head tavern, in Cheapside. The official register shows that he was consecrated at Lambeth.

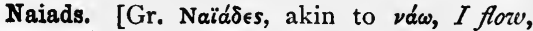
vaûs, a ship, L. nare, to swim, Skt. snâ, to wash.] (Gr. Myth.) Nymphs inhabiting fountains, rivers, and streams.

Naiant. (Her.) In a horizontal position, as if swimming [Fr. nagéant].

Naick. (Mil.) Corporal of sepoy troops.

Nail. As a measure of length, the sixteenth part of a yard, two inches and a quarter.

Nail a gun, To. I.q. Spike.

Nainsook. A thick jaconet muslin, formerly made in India.

Naissant. [Fr., being born.] (Her.) Rising from the centre of an ordinary.

Naïveté. [Fr. naif, fem. naïve, simple, ingenuous, L. nātīvus.] Simplicity, artlessness.

Naked flooring. (Arch.) The open timberwork supporting a floor.

Nakhadah, or Nacodah. (Naut.) An

Arabian sea-captain.

Namaz. (Muezzin.)

Name. Of a ship, includes that of the port of registry.

Naming a member. A member of the House of Commons, having been called to order, and persisting in disregarding the rules of the House, may be named by the Speaker, who leaves him to the censure of the House : the member must then withdraw.

Nanism. [Gr. vầos, L. nānus, a dzvarf.] The condition of a dwarf.

Nankeen. A buff-coloured cotton cloth, chiefly manufactured at Nankin, in China.

Nankin Porcelain Tower. It was of brick cased with porcelain, and was $26 \mathrm{r}$ feet high, built A.D. 1403-I424; destroyed by the Taepings, 1853 .

Nankin ware. (Exported from Nankin.) The blue and white Oriental china. 
Nantes. A kind of brandy (made at Nantes, in France).

Nantes, Edict of. (Edict of Nantes.)

Naos. [Gr.] In Gr. Arch., this word, which is the same as our nave, denoted the part of a temple inclosed by the walls, the front part being called pronāos, the part in the rear being the opisthŏdŏmus, $\mathbf{L}$. postîcum.

Naphtha. [Gr., Pers. nafata, to exude.] 1. A bituminous, volatile, inflammable product of distillation from carbonaceous shales and pitcoal. 2. The native hydro-carbon peetrǒlězum, or rock-oil, native naphtha.

Napier's bones or rods. A mechanical contrivance, invented by Napier of Merchison, for multiplying and dividing numbers : one of the earliest calculating-machines.

Napiform root. (Bot.) Of the shape of a turnip [L. nāpus]; e.g. swede, and some radishes.

Naples yellow. A gold-coloured pigment used in oil-painting, composed of the oxides of lead and antimony.

Napoleon, Code of. The great code, drawn up by order of Napoleon Bonaparte, consolidating the revolutionary laws already in existence. It is both penal and civil; but the term is more generally used to designate the latter.

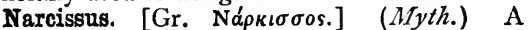
beautiful youth, said to have been loved by the Echo, and to have been turned into the flower narcissus after his death. But the name denotes simply lethargic sleep.

Narcotic. (Poison.)

Narcotico-acrid. (Poison.)

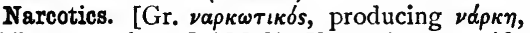
stiffness, numbness.] (Med.) Hypnotics; soporific medicines, diminishing the action of the nervous system, relieving pain, and producing sleep.

Nard. (Spikenard.)

Narration. [L. narrationem.] (Rhet.) The second division of an oratorical discourse, stating the facts from which the conclusions are to be drawn. (Exordium; Peroration.)

Narrow gauge. (Gauge.)

Narthēx. [Gr.] In Eccl. Arch., the first section or division in the Roman basilicus, to which the women, the Energumens, and the lapsed were restricted. (Exedra.)

Narwhal. [Ger. narwall, nose-whale.] (Zool.) Sea-unicorn; gen. and spec. (Mŏnŏdon mŏnŏcěros) forming fam. Mŏnǒdontřdæ, ord. Cētācěa. The lower jaw is toothless; the teeth in the upper jaw are rudimentary, except that the left canine in the male projects eight or ten feet in a straight line with the animal's body, which is about fifteen feet long. This is, no doubt, the unicorn's horn, once held to be an antidote to poison.

Nasal. [L. nāsus, nose.] (Mil.) Projecting iron nose-guard, vertical, sometimes sliding; in head-piece of eleventh and twelfth centuries.

Nasturtium. (Bot.) Properly a gen. of Cruciferæ, of which the water-cress (N. offrcinale) is the type; but applied commonly in gardens to Tropæolum majus.

Nasute. [L. nasūtus, from nasus, nose.] Quick-scented; hence critically nice, captious.
Nataliria. [L.] Birthdays.

Natant. (Naiant.)

Nătātöres. [L., swiminers.] (Ornith.) Swimming-birds, i.q. Palmipědes [L., palm-, i.e. broad-, footed] or Ansěres.

National debt. The amount owed by a state to those who have advanced money for expenses incurred by the Government over and above its ordinary income. In England the first loan of a permanent character arose out of the chartering of the Bank of England, 1694, when its capital of $£ 1,200,000$ was lent to the public at eight per cent. interest ; the Crown reserving power of repayment, but not allowing a corresponding right of demanding payment.

National Guard. In France the civilians who armed themselves to keep order during the first revolution.

Natrix. [L., swimming.] (Zool.) A gen. of snakes, having no poison fangs. Common ringed snake of England, N. torquata, is a spec.

Natter-jack. (Zool.) One of the two spec. of British toads, about three inches long, with a yellow line down its back, and black bars on the legs; seldom approaching the water, except in the breeding season. Būfo călămìta, gen. Bufonidæ, ord. Anoura, class Amphibia.

Natural death. (Civil death.)

Naturalism. A word used somewhat vaguely to denote (I) the mere state of nature, especially the pure influence of nature, when rightly understood, upon art-as e.g. in Wordsworth ; (2) the theory which denies the possibility of supernatural agency in the life of man; and (3) the doctrine which asserts that the universe is ruled by forces not originating in an intelligent will.

Naturalistic school of poets, etc. (Naturalism.)

Natural numbers; N. philosophy; N. sines, cosines, etc. (Math.) The Natural numbers are the series of integral numbers, beginning with unity, i.e. 1, 2, 3, etc. $N$. sines, cosines, etc., of angles, are the actual sines, cosines, etc., of angles from $0^{\circ}$ up to $90^{\circ}$; they are in most cases calculated for every minute, and arranged in a tabular form ; so called to distinguish them from their logarithms, which are Logarithmic sines, cosines, etc., and which are most commonly employed in astronomical and other calculations. $N$. philosophy, the term used by Newton for the investigation of laws in the material world, and the deduction of results not directly observed.

Natural order. (Bot.) One belonging to the natural system of classification, and exhibiting affinities really existing; as distinguished from an artificial arrangement made for the student's convenience.

Natüram expellas furcă; tamen usque recurret. [L.] You may thrust out nature with a pitch. fork; but it will find its way back (Horace).

Natūra natürans. Natüra nātūrāta. [L.] Nature as a forming power. Nature as a formed result.

Nature-printing. The art of taking impressions from plants on soft metal, and from these taking an electrotype plate, by means of which impressions are multiplied.

Naucräry. [Gr. vav à $\{a$.$] In Gr. Hist.,$ 
naucraries were political divisions of the Athenian people, the naucrarians [vavkpāpol] being simply householders. After the time of Solon each naucrary was called on to provide one war-ship, and thus the word came to be connected with vav̂s, $a$ ship, and the navy; though akin rather to the verb vaí, I inhabit.

Naulage. [Gr. vav̂̀ou, L. naulum, passage money.] (Naut.) A freight or fare.

Naulum. [L., Gr. vav̂̀os, passage money.] In Gr. and Rom. usage, a piece of money put into the mouths of the dead to enable them to pay Charon for taking them over the Styx.

Naumăchǐa. [Gr., a sea-fight.] In ancient Rome this word was applied to the representations of sea-fights exhibited for the amusement of the people, who were ranged on seats along the banks as in an amphitheatre.

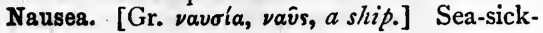
ness, inclination to vomit.

\section{Nautical Almanac. (Ephemeris.)}

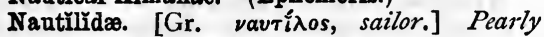
nautilus. (Conch.) Fam. and gen. of mollusc with chambered shell. Indian and Pacific Oceans. Ord. Tetrabranchřāta, class Cěphălŏpŏda.

Naval Reserve. Merchant seamen and fishermen, enlisted for service in the navy if required, and annually trained.

Nave. [O.E. nafu.] The centre of a wheel. Navel point. (Escutcheon.)

Navicular disease. In the horse, inflammation arising from a strain of the strong flexor tendon of the foot, where it passes over the navicular bone-a boat-shaped bone [L. nāvǐcŭla, a little ship], the upper of two rows of the carpus [L., wrist].

Navigation laws. Enactments securing to home shippers a monopoly of the carrying trade, either by prohibiting the importation of goods in foreign vessels, or by levying differential duties on such goods. The English N. L. have been repealed, and new regulations substituted by the Acts of 1849 and 1853 .

Naviget Antǐç̆ram. [L.] Let him sail to Anticyra (Horace), to be cured (of his madness) by the hellebore which grows there.

Navire. [Fr.] An order of knighthood instituted by St. Louis, King of France, 1269; so called, perhaps, because the knight's collar had a ship pendent from it.

Navvy. [Abridged from navigator.] A labourer on canals for internal navigation; hence a labourer on railways, embankments, etc.

Navy agents. Certain firms appointed to see to the receipt, etc., of an officer's pay, prizes, etc.

Nawâb, Naib. [Hind.] A deputy or ruler of a province in the empire of the Moguls, under the subahdar, the ruler of a subah, or larger province.

Nazarenes. 1. The name given in the East by Moslems and Jews to Christians, as followers of Jesus of Nazareth. 2. A sect of the second century, which tried to combine Judaism and Christianity, and thus resembled the Ebionites.

Nazarite, more properly Nazirite. In Old Testament Hist., one bound by a vow to be set apart for the service of God. The dedication was usually for a definite term ; but Samson is called a Nazirite for life.

Nealed-to. (Naut.) Said of a shore having deep soundings close in.

Neap. 1. The tongue or pole of a waggon. 2. A prop for the front of a cart, etc.

Neaped. (Naut.) Said of a ship left aground by the spring-tides in a harbour, so as to have to wait for the next springs before she can go to sea or be floated off.

Neapolitan sixth. (Music.) A chord composed of a minor third and minor sixth occurring on the subdominant of a minor key; e.g. (in $\mathrm{C}$ minor) $\mathrm{F} \curvearrowleft, A \cap, D n$, with $F$ in the bass. Its derivation is matter of dispute.

Neap-tides take place shortly after the first and third quarters of the moon, when the difference between high and low tide is least.

Near, and No near, also No higher. (Naut.) Don't let her come up to the wind. (Off.)

Neat. According to Wedgwood, any brute animal, from A.S. ne witeen, like the Gr. alǒgon, an irrational creature. The Greek word is now limited to horses, the English to cattle. Skeat, Etym. Eng. Dict., refers neat to A.S. niotan, to use, employ, enjoy.

Nëbŭla [L., vapour, cloud]; Irresolvable N.; Resolvable N. (Astron.) A patch of faint diffused light in the stellar regions. A Resolvable $N$. is one which, when viewed through a powerful telescope, is seen to consist of a group of bright points - to be, in fact, a cluster of stars. Of the other, or Irresolvable $N$., some are probably masses of incandescent gas; others groups of bright points too small to be seen individually.

Nebular hypothesis. (Astron.) The hypothesis that the sun and planets have been gradually condensed into their present state from that in which their matter formed a huge cloud. It is favoured by many eminent astronomers, and by some is regarded as an ascertained fact.

Nebulosity. [L. post-class. něbŭlōsĭtas, mistiness.] (Astron.) The faint mist observed to surround certain stars.

Nec deus intersit, nisi dignus vindice nodus. Let not a god be brought in, unless the knot be one which really needs his aid to untie it (Horace).

Necessaries. (Mil.) Include such articles as a soldier is required to keep up at his own expense, in the way of underclothing, small implements, and cleaning materials

Necessitarians; Necessarianism. The doctrine of necessity is that liberty can be predicated only of actions done in consequence of volitions; but not of the volitions themselves; of which last motives, they say, are the cause; while the doctrine of liberty is that motives are not the cause, but the occasion. Calvinists have generally been $\mathrm{N}$.

Necessitas non habet lëgem. [L.] Necessity owns no laze.

Nechiloth. (Nehiloth.)

Neck-mouldings. In O.E. Arch., the mouldings which connect the capital with the shaft.

Nec mirum. [L.] And no wonder.

Nec plurǔbus impar. [L.] A match for many.

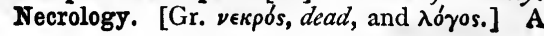


name sometimes applied to lists of deceased benefactors of cathedrals, monasteries, etc.

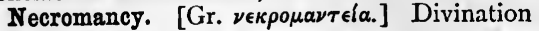
by means of the dead.

I Necropolis. [Gr., a city of the dead.] A term applied to ancient burial-places in Egypt, but

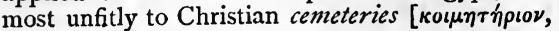
a sleeping-place].

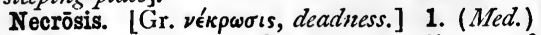
Mortification of bone. 2. (Bot.) A disease of plants, seen in the black spots of leaves, fruit, etc.

Nec soire fas est omnia. [L.] We may not know all things (Horace).

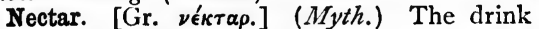
of the Olympian gods. The word agrees in meaning with Ambrosia. (Soma.)

Nectary. [L. nectar, nectar, the drink of the gods.] (Bot.) Formerly vaguely used, now = any honey-secreting or honey-receiving organ of a flower; $e . g$. spur of columbine.

Née. [Fr.] Born ; fem. of né, part. of naître, to be born; née Williams $=$ whose maiden name was W.

Needle. [O.E. noedl.] A slender bar of mag netized steel, which, when properly suspended, points $\mathbf{N}$. and $\mathrm{S}$. on the compass. (Magnet.)

Needle-gun. (Mil.) Rifle fired by its trigge striking a needle into the percussion cap, fixed to the bottom of the cartridge.

Needles. (Geol.) 1. Detached masses of rock, separated by water erosion from their cliffs or shores; e.g. off Isle of Wight. 2. I.q. aiguilles (q.v.).

Neese. [A.S. niesan.] 2 Kings iv. 34 ; Job xli. 18 ; to sneeze, which is a later form of the word.

Në exeat regno. [L., let him not go out of the kingdom.] (Leg.) A writ formerly confined to political and State purposes, sometimes resorted to now in equity, where one is about to leave the country so as to frustrate or hinder the recovery of an equitable demand.

Negative. A photograph upon glass, in which the light portions of the original are represented in some opaque material, and its dark portions by the transparent ground.

Negative electricity is electricity in a degree below the natural amount for a given body.

Negative eye-piece; N. quantity; N. sign. The Negative sign is the minus sign, or sign of subtraction; e.g. I8 - I I = 7. N. quantity, a number with the negative sign prefixed. Such a quantity, by a simple extension of the primary meaning of the sign, is understood to be measured in a direction opposite to that which is regarded as the standard direction; as, on a thermometer, - $8^{\circ}$ means $\delta^{\circ}$ below zero. (For $N$. eye-piece, vide Eye-piece.)

Negative proposition. [From L. nego, I deny.] In Logic, one which denies the agreement between the subject and its predicate.

Neginoth. In title of Ps. iv., vi., "denotes an accompaniment of stringed instruments" (Speaker's Commentary).

Neglect. (Naut.) In complete-book, a charge, not exceeding $£ 3$, against a seaman, for ship's stores lost overboard or damaged by gross carelessness.
Negotiable instruments. In Law, bills of exchange, promissory notes, and other documents on which the right of action passes by assignment notified generally by endorsement.

Negro-head. (Cavendish.)

Nehiloth. In title of Ps. v., " probably means an accompaniment of flutes" (Speaker's Commentary).

Nemătŏneura. [Gr. $\nu \hat{\eta} \mu \alpha,-\alpha \tau o s, a$ thread, $\nu \in \hat{v} \rho o \nu$, a nerve.] (Zool.) Div. of Radiata of Cuvier, with a traceable nervous system; as the sea-mats, Flustra.

Nem. con. A contraction for [L.] Nemine contradicente, no one contradicting.

Nem. diss. A contraction for [L.] Nemine dissentiente, no one dissenting.

Neměan games. One of the four great Greek festivals common to the Greek cities generally, celebrated at Nemea, in the north-east part of the Peloponnese.

Něměsis. [Gr., distribution.] 1. In the Iliad, this word denotes any cause of anger or righteous wrath. In the Hesiodic theogony, it is the name of a daughter of the night, who gradually becomes the punisher of the favourites of Fortune. 2. Retributive justice.

Nemo me impūne lacesset. [L.] No one shall provoke me with impunity. Motto of the Orde: of the Thistle of St. Andrew.

Nemo mortālium omnibus hōris săpit. [L.] No one of mortal men is wise at all times.

Nemo repente fuit turpissimus. [L.] No one ever becoines utterly bad all at once.

Nemo sōlus săpit. [L., no one is wise by himself alone.] "In the multitude of counsellors there is safety."

Nēmo těnētur seipsum accūsăre. [L.] A maxim in Law : No one is bound to accuse himself, convict himself; a witness need not answer questions tending to criminate himself.

Neocomian rocks = Lower greensand + Atherfield clay, Wealden, and possibly Purbeck beds; largely developed near Neuchâtel (Neocomium).

Neo-Latin languages. I.q. Romance: French, Italian, Spanish, Portuguese, Wallachian, and Roumanian.

Neolithic. (Prehistorio archæology.)

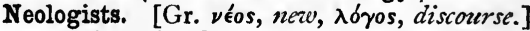
A name given in the last century, by orthodox German divines, to the theologians who then applied novel systems of interpretation to the Scriptures.

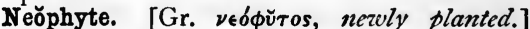
In the primitive Church, any newly made convert.

Neoplatonism. The philosophy of the school which sprang up at Alexandria under Philon, or Philo Judæus, in the first century, and was more fully developed by Ammonius Saccas and Plotinus, a century later. It may be described as an effort to reconcile the Platonic philosophy with the language of the Old Testament. (Eclectics.)

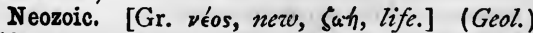
Life-periods being taken, rather than rock. systems, as the true Geol, divisions, we have : 1 Cainozoic [kaıvós, fresh] $=$ Tertiary and Post. 
Tertiary epochs. 2. Mesozoic [uéros, middle] = Secondary ; or Cretaceous, Oolitic, and Triassic.

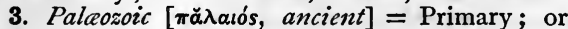
Permian, Carboniferous, Devonian, Silurian, Cambrian, and Laurentian. Another mode of division is : 1. Neozoic $=$ Post-Tertiary or present epoch, Tertiary, Cretaceous, Oolitic, and Triassic. 2. Palaozoic $=$ Permian, Carbonifer ous, Devonian, Silurian, Cambrian, and Laurentian. As any rocks may become metamorphic, that term is not now applied to a division or system ; and, as the oldest known rocks (gneiss) have been stratified, and may once have been fossiliferous, the terms Azoic [à neg., $\zeta \omega \dot{\eta}$, life] and Hypozoic [ixró, beneath] are no longer used as systematic.

Nepe. A square piece of blanket, used by N.-American Indians as a sock.

Nëpenthë. [Gr. $\nu \eta \pi \epsilon \nu \theta \eta \bar{s}$, without sorrow.] 1. (Myth.) A magic potion given by Helen to the guests of Menelaos. 2. Any remedy for grief or pain.

Nephew, Jol, xviii. 19, = L. něpos, grandchild, descendant; so I Tim. v. 4, nepherws [Gr.

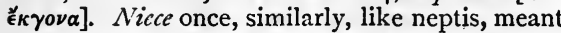
descendants, both male and female.

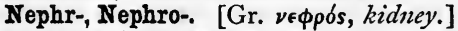

Nephrite, Jade, Axe-stone. A mineral, composed of silica (one-half), magnesia (a fourth), lime, iron, alumina; with coarse splintery fracture ; tough, translucent at the edges; greenish ; slightly greasy to the touch ; cut into implements, ornaments, images, charms, etc. ; once thought

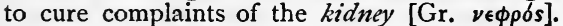
Tartary, New Zealand, etc. (Jade.)

Ne plus ultra. [L., do not go beyond.] Used often in the sense of the impossibility of going further, as "the ne plus ultra of artistic perfection."

Nepotism. [L. nepos, nepōtis, a nephew.] Lit. fondness for nepheres. Hence undue attachment to kinsfolk, showing itself in abuse of patronage or in other ways.

Neptune's sheep. In Naut. parlance, crested waves.

Neptunian rocks $=$ stratified or aqueous ; opposed to igneous, volcanic, or Plutonic. (Huttonian.)

No puěro glădium. [L.] Do not trust a boy with a sword.

Neque semper arcum tendit Apollo. [L.] Apollo is not always bending his bow (Horace). There are times of rest from toil.

Ne quid nimis. [L., do nothing in excess.] Beware of overdoing anything. So Gr. $\mu \eta \delta \epsilon \nu$ ¿rov.

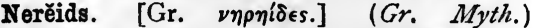
Daughters of Nereus, the god of the sea. Amphitrìte, Galatēa, and Thĕtǐs the mother of Achilles, were among their number. (Naiads;

Nymphs.)

Nereus. (Nereids.)

Neri. (Bianchi and Neri.)

Neroli. [It.] A scent obtained by distilling the flowers of the bitter orange.

Nerves [Gr. $\nu \in \hat{v} \rho o \nu$, sinew, nerve], Nine pairs of. Their order being that of their transmission through the forāmIna at the base of the skull, from the front backwards. (I) Olfactory; (2) Optic ; (3) Mōtōres oculorum; (4) Pathetic ; (5) Trifacial; (6) Abdūcentes; (7) Portio dura, or facial ; Portio mollis, or auditory ; (8) Glossopharyngeal, Par vāgum, called also pneumogastric, + spinal accessory ; (9) Hypoglossal.

Nescit vox missa reverti. [L.] The word uttered cannot be unspoken (Horace).

Nessun maggior dolore Che ricordarsi del tempo felice Nella miseria. [It.] No one greater grief is there in one's misery than to remember happy times (Dante).

This is truth the poet sings,

That a sorrow's crown of sorrow is remembering happier things.

Tennyson, Locksley Hall.

Nessus, Shirt of. In Gr. Myth., the garment dipped in the blood of the centaur Nessus, sent by Deianeira to Heracles (Hercules), whose death it caused by eating his flesh away.

Nestorians. (Eccl. Hist.) The followers of Nestorius, Patriarch of Constantinople, in the fifth century, who forbade men to entertain any combined notion of the divine and human nature in Christ. Nestorius was opposed in the Council of Ephesus, A.D. 43I, by Cyril of Alexandria. His opinions spread far Eastwards ; in the West they were met by the opposite theories of Eutyches. (Eutychians; Monophysites; Monothelites.)

Ne sūtor nltra crěpìdam. [L., let not the cobbler go beyond his last.] Things not understood should be left alone.

Net. [Fr. net, from L. nĭtŭdus, shining (Wedgwood).] (Com.) 1. Things pure and unadulterated. 2. What remains after the Tare has been taken out of merchandise. 3. The price obtained by any commodity after deducting all tare and charges.

Nethinims. In Old Testament, the hewers of wood and drawers of water for the priests and Levites, an office to which the Gibeonites are said to have been condemned by Joshua.

Net profit. (Net.)

Netting. (Naut.) Boarding $N$. runs along the gunwale, and is carried some height up the rigging to prevent an enemy from jumping on board. Splinter $N$. is a horizontal net, about twelve feet above the quarter-deck, stretched from the main to the mizzen mast, to prevent any one from being injured by falling spars, etc., in action.

Nettle-cloth. A thick japanned cotton stuff used as a substitute for leather.

\section{Nettle-rash. (Urticaria.)}

Nettles. (Naut.) (Knittles.)

Neumes. [(?) Gr. $\pi \nu \in \hat{\nu} \mu a$, breath.] (Music.) Certain marks, accents, directions - seven in number -as to raising or lowering the voice, which grew out of the old accents, acute, grave, circumflex; used from eighth or ninth to twelfth century; the foundation of modern musical notation.

Neur-, Neuro-. [Gr. vev̂pov, a nerve.] Neural, having to do with the nerves.

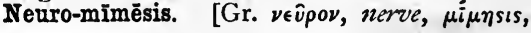


imitation.] Sir J. Paget's substitute for the term Hysterical joints; a nerve-condition which simulates joint-disease, especially at the hip and knee.

Neuroptěra. [Gr. $\nu \in \hat{v} \rho \circ \nu, a$ nerve, $\pi \tau \epsilon \rho \delta \nu, a$ wing.] (Entom.) Ord. of insects, with four membranous, reticulated, net-like wings; as dragon-flies, Lỉbellŭlǐdæ.

Neurōsis. [Gr. $\nu \in \hat{v} \rho \alpha$, nerves.] (Med.) A proposed substitute for the word Hystěria.

Neutral axis. A beam bent by forces applied transversely is found to be stretched below a certain line and compressed above it ; that line which is neither stretched nor compressed is the N. A. of the beam.

Neutral salt. A salt in which none of the properties either of the acid or base are perceptible.

Neutral ships. In Com., ships belonging to neutral states engaged in trade with the ports of belligerents.

Neutral state. A country which binds itself not to give aid or support to either of two belligerents, and in its turn is not to be molested.

Neutral tint. A grey water-colour composed of blue, yellow, and green, in various proportions.

Neuvaine. [Fr.] In the Latin Church, prayers offered up for nine days for some specified.purpose. In Latin, Novèna.

Névé. [L. nǐvāta, fem. of nivatus, part. of nivo, $I$ coat with snow.] In a glacier, snow melted, but not yet compressed, etc., into ice by regelation.

New Connexion Methodists. Wesleyans who withdrew with Alexander Kilham from the old society on account of the great powers given to the Conference. Hence called Kilhamites.

Newel. [O.Fr. noial, nual, from L. nŭcālis, belonging to a nut (nux, nucis).] (Arch.) The upright post round which the steps of a circular staircase wind.

New England. The settlement established by the Pilgrim Fathers. It was the nucleus of Massachusetts, from whence were developed gradually New Hampshire, Vermont, Connecticut, and Rhode Island. In 1643 these settlements formed the first American Confederation.

Newgate Calendar. A series of memoirs of great criminals.

New Jerusalem Church. (Swedenborgians.)

New Learning, The. A name sometimes given to the revival of letters at the close of the fifteenth century.

Now Red, i.e. Sandstone, = Triassic, above the Permian and Carboniferous series ; the Old Red being below. The Permian formerly was included in N. R.

New Style. In Chron., the calendar of Gregory XIII., correcting the errors of the OId, or Julian, Style or calendar. The change was made in 1582 , when the day after October 4 was called October 15. It came into use in England in 1752, when the day after September 2 was called September 14.

Newtonian philosophy ; N. telescope. Newton's view of the system of the world, as opposed to that of Descartes. (For $N$. telescope, vide Telesoope.)
Newton's rings. The rings of colour produced when two slightly convex lenses are pressed together; they are one case of the colours of thin plates.

\section{Newton's scale of colour. (Colour.)}

Nexi. [L., bound.] Amongst the ancient Romans, free-born persons bound to a creditor for debt, and compelled to serve him until the debt was discharged. The condition of the man so bound was called Nexum.

Next friend of an infant or of a married woman. In Law, one who institutes suits in equity, acting in them on behalf of either infant or one under age, or for a married woman, and being responsible for the costs.

Niaiseries. [Fr.] Follies, sillinesses, nonsense. Fr. niais is the L. nidācem, a fledgling.

Nibelungen, Lay of the. The oldest of all existing German epic poems, known as the Nibelungen-lied. (Minnesingers.)

Nibelungen-lied. (Nibelungen Lay of the.)

Nicaragua wood. A red dye-wood brought from Nicaragua.

Nicene Creed. In Eccl. Hist., the creed drawn up by the Council of Nice, A.D. 325, and com. pleted by the Council of Constantinople, A.D. 381. The words filioque were added after $a$ Patre by the Western Church, early in the fifth century.

Nick. (Printing.) A notch in the shank of a type, for holding it by.

Nick, Old. A popular name for the devil. The name denotes a water-spirit, Nix, Nixie [Gr. $\nu \eta^{\prime} \chi \omega$, to swim]. So Old Harry is derived from Ahriman. (Naiads; Nymphs.)

Nickel. [Ger., from kupfer nickel, base copper, as it was thought to be a base ore of copper.] A brilliant white metal strongly magnetic.

Nick Frog. (Bull, John.)

Nicolaitans. One of the earliest Christian sects, mentioned in the Apocalypse, where they are described as inclining to the licentious practices of the Gentiles.

\section{Nicol's prism. (Prism.)}

Nicotine. The chief alkaloid contained in tobacco (introduced into France by Nicot, I550).

Nictating, Nictitating, membrane. [L. nicto, I wink.] (Anat.) In birds, amphibia, and some mammals, the suspensory muscle of the eye, which is thrust forth and drawn back, so as to sweep away irritating particles.

Niddin. (Heb.) The minor excommunication among the Jews, the next being the cherem, and the most severe the scammatha.

Nide. [Fr. nid, from L. nidus, nest.] A brood of pheasants.

Nidification. [Fr., from L. nidificāre, nidus, nest, facio, I make.] The art of building a nest, including also the hatching and feeding of young.

Nidorosity. [L. nïdor, smell as of roasting, boiling.] Eructation, with the taste of undigested roast meat.

Niello. [It.] Filling a pattern cut on gold or silver with a melted black composition, and afterwards scraping and burnishing the metal. 
so as to present the effect of a black drawing thereon.

Niflheim. In Norse Myth., the home of the Niflungs or Nibelungs, or children of the mist [cf. Gr. $\nu \in \phi \in ́ \lambda \eta$, L. nebŭla, $a$ cloud] -the dreary realm beneath the earth, ruled by the goddess Hel. (Nibelungen, Lay of the; Yggdrasil.)

Nigged ashlar. (Arch.) A mode of dressing stone, in which the face is left rough. Also called Hammer-dressed.

Night-hawk. [Heb. tachmâs ; Lev. xi. 16.] (Bibl.) Probably spec. of owl.

Night-jar. (From nocturnal habits and cry.) (Goat-sucker.)

Night Thoughts. A poem by the Rev. Edward Young ( $1684-1765)$, in blank verse; consisting of nine nights of reflexion upon life, death, immortality.

Nihil album. [L., white nothing.] White oxide of zinc (from the extreme lightness of its particles).

Nihil erat quod non tetigit: nihil quod tetigit non ornāvit. [L.] He (touched) handled everything, and all that he handled he adorned.

Nihil est ab omni parte beätum. [L.] There is nothing absolutely happy (Horace).

Nihil est in intellectu quod non prius in sensu. [L.] There is nothing in the intellect which did not exist before in the senses - the addition of Descartes to this dictum being nisi ipse intellectus, except the intellect itself.

Nihilism. [L. nihil, nothing, $=\mathrm{ni}$ filum, not a thread.] Nothingness; hence the doctrine that nothing can be known. Russian nihilism seems to be a protest against all faith, order, law.

Nil admīräri. [L.] To wonder or feel astonishment at nothing; the cool and phlegmatic temper recommended by Horace as the most likely to ensure human happiness.

Nil ad rem. [L.] Nothing to the purpose.

Nil conscīre sĭbi ; nulla pallescěre culpā. [L.] To be conscious of no wrong; to grow pale at no charge (Horace). Sir R. Walpole quoted this in the House of Commons as "Null $i$ pallescere culpe." Pulteney, afterwards Earl of Bath, pointed out the mistake. Walpole offered a bet of a guinea, which on a reference to the book was lost. Pulteney remarked that it was probably the only money he had given in the House which had not caused a blush both to the giver and the receiver.

Nil dēspērandum. [L.] Never despair.

Nil fuit nnquam sic impar sibi. [L.] Nothing was ever so unlike itself (Horace); spoken of inconsistent and self-contradictory characters.

Nill. Shining sparks sent off from melted brass.

Nil mortālibus arduum est. [L., nothing is difficult for men (Horace).] Men will attempt anything.

Nilometer. A graduated pillar on an island opposite to Old Cairo, for marking the daily rise of the Nile. The first pillar was set up A.D. 715 , the second in 860 .

Nil sine magno Vita labōre dedit mortālíbus. [L.] Life yields nothing to men without hard toil (Horace).
Ni l'un ni l'autre. [Fr.] Neither the one nor the other.

Nimbus. [L.] 1. A dark, heavy rain-cloud. 2. In Eccl. Art, a circular disc round the heads of saints and angels. (Aureole.)

Nimis poēta. [L.] Too much a poet.

Nimīum ne crěde colōri. [L., do not trust too much to colour (Virgil).] All is not gold that glitters.

N'importe. [Fr., no matter.] Never mind.

Nǐb̆ē. [Gr.] A mythical name commonly known through the sculptured group at Florence, called "Niobe and Her Children." She is said to have wept herself to death when her children were killed by Phœbus and Artemis. The story, as well as her name, expresses seemingly the

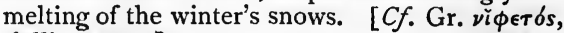
falling snow.]

Niobium. [From L. Niobe, daughter of Tantalus.] (Tantalum.)

$\mathrm{Ni}$ plus ni moins. [Fr.] Neither more nor less.

Nippers. ( $\Lambda^{\top}$ aut.) Sound yarns taken from condemned rope and marled together. Selvagee $N$., a stronger kind of $\mathrm{N}$. (Selvagee.)

Nippers of a horse. The six front teeth above and six front teeth below; next to these are the tushes, i.e. canine teeth.

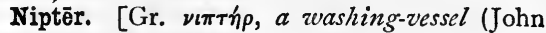
xiii. 5).] The washing of feet on Good Friday in the Greek Church. The office is in the Euchologium (q.v.).

Nirvãna. (Buddhism.)

Nisan. Post-Babylonian name for $A b i b$ (q.v.).

Nisi prins. [L., unless before.] A legal fiction which ordered causes to be tried at Westminster unless they were previously tried by the judges in the counties to which they belonged, as, in fact, was always the case. The nisi prius proviso has been disused since 1852 .

Nisroch. The hawk-headed god of the Assyrians.

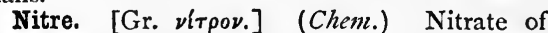
potassium, also called saltpetre. Two acids are derived from it, nitric and nitrous, the salts of which are called nitrates and nitrites respectively. Cubic nilre is nitrate of soda, which crystallizes in cubes.

Nitrification. [Nitre, and L. facere, to make.] The artificial production of nitre.

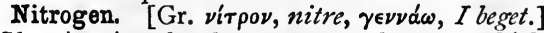
(Chem.) A colourless gaseous element, which will neither burn nor support life. It forms nearly four-fifths of the atmosphere.

Nitro-glycerine. A singular liquid, discovered in Paris, 1848 , obtained by the action of a mixture of nitric and sulphuric acids on glycerine; the sulphuric acid being simply an agent in bringing about the chemical union of the other two; used in various blasting agents. (Dynamite; Litho-fracteur.)

Nix. (Nick, Old; Undines.)

Nizam, properly the Viceroy of the Great Mogul. The title of one of the native sovereigns of India, derived from Nizam-ul-Mulk (Moloch), who, in the beginaing of the eighteenth 
century, gained possession of the Mohammedan conquests in the Deccan. (Nawâb.)

N.I. Written upon a tablet after a judicial trial in ancient Rome, is $=\mathbf{L}$. non liquet, it is not clear, not proven.

Nobel. The lion in Reinecke the Fox (q.v.).

Noble. An O.E. coin, value $6 s$. $8 d$., in the reign of Edward III.

Noblesse oblige. [Fr.] Nobility imposes on us the duty of noble conduct.

Nocet differre parātis. [L.] Delay injures those who are ready.

Nocet emta dolöre voluptas. [L.] Pleasure bought at the cost of pain is mischievous (Horace).

Noctes cœnæque Deûm. [L.] Nights and banquets of the gods (Horace).

Noctillio. [L. noctem, night.] (Zool.) Gen. of bat with long incisors, giving its name to fam. Noctǔlīonǐdæ. Mostly found in Trop. America. Ord. Cheiroptěra.

Nocťlūca. [L., night-shining.] (Zool.) Phosphorescent marine animalcule. Class Infüsōrĭa.

Nocturns. [L. nocturnus, nightly.] In the Latin Church, a nightly office, which now forms part of the Matins.

Nodal figures; N. lines; N. points. [L. nōdus, a knot.] The points or lines of a vibrating body which remain at rest during the vibration, are its $N$. points and lines. In the case of a vibrating plate, these lines and points are shown by strewing sand on it before it is set in vibration; during the motion the sand becomes heaped on the N. lines, and forms $N$. figures, or the figures of Chladni of Wittenberg (1756-1827), who was the first to investigate them.

Noddy. (From its stupid inactivity ; cf. booby.) (Ornith.) Widely distributed spec. of tern, fourteen to fifteen inches long. Buff head, brown body. Sterna stŏlĭda. (Sternidæ.)

Node [L. nōdus, a knot]; Ascending N.; Descending $\mathrm{N}$.; Line of nodes. 1. (Geom.) The oval made by the intersection of one branch of a curve with another, as either loop of a figure of eight. 2. (Astron.) Either of the points in which the orbit of a planetary body intersects the ecliptic. The Ascending $N$. is that through which the planet moves from south to north of the ecliptic; the other is the Descending $N$. The straight line joining these two points is the Line of nodes.

Node. [L. nödus, a knot.] In Bot., the situation on a stem where any lateral member grows out; e.g. leaf or leaf-scale; the part of the axis between two successive nodes being an Internode.

Nodes. [L. nōdus, $a$ knot.] (Music.) Fixed or nearly fixed points, at which a sonorous string divides itself into vibrating segments, which produce the harmonic sounds.

Nodule. [L. nōdŭlus, dim. of nōdus, a knot.] (Geol.) A round or oval mass of rock-matter, segregated from the surrounding matrix, either with or without a nucleus; e.g. N. of ironstone, flint, cement-stone, agate. When the fissures formed by contraction are filled up with mineral matter, the N. becomes a septarium [septum, an inclosure], or Ludus helmontii; when it is hollow, it is a geode. An eagle-stone has an irony crust and ochreous centre.

Noetians. (Eccl. Hist.) The followers of the Ephesian Noetus, the master of Sabellius (Sabellians). As acknowledging only one Person in the Godhead, they were charged with holding that the Father had suffered on the cross. (Patripassians.)

Nogging. [Eng. nog, a square piece of wood to support the roof of a mine.] A partition of scantlings filled with bricks.

No higher. (Naut.) (Near.)

Noils. [Fr. noyau, a core, or kernel.] Short pieces and knots of wool, separated by combing them.

Nola, or Campana. A bell. Bells are said to have been introduced into churches by Paulinus, Bishop of Nola, in Campania. Hence A.S. cnyllan, to knoll, sound a knell.

Nölens vŏlens. [L., willing or unwilïng.] Whether he will or not.

Nōli me tangĕre. [L., touch me not.] 1. (Lupus.) 2. (Bot.) Elegant wild plant, spec. of Impatiens balsam, ord. Balsamineæ.

Nolition. [A word coined from L. nolo, I am unwilling, $=$ non volo.] The opposite of Volition.

Nolle prosěqui. [L.] In Law, an acknowledgment on the part of the plaintiff that he will not further prosecute in a suit, either as to the whole or as to some counts in the declaration.

Nolo episcopäri. [L.] I do not wish to be made a bishop; now applied commonly to those who affect a reluctance for promotion which they do not feel. Said in one or two historical instances; but not said, as is often fancied, by all to whom bishoprics are offered.

Nolŭmus lēgěs Ángliø mutāri. [L.] We do not choose the lazes of England to be changed.

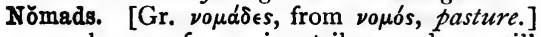
A general name for roving tribes, such as still inhabit the vast country of Mongolia.

No-Man's Land. (Naut.) A space amid. ships, between the after part of the belfry and fore part of the boat in the booms, used to keep blocks, ropes, etc.

Nombril [Fr., navel] point. (Escutcheon.)

Nom de guerre. [Fr., name of war.] An assumed name for purposes of literary controversy.

Nom de plume. [Fr., pen name.] An assumed name by which an anonymous author's writings are known as coming from one man; e.g. Boz.

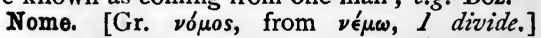
(Hist.) The Greek name for the provinces into which the ancient empires of Egypt and Persia were divided.

\section{Nomen. (Prænomen.)}

Nomenclature. [L. nomenclātor, one who calls out names.] A word denoting the language peculiar to each science or art.

Nominalists. [L. nominālis, relating to $a$ name.] The followers of John Roscelin, of Compiègne, who, in the eleventh century, asserted that general terms have no corresponding reality, being mere words or names and nothing more. 
This doctrine caused great alarm among the Schoolmen, who had thus far believed that all that was real in nature depended on those general notions which described their essences. Roscelin was compelled to retract his opinions ; but they were taken up by Abelard, who went with a body of his followers to Paris, and brought about the founding of the celebrated university in that city. The next Nominalist after Abelard was William of Ockham, who may be styled a Conceptualist, since he allowed to general terms a kind of subjective reality, as the signs of an actual process of thought, although they were neither distinct objects of consciousness nor realities in nature. Those who affirm that they are neither and deny to them this subjective reality, are Ricalists. (Schoolmen.)

Nominal partner. In Law, one who allows his name to appear as having a share in a concern in which he has, in fact, no interest, and thus subjects himself to its liabilities.

Nominis umbra. (Stat magni nominis umbra.) Nŏmŏcănon. [Gr. $\nu \delta \mu o s, ~ l a w, ~ \kappa a \nu \omega \hat{\nu, ~ a ~ r u l e .] ~}$ (Eccl. Hist.) A work in which the canons of the Church are compared with the imperial laws on the same subject: The best known of such works is that of Photius, Patriarch of Constantinople.

Non-age. In Law, the being under the age at which a person is qualified to do certain acts which he could not legally do before that age; e.g. thirteen is non-age for the choice of a guardian ; twenty is non-age for the alienation of lands.

Nonagesimal. [L. nōnāgēsimus, ninetieth.] The highest point of the ecliptic at any time, i.e. the point which is $90^{\circ}$ from its intersections with the horizon.

Nonchalance. [Fr.] Coolness.

Non-commissioned officer. (Mil.) One raised from the ranks, without the intervention of royal authority, to perform the subordinate duties of the army.

Non-committal. The not pledging one's self to any particular measure; a political term in frequent use.-Bartlett's Americanisms.

Non compos mentis. [L.] The legal phrase for one mentally incapacitated for the management of affairs.

Non-condensing engine. (Steam-engine.)

Non-conductor. A substance through which electricity or heat passes with difficulty or not at all.

Non cuivis homini contingit adire Corinthum. [L., it is not every one who can go to Corinth (Horace).] Luxuries are not within the reach of all.

Non eădem est ætas, non mens. [L.] I am not of the same age or the same habits of thinking (as in times past) (Horace).

Non ego. (Subjective and objective.)

Non equĭdem invìděo, miror magis. [L.] For my part I feel more astonished than envious (Virgil).

Nones. [L. nōnæ.] In the old Latin calendar, a division of the month; so called because they fall on the ninth day before the Ides. (Canonical hours.)
Non est ad astra mollis a terris via. [L.] There is no soft (easy) road from the earth to the stars (Seneca).

Non est inventus. [L., he is not found.] The old legal phrase in the sheriff's return to a writ of capias or arrest, when the defendant was not forthcoming.

Non-feasance. The legal phrase for the offence of omitting what ought to be done. (Dolce far niente; Rois Fainéants.)

Non ignara mali. (Hand ignara mali.)

Nonjurors. Clergy not swearing allegiance to William and Mary, and holding that the Stuart family had not been lawfully deposed.

Non magni pendis quia contigit. [L.] You think little of it because it was a windfall (Horace).

Non missura cutem, nisi plena cruōris, hirūdo. [L.] A leech not likely to loose its hold until it is gorged with blood (Horace).

Non multa, sed multum. [L., not many things, but much.] Excellence rather than variety.

Non-naturals. Of the sick, with the old physicians, things not entering into the composition of the body, but necessary to existence ; as air, food, motion, rest, sleep, retentions and excretions, affections of the mind.-Hooper's Medical Dictionary.

No! no! The answering hail of a boat having a midshipman or warrant officer on board.

Non obstante. [L., notzvithstanding.] In O.E. usage, a licence from the Crown for doing something which, although permissible by common law, was restrained by Act of Parliament. (Dispensing power.)

Non omnia possŭmus omnes. [L.] We cannot all do everything (Virgil).

Non omnibus dormio. [L., lit. I am not asleep to every one.] I choose for myself whose faults to wink at and whose to correct.

Non omnis moriar. [L., I shall not all die (Horace).] I shall leave a name behind me.

Nonpareil. [Fr. nonpareil, unequalled.] A small kind of printing type, as-

\section{Easter.}

Non plus. [L., not more.] A phrase used when a man can say no more in answer to an argument, and is therefore put in a fix, or nonplussed.

Non possŭmus. [L., we cannot.] We cannot even take the matter into consideration.

Non quo, sed quomŏdo. [L., not by what means, but how.] The doing of the work is more im. portant than the agent.

Non ragionam di lor, ma guarda é passa. [It., let us not discourse about them, but look (thou) and pass.] So Virgil answers Dante's questions about the lost souls, as he leads him in the Inferno (canto iii.).

Non sequitur. [L.] It does not follow. Spoken of conclusions not warranted by the Premisses. (Syllogism.)

Non sibi, sed patriæ. [L.] Not for himself, but for his country.

Non sine dis animäsus infans. [L.] $A$ child 
whose strength and spirit are a gift from the gods (Horace).

Non sum qualis eram. [L.] I am not what I was.

Non tāli auxǐlio, nec dëfensōribus istis tempus ĕget. [L.] It is not that kind of help, nor defenders like these, that the time needs (Virgil); but different men, better resources, higher principles of action.

Non tangenda, non movenda. [L.] Things not to be touched or moved.

Nōnum premātur in annum. [L.] Keep what you have written for nine years before you publish it (Horace).

Non vi, sed sæpe cadendo. [L.] (Gutta cavat lapidem.)

Noon; Apparent N.; Mean N.; sidereal N. Apparent noon is when the apparent (i.e. the actual) sun, Mean $N$. when the mean sun, Sidereal $N$. when the first point of Aries,-is on the meridian of the station at which the time is reckoned.

Norbertines. (Premonstratensians.)

Norimon. A Japanese palanquin.

N. or M. (Abbreviations.)

Normal. [L. normālis, belonging to a carpenter's square (norma).] (Geom.) A perpendicular line; particularly the line perpendicular to the tangent at the point of contact with the curve.

Normal schools. [Fr. école normale, L. norma, a rule, pattern.] Institutions where teachers are taught the principles of their profession and trained in the practice of it.

Norns. (Scand. Myth.) The Fates. Their names were said to be Urd, Werdand, and Skuld, or Past, Present, and Future; but this is evidently the notion of later times.

Norroy. [North king, from Fr. nord, north, roi, king.] (Her.) The third king-at-arms (presiding over the provinces north of the Trent).

North, Magnetic; N. point; N. Pole; N. star. The North Pole : 1, (Geog.) the point between Asia and Greenland, in which the axis of rotation meets the surface of the earth; 2, (Astron.) the point in the heavens vertically over the North Pole of the earth, situated in the prolongation of the earth's axis. The $N$. point is the point in which a vertical circle drawn through the North Pole cuts the horizon. Magnetic $N$., the point near the north point to which a magnet points. The $N$. star (called also Pole-star, Polaris, a Ursæ Minoris, and Cy̆nǒsūra), a star of the second magnitude, situated about $I^{\circ} 20^{\prime}$ from the North Pole.

North, Rising of the. A name given to the rising, in 1569 , of Roman Catholics under the Earls of Northumberland and Westmoreland; dispersed by the Duke of Sussex.

Northampton Tables, or Taples of Mortality. (Life assurance.)

North Briton. (Liberty Wilkes.)

Northern lights. (Aurora borealis.)

Nos besoins sont nos forces. [Fr.] Our needs constitute our strength.

Nosoitur e sochis. [L., he is known by his society.] Birds of a feather flock together.
Nosing. (Arch.) The projezting moulding on the edge of a step.

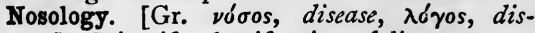
course.] Scientific classification of diseases.

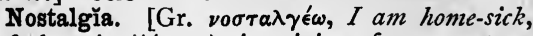
I feel pain (a $\alpha^{\prime}$ yos $)$ in pining for a return

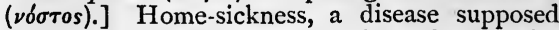
to be common amongst the natives of mountainous countries, when away from their homes.

Nostalgie. [Fr.] (Nostalgia.)

Nostrum. [L., our own.] Our special invention. Often applied to quack medicines.

Notā bene. [L.] Mark well. The abbrev. is N.B.

Notables. In Fr. Hist., the deputies of the states under the Ancien régime. They met for tise last time in 1786 .

Notanda. [L.] Things to be noted.

Notăries, Apostolical and Imperial. Notaries appointed by popes and emperors by virtue of their supposed authority over the realms of other princes. The imperial notaries were forbidden by Edward II. to reside in England.

Note. [L. nŏta, a mark, sign.] (Phys.) The musical sound produced by a string or other vibrating body, consisting of the fundamental tone and its harmonics; the latter are of slight intensity, but impart quality or timbre to the fundamental tone, and any one of them can be heard as a distinct tone by means of a properly chosen resonator.

Notionable. Anything existing in notion or fancy only, unreal, imaginary.

Nötitia. [L.] 1. A roll or register, as a list of gifts to a church or monastery. N. forbanditoria is a deed of renunciation. 2. The collective amount of what is known on some special sub. ject ; as Notitia Euchăristǐca.

\section{Notos. (Wind.)}

Notre Dame. [Fr.] Our Lady; the Blessed Virgin.

Nougat. [Fr., from L. nux, nut.] A sweetmeat made of almonds and honey.

\section{Noun. (Nominalists.)}

Nourriture passe nature. [Fr.] Good breed. ing is of more consequence than birth.

Nous. [Gr.] Mind; often used by itself as equivalent to the vulgar word Gumption.

Nous avons change tout cela. [Fr.] We have changed all that; as the pretended doctor says, in Molière's Médecin Malgré Lui, backing out of the blunder that "the heart is on the light side."

Nous verrons. [Fr., we shall see.] Time will show.

Novatians. The followers of Novatianus, a Roman presbyter, who, in the second century, insisted that the lapsed should never be readmitted to the communion of the Church. When his opponent, Cornelius, was elected Bishop of Rome, Novatianus set up a sect of his own, styled Cathări or Puritans.

Novels. [L. Novellæ Constitutiones, Nerv Constitutions.] In Rom. Law, supplementary constitutions of some emperors, as of Justinian, which appeared after their collections of law had been made public. (Pandects.) 
Novēna. [L.] (Neuvaine.)

Novensules. A word of uncertain origin, used by the Latins as the name of the nine Etruscan gods who had the privilege of hurling thunderbolts.

Nōverrint, The trade of. Once $=$ the occupation of a lawyer's clerk; writs usually beginning Nōvěrint ūnǔversi, let all men know.

Novice. [L. novitius.] A person admitted into a religious house for the probation termed the novitiate.

Novissima verba. [L.] Last (lit. newest) words.

\section{Novitiate. (Novice.)}

Novum Orgănon. New Instrument [Gr.

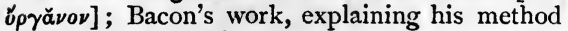
of inductive reasoning.

Norus homo. [L., a new man.] In Rom. Hist., a man who was the first of his family to obtain a curule magistracy (q.v.).

Nowed. (Her.) Having the tail twisted like a knot [Fr. noeud].

Nowel. [Fr. noyau, a kernel.] The core or inner wall of a mould for casting large cylinders.

Noyades. [Fr.] In Fr. Hist., the name of a mode of massacre by which the victims were sent adrift in a boat with a hole driven through the bottom.

Noyau. [Fr., a kernel.] A liqueur flavoured with the kernels of peach stones.

Nuances. [Fr. nue, a cloud, L. nübem.] (Music.) Light and shade in expression.

Nŭcifrăga. [L. nŭcem, nut, frango, $I$ break.] (Ornith.) Nut-cracker; gen. of birds. Greater part of Europe and Asia. Sub-fam. Corvinæ, fam. Corvĭdæ, ord. Passěres. One spec. (N.

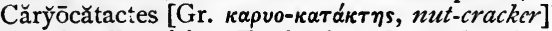
occasionally visits England. General colour brown, white spots ; wings and tail brown.

Nŭcleus. [L., a small nut, kernel, dim. of nux.] 1. (Astron.) The central part of the head of a comet. 2. (Bot.) The centre of an ovule.

Nūdǐbranchǐäta, Nudibranchiates. [L. nūdus,

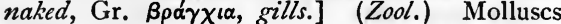
with unprotected breathing organs, as Doris, sea-lemon.

Nudum pactum. [L., a nude pact.] In Law, a naked contract, without any consideration.

Nugæ canōræ. [L.] Melodious trifles (Horace).

Nuggets. The larger lumps of gold, found in the gold-diggings. They are always waterworn.

Nugis addère pondus. [L., to give weight to trifles (Horace).] To make mountains out of mole-hills.

Nulla aconita bibuntar fictílibus. [L., people do not drink poison out of earthenware (Juvenal). The danger is for those who drink out of gold and silver.

Nulla bŏna. [I., no goods.] No assets.

Nulla dies sine linĕa. [L., no day without a line.] For the artist, no day without practice in drawing. For all, no day without toil.

Nulla est sincēra voluptas. [L.] No pleasure is unalloyed (Ovid).

Nullah. The Hindu name for small rivers and streams, or for their channels when dry

Nullā pallescěre culpā. (Nil conscire sibi.)
Nullipore. [L. nullus, none, pŏrus, a passage ; i.e. once thought ' to be coral without pores.] (Geol.) Lime-bearing seaweeds, helping to form some Tertiary limestones, as in Malta and near Vienna ; used as building-stones.

Nullius addictus juräre in verba magistri. [L., not bound to swear by the words of any master (Horace).] Free and independent in thought and word.

Nullius in bonis. [L., in or belonging to the goods of no one.] Unclaimed, or ownerless, property.

Nullum tempus occurrit regi, or Ecclesiæ. [L.] A Law phrase, denoting that the rights of the Crown, or of the Church, cannot be put into abeyance by lapse of time (time does not bar the right of the king or of the Church).

Number. [L. numerus, Gr. vónos.] 1. Any particular aggregate of units. (For Abstract N., Cardinal N., Prime N., etc., vide Abstract number; Cardinal numbers; Prime meridian; etc.) 2. (Naut.) Ships are distinguished by numbers for signalling. Losing the N. of one's mess, dying suddenly, killed, or drowned.

Numeration. The art of naming numbers. The chief words employed for this purpose are the names of the digits, ten, a hundred, a thousand, and a million. Words for expressing numbers more than a million are of. somewhat uncertain use ; e.g. a billion means, in England, a million millions, in the U.S., in France, etc., a thousand millions.

Numerical equation; N. value. In a Numerical equation every quantity except the unknown quantity is a particular number, as $x^{4}-7 x^{3}+$ $4 x^{2}-5=0$. The $N$. value of an algebraical formula is the number obtained by substituting numbers for their equivalent algebraical symbols which compose the formula, and reducing the result to its simplest form; thus if $s=\frac{1}{2} f^{2}$ when $f=32$ and $t=5$, the N. V. of $s$ is 400 .

Nummulite. [L. nummus, money.] (Geol.) A gen. of fossil foraminifera, circular, coin-like ; their shells forming large masses of $N$. limestone. Eocene.

Nuno aut nunquam. [L.] Now or never.

Nuncio. [It., from L. nuntius, a messenger.] A papal envoy accredited to a foreign court.

Nuncŭpative will. [L. nuncūpo, I name.] In Law, a will delivered by the testator by word of mouth. By Eng. usage, this mode of making a will is allowed only to soldiers and seamen on active service.

Nundĭnæ. [L.] The old Latin market days ; so called as recurring every ninth day.

Nun of Kent, Holy Maid of $\mathbf{K}$. Elizabeth Barton; she denounced Henry VIII.'s separation from Catherine; executed, with others, at Tyburn.

Nunquam minus solus quam cum solus. [L.] Never less alone than when alone; said of true philosophers.

Nuremberg, Peace of, July, 1532, signed by Charles V., granted liberty of conscience to Protestants. (Smalcald, League of.)

Nursing generation. (Alternate generation.) Nut. [Akin to L. nux.] A small block of 
metal or wood pierced by a cylindrical hole within which is cut the worm of a female screw to work with the screw cut on a bolt.

Nutation. [L. nūtātio, -nem, a nodding.] 1. (Astron.) A small and slow gyratory movement by which, if subsisting alone, the Pole would describe among the stars, in a period of about nineteen years, a minute ellipse, whose longer axis is about $19^{\prime \prime}$ and shorter $14^{\prime \prime}$. Its effect is to produce a small periodic variation in the motion of the equinox and in the obliquity of the ecliptic. 2. (Mled.) Constant involuntary shaking of the head.

Nutrid skins. [Sp. nutria, L. lutra, Gr. évvipis, an otter.] The fur of a Brazilian animal resembling a beaver.

Nux vomica. [L., disgusting nut.] The seed of a tree growing on the Coromandel coast, from which strychnine is obtained.

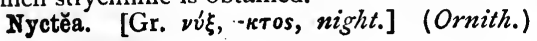

Snozvy owl; gen. and spec. N. America and N. Europe. Fam. Strĭgĭdæ, ord. Acč̌prtres.

Nycthëmĕron. [Gr. $\nu v \chi \theta \eta \mu \in \rho o \nu$.$] (Astron.)$ A space of a night and a day.

Nye. (Nide.)

Nylghau. [Pers. nīl-gāo, blue cozv.] (Zool.) A ruminant ; gen. and spec. of bovine antelope, the largest of its kind, more than four feet high at the shoulder; male, slate blue, with horns; female, reddish grey, without. India. Portax, sub-fam. Trăgělăphinææ, fam. Bŏvĭdæ, ord. Ungŭlāta.

Nympho-lepsy. 1. The being caught by a nymph [Gr. $\nu v \mu \phi \delta-\lambda \eta \pi \tau o s]$, fascinated by the actual sight of one; and 2, generally a state of rapture, the Muses being often called nymphs.

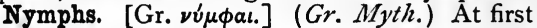
female inhabitants of the waters; afterwards of trees and forests also. (Dryads; Hamadryads; Naiads; Nereids.)

0.

0. Of this letter the Greeks had two formsone equivalent to the short, the other to the long, pronunciation of this letter in other countries. Among the Irish the letter $\mathrm{O}$ prefixed to a name is equivalent to Fitz in England, meaning son. $\mathrm{O}$ in Music is the semibreve.

Oaf. [Collat. form of elf.] A changeling. A child left by the fairies in place of one taken away by them. Hence a dolt or blockhead.

oak leather. A kind of fungus spawn, found in old oaks ; sometimes used for spreading plasters.

0akum. [O.E. ácumba.] Loose hemp formed by untwisting old ropes.

0āses. [Gr., probably a Copt. word.] Fertile spots found scattered in the great sandy deserts of Africa; owing their richness to the springs which abound among them.

Oast-house. [D. ast, est, a kiln; the word probalsly imported with the cultivation of hops (Wedgwood).] Kiln for drying hops.

Oath of Allegiance. [A.S. ath.] Binds to faithful and true allegiance to the sovereign. O. of Supremacy or of the Queen's Sovereignty, in substance abjures the doctrine that princes excommunicated or deprived by the pope may be deposed or murdered; and declares that no foreign person or state has any jurisdiction in England. (See the "Ordering of Deacons.")

obbligatō. [It., bound, made necessary.] (Music.) Accompaniment which cannot be dispensed with.

Obēah. (Obi.)

Obedience, Passive. In Politics, the absolute submission supposed by some to be due to the sovereign.

Obelisk. [Gr. ỏ $\beta \in \lambda i \sigma \kappa o s, \operatorname{dim}$. of ỏ $\beta \in \lambda \delta s, a$ spit, pointed instrument.] 1. In Printing, a dagger $(t)$ referring to a note in the margin, or at the bottom of the page. 2. (Aristarchian criticism.)

\section{Obelize. (Aristarchian criticism.)}

Obělus. (Obelisk.)

Oberron. In Med. Myth., the king of the fairies. The name was originally Auberon, Alberon, the first syllable of which reproduces the O.G. alb, our elf, fairy. (Elves.) It occurs in the Heldenbuch (Minnesingers) in the form Alberich, or Alban.

Obi, Obeah. The name of a kind of witchcraft among the negro tribes of W. Africa, an Obeah-man or -woman being one who practises O., advising in sickness and other emergencies ; selling charms, philtres, etc. ; and skilled in the art of poisoning, "the most practically important element in O." (Kingsley, At Last, p. 288 ; Tylor, Primitive Culture). (Fetish.)

Obiit sine prōle. [L.] Died withcut issue. Often given under the initial letters O.S.P.

Obitter dictum. [L.] A thing said by the way, incidentally, in passing, not expressive of deliberate judgment; generally applied to some opinion of a judge which is not judicially decisive, not of the essence of the matter which has been argued before him.

Obits. [L. obbitus, death.] In the Latin Church, a service for the repose of a departed soul.

Object; Objective. (Subject; Subjective and objective.)

Object-glass. The lens at the end of the tube of a microscope or telescope which is turned towards the object to be viewed.

Oblate. [L. oblātus, offered.] (Eccl.) A person who makes a donation or assignment of his property to a religious community, either permanently or for a definite time.

Oblate spheroid. (Ellipsoid.)

Oblation. [L. oblātio, -nem, an offering.] In the Eucharistic Office of the Latin Church, the Lesser $O$. is the offering of the bread and wine 
in the offertory; the Greater $O$. is that of the elements after consecration.

Oblique. [L. obliquus, oblique.] (Geom.) Inclined at any angle not a right angle, as an $\mathrm{O}$. angle, $\mathrm{O}$. co-ordinates, etc. The great sphcre is said to be oblique when a pole is not in the zenith or horizon of the spectator.

Oblique motion. (Music.) (Motion.)

Oblique prismatic system. (Crystallog.) Consists of those crystals which have one axis at right angles to the other two, which are not at right angles to each other; when transparent, they are optically biaxal; as oxalic acid.

Oblique sailing. (Naut.) The application of oblique-angled plane triangles to ascertain a ship's position at sea by means of objects observed.

Oblong. (Quadrilateral.)

Obmutescence. [L. obmūtesco, I become dumb.] Loss of speech.

Oboe, or Hautboy (q.v.). A flute-like instrument, at first the simple pastoral chalumeau or reed-pipe, now, after various improvements, a kind of clarionet, but with double reed, beautifully expressive. Oboist, performer on the O.

Obrine. A Polish military order of the thirteenth century; called also the Order of Jesus Christ.

Obrok. A Russian word used in two senses : (I) for a rent paid by the peasants; (2) for the poll tax paid by those who, being dependent on lords, have been sent out to learn some manufacture, or have of their own will quitted their feudal abode.

Obscurantism. The condition of one who wishes to keep things dark or who opposes the progress of knowledge.

Obsecration. [L. obsěcrātio, -nem, prayer.] In the Litany, the suffrages which begin with the word "By."

Observants. (Recollects.)

Observation. [L. observātiōnem, from observo, 1 mark.] 1. (Nat. Phil.) The exact determination of the circumstances of phenomena whose occurrence is independent of human contrivance ; thus astronomy is a science of observation, chemistry of experiment, though a chemist observes (in a less technical sense) the phenomena whose occurrence he has brought about. 2. (Naut.) Ascertaining the time, or longitude, also the lunar distances, by taking the altitude of the sun or other heavenly body with a quadrant or sextant.

Observatory. A building containing, and constructed for facilitating the use of, instruments for observing certain kinds of natural phenomena; as a magnetic $O$. When used without qualification, the word commonly means an astronomical $\mathrm{O}$.

Obsession. [L. obsessio, -nem, a besieging.] The state of a person besieged by evil spirits, as distinguished from one who is internally possessed by them.

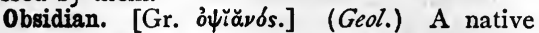
glass, volcanic, more or less felspathic ; of various colours, generally black ; ornamental, and used for knives, arrows, lances, and for lookingglasses in Mexico and anciently.
Obsidional crown. [L. corōna obsidiōnālis.] In Rom. Hist., a crown granted to the general who raised the siege [obsidionem] of a beleaguered place.

Obsolescent. [L. obsolescentem, part. of obsŏlescěre, to wear out, fall into disuse.] Said of words or things going out of use.

Obstacle. [L. obstäculum, $a$ hindrance.] (Mil.) Any artificial impediment erected for the interruption of the movements of troops, either in their march or more frequently so placed as to demoralize them within point-blank range of an enemy.

Obstetrics. [L. obstētrix, a midwife.] The practice of midwifery, or the delivery of women.

Obstruent [L. obstrŭentes] medicines. Those which close up the orifices of ducts or vessels. (Deobstruent.)

Obtrectation. [L. obtrectātiōnem, from obtrecto, I detract through envy.] Slander, calumny.

Obtuse angle. (Angle.)

Obvention. [L. obventio, -nem, a falling to one's lot.] 1. An incidental advantage. 2. (Eccl.) An offering. (Altarage.)

Ocarina. [It.] A musical instrument of terra cotta pierced with holes; Italian. Seven make a set.

Occæcation. [L. occæco, I make blind.] The making or becoming blind.

Occident. [L. occildentem; lit. the setting sun.] The West.

Occipital. Pertaining to the occiput [L.], or back of the head.

Occlusion. [L. occludo, I shut up.] The retention of gases within solid bodies.

Occultation. [L. occultationem, a concealing.] (Astron.) The hiding of a star or planet by the moon passing between it and the spectator; or of a satellite by its primary.

Occultation, Circle of perpetual. The circle or the great sphere for a given station which separates the part that comes above from the part that never comes above the horizon; thus, for a station in latitude $51^{\circ} \mathrm{N}$. the circle of perpetual occultation is the parallel of declination of $39^{\circ} \mathrm{S}$.; no star whose declination exceeds $39^{\circ} \mathrm{S}$. ever coming above the horizon.

Occult sciences. [L. occultus, hid.] A general name for the pretended sciences of the Middle Ages, such as Alchemy, astrology, and magic.

Ocoupy till I come. Luke xix. I3 ; Gr. $\pi \rho a \gamma \mu \alpha-$ $\tau \in \dot{v} \sigma \alpha \sigma \theta \epsilon$, retains an idea, surviving in the word occupation, of using, trading with what one possesses.

Oceāna, published 1656, by James Harrington. An elaborate project for establishing a pure republic upon philosophical principles; of which the basis is an elective administration in which the various offices are held by a system of rotation; his theory being a counterpart to Hobbes's Leviathan (q.v.).

Ocelot. [Mex. ocelotl.] (Zool.) Gen. of tiger-cats, Fēlis pardălis, spotted like leopards. Trop. America.

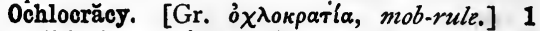
A political state in which the mob has gained 
illegal power; or, 2 , one in which the laws give too much power to the people.

Ochreate. A misspelling for Ocreate (q.v.).

Ochres. [Gr. ڤ̇xpós, pale.] (Geol.) Clays coloured with oxides of iron, sometimes pulverulent; sometimes in thick beds; e.g. Shotover, Oxford, Canada. Siena earth is from $\mathrm{S}$. , in Tuscany.

Ocreate. [L. ocreātus, greaved.] (Bot.) Having an ocrea, a sheath-like stipule through which the stem passes, formed by consolidation of two opposite stipules; $\epsilon . g$. polygŏnum.

Octagon. (Polygon.)

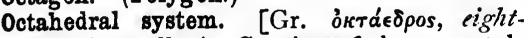
sided.] (Crystallog.) Consists of those crystals which have three axes at right angles to each other and equal parameters; when transparent exhibiting only ordinary refraction ; as fluor-spar.

Octahedron. (Polyhedron.)

Octave. [L. octāvus, eighth.] In Church usage, the eighth day after a feast, the feast itself being included. (Quinzaine.)

Octavo. [L. octävus, eighth.] A book composed of sheets folded so as to make eight leaves.

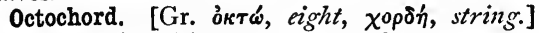
An eight-stringed instrument ; e.g. lute.

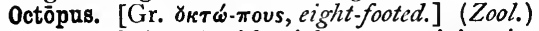
Gen. of cephalopod with eight arms, giving its name to fam. Octōpǒdǐdæ; found in all temperate and tropical seas.

Octoroon. [L. octo, eight.] The offspring of a white and a Quadroon, i.e. having one black great-grandparent, or one-eighth black blood. (Mulatto.)

Octroi. [Fr., from L. auctōritātem, authority.] Originally any right granted to a subject by the sovereign. In later times the word has denoted especially the taxes levied by the corporations of French towns on all articles of consumption brought within the barriers.

Ocular. [L. oculāris, relating to ocŭlus, eye.] (Optics.) The eye-piece of telescope or microscope.

Odalisques, properly Odaliks. Female slaves employed in the odas or chambers of the sultan's harem.

Odeion. (Odeum.)

Odēum, properly Odeion. [Gr. $\dot{\omega} \delta \epsilon_{\hat{\epsilon}} 0 \nu$.] At Athens, a building for musical rehearsals before the celebration of the great festivals.

Odin, Woden. The all-father of the Teutonic

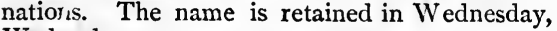
Wednesbury.

Odisse quem læsěris, proprium humāni est ingenii. [L.] It belongs to human nature to hate one whom you have injured (Tacitus).

Odometer, properly Hodometer. [Gr. $\delta \delta o ́ s$, a way, $\mu$ é $\tau \rho o \nu$, measure.] An instrument for measuring distances; as e.g. by registering the number of turns of a carriage-wheel.

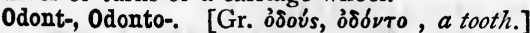

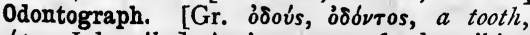
$\gamma \rho \alpha \dot{\phi} \omega$, I describe.] An instrument for describing the teeth of wheels.

Odyle. "A new imponderable," which Baron von Reichenbach professed to have discovered; a force pervading all nature, having, like magnetism, positive and negative poles; known to "sensitives" by sight, smell, feeling. But see Carpenter's Mental Physiology, p. 159, and elsewhere.

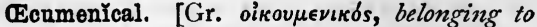
the inhabited world, universal.] In Eccl. Hist., anything with universal authority. Thus CEcumenical Councils are Councils resting on the authority of the whole Church, as being represented in it. Some patriarchs of Constantinople styled themselves CEcumenical, in opposition to the claims of Roman bishops.

Edēma. (Edema.)

Edīpus. [Gr. Oisimous.] In Gr. Myth., a king of Thebes, who solved the riddle of the Sphinx, and so became noted for extraordinary wisdom.

\section{Egir. (Ogre.)}

Enanthic. [Gr. oivan $\nu \eta$, the flower of the wild vine.] Having the characteristic odour of wine.

Enothera. [Gr. oivotńpas, some plant with roots smelling like wine (olvos).] (Bot.) Evening primrose, $O$. biennis ; ord. Onagrariæ.

EEnōnē. (Paris, Judgment of.)

Esophăgus. [Gr. oíoфáros.] (Anat.) The gullet; the tube leading from the pharynx to the stomach.

Eufs de Pâque. [Fr., Easter eggs.] A survival of the old custom which regarded the egg as a symbol of the re-creation of the world in spring. In the Vedic theogony, Brahma produces himself from the great mundane egg, out of which all living things come into existence.

Oferlanders. (Naut.) Small vessels of the Rhine and Meuse.

Off. (Naut.) 1. Opposed to Near; as nothing off, keep her to the wind. 2. From; as on and off $a$ shore, i.e. towards and away from it. 3. Abreast of or near, as off the Nore. 4. In driving, the $O f f$ side is the right; the Near side is the left.

Offal, once written off-fall. Properly, anything that falls off, whether valuable or not. $O$. -wood is sold by auction in H.M. dockyards.

Office, Holy. A name by which the Inquisition is sometimes called; properly, i.q. the Congregation of the H.O., established by Paul III., A.D. 1542, to which the direction of the Roman tribunal of the $I$. is subject.

Office found. In Eng. Law, an inquiry instituted by officers of the Crown when events have occurred by which the Crown becomes entitled to take possession of real or personal property.

Office of Judge promoted. (Eccl.) The institution of a suit in the Court of Arches $(q . v$.$) by$ the sending letters of request signed by the bishop of the diocese in which the suit has arisen.

Official. [L. officium, duty.] In Canon law, the deputy of a bishop or abbot. The chief official of the bishop is his Chancellor.

Officinal. [L. offícina, a shop.] 1. (Med.) Made according to recognized prescriptions. 2. (Bot.) Used in medicine. 
Offĩcinälis. [L. offícina, a workshop, laboratory.] As an epithet in Bot. ; used in medicine.

offing. (Naut.) To seaward, beyond anchorage. To keep a good $O .$, to keep well clear of the coast.

Off-reckonings. (Mil.) Certain margin in expense allowed to the full colonels of regiments in providing the clothing and accoutrements for their men.

Off-set. In Surveying, a short distance measured at right angles to the chain-line, for which purpose an Off-set staff is used.

Offward. (Naut.) Leaning away from the shore; spoken of a ship aground. The ship heels $O$. and lies with her stern to the $O$., means inclined and with her stern to the sea.

Ogee. [Fr. ogive.] (Arch.) A moulding which is partly convex and partly concave.

Ogee arch. (Arch.) An arch formed on each side by two contracted curves. Common in Continuous or Perpendicular work. By an ogival arch the French mean simply an arch struck from two centres. (Arch.)

Oghams. The name of the characters in certain old Irish inscriptions. They are adaptations of the Runic alphabet to the needs of writing on wood, the runes or letters being expressed by a convenient notation consisting of notches cut with a knife on the edge of a squared staff instead of being cut with a chisel on the surface of a stone.-Isaac Taylor, Greeks and Goths, p. 109.

Ogival, Ogive. (Ogee arch.)

Ogre. A man-devouring monster, a bugbear. Ogir was the Norse god of the sea. Grimm regards the word as akin to the Goth. ôg, fear, horror. The name came to denote any object of overpowering terror.

Ogygian deluge. The flood of Deucalion is sometimes so called as occurring in the reign of the mythical Ogȳges.

Ohm. (From the Danish electrician, Ohm.) The unit of electrical resistance, equal to a force capable of lifting ten million grammes one foot in one second.

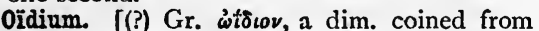
Gr. $\dot{\omega} b \nu$, an egg.] (Bot.) A gen. of nakedspored fungi, of which $O$. Tuckeri is that connected with the vine mildew. $O$. albicans grows on the mouth, fauces, and œsophagus of infants.

Oil-box, Oil-cup. A cup containing oil placed above a hole or passage through which the oil passes to lubricate the bearing of an axle or other moving part of a machine.

Oil-cake. Compressed husks of rape seed, etc., from which oil has been extracted.

oil-cloth. Cloth oiled or painted, for covering floors.

Oil of vitriol. Sulphuric acid, from its oily appearance.

Okkals. (Druses.)

Old Catholics. A body of Latin Catholics who refused adhesion to the decree of the Vatican Council respecting papal infallibility. One of the most eminent members of this body is Dr. Döllinger, of Munich.

old Dominion. The state of Virginia, pro- bably because $V$. was the original name of all the English colonies in America.-Bartlett's Americanisms.

Old Foundation, Cathedrals of the. (Cathedrals of the New Foundation.)

Old Harry. (Nick, Old.)

Oldhaven beds. (Geol.) Sạds, oyster-beds, and pebbly strata lying on the Woolwich beds in the S.E. of England.

Old Man of the Mountain. The European name for the sheikh of the Assassins.

Old Nick. (Nick, Old.) Butler, in Hudibras, erroneously ascribes it to Nicholas Machiavelli. (Machiavellism.)

old Red. (New Red.)

Oldsters. (Naut.) Midshipmen of four years, master's mates, etc.

old Style. (New Style.)

Olefiant gas. [L. oleum, oil, fièri, to become.] Carburetted hydrogen, containing two atoms of carbon to four of hydrogen (which, combined with chlorine, forms an oily compound).

Oleograph. [L. oleum, oil, Gr. $\gamma \rho \alpha ́ \phi \omega, I$ write.] A picture produced in oils by a process resembling lithography.

Oleomargarine. An article made from fat, grease, and oily substances ; large quantities of which find their way to market in various European countries, where it is sold as butter. Bartlett's Americanisms.

Oleron, Iaws of. A code of maritime law ; so called from the Isle of Oleron, and compiled not later than 1266. (Amalfian Code; Wisby, Ordinances of.)

Olibănum. [Gr. $\lambda$ ißavos, the frankincense tree.] A fragrant gum-resin, used in incense.

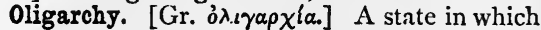
only a few out of one class exercise supreme power, in contrast with an aristocracy, in which the whole class of nobles rules.

Olitory. [L. olitōrius, olus, olĕris, vegetables.] Belonging to a kitchen garden.

Olive-Branch Petition. Sent, in 1775, by "Congress" of the "United Colonies" to George III., as a last appeal. Not received, as coming from an illegal body.

Oliver. A small lipped hammer worked by the foot.

Olivine, Green-earth. (Geol.) An olive-green magnesian earth and crystals (chrysolite), common in volcanic rocks.

olla. [Hind.] A palm leaf for writing upon.

Olla podrida. [It., L. olla putrída, rotten jar.] 1. A hotch-potch, a pot-au-feu, into which all kinds of scraps are thrown and stewed; and so, 2, literary odds and ends, stories, anecdotes, collected together, having no reference to any subject or plan; so farrägo [L.] a medley, lit. mixed food of spelt [L. far].

Olney Hymns. Published 1776; the joint work of John Newton, Curate of Olney, Bucks., and the poet Cowper.

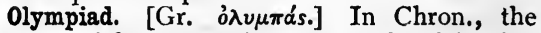
interval of four years between each celebration of the Olympic games, forming the common era of Greek computation, and beginning, it was said, B.c. 776 . 
Olympio games. The greatest of the Greek Panhellenic festivals, celebrated once in every four years at Pisa, or Olympia, in Elis. The first recorded victory is that of Corœbus, B.c. 776 .

Omāsum. [L., a paunch.] (Anat.) Third stomach of a ruminant.

Ombrometer. (Rain-gange.)

Omens. [L. omina.] Accidental signs, supposed to betoken future events. (Angurs.)

Omentum. [L., a caul.] A broad band of membrane, connecting two or more of the abdominal viscera, the chief being the great O., or caul, a network of fatty tissue.

Omer. Exod. xvi. 36 ; " the tenth part of an ephah," which was an Egyptian measure, and, according to Josephus, = six cŏty̆læ, or halfpints; but "the measures varied at different times" (Speaker's Commentary).

Ommiad caliphs. In Moham. Hist., the caliphs who succeeded Mrawiyah, son of Abu Sophian, who gained the caliphate after the murder of Ali. (Abbasides; Shiahs; Sounites.)

Omne vivum ab ōvo. [L.] All life comes forth from an egg; a supposed axiom of biology; in former times. (Eufs de Pâque.)

Omnia munda mundis. Unto the pure all things are pure (Titus i. 15).

Omnia præsūmuntur rīte esse acta. [L.] A maxim in Law : all acts are presumed to have been rightly done; i.e. all acts preliminary to some act proved in itself to be legal ; e.g. a marriage having been proved, the church in which it took place will be presumed to have been consecrated for service.

Omnium. [L., of all.] A term formerly used on the Stock Exchange to denote the various kinds of stock created on the negotiation of a loan by Government which provided for the extinction of the debt partly by consols, partly by stock bearing high interest, and by annuities. Speculations in all these jointly were known as ominium.

Omophagous. [Gr. $\dot{\omega} \mu \circ \phi \alpha ́ \gamma o s$, from $\dot{\omega} \mu \delta s$, raze, $\phi a \gamma \in i \nu$, to eat.] Eating raw flesh.

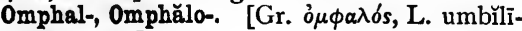
cus, the navel.]

Omrah. [Ar., a chief.] One of twenty-four councillors of the Great Mogul. Emir, Amir, Ameer, are other forms of the same word. (Miramamolin.)

On a bowline, or On a wind. (Naut.) Sailing close-hauled in the direction from which the wind comes.

Oncin. [L. uncus, a hook.] A weapon having a hook and spike on a long handle; somewhat like a boat-hook ; eleventh century.

Oneirocriticism. [Gr. оेєєрокрเтькós, from

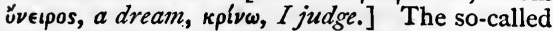
science of interpreting dreams.

Onges. (Geol.) The solid rock which bounds a vein of ore.

Onб̌mastícon. [Gr., from ǒvoua, a name.] A dictionary or commonplace-book; as that of Julius Pollux.

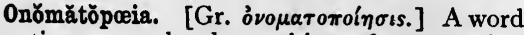
denoting properly the making of names, but more commonly applied to words expressing by their sound the thing signified; as cuckoo, peewit, etc.

On se fait à tont. [Fr.] One gets used to anything.

On the beam. (Naut.) At right angles to the keel, and without the ship. On the bow. (Bow of a ship.) On the quarter, within the angles contained by a line drawn right astern and four points on either quarter.

Onus prŏbandi. [L.] The burden of proving is said in Law to lie generally on the party who maintains the affirmative of the question in dispute.

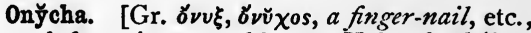
named from its resemblance, Heb. shechêleth (Exod. xxx. 34).] (Bibl.) The opercŭlum [L., lid] of some gasteropodous mollusc (probably of fam. Strombirdæ) abundant in the Red Sea; said to be at this day employed in the composition of perfume (Speaker's Commentary).

Ony̆chitis. Inflammation of the nail [Gr.

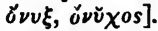

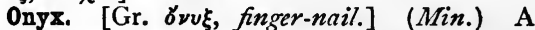
piece of agate with layers of chalcedony, one of which is flesh-coloured : but the dark and white layers of artificially prepared agates are often used.

Ooïd, 0oïdal. 1. Like an egg [Gr. ஸ́óv] in shape ; or, 2, as having albumen.

Oolite [Gr. $\dot{\omega} \delta \nu$, an egg, and $\lambda_{\imath} \theta \dot{\delta} s$ ], or Roestone. (Geol.) A variety of limestone, with roelike grains cemented together. O. group, Oolitic or Jurassic system, = Lias + Oolite + the Purbeck.

Oolong. [Chin., green dragron.] A variety of black tea, possessing the flavour of green tea. land.

0oze. [From a root from which have sprung many families of words having a common meaning of moisture; as Exe, Usk, Aix, and eaux, i.e. aquas; Uisgah (whisky), etc.] 1. The liquor of a tan-vat. 2. In Geol., e.g. O. of the Atlantic, a fine, whitish, sticky mud-chalk in process of formation, and now accumulating over wide areas, eighty per cent. being the calcareous deposit of globigerinæ and various other minute organisms.

Opal. [L. ŏpălus.] (Min.) A mineral, hydrate of silica, chatoyant; allied to chalcedony, but amorphous, and containing more water. Precious $O$., containing ten per cent. There are many varieties. Stalagmitic in fissures of volcanic rocks; Hungary, Mexico, Queensland.

Open, or Dispersed, harmony (Music) is of parts separated by intervals as wide as may be. Close $H$. is of parts brought near to one another.

Open diapason, or Principal. (Niusic.) In organs, the chief open foundation stop, generally of metal ; in the pedals generally of wood.

Open hawse. (Naut.) With two anchors out and the cables not crossed.

Open list. (Naut.) A ship's book, contain. ing the names of officers and crew, by which rations are issued and the crew mustered.

Open order. (Naut.) More than a cable's length apart. 
Open verdict. After an inquest, is = a declaration of the jury that there has not been produced sufficient evidence for any decision.

Open work. (Mil.) One which is not protected at the gorge $(q . v$.$) , by a parapet or$ obstacles, from a sudden attack.

Opercu-lar, -late, -lated. (Nat. Hist.) Having $a$ lid or cover [L. ǒpercŭlum].

Opercŭläta. (Zool.) Molluscs possessing an opercülum (q.v.).

Opercŭlum. [L., covering, from ŏperio, I cover.] 1. (Conch.) The horny or nacreous plate, more or less completely closing the mouth of the shell in certain gasteropodous molluscs. 2. (Bot.) The lid of anything, as in the pitcher of Nēpenthes; especially applied to the sporecase of urn-mosses.

Ophicleide. [Gr. ó $\phi(s, a$ serpent, $\kappa \lambda \epsilon i s, a$ key.] A large brass wind instrument, modern, orchestral, powerful; its compass being three octaves from double $\mathrm{B} b$.

Ophǐdřa, Ophidians. [Gr. ỏ $\phi\{\delta ı$, dim. of cois, a serpent.] (Zool.) The first ord. of reptiles, serpents.

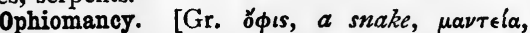
divination.] Divination by means of serpents, as from the number of their coils or of the victims which they devour.

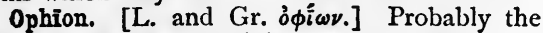
noufflon (q.v.) of Sardinia.

Ophir. A country with which the ships of Solomon carried on an extensive trade. It was perhaps the island of Ceylon, which was named Abhira.

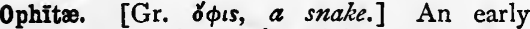
Christian sect, of Gnostic origin, which worshipped the serpent as the author of all sciences. Ophthalmia. Iniflammation of the eye $[\mathrm{Gr}$. $\dot{\delta} \phi \theta a \lambda \mu \delta s]$.

Opiricus. An heraldic animal having wings like a griffin, and a short tail like a camel.

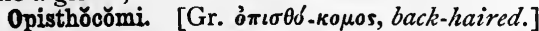
An ord. of birds consisting of one gen. containing one spec. The hocco of Guiana, a gregarious bird about the size of a peacock ; plumage brown. Equatorial America. It may indicate the former existence of a group of birds otherwise extinct.

Opisthŏdŏmns. (Naos.)

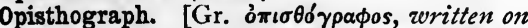
the back.] In Gr. and Rom. Ant., any roll of parchment or paper, written over both on back and front.

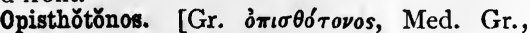
drawn backwards, from ŏ $\pi \iota \sigma \theta \epsilon$, from behind, and $\tau \epsilon i \nu \omega, I$ stretch.] The being drawr back by tetanic spasms of the muscles of the back.

Opium. [L., Gr. ó $\pi\llcorner o \nu$.] The concrete juice of the white poppy.

Opobalsam. [Gr. ö Gilead.

Opodeldoc. [A word coined by Paracelsus.]

1. A kind of plaster for external injuries.

A saponaceous camphorated liniment.

Opopanax. [Gr.] A fotid gum-resin imported from Turkey.

Oppilation. [L. oppilo, I stop up.] (Med.)
Obstruction of the passages by increased secretion or foreign matter.

Opposite leaves. (Bot.) Two only, and developed on the same plane ; e.g. pink, jasmine. Alternate, one a little above or below the other; e.g. rose, laurel.

Opposition. [L. oppositiōnem, from oppōno, I oppose.] (Astron.) Two heavenly bodies are in $\mathrm{O}$. when their geocentric longitudes differ by $180^{\circ}$, i.e. when they are diametrically opposite to one another with reference to the earth.

Opprobrium. [L.] Reproach, combined with contempt or disdain.

0. P. Riots. When Covent Garden Theatre, rebuilt after the fire, was opened in 1809 , the prices for admission were raised. Riots followed for the restoration of the O. P., or old prices.

Ops. (Saturn.)

Opsiometer. An optometer (q.v.).

Optical angle; 0 . axis ; 0 . centre. The Optical axis of a doubly refracting crystal is that direction along which a ray of light passes without undergoing bifurcation. (For O. angle, vide Visual angle; for $O$. centre, vide Centre of a lens.) Optics [Gr. $\dot{\eta}$ on $\pi$ ik' sight]; Geometrical 0.; Physical 0. The science of light and vision. In Geometrical optics the properties of mirrors and lenses are deduced from the laws of reflexion and refraction of light, and these properties are applied to explain the construction of telescopes, microscopes, etc. In Physical O., the phenomena of reflexion, refraction, polarization, interference, etc., of light are traced back to their physical cause, viz. the undulatory motion of the ether.

Optimātēs. [L.] (Hist.) The Roman nobility, as distinguished from the plebeians.

Optimism. (Theodicæa.)

Optimist. One who takes the best, most hopeful, view of a matter; Pessimist, the exact contrary: both being somewhat unpractical. [L. optimus, best, pessimus, worst.]

Optimus Maximus. [L., Best and Greatest.] Latin epithets of Jupiter, indicating his greatness and goodness.

Option. [L. optio, -nem, a choosing.] On the Stock Exchange, a percentage given for the option of selling or buying stock in time bargains at a certain price.

Optometer. [From a Gr. root ó $\pi \tau-$, seeing, $\mu \in ́ \tau \rho o \nu$, measure.] An instrument for determining the distance or limiting distances of most distinct vision, and hence for finding the focal length of a lens proper for a long-sighted or a short-sighted person.

Opus magnum. [L., great work.] A phrase denoting works which are monuments of vast labour and research, as the Decline and Fall of the Roman Empire, by Gibbon.

Opus operantis. [L., the work of the worker.] (Theol.) The effect of the celebrant's intention in the administration of sacraments. (Intentio sacerdotis.)

Opus operätum. [L., work done.] (Theol.) A term denoting the effects of sacraments irrespective of the dispositions of those who receive them. 
Or. [Fr., from L. aurum, gold.] (Her.) The metal gold in coats of arms, represented in engraving by small dots.

Ora. [A.S., metal or money.] O.E. money. The greater and lesser $\mathrm{O}$. in Domesday-book are estimated at twenty and twenty-six pence. In Sw. and Dan., the word also denotes a measure of land.

Oracle. [L. orācŭlum, from os, a mouth.] 1. An answer given by heathen deities to those who consult them. 2. The place at which such answers are given, as the $O$. of Delphi, of Dodōna, etc.

Oragious. [Fr. orageux, orage, a storm, L. aurāticum, aura, a breeze.] (Naut.) Tempestuous, or stormy.

Oramby. (Naut.) A State barge of the Moluccas ; some row 100 paddles. (Koracora.)

Orange. 1. (Her.) A roundlet or disc of an orange colour. 2. (Geog.) A town and small district [L. Arausion, -em] giving the title of Prince of Orange.

Orangemen. (Hist.) The name of an Irish society, instituted in 1795, to uphold Protestant ascendancy.

\section{Orārium. (Stole.)}

Oratorians, or Priests of the Oratory. A title specially given to the congregation of regular clerks founded by St. Philip Neri at Rome, early in the sixteenth century. The Oratory at Paris, founded by Cardinal de Bérulle, in 1611 , produced many eminent men, among them Malebranche and Massillon.

Orb. [L. orbis, a circle.] An emblem of sovereignty, consisting of a globe surmounted by a cross.

Orbicular leaf. [L. orbĭcŭlus, a small disc.] (Bot.) Circular, or nearly so ; it is generally peltate; e.g. the garden nasturtium (Tropæǒlum).

Orbilius. By meton., = a schoolmaster ; the name of Horace's master, who was fond of flogging [L. plāgōsus] (Ep. ii. i. 70).

Orbit. [L. orbita, a rut, an orbit.] 1. (Astron.) The path described by a planet or other heavenly body round its primary; as the orbit of Jupiter or of one of the components of a double star. 2. (Anat.) The cavity in which the eye is embedded ; formed, in man, by seven orbital bones.

Orchestra. [Gr. o’ $\rho \chi \eta \sigma \tau \rho \alpha$, from ò $\rho \chi \in ́ o \mu \alpha \iota, I$ dance.] 1. In the Gr. theatre, a circular level space in front of the spectators, for the evolutions and dances of the chorus. 2. The place in a concert-room or theatre for the band; or, by meton., 3, the full band itself.

Orchil, Orchilla weed. (Archil.)

Ordeal. [L.L. ordalium, Ger. urtheil, judgment.] The referring of the guilt or innocence of the prisoners to the judgment of God. The $O$. was at first under the special protection of the clergy, whose subsequent opposition tended to bring it into disfavour. Among the most re. markable ordeals was the trial by the Eucharist, in which it was supposed that the guilty person would be choked by the Host, as Godwin, father of King Harold, was thought to have been; the ordeals of hot water; of carrying a heated iron bar in the hand ; of stepping over red-hot ploughshares ; etc.

Ordeal bean. (Calabar bean.)

Order. [Fr. ordre.] 1. (Nat. Hist.) A group inferior to class and sub-class; superior to family, tribe, genus, etc. 2. (Arch.) A system of parts in certain established proportions, determined by the office which each has to perform, the whole consisting of ( 1 ) column and (2) entablature. Of these the former is subdivided into base, shaft, and capital; the latter into the architrave, frieze, and cornice. The classical orders are the Tuscan, Doric, Ionic, Corinthian, and Composite.

Orderly. (Mil.) Officer or soldier appointed to await the orders of a superior officer, to attend on him personally during his tour of duty; or one "who' exercises special duties whilst his comrades are unemployed. O.-room is the commanding officer's office in a regiment.

Order of the day. In Parl., a question proposed to the House may be superseded by moving "for the order of the day to be read." If this is carried, the orders are read and proceeded on in the course in which they stand. But this, in its turn, may be superseded by a motion to adjourn. (Previous question, Moving the.)

Orders, Mendicant. Religious bodies of persons under vows to subsist by begging. The chief mendicant urders were those of the Dominicans and the Franciscans. The Carmelites and Augustinians are also to be reckoned among them.

Orders, Religious. Societies bound by a rule of religion. They may be (I) monastic, (2) military, or (3) mendicant. The monastic orders were distinguished by the rule to which they adhered; as the Bonedictines, the Basilians, the Augustinians. Of the military orders the most prominent were (I) those of St. John of Jerusalem, or the Knights of the Hospital, known afterwards as Knights of Rhodes and Knights of Malta; (2) the Knights Templars. and (3) the Teutonic Knights (Teutonic Order). The chief mendicant orders are the Dominicans and the Franciscans.

Orders in Council. 1. Orders by the sovereign, with the advice of the Privy Council, having the force of law, dealing generally with matters of trade, revenue, public health, etc., as to which Parliament has delegated its authority to the Queen in Council; but also, 2, in times of emergency-war, deficient harvest, etc.-going beyond the already delegated powers, in expectation of future Parliamentary protection.

Ordinal. [L. ordināle.] 1. The book containing the forms of making, ordaining, and consecrating of deacons, priests, and bishops. 2. A book containing the rubrics of the Mass.

Ordinal numbers [L. ordinālis, ordinal] answer the question, "In what order?" as, first, second, third, etc.

Ordinance, Self-denying. (Hist.) A resolution of the Long Parliament, in 1644, by which its members bound themselves not to take certain offices, especially commands in the army. The result was the strengthening of the Independent party at the expense of the Presbyterian. 
Ordinary. [L. ordinnārius, an overseer who kceps order.] 1. (Ecci.) One who has, in his own right, immediate jurisdiction. 2. (Leg.) In the Civil Law, a judge empowered to take cognizance of causes in his own right, not by delegation. In Eng. Law, the term is applied to ecclesiastical judges only. 3. In the Court of Session in Scotland, a single judge sitting in the outer house to decide causes in the first instance. 4. (Her.) A part of an escutcheon contained by straight or other lines. It is the most ordinary species of charge. The honourable ordinaries are the chief, pale, bend, bend sinister, fess, bar, chevron, cross, saltier (q.v.). The other ordinaries are called suborcinate.

Ordinary, Laid np in. (Naut.) Laid up out of commission.

Ordinary seaman. (Naut.) One who can make himself useful aloft, etc., though not an $A . B .(q . v$.$) .$

Ordinate. (Co-ordinate axes.)

Ordnance. [Gens d'ordonnances, the ordinary men of arms of France, the artilliers, i.e. crossbowmen, etc., first reduced, under orders, by Charles VII., I444 (Richardson; see Brachet, s.v. "Artillerie").] (Mil.) 1. Any kind of cannon. 2. The Board of O. (now abolished) had the charge of barracks and their furniture as well as of all $O$.

Ordnance corfs. (Mil.) Royal Artillery and Engineers.

Ordonnance. [Fr.] In Arch., the general arrangement of the plan and the superstructure of a design.

Ore. [A.S. or.] Metal combined with other substances; opposed to Native metal.

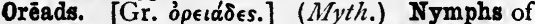
the mountains. (Dryads; Naiads; Nereids.)

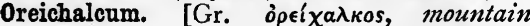
bronze.] With the Greeks and Romans, a mixed metal, of which the basis was brass; but its precise composition is not known.

Orembi. (Oramby.)

Orestes. (Pylades and Orestes.)

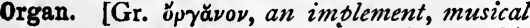
instrument.] (Music.) If complete, is a combination of five instruments : 1 . Choir $O$., having more delicate stops for accompanying the voice, the manual being the lowest. 2. Great 0 ., having pipes more in number, larger, and louder voiced, for grand effects, the manual being second from the bottom. 3. Swell $O$., inclosed in a shutter box, or Venetian swell, opened and closed by a pedal. 4. Solo O., a separate manual for fancy stops, as cremona, vox humāna. 5. Pedal $O$., played by the feet.

Organical description of a curve. [Gr.

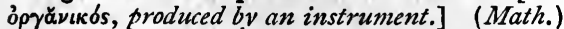
Description by an instrument; as of a circle by a pair of compasses.

Organic laws. Laws affecting the fundamental principles of the constitution of a state. According to some French writers, O. L. are positive enactments, sanctioned by punishments, while the fundamental laws on which they rest are merely declaratory.

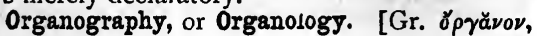

an instrument.] (Bot.) Study of the structure of the organs of plants.

Orgănon. [Gr., instrument.] A name for a work laying down rules for the direction of the scientific faculty, either generally or with reference to some special department of science ; as the Organon of Aristotie or of Bacon.

Organvine. [Fr. organsin.] Fine silk twisted like a rope with different strands.

Orgasm. [Gr. ó $\rho \gamma \alpha \sigma \mu \delta s$, from ò $\rho \gamma \alpha ́ \omega, I$ swell.] (Med.) Immoderate excitement.

Orgeat. [Fr., from orge, barley.] A liquor extracted from barley and sweet almonds.

Orgies. [Gr. ópyıa.] Originally any religious rites or performances. The word was afterwards applied especially to the Dionysiac Mysteries, and then to mysteries in general. (Bacchanalian; Eleusinian Mysteries.)

Orgoglio. [It., pride.] "A hideous giant," brutal and ignorant, born of Earth and Wind, foster-child of Ignorance; an impersonation of Pride (Faëry Queene, bk. i. c. vii.).

Oriel. [Fr. oriol, L.L. oriolum.] (Arch.) A projection from a building, or a recess within it ; (?) $c f$. orillon.

Orient. [L. ŏrien, -tem; lit. the rising sun.] The east.

Orientation. [L. oriens, the rising (sun), the east.] (Eccl.) The deviation from the true east in the direction of a church or chancel. There is a theory that churches had their choirs or chancels facing the point at which the sun rose on the day set apart for their dedication.

\section{Oriflamme. (Auriflamme.)}

Origĕnists. (Eccl. Hist.) Followers of Origen. (Catechists.) They asserted that Christ was the Son of God by adoption (Adoptians), and denied the endlessness of punishments.

Original. 1. In Art, a work done by the artist himself, not copied by another. When the artist copies his own work, this copy is called a duplicate, or Replica. 2. In Law, the part of an indenture executed by the grantor, where the several parts are interchangeably executed between the parties, the other parts being called counterparts.

Origin of a muscle. (Anat.) Its more fixed attachment.

Orillon. [Fr., from oreille, an ear, L. auricŭla.] (Fortif.) Rounded prolongation of the face of a bastion at the shoulder angle, to conceal a gun in the extremity of the flank.

Oriole, Golden. [L. aurěŏlus, dim. of aureus, golden, through Fr. oriol, which has now the def. art., and has become loriot.] (Ornith.) Spec. of bird, about ten inches long; plumage, black and yellow. S. Europe, occasionally Great Britain. Örrǒlus galbŭla [L. galbus, yellow], gen. Ōriŏlus, fam. Örĭlĭdæ, ord. Passĕres.

Orīōn. [Gr.] (Myth.) A mighty giant and hunter who, after his death, was placed amongst the stars. The name is probably Semitic.

Orlando Furioso. (Rhodomontade; Roland.)

Orle. [O.Fr., a margin.] (Her.) An ordinary composed of a narrow band following the outline of the escutcheon at some distance from the edge. 
Orlop, or Orlop-deck. (Decks.)

Ormolu. [Fr. ormoulo.] A variety of brass, 25 parts of zinc +75 of copper, more golden in colour than ordinary brass ; improved sometimes by a gold lacquer. Also called Mosaic gold.

Ornaments. (Eccl.) Of the church and of the minister, are the "ornāmenta," i.e. fitting"s, apparatus, whether ornamental or not.

Ornaments Rubric. That beginning "And here it is to be noted," immediately preceding the order for Morning Prayer.

Ornithichnite. (Ichnites.)

Ornithǒdelphĭa. [Gr. o้ $\rho \nu t s$, б $\rho \nu i \theta o s$, bird, $\delta \in \lambda \phi u ́ s$, zuterrus.] (Zool.) Having a uterus resembling that of birds. The third and lowest sub-class of mammals. (Monotremata.)

Ornithology. [Gr. o $\rho \nu \imath \theta 0-\lambda \delta$ yos, treating of birds.] The science of the natural history of birds and their classification. The latter is somewhat unsettled. We have followed that adopted by $\mathrm{Mr}$. Wallace, in his Geographical Distribution of Animals, as below.

Orders.
I. Passĕres.

II. Pīcārìz.

III. Psittăci.

IV. Cǒlumbæ.

V. Gallinæ.

VI. Opisthǒcŏmi.

VII. Accipitres.

VIII. Grallæ.

IX. Ansěres.

X. Strūthǐones.
Examples.

Including the great mass of the smaller birds-crows, finches, flycatchers, creepers, honey-suckers,

Including woodpeckers, cuckoos, toucans, kingfishers, swifts, etc.

Parrots only.

Pigeons and the dodo.

Grouse, pheasants, curassows, moundbuilders, etc.

The hocco only.

Eagles, owls, and vultures.

Herons, plovers, rails, etc.

Gulls, ducks, divers, etc.

Ostrich, cassowary, apteryx, etc.

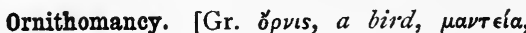
divination.] Divination by the flight of birds. (Augurs.)

Ornithorhynchus părădoxus. [Gr. б̆ $\rho \nu$ s, $-\theta 0 s$,

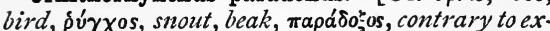

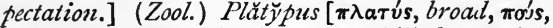
foot], Duck-bill, Mullingong; a billed, ovoviviparous, aquatic, burrowing mammal, eighteen to twenty inches long, with soft dark fur, somewhat like an otter. Australia. Ord. Mŏnotrēmăta.

Orology. Study of mountains [Gr. ópos, mountain].

Oromazdes. The same as Ormuzd. (Ahriman.)

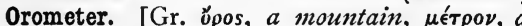
measure.] An instrument for measuring hills in military surveying, combining all the necessary scales and tables for carrying out the different processes.

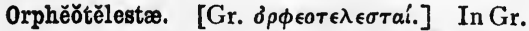
Hist., an obscure sect, the members of which went about undertaking to release people from their sins by songs and sacrifices.

Orpheus. [Gr., Skt. Abhu and Ribhu, names for the sun and the storm-zind.] (Myth.) A son of the river CEăgrus and the Muse Calliŏpe, whose name has become a proverbial expression for the power of music. Men, beasts, trees, stones, and rocks all moved to the sound of his harping; and at his bidding, the ship Argo descended gently into the water, when the Argonauts were unable of themselves to stir it. The threeheaded dog Cerberus, which guarded the gates of Hades, could not resist the spell ; and Hades himself, under the same influence, allowed him to lead away his wife Eury̆diceē, who had died from a snake-bite, and who all but returned to dwell with him in the upper world. Orpheus reappears in The Piper of Hameln (Browning), and both are the singing winds.

Orphic Mysteries. (Hist.) Mysteries celebrated by certain societies, seemingly ascetic, which at the first rise of Greek philosophy assumed the name of Orpheus.

Orphrey, or Orfray. [O.Fr. orfrais, L.L. auriphragium.] A fringe or band of gold, sometimes richly embroidered, sewn on Albs, Dalmatics, and altar frontals.

Orpiment. [L. auripigmentum, pigment of gold.] (Chem.) Trisulphide of arsenic, a bright yellow pigment. It is also called yellow arsenic, or king's yellow. Red orpiment is another name for realgar (q.v.).

Orpin. [Fr., stonecrop.] A yellow colour resembling these flowers.

Orpine. (Bot.) A kind of stonecrop, Sědum tělěphium [Gr. $\tau \epsilon \lambda \epsilon ́ \phi \iota \nu]$, ord. Crassulaceæ (Sedum).

Orrery. A toy for showing children the motions of the planets; called after the Earl of Orrery, the Hon. C. Boyle of the Battle of the Books (q.v.).

Orris. [Corr. from Orphreys.] A pattern work of gold or silver.

Orris-root, Orrice-root. [Corr. from Iris.]

The violet-scented rhizome of Iris florentina and I. germanica ; sometimes called Iris-root.

Orsedew. Dutch gold. (Dutch clinker.)

Orthoclase. (Geol:) Common felspar, Potash $F_{.}$; because it has a flat straight cleavage $[\mathrm{Gr}$. óp $\theta \dot{\eta} \kappa \lambda a ́ \sigma \iota s]$.

Orthodox Church. [Gr. a $\rho \theta \delta \delta \circ o \xi o s$, of right belief.] (Eccl. Hist.) The title of the Eastern or Greek Church.

Orthoepy. [Gr. ò $\rho \partial \delta$, right, exact, є̌nos, word.] In Gram., properly the right use of words, but generally applied to prosody as dealing with their proper pronunciation; as Orthography deals with their proper representation.

Orthognathic. [Gr. o $\rho \theta \dot{\eta}$, sc. $\gamma \hat{\omega} \nu i^{\prime} \alpha, a$ right

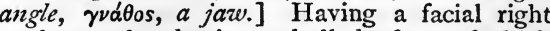
angle, nearly; having a skull the front of which scarcely projects beyond the jaw; opposed to

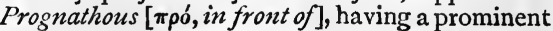
jaw.

Orthogonal. [Gr. o’ $\rho 0 \gamma \omega$ vios, rectanoular.] Any line taken down a hill at right angles to a system of contours (q.v.). (Orthographic.)

Orthographio projection of a line or lines

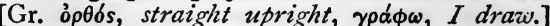
Its representation on paper obtained by letting fall from each point of the line a perpendicular to the plane of the paper; or, it is the perspective representation of the line (or lines) made on the suppositions that the eye is infinitely distant and the plane of the paper at right angles to the direction of vision.

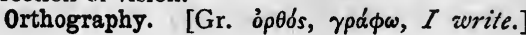


1. (Gram.) The method of denoting sounds by visible signs. (Orthoepy.) 2. (Arch.) A geometrical drawing of a building in elevation or section.

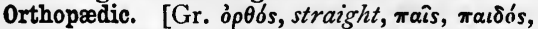
a child.] Relating to the correction of deformity in children.

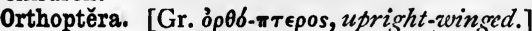
(Entom.) Ord. of insects, properly with four wings ; the fore pair generally leathery, the hind pair folding like a fan, as grasshoppers; sometimes wingless, as female cockroaches. The earwigs, dermaptĕra, belong to this ord.

Ortolan. [Fr., from L. hortŭlānus, a gardener, belonging to a garden.] (Ornith.) A migratory bunting, length about six inches; plumage, brown, black, green, and buff. S. Europe, occasionally Great Britain. Embĕrīra hortŭlāna, subfam. Emběrīrŭdæ, fam. Fringillǐdæ, ord. Passěres.

\section{Ortygia. (Ortygian shore.)}

Ortygian shore. In Shelley's poem Arethusa, the eastern shore of Sicily, near Syracuse. The island of Delos was also called Ortygia, or the quail-land, the quail [in Skt. vartikâ, the returning bird] being one of the birds which come with the first return of spring. It thus became one of the names of the dawn, and was applied to Delos [Gr. $\Delta \hat{\eta}$ ios, the bright land], in which Phœbus and Artěmis were born.

Orus, or Horus. (Harpocrates.)

Orvietan. A supposed antidote to poison, ascribed to a mountebank of Orvieto, in Italy.

Oryctology. Study of objects dug up [Gr. oอvктбs], whether Archæol. or, more particularly, Geol. ; but the term is not often used.

0schophoria. [Gr.] An Athenian festival in honour of Dionysus and Athena; so called from the carrying of $\tilde{\sigma} \sigma \chi \alpha \iota$, or vine branches with grapes.

Oscillating engine. (Steam-engine.)

Oscillation, Centre of. (Centre.)

Oscillum. [L., a little face; dim., through oscŭlum, of os, mouth, face.] A term applied to faces or heads of Bacchus, suspended in vineyards, to be turned in every direction by the wind; supposed to make the vines fruitful in the quarter towards which they looked (see Virgil, Georg: ii. 388).

Osculating circle [L. osculans, -tis, kissing]; 0. plane; at any part of a curve, passes through three consecutive points of the curve ; its radius is the radius of curvature. The $O$. plane passes through three consecutive points of a tortuous curve (or curve of double curvature), such as the thread of a screw.

Osculatorium. (Pax.)

Osiandrians. (Eccl. Hist.) The followers of Osiander, who differed from Luther and Calvin as to the efficient cause of justification.

Os innōminnātum. [L., bone without a name.] (Anat.) Each lateral bone of the pelvis; that apparently single bone into which the three ossa-ischium, ilium, and pubis, i.e. hip-bone, haunch-bone, and share-bone-grow.

Osiris. In Myth., one of the chief deities of Egypt, brother and husband of Isis, and more especially the judge of the dead. As such he was called Rhot-amenti, of which the Grecized form is Rhadamanthys. $\mathrm{He}$ was worshipped under the form of the bull Apis. (Serapis.)

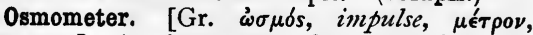
measure.] An instrument for measuring the amount of osmose (q.v.).

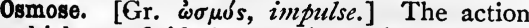
by which two fluids become intermixed through an intervening membrane or other porous substance. The flow towards the fluid which increases in volume, generally the denser, is called endosmose, the other current exosmose.

Osmium. [Gr. ó $\sigma \mu \hat{\eta}$, a smell.] A hrittle grey metal, from the acrid odour of its oxide.

Osnaburgs. Coarse linens, originally imported from Osnaburg, in Germany.

O.S.R. (Obiit sine prole.)

Osprey. [L. ossifrăga, bone-breaker; cf. Fr. orfraie.] (Ornith.) Ossifrage, Fishing hawk, Bald buzzard; spec. of bird, about twenty-two inches long; whitish head, brown back, white belly ; gen. Pandion: Universally distributed, except south part of S. America. Fam. Pandiŏnǐdæ, ord. Accǐpĭtres.

Osseous. [L. ǒs, ossis, a bone.] Bony.

Osseous fishes. [L. Ossěus, bony.] (Ichth.) In Cuvier's system, one div. of fishes, the other being Chondroptěry̆gizi. O. F. are divided into Acanthoptěry̆gĭi and Mălăcoptery̆güi (q.v.).

Ossian's poems. Poems said to have been written by Oisin, or Ossian, a Scottish bard of the third century, and published by MacPherson, in 1760 . The controversy as to their genuineness went on for nearly half a century, and ended much to the discredit of MacPherson's assertions. The materials of the poems, however, seem to be undoubtedly ancient, and were probably obtained by him orally in the Scottish Highlands.

Ossicle. [L. osšrcŭlum, dim. of os, a bone.] A small bone. Ossiculated, furnished with small bones.

Ossifrage. [Peres (Lev. xi. 13), the breaker.] (Bibl.) (Lammergeier.)

Ossuary. [L. ossa, bones.] A charnel-house, a tomb.

Os suffräginis. [L.] (Anat.) The joint in the hinder leg of a quadruped, which is bent back ; the pastern.

Ostāra. (Myth.) An ancient German deity whose name reappears in our word Easter, and may be connected with that of the Semitic Ashtoreth, or Astarte.

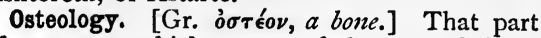
of anatomy which treats of bones and bone tissue, their chemical and physical properties; their shape, growth, articulation, etc.

Osteria. [It.] An hostelry.

0stiārius. [L., a doorkeeper.] 1. (Eccl.) In the Latin Church, the last of the four minor orders. (Hostiarins.) 2. (Rom. Hist.) Among the ancient Romans, a slave stationed at the door of a house, like the French concierge. Hence Eng. usher.

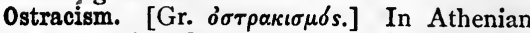
Hist., a vote by which, if given by at least 6000 citizens, the person condemned by it had to go into exile for ten years. The name of the 
person subjected to $O$. was written by each voter

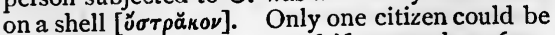
so banished at a time; and if more than 6000 votes were recorded against two or more citizens, the one who was condemned by most votes was alone banished.

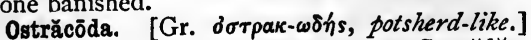
(Zool.) Small bivalve crustaceans, as Cyprĭděs, common in fresh water.

Ostrěřdæ. [L. ostrěa, oyster.] (Zool.) Fam. of molluscs, oysters and scallops. Cosmopolitan. Class Conchĭfěra.

Ostrich. [O.Fr. ostruche, L. avis strūthio,

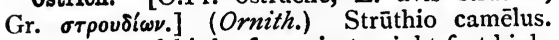
The largest of birds, from six to eight feet high. The quill feathers of the wings and tail furnish plumes. Deserts of Africa and Arabia. The S.-African O. (S. austrālis) is sometimes reckoned a distinct spec. The American ostriches (Rheas) inhabiting the S.-American plains are much smaller. Ord. Strūthiōnes.

Os vespertilionis [L.], i.e. bone with extended wings, like $a$ bat; former name for sphenoid bone (q.v.).

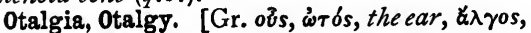
pain.] Ear-ache.

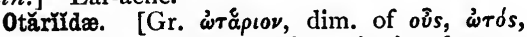
ear.] Otaries, eared seals; pinnigrade carnivorra, sea-lions and bears, able to use their hind limbs freely. Northern parts of N. Pacific, and corresponding south latitudes. Ord. Carnǔvǒra.

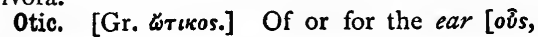
ढ̇rós].

Otitis. Inflammation of the ear [Gr. oiss, فेrós].

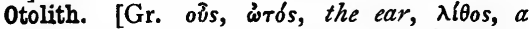
stone.] A loose chalky secretion in the auricular sacs of Articulata (q.v.), especially fishes, indicating, probably, the direction and degree of sound.

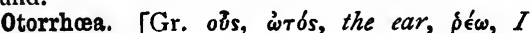
flow.] Discharge of the ear.

- Ottara rima. [It.] The stanza of eight lines always employed by the romantic and narrative poets ; that to which Spenser added the Alexandrine, as a ninth.

0tto. (Attar.)

Ottoman empire. The empire of the Ottoman race of Turks.

Ottoman race. (Ethn.) The youngest branch of the great Turkish family or stem; so called from Othman, who ruled them from 1299 to 1326.

Oubliette. [Fr., from oublier, L. obliviscor, $I$ forget.] A dungeon open only at the top, for persons condemned to imprisonment for life or to a secret death.

Ouches. 1. In Exod. xxviii. 25; ornaments of gold, collets, probably of cloisonnée (q.v.) work, according to Speaker's Commentary. 2. With Shakespeare and others, jewels generally. [Richardson assigns the same meaning and use to (I) nouche, Fr. niche, notch; and (2) ouche, Fr. oche, a notch, ocher, to cut into.]

Ounce. [L. uncia.] 1. The twelfth part of a pound troy. 2. The sixteenth part of a pound avoircupois. The ounce troy $=1_{173}^{17}$, nearly
I 1 , ounce avoirdupois. 8. The fluid ounce is the sixteenth part of an imperial pint, and by weight is reckoned 5467 grains, or $1 \frac{1}{4}$ ounce avoirdupois.

Ourology. The knowledge of disease, as learnt from the urine [Gr. oupov].

-ous. (-io.)

Out-board. (Naut.) Outside a vessel ; opposed to In-board.

Outlawry. (Leg.) Exclusion from the protection of the law, depriving the outlaw of the power of bringing actions, and confiscating his property to the Crown. Inflicted, generally, for nonappearance to an indictment, or for absconding after judgment, leaving the judgment debt unpaid.

Outlier. 1. (Geol.) An isolated portion of stratified rock; separated by denudation from the main rock. 2. One who resides away from the place of his office or duty.

Outpeny. (Inpeny.)

Out-ports. (Naut.) Those on the coast. All in the United Kingdom other than London.

Outré. [Fr.] In Art, exaggerated or overstrained in form or colour.

Outrecuidance. [Fr.] Excessive opinion of one's self; from verb outrecuider, L. ultrà, beyond, cogitāre, to think.

Outrigger. (Naut.) 1. A strong bearn passed through the ports, lashed to the gunwale, and guyed to bolts at the water-line and the masts, to counteract the sirain on them during careening. 2. A boom projecting from a vessel, to hang boats by. 3. Any spar rigged outboard, as the bumpkin, or boomkin. 4. A log of wood, etc., rigged out from the side of a canoe or narrow boat, to prevent it from capsizing. 5. A light rowing-boat, having its rowlocks out-board, supported on iron stays.

Outspan. [Ger. spannen, to yoke, to put to.] To release oxen from the yoke.

Outworks. (Mil.) All parts of a permanent fortification in front of the inside rampart, but more or less defended by it.

Oval chuck. A lathe chuck constructed to hold the piece to be turned in such a way that the cutting tool traces an ellipse instead of a circle.

Ovation. [L. ōvātio, -nem.] (Hist.) The inferior triumph granted to successful Roman generals. (Triumph.)

Overcasting. Sewing by running the thread over a rough edge.

Overies, St. Mary. The ancient name of St. Saviour's Church, Southwark. (?) St. Mary of the Ferry, as given by Stowe, in his Chronicles; (?) over-ey, i.e. over the water, as given by Camden, in his Britannia.-Mrs. Boger, Southwark and its Story, p. 5.

Overlap. (Geol.) The extension of one stratum or set of strata beyond the limits of the lower strata. Very important, as showing that the area of deposition was widening, probably by subsidence; if accompanied by unconformity, it is an evidence of great lapse of time, accompanied by disturbances.

Overseers of the poor. Officers annually nominated by the parish vestry, and appointed by 
magistrates at petty sessions ; their duty being to provide relief for indigent parishioners out of funds collected by them according to a rate made at a vestry meeting. (Poor laws.)

Overshot-wheel. (Water-wheel.)

Overstory. (Arch.) The same as Clerestory. Ovŏlo. [It.] (Arch.) A moulding, whose profile is the fourth part of a circle.

Ovoviviparous. [L. ōvum, egg, vīvus, living, părio, to produce young.] Producing young from eggs, but hatching them before birth.

Ovule. [As if from a dim. of L. ōvum, an egg.] (Bot.) A rudimentary unfertilized seed.

Owenites. (Hist.) The followers of Robert Owen, of Lanark, who maintained the principle of the community of property.

0wl. [Heb. bach-hayya 'anāh.] (Bibl.) Lev. xi. I6; probably the ostrich.

Owler. (Naut.) A smuggler, more particularly of wool.

Owling. In Law, the transportation of sheep or wool out of the kingdom. The statutes relating to this offence have all been repealed.

Owl-glass. (Enlenspiegel, Tyll.)

0x, Wild. (Bibl.) Deut. xiv. 5. (Ball, Wild.)

Oxalio acid. [Gr. $\delta \xi \alpha \lambda i ́$, sorrel.] A poisonous acid, found in wood-sorrel, etc. Its salts are called Oxalates.

Oxford, Provisions of. (Eccl. Hist.) Enactments of the Council held at Oxford (called by its enemies the Mad Parliament), 1258, to remedy the grievances which had arisen from the evasion of the obligations imposed on the king by the Great Charter. (Charta, Magna.)

Oxford Act. (Five-Mile Act.)

Oxford clay. (Geol.) Dark-blue and greyish clays and shales; fossiliferous, with clayey limestone nodules. Middle Oolite.

0x-gang. (Carucate.) 0xide. [Fr.] A compound of oxygen with a base.

Oxygen. [Gr. ơvus, acid, $\gamma \in \nu \nu a ́ \omega, I$ generate.] A gaseous element, supporting life and flame, and originally supposed to be an essential part of every acid.

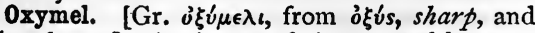
$\mu \boldsymbol{c}^{\lambda}$ l, honey.] A mixture of vinegar and honey.

Oxymöron. [Gr., pointedly foolish.] (Rhet.) The application of paradoxical epithets to the subject of a proposition, often involving a kind of contradiction; as if we were to speak of the cruel kindness of indulging children.

0xytone. [Gr. ó̧útovos.] In Gr. Gram., a word having the acute accent on the last syllable.

Oyer. [O.Fr., L. audīe, to hear.] In Law, a defendant, before pleading to an action on a bond, might crave $O$. of the instrument on which the action was brought, i.e. demand to hear it read. O. was abolished in 1852 .

Oyer and terminer. In Law, the commissions for hearing and deciding causes, under which assizes are held in the different counties.

0 yes! (Oyez!)

Oyez! [Fr., hear ye!] The cry of Norman ushers in courts of justice, metamorphosed by English criers into "O yes!"

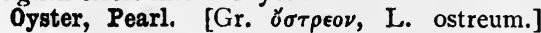
Ăvǐcŭla margărìtı̌ferra ; furnishes pearls, and the best mother-of-pearl. W. coast of Ceylon, Coromandel, Algeria, Columbia, Panama. 'Fam. Ǎvǐcŭlĭdæ, class Conchǐfěra.

Ozæna. [Gr. ǒ $\zeta \alpha \iota \nu \alpha$, from $\delta \zeta \omega, I$ smell.] Fœtid, purulent discharge from the nostrils.

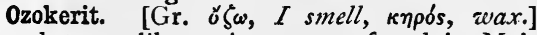
A substance like resinous wax, found in Moldavia, and used in making candles.

Ozone. [Gr. ó $\zeta \omega, I$ smell.] Oxygen in a peculiar state, in which its powers are intensified and it becomes perceptible to the smell.
P. A consonant of the labial series; is, as we might expect, interchangeable with $b$ in nearly all known languages. As an abbrev., it stands in Latin for Publius; and it is sometimes used, in medicine, for Pugillus, the eighth part of a handful; p.æ. stands for partes æquâles, or equal parts; and P. in Music is piano, or soft.

Pābǔlum. [L.] Lit. food; and so material for thought, learning, instruction.

Pace, Geometrical. [L. passus, Fr. pas.] The distance from where one foot is put down to where it is put down again; and so a measure of five feet.

Pảcè tǔâ. [L.] With your good leave.

Pacha. (Pasha.)

Pachacamac. The ancient Peruvian name for the Creator of the universe.

Pacha's standard. A horse's tail fixed on a lance. (Pasha.)

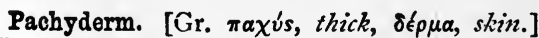
(Zool.) Thick-hided; with Cuvier, = hoofed nonruminant mamalia ; e.g. elephant, hippopotamus, tapir, pig, horse.

Pācíficæ littëræ. (Dimissory letters.)

Pacification, Edicts of. In Fr. Hist., edicts of French kings in favour of their Protestant subjects, as the Edict of Nantes.

Pack. Of wool, is 240 lbs.

Packfong. [Chin.] German silver.

Pack-ice. lce in the state of large floating pieces.

Packwax, Pax wax (?). (Anat.) A large strong sinew in the neck of quadrupeds; the ligämentum nuchæ, ligament of the nape of the neck.

Pacte de Famine. In Fr. Hist., an association, in the reign of Louis XV., for raising the price of corn by exporting it and by reintroduc. ing it at a vast profit.

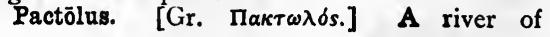


Lydia, which was said to bring down golden sands.

Padding. The impregnation of cloth with a mordant.

Paddle. An instrument for stirring the sand and ashes in a glass furnace.

Paddlewood. A light strong wood from Guiana, used by the natives for paddles, by us for cotton-gin rollers.

Paddy. Rice still in its husk.

Paddy-boat. (Naut.) A Ceylon boat for carrying rice and other necessaries.

Paddy's hurricane. In Naut. slang, not wind enough to extend a flag.

Padishah. A title of the Turkish sultan and of the Persian shah.

Padrone. [It.] (Naut.) The master of a Mediterranean craft.

Paduan. (Naut.) A Malay pirate armed with one gun forward and another aft.

Paduan coins. Coins forged by Cavino and Barsiano, the artists employed on the pope's medals from Julian III. to Gregory XIII., I5501572.

Paduasoy, corr. into Fr. pou de soie. A silk stuff, originally made at Padua.

Pæan. [Gr. raıáv.] Among the Greeks, (I) a hymn in honour of Apollo; (2) a war-song before or after battle. Hence any exulting or triumphant cry.

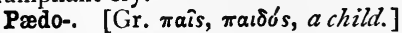

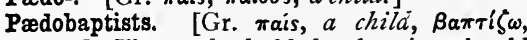
I baptize.] Those who hold that baptism should be administered in infancy. (Anabaptist.)

Pænŭla. (Chasuble.)

Pæon. [L., Gr. $\pi a \iota \omega \dot{\nu}$.] A metrical foot of four syllables, three short and one long. $P$. is primus, secundus, tertius, quartus, according to the position of the long syllable; e.g. $-\backsim \cup \checkmark$,

- vu, vuーv, vvv-.

Paganism. Properly, the condition of a pagan, or inhabitant of a country district. (Paynim.) Commonly, the religious state of the whole human race exccpt of those who are Christians, Jews, or Mohammedans.

Page. A word of uncertain origin, applied to youths in the service of noble or royal personages.

Pagination. [L. pagina, page.] The marking of the pages of a book.

Pagōda. [Pers. but-kadah, house of gods.] 1. (Arch.) A temple containing an idol. 2. The name of a coin, both gold and silver.

Pahi. (Naut.) Large war-canoe of Society Isles.

Paigle, Pagle, Peagle. [Probably épingle, "the style and stigma being stuck, as a pin, into the germ" (Latham).] The cowslip.

Paillasse. [Fr. paille, straw.] An undermattress of straw.

\section{Painim. (Paynim.)}

Pains and Penalties, Bill of. A process for punishing State offenclers out of the ordinary course of justice. The last instance was the Bill passed by the House of Lords against Queen Caroline, 1820 , but not carried into the House of Commons.
Painter. 1. (Naut.) A rope in the bows of a boat to make her fast with. 2. (Zool.) (Couguar.)

Pair. [L. păres, equal.] Of stairs, cards, organs, = a set ; so "Peers," in House of Lords, a body of equals, in deliberation.

Pair off. When two voters opposed to each other agree to abstain from voting, and thus neutralize each other, they are said to pair off.

Palace. (Alhambra; Cloud, Palace of St.; Escurial; James, Palace of St.; Kremlin, The; Stephen, Palace of St.; Truileries; Vatican; Versailles, Ralace of; Whitehall; White House.)

Palace Court. A court of justice, established by Charles I., for trying personal actions within a liberty extending to twelve miles round Whitehall. Abolished 1849 .

Palădins. 1. Properly, officers of the palace, the L. comites palatii, counts of the palace, or palatini, of the Byzantine court. 2. In early French romances, any lord or chief. Hence especially the heroes or warriors of Charles the Great (Charlemagne).

Palæocrystic Sea. That around the Poles, a

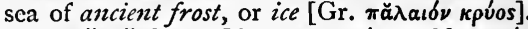

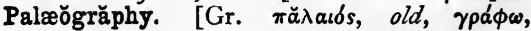
$I$ write.] The science of deciphering ancient inscriptions. (Diplomatics.)

Palæolithic. (Prehistoric archæology.)

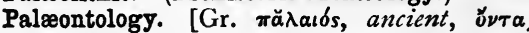
bcing.] That part of Geology which deals with organic life, of plants and of animals, their remains, and (e.g. ichnites) their records.

Pălæŏthërium. [Gr. $\theta$ níov, a beast.] (Geol.) A gen. of extinct pachyderms ; in size from that of a sheep to that of a horse, in appearance and probably in habits like the tapir, but much slimmer. Eocene; England.

Palæozoic. (Neozoic.)

Palæstra. [Gr. $\pi \alpha \lambda a i ́ \sigma \tau \rho a$, from $\pi a \lambda a i ́ \omega, I$ zurestle.] A place or school for wrestling. In Greece, the palæstra was a part of the Gymnasium.

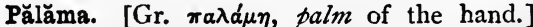
(Zool.) Membrane or web between the toes of web-footed animals.

Palanquin. [Javan pâlangki.] A covered litter borne on men's shoulders.

Palatals. The letters $d, g, j, k, l, n, q$; so called from the organ chiefly used in pronouncing them.

Palatinate. The name of two German states, called the Upper and Lower Palatinates, which remained under the same sovereign till 1620 . The word means properly the lordship of a palatine (Paladins). Hence the Ger. pjalagraf and the Eng. palsgrave.

\section{Palatine. (Tavernicus.)}

Pale. [Fr. pal.] (Her.) An ordinary bounded by two vertical lines, and containing the middle third part of the escutcheon.

Pale, The, or Within the Pale. In Ir. Hist., that portion of Ireland within which the dominion of the English was for some centuries confined after the conquests of Henry II.

Pales, Paleø. [L.] (Bot.) Chaff-like scales, 
such as the inner scales of the flower of grasses.

Palestine, Palestina. Exod. xv. 14; Isa. xiv. 29; Joel iii. 4; is simply Philistia, the country along the coast, held by the Philistines.

Paletot. [Fr.] A loose overcoat.

Palette. [Fr.] An oval tablet, with a thumbhole for holding it, on which a painter lays and mixes his colours.

Palfrey. [Fr. palefroi.] An easy-going roadster, especially for a lady or an ecclesiastic.

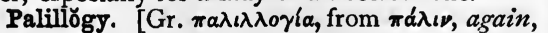

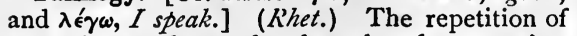
a word or a phrase, for the sake of greater impressiveness, as "The living, the living, he shall praise Thee."

Palimpsest. [Gr. $\pi \alpha \lambda i \mu \psi \eta \sigma \tau o s$, rubbed again.] A parchment from which one writing has been erased to make room for another. In this way many valuable ancient works have been lost. A few have been recovered from the writing by which they had been overlaid.

Palindrome, Palindromio verses. [Gr. $\pi \alpha \lambda$ i $\nu$ Spopos, running back, running backwards and torwards.] Words or verses which may be read backwards as well as forwards; as "Roma tibi subito motibus ibit amor," Rome, to thee love will suddenly come with its tumults; "Signa te signa temere me tangis et angis." The matter of such verses must always be worthless.

Paling-board. One of the outside slabs sawed from the four sides of a tree to square it (used for palings).

Palingenĕsiss. [Gr., from $\pi a ́ \lambda \iota \nu$, again, and

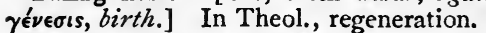

Palinode. [Gr. $\pi \alpha \lambda \iota \nu \omega \delta$ i $\alpha$.] In poetry, a recantation, or withdrawal of invectives expressed in a previous poem.

Palisades. [Fr. palissade, It. palizzata.] (Mil.) Row of triangular wooden stakes about ten feet long with six-inch faces, sunk upright in the ground for one-third of their length, and placed about three inches asunder.

Palissy ware. Made at Saintes and Paris by Bernard de P. and his assistants, temp. Henri II.Henri IV. Characterized by coloured reliefs, especially of fish and reptiles. The moulds are still in use.

Palkee. [Hind. pâlkî.] A palanquin.

Pall. (Her.) A charge shaped like a Y, in imitation of the ecclesiastical pall. (Pallium.)

Pallădium. [Gr. $\pi \alpha \lambda \lambda a ́ \delta$ iov.] 1. A wooden statue of Pallas, supposed to be the safeguard of Troy. Hence any special safeguard or defence, as of trial by jury, or a free press for the British constitution. 2. A rare, steel-grey metal, very infusible (from the planet Pallas, discovered a year earlier).

Pallas. In Gr. Myth., a name of Athena, probably as the virgin goddess [Gr. $\pi \alpha \dot{\lambda} \lambda a \xi, a$ maiden].

Pallet. [Fr. palette.] 1. (Her.) A diminutive of the pale, being one-half its size. 2. A gilder's tool for taking up and applying gold-leaf. 8 . The projecting piece at the end of a clock escapement, by which it acts on the scape-wheel.

Palliobranchiata. (Brachiopoda.)
Pallium. [L., a cloak.] (Eccl.) A vestment sent from Rome to archbishops on their accession to their sees. It has now become a mere white woollen band, worn round the shoulders, with one end hanging in front, the other on the back.

Palm. (Naut.) 1. The face of an anchorfluke. 2. A flat piece of metal set in leather or canvas, and fastened in the palm of the hand, for forcing a needle through canvas.

Palm, Order of the Fruitful. A German society, formed 1617, dissolved 1680, for preserving and cultivating the German language.

Palmair. [Fr. palmaire, relating to the palm of the hand.] (Naut.) 1. Old name for a rudder. 2. A pilot.

Palmam qui mĕrŭit fĕrat. [L.L.] Let the deserving bear the palm (the prize of victory). (Olympic games.)

Palmary. [L. palmärius, deserving the palma, prize.] Pre-eminent, palmy, chief.

Palmate leaf [L. palmātus, shaped like the palm of the hand (palma)], or Quinate [quini, five each]. (Bot.) One with five lobes, as marsh cinquefoil. Digitate [dĭgŭtätus, having fingers], one with five leaflets, more or less, radiating separately from each other from one point, as cinquefoil, tormentil.

Palmers. (Hist.) C.rusaders returned from the East; so called from the palm branch which they commonly carried with them.

Palmerworm. [Heb. gâzâm (Joel i. 4), one who bitcs off.] (Bibl.) Larva of locust.

Palmetto State. S. Carolina, the arms of which contain a palmetto.-Bartlett's Americanisms.

Palmiped. [L. palma, a palm, hand.] Webfooted.

Palmistry. [L. palma, the hand.] The divination which professes to tell a man's fortune by the lines on his hands or fingers. Called by the Greeks $\chi \in \iota \rho \rho \mu \alpha \tau \epsilon i \alpha$, Chiromancy.

Palpebral. [L. palpebrālis, from palpebra, eyelid.] (Anat.) Pertaining to the eyebrow.

Palpi. [L. palpus, a touching softly, hence the instrument with which this is done.] (Entom.) Feelers attached to the mouths of insects, spiders, crustaceans, and acephalous molluscs.

Palūdamentum. [L.] In Rem. Ant., a military cloak, worn by generals.

Paly. (Her.) Covered with bands alternately of two tinctures, vertical like a pale $(q . v)$.

Pamban manché, or Snake-boat of Cochin. (Naut.) A canoe, from thirty to forty feet long, cut out of a solid tree, and propelled by paddles, double-banked. Used on the rivers and backwaters of Cochin.

Pamela, or Virtue Rewarded. Richardson's novel, 1740. P. is the virtuous, persecuted servant, who becomes the wife of her rich young master.

Pampas. The treeless plains of Patagonia and La Plata.

Pampero. A dry north-west wind, blowing from the Andes to the coast over the Pampas.

Pamplēgiă. [Gr. $\pi \hat{\alpha} \nu$, all, the whole, $\pi \lambda \eta \gamma \dot{\eta}$, stroke, blow.] General paralysis. (Hemiplegia.)

Pan. [Gr.] (Myth.) A rural deity, de 
described as playing on his harp among the reeds and rushes. His name was supposed to be the same as the word $\pi \hat{\alpha} \nu$, all; but it really represents the Skt. Pavana, the soft puffing breeze [L. Făvōnius], which discourses only sweet music. (Orpheus.)

Pan. A mixture of areca nut, betel, and lime, chewed by Asiatics.

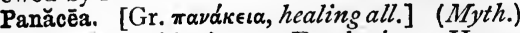
A daughter of Asklepios, or Esculapius. Hence any supposed remedy for all diseases.

Panache. [Fr.] A plume worn on the helmet.

Panagia. [Gr., All-lady.] The blessed Virgin.

Pan-Anglican Synod. A Synod with representatives from all Churches in communion with the Church of England.

Panathenaic festival. (Hist.) Two great festivals of the inhabitants of Attica, in honour of Athena, were so called; the greater celebrated once in five years, the lesser every third year, or perhaps yearly. In the former, the Peplos, or sacred robe of the goddess, was hung like a sail on a vessel like a ship, and carried to the Acropolis, where it was placed on her statue.

Panchatantra. [Skt., five books.] An ancient collection of tales in Sanskrit. The Persian translation, called the Book of Calila and Dimna, is attributed to Bidpai, or Pilpay. Another set of tales, called the Story of the Seven Sages, was also translated into Persian from Sanskrit; but the Sanskrit original has not been discovered. These stories found their way into Europe, and were reproduced in collections such as the Gesta K'omanorum, in which they were made to answer a strictly theological purpose. (Hitopadesa.)

Pan coupé. [Fr. pan, skirt, flat front.] (Mil.) The junction of the two adjacent superior slopes of a parapet at the salient of a work, when cut flat for the purpose of enabling a frontal fire to be brought on the capital (q.v.).

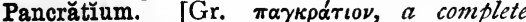
victory.] A kind of athletic contest, in which wrestling and boxing were united.

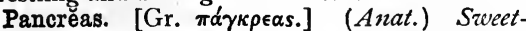
bread, a conglomerate gland across the posterior wall of the abdomen, secreting a fluid which is supposed to render absorbable the oily parts of food.

Pandects. [Gr. $\pi \alpha \nu \delta \delta^{\prime} \kappa \tau \alpha l$, plu. of $\pi \alpha \nu \delta \in \varepsilon^{\prime} \kappa \tau \eta s$, all-receiving.] The great compilation of Roman law executed under Justinian, sixth century. (Digests.)

PandēmŏnǏum. [Gr. $\pi \hat{\alpha} \nu$, all, $\delta a i \mu \omega \nu, a$ demon.] Milton's name for the "high capital of Satan and his peers."

Pandits. 1. Learned Brahmans in India. 2. Pretenders to learning.

Pandōra. [Gr. $\pi \hat{\alpha} \nu, a l l, \delta \hat{\omega} \rho o \nu, a$ gift.] (Myth.) According to Hesiod, the first woman; so called as being given to men by all the gods. Being presented to Epimetheus, she lifted the lid of the box on his threshold, and let loose all the evil things shut up in it.

Pandora's box. (Pandora.)

Pandore. (Bandore.)

Pandour. A Hungarian foot-soldier in the Austrian service. They were originally raised in the mountainous districts of Lower Hungary, near the village of Pandur.-Webster, Eng. Dict.

Panduriform leaf. (Bot.) Oblong, contracted in the middle, something like a fiddle [L. pandūra] ; e.g. leaves of Rŭmex pulcher.

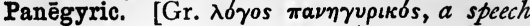

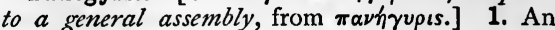
oration in praise of an individual or of a body of men, especially at the great games. The P. of Isokrates was composed for the Olympic festival, but was not recited. 2. (Eccl.) Sermon in honour of particular saints.

Panel. [O.Fr.] 1. (Arch.) A compartment with raised margins, as in ceilings, wainscotings, etc. 2. In Law, a roll on which are written the names of those who are to serve on a jury. 3. In Scot. Law, the defendant in a criminal cause is called pannel (Wedgwood, Dict. of Etymology, s.v. "pane," "pannel "). 4. A thin board for painting a picture on. 5. A heap of ore dressed ready for sale. 6. A square section of a coal-seam worked separately. \%. A portion of solid rock left unworked in a mine.

Pānem et Circenses. [L.] Bread and the Circensian games; that is, popular indulgences which the mob insist on receiving. (Circus.)

Pangaia. (Naut.) E.-African vessel, resembling a barge. Its planks are fastened by wooden pegs, and sewed with twine. It sets one sail made of cocoa-nut leaves.

Pangloss. A poor and conceited pedant in Colman's play of The Heir-at-Law ; the name implying a knowledge of all tongues [Gr. $\gamma \lambda \hat{\omega} \sigma \sigma \alpha$ ].

Panic. Any sudden and groundless alarm. This meaning of the word is explained by the myth, that on the Indian expedition of Bacchus, Pan, being surrounded by his enemies, so scared them with the echoes of a rocky valley that they all instantly fled.

Panic, Commercial. The crisis produced when the bounds which separate overtrading and rash speculation from legitimate commercial risk have been passed. When bankers contract their accommodation, the discounter draws on the resources of the Bank of England, which attempts to check such applications by raising its rate of discount. If the rate be raised to a height which causes a collapse of credit, large bankruptcies follow, and the result is a panic ; traders of undoubted solvency, and possessed of a capital more than able to meet all claims, being often involved in the calamity.

Panicle. [L. pānǐcŭla, a tuft, panicle, dim. of pānus, a bobbin-thread.] (Bot.) A compound raceme, the inflorescence loosely rising from branched pedicels; most common in grasses.

Pânini. The most celebrated of the Sanskrit grammarians; his work being even now the standard of Sanskrit grammar; many centuries B.C.

Pannag. Ezek. xxvii. I7; occurs nowhere else, and is left untranslated. The Syriac Version renders it "millet;" Ewald, "sweet-wares." Fürst inclines to the name of a fertile placeperhaps Pingi, mentioned in the Mishna, between Baalbec and Damascus. - Speaker's Commentary. 
Pannyar. (Naut.) Kidnapping negroes on the African coast.

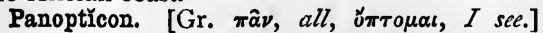
A name coined by Jeremy Bentham for his model prison, in which the cells were so arranged that the inspector could see each prisoner at all times without heing seen himself.

Panorama. [Gr. $\pi \hat{a} \nu$ ő $\rho \bar{\mu} \mu \alpha$, all viezw.] A circular painting exhibited on the walls of a building of the same form.

Pan's pipes, Pandean pipes. A combination of pipes graduated in length and tone; the upper ends open, level, played upon by the mouth; the lower ends closed. Very ancient. I.q. $\sigma \hat{v} \rho \iota \gamma \xi$ and fistula; the first idea of an organ.

Pansterěŏrāma. [Gr. $\pi \hat{\alpha} \nu$, all, $\sigma \tau \epsilon \rho \epsilon \delta$, solid, op $\rho \tilde{\alpha} \mu \alpha, a$ view.] A model of a town or country erected in cork, wood, or any other solid substance.

Pantagruelism. The theory or practice of the medical profession, from Pantagruel, a character of Rabelais.

Pantaloon. [It. pantalone.] A chief character in pantomimes.

Pantheism. [Gr. $\pi \hat{a} \nu$, Đéos, God.] In Philosophy, the theory which makes God and the universe in its totality, identical; and by inference denies the existence of a conscious mind outside of nature.

Pantheon. [Gr.] A temple dedicated to all the gods. Such was at Rome the structure ascribed to Agrippa, son-in-law of Octavius (Augustus).

Pantile. A tile with a curved surface.

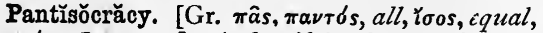
$\kappa \rho \alpha \tau \epsilon ́ \omega, I$ govern.] A fanciful scheme of equal government, that is, of socialism, suggested by some enthusiastic admirers of the French Revolution, amongst whom at one time were Southey and Coleridge.

Pantograph. [Gr. $\pi \hat{a} s, \pi \alpha \nu \tau \delta s$, all, the whole, $\gamma \rho \alpha \dot{\phi} \omega, I$ draw.] An instrument for producing enlarged or reduced copies of drawings.

Papal States. Formerly, an irregular group of states, Z-shaped, the northern and eastern portions, Romagna and The Marches, being connected by a strip across the Apennines with the southern, or States of the Church. Romagna annexed formally to kingdom of Sardinia, 1860 ; the rest to kingdom of Italy, 1870.

Papeterie. [Fr.] An ornamental case containing writing-paper, etc.

Papier-maché. [Fr., chewed paper.] Paper pulp, or sheets of paper glued and pressed together, for making mouldings, trays, etc.

Papilionaceous plants. [L. pāpǐlío, a butter fy.] (Bot.) Those leguminous plants which have the pea-like, five-petalled flower, i.e. vexillum, standard, the large $P$. at the back; ālæ, wings; and cărina, keel, which is made up of two petals, generally united by their lower edges.

PāpǔlǐōnǏdes. [L. pāpǔlǐōnem, a butterfly.] (Entom.) Butterflies, Lëpřdoptěra with knobbed

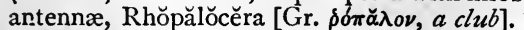

Păpillæ. [L., pimples.] 1. (Anat.) Minute conical processes at the surface of the trie skin, in several parts; highly vascular and nervous, and actively concerned in the sense of touch. 2 . (Bot.) Certain cellular growths on the margin or upper surface of the fronds of ferns.

Pappus. [L.] The seed-down by which the fruit of some plants, especially Compǒsĭtæ, is carried through the air; $e . g$. dandelion.

Papyri. [L.] Scrolls written on a surface made from the stalks of the Egyptian plant papyrus.

Papyrine. [Fr. papyrine, made of paper.] Parchment paper. (Parchment paper.)

Papyrography. [Gr. $\pi \dot{\pi} \pi \bar{u} \rho o s$, papȳrus, $\gamma \rho \alpha ́ \phi \omega, I$ write.] Printing from pasteboard covered with a calcareous substance, instead of the stone used in lithography.

Păpȳrus. [Gr. $\pi \alpha$ ávópos.] (Bot.) A gen. of plants, ord. Сy̆pēraceæ. P. antīquorum, a water-plant, from whose soft cellular flowerstem the most ancient "paper" was made.

Pâque. The French form of the word Pascha, meaning Easter.

Par. [L., equal.] The exact correspondence of a public security or stock with the sum which it represents. Absolutely safe investments will always be at par, if the capital value is not likely to be increased or diminished.

Parable. In Ezek. xx. 49, "Doth he not speak P.?" Ps. lxxviii. 2 ; Numb. xxiii. 7 ; Job xxvii. I, and many other passages, is = riddle, mysterious or strange language. So Jotham's "parable" in the heading of Judg. ix. (which is not a parable but a fable) is $=$ his riddle, his perplexing question; (?) because parables, being words to the wise, were often riddles; or (?) Gr. ; $\pi \alpha \rho \alpha \beta o \lambda \eta^{\prime}$, in its occasional meaning of obliquity.

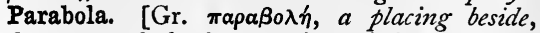
and so a parabola, because its axis is parallel to the side of the cone.] (Math.) The curve obtained by cutting a cone by a plane parallel to a tangent plane. It would be traced out by a point moving in such a way that its perpendicular distance from a fixed line equals its distance from a fixed point, its focus.

Părăbŏlāni. [Gr. $\pi \alpha \rho \alpha \beta o \lambda \eta ́$, a venture, risk.] In the ancient Church, officers who attended upon the sick; ready also to engage in quarrels between Church and State; e.g. that between Cyril and Orestes of Alexandria.

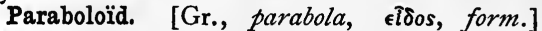
(Math.) The solid generated by the revolution of a parabola round its axis of symmetry.

Paracelsists. Followers of the quack or empiric Paracelsus, who, in the sixteenth century, opposed the traditionary doctrines of the schools of Hippocrates and Aristotle.

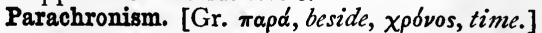
An error in chronology, which assigns too late a date to any event.

Parachute. [Fr., from parer, to ward off, chute, fall.] An umbrella-shaped machine, for breaking the fall of anything let drop from a balloon.

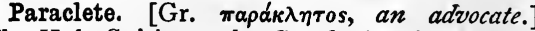
The Holy Spirit, as the Comforter of mankind. In the early ages, some believed that the Paraclete would appear corporeally on the earth. 
Hence Simon Magus, Manes, Montanus, and others pretended to be this expected Paraclete. (Manichæans; Montanists.)

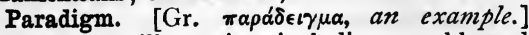
(Rhet.) Any illustration, including parable and fable.

Paradise. (Parvise.)

Paradise of fools. (Limbas.)

Parados. [Fr., from parer à dos, to parry behind.] (Fortif.) Embankment of earth to protect the occupiers of a fortification work from the fire of an enemy in their rear.

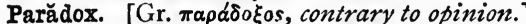
A proposition which seems to be absurd, or inconsistent with previous experience or previously ascertained truths, although it may turn out to be perfectly well founded.

Paraffin. [L. părum affīnis, but little akin, i.e. chemically indifferent, resisting strong acids and alkalies.] A hydro-carbon, from distillation of wood, peat, bituminous shale, coal ; very abundant in beech-tar.

Paragium. (Appanage.)

Paragōgē. (Metaplasm.)

Parăgon. [Fr.] 1. A model, or pattern, with the connotation of special perfection. 2. A kind of type, as-

\section{Cape.}

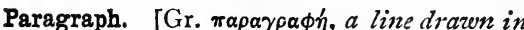
the margin.] A mark used in printing; thus: I

Paraleipsis. [Gr., from $\pi \alpha \rho a \lambda \epsilon i \pi \omega, I$ leave on one side.] (Rhet.) The artfully displayed omission of details, in order to rouse the emotions of the hearer.

Parălĭpŏmĕna. [Gr., things left on one side.] The name given in the Septuagint to the two Books of Chronicles, as supplementing those of the Kings.

Parallactic instrument. (Parallax.) An ancient instrument for observing the zenith distances of stars.

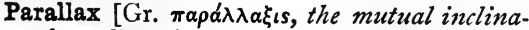
tion of two lines forming an angle]; Annual P.; Binocular P.; Diurnal P.; Equatorial P.; Geocentric P.; Horizontal P. Parallax is the change in the angular position of a point when seen first from one station and then from another. When a point is viewed by one eye and then by the other (without moving the head), the change in the direction in which it is viewed is a $\mathrm{P}$., and is sometimes called a Binocular $P$. The Diurna or Geocentric $P$. of a heavenly body is the difference at any instant between its position as seen by the spectator, and its position as it would be seen by a spectator having the same zenith occupying the position of the centre of the earth. The Diurnal $P$. is commonly called simply the $P$. of a heavenly body. The Horizontal $P$. of a heavenly body is its P. when on the spectator's horizon; it is the angular magnitude of the earth's radius as seen from the heavenly body. In the case of the moon, this angle is reckoned with respect to the radius of the earth's equator, and is called the moon's Equatorial horizontal P. The Annual $P$. is a small change of position observable in a few fixed stars when seen from different points of the earth's orbit; it is the angle subtended at the star by a radius of the earth's orbit.

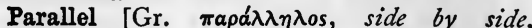
parallel]; P. motion; P. of declination; P. of latitude. Two straight lines are Parallel when, being in the same plane, they may be produced indefinitely in both directions without meeting; planes are $\mathrm{P}$. when, being produced indefinitely in all directions, they never meet. The $P$. motion is a piece of linkwork connecting the end of a piston-rod to the end of the beam of a steam-engine in such a manner that the end of the former, while moving up and down a straight line, causes the latter to move backwards and forwards in a circular arc; the force being transmitted, whether a pull or a push. $P$. of latitude, (I, Geog.) a small circle parallel to the earth's equator; (2, Astron.) a small circle on the great sphere parallel to the ecliptic. $P$. of declination, a small circle on the great sphere parallel to the celestial equator.

Parallel. (Mil.) Large trench with covering parapet embracing the fronts of a fortification to be attacked, and serving as a communication between the different approaches.

Parallel. (Naut.) Latitude. P.-sailing, sailing due $\mathrm{E}$. or $\mathrm{W}$.

Parallelepiped. (Math.) A solid contained by six parallelograms.

Parallelism. [Gr. $\pi \alpha \rho a ́ \lambda \lambda \eta \lambda$ os, side by side.] In Hebrew poetry, the rhythm obtained by expressions balancing each other, as, "The Lord is my light; whom shall I fear? the Lord is the strength of my life; of whom shall $\mathrm{I}$ be afraid?"

Parallelogram [Gr. $\pi \alpha \rho \alpha \lambda \lambda \eta \lambda o^{\prime} \gamma \rho \mu \mu \mu \nu, a$ parallelogram ] P. of forces; $\mathbf{P}$. of velocities. A four-sided figure whose opposite sides are parallel. If two adjacent sides represent in magnitude and direction two forces (or velocities) acting on (or moving) a particle at the angular point, the single force (or velocity) equivalent to the two is represented in magnitude and direction by the diagonal drawn through that angular point. This theorem is called the $P$. of forces (or velocities).

Parallel-veined leaves. (Bot.) 1. Those of endogens generally; the veins running straight to the margin, from and parallel to the midrib; as grass, lily. 2. Reticulated venation [L. rētícŭlum, dim. of rēte, a net], that of exogens generally; the veins leaving the midrib at greater or less angles, and giving off other veins again; as oak, rose, laurel. 3. Furcate $V$. [L. furca, a fork], that of acrogens generally; the veins leaving the midrib as in No. 2, then dividing in a forked way; as in ferns.

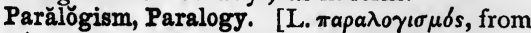

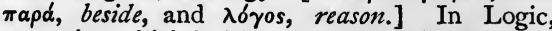
reasoning which is false in form, i.e. in which the conclusion does not follow from the premisses. (Syllogism.)

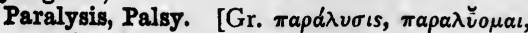
I am disabled at the side.] (MTed.) A loss, more or less complete, of the power of motion, 
and, in some cases, of sensation also. (Hemiplegia ; Pamplegia ; Paraplegia.)

Paramagnetic bodies. [Gr. rapá, alongside of,

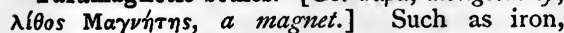
nickel, manganese, etc. A bar of either of these substances tends to place itself in a direction parallel to that of a magnet in its neighbourhood. The direction of their magnetization is the same as that of the field in which they are placed. Other bodies, as bismuth, zinc, etc., have the direction of their magnetization opposite to that of the field; these are Diamagnetic

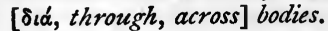

Paramatta (from Paramatta, in Australia). A fabric resembling merino, made of worsted and cotton.

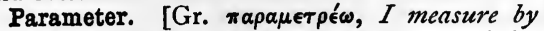
something else.] 1. (Math.) Any one of the constants which connect the variables of an equation. If the equation represents a curve, the parameters distinguish curves of the same kind from each other; thus $(x-a)^{2}+(y-b)^{2}$ $=c^{2}$ is the equation to a circle; $a, b, c$, are the parameters, and for different values of them we have circles of different sizes in different positions. 2. (Crystallog.) The parts of the axes cut off by any one face or cleavage plane, or any three lines proportional to them, are the parameters of the crystal.

Paramos. Mountainous districts in S. America, in which a damp cold prevails perpetually.

Paramonnt. (Paravail.)

Para nut (from Para, in Brazil). The Brazil nut.

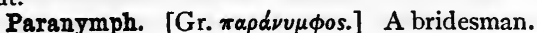

Paranzello. (Naut.) Small, pink-sterned vessel, with lateen mainsail and mizzen, and large jib ; Mediterranean.

Parapet. [Fr. parapet, from It. parapetto, parare, to cover, petto, the breast.] (Fortif.) Bank of earth covering men and guns behind it ; its interior slope very steep, and the superior or upper one declined gently outwards, to facilitate the operation of firing from behind it.

Paraphe. [Through Fr. parafe, initials, or a flourish, and L. paragraphus, from Gr. $\pi a \rho a$ ypaфos, a mark made by the side.] An arbitrary addition to a signature or monogram.

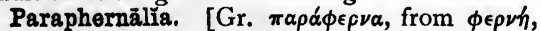
$a$ dowry.] In Law, the apparel, jewels, etc., of a wife, resarded as belonging to her in separate property.

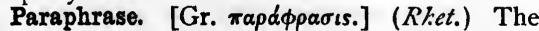
rendering of a passage in easier and simpler language.

Paraphrase of Erasmus. (Bible, English.)

Paraphrases, Chaldee. (Chaldee Paraphrases.)

Părăplëgǐă. [Gr.] (Med.) Paralysis of onehalf of the body, taken transversely. (Hemiplegia.)

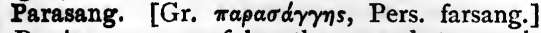
A Persian measure of length, somewhat exceeding our league, according to Herodotus. Others make it twice this length.

Paraselene. [Gr. rapá, beside, $\sigma \in \lambda \eta \eta \eta \eta$, moon.] A meteor which consists in the simultaneous appearance of several moons. (Parhelion.)

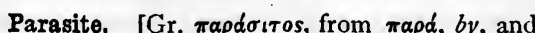
oiros, food.] One who lives by eating at the table of a patron. Hence a flatterer or fawner.

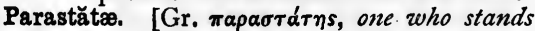
near another.] '(Arch.) Pilasters or square pillars, standing out from the wall along which they are arranged.

Parătaxis. [Gr.] In Gram., the ranging of propositions one after the other, without marking their dependence or interconnexion, as is done in Syntax.

Parathesis. [Gr. $\pi a \rho d \theta \in \sigma \iota s, a$ putting beside.] The printed matter contained within brackets.

Paravail. In Feud. Law, the inferior who holds of the superior lord or paramount. The words were suggested by the contrast of mountain and valley.

Parbuckle. (Naut.) To lower or raise any cylindrical object, by making fast the bight of a rope to a post, and passing the ends under and over the object, and hauling.upon or slacking them, as it is required to raise or lower the object. Casks, are often thus lowered into cellars. Parcæ. (Fates.)

Parcel, To. (Naut.) To wind parceliing, i.e. tarred canvas, round a rope.

Parcel gilt. Partially gilt.

Parcener. [O.Fr. parçonnier, from L. pars, partis, a portion.] In Law, a coheir, or one of two or more persons to whom an estate descends jointly, and by whom it is held as one estate.

Parchment paper, Vegetable parchment. A substance like parchment, made by immersing bibulous paper in sulphuric acid and water.

Parclose, or Perclose. [L. per, through, clausus, part. of claudo, $I$ shut.] A barrier, separating a chancel, chapel, or tomb from the rest of the church.

Pardon. [Fr.] In Law, the regal prerogative of pardoning offences against the Crown or public, with certain exceptions. $P$. cannot be pleaded to a Parliamentary impeachment so as to stop the inquiry.

Parecbăsis. [Gr.] (Rhet.) The Greek word for the Latin digressio, digression.

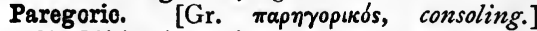
$(M c d$.$) Mitigating pain.$

Parembŏlë. [Gr.] (Rhet.) The insertion of a paragraph in the middle of a sentence, in order to explain something. Also called Paremptōsis.

Paremptōsis. [Gr., from $\pi \alpha \rho a$, by the side of; '่ $\nu$, in, $\pi \tau \hat{\omega} \sigma \iota s$, a falling.] (Parembole.)

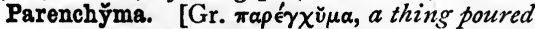
in beside, and in Gr. Med. = the substance of lungs, liver, etc., as if formed separately from muscular flesh.] 1. (Med.) The substance, basis, of a glandular organ. 2. (Bot.) Cellular tissue, showing hexagonal cells when cut across, filling the spaces between the veins of leaves.

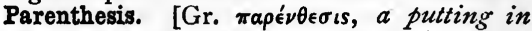
beside.] A mark used in printing ; thus (), inclosing words in a sentence which may be omitted without injury to its grammatical construction.

Păres cum părĭbus facillĭme congregantur.

[L.] Birds of a feather flock together.

Par excellence. [Fr.] Pre-eminently. 
Parget, Pargetting. [From L. păřes, părǔtis, a wall.] (Arch.) Plaster-work, decorated with figures in relief or sunk in the surface.

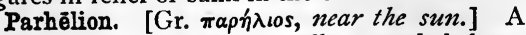
mock-sun. Halos are usually attended by a horizontal white circle, with brighter spots near their intersection with this circle; these spots are parhelia. (Paraselene.)

Parrah. (Parias.)

Parian. A fine porcelain clay, used for making statuettes, etc. (from its resembling Parian marble).

Parian Chronicle. A chronological register, giving the chief events in Gr. Hist. to about the middle of the third century B.c., found in the island of Paros, and now included in the English collection of Arundelian marbles.

Parian verse. Iambio verse, Archilŏchus, the first great master of it, having been a native of the island of Paros.

Parian ware. A delicate yellowish white ware, nearly approaching porcelain, invented about I 845 . It shrinks seventy-five per cent. in firing.

Parias. The lowest class of inhabitants in some parts of India, who have no caste. The word is sometimes applied to all who do not belong to the four Hindu castes, the members of which are an extremely small minority of the population. Hence pariah $=$ any outcast. (Caste.)

Parietal parts. [L. părǐes, păriětis, $a$ wall.] 1. (Anat.) Those which inclose cavities; e.g. $P$. bones form the sides and upper parts of the crānium. 2. (Bot.) Growing from the lining of anything; e.g. the placentæ of the poppy, from the walls of the ovary.

Paring and burning. (Agr.) Paring the root-matted surface off land, and then burning it to prepare the soil for ploughing.

Pări passu. [L., with equal pace.] Evenly, or together.

Paris, Judgment of. This phrase refers to the myth of the golden apple which, as not being bidden to the feast, Eris, the Greek goddess of strife, threw down on the banquettable at the wedding of Pēleus and Thětis, with an inscription denoting that it was a gift for the fairest. Hēra, Athena, and Aphrodite at once asserted each her claim. Zeus appointed Paris, son of the Trojan Priam, and husband of CEnōne, the judge ; and the prize was by him adjudged to Aphrodite, who promised him the fairest of women as his wife. This woman was Helen, whose abduction by Paris from the house of Menelaos led to the war between the Greeks and the Trojans, and the destruction of Ilion.

Parish. [Gr. maposkía, a neighbourhood.] Originally a civil division; then the district or diocese of the bishop; afterwards an ecclesiastical division of a town or district placed under the ministry of one pastor. In England they are mentioned as early as the reign of Edgar, 970.

Parisian Massacre. (Bartholomew, st., Massacre of.)

Park. [Fr. parc, an inclosure, L.L. parcus.]
The artillery $P$. is the place where the guns and tumbrils are collected in a camp; and the engineer $\mathrm{P}$. the depôt for intrenching tools, pontoons, and engineer stores.

Parker's Bible. (Bible, Inglish.)

Parliament. (Addled Parliament; Convention; Iong Parliament; Mad Parliament; Parliament, Devil's ; Parliament, Drunken ; Parliament, The Good ; Provisions of Oxford.)

Parliament, Barebone's. (Barebone's Parliament.)

Parliament, Devil's. The Parliament convened at Coventry by Henry VI., I459. So called as having attainted the Duke of York and his supporters.

Parliament, Drunken. The Parliament assembled at Edinburgh, 1661.

Parliament, Iong. (Long Parliament.)

Parliament, Mad. (Provisions of Oxford.)

Parliament, Privilege of. This term denotes the privileges of the several members of either House, enjoyed by virtue of their seats. To a great extent they are customary; and the Houses themselves are the only tribunals by which questions arising on this subject can be tried. Among these privileges are freedom of speech in debate, and freedom from arrest in civil suits. The Lords possess further the privilege of voting by proxy and of entering protests against measures of which they disapprove.

Parliament, Rump. (Long Parliament.)

Parliament, The Good, 1376 . Opposed and set itself to reform the corruption and misgovernment of Edward III. at the decline of his life ; banished Alice Perrers, etc. ; marking a new stage of opposition to illegal government.

Parliament-heel. (Naut.) Spoken of a vessel slightly careened by shifting the ballast, etc., so as to clean the exposed part of her bottom.

Parmĕnianists. (Eicl Hist.) The Donatists were sometimes so called, from Parmenianus, Bishop of Carthage, one of their chief leaders.

Parnassus. A mountain in Greece, sacred to Phœbus and the Muses. On its southern side was Delphi with its oracle, and the Castalian spring. Hence steps to Parnassus denotes helps towards proficiency in poetry.

Parnassus, Grass of. (Bot.) Beautiful bog plants (said to have been produced on Mount P.). Parnassia pălustris, ord. Droseraceæ, common in bogs, especially among mountains of N. Britain.

Par nōbìle frātrum. [L.] $A$ noble pair of brothers (Horace).

Părŏchìa. Corr. of Păracia. (Paroikia.)

Parody. [Gr. $\pi \alpha \rho \varphi \delta \delta^{\prime} \alpha$.] A composition in which grave or serious writings are burlesqued by exaggerating their characteristic features. Prose writings are seldom parodied.

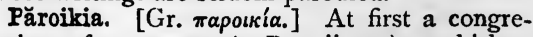
gation of strangers (1 Pet. ii. I1); a bishop

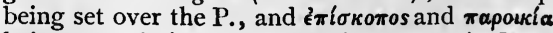

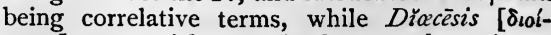
$\kappa \eta \sigma \iota s]=a$ parish. But in the seventh or eighth century parish churches being frequently founded in villages, părŏchĭa (q.v.) came to mean th. presbyter's cure, and diøecēsis, diocese. 
Parole, Parol. [Fr. parole, L. parabŏla.] 1. In Law, word of mouth, a parol agreement being contrasted with a written one. 2 . In military language, the verbal pledge of a prisoner to reappear when called for. 3. Secret watchword given only to commanders, tc enable parties to pass the guards in a camp. (Countersign.)

Parŏnŏmăsia. [Gr.] (Rhet.) The use of the same word in different senses in a single sentence, or the opposition to each other of words similar in sound. A kind of play, or punning.

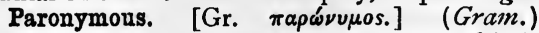
Words of similar derivation; as man, mankind, manhood.

Parōtitis, or Mumps. (Med.) Inflammation of the parotid gland [Gr. $\pi \alpha \rho \omega \tau i s$, from $\pi \alpha \rho \alpha$, near, and oûs, $\dot{\omega} \tau \delta$ s, the ear].

Parqueterie. [Fr. parquet, the bar of a court of justice, wooden flooring.] Parquetry, inlaid wooden flooring.

Parr. [Perhaps Gael. bradan.] A small fish found where salmon congregate. Whether it be young salmon, or a spec. of trout, has been doubted.

Parrals, or Parrels. (Naut.) Bands of rope or iron collars on which the yards travel up or down a mast. P.-ropes, etc., various devices for fastening yards to masts.

Parricide. [L. parrǐcīda, from pater, a father, cædo, $I$ kill.] Properly the murder or murderer of a father, but often extended to the murder of any near relation, and in some countries to that of distinguished and sacred persons. English law treats it as simple murder.

Parsee. (Guebers.)

Parsing. In Gram., the resolution of a sentence into its parts [L. partes].

Parson. [L. persōna ecclesiæ.] In Law, one who has full possession of the rights of a parochial church, and, as such, is a corporation sole. (Rector.)

Parted, Party. [O.Fr. parti, divided.] (Her.) Divided by a line or lines in the direction of one or more of the honourable ordinaries; as, parted per pale and per bend sinister, which signifies that the escutcheon is divided by a vertical line down the middle (per pale), and a diagonal line from the sinister chief to the dexter base (per bend sinister).

Parterre. [Fr.] The pit in a French theatre ; so called because originally meaning that ground which spectators stood upon in front of a stage erected in the yard of an inn, where formerly performances often took place. So pit recalls the fact of representations often taking place, with us, in cockpits.

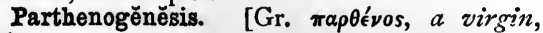

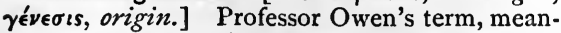
ing (I) the production of successive procreative generations from a single ovum, the parthenogenetic individual being either sexless or virgin females; meaning also (2) propagation by a plant or animal by self-division, by gemmation from within or without, or by any other method than impregnation.

Parthenon. [Gr.] The temple of the virgin

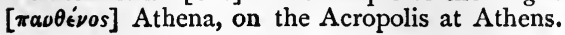

The chief sculptures taken from it form the English collection known as the Elgin marbles.

Parthenopæan Republic. Naples.

Parthian retreat. The Parthians were able to discharge their arrows while riding at full speed from the enemy. Hence a Parthian retreat is one which practically prevents pursuit.

Particeps criminis. [L., a sharer of guilt.] (Leg.) An accessory to crime.

Participants. [L. partǐcīpāre, to share.] An order of knighthood founded by Sixtus V., I 586 , in honour of the Virgin of Loretto. It soon came to an end.

Particle. [L. particŭla, a small part.] In Math. Phys., a portion of matter having mass and position, but so small that its dimensions do not come into consideration.

Particular Baptists. (Particularists.)

Particularists. (Theol.) Those who hold the doctrine of particular reprobation and salvation. Such are the Particular Baptists. (Universalists.)

Particular propositions. In Logic, propositions which affirm or deny anything of only certain members of a class; as, "Some men are truthful" or " are not truthful."

Partidas, Las Siete. [Sp., The Seven Parts.] An ancient Spanish code of laws drawn up in the thirteenth century; so called from the number of its chief divisions.

Partington, Mrs. Speaking of the rejection of the Reform Bill, in 1831 , by the House of Lords, Sydney Smith compared the Lords to Mrs. Partington trying with her mop to keep out the waves of the Atlantic. The incident is said to have occurred at Sidmouth in a great storm which flooded Mrs. Partington's house, with many others.

Partisan. [Fr. pertuisane, L. pertundĕre, pertüsum, to pierce.] A kind of pike with which officers were armed in some regiments as late as the time of Marlborough.

Partners. (Naut.) Thick plank-frames round the masts, capstan, etc., to support them, bolted to the deck-beams.

Part owners. In Law, persons holding property (chiefly in ships) in shares, without liability for each other's engagements.

Partridges. (Naut.) Grenades fired from mortars.

Partridge-wood. A Brazilian variegated wood used in cabinet-work.

Parturition. [L. partŭrio, I am in labour.] A bringing forth of young.

Parturiunt montes, nascetur ridicŭlus mus. [L.] $A$ mouse is the outcome of a mountain's labour (Horace).

Party wall. (Arch.) A wall built upon the joint lands of two tenants or owners.

Parvise, or Paradise. [The L. paradisus, and

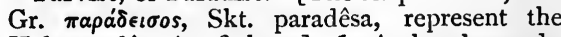
Heb. pardês, Ar. firdans.] 1. A church porch. 2. A room over the porch. 3. An open space before the entrance of a church,

Parvum parva dĕcent. [L.] Small things become the humble man.

Paschal. Relating to the Pascha, or Passover. 
Paschal cycle. The cycle which determines when Easter falls.

Pas de Calais. [Fr.] Straits of Dover.

Pas de souris. [Fr., mouse-steps.] (Mil.) Masonry steps from a ditch up the counterscarp to the ground above, placed in the most protected angles.

Pasha. In the Turkish empire, a title of honour bestowed on the ministers and officers of the sultan, more especially on the governors of provinces termed pashaliks. " The higher pashas have three horse-tails carried before them as standards, the lower have two; and are hence known as pashas of two tails or three tails respectively.

Pasigrăphy. [Gr. $\pi \hat{a} s$, all, $\gamma \rho a ́ \phi \omega$, I write.] A word invented to denote the imaginary language which is one day to be written and spoken by all nations. This was the idea of Leibnitz and of Bishop Wilkins in the time of Charles II.

Paspy, i.e. Passe-pied. [Fr. passe, L. passus, a step.] A kind of minuet, in triple time, of French origin, popular in Queen Elizabeth's time and for some time after.

Pasque flower. (Bot.) A gen. of plants, ord. Ranunculaceæ; Anemone pulsatilla, a native of our chalky pastures; having violet-blue flowers about Easter-time [Pâque, formerly Pasque].

Pasquănäde. [It. pasquināta.] A satire or libellous criticism; so called from a statue of a gladiator, dug up at Rome, and named by the people Pasquino. To this statue and to another called Marforio, satirical placards were affixed at night. These frequently bore the form of a dialogue between the two statues, and reflected on the Roman Church and court.

Pasquino and Marforio. (Pasquinade.)

Passacaglia. (Chaconne.)

Passant. [Fr.] (Her.) Passing or walking.

Passaree, or Passarado. (Naut.) A rope by which the clews of the foresail are hauled out towards tail-blocks on the booms, so as to extend its foot when before the wind with lower studding-booms out.

Passed boys. (Naut.) Those who have passed through a training-ship.

Passement. [Fr.] In the history of lace, a term applied as far back as the beginning of the seventeenth century to every variety of lace. Mrs. Palliser, History of Lace.

Passe-partout. [Fr.] 1. An engraving of an ornamental border, on metal or wood, the centre of which was cut out to allow the insertion of another engraving to which the border formed a frame. 2. A master-key.

Passěres. (Ornithology.)

Passe-volant. (Naut.) 1. A Quaker, or wooden gun. 2. Any movable big gun.

Passim. [L., everyzuhere.] In all parts of a book.

Passionists. A congregation styling themselves Discalced Clerks of the Passion, founded by St. Paul of the Cross, I728, for the purpose of giving retreats and holding missions.

Passion Sunday. The Fifth Sunday in Lent, being the Sunday before Palm Sunday; often so called by the Latins especially (Wheatly):
Passion Week being the last week in Lent, commencing with Palm Sunday; called also Great Week and Holy Week.

Paste. [It. pasta.] 1. In pottery or porce. lain, clay as prepared and mixed ready for use. It is distinguished into Hard P. and Soft P.; e.g. stoneware bottles and ordinary flower-pots respectively, in pottery. Similarly in porcelain, $S$. $P$. can, $H$. $P$. cannot, be easily cut with a file; but the line is a difficult one to draw. H. P. stands heat better than S. P. does. Glazes generally vary in hardness with the pastes. 2. Artificial gems; glass containing an extra proportion of metallic oxide.

Pasteboard. A stout substance, formed of sheets of paper pasted together and pressed.

Pastel. [Fr.] 1. A coloured crayon. 2. Woad.

Pastern, Pastern-joint. [Fr. pasturon; and this from pâture, a tethering-cord for animals pasturing.] That part of the leg of a horse between the joint next the foot and the hoof.Johnson.

Pasticcio. [It., a pasty.] 1. In design, a patchwork from two or more originals; also, a picture imitating another artist's style and colouring. 2. In literature, a medley. (Compare Farrago; Olla podrida.)

Pastille. [Fr.] A small cone, made of benzoin and other aromatic substances, for fumigating a room.

Paston Letters. A valuable collection of original letters of the Paston family in Norfolk, ranging from the reign of Henry VI. to that of Henry VII. inclusively.

Pastoräle. [It., pastoral.] (Music.) A melody or set composition, generally in $\frac{6}{8}$ time ; of simple, rustic character; the words, if any, relating to pastoral life or incident.

Pastoral Epistles. In the New Testament, $I$ and 2 Tim., and Epist. to Titus.

Pastoureaux. [O.Fr., shepherds.] (Hist.) Peasants who took up arms, during the absence of St. Louis of France on his Crusade, under a Cistercian monk, who called himself Jacob, Master of Hungary. Another insurrection, so named, broke out seventy years later.

Pastourelles. (Troubadours.)

Patache. (Naut.) A Portuguese tender, armed and swift, for carrying treasures; 200 to 300 tons burden.

Patallah. (Naut.) An Indian baggage or cattle boat.

Patamar. (Naut.) Old class of Indian adviceboats, swift and roomy, about 76 feet long by 2 I feet broad, and II feet deep, with a prowstern.

Patavinity. [L. patāvīnı̌ta, -tem.] The use of provincial idioms in speech is sometimes so called, from the fact that the historian Livy, who is said to have had this fault, was born at the provincial town of Patavium (Padua). It cannot, however, be said that Livy's faults have ever been pointed out clearly.

Pataxos. (Naut.) A small Spanish boat, formerly used as an advice-boat.

Patchouly. [Hind.] A scent distilled from a Malayan plant. 
Pâte, Dure, Tendre. (Paste.)

Pătella. [L., a small dish.] (Anat.) The knee-cap; a sesamoïd (q.v.) bone, heart-shaped; the apex being downwards, anteriorly convex.

Paten. [L. patěna.] (Eccl.) The stand or saucer on which the chalice rests; or the plate in which the bread is placed, in the Eucharistic Office.

Patent. [L. patentem, open.] An act of the executive, by which some exclusive privilege is granted to an individual or a company; so named as being in the form of an advertisement to all men. Political or other privileges, such as those which constitute a man a bishop or a peer, are thus granted.

Pătĕrfămullias. [L.] The father or head of $a$ family.

Paterines. [L. Patěrīnī.] (Eccl. Hist.) A name given to the Western Manichæans (Milman, Hist. of Latin Christianity, bk. ix. ch. 8), and also by the married clergy of Milan to the monkish party in the controversy respecting clerical marriage (ibid., bk. vi. ch. 3 ).

Pater noster. The Latin name of the Lord's Prayer, from its first two words.

Păter patrãtus. [L.] The chief of the

Fetials.

Păter pătrīø. [L.] Father of his country.

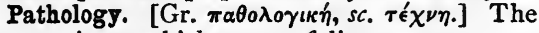
art or science which treats of diseases.

Patibulary. Belonging to a Patibulum.

Patibŭlum. [L.] 1. A fork-shaped yoke placed on the neck of criminals, to which the hands were tied. 2. The transom of a cross.

Patina. [L.] In Numismatics, the fine rust with which coins become covered by lying in peculiar soils, and which is regarded as ornamental. It varies greatly in colour, and is, in fact, a natural varnish, not producible by any human art.

Patois. [(?) Corr. from an older form, patrois, L.L. patriasis, belonging to patria, country; hence the speech of nations.] A French word, used generally to denote dialects of the lower classes. Applied also to local dialects; e.g. the French of the Channel Islands or of Provence.

Patonce. [Fr. patte d'once, leopard's paw.] (Hler.) Having its ends terminated in leopards paws.

Patres Conscripti. (Conscript Fathers.)

Patria pŏtestas. [L.] In Rom. Law, $a$ father's control over his legitimate and his adopted children; at first giving him their property, and even power of life and death ; but much diminished afterwards, especially under the emperors.

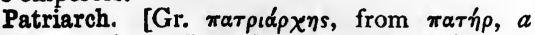
father, and h $\rho \chi \omega$, I rule.] A name given, in Acts vii. 8 , to the sons of Jacob; but more especially applied to the bishops of the most important cities of the Roman empire, as Rome, Constantinople, Antioch, Alexandria.

Patriarchal, Cross (because carried before patriarchs). A cross formed of an upright piece with two smaller cross-pieces more than halfway up, the higher cross-piece being the shorter.

Patricians. [L. patres, fathers.] (Hist.)
The original body of Roman citizens, known as the populus [Gr. $\pi \delta \delta_{\imath \iota s}$ ], as opposed to the plebs $[\pi \lambda \hat{\eta} \theta 0 s]$, the inferior crowd, which gradually acquired civic rights.

Patrick, St., Order of. An Irish order of knighthood, founded by George III., in 1783 .

Patripassians. [L. pater, father, patior, I suffer.] (Eccl. Hist.) Those who held that it was the Father who suffered at the Crucifixion. (Noetians; Sabellians.)

Patris est fillus. [L., he is his father's son.] A chip of the old block.

Patrol. [Fr. patrouille, formerly patouille, from It. pattuglia, a night watch.] (Mil.) A party of soldiers who, in field operations, are constantly moving along the line of advanced sentries, searching for intelligence, and keeping up the communications. In garrison they prevent soldiers from creating disturbances in the streets.

Patron. [L. patrōnus, from pater, father.] In ancient Rome, the correlative term to Client.

Patronage. In Eccl. Law, the right of presentation to a benefice.

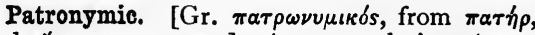
and ó $\nu \mu \alpha, a$ name.] A name designating a person by reference to an ancestor immediate or remote, as Pelides for Achilles, son of Pēleus, etc.

Patroon. [D.] An owner (patron) of land, with rights of entail under the Dutch governments of New York and New Jersey.

Pattee, Cross. [Fr. patté, from patte, a paw.] A cross formed of four equal arms, growing much wider towards the ends.

Pattern. [Fr. patron.] A full-sized model of a metal casting, commonly made of wood, and in several pieces, by which the mould is formed for receiving the melted metal. (Ratchet.)

Pauldron. Overlapping plates of metal, working on rivets, covering the shoulder [Fr. épaule] at the exposed junction of the body and arm pieces.

Paulianists. (Eccl. Hist.) The followers of Paul of Samosăta, Bishop of Antioch, in the third century, who held Sabellian opinions.

Paulicianism. (Paulicians.)

Paulicians. (Eccl. Hist.) A Christian sect, which seems to have arisen in Armenia in the ninth century, and to have adopted the name of Paulus, one of their leaders, to disavow connexion with the Manichæans. Their opinions are known only from the accounts given by their opponents, who charge them with dualism (Ahriman). A colony of Paulicians spread westwards, and has been supposed to be connected with the Albigenses.

Paullo mājōra cănāmus. [L.] Let us sing a higher song (take a higher range) (Virgil).

Pauls, or Pawls. [Welsh pawl, a pole, or stake.]. (Naut.) Pieces of wood or iron fastened to the capstan, or windlass, and falling into notches, so as to prevent it from recoiling.

Paunch. [Fr. panse, L. panticem.] The first stomach of ruminants.

Paune. [N.-Amer. Ind.] (Pone.)

Paupěres Christi. (Biblia pauperum.) 
Paupěris, In formā. [L.] (Leg.) The court has power, under certain circumstances, to admit a man to sue or defend in the character of $a$ poor person, counsel and attorneys being granted free of charge. (Dispauper.)

Pauperism. In Law, the condition of those who are dependent for their maintenance on the aid of the public, this aid being supplied by funds raised by rates levied on the ratable value of landed property, and on tithes and rent-charges. The first statute for the relief of the poor was passed in the reign of Edward VI., I 547. (Overseers of the poor.)

Pavan. [(?) L. pāvō, a peacock.] A slow and stately dance, still in use in Spain.

Pavise. [Fr. pavois.] In mediæval warfare, a large shield used by troops assailing the walls of fortresses.

Pāvōnīnæ. [L. pāvō,-nem, peacock.] (Ornith.) Birds of the peacock sub-fam. (as the Argus pheasant). India, Thibet, China, and islands. Fam. Phāsīānǔdæ, ord. Gallīnæ.

Pawn. [L. pannus, a cloth, a piece of clothing being the readiest article to give in pledge.] Something given as security for the repayment of money.

Pawn. [O.Fr. pieton, a footman.] One of the least valuable pieces in chess. (Peonage.)

Pax. [L.] 1. (Myth.) The Roman goddess of peace. 2. A small image of the Saviour, to which the people, on leaving the church, gave the kiss of peace. 3. A metallic plate with a crucifix engraved on it, called also osculatorium, used for the same purpose.

Pax vōbiscum. [L.] Peace be with you.

Pay, To. [Fr. poix, pitch.] (Naut.) To P. a seam, to pour pitch and tar, etc., into it after caulking. (Devil.) To P. a mast or yard, to dress it with oil, varnish, etc. To $P$. a ship's bottom, to cover it with tallow, sulphur, resin, etc. To pay [Fr. payer, L. pācare, to satisfy] awvay, or out, to slack a rope off. To $P$. off, to fall off from the wind. To P. round, to turn her head.

Pay-dirt. In America, auriferous earth rich enough to pay the labour of extracting the metal. Similarly, Pay-rock, quartz, or other rock that will pay for mining.--Bartlett's Americanisms.

Paynim, or Painim. [L. pāgānus, belonging to a pagus, or country district.] A word used in the Middle Ages to denote all who were not Christians, but applied especially to Mohammedans.

Pays de Cocagne. [Fr.] A land like Utopia, or El-Dorado. (Cocagne.)

Peace of God. (Truce of God.)

Peak, or Peek. (Naut.) The top outer corner of a sail extended by a gaff. $T o P$., to raise the gaff, or a lateen yard, nearer the perpendicular. To stay $P$., or ride a short-stay $P$. (A-peek.)

\section{Pea-nut. (Arachis.) \\ Pearl. A kind of printing type, as- \\ Proportion.}

Pearlash (from its appearance). A partially purified carbonate of potash, obtained by calcining the commercial potashes (g.v.).
Pearl-edge. A projection on the side of some ribbons; also a narrow kind of thread edging to be sewed on lace.

Pearl-powder, or Pearl-white. Subnitrate of bismuth, used as a cosmetic.

Peasants' War. In Germany, a struggle of peasants headed by Munzer, who demanded community of goods (1 524-25).

Peat. [O.E. bete, to mend or kindle a fire.] (Gcol.) Decomposed vegetable matter, spongy, fibrous or homogeneous, accumulated in moist places, on mountains, and in plains.

Pebble. [A.S. pabol.] Round or oval stone, water-worn on a beach.

Peccant. [L. peccantem, offinding.] ( $M e d$. Morbid, injurious to health.

Peccary. (Native name.) (Zool.) American representative of swine. Two spec., one about the size of a small pig, the other rather larger; gregarious. Paraguay to Texas. Dicǒty̆les, fam. Scǔidæ, ord. Ungŭläta.

Peccāvi. [L., I have sinned.] I confess.

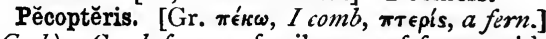
(Geol.) Comb-fern, a fossil gen. of ferns, with fronds divided into comb-like leaflets; allied to the living Pteris, bracken. Very abundant in the coal-measures ; also in Jurassic.

Pěcŏra. [L., cattle.] Linnæan name for ruminants.

Pectinate. (Bat.) Divided into close, narrow, straight segments, like a comb [L. pecten, pectinis]; e.g. leaf of water-milfoil.

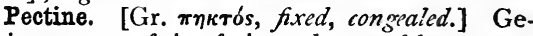
latinous gum of ripe fruits and vegecables; vegetable jelly.

Pectoral. [L. pectorālis, from pectus, the breast.] A covering for the breast; sometimes applied to the morse, or clasp, of a cope.

Pectoriloquy. [L. pectus, -oris, the chest, loquor, I speak.] (Med.) The clear sounding of the voice from that part of the chest to which the stethoscope is applied.

Pectous. [Gr. $\pi \eta \kappa \tau \delta s, ~ f i x e d$, compaited.] Coagulated; passing from the colloild to the more crystalline condition.

Pectus facit theŏloggum. [L.] It is heari, not head, that makes a divine.

Peculation. Strictly, the stealing of Peculium; but often used to mean embezzlement or malversation generally.

Peculiar. In Eccl. Law, jurisdictions not under the Ordinary of the diocese. Such are the peculiars of archbishops, bishops, deans, chapters, and the like.

Peculiar People. A modern sect, which takes its stand on the literal interpretation of texts in the Epistle of St. James and other parts of the New Testament, and on this ground objects to medical treatment of the sick.

Peculiars. Parishes exempted by the pope from episcopal jurisdiction; by an oversight not restored at the Reformation, but remaining under the sovereign, or, by custom or purchase, under some other person; now in nearly all dioceses abolished.

Peculiars, Courts of. (Court, Christian.)

Peculium. [L., lit. property in cattle (pecus).] 
In Rom. Law, the savings of a son or slave with the consent of the father or master.

Pedagogue. [Gr. $\pi \alpha \iota \delta \alpha \gamma \omega \gamma \delta s$, from $\pi \alpha \hat{\imath} s, b o y$, and ảywrós, leader.] 1. Properly a slave who conducted his master's sons to school, and was charged with the care of them generally. 2. A schoolmaster.

Pedal curve. (Math.) The curve described by the point of intersection of a line moving so as always to touch a given curve with the perpendicular drawn to it from a fixed point.

Pedalmaschi. A Turkish officer, who looks to the interests of the sultan in cases of legacies.

Pedestal. [L. pes, pedis, a foot.] (Arch.) The substructure to a column or a wall, the height varying from a quarter to one-third of the height of the column with its entablature. (Order.)

Pedicel. (Peduncle.)

Pědícŭlaria. [L. pědícŭlus, a louse.] General term for skin-disease, when caused by lice, i.q. Phtheiriasis.

Pědiculus. [L.] A foot-stalk; but Pedícǔlus, Pedicellus, and Pedunculus are $=$ the crawling insect.

Pedĭment. [L. pes, pĕdis, $a$ foot.] (Arch.) The triangular mass, answering to a gable, over the front of a building, portico, etc. It is frequently filled with sculpture, as in the Parthenon. (Elgin marbles.)

Pedometer. [L. pes, pědis, a foot, Gr. $\mu$ é $\rho \circ \nu$, measure.] An instrument, like a watch, for registering the number of steps taken in walking; and so of measuring the distance walked.

Pedropee. (Naut.) Setting one foot on a seam, kicking the other backwards and forwards, and then setting it down in front of the former. A test of being sober.

Peduncle. [As if pĕduncŭla, a coined dim. of L. pes, pĕdis, a foot.] (Bot.) A flower-stalk. Pedicels [pédiculus], the small branches into which a $\mathrm{P}$. is sometimes divided.

Peel. 1. [Fr. pelle, L. pala, a shovel.] A broad iron shovel with a long wooden handle, used by bakers. 2. A T-shaped piece of wood with a long handle, for hanging up the sheets of a book to dry, etc. 3. [Celt.] (Geog.) A stronghold.

Peep. As in Isa. viii. 19; to cry like a little bird [L. pipio, I chirp].

Peeping Tom. In the Coventry legend, the lad who saw the Lady Godiva as she rode through the town. The incident belongs to the story of the Master Thief.

Peep o' Day Boys. In Ir. Hist., insurgents, in 1784 , who visited the houses of their enemies at daybrak.

Peepul. (Botree.)

Peer. [L. par, Fr. pair, equal.] 1. In common law, those who belong to the same rank of life, trial by jury being said to be trial by peers or equals; a relic of feudal usage, by which all classes were banded together for self-defence and the settiing of quarrels. 2. In a more limited sense, the highest class in a country, as the peers of France or of England. (Paladins; Parliament, Privilege of.)
Peert, Peart. Brisk, lively, (?) a corr. of pert. An old word, still provincial in some parts of England; used in America both in a good and in a bad sense. - Bartlett's Americanisms.

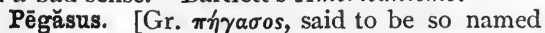
as appearing first near the $\pi \dot{\eta} \gamma a$, or fountains, of the ocean.] 1. (Myth.) The horse which, with Chrysāon, the lord of the golden sword, sprang from the head of Medūsa, the mortal Gorgon. This horse Bellerophon caught, and on it rode to encounter the Chimerra. A blow of its hoof is said to have discovered Hippŏcrēnē, the horse-fountain, on Mount Helícōn, during the contest of the Muses with the Piěrídes, the nine daughters of Pieros. 2. (Zool.) Pacasse, or Pagasse. Spec. of buffalo. W. and Central Africa.

Peh-tun-tze. [Chin. peh-tun, white paste, with the dim. tze added.] Strictly, the fusible material of China paste (Pegmatite of some authors), felspar partly decomposed; vaguely, any white material made up in small bricks, and used in the manufacture of porcelain.

Peine forte et dure. [Fr., strong and hara pain.] (Hist.) The name for the practice of pressing with weights of iron prisoners who refused to plead or answer.

Pékin. A word used in France by soldiers to denote contemptuously all who are not military.

Pekinade (from Pekin). A woollen stuff with silk stripes, for covering furniture.

Pekoe. [Chin. pikhaou.] A fine black tea formed of the leaf-buds picked before they expand. Pelagians. (Eccl. Hist.) The followers of Pelagius, a British monk of the fifth century, who asserted that men inherit no depravity, and that their own powers are sufficient for their justification. The condemnation of Pelagius by Innocent I. was reversed by his successcr Zosimus, who afterwards, in obedience to an imperial rescript, anathematized his doctrine. Eighteen bishops refused to condemn Pelagius unheard, and appealed to a General Council. Among these was Julianus, of Eclana, the reputed founder of Semi-Pelagianism, which asserted the necessity of divine grace for the practice of holiness.

Pelerine. [Fr., as being worn by pilgrims, pélérin, It. pellegrīno, L. peregrinus, from per, across, agrum, field.] A long cape with ends coming down in front.

Pele towers. Small towers or defences on the Scottish borders, properly pile towers, pile being used in the sense of fortress. (Peel.)

Pell. [L. pellis, a skin.] 1. The skin or hide. 2. A roll of parchment.

Pellagra. [From L. pellis, the skin : after the analogy, probably, of pŏd-agra, chir-agra.] The name of a loathsome skin-disease, accompanied with mental phenomena, amongst them melancholia, often suicidal; once thought to be endemic in N. Italy, and to arise from the use of maize as almost the only food; but now known to be due to a combination of poverty, insufficient nourishment, filth, toil, etc.

Pellet. [Fr. pelote, a ball of thread.] (Her.) A black roundlet or disc. 
Pellicle. [L. pellǐcŭla, a small skin.] A thin skin or film, especially one formed on the surface of solutions during evaporations.

Pellitory. [L. părǐtāiria, păries, $a$ wall.] (Bot.) 1. Wall pellitory; native plant, $\mathrm{P}$. officinalis, ord. Urticaceæ; with small reddish flowers, and black shining fruit ; on old walls, heaps of rubbish. 2. P. of Spain, Anacyclus pyrethrum, ord. Compositæ ; allied to chamomile, a powerful irritant; valued in medicine.

Pells, Clerk of. An officer of the Exchequer, who made certain entries on parchment rolls [O.Fr. pel, skin, L. pellis]; the office a sinecure place for life, worth $£ 3000$ a year, tenable with a seat in the House of Commons ; abolished 1834.

Pelops. (Tantalize.)

Pelotage. [Fr.] Bales of Spanish wool.

Pelt. [Ger. pelz.] The skin of a beast with the hair on. Pelt-wool, wool plucked from the pelts of sheep after they are dead.

Peltasts. [Gr. $\pi \in \lambda \tau \alpha \sigma \tau \alpha$ i.] (Hist.) Ancient Greek infantry, light armed; so called from carrying the $\pi \epsilon \lambda_{\tau} \eta$, or target.

Peltate leaf. [L. peltātus, furnished with a small light shield (pelta).] (Bot.) Having the stalk inserted in the middle, like an arm holding a shield; e.g. pennywort, garden nasturtium.

Peltry. [Fr. pelleterie.] The furred skins of animals.

Pelvis. [L., a basin.] (Anat.) The bony ring, composed of the two ossa innominata (q.v.) and sacrum and coccyx; which contains various viscera, and transmits the weight of the spinal column to the lower extremities.

Pemmican. (N.-Amer. Ind. name.) A farfarned provender in the wilds of N. America, made by pounding the choice parts of the meat very small, dried over a slow fire or in the frost, and put into bags made of the skin of the slain animal, into which a portion of melted fat is then poured; with proper care it will keep a long time.-Bartlett's Americanisms.

Penal servitude. In Law, the punishment now substituted for transportation beyond the seas.

Penance. (Penitence.)

Penang lawyer. In Naut. slang, a cane.

Penarth beds. (Rhætic formation.)

Pěnātēs. [L.] The ancient Latin household gods ; so called as guarding the permus, or store of food. This general term included the Lares. There were $P$. of the state or city, as well as of families.

Pencel. [L. pēnǐcillum, a little tail.] (Naut.) A small streamer, or pennon.

Pencil. Until comparatively lately kepts its classical meaning of a painter's brush [L. pēnĭcillum].

Pencil of rays. An assemblage of rays proceeding from a luminous point.

Pend, Penock. Oil-cake (so called in India).

Pendant. [L. pendeo, I hang.] 1. In Eng. Arch., (I) a polygonal piece of stone or timber, richly ornamented, hanging from a vault or roof. Some of the most elaborate specimens are those in Henry VII.'s Chapel, Westminster. part hanging from the label resembling the drops in the Doric frieze. (3) A companion picture or work of art. 2. (Naut.) (I) I.q. Pennant. (Flag.) (2) Single or double ropes, to which blocks or tackles are attached. (3) Rudder P., ropes fastened to the rudder by chains to pre. vent its being lost if unshipped.

Pendente litě. [L.] Pending a suit, or trial.

Pendentive. [Fr. pendente, from L. pendeo, I hang.] (Arch.) The portion of a vault between the arches of a dome.

Pendulum [L. pendŭlus, hanging] ; Ballistio P.; Compensation P.; Compound P.; Conical P.; Gridiron P.; Mercurial P.; Simple P. A suspended body that swings backwards and forwards. If the body is treated as a particle, and the thread by which it is suspended as weightless and perfectly flexible, the combination, which is purely ideal, is a Simple $P$. Any actual swing. ing body is a Compound $P$. The time of oscillation of a compound $\mathrm{P}$. is found by ascertaining the length of the corresponding simple $P$. The end of a line as long as the simple P. drawn from the point of suspension through the centre of gravity is the centre of oscillation ; so long as this point remains fixed, the time of oscillation will be unchanged. A P. whose parts are so contrived that the centre of oscillation remains fixed when the parts expand or contract by change of temperature, is a Compensation $P$. If the compensation is effected by suspending the bob from a system of parallel bars of steel and brass, it is a Gridiron $P$.; if by suspending a vessel containing mercury by a steel rod, it is a Mercurial $P$. When the bob is made to move continuously in a circle, so that the rod describes a conical surface, we have a Conical $P$. Such a contrivance is competent to regulate the motion of clockwork, though it is not a swinging body. The Ballistic $P$. is used for determining the velocity of shot; it consists either (I) of a suspended block of wood into which the shot is fired; the velocity being inferred from the arc through which the block is observed to swing ; or (2) of a framework suspended on knife-edges and carrying the gun; the velocity of the shot is inferred from the arc of the gun's recoil.

Penĕlöpë's web. (Myth.) A web woven each day by Penelope, the wife of the absent Odysseus (Ulysses), in the Odyssey, and undone each night ; as a device for baffling her suitors, who were told that she would choose one of them as her husband when the web was finished.

Penests. [Gr. $\pi \in \nu \epsilon ́ \sigma \tau \alpha \iota$, labourers.] (Hist.) The ancient Thessalian serfs, who answered to the Spartan Helots.

Penetralia. [L.] The recesses or inmost parts of a temple, house, or other building.

Penfish. (Squid.)

Penguin. [Celt. pen gwenn, white head, from the white patch or line between the bill and the eye, the head itself being black.] (Ornith.] Fam. of Southern birds corresponding to auks (Alcrdæ) in the North. Their wings are flippers, serving as paddles in the water, and sometimes as fore legs on the land. Fam. Sphēniscǐdæ, ord. Anserres. 
Penitence, Penance. [L. pœnitentia.] In the Latin Church, (I) one of the seven sacraments; (2) also the works enjoined on the penitent by his confessor.

Penitential Psalms, The Seven. Ps. vi., xxxii., xxxviii., li., cii., cxxx., cxliii.

Penitentiaries. 1. In the ancient Church, presbyters appointed to receive private confessions, in aid of, not in prejudice to, public discipline. 2. In foreign cathedrals, a confessor appointed by the bishop.

Penitentiary, Grand. An officer of the Roman Church, usually a cardinal, commissioned by the pope to grant absolution in cases reserved for the papal authority, such as dispensations for marriages, etc.

Penitents. [L. pœnitentes.] Certain religious fraternities in the Latin Church have been so called, the most prominent being the White Penitents, who appeared in N. Italy in I399; so called from their white dress.

\section{Pennant. (Flag.)}

Pennant-ship. (Naut.) 1. A commodore's ship. 2. A Government ship. 3. A merchant ship in a convoy, delegated to assist in keeping it together.

Pennon. [Fr., from L. penna, a feather.] In the Middle Ages, the pointed flag of a knight who had not reached the dignity of banneret.

Pennoncelle. The little streamer at the head of the lance of a mounted lancer.

Pennyweight. The weight of the silver penny in the time of Edward I., equal to the twentieth part of an ounce troy.

Pensionary, The Grand, of Holland. (Hist.) The prime minister of the states of the province of Holland. His office was for five years, and he might be re-elected.

Penstock. Any wooden tube for conducting water.

Pent-. [Gr. $\pi \epsilon ́ \nu \tau \epsilon$, five.]

Pent-, Penta-. (Chem.) A prefix denoting that a salt contains five atoms [Gr. $\pi \epsilon^{\nu} \nu \epsilon$, five] of the element thus marked; as a pent-oxide, penta-chloride, which contain five atoms of oxygen, chlorine, in each molecule.

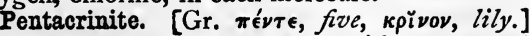
(Geol.) A fossil crinoïd (q.v.), with pentagonal stem. Lias and Oolite principally. Pentacrinus, the living representative.

Pentagon. (Polygon.)

Pentalpha, or Solomon's seal. A Pythagorean symbol ; magical; mentioned by Lucan; found on Jewish stonework and on Greek coinage. A five-pointed star, as if made by five Greek alphas : "Solomon's," on account of the magical powers widely attributed to him in the East.

Pentămĕter. [Gr. $\pi \in \nu \tau a ́ \mu \in \tau p o s$, of five measures.] A verse consisting of five feet, and, with a preceding verse of six feet called the hexameter, making up the elegiac couplet.

Pentăpolis. [Gr., with five cities.] The Greek name for any district or region with five cities. But the most prominent was the Pentapolis of Cyrēne, in Africa. Compare Decapolis.

Pentaptych. A painting having many leaves ; as the altar-piece of Van Eyck in the Church of St. Bavon, in Ghent. (Diptych; Triptych.)

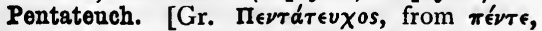
five, $\tau \in \hat{v} \chi 0$ s, in post-Alex. Gr., $\boldsymbol{a}$ book.] A name given by the LXX. translators to the five books, in one volume, of Moses; the Jewish name being Torah, the Law.

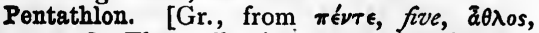
$a$ contest.] The collective name for the five chief bodily exercises of the Greeks-running, leaping, quoit-throwing, javelin-hurling, and wrestling. The Latin term is Quinquertium.

\section{Penteconter. (Trireme.)}

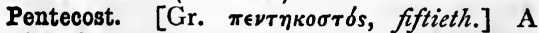
Jewish feast; so called as being kept on the fiftieth day after the Feast of the Passover; that is, the $15^{\text {th }}$ of the month Nisan, and on the next day after the Feast of Unleavened Bread. As coming seven weeks after the Passover, it was also called the Feast of Weeks.

Penult. [L. pæne ultima, almost last.] In Gram. and Pros., the last syllable but one of a word.

Pënumbra. [L. pæné, nearly, umbra, shadow.] The shadow of an opaque body, as the earth or moon, illuminated by a large distant body, as the sun, consists of two conical regions : the one, that within which no ray of light enters, viz. the Umbra; the other, which is entered by rays from part only of the sun, is the Penumbra.

Peonage. [Sp. peonajè, from peon, one who goes on foot.] A form of servitude introduced into Mexico after the Spanish Conquest. (Pawn.)

Peotta. (Naut.) A small vessel of the Adriatic, propelled by sails and oars.

Peplus. [L., Gr. $\pi \epsilon ́ \pi \lambda$ os.] An upper garment worn anciently by Greek women. The P. of Athena was carried yearly in procession at Athens, and presented to the goddess. (Panathenaic festival.)

Pepper-corn rent. The merest nominal rent, as an acknowledgment of tenancy, in the case of lands held rent free.

Pepper-pot. A W.-Indian stew of vegetables and cassareep.

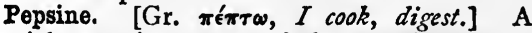
special organic matter of the gastric mucous membrane, and obtainable from it, on which its digestive power depends.

Pepys' Memoirs and Diary. (Samuel P., 16321703.) Written in a kind of cypher after his retirement from the Secretaryship of the Ad. miralty ; a most curious and minute picture of contemporary persons and manners.

Per-. [L., through.] (Chem.) 1. Prefixed to salts in -ate, denotes increase of oxygen, as a per-chlorate, which contains more oxygen than the chlorate. Hyper- [Gr. inté $\rho$, over] has also this force. 2. Prefixed to salts in -ide, denotes a maximum of the element thus marked, as per-chloride of iron contains more chlorine than any other chloride of iron.

Perambulation of parishes, i.e. of boundarles, to keep them in remembrance, or Beating bounds, is made, in some parishes, about Ascension Day, by the minister, churchwardens, 
and some parishioners. Originally psalms and prayers were used. (Rogation days.)

Perambulator. [L. perambŭlo, I traverse.] 1. A way or distance measurer, a kind of hodometer. (Pedometer.) 2. A child's carriage, propelled from behind.

Per annum. [L.] By the year, yearly.

Per centum. [L.] By the hundred.

Percĭdæ. [L. perca, a perch.] (Ichth.) Fam. of carnivorous fishes, as the common perch, fresh and salt water. Universally distributed. Ord. Ǎcanthoptěry̆ğii, sub-class Tělěostěi.

Per contra. [L.] On the other side; a commercial term.

Percussion. [I. percŭtio, I strike.] (Med.) The tapping of the surface of the body, especially the chest, to learn, by the sound, the condition of some internal organ below the part struck.

Percussion, Centre of. (Centre.)

Percy's Reliques of Ancient English Poetry, published 1765. A collection of old minstrel ballads of the Middle Ages, many existing in MS. only, then for the first time systematically examined ; by Bishop Percy, friend of Johnson ; valuable in itself, and very important, as a main cause of the revolution in English taste and literature, which replaced artificial classicism by romance.

Per ďem. [L.] Daily.

Père-la-Chaise. The most important cemetery of Paris; so called after the confessor of Louis XIV., who had a house on its site.

Perennial. [L. pĕrennis.] (Bot.) Opposed to Annual and to Biennial, subsisting for a number of years, though dying down yearly; e.g. tubers and bulbs.

Perennibranchiate. [L. perennis, perennial,

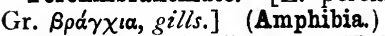

Pereunt, et impuntantur. [L.] A common motto on sun-dials : they, i.e. the hours, pass away, and are placed to our accoint; i.e. we have to give account of them (Martial).

Per fas ot nĕfas. [L., by fair means or foul.] By hook or by crook; through thick and thin.

Perfect number. (Math.) A number equal to the sum of its divisors, including unity; as, $28=1+2+4+7+14$.

Perfervĭdum ingĕnĭum. [L.] A too vehement or enthusiastic temper.

Perfídus ille Deo, sed non et perfidus orbi. [L., a man faithless to God, but not faithless to the world also.] So the Christian poet Prudentius speaks of Julian the Apostate as being " a lover of his country," and one who "deserved the empire of the world ". (vide Gibbon's Decline and Fall, ch. xxii., ad fin.).

Perfoliate stem. (Bot.) One which apparently pierces, goes through the leaf [L. per folium]; in reality the lobes of the leaf are not only amblexicaul $(q . v$.$) , but grow together where their$ margins come in contact. $P$. leaf, one through which the stem passes; e.g. yellow-wort, chlora.

Pergunnah. [Hind. pargana.] In British India, a district comprising several villages, and forming part of a zillah.

Péri. [Pers. perī, masc. and fem. (?) from per, $a$ wing $=$ winged (Littré).] A fairy, good genius, offspring of fallen spints excluded at present from paradise. (Fairies.)

Peri-. [Gr. $\pi \in \rho l$, around.]

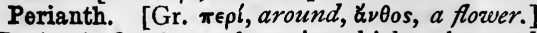
(Bot.) A floral envelope, in which calyx and corolla, though often both present, are not easily distinguished ; e.g. crocus, tulip, lily.

Perĭbǒlos. [Gr., from $\pi \in \rho l$, around, $\beta \dot{\alpha} \lambda \lambda \omega$, $I$ cast.] (Arch.) The walled inclosure of a temple.

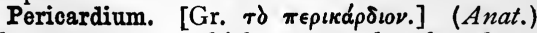
The membrane which surrounds the heart

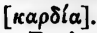

Pericarp. [Gr. $\pi \in \rho l$, around, $\kappa \alpha \rho \pi \delta s$, fruit.] (Bot.) All that is around the fruit or the ripened seed; i.e. usually the Epicarp [द் $\pi$, upon] or outermost layer; with Mesocarp, the middle

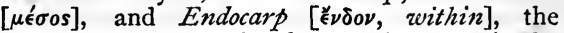
innermost. In peach, cherry, plum, M. is the fleshy part, End. is the stone.

Perichondrium. [Gr. $\chi \delta \delta \delta \rho o s$, cartilage.] Fibrous tissue, investing the cartilages.

Periclinal. [Gr. $\pi \in \rho i$, around, $\kappa \lambda i \nu \omega, I$ bend.] (Geol.) Dome-shaped strata dipping away outwards in every direction, like basins placed one over another. (Quaquaversal strata.)

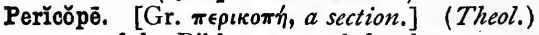
A passage of the Bible extracted for the purpose of reading in any portion of the ritual.

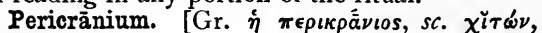
clothing.] (Anat.) The membrane which invests

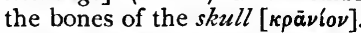

Perīcǔlōsæ plēnum ŏpŭs ālëæ. [L.] A task of dangerous hazard (Horace).

Peridot. [Ar. feridet, a precious stone.] A variety of chrysolite. (Topaz.)

Peridrome. [Gr. $\pi \epsilon \rho^{\prime} \delta \rho o \mu o s$, from $\pi \epsilon \rho i$, around,

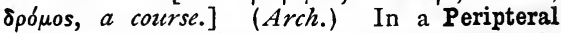
temple, the space between the walls of the cella and the columns.

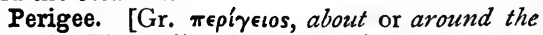
earth.] The point of the moon's orbit nearest the earth.

Perihēlion. [Gr. $\pi \in \rho$ l, about or around, $\ddot{\eta} \lambda \iota s$, the sun.] (Astron.) The point of the orbit of planet or comet nearest the sun.

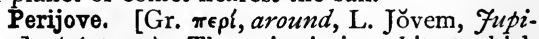
ter.] (Astron.) The point in its orbit at which any one of his satellites is nearest to Jupiter.

Periko. (Naut.) Bengalese boat of burden, undecked.

Perils, or Perils of the sea. (Naut.) Not dangers, but accidents, unpreventable by care and skill of the master and crew.

Perimeter. [Gr. $\pi \in \rho$ i $\mu \in \tau \rho o s$, the line forming a circumference.] The length of the sum of the sides of any inclosed space.

Per incüriam. [L.] By an oversight, through want of care; e.g. the Act which substituted the Judicial Committee of the Privy Council for the Court of Delegates created, per inc., a new Final Court of Appeal in spiritual causes.

Period. [Gr. replodos, a circuit.] 1. (Rhet.) A sentence, the meaning of which cannot be fully apprehended before its close. 2. (Math.) When an algebraical or numerical expression consists of a number of groups of terms, or when it has 
a number of groups of values, each group consisting of the same elements in the same order, any one group is a P.; as in the number 2.5732732732 , etc., the group 732 is a period. 3. The time in which an harmonic motion goes through one complete set of changes. 4. In Printing, a completed sentence; hence a full stop.

Periodical colours. Such as recur according to a fixed scale ; as in Newton's rings, and other interference phenomena.

Periodic function; P. time. One whose successive values keep on recurring in the same order. The F.time of a planet is the time in which it makes one complete revolution.

Periœcians, or Perioikoi. In Gr. Hist., the freemen of the Laconian townships, as distinguished from the genuine Spartiates, or citizens of Sparta itself.

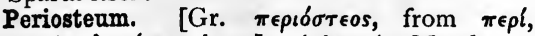

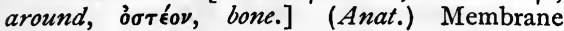
which invests the bones generally.

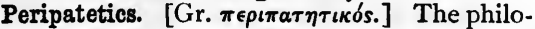
sophers of the school of Aristotle, who instructed

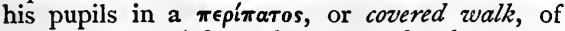
the Lyceum at Athens, but not, as has been supposed, walking up and down during the whole time of instruction.

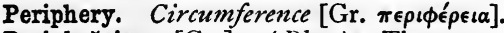

Periphrăsis. [Gr.] (Rhet.) The use of several words to denote a single object, which for whatever reason it is thought better not to name.

Perīplus. [Gr. $\pi \in \rho i \pi \lambda$ ous.] 1. Lit. a sailing round, or circumnavigation. 2. The narrative of such a voyage as the Periplus of Scylax (Skylax), in the time of Augustus, and of Cosmas, called Indicopleustēs from his voyages to the East.

Periptěral. [Gr. $\pi \epsilon \rho i \pi \tau \epsilon \rho o s$.$] (Arch.) A$ building surrounded with a wing, aisle, or passage. With the ancient Greeks, a temple surrounded by a single row of columns, those with two rows being called dipteral.

Peris. (Peri.)

Periscians. [Gr. $\pi \in \rho i \sigma \kappa \iota s$, from $\pi \in \rho l$, and $\sigma \kappa i a$, shadow.] In Geog., the inhabitants of the Arctic and Antarctic circles, whose shadows describe an entire circumference in their summer season.

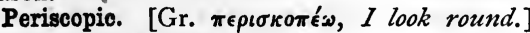
Viewing on all sides.

Periscopic spectacles. Those furnished with menniscus lenses to increase the distinctness of vision when objects are viewed obliquely.

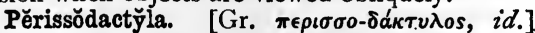
(Anat.) Having an odd number of toes, as the horse, all being inclosed in a single envelope; a div. of Ungǔlāta.

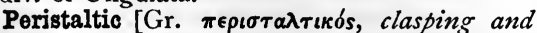
compressing] action. (Med.) Especially of the bowels ; that vermicular action, of alternate contraction and relaxation, by which their contents are propelled throughout.

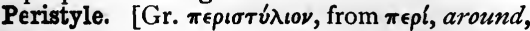
$\sigma \tau \hat{v} \lambda o s$, a column.] (Arch.) A court, or cloister, with columns on three sides.

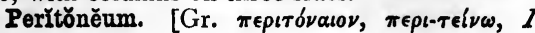

stretch around.] (Anat.) A large serous membrane, more or less investing all the viscera lying in the abdominal and pelvic cavities, and then reflected upon the walls of the abdomen.

Perkinism (Dr. Perkins, inventor). The use of metallic tractors (q.v.).

\section{axis.)}

Permanent rotation, Axis of. (Principal

Permian system (developed in district of Perm, Russia) (Geol.) = Lower New Red Sandstones + magnesian limestones, marlslate, etc. ; in Germ. called Dy̆as [Gr. Súás, a group of two]; of. the word Triassic.

Permissu sŭpěriōrum. [L.] With the leave of the superiors; a phrase used in the Latin Church for books issued with authority.

Permitte Divis cæterra. [L., leave the rest to the gods (Horace).] Do your duty, and trust the rest to God.

Permutations of things. The different orders in which they can be arranged; as, $a b, b a, a c, c a$, $b c, c b$, are the permutations of $a, b, c$, taken two and two together.

Per my et per tont. In Law, joint-tenants are said to be so seised, i.e. by the half and by all; each having entire possession of every parcel of land as well as of the aggregate whole.

Pernancy. [Norm. Fr. pernér.] (Leg.) The receipt or enjoyment of the profits of an estate, the receiver being called the Pernor.

Pernoctation. [L. pernocto, I pass the night.] 1. (Med.) Passing the night in sleeplessness. 2. (Theol.) In watching and prayer.

\section{Pernor. (Pernancy.)}

Peroration. [L. perorātiōnem, a speaking through; i.e. reaching the end of a speech.] The last part of an oration, containing generally a summary and application of the arguments.

Perpendicular. [L. perpendřculum, adj. -āris, a plumb-line.] (Fortif.) The line drawn inwarts at right angles to the centre of each side of the polygon till it strikes the lines of defonce (q.v.) drawn from the angles of the polygon.

Perpendicular style. The latest style of genuine English architecture; also called Continuous. Its later or Dibased form immediately preceded or accompanied the Renaissance, or classical revival. (Geometrical style.)

Perpendt stone. (Arch.) A stone which goes through the walls; also called Perpender, Perpend.

Perpeyn wall. A pier or buttress, built in Perpendt ashlar.

Per rectè et retrò. (Music.) Lit. by forward and backward; said when the order may be reversed; e.g. Crotch's chant in $\mathrm{G}$, the third part being $=$ first (and the fourth $=$ second) played backwards. (Inversion.)

Perron. [Fr., for pierron, from pierre, a stone,

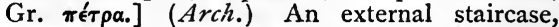
steps leading to a first story.

Perruquier. [Fr.] One who makes pcrukes, or wigs.

Perry. 1. [Fr. poiré, from poire, a pear.] The fermented liquor made from pears. 2. In Naut. slang, a sudden squall. 
Per saltum. [L.] By a leap (as when any one is promoted to a high dignity without passing through the intermediate grades).

Per se. [L., by itself.] In itself.

Persěphŏnē. [Gr.] (Myth.) The daughter of Dēmētēr, and wife of Hades. (Eleusinian Mysteries.)

Persian berries. A kind of yellow berries used in dyeing.

Persiani. [It.] Venetian blinds.

Persian powder. The pulverized flowers of Py̆rellivum carneum, a native of the Caucasus ; a valuable insecticide; used in Russia, Persia, Turkey, Britain, France.

Persian ware. A fine fayence (Gombroon) approximating to porcelain brilliantly enamelled.

Persicot. [Fr., from L. persicŭm, a peach.] A liqueur made of the kernels of stone fruits.

Persiflage. [Fr. persifler, from per, the L. per, an intens. particle, and siffler, to hiss, whistle, L. sibilare, through a popular form sifilare, according to Brachet.] Bantering, quizzing.

Persis. A kind of dye obtained from lichens.

Persistent. [L. persistentem, remaining; (Bot.) Not falling off; as the petals of St. John's wort, Hypericum.

Person. As in Acts x. 34 and elsewhere, "respecter of persons ;" the part or rôle in a play, $L$. persōna being (1) a mask, (2) a part acted; so also Gr. $\pi \rho 0$ ( $\sigma \omega \pi o \nu$, i.e. with God the question is not what person each sustains, but how.Trench, Select Glossary.

Personable. 1. Graceful, or well formed, in body. 2. In Law, able to maintain pleas in court.

Personal equation. (Astron.) The correction to be applied to an astronomical observation on account of the peculiarities of the nervous system of the observer at the time of observation. In virtue of these organic peculiarities, one observer will note the occurrence of a phenomenon (such as the bisection of a star by a wire of a transit instrument) some tenths of a second earlier or later than another would note it.

Personal identity. (Identity, Personal.)

Personate flower. [L. persōna, a mask.] (Bot.) A labiate with compressed lips ; e.g. snapdragon.

Personnel. [Fr.] The body of persons employed in any occupation, as distinguished from the materiel on which they work.

Perspective [L. perspectivus, belonging to close inspection], Aerial; Isometrical P.; Linear P.; P. projection. The geometrical art of representing on paper the appearance of a solid body as seen by a single eye in a given position. If lines supposed to be drawn from the eye to the boundaries of the body are cut by a plane, their points of intersection with the plane give the required representation, or its $P$. projection. The position of the eye is the point of sight, or projecting point ; the plane-which in most cases is supposed to be vertical-is the plane of projection or of the picture. Aerial $P$. refers to the gradations of colours according to distance. (For Isometrical $P .$, vide Is0-.)
Perth, Five Articles of. Voted by the Scotch bishops at the General Assembly at Perth, 1618, to serve as a basis for Liturgy and Canons.

Perturbation. [L. perturbatio, -nem, disorder.] (Astron.) An inequality in the motion of moon or planet not included in the expression of Kepler's laws, and arising, in the case of primary planets, from their mutual gravitation; and in the case of the moon, from the unequal attraction of the sun on the earth and moon.

Peruvian bark. I.q. cinchona (q.v.).

Peschito. [Syr.] The earliest Syriac version of the Scriptures; so called as being simple and literal, rendering word for word. Introduced into Europe in the sixteenth century.

\section{Pessimism. (Theodicæa.)}

\section{Pessimist. (Optimist.)}

Pestalozzian method of teaching. So far as it can be given in a few words-concrete, and by means of objects themselves ; with graduated lessons, personal study of individual children and their separate minds, character, etc. To no one has primary instruction been more indebted than to Pestalozzi, of Zürich (1745-1827).

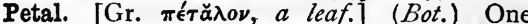
of the parts of a corolla when this is made up of many pieces; when all in one piece, it is styled monopetalous.

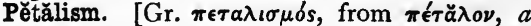
leaf.] In Gr. Hist., the Syracusan form of what at Athens was known as Ostracism, leaves being used by the voters instead of shells. The exile also lasted only five years instead of ten.

Petard. [Fr.] (Mil.) Metal explosive case formerly used for blowing open gates.

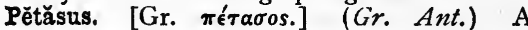
broad-brimmed hat, used by travellers. Such $a$ hat with wings is an emblem of Hermes.

Petäte. (Central Amer. name for a palm mat.) Dried palm leaves or grass used for plaiting into hats and mats.

Petechiæ. [It. petecchia, L. pĕtīgo, an erup. tion.] $(\mathrm{Med}$.) Purple spots of effused blood, like flea-bites, in the skin, appearing in some severe fevers, as typhus.

Peter-boat. (Naut.) A Thames and Medway fishing-boat, about twenty-five feet by six feet, shallow with sharp stem and stern, with a fishwell amidships.

Peterloo Massacre. The dispersal by the military of a large meeting, chiefly of operatives, held in St. Peter's Field, Manchester, July I6, I8I9, to agitate for Parliamentary reform. ( $P$. a sarcastic name, suggested by Waterloo.)

\section{(Blanketeers.)}

Peter's fish. A haddock; so called because the spots on either side are supposed to be the mark of St. Peter's fingers impressed on the fish which he caught to pay the tribute.

Peter's pence. Originally a voluntary offering by the faithful to the Roman see. Afterwards levied from every house, under the name of Romefeoh, or Romescot. In this country the impost was finally abolished under Henry VIII.

Petiole. [L. pětrŏlus, a little foot, a stalk.] (Bot.) A leaf-stalk ; which, with the blade or limb, makes up the leaf. 
Petit bourgeois. [Fr.] A second-rate citizen. Petitioners and Abhorrers. (Abhorrers.)

Petition of Right. An enactment of the Parliament of 1628 ; so named to make it clear that the franchises or rights specified in it were not newly gained, and that the statute merely explained the existing constitution. (Bill, or Declaration, of Rights.)

Petitro principii. [L., a demand of the principle.] (Log.) A begging of the question; that is, the treating of a proposition as already proved, when it is only a premiss of the Syllogism by which it is to be proved.

Petit littérateur. [Fr.] A dabbler in literature.

Petit maître. [Fr., a little master.] A coxcomb.

Petit mal. [Fr.] (Fant mal.)

Petit soins. [Fr., small cares.] Little attentions.

Petrel. [(?) Dim. of Peter, as seeming to walk on the waves ; $c f$. Ger. Peter's vogel.] (Ornith.) A cosmopolitan gen. of sea-birds, as the stormy petrels, Mother Carey's chickens; about six inches long ; black, with white on wings and rump. Prŏcellārŭa, fam. Prǒcellārŭdæe, ord. Ansěres. "The most aerial and oceanic of birds," yet one spec. (Puffinŭriæ Bĕrardi, Tierra del Fuego) has the appearance and habits of the auk, or grebe.

Petrine Iiturgy. That of St. Peter, or the Roman. (Liturgy.)

Petrobrusians. (Eccl. Hist.) The followers of Peter Brueys, or De Bruys, who in the twelfth century denounced the vices of the clergy, and gained many disciples in S. France.

Petrŏleum springs. [L. petra, rock, ŏlěum, oil.] Naphtha, etc. ; liquid bitumens found in several parts of Europe, in Persia, W. Indies, and in profuse abundance in U.S. and Canada.

Petty average. (Naut.) Charges for towing, etc., borne partly by ship and partly by cargo.

Petty bag. A little bag or sack in which some of the writs issuing out of a court or office of Common Law (which, with the Court of Equity, made up the Court of Chancery) were originally kept. Other writs issuing out of the same court (i.e. of Common Law) were generally kept in a hamper. Whence the Hanaper Office. (Hanaper.)

Petty jury. In Law, the jury who give their verdict in criminal cases for which a true bill has been found by the grand jury.

Petty larceny. The stealing of goods below the value of one shilling, thefts of larger amounts being known as Grand larceny. The distinction was abolished in 1807 .

Petty officers. (Naut.) Sailors of first class, ranking with non-commissioned officers in the army.

Petty sessions. As distinguished from Quarter sessions, a court constituted by two or more justices of the peace.

Petuntse. [Chin.] (Peh-tun-tze.)

Peutingerian table, or map (so called from Conrad Peutinger, who first made it generally known). A map of the ancient Roman roads; supposed to have been drawn up early in the third century.

Pewter. [Ger. spiauter.] An alloy of four parts of tin and one of lead.

Pfahlbauten. Pile-drvellings. (Lake-dwellings.)

Pfennig. [Ger.] A coin worth about an eighth or a twelfth of a penny ; in N. Germany the $\frac{1}{28} 8$ th part of a thaler ; in S. Germany the ${ }_{2}^{1} \frac{1}{40}$ th part of a florin or gulden.

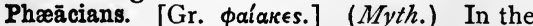
Odyssey, the inhabitants of an island called Scheria, whose ships have the powers of thought and speech, and perform their voyages without rudder, tackling, oarsmen, or sails. They are, in other words, the dwellers in Cloud-land, and are, in fact, the clouds.

\section{Phænogams. (Cryptogams.)}

Phaěthōn. [Gr., ciear-shining.] (Myth.) The child of the sun, Helios, who, being entrusted with his father's chariot, lost control over the horses, who, approaching too near the earth, scorched it up. He was killed by a thunderbolt of Zeus.

Phalanger. [From phalanx (q.v.).] (Zool.) A marsupial quadruped, of gen. Phalarista. Australia, Tasmania, etc. Nocturnal in habits, and living in trees.

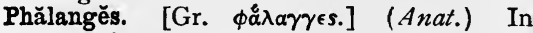
men and animals, the small bones of the fingers and toes.

Phalanstery. [Fr. phalanstère, said to be from Gr. $\phi \alpha \dot{\lambda} \alpha \alpha \xi$, phalanx, $\sigma \tau \epsilon \rho \in \delta s$, firm.] The dwelling of a Fourierite association, maintaining community of property and goods.

Phălanx. [Gr.] The order of battle in which the Greek Hoplites were usually drawn up.

Phălăris, Epistles of. A collection of forged letters, ascribed to Phalaris, tyrant of Akrăgas (Agrigentum), in Sicily ; known chiefly through the controversy on the subject of their spuriousness, between Bentley, and Boyle who maintained that they were genuine.

Phanariots. Greek officials of Constantinople ; so called as living in the Phanar, the quarter of the city in which the patriarch resided.-Finlay, Hist. of Greece, iv. 252.

\section{Phanerogams. (Cryptogams.)}

Phantasmagoria. [Gr. $\phi \alpha \dot{\nu} \tau \alpha \sigma \mu \alpha$, an appear. ance, à $\gamma \in i \rho \omega, I$ bring together.] An exhibition of images thrown on a screen by a magic lantern.

Pharisees. [Heb. perûshim, separated.] A religious party among the Jews, who held that God revealed to Moses an oral law (Masorah), which had been handed down by tradition, to supplement the written Law, and that this oral law declared the continuance of life after death and the resurrection of the dead. (Sadducees.)

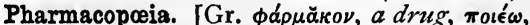
$I$ make.] An authoritative work, giving directions for the preparation of medicinal substances.

Phăros. 1. An island at the mouth of the harbour of Alexandria, on which a lighthouse was erected. 2. Any lighthouse.

Phărynx. [Gr. фắv $\gamma \xi$, throat, pharynx.] (Anat.) That part of the alimentary canal which lies behind the nose, mouth, and larynx. 
Phase. 1. (Astron.) A change of appearance [Gr. $\phi \dot{\alpha} \sigma i s]$ of moon or planet caused by a larger or smaller portion of its illuminated surface being visible. 2. (Phys.) The propagation of a wave-motion through a medium is due to each particle in succession being caused to make small oscillations like those of a pendulum; the $P$. of the motion of a particle is the fractional part of the time of one oscillation since it last passed through its position of rest in the direction of the wave-motion.

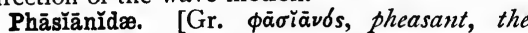
bird of the Phasis, or Rheon, in Colchis, now Faisz-Rhioni, in Georgia.] (Ornith.) Fam. of birds comprising pheasants, peacocks, guineafowl, turkeys, and jungle-fowl. Almost cosmopolitan, but chiefly E. Asia. Ord. Gallinæ.

Pheidirǐa. [Gr.] A later name for the Spartan Syssītǐa.

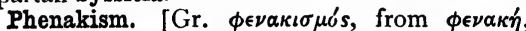
false hair.] Saying what is not meant, cheating.

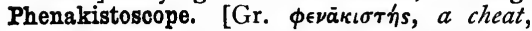
$\sigma \kappa o \pi \epsilon ́ \omega$, I look at.] A toy, in which advantage is taken of the persistence for an appreciable time of an impression on the retina, to make a succession of pictures imitate the movements of animals. There are several toys founded on the same principle, called by different names,

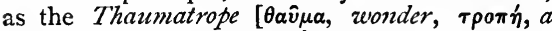
turning], the Zoetrope [ $\zeta \omega \omega_{0}$, an animal] or Wheel of life, Faraday's wheel, etc.

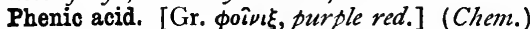
Carbolic acid.

Phenicine. [Gr. $\phi_{0}(\nu \iota \xi$, red.] A purple powder obtained from indigo.

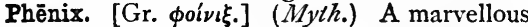
bird, said to live 500 or 600 years in the desert, and then to kindle its own funeral pyre, from which it emerged with a new life. It thus became a symbol of immortality. But this story is told with many variations.

Pheon. [O.Fr.] (Her.) A cross-bow bolt, shaped like a broad arrow-head.

Phigaleian marbles. A part of the collection in the British Museum, known as the Elgin marbles. They were discovered near the site of the Arcadian town Phigaleia.

Philabeg. (Fillibeg.)

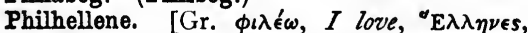
Greeks.] One strongly attached to the cause of Greece in the present day.

Philibeg. (Philabeg.)

Philippics. 1. Orations of Demosthenes against the policy of Philip, King of Macedonia and father of Alexander the Great. 2. The name was applied to the speeches by which Cicero drove Marcus Antonius from Rome; and hence, $\mathbf{3}$, to severe invectives generally.

Philistinism. A word used to describe the supposed lack of sweetness and light in inferiors by those who think themselves superior.

Philoctētēs, Arrows of. (Myth.) Weapons without which Troy could not be taken, and which had belonged to the hero Heracles (Hercules).

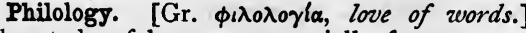
The study of language, especially for purposes of science, which chiefly rests on the comparison of languages - the method used being that of Comparative philology.

Philosopher's stone. A stone by which, when obtained by a long series of processes, the alchemists believed that they would be able to transmute the baser metals into gold.

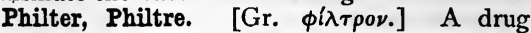
or potion supposed by the ancient Greeks and Romans to have the power of exciting love.

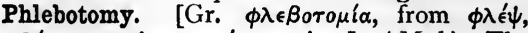
$\phi \lambda \epsilon \beta \delta$ s, a vein, ro $\mu$ '́, cutting.] (Med.) The opening of a vein for blood-letting.

Phlěgěthōn. [Gr., burning.] (Myth.) One of the rivers of the infernal regions; called also Pyriphlegethon, flaming with fire.

Phlegmatic. [Gr. $\phi \lambda \epsilon ́ \gamma \mu \alpha$, (I) inflammation, (2) as its result a cold watery humour.] 1 . Abounding in phlegm. 2. Cold, sluggish, not easily excited.

Phlegræan Plains. The volcanic region of Campania, in Italy, was so called. The Greek Phlegra denotes any burning land.

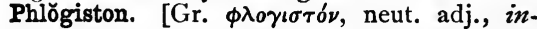
flammable.] An imaginary principle of combustion, resident in matter, and accounting for combustion. (Stahlianism.)

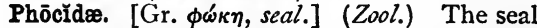
family, aquatic carnǐvora.

Phœbus Apollo. [Gr. Фoißßos 'A $\delta \delta \lambda \lambda \omega \nu$.] The sun-god of the Greeks, born in Delos, the bright land, ruling in Lycia, the land of light, and having his great sanctuary at Delphi, under Mount Parnassus. His face and form were represented as the perfection of beauty, no razor being suffered to touch the golden locks (rays) which streamed over his shoulders. (Ortygian shore.)

Phōlas. [Gr. $\phi \omega \lambda \alpha$ s, lurking in a hole ( $\phi \omega \lambda \in \delta s)$.] (Zool.) Gen. of bivalve molluscs, giving its name to fam. Phōlădĭdæ (piddocks and shipworms), boring holes in wood and stone. Class Conchĭferra.

Phonetic spelling. [Gr. $\phi \omega \nu \eta$, , a sound.] 1. A system which aims at spelling the words of all languages precisely according to their sound. The difficulty seems to be to arrive at an agreement as to the signs which are to represent these sounds, and 2 , to ensure uniformity, and 3 , permanence, in vowel-pronunciation.

Phonetic writing. Writing in which signs represent sounds, as distinguished from ideo. graphic, in which signs represent objects. (Hioroglyphics.)

Phonolite. (Clinkstone.)

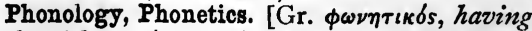
to do with $\phi \omega \nu \eta$, sound, the sound of the voice.] The science of articulation; the science of vocal sounds in their relation to language.

Phosphor. 1. (Astron.) The planet Venus when appearing as the morning star [Gr. $\phi \omega \sigma$. фópos, i.e. the light-bringer]. 2. (Chem.) One of the elements, resembling yellow wax, very inflammable. Baldwin's phosphorus, fused nitrate of lime, which, after exposure to the sun, emits light in the dark. Canton's phosphorus, a substance possessing the same properties, and 
made by exposing calcined oyster-shells and sulphur to a red heat.

Phosphŏrus. (Phosphor.)

Photinians. (Eccl. Hist.) Followers of Photinus, who, in the fourth century, maintained opinions akin to those of the Cerinthians, Ebionites, and Sabellians.

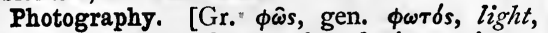

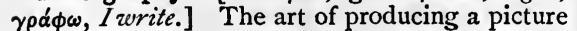
by the agency of light.

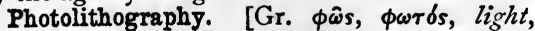
and lithography.] A mode of lithographing in which a photographic picture is taken on the prepared stone.

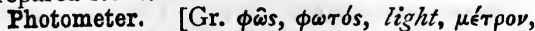
$a$ measure.] An instrument for measuring the intensity of a light with reference to some other light taken as a standard.

Photophone. Professor Graham Bell's instrument which, by the agency of a beam of light [Gr. $\phi \hat{\omega} s, \phi \omega \tau \delta s]$, reproduces sounds and articulate speech [ $\phi \omega \nu \eta$, sound, voice] in distant places. This invention has lately led to the discovery that light may not only be made to convey sounds, but actually to produce them by its action upon most known substances.

Photosphere. [Gr. $\phi \hat{\omega} s$, light, $\sigma \phi \alpha i \hat{p} \alpha$, sphere.] (Astron.) The luminous envelope surrounding the sun.

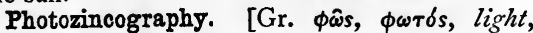
and zincography.] Printing from prepared zinc plates, on which a photograph has been taken.

Phratry. [Gr. фparpía, a brotherhood, or clan.] In Gr. Hist., the union of a certain number of families by the bond of a common worship. It answered to the Latin gens. The union of a certain number of Phratries on the same principles formed a Phȳlē, or tribe; and the like union of tribes constituted a Pŏlis, or city, Latin populus. (Apaturia.)

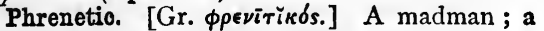
frantic person is lit. suffering from phrenitis.

Phrenic. Relating to the diaphragm [Gr. $\phi \rho \eta \nu, \phi \rho \in \nu 6 s]$.

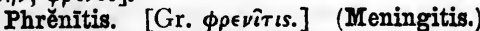

Phrygian mode. (Greek modes.)

Phrygians. (Eccl. Hist.) An early Christian sect; so called as abounding in Phrygia, and following the teaching of Montānus. (Montanists.)

Phtheiriasis. [Gr. $\phi \theta \epsilon \iota \rho$ lā $\iota s, \phi \theta \epsilon i \rho, a$ louse.] (Pedicularia.)

Phthǐsis. [Gr. $\phi \theta i \sigma \iota s, \phi \theta^{\prime} \omega, I$ decay.] (Med.) Pulmonary consumption.

Phycology. Study of seaweed [Gr. фîkos].

Phylactery. [Gr. $\phi v \lambda \alpha \kappa \tau \eta ́ p \iota o \nu$, from $\phi v \lambda \alpha \dot{\sigma} \sigma \omega \omega$, $I$ guard.] An amulet or preservative. The phylacteries of the Jews consisted of slips of parchment inscribed with verses of the Law, worn during prayer on the arm and between the eyes (Exod. xiii. 9).

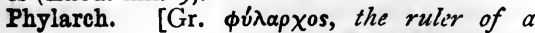
$\phi v \lambda \eta$, or tribe.] An Athenian officer who superintended the registering of the members of each tribe.

Phȳlē. (Phratry.)

Phyllödium. [Gr. $\phi v \lambda \lambda \omega \delta \eta \bar{s}$, like a leaf
( $\phi \dot{v} \lambda \lambda o \nu)$.$] (Bot.) A petiole transformed into a$ leaf-like body; e.g. the Australian acacias.

Phyllome. [Gr. $\phi \dot{v} \lambda \lambda \omega \mu \alpha$, foliage.] A term lately introduced into Botany, including all distinct lateral members borne upon stems or branches.-Bettany, Practical Botany.

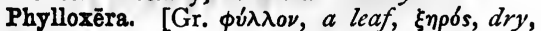
parched.] A grub which, attacking the roots of vines, eventually destroys whole vineyards.

Physical force. Any force which is sufficiently defined as a cause that changes or tends to change the state of a body as to rest or motion. (For $P$. astronomy, $P$. geography, $P$. optics, vide Astronomy ; Geography ; Optics.)

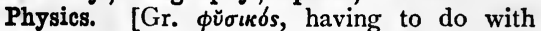
nature.] 1. The laws of the phenomena of matter. 2. A general term for the group of sciences-mechanism, mechanics (kinematics, dynamics), heat, sound, light, electricity, and magnetism.

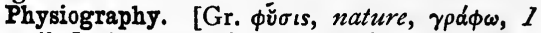
describe.] A systematic account of the particular phenomena of nature.

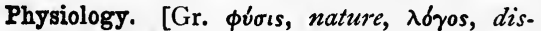
course.] The science which treats of the phenomena of life in animals and plants.

Phȳsostŏmi. [Gr. $\phi \hat{v} \sigma a, a$ bladder, $\sigma \tau \delta \dot{\alpha} \alpha, a$ mouth.] (lchth.) The fourth order of tele-

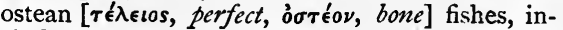
cluding cat-fishes, carps, herrings, eels, and more than twenty other families.

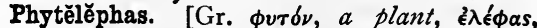
ivory.] Vegetable ivory, being the hardened albumen of the Cabeza de Negro or Fagna, a gen. of palm-like plants inhabiting S. America.

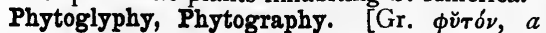
plant, $\gamma \lambda u ́ \phi \omega, I$ engrave, $\gamma \rho \alpha \dot{\phi} \omega, I$ draw.] Nature-printing.

Phyto, -logy. (Bot.) Treats of plants in general ; -tomy, of their anatomical structure; -graphy is the art of describing them. [Gr.

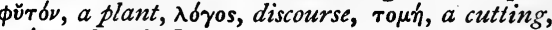
$\gamma \rho \alpha \dot{\phi} \omega, 1$ write.]

Piacular. [L. piāculāris.] Expiatory; having power to appease.

Pia mater. (Dura mater.)

Piarists. [L. Patres Schŏlārum Pūanum, Fathers of pious schools.] An order devoted to education, founded at Rome by Casalanzio, a Spanish nobleman, in the seventeenth century.

Piassava. [Port.] Fibre from a kind of Brazilian palm, used for brooms, etc.

Piaster, Piastre. An Italian coin worth about 3s. $7 d$.; a Spanish piaster, or hard dollar, is worth 4s. $2 d$.; the Turkish piaster is worth about $2 d$.

Piazza. [It.] (Arch.) A square open space surrounded by buildings.

Pibroch. [Gael. piobaireachd, piobracht, the pipe summons.] The music of the bagpipes, but not the bagpipe itself. Every clan had its own pibroch.

Pica. [L., a magpie.] ( $M c d$.$) Morbid de-$ praved appetite for things unfit for food.

Pica. A kind of type, as-

\section{Young}

(from its being used to print the pye (Pie) or table 
of daily services in the old Roman servicebook).

Pica, Small; Double P. Two kinds of type, as-

\section{French. Dutch.}

Picador. [Sp.] A horseman who excitos and irritates the bull at a bull-fight.

Picard. (Naut.) A Severn trading-vessel of old time.

Picards. (Hist.) The followers of the Flemish Picard, who, in the fifteenth century, gave himself out as the new Adam, and professed to restore the state of primeval innocence.

Picäriææ. [L. picus, woodpecker.] (Ornithology.)

Piccalilli. [Hind.] An E.-Indian pickle.

Piccaroon. [A picker, i.e. stealer.] 1. A thief or swindler. 2. A pirate-ship.

Piccary. (Naut.) Petty piracy.

Piccolo. [It., little.] (Music.) 1. A wooden stop in an organ, two feet in length, of clear, bright tone. 2. A flute, of which the notes are an octave higher than those of the common flute. 3. A small piano is sometimes called a $P$.

Picídæ. [L. picus, woodpecker.] (Ornith.) Woodpeckers. Widespread fam. of birds, but not found in Australia. Sub-ord. Scansōres, ord. 'Pīcārĭæ.

\section{Pickage. (Stallage.)}

Picked out. Relieved with stripes of a different colour [cf. Fr. piqué, spotted].

Pickerel. [Dim. of pike, a kind of fish, from Celt. pic, a point, from its pointed jaws; $c f$. Fr. brochet, id., and broche, spike.] (Ichth.) A small pike. Esox lücius, fam. Esŏcřdæ, ord. Phȳsostŏmi, sub-class Tělěostěi.

Pickerie. (Naut.) Old word for stealing. Under this name theft was punishable by duckings.

Picket. (Mil.) Short stake [Fr. piquet] (which came to mean also cavalry, whose horses were fastened to the same P.) for driving into the ground to secure horses, tents, and revetments, or to mark out fieldworks.

Picklock. A superior kind of selected wool.

Pickthank. One who thrusts himself into matters with which he is not asked to meddle; a flatterer or talebearer.

Pick up a wind, To. (Naut.) To get from one trade-wind to another with the least amount of calm possible.

Picric acid. [Gr. $\pi \iota \kappa \rho \delta s$, bitter.] (Chem.) A bitter acid used as a yellow dye.

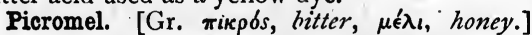
A sweetish-bitter substance existing in bile.

Picts' Wall. One of the barriers raised by the Romans to prevent the incursions of the Scots into S. Britain.

\section{Piddock. (Pholas.)}

Pie. 1. In Printing, a mass of unsorted types. 2. The table used before the Reformation for finding out the service for the day. The word is of doubtful origin, some referring it to Gr. $\pi$ iva , a tablet; others to the Litera Picata, the large black letter marking the beginning of each new order in the service. (Pica.)

Pièce de résistance. [Fr.] 1. The substantial joint in a dinner; a piece to cut and come again. Hence, 2, the important piece in a theatrical entertainment, as distinguished from what is before and after ; and generally, 3, the principal thing in a day's business or pleasure.

Piece goods. Dry goods sold by the piece, as longcloths, sheetings, etc.

Piecener. [Eng. piece.] A workman who supplies rolls of wool to the slubbing-machine.

Piece of eight. A hard dollar, or Spanish piaster $(q . v$.$) , worth about 4 s .2 d$.

Pièces justificatives. [Fr.] A French phrase for passages cited at the end of a work in support of the author's statements or conclusions.

Pied-à-terre. [Fr.] Foot on earth.

Pio poudre court. In Law, a court for deciding on the spot disputes arising at fairs and markets ; called in L. curia pedis pulvěris, etc., from the dusty-footed dealers [O.Fr. pied pouldreux] who frequented it. Now disused.

Pier arches. (Arch.) The main arcade of a church, supporting the Triforium and Clerestory.

Pierced. (Her.) Having a round hole through the middle.

Piěrǐděs. [Gr.] According to some, a name of the Muses, from Mount Pieros, in Thessaly. Others speak of them as the daughters of Pieros, King of Emathia, who were worsted in their rivalry with the Muses. (Pegasus.)

Pierrier. [Fr. pierre, a stone, L. petra.] (Mil.) A kind of cannon once used for throwing stones.

Piers Ploughman. Two poems, the one called the Vision, the other the Creed, of Piers the Ploughman, are supposed to have been written by Robert Langland, in the fourteenth century. They are in the old English alliterative verse, and speak very plainly of the ecclesiastical abuses of the time.-Milman, Hist. of Latin Christianity, bk. xiv. ch. 7 .

Pietantia. [L.L. of the Middle Ages.] The zest or relish given to make the rest of the fare more palatable; from which, probably, the modern pittance, meaning the whole of a donation, which is nevertheless small in amount.

Pietists. Certain reformers of the Lutheran Church in the seventeenth century were so called, as wishing to awaken a more religious spirit and greater strictness of life. Their efforts led to the growth of the more vehement and enthusiastic school, which found its great interpreter in the mystical Jacob Böhm or Behmen.

Pietra commessa. [It., joined stone.] Inlaying with veneers or precious stones.

Pietra dura. [It., hard stone.] Ornamental work in coloured stones, representing fruits, birds, etc., in relief.

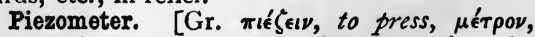
measure.] An instrument for measuring the compressibility of liquids.

Pigeon English. A jargon employed by Chinese at Hong-Kong and elsewhere, in their intercourse with the English. It is said to be a corr. of Business English. 
Pig iron. (Sow.)

Pigment. [L. pigmentum, paint.] (Anat.) Colouring matter of any tissue ; e.g. in freckles; in the skin of dark races; in the P. nigrum, on the inner surface of the choroid coat of the eye.

Pignoration. [L. pignorātiōnem, from pignus, pignŏris, a pledge.] The act of pledging or pawning.

Pignut. (Bot.) Root of Bunium [Gr. Boúvıv] flexuosum, ord. Umbelliferæ ; like a small potato, with aromatic, sweet taste. Found in S. and W. Europe, and plentiful in Britain.

Pike. [Fr. pique, a thing peaked.] (Mil.) Arm of many infantry soldiers down to the end of the seventeenth century. An ash-handled spear, surmounted by a steel head, and protected for a distance of four feet by metal plates ; length fifteen to sixteen feet.

Pilaster. [It. pilastro.] (Arch.) A square engaged pillar, projecting from the wall, usually about the fifth part of its width.

Pile. [Fr. poil.] The nap of cloth, velvet, etc

Pile. [L. pilus, a stake.] (Her.) A wedgeshaped ordinary formed by lines drawn from the dexter and sinister chief to the middle base. (Escutcheon.) Swords or other charges arranged in this shape are said to be borne in pile.

Pile arms. (Mil.) To rest three muskets against one another by securing their ramrods; preventing the necessity of laying them on the ground.

Pilo-driver. An engine for driving in Piles.

Pile-dwellings. (Lake-dwellings.)

Piles. (Arch.) Pieces of timber or iron, used for supporting the foundations of a building or the piers of a bridge.

Pilěus. [L., $a$ cap.] (Bot.) The cap of a mushroom.

Pilgarlic. "A sneaking or hen-hearted fellow" (Johnson). "One who peels garlick for others to eat," enduring hardships while others enjoy themselves (Wedgwood). (For a full account of this disputed word, see Latham's Johnson's Eng. Dict.)

Pilgrimage of Grace. A rebellion in the N. of England, 1536; headed by Aske, and caused chiefly by the dissolution of the smaller mon. asteries. So called because the insurgents bore banners displaying the five wounds of the Saviour. Scroop, Archbishop of York, who joined them, was executed in 1537 .

Pilgrim Fathers. Nonconformists, who, sailing from Southhampton in the Mayflower, landed at Plymouth, Massachusetts, December, I620.

Pill. [C f. L. pellis, skin.] As in Gen. xxx. 37,38 ; Isa. xiii. ; to peel, to take off the rind : but pill, = to plunder, is Fr. piller, It. pigliare, a military term.

\section{Pillared saints. (Stylite saints.)}

Pillars of Hëracles, or Hercules. The name by which the Greeks and Romans knew the Straits of Gibraltar, the pillars being the two hills Abila on the African side, and on the European Calpe, which has received its present name, Gibel al Tarik, or the Rock of Taric, from the Arab general who destroyed the Gothic monarchy of Spain in the person of Roderick. (Heracles.)

Pillau. [Turk. pilaw.] A Turkish dish of boiled rice and mutton fat.

Pillöry. [Fr. pilori, perhaps from pilier, $a$ pillar.] A wooden instrument which exhibited the head and person of a criminal to public view and insult. (Healfang.)

Pillow; P.-block. 1. [O.E. pilwe, L. pulvinus.] A block with a cylindrical hole for supporting a revolving axle or journal. 2. Pillow of a plough is a wooden cross-piece for raising or lowering the beam. 3. [Fr. pelu, hairy.] A plain, coarse fustian. 4. (Naut.) The timber on which the inner end of the bowsprit rests.

Pulosity. [L. pǔlōsus, hairy.] Hairiness of surface.

Pilot. [D. piloot.] A man experienced in the channels, currents, shoals, etc., who has charge of a ship's course. Branch $P$., one who holds the authority of the Trinity House to act as such. P.'s anchor, one used to drop a vessel down a stream, or in a tideway. $P$.'s fairway, or water. (Fairway.)

\section{Pilpay, Fables of. (Hitopadesa.)}

Pimento. [Sp. pimiento.] Allspice.

Pina cloth. A soft yellow material for ladies' dresses, made from the fibre of the pine-apple leaf.

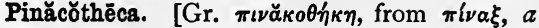
tablet, or picture.] In ancient Arch., a place for the exposition of paintings. The National Gallery at Munich is named Pinakothek.

Pinax. [Gr.] A tablet; hence a register.

Pinchbeck (made known by a man so named). An alloy of copper and zinc, somewhat like Mosaic gold, first made in 1783 .

Pinch-gut. In Naut. slang, a niggardly purser. P.-G. pay, short allowance money.

Pine-needle wool. A fibre from the buds and leaves of pine.

Pinion. [Norm. Fr. pignon.] A small toothed wheel made to work with a rack, or with a larger wheel; as rack and pinion, wheel and pinion.

Pink. 1. (Ichth.) The salmon in its first year. (Peel; Grilse.) 2. (Naut.) A narrowsterned ship, with a small square part above. Pink-stern, a very narrow Severn boat.

Pinking. Cutting in small scallops or angles.

Pink salt. A double chloride of tin and ammonium, used as a mordant.

Pin money. In Law, an annuity settled on a married woman for personal expenses.

Pinna. [L., feather.] (Zool.) Gen. of bivalves

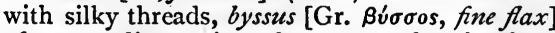
of extraordinary size, thrown out by the foot. Fam. Ǎvǐcŭlĭdæ, class Conchîfĕra.

Pinnace. [Fr. pinasse, It. pinazza.] (Naut.) 1. A ship's boat, carvel-built and schooner-rigged, smaller than the barge, and fitted for rowing. 2. French-armed P., mounting a long twenty. four pounder, from sixty to eighty tons burden, and carrying a hundred men.

Pinnacle. [L. pinnacula, dim. of pinna, $a$ turret.] (Arch.) A small pillar, square or polygonal, at the angles of a tower, or on the 
buttresses between windows, ending pyramidally at the top, and generally ornamented with foliage. The $P$. of the temple, mentioned in the narrative of the temptation (Matt. iv. 5), was a wing of the building, overhanging a steep valley.

Pinnate leaf. [L. pinnātus, furnished with a feather (pinna).] (Bot.) One divided into several pairs of leaflets; e.g. ash. Bipinnate, when each leaflet is again so divided; e.g. mimosa. Pinnatifid [findo, I cleave], divided in a pinnate manner nearly to the midrib; e.g. leaf of oak.

Pinnatifid. (Pinnate leaf.)

Pinnatiped. [L. pinnātus, finned, pědem, foot.] Aquatic birds with membranes on each side of the toes.

Pinner. The loose lappet of a head-dress.

Pinnigrade, Pinnipědía. [L. pinna, fin, grădior, I walk, pědem, foot.] (Zool.) Aquatic carnřvŏra ; as seals.

Pinnock. (Ornith.) Tomtit, Pārus.

Pinole. [Sp.] An aromatic powder used in Italy for making chocolate.

Pintail duck (from its pointed tail). (Ornith.) Sea-pheasant; length about twenty-six inches; plumage variegated; tail long. Migratory in Great Britain. Dăfr̂la ăcūta [L., sharp], or caudăcūta [L., sharptail], gen. Dăfúla, fam. Anătı̆dæ, ord. Ansěres.

Pintles, properly Pin-tails. (Naut.) Hooks by which the rudder is hung.

Pinus. [L., a pine tree.] (Bot.) A gen. of trees, ord. Coniferæ, as now limited is distinguished by leaves in all kinds evergreen, needle-shaped, growing in pairs, threes, fours, or fives, with membranous sheath at the base; e.g. Scotch P., Canadian red P., stone P., etc.

Piny, Piny tallow. A vegetable tallow obtained from the seed of an Indian tree, Vatera Indica.

Piny varnish. A resin obtained from the bark of the above tree (Vatera Indica).

Pioneer. [Fr. pionnier, from pion, a pazen, $a$ foot-soldier, L. pědōnem.] (Mil.) One of a small party of soldiers who precede each regiment on the march, furnished with digging and cutting implements to clear away obstacles.

Pip, Chip, or Roup. A disease of poultry, generally of young poultry, especially chickens, turkeys, and pheasants; sometimes attacking many, old and young; considered highly contagious ; a kind of influenza.

Pipe, Roll of the. A record of the revenue, beginning from the reign of Henry II. The Pipe Office was abolished 1833 .

Pipe of wine. About two hogsheads; a pipe of port is 115 gallons, of sherry xo8 gallons, of Sicilian 93 gallons, etc.

Piper of Hameln. (Orpheus.)

Pipette. [Fr., a little pipe.] A small glass tube with a bulb in the middle, used by chemists for transferring liquids.

Piping. 1. A kind of fluted trimming for ladies' dresses. 2. [L. pipio, I chirp.] In horses, a kind of whistling ; a noise produced by contraction of the opening of the larynx.
Pipistrelle. [Fr., It. pipistrello.] (Zool.) A kind of bat, fam. Vespertiliōnidæ.

Piqué. Hard-spun white twilled stuff for dresses.

Piquet. (Picket.) (Mil.) Two detachments of troops who protect the camp from surprise, the outlying one being at a considerable distance in front, with double sentries pushed beyond it ; the inlying one remaining accoutred in camp, ready to turn out in support.

Piragua, or Pirogue. (Naut.) A canoe hollowed from the trunk of a tree, called in $\mathrm{N}$. America, a dug-out.

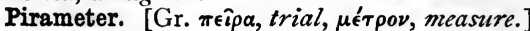
(Mech.) An instrument for measuring the power required to draw a carriage.

Pirling. Twining, as horsehair, for fishinglines.

Pirn. A bobbin on which yarn is wound.

Pirogue. (Piragua.)

Pis aller. [Fr.] A last resource, a makeshift. [Pis, a comp. and superl. from $L$. pējus. The reader who is interested in philology should consult both Littré and Brachet, s.v. "aller;" which is most probably L. adnāre, to come, originally, by water; as Fr. arriver is, originally, to touch the shore, L. adripaare, and so to reach a thing, generally.]

Pisciculture. [L. pisces, fish, cultüra, culture.] The artificial propagation and nurture of fish.

Piscina. [L., a fish-pond.] (Eccl. Arch.) A water-drain near the altar, on the south side. Sometimes double.

Piscis. [L., a fish.] (Ichthys.)

Pisolite. [L. pīsum, pea.] (Geol.) Oolite roe-stone (q.v.) when the concretions are larger, resembling peas.

Pistachio. [It. pistacchio.] The almond-like kernel of the nut of a kind of turpentine tree imported from Sicily.

Pistil. [L. pistillum, a pestle.] (Bot.) The female organ of a plant; a slender column composed of ovary, style, and stigma.

Piston [Fr. piston, L. pistōnem, from pistare, to pound]; P.-rod. (Mech.) A short, solid cylinder which exactly fits a hollow cylinder, as that of a pump or steam-engine; it is connected by a $P .-$ rod to a point outside the cylinder, by which in some cases it is moved, and which in other cases it moves.

Pita. [Sp.] The strong white fibre of the American aloe, used for making cordage.

Pitch ; P. circle; P. line; P. of rivets; P. of a screw; $\mathbf{P}$. of a wheel. When two toothed wheels work together, their motion is the same as that of two circles on the same centres moving by a pure rolling contact ; the circle corresponding to either wheel is its Pitch sircle or P. line, each tooth of the wheel is partly within and partly projects beyond the pitch circle. The $P$. of $a$ wheel is the distance from one side of a tooth to the same side of the next tooth, i.e. the distance occupied by one complete tooth and space measured along the pitch circle. The $P$. of a screw is the distance between two consecutiva turns of the thread measured parallel to the axis. 
The $P$. of rivets is the distance from centre to centre of any two adjacent rivets.

Pitched market. One in which the articles are not sold by sample, but produced in bulk.

Pitch of a saw. The slope of the face of the teeth.

Pitch of a tone. (Acoustics.) Its sound as determined by the number of (double) vibrations made by the body and therefore by the particles of air.

Pithecoïd; e.g. skull, apelike [Gr. $\pi \check{i} \theta \eta \kappa o s$, an ape].

Pitons. [Fr., a screw-ring, a peak.] Conical hills, in W. Indies; a French term; origin unknown.

Pitot's tube. An instrument for measuring the velocity of a stream, consisting of a funnel with a vertical tube; the funnel being presented to the stream, the water rises in the tube to a height nearly corresponding to the velocity.

Pit-pan. (Naut.) A flat-bottomed canoe of the W. Indies and Spanish Main.

Pittacal. [Gr. $\pi^{\prime} i \tau \tau \alpha$, pitch, $\kappa \alpha \lambda \delta s$, beautiful.] A substance like indigo, obtained from woodtar.

\section{Pittance. (Pietantia.)}

Pituitous. Full of phlegm [L. pītǔīta]

Pius IV.'s Creed. (Creed of Pius IV.)

Pivot. [Fr.; origin unknown.] 1. (Mil.) Flank round which the troops move in executing military evolutions. 2. (Mech.) The end of an axle which presses endwise against its bearing.

Pivot-man. (Mil.) The soldier who marks the centre while a line is wheeling.

Pirot-ship. (Naut.) In evolutions, is the one on which a new line or formation is made.

Pizzicato. [It.] To be pinched, twitched with the finger, not played with the bow ; said of violin-strings.

Place aux dames. [Fr.] Room for the ladies.

Placêbo. [L., I shall please.] 1. In the Latin Church, vespers for the dead; so called from the first antiphon to the psalms. 2. A medicine which pleases and quiets, but does not otherwise benefit the patient.

Placebrick. A poor kind of brick, ill burnt, through being on the outside of the kiln.

Pläcenta [L., a cake], or Afterbirth. 1. (Med.) A temporary organ, spongy, vascular; developed, in mammalia, during pregnancy, and forming the connecting vascular medium between mother and ovum; expelled shortly after the birth. 2. (Bot.) A process of the ovary, to which the ovules are attached.

Place of a heavenly body. (Astron.) Its position as defined (I) by its right ascension and declination; (2) by its longitude and latitude.

Place of arms. (Mil.) Enlargement at the salient and re-entering angles of the covered way of a fortress.

Placita. [L.] In the Middle Ages, courts in which the sovereign took counsel on affairs of the state; termed Generalia, as including both clergy and laity.

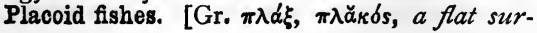

face.] (Ichth.) With Agassiz, an ord. including all cartilaginous fish, except the sturgeon; their scales-e.g. shark, dog-fish,-being hard plates, laid together in the skin; not imbricated, (Ichthyology.)

Plagal cadence. [(?) Gr. $\pi \lambda a \dot{\gamma} \gamma ı s$, oblique, indirect.] (Music.) 1. When the major or minor of the subdominant precedes the concluding chord of the tonic. 2. Plagal modes. (Greek modes.)

Plagiarism. [L.L. plagium, kidnapping, or stealing.] The using of the thoughts or words of another without acknowledgment, in literary composition.

Plagihedral crystal. [Gr. $\pi \lambda a ̆$ yıs, oblique,

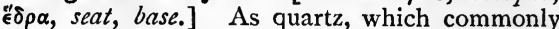
takes the form of a six-sided prism terminated by a pyramid. In some cases the solid angles at the junction are replaced by secondary planes obliquely placed; the form of crystal is then said to be plagihedral, and may be right-handed or left-handed according to the direction of the secondary planes. This difference in the form of the crystals corresponds to a difference in their action on polarized light.

Plague. Originally a blow, stroke, calamity [Gr. $\pi \lambda \eta \gamma \hat{\eta}$, L. plāga]; so in the Bible and in Prayer-book frequently; e.g. the P. of the death of the firstborn;" "P. of rain and waters."

Plaid. [Gael. plaide.] A striped or variegated stuff worn by the Highlanders of Scotland.

Plain song. [L. Cantus firmus.] (Music.) A kind of chant of Jewish and of early Christian worship, extremely simple, admitting double measure only, and notes of equal value. These Church modes, which have affected the character of all the best Church music ever since, were, as regards structure, substantially one with the ancient Greek modes (q.v.).

Planchette. [Fr., a small board, or plane.] A heart-shaped piece of wood, so prepared, it was said, as to guide the hand of any one writing upon it to answers on subjects beyond his powers of discernment or knowledge.

Plane; True P. [L. plānus, level.] (Math.) A surface, supposed to be capable of indefinite extension, such that the straight line joining any two points in it lies wholly in the surface. A True $P$. is a mechanical approximation to a theoretically true $\mathrm{P}$., invented by Sir J. Whitworth, and produced by working on the principle that, if three bodies having faces A, B, C, such that if $\mathrm{A}$ and $\mathrm{B}$ can be brought by superimposition to coincide point by point with $\mathrm{C}$ and likewise with each other, all three are true planes.

Plane of picture; $\mathbf{P}$. of projection ; $\mathbf{P}$. of reflexion; $\mathbf{P}$. of refraction. The plane on which the picture is supposed to be drawn in the various kinds of projection is called the Plane of the picture, or the $P$. of projection. The $P$. of reflexion (or refraction) is the plane which contains the incident and reflected (or refracted) rays.

Plane of site. (Mil.) One supposed to pass between the summit of a height and any terreplein (q.v.).

Plane sailing. (Naut.) Navigating by means 
of plane right-angled triangles, i.e. on the supposition that the earth is a plane, and that the meridians and lines of latitude are equidistant, parallel straight lines, at right angles to each other.

Plane scale. A flat piece of ivory, metal, or wood, on which are engraved various scales of equal parts, e.g. of inches or parts of an inch ; it also contains scales for the construction of angles of any number of degrees, and of their chords, sines, etc.

Planet [Gr. $\pi \lambda \alpha \nu \eta \tau \eta s, a$ wanderer]; Exterior P.; Inferior P.; Interior P. ; Primary P. ; Secondary P.; Superior P. A heavenly body revolving round the sun in an orbit, not greatly differing from a circle; as seen from the earth planets are distinguished from the fixed stars, partly by their appearance, but chiefly by their visibly changing their place among the stars when observed on successive nights for a few days or weeks together. A Secondary $P$. revolves round a Primary $P$., and with the primary round the sun; as the moon revolves round the earth, and with the earth round the sun. The Interior or Inferior planets are those which revolve within the earth's orbit-Mercury and Venus ; the Exterior or Superior planets, the rest, which revolve outside.

Plane table. A drawing-board, graduated at the edge so as to show in degrees the angle at the centre, with a movable rule furnished with sights; for plotting on paper in the field the lines of a survey.

Plănētārium. An orrery (q.v.).

Planetary nebula. (Astron.)

A nebula having a near and in some cases a perfect resemblance to a planet; presenting the appearance of a disc round or slightly oval ; in some cases quite sharply terminated, in others a little hazy or softened at the border.

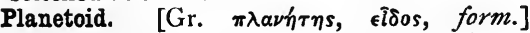
(Astron.) One of the small planets (Vesta, Ceres, etc.) whose orbits are situated between those of Mars and Jupiter. Called also Asteroids and Minor planets.

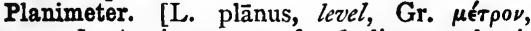
measure.] An instrument for finding mechanically the area of any inclosed plane drawn on paper.

Planishing. [O.Fr. planir.] Rendering level by light blows of a smooth hammer, called a planisher.

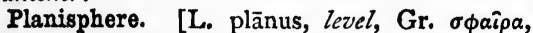
sphere.] (Astron.) 1. A stereographical projection of the great sphere; by a proper delineation of the stars at a given place, a movable circle placed on the picture can be made to show the positions of the stars at any hour of any night relative to the zenith and horizon of that place. 2. Any projection of the great sphere on any plane.

\section{Plank-sheer. (Gunwale.)}

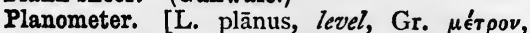
measure.] A plane hard surface used as a standard gauge for ascertaining whether surfaces are accurately plane.

Plantăgenet. kings who reigned between Stephen and Henry VII., from the sprig of the broom plant [Fr. plante de genêt], which they bore as their device.

\section{Planta gěnista. (Genista.)}

Plantain. [From L. plantāgīnem.] (Bot.) A plant of gen. Plantago, with many spec. The most remarkable of these are the Musa paradisiaca, or banana, and the M. sapientum, or plantain.

Plantar. Relating to the sole of the foot [L. planta].

Plantation. [L. planta, a plant.] 1. Formerly $=$ Colonies. 2. In new and especially in hot or tropical countries, a name applied to an estate appropriated to the production of staple crops, as the sugar-cane, cotton, rice, tobacco, coffee, etc. (Bartlett's Americanisms).

Plantigrades. [L. planta, sole, grădior, I walk.] (Zool.) Carnivoora walking on the soles of their feet ; as bears.

Plaque. [Fr.] A flat plate of metal, on which enamels, etc., are painted.

Plash, or Pleach. [O.Fr. plesser, to make a

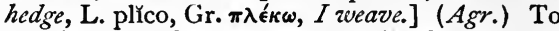
entwine branches; to cut partly through the stems forming a hedge, bend them down, and interweave them with the hedge.

Plasma. [Gr., anything moulded, or shaped.] (Min.) Chalcedony coloured green by some metallic oxide, probably copper or nickel; a

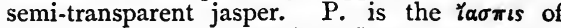
Rev. xxi. 19 (King, Antique Gerns).

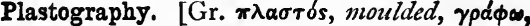
I draw.] The art of forming figures in plaster.

Plaster of Paris. Anhydrous sulphate of lime, obtained by burning gypsum, large beds of which exist near Paris.

Plastio clay. [Gr. $\pi \lambda \alpha \sigma \tau \iota k o ́ s$, fit for mould. ing.] Such as can be used for pottery and china-ware. The best in England are the white clay of the Bracklesham beds, the mottled clay of the Woolwich and Reading series, and the fire-clays of the coal-measures.

Plastron. [Fr., a breast-plate; cf. It. piastrone, from piastra, a plate of metal, $a$ dollar. 1 . The under shell of tortoises and turtles. 2. A leather pad worn on the breast by fencers.

Plate. [Sp. plata, silver.] (Her.) A silver roundlet or disc.

Plateau. [Fr., a plateau, tray, formerly platel, from plat, flat.] (Geog.) An extensive plain at a considerable height above the sea; a table-land.

Plate-glass. Glass composed of silicates of soda and lime, made by blowing a long cylinder, removing the ends and cutting open the side, and spreading it when reheated on an iron table.

Plateiasmus. [Gr. $\pi \lambda \alpha \tau \epsilon \iota \alpha \sigma \mu o ́ s$, from $\pi \lambda \alpha \tau u ́ s$, flat, or broad.] A broad dialect or accent, a brogue.

Platelayer. A workman who lays down the rails and fastens them to the sleepers of a railway.

Plate-mark. A mark on gold and silver plate, to show the place and date of manufacture, and fineness of metal. 
Plate-metal. White cast iron.

Platen. In a printing-press, the part which, under the influence of the lever, gives the impression to a sheet.

Plate tracery. (Arch.) The earliest form of tracery, in which the surface of the window is flat, with openings pierced through it.

Platform. (Fortif.) 1. Flooring of wood or stone at the bottom of the interior slope of a parapet, to prevent the gun-carriage wheels from sinking into the ground. 2. In the American use (= general political plan), an older Eng. use survives; that of (I) ground-plan of a building, (2) general pattern or principle [It. piatta forma].

Platinum, Platina. [Sp. plata, silver.] (Min.) A hard, whitish metal, very heavy and not easily acted on by acids. Platinum black is platinum in the form of a black powder. Spongy platinum is the metal in the form of a porous brown mass. Platonic bodies. (Polyhedron.)

Platoon. [Sp. pelotón, a large ball, a crozvd.] (Mil.) This word formerly meant a very small body of soldiers ; it is now applied only to firing exercise with a musket or ritle.

Platy̌oephălous. [Gr. $\pi \lambda a ́$ ís, broad, flat, $\kappa \in \phi a \lambda$, head.] Broad-headed.

Plăty̆pns. [Gr. $\pi \lambda \alpha \tau u ́-\pi o u s$, broad-footed.] (Ornithorhynchus paradoxus.)

Playte. (Naut.) Old name for a river-boat.

Pleach. (Plash.)

Pleading. [Plea, Fr. plaid, a plea, a sitting of the court, is the L. plăcitum.] The technical terms, though now little in use, are these: The plaintiff's cause of complaint is the declaration, and the defendant's answer the plea; plaintiff then makes his replication, to which defendant answers by rejoinder; upon which follow plaintiff's sur-rejoinder, and defendant's rebutter, answered by plaintiff's sur-rebutter.

Please the pigs. [A.S. piga, $a$ maiden.] If it please the Virgin.

Plebeians. [L. plebs, Gr. $\pi \lambda \hat{\eta} \theta 0 s$, the multitude.] Roman citizens not included in the patrician class, who for a long time kept the whole power of the State wholly in their own hands. (Client; Tribune.)

Plebiscite. [L. plēbiscitum, a decree of the plebs.] 1. In Rom. Hist., a law passed by the comitia, or assembly of tribes. 2. In Mod. Fr. usage, a popular vote taken to ratify a measure already resolved upon, as the election of an emperor.

Plebs. (Patricians.)

Plectrum. [L., Gr. $\pi \lambda \hat{\eta} \kappa \tau \rho o \nu$.] A quill or similar piece of ivory, wood, metal, for twitching the strings of some musical instruments.

Pledget. [Cf. plug, Ger. pflocke.] (Med.) A small mass or tent of lint.

Pleiădes. [Gr.] (Myth.) Seven sisters, assigned to many parents. Of these seven six are visible ; the disappearance of the seventh is accounted for in various ways. They are sisters of the Hyades.

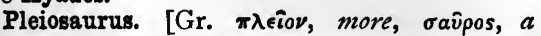
lizard.] (Geol.) A marine reptile, intermediate between plesiosaurus and ichthyosaurus.

Pleistocene. (Eocene.)
Plenarty, [L. plenita, -tem, fulness.] The state of a church when full, having an incumbent; as opposed to Avoidance.

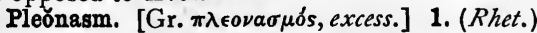
Any redundant phrase or expression. 2. (Med.) Overgrowth in quantity or in number of parts.

Plërōma. (Valentinians.)

Plësiosanrus. [Gr. $\pi \lambda \eta$ oios, near to, $\sigma a \hat{v} \rho o s$, a lizard, i.e. more like a reptile than is ichthyosaurus.] (Geol.) A singular gen. of fossil seareptiles. Remains occur in the Lias, Oolite, and Cretaceous strata.

Plëthöra. [Gr. $\pi \lambda \eta \theta \dot{\prime} \rho \eta, \pi \lambda \hbar \theta \omega, I$ am full.] (Med.) Redundancy of blood, general or local.

Pleuræ. [Gr. $\pi \lambda \epsilon v \rho \alpha ́$, rih, side.] (Anat.) Two independent serous sacs, inclosing the whole of each lung, except where the vessels enter; and reflected upon the inner surface of the chest.

Pleurisy. [Gr. $\pi \lambda \in v \rho \hat{\tau} \iota s$.$] ( M e d$.) Inflammation of the pleura; Pleuro-pneumonia, of the pleura and lungs [ $\pi \nu \in \dot{v} \mu o \nu \in s]$ together.

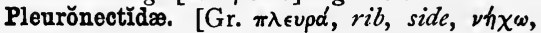
I swim.] (Ichth.) Fam. of salt-water fishes, ord. Ănăcanthĭni, found on all coasts. One side is brown, or mottled, resembling the sea-bottom on which they live, the other is white; the spine being wrung round near the head, bringing both eyes on the upper side; e.g. flounder and turbot.

Pleuro-pneumŏnia. (Pleurisy.)

Plevin. [Fr. plevine.] An obsolete word, denoting a warrant of assurance.

Plexus. [L. plecto, I plait, braid.] (Anat.) Portions of nerves, or of vessels, interwoven.

Plinth. [Gr. $\pi \lambda$ intos, a brick.] (Arch.) The projecting face at the bottom of a wall immediately above the ground.

Pliocene. (Eocent.)

Plot. (Geom.) To draw to scale, particularly the plan of a field or other area that has been surveyed.

Plotting. (Mil.) Laying down on paper with the aid of instruments the observations which have been taken in surveying.

Plough Monday. Anciently, Monday after Epiphany, first day of work after Christmas holidays.

Plumassier. [Fr.] A dealer in feathers [Fr. plume, L. plüma].

Plūmātella. [L. plūma, doren.] (Zool). Lŏphŏpus [Gr. $\lambda \delta \phi o s$, crest, nov́s, foot]; the first discovered Pǒlȳzōon, very common fresh-water mollusc, with plume-like tentacles visible to the naked eye. Class Pŏlȳzōa.

Plumbägō. [L. plumbum, lead.] Black lead as used in pencils. It is a form of carbon.

Plumbing. [L. plumbum, lead.] The art of working in lead, as laying lead pipes, etc.

Plumbism. [L. plumbum, lead.] (Med.) Leadpoisoning ; aggregate of symptoms arising from handling lead preparations.

Plummer-block. A pillow-block (q.v.).

Plumming. [Eng. plumb-line, from L. plumbum, lead.] Finding by means of a compass which way a lode inclines, where to sink an air. shaft, etc. 
Plumule. [L. plūmŭla, dim. of plūma, a soft feather, down.] (Bot.) The rudimentary stem of the embryo plant; the rudimentary root being a radicle [rädīcŭla, rootlet, dim. of rādix].

Plunger. (Mech.) A solid cylinder used in forcing-pumps, etc., instead of a piston and piston-rod.

Plurality. In Eccl. Law, the holding of more than one benefice; the holder being a Pluralist.

Plurative. In Log., = more than not. (I) "Men are mortal," i.c. all men, is a universal proposition. (2) "Men have made great discoveries," i.e. some men, is particular. (3) "Men are prejudiced," i.e. more [plüres] than not-more than half-are prejudiced, is plurative. From two $\mathrm{P}$. as premisses-though not universals, but particulars-a particular-conclusion may sometimes be drawn; thus, "Fivesixths of the army were Persians; five-sixths of the army fled: therefore some Persians fled." (Vide Archbishop Thomson's Laws of Thought.)

Plush. [Fr. plucher.] 1. A stuff with a velvety nap on one side. 2. (Naut.) Grog is served out in a tot or toit (a cup rather under half a pint), so that there is an overplus from each mess, which, under the name of P., is given to the cook of the day for his trouble.

Plüto. [Gr. $\pi \lambda$ ovi $\tau \omega \nu$, wealthy.] (Myth.) The name of Hades, as lord of the treasures of the under world.

Plutonic. (Igneous; Neptunian rocks.)

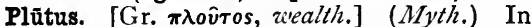
the Hesiodic theogony, the giver of wealth to all whom he approaches. His wish, it is said, was to befriend only the wise and good; but Zeus blinded him, that he might bestow his gifts at random.

Plnviäle. [L.] A cope, used originally as a defence against rain.

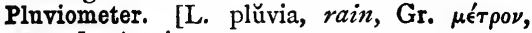
measure.] A rain-gauge.

Ply. [Fr. pli, a fold.] A fold or thickness of web, as a three-ply carpet, which consists of three cloths woven together.

Ply, To. (Naut.) 1. To carry for hire on short trips. 2. To work to windward. To $P$. an oar, to row.

Plymouth Brethren. A name applied to a body of Christians, who admit the title only as describing their individual state, maintaining that they exist only to protest against sectarianism. Some among them lay stress on the doctrine of a community of goods.

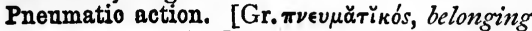
to wind $(\pi \nu \in \hat{v} \mu a)$.] In an organ, lightens the touch by the liberation of compressed air, which then rushes into a small bellows placed near the key.

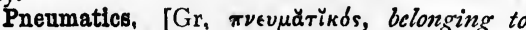
zind, air $(\pi \nu \in \hat{v} \mu \alpha)$.] The doctrine of the equilibrium of elastic fluids,

Pneumatio trough, A small tank fitted with a shelf, used for collecting gases [Gr, $\pi \nu \in u ́ \mu \alpha \tau a]$ over water or mercury,

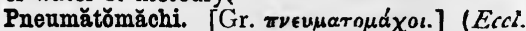
Hi.st.) A name of reproach for those who, in the fourth and fifth centuries, denied the divinity of the Holy Ghost. (Macedonians.)

Pneumătōsis. [Gr. $\pi \nu \in v \mu a ́ \tau \omega \sigma$ ss, inflation.] (Med.) A collection of air in the cellular membrane. (Emphysema.)

Pnyx. [Gr. $\left.\pi \nu v_{\xi}.\right]$ In ancient Athens, the place for the popular assembly, on sloping ground to the west of Arēŏpăgus. The Bēma, or tribune on the north side, faced the Acropolis, and commanded a view of the sea in the rear.

P.0. (Naut.) Petty officer.

Poak. The waste from the preparation of skins.

Poblādos. [Sp.] Inhabited regions of S. America, as distinguished from those uninhabited, Des Poblados.

Poco curante. [It.] One who cares little. A devil-may-care.

Pŏdägra. [Gr.] Gout in the feet.

Podesta. [It., from L. potestas, power.] The chief magistrate of the Italian cities in the Middle Ages.

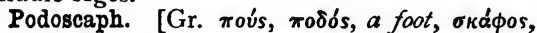
a ship.] Small boats worn on the feet, for walking on water.

Poe. (Native name.) A food made of the baked roots of the taro plant, used in the Sandwich Islands.

Pœčllē. [Gr. $\dot{\eta} \pi \circ \iota \kappa i ́ \lambda \eta$, sc. $\sigma \tau o d$.$] A portico$ or hall at Athens, adorned with paintings by Polygnōtus, representing the battle of Marathon.

Poēta nascǐtur, non fit. [L.] $A$ poet is borm, not made.

Poetaster. [Fr. poétastre.] A petty poet, a pitiful writer of verses.

\section{Poetical metaphor. (Metaphor.)}

Poet-Laureate. [L. laurěătus, crowoned with laurel.] Most European sovereigns have assumed the right of nominating a court poet; the first example being that of Petrarch, made P.-L. at Rome. In England, Poeta Laureatus was originally a graduate in rhetoric; one such would be made King's $L$. The P.-L. is an officer of the royal household, in the Lord Chamberlain's department.

Poignard. [Fr., from poing, the fist, L. pugnus.] A kind of dagger.

Point [L. punctum]; P. of sight; Projecting P. 1. $A$ mark of position which has no magnitude. 2. Used in several connexions with a meaning plain from the context; as, zero point, equinoctial point, point of contrary flexure, etc. (For P. of sight, or Projecting P., vide Perspective.)

Point, Principal.

Point. (Switch.) (Accidental point.)

Point d'appui. [Fr., support, from appuyer, L. appǒdiare.] 1. (Mil.) The place in an alignment $(q . v$.$) upon which any military formation$ is executed. 2. Generally, a fulcrum, point of support.

Pointed architecture. The styles of architecture in which the pointed or two-centred Arch is systematically used, in contrast with the Romanesque styles, which are marked by the use of the round arch. (Geometrical style.)

Point-lace. Lace wrought with a needle. 
Poison. [Fr., from L. potio, -nem, a drink.] Any substance which, through the blood, has a noxious or deadening action upon living beings is : 1. Irritant-exerting a direct local action upon the stomach, if it gets so far ; as arsenic. 2. Narcotic-causing paralysis of the brain; as morphia. 3. Narcotico-acrid-first irritant, then acting on the nervous system; as strychnine, some fungi, etc.

Poisson d'Avril. [Fr. (1) mackerel, (2) April fool.] Of explanations offered, Littré does not mention any, probably thinking none satisfactory.

Poitrinal. (Mil.) Armour for a horse's chest [Fr. poitrine].

Polacca, or Polonaise. (Music.) 1. A Polish national dance, in $\frac{3}{4}$ time, of slow movement. 2. A melody more or less similar in character.

Polacre. (Naut.) A Mediterranean ship or brig, without tops or cross-trees.

Polar axis; P. circles; P. clock ; P. co-ordinates ; P. distance; P. forces. (Geog.) The Polar axis of an equatorial instrument is that axis of rotation which, by adjustment, is made parallel to the earth's axis. $P$. circles, the Arctic and Antarctic circles, i.e. parallels of latitude whose angular distances from the Poles are the same as the obliquity of the ecliptic, viz. about $23^{\circ} 28^{\prime}$. $P$. clock, an instrument for telling the time of day by observing the direction of the plane of polarization of the scattered sunlight from the regions near the Pole. P. distance, the distance of a star from either Pole, measured along a declination circle. $P$. forces are conceived to act with equal intensity in opposite directions at the ends of an axis of molecules. (For P. co-ordinates, vide Radius-vector.)

Polaris. (North star.)

Polariseope. An instrument for polarizing light and analyzing it when polarized.

Polarity. [L. polus, the pole.] That condition of a body in virtue of which it exhibits opposite properties or powers in two opposite parts or directions.

Polarization [L. polus, the North Pole]; Angle of P.; Circular P.; Elliptical P.; Plane of P.; P. of light; Plane P. When a ray of light passes through a crystal of Iceland-spar it is in general divided into two rays, each of which has certain characteristic properties, in virtue of which they are said to consist of polarized light. One of these properties is that a ray of polarized light will not pass through a second crystal of Iceland-spar held in certain definite positions. Any process by which light acquires these properties is the Polarization of light. When light is reflected at a certain angle (which in the case of glass is $54^{\circ} 35^{\prime}$ ) it becomes polarized; this angle is the Angle of $P$. The properties of polarized light can be deduced with great exactness from the supposition that the undulatory motion of the ether takes place in such a way that its particles move in parallel lines at right angles to the direction in which the light is propagated; such light is said to be in a state of Plane $P$. A plane at right angles to the direction of the vibration is the Plane of $P$. If two rays of plane polarized light combine under certain circumstances, the particles move in circles or ellipses (having their major axes parallel to each other) in planes at right angles to the direction in which the light is propagated; such light is in a state of Circular, or Elliptical, $P$.

Polarizer. The part of a polariscope which polarizes light; it may be a surface from which light is reflected at the polarizing angle, or a portion of a doubly refracting crystal by passing through which the light is polarized.

Polders. [D.] Non-tidal marshes in the Low Countries, artificially drained by a series of canals at successively higher levels, by which they are also irrigated when required.

Poldway. Coarse sacking.

Pole [L. pollus, a pole, the N. Pole]; Magnetic P. 1. (Geog.) One of the points in which the axis of rotation meets the surface of the earth. 2. (Astron.) One of the points vertically over the poles of the earth, round which the great sphere seems to revolve. 3. (Geom.) One of the extremities of the diameter drawn at right angles to the plane of a circle on a sphere (also vide Radius-vector). 4. (Phys.) One of the opposite points in which a polar force is exerted; as the poles of a battery, of a magnet, etc. (For Magnetic $P$., vide Magnetio battery.) 5. Of the face of a crystal, the end of that radius of the sphere of projection which is drawn at right angles to the face.

Polecat. [D. pool-kat, O.Fr. pulent, pullent, stinking.] (Zool.) Pŭtōrius fœtidus ; an animal of the weasel kind (Mustēlídæ), about two teet long, dark brown on back, lighter beneath. Ord. Carnivǒra. I.q. Fitchett, or Foumart (? foul marten).

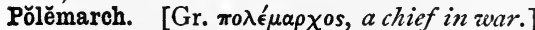
A name for military commanders generally. At Athens, the P. was the third of the nine Archons.

Polenta. [L., pearl barley.] An Italian dish, of koiled chestnut or maize-flour.

\section{Pole-star. (North star.)}

Police Gazette. A journal containing the names of prisoners convicted of crime, of absconders, of persons for whom search is being made, as well as deserters from the army. (Hue and Cry.)

Policy. 1. Applied to life insurances, this word is said to be a corr. of the Gr $\pi 0 \lambda v \pi_{\tau} v \chi 0 \nu$, or tablet folded into many leaves, used when the Diptych was too small. It is found in the transitional forms puletium and pollegium. 2. (Naut.) The written contract of insurance against sea-risks. Interest $P$., where the insurer has an assignable, Wager $P$., where he has no substantial, interest in the thing insured. Open $P$., where the amount of interest is not specified, but has to be ascertained in case of a loss. Valued $P$., where the goods or ship is insured for a specific amount.

Poling. Stirring molten copper with a pole of green wood, to purify it of oxygen.

Polis. (Phratry.)

Politesse. [Fr.] Politeness.

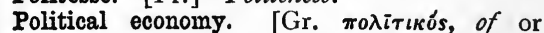

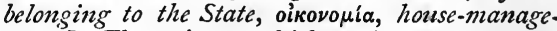
ment.] The science which seeks to determine the nature and properties of the forces which act on the social faculties of man, so far as the 
results of these may be estimated by some re cognized standard of value. It deals, therefore, with laws which are beyond the control of the human will, and with consequences which follow inevitably from those laws. The modern system of political economy must be ascribed to Adam Smith, whose Wealth of Nations was published in 1776 .

Pollack. (Ichth.) Fish of the cod tribe, olive-brown back, white sides, yellow-mottled. British seas. Merluccius pollächius, fam. Gadĭdæ, ord. Ănăcanthĭni, sub-class Tělěostěī.

Pollard. [Cf. D. polle, head.] 1. (Zool.) A stag that has cast his horns. 2. The chub, or sometimes the miller's thumb; large-headed. 3. A mixture of bran and meal. 4. A tree which has been polled, or had its head cut off.

Polled cattle. [Cf. D. polle, head.] Hornless cattle.

Pollen. [L., fine flour, or dust.] (Bot.) The fertilizing powder emitted by the anthers.

Poll-evil. In a horse, a painful swelling on the poll, fluctuating to the touch ; from the head suddenly lifted and struck against a beam, etc., or from straining against the halter.

Pollicitation. [L. pollicitātiōnem, from pollicitāri, to promise.] In Civil Law, a promise which has not been accepted by the person to whom it is made.

Poll tax. A tax levied on the heads (polls) or persons of all members of the State, with the exception of the very poorest.

Pollux. (Castor and Pollux.)

Polo. An Eastern game, much played in Tartary; introduced into England in 1872 , by some Indian officers; may be described as hockey played on horseback.

Polonaise. (Polacca.)

Polony. (From Bologna, in Italy.) A dry sausage made of meat partly cooked.

Poltergeist. [Ger.] A hobgoblin, supposed to show his presence by the clattering of pots and pans.

Poltroon. [Fr. poltron; connected by some with Eng. bolster, as denoting one who lies lazily in bed; but by others referred to $\mathrm{L}$. pollice truncus, one maimed in the thumb, in order to disqualify himself for military service.] A coward, a dastard.

Polverine. [It. polverino, pozuder.] The ashes of a plant brought from the Levant, used for making white glass.

Poly-. [Gr. moגús, many, much.]

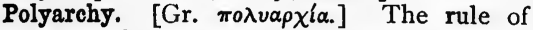
many (whether nobles or commoners); as opposed to Monarchy.

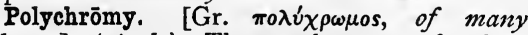
colours.] (Arch.) The employment of colour in adorning the surface of buildings or works of art.

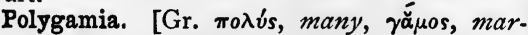
riage.] (Bot.) Linnæan class xxii.; plants in which the spec. have male, female, and hermaphrodite flowers on the same or different individuals.

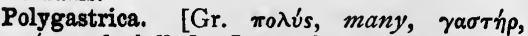

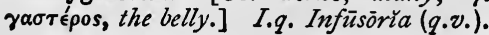

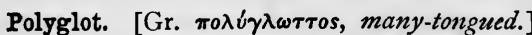
A word generally applied to Bibles printed with the text in various languages. (Hexapla.) Thus the edition of Cardinal Ximenes, called Complutensian, as printed at Complutum, or Alcala, in Spain, has the text in four languages. Among such editions are also the Plantin (Antwerp, 1572); the Polyglot of De Sacy (Paris, 1645); the English, or Walton's Poly. glot (1657). Hutter's Polyglot (Nuremberg, I599) contains twelve languages.

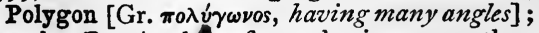
Regular P. A plathe figure having more than four sides and angles; it is Kegular when its has equal sides and angles; it is called pentagon, hexagon, octagon, decagon, etc., when it has respectively five $\left[\pi \epsilon^{\prime} \nu \tau \epsilon\right]$, six [ $\left[\epsilon^{\epsilon} \xi\right]$,

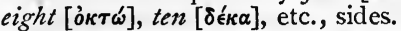

Polygonal numbers. If an arithmetical series whose first term is unity be written down, and the sum of the first two, first three, first four, etc., terms be taken, these sums are a series of P. N.; the order being two more than the common difference of the arithmetic series. Thus, if the series is $1,5,9,13,17$, etc., the corresponding polygonal numbers are $6,15,28$, 45 , etc. ; and as the common difference of the arithmetical series is 4 , the P. N. are, in this case, hexagonal $(4+2=6)$.

Polygon of forces. If any number of forces act on a particle, and lines be drawn paralle] and proportionate to the forces, each line from the end of the one drawn before it, and in the same direction as the force acts, the line required to make the figure a complete polygon represents the resultant of the forces; this proposition is called the $\mathrm{P}$. of $\mathrm{F}$.

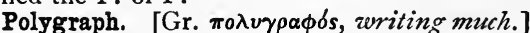
An instrument for multiplying copies of a writing.

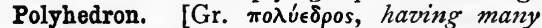
sides.] A solid bounded by many plane faces; a Tetrahedron is contained by four equilateral triangles; a Hexahedron, or cube, by six squares ; an Octahedron, by eight equilateral triangles; a Dodecahedron, by twelve regular pentagons ; an Icosahedron, by twenty equilateral triangles. These five are the regular solids or bodies, or

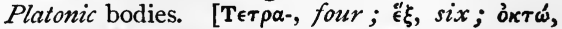

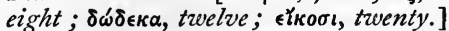

Polyhymnia. [Gr. $\pi 0 \lambda v$-v $\mu \nu t a$.$] (Myth.) The$ Muse of lyric poetry.

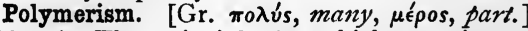
(Chem.) The principle by which a series of chemical compounds exists having a common formula.

Polymorphic genera. [Gr. $\pi \circ \lambda \dot{v}-\mu o \rho \phi o s$, multiform.] (Zool.) Protean G. ; those G. in which individual differences exist to such an extent as to make the determination of species and varieties almost impossible; e.g. the snail (Helix).

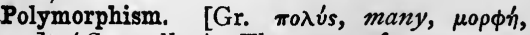
form.] (Crystallog.) The case, of rare occurrence, in which a substance crystallizes in more than two different systems.

Polyonymy. (Metaphor.)

Polype. (Zool.) The Pŏlȳzōa and Colentě- 
rāta are frequently thus termed; the name properly belongs to the Actinōzōa; e.g. seaanemones.

Polypide. (Polypus.) The separate zoöid of a Pŏlȳzōon.

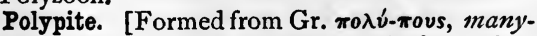
footed, polypus.] The separate zoöid of a Hydrōzöon.

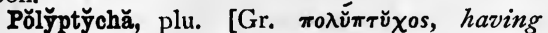
many tablets.] 1. Account-books, registers ; especially, 2, Eccl. registers of goods belonging to churches, with copies of charters, etc. (Policy.)

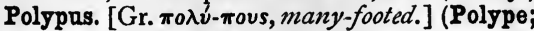
Octopus.)

Polystyle. [Gr. $\pi 0 \lambda u ́ \sigma \tau u ̄ \lambda o s$.$] (Arch.) A$ building with many columns.

Pŏly̌synděton. (Asyndeton.)

Polysynthetio. (Agglomerative languages.)

Polysynthěton. (Asyndeton.)

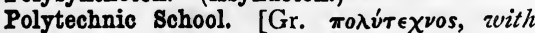
many arts.] (Hist.) A school, so called, was set up in Paris, in 1794, by a decree of the National Convention. By Napoleon Bonaparte it was converted into a school of preparation for the artillery and for civil and military engineering.

\section{Polytheism. (Monotheism.)}

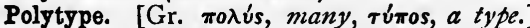
A fac-simile copy in metal of an engraved block, matter in type, etc., for printing from.

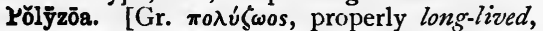
but here consisting of many animals.] Brȳozóa

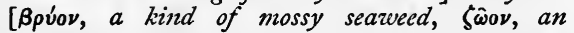
animal]; applied by Busk, after Thompson, to the lowest class of molluscoids, as Flustra, sea-mats, and Plūmätella, the other classes being Brāchiǒpǒda, or Pallǐobranchĭăta, and Tŭnǐcäta.

Pomace. [L. pōmum, an apple.] Apples or similar fruit crushed by grinding. (Pommage.)

Pomander. [Corr. from Fr. pomme d'ambre, apple of amber.] A round hox containing perfumes, formerly carried by ladies.

Pome. [L. pōmum.] (Bot.) A fruit, like apple, pear ; the pulpy mass made of calyx with epicarp and mesocarp ; the endocarp being scaly with separate seed-cells. (Pōmum, though often transl. apple, is = fruit generally.)

Pomey. [Fr. pomme, an apple.] (Hler.) A green roundlet or disc.

Pommage, Pummice. [Fr. pomme, an apple, L. pōmum, a fruit.] The pulp of apples crushed for making cider. (Pomace.)

Pommee. [Fr. pomme, an apple.] (Her.) Having the ends terminated in knobs like apples.

Pommel. [Fr. pommeau.] 1. The knob on a sword-hilt. 2. The protuberant part of a saddle-bow.

Pomœrium. [L.] In Rom. Ant., a space of ground, within and without the walls of a city, kept clear of buildings by virtue of special consecration.

Pōmōna. [L.] The old Italian goddess of fruit trees and fruit. (Vertumnus.)

Pompadour. (Rose de Pompadour.)

Pompet, Pumpet. [O.Fr. pompette.] In Printing, a ball, formerly used for inking types.

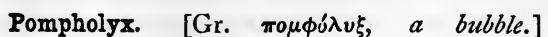
Flowers of zinc. (Flowers of sulphur.)

Pōmum Adami. (Adam's apple.)

Poncho. [Sp.] A cloak worn by SpanishAmericans, like a blanket having in the middle a hole for the head.

Ponderanda sunt testimornǐa, non numĕranda. [L.] Testimonies should be zeeighed, not counted, the quality being of the first importance.

Pone, more correctly written Paune. Food consisting of Indian meal made into dough and baked; so called by American Indians. To be distinguished from the Asiatic Pan, which is also sometimes written pazun.

Pongee. A poor kind of Indian silk.

Pons Asinörum. [L.] The asses' bridge; a name given to the fifth proposition of the first book of Euclid, as being the first difficulty met with ; and perhaps from its figure.

Pontac. (From Pontac, in S. France.) A kind of constantia made at the Cape.

Pontec. [Fr. pontil.] An iron instrument for holding glass in the process of manufacture.

Pontiff. [L. pontyfex.] The highest sacerdotal title of the ancient Romans. The chief of the pontiffs was styled Pontifex Maximus. The word has nothing to do, as was supposed, with the making of bridges (pontes facere), but is only another form of pompifex, the orderer of processions and other religious rites. The title is now given to the pope only.

Pontifical. [L. pontificālis, from pontifex, a Latin form of pompifex, one who arranges poinps, i.e. processions or ceremonies.] In the Latin Church, a book containing the ceremonies relating to bishops and prelates.

Pontoon. [Fr. ponton, L. pontönem.] 1. (Naut.) A large, flat-bottomed boat, fitted with cranes, etc., for careening vessels. 2. Portable boats for making tempnrary bridges. 3. (Mil.) A boat, cask, or cylindrical metal vessel ; one of the floating piers of a portable military bridge for the passage of rivers; each raft being completed and joined to the next one by baulks.(q.v.) and chesses (q.v.).

Pood. A weight of forty Russian pounds, = 36. I I 4 English pounds avoirdupois.

Poojah. [Hind.] Ceremonial prayer before an image.

Pooler. An instrument to stir a tan-vat.

Poonac. Cocoa-nut oil-cake.

Poonwood. An E.-Indian wood, light and porous, used for ship-building.

Poop. [L. puppis.] (Naut.) The highest and aftermost part of the hull. $P$. or $P$.-deck. (Decks.) P.-lantern, distinguishing mark of flag-ship at night. $P$.-royal, a short deck above the aftermost part of the $P$.-deck in the largest French and Spanish men-of-war, called also Top-gallant $P$.

Pooped. (Naut.) Caught by a sea which breaks over the stern, when running before the wind.

Poor laws. Laws for the relief of the poor. By those of Elizabeth, the poor were entitled tc relief in the parish where they had their Settle. ment. By the amended law of 1833 , the smaller 
parishes were classified into unions, each administered by a board of guardians of the poor, subject to the rules of the Poor Law Board. The funds needed are raised by poor rates, assessed on the ratable value of real property. (Overseers of the poor.)

Poor rates. (Pauperism; Poor laws.)

Pope Joan. A woman who was supposed by some to have been elected pope on the death of Leo IV., A.D. 855. The story has been dealt with effectually by Dr. Döllinger in his PapstFabeln.

Popinjay. [Ar. balbarga, parrot; of. Fr. papegai,.Sp. papagayo, It. pappagallo, parrot.] (Ornith.) 1. Green woodpecker; length about thirteen inches, plumage mainly green and scarlet. Europe and Asia. Pīcus virĭdis, gen. Pìcus, fam. Pīcĭdæ, ord. Pīcārǐæ. 2. Colloquially, the parrot.

Popish Plot. (Mea]-Tub Plot.)

Poplin. [Fr. popeline.] A stuff made of silk and worsted.

Popliteal, Poplitic. Having to do with the knee [L. poplítem].

Popliteal region or space. (Mea.) That behind the knee-joint [L. poplitem, the ham of the knee].

Poppyheads. (Arch.) The carved finials on the upright ends of stalls or seats in churches are sometimes so called.

Populus. (Phratry; Plebs.)

Pŏpŭlus vult decîpi: decǐplātur. [L.] The people like to be fooled: let them be so.

Porbeagle. [Perhaps connected with Prov. porc, and Fr. barbillon, spec. of sharks.] (Ichth.) A spec. of shark, Lamna cornubica. Also written Probeagle.

Porcelain. [It. porcellāna.] A translucent substance composed of kaolin and peh-tun-tze (qq.v.). (Paste.)

Porism. [Gr. $\pi \delta \rho \iota \mu \alpha, a$ corollary.] A proposition affirming the possibility of finding such conditions as will render a certain problem capable of innumerable solutions. Euclid wrote three books of porisms, which are lost, and the question what he meant by a P. has been much discussed.

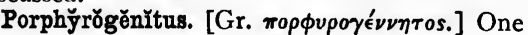
born in the purple, i.e. in an apartment of the palace lined with porphyry. A term in the Byzantine court for a child born to the reigning emperor.

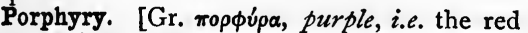
of Egyptian porphyry.] (Giol.) 1. Strictly, a felspathic rock with crystals of felspar. 2. Any rock in which crystals are embedded in a compact base; e.g. porphyritic granite, porphyritic trap, augite porphyry, etc.

Porporino. [It.] A mixture of quicksilver, tin, and sulphur, formerly used instead of gold in painting.

Porrigo. [L., scurf.] (Med.) Ringworm, a pustular and contagious affection of the scalp.

Port. (A-beam.) $P$. the helm, = put the tiller towards the left side of the vessel.

Portage. A carrying place over land between navigable waters or along the banks of rivers, round waterfalls or rapids, etc. ; a word universal in N. America.-Bartlett's Americanismis.

Portate. [L. portātus, carried.] (Her.) Borne not erect but athwart an escutcheon.

Portcullis. [Fr. porte-coulisse, a sliding-gate.] (Mil.) Strong iron grating with projecting points along the bottom, sliding in grooves in the gateway of a castle, through which it can be dropped when necessary.

Porte, The Sublime. The official title of the Turkish government; said to be derived from Bab Humayoon, a gate of the palace at Broussa.

\section{(Seraglio.)}

Porte cochère. [Fr.] Gate for carriageentrance, by a road leading through the front of the house to the back.

Portefeuille. [Fr.] A Portfolio.

Portemonnaie. [Fr.] A pocket-book for carrying money; a purse.

Porteous Riots, in Edinburgh, 1736. After the execution of Wilson, a smuggler, the mob, sympathizing, attacked the soldiers with stones. Captain P., firing upon them, was tried and condemned to death. Reprieved by Queen Caroline, he was hung by the mob. P. R. were made interesting by Sir Walter Scott's Heart of Midlothian.

Portfire. (Mil.) A composition of fine gunpowder pressed into a paper tube, used as a match for firing guns.

Portfolio. [L.L. portîfórium ; a small book of prayers, which may easily be carried out of doors, portāri foras.] Often, by meton., = secretaryship.

Portière. [Fr.] A curtain filling a doorway, or dividing two rooms.

\section{Portǐtōres. (Publicans.)}

Portland stone. (Bath-stone.)

Portland vase. A cinerary urn, found in a tomb arbitrarily assigned to the Emperor Alexander Severus. It passed from the possession of the Barberini at Rome into that of the Portland family, who in 1810 placed it in the British Museum. It was found about 1550 in a sarcophagus in the sepulchral Monte del Grano, near Rome. It consists of two layers of glass, the upper one white, the lower dark blue, cut (cameo-fashion) into a design of seven figures. It originally belonged to the Barberini family. It has been copied by Tassie in plaster of Paris, and by Wedgwood in jasper.

Portlast, or Portoise. (Naut.) The gunwale $(q . v$.$) .$

Portmen. (Naut.) 1. Inhabitants of the Cinque Ports. 2. Spanish burgesses.

Portreeve, or Portgrave. [A.S.] The chief magistrate in the ancient English seaports.

Port Royalists. Members of the Convent of the Port Royal des Champs. The house was suppressed by Louis XIV. as a stronghold of the Jansenists. Among the distinguished men connected with it are Pascal, Arnauld, and Tillemont. The school-books published by the Port Royalists long maintained their reputation.

Ports. [L. porta, a door, or opening.] (Naut.) Square holes in a ship's side, for firing guns 
through or loading a cargo. Gunroom $P$. are in the stern; Bridle $P$. , in the bows.

Posé. [Fr., placed.] (Her.) Standing still with all his feet on the ground.

Position; Angle of P.; Geometry of P.; P. miorometer. A rule for solving certain arithmetical questions in which an assumed number (or numbers) is used instead of the unknown $x$ of algebra. The Angle of $P$. is the angle made with a fixed line by the line joining two neighbouring stars. The angle of $P$. in the case of double stars and the like is measured by a $P$. micrometer. (For Geometry of P., vide Geometry.)

Positive. A photograph corresponding in its lights and shades with the original, instead of their being reversed as in a negative.

Positive electricity is the electricity which a body contains above its natural quantity.

Positive quantity; P. sign. In Algeb., a quantity affected with the Positive sign, or sign of addition $(+)$; as, $+a b$. (For $P$. crystal, $P$. eye-piece, vide Crystal ; Eye-glass.)

\section{Positivism. (Positivists.)}

Positivists. The followers of Auguste Comte, the founder of a philosophy called Positivism, which limits itself strictly to human experience, and therefore ignores the life to come and the relations of man with God. For practical purposes the school is merely negative.

Posse comitātus (i.e. cum potestate). In Law, the power of the county, which the sheriff may raise in case of riot or other opposition to the course of justice.

\section{Possession. (Obsession.)}

Possǐdentis in æquāli jūre mĕlior est conditio. (Leg.) When the rights of plaintiff and of defendant are equal, the latter is considered to have the better case.

Possunt, quia posse videntur. [L.] Lit. they are able, because they seem to be able; they succeed who are credited with probability of success.

Post. A large kind of writing-paper.

Postal. In America, a post-card.

Post-captain. Formerly, title of a naval captain of three years' standing. Disused.

Posted. (Naut.) Promoted to the rank of captain R.N. A term no longer in use.

Posted-np. Well-informed; a metaphor from commercial activity.

Post-entry. In Com., a supplemental entry made by a merchant who finds that his entry of goods already weighed and measured is too small.

Postern. [Fr. poterne, formerly posterne, L. postěrŭla, a secret passage.] (Mil.) Covered passage leading under a rampart from its terreplein to the ditch in front.

Post hoc. [L.] After this.

Post hoo, ergo propter hoo. [L., after this; so owing to this.] The assumption of cause and effect, where there may be only sequence.

\section{Posticum. (Na.0s.)}

Postil. [Said to be from L. post ill-a, after them.] (Eccl.) A homily or sermon delivered after and upon a lesson from Scripture.

Postliminium, or Jus postliminii. 1. In the Middle Ages, the act by which a citizen, de- parting to another land, reserved his rights in his own country for resumption on his return. 2. In National and Civil Law, the right by which prisoners of war regain their freedom on the ending of hostilities.

Postmaster. At Merton College, Oxford, a scholar; corr. of portionista, one who has a share [L. portio] of the endowment.

Post meridiem. [L.] P.m. ; afternoon.

Post-mill. A windmill standing on a post, so that it can be turned round.

Post-mortem examination. [L.] An examination of the body after death.

Post-note. In America, a bank-note intended to be transmitted to a distant place by mail, payable to "order ;" not, like a bank-note, to "bearer." -Bartlett's Americanisms.

Post-obit. [L. post obirtum, after death.] A bond given to secure a sum of money on the death of some given person.

Post prandium. [L.] After dinner; thus, a post-prandium speech.

Postscenium. [L.] (Arch.) The part of a theatre behind the scenes.

Postscriptum. [L., written after.] A postscript ; abbrev., P.S.

Post těněbras lux. [L., after darkness, light.] After a storm, a calm.

Postumiana imperia. [L.] A phrase with the same meaning as Manliana imperia.

Potash, Potassa. [Eng. pot ash.] (Chem.) Oxide of potassium. Caustic potash is hydrate of potassium. The commercial potashes are impure carbonate of potash, obtained from wood ashes by lixiviation and evaporation.

Potassium. A soft, silvery-white metal, obtained from potash.

Potato-stones. (Geode.)

Poteen. [Ir. poitin, a small pot.] Irish whisky illicitly distilled.

Potent. (Her.) A fur covered with small T figures, like a crutch [Fr. potence], ranged in lines. When the heads of each line of crutches touch those of the next line, it is called counterpotent.

Potential. [L. pǒtentia, force.] The work required to move a unit of mass from a certain point to an infinite distance against the attraction of a body is the P. of the body on that point. If the mass of each particle of the body be divided by its distance from the point, their sum is the $\mathrm{P}$. of the body at the point.

Potential, Electrical. [L. pŏtentia, power.] The degree of electrical tension at any point, depending on the amount of electricity there relatively to that at adjacent points.

Potential qualities. In scholastic philosophy, qualities existing in a body in potentia only, without any actual development.

Potichomanie. [Fr. potiche, a porcelain vase, manie, mania.] The process of coating the inside of glass vessels with engravings or paintings, to make them look like painted china.

Pot-metal. 1. A kind of stained glass, the colours of which are incorporated with it while fused. 2. A poor kind of brass used for casting cocks, etc. 
Potoroo, Pottoroo. Native name for a small marsupial, the kangaroo rat (Hypsiprymnus minor); brownish black; a little more than two feet long, including the tail. Australia.

Pot-paper. Paper fifteen inches by twelve and a half.

Potteries, The. A populous district, about $=$ forty-eight square miles, of which Burslem may be taken as the centre, at which place Wedgwood was born, 1730 .

Potting. Putting sugar in casks for draining.

Pot-waller, Pot-walloper, Pot-wabbler. Before the Reform Act of 1832 , in constituencies such as Ilchester, Old Sarum, etc. ; one who proved himself a housekeeper, and so an elector, by boiling a pot over a fireplace erected in the air ; to "wallop" meaning to sway, to move to and fro like boiling water.

Pouch. [Cf. Fr. poche, A.S. pocca, Eng. pocket, etc.] (Mil.) A leather case in which ammunition or percussion caps are carried and kept dry.

Pouches. (Naut.) 1. Small compartments in the hold, for stowing corn, etc. 2. Bulkheads to prevent grain, or such like cargo, from shifting.

Poudrette. [Dim. of Fr. poudre, powder.] Dried nightsoil mixed with earth and used for manure.

Pouldron. [(?) Fr. épaule, shoulder.] (Mil.) Shoulder-piece of a set of armour.

Poulpe. [Fr., from polypus (q.v.).] (Argonauta ; Octopus.)

Pounce. [Fr. pouce, pumice.] Powdered sandarach, used to prevent ink from spreading on paper.

Pound. [Akin to L. pondus, weight.] 1. The pound avoirdupois is the British standard unit of mass ; the quantity of matter in any body is one $P$. avoirdupois when in a perfectly just balance it would exactly counterpoise a certain lump of platinum, kept in the Exchequer Office, called the standard P. 2. A P. troy (which is the same as a P. in apothecaries' weight) is 144 of a $P$. avoirdupois. 3. A piece of money, of gold, of a certain degree of fineness (viz. 22 carats), 1869 of which weigh forty pounds troy. 4. The P. now common in Germany is half a kilogramme. 5. Nearly every principal city in Europe had its own P. ; thus at Amsterdam it was 7636 , at Cologne 7218, at Madrid 6544, at Paris 756r, at Venice 7368, English grains; and in some cities two or three different pounds were used for different purposes, as at Amsterdam and Venice.

Pound. (Naut.) Water fenced so as to keep fish from getting away. Pound-and-pint idler, the purser.

Pour comble de bonheur. [Fr.] To complete one's happiness or luck.

Pour encourager les autres. [Fr.] To encourage the rest.

Pourparler. [Fr.] A parley, or consultation.

Pourparty. [Fr. pour, for, parti, part, party.] (Leg.) A divided share.

Pour passer le temps. [Fr.] By way of pastime, or of killing time.

Powder, To. In Naut. slang, to salt slightly.
Powdering-tub, pickling-tub. Powder-monkey, the boy who carried cartridges; now P.-man.

Power. [Fr. pouvoir.] 1. (Algeb.) The result of multiplying a number by itself two or more times; so the fourth power of 5 , or $5^{4}$, is $5 \times 5 \times 5 \times 5$, or 625 . 2. (Mech.) The work done by an agent at the driving point of a machine. 3. The agent that does the work ; as steam-P., water-P., etc. 4. (Optics.) The degree of magnification produced by a lens, microscope, etc. A P.-loom is a loom driven by steam or water power. (For Horse-P., vide Horse-power; for Mechanical $P$., vide Mechanical.)

Power of attorney. In Law, an instrument by which a party empowers another to act.for him, either generally or for a specified purpose.

Pow-wow. 1. The name given by the early chronicles to the feasts, dances, and other public doings of the Red men, preliminary to a grand hunt, a council, a war expedition, and the like ; and so, 2, in political talk, any noisy meeting, with more of clamour than of counsel.-Bartlett's Americanisms.

Poy. [Akin to poise, L. pensare, to weigh.] A rope-dancer's pole.

Poyal. [Sp.] A striped stuff for covering chairs, etc.

Poyning's Law. Known also as the Statute of Drogheda. An act of the Irish Parliament, 1495, containing provisions for the orderly government of the inhabitants of the Pale, and for strengthening the power of the Crown.

Pozzolana. Volcanic ashes (from Pozzuoli, in Italy), used for making a kind of mortar which hardens under water.

Praam. (Pram.)

Præconization. [L. præcōnem, a crier, herald.] A summoning, a general publishing; a "call of the House" of Convocation.

Præcordia. [L.] The parts about the heart.

Prædial tithe. (Tithes.)

Præfect. [L. præfectus, set over.] (Rom. Hist.) The title of certain superior officers in their own departments. Among them were (I) the $\mathrm{P}$. of the city, who had the Imperium during the absence of the consuls from Rome; (2) the Pratorian P., who commanded the Prætorian cohorts; (3) the Prafectus Vigilum, or captain of the Roinan night-watch; and others. The Governor of Egypt was also called P.

Prælector. [L.] A reader or lecturer, in the universities or elsewhere, his lectures being called prælections.

Præmūnīre. (Leg.) 1. A kind of contempt against the king, with severe penalties attached. 2. The writ Præmŏneri facias, i.e. cause the offender to be warned to appear. Several statutes of $\mathrm{P}$. have been passed-to restrain Romish clergy, to enforce oaths of allegiance or supremacy, etc.

Prænomen. [L.] Among the Latins, the name which distinguished the individual f:om his gens or clan and his family, the former of these two coming between the prænomen and the latter which was called the cognomen. Sometimes a fourth name, called agnömen, 
marked some characteristic feature or fact. Thus in Publĭus Cornēlius Scǐpı̌o Barbātus, Publius is the prænomen, Cornelius the gentile, and Scipio the family name, the agnomen Barbatus distinguishing him by his beard. So Fr. prénom, Christian name.

Prø-raphøelite. In Painting, a term applied to a modern revival of the art of the fifteenth century, before the time of Raphael. Its main principle is said to be a faithful representation of all natural forms.

Prærogative Court. (Court, Christian; Prerogative Court.)

Prætexta. (Toga.)

Prætor. [L., one who goes before.] The original title of the Roman Consuls. The office specially so called was, according to Livy, instituted after the election of the first plebeian consul, the patricians refusing to ratify the election unless a prætor and two curule ædiles were elected by way of compensation out of their own body. A century later, a second P. was appointed to judge in suits between Roman citizens and foreigners, and was hence called $P$. Peregrinus, the former being now called $P$. Urbanus. Two more were added subsequently for Sicily and Sardinia and for Spain. (Curule magistracies.)

Prætorian cohorts. (Kom. Hist.) A body of guards, instituted by Octavius (Augustus), in nine cohorts, three of which were stationed in Rome. Tiberius brought them all to Rome, and placed them in a permanent camp. Their constitution was entirely altered by Sevērus; they were deprived of their privileges by Diocletian, and suppressed by Constantine.

Prætōrum. [L.] The head-quarters of the Prætor.

Prætor Peregrinus. (Prætor.)

Prætor Urbanus. (Prætor.)

Pragmatic Sanction. In the later Roman empire, a public or solemn constitution, distinguished from the simple rescript referring to a particular case. Among the important instruments which have borne this name are the ordinance of Charles VII., assuring the liberties of the Gallican Church, and the Pragmatic Sanction of the Emperor Charles VI., which caused the Bavarian war of succession, 1740.

Prahu. [A Malay word.] (Naut.) Larger Malay war-ship, from 55 to 156 feet long, manned by 76 to 96 rowers, and 40 to 60 fighting men, carrying small brass guns, and very swift.

Prakrit. A later form of Sanskrit, spoken by the general body of the people. It thus became the source of the modern Indian vernaculars.

Pram, or Praam. (Naut.) Dutch and Baltic lighters. Some, mounting heavy guns, were used by the French for harbour defence.

\section{Pramantha. (Promethean.)}

Pratique. [Fr.] (Naut.) Licence to trade or land, after quarantine, or on production of a clean bill of health.

Praxeans. (Eccl. Hist.) The followers of Praxeas, who, in the second century, put forth the opinions of the Monarchians, Sabellians, and Patripassians.
Praying insects. (Mantis.)

Praying-wheel. An instrument used by Buddhists for the mechanical offering of prayers. The wheel revolves with the wind or is turned by the hand or by water-power, and as the written prayers come round, they are supposed to count as offered by the writer or the owner. Prayers on strips of parchment are fastened to the twigs of bushes and trees, for the same purpose.

Pro-adamites. Eastern legends speak of nations existing before the creation of Adam, and of dynasties of kings who ruled over them.

Prebend. [L. præbenda, to be given.] The share of the estate of a cathedral or collegiate church to be received by a prebendary.

Prebendary. (Prebend.)

Precentor. [L. præcentor.] The leader of a choir. In most cathedrals of the old Foundation, the $P$. ranked next to the dean. In the more modern foundations, the $P$. is usually a minor canon.

Preceptories. Benefices held by Knights Templars, who were created by the Grand Master Praceptores Templi. It is said that there were sixteen $P$. in this country. Similar foundations among the Knights Hospitallers were called Commanderies.

Precession [from L. precessum, sup. of precedo, $I$ go before ]; P. of the equinoxes; Iuni-solar P.; Planetary P. A slow movement of the axis of the earth, in virtue of which the points of inter. section of the equator and the ecliptic (the equinoxes) move in the direction opposite to that of the sun's proper motion at the rate of about 50" a year. It is therefore called the Precession of the equinoxes. It is due mainly to the fact that the attractions of the sun and moon on the earth do not pass accurately through its centre. The part of the whole phenomenon due to this cause is therefore called the Luni-solar $P . ;$ a small part of it is due to the attraction of the planets, which produces a very slow oscillation of the plane of the ecliptic, and is called the Planetary $P$.

Precious metals. A general name for gold and silver.

Precipitate. [L. precipitātum, sup. of precipitāe, to throw down headlong.] (Chem.) Any substance thrown down to the bottom of a solution by the addition of another liquor. Red precipitate, mercuric oxide. White precipitate, an ammoniacal chloride of mercury:

Précis. [Fr.] A precise [L. præcīsus, cut down], i.e. abridged statement or summary; an abstract.

Predicable. [L. prædìcābilis, that may be said of anything.] (Log.) Any term which may be applied to explain other terms. The notions expressed by such terms are the results of the process called abstraction. The terms themselves are distributed under five classes-genus, species, difference, property, and accident.

Predicaments. (Log.) General heads, summa genera, under which all terms may be arranged. Also called Categories.

Predicate. (Log.) In a proposition, the 
term which is affirmed or denied of the subject. (Predicable.)

Predorsal. [L. præ, before, dorsum, the back.] (Anat.) Situated in front of the back.

Predy, or Priddy. (Naut.) Get ready [Fr. prêt, L. præstus].

Pre-emption [L. præ, before, emptio, -ōnem, a buying], or Prerogative of purveyance. 1. A right of the Crown to buy up, at an appraised valuation, before others, and without the owner's consent, provisions, etc., for the king's needs; and to impress carriages and horses for the king's business on the public roads. 2. A term now used in a few instances; as of the right sometimes given in a mortgage-deed to the mortgagee, of having the refusal, if the property should be sold.

Preen. [O.E. preon, a bodkin.] A forked instrument used in dressing cloth.

Pro-existence. In Philosophy, the idea, insisted on by Plato, that the human soul has existed in former conditions before being joined with the body. He argued especially from the rapidity with which children learn, and which could only be explained as an effect of reminiscence, or Anamnésis. This notion is propounded by Wordsworth in his Ode on the Recollections of Childhood.

Prefect. (Præfect; Préfets.)

Préfets. [Fr.] Local officers of departments and cities in France, with powers exceeding those of our sheriffs, the arrondissements or districts of departments being under Sous-préfets appointed by the préfets.

Prefix. [L. præfixus, fixed before.] (Gram.) The first element in a compound word, as is pre in prefix. (Affix.)

Prefloration. [L. præ, before, flōr-em, a flower.] A term preferred by many botanists to Estivation, expressing the condition of the floral members in the flower-bud, before the expansion of the flower.-Bettany, Practical Botany. (Prefoliation.)

Prefoliation. [L. præ, before, fólium, leaf.] A term preferred by many botanists to Vernation, as expressing the condition of leaves in the leafbud before its expansion, their mode of folding, etc. (Prefloration.)

Pregnant instance. Evidence or argument implying more than appears on its surface.

Prehistoric archæology is divided as to pe-

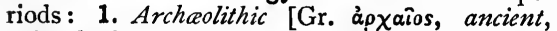

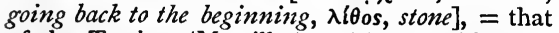
of the Tertiary (Mortillet); with a problematic variety of stone implement fashioned by fire and breakage rougher than the chipping which cha-

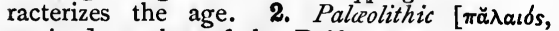
ancient], = that of the Drift; age of chipped tools, with the mammoth, cave-bear, woollyhaired rhinoceros. 3. Neolithic [véos, new], $=$ later Stone age, of ground and polished weapons and instruments, gold ornaments. 4. Bronze age, $=$ of bronze used for arms and all cutting instruments. 5. Iron age, $=$ of iron instead of bronze for arms, knives, and bronze for ornament only. But the ages of stone, of bronze, and of iron were, in different places, co- existent. Indeed, in some countries the stone age still continues, the people being unacquainted with the use of metal. (See Lubbock, Prehistoric Archaology.)

Prelate. [L. ' prælätus, preferred.] (Eccl.) A term denoting the order of bishops, and including, in the Latin Church, those who have episcopal rank.

Prelumbar. [L. lumbus, a loin.] (Anat.) Situated in front of the loins.

Premices. [L. prīmítiæ.] (Eccl.) Firstfruits. Premier coup. [Fr., first stroke.] (Alla prima.)

Premisses. [L. præmissa, sent before.] (Log.) The two propositions or antecedents in a Syllogism, from which the conclusion or consequence follows.

Premonstratensians. Regular canons, instituted I I20, by St. Norbert (whence also called Norbertines), at Premonstrātum [L., pointed out, it was said, by the Virgin], in Picardy. They were also called White Canons, from the colour of their dress.

Prendre la lune avec les dents. [Fr., to seizc the moon with one's teeth.] To perform or attempt to perform impossibilities.

Prepense. [L. præ, before, pendo, $I$ weigh.] In Law, an epithet to malice, denoting its deliberateness.

Prepotent. (Biol.) Inherently, antecedently efficacious; $e . g$. the pollen of a distinct variety may have a P. effect over a flower's own pollen. Pre-raphaelite. (Præ-raphaelite.)

Prerogative Court. [Lit. having, L. prærŏgativa, preference.] The court which had the jurisdiction now transferred to the Court of Probate.

Prerogative of purveyance. (Pre-emption.)

Presanctified, Mass of the. In the Eastern and Latin Churches, a Mass in which the elements used have been consecrated in a previous Mass. (Liturgy.)

Presbyōpia. [Gr. $\pi \rho \epsilon ́ \sigma \beta v s$, an old $\operatorname{man}, \omega \psi$ the eye.] Long-sightedness, inability to discern objects as closely as in former years. (Longsighted eye.)

Presbyterians. (Eccl.) The name given to those who reject episcopal government in the Church.

Presbyters. [Gr. $\pi \rho \epsilon \sigma \beta \dot{r} \epsilon \rho o s$, elder.] An order of ministers in the Christian Church, mentioned in the New Testament as being charged with the care of distinct congregations.

Presbytery. [Gr. $\pi \rho \epsilon \sigma \beta \nu \tau \epsilon \rho$ ǐ $\delta$, belonging to the elders.] (Arch.) The space between the altar and the easternmost stalls of the choir, answering to the Solěa of the ancient basilicas.

Presoriptive. [L. præscriptio, a prescribing (Leg.) for title, or the right so acquired.] Acquired by or consisting in immemorial use.

Presently. [Fr. presentement.] Matt. xxi. I9 [Gr. $\pi \alpha \rho \alpha \chi \rho \hat{\eta} \mu \alpha]$ and elsewhere in the Bible, immediately.

Presentoir. [Fr.] A shallow cup with a tall and rich stem.

Present value. The sum of money reckoned at an agreed rate of interest which must be paid 
down in lieu of a sum that becomes due at a certain future time. If, as in payments connected with life assurance, the future payment is contingent, the present value is the sum above determined, multiplied by the probability of the contingency.

Press-gang. A name denoting the detachments of seamen in the royal navy who were formerly empowered to seize on any seafaring men in time of war, and compel them to serve on board the king's ships.

Pressure. (Mech.) 1. A force counteracted by another force or forces so that no motion is produced. 2. A stress or distributed force so exerted as to cause compression; as atmospheric pressure, fluid pressure, etc.

Prest. [Cf. Fr. prêt, ready, formerly prest, L. præstus.] (Naut.) Quick, ready, etc. Prest man, one willing to enlist for a stipulated sum ; opposed to Pressed man. (Press-gang.)

Prester John. A mysterious personage, said to have lived in the twelfth century, as the Christian king of an immense empire in Asia, being at the same time a priest. Some have supposed that he was Joyhoul Wang Khan, who was killed in a battle with Gengis Khan, 1203. It is also said that the name Prester John was applied in the West to a dynasty of Tartar sovereigns.

Prestidigitation, meaning leger-de-main, seems to be a corr. of Prestigiation [L. præstígiæ], suggested by It. presto, ready, and L. dìgitus, finger.

Prestige. [Fr.] Lit. the repute of skilful jugglery', or prestidigitation, or, more correctly, prestigiation.

Prest money. Money paid to men on enlisting, because they thereby hold themselves prest, i.e. ready to march at command.

Presto. [L. præsto, at hand, ready.] In Music, fast. P. assai, very fast. Prestissimo, very fast indeed.

Presumptions, Doctrine of. Another name for circumstantial evidence.

Pretender. (Eng. Hist.) The name applied to the princes of the Stuart family who laid claim to the English Crown after the revolution of I688. The line was closed (I807) with the death of the Cardinal of York, who styled himself Henry IX.

Preterist. [L. præterĭtus, past.] 1. One who lives in the past rather than in the present. 2 . One who regards the Apocalypse as a series of predictions which have been already fulfilled.

Preux chevalier. [Fr.] A gallant knight.

Prevent. [L. prævěnio, $I$ go before.] 1. To anticipate, as in Ps. cxix. 148, and passim. 2. To assist, as in Collect, "Prevent us, O Lord," etc. ; to go before and clear the way.

Preventer. (Naut.) A strengthener, or additional rope, etc., used to assist the ordinary ones.

Previous question, Moving the. In the House of Commons, a method of avoiding a direct vote Aye or No, or amendment. The Speaker is about to put a question to the vote; but a member may raise the question whether it is desirable to decide one way or the other. This latter becomes a previous question, taking precedence of the main question, and the Speaker must put it to the House, "That the question be now put." By negativing this, the House shelves the question for that day. Affirming this, the House must at once vote Aye or No, without amendment, debate, or adjournment.

Priam. (Paris, Judgment of.)

Prick, To. (Naut.) To P. a sail, to stitch down the centre of a seam. To $P$. for a soft plank, to choose one to sleep upon. $P$. her off, to find and mark a vessel's position upon a chart.

Pricket (?) = having pointed horns. (Deer, Stages of growth of.)

Prickly heat. Popular name of Lichēn trŏpiccus (q.v.).

Prick-song. Music written, not extemporaneous ; notes having been originally [L. puncta] points ; cf. counterpoint.

Priddy. (Predy.)

Pride's Purge. (Long Parliament.)

Priedieu. [Fr., pray God.] A kind of desk at which to kneel.

Priest. [Gr. $\pi \rho \in \sigma \beta u ́ \tau \epsilon \rho$ os.] A later form of the word Presbyter.

Prill. [Fr. briller, to shine.] 1. A solid piece of virgin metal in a mine. 2. The button of metal from an assay.

Prillion. [Fr. brillant, shining.] Tin extracted from the slag.

Prima donna. The first female singer at the Italian Opera.

Prima facie. [L.] At first sight.

Primage. An allowance paid to the seamen and master of a ship by the shipper or consignee, for the loading of goods.

Primary assemblies. (Hist.) Assemblies in which every citizen has the right of speaking and voting, as distinguished from representative parliaments, which are Secondary assemblies. Such assemblies are necessarily practicable only in small states, as in the ancient Greek republics.

Primary colour. [L. primārǔus, principal.] One of the three primary colour-sensations, viz. red, green, or violet. The popular notion that the primary colours are red, yellow, and blue, is erroneous as to mixtures of light, though it has a certain approximate truth with regard to pigments.

Primary rocks. [L. primàrius, of the first order.] In the early days of Geol., = nonfossiliferous, opposed to Secondary or fossiliferous. Now the Palaozoic are = Primary, being the first met with in the ascending scale. The actual primitive rocks are not supposed to exist now, having been all worn away or altered.

Primate. [L. primas, primātis.] A prelate of superior dignity. The Archbishop of York is P. of England, and the Archbishop of Canterbury P. of all England.

Prīmātēs. [L. prīmātem, principal.] (Zool.) The highest class of mammals next below man (if he is not included), having pectoral mammæ (except the aye-aye), and opposable thumbs on one pair at least of the limbs ; as monkeys and lemurs. Linnæus includes men (Bı̆măna) and bats (Cheiroptěra). 
Prime. 1. (Mech.) A steam-engine is said to $P$. when water passes from the boiler into the cylinder along with the steam. 2. (Eccl.) (Canonical hours.)

Prime meridian; P. mover; P. number; $\mathbf{P}$. vertical. Prime meridian, or First meridian. (Meridian.) $P$. mover, an engine which serves to transfer energy from those bodies which naturally develop it, to those by whose means it is to be employed; as the steam-engine, which transfers the energy of steam to the machinery of a cotton-mill, etc. $P$. number, one which cannot be resolved into factors less than itself; as $17,23,29$, etc. $P$. vertical, a vertical circle at right angles to the meridian; it passes through the zenith and through the east and west points of the horizon.

Primer. [L. primārius.] A book of primary or elementary instruction. A primer of the Salisbury Use was printed in 1527 . Primers may at first have been mere spelling-books for children, but the lessons were taken from the office-books of the Church. In course of time, they came to be Prayer-books, containing different selections according to the choice of the compiler. King Henry VIII.'s P., published in 1545, was one of many such books which appeared in his reign and in those of Edwảrd VI. and Elizabeth.

Primer, Long; Great P. Two kinds of type, as-

\section{Oxford, Oxford,}

respectively.

Primer seisin. [Norm. Fr.] The ancient prerogative by which the Crown possessed, for a year, the lands and tenements of which a tenant-in-chief died seised, if the heir was of full age, and if not, until he was of age.

Prime staff. (Clog almanack.)

Priming. The first colour laid on canvas as a ground.

Priming and lagging of the tides. The variations in defect and excess of the interval between two successive high tides from its mean value.

Primǐtiæ. [L.] Firstfruits, which amongst all ancient peoples were set apart as devoted to the deity. (Premices.)

Primitive circle. In the projection of the sphere, the circle on whose plane, produced if necessary, the surface of the sphere is represented; the plane is the plane of projection.

Primitive Methodists. (Ranters.)

Primordial. [L. primordium, a first beginning.] (Geol.) A name given to a zone, in the Lower Silurian, once thought to have the oldest fossils.

Primrose. Properly the daisy, whose name has nothing to do with rose. It is really the primirole [Fr. primiverole, It. prima verola, dim. of prima vera, the early spring]. Primirole became Anglicized first into primerole, then into primrose.

Primum mōbile. [L., the first thing that can be sct in motion.] In the Ptolemaic astronomy, the outermost, generally reckoned the ninth, sphere of the heavens; by revolving round the earth, which was placed in its centre, it gave motion to the other spheres (viz. those of the sun, of the moon, of each of the five planets, and of the fixed stars), to which the heavenly bodies wese supposed to be fastened.

Primus inter păres. [L.] First among peers. Prince of the Captivity. (Echmalotarch.)

Princeps Senatus. [L.] The first, or chief, in the Roman senate. This title served as the foundation of the imperial authority of Octavius (Augustus) and his successors.

Prince's metal. An alloy, composed of three parts of copper to one of zinc ; in imitation of gold ; also called Prince Rupert's metal.

Prince's wood. A W.-Indian wood, lilse satinwood, but darker.

Princettas. A worsted fabric, sometimes with a cotton warp.

Principal axis. If a body is made to rotate, and then withdrawn from the action of all external forces, the axis of rotation will, in general, be continually shifting within the body; but there are, at least, three lines at right angles to each other, round either of which it will continue to rotate, if the rotation is communicated to it round that line. These three lines are called principal axes, or axes of permanent rotation.

Principals. (Arch.) The assemblage of timbers forming the support of a roof.

Princlpes. (Hastati.)

Princlpia. [L., beginnings, principles.] The shortened title by which Newton's great work, Philosophice Naturalis Principia Mathematica, is known; the publication of which, in 1687 , is the most remarkable epoch in the history of science.

Principlis obsta. [L., meet things at the outset (Ovid).] Make a stand against the beginnings of actions, habits, etc., if you would avoid evil results. A stitch in time saves nine.

Prink. [Akin to prank.] To dress for show, or in a foppish and finical manner.

Prisage. In O.E. usage, the right of taking for the revenue two tuns of wine out of twenty from every ship importing twenty tuns or more into England.

Priscillianists. In Eccl. Hist., the followers of Priscillian, a Spanish bishop, put to death in A.D. 382, by Maximus, tyrant of Gaul. Their opinions are said to have been Manichæan. Milman, Hist. of Latin Christianity, bk. ii. ch. 4 .

Prism [Gr. $\pi \rho i \sigma \mu \alpha$, a thing sazen, a prism] ; Achromatic P.; Nicol's P. 1. (Geom.) A solid whose sides are parallelograms and ends similar and equal figures in parallel planes. 2. (Optics.) A wedge-shaped piece of glass. When a ray of sunlight passes through such a prism, it is bent from its original direction and decomposed into several coloured rays. An Achromatic $P$. consists of two prisms of different kinds of glass (e.g. crown-glass and flint-glass) joined together, with their edges turned opposite ways, and with angles so adjusted with reference to their refractive indices, that a ray of light passing through them, though bent from its original direction, is not decomposed into rays of coloured light. A Nicol's $P$. is an instrument that can be used 
either as a polarizer of light or an analyser of light already polarized. If a ray of light is made to pass through a crystal of Icelandspar, two polarized rays with different refractive indices are obtained; but if it is cut at a suitable angle, and the parts joined by a layer of Canada balsam - a transparent substance, with a refractive index intermediate to those of the two rays-one of the polarized rays is internally reflected, and only one polarized ray gets through. Such a crystal, properly mounted, is a Nicol's $P$.

Prismatio system. (Crystallog.) Consists of those crystals which have three rectangular axes and three unequal parameters ; when transparent, they are optically biaxal ; as topaz.

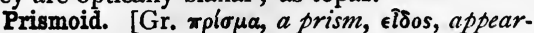
ance.] A solid, whose ends are quadrilateral figures in parallel planes, and sides trapezoids.

Prismoidal formula. A rule for calculating the volume of a prismoid. The calculation of the volumes of railway cuttings and embankments depends on this formula.

\section{Privateer. (Letters of marque.)}

"Privilege! Privilege!" The loud cry raised at Charles I., as he returned from the House of Commons, January 4, I642, whither he had gone in person to arrest five members.

Privileged copyholds. (Leg.) A superior kind of copyhold, commonly known as customary freehold, the tenant holding by copy of court roll, and not at the will of the lord.

Priv̌lēgrum clērǐcăle. [L.L.] (Benefit of clergy.)

Privy Chamber, Gentlemen of the. The officers of the royal household.

Privy Seal, Lord. The officer of State who has charge of the privy seal of the sovereign, used for pardons, charters, etc., before they come to the Great Seal. (Chancellor, 3.)

P.R.N. $($ Med. $)=[\mathrm{L}$.$] pro re nātā, according to$ the occasion.

Proa, Flying. A narrow canoe, about thirty feet long and three wide, used in the Eastern seas, and constructed on the principle of an outrigger. (Prahu.)

Pro aris et focis. [L., for our altars and hearths.] For God and our country.

Probabilism. [L. probābullis, likely.] (Theol.) The theory which regards it as allowable to follow a probable opinion on doubtful points, even though another should be more probable. Hallam, Literature of Europe,pt. iii. ch. 4 I 3 .

Probabilists. Those who maintain the theory of Probabilism.

Probability; Calculus of P.; Theory of P. A numerical estimate of our judgment as to the happening of an event. If we reduce all events of the same kind to a certain number of cases, which in the existing state of our knowledge (or ignorance) we judge equally possible, and determine the number of cases favourable to the happening of the event; the ratio of this number to the whole number of possible cases is the probability of the happening of the event. If we throw a die, there are six possible cases, all, as far as we know, equally probable. The proba- bility that either three or four will turn up is therefore $\frac{2}{6}$ or $\frac{1}{3}$; as there are two favourable cases out of six. The rules for calculating P. in various cases, and the investigation of those rules, form the Calculus of probabilities, or the Theory of probabilities.

Probable error. From numerous measures of a given magnitude - all being made under equally favourable circumstances, e.g. by the same observer with the same instrument-a certain number can be calculated in regard to which it can be affirmed that it is an even chance, that the error in any one measure is less than that number, whether in excess or defect. This number is the P. E. of the measures individually; it serves-amongst other things - as a test of the degree of accuracy attained under the circumstances.

Probable life. (Expectation of life.)

Probang. (Med.) A flexible piece of whalebone with rounded end, e.g. of sponge, to force down anything stuck in the gullet.

Probate of a will. In Law, the exhibiting of a will by the executor before the proper court, this court being the High Court of Justice in the Judicature Act, 1873 .

Probeagle. (Porbeagle.)

Problem. (Proposition.)

Pro bŏno publico. [L.] For the public weal.

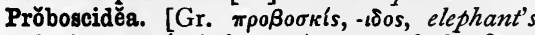
trunk, from $\pi \rho \delta$, before, $\beta b \sigma \kappa \omega, I$ feed, $\in[\delta o s$, kind.] (Zool.) The eighth order of mammals, consisting of the two spec. of elephants.

Process. [L. prōcessus, Cels.] (Anat.) A protuberance, eminence of a bone or of any other part.

Procès verbal. [Fr.] (Leg.) An authentic minute of an official act, or statement of facts.

Proconsul. [L.] In Rom. Hist., an officer with consular command, but without the office, which he may have filled during the previous year. The provinces at first governed by Prætors were afterwards put under proconsuls and proprætors, who entered on their government immediately after the expiration of their office as consuls or prætors.

Procris, Kephălos (Cephalus) and. A wellknown pair in Myth., Procris, whose name signifies the sprinkled dew-drops, being the daughter of Hersē, the dew, and Kephalos, the head of the sun, who unwittingly slew her with his spear; as the sun dries up the dew, which he is said to love.

Prǒcrustes, Bed of. In Gr. Myth., a bed to

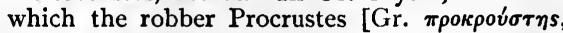
the stretcher] adapted the limbs of his victims by force. Hence an instrument of torture.

Proctors. [L. procurātor.] 1. In the English universities, two Masters of Arts, who serve as the chief magistrates of the university police, and with legislative authority. 2. In Convocation, the representatives of the clergy ; so called as having been entrusted with the assessment of taxes granted by that body. 3. In the Eccl. courts, pleaders who conduct causes for payment.

Procuration. [L. procūratiōnem, a taking care of.] A pecuniary composition from an 
incumbent, instead of the provision due to an ordinary when holding a visitation. (Synodals.)

Procūrātor. [L.] (Hist.) A Roman magistrate, who looked to the revenue of a province, and to suits in connexion with it. Sometimes he also governed the province, as Pontius Pilate governed Judæa; in which case he could inflict the penalty of death.

Procurator, Fiscal. The public prosecutor of the inferior courts of Scotland.

Procureur-Général. Under the Fr. monarchy, the public advocate' of the Crown.

Prodigy. [L. prodĭgium.] Among the Romans, any strange or inexplicable event or phenomenon, all such being regarded as signs of the will of the gods.

Prodŏmus. [Gr. $\pi \rho \delta \delta o \mu o s$.$] (Arch.) The same$ as the Pronaos. (Naos.)

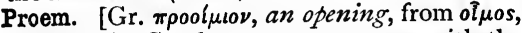
a path.] The Greek term synonymous with the Latin preface.

Pro et contra, Pro et con. [L., for and against.] On both sides.

Prŏfannum vulgus. [L., the common herd (Horace).] Lit. the crowd who stand in front of the temple, and are not admitted within it.

Profile. [Fr. profil, from It. proffilo.] (Fortif.) A section made by a vertical plane at right angles through the direction of the works. When the cutting plane strikes at an oblique angle, it is simply a section.

Pro forma. [L., for form's sake.] Formally.

Profound Doctor. (Doctor.)

Prognathous, Prognathic. (Orthognathic.)

Progresses. [L. progressus, a going forward.] In the O.E. phrase, the State journeys of royal personages.

Progression, Arithmetical; Geometrical P.; Harmonical P. A series of numbers are in Arithmetical progression when each is greater (or less) than the one before it by a constant difference ; as 7, 10, 13, 16, etc. ; in Geometrical $P$. when each is obtained from the one before it by multiplying it by a constant number (or fraction); as 5, 15, 45, 135, etc. ; in Harmonical $P$. when any three consecutive numbers are such that the first has to the third the same ratio as the excess of the first above the second has to that of the second above the third; as $\frac{6}{5}, 1, \frac{6}{4}, \frac{3}{4}$, etc. When strings, in other respects alike, have their lengths in harmonic P., the frequencies of their vibrations-on which the pitches of their tones depend-are in arithmetical $\mathrm{P}$.

Progressive atrophy. Fatty degeneration.

Pro hac vioě. [L., for this turn.] For this time.

Prohibition. [L. prohibytiōnem, a hindering.] (Leg.) A writ to forbid any court from proceeding in a cause then depending, on suggestion that the cause does not properly belong to that court.

Projectile. [L. projectum, sup. of projicio, $I$ cast forth.] (Mil.) Shot or bullet fired from any firearm.

Projection. (Globular projection; Gnomonical projection ; Mercator's projection ; etc.)

Prolate spheroid. (Ellipsoid.)
Prolĕgrmĕna. [Gr., things said before.] 1. A prefatory dissertation prefixed to a work; or 2 , an introductory treatise on a subject to be dealt with at length hereafter.

Prolēpsis. [Gr., an anticipation.] (Rhet.) A figure by which the speaker anticipates objections to his arguments.

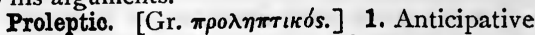
historically; e.g. "the Duke of Wellington, at Assaye," etc., is said proleptically, for he was not then D. of W. 2. In point of thought, and by way of presentiment as opposed to experience.

Proletarians. [L. prōlētārŭus.] (Rom. Hist.) In the constitution ascribed to Servius Tullius, citizens who, being unable to pay for admission into the lowest class, could offer only their children for the service of the state. Hence, generally, the destitute. (Capite censi.)

Prōlöcūtor. [L., not in class. sense of advocate, but =speaker. $]$ The president of the Lower House of Convocation of Canterbury.

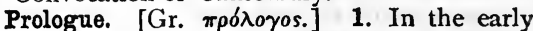
Greek dramatists, all before the first chorus; afterwards, 2, a monologue, or an address to the audience, introductory of the main action of the play. (Epilogue.)

Promethean. Relating to Promētheus, in Gr. Myth., the being who gave men fire, and thus raised them from the lowest depths of misery. For thus aiding them he was chained on the crags of Caucasus, where an eagle gnawed his liver. By the Greeks the word was supposed to

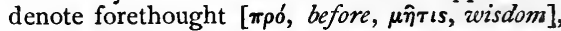
and accordingly they invented Epimetheus, as an embodiment of after-thought. (Pandora's box.) But it only reproduces the Hindu Pramantha, or wooden churn for kindling fire from dried pieces of wood.-Cox, Mythology of the Aryan Nations, 433.

Promēthens. (Promethean.)

Promptuary. [L. promptuārium, from prōmo, $I$ draw, a store from which things may be drawn.] Any summary or handbook in which subjects are arranged so as to be ready for use.

Pronāos. [Gr.] (Arch.) The front porch of a temple. The same as the Narthēx of the early Christians. (Naos.)

Prōnātor muscles. [L. prōno, I bend forward.] (Anat.) Those which turn the palm of the hand downwards; Supinator, upwards [sŭpino, I lay backwards].

Proof. [A.S. profian, to prove.] A trial impression from types, taken for corrections ; called also proof-sheets. Engravers' proofs are the first impressions taken from a plate, as being in spected by the engraver. India proofs are those taken upon India paper. Proofs before letters are those taken before any writing is engraved upon the plate.

Proof spirit. A mixture of pure alcohol and water in the proportion by weight of 100 parts of alcohol to $103^{\circ} 09$ of water.

Propædentics. [Gr. $\pi \rho 0 \pi \alpha \iota \delta \in \dot{\omega}, I$ instruct beforehand.] A word applied in Germany to preliminary instruction in any art or science.

Propaganda. [L.] (Eccl. Hist.) The congregation de propagandā fide, as a missionary society 
in the interests of Latin Christianity, was established at Rome by Gregory XV., in $\mathbf{1 6 2 2}$. The word is often used to denote associations for spreading hurtful opinions.

Propemptřkon. [Gr., from $\pi \rho \pi^{\prime} \epsilon \pi \omega, I$ send forward.] A poem addressed to one about to set out on a journey.

Proper. (Her.) Having its own [Fr. propre] natural colour.

Proper motion. Of the sun or planets, that by which they change their apparent positions relatively to the fixed stars; the sun's P. M. takes place along the ecliptic in the opposite direction to the diurnal motion of the heaven, and in the same direction as that of the earth's actual rotation, viz. from west to east ; a planet's P. M. is direct when in the same direction with, and retrograde when in the opposite direction to, that of the sun.

Properties. In the language of the theatre, = all accessories to scenic illusion; costume, scene-paintings, machinery, etc.

Property. (Log.) A predicable denoting something involved in the essence of the species, as rationality in man.

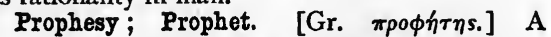
prophet is (I) properly one who speaks for or in the name of another. This is the highest meaning of the word in the Old and New Testaments. "Thou, child, shalt be called the prophet of the Highest." It is also used (2) to denote the foretelling of events still future; and (3) the working of wonders: "After his death his body prophesied;" (4) a state of excitement or ecstasy (I Sam. x.); (5) singing to musical instruments (I Chron. xxv. 3); (6) the exercise of superhuman knowledge (Matt. xxvi. $68)$; (7) the extraordinary gift, so named, in the Acts and in the Epistles of St. Paul.

Prophesyings. Religious exercises of the clergy, temp. Queen Elizabeth, "clerical meetings" in market towns, for exposition [Gr. $\pi \rho 0$ $\phi \eta \tau \in\{a]$ of Scripture, under a moderator; abused, and, under Canon LXXII., restrained.

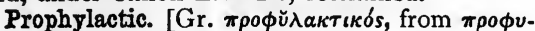
$\lambda \alpha ́ \sigma \sigma \omega, I$ keep guard before.] (Med.) Precautionary, preventative; e.g. belladonna is P. against scarlatina. Subst., Prophylaxis.

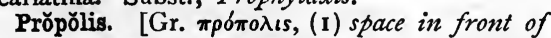
a town, (2) propolis.] Reddish-brown, aromatic, gummy substance, collected from wild poplar and other trees, with which bees close up crevices in their hives and strengthen the margins of the cells of the comb.

Proportion. [L. prōportiōnem.] The relation existing between four magnitudes when the ratio of the first to the second equals that of the third to the fourth; the first and fourth magnitudes are the extreme, the second and third the mean, terms of the P.

Proportional ; P. compasses; Directly P.; Fourth P.; Inversely P.; P. logarithms; Mean P.; Reciprocally P.; Third $\mathbf{P}$. Of two variable magnitudes, the first is Proportional, or Directly $P$., to the second: when any two values of the former have to each other the same ratio as that of the corresponding values of the latter; thus, at a given time and place the length of a man's shadow is proportional to his height, because the ratio of the heights of any two men is the same as that of the lengths of their shadows. They are Inversely or Reciprocally $P$. when the ratio of the first to the second value of the former magnitude equals that of the second to the first value of the latter magnitude ; as in equal triangles the base is reciprocally $P$. to the height. If three magnitudes are given, a Fourth $P$. will be such that the first bears to the second the same ratio that the third bears to the fourth. If three magnitudes are given, the first bears to the second the same ratio that the second bears to the Third $P$. If two magnitudes are given, the first bears to the Mean $P$. the same ratio that the M. P. bears to the second. $P$. compasses are so constructed that lines needsured by them from a plan are transferred to the copy lengthened or shortened in a fixed proportion. $P$. logarithms are logistic logarithms (q.v.).

Proposition. [L. propoš̌to, -nem, a setting forth.] 1. In Log., an indicative sentence, that is, one which affirms or denies, consisting of a Subject and Predicate connected by the Copula. (Syllogism.) 2. (Geom.) The statement of a fact proposed to be proved or of a construction proposed to be made. In the former case the proposition is a theorem; as, "Any two sides of a triangle are greater than the third." In the latter, a problem; as, "On a given straight line to make an equilateral triangle."

Proprætor. [L.] A Roman magistrate standing to the prætor in the relation of the proconsul to the consul. Under the empire, the imperial provinces were under proprætors; those of the senate under proconsuls. (Proconsul.)

Proprement dit. [Fr.] Properly so called.

Proprio mötu. [L., of his (or her) own movement.] Spontaneously.

Propter vitam vīvendi perdĕrĕ causas. [L.] For the sake of life to throw away all inducements to life.

Pro pŭdor. [L.] Shame!

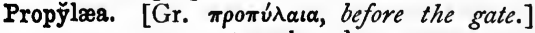
Any entrance to a temple; but, more particularly, the approach to the Acropolis of Athens. The Athenian propylæa were finished in the time of Pericles, B.c. 432.

Pro rătā. [L.] In proportion.

Pro re nātā. [L., according to the case arising ; lit. the thing born.] As need requires.

Pro sălūte ănimm. [L.] For the safety or saving of his soul-a phrase used in Eccl. courts.

Pros and cons. Arguments for [L. pro] and against [contra].

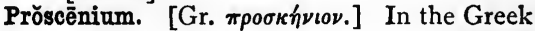
theatre, the whole space between the scêna $[\sigma \kappa \eta \nu \eta]$, i.e. the wall by which the back side of the wall was closed, and the orchestra $(q \cdot v$.$) ;$ what we should call the stage.

Proscription. [L. proscriptiōnem, from pro, before, and scribo, I write.] In Rom. Hist., the setting forth on a list the names of outlawed persons; as the proscription of the triumvirs 
Octavius, Antony, and Lepidus, in which Cicero was killed.

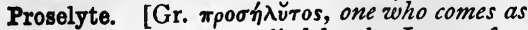
a stranger.] A term applied by the Jews, after they became connected with the Greeks, to foreigners who embraced Judaism. The $P$. of the gate renounced idolatry; the $P$. of righteousness submitted to circumcision.

Proserpine. (Eleusinian Mysteries.)

Proses, Prosæ. [L. prōsa, i.e. oratio, collat. form of prorsa, straightforward, continuous.] In the Roman Church, hymns sung-from latter end of the ninth century-after the Gradual ; called therefore Sequentice also. Riming, but not scanning ; e.g. Stabat Mater.

Prosody. [Gr. $\pi \rho 0 \sigma \omega \delta i^{\prime} a$.] The science which treats of the laws of harmony, accent, and quantity, whether in prose or verse.

Prosopogrăphy. [Gr. $\pi \rho \delta \sigma \omega \pi o \nu, a$ figure,

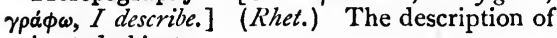
animated objects.

Prosopolepsy. [Gr. $\pi \rho \circ \sigma \omega \pi o \lambda \eta \psi i \alpha$, from $\pi \rho \delta \sigma \omega \pi \nu \nu$, a face or person, and $\lambda \hat{\eta} \psi(s$, a taking.] Respect of persons ; partiality. (Person.)

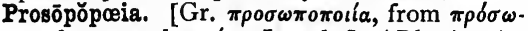

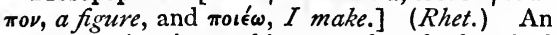
address to inanimate things as though they had life and power of hearing.

Prosphōnēsis. [Gr.] A Bidding prayer (q.v.); frequent examples occur in the ancient Liturgies.

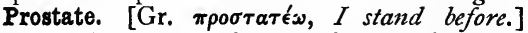
(Anat.) A compact, chestnut-shaped, glandular body, in males, situated just below the neck of the bladder.

Prosthaphæresis. [A word made up of the Gr. $\pi \rho \delta \sigma \theta \epsilon$, in front of, and à $\phi a i p \epsilon \sigma \iota s$, subtraction. (Astron.) A term used by old astronomical writers to signify the difference between the true and mean motion, or the true and mean place of a planet, or the quantity which must be taken from or added to the mean anomaly in order to get the true anomaly.

\section{Prosthěsis. (Metaplasm.)}

Prostyle. [Gr. $\pi \rho \delta \sigma \tau \bar{v} \lambda o s$.$] (Arch.) A temple$ with a row of detached columns supporting the pediment on its front elevation.

Prosyllogism. (Log.) A syllogism essential to the proof of another syllogism. The word is used also in the sense of Enthymeme.

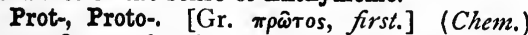
A prefix to chemical names, having the same force as mon-, mono- (q.v.).

\section{Protamœba. (Amœba.)}

Prōtandrous, or (more correctly) Prŏterandrous

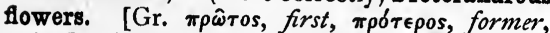
prior.] (Bot.) Those in which the anthers are developed before the pistil. Protogynous, or Proterogynous flowers, those in which the reverse is the case.

Pro tanto. [L., for so much.] So far as something named is concerned.

Protžsis. [Gr., a stretching forth.] In Gram. and Rhet., the hypothetical or limiting clause of a sentence, answered by the apoddosis.

Protected states (in India). Certain native states, as the dominion of the Nizam, etc., which, keeping their independence, subject to certain limitations, are guaranteed by the British Government against external attacks, etc.

Protector. [L., a defender.] (Hist.) This title has been borne by three English statesmen : (I) Richard, Duke of York, I453; (2) Duke of Somerset, 1548 ; (3) Oliver Cromwell, 1653.

Protégé. [Fr.] Lit. one who is protected; hence a favourite of one high in society. Fem., Protégée.

Pro tempŏre. [L.] For the time. In shortened form, pro tem.

\section{Prŏterandrous flowers. (Protandrous.)}

Proterogynous flowers. (Protandrous.)

Protest. (N'aut.) Formal declaration, in writing, properly attested, by the master and others of a ship's crew, to the effect that damage sustained by the ship was not caused by their negligence or misconduct.

Protestants. [L. protestor, I bear zvitness.] (Eccl. Hist.) 1. Properly those who, in 1529 , protested against an edict of the Diet, at Spires, which postponed the settlement of religious differences to the meeting of a General Council at some indefinite time. The $P$. insisted that the General Council should be summoned at once. Hence, 2, generally, those who protest against the doctrines or discipline of the Latin Church.

Prōteus. [Gr.] Any one who easily changes his opinions or his practice is so called, from the Greek sea-god, who had the power of changing his shape at his will, until he had exhausted his powers of transformation.

Prōtēus anguiněus. [Aug. L., snake-like.] Amphibian inhabiting underground pools ; about twelve inches long; nearly white, with scarlet external gills, rudimentary eyes, and four legs. Central Europe. Fam. Prōteïdæ, ord. Ūrŏdēla. (Proteus.)

Prōtēus animalcule. (Amœba.)

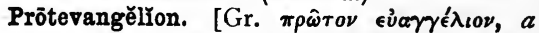
first Gospel.] 1. A Gospel of the birth of the B. V. Mary, and of our Lord, attributed to St. James. (Pseudo-Gospels.) 2. A rudimentary Gospel ; one by anticipation; e.g. in the types of the Old Testament.

Prŏthĕsis. [Gr., a placing before.] In the Eastern Church, the apse of the right aisle, where the Credence table is placed.

Prothonotăry, more properly Protonotăry. [L.L. prōtŏ-nŏtārius, first secretary.] In the Greek Church, the chief secretary of the Patriarch of Constantinople. In the papal court, the college of twelve apostolic notaries register all the solemn acts of the Church.

Proto-. [Gr. $\pi \rho \hat{\omega}$ Tos, first.]

Protocol. [L. protocollum, a word made up

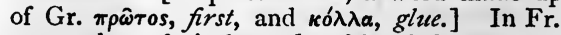
usage, the technical words of legal documents ; in German, the rough draft of an instrument. The latter is the frequent diplomatic sense of the term.

Protogynous flowers. (Protandrous.)

Protonotăry. (Prothonotary.)

Protoplasm. [Gr. $\pi \rho \omega \hat{\tau}$ os, first, $\pi \lambda d \sigma \mu \alpha, a$ thing formed.] The physical basis of life, "in its simplest condition a mere formless slime, but 
differing from dead matter in possessing the qualities of irritability, of spontaneous movement, of assimilation of foreign substances, and of self-multiplication."

Prototype. (Arohetype.)

Prōtōzōa. [Gr. $\pi \rho \hat{\omega} \tau o s$, first, \ஸ̂ov, an animal.] (Zool.) Sub-kingd. of invertebrates, containing the lowest animal organisms, composed of jelly-like sarcode, destitute of definite parts or body-cavity, mostly aquatic, and minute, tlough sometimes forming large colonies, as sponges.

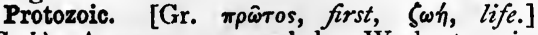
(Geol.) A name proposed by Warburton, in I843, for the Cambrian and Silurian, but not widely adopted.

Protract. [L. prōtrăho, I lengthen out.] (Math.) 1. To draw to scale. 2. To draw an angle with the aid of a protractor $(q . v$.$) .$

Protractor. (Math.) An instrument for drawing angles of any required number of degrees.

Proud flesh. [Cf. Fr. preux, gallant.] Coarse, luxuriant granulations, in wounds, ulcerated surfaces.

Provençal language. The language of the Troubadours, one of the Romance dialects which sprang up on the decline of the literary Latin.

Provençal poetry. (Troubadours; Trouvères.)

Province. [L. provincǐa, an abbrev. form of providentia, meaning originally $a$ duty, or matter entrusted to a person.] In Rom. Hist., a conquered country administered by a Roman officer commissioned for the purpose.

Provinces, Roman. To the time of the battle of Actium (B.C. 3I), the Roman provinces were: Sicily ; Sardinia and Corsica ; hither and further Spain; hither Gaul; Gallia Narbonensis; Illyrium; Macedonia; Achaia; Asia; Cilicia ; Syria; Bithynia and Pontus ; Cyprus ; Africa ; Cyrene and Crete; Numidia ; Mauretania. Some were subsequently added ; and the number was also increased by the subdivision of old provinces.

Pro virili (sc. parte). [L., for his part as a man.] To the utmost.

Provision. [L. prōvīsio, -nem, forethought.] A suspension, by the popes, of the right of patronage of benefices in England, that they might provide for their own foreign nominees.

Provisions of Oxford. (Oxford, Provisions of.)

Proviso. (Naut.) A stern-rope fastened to the shore.

Provisors, Statutes of. (Hist.) Statutes passed in the reigns of Edward I., Edward III., and Richard II., to check the papal claims of presentation to ecclesiastical benefices in England. (Provision.)

Provost. [L. præpǒšrtus, one set over.] 1. In Scotland, a mayor. 2. In some colleges, the head; in some cathedrals, the dean; sometimes also answering to chancellor ; sometimes, before the Reformation, to archdeacon.

Provost-marshal. (Mil.) The officer who is the head of the police of a garrison or camp, having, previous to the Army Discipline and Regulation Act, I879, power of summarily punishing soldiers or camp followers detected in the actual commission of crime ; but now only of arresting and detaining for trial. $\mathrm{He}$ executes punishments awarded by a court-martial.

Prow. [Fr. proue, L. and Gr. prora.] (Naut.) 1. The foremost end of a vessel. 2 The beak of a xebec, or felucca.

Proxĕnos. [Gr.] In Gr. Hist., any citizen of a state who guarded in his own city the interests of citizens of another state. If appointed by the latter, he was called $P$. If he took the charge on himself, he was Ftheld- $P$.

Proxǐmus ardet Ūcălĕgon. [L.] Your nearest neighbour, Ucalegon, is on fire (Virgil), $=$ Look out $!$ danger is coming very close to you. (Tua res agitur.)

Proxy. (Parliament, Privilege of ; Peer.)

Prud'hommes. [L. prudentes homines, prudent men.] In Fr. Hist., citizens chosen to serve in municipal tribunals possessing an equitable or conciliatory jurisdiction.

Prunella. [Dim. from L. pruīna, hoar-frost.] Fused nitre in cakes or balls (because nitre is found as a white incrustation on the ground).

Prunella, Prunello. [Fr. prunelle, a sloe.] A smooth woollen stuff (from its dark colour).

Prunello. [Fr. prunelle, dim. of prune, $a$ plum.] A kind of dried plum.

Prürigo. [L., itching.] A papular affection of the skin, with intense itching; not contagious.

Prussian blue. A pigment consisting of prussic acid combined with iron.

Prussio acid. Hydrocyanic acid (formerly obtained from Prussian blue).

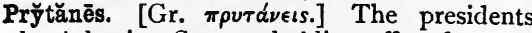
of the Athenian Senate, holding office for onetenth part of the year, the Prytanes being fifty in number, and the whole senate, all the members of which presided in rotation, being 500 .

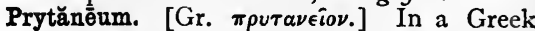
city, the home of the community, where the Prytanes assembled, and where the sacred fire was always kept burning as on the hearths of private houses.

Psalm. In Ps. Ixxxi. 2, a psaltery (q.v.).

Psaltery. [Gr. $\psi \alpha \lambda \tau \eta \operatorname{n\rho }$ ment.] 1. In I Sam. x. 5 and elsewhere, in Heb. nebel, a kind of lyre or harp with ten strings, in the shape of an earthern wine-bottle [nebel]; i.e. somewhat conical; i.g. "psalm" in Ps. lxxxi. 2. 2. The dulcimer, or Sautry, a corr. of $\mathrm{P}$.

Pseudepigraphy. [Gr. $\psi \in v \delta \in \pi i ́ \gamma \rho \alpha \phi o s$, falsely inscribed.] The assigning false names of authors to works.

tive.

Pseudo-. [Gr. $\psi \in u ́ \delta \omega, I$ deceive.] False, decep-

Pseudo-bulb. (Bulb.)

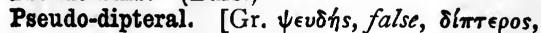
with two wings.] (Arch.) A building with sufficient space between the wall and the columns in front of it for two rows of columns, there being only one.

Pseudo-Gospels. [Gr. $\psi \in v \delta \eta ́ \eta s$, false.] Pretended Gospels of St. Joseph, St. James, St. Paul ; the Epistle of Christ to Abgarus, etc.

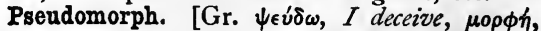
form.] Any mineral that has taken the place 
and shape of another mineral, by the agency of infiltrating water, etc.

Pseudonym. [Gr. $\psi \in v \delta \omega ́ v v \mu o s$, falsely named.] In Lit., a false name assumed by a writer. Those who write under a fanciful name, as the "Letters of Junius," are, properly, anonymous writers.

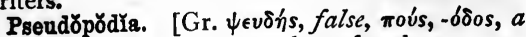
foot.] Extensions of protoplasm for the purpose of grasping or moving about. (Protoplasm.)

Psilanthropists. [Gr. $\psi \iota \lambda \delta s$, mere, a $\alpha \theta \rho \omega \pi o s$, man.] (Eccl. Hist.) Those who hold that Jesus Christ was an ordinary man.

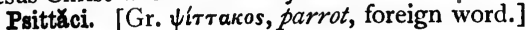
(Ornithology.)

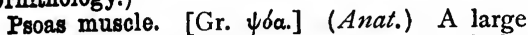
muscle upon the fore part and sides of the lumbar vertebræ.

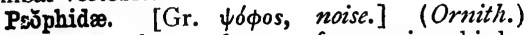
Trumpeters; fam. and gen. of gregarious birds. Amazon valley only. Though able to fly, each spec. appears to have its range defined by a river, as agami (P. crephitans) $q . v$. , by Rio Negro. Ord. Grallæ.

Psōra. (Itch.)

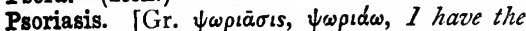
itch.] (Med.) A skin-disease, exhibiting rough, patchy or continuous scales, with chaps and fissures.

Psȳche. [Gr.] This word means strictly the breath; hence the soul. The well-known tale of Psyche and Eros (Amor), related in the Golden Ass of Apuleius, belongs to the class of stories which includes Beauty and the Beast. Psyche is told by her sisters that she is married to a monster. Holding a lamp to see, she finds her husband surpassingly beautiful, but a drop of oil falling on him awakens him, and he vanishes away; nor is she reunited to him until after a very long and painful search.

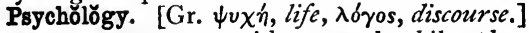
A term synonymous with mental philosophy; but sometimes limited to the classification of the phenomena presented by the lower faculties of the mind. (Association.)

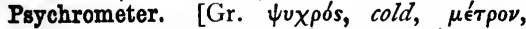
measure.] An instrument for measuring the tension of the aqueous vapour in the atmosphere.

Ptarmic [Gr. $\pi \tau \alpha \rho \mu \kappa \kappa o ́ s, \pi \tau \alpha l \rho \omega, I$ sneeze], or Sternutatory. Causing to sneeze.

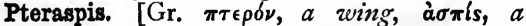
shield.] (Geol.) The oldest known fish, small, with long body-shield, found in the Lower Ludlow strata.

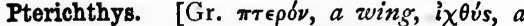
fish.] (Geol.) A fossil fish, with long bodyshield and movable side-spines, found by Hugh Miller in the Old Red Sandstone.

Ptĕro-. [Gr. $\pi \tau \epsilon \rho \delta \nu^{\prime}$ ] With wings, fins.

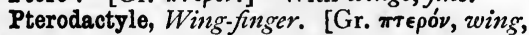

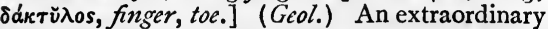
gen. of fossil lizards, with bat-like wings attached to the fifth finger. Lias, Oolite (especially Solenhofen), chalk.

Ptĕrŏmys. [Gr. $\pi \tau \in \rho \delta ́ v$, wing, $\mu \hat{v} s$, mouse.] (Flying squirrel.)

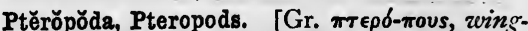
foot.] (Zool.) Class of molluscs, small, with wing-like fins ; some with, some without, shells ; the chief food of the whale. All open seas.

Ptisan, Tisane. (Med.) Any decoction like

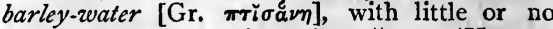
medicinal agent; ptisanārium ŏrȳzæ (Horace, Sat. ii. 3), rice-broth.

Ptolemāic system. The system of astronomy which received its full development at the hands of Claudius Ptolemæus, in the second century of our era, and which regarded the earth as the stationary centre about which the sun and stars performed their revolutions. (Heliocentrio theory.)

Ptyaline. A supposed animal matter found in saliva [Gr. $\pi \tau \tilde{\tau} \tilde{a} \lambda o \nu]$. Ptyalism, salivation.

Pubescent. [I.q. L. pübes, adj.] (Bot.) Covered with soft down.

Publicans. [L. publicanini, from publicum, the treasury of the patricians.] The farmers of the public revenues at Rome. They formed two distinct classes - the farmers-general being men of high rank and importance, while their deputies [portítōres, toll-gatherers, strictly, at a sea-port, portūs] were of an inferior grade and of very doubtful reputation. It is of the latter that the New Testament speaks under the title of tĕlōnai.

Public Safety, Commtttee of. (Fr. Hist.) A body formed (1793) out of the Revolutionary Convention. It came to an end in 1794, on the introduction of the New Constitution. (Assembly.)

Public Weal, War of the. (Fr. Hist.) The contest between the feudal nobles and the Crown, which ended in the defeat of the confederation called the League of the Public Weal, by Louis XI., 1472.

Pnblic Worship Regulation Act, of 37 and 38 Vict. It provides for the appointment of a Judge of the Provincial Court of Canterbury and York, invested with the duties also of the Official Principal of the Arches Court of Canterbury ; to try alleged offences against the laws of public worship: but this Act does not interfere with the Church Discipline Act of 5840.

Puccoon. (Blood-root.)

Pucelle, Ia [Fr.], Pucella, Ia [It.]. The Maid; i.e. of Orleans, Jean Darc.

Puck. (Myth.) The "merry wanderer of the night" (Shakespeare, Midsummer-Night's Dream). The name is traced to the Slav. bog; deity, Eng. bogy; the connexion of which with bug is attested by the expression bug-bear, for any object which scares or terrifies. (Bogy.)

Pudding-stone. (Geol.) A conglomerate of water-worn pebbles, cemented by siliceous, argillaceous, ferruginous, or calcareous paste; $e . g$. Hertfordshire P. has siliceous cement.

Pudding-time. Dinner-time, pudding being formerly the first dish.

Pnddle. Earth prepared as an impervious lining for canals and ponds.

Puddling. 1. The process of melting cast iron in a reverberatory furnace and stirring it to get rid of the carbon in making wrought iron. 
2. Making impervious to water by means of clay.

Puellis idōněus. [L.] A ladies' man (Horace). Puer. Dogs' dung used in preparing skins for tanning.

\section{Puff-birds. (Bucconidæ.)}

Puffin. [Fr.] (Ornith.) Marine rock-bird length about twelve inches; plumage black and white; bill large, with orange stripes. North of tropics. Gen. Frātercŭla, fam. Alcĭdæ, ord. Ansěres.

Puffs. In a horse. (Spavin.)

Puggaree. [Hind.] A white covering for the hat, for the sake of coolness.

Pug-mill. A mill for grinding and mixing clay (called pugging).

Puisne Judge. [Fr. puiné, O.Fr. puisné, L. protnātus, born after, younger, hence inferior. A term applied to the judges who are not Chief Justices or Chief Barons.

Pull-away boys. I.q. kroomen (q.v.).

Pulley. A wheel capable of turning round an axle which may have a fixed or movable bearing; the rim of the wheel is properly shaped to carry a rope or band by which force may be transmitted. When two or more pulleys are combined, they form a system of pulleys.

Pull foot, To. (Naut.) To run, to hurry.

Pulmonary. [L. pulmo, pulmōnis, a lung.] Relating to the lungs.

Pulping. Removing the pulp, or aril, from coffee berries.

Pulpitum. [L.] In the Greek theatre, where

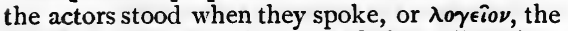
speaking-place, was the part of the próscēnium nearest the orchestra.

Pulque. [Sp.] A kind of wine made from the American aloe in Mexico.

Pulses. [L. pulsus, a pushing, a beating of the pulse.] Undulations, or vibrations (q.v.).

Pultaceous. Like pap [L. pultem] in consistency.

Pulteney guinea, The. (Nil conscire sibi.)

Pulu. (Native name.) A kind of cotton from the Sandwich Islands.

Pulverulent. [L. pulvěrŭlentus, covered with dust (pulvis).] (Bot.) Having a powdery appearance; e.g. the mullein Verbascum pulverulentum.

Pulvinated. [L. pulvinar, a pillow.] (Arch.) A term denoting a swelling in any part of an Order, as that of the frieze in the modern Ionic.

Pulwar. (Naut.) Ganges passage-boat.

Pumice-stone. [L. pūmex, pümǐcis.] (Geol.) A felspathic lava, light, grey, rough, fibrous, spongy from the action of the escaping steam ; chemically agreeing with obsidian (q.v.).

Pummice. (Pommage.)

Pump. (Chain-pump; Forcing-pump; Suction, etc.)

Pumpernickel. [Ger.] Westphalian branbread (so called in contempt).

Punch. A small, powerful cart-horse, for which Suffolk was once noted; now superseded by larger breed, sometimes called, incorrectly, by the same name.

Panch. [L. pungo, I puncture.] A steel implement for stamping or cutting out holes in metal.

Punch and Judy. A popular puppet-show. The common notion, that it is so called from Pontius (Pilate) and Judas (Iscariot), is rejected by Mr. Skeat, who traces Punch, as a shortened form of Punchinello, to the L. pullus, the young of anything ; Judy coming, as he supposes, from Judith, once a common female name.

Puncheon. A measure of capacity; 84 gallons $=$ one puncheon of wine.

Pundit. (Pandits.)

Pundum. Piny varnish (q.v.).

Punică fides. [L.] The faith of Carthaginians, who were supposed to be systematically false, as were the Athenians; hence also

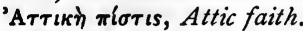

Punic language. The language of the Carthaginians, differing little from the Hebrew.

Punio Wars. The wars between Rome and Carthage, beginning B.C. 264, and ending with the destruction of Carthage, 147. The Second Punic War (B.C. 218-202) is also known as the Hannibalian War.

Punkah. [Hind. pankhâ, a fan.] A large fan worked by a cord.

Punt. [A.S.] (Naut.) Flat-bottomed boat propelled by puoys, or quants, i.e. long poles with a triangular block near the bottom, to prevent their sinking in the mud; or by halers, or spreaders, with a splayed iron fork at the foot.

Puny Judge. (Puisne Judge.)

Puoy. (Punt.)

Pūpa. [L., a doll.] (Entom.) 1. The last stage but one of an insect; sometimes called Aurèlia or Chrysălis when quiescent, and Nympha when active. 2. Gen. of land-snails; so named from shape of shell. Pulmoniferous molluscs, fam. Hělìcǐdæ.

Pūpìpăra. [L. püpa, a pupa, părio, I bring forth.] (Entom.) Applied to insects which do not produce their young till advanced to the pūpa stage ; as the forest fly.

Pūpǐvŏra. [L. pūpa, a pupa, vŏro, I devour.] (Entom.) Tribe of hymenopterous insects whose larvæ are parasitic within the larvæ and pūpæ of other insects ; as the ichneumons.

Purāna. [Skt., a poem.] The Hindu sacred books, containing the explanation of the Shaster. They belong probably to the earlier centuries of the Christian era.

Purbeck marble. (Geol.) A beautiful building. stone formed of Palüdinæ, from the P. beds, i.e. well developed in the Isle of P. ; a group of freshwater strata, usually referred to the Upper Oolite, but by some to the Neocomian rocks (q.v.).

\section{Purcellaine. (Purslane.)}

Purchase. [Fr. pourchasser, to pursue eagerly, to chase, i.e. L. captiare.] In New Testament, to acquire [Gr. $\kappa \tau \hat{\alpha} \sigma \theta \alpha \iota, \pi \in \rho เ \pi 0 \iota \epsilon \hat{\sigma} \theta \alpha t]$; never to buy.

Purfling. [O.Fr. pourfiler.] Decorating with a wrought or flowered border.

Purgatory. [L. purgātōrius, purifying.] In the theology of the Latin Church, a place for the infliction of temporal punishment for sins on those who die in the grace of God. 
Puriform. (Med.) In the form of pus [L. pus, pūris].

Purim. [Heb., lots.] A movable feast of the Jews, commemorating their deliverance from the wiles and stratagems of Haman, as recorded in the Book of Esther (ix. 24), he "had cast Pur, that is, the lot, ... to destroy them."

Purism. Affectation of purity, especially in writing.

Puritans. In Eng. Hist., a name generally applied to dissenters from the Church of England, in the reigns of Elizabeth, James I., and Charles I. (Cathari.)

Purl. [Contracted from Eng. purple.] 1. An inversion of stitches in knitting, giving a ribbed appearance. 2. A kind of hot spiced beer.

Purlieu. [Fr. pur, pure, lieu, place.] 1. The ground near a royal palace, made pure or free from the forest laws. 2. The outer portion, or environs, of any place.

Purlin. [Of uncertain origin.] (Arch.) A horizontal timber lying on the principal rafters of a roof, to lessen the strain on the common rafters.

Purple of Cassins. (Cassing, Purple of.)

Purple wood. A Brazilian wood, chiefly used for ramrods and decorative veneering.

Purpure. [L. pürpŭra.] (Her.) The purple colour in coats of arms, represented in engraving by lines sloping downward from the sinister to the dexter side.

Purree. (Indian red.)

Purser (Naut.), now Paymaster. The officer having charge of provisions, etc., on board ship, having little to do with money matters. $l$ '.'s dip, the smallest dip candle. P.'s grins, sneers. P.'s name, assumed name. $P$.'s pound, seven-eighths of imperial pound.

Purslane, Purcellaine. A succulent annual, Portulaca ŏlěrācea ; a pot-herb, once used in soups and salads, now neglected.

Pursuer. In Scotland, the plaintiff; so exactly the Gr. $\delta \delta \iota \omega \kappa \omega \nu$.

Pursuivants. (College of Heralds.)

Purtenance. Exod. xii. 9; inner parts, entrails.

Purveyance. [Fr. pourvoir, L. provǐdēe, to provide.] A former privilege of the English kings, which enabled the officers of the royal household to take corn and cattle for the use of the sovereign, and to employ beasts of burden in his service. Payments were made in tallies on the exchequer, and were precarious and often long in arrear. The burdens of the system were thus felt to be very heavy. (Pre-emption.)

Pus. [L.] (Med.) Thick yellow fluid, product of inflammation resulting in suppuration.

Push. In popular language, small boil ; $c f$. pus (?).

Pustule. [L. pustŭla, from pus.] (Med.)

Pimple, small boil, pock.

Put and call. (Puts.)

Putchuck. A root from Scinde, used in China for incense.

Putlog. In building, the holes left in walls for the use of workmen in raising scaffolding, the logs or beams of the scaffold being put or laid in them.
Puts. When stocks are thought to be going down, and a small operation without much risk is desired, a small sum is given for the privilege of delivering a small amount of stock at a certain price ; e.g. cash price of Erie being 57 per cent., a speculator would give fifty dollars to "put," or deliver, 100 shares at $56 \frac{1}{2}$ say in ten days. He can only lose his fifty dollars if the market should go up, but if it goes down to 56 , he gets his money back, and all that is below is so much profit.-Bartlett's Americanisms.

Putty. [Fr. potée.] A mixture of linseed oil and whitening. Putty pozvder is burnt dioxide of tin, used for polishing metals and glass.

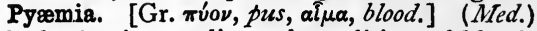
Blood-poisoning, a diseased condition of blood, supposed to be owing to the absorption of pus, or other septic fluid.

Pye. (Pie.)

Pygarg. [Gr. $\pi \dot{\gamma} \gamma$-apyos, white-rump, Heb. dîshôn (Deut. xiv. 5), the leaper.] (Bibl.) Probably addax, a large antelope with twisted horns. Sub-fam. Ory̆gĭnæ, fam. Bǒvĭdæ.

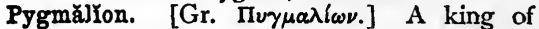
Cyprus, who, falling in love with an ivory statue which he had made, prayed to Aphrodite to endow it with life. Aphrodite did so, and the vivified statue became his wife.

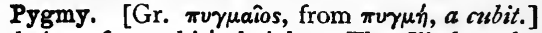
A being of a cubit's height. The Iliad speaks of a race of pygmies perpetually at war with cranes. Some supposed them to live in Ethiopia ; others in India. The Dwergar, ordwarfs, of the Northmen, were probably Esquimaux.

Pykar. (Naut.) A small vessel, temp. Edward III.

Pyke, To. (Naut.) To haul on a wind. To $P$. off, to go away noiselessly.

Pylădes and Orestes. A pair of inseparable friends. Orestes was the son of Agamemnon and of Clytemnestra, whom, by the help of Pylades, he murdered.

Pylagǒras. [Gr.; so called from the gathering of the Amphictyons at Pylæ or Thermǒpy̆læ.] The second of the two deputies sent by each Greek city of the confederacy to the Amphictyonio Council, the other being the Hiěromnemon

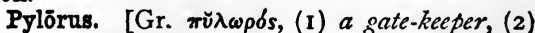
pylorus.] (Anat.) The small end of the stomach, or opening into the duodēnum, which entrance it as it were guards.

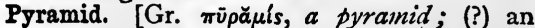
Egypt. word.] A solid whose base is a rectilineal figure, and whose sides are triangles having a common vertex.

Pyramidal system. (Crystallog.) Consists of those crystals which have three rectangular axes, and two of their three parameters equal; as ido. crase, copper pyrites, etc. When transparent, they are optically uniaxal.

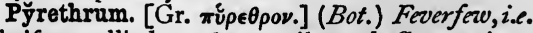
febrifuge, allied to chamomile, ord. Compositæ; a gen. of perennial plants. In waste places of Britain, and many other parts of Europe.

Pyretics. (Med.) Medicines for the cure of

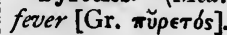


Pyrětolŏgy. (Med.) The theory of fever [Gr.

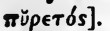

Pyrheliometer. [Gr. $\pi \hat{v} \rho$, fire, $\eta \lambda_{i o s}$, the sun,

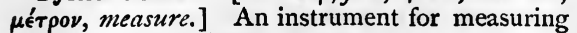
the sun's radiant heat.

\section{Pyriphlěgěthōn. (Phlegethon.)}

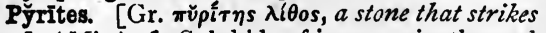
fire.] (Min.) 1. Sulphide of iron, anciently used for strike-a-lights; now, $2,=a$ group of minerals, compounds of metals (iron, copper) with sulphur, which in decomposing give out considerable heat.

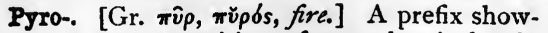
ing that the composition of any chemical substance has been altered by heat.

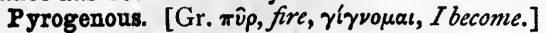
(Geol.) I.q. igneous.

Pyroligneous acid. [Gr. $\pi \hat{v} \rho$, fire, L. lignum, wood.] Impure acetic acid obtained by the dry distillation of wood.

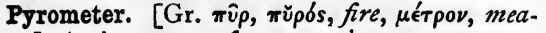
sure.] An instrument for measuring temperatures above the range of a mercurial thermometer.

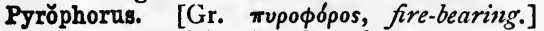
Any substance which takes fire when exposed to the air.

Pyrosoope. [Gr. $\pi \hat{v} \rho$, fire, $\sigma \kappa o \pi \epsilon ́ \omega, I$ view.] An instrument for measuring the intensity of radiant heat.

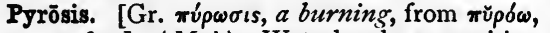
$I$ set on fire.] (Med.) Waterbrash, a vomiting of a thin, watery liquid.

Pyrotechnics. [From Gr. $\pi \hat{v} \rho, \pi \check{v} \rho \delta s$, fire, and

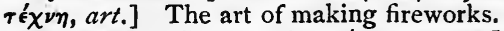

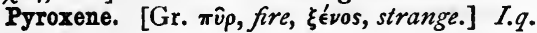
augite (a.v.).

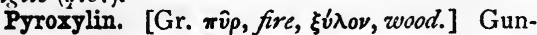
cotton.

Pyrrhic dance. A warlike dance, said to have been invented by Pyrrhus (Neoptŏlěmos), for the funeral games of his father Achilles.

Pyrrhic foot. (Pros.) One of two short syllables used in the P. war-song; e.g. dŭcě.

Pyrrhio victory. Pyrrhus, King of Epirus
(Epeiros), is said to have exclaimed after the battle of Ascalum, "Another such victory, and we are lost." The story is worthless ; but the phrase has come to denote successes obtained at too great a cost.

Pyrrhornists. (Hist.) The followers of Pyrrhon, a philosopher of Elis, and disciple of Anaxarchus, in the fourth century B.c. ; noted for his singular scepticism.

Pyro-electricity. [Gr. $\pi \hat{v} \rho$, fire, and electricity.] Electricity developed by heat.

Pythagoreans. (Hist.) The followers of the Samian Pythagoras, called the first of the Greek philosophers. His lifetime is uncertain. He is said to have resolved all philosophy into the relations of numbers, God being the original unity; and to have drawn up a table of opposites [Gr.

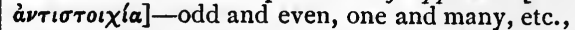
which points to a system of dualism. (Ahriman; Metempsychosis.)

Pythagorean system. (Astron.) A name sometimes given to the true or Copernican system of the heavens, though it is not in any degree probable that Pythagoras taught that the earth revolves round the sun, or that it rotates on its own axis.

Pythria. [Gr.] The priestess of the Delphian oracle of Apollo.

Pythian games. (Hist.) The great Greek festival, held in every fifth year at Delphi.

Python. [Gr.] 1. (Myth.) A dragon slain at Delphi by Apollo, and said to have been left to rot [Gr. $\pi \dot{u} \theta \epsilon \iota \nu, \mathrm{L}$. putēre], in order to explain the name, which reappears in that of the serpent Fafnir, the dragon of the Glistering Heath, in the Volsunga Saga. (Sagas.) 2. (Zool.) Gen. of large snake with rudimentary hind legs, giving its name to fam. Pȳthōnĭdæ; not venomous, killing prey by constriction. India, Borneo, and adjacent islands.

Pyx. [Gr. $\pi \dot{v} \xi \iota s, a b o x$.$] 1. In the Latin$ Church, a vessel in which the host is kept. 2. A box for holding a sample coin to be assayed before issue.
Q. As an abbrev., stands for $\mathbf{L}$. quintus ; it also denotes question, Qy. query; Q.E.D. stands for the Latin words, Quod erat demonstrandum, which was to be shown, as in the propositions of Euclid. (Qnirites.)

Q.A.B., Queen Anne's Bounty. The produce of the firstfruits and tenths due to the Crown, made over by Queen Anne to the Bounty Board (q.v.), for augmentation of poor livings.

Quad. In Oxford and elsewhere, a colloquial term for the quadrangles in colleges, etc.

Quade. (Naut.) Unsteady, shifty; as Quade wind.

Quadragesima. [L., fortieth.] The Lenten season, as consisting of about forty days; hence Fr. carême.
Quadrant. [L. quädrantem, $a$ fourth part.] (Math.) 1. A fourth part of a circle. 2. An instrument not differing materially from a sextant.

Quadrant, Mural. (Math.) An ancient astronomical instrument, superseded by the mural circle.

Quadrantal triangle. (Math.) A spherical triangle, one of whose sides is a quadrant.

Quadrat. [Fr., from L. quadrātus, squared.] In Printing, a piece of type-metal cast lower than the types, so as to leave a blank in printing. (Quads.)

Quadrate. [L. quadrātus, squared.] (Her.) Square. A cross-quadrate is a cross having a small square described in each of its angles, so 
that it looks as if its centre were covered by a square.

Quadratic equation. One in which the highest power of the unknown quantity is its square; as, $x^{2}+17 x-60=0$.

Quadrature. [L. quădratūra, a squaring.] 1. (Geom.) The process of finding a square whose area equals that of a figure bounded wholly or partly by a curved line; as the quadrature of the circle. 2. (Astron.) The moon is in quadrature when her longitude differs from that of the sun by $90^{\circ}$.

Quadrifid. [L. quadrĭfidus, four-cloven.] (Bot.) Divided half-way from the margin to the base into four clefts, as a Q. pcrianth ; or into four segments, as a $Q$. leaf.

Quadrĭlatěral. [L. quadrǔlătěrus, of four sides.] 1. A name applied to countries forming a sort of square, guarded by four fortresses, as the Q. of Peschiera, Verona, Legnano, and Mantua. 2. (Geom.) A plane figure bounded by four straight lines. If no two sides are parallel, it is a Trapezium; if it has only one pair of sides parallel, it is a Trapezoid; if it has two pairs of parallel sides, a Parallelogram, which is a rectangle or oblong when its angles are right angles, and a square if the four sides are equal and the angles right angles; if the four sides are equal but the angles not right angles, it is a Rhombus. (Rhomboid.)

Quadrireme. [L. quadrĭrēmis, from quātuor, and remus, an oar.] In ancient Hist., a warship, with four banks of oars. (Quinquereme; Trireme.)

Quadrivial, [Cf. quadrivium.] Having four ways meeting in a point.

Quadrivium. [L.] (Schol.) The four lesser arts--arithmetic, astronomy, music, geometry. - Hallam, Lit. Hist., pt. i. ch. i. § 3. (Trivium.)

Quadroon. [L. quātuor, four, through $\mathrm{Fr}$. quarteron, quateron, Sp. cuarteron.] The offspring of a white and a mulatto, i.e. one having one black grandparent, or one-fourth black blood. (Mulatto.)

Quādrŭmăna. [L. quātuor, four, mănus, hand.] (Zool.) Four-handed, as apes; the opposable thumb is sometimes wanting to the fore limbs.

Quadruple Alliance. (Triple Alliance.)

Quads and Spaces. In Printing, type-metal cast lower than types, and used as blanks, for filling out lines, and to place between words, viz. en, em, two-em, ... three-em quads ; and | hair, I five-to-em, I four-to-em, and [ three-to-em spaces. (Em; Quadrat.)

Quæ căret öra cruōre nostro? [L.] What country is without our blood? (Where have we not bled and suffered ?).

Quæ cum ita sint. [L.] This being so.

Quæstor. [L.] In ancient Rome, officers of two kinds : (I) Q. classici, collectors of revenue ; (2) Q. parricidii, public accusers in criminal cases. Quail-land. (Ortygian shore.)

Quaker. In Naut. slang, a sham gun.

Quakers, or Friends. The followers of George Fox, who, in the seventeenth century, asserted that the operation of religion on the heart was independent of all ritual observances; and who therefore reject sacraments, and have no order of ministers. They have also persistently refused to take oaths in courts of justice.

Quālis rex, tālis grex. [L., as is the king, such are his people.]' Like master, like man.

Qualitative analysis. [L. qualitas, quality.] (Analysis.)

Quality. [L. quālritas, from qualis, of what sort.] (Log.) The character of a Proposition, as affirmative or negative.

Quality of a musical note. Its peculiar character, depending on the harmonics which coexist with the fundamental tone, and their relative intensities.

Quamdiu se běně gessěrit. [L.] So long as he shall behave well; applied to those who hold office during good conduct.

Quandoque bŏnus dormitat Homērus. (Aliquando bonus.)

Quant. [(?) L. contus, a pole.]. (Naut.) 1. A punting-pole. (Punt.) 2. A small piece of board at the foot of a leaping-pole. 3. A long pole used for pushing a barge along.

Quantitative analysis. [L. quantitas, quantity.] (Analysis.)

Quantity. [L. quantítas, from quantus, how great.] (Log.) The character of a proposition according to the extent to which the predicate is affirmed or denied of the subject. If it be extended to the whole subject, the proposition is universal; otherwise it is particular. (Prosody.)

Quantity of heat. (Thermal unit.)

Quantity of matter. Mass (q.v.).

Quantity of motion. Momentum (q.v.).

Quantum mutatus ab illo! [L.] How changed from his old self! (Virgil); said of Hector after his death.

Quantum sufficit. [L., as much as suffices.] In sufficient quantity.

Quantum valeat. [L.] For zohat it may be worth.

Quaquaversal strata (Geol.) = dipping on aii sides [L. quâquâ, wheresoever, versus, adv., towards]; now termed Periclinal (q.v.).

Quarantine. [It. quaranto, forty.] 1. In Law, the forty days during which a widow is by Magna Charta entitled to remain in her husband's chief messuage after his death, for the resignment of her dower. 2. (Naut.) The time, now variable, during which a vessel arriving from an infected port is not allowed to communicate with the shore. (Truce of God.)

Quärē impědit? [L., wherefore does - hin. der?] The ordinary action in Law, to establish a patron's disputed right to present to a benefice.

Quarles's emblems. A set of designs illustrating verses by Francis Quarles (I 592-1644). The plates and plan of the work seem to have been borrowed from the "Pia Desideria" of Hermann Hugo, a Jesuit of Brussels.

Qnarrel. [L.L. quadrellus, Fr. carreau.] In mediæval warfare, the arrow or bolt for the cross-bow ; so called from its four-sided head.

Quarrel, Quarry. [Fr. carré, L. quadrātus, square.] 1. A diamond-shaped pane of glass. 2. A glazier's diamond 
Quartan. [L. quartānus.] (Med.) Occurring every fourth day; quartānă, sc. febris, fever of which the paroxysms occur every fourth day; tertian [tertiana], every third day; so quintan [quintāna], every fifth day.

Quartation. [Fr., from L. quartus, fourth.] (Chem.) Making an alloy of three parts of silver and one of gold, and then dissolving the silver by nitric acid, so that the remaining fourth is pure gold.

Quarter. 1. (Arith.) Twenty-eight pounds avoirdupois are a Q., viz. of a hundredweight. 2. Sixty-four gallons, or eight bushels, are a Q., viz. of a ton of grain. 3. (Astron.) A Q. is a fourth part of the moon's monthly course; as when she is in her third $Q$.

Quarter. 1. (Mil.) (I) To quarter troops is to give them billets on the inhabitants of a town; (2) officers' barracks are called quarters ; (3) to give $Q$. , to spare the life of a conquered enemy [(?) as being = to keep within bounds ; or (?) Q. as = friendliness. De Brieux says Q. is portion of pay, promised as ransom]. 2 . (Naut.) From $45^{\circ}$ abaft the beam to the stern. Q.-boat, one hung over the quarter. Q.-deck. (Decks.) Q.-galley, a Barbary cruiser. Q.master, petty officer, whose duty it is to assist the master and mates in their duties.

Quarter-guard. (Mil.) One posted in front of each encamped regiment.

Quartering arms. (Her.) The arranging of various coats of arms in squares or quarters on one escutcheon, so as to show the alliances of one family with the heiresses of others. Each of these squares is called a quartering.

Quartermaster. (Mil.) An officer in the army who has charge of the barracks and stores, and the issue of clothing, fuel, food, and ammunition.

Quartermaster-general. (Mil.) Staff officer in charge of the marching, embarkation, and quartering of troops; together with all matters relating to military science and topography.

Quarter-pierced, Cross. (Her.) A cross from which the middle has been removed, so as to leave a square hole.

Quarter-staff. Old weapon about the height of a man, consisting of a tough thick stick, which was held by the centre.

Quarter-tones. (Music.) A word often used loosely for any interval less than a semi-tone.

Quarto. [L. quartus, fourth.] A book composed of sheets folded so as to make four leaves.

Quartǒděcìmans. [L. quartus decimus, fourteenth.] In Eccl. Hist., those who celebrated Easter on the fourteenth day of the Paschal moon, instead of on the Sunday following. This was the practice of the Eastern Christians.

Quartz. [Ger, term.] (Geol.) A crystallized variety of silica (q.v.); clear, transparent $Q$. is rock-crystal; purple, amethyst; brown, cairnsorm. Common in veins and nests in many metamorphic rocks.

Quartzite. (Geol.) A granular variety of quartz; sandstones altered by pressure and heat assume the aspect of quartz; usually metamorphic.
Quăsi. [L.] As though, as it were; as in the phrase, Quăsi in lŏco parentis, as it were in the place of a parent.

Quasimódo. [L.] In the calendar of the Roman Church, the First Sunday after Easter ; so called from the first words of the Introit. It is also known as Dominica in Albis, as, then, those who had been baptized on Easter Sunday deposited their white robes in the sacristy.

Quass. [Russ. kwass.] A thin sour beer made with rye or barley meal.

Quassia chips. A bitter extensively used in Europe ; the wood of Q. excelsa, a tree of Trop. America ; its medicinal virtues first made known by a negro, "Quassy."

Quaternary. [L. quaternārius, i.e. nŭměrus, the number 4.] (Geol.) Post-Tertiary, all above the Tertiaries.

Qnaternion. [L. quaterniōnem, from quaterni, sets of four.] A group of four words, phrases, or the like. (Triads.)

Quatrain. [It. quattrino.] A stanza of four verses, the rime being usually alternate; but sometimes the first and fourth, and the second and third, rime together.

Quatrefoil. [L. quatŭor, and follum, a leaf.] (Arch.) In tracery, a figure with four cusps. Also, as an ornament, a conventional flower with four leaves.

Quattro occhi, A. [It.] Of two persons only ; said of a dinner, conversation, etc. ; lit. with four eyes. A tête-à-tête.

Quătuor mărĭa. [L.] The four seas; i.e. those around Great Britain.

Queche. (Naut.) Small Portuguese smack.

Queen Anne's Bounty. (Q.A.B.)

Queen-post. (Arch.) A suspending post in a trussed roof, resting on the tie-beam, and supporting the principal rafters.

Queen's counsel. (Leg.) The standing counsel of the Crown. As the Crown is the nominal prosecutor in criminal proceedings, barristers who have received the appointment of Queen's counsel cannot appear in any cause against the Crown, or defend a prisoner without a licence.

Queen's messenger. Generally an officer retired from the army or navy, entrusted with the conveyance and delivery of State documents.

Queen's metal. (Chem.) An alloy of nine parts of tin and one part of antimony, of bismuth, and of lead.

Queen's ware. An improved cream ware made by Wedgwood, in 1759; named after Queen Charlotte.

Queen's yellow. A sulphate of mercury, used as a pigment.

Quem Deus vult perděre prius dementat [L.] Whom the god wishes to ruin he first maddens; a phrase applied to cases of what is called judicial madness.

Quem $\mathrm{Di}$ diligunt adolescens moritur. [L.] He whom the gods love dies young (Plautus).

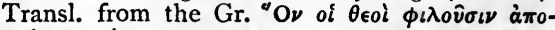

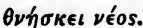

Quercitron. [Fr., from L. quercus, oak, citrus, citron tree.] The bark of the black oak, used in tanning and in dyeing yellow. 
Quern. [A.S. cweorn, akin to corn, grain, etc.] A machine for grinding. Frodi's quern (Myth.) is the inexhaustible source of wealth, producing meal without being replenished.

Que savons nous. [Fr.] As far as we knowe.

Question. [L. questionem, an inquiring or search.] The judicial term for the application of torture to prisoners.

Question, Begging the. (Petitio principii.) the.)

Question, Previous. (Previous question, Moving

Questmen. [Quest, i.e. inquiry.] Formerly assistants to the churchwardens; anciently summoned by the bishop as "Synod's-men," corr. into sidesmen, to give information as to parishes and clergy.

Quǐa emptōres. [L.] The statute 18 Edward I., which forbade Subinfeudation; so named from the words with which it begins.

Quick. In the Bible, always = living [A.S. cwic]; so a quick hedge, i.e. growing, as distinct from palings; cut to the quick, quicksilver.

Quicken, To. (Naut.) To give a greater curve in building a ship.

Quicken tree. (Rowan.)

Quick fence. (Quick.)

Quicklime. [Eng. quick, living.] (Chem.) Oxide of calcium, a caustic substance obtained by burning limestone.

Quicksand. Moving, unsolid sand, mixed with water, and such as will not support the weight of a man attempting to pass over it.

Quickwork. (Naut.) 1. The immersed part of a loaded ship. 2. (Spirkitting.)

Quicquid ăgunt hŏmines . . nostri est farrägo libelli. [L.] Men's doings, all of them, make up the medley of my little book.

Quicquid plantātur sǒlo, sǒlo cedit.

In Law : whaterier is annexed to the soil, goes with the soil; upon this the law of fixtures is founded. (Ruta cæsa.)

Quiddity. [L. quidditas, from quid, what.] That which answers to the question, What is this ?-the essence of a thing.

Quid lēges, siñe mörǐbus Vānæ, proficiunt? [L.] What good can lazus alone effect, which without morals are uscless? (Horace).

Quid non mortālǐa pectǒra cöğ̌s, Auri sacra

fames? [L.] To what crimes cannot the cursed hunger for gold drive men? (Virgil).

Quidnunc. [L., what noze?] A collector of news, a gossip, or tattler.

Quidquid delīrant rëges, plectuntur Achivi. [L.] Kings go astray, and their subjects pay the penalty (Horace).

Quiēta non movēre. [L.] Make no stir when things are still.

Quietists. (Mystics.)

Qui facit per alium facit per se. [L., he who acts through another acts himself.] A man cannot free himself from guilt by using another as his agent; a man is responsible for his servant's negligence.

Quignon's Breviary. (Breviary of Quignon.)

Qui labörat örat. [L., he who labours prays.] Work is worship.

Quill. [Ger. kiel.] A piece of reed on which is wound the thread that forms the woof of cloth.

Quilling. A narrow border of lace, etc., folded like a row of quills.

Quinate. (Palmate leaf.)

Quincunx. [L.] 1. Properly, any five objects which occupy the corners of a square and the point of intersection of the diagonals. 2. The arrangement of troops, or other objects, in a triangular figure of five divisions on each side.

Quinděcemvirir. [L., fifteen men.] (Hist.) Roman magistrates, charged with the care of the Sibylline books (q.v.).

Quinoa of Peru. A goosefoot, q.v. (Chēnopodium Quinoa); ripening at a height of nearly 13,000 feet ; the great article of agriculture in $\mathrm{S}$. Peru; yielding abundant seeds of the size of millet, used much as rice is used in India ; and from which an agreeable beer is obtained.

Quinquagĕsìma. [L., fiftieth.] In the Eccl. calendar, the Seventh Sunday before Easter; so called as falling about fifty days before it.

Quinquarticular Controvorsy. (Eccl. Hist.) That between Arminians and Calvinists upon the five points [L. quinque artículli] of : ( $\mathrm{I}$ ) Particular election; (2) particular redemption; (3) moral inability in a fallen state ; (4) irresistible grace ; (5) final perseverance of the saints. Quinquennālia. [L.] Games or festivals celebrated every five years [quinque anni].

Quinquĕreme. [L. quinquĕrềmis.] Roman war-ships, with five banks of oars. (Quadrireme ; Trireme.)

Quinquertium. (Pentathlon.)

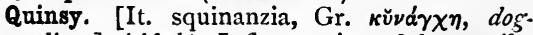
throttling.] (Med.) Inflammation of the tonsils. Quinta. [Sp.] A country-seat, villa.

Quintain. 1. A wooden post set up for military exercises, sometimes turning on a pivot. 2. An O.E. game. A board, hanging like a signboard, is tilted at by a rider, who has to strike it before a balancing weight, hanging opposite to the board, has time to swing round and strike him.

Quintal. [Fr. quintal, Ar. quintâr, $a$ hunn. dredweight.] One hundred kilogrammes, nearly equal to two hundredweights.

Quintan. (Quartan.)

Quintessence. [L. quinta essentia.] The fifth essence, requiring five processes for extraction; the extremest possible concentration; a term of the old chemists, or rather alchemists.

Quinzaine. The fourteenth day after a feast. (Octave.)

Qui pro quo, or Quid pro quo. [L.] A phrase used by the French to denote the error of mis. taking one thing for another; in England, usually to signify an equivalent.

Quire. [Fr. cahier, copy-book.] Twenty-four sheets of paper.

Quiritēs. A people whose name is joined with that of the Romans in the phrase P.R.Q. popŭlus Romānus Quirites. They may have belonged to a town called Cures or Quirium; but the fact cannot be proved. Some trace the name to the word curis, a spear.

Quis custodiet ipsos custodes. [L.] Who shall guard the keepers thamselves? (Juvenal). 
Quis expědivit psittăco suum $\chi \alpha \hat{\imath} \rho \in$ ? [L.] Who got out of the parrot that "How d"ye do?" of his? the answer being hunger; which makes poets also sing (Persius, Prologue to Sat.).

Quisque suos pătímur mānes. [L.] We suffer, every one of us, our lower-world punishments.

Quis tulĕrit Gracchos de sedítǐone quěrentes. [L.] Who can put up with complaints about sedition from the Gracchi? (these being supposed to be notoriously seditious themselves).

Qui tam action. In Law, a popular action, in which one part of the penalty recovered is given to the king, the poor, or to some public use; brought by one, qui tam pro domino rege, quam pro se ipso ... sequitur, who sues as well for the king as for himself.

Quit-rent. A small rent payable by tenants of old manors, by which they go quiet [O.Fr. quite, discharged, free, L. quiētum]. foot.

Quittor. In a horse, chronic abscess of the

Qui vive? [Fr., lit. who lives? i.e. is moving?] With the French, = Who goes there? of our sentries.

Quixotism, or Quixotry. A word generally used to denote absurd or extravagant actions done from a sense of duty, like those of Don Quixote in the great romance of Cervantes.

Quocunque mŏdō. [L., by whatever means.] In some way or other.

Quocunque nomine gandes. [L., in whatever name you rejoice.] Whatever may be your name.

Quoddy. A kind of scaled herring, cured in N. America.
Quod erat demonstrandum. (Q.)

Quod erat făciendum. [L.] Which was to be done; appended to problems under the initial letters Q.E.F.

Quod fieri non debuit, factum valet. [L.] What ought not to have been done is valid when done (as in the case of marriage at an illegal age).

Quod ubique, quod semper, quod ab omnibus. (Vincentian rule.)

Quoin. [Fr. coin, Gr. $\gamma \omega \nu$ ia, an angle.] 1. (Arch.) An angle of a building. 2. In Printing, a wedge for securing pages in the chase.

Quorum. [L., of whom.] A term derived from the words of the Latin form of commission to justices of the peace, "Quorum unum A. B. esse volumus," of whom we will $A$. $B$. to be one. Hence two or more persons, when the presence of more than one is needed, may be said to constitute a quorum.

Quorum pars magna fui. [L., lit. of which (persons, or things, or times) I was an important element.

Quo sĕmĕl est imbūtă rěcens, servābit ǒdōrem Testa diu. [L., the jar will long keep the odour which it received when new (Horace).] Early impressions are lasting.

Quotation. In Printing, a piece of hollow type-metal, lower than type, used in the blank spaces at the beginning and end of chapters, etc.

Quot homines, tot sententiæ. [L.] As many opinions as men.

Quot servi, tot hostes. [L.] All your slaves may prove your enemies; as many enemies as servants.

Quum talis sis, utinam noster esses. (Talis quum sis, utinam noster esses.)
R. As an abbrev., stands for Rex or Regina, king or queen; in medical prescriptions for Rěclipe [L., take]; in the Naut. muster-book, $R$. denotes run, placed against the names of deserters, and of those who have missed three musters; R.P. for Respublica, republic.

Rab. A rod used in mixing hair with mortar.

Rabbet. [Fr. rabot, a plane.] 1. A sloping cut made on the edge of a board so that it may form a joint with another board similarly cut by sapping. 2. A rectangular groove cut along the edge of a board to receive a corresponding projection upon the edge of another board.

Rabbeting. [Fr. rabot, a plane.] (Arch.) A process in wood answering to joggling in stone. (Joggle-joints.)

Rabbinism. The body of the doctrine of the rabbis, contained in the Talmud and other books.

Rabble. A tool used to stir the melted iron in puddling. (Rab.)

Răbies. [L., rage, madness.] I.q. hydrophobia.

Raca. [Syr., vanity, or folly.] A word by which the Jews expressed vehement indignation. (Anathema; Maran-atha.)

Race. (Naut.) A strong and dangerous current producing overfalls.

Race, of ginger, etc. [L. radix.] (Bot.) A root.

Raceme. [L. răcēmus, $a$ bunch, cluster.] (Bot.) A spike-like inflorescence, differing from a true spike in having each flower upon a small footstalk; e.g. the currant blossom.

Răchis. [Gr. sáxıs, spine.] 1. (Bot.) The axis of inflorescence; the stem which supports the flowering head. In ferns, the divisions of the petiole of the leaves. 2. The shaft of a feather.

Răchitis [Gr., from $\rho a ́ \chi \imath s$, the spine], sometimes Rickets $(q . v)$. Inflammation of the spine.

Rack. [A.S. ræcan, to stretch out.] 1. (Mech.) A straight bar furnished with teeth to work with a toothed wheel or pinion. 2. An instrument of torture, always illegal in this country.

Racking. 1. Washing ores on an inclined frame called a rack. 2. Drawing off wine, etc., from the lees. 
Racking a tackle, or lanniard. (Naut.) Fastening two running parts together, with a seizing called racking, so as to stop it from rendering (q.v.).

Rack-punch. Punch made with arrack.

Rack-rent. (Leg.) A rent raised as nearly as possible to the full annual value of the premises.

Rack-saw. A saw with wide teeth.

Racoon. (Zool.) Prǒcy̌on, an animal with grey fur, somewhat like a small fox. America. Fam. Prǒcy̌ŏnǐdæ, ord. Carnivvŏra.

Racovians. (Eccl. Hist.) The Unitarians of Poland; so called from the city of Racow, where Jacobus à Senna erected for them, in 1600 , a seminary, in which the Racovian Catechism, drawn up by Socinus, was published.

Raddle, To. (Naut.) To interlace.

Raddock, Ruddock (from its red, ruddy, breast). (Ornith.) Robin redbreast, Sylvia rŭbēcŭla, fam. Sylvŭdæ, ord. Passěres.

Radiant. [L. radius, a ray.] (Her.) Having rays proceeding from it.

\section{Radiant heat. (Radiation.)}

Rădīäta. [L., provided with ray's, or spokes.] (Zool.) Cuvier's lowest animal kingdom, named from the radiated form of some of its constituents, as sea-urchins and star-fish (Ěchinŏdermăta). These are now reckoned as Annǔloïda,

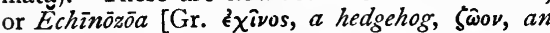
animal], with Scōlēcĭda $[\sigma \kappa \omega \dot{\lambda} \eta \xi, a$ zvorm], i.e.

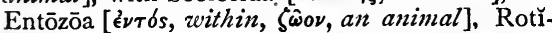
fĕra, and some others. Cuvier's Pǒlȳzōa are placed among mollusca, as Molluscoidea; the Prōtōzōa form a sub-kingd. by themselves; the remainder form the sub-kingd. Cœlenteranta.

Radiation. [L. rădiātiōnem, an emission of beams of light.] Consists in the transmission of energy from one body to another by propagation through an intervening medium in such a way that the progress of the transmitted energy may be traced after it has left the first body and before it reaches the second; travelling through the medium with a certain velocity, and leaving the medium behind it in the condition in which it found it: thus light radiates from a luminous body, and heat, when transmitted in like manner, is radiant heat.

Radical. [L. radix, radicis, a root.] (Chem.) A salt $R$. is a simple body which with hydrogen forms an acid, or with metals a salt. A compound $R$. is a compound which takes the place of a metal in chemical combinations; these are met with chiefly in organic chemistry.

\section{Radical metaphor. (Metaphor.)}

Radical quantity; R. sign. (Math.) The Radical sign is the sign which indicates that a certain root is to be extracted. A $R$. quantity is a number or algebraical expression with the radical sign prefixed; thus, $\sqrt{ } \mathbf{I} 57$ is a radical quantity, the radical sign $(\sqrt{ })$-originally $r$, for rādix, root-prefixed to 157 signifying that the square root is to be extracted, so that $\sqrt{ } 157$ denotes an incommensurable number whose square is 157 , and which is very nearly equal to $12 \cdot 53$.

Radical reformers. In Eng. Hist., an indefinite name applied to politicians who are sup. posed to wish for the rooting out of the evils which affect the commonwealth.

\section{Radicle. (Plumule.)}

Radiometer. [A word coined from L. rădius,

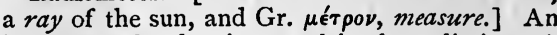
instrument for showing repulsion by radiation. A glass bulb about three inches in diameter has in it a fine glass stem, with a disc of pith at each end, suspended by a cocoon fibre. If a hot body is placed outside the bulb near one of the discs a convexion current is set up and the disc is attracted. If now the air is progressively exhausted, the attraction, though enfeebled, continues; but when the exhaustion becomes very perfect, as when its pressure is decidedly below that of a millimetre of mercury, repulsion takes place. The object of the instrument is to show this repulsion. Several explanations of this unexpected phenomenon have been proposed. The instrument is made in a variety of forms. Called also, from its inventor, Crookes's radiometer, and sometimes a Light-mill.

\section{Radius. (Ulna.)}

Radius-vector. [L. vector, one that carries.] (Math.) If we suppose a line to revolve round one end, its other end may be made to trace out any curve provided its length is duly altered; such a line is the R.-V. of the point which describes the curve. The fixed point is the pole. The position of the moving point at any instant is defined by the length of the R.-V. and the angle between it and a fixed line; these are the polar co-ordinates of the point. In Astron. the R.-V. of a planet (or satellite) is the line joining its centre to that of the sun (or primary).

Rädix. [L., root.] (Math.) The number which serves as the base of a system of numbers; thus Io is the radix or base of the ordinary system of numeration.

\section{Raffaelle china, Raffaelle ware. (Faience.)}

Raft. [Akin to rafter.] 1. (Mil.) A floating bridge of casks or boats, for conveying troops and guns across rivers. 2. (Naut.) A number of timbers, casks, or other buoyant objects, lashed together so as to make a kind of float. R. $-d o g$, a broad piece of iron with the ends pointed, and bent to a right angle, used to fasten a raft together. R.-port, a square hole in the stem or stern, for loading or unloading a timber-ship.

Rafts of the Mississippi, when flooded in spring-time. Accumulations in certain spots of an immense number of trees torn up and carried down; one has been known no less than ten miles in length. (Floating islands.)

Rag, Roach (probably corr. from Roche, rock), Ragstone. (Geol.) A coarse limestone, easily breaking under frost, etc., with ragged fracture.

Rag-bolt. An iron pin with barbs on its shank to hold it tight.

Ragman Roll. A name, of uncertain origin, denoting the instrument by which the Scottish nobility and gentry subscribed allegiance to Edward I., in 1296.

Ragulé, Raguly. (Her.) Ragged, like the trunk of a tree having its boughs lopped off.

Raiah, Rayah. [Turk. raia, a flock, a dog of a Christian.] Mussulman name for Christian 
inhabitants of Turkey, who pay the capitation tax.

Raid of Ruthren. A conspiracy of the Earl of Gowrie and others against James VI. of Scotland, afterwards James I. of England, 1583 .

Raiidø. [L. raia, the ray.] (Ichth.) Fam. of fish of sub-ord. Bătǒinèi (rays), without serrated caudal spine. Temperate and tropical latitudes. Ord. Plăgiostŏmăta, sub-class Chondroptěry̆güi.

Rail (from its cry). (Ornith.) Fam. of wading-birds; Rallidæ. Universally distributed. Ord. Grallæ.

Railroad nomenclature in $\mathbf{0 . 8}$. Railway and $R$. station are, in U.S., railroad and $k^{\prime}$. depôt; engine-driver and stoker are engineer and fireman; carriage and luggage-van are passenger-car and baggage-car; goods train is freight train; line, siding, crossing plate, points, are track, turn-out, frog, switches.Bartlett's Americanisms.

Railway mania. The excessive speculation in the earlier days of railway construction in this country.

Rainbow; Lunar R.; Primary R.; Secondary R.; Spurious R.; Supernumerary R. (Phys.) The coloured arch seen when the sunlight falls on a spray of water, and particularly on a shower of rain ; it is due to the sunlight undergoing internal reflexion within the spherical drops of rain. The Primary rainbow is produced by the rays that are reflected once within the rain-drop; the Secondary $R$., which is external to the primary, by those which have been reflected twice within the rain-drop. As coloured lights tend to produce arches of different radii, the colours are separated in much the same way as when sunlight passes through a glass prism; within the primary and without the secondary rainbow are often seen a succession of red arches with intermediate colours; these are the Spurious or Supernumerary $R$. A Lunar $R$. is formed by moonlight in the same way that an ordinary rainbow is formed by sunlight ; but its colours are fainter, and it is much more rarely seen.

Rain cats and dogs. Sailors say, "The cat has a gale of wind in her tail; " and in old German paintings the wind is represented as the head of a $\operatorname{dog}$ or a wolf. Hence "to rain cats and dogs" denotes a downpour of rain with a violent wind.

Rain-gauge. An instrument for measuring the depth of the rainfall.

Raised beaches. (Beaches.)

Raison d'être. [Fr.] Lit. the reason of the existence of a thing; the purpose it is intended to fulfil ; the reason why it is what it is.

Raja. [From Skt. raj, to shine, akin to L. rex, rēgis, a king.] The title of the hereditary Hindu princes, belonging, or supposed to belong, to the Kshatrya or warrior Caste.

Rake. (Naut.) 1. The projection of both ends of the ship's body away from the keel. 2 . The inclination of masts forward or aft. 3. To $R$. a ship, to fire along her whole length.
Rake, Rake vein. [Ger. ragen, to jut out.] (Giol.) An oblique vein of ore.

Raki. A common Russian brandy.

Rakish vessel. (Naut.) One appearing formidable or suspicious, and a swift sailer.

Rakshasas. Evil spirits of Hind. Myth. Their chief was Ravana, who stole away Sita the wife of Rama. (Ramayana)

Rallentando. (Ritenuto.)

Ralph Roister Doister. The oldest English comedy, written by Nicholas Udall, Head-Master of Eton College, who died 1564. It gives a picture of contemporaneous London citizen life.

Ram, generally called Battering-ram. 1. (Mil.) It consisted of a large beam of wood shod with a piece of heavy metal in the shape of a ram's head, for breaking down walls ; usually suspended by ropes or chains in a roofed fiame borne on wheels, and impelled by the protected soldiers inside giving it a swinging motion. 2. (Naut.) The offensive prow of an armour-clad ship of war. (Steam-ram.)

Ramădan. The Mohammedan Lent, beginning with the new moon of the ninth month of the year, and ending on the day preceding the great festival of Bairam.

Ramayăna. [Skt., the career of Rama.] A great Hindu epic poem, describing the life of Rama and his wife Sita, and his expedition to Ceylon to rescue her from the tyrant Ravana.

Ram down cartridge. (Mil.) The old word of command used in charging any muzzle-loaded musket.

Ramequins, Rammekins. [Ger. rahm, cream, and -chen, a dim. suffix (Littré).] An old word lately revived, meaning a fondue.

Ramists. (Hist.) The followers of Pierre de la Ramée, Latinized Ramus, professor of rhetoric and philosophy at Paris, in the reign of Henry II. He was killed in the Massacre of St. Bartholomew. His system was opposed to the Aristotelian logic.

Rampant. [Fr. ramper, to climb.] (Her.) Standing upright, with the feet in the attitude of an animal climbing.

Rampart. [Fr. rempart; se remparer, to fortify one's self.] (Fortif.) Mass of earth inclosing a fortified place, to protect the interior and to give the guns of the defenaers a command over the besiegers.

Rampe. [Fr., fight of stairs, ascent, ramper, to creep.] (Fortif.) Gentle earthen ascent used along the interior slope of a rampart.

Ranch. [Sp. rancho, originally a mess-room.] In Sp. Amer., a rude hut, lodgings for herdsmen, etc., at night ; farming establishment with many such huts ; hacienda [landed estate] being a cultivated farm, with good house.

Rand. [Ger. rand, a rim.] A thin inner sole for a shoe.

Randan. (Naut.) Rowing with a bow and a stroke oar and a pair of sculls between them.

Random. [O.E. randon.] (Min.) The depth below a given surface in mining.

Range, To. (Naut.) To sail parallel and near to anything.

\section{Ranger. (Regarder.)}




\section{Rank, in Army and Navy.}

r. Admiral of the fleet ranks with 2. Admiral

3. Vice-admiral

Rear-admiral

5. Captain of the fleet

6. Commodore

7. Captain of 3 years

8. Captain under 3 years

9. Commander ranks junior to

r1. Lieutenant under 8 years

12. Sub-lieutenant

13. Midshipman

d-marshal

General.

" Lieutenant-general

"Major-general.

", Brigadier-general.

Ditto.

" Colonel.

Lieutenant-colonel.

Ranters.

" $\quad$ Lientenant.
connexion, on the ground that the latter lacked earnestness in street and field preaching. In England, the Primitive Methodists are called Ranters.

Ranz des vaches. [Fr., Ger. kuhreigen, kuhreihen, the call to the conss.] The tunes used by Swiss herdsmen in driving their cattle to and from pasture.

Răpāces. [L., rapacious.] (Ornith.) I.g. Accipitres (q.v.).

Rape. [Perhaps akin to rope, like the Gr. oxoivos, which is both a rope and a measure of length.] 1. A territorial division. Sussex is the only county divided into rapes, each containing three or four hundreds. The Norw. repp denotes a parish district. 2. The refuse of raisins after making wine.

Rap-full, Keep her. (Naut.) An order $=$ do not let her sails shake.

Răphē. [Gr. ́̊̆̆ central raised line, looking as if the parts had been sewn together. 2. (Bot.) Line of communication between the hilum and chalaza.

Rapier. [A word introduced from Spain.] A long narrow sword with a straight handle.

Rapparee. A term common in the seventeenth century, denoting a wild Irish plunderer, generally armed with a rapary, or half-pike.

Rappee. [Fr. râpér, from râper, to grate.] A strong, dark snuff.

Rapprochement. [Fr.] The drawing nearer to each other; the beginning of a better understanding.

Raptōres. [L., snatchers.] (Ornith.) I.q. Accïputres (q.v.).

Rara avis in terris nigroque simillima cygno. [L.] A very rare bird, most like a blach swan (Ovid) - which was not then known to exist.

Rascal deer, or other animals. Lean, worthless ones. $\left[R_{.}=\right.$refuse scrapings ; cf. amongst other forms, It. raschiare, to scrape, as if from L. rāš̌cŭlare, dim. of rādo, sup. rāsum.]

Rasee. [Fr. rasèe, scraped or shaved down, L. rasus.] (Naut.) A line-of-battle ship cut down a deck, or having her upper works reduced.

Raskolniks. [Russ., schismatics.] Dissenters from the Greek Church in Russia, calling themselves Starowerzi, Orthodox. Their differences seem to be confined to outward forms and discipline.

Räsöres. [L., scrapers.] (Ornith.) (Gallinæ.) Rasp. [O.E. raspe.] A coarse file.

Rat. (Naut.) 1. A machine concealed in an insured vessel, and worked by her motion, with the criminal purpose to scuttle and sink her, and so secure the premium. 2. A current chafing the cable against sharp rocks.

Ratafia. [Malay arak, arrack, tâfia, white rum.] A kind of liqueur.

Ratchet [Fr. rochet]; R.-wheel. A Ratchetwheel has teeth of which the one face is in the direction of a radius and the other slightly inclined to the circumference. Let a rod move backward about one end, and to the other let an arm or link be loosely attached, an end of which rests on the top of the wheel; when the rod moves back, the end of the link slides over a level face of the tooth and falls on to the leve! face of the next tooth ; but when the rod moves forward, the end of the link presses against the upright face of the tooth, and thus drives the wheel : the arm or link is called a Ratchet, and sometimes a Paul or a Click. A link or arm capable of moving round a fixed point near the top of the wheel, which allows the level face of the tooth to slide under it, but by pressing against the upright face of the tooth detains the wheel if it attempt to turn in the opposite direction, is a Detent, but it is also called a R.

Rate. (Naut.) The old classes into which men-of-war were divided were: First-R., 100 guns and upwards, ranging from 42-pounders on lower deck to 6-pounders on quarter-deck, carrying 850 men or more. Second-R., 90 to 100 guns. Third-R., 80 to 84 guns, the smallest line-of-battle ship. Fourth-K., 60 to 74 guns. Fifth-R., 32 to 40 guns, or even 60 guns. Sixth-R., carrying any lower number, or none, but commanded by a captain. 'Sloops, ships commanded by a commander.

Ratio. [L. ratiōnem, a reckoning, a relationship.] The relation which one magnitude bears to another of the same kind in respect of quantity; thus a distance of five miles bears to a distance of two and three quarter miles the ratio of 20 to 11 . The first term is the antecedent, the second the consequent.

Ratiocination. [L. ratiocinātiōnem, from ratio, reason.] The act or process of deducing conclusions from premisses.

Rationalists. (Supranaturalists.)

Rătio ultíma rēgum. [L.] The last argument of kings ; i.e. war.

Rătītæ. [L. rătītus, provided with a raft, rătis.] (Ornith.) Birds without a keel to the breast-bone; running-birds which cannot fly, as the ostrich.

Ratlines, or Ratlings. (Naut.) Small lines fastened across the shrouds, like rungs of a ladder, parallel with the deck.

Rattan. [Malay rôtan.] The tough stem of an Indian plant resembling cane. (Calamus.)

Ratteen. [Fr. ratine.] A thick twilled woollen stuff.

Rattinet. A thin kind of ratteen.

Rattle. The sound of air gurgling in the windpipe, which, especially at death, the lungs have not power to send out.

Rattle down rigging, or Rattle the shronds, To. (Naut.) To fix the ratlines parallel with the deck. 
Raucity. [L. rauč̌tātem.] (Med.) Hoarseness. Ravana. (Rakshasas.)

Ravelin. [Fr., from It. rivellino.] (Mil.) Salient work, having two faces sometimes terminated by flanks, placed in front of the curtain at the counterscarp of the main ditch of a fortress.

\section{Ravenna, Exarchate of. (Exarch.)}

Ravensduck. [Ger. rabentuch, from raben, raven, tuch, cloth.] A kind of sail-cloth (from its colour).

Ray. [L. rădius, a staff, spoke of $a$ wheel.] 1. (Geom.) Any one of a number of lines diverging from a point. 2. (Phys.) A line along which light or radiant heat is propagated.

Rayah. (Raiah; Ryot.)

Razor-bill. (Ornith.). Spec. of auk, Alca tarda, resembling the common guillemot. (Guillemot.)

Razor-shells. (Zool.) Nearly oblong bivalves; edible. Temperate and tropical seas. Burrows in the sand. Fam. Solenidæ, class Conchifferra.

Razzia. [It., from Ar.] A plundering incursion, a raid.

Reach, To. (Naut.) To stand off and on; to sail by the wind on one tack.

Reaction. 1. (Math.) When two bodies (A and B) act on each other the action is mutual ; if the force exerted by $\mathbf{A}$ on $\mathbf{B}$ is regarded as the action, the force exerted by $B$ on $A$ is the $R$. In most cases there is some obvious reason for regarding one of the forces as the action; thus when a horse draws a cart, the force exerted by the horse on the cart would be called the action, that exerted by the cart on the horse the R. 2. (Chem.) The changes produced by the mutual action of two substances on each other.

Reader. One who corrects the proof-sheets of a printed book.

Reading in. In the Church of England, the reading of Morning and Evening Prayer, and of the Thirty-nine Articles, by a newly appointed incumbent.

Reagent. [L. re-, again, agĕre, to act.] (Chem.) A substance used to discover the presence of other bodies in a compound, by the chemical reaction which takes place.

Reaggravation. In the usage of the Latin Church, the final admonition issued before excommunication.

Real. [Sp., = L. regālis, royal.] The legal money of account in Spain; twenty reals equal one duro or hard dollar.

Realgar. [Sp. rejalgar, from Ar. rahdj-algâr, cavern powder, because it was obtained from silver-mines.] (Chem.) Bisulphide of arsenic, a brilliant red pigment.

Realists. (Nominalists.)

Reaming. [Ger. räumen, to clear away.] Enlarging a hole in metal.

Rear-admiral. (Rank.)

Rearmouse, Reremouse. [O.E. hrére-mus, id., hreran, flutter; $c f$. flitter-mouse.] The bat.

Rebate. (Rabbet.)

Rebec, Rebeck. [Ar. rabāb (Littré).] (Poet.) A viol; properly a three-stringed instrument, Arabian or Turkish, introduced by the Moors into Spain ; played with a bow (Childe Harold, I. xlvi.).

Rebecca riots broke out in Wales, 1843 , having for their object the abolition of tolls, the destruction of turnpikes, and the "possession of the gate," like the "seed of" R. ! (Gen. xxiv. 6o).

Rebellion, The Great. (Eng. Hist.) A name for the revolt of the Long Parliament against the authority of Charles I.

Re-biting. Restoring worn lines in an engraved plate by acids.

Rebus. 1. The representation of letters and syllables by signs, as an eye and a ton for Eyeton. The word is said to have been suggested by squibs or satires "de rebus quæ geruntur." 2. (Her.) A coat of arms which bears an allusion to the name of the owner, as three cups for Butler.

Receiver. 1. (Chem.) A vessel for receiving and condensing the product of distillation. 2 . The glass vessel from which the air is exhausted by an air-pump, and in which experiments on a vacuum are made.

Recess of the Empire. (Hist.) The judicial name for the decrees of the German Diet-perhaps as being pronounced when the diet was about to recede or separate.

Rechabites. (Jewish Hist.) The followers of Jonadab the son of Rechab, who charged them to plant no vines, drink no wine, and build no houses (Jer. xxxv. 6, 7).

Réchanffage. [Fr.] A warming $u p$, or a dressing up of what is old.

Recherché. [Fr.] Refined; lit. sought afresh. In Eng. exquisite.

Rĕcîpě. (R.)

Reciprocal. [L. reciprŏcus, returning, reciprocal.] (Arith.) When the product of two numbers is unity, either is the R. of the other ; thus, $\frac{1}{2 \pi}$ is the R. of 20 .

Recitative. [It. recitatīvo, L. rěcĭto, $I$ recile.] Musical recitation or declamation, without reference to time or rhythmical melody; existing in Greek music, and revived it is said by Rinuccini, I 594; used to express some passion or relate some event, etc., often introductory to amelody ; e.g. "There were shepherds," in the Messiah.

Reciting note. In chanting, the first note of each half or strain of a chant; that on which syllables few or many, according to the length of the half-verse, are sung. (Mediation.)

Reckon. [A.S. recnan.] As in Rom. viii. I8;

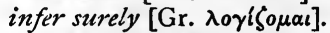

Reckoning, ship's, To make \&. (Naut.) To ascertain her position by combining her known direction and distance run since the last observation, and correcting this by an observation. Dead-reckoning, when uncorrected by observation.

Recluse. The general term for all persons dwelling in religious houses. (Cœnobites; Hermit.)

Recognition. In Scot. Law, the preliminary examination of witnesses, in order to determine whether there is a case for trial or commitment.

Recollects [Fr., L. recollectus, gathered $u p$, as 
for religious meditation] were, like the Observants, a reformed body of the Franciscan order. (Orders, Mendicant.)

Reconnaissance. [Fr., examination, from reconnaitre, to explore.] (Mil.) Examination of any theatre of operations with the view of making accurate plans of the ground, together with written reports on its capabilities for military movements.

Reconnoitre. (Mil.) To make a reconnaissance $(q . v$.$) .$

Recorder. 1. At first probably, persons to whose remembrance or record of what had taken place in judicial proceedings the law gave credit, owing to their official or personal dignity. 2. The chief judicial officer in a borough possessing the jurisdiction of a court of record. 3 . A musical instrument, like a flageolet, now out of use.

Recrudescence. [L. recrüdesco, I break open afresh, said of wounds.] (Med.) The breaking open afresh of wounds.

Rectangle. (Quadrilateral.)

Rectification. [L. rectus, right, facěre, to make.] 1. Refining by repeated distillation. Rectified spirits, spirits fifty per cent. above proof. 2. (Math.) The determination of a straight line of the same length as the arc of a curve included between given points.

Rectilineal, or Rectilinear. [L. rectǐ-lineus.] Consisting of or bounded by straight lines.

Recto; Verso. In early printed books, the right-hand and the left-hand pages; $\mathrm{R}$. the first page of the leaf lying open, $V$. the page of the leaf when turned; R. being the only numbered pages.

Rector. [L. rector, sc. ecclesiæ, ruler of the church.] (Eccl.) Properly the person, or parson, who has charge of a parish church and is possessed of the great tithes; but as these were before the Reformation often appropriated by religious societies, the latter appointed a vicar, with the small tithes as his remuneration.

Rectum. (Anat.) Termination of the large intestine, which is comparatively straight [L.rectus].

Rectus in curia. [L., right in the court.] (Leg.) One who comes out of court with clean hands.

Recuperative. [L. rěcŭpěro, I regain.] (Med.) Effective towards recovery.

Recurring series. (Arith.) One, each of whose terms equals a fixed number of preceding terms each multiplied by a certain constant; thus, I, 5, I7: 53, I6I, etc., is a R. S., for any term equals the excess of four times the term before it above three times the term but one before it ; as, $161=4 \times 53-3 \times 17$.

Recursant. [L. recursantem, part. of recursāre, to run back.] (Her.) Of an eagle; displayed with its back towards the spectator.

Recusants. [L. recūsantes.] In Eng. Hist., those who refused to acknowledge the royal supremacy in matters ecclesiastical.

Rédacteur. [Fr.] Editor of a newspaper, etc.

Redan. [Fr., originally a toothed work, and spelt Redent.] (Mil.) Work consisting of two faces, forming together a salient angle, and open at the gorge.
Redargue. [L. redargǔĕre, from re-, red-, back, argǔĕre, to charge with, accuse.] To argue against, to refute.

Red Book of the Exchequer. A register, giving the names of all who held lands per baroniam under Henry II.

Red Cross Knight. An impersonation of Holiness, bk. i., Faëry Queene; the true Saint George, or knightly England, doing battle for Una, " a lovely ladie," i.e. Truth (see canto x. 6i).

Redemptŏrist. (Eccl.) A religious order, also called Liguorists, as founded by Liguori, in Naples, in 1732 ; but styling themselves members of the order of the Holy Redeemer. Their chief work is education.

Redintegration. [L. rĕdintegrātio, -nem, $a$ renewal, a restoration.] In Moral Phil., a name proposed for what is generally known as Assaciation. "Thoughts which have at any time, recent or remote, stood to each other in the relation of coexistence, or immediate consecution, do, when severally reproduced, tend to reproduce each other."-Fleming's Student's Moral Phil., p. 47.

Redŏlet lŭcernam. [L.] It smells of the lamp; said of work done in the late hours of the night.

Red orpiment. Another name for realsar (q.v.). (Orpiment.)

Redoubt. [Fr. redoute, from It. ridotto.] (Mil.) Any closed fortification, the parapet of which nowhere forms re-entering angles; generally constructed on a small polygon. (Réduit.)

Redshank. (Ornith.) Cosmopolitan gen. of wading-bird. Tŏtănius, fam. Scŏlōpācĭdæ, ord. Grallæ.

Redshort. Brittle when red hot.

Red snow. An appearance due to the presence of Prōtǒcoccus nǐvālis, one of the simplest forms of plant-life.

Red spider. (Entom.) Ěrythræus tēlārŭus, spec. of mite (Ăcărus), troublesome in greenhouses.

Red tape. An excessive stiffness in the management of official concerns ; servile adherence to precedent and to routine. (Circumlocution Office.)

Reductio ab absurdum. [L.] In Geom., the proving of a proposition by showing that the maintenance of the contrary is an absurdity.

Reduction. [L. reductiōnem, a bringing down.] 1. (Arith.) The process of expressing in assigned units a quantity given in other units; as the reduction of 753 half-crowns to $£$ s. $d$. 2. (Astron.) The process of applying to the place of the observed heavenly body as read off on the instruments (supposed perfect and in perfect adjustment), five distinct and independent corrections, viz. those for refraction, parallax, aberration, precession, and nutation. 3. (Chem.) The separation of a metal from the substances with which it is chemically combined.

Réduit (same word as Redoubt; origin L. rěductus, drawn back). (Mil.) Inner fortification for prolonging the defence and securing the retreat of the defenders when its outer work has been taken.

Reduplication. [L. reduplicātiōnem, a doubling.] (Lang.) The repetition of a sound in 
consecutive syllables. In the earliest forms of speech most words exhibited this characteristic, which is seen in such words as titillate, cachinnation.

Red wolf. (Zool.) Canis Mexǐcānus (Linnæus), C. jŭbātus (Cuvier); Agouara-gouarou, great fox ; Azara; cinnamon-coloured, short black mane along back; solitary. Marshes of Trop. America.

Reed. 1. In Music, a strip of metal or wood, formerly of reed, set vibrating by a current of air ; not itself producing sound, but dividing the current into a succession of rapid puffs, which produce sound; $e . g$. oboe, clarionet. A striking $R$. beats against its seat, as in organ generally; a free $R$., as in harmonium, passes in and out of the opening. 2. A frame of parallel flat strips of wood through which the warp-threads pass in weaving.

Reef. [Formerly riff, akin to rift.] A line of rocks lying just above or just below the surface of the sea.

Reef of a sail. (Naut.) A portion of the sail which can be drawn together by small cords. R.-points, reducing the size of the sail. $R$.-lines, lines passed through the eyelet-holes of the reef and over the head of the sail, to aid sailors when reefing. R.-band, a strip of canvas running across the sail to strengthen it where the eyelet-holes are. Close-reefed, with all the reefs of the topsails taken in. Reefers, midshipmen.

Re-entering. Cutting deeper the lines of an engraving which are too faint.

Ro-entering angle. 1. (Math.) An angle of a polygon which, measured internally, exceeds two right angles. 2. (Fortif.) One which recedes inwards towards a fort from the surrounding country.

Reeve. [A.S. gerefa.] A general title for a ruler or governor; still found in sheriff, or shirereeve, portreeve, etc.

Reeve. (Zool.) Female of Ruff (q.v.).

Beeve, To. (Naut.) To pass the end of a rope through a block, etc. To unreeve, to take it out.

Refectory. [L.L. rěfectōrium, from refício me, I refresh myself.] In the conventual life, the rooms where meals are taken by all together.

Referendaries. [L. referendus, to be referred.] (Hist.) Officers whose duty it was to draw up and despatch diplomas and charters.

Reflecting circle. (Math.) An instrument constructed on the same principle as a sextant, but such that angles can be read on it round the whole circumference of a circle from $0^{\circ}$ up to $360^{\circ}$, instead of only from $0^{\circ}$ up to about $120^{\circ}$.

Reflector. The mirror of a reflecting telescope.

Reflex. [L. reflexus.] Illuminated by light reflected from another part of the same picture.

Reflex, or Excito-motory, action. (Physiol.) 1. When an afferent nerve stimulated produces motion in a muscle supplied by an efferent, the mind taking no part ; e.g. coughing, swallowing (see Carpenter's Mental Physiology, pp. 46, et seqq.). 2. Similarly, action, not produced by volition or emotion, but by prepossessed mind ; e.g. an acted dream.

Reflexion [L. reflexiōnem, a bending back]; Law of $\mathbf{R}$. The return of rays of light, heat, etc., from the surface on which they strike. The Law of $R$. is the following :-If a perpendicular to the surface is drawn from the point of incidence, the incident and reflected rays are in the same plane with the perpendicular and are equally inclined to it on opposite sides; or, the angles of incidence and reflexion are equal.

Refocillate. [L. refocillāre, from re-, again, fócillāre, to revive by warmth, focus, $a$ hearth.] To refresh, strengthen.

Reformatio Legum Ecclesiasticārum. [L.] A revision, by Cranmer, A.D. 1552, of Eccl. law, with fifty-one titles, after the manner of Justinian's Digest; an attempt to accommodate the Canon laws, or to substitute better; never enacted.-Blunt, Reformation.

Reformed Presbytery. (Macmillanites.)

Reformers. (Calvinists; Lutherans; Syncretists ; Zuinglians.)

Refraction [L. refractiōnem, a breaking off]; Angle of R.; Astronomical R.; Atmospheric R.; Conical R.; Double R.; Extraordinary R.; Index of R.; Law of R.; Ordinary R.; Terrestrial R. The change in the direction of a ray of light when it passes out of vacuum into a transparent medium; it also takes place when light passes from one medium into another, and when the density of the same medium varies. If a perpendicular to the surface of the medium is drawn from the point of incidence, the incident and refracted rays are in the same plane with and on opposite sides of it, but the refracted ray is inclined to it at a less angle than the incident ray; the former of these angles is the Angle of $R$., the latter the angle of incidence. The Law of $R$. is the fact that the sine of the angle of incidence bears a constant ratio to the sine of the angle of $R$. ; the numerical value of that constant for a given medium when the light passes out of vacuum into the medium is the Index of $R$., or the Refractive index, of that medium. In most crystallized media the incident ray is divided into two refracted rays, of which in some crystals one and in others both are refracted according to a law more complicated than that above stated; this is Double $R$. If the ray is refracted according to the law above stated, it undergoes Ordinary $R$., if not, Extraordinary $R$. In some crystals, when the ray enters them in a certain determinate direction, it forms a conical surface of rays instead of only two rays; this is Conical $R$. When a ray of light from a heavenly body passes into the atmosphere, it undergoes refraction, and consequently the heavenly body appears nearer the zenith than its true position; this is Atmospheric R., or Astronomical $R$. Atmospheric $R$. also occurs in the case of light coming from distant terrestrial objects on account of variations in the density of the intervening air ; this is Terrestrial $R$.

Refractive index. (Refraction.)

Refractory. [L. refractārius, stubborn.] (Chem.) Difficult to fuse by heat. 
Refrain. [O.Fr. refrainer, L. refringĕre, to break up.] (Music.) The burden of a song, the phrase or verse, which, recurring, breaks it into equal parts.

Refresher. In Law, an additional fee paid to a counsel when a cause is not heard in the term for which it was set down.

Refreshment sunday. Mid-Lent Sunday, the Fourth Sunday in Lent; the Gospel being John vi. I, etc. (Simnel bread.)

Refrigeratory. [L. refrīgeratōrius, cooling.] A vessel of cold water for condensing the vapours from a still.

Refuge, Cities of. In Jewish Hist., six cities to which those might fly who had caused accidental homicide. The deliberate murderer was to be handed over to the avenger of blood. -Josh. xx.

Ré galantuomo. [It.] A title sometimes applied to the King of Italy, as a gallant leader and statesman.

Rēgāle [L.], i.e. jus. The royal right by which kings of France enjoyed the revenues and patronage of bishoprics.

\section{Regal fishes. (Royal fishes.)}

Regālia. [L., royal things.] In Eng. Hist., the royal insignia and Crown jewels.

Regals. Small portable organs used in the Middle Ages, often represented in paintings as carried by angels or saints.

Regard, Court of. (Forest courts.)

Regardant. - [Fr., lookingat.] (Her.) Looking back towards the sinister side of the escutcheon.

Regarder. The old title for the ranger of a forest.

Regelation. [L. rěgĕlatiōnem, in a new sense, = freezing again, not its proper sense of thazeing.] When two pieces of ice with moistened surfaces are placed in contact, they become cemented by the freezing of the film of water between them, even when the surrounding medium has a temperature above $32^{\circ} \mathrm{Fahr}$.; this is the $R$. of ice, or Regelation.

Regent, The Good. Name sometimes given to the Earl of Murray, prime minister and adviser of Mary, Queen of Scots, I 56I.

Regent Masters. Formerly in universities, a term for graduates privileged to give public lectures in the schools, and bound to deliver such within a certain period after their degree. (Faculty.)

Regest. [L. rěgesta, things recorded.] A record; hence the altered form rěgistrum, Fr. regitre, register.

Rëgifŭgium. [L., the king's flight.] In Rom. Hist., a festival said to have been instituted to commemorate the expulsion of Tarquinius Superbus. (Sibylline books.)

Register, To. [L. rěgesta, things recorded.] To correspond in relative position, line for line, as the columns or pages of a printed sheet.

Register, Lord, or Lord Clerk Register. A Scottish State officer who has charge of the archives, and is thus called also Custos Rotulorum.

Register of voice. [L.L. rĕgistrum.] Its compass : Lower R., or Chest voice, that which comes out freely and naturally ; Upper $R$., Fal. setto, or Head voice, produced by strained contraction of the glottis, is of a higher pitch, flutelike, but not so open and impressive ; Middle $R$. , such notes of chest voice as may be produced by falsetto.

Register-ship. A Spanish galleon or platevessel.

Regium Dōnum. [L., royal gift.] (Hist.) A yearly grant of money for maintaining the Presbyterian clergy in Ireland, instituted in 1690 by William III.

Regius morbus. [L., the king's evil.] Scrofula, which was supposed to be cured by the touch of the king's hand.

Regius professors. [L.] In the universities of Oxford and Cambridge, the professors whose chairs were founded by Henry VIII.

Reglets. [Fr. réglette, dim. of règle, $a$ rule.] In Printing, thin parallel wooden furniture (q.v.), made to the thickness of any type from pearl upward, to separate the lines of type more widely.

Regrating, or Forestalling. An offence of the commun law, that of buying or getting into one's hands at a fair or market any provisions, corn, or other dead victual, with the intention of selling the same there, or within four miles, at a higher price: he who does this thing being a Regrator. (To regrate is to scrape or dress cloth, etc., so as to sell it again.)-Brown, Law Dictionary.

Regular solid. (Polyhedron.)

Regulars. [L. regŭla, $a$ mule.] In the Latin Church, those who bind themselves to the vows of poverty, chastity, and obedience, under a fixed rule, as of St. Benedict, or any other; as opposed to Seculars, for instance parish priests, who live in the world and are bound only to celibacy.

Regular body. (Polyhedron.)

Regular system. (Crystallog.) The octahedral system (q.v.).

Regulating Act, 1773, of Lord North's Ministry, made important changes in the government of India. The Presidency of Bengal was to exercise a control over the other possessions of the East India Company ; the chief to be styled Governor-general, and to be assisted by four councillors; a Suprenie Court of Judicature, independent of G.-G., to be established at Calcutta, having a chief justice and three inferior judges ; Warren Hastings appointed G.-G. for five years.

Regŭlus. [L., a little king.] (Chem.) The pure metal which in the melting of ores falls to the bottom of the crucible.

Regur. The name of the cotton-growing soil of India.

\section{Reichofsrath. (Aulic Council.)}

Reichskammergericht. (A ulio Councill.)

Reichsrath. [Ger., council of the kingdom.] The German Parliament. (Aulic Council.)

Reichstadt. [Ger.] A free city of the empire. (Hanseatic League.)

\section{Reichstag. (Diet.)}

Reign of Terror. In Fr. Hist., the term applied to the period of the worst excesses of 
the first revolution. It may be set down roughly as the time between October, 1793, when the Girondists fell, to July, 1794, when Robespierre and his associates were put to death.

Reim. A strip of ox-hide used for twisting into ropes, etc.

Reinecke Fuchs. A popular German epic poem, first known in a Low-German version in the fifteenth century, relating the adventures of the fox scheming his way to favour at the court of the lion by sheer cunning and hypocrisy. The poem is thus a satire on the intrigues and the iniquities of courts.

Re infectâ. [L., the thing being unfinished.] Without accomplishing a purpose intended. In Gr., árрактоs.

Reinforce a gun. In Eng. formerly, and in America now, to strengthen it about the breech.

Reis, Rais, or Ras. [Ar., head, or prince.] A general title of dignity given to captains of ships, etc. Sometimes joined with Effendi, and thus a tautology.

Reiters. German cavalry of the fourteenth and fifteenth centuries.

Relapsed. [L. relapsus, part. of relabor, $I$ fall back.] A term denoting those who have fallen back into errors previously abjured. (Montanists; Novatians.)

Relapsing fever, once known as Five-day $F$., Seven-day F., Mild yelloze $F$. (Med.) A continued F., chiefly epidemic, attacking the ill fed, marked by abrupt relapses; one of the continued fevers known in this country, the others being typhus and typhoid.

Relative keys. (Music.) If any note of the common chord of a key occurs in the scale of another key, the former is said to be related to the latter. Thus to the key of $\mathrm{F}$ major, the keys of $\mathrm{G}$ minor, $\mathrm{A}$ minor, $\mathrm{B} b$ major, $\mathrm{C}$ major, and $\mathrm{D}$ minor are related.

Relative pronoun. In Gram., a part of speech which may represent any noun or pronoun, and makes the clause which it introduces practically adjectival.

Relative terms. (Log.) Words implying a relation, as father and son, king and subject. (Correlation.)

Relay. A magnet which transmits the circuit current to a local battery, called the relay battery.

Relevant. [Fr.] Pertaining to, properly applicable to, an argument, etc.

Relief. (Mezzo-relievo.)

Relief. [Fr. relief, L. rělěvare, to raise up.] 1. Of a fortification, the total height from the bottom of a ditch to the top of the parapet. 2 . Those of the guard who go round to change sentries.

\section{Relief Church. (Marrow Controversy.)}

Relief synod. (Eccl. Hist.) A body of Presbyterians, who, protesting against the mode in which lay patronage was exercised in the Established Church, set up the Secession Church and the Relief, 1752.

Reirgro Laici, The Religion of a Layman. Dryden's work, exhibiting the struggles which ended in his becoming a Roman Catholic.
Relĭgǐo lǒci. [L.] The religion of the place. The special feelings of awe or of affection called forth by any particular spot.

Rēliggio Médǐci, published 1642. A kind of confession of faith, with which other matters are intermixed, by Sir Thomas Browne, physician, antiquary, and philosopher, of Norwich.

Religgiosōrum, De Asportatis. One of the chief of the statutes intended to check the aggressions of the papacy, 35 Edward I., which forbids "alien priors" assessing taxes or withdrawing money on that head out of England. Brown, Law Dictionary. (Provisors; Præmunire.)

\section{Religious Orders. (Orders, Religious.)}

Reliquary. A receptacle for relics, generally of small size; as distinguished from a case [Fr. châsse], which may contain a whole body.

Relíquræ. [L.] Remains of the dead, relics. Relume. [O.Fr. relumer, to light again.] To rekindle.

Rema, or Reume. [(?) Gr. $\oint \in \hat{v} \mu \alpha$, stream, fiood.] The tide.

Rem ăcu tĕtĭgisti. [L., lit. thou hast toneched the matter with a needle-point (Plautus).] You have hit the nail on the head.

Remainder. (Leg.) A remnant of an estate in land, depending upon a particular prior estate, created at the same time and by the same instrument, and limited to arise immediately on the determination of that estate. Kent.

Rĕmănet. [L., it remains behind.] (Leg.) A name given to causes, the trial of which is deferred from one sitting to another.

Remberge. (Naut.) An O.E. war-vessel, long and narrow, and propelled with oars.

Remblai. (Déblai.)

Remembrancers. Certain officers of the Court of Exchequer, and of some corporations, with various functions.

Rēmiges. [L., rozvers.] (Ornith.) The quill feathers of a bird's wing.

Reminiscence. (Pre-existence.)

\section{Remoboth. (Sarabaites.)}

Remonstrance, The. (Hist.) A document, recapitulating the grievances of the kingdom, presented to Charles I., November, I641.

Remonstrants. (Arminians.)

Rĕmŏra. [L., (I) delay, (2) the fish ěchĕnēis, Gr., ship-stopping.] Echěnēïs [Gr. é $\chi \epsilon-\nu \eta t s$,

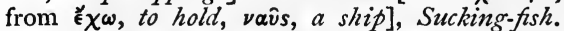
(Ichth.) Various spec. of marine fish with laminated cartilaginous plate on its head, by which it adheres to external objects, as the bottoms of ships, producing a vacuum by erecting the laminæ; fabled thus to stop ships, hence its Gr. and L. names. The spec. vary in size, from eight inches to two feet. Gen. Naucrătes

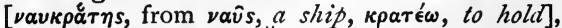
fam. Scombrĭdæ, ord. Ăcanthoptĕry̆gĭi, sub-class Tělěostěĩ.

Remount. (Mil.) Horse supplied for training for the cavalry service.

Remphan. A god worshipped by the Israelites in the wilderness, the name being probably an Egypt. equivalent substituted by the Sep tuagint for Chiun, or the Dog-star. 
Remplissage. [Fr., from remplier, to fill up.] 1. (Music.) Intermediate parts. 2. Generally, as to literary style, mere padding.

Renaissance. [Fr., a revival, renewal.] (Arch.) A name for the style which sought to reproduce the forms of Greek or so-called classical ornamentation. The growth of this style may have been a consequence of the revival of letters, but it had nothing to do with the movements which ended in the Reformation. The term itself has been very loosely used to denote various styles, which have very little in common. Many Renaissance buildings are classical only in their details, their form and spirit being entirely Gothic, as the Church of St. Eustace, Paris, and of the Annunziata at Genoa.

Renal. (Anat.) Pertaining to the kidneys [L. rēnes].

Renardus Vulpes. (Reinecke Fuchs.)

Render, To. (Naut.) To yield to force applied.

Rendering. [Fr. rendre.] Boiling down and clarifying.

Renegade. (Runagate.)

Reniform. [L. rēnēs, kidneys, forma, shape.] (Anat., Bot., Min.) Kidney-shaped; so, e.g. the leaf-blades of some plants are called.

Rennet. [A.S. rennan, to curdle.] The prepared inner surface of the calf's fourth stomach for curdling milk.

Rentes. [Fr.] The Fr. equivalent to our Government Funds [L. rendĭta, rent], renděre being a nasalized form of redděre.

Rentier. [Fr.] One who has an income from stocks, or Rentes.

Rep. A kind of stuff having a fine cord-like substance.

Repeater. A watch that strikes the hours at the touch of a spring.

Repeating decimal. (Decimal.)

Repeat signals, To. (Naut.) To hoist on another vessel the admiral's signals, so as to transmit them to distant vessels.

Repertory. [L. repertorlum, from reperio, I open.] A storehouse; a place where things stowed away can easily be found, as an index.

Repetend. (Decimal.)

Replevin. In Law, a personal action which lies to try the validity of a distress, or to recover goods unlawfully distrained. (Distress.)

Replica. [It.] A copy of a painting, made by the painter of the original picture.

Rĕplum. [L., a central rail against which folding doors both close, repleo, I fill up.] (Bot.) The partition through the length of the fruit of Crucifers, to which the seeds are attached; e.s. wallflower.

Reporting progress. If, in a Committee of the (whole) House of Commons, a debate be not finished, or matters referred to it not fully considered, the Chairman "is directed to report progress, and ask leave to sit again." In the Lords, when any peer moves that the House be "resumed," the Chairman of Committees moves that "the House be in Committee on a future day."

Repoussé. [Fr., pushed back.] Ornamental metal work in relief, produced by beating the metal from the back.

\section{Reprisal. (Marque, Letters of.)}

Reprobation. [L. reprǒbātio, nem, disapproval, rejection.] (Theol.) A term denoting the Supralapsarian theory respecting the destiny of man. (Sublapsarians.)

Reprove. Job vi. 25 ; disprove [L. reprobare, I reject].

Repsilver. [Reapsilver.] Money paid formerly by tenants to be quit of the service of reaping the lord's corn or grain.

Reptilia, Reptiles. [L., creeping, rēpo, I creep.] (Herpetology.)

Republicans. In the politics of the United States, those who resisted the extension of slavery; the pro-slavery party being styled Democrats.

Request, Letters of. An instrument by which an inferior ecclesiastical judge, waiving his own right, remits a case to the judge of a superior court for determination; under the Statute of Citations, 23 Henry VIII.

Requests, Court of. 1. A court of equity, inferior to the Court of Chancery; abolished in the time of Charles I. 2. Local courts for the recovery of small demands; now superseded by the County courts.

Requiem. 1. In the Latin Church, a Mass for the repose of the dead; so called from the prayer, "Requiem æternam dona eis, Domine," Lord, grant them eternal rest. 2. Incorrectly, a musical performance in honour of illustrious men deceased.

Requiescat in pace. [L.] May he rest in peace; appended to epitaphs under the initial letters R.I.P.

Requisition. (Mil.) The enforcement of supplies from the inhabitants of a country. (Indent.)

Reredos. [Fr. arrière-dos, from L. dorsum, the back.] (Arch.) A screen behind an altar. In Winchester, Durham, and St. Albans, these screens are magnificent, but so large as to interfere with the general view of the choir.

Rereward. Numb. x. 25, and elsewhere; rear-ward, i.e. rear-guard.

Res angusta dŏmi. [L.] Stinted means at home; poverty (Juvenal).

Resch Glutha. (झEchmalotarch.)

Rescissory Act. (Covenanters.)

Rěsēda. [L. rěsēdo, I assiage, heal.] (Bot.) Rocket ; herbaceous plant ; several spec. ; typ. of ord. Rěsēdaceæ; R. ŏdōrāta, mignonette, a popular garden annual.

Reservation. [L. reservātionem.] In the Latin Church, the retention of the consecrated host for subsequent administration.

Reserve. [L. reservo, I keep back.] (Theol.) The system which would set before the people only such truths as they are considered able to comprehend or receive to their benefit. Also called the Economy. (Arcani Disciplina.)

Reset of theft. The Scottish term for the receiving of stolen goods, knowing them to be stolen.

Res gestæ. [L., things cione.] Transactions, exploits. 
Residuary legatee. In Law, the person to whom, after other bequests specified, the residue of an estate is bequeathed.

Resilience. [L. rěsĭlio, $I$ spring back.] The power of a body to recover its form when strained; measured by the product of the greatest strain it can undergo with safety and the mean force (or stress) required to produce that strain.

Resinous electricity. Negative electricity (because excited by rubbing resinous bodies).

Resipiscence. [L. resipiscentia, from resipisco, $I$ recover sense.] Wisdom gained by experience; repentance.

Resist. (Chem.) A substance used to prevent a dye from colouring any but the required parts.

Resistance, Solid of least. The solid of revolution which, standing on a given circular base and having a given height, will in moving through a fluid in the direction of its axis experience the least resistance.

Resolution [L. resolutio, -nem, a loosening]; $\boldsymbol{R}$. of a force; $\mathbf{R}$. of a nebula; $\mathbf{R}$. of a velocity. To find two forces (or velocities) equivalent to a single force (or velocity) is to find the Resolution of that force or velocity. When certain nebulæ are examined through a very powerful telescope, they are found to consist of a congeries of distinct points of light; this is the $R$. of such nebula.

Resolution of a discord. (Music.) The movement upwards or downwards of a discordant note, by which a discord is resolved into a concord; indicating the particular place to which the discordant note must move.

Resonance. [L. rěsŏnantia, an echo.] The prolongation or strengthening of a sound by the sympathetic vibration of bodies other than that which produces the sound.

Resonator." [L. rěsŏno, act. and neut., I reecho.] A small hollow globe of thin brass or glass, made of such dimensions that the air within it may vibrate sympathetically in unison with some definite tone. By means of a set of resonators, a musical note can be analysed audibly into a fundamental tone and the harmonics which give it its quality, each $\mathrm{R}$. strengthening one particular harmonic.

Respectant. (Her.) Aspectant.

Respǐce, aspice, prōspicee. [L.] Look back, look on, look forward (St. Bernard). (Norns.)

Respice finem. [L.] Look to the end (of an undertaking before you begin it).

Respirator. [L. respīrāre, to breathe out.] A fine network covering for the mouth to breathe through.

Respond. [L. respondeo, I answer.] (Arch.) A half pillar or pier attached to a wall, and supporting an arch.

Responds, Responsories. [L. respondeo, I answer.] In Preface to Prayer-book, certain responses, or suffrages, which, in the unreformed ritual, "broke the continual course of the reading of the Scriptures."

Responsible government. The government of the country, as in England, by executive ministers, responsible to Parliament, the members of which are responsible to their constituencies.

Responsories, or Responds. In the offices of the Latin Church, short verses from Scripture, repeated as verse and response, after the Lessons at Matins.

Restaurateur. [Fr.] One who restores or refreshes, the keeper of a house of public entertainment.

Rest-harrow. (Bot.) A wayside plant

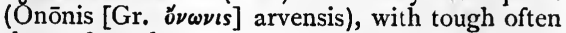
thorny branches and pink, pea-shaped flowers. Ord. Legüminosæ.

Restitution, Writ of. In Law, a writ issued when judgment has been reversed, to make up what the defendant has lost by the effect of the judgment so reversed.

Restitution of Conjugal Rights. The name of a suit to compel cohabitation, if refused; brought by either a husband or a wife against the other in the Court of Divorce and Matrimonial Causes.

Restoration, The. In Eng. Hist., a term especially applied to the re-establishment of monarchy after the Commonwealth, by the restoration of Charles II.

Restriction of cash payments. A power of issuing notes for which the holder cannot demand gold in exchange. This power was granted to the Bank of England in 1797, and resumed in 1820 .

Restuation. The opposite process to Estuation [L. æstuātiōnem, a singeing $u p$ ], excitement or agitation (as of a fluid).

Resultant. (Composition of forces.)

Résumé. [Fr.] A recapitulation, or summary.

Resumption of cash payments. (Restriction of cash payments.)

Ret, To. (Naut.) To soak or rot timber, etc. Retable. (Eccl. Arch.) A shelf or ledge behind an altar, for holding lights or vases. Wrongly called Superaltar, which is properly a stone let into a wooden frame and constituting the upper surface of the altar itself.

Retainer. [L. retinĕo, I keep back.] 1. In O.E. Law, a servant wearing his master's badge or livery, and attending him when called on to do so; a relic of the times of private wars. (Truce of God.) 2. A fee to a barrister, securing his services or preventing their being secured by others.

Retaining fee. (Retainer, 2.)

Retaining wall. A wall designed to support the pressure of a bank of earth abutting on it.

Rètiārians. [L. rětiārüi, from rète, $a$ net.] A class of Roman gladiators, armed with a trident and net. (Mirmillones.)

Retiary. (Entom.) A spider, as acting like Retiarians, and catching by means of a net.

Reticulated veins. (Bot.) (Parallel-veined leaves.)

Reticulated work. (Arch.) Masonry in which the s'ones are laid lozenge-wise, like the meshes of a net.

Rētǐcŭlum. [L., little net.] (Anat.) The second stomach of a ruminant, having honeycomb-like cells on the inner surface. 
Rētĭna. [It., a dim. formed from L. rēte, $a$ net.] (Anat.) A netlike continuation and expansion of the optic nerve at the back of the eye; the seat of vision.

Retort. A vessel used in distilling by heat. It consists of a bulb, with a long neck bent over [L. retortus, bent back] to enter a receiver.

Retractor muscle [L. rětrăho, I draze back] (Anat.) draws back that to which it is attached.

Retreat. (Mil.) Beating of infantry drums or sounding of cavalry trumpets every sunset.

Retreat of the ten thousand. The celebrated march of the Greeks, under Xenophon, from the field of Kunaxa (where Cyrus fell in his attempt to dethrone his brother Artaxerxes, B.C. 40I) to Kotyora on the southern coast of the Black Sea.

Retrenchment. [Fr. retranchement, retrancher, to intrench.] (Mil.) Any earthwork thrown up to cover from attack and to give the defenders an advantage over assailants.

Retrograde motion of a planet. (Proper motion.)

Retroversion. (Anteversion.)

Retting (i.e. rotting). Steeping flax to separate the fibres from the woody parts.

Return. 1. (Arch.) A moulding or wall continued in a different direction from that originally taken by the body returned. 2. (Fortif.) The termination of zigzag trenches which are slightly thrown back and used as receptacles for tools. 3. Military or other documents containing information drawn up according to form.

Rěvălenta Arăbǐca. An empirical diet for invalids, a preparation of lentil, or "ervum lens ;" a slight transposition of letters affording a pun on re, again, văleo, I am well.

Réveille. [Fr. réveiller, to awake, L. re, ex vighilare.] (Mil.) Beating of drums at daybreak where troops are quartered, to wake up the garrison.

Réveillon. [Fr.] In France, a festive gathering at Christmas; once connected with the midnight Mass of Christmas Eve.

Revels, Master of the. The officer, called also Lord of Misrule, who in royal and great houses presided over the Christmas entertainments. They seem to disappear at the end of the seventeenth century. (Fools, Feast of.)

Revenons à nos moutons. [Fr., let us go back to our sheep, i.e. our subject.] In a French farce, Patelin, Guillaume, a draper, is robbed of some sheep by his shepherd, Agnelet, and of some cloth by P., an advocate. At the trial of A., G. recognizes in A.'s advocate the thief P., and, confusedly mixing up in his answers cloth and sheep, is recalled by the judge, who says, "Revenons," etc.

Reverberatory furnace. [L. reverberrāre, to reflect.] A furnace with a low roof, so that the flame in passing the chimney is reflected down on the hearth where the materials are placed.

Reverse fire. (Mil.) The trajectory of an enemy's shot when received in rear by troops.

Reverse flank. (Mil.) Opposite extremity of a line of soldiers to that which is guiding its march.
Reversion. [L. rěversiōnem, a returning.] 1. In Law, the reversion of an estate to the grantor or his heirs, after the grant is determined. 2. (Phys.) The reappearance of apparently lost characteristics of a perhaps very remote progenitor. (Atavism.)

Revetment. [Fr. revêtement, from revêtir, to clothe.] (Mil.) Facing to earthworks, composed of sods, gabions, fascines, sand-bags, or brickwork, to support the earth in a steeper position than it would otherwise assume.

Revŏcāre grădum. [L.] To recall or retrace a step.

Revolution. (Stroke.)

Revue. [Fr.] In France, a kind of burlesque at the end of the year, at which the political events of the year are reviezued in a jocular vein, with accompaniments of scenery and comic songs.

Reynard the Fox. (Reinecke Fuchs.)

Rex oonvivii. [L.] The king or master of $a$ feast. (Symposiarch.)

Rex vini. [L.] The same as Rex convivii.

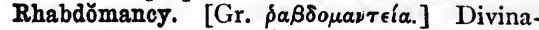
tion by means of a rod [ $\left.\rho \alpha^{\prime} \beta \delta o s\right]$. The practice of it is described by Sir W. Scott, in the Antiquary. Rhadamanthys. (Osiris.)

Rhætic formation. (Geol.) The beds between the Trias and Lias, formerly referred to the latter in England and to the former in Germany ; well developed in the Rhrtian Alps; contain some remarkable bone-beds, with the earliest mammalian remains (Microlestes); known also as Penarth beds.

Rhampsinitos, The Treasures of. A story told, by Herodotus, of an Egyptian king whom he so names. The tale is essentially that of the Master Thief, which is common to most of the Aryan languages. Among the Greeks the Master Thief was Hermes.

Rhapsodists. [Gr. $\delta a \psi \varphi \delta \delta \delta$, from $\rho a ́ \pi \tau \omega, I$ secw, or stitch, and $\psi^{j} \delta \dot{\eta}, a$ song.] A name for the minstrels who recited the Homeric poems in Greece, more especially before these were committed to writing.

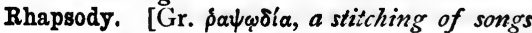
together.] 1. In Music, fragmentary, irregular composition. 2. In a general sense, " any number of parts joined together, without necessary dependence or natural connexion" (Johnson); as "a R. of words" (Shakespeare); "a R. of difficulties" (Hammond).

Rhemish Bible. (Bible, English.)

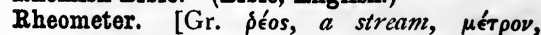
measure.] An instrument for measuring the velocity of electric currents.

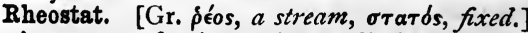
An instrument for increasing or diminishing the electrical resistance of a circuit.

Rhetoric. [Gr. the art of prose composition in general, but usually applied to the art of addressing public assemblies in set speeches.

Rhëum. (Bot.) Technical name of the gen. familiarly known as rhubarb [Gr. $\hat{\beta} \hat{n o v}$, or $\hat{\rho} a ̂]$, from the river Rha, in Pontus, on whose banks it grows. 
Rhoum. [Gr. $\rho \in \hat{v} \mu \alpha$, (I) that which flcwes, (2) rheum.] (Med.) Increased discharge from mucous membrane, or glands ; defluxion.

Rhimer. (Rimer, Thomas the.)

Rhinal. Pertaining to the nose [Gr. $\rho i s, ~ \delta i v o s]$. Rhine, Confederation of the. (Hist.) A confederation of certain German princes who, in I806, placed themselves under the protection of the French Emperor Napoleon.

Rhinophōnia. [Gr. $\phi \omega \nu \eta$, the voice.]. Speaking through the nose [ $\left[i^{\prime}, \phi^{\prime}\right.$ iv $\left.\delta s\right]$.

Rhizöme. [Gr. $\delta^{t} \zeta \omega \mu \alpha, a$ mass of roots.] (Bot.) A creeping procumbent root-stock, sending out roots downwards and leaves upwards; e.g. iris.

Rhodian ware. So called. (Persian ware.)

Rhodium. [Gr. $\$ \delta \delta o \nu$, rose, from the rose colour of its salts.] (Min.) A very hard, refractory metal.

Rhodomontade. Bragging bluster, from Rodomont; a boastful personage in the Orlando Furioso, by Ariosto. The name is thought by some to be connected with the name Rhadamanthys. (Osiris.)

Rhomb [Gr. sb $\mu \beta$ os, a spinning motion, a rhomb] ; Fresnel's R. A plane figure with four equal sides, but having angles which are not right angles. Fresnel's $R$., a parallelepiped of glass whose ends are inclined to two of the sides at angles of about $54 \frac{1}{2}^{\circ}$, which has the following property :-A ray of light entering the $R$. in a direction at right angles to one end will emerge in a direction at right angles to the opposite end after two internal reflexions; if the incident ray is plane polarized in a plane inclined at half a right angle to the plane of reflexion, the emergent ray will be circularly polarized.

Rhombic system. (Crystallog.) The prismatic system (q.v'.).

Rhombohedral system. (Crystallog.) Consists of crystals having three axes equally inclined to each other, and three equal parameters; when transparent they are optically uniaxal, having the optic axis equally inclined to the three axes; as Iceland-spar.

Rhombohedron. [Gr. $\delta \delta \mu \beta o s, a$ rhomb, є̇ $\delta \rho \alpha$, $a$ base.] A solid contained by six equal rhombs.

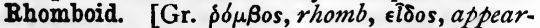
ance.] (Math.) A parallelogram whose angles are not right angles, nor all its sides equal. (Quadrilateral.)

Rhopalic verse. One with words increasingly long towards the end, as a club [Gr. $\delta \delta \pi a ̆ \lambda o \nu]$ is thicker towards the end; as, "Si sedes liceat contingere cælicolarum."

Rhot-amenti. (Osiris.)

Rhumb, or Rhomb [i.e.forming, with meridian, two sides of a rhomb, Gr. $\delta \delta \mu \beta o s]$. A Rhumb. line is the prolongation of any of the lines on the compass, other than those showing the four cardinal points, which last represent the meridian and parallel of latitude. Line of rhumbs, the eight points of one quarter of the compass-card set off upon its chord by striking consecutive circles through them from the extremity of the chord.

Rhumb-line. (Loxodromic curve.)

Rhythm of the heart. (Diastole.)
Ribald. (Ribandequin.)

Ribaudequin. [L.L. ribandequinus, perhaps from riband, ribald, a name denoting the lower classes of foot-soldiers.] In mediæval warfare, a cart armed with spikes, and furnished with small cannon.

Ribbon, Riband. [Fr, ruban.] (Her.) A diminutive of the bend, being one-sixth its size. Blue ribbon [Fr. cordon bleu], the ribbon suspending the badge of the order of the Garter. Red ribbon, the ribbon suspending the badge of the order of the Bath.

Ribes. (Bot.) A gen. of plants, and the only one, of ord. Grossulariæ ; including the various kinds of currant and gooseberry, together with many ornamental shrubs.

Ribs, False, or Floating. (Anat.) In man there are twelve ribs on each side : the first, or upper, seven, being more directly connected through intervening cartilages with the sternum, or breast-bone, than the remainder, are called the Vertebro-sternal or True $R$. ; the other five are known as False $R$., and of these the last two, being quite free at their anterior extremities, are called Floating $R$.

Rice-paper. A thin delicate paper made from the pith of a Chinese plant.

\section{Richard Roe. (John Doe.)}

Rickets. [Corr. of Rachitis (q.v.), with meaning somewhat altered.] A disease, mostly in children, known by large head, tumid belly, distortion of the spine and other bones, from deficiency of hardening matter in the bones; allied to scrōfula.

Ricochet fire. [Fr. ricocher, to ricochet; origin unknown; but see Littré.] (Mil.) When, the charge being small and elevation slight, the shot from a gun makes several bounds during its course. Employed principally for dismounting the guns along a rampart.

Riddle. [O.E. hriddel, id., hridrian, to sift.] (Agr.) A sieve.

Ride a-port last, To. (Naut.) To do so with the lower yards on the gunwale.

Rideau, Lever le. The French term for draw. ing up the curtain at the beginning of a play. Tirez le rideau $=$ drop the curtain.

Rider. 1. An additional clause to a Bill passing through Parliament, or to a resolution put before a meeting, or in a deed. 2. (Math.) A proposition or theorem of minor importance, solved by the aid of one or more of Euclid. 3 . (Geol.) A mass of rock dividing a vein into two parts.

Ridge-work. (Agr.) A system of irrigation in which the land is laid in ridges with a feeder, or float, along the top of each, to distribute the water, and a drain between each pair to carry it off.

Ridings. The three divisions of the county of York, the word being a corr. of trithings or triding, the third part. In the Domesday Survey, the word is applied to Lincolnshire also.

Rifacimento. [It.] A making, or dressing; up again of old things.

Rifler. In the language of hawking, a hawk that catches its prey by the feathers only. 
Rigg, i.e. ridge (?). (Stetch.)

Rigging. (Naut.) All ropes or chains used about the masts, yards, or sails. Standing $R$. is opposed to Running $R$., or that which is used to set the sails, trim the yards, etc.

Right. (Naut.) To R., to regain a horizontal position. $R$. the helm, put it amidships. $R$. sailing, sailing due N., S., E., or W. R. up and dozen, no wind at all.

\section{Right angle. (Angle.)}

Rigid body. A collection of particles whose mutual distances are unchanged by the forces applied to them.

\section{Rĭgor. (Algor.)}

Rig Veda. (Veda.)

Rilievo. [It., from L. rělěvāre, to lift up.] A word used to denote carvings in relief. (Mezzorelievo.)

Rimer, Thomas the. In Scottish tradition, a poet, known also as Thomas of Ercildoune, or True Thomas, as having predicted, it is said, the accidental death of Alexander III., 1283; supposed author of Sir Tristrem, a romance of the Arthur cycle, edited by Sir W. Scott, 1804 .

Rim stock. (Clog almanack.)

Ring-bone, and side-bone. In a horse, bony growths about the joints of the os corooñe ; R. when on the side of the os suffräginis, S. when on that of the os pedis, or coffin-bone.

Ringent flower. [L. ringor, I open the mouth wide.] (Bot.) A labiate with lips widely separated; e.g. Lamium, or dead-nettle.

Ringer. A miner's crowbar (from the sound).

Rings, Fairy. (Fairy rings.)

Ring-tail. (Naut.) A kind of studdingsail, hoisted perpendicularly to the after edge of a boomsail.

Ringworm. Popular name for porrigo (q.v.).

Riot Act. Passed by Parliament for the prevention of tumultuous assemblies; after the reading of which to a mob by a civil magistrate, if they do not disperse, troops may fire upon them until they have brought them to order.

Rippers, or Ripiers. [L. rīpārius, frequenting river-banks; and cf. Rivicra (q.v.).] Coast-men who hawk fish inland.

Rippling. [Ger. riffeln, to hatchel.] Removing the seeds from the stalks of flax with a wire comb called a ripple.

Ripsaw, Rippingsaw. A handsaw with coarse teeth, used for cutting wood in the direction of the fibre.

Rishis, The Seven. In Skt. Myth., the seven sages who were thought to live in the seven stars of the constellation called by us the Great Bear. But these stars had been originally called the Seven Rikshas, or Shiners, a word probably akin to the Gr. kpктоs and the L. ursa; and thus, when this name was gradually restricted to the bear, the seven shiners became seven bears,

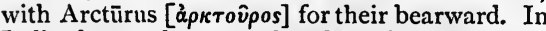
India the word was confounded with rishi, wise, and the seven stars became the abode of seven sages or poets, who reappear as the Seven Wise Men of Greece, the Seven Champions of Christendom, the Seven Sleepers, etc.

Rīsus sardŏnǐcus. (Med.) A convulsive, horrible grin, chiefly in tetanus and inflamed diaphragm [ $\left.\Sigma_{\alpha \rho} \delta \delta \nu เ o s \quad \gamma \in \dot{\lambda} \omega s\right]$; perhaps pointing to the idea of the Sardinian ranunculus, and the face of the eater screwed up; but the earlier

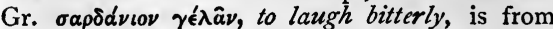

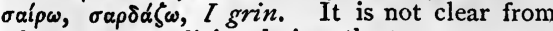
what source medicine derives the term.

Ritenuto [It.], Rit. (Music.) Holding back, slackening the time, for a few notes, while Rallentando, slackening, isof a longer passage.

Ritornello. [It., from ritornāre, to return.] (Music.) 1. Properly a short, instrumental repetition of the ending of a song. 2. An interlude.

River-terraces. (Geol.) Level terraces of sand, gravel, etc., at the slopes of most inland valleys ; evidences of former fresh-water levels, when the valley, not yet alluvial land, was occupied by a lake at the height of the $R$.

Rivet. [Fr.] A pin or bolt clinched at both ends.

Riviera, The. [It., coast, sea-shore.] The seacoast from Cannes to Spezzia. R. di Ponente, i.e. of the setting sun, is from Genoa, westwards; R. di Levante, i.e. of the rising sun, from G. eastwards. (Corniche.)

Rix-dollar. (Dollar.)

Roach of a sail. (Naut.) The curvature in the lower part of an upper squaresail.

Road, or Roadstead. (Naut.) An anchorage off shore, where a well-found vessel can ride out a gale.

Road-metal. Broken stones for macadamized roads.

Roadster, or Roader. (Naut.) A coastingvessel which lies up in a roadstead during adverse winds and tides.

Roan. [Fr. rouan, roan-coloured.] An imitation of morocco, for bookbinding, made from sheepskins.

Roaring. In a horse, a disease of the airpassages, caused by "(I) inflammation, which has left a thickening or ulceration of the mucous membrane, or a fungous growth from it; (2) paralysis of the muscles; (3) alteration of the shape of the cartilages of the larynx, produced by tight reining."-Stonehenge, The Horse in the Stable and in the Field, p. 486.

Roaring forties. Popular name with sailors for the stormy seas between $40^{\circ}$ and $50^{\circ} \mathrm{N}$. latitude.

Roast-beef dress. In Naut. slang, full umiform.

Roasting. (Chem.) Heating so as to drive off the volatile parts.

Rob. [Ar. robb.] The juice of ripe fruit boiled down to the consistency of syrup.

Robands, Robbens. (Rope-bands.)

Robin Hood and Iittle John. Outlaws or freebonters of the time of Richard I. Some of the incidents related of Robin Hood (Locksley) by Walter Scott in his Ivanhoe, belong to poptular European romance, and reappear in the story of William of Cloudesley, Tell, and other mythical heroes.

Roborant. [L. rōbŏrantem.] (Med.) Strengthening medicine.

Rochdale school = co-operation; of which 
the first example was the Equitable Pioneers' Co-operative Store, founded at Rochdale by a few poor flannel-weavers, circ. 1844; their capital of $£ 28$ producing in sixteen years more than $t, 120,000$.

Rochelle salt. (From Rochelle, in France.) A tartrate of soda and potash, used in Seidlitz powders.

Roches moutonnées. [Fr.] (Geol.) Sheeplike rocks, in the Alps and elsewhere; projections worn by glacier action, and like sheep's backs.

Rochet. [Fr., It. rochetta.] A linen garment worn by bishops under the Chimere.

Rock. In Geol., includes all substances of which the earth's crust is composed ; clay, sand, earth, as well as stones.

Rock-crystal. (Quartz.)

Rocket-boat. (Naut.) A flat-bottomed boat fitted for firing rockets.

Rock harmonicon. (Music.) An instrument composed of pieces of clinkstone, or phonolite, of different lengths, placed over a soundingboard, and struck by hammers held in the hand.

Rockingham Ministry. From March to R.'s death in July, I782, succeeded North's, after the surrender of Cornwallis; made up of equal numbers of old or "Revolution" Whigs, and those Whigs who had followed Chatham; with the Tory Lord Chancellor Thurlow.

Rockingham ware. A brown stone ware made on an estate of the Marquis of R., at Swinton. Other pottery and porcelain were made there. Mark, a griffin, the R. crest.

Rocking-stones, or Loggans. (Geol.) Blocks weatherworn, and poised so finely as to oscillate, by a little force; chiefly granitic; some seem to be artificial. The harder masses of granite, remaining when denudation, acting along the fissures due to consolidation, has removed the rest, leave tors and sometimes poised stones.

Rock-oil. (Petroleum springs.)

Rock-rose, or Cistus. (Bot.) A gen. of exogenous shrubs or herbaceous plants, with showy red, yellow, or white flowers; typ. of ord. Cistaceæ; many of S. Europe and the Levant are resinous, yielding lādănum. The wild yellow $R$. is Hēlianthěmum vulgare.

Rock-salt. Common salt, chloride of sodium, in rock-masses. Geol. position various, the R.-S. of Cheshire and Worcestcrshire is in the New Red Sandstone. In Poland and Spain, R.-S. is cretaceous.

Rocoa. [Braz. urucu.] The reddish pulp of the fruit which yields annatto.

Rococo. [Fr. rocaille, rockwork (Littré).] A name given to the very debased ornament and decoration in Arch., furniture, china, etc., which succeeded the first revival of It. Arch.; utterly devoid of principle or of taste.

Rōdentra. [L., gnazing animals.] (Zool.) The tenth class of mammals, characterized specially by continually growing incisors, which by continual attrition constantly preserve a sharp edge ; as rats, rabbits, beavers.

Roderick, the last of the Goths. (Pillars of Heracles.)
Roe, Roebuck. [Heb. tzĕhî (Deut. xii. I5, etc.), the beautcous one.] (Bibl.) The gazello. Sub-fam. Gazellinæ, fam. Bǒvĭdæ.

Roebins. (Rope-bands.)

Roe-stone. (Oolite.)

Rogation days. [L. rŏgationem, an entreaty.] Monday, Tuesday, Wednesday, before Ascension Day; so called from the Litanies which were recited by clergy and people in public procession.

Roger. (Jolly.)

Rogue's march. Tune only played on the drums and fifes, when a soldier is being drummed out of the army for some disgraceful conduct.

Rogue's yarn. (Naut.) Formerly a yarn twisted contrary to the rest, in the centre of each strand of rope used in the navy; tarred in white, and white in tarred, rope. Now a thread of worsted, of a different colour for each royal dockyard. (Royal.)

Rois d'Yvetôt. [Fr.] So the lords of Yvetôt, in Normandy, are called in old chronicles; it is not clear why. Now the name means an imaginary burlesque potentate. With Béranger he is $=$ a very good little king.

Rois Fainéants. [Fr., do-nothing kings.] (Hist.) A name for the later degenerate princes of the Merovingian dynasty, finally dispossessed by Pepin, A.D. 752.

Roland. In the Carolingian tradition, a Paladin of Charles the Great, who fell in the battle of Roncesvalles, and whose exploits are celebrated in the Orlando Furioso of Ariosto.

Roland for an Oliver, A. (A Roland for an Oliver.)

Rôle. [In Fr., a roll, L. rŏtŭlus, dim. of rŏta, a wheel.] The part assigned to an actor in a drama. Hence the part taken by any one in any line of action.

Rolfganger. Rolf (Rollo), the Norwegian conqueror of Normandy, A.D. 876 , was so called because he was obliged, it is said, always to go on foot, no horse being able to bear his weight.

Roll. (Geol.) Said of a set of strata bent into numerous troughs and ridges, or into undulations ; sometimes an elevated fold of rock is pushed forward and over, so that the strata are said to be inverted.

Roller. (Surg.) A long broad bandage.

Roller-bolt. The bar in a carriage to which the traces are attached.

Rollers. (Naut.) Large ocean-waves, rising from five to fifteen feet above the ordinary height, which precede the northers of the Atlantic.

Rolling tackles. (Naut.) Those which hinder the yards from swaying when the ship rolls.

Rolls, Master of the. A high officer of the Court of Chancery, ranking next to the Lord Chancellor. He holds his office for life, and is so styled as being keeper of the records of Chancery. (Register, Lord.)

Romagna. A part of the Papal States (q.v.), made up of the four northern legations of Bologna, Ferrara, Forli, and Ravenna ; annexed 
formally to the kingdom of Sardinia, 1860, and now part of the kingdom of Italy.

Romaic. A name sometimes applied to the language of the modern Greeks, who called themselves Romans, by a tradition which has survived the overthrow of the Eastern empire.

Romal. [Hind. rûmâl, $a$ handkerchief.] An Indian silken fabric.

Romance. [Fr. roman, It. romanzo.] 1. A general name for works of fiction in prose or verse, from the Romance languages, in which they were first chiefly written and circulated. 2. (Music.) A simple rhythmical melody, suitable to a story of romance.

Romance languages. Languages which are modifications of the old Italian dialects. These are the languages of Spain, Portugal, Italy, France, Wallachia, and the Grisons of Switzerland. The Provençal, spoken by the Troubadours, is now a patois.

Roman cement. A kind of hydraulic cement, hardening under water.

Romancěro. The Spanish term for a collection of national ballads and romances.

Romanese language. The language of the Wallachians, who call themselves Români, or subjects of the old empire.

Romanesque. Decoration with fantastic representations of animals and foliage (admired in the time of the lower Roman empire).

Romanesque styles. (Arch.) The styles which employed the arch and the entablature together, gradually reducing the latter to the form of a capital. The introduction of shafts, running up from the piers and dividing the upper stories into compartments, marked the point of transition from the Romanesque to the principle of the Gothic styles. (Geometrical style.)

Roman ochre. A rich orange-yellow pigment.

Romany. The language spoken by the gypsies is sometimes so called.

Romanzieri. In It. Lit., poets who treated chiefly of the exploits of Charlemagne and his Paladins. The earliest of these poets belongs to the latter part of the fifteenth century.

Romaunt of the Rose. A translation by Chaucer-some say by another-of the first part of a famous and very popular French allegory, Le Roman de la Rose, of which the first part was by Guillaume de Lorris, and the latter by Jean de Chéun.

Rombowline, or Rumbowline. (Naut.) Condemned rope, canvas, etc.

Rome-scot. A tax on houses in England, formerly paid to the Roman court ; called also Rome-feoh and Peter's pence.

Rondean. [Fr. rond, round.] 1. In Fr. poetry, a little poem of thirteen lines, of which eight have one rime, and five another, divided into three unequal strophes; the two or three first words of the first line serving as the burden, and recurring after the eighth and thirteenth lines. Hence, 2, in Music, (1) Rondo, a light composition of three or more strains, the first closing in the original key, the others recurring, by easy modulation, to the first strain; and (2) more gene- rally, any light piece in which the subject recurs frequently.

Ronde bosse. [Fr., a round swelling.] Sculptured objects in their full forms, as opposed to those in relief.

Rood. [A.S. ród, a rod or pole.] The crucifix, with the images of the Virgin and St. John. The structure on which it is placed is called the roodloft. Most of these were destroyed at the Reformation; but some fine specimens remain, as at Charlton-upon-Otmoor.

Rood-loft. (Rood.)

Roof. [O.E. hrôf.] (Geol.) The rock immediately overlying a bed of coal.

Roof of the World. Local name for highest part of Pamir table-land, 15,000 to 16,000 feet high, in Central Asia.

Room, Roomer, or Going-room. (Naut.) Old term for sailing away from the wind.

Roosa oil. A volatile oil used for adulterating otto of roses ; also called oil of geranium.

Roost. [Icel. rost.] (Naut.) A strong tide or current, especially in a narrow channel, as between the Orkney and Shetland Isles.

Root and Branch Bill. A Bill for entire abolition of episcopacy and of cathedral bodies introduced into the House of Conmmons, May, 1641, passed September, 1642, and, after four months, adopted by the House of I.ords.

Root-fallen. ( $A g r$.) The condition of crops when their roots fail to act properly.

Rope-bands (pronounced Roebins). (Naut.) Small lines fastening the head of a sail to its yard.

Ropes. (Naut.) All cordage above an inch in circumference, used in rigging a vessel.

Roric figure. (Breath figure.)

Rorqual. [Sw. rœr, $a$ tube, hval, whale.] (Zool.) Piked whale, Bălanoptĕra; the largest cetacean, sometimes a hundred feet long, with dorsal fin, skin furrowed; fierce, and of small value. Temperate and cold latitudes.

Rosaceons corollas. (Bot.) Like those of the rose tribe, having five spreading petals, without claws ; e.g. strawberry.

Rosaniline. [Rose and aniline (q.v.).] (Chem.) An aniline dye, from which magenta is derived.

Rosary. [L.L. rosārium, $a$ chaplet.] In the Latin Church, a devotional practice, in which the Lord's Prayer is said fifteen times, and the Ave Maria 150 times ; but as the computation is made by means of Beads, the string of beads has come to be popularly called a R., which consists of fifteen decades, or three chaplets of five decades each.

Rosch-galuth. (Exchmalotaroh.)

Roscius. A Roman comic actor, friend of Cicero, so celebrated that his name has become a proverb for excellence in dramatic art.

Rose de Pompadour. (Bot.) A delicate rose colour, named after the Marchioness de Pompadour, mistress of Louis XV.; also called Rose du Barri, after the Countess du Barri.

Rose-noble. A gold coin of the reign of Edward III., valued at $6 s .8 d$.

Rose of Jericho. (Anastatica.) (Bot.) The name 
is also applied to a mesembryanthemum, the capsules of which have hygrometric properties.

Rŏsěŏla. [L., dim. coined from rŏsěus, rosy.] (Med.) Kose-rash (from its colour), an affection of the skin, in patches ; generally a symptom of some constitutional irritation.

Roses, White and Red. (Eng. Hist.) The emblems or tokens of the houses of York which had the white, and of Lancaster which had the red rose. The Wars of the Roses, after lasting for more than thirty years, were ended by the victory of Henry Tudor over Richard III., on Bosworth Field. Henry united both the titles in his own person-that of Lancaster through his mother, that of York as having married the daughter of Edward IV.

Rosetta Stone. A celebrated stone, discovered at Rosetta, in Egypt, and now in the British Museum. It exhibits three inscriptions : (I) in the sacred character called hieroglyphics; $(2)$ in the enchorial, or popular, a modification of the hieroglyphics; and (3) in Greek. The means were thus furnished for attempting the task of deciphering the Egyptian hieroglyphics; and this task was undertaken by Young and Champollion.

Rosetta wood. A hard Indian wood of a dark orange colour.

Rose window. (Arch.) A circular window, with geometrical or flowing tracery ramifying from the centre. Sometimes called Marigold window and St. Catherine's wheel.

Rosicrucians. In 16 ro a treatise appeared in Germany, entitled The Discovery of the Brotherhood of the Honourable Order of the Rosy Cross. It is ascribed to a Lutheran clergyman, Valentine Andreä. This was followed by a swarm of tracts on the subject, leading people to suppose that the members were sworn to keep the existence of the fraternity a secret for a century after its foundation, and that they were to meet secretly once a year. Hence they were thought to have a connexion with the Freemasons; but there is no evidence that the society ever existed. The title became a term denoting every kind of occult and magical science and practice ; and the Rosicrucians were confounded with Cabalists (Cabala), Illuminati, etc.

Rosière. [Fr.] The girl who wins the rose of the village for good conduct. (Golden rose.)

Rossing. Removing the rough, scaly substance (of bark).

Rosso antico. [It., red antique.] (Geol.) A name for the red porphyry of Egypt.

Roster. [(?) Corr. of register.] (Mil.) Register of the names of officers or soldiers in succession for duty.

Rostra. [L., beaks.] The stage of the Roman forum, from which the orators addressed the people; so called as being decorated with the beaks of vessels taken from the enemy.

Rota. [It.] An ecclesiastical court at Rome, dealing with suits of appeal.

Rota Club. Founded by James Harrington, contemporary of Milton ; a society of " philosophical republicans, who met for the discussion of their theories; ... the Girondins of our
English Revolution."-T. Shaw, Student's Eng. Lit., p $22 \mathrm{I}$.

Rotation of crops. (Agr.) Such a sequence of them as will rest the land and obviate yearlong fallows; e.g. the four-course shift of (I) turnips ; (2) spring wheat or barley ; (3) clover and rye-grass ; $(4)$ oats or wheat.

Rotatory engine. A steam-engine in which rotation is produced by the direct action of the steam, without the use of the reciprocating motion of the piston. The rolipile is a very simple kind of R. E.

Rother. (Rudider.)

Rother-beasts. [O.E. hruðer, neat cattle.] Horned cattle, black cattle.

Rŏtĭfĕra. [L. rŏta, a wheel, fěro, I carry.] (Zool.) Wheel-animalcules, minute aquatic Annŭlŏìda, mostly free-swimming, with ciliated disc, by which they swim, and sweep food into their mouths. By some reckoned among Annelids, sub-kingd. Aunŭlōsa.

Rotten-stone. (Geol.) A soft stone, used for polishing and grinding; chiefly aluminous, with silica and carbonaceous matter; a decomposition of impure limestone by carbonated water.

Roturier. [Fr., L. ruptūra, a breaking up of ground for cultivation.] A plebeian. (Churl.)

Rouble. [Russ. rublyn.] A Russian silver coin, worth about $3^{s .2}$ 2d. ; 100 copecks $=1$ rouble.

Roué. [Fr., lit. one broken on a wheel.] A name applied to the unprincipled and profligate companions of the regent Duke of Orleans, 1715-1723; hence any unprincipled person, as deserving to be placed on the wheel (Littré).

Rouen ware. 1. Blue, and polychrome; characteristic decoration of the latter, a cornucopia with bright flowers. Manufactory established sixteenth century. 2. A kind of thick porcelain was also made at $R$.

Rouge. [Fr., red.] A cosmetic for reddening the cheeks or lips.

Rouge croix. (Her.) One of the pursuivants, named from the red cross [Fr. rouge croix] of St. George.

Rouge et noir. [Fr., red and black.] A game at cards, played on a table marked with red-andblack compartments.

Rough riders. (Mil.) Cavalry soldiers who break in the troop horses.

Roulade. [Fr. rouler, to wheel.] (Music.) A florid passage, a run of many notes sung on one syllable.

Rounce. [Perhaps from Fr. ranche, a round, $a$ rack.] In Printing, the apparatus by which the paper to be printed is run under the platen and out again.

Round churches. Four churches in EnglandSt. Sepulchre, Cambridge, the Temple Church in London, St. Sepulchre at Northampton, and Little Maplestead, have round naves, suggested by the Church of the Holy Sepulchre at Jerusalem.

Roundel. [Fr. rondelle.] A small circular shield borne by foot-soldiers in the fourteenth and fifteenth centuries.

Roundelay, Roundel. I.q. Rondear; also a 
simple rustic melody to which a $R$. might be sung.

Roundheads. The cavaliers in the civil war so named the Puritans, it is said, from the close black skull-cap which they wore; but perhaps from their custom of having their hair cut close to the head.

Round-house. (Naut.) 1. (Deck-house.) 2. Also the square cabin on the quarter-deck, having the poop for a roof, sometimes called the coach in men-of-war; it has a passage all round it. 3. A lock-up in a village or small town.

Roundlet. (Her.) A small round figure borne as a charge.

Rounds of the galley. In Naut. parlance, open expressions of disapproval by one's shipmates.

Round Table, Knights of the. An association of knights brought together by Arthur, for the quest of the Holy Grail. (Arthur, King; Sangreal.)

Roup. 1. In Scotland, an auction; lit. a crying out $[c f$. Ger. rufen, to call] . 2. (Pip.)

Roust. (Roost.)

Route. [Fr., L. rupta, sc. via, a cross-road.] (Mil.) The order for troops marching, with times and places of halting, by which the civil authorities are required to provide facilities of transport and billets.

Route-marching. (Mil.) The exercising along a ruad of troops carrying the full complenient of kit, inuring them to fatigue, for the purpose of keeping them in efficiency.

Rove. 1. A roll of wool drawn out and slightly twisted, for spinning into thread or yarn. 2. (Naut.) (Reeve.)

Roving. (Rove.) Forming roves, or slubs.

Rowan, Fowler's service, Quicken tree. (Bot.)

The mountain ash, Py̆rus aucŭparia [L. auceps, a fowler ] ; ord. Rosaceæ.

Rowel. [Fr. rouelle, from L. rŏtŭla, a little wheel.] The wheel of a spur.

Rowel, Rowelling. (Vet. Surg.) A kind of seton, now but little used; a circular piece of leather, two or three inches in diameter, with a hole in the middle, placed under the skin of the horse.

Rowlocks. (Naut.) Spaces in a boat's gunwale for the oars to work in.

Roxburgh Club. A club formed in commemoration of John, third Duke of Roxburgh, whose library, when sold, realized enormous prices. One of the members was called upon each year to print, at his own cost, some rare book, of which only impressions enough for the club were struck off.

Royal. Paper, usually twenty by twenty-five inches or more.

Royal. (Naut.) 1. R.-sail, a light sail set above the top-gallant, and formerly called topgallant-R. 2. R.-yard, the fourth from the deck, on which the R. -sail is set.

Royal Academy. (Academy.)

Royal dockyards, The. In England these are Deptford, Woolwich, Chatham, Sheerness, Portsmouth, Devonport, and Pembroke.
Royal domain. In Fr. Hist., the domain of the Carolingian kings, which, in the reign of Louis d'Outremer, A.D. 936-954, was narrowed to the city of Laon and a small surrounding district, the result of the growing power of the great dukes and counts who were nominally their vassals.

Royal fishes, i.e. at common law, the property of the Crown: the whale and the sturgeon, when thrown on shore, or caught near the coast; but this right is subject to local modifications.

Royal Institution. A corporation founded by

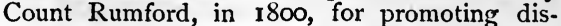
coveries and spreading a taste for science amongst the public generally. Its celebrity is in great measure owing to Sir Humphry Davy and Faraday.

Royal society. A philosophical society, organized 1660, and constituted a body politic by Charles II., in 1662.

Rubble. [Fr. rabascher, to rumble, rattle (Wedgwood).] (Geol.) Accumulations of angular rock-fragment; the result of whatever cause, drift, frost, etc.

Rubble-work. (Arch.) Coarse walling, composed of rough tones of various sizes and shapes, embedded in mortar.

Rubellite. (Tourmaline.)

Rŭbĕŏlæ. [Dim. coined from rŭbēus, red, reddish.] (Med.) Measles.

Rubezahl. (Myth.) A spirit of the Riesengebirge, in Germany, answering to the English Puck.

Rubicon, Passing the. A phrase denoting the taking of a decisive step, the Rubicon being, it was supposed, a small stream forming the frontier of his province, which Cæsar is said to have crossed, B. c. 49 , and so declared himself in open opposition to Pompeius.

Rubidium. A silvery alkaline metal, distinguished by giving two brilliant red [L. rŭbǐdus] lines under spectrum analysis.

Rúbrica. [L.] Red earth; and so the title of a law, and (Eccl.) of a direction, as being written or printed in red ink; hence rubric $=$ order of the Liturgy.

Ruby. [Fr. rubis, from L. ruber, red.] 1. A name applied by lapidaries to several stones, distinguished by their colours, the scarletcoloured being called Spinelle $R$., the pale or rose-red Balais or Balas $R$. 2. A kind of type, as-

\section{London.}

Ruche. [Fr.] A kind of plaited or goffered quilling.

Rudder. ' [Cf. Ger. ruder, L. arātrum, Gr.

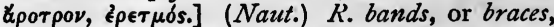
the hinges on which it hangs. $R$. case, or trunk, a wooden casing through which the rudder stock and head pass. R.-chains fasten the $R$. to the stern to prevent its loss if unshipped. R.-head, upper part of the stock. $R$.-pintles, the hooks which fit into the braces. $R$.-rake, aftermost part of $R_{\text {. }} R_{\text {.-stock, its main }}$ piece. 
Rudder-bands. Acts xxvii. 40. Ships were steered anciently-(?) up to the fourteenth century, as in some countries in modern times also - not by hinged rudders, but by two paddles, one on each quarter; these, when not used, were lifted out of the water and secured by lashings, or rudder-bands. (Cf. Eur., Hel., 1536; and so in the Bayeux Tapestry.)

Ruddle. [Welsh rhuddell.] Red ochre. (Hæmatite.)

\section{Ruddock. (Raddock.)}

Rudenture. [Fr., from L. rudens, a rope.] (Arch.) The rope-shaped ornament with which the lower parts of the flutings of columns are often filled.

Rudis indigestaque moles. [L.] A rude and undigested mass; said of confused or ill-arranged matter, as in a book.

Rudolphine Tables. Astronomical tables computed by Kepler on the observations of Tycho Brahe. So called in honour of the Emperor Rudolph II., who on Tycho's death in I60I undertook the cost of their preparation. They are the first tables calculated on the hypothesis that the planets move in elliptic orbits.

Ruff. (Ornith.) Gen. and spec. of wadingbird, about twelve inches long; male develops large purple-black chestnut-barred ruff in breeding season; the hen is called the Reeve. $\mathrm{N}$. Europe, N. Asia, Hindustan. Măchētēs [Gr., a fighter] pugnax, fam. Scŏlopācĭdæ, ord. Grallæ.

Ruffle of drums. (Mil.) A gentle continutous roll on the drums of a regiment.

Rufflers. In Naut. slang, beggars who pretend that they have served in the wars.

Rugging. A coarse cloth for wrapping blankets.

Rule. [A.S. regol, L. regŭla.] 1. In Law, an order of the superior courts of common law. 2. (Eccl.) (Regulars.)

Rule of three. (Arith.) The rule for finding a fourth proportional to three given numbers.

Rules of the road. (Naut.) Those by which it is determined which of two vessels is to give way to the other: $e . g$. a steamer gives way to a sailing-vessel; a sailing-vessel running free, to one sailing near the wind ; one on the port, to one on the starboard tack.

Rumble. 1. A revolving cask used to polish small articles by their mutual friction. 2. A box behind a carriage, with a seat above it.

Rumbling drain. One made by throwing loose rubble stones into the trench.

Rumbo. In Naut. language, rope stolen from a royal dockyard.

Rumbowline. (Rombowline.)

Rümen. [L., throat, gullet.] (Anat.) The cud, or first stomach of a ruminant.

Rūminantǐa [L.], Ruminants. (Zool.) Those mammals of the ord. Ungŭlāta (hoofed animals) which cheze the cud; i.q. Pěcŏra of Linnæus.

Rummage. (Naut.) 1. Search by officers of customs for contraband. 2. Contraband goods found concealed.

Rummer. [Ger. römer.] A drinking-cup.

Rump, The. (Long Parliament.)
Runagate. [Fr. renegat, from L. renegāre, to deny.] A vagabond; one who apostatizes; a renegade.

Runcinate leaf. [L. runcina, a plane, a large sazw.] (Bot.) Having curved indentation, and lateral lobes turned backwards; e.g. dandelion.

Runes. The letters of the Futhorc, or alphabet of the Gothic tribes, obtained by them from the Greeks of the Greek colonies on the shores of the Black Sea.

Rung. [Ger, runge, a short thick bar.] One of the rounds of a ladder.

Runner. 1. One of the curved pieces on which a sledge slides. 2. A channel on the top of a mould into which the molten metal is poured.

Running-part of a tackle. (Standing-part.)

Running title. The title of a book as printed on the top of each page.

Rupee. [Skt. rûpuya, from rûpa, shape; and according to Pânini, = struck with the shape of a man; very important, as giving a very early date to coinage with human figure impressed. (see Chambers's Encyclopadia, s.v.).] A silver coin weighing I 80 grains, of which 165 are pure silver, and worth about Is. Iod.; this is the Company's R., which is of the same weight and purity as the Madras R. ; the Sicca R. is worth a fifteenth part more, i.e. about 2s. Lac, Lakh, 100,000 rupees. Crore, 100 lakhs, or $10,000,000$ rupees.

Rupert's drop (from Prince Rupert). A glass drop with a long tail, which bursts into frag. ments when the tail is broken.

Ruptuary. One not of noble blood, a Rotorier.

Rural dean. (Eccl.) An officer, not having jurisdiction, who within a certain district gathers information for the bishop as to the conduct of the clergy, condition of ecclesiastical buildings, etc., the opinion of the clergy as expressed in meetings.

Ruse de guerre. [Fr., a trick of war.] A stratagem.

Rus in urbe. [L.] Country in town; said of situations which are thought to have the advantages of both.

Rusma. [Turk. khyryzma.] A compound of iron and quicklime, used as a depilatory.

Russia leather (made in Russia). A soft leather scented with an oil obtained from birch bark.

Rustem. In Pers. Myth., a hero who slays Isfendyar by casting a thorn into the one spot where he is vulnerable.

Ruta cæsa, or Ruta et cæsa. [L.] In Rom. Law, things dug up, and things cut down, which were movable and not fixtures, and therefore did not pass with the land sold. (Quicquid plantatur solo.)

Rūta-mūrāria. [L.] (Bot.) Wall-rue, ord. Rutaceæ. (Asplenium.)

Ruthenium: A hard grey metal, extracted from platinum ore.

Rutilate. [L. rutilāre, to shine.] To emit rays of light. 
Rye-House Plot. (Eng. Hist.) A plot-so called from the intention of carrying it into execution at the Rye House, near Newmarketfor seizing Charles II., and so bringing about the redress of grievances. For his share in this conspiracy, Lord William Russell was executed, July, I683.

Ryot. [Ar., a serf, or peasant.] The cultivators of the soil in India. In the Turkish empire they are called Rayahs.

S.

s. A letter common to all languages. As an abbrev., it stands for L. sacrum [sacred], sibi [for himself, herself, etc.], socius [fellow], society, solo, south, etc.

Sabaism. [Heb. sabaoth, army or host of heaven.] The worship of the heavenly bodies; a religion which had its special stronghold in Chaldea, the birthland of astronomy.

Sabaoth. (Sabaism.)

Sabbatarians. (Eccl. Hist.) Various sects have been so called; among these certain Anabaptists in the sixteenth century, who kept the Jewish sabbath.

Sabbath day's journey. Acts i. 12; 2000 cubits, or about six furlongs, from the wall of Jerusalem; in compliance, according to Jewish doctors, with the injunction of Exod. xvi. 29, "Let no man go out of his place on the seventh day" (to gather manna); taken in connexion with the definition of "suburbs," or pasturegrounds, in Numb. xxxv. 5 .

Sabbatians. (Eccl. Hist.) In the fourth century, the followers of Sabbatius, a Novatian bishop.

Sabbatical year. By the Jews every seventh year was so called, according to the commands given in Exod. xxiii. 10; Lev. xxv. 3, 20. (Jubilee year.)

Sabbatic river. (Intermittent springs.)

Sabellians. (Eccl. Hist.) The followers of Sabellius in the third century, who regarded the Father as the sole Person, and the Son and the Holy Spirit as attributes or emanations from Him. This scheme has been known in later times as that of the Modal Trinity. The followers of Praxeas, who adopted these views, asserted that the Father had united to Himself the human nature of Christ, and were hence called Monarchians; while, as holding that the Father suffered in the death of Christ, they were called Patripassians.

Sabians. (Eccl. Hist.) A Christian sect, known also as Christians of St. Fohn.

Sabica, Savicu wood. A Cuban timber, used for shipbuilding.

Sable. [O.Fr. for the animal called the sable.] (Her.) The black colour in coats of arms, represented in engraving by vertical and horizontal lines crossing each other.

Sable iron. A superior kind of Russian iron, originally stamped with the figure of a sable.

Sabot. [Fr.] A wooden shoe.

Sabre. [Fr.] (Mil.) Broad, heavy-bladed sword worn by cavalry.

Sabretasche. [Sabre (q.v.), Ger. tasche, pocket.] (Mil.) Flat leather case for holding papers, suspended with the sword on the left side by horsemen.

Sabulous. [L. sabulosus, from săbŭlum, coarse sand.] (Med.) Said of sandy, gritty deposits in the urine.

Sao. [L. saccus, a sack, bag.] (Anat.) Any small cavity in the body, pouch, bag, cyst.

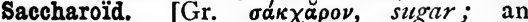
Eastern word.] (Geol.) In texture like loafsugar; as white statuary marble.

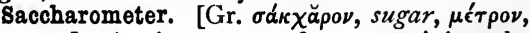
measure.] An instrument for ascertaining the quantity of sugar in a solution. The common $\mathrm{S}$. is a kind of hydrometer, the reading depending on the specific gravity of the solution. In the polarizing $\mathrm{S}$. the determination is made by observing the angle through which the solution will turn the plane of polarization of a ray of polarized light transmitted through it.

Sachentege. A very heavy instrument, "which two or three men had enough to do to carry, . . . fastened to a beam, having a sharp iron to go round a man's throat and neck, so that he might no ways sit, nor lie, nor sleep, but he must bear all that iron."-English Chronicle.

Sachet. [Fr.] A bag or packet containing scent.

Sack. [L. saccus, $a$ bag.] Of wool, 26 stones, or 364 lbs. ; of flour, 280 lbs.

Sackbut (Dan. iii.), or Sabeca [lit. elder wood, because made of it]. 1. Some kind of harp, probably Egyptian; sabeca, L. sambūca, Eng. sackbut, being different forms of some Oriental word. 2. But the Eng. S. was a kind of trombone, a bass trumpet with a slide.

Sacrament. [L. sacramentum.] 1. Properly the military oath of obedience to their general taken by the Roman soldiers. Hence, 2, (Eccl.) Baptism, in which the neophyte bound himself to the service of God. The term is now applied to Baptism and the Eucharist, as being, both, outward signs of inward grace.

Sacramentary. Anciently, in the Latin Church, a book containing the Collects, Prefaces, and Canon of the Mass. The most important sacramentaries are those of Leo and Gelasius in the fifth, and of Gregory the Great in the sixth, centuries.

sacred College. The College of Cardinals at Rome. (Cardinal.)

sacred Wars. In Gr. Hist., the name given to three wars : the first said to have been waged against the people of Kirrha in the time of Solon; the second between the Thebans and Phokians. $357-346$ B.C. ; the third, 339 B.C. 
Sācrǔficāti. [L.] Christians who repented, having sacrificed to idols, to avoid condemnation at a heathen tribunal. Called also Thūrĭfícati, having offered incense.

Sacring bell, or Sanctus bell. In the Latin Church, a bell used in Mass at the time of the elevation.

Sacristan. [L.L. sacristanus.] The person to whose charge the vestments used in divine service are committed. The word is now corrupted to Sexton.

Sacrum, Os sacrum. [L., sacred bone ; according to the rabbis, because containing the germ of the future body; others say as being connected with sacrifice.] (Anat.) The triangular bone at the lower part of the vertebral column, the key-stone of the pelvic arch, wedged in between the ossa innōminata.

Sacti. In Hind. Myth., the female power of the universe, as distinguished from the male power, Siva. The word is the same as Suttee. (Trimurtee.)

Sadder. [Pers.] A summary of portions of the Zend-Avesta. The book is of very doubtful date.

Saddleback. In popular language, $=a n t i$ clinal strata (q.v.).

Saddlebow. [O.E. sadelboga.] The arch in front of a saddle.

Sadducees. A religious school among the Jews, which allowed authority to the written Law only, and none to the oral law; hence they denied the future life, on the ground that the written Law was silent on the subject. They are said by some to be so named from Zadok, a disciple of Antigonus of Socho. Others regard the word as denoting the righteous.

Safe-conduct. Either a guard or a written warrant, protecting a person in an enemy's country.

Safety-lamp. (Davy lamp; Geordy lamp.)

Safety-valve. A valve in the boiler of a steam-engine : ( $\mathrm{I}$ ) external, held down by a regulated force so as to open when the steam pressure exceeds a certain amount, and thus both relieve the pressure and give notice to the engine-man ; (2) internal, to relieve the pressure of the external air by letting in air when the cooling of the stean produces a vacuum within the boiler.

Safflower. [Eng. saffron and flower.] The dried flowers of bastard saffron, used as a dyestuff.

Saffron. [It. zafferano.] Cant. iv. I4 ; Crŏcus sătivus, Ar. kurkum, the sweet-smelling dried stigmas of which are used for perfume, seasoning, etc.

Sagas. [A Teut. and Scand. word, akin to sagen, to say.] Ancient works giving the mythi$\mathrm{cal}$ and the early historical traditions of Northern Europc. Among the mythical sagas the most important are the Voluspa, Hervarar, Volsunga, and Vilkina or Wilkina, with the saga of Ragnar Lodbrog. Many of the historical sagas are collected in the Heimskringla of Snorro Sturleson.

sagathy. [Fr. sagatis.] A mixed stuff of silk and cotton, also called Sayettc.
Sage, or Sage-brush. (Bot.) A general name in some of the western states of $\mathbf{N}$. America for some spec. of Artemisia, which impart a greyish appearance to large tracts of country.

sagene. The Russian fathom; it equals three arshines, i.e. about seven English feet.

Sagger. [Corr. from safeguard.] A pot in which fine earthenware is baked.

sago. [Malay sâgu.] A kind of granulated starch, prepared from the pith of several $E$. Indian palms, and used as food.

Sails. (Naut.) Square-S., courses, topsails, topgallant-sails, royals, and skysails. Fore-andaft $S$., jibs, staysails, trysails, boom, main, and fore sails, spanker or driver (on the mizzen), gaff topsails, studding-sails, and the flying-kites. Sheer-S. (Driftsail.) Lug-S., nearly square, set on a slanting yard, not suspended from the middle, and with the longer arm the higher.

Sainfoin. [Fr., from L. sānum fœnum, sound hay.] (Bot.) Common, wild, clover-like plant, Onŏbry̆chis sătiva, ord. Leguminaceæ, cultivated

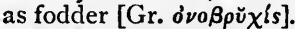

St. Andrew's cross. (Cross.)

St. Anthony's cross. (Cross.)

St. Anthony's fire. Erysipelas (q.v.), believed to have been miraculously healed by him.

St. Cuthbert's beads. In N. England, joints of the stems of encrinites, formerly pierced for rosaries (see Marmion, canto ii. Ib).

St. Elmo's fire. (Elmo, Fire of St.)

St. James, Iiturgy of. (Liturgy.)

St. John, Liturgy of. (Liturgy.)

St. John of Jerusalem, Knights of. (Orders, Religions.)

St. John's bread. (Algaroba.)

St. Iuke's summer. The fine weather frequently occurring about October 18 ; so $S t$. Martin's summer, in the Mediterranean, about November II.

St. Martin's summer. (St. Iuke's summer.)

St. Simonians. (Hist.) The followers of Claude Henri, Count of St. Simon (1760-1825), who wished to set up a theocratic government, in which all property should be held in common.

st. Sophia. The Church of, at Constanti. nople, is now a mosque. It was built by Justinian, and dedicated, A.D. 537, in the name of

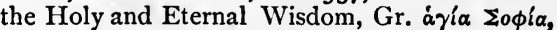
which answers to the Logos of the New Testament. The Latin term, Sancta Sophia, which

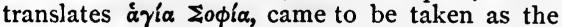
name of a human person, and St. Sophia was said to have been martyred along with her three daughters, Fides, Spes, Carĭtas, Faith, Hope, Charity.

St. Vitus's dance. 1. Now i.q. chörēa (q.z'.), but originally, 2, dancing manic (q.v.), or tarantism; so called from pilgrimages, in Swabia, to the chapel of St. Weit.

Saints, Island of the. Ireland, which received Christianity from Palladius in the fourth century and from St. Patrick in the fifth cen. tury. Her schools were the resort of foreigners ; amongst her missionaries was St. Columba, Apostle of the Hebrides, 540-615.

Saker. (Musket.) 
Salaam. [Heb, shalom, salem, peace.] The ordinary salutation in Eastern countries.

Salade. [Sp. celada, L. cælata, carved helmet.] Metal head-covering, shaped like a sou'-wester, worn by archers early in the fifteenth century.

Saladier. Crescent-shaped plate for salad [It. salata].

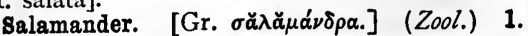
Lizard-like amphibian, as the newt, or watersalamander (Triton), with compressed tail; land-salamanders (Salamandra) have round tails. Central and S. Europe and N. Africa. Ord. Urŏdēlæ. 2. A fabulous creature which was supposed to be able to live in fire.

Sal ammoniac. [L. sal, salt.] (Chem.) Chloride of ammonium.

Sal Atticum. [L., attic salt.] The brilliant wit of Athenian writers.

Salep. [Ar. sahleb.] A substance prepared from the root of several kinds of orchis, used as food or for making a drink like tea.

Salic law. (Hist.) The law of the Salian Franks, who held the country between the Meuse and the Rhine. It was reformed by Charles the Great (Charlemagne), 798. It especially provides that no Salic land shall pass into the hands of females; but the extent of these lands has been a subject of keen controversy. To this rule, however, has been ascribed the exclusion of females from the French crown. The claim of Edward III. was barred only by this law. Hence arose the Hundred Years' War between England and France. (Bretigny, Peace of.)

Salicylic acid. An acid prepared from the bark of a kind of willow [L. salix].

Salient. (Her.) Springing forward [L. salientem].

Salient angle. (Fortif.) One in which the works project towards the country.

Salinas. [L. sălinæ, salt-zvorks.] In S. America, once sea-reaches and lagoons, now great plains and elevations, with white saline incrustation.

Salivary glands. [L. sălīva, spittle.] (Anat.)

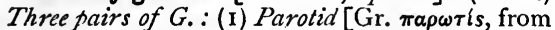

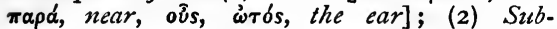
maxillary, sub maxilla [L., under the jaze-bone]; (3) Sub-lingual, sub linguā [under the tongue]. Each conveys into the mouth secretions which, mixed with those of the follicles of the mucous membrane, constitute saliva.

Salivation. An abnormally abundant flow of saliva, generally by the action of mercury on the parotid glands, sometimes spontaneous.

Salle-a-manger. [Fr., a room for cating.] A dining-room.

Sallenders. (Mallenders.)

Sallet-herbs. [Fr. salade, from It. salata, or insalata, salted.] Herbs for salad.

Sallyport. (Fortif.) 1. Opening cut in a parapet for a passage through it, generally barricaded by a strong door. 2. A gate from which sallies [Fr. saillie] are made.

Salmagundi. [Fr. salmigondis.] A dish made of chopped meat and pickled herring, with oil, vinegar, pepper, and onions.

salmasius. (Defensio populi Anglicani.)
Salmon peal, s. peel. (Grilse.)

Saloop, or Sassafras tea. With milk and sugar, a drink still sold to the working classes in the early morning in London. (Sassafras.)

sal prunella. (Chem.) Fused nitre in cakes or balls.

Sal soda. [L. sal, salt, and soda.] (Chem.) Impure carbonate of soda.

Salsŏla. [L. salsus, salted.] (Bot.) A gen. of plants, ord. Chēnŏpŏdiaceæ, many spec. of which yield kelp and barilla.

Salt. [L. sal, salt.] Any chemical compound of an acid and a base.

Saltant. [L. saltantem, dancing.] (Her.) Springing forward.

Salt-box. (Naut.) Box under the charge of the cabin-door sentry, and containing great-gun ammunition for instant use.

Salt-cake. Crude sulphate of sodium, obtained in the manufacture of soda (carbonate of sodium) by heating salt mixed with oil of vitriol.

Salt-cat. A mixture of salt and lime for pigeons. Other ingredients are sometimes adde.d.

Salt-eel. In Naut. slang, a rope's end.

Salterns. Salt-works.

Saltigrades. [L. saltus, a leap, grădior, 1 proceed.] (Entom.) Tribe of spiders which spring upon their prey.

Saltire, Saltier. [Fr. sautoir.] (Her.) An ordinary consisting of a cross in the form $X$, otherwise called St. Andrew's cross.

Salt of lemons. (Lemons, Salt of.)

Salūs populi suprema lex. [L.] The welfare of the people is the supreme law, in the sense that everything else is to be subordinated to this end.

Salvā dignitate. [L.] Saving his dignity.

Salvage. [L. salvus, safe.] (Naut.) 1. An allowance to those, other than the crew, who rescue a ship or goods from the perils of the sea or from enemies. 2. The goods, or thing saved.

Salvo jure. [L.] Saving his right.

Sal volatilě. (Chem.) Carbonate of ammonia.

Salvo pudore. [L.] Without offence to modesty.

Salvum fac regem. [L.] God save the king. Salvam fac reginam, God save the queen.

Salzkammergut. [Ger., salt-exchequer pro. perty.] A name given to a district forming the south-west angle of Upper Austria, wedged in between Salzburg and Styria, traversed by the river Traun, about 250 square miles; its springs and mines yielding an enormous supply of salt ; a Government monopoly. Called also Austrian Switzerland.

Samakeen. (Naut.) Turkish coasting-vessel.

samanæans. Indian philosophers who are specially distinguished from the Brahmans by those who mention them. The name seems to be found in the Hind. schamman, a sage, in the Cha-men of the Chinese, and the Sammonlodom of Siam.

Samăra. [L., seed of the elm.] (Bot.) An indehiscent fruit, producing a membranous winglike expansion from its back or end; e.g. maple, sycamore. 
Samaritans. In Jewish Hist., properly the people of Samaria, a city built by Omri, father of Ahab. Generally, the population of the northern part of Palestine after the Captivity, which, as being greatly mixed with foreigners, was looked down upon by the people of Judxa.

Sama Veda. (Veda.)

Sambūca. (Sackbut.)

Sambucco. (Naut.) An Arabian pinnace.

Samian ware. A lustrous ware (like dull-red sealing-wax) with relief ornaments, originally made in Samos, afterwards in Italy, Gaul, Germany; found throughout the Roman empire. (Aretine ware.)

Samiel. [Turk. sam-yeli, from Ar. samm, poison, Turk. yel, wind.] A hot, destructive wind blowing from the desert. (Simoom.)

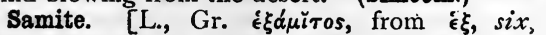

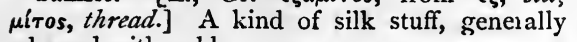
adorned with gold.

Sammarinesi. Inhabitants of the republic of San Marino, in Italy.

Sammuramit. (Semiramis and Ninus.)

Samoyeds. (Geog.) Tribes inhabiting part of the coasts of the Arctic Ocean.

Bamp. [N.-Amer. Ind. sâpac, softened.] A kind of porridge made of bruised maize.

Sampaan, or Sampan. (Naut.) A Chinese hatch-boat, used for passenger traffic, and also as a dwelling by Tartar families.

Samphire, Sea samphire (i.e. St. Pierre, St. Peter's plant). (Bot.) Crithmum [Gr. крi $\theta \mu \nu \nu]$ măritimum, an aromatic plant, on seaside rocks ; ord. Umbelliferæ; a favourite ingredient in pickles, and used medicinally.

Sampi. An old Phœnician letter, retained in Greek as a numeral $=900$. (For its history and changes, see Taylor's History of the Al. phabet.)

Samshu. [Chin., thrice-fired.] A spirituous drink, distilled from water in which boiled rice has been long fermented.

Samson's-post. (Naut.) A movable post, to which a leading, or snatch, block is fastened, enabling more men to haul on a rope.

Sanchoniathon. A writer who is said to have lived in the time of Semiramis. The fragments which bear his name are late forgeries.

sancta sanctorum. [L.] Holy of holies. Hence sanctum is used to denote any place strictly set apart, and not open to strangers.

Sanctōrāle. [Eccl. L.] A book containing lives of saints. (Acta sanctorum.)

Sanctus. (Ter-Sanctus.)

Sanctus bell. (Sacring bell.)

Sancus. (Semo Sancus.)

Sandal. (Naut.) An open vessel of Barbary, long and narrow, and having two masts.

Sandalwood. [Ar. zandal.] An odoriferous wood, the produce of several spec. of Santalum, Sandalwort; trees or shrubs of Asia, Australia, Pacific Isles.

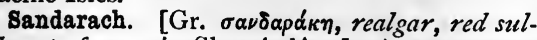
phuret of arsenic, Skt. sindûra.] A transparent African resin, used for varnish, etc. (Pounce.)

Sand-bath. A box of hot sand, used by chemists for heating vessels, etc.
Sand-blindness. An affection, in which small particles appear to fly before the eyes.

Sand-crack. A crack in the thinnest part of the hoof of a horse ; one cause of which is excessive dryness.

Sandemanians. In Eccl. Hist., a small sect, who are called in Scotland Glassites, from John Glass, who, in 1727 , denounced all Church establishments, and formed his followers after what he regarded as the primitive model. In 1755, the letters of his son-in-law, Robert Sandeman, led to the formation of similar bodies in London and elsewhere. The Sandemanians do not acknowledge the name.

Sanderling. (Ornith.) Ruddy plover; wadingbird about eight inches long. Everywhere but Australia. Gen. and spec. Călĭdris, fam. Scǒlōpāč̌dæ, ord. Grallæ.

Sanders, Red sanders. (Bot.) Red sandalwood.

Sandhi. [Skt., a binding, from sam, together, dha, to place.] The symphonic system in Sanskrit grammar, relating to words in that language. (Assimilation.)

Sandiver. [Fr. sel de verre, salt of glass.] (Glass-gall.)

Sandstone. (Geol.) Sand consolidated by pressure, or cemented by oxide of iron, clay, etc. s., limestone, clay, are the three great divisions of sedimentary rock-masses.

Sand-strake. (Garboard-strake.)

Sand-warpt. (Naut.) 1. Left on a shoal by the tide. 2. Striking on a shoal at half-flood. (Warp.) Sane memory. In Law, in making contracts, in commission of crime, etc., that essential of sound mind and clear recollection which infants, idiots, lunatics, the childish, have no:.

Sangaree. [Sp. sangria, blood-letting.] A beverage of red wine, lemon, and water (from its colour).

Sangfroid. [Fr., L. sanguis frigidus.] Cold blood. Hence coolness, assurance.

Sangreal. In the Arthurian legend, the platter, or dish, in which the Saviour ate the Passover before his passion, and in which Joseph of Arimathæa gathered up the drops of blood which fell from His side when pierced by the centurion's spear. On this sustenance alone Joseph was nourished through his imprisonment of fortytwo years; and when, having been brought by him to Britain, this vessel was shrined in a magnificent temple, it supplied to all the most delicious food, and preserved them in perpetual youth. It was afterwards lost, and the search for it became the great work of the knights of King Arthur's Round Table. Lancelot all but succeeded in the quest, which was at length achieved by his son, the prince Sir Galahad. The name is said to be made up of the two words, sang real, which are declared to mean real blood, although they should mean royal blood; but the second word is the L.L. gradale, L. crater, Gr. крати́p, a сup (Skeat, Etym. Eng. Dict.).

Sanguine. [L. sanguineus, bloody.] (Her.) The blood-red colour in coats of arms, represented in engraving by diagonal lines crossing each other.

sanguisuges. [L. sangui-sūga, a bloodsucker.] 
(Zool.) 1. Leeches. 2. Hemipterous insects ; as the bed-bug (C.ìmex lectŭlāriuus).

Sanhĕdrim, more properly Sanhedrin. [A

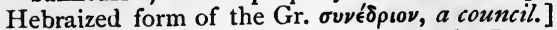
The highest judicial tribunal among the Jews, consisting of seventy-one members, including the high priest.

Sanhita. (Veda.)

Sănies. (Ichor.)

Sanio-purulent. (Med.) Having a combination of sanies and pus.

Sanjak. The Turkish word for a standard. The Sanjak sherif is the S. of the prophet.Finlay, Hist. of Greece, v. 250.

Sans-culottes. [Fr.] A contemptuous name, denoting the beggary of those who go with their legs bare ; applied to the Jacobins of the French Revolution, but afterwards assumed by themselves as a title of honour. In the new calendar the five supernumerary days were called Sansculottides.

Sans-façon. [Fr.] Without ceremony.

Sanskrit. The name, meaning lit. polished, of the ancient language of the Hindus, which ceased to be spoken in the fourth century B.c. The attention of European scholars was drawn to it by Sir W. Jones. The consequences of his discovery have been most important. (Comparative grammar; Comparative mythology; Prakrit; Veda.)

Sans peur et sans reproche. [Fr.] Without fear and without reproach. Said of the Chevalier Bayard (1476-1524).

Sans phrase [Fr.] = in few words; going straight to the point, perhaps somewhat bluntly.

Sans-souci. [Fr., without care.] Free and easy.

Santaline. [Fr.] (Chem.) The colouring matter of red sanders. (Sanders.)

Santonine. [Gr. $\sigma \alpha \nu \tau \delta \nu: o \nu$, zeormwood.] The bitter principle of wormwood, obtained from the flower-heads of some of the Artemisias; a most powerful anthelmintic.

Sap. [Fr. sape, L. sappa, a pick, in Isidore of Seville (Brachet).] (Mil.) Trench covered on one side by gabions, by which a fortress is approached for purposes of attack. S.-faggot is a short fascine for placing between gabions. $S$.roller is a large gabion filled with fascines, for rolling on the ground and protecting the sapper working behind it.

Sapan wood. [Malay sapang.] A red dyewood from Siam, Pegu, etc.

Sap green. A water-colour, made from the juice of buckthorn berries.

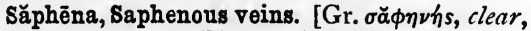
distinct.] (Anat.) The two long, important subcutaneous veins, extending from the foot to the groin.

Sapiens dominabitur astris. [L.] The wise man will rule the stars; said of those who rise above astrological or other superstitions.

săpientis supplet ætātem. (Malitia supplet ætatem.)

Săpor. [L.] Taste.

Sapphic. The name of a Greek stanza, or strophe, supposed to have been invented by Sappho, consisting of three verses of eleven syll., followed by an Adōnic verse of five syll., a dactyl and a spondee.

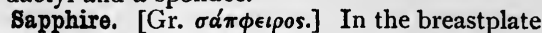
of Aaron, Exod. xxviii. 18, and of Rev. xxi. I9; probably Lapis lazuli (q.v.). (Sapphire is pure alumina, mostly blue, sometimes colourless.)

Sapsago. [Ger. schabzieger, from schaben, to scrape, zieger, whey.] A dark-green Swiss cheese.

Sarabaites. Ancient Eastern monks, who are supposed to be the same with the Remoboth mentioned by St. Jerome.

Saraband. [Sp. zarabanda.] 1. A stately Spanish dance, with castanets, in triple time, of Moorish origin. 2. Music for the S., or of a similar kind; e.g. those of J. S. Bach, Handel.

Saragossa, Maid of. [Sp. Zaragoza, L. Cæsar-Augusta.] Angostina, the life and soul of the city, when besieged by the French, and taken, 1809, after a most heroical defence.

Sarānyû. (Erinyes, The avenging.)

Sarcocolla. [Gr. $\sigma a ́ p \xi, \sigma \alpha \rho \kappa \delta ́ s, ~ f l e s h, \kappa \delta \delta \lambda \lambda \alpha$, glue.] A gum-resin from Arabia and Persia.

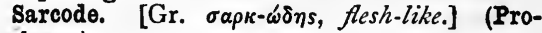
toplasm.)

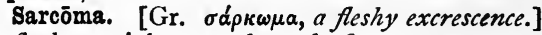
A fleshy, painless, moderately firm tumour.

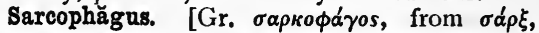
flesh, $\phi a \gamma \epsilon i v$, to eat.] A stone coffin. The stone of Assos, in Asia Minor, used for such coffins, was supposed to corrode bodies entirely in forty days; hence the name.

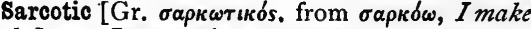
fleshy], or Incarnative. (Med.) Helping the flesh to grow.

Sard, Sardius. [Gr. $\sigma a ́ p \delta$ เos.] (Chalcedony.)

Sardius. Of Rev. xxi. 20; fine carnelian.King's Precious Slones.

Sardonic laughter. (Risus sardonicus.)

Saree. [Hind.] An embroidered scarf ot gauze or silk.

Bargasso, Gulf-weed, Tropic grape. (Bot.) Sargassum vulgare, ord. Algæ; a seaweed, growing in immense fields in some parts of the Atlantic, Pacific, and Indian Oceans; the $S$. Sea is where the Gulf Stream sends off its more southern branch towards the Azores.

sarking. Thin boards for putting under slates, etc.

Sarong. A kirtle worn by Eastern women.

Saros. A name which the Chaldeans are supposed to have given to a period of 223 luna. tions, or 18 years 1o days, after which eclipses recur in nearly the same order and magnitude.

Sarpēdōn. [Gr.] In the tale of Troy, a Lycian chief slain by Patroclus. The carrying of his body to his home by Sleep and Death (Hypnos and Thănătos) has furnished a subject for well-known sculptures. (Hermes.)

Sartōrius [L. sartor, a tailor], Tailor's muscle. (Anat.) A muscle of the thigh, serving to throw one leg across the other.

Sartor Rĕsartus (The Tailor Re-stitched). By Thomas Carlyle, professing to review a German work on dress, attacks the garb of falsehood 
and unreality by which true ideas are often overlaid in human life.

\section{Sarum Use. (Use.)}

Sash. (Mil.) Scarf worn round the waist or over the shoulder by combatant officers, originally intended for carrying the wearer in when wounded.

Sasine and livery. (Seisin, Livery of.)

Sassafras. [L.saxiffăgus, rock-breaking.] (Bot.) A gen. of Lauraceæ, trees; of which $\mathrm{S}$. off ícinale is a native of $\mathrm{N}$. America. The root, wood, and bark have stimulant and sudorific properties: of the leaves, young shoots, and fruits various medicinal and other preparations are made. (Saloop; Saxifrage.)

Sassanides. A dynasty of Persian kings, founded by Ardshir (Artaxerxes), A.D. 226.

Sassernach. The name by which the Teutonic conquerors of the British Islands were known to the Celtic inhabitants, the Saxons being those with whom they were most in contact.

Sassoline. [Fr. sassolin.] Native boracic acid.

Sat cito, si sat tnto. [L.] Quick enough, if safe enough.

Satellite. [L. sătellĭtem, an attendant.] A small or secondary planet revolving round a larger or primary planet; as the moon round the earth.

Satin-wood. (Bot.) A lemon-coloured wood from India, taking a lustrous finish, and used chiefly for veneering.

Satire. [L. satĭra, a word of uncertain origin.] At first a poem full of miscellaneous matter without orderly method; but afterwards, a composition chastising or ridiculing vice.

Satis, superque. [L.] Enough, and more (than enough).

Sătiva, fem. of L. adj. sătivus. In Bot., cultivated; opposed to Agrestis, wild.

Sat pulchra, si sat bona. [L., fair enough, if good enough.] Handsome is that handsome does.

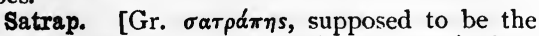
same as the Pers. schah-derbân, the king's doorkeeper.] The title of provincial governors in the ancient Persian kingdom.

Satsuma ware. A yellowish-white Japanese fayence, slightly rose-tinted, with the glaze slightly crackled, and decorated with flowers and landscapes. (Crackle.)

Saturation. [L. satŭratiō, -nem.] (Chem.) The combination of two substances in such proportion that no more of either will enter into the combination.

\section{Saturn. (Planet.)}

Saturn. [L. Saturnus, Sæturnus, akin to sero, sătum, $I$ soze.] An Italian god of seed-time and harvest. His wife was named Ops, wealth or plenty. By late poets he was identified with the Greek Krŏnos, Cronus, with which he has nothing in common.

Saturnālia. [L.] The feast of Saturn, in which a large amount of licence was allowed, slaves being waited on at table by their masters. Hence any time of wild and furious merriment. (Fools, Feast of.)
Satyr. [Heb. sā'îr (Isa. xiii. 2r), the hairy one.] (Bibl.) Probably some large kind of ape.

Satyric drama. In the Greek theatre, a semi. burlesque piece presented after the performance of the regular dramatic Trilogy. The fou formed the Tetralogy.

Saucisson. [Fr., a sausage, saucisse, L. salsitia.] (Mil.) Hose of coarse cloth, about threequarters of an inch in diameter, for conveying the train of powder to the charge of a mine.

Sauerkraut. [Ger., sour cabbage.] Cabbage salted and allowed to ferment.

Saunders blue. [Fr. cendres bleues, blue ashes.] (Ultramarine.)

Saunterer. Properly one who has performed the pilgrimage to the Holy Land [L. Sancta Terra]. Hence a wanderer, or vagabond.

Saurǐa, Saurians. [Gr. oav̂pos, a lizard.] (Zool.)

1. Lizards (Lăcertǐlìa) and crocodiles (Lörīcāta). 2. Any reptile externally like a lizard.

Sauropsǐda, Sauropsidans. [Gr. oav̂pos, lizard, $\check{u} \psi i s$, appearance.] A name for the combined classes of birds and reptiles.

Sauterelle. [Fr., a grasshopper.] An instrument used by stone-cutters and carpenters in measuring angles.

Sautry. A dulcimer. (Psaltery.)

Sauve qui peut. [Fr.] Let him save himself who can; said to troops utterly defeated, as (it is alleged) by Napoleon after the last charge at Waterloo.

Savanna. [W.-Ind. savana.] An open plain or meadow, without wood. The $\mathrm{S}$. is not a prairie ; it is a level tract of land, one or two feet lower than the level land about it-(?) the basin of a former lake, filled up by soil and vegetable matter-clothed in perpetual verdure, abounding in flowers; except in winter, when it is under water. The Prairie differs not from other land except in the absence of timber, supposed to have been previously destroyed.Bartlett's Americanisms.

Savants. [Fr., L. sapientes.] Learned men. Save-all, or Water-sail. (Naut.) One set below the lower studding-sail.

Saveloy, or Cervelat. [It. cervellāta.] A kind of sausage, properly made with brains [It. cervello, $L$. cerebellum]

\section{Savicu wood. (Sabica.)}

Savitar. In Hind. Myth., the golden-handed sun.

Savoir-faire. [Fr., to knozv (hoze) to do.] The power of contriving and executing successfully. "To have one's wits about one."

Savoir-vivre. [Fr.] Good breeding, good manners.

Savoy Conference. Held at the Savoy Palace, London, I66I, between twelve bishops, with others, and certain Presbyterians, to ascertain what concessions, as to the Liturgy, would conciliate the latter.

Sawyer's dog. An iron bar turned down at each end for driving into two contiguous beams of wood and clamping them tightly together.

Saxifrage. [L. saxifrăgus, breaking rocks.] 1. A name given to many plants supposed to possess the power of splitting rocks, like the 
Snake leaves of Teutonic and Indian stories, and the Sesame of the Arabian tale. The colour is blue, yellow, red, or white, from the different hues of the lightning, and from these the notion of Saxifras plants is derived. (Sassafras.) 2. (Bot.) A large gen. of the ord. Saxifragaceæ; most of them being dwarf herbs, with tufted foliage, and panicles of white, yellow, or red flowers; many being natives of Britain, and cultivated to decorate rockeries, etc.

Saxon architecture. A name sometimes used to denote the architecture of England before the Norman Conquest. It was a form of Romanesque. (Pointed architecture.)

Saxon blue. A solution of indigo in sulphuric acid, used for dyeing. Saxon green is produced by dyeing with yellow upon a ground of Saxon blue.

Sayette. (Sagathy.)

Sbirri. [It.] The police of Italy.

Scab. (Mange.)

Scăbies. (Itch.)

Scad. (Ichth.) Horse-mackarel, Trāchūrus trāchūrus [Gr. $\tau \rho a ́ \chi$-ovpos, from $\tau \rho \bar{a} \chi v \dot{v}$, rough, oủpá, tail]. Fam. Carangĭdæ, ord. Acanthoptěry̆ghii, sub-class Tělěostěì.

Scagliōla. [It.] (Arch.) A composition of gypsum, or sulphate of lime, sometimes called Mischia, from the colours employed in it to imitate marble.

Scald. [Norse skálld.] $A$ poet, or bard. In the ancient literature of $\mathrm{N}$. Europe, poems, whose writers are known, are said to be written by scalds. When their authors are unknown, they are called Eddas. (Edda.)

Scaldings! (Naut.) Get out of the way! Used by a man with a load.

Scale. [L. scāla, staircase, ladder.] 1. A graduated line, used to show the distance of a movable point from a fixed point; as the scale of a thermometer. 2. A graduated line showing the proportion between a picture and the thing it represents; as the scale attached to a plan. 3. The ratio of a distance on a map to the same distance on the ground; as the scale of an inch to the mile. 4. The radix or base of a numerical system ; as the decimal scale. (For Scale of colour, vide Colour.)

Scaleboard. A thin slip of wood used by printers for filling up gaps in a page of type.

\section{Scalene triangle. (Triangle.)}

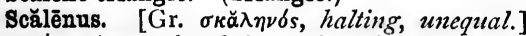
(Anat.) A muscle of the neck which bends the head and neck.

Scalled head. Popular name for a variety of Eczèma of the scalp.

Scallop. [Fr. escalope, shell.] (Zool.) Gen. of free bivalve mollusc, swimming by the rapid opening and closing of its shell. Fam. Ostrěĭdæ, class Conchǐfẽra.

Scalloping. Cutting the edge of anything into segments of circles, so as to be like a scallop. shell.

Scalpel. [L. scalpellum, from scalpo, $I$ cut, scrape.] (Surg.) Knife used in dissection.

Scalprum. [L., a chisel.] (Anat.) The cutting edge of incisor teeth.
Scamars. A tribe of robbers who existed in Thrace down to the eighth century.-Finlay, Hist. of Greece, i. 408.

Scammatha. (Niddin.)

Scammony. [Gr. $\sigma \kappa a ̆ \mu \omega \nu i a$.$] (Med.) A pur-$ gative; the gum-resin of the root of Convolvulus scammonia, of the Levant.

Scampavia. (Naut.) A war-boat of Naples and Sicily, ranging up to 150 feet in length, carrying a brass six-pounder forward, and propelled by sweeps and sails.

Scandălum magnātum. In Law, an action for words in derogation of a peer, judge, or other great officer of the kingdom, which need not be actionable in the case of other persons. The last action of this kind was brought in the reign of Anne.

Scansōres. [L.] (Ornith.) Climbing-birds, as woodpeckers, sub-ord. of Pícāriæ. Otherwise, group of birds characterized by having two toes directed forward and two backward; as wood peckers, parrots, toucans.

Scantling. [Fr. échantillon, a pattern or sample.] 1. The dimensions of a piece of timber in breadth and thickness. 2. A piece of timber less than five inches square.

Scape. [L. scāpus, a shaft, stalk; cf. Gr. $\sigma \kappa \hat{\alpha} \pi$ os, Dor. for $\sigma \kappa \hat{\eta} \pi \tau \rho \nu^{\prime}$.] (Bot.) A leafless flower-stalk; e.g. hyacinth.

Scapement, scape-wheel. (Escapement.)

Scaphism. [Fr. scaphisme, Gr. $\sigma \kappa \alpha \phi \epsilon u ́ \omega$, I lay in a trough.] A Persian punishment, by which criminals were confined in a hollow tree till they died.

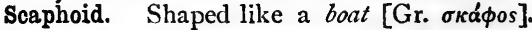

Scappling. [L. scaber, rough.] Reducing (stone) to a straight surface without working it smooth.

Scăpŭla. [L.] Shoulder-blade; a flat triangular bone, extending at the back and the side from the first to about the seventh rib.

Scapulars. [L. scăpŭlæ, shoulder-blades.] (Wings.)

Scapŭlăry. [L. scapŭlæ, the shoulders.] In the dress of the monastic orders, two bands of woollen stuff, one crossing the back or shoulders, the other the stomach.

Scar. [Sw. skär.] Abrupt precipice of broken rock; e.g. Scar-borough. Scar-limestone, i.q. mountain limestone.

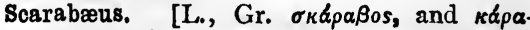
Bos, a beetle; in Skt. garabha is a locust, akin to Ger. krebs, Eng. crab.] A well-known emblem in Egyptian architecture, and also worn as an amulet. As the beetle, represented by it, lays its eggs in a ball of earth, the Egyptians may have seen in this a sign of the world or universe as instinct with life.

Scaramouch. [It. scaramuccio, skirmish.] In the old Italian comedy, a braggadocio, always beaten by Harlequin.

Scarfing. (Arch.) The formation of a beam out of two pieces of timber. The joint thus formed is a Scarf-joint.

Scarf-skin. (Cuticle.)

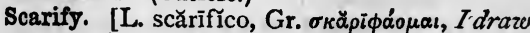
with a okápílos, etching tool.] 1. (Med.) To 
make incisions in the skin, especially in cupping. 2. $(A g r$.$) To tear up the surface soil with an$ implement (scarifier) having triangular teeth set horizontally at the lower end of curved, vertical, iron rods.

Scarious. [Fr. scarieux.] Thin, dry, shrivelled.

Scarlet rod. The gentleman usher of the order of the Bath (from his wand of office).

Scarpe, scrape. [Fr. écharpe, a scarf.] (Her.) The diminutive of the bend sinister, being onehalf its size.

Scărus. [L., Gr. okápos.] (Ichth.) Parrotfish; gen. of fish, so called from colouring and parrot-bill shape of teeth. S. crētensis (Mediterranean), highly esteemed by ancients. Fam. Labrĭdæ, ord. Ácanthoptĕry̆gĭi, sub-class Tĕlĕostěĩ.

Scatches. [D. schaats, a skate.] Stilts for walking over dirty places with.

Scauper. A tool with a semicircular face for scooping out the spaces between the lines of an engraving.

Scavenger's danghter. [Corr. from Skevington's daughter.] An instrument of torture invented by Sir W. Skevington. (Maiden.)

Scazōnic. [Gr. $\sigma \kappa a ́ \zeta \omega \nu$, limping.] An iambic verse with a spondee or trochee in the sixth or last foot. I.q. Choliambic.

'Scend, Send, To. (Naut.) To rise, ascend, after pitching.

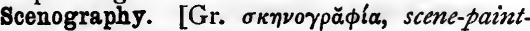
ing.] The art of perspective.

Schatzuma ware. (Satsuma ware.)

Schechinah. [Heb.] (Shechinah.)

Scheiks. Hereditary Arab chiefs. The highest among them, being descendants of Mohammed, are called Sherifs. (Mufti.)

Schemer. (Naut.) The person in charge of the hold in a North-Sea ship.

Schenk beer. [Ger. schenken, to pour out.] A mild German beer, not made to be kept, but to be poured out at once.

scherzo. [It., jest, sport, Ger. scherz.] A bright, merry movement in a sonata.

Schiedam. Hollands gin, much of which is made at Schiedam.

Schilling. [Ger.] In Hamburg and Lübeck the currency is twelve pfennings, equal to one schilling, sixteen schillings being equal to one mark; the (Cologne) markweight of fine silver (3608 grains) being coined into thirty-four marks currency. This, however, is the old reckoning. (Mark.)

Schism Act, I3 Anne, required from every master of a public or private school, and every teacher, a declaration of conformity to the Church and a licence from the bishop; repealed, 5 George I.

Schist. [Gr. $\sigma \chi \imath \sigma \tau \delta s$, split, divisible.] (Geol.) Fissile rocks, greatly metamorphosed, and having irregular cleavage; e.g. mica-schist.

Schlich. [Ger.] The ore of a metal, especially gold, pulverized and prepared for further working.

Schmelze. [Ger., smelting.] Coloured glass fused so as to resemble precious stones.
Schnapps. Hollands gin.

Scholastic philosophy. (Nominalists; Realists; Schoolmen; Scotists ; Thomists.)

Scholiast. A commentator [Gr. $\sigma \chi 0 \lambda \iota a \sigma \tau i\} s]$; writer of a $\sigma \chi \delta \lambda \iota s \nu$ [L. schŏlium], a comment, a short note.

Schŏlium. [Gr. $\sigma \chi \delta \lambda_{\iota} \circ \nu$, an interpretation, comment.] A remark added in some cases to a mathematical proposition, or treatise; as the S. generale at the end of the Principia.

schoolmaster abroad. A phrase sometimes used to denote the exposure of ignorance, in order to frighten those who have a vested interest in it.

Schoolmen. In Eccl. Hist., a name given to a class of learned men who first attempted to form a systematic theology. The father of the Schoolmen was perhaps John Scotus Erigĕna, i.e. a native of Ireland, in the ninth century ; but the scholastic philosophy did not attain its full power before the century which produced Roscelinus, Abelard, and Peter Lombard, the great Nominalists of the second era. To the first era belonged Berenger, Lanfranc, Anselm, and Hildebert. The third period is marked by the introduction of the writings of Arabian philosophers into Europe, and was rendered illustrious by the names of Albert the Great, Thomas Aquinas, and Duns Scotus, the followers of the two latter being known respectively as Thomists and Scotists. In the fourth and last period of the scholastic philosophy, William of Ockham secured the ascendancy of the Nominalists with some modifications of their old system.

Schooner. (Naut.) Strictly, a two-masted fore-and-aft vessel, without tops; but used for any two-masted fore-and-aft vessel. A topsail $\mathrm{S}$. is one having one or more square topsails. There are also three-masted schooners. When the first schooner was launched, I713, a bystander, it is said, exclaimed, "How she scoons (skims, glides along)!" and the builders replied, "A scooner let her be."

Schuyt. (Naut.) A small galliot-rigged Dutch vessel, used in river traffic and the Eng. lish trade.

Sciagraphy. The art of delineating shadows [Gr. $\sigma \kappa \iota \dot{a} \gamma \rho \alpha \bar{\phi} \dot{i} \alpha]$.

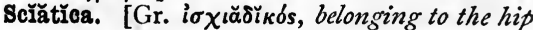
(i $\left.\sigma \chi^{i}(0 \nu).\right] \quad(M e d$.$) Neuralgia of the great$ sciatic nerve, which extends from the inner portion of the buttock along the back of the thigh to the ham; also, inaccurately, applied to all rheumatic affections about the hip-joint.

Scientia, Contrariorum eadem est. A maxim of the Schoolmen; i.e. we never really know what a thing is, unless we are also able to give a sufficient account of its opposite. (See Mill, System of Logic: On Fallacies.)

Scientia popinm. [L., the science of the cookshop.] The art of cookery.

Scientific frontier. (Mil.) One commanding the natural features of a country, with possession of its chain of fortresses, towns, passes, and fords ; having easy communication in rear, strong line of defence when invaded, and power of subjecting its front. 
scilicet. [L.] That is to say; i.c. scire licet, one may know.

Scimitar. [Perhaps from Pers. schimschir.] (Mil.) Turkish sword, with its cutting edge made very convex.

Sciolist [L. sciŏlus], sciolous. Knowing many things, but superficially only ; a smatterer.

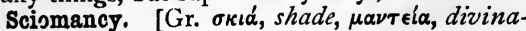
tion.] Divination by means of shadows.

Scîrĕ făcĭas. [L., make it known.] In Law, a judicial writ founded upon some matter of record, calling upon a person to show why the party bringing it should not have the advantage of the record; e.g. if it is sought to repeal letters patent.

Scirrhus. [Gr. okipos, (I) stucco, (2) scirrhus.] (Med.) A cancerous tumour, indolent, hard, fibrous.

Scissel. [L. scissilis, easily cut.] Clippings of metal, especially the slips out of which discs of metal have been punched for coinage.

Scīuriù̃, Sciurines. (Zool.) The squirrel tribe, including flying $S$. and marmots.

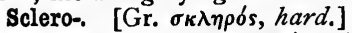

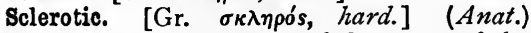
The white of the eye; one of the coats of the eye ; a strong, dense, opaque, fibrous structure, covered by the conjunctiva.

Sclerotomy. Incision of the sclerotic (q.v.).

Scobs. [L. scǒbio.] Scrapings of ivory, metals, etc.

Scolopācĭdæ. [Gr. $\sigma \kappa o \lambda \omega \pi \alpha \xi$, or $-\delta \pi \alpha \xi$, snipe, or woodcock.] (Ornith.) Fam. of wading-birds, as snipes. Cosmopolitan. Ord. Grallæ.

scolopendra. [Gr. $\left.\sigma_{\kappa o \lambda} \delta \pi \epsilon \nu \delta \rho a.\right]$ (Zool.) The centipede. British spec. are harmless ; trop. spec. (twelve inches or more long) dangerous. Ord. Chīlŏpŏda, class Mȳrǐŏpŏda.

sconce. [Ger. schanze, bulwark.] A kind of candlestick.

Sconce, Squinch. (Arch.) A small arch in the angles of towers, etc., to support the alternate sides of octagonal buildings above them.

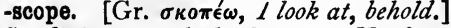

Scorbutus, popularly Scurvy. [L. form of the D. word scheurbuik.] (Med.) A disease, once very fatal in our navy, brought about by prolonged abstinence from vegetables; marked by extreme debility, melancholy, by petechia $(q . v$.$) ,$ diarrhœa, hemorrhage.

Score. [A.S. scor, notch line.] A copy of a musical composition, vocal or instrumental, with parts for each voice or instrument.

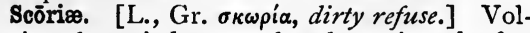
canic ashes, cinders, or the slag rejected after the reduction of metallic ores.

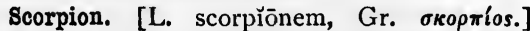
A lobster-like venomous insect, sometimes nine or ten inches long. Fam. Scorpīōnidæ, class Ărachnǐda, sub-kingd. Annŭlōsa.

Scot and lot. [A.S. sceat, part, or portion.] A phrase denoting the payment of parochial rates. Hence scot-free is one who is not bound so to contribute.

Scotch pebbles. Agates, from the amygdaloids of Ochill Hills, Sidlaw Hills, etc. ; quarried, or found among débris.

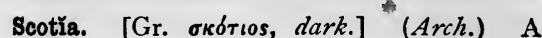
hollow moulding, chiefly used between the tori in the bases of columns.

Scotists. (Schoolmen.)

Scourge of God. Attila, King or Leader of the Huns (died 453); so called by the Christian world of that time.

Scout. [O.Fr. escoute, L. auscultare, to listen.] (Mil.) Cavalry soldiers sent out beyond the outposts to obtain intelligence of an enemy's movements.

Scow. [D. schouw.] (Naut.) A large flat-bottomed boat. S.-banker, (I) he who works a scow ; (2) a lubberly fellow.

Scrabble. [Akin to scrape, scribble, etc.] 1. (Naut.) A badly written log; one scribbled, as it were. 2. To make marks upon a wall ; as in I Sam. xxi. 13.

Scrape. (Scarpe.)

Scraper. (Naut.) 1. A triangular iron for scraping spars, etc. 2. A cocked hat.

Scrap iron. Waste clippings and scraps of wrought iron.

Scratch brush. A bundle of fine wires, tied in the middle so as to form a brush at each end, used for scratching and cleaning metals before they are plated.

screen. [A.S. scrin, (?) scéran, to divide.] (Agr.) A large oblong sieve. To S. gravel or coal, etc., to pass it through a screen set in a slanting position.

\section{Screen, Rood. (Rood-loft.)}

Screw [a word common to many Aryan languages]; Female S.; Micrometer S. A wellknown instrument, consisting of a cylinder round which runs a projection or thread at a constant inclination; it commonly works in the cylindrical cavity of a nut, on the inner surface of which is cut a groove to receive the thread; the cavity and the groove are the Female $S$. A screw carefully cut and provided with a properly graduated head is a Micrometer $S_{.}$; its advance in a fixed nut is a very accurate means of measuring small distances. (For Endless $S$. vide Endless band; for Right-handed and Left-

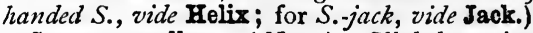

Screw-propeller. (Naut.) Slightly twisted fans driving a ship forward by their rotation on a principle similar to that by which wind causes the sails of a windmill to rotate.

Scribbet. [L. scriběre, to write.] A painter's pencil.

Scribbling. The first rough carding of wool.

Scribendi cacoēthĕs. [L.] The itch of writing.

Scriber. A sharp tool used by joiners in marking planks, etc.

Scribes. [L. scriba, a writer.] Among the Jews, the expounders of the Law, in commen. taries known as Midrashim, i.e. searchings. Starting with extreme reverence for the letter of the Law, they came to insist on the paramount authority of its interpreters. Hence the references in the Gospels to the sayings of the men of old time as overriding the Law. (Tabellions.)

Scribing. [L. scribere, to write.] Fitting two pieces of board together, especially in such a 
way that their fibres are perpendicular to each other (because the wood is marked before cutting it).

Scrine. [L. scrinum.] A case for keeping papers or tooks, a shrine.

Script. [L. scriptum, written.] A kind of type in imitation of handwriting, as-

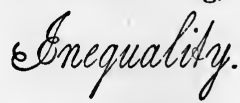

Scriptōrium. In the conventual life of the Middle Ages, was the room devoted to making copies of the Bible, or parts of it ; the illumination of missals, etc.

Scrivello. An elephant's tusk weighing less than eighteen pounds.

Scriveners, Money. In O.E. usage, persons who received money to place it out at interest, and supplied to borrowers money on security.

Scrivener's palsy, popular term for Writer's spasm. A form of paralysis, affecting principally the muscles of the thumb and forefinger, to which persons who write very much are liable.

Scrōfŭla. [L. scrōfülæ, swollen glands, to which it was said that the sonv (scröfa) is subject ;

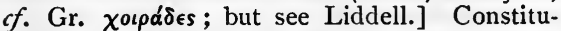
tional disease, with tendency to deposit tubercle.

Scroll. [Fr. escrol.] (Arch.) The volute of the Ionic and Corinthian capital.

\section{soroll-head. (Fiddle.)}

Scrovies. (Naut.) Worthless men shipped by crimps as A.B.'s.

Scrows. A currier's clippings from skins (from their curling into scrolls).

scud. [Probably akin to shoot.] The lower drift-clouds. To S., to run before the wind.

Sculls. (Naut.) Short oars, the handles of which, when shipped, just overlap amidships, so that they can be used by one man. To scull, (I) to row with sculls, (2) to propel a boat by a single oar shipped over the stern.

scumbling (from scum). Blending tints by means of a semi-transparent neutral colour, swept over them with a nearly dry brush.

Scuppers (probably from scoop). (Naut.) 1. Metal-lined holes cut through a ship's side to carry off water from the decks into the sea. 2. Their locality, i.e. the angle between the deck and bulwarks ; as, he rolled into the lee scuppers.

Scurvy. (Scorbutus.)

Scutage, or Escuage. [L. scūtum, a shield.] (Hist.) A commutation paid by military tenants for personal service in foreign wars.

Scutcheon (from escutcheon). 1. (Her.) (Escutcheon.) 2. The brass plate which surrounds a key-hole.

Scutching. [Gael. sgoch, to cut.] Beating so as to separate the fibre.

Scuttle. [O.Fr. escoutille, from écouter, to listen, a place or aperture for hearing.] (Naut.) 1. A small port in a vessel's side. 2. A small hatchway. To S., to cut or bore holes in a

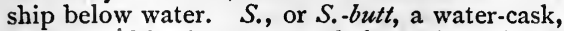
lasned, and having a square hole cut in its head, through which to get the water out. S.-hatch, lid or covering of a scuttle.
Scylla. [Gr. $\sigma \kappa \dot{v} \lambda \lambda a$.$] (Myth.) 1. A daughter$ of Nisus, who cut off the purple lock of hair, the Palladium of Megara, from her father's head, and so betrayed the city to Minos (Menu). 2. In the Odyssey, a monster with six mouths, haunting the Italian coast, and swallowing shipwrecked seamen, like the neighbouring Charybdis. Hence the proverb which speaks of those who wish to avoid the latter, as falling into the jaws of the former. (Incidit.)

Seytălē. [Gr. $\sigma \kappa v \tau a ́ d \eta$.] (Hist.) An instrument by which the Spartans sent orders to officers serving abroad. A parchment was rolled round a rod, and unwound by another rod in the officer's possession.

Scythian lamb. (Barometz fern.)

Sea-biscuit. (Cocket-bread.)

Sea-breeze. A breeze blowing from the sea inland.

Sea-brief. (Naut.) A document specifying the nature and quantity of a cargo, its place of origin and destination.

Sea-cunny. ( $N^{\top}$ aut.) The steersman of an E. -Indian country vessel manned by Lascars.

Sea-gate, or S.-gait. (Gate.)

Sea-horse, Hippocampus. [Gr. i $\pi \pi \delta \kappa a \mu \pi o s$, the fish-tailed horse on which the sea-gods rode.] (Ichth.) Gen. of small fish with bony covering, prehensile tail, horse-like head. One spec. found on British coasts, more in Mediterranean Sea and Atlantic; most in Indian and Pacific Oceans.

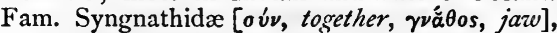
ord. Lophobranchii, sub-class Tělěostěī.

Seal, Great. The Great Seal of England, kept by the Lord Chancellor.

Seal, Privy. The personal seal of the sovereign.

Sealed books. (Eccl. Ifist.) Copies of the Prayer-book of 1662 , issued under the Great Seal of England to all cathedral and collegiate churches, the Courts of Westminster, and the Tower of London, to ensure the preservation of the text in its integrity. These books were compared, before issue, with the book annexed to the Act 13 and 14 Carolus II.

Sealing of ulcers. (Surg.) The exclusion of air during granulation, by soap-plaster and oiled silk.

Seam. (Geol.) A bed, as distinguished from a vein, of coal, etc.

Seaman. (A.B.; Landsman; Ordinary seaman.)

Seamanship. The art of rigging and working a ship, distinguished from the science of Navigation.

Sea-marks. Landmarks, etc., noted on charts.

Sea-monsters. Lam. iv. 3. (Whale.)

Séance. [Fr.] $A$ sitting, or session, as of a public body.

Sea-pen. Popular name for Pennätülìda [L. pennātŭlus, dim. of pennātus, feathered], fam. of feather-like corals, ord. Alcy̆ŏnārǐa. P. phosphorrea is common on N.-British coast.

Search. (Naut) (Visitation and search.)

Searment. Another form of cerement. (Cere.)

Sea-serpent. [L. serpentem, a serpent, i.e. the creeping one.] (Zool.) Hy̆drŏphŭdæ, or veno- 
mous sea-snakes, ranging to ten feet in length; abound in the Indian and Chinese seas. The great sea-serpent, ranging, it is said, to $600 \mathrm{feet}$ in length, has hitherto, whenever thoroughly investigated, proved a delusion.

Sea-slugs. (Zool.) Opisthobranchīāta, ord. of molluscs. (Malacology.)

Sea-swallow. (Sternidæ.)

Seat of eggs. I.q. Clutch.

Sea-trumpet. (Conch-shell.)

Sebaceous. [L. sēbum, suet.] Fatty. (Adipose tissue.)

Sebastianists. Believers in the survival of Sebastian, King of Portugal, after the battle of Alcazarquiver, 1578. Such believers have been found down to the present century. The like belief has prevailed about Harold of England, and many others. The epitaph of Arthur says, " Hic jacet Arthūrus, Rex quondam rexque futurus,"

Sebat. Zech. i. 7; fifth month of civil, eleventh of ecclesiastical, Jewish year ; January -February.

Secant. 1. A straight line cutting [L. sěcantem] a curve in two or more points. 2. One of the trigonometrical functions (q.v.).

secco. [It.] A kind of fresco painting in which the colours look $d r y$ and sunken, being absorbed into the plaster.

Secession Church. (Marrow Controversy ; Relief Synod.)

Secle. (Secular games.)

Secondaries. 1. The inferior members of cathedrals, as vicars-choral, etc. 2. In Myth., beings who reflect the greatness of others with whom they are closely related, as Phaethon of Helios, Telemachos of Odysseus (or Ulysses), and Patroklos of Achilles.

Secondary assemblies. (Primary assemblies.)

Secondary circle. A great circle passing through the poles of a given great circle.

Secondary colours. [L. secundarius, from secundus, second.] Colours derived from the mixture of two primary colours.

Secondary fever. (Med.) That arising after a crisis or some critical effort ; e.g. the discharge of morbid matter.

Secondary planet. A Satellite.

Secondary rocks. (Primary rooks.)

Second intention. (Intention.)

Second Pointed style. (Geometrical style.)

Seconds. A coarse kind of flour.

Secos. (Adytum.)

Section. [L. sectiōnem, a cutting.] The figure that would be obtained by cutting a solid body by a plane; as a conic S. or a S. of a building.

Sector. [L., one who cuts.] The part of a circle included between two radii. (For Zenith $S$. , vide Zenith.)

Secular [L. sæculāris, from sæcŭlum, an age]; s. inequality. Going on from age to age; as the secular cooling of the earth. A Secular inequality in a planetary motion results from the gradual accumulation of the effects of shorter variations which do not exactly compensate for each other; thus the eccentricities of the orbits of Jupiter and Saturn are subject to a S. I. which will go through all its changes in a period not less than about 70,000 years.

Secular clergy. (Regulars.)

Secŭlar games. In Rom. Hist., games celebrated once in each sæculum, or siècle of 100 , or perhaps I Io years. Sometimes the interval was shortened.

Secular poem. A poem recited at the Secular games, as the Carmen Saculare of Horace.

Seculars. (Regulars.)

Secundines. (Med.) Placenta (q.v.), or afterbirth.

Secundum artem. [L.] According to art ; skilfully.

Secundum quid. In Phil., = reiativelv; with reference to a certain thing; e.g. when a house is on fire, to throw valuables out of the window would be not a voluntary act simpliciter, but secundum quid.

\section{Sěcūres. (Fasces and secures.)}

Secure you. Matt. xxviii. 14; not make you safe, but make you free from anxiety [L. sēcūros, i.e. sine cura, Gr. á $\mu \in \rho i \mu \nu 0 u s]$.

Secūtōrěs. [L., followers.] The opponents of the Retiarians in the gladiatorial shows. Some take the word also to mean those who follow to take the place of gladiators already slaughtered. (Mirmillones.)

Sedan chair. A covered chair borne on poles by two men (first made at Sedan, in France).

Sedilia. [L.] Seats of the officiating priests, placed generally on the south side of the chancel.

Sedimentary rocks [L. sědimentum, a settling down] = formed out of matter settled in water ; e.g. clay, sandstone.

Sědum, Stonecrop. [L. sědeo, $I$ sit; as if sitting close, holding fast.] (Bot.) A gen. of plants, ord. Crassŭlaceæ, having numerous spec. ; with fleshy, roundish leaves, and starlike flowers, commonly yellow, sometimes white or blue; found in dry, barren, rocky places of temperate regions.

Seed lac. (Lac.)

Seerhand. An Indian muslin, which retains its clearness when washed.

\section{Sefatians. (Separatists.)}

Seggar. (Sagger.)

Segment. [L. sěcāmentum, a cutting, carving.] (Math.) A part cut off; as of a circle by a straight line, or of a sphere by a plane.

Segmental arch. (Arch.)

Segreant. (Her.) Spreading its wings as if about to fly.

Segregation. [L. segregātiōnem, from se-, $a$ part, gregem, $a$ flock.] A separation of parts ; as of crystals from the mass.

Seicentisti. The name by which the Italians speak of their own writers of the seventeenth century. As their repute was less than that of their predecessors, the word came to denote general inferiority in taste and language.

Seigniorage. [Fr., from L. senior, older.] The charge made by Government for paying the expenses of coining metal, the coin being thus made more valuable than bullion. 
Seigniory. [Fr. seigneurie.] (Feud.) A manor or lordship.

Seine. [Fr., from L. sagēna, Gr. $\sigma \alpha \gamma \dot{\eta} \nu \eta, a$ net.] A large net for catching fish.

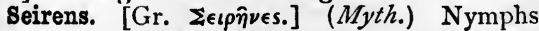
who, by charming mariners with their song, drew them on into shoals and reefs, and caused their destruction. Odysseus (Ulysses) escapes them by stuffing his sailors' ears with wax, and having himself bound to the mast.

Seisachtheia. [Gr., a shaking off of burdens.] In Athen. Hist., an ordinance by which Solon relieved the misery of the poorer Attic freemen. It consisted in the removal of the marks of Eupatrid ownership of land, and in lessening the amount of produce or money hitherto exacted from the tenants, the payment now taking the form of rent. This is the account given by Solon himself. Later writers introduced into it many new features, which they explained in detail.

Seisin, Livery of. The formal delivery of the possession of land, now accomplished by conveyance. (Livery.)

Seismochronograph. [Gr. $\sigma \in \iota \sigma \mu o ́ s$, an earthquake, $\chi \rho \delta$ vos, time, $\gamma \rho \alpha \dot{\phi} \omega, I$ describe.] A kind of seismometer (q.v.).

Seismograph. [Gr. $\sigma \in \iota \sigma \mu o s$, an earthquake, $\gamma \rho a ́ \phi \epsilon \iota \nu$, to write.] An instrument for registering the intensity of earthquake shocks.

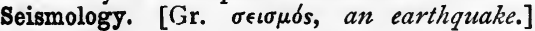
The theory of earthquakes; their nature, force, direction, recurrence, etc.

Seismometer. [Gr. $\sigma \epsilon \iota \sigma \mu \delta s$, an earthquake,

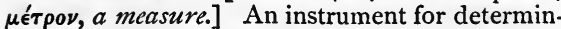
ing the circumstances of an earthquake; as direction of commotion or shock, kind of shock, etc.

Seize, To. (Naut.) To fasten two ropes, or parts of one rope, together, by winding cord or line (seizings) round them. $\operatorname{legs}$

Sejant. (Her.) Sitting [Fr. séant] on its hind

Selection, Natural. (Evolution.)

Sělēnē. (Endymion, sleep of.)

Selenium. [Gr. $\sigma \in \lambda \dot{\eta} \nu \eta$, the moon.] An element of a brown colour, resembling sulphur in its properties.

Selenography. [Gr, $\sigma \in \lambda \eta \eta \eta \eta$, the moon, $\gamma \rho a$ d $\phi \omega$, $I$ describe.] A description of the surface of the moon.

Self-coloured. Of a uniform quiet or neutral tint.

Seljuks. A dynasty of Seljukian Turks, founded in Persia, under Togrul Beg, 1039.

Seltzer water. An effervescing mineral water (from Seltzer, in Germany).

Selvage. [Perhaps from self and edge, as being itself its own border.] The edge of any stuft, woven so as to prevent ravelling.

Selvagee. (Naut.) A hank or untwisted skein of yarn bound round with twine, etc.

Semaphore. [Made up, improperly, of $\sigma \hat{\eta} \mu \alpha$, $a$ sign, and $\phi \dot{\epsilon} \rho \omega, I$ bear, which should have made semato-phore.] (Mil.) Consisting of an upright post and two movable arms, conspicuously placed, by which signals may be transmitted in the day-time to distant stations. A kind of $\mathrm{S}$. with lights is used on railways.
Semble. In Law, for ce semble [Fr., as it seems]; $=$ as we may pretty safely assume; although it has not been positively decided.

Sĕmĕlē. [Gr.] (Myth.) The mother of Dionȳsos or Bacchus. (Bacchanalian.)

Semi-Arians. (Eccl. Hist.) Arians, who denied the Homoousion of the Nicene Creed, but admitted the Homoiousion.

Semi-Pelagianism. (Pelagians.)

Semirămis and Ninus. Mythical founders of the Assyrian empire. The Assyrian form of Semiramis is Sammuramit.

Semitertian fover. (Med.) One having two paroxysms on each alternate day, and one only in the interval.

Semitic languages. The family of languages composed of the Aramaic, Hebraic, and Arabian dialects. (Chaldee language; Peschito.)

Semolina. [It. semolino, dim. of semola, bran.] The fine hard parts of wheat rounded by the action of the millstones.

Semo Sancus. [L. sēmen, seed, sancio, I bind religiously.] (Myth.) An ancient Roman or Sabine god. The two names seem to have belonged originally to two distinct gods, Semo being the guardian of sown crops (Saturn), and Sancus, presiding over oaths and covenants, and answering to the Zeus Horkios and Pistios of the Greeks.

Semper idem, Semper eadem. [L.] Always the same.

Sempervivum. [L., always living.] (Bot.) A gen. of plants, ord. Crassulacex, to which common houseleek belongs.

Sempiternal. [L. sempiternus.] Of continuous and permanent duration.

Sempster. [Corr. of seamster.] Formerlybesides its meaning of a warker with the needle - a dealer in sewn goods, a linen-draper.

Sempstresses' palsy or cramp. In which the power of using the needle is lost.

Senate of Lilliput. Title of imperfect reports of some discussions of the House of Commons, with feigned names, or single initials, for speakers ; between the accession of the Georges and the appearance of the great journals.

Send. (Naut.) ('Scend.)

Sendal. [O.Fr. cendal.] A light fabric of silk or thread.

Senegal. A dark-red gum like gum-arabic, found near the river Senegal, in Africa.

Seneschal. [O.G. senescale, Fr. sénéchal.] A French title, answering to that of steward, or high steward, in England.

Seniōres priōres. [L.] Elders first.

Senlac, Battle of. Commonly known as the battle of Hastings.

Sennit. [From seven and knit.] Plaited straw or palm leaves for making hats.

Sensational school. The school of thinkers who have adopted the doctrine of Locke, that all ideas are derived from experience, through the senses and through reflexion on that which the senses reveal to us. (Ideology.)

Sensitivity. In Moral Phil., i.q. Feeling, regarded as one of the three manifestations of consciousness. (Cognition.) 
Sensitize. To prepare paper, etc., for photography by making it sensitive to the action of light.

Sensorimotor action. Instinctive actions resulting from sensation; e.g. the closing of the eyes in a bright light.

Sensörium. [Late L.] (Physiol.) The central common seat of consciousness; the aggregate of sense-ganglia, through which we are conscious of external sense-impressions.

Sensualism. The name given to the philosophy of Condillac, who thought that he was following out the principles of Locke to their legitimate consequences. (Association; Ideology; Sensational school)

Senza. [It. (the L. sine), without.] As in Music, S. fiori, S. replica, S. tempo, without ornaments, without repetition, not in definite time.

Sepals. [L. seppio, I inclose.] (Bot.) The modified leaves which make up the calyx.

Separatists, or Motazalites. The Mohammedan followers of Wasel Ibn Orta, who not long after the death of Mohammed denied the chief points of his faith. They were especially opposed by the Sefatians; so called as maintaining the eternal attributes of God.

Sepia. [L., Gr. $\sigma \eta \pi i ́ a$, cuttle-fish.] A pigment, used as a water-colour; prepared from the secretion of a peculiar organ, the ink-bag, of cuttlefishes; insoluble in water, but very diffusible. Indian ink is made of the dry sediment. Treated with caustic potash, it yields the brown pigment, S. proper.

Sepoys. [Hind. sipahi, a soldier.] The native troops of the British army in India. The word is another form of the Turk. spahi, sipahi.

Septarian nodules, Septarium. (Fissures-ofretreat; Nodule.)

Septembrists. (Fr. Hist.) The name given to those who took part in the horrible massacres which took place in Paris in September, 1792.

Septennial Act. The Act of George I., extending the duration of Parliament for seven years, unless previously dissolved. (Triennial Act.)

Septfoil. [L. septem folia, seven leaves.] (Bot.) Tormentilla officinālis; a plant having astringent roots, used in tanning and dyeing.

Septicidal dehiscence. [L. septum, an inclo. sure, cæedo, I cut.] (Bot.) When dissepiments clivide into two plates, and compound fruit is again resolved into its original carpels; e.g. capsule of thorn-apple. Septifrăgal [frango, $I$ lreak], when the dissepiments remain attached to the centre, the fruit dehiscing by dorsal suture ; e.g. capsule of colchicum.

Septuagěsima. [L., seventieth.] The Third Sunday before Lent. (Quinquagesima.)

Septŭăgint. [L. septuăginta, seventy.] The name given to the Greek translation of the Old Testament made at Alexandria for the Jews of Egypt, who had lost the use of the Hebrew language. The story ran that seventy translators were shut up in separate cells by Ptolemy Philadelphos, and that their seventy versions :all agreed to a letter. It is supposed, however, that the translation is the work not only of different hands but of different times. The Septuagint contains the Apocryphal books, which are therefore included by the Latin Church in the Canon of Scripture. The Old Testament quotations in the New Testament are usually given from the Septuagint.

Septum. [L., anything inclosed.] 1. (Anat.) A wall separating two cavities. 2. (Arch.) The inclosure of the chancel, as marked by the cancelli, or rails. (Dissepiment.) 3. (Chem.) A membrane or other substance used as a partition between two liquids or gases.

Sepulchre, Fospitallers of the Holy. An order of knights, instituted in Palestine and afterwards transferred to France.

Sĕquēla. [L., a consequence. $]$ (Med.) A morbid affection consequent upon a preceding one. Something left behind by an illness; e.g. kidney mischief, after scarlatina.

Sequence. [L. sěquentia, a following.] In Music, a progression of similar chords or intervals, ascending or descending. (Proses.)

Sequestration. [L. sequestrationem, a placing in the hands of a third party.] A reservation by the bishop from the profits of a living for supply of the cure when void by death, or to satisfy the debts of the incumbent, and under other circumstances.

Sequin, Zecchino. [From Ar. sekkah, a die, or stamp.] A gold coin of Italy and Turkey; not of uniform value; the Venetian $\mathrm{S}$. is worth about $9 s .6 d$.

Sĕquĭtnr. [L., it follozes.] A consequence.

Seraglio. [It., a dim. form of the Oriental serai.] The palace of the Turkish sultan in Constantinople. Its chief gate is called $\mathrm{Babi} \mathrm{Hu}$ mayun, or Sublime Gate. Hence Sublime Porte, as the official name for the Turkish Government.

Serai. [Pers.] A hall of a palace, an inn, as in caravan-serai, Caravansary.

Serang. (Naut.) Lascar's boatswain.

Sëră nunquam est ad bŏnōs mörēs vĭa. [L. the way to good manners is never too late.] It is never too late to mend.

Serape. [Sp.] A shawl worn by Mexicans.

Serapëum. A splendid temple of the Egyptian god Serāpis at Alexandria, destroyed by order of the Emperor Theodosius, A.D. 390.

Seraphic Doctor. (Doctor.)

Seraphim, or Jesus, Order of the. A Swedish order of knighthood, instituted 1334 .

Seraphine. [Heb., seraph.] Precursor of the harmonium, but coarse in tone, and much inferior to it.

Seraphs, Serăphim. [Heb.] In the angelic hierarchy of the Jews, the angels of the highest order, immedjately surrounding the divine throne.

Serapis. A Gr. corr. of the Egypt. Osir-hapi, or the dead Apis, the living Apis being known as Hapi-anch. (Apis.)-Brown, Great Dionysiak Myth., i. 198 ; ii. 122.

Seraskier. [Pers. ser, head, Ar.'asker, army.] With the Turks, a general commanding a separate army ; a commander-in-chief, or minister of war.

Serbonian Bog. A marsh or lake in Egypt near the borders of Judæa. 
Serf. (Helots; Peonage; Ryot; Villein.)

Serge. [Fr., from L. sēricus, silken.] twilled stuff, the warp of which is worsted and the weft wool.

sěriätim. [L.] Severally, one by one; as in the delivery of judgments by judges.

Series. [L.] (Math.) A succession of numbers, each of which is related to the one before it according to some determinate rule; as a geometrical series or progression. (Progression.)

Serjeant. [Fr. sergent, from L. servien, -tem, serving.] 1. In the army, a non-commissioned officer, of higher rank than a corporal. 2. The Common s., a judicial officer of the corporation of the City of London. 3. s.-at-law, a lawyer of the degree above a barrister. The degree is now no longer conferred. 4. s.-atarms; in old usage, an attendant on the sovereign or on the Lord High Steward when sitting in judgment on a traitor, etc.

Serjeanty, Grand and Petty. Feudal tenures, that of Grand $S$. being when a tenant holds land of the king by service, as in war, to be performed in his own person; Petty $S$. being where the owner has to provide some small thing, as a sword or spear, etc.

Sermo pëdester. [L.] A plain style of writing ; prosaic, without poetic flights.

Seroon. [Sp. seron, a pannier.] In Com., a weight varying with the substance to which it is applied.

Serpent. A wooden instrument, compass about two octaves, used in Gregorian music, in Roman Catholic Churches, precursor of the powerful instrument used in bands, which latter is nearly superseded by the ophicleide.

Serpentine, i.e. spotted, veined, in appearance like a serpent's skin. (Geol.) A metamorphic rock, of silica + magnesia ; green, black, red.

Serpents, Fiery. [Heb. hannchâshîm hassrâphîm (Numb. xxi.), id.] (Bibl.) Unidentified.

Serpiginous. [L. serpo, I creep.] (Med.) Spreading slowly over the surface of the skin.

Serpŭla. [L., a little snake, serpo, I creep.]

(Zool.) (Tubicolæ.)

Serrate. (Crenate.)

Sěrum. (Crassamentum.)

Servābit ǒdorem, or Quo sĕmel est imbūtă rĕcens, servābit ǒdōrem Testa dĭn. [L., a jar will long preserve the smell with which it was once impregnated when new (Horace).] Early impressions last long.

Serval. (Zool.) Fēlis serval, Lěŏpardus S., spotted tiger-cat, about three feet long, tail inclusive. S. Africa.

Serve, To. (Naut.) To wind spun-yarn, etc., round a rope, or cable.

Servetists. (Eccl. Hist.) The followers of Michael Servētus, burnt at Geneva, through the treachery of Calvin, 1553.

Service. 1. (Music.) A musical setting of the Canticles, Gloria, etc., and other words sung by the choir. 2. (Naut.) Spun-yarn wound round a rope with a serving-board or mallet.

Service [L. sorbus], or Sorb. (b'ot.) Wild S. tree, Py̆rus torminnalis (good against colic, tormina, plu.). Ord. Rosaceæ; growing in hedges, and in Middle and S. Europe; having valuable heavy wood.

Service, To see. Actual performance of military duty before an enemy.

Service-pipe. A pipe connecting a main (as of gas or water) with the house.

Serviette. [Fr.] A table-napkin.

Servile War. In Rom. Hist., the revolt of the gladiators, slaves, and oppressed labourers, under Spartăcus, against their masters, B.C. 73-72.

Servites. Servants of the Blessed Virgin ; an order under the Augustinian rule, established in Tuscany, 1233.

Servum pecus. [L.] Slavish cattle (Horace); said of fawners and flatterers.

Servus Servorum Dei. [L.] Servant of the servants of God; a title assumed by Gregory the Great, and retained by all succeeding pontiffs.

Sēsămē. (Saxifrage.)

Sesamoïd. (Med.) Like small seeds or grains, lit. of sēsămēe (q.v.).

\section{Sesostris. (Tosorthrus.)}

Sesqui-. [L. sesqui, one and a half.] A prefix denoting that one and a half equivalent of the substance to the name of which it is prefixed are combined with one equivalent of the other substance mentioned; as sesquioxide of - , which contains one and a half equivalent of oxygen to one of -

Sesquialtěra. [L., onc and a half.] In an organ, a stop containing from two to five ranks of pipes; used to give brilliancy in playing voluntaries, etc.

Sesquiplicate. [From L. sesquĭplex, half as much again; but with altered meaning.] If the squares of two numbers have the same ratio as that of the cubes of two other numbers, the former numbers are said to be in the $\mathrm{S}$. ratio of the latter; thus, when Newton proves that Kepler's law for the periodic times of planets follows from the law of gravity, he says, "The periodic times of bodies moving in ellipses are in the sesquiplicate ratio of the major axes."

Sessile. [L. sessǐlis, low-growing, from sědeo, 1 sit.] (Bot.) Not having a stalk, or having a short one; like the acorn of the durmast oak.

Sesterce. [L. sestertius, originally sēmistertius, or the equivalent of two asses and a half.] An old Roman coin, about twopence of our money. The sestertium was $=1000$ sesterces.

Sethians. (Eccl.) An Egyptian sect of the second century, which maintained the identity of Jesus Christ with Seth, the son of Adam.

Seton. [L. sēta, a bristle.] (Surg.) A twist, e.g. of silk, drawn with a flat needle through a fold of the skin; to keep an open wound. (Rowel.)

Setose. (Bot.) Covered with bristles [L. sētæ], or thick stiff hairs; as the stems of many brambles.

Set-screw. (Mcch.) A bolt on which is cut a screw, which takes so firm a hold of the substances to be joined that a nut is not required. It is used, in fact, like a small carpenter's screw. Called also a tap-bolt. 
Sett. A piece placed on the head of a pile that the hammer may reach it.

Settee. 1. A seat with back and arms, wide enough for several people. 2. (Naut.) A single-decked, sharp-prowed Mediterranean vessel, lateen-rigged, and without topmasts.

Setting the Thames on fire. Doing some wonderful act, or showing extraordinary power. Thames is thought by some to be here the word temse (a sieve), the rim of which might be set on fire by an active workman; as the Seine also may be both the river and a fishing-net. But this seems very doubtful.

Setting up. Putting into type for printing.

Settlement. In Law, the right to parochial relief acquired by the pauper in the parish or district to which he legally belongs. (Poor laws.)

Settlement, Act of. The Statute of William III., vesting the succession to the Crown, after the death without issue of William III. and of Anne, in the princess Sophia, granddaughter of James I., and the heirs of her body being Protestants.

Seven Bishops, The trial of the, June 29, 1688. That of Archbishop Sancroft, Bishops Lloyd of St. Asaph, Turner of Ely, Lake of Chichester, Ken of Bath and Wells, White of Peterborough, Trelawney of Bristol, for refusing to cause their clergy to read, in divine service, James II.'s Declaration for Liberty of Conscience, under which it was attempted to establish the Roman faith.

Seven Champions of Christendom.

\section{The Seven.)}

Seven deadly sins. In Med. Theol-_taking Spenser's account, Faëry Qucene, bk. i. canto iv.-Falsehood, idleness, gluttony, fornication, avarice, envy, wrath ; another list is-Pride, covetousness, lust, gluttony, anger, envy, sloth ; but the enumeration is worthless.

Seven hills of Rome. Palatine, Capitoline, Esquiline, Cælian, Aventine, Quirinal, Viminal. There was an earlier tradition of seven hills, of which the names are given as Palatium, Velia, Cermalus, Cælius, Fagutal, Oppius, Cispius.

Seven principal virtues. The three theological (q.v.) with the four cardinal (q.v.) are so termed; but the enumeration is without value.

Seven Rishis. (Rishis, The Seven.)

Seven sleepers. (Rishis, The Seven.)

Seven Wise Men of Greece. (Rishis, The Seven.)

Seven works of mercy. 1. Corporal: "Seven works are usually assigned to mercy ... (I) to feed the hungry; (2) to give drink to the thirsty; (3) clothes to the naked ; (4) to redeem captives ; (5) to visit the sick ; $(6)$ to entertain strangers ; $(7)$ to bury the dead." 2. Spiritual :

Counsel, rebuke, instruct in wisdom's way, Console, forgive, endure unmoved, and pray. Bishop Andrewes, Devotions.

(See also Faery Queene, bk. i. x. 36.)

Seven Years' War. (Hist.) A war between Austria and Prussia and the allies on either side, $1756-1763$, remarkable chiefly for the campaigns of Frederick II. ; ended by the peace of Hubertsburg.
Sèvres. China made at S. ; of soft porcelain alone, vieux Sèrres, before 1769 ; of hard porcelain subsequently.

Sewed, sued. [O.Fr. essuier, L. easiccāre, to drain dry.] (Naut.) A ship resting on the ground through the water falling is said to be served.

Sewer. [Of uncertain origin.] One who directed the arrangement of dishes on the table; originally one who tasted, made trial of $[\mathrm{Fr}$. essayeur] each dish to prove that there was no poison in it. (Skeat prefers to derive from sew, originally meaning juice, then sauce, etc. ; A.S. seaw.)

Sexagěsima. [L., sixtieth.] The Eighth Sunday before Easter. (Quinquagesima.)

Sexagesimal. [L. sexāgēsĭmus, sixlieth.] Proceeding by sixties; as the S. division of the angle or of the hour into minutes and seconds.

Sext. (Canonical hours.)

Sextant [L. sextantem, a sixth part] ; Hadley's s. ; Pocket-s. 1. A sixth part of a circle. 2. For the exact measurement of the angle subtended at the eye of the observer by the line joining two distant points, an instrument mounted on a stand is commonly required; but in the case of Hadley's $S$. (which is often called simply a Sextant), by the use of mirrors properly attached to the instrument, the stand is dispensed with, and the instrument is merely held in the hand ; it is, therefore, adapted for making astronomical observations at sea. A Pocket-S. is a small sextant with certain unessential variations in the arrangements of its parts, the varia. tions being designed to increase its portability.

\section{Sexton. (Sacristan.)}

\section{Seyd, syud. (Cid; Sherif.)}

Sfregazzi. [It. sfregare, to rub.] A kind of glazing made by drawing the finger over the canvas.

sfumato. [It., smoked.] Misty in appearance.

Sgraffiato ware. [It., painted in a kind of sgraffito (q.v.).] Ware decorated by scratchings in engobe (q.v.).

Sgraffito. [It., scratched.] 1. Formed by scratching away a white surface so as to show the dark ground underneath. 2. As noun, a scratched inscription.

shabraque. [Ger. schabracke, housing.] (Mil.) Embroidered saddle-cloth worn on the horses of mounted officers.

Shaft. [A.S. sceaft.] 1. (Arch.) The column between the base and the capital. 2. (Mech.) An axle carrying wheels or other rotating pieces which convey and distribute energy from the prime mover. An axis is the general and scientific term; shaft the millwright's general term, and spindle his term for a smaller shaft. Axle is the wheelwright's word; and arbor the watchmaker's. 3. In Mining, a well-like excavation for reaching ore and bringing it to the surface.

shag. [A.S. sceacga, $a$ bush of hair.] 1. Cloth with a long coarse nap. 2. Strong dark tobacco cut into fine threads.

Shagreen. [Turk. sághrí, a horse's back.] An untanned leather covered with small granulations, produced by pressing small seeds into it 
while moist, scraping off when dry the ridges thus formed, and raising the hollows into relief by soaking. Originally of skin of horse or ass ; then of shark.

Shah. The King of Persia. (Padishah.)

Shahnamah. [Pers., The Book of Kings.] The Persian Epio of Firdusi, written about A.D. 1000 .

Shake, To. (Naut.) To cast off fastenings. To $S$. in the zvind, to come so near that the sails shiver. Shaking a cloth in the wind, being rather tipsy. Shakings, canvas, cordage, or other refuse, used for oakum or paper-making.

Shakers. (Eccl. Hist.) A body of seceders from the Society of Friends, or Quakers. Now found chiefly in America. So called from the contortions of their bodies during worship.

shale. [Ger. schälen, to peel, shell.]. (Geol.) Consolidated mud, generic name for laminated argillaceous rocks, easily pulverized; bituminous $\mathrm{S}$. passes into coal.

Shalli. A twilled cloth of the wool of the Angora goat.

Shalloon. A worsted stuff first made at Chalons, in France.

Shallop, Shalloop, or sloop. [Fr. chaloupe.] (Naut.) 1. A small fishing-vessel having only a fore-and-main lugsail. 2. A large, heavy, open boat, with one mast, boom mainsail, and jib foresail. 3. A small row-boat for one or two men.

Shallow-waisted. (Naut.) Flush-decked. (Decks.)

Shamanism. The name for the religions of many barbarous tribes, including the Finnish, as far as the Pacific Ocean. (Samanæans.)

Shambles. [A.S. sceamel, a bench.] Platforms left in a mine to receive the ore, which is thrown from one of them to another till it reaches the surface.

Shamefacedness. I Tim. ii. 9; "shamefaced" is a corr. of shamefast, A.S. scamfæst, from scamu, shame, and frest, fast, i.e. firm. The confusion easily arose from the fact of shame showing itself in the face. The proper spelling appears in the Revised Version.

Shammy. Soft pliant leather originally made from the skin of the chamois.

shamoying (from chamois leather, which is thus prepared). Preparing leather with oil instead of astringent bark.

Shank. [A.S. scanc.] 1. In Printing, the body of a type. 2. A large ladle used in founding.

Shanty. [Amer. ; a corr. of Fr. chantier, originally a wooden horse (L. cantherius, a packhorse) on which carpenter's work is done; then a hut in a dockyard; then the yard itself.] A mean cabin or shed; a hut such as a settler or backwoodsman first constructs, of logs.

Shard-borne. Borne on shards, or on wings like shards (i.e. fragments of earthen vessels or shells).

Share. [O.E. scear, id., scéran, to divide.] (Agr.) That part of the plough which cuts the soil in a horizontal plane.

Sharon, Rose of. Cant. ii. I ; probably nar- cissus, abundant on the plain of S., between Joppa and Cæsarea, if this is the S. intended. Another S., which means plain, or field, is between Mount Tabor and the Sea of Tiberias (Speaker's Commentary).

Shaster, more properly Sastra. The Hindu name for books explaining the Vedas by sasta, science. (Purana.)

-shaw. [A.S. sceagor.] (Geog.) A shady place, a wood; e.g. Brad-shaw (see Taylor's Words and Places).

Shawm. Precursor of the modern clarionet. (Chalumean.)

Shea. A butter obtained from an African tree.

shear. [From a root meaning dizision; $c f$. share (q.v.), sheer, shire, shore, shard, sherd, shred.] (Mech.) 1. A tangential stress which tends to separate a body by making its two parts slide one upon the other in opposite directions. 2. A contrivance for lifting heavy weights, consisting of two or more spars lashed together at the top, and furnished with the necessary tackle. 3. Plu., a cutting instrument, as a large pair of scissors.

Shear-hog, shearling.

\section{growth of.)}

shear-hooks. (Naut.) Sickles formerly attached to the yardarms, to cut an enemy's rigging.

Shear-steel. A highly wrought steel for making shears, scythes, etc.

Sheath-bill. (Ornith.) Gen. (two spec.) and fam. of wading-birds, about fifteen inches long ; white, with horny sheath protecting nostrils. Antarctic islands. Gen. Chǐŏnis, fam. Chǐŏnǔdĭdæ, ord. Grallæ.

Sheave. 1. (Mech.) The wheel of a pulley which works in a block, and carries the rope on its rim. 2. (Naut.) (I) Wheel of a block, etc. (2) The number of tiers in cables, or hawsers, when coiled. S.-hole, (I) that in which a sheave is fitted; (2) the groove through which a rope is rove in a block.

Shechinah, Shekinah. [Heb., presence of God.] In Old Testament, the glory resting on the tabernacle, or before the people.

Sheep, stages of growth of. Wether and ram (or tup) lambs become Hogs, Hoggerels, Hogsets, or Tags, as soon as the next year's lambs begin to fall; on shearing they become Shear-hogs, Shearlings, Dinmonts, Tups, or Twotoothed Tags, as the case may be. After the next shearing the wether is termed a Four-toothed wether, or Two-shear hog, and so on. Rams (or tups) also are distinguished by the number of their annual shearings. The corresponding stages in the females are (I) Ewe lamb, Gimmer L., or E. tag. (2) Shearling E., Two-loothed E., or Thaive. (3) Thaive, Two-shear E., or $G$., or Four-toothed E. (4) Three-shear. (5) Full-mouthed. The E., on losing her teeth, is termed a Crone. But names vary locally.

Sheepmaster. 2 Kings iii. 4. Master here is owner. So beemaster, etc.

Sheepshank. (Naut.) A contrivance to shorten a rope in the middle temporarily, by 
doubling it and knotting each end of the doubled part in a peculiar way.

Sheer. (Naut.) 1. The curve in a vessel's length. 2. The position in which a vessel at single anchor is kept to prevent her fouling it. To break S., to shift from that position. S.-hulk, an old vessel fitted with sheers (q.v.), etc. Sheering, sailing in a wavy line. S.-mast, a pair of sheers in which a fore-and-aft mainsail works instead of being hoisted on a mast.

sheers. (Naut.) Two or more spars set up at an angle, lashed together near their upper ends, and supported by guys. Used to lift weights, rig masts, etc.

sheet. (Naut.) A rope or chain attached to the lower corner or corners of a sail, to regulate its position.

Sheet anchor. (Anchors.)

Sheik. (Scheiks.)

Sheikh-ul-Islam. (Mufti.)

Sheldonian Theatre. The building at Oxford answering to the Senate House at Cambridge ; so called from Gilbert Sheldon, Archbishop of Canterbury, who built it.

Sheldrake. [Sheld, i.e. spotted; perhaps akin to A.S. scylan, from skel, to distinguish. (Ornith.) Sheld-drake; spec. of variegated wild duck, twenty-four to twenty-seven inches long ; builds in rabbit-holes. Gen. Tădorna, fam. Ǎnătǐdæ, ord. Ansĕres.

Shellac. (Lac.)

Shelling. Groats (because the husk or shell is removed).

Shell-jacket. (Mil.) Uniform coat only reaching to the waist.

Shelter-trench. (Mil.) Slight earthen parapet thrown up from a shallow ditch; a hasty and temporary cover to troops from the fire of an enemy.

Sheminith. In title of Ps. vi., xii., both penitential; the eighth or octave; i.e. probably with bass voice or accompaniments.

Sheol. Hidden; Heb. equivalent of the Gr. Hades, the abode of the departed.

Shepherd kings. Ancient kings ruling in Egypt, sometimes called Hycsos. They are supposed to have been expelled on the rise of the eighteenth dynasty, about B.C. 1625 .

Shepherd's Calendar. Edmund Spenser's series of pastorals, divided into twelve monthly parts-the scenery, climate, names, English-in which, as in Virgil's Bucolics, questions of morality and State are treated in idyllic dialogue ; with praises of living persons.

Shepherd's-purse. (Bot.) A common weed, Capsella bursa pastōris, ord. Crŭč̌fěræ; an annual, abundant in our gardens and corn-fields one of the few plants found almost all over the world.

Sherbet. [Ar., a draught.] A perfumed lemonade used in the East.

Sherif. [Ar., lord, or master.] One who is descended from Mohammed through his daughter Fatima, the wife of Ali. The sherifs are also called Emir and Seyd, or Syud, and have the right of wearing the green turban. (Scheiks.)

Sheriff. [Originally shire-reeve, = vice-comes, or deputy of the earl.] The chief officer in each county; the bailiff of the Crown.

Shewbread. In Jewish Hist., the name given to the twelve loaves of bread, one for each of the tribes, which were placed every sabbath "on the pure table before the Lord," to be eaten there, and only by the priests.

Shiahs, shias. Mohammedans who consider Ali, the fourth caliph, as the rightful successor of the prophet, and look on his predecessors, Abubekr, Omar, and Othman, as usurpers. The Persians generally belong to this body. Their opponents are called Sonnites or Sunniahs.

Shibah. (Naut.) A small Indian vessel.

Shibbǒleth. 1. A Hebrew word [(I) an ear of corn, (2) a stream \}, used by Jephthah (Judg. xii. 6) to distinguish from his own men, who pronounced the sound sh, the Ephraimites, who, sounding only $s$, said sibboleth. Hence, 2 , the test-word of any party.

Shield-ship. (Naut.) One having a massive iron shield, or shields, to protect its heavy gun, or guns. $S$. tower or turret, an armoured revolving turret to protect guns.

Shieve, To. (Naut.) 1. To have headway. 2. To row the wrong way to assist in steering.

Shifting. (Naut.) S. a tackle, moving the blocks further apart; called also fleeting. $S$. backstays or preventers, those that can be mover from one side of a ship to the other. $S$. ballast, moving pigs of iron, bags of sand, etc., to trim the ship. Also applied to "live lumber," i.e. live stock, and human beings who do not form part of the crew. S. boards, bulkheads running the length of a hold.

Shift the helm. (Naut.) An order to move it from port to starboard, or vice versa.

Shiites. (Sunnites.)

Shiggaion. In title of Ps. vii., probably $=a$ lyrical composition expressing mental excitement (Speaker's Commentary).

Shillelah. An oaken cudgel (from the Irish forest of Shillelah).

Shilling, Taking the. Until very lately, = enlisting; from the shilling given to the recruit on the occasion. But no money passes to the recruit now, since the Army Discipline and Regulation Act, I879.

Shim. 1. A kind of hoe. 2. A thin slip of metal placed between two parts to make a fit.

shingle. [Ger. schindel.] A thin plank with one end thicker than the other, used for roofing.

Shingle beaches. (Beaches.)

Shingles. (Herpes.)

Shingle-tramper. In Naut. slang, a coastguardman.

Shingling. Hammering puddled iron to make it into blooms.

Shin-plaster. In America, slang for papermoney.

Shin up, To. (Naut.) To climb up a rope or spar by griping it with hands and legs.

Ship. [A word containing the root of shape, A.S. sceapan, scippan, Ger. schaffen, Gr.

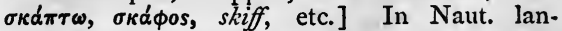
guage, strictly, a three-masted, square-rigged 
vessel. S.-breaker, one who buys old vessels, and takes them to pieces. S.-broker, an agent between shipowners, merchants, etc. S.-chandler, one who supplies sea-stores. S.-controller, the charterer or freighter. $S$. cut down (Rasee.) S.-keeper, (I) a stay-aboard officer; (2) the man in charge of a vessel, whose crew is not on board. S.-lord, old name for a shipowner. S.-man, the master of a barge. S.-man's card, (I) a chart; (2) the compass card. S.-master, the master, or captain. S. raised upon, one having had her upper works heightened. Ship's husband. (Hus-

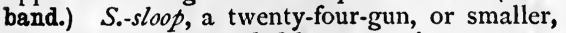
man-of-war, commanded by a captain.

Ship money. (Eng. Hist.) A tax imposed by Charles I. without authority of Parliament ; and the discontent thus caused led, with other things, to the civil war. The maritime and perhaps some of the inland counties had in remote times been taxed for the support of the navy in cases of emergency or invasion. But this assessment was made on all counties; it was not for the support of the navy, or of the navy only; and it was believed to be imposed with the view of curtailing the national liberties by raising taxes without the consent of the governed.

Ship's husband. (Husband.)

Ship-worm. (Teredo.)

Shiremote. In O.E. Law, the meeting of the shire, or the sheriff's court.

Shirred. [O.Ger. shirren, to prepare.] Having bands of elastic, etc., inserted between the faces of the stuff, as in a pair of braces.

shirt of need. In the Middle Ages, a garment called by the Germans noth hemd, supposed to make the wearer invulnerable. (Tarnkappe.)

Shittah tree (Isa. xli. 19), Shittim wood (Exod. xxvi., xxxvi.). An acacia, largest timber tree of the Arabian desert; having hard brownish wood, and yielding gum-arabic.

Shiver. (Naut.) I.q. sheave (q.v.).

Shoal. [Akin to shallow, shelf, etc.] A shallow place, or sandbank.

Shoddy. A fibrous material obtained by tearing to pieces old woollen goods.

shoepack. A moccasin made of tanned leather, with the black side in.

Shogoon. (Tycoon.)

Shook. A set of staves for making a barrel, or of boards for a sugar-box.

Shoot. In Mining, a vein of ore running in the same direction as the strata in which it occurs.

Shoot, To. (Naut.) S. the compass, to go wide of the mark. S. the sun, take an observation.

Shooting star. A small body which, coming out of space into the atmosphere, is ignited by the heat developed by the check to its motion caused by the resistance of the air. (Meteoric shower.)

Shooting-stick. A tapering piece of wood or iron, used by printers to drive up the quoins in the chase.

Shorling. The fleece shorn from a living sheep.

Short boards or tacks. Short runs, or legs, made successively in tacking.
Shorter Catechism. (Catechism.)

Short-service. (Naut.) That which protects a small part of a hemp cable. (Service, 2.)

short-sighted eye. One which has too great a refractive power, and brings rays from a distant object to convergence in front of the retina; it cannot, therefore, see such objects distinctly, though they are clearly discerned by the human eye in its ordinary state.

Shoshannim. In title of Ps. xlv., lxix., lxxx. ; lilies; the name of a melody (?) or metaph. (?) = bridesmaids; a melody fit for nuptials.

Shot silk. Silk having the warp-threads all of one colour and the weft of another.

Shoulder angle. (Mil.) That formed by the meeting of a face and a flank of a bastion.

Shoulder-of-mutton sail. (Naut.) A triangular sail, like the mainsail of a'Mudian (q.v.).

Shoulders. (Undersetters.)

shout. [D. schuyt.] (Naut.) A light and nearly flat-buttomed fen-boat.

Shoute-men. (Naut.) Thames lightermen.

Shovel-board. At which, according to Macaulay, the squuire and his chaplain played together on wet days-" a game played on a long board, by sliding metal pieces at a mark."-Johnson's Dictionary.

Shoveller. (Ornith.) Gen. of wild duck, with bill broadening at tip. Gen. Spătŭla, fam. Ǎnătı̆dæ, ord. Ansěres.

Shrapnel shell (General S., of R.A., inventor), or Spherical case-shot. (Mil.) Thin shell filled with musket-balls mixed with a bursting charge of powder, having a short fuze for bursting it before the completion of its range.

Shrike (from its shrieking). (Ornith.) Fam. of dentirostral birds; rapacious; e.g. common butcher-bird. Almost cosmopolitan, except Central and S. America. Lănĭĭdæ, ord. Passĕres.

Shrinkage. [A.S. scrincan, to contract.] Contraction of heated metals, castings, etc., on cooling.

Shrinking head. A supply of molten metal connected with a mould for making good the loss caused by shrinkage as the casting cools.

Shrink-on, To. To place on a cylindrical body, as a cannon, a heated metal hoop, which, when cool, has a diameter slightly less than that of the cylinder; the fit is tight when the ring is hot, and consequently when it is cool it grasps the cylinder with a great force, due to its tendency to contract.

Shroff. [Ar.] A banker or money-changer.

Shroud-rope. (Naut.) Hawser-laid rope of extra quality.

Shrouds. (Crouds.)

Shrouds. [A.S. scrúd shroud, screáde, shred.] (Naut.) Those ropes by which lateral support is given to a mast, or to the bowsprit. S.-stopper. (Stopper.) S. -trucks. (Truck.)

shude. [Ger. scheiden, to separate.] Rice husks, etc., for adulterating oil-cake.

shumac. [Ar. summâk, from samaka, to be long.] Fustet (o.v.).

Sinushan-eduth. In title of Ps. lx. ; the lily of testimony. (Shoshannim.) 
Shnt. [A.S. scythan, to shut.] The line of closure where two pieces of metal are welded together. Cold shut is the imperfect junction caused by insufficient heat in either piece of metal.

Shuttle. [A.S. scyttel, from sceótan, to shoot.] An instrument used in weaving for shooting the thread of the woof backwards and forwards between the threads of the warp.

Shwan pan. The Chinese Abacus.

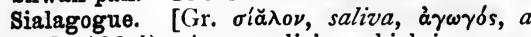
guide.] (Med.) Any medicine which increases the flow of saliva.

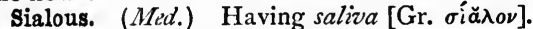
Sibilant. [L. sibilantem.] A letter uttered with a hissing sound, as $s$.

Sibyl. [Gr. 乏i $\beta v \lambda \lambda a$.$] A prophetess, as the$ sibyl of Cumæ, in the AEneid. Ten sibyls are named by some authors.

Sibylline books. Books which were supposed to contain the fortunes of the Roman state. These were brought by the sibyl to Tarquin the Proud, who refused them at the price asked. Having burnt six, the sibyl asked the same price for the remaining three. The king then bought them, and they were kept in the temple of the Capitoline Jupiter. A similar tale is told of a Hindu king.

Sic. [L., thus.] A word used by writers, when quoting, to draw attention to blunders in the writing or printing, especially to such as seem to be the result of culpable ignorance or negligence.

sicca. (Rupee.)

Siccum lūmen. [L., dry light.] In the $\mathrm{Ba}$ conian philosophy, the handling of questions without prejudice or partiality, thus placing them in a light free of all distorting vapour.

Sicilian Vespers. (Hist.) The massacre of the French soldiers and subjects of Charles of Anjou in Sicily, in $\mathbf{1 2 8 2}$, is called by this name. On the expulsion of Charles, the Sicilians placed themselves under the protection of the King of Aragon.

Sicilies, The Two. Sicilia Citeriore, S. on this side, with reference to Naples, $=$ about one-third of Italy; and S. Ulteriore, or the I. of Sicily.

Sic itur ad astra. [L.] Thus it is gone to the stars; such is the path to immortality.

Sick Man, The. The Sultan of the Ottoman Turks. So called by the Emperor Nicholas, in a conversation with Sir H. Seymour, April, 1853, with reference to a proposed division of effects.

Sic sědēbat. [L.] So he used to sit; on statues.

Sio transit gloria mundi. [L.] So passes away the world's glory. The pope, at his coronation, is thus addressed by a clerk of the chapel, who holds in his hand a stick with lighted tow.

Sic utĕre tro, ut aliēnum ne lædas. [L.] In Law, so use what is thine owen, as not to injure that which is another's. This maxim is the only limitation upon the enjoyment of a tenant in fee simple; so in the case of mines, it is sometimes an entire denial of the right of enjoyment. Brown, Law Diclionary.
Sic vŏlo, sio jŭbĕo. [L., so I zeill and command.] A despotic command. (Stet pro ratione voluntas.)

Sic volŭmus. [L.] So we will it; of arbitrary decisions.

Sio vos non vōbis. [L.] So ye not for your selves (Virgil). A phrase for work in which the workman's reward goes to others.

Side-arms. (Mil.) The sword or bayonet carried at a soldier's side.

Side-bone. In a horse. (Ring-bone.)

Side-lever. The part of a marine steamengine corresponding to the beam in the ordinary stationary steam-engine.

Sidereal clock [L. sỉděrěus, belonging to the stars] ; S. day; S. time; S. year. Sidereal time is time reckoned by the diurnal motion of the stars, or more strictly by that of the (mean) first point of Aries, just as ordinary (mean) time is kept by the motion of the (mean) sun. A $S$. clock is regulated to show the sidereal time of any instant : e.g. it shows $3 \mathrm{hrs}$. when the first point of Aries is $45^{\circ}$ or $3 \mathrm{hrs}$. west of the meridian. (For S. day, vide Day; for S. year, vide Year.)

siderography. [Gr. $\sigma i \delta \eta p o s$, iron, $\gamma \rho d \phi \in \omega, I$ $d r a z v$.] A process of copying an engraved steel plate by first rolling over it, when hardened, a soft-steel cylinder, and then rolling the cylinder, when hardened, over a soft-steel plate.

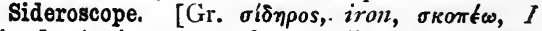
view.] An instrument for revealing the presence of iron in any substance by means of magnetic needles.

Sidesmen. Men appointed to assist churchwardens. Canon XC., I603, "Side-men, or Assistants." (Questmen.)

Siena, Terra di sienna, Raw sienna. A brownish-yellow earth from Sienna, in Italy, used as a water-colour. Burnt sienna is of a deep orange tint, and is made by burning raw sienna. (Ochres.)

Sierra. [Sp., L. serra, a sazv.] The Spanish name for a chain of hills, properly with jagged summits, as the Sierra Nevada, or swowy range.

siesta. [Sp., a sitting down.] The Spanish name for the rest taken within doors during the heat of the day.

sight. (Mil.) A piece of metal secured to the upper side of the barrel of any firearm, for assisting the aim and showing the extent of range.

Sĭgillāria. (Geol.) A gen. of fossil tree-stems, with leaf-scars, like impressions of a seal [L. sigillum]; characteristic of Carboniferous system.

Sign, Algebraical. A symbol denoting a certain operation performed on or relation between other symbols denoting numbers; thus, + is the sign of addition, - of subtraction, = of equality, etc. ; as, $5+7=12$, and $8-3=5$, etc.

Signature. [L.L. signātūra, a sealing, mark ing.] 1. In Music, the flats and sharps placed after the clef, and indicating the key. 2. In Printing, a small letter, or sometimes number, placed at the foot of the first sheet or section- 
which generally contains sixteen pages-of any book.

Signatures, Doctrine of. This term denotes the old notion that natural substances indicate, by their outward form or colour, the diseases for which they may be used as remedies. Thus turmeric, being yellow, must cure jaundice, etc.

Signet, Privy. 1. One of the royal seals, for private letters and grants under the sign-manual, kept by the Secretary of State for the Home Department. 2. In Scotland, the signet authenticates royal letters and writs for purposes of justice. Hence the title, Clerks or $W$ riters to the $S$.

Signǔfícāvit. [L.] (Leg.) A clause in a writ, or the writ itself, wherein a judge or other competent authority has signified to the king that the person against whom the writ has been directed was manifestly contumacious, openly disobeying an order of the court.

sign-manual. The royal signature, superscribed on bills of grants and letters patent, which are then sealed with the privy signet or the Great Seal.

Signs of the Zodiac. (Zodiac.)

sigurd. The great hero of the Volsunga Saga, and the Nibelungen-lied.

Silentiary. [L. silentiārǐus, from silentium, silence.] In Rom. Hist., one whose duty it was to maintain silence in the imperial palace. In the Latin empire the cabinet secretaries were so called.

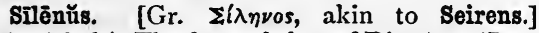
(Gr. Myth.) The foster-father of Dionysos (Bacchus), usually represented as riding on an ass, with a pitcher in his hand, and as endowed with prophetic powers.

Silhouette. 1. A profile, or shadow-outline of the human figure, filled in with a dark colour, the shadows, etc., being indicated by the help of some shining material; practised by the ancients also; e.g. the monochromes on Etruscan vases. 2. Profiles cut out of black paper. S., the name of a very economical minister of finance in France, 1759, became by meton., = something plain and cheap.

silica, Silicic acid. [L. sullicem, a flint, of which it is the essential constituent.] A compound of oxygen with sillicium, or sillicon; the most abundant of the solid constituents of the earth. Quartz, chalcedony, opal, flint, jasper, are its chief varieties; and silica is also widely distributed as a constituent in minerals, as felspar, etc.

Silicates. [I. sulicem, a flint.] Compounds of sillica with certain bases; e.g. all forms of clay, felspar, hornblende, mica, serpentine, etc., are compounds of this kind.

silicium, silicon. [L. silicem, flint.] An element, the chief constituent of flint.

siliqua [L.], Silique. (Bot.) The long podlike fruit of crucifers, having a dissepiment to which the seeds are attached; e.5. wallflower. (Replum.) Silicle [sǐlicŭla], a small siliqua; e.g. garden cress.

Silk gown. In legal language, a Queen's counsel; so called as wearing a silk gown.
Silly season. The season in which newspaper writers are supposed to indulge in silly writing, from the lack of matter of a better sort, caused by the recess of Parliament and by general holiday-making.

silt. Miscellaneous matter (argil., calc.), deposited by standing or running water; perhaps the thing siled; to sile being to strain; the sediment.

Silurian system. (Geol.) Sir R. Murchison's name for the greywacke series; a large, enormously thick division of Palæozoic rocks, below the Old Red Sandstone ancl above the Cambrian; studied by him in the parts of Wales and England which are $=$ British kingdom of the Silhires.

Sǔlūrừæ. [L. sĭlürus, probably the sheatfish, oinoupos.] (Ichth.) Fam. of fish divided into eight sub-fams. and seventeen groups ; fresh and salt water, without scales, and with barbules; as the sheat-fish, or sly silurus. Temperate and tropical rivers and coasts. Ord. Phȳsostŏmi, sub-class Tělěostěì.

Silver Age. (Ages, The four.)

Silverling. Isa. vii. 23 ; small silver coin.

Silvictura, or Forestry. The cultivation and management of forest trees.

\section{Simeon Stylitës. (Stylites.)}

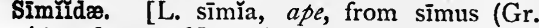
oinds), flat-nosed.] (Zool.) The anthropoid apes, i.e. the most human-like of the monkey tribe ; as the gorilla. Trop. W. Africa, Sumatra, Borneo, etc., and Assam to S. China.

Similar figures. (Math.) Alike in form but different in magnitude; thus two plane rectilineal figures are similar when their angles are equal, each to each, and when the sides about equal angles are proportional.

Similar motion. (Music.) (Motion.)

Simmlěe. [L., like.] In Rhet., a comparison, a metaphor drawn out.

Simülia similibus curantur. [L.] Things are cured by their likes; the principle of homœepathy.

Similor. [L. simullis, like, Fr. or, gold.]

alloy of copper and zinc, resembling gold.

Simious. Ape-like. (Simiidæ.)

Simnel bread. [L.L. simnellus.] Fine wheatflour cake eaten on Simnel Sunday, the Fourth Sunday in Lent, or Refreshment Sunday (q.v.).

Simonians. (Eccl. Hist.) The followers of Simon Magus, Acts viii.

Si mŏnŭmentum rěquirịs, circumspice. [L.] If you want a monument (for him) look round; from Wren's epitaph in St. Paul's Cathedral.

Simony. In Law, an unlawful contract for presenting a clergyman to a benefice. The word refers to Simon Magus, Acts viii.; but our laws are directed against offences unlike those which are ascribed to him.

simoom. [Ar. samûm, from samm, poison.] $A$ wind heated and dried by blowing over the parched deserts of Africa, Arabia, etc. The Khamseen of Syria, the Samiel of the Turks, and the Sirocco and Sorana of other countries.

Simous. (Simiidæ.) Flat-nosed.

Simple homage. (Homage.) 
Simplex munditiis. [L.] Simple in thy ornaments (Horace). "Plain in thy neatness" (Milton).

Simŭläcrum. [L., a likeness, imagee.] 1. The form or image of something, as presented to the mind. 2. (With the idea of imitation, unreality) a shadow, semblance, false idea. So the Gr. $\epsilon \nmid \delta \omega \lambda o \nu$, in both senses.

Sinaitic Codex. (Abbreviations; Codex.)

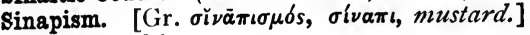
A mustard poultice.

Sinciput. [L. semi, half, caput, the head.] Fore part of the head, from the eyes to the coronal suture.

Sine. (Trigonometrical function.)

Sinecure. 1. A benefice without cure [L. sŭnĕ cūrā] of souls. 2. Any salaried office with no work attached.

Sine dis. [L., without (naming) a day.] Indefinitely.

Sine quâ non. [L., without which not.] An indispensable condition.

Singers of Germany. This term includes the Minnesingers; but is more especially used to denote the meistersingers, or mastersingers, of Germany, who became known in the fourth century, and were incorporated by Charles IV., in 1.378 , under the title of Meistergenossenschaft.

Singhala. One of the native names for Ceylon. Adj., Singhalese.

Single. In the language of hawking, a hawk's talon.

Singles. The reeled filaments of silk, twisted to give them firmness.

Single-Speech Hamilton. William Gerard Hamilton (1729-1796) was so known from the extraordinary impression made by the first and almost the only speech which he made in Parliament.

Singletree, corr. of Swingletree. [A.S. swingan, to swing.] The cross-piece to which the traces of a horse are fastened.

singlo. A fine tea with large flat leaves not much rolled.

Singular point. (Math.) A point on a curve possessing some property distinguishing it from the other points of the curve ; as a ic it of contrary flexure where the direction of the curvisture changes, a multiple point throngh whicn \&wo or more branches of the curve pass.

Singultus. [L.] (Med.) Hiccougir.

Sinister. [L., on the left hand.] 1. Unlucky, unpropitious, according to (ireek usage, the Greek augur having his face to the north. The Roman looked south. Both regarded the evil omens as coming from the west. 2. (Her.) The left-hand side of an escutcheon, which is, of course, to the right hand of a person facing it.

sinking fund. A fund for reducing the capital of the public debt. It has been found that there is no effectual method of doing this except by an excess of revenue over expenditure, the excess being employed for the extinction of a portion of the debt, and not to a separate fund accumulating at compound interest.

sinnet. (Sennit.)
Si non è vero, è ben trovato. [It.] If it be not true, it is well made up; said of plausible stories. Sinter. (Calc-sinter.)

Sintoos. In Japan, the adherents of the Sinsyn, or ancient religion of the country, before the introduction of Buddhism.

Sipahi. (Sepoys.)

Siphon. [Gr. $\sigma i \phi \omega \nu$, any kind of tube, a siphon.] 1. (Mech.) A bent tube for conveying a liquid over the edge of a vessel containing it into another vessel at a lower level. 2. (Zool.) (I) The tube running through the chambered shell of a mollusc. (2) That formed by the mantle of certain univalve and bivalve molluscs. (3) The mouth (Latreille) of some insects.

siphunculated. Having a little siphon, or spout.

Si quis. [L.] A notice, read in his parish church, that A B desires ordination, and that if any one knows of any impediment, he should declare it then, or acquaint the bishop.

\section{Sirat, Al. (Al-sirat.)}

Sir Charles Grandison. An ideal portrait, in S. Richardson's novel so named, of the combination of moral and religious perfection with social graces and accomplishments.

sirdar. [Pers. and Hind.] A chief.

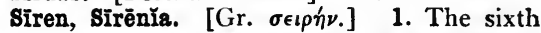
ord. of mammals. (Manatidæ.) 2. Gen. of amphibians, like eels, but with front legs. S.E. of U.S., America. Ord. Ürŏdēla.

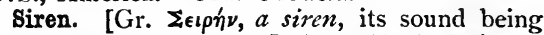
like a clear, sweet voice.] 1. In Myth., Seirens. 2. (Music.) An ingenious invention of M. de la Tour; an instrument which determines the number of aerial vibrations corresponding to a note of any given pitch.

Sīrius. [L., Gr. ofípıs.] (Astron.) The Dog-star (q.v.).

sirocco. [It. scirocco, from Ar. shark, sunrise.] An oppressive, relaxing wind blowing in Italy, etc., from the Libyan deserts. (Simoom.)

Si Romø sitis Romāno vivite more. [L.] Do at Rome as the Romans do; lit. survey in Roman fashion.

sir Roger de Coverley. Type, very admirably drawn, of the old-fashioned country gentleman; in the Spectator.

Sirventes. (Troubadours.)

Sisal grass. (Bot.) The dressed fibre of the American aloe, imported from Sisal, in Yucatan, and used for cordage.

Siste, viātor! [L.] Stop, wayfarer! a common beginning for epitaphs.

Sistrum. [Gr. $\sigma$ eí $\sigma \tau \rho o \nu$, from $\sigma \in i \omega, I$ shake.] An Egyptian timbrel, which the priests of Isis shook at her festivals.

Sisyphus. [Gr. olovфos, redupl. form of

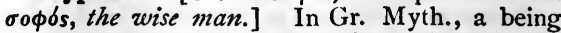
who is condemned to roll daily to the top of a hill a huge stone, which immediately rolls down again. The stone is the orb of the sun, which. no sooner reaches the zenith in its ascent from the horizon than it sinks down to it again.

Sita. (Rakshasas.)

Sítŏmănia. Insanity [Gr. $\mu a \nu l \alpha$, madness] ac.

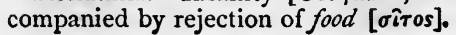


Sit tibi terra lěvis. [L.] Light be the earth upon thee; often put on epitaphs, under the initial letters S.T.T.I.

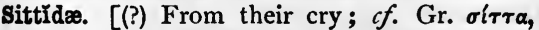
a cry of drovers to their flocks.] (Ornith.) Nuthatches; fam. of tenuirostral climbing-birds, with only one posterior toe, climbing upwards or downwards indifferently, making no use of tail in climbing. N. Europe, and N. America, Asia, and Australia; only one spec. in Europe, slate-coloured back, salmon-coloured belly, Sitta cæsia, gen. Sitta, fam. Sittǐdæ, ord. Passěres.

sitz-bath. [Ger. sitzbad.] A tub for bathing in a sitting posture.

Siva. (Mahâdeva.)

Si vales, bene est: ego quoque valeo. [L.] If you are well, it is good: I too am well; often prefixed to old Roman letters, under the initials 8.V.B.E.E.Q.V.

Sivan. Esth. viii. 9 ; ninth month of civil, third month of ecclesiastical, Jewish year; May-June.

si vis pācem, parā bellum. [L.] If thou wishest peace, make ready for war.

Six Acts, The, November, 1819, after the Peterloo Massacre (q.v.), had reference to (I) delay of trial for misdemeanour ; (2) prevention of training in arms and military evolutions ; (3) blasphemous and seditious publications ; $(4)$ the seizing of arms in disturbed districts ; (5) regulation, by a required stamp and otherwise, of certain pul.lications; (6) seditious assemblies.

Six Articles, Statute of the. A Bill passed by the Parliament, 1539, at the instance of Henry VIII., enforcing doctrines and practices not acceptable to the reforming parties, while those who would be disposed to accept them refused to admit the royal supremacy. The Act thus told against all sides equally.

six-upon-four. (Naut.) Reduced allowance, six men bcing put on the rations of four. Sixwater grog, six parts water, etc., to one part rum, given as a punishment, instead of the usual four-water grog.

Sizars. The lowest class of students at Cambridge; so termed from the sizings or rations of bread, meat, etc., allowed free to them.

size. [Welsh syth.] A weak glue used by paperhangers, bookbinders, painters, etc.

Sirel. (Scissel.)

skald. (Scald.)

skate-lurker. (Naut.) A beggar dressed as and pretending to be a sailor.

skelp. The rolled metal from which a gunbarrel is made.

Skew-arch; \$.-bridge. An arch whose shape is obtained from that of a cominon arch by distorting it in a horizontal plane, so that the space it covers between the abutments is no longer a rectangle, but a parallelogram whose angles differ more or less from a right angle. A $S$. bridge is built with a skew-arch, and is commonly used when a railway passes under or over a road, canal, etc., whose direction is not at right angles to that of the railway.

skid. A shoe for fastening the wheel of a waggon, so as to prevent its turning in descending a hill.
Skidbladnir. In Teut. Myth., a ship capable of holding all the Asir, or gods of Valhalla, and also of being folded up like a handkerchief. It is the same as the ships of the Phrakians (Phæacians), which go straight to their mark without helm, sails, or mariners, and which are, in short, the clouds.

skiff. (Ship.) 1. Any small boat. 2. A sailing-vessel carrying a fore-and-aft mainsail, jib foresail, and jib, and having no topmast.

Skillet. [O.Fr. escuellette, L. scutella, dim. of scutra, $a$ dish.] A small iron vessel for heating water.

Skilly. Slang term for weak oatmeal gruel.

skimmington, To ride. A phrase of unknown origin; said of a man who, having been beaten by his wife, is made to ride on a horse behind a woman, with a distaff in his hand. It is sometimes written Skimatry and Skimmerton.

skin. (Naut.) The inner planking. S. of a sail, that part of a sail which is outside when it is furled. To S. up a sail in the bunt, give it a smooth skin by furling it well up on the yard.

Skipetar. The name by which the Albanians, or Arnauts, are called among themselves.Finlay, Hist. of Greece, i. 335.

skive. The iron lap in which a diamond is held during the finishing of its facets.

Skiver. [Ger. schiefer, a flake.] A poor leather made of split sheepskin, used for lining hats, etc.

Skow. (Scow.)

skuld. (Norns.)

Skunk. [Contracted from Abenaki segankū.] (Zool.) Merphitis, the most offensive of the weasel tribe (Mustēlǐdæ) ; about the size of a cat; when irritated or alarmed, it squirts over its assailant a foetid liquid, secreted by special glands near the root of the tail. America.

Skysail. (Naut.) That above the royal. S.mast, either the top of royal-mast, or a sliding gunter, i.e. a small spar rigged abaft the mast.

Sky-scraper. (Naut.) A triangular sail above the skysail. Where squaresails are set above a skysail, they are called, first, moonsail, second, star-gazer, etc.

slacken, slakin. [Ger. schlacke, dross.] Spongy, half-vitrified substances mixed with ores to prevent their fusion.

slag. [Ger. schlacke.] The vitrified cincler: of a blasting furnace.

slashed. Having long slits, through which may be seen the under vesture.

slat. A narrow, flat piece of wood, as the cross-bars of a chair.

Slavonic languages. The dialects of Lithuania, Russia, and Poland.

Sleave silk. [Ger. schleife, knot.] Raw, untwisted silk, as used for weaving.

Sleep. (Naut.) (Asleep.)

Sleeper. 1. (Arch.) A timber or plate, under the floor of a building, on which the joists rest. 2. (Mil.) In gunnery, joists forming the framework of a gun platform in the direction of its length, and across which the planks are laid.

sleep of plants. The folding up of their leaves, mostly by night. (Irritability of plants.) 
Sleipnir. In Teut. Myth., the eight-footed white horse of Odin.

Sleuth-hound, Slouth-H., Sluth-H. [Scand. sleuth, track known by scents, O.N. sloz, track, path, Gael. slaod, trail along the ground (Wedgwood).] (Zool.) A keen-scented dog, as the bloodhound, hunting by the sleuth, or slot.

sleying. Parting the threads to arrange them in a sley, or reed. (Reed.)

slide-rest. The part of a lathe in which the cutting tool can be held, instead of being held by the hand.

Slide-valve. A dish-shaped rectangular piece, with an accurately plane surface, which is caused by the eccentric to slide in the steam-chest of a steam-engine, so as to open and shut alternately the passages or ports by which the steam enters the cylinder.

sliding-keel. (Naut.) Planks, or plates of metal, making a false keel, but so constructed that, on touching the ground, etc., they slide up through the keel.

sliding-rule, or slide-rule. (Math.) A rule used for gauging, etc., furnished with one or more graduated slips, which are capable of sliding in grooves cut in the body of the rule ; by properly adjusting these slides to the length, breadth, etc., of surfaces or solids, their areas, volumes, etc., are obtained by merely reading the graduations.

sliding-scale. In Finance, the regulation of prices, by varying the rates of taxation on imports in proportion to the price at which the same articles produced at home are offered for sale.

Slime. Gen. xi. 3 ; Heb. chemer, bitumen. So in the building of Babylon they used $\dot{\alpha} \sigma \phi \alpha \dot{\lambda} \tau \omega$ $\theta \in \rho \mu \hat{\eta}$ (Herod., i. 179).

slip. In Keramics, is potter's clay of the consistence of cream; called also Slop.

slipped. (Her.) Severed from the branch, as slips are taken from a plant.

Slit-and-tail bandage. (Surg.) The strips or tails of one part passing through holes in another part.

Slogan. [Gael.] The war-cry of a Scottish clan.

Sloop. A vessel similar to a cutter, but the bowsprit is not a running one, and the jib is set on a stay. In N. America, it sets on by a mainsail and jib foresail. S, in navy. (Rate.)

Slop. (Slip.)

Slot. (Mech.) A mortise or slit cut in a plate of metal to receive a key-bolt or other part of a machine.

Slot. (Sleuth-hound.)

Slouth-hound. (Sleuth-hound.)

Slow-worm. (?) The creeping worm [cf. Ger. blindschleiche, schleichen, to creep (Wedgwood); $e i$ in Ger. being often $=0$ in Eng.]. (Blind-worm.) Others take it as the slayingworm [A.S. slá-waurm].

Slubbing. Drawing out and slightly twisting (wool).

Slugs. (Mil.) Small pieces of lead, of irregular shape, fired from a musket at short range, to give a jagged wound.
Sluice. [A word common to many European languages, derived, perhaps, from L. exclūsa ; sc. aqua, water shut out.] A flood-gate, a vent for water.

Slur. [Cf. L.G. sluren, to wabble, and other cognate words (vide Wedgwood).] (Music.) A curved line over two or more notes to be played legato.

Slush. A mixture of white lead and lime, with which the bright parts of machinery are painted to keep them from rusting.

sluth-hound. (Sleuth-hound.)

Smack. (Naut.) Merchant or passenger vessels ranging to 200 tons, generally cutterrigged.

Smalcald, League of. A combination of Protestant princes of Germany, I 530, to support the cause, generally, against Charles V.; but especially to prevent the assembling of any Council professing to represent the whole Church, unless independently of papal influence.

Small arms. (Mil.) Every kind of firearm which can be carried by hand.

Smalt. [Ger. smalte.] A deep blue glass coloured with oxide of cobalt, and used, when powdered, in paper-staining.

Smart money. Previous to the Army Discipline and Regulation Act, 1879, a fine of 20 . levied by a J. P. on a recruit who desires release from his engagement between the time of being enlisted and of being attested. Enlistment now follows upon attestation; and the recruit may, within three months, be discharged on payment of $f$ io. (Chest of Chatham.)

Smectymnuus. In Eng. Hist., the title of a work against episcopacy, published soon after the assembling of the Long Parliament. It was formed by putting together the first letters of the Christian and surnames of the authors-Stephen Marshall, Edmund Calamy, Thomas Young, Matthew Newcomen, and William Spurstow.

Smeir. [Ger. schmier, grease.] A kind of half-glazing, made by adding salt to earthenware glazes.

smelting. [Ger, schmelzen, to smelt.] Melting in a furnace, so as to purify.

Smūax. [L., Gr. $\sigma \mu \hat{i} \lambda \alpha \xi$, bindzueed; but in Greek a name of other very different plants also.] (Bot.) A gen. of half-shrubby exogens, mostly climbers, ord. Smilaceæ. In temperate and tropical parts of Asia and America. The rhizomes of several yield sarza, or sarsaparilla. Some have fleshy, nutritious tubers.

Smitt. [Ger. schmitze, from schmitzen, to besmear.] Fine ochre in balls, used for marking sheep.

Smock-mill. A windmill of which only the cap turns round to meet the wind.

Smoke-box. (Mech.) The part of a locomotive engine in which the smoke collects from the fire-tubes before it goes up the chimney.

Smoke-sail, Grime-sail. (Ghrime-sail.)

Smriti. (Veda.)

Smug-boat. (Naut.) One smuggling opium into China.

Smut, Bunt, or Pepper-brand. (Bot.) 
fungus in corn [L. urēdo fotǐda], contained in the body of the grain, dispersed in grinding, and perpetuating the disease.

snaffle. [Ger. schnabel, a snout.] A bit jointed in the middle.

snap, Scotch. In Scotch melodies, and imitations of them; when a semiquaver at the beginning of a bar is followed by a dotted quaver; the emphasis thus rapidly thrown on to the second longer note gives spirit to the tune.

Snaphance. [Dan. snaphane, D. snaphaan.] A spring-lock for discharging a firearm; hence the firearm itself.

Snarling. Forming raised work on metal by the rebound of one end of a fixed tool, the other end of which is struck with a hammer.

Snatch. (Naut.) An open groove for leading a rope. $S_{.}$-block, a single iron-bound block with an opening in one side above the sheave, so that a rope can be placed in it without being rove; called also notch-block.

snood. [O.E. snod.] A fillet worn by Scottish maidens.

Snow. [From Ger. snau, schnau, snout, or beak.] (Naut.) A brig with the boom-mainsail set on a mast close abaft the mainmast.

snow-line. (Geol.) The line of altitude above which snow is always found on mountains.

Snow-shoe. An open framework attached to the sole, for walking on snow.

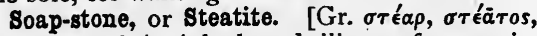
suet.] (Geolg.) A hydrated silicate of magnesia, greasy, yielding to the nail.

Soare, i.e. of sorrel colour (?). (Deer, Stages of growth of.)

Sobole. [L. sŏbŏlēs, a sprout.] (Bot.) A creeping, rooting stem.

Sobriquet. [Fr.] A nickname; said by some to be derived from L. subridentem, one smiling,

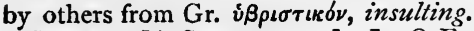

Socage. [A.S. soc, sway.] In O.E. Law, a tenure of lands by a determinate service.

Socialists. A name lately applied especially to the followers of Robert Owen, of Lanark, who made community of property a necessary condition of political improvement.

Social War. 1. In Gr. Hist., a war between Athens and the chief cities in her confederation, B.C. $357-355$. 2. In Rom. Hist., a struggle on the part of the Italians for the privileges of Roman citizenship, B.c. 9I-88.

Bociété anonyme. In France, a joint-stock company.

Socinians. The followers of Socinus, uncle and nephew, who, in the sixteenth century, maintained opinions in most points resembling those of the Arians. There seems to have been no organized body during their lifetime; but after their death their views were adopted by many communities, especially in Poland.

Sociology. [L. socius, fellow, Gr. $\lambda$ b́ros.] A barbarous word, sometimes used to denote the philosophical or religious system of the Positivists.

Sock. [L. soccus, akin to Eng. sack.] The shoe worn by the Roman comedians. Comedy itself. (Buskin.)
Socratio. Anything belonging to the system of Socrates; but more especially to his method of reaching conclusions by means of question and answer.

Soda. [It., from L. salsus, salted.] (Chem.) Oxide of sodium. Caustic soda is hydrate of soda. Soda ash is the commercial name of crude carbonate of sodium, obtained from black-ash $(q . v$.$) by lixiviation and evaporation.$ The residue, a mixture of unburnt coal and oxysulphide of calcium, is called soda waste.

Sodium. A very soft, light, silvery metal obtained from soda.

Sodom, Vine of. Deut. xxxii. 32 ; probably a colocynth, Citrullus colocynthus, growing near the Dead Sea; which is the same, probably, as the wild gourd of 2 Kings iv. 39, which was "death in the pot." The apples of Sodom of Strabo, Tacitus, Josephus, resemble oranges, but their rind covers only dark, ashlike contents and seeds. Like the oak-apples, they are the work of insects.

Soffarides. A Persian dynasty, which supplanted that of the Taherites in 872 , and lasted for thirty years.

Soffit. [Fr. soffite, It. soffitta.] (Arch.) The same as Intrados.

Sofis. [Pers., probably a corr. of Gr. $\sigma \delta \phi o s$, wise.] A title of the Dervishes. (Sufism.) The kings of the dynasty preceding that which now occupies the Persian throne were also so called. (Soofis.) The system of the Sofis seems to have many points of likeness with that of the Quietists.

Soft paste. (Paste.)

Soft tack, Soft tommy. In Naut. slang, loafbread.

Soi-disant. [Fr., L. se dicentem.] Self-styled; pretending.

Soil, To. [Fr. soûl, satiated, O.Fr. saoul, L. sătullus.] (Agr.) To feed animals with cutgreen food indoors; to feed highly.

Soirée. [Fr., from soir, evening.] An evening party.

Soit fait comme il est desiré. (La royne le veult.)

Solander, Solan goose. I.q. gannet (q.v.).

Solano. [Sp., from L. sōlānus ventus, wind of the sun.] An oppressive east wind blowing in Spain.

Solanoïd. In shape or consistency like a potato (Sōlānum tūběrōsum).

sōlānum. (Bot.) Nightshade, a very extensive gen. of plants, mostly narcotic and poisonous. Ord. Solaneæ, including $S$. tūběrōsum (potato); common and woody and other nightshades, egg-plants, tomato, etc.

Solar. [L. solārium, from sol, the sun.] A room into which the sun shines. In the domestic architecture of the Middle $A g e s$, a room built over the great hall of a house.

Solarization. [L. solāris, belonging to the sun.] Too long exposure of a photograph to the light while being taken.

Solar plexus. (Sympathotic system.)

Solar spots; S. system; S. time. (Astron.) 2. Solar spots are black spots, surrounded with a less dark space, observable from time to time on 
the surface of the sun. The $S$. system is the sun, with the planets, their attendant satellites, and the asteroids, which circle round it. Solar time is either apparent or mean (Time). (For S. cycle, $S$. day, vide Cycle; Day; etc.).

Soldan. (Sultan.)

Solder. [O.Fr. solider, to solidify.] (Chem.) An alloy of three parts of lead and one of tin. Fine solder, used for tinning copper, contains two parts of tin and one of lead. Hard solder, used for brazing, is an alloy of brass and zinc.

Soldier's wind. In Naut. parlance, one which serves either way.

Solěa. [L.] (Arch.) The part of the Roman basilica answering to the Presbytery in more modern churches.

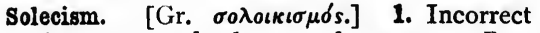
speaking, as regards the use of sentences; Bar.

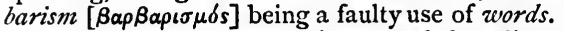
2. Metaph., an error against good breeding, manners ; said to have meant, originally, a corr. of pure Attic by the colonists of Sŏli in Cilicia ; but (?).

Solenhofen. (Geol.) Lithographic stone; Bavaria; a famous fossiliferous limestone; finegrained, homogeneous, stratification very parallel ; valuable in lithography. Upper Oolite.

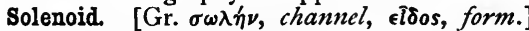
A spiral coil, having one end turned back so as to form the axis of the spiral, used in electrical experiments.

Sol-fa. (Music.) A general name for the notes of the scale ; e.g. tonic sol-fa. Guido Aretino, a Benedictine monk in the earlier part of the eleventh century, is said to have formed a new system of solfeggio, having observed the fitness of certain opening sounds of each half-line of a hymn to St. John, which ran thus : "UT queant laxis RE sonare fibris MIra gestorum FAmuli tuorum SOLve polluti LAbii reatum SAncte Johannes." Do was substituted for Ut ; Si was perhaps suggested by "Sancte Johannes," or was changed from $s a$ in "Sancte."

sol-faing. The system of singing which employs the names of notes instead of words. (Sol-fa.)

Solfatara. [It. solfáre, to fumigate with sulphur.] A volcanic vent, from which sulphur and sulphureous, watery, and acid vapours are emitted.

Bolfeggi. (Music.) Exercises in sol-faing(q.v.).

Solicitor-general. A law officer of the Crown, who holds by patent and ranks next to the Attorney-general.

Solicitors. Persons admitted to practise in the Court of Chancery; formerly styled attorneys in the courts of common law.

solid angle. (Math.) The angle formed by the meeting of three or more plane angles at a point ; as the apex of a pyramid.

Soli Deo gloria. [L.] Glory to God alone.

Solid of least resistance. (Resistance, Solid of least.)

Solid of revolution. A solid of the same form as the space traced out by a plane figure during its revolution round an axis in its plane; as a cone, which is traced out by the revolution of a right-angled triangle round one of the sides containing the right angle.

Solifidians. [L. solus, alone, fides, faith.] Those who maintain that men are justified by faith only without works. (Antinomians.)

Solitudrnom facǐunt, päcem appellant. [L.] They make a solitude, and call it peace (Tacitus). solmisation. I.q. Sol-faing (q.v.).

Solomon's seal. 1. Pentalpha (q.v.). 2. (Bot.) A gen. of liliaceous but not bulbous plants; Pŏly.

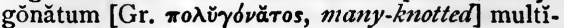
flörum being the most frequent spec. in England.

Solstitial colure; S. points. (Astron.) The points of the ecliptic $90^{\circ}$ east and west of the first point of Aries; the sun is in the former point at the midsummer of the northern hemisphere, and is then at his greatest distance north of the equinoctial ; he is in the latter point at midwinter, and is then at his greatest distance south of the equinoctial. (For S. colure, vide Colure.)

sōlns Deus hærēdem, sc. facit. [L.] God alone makes an heir-at-lazv; a maxim in Law : man may make a devisee, but circumstances beyond his control help to make his heir-at-law at the time of his death.

Solvitur ambulando. [L.] The difficulty " is solved by walking;" i.e. the theoretical difficulty is got over by actual trial. An allusion to a very old fallacy of Zēno of Ělěa, mentioned by Aristotle. Achilles, though going ten times as fast as the tortoise, will never overtake him, if he give him a start of $\frac{1}{10}$ of the course ; because by the time A. shall have run that $\frac{1}{10}, T$. will still be ahead by $\frac{1}{10}$ of that $\frac{1}{10}$ i.e. $\frac{1}{00}$; when $\mathrm{A}$. shall have run that $\frac{1}{\mathrm{I} n \pi}$, T. will be ahead by $\frac{1}{1000}$; therefore $A$. will never overtake $T$. The answer is (I) Solvitur, etc. ; actual trial proves that $\mathbf{A}$. will overtake, and where; i being $=\frac{1}{9}$. (2) Logically, the major premiss, in which it is assumed that the sum of an infinite series is infinite, is false.

Solvuntur risu tăbŭlæ. [L.] The indictment is quashed with a linugh (Horace).

Soma. A Japanese trading-junk.

soma. The drink which reinvigorates the Vedic or Hindu gods, as the Nectar refreshes the deities of Olympus.

Soma-, Somăto-. [Gr. $\sigma \hat{\omega} \mu \alpha, \sigma$ ónaros, the body.]

Sombrero. [Sp., from sombra, shade.] A broad-brimmed hat.

Sompnour, or Sumner (i.e. Summoner). Formerly, an officer in the dreaded ecclesiastical courts, whose duty it was to summon those who had offended against the Canon laws.

Sonāta. [It. 'sonāre, to sound.] (Music.) At first, a musical composition of but one movement, an air set instrumentally. Then, of more elegant character, were the S. di Chiesa, Church S., slow and solemn; and S. di Camera, Chamber $S$, admitting airs such as the Allemande, Sarabande, etc. Now a $\mathrm{S}$. has generally a first movement, allegro; a second, the slow movement; and a final allegro, of light character. Sometimes a fourth movement is interposed, a scherzo, or minuet and trio, between the slow movement and the final allegro. 
Sonderbund. [Ger., a separate league.] A name given to the league of the seven Catholic cantons of Switzerland against the Federal Diet, 1846. The league was dissolved in 1847 .

Sonnites. (Shiahs.)

Sonometer. [L. sǒnus, sound, $\mu$ érpov, measure.] (Phys.) An instrument employed for the determination of the frequency of vibration of a note of given pitch, consisting of a catgut of metallic wire stretched by a weight passing over a pulley, and furnished with a movable bridge, which can be adjusted till the string yields a note of any required pitch; the frequency can then be calculated from the weight and the observed length of the string from its fixed end to the bridge.

\section{Sonorous figures. (Nodal figures.)}

Sons and Daughters of Iiberty, Societies of. After Townsend's imposts on tea, glass, and paper, 1767 ; refused to use imported goods; they were first set up in Massachusetts, afterwards numerous in other colonies.

Soocey. A striped Indian fabric of silk and cotton.

Soofis, or Sofis. A dynasty of kings ruling in Persia, founded by Ismael Shah Sufi, 1502.

Soojee. Coarsely ground Indian wheat.

Soorma. An Indian cosmetic for the eyelids, made of antimony.

Sophis. (Sufism.)

Sophism. (Fallacy.)

Sophist. [Gr. $\sigma 0 \phi i \sigma \tau \eta s$, from $\sigma o \phi i \zeta \omega, I$ make wise or skilled.] 1. Any one who is master in his craft. 2. The class of teachers of youth in Athens and other Greek cities. 3. Persons accused of maintaining in their own interests systems of philosophy which they know to be false. Hence, 4, cheats and tricksters in matters of opinion.

\section{Sorana. (Simoom.)}

Sorb. (Service.)

Sorbonist. A doctor of the Sorbonne.

Sorbonne. A college at Paris for the study of theology, founded 1253 by Robert of Sorbonne in Champagne. It attained its greatest celebrity in the sixteenth and seventeenth centuries.

Sōri, i.c. heaps. [Gr. owpós, a heap.] (Bot.)

The small clusters of spore-cases upon the backs of the fronds of ferns.

Sŏrǐcĭdæ. [L. sŏrĭcem, shrezv-mouse.] (Zool.) Shrews, shrew-mice; fam. of Insectivora, not to be confounded with mice, or dormice, which are rodents; Sörex Etruscus, two inches and a half long, tail inclusive, is the smallest known mammal. S. are found everywhere, except $S$. America, W. Indies, the Australian district, and Polynesia.

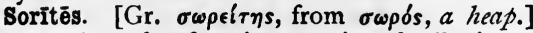
(Log.) A mode of stating a series of syllogisms, in which the conclusion of the last is a premiss of the next one, as $A=B, B=C, C=D$; therefore $\mathrm{A}=\mathrm{D}$.

Soritic. (Sorites.)

Sorrōsis. [Gr. owpós, a heap.] (Bot.) The fleshy consoliclation of many flowers, seed-vessels, and their receptacles; as pine-apple, breadfruit.
Sorrel (? from the colour). (Deer, Stages of growth of.)

Sortes Biblǐcæ, Homērǐcæ, Sanctorum, Virgilianæ, etc. [L.] Divination practised by opening the pages of the book at random, and using the passage which first meets the eye as applying to the question or case to be determined.

Sortie. [Fr., from sortir, to go out.] (Mil.) 1. A body of soldiers occasionally sallying out of a besieged town to interrupt the attack. 2. A sally.

Sortilege. [L. sortǐlěgus, gathering lots.] Divination by drawing lots.

Sotadic verse. So called as used by the Athenian comic poet Sotades. (Palindromic verse.)

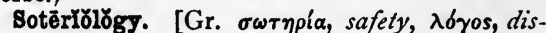
course.] A term denoting (I) treatises on the preservation of health, (2) the doctrine of salvation by Jesus Christ.

Sothic, or Sothiac, period. (Sothis, Egyptian name for Dog-star.) A period of $4 \times 365^{1}$, or 1461 years of 365 days. The ancient Egyptians used an official year of 365 days, though they knew that the actual length of the year is about $365^{\frac{1}{1}}$ days, and consequently that their official year would not continue in a constant relation to the seasons; they therefore deduced the S. P., in which their official year passed through all its relations to the seasons.

Sotto voce [It. sotto, prep., under, vóce, voice] or Sottovóce. Speaking softly, in an undertone.

Sou, or Sol. (Livre.)

Souchong. [Chin. se ou chong, small good quality.] A fine black tea.

Soul-shot. (Mortuary.)

Sound dues. Duties formerly levied by Denmark on vessels entering the Baltic. These duties were done away in 1857 , for a sum of more than three millions sterling paid to Denmark by Great Britain, Russia, Prussia, and other states.

Sounding. (Naut.) Ascertaining the depth of water and nature of the bottom by means of a lead and line. Soundings, not deeper than 100 fathoms.

\section{Sounites, Sonnites. (Shiahs.)}

Sour-bread. (Adansonia.)

Sourkrout. (Sauerkraut.)

Soutane. [From L. subtus, under (Littré).] The French word for a cassock.

Southcottians. The followers of Joanna Southcott, born at Gittisham, Devon, 1750. Having for years claimed for herself a divine mission, she at last, in 1814 , announced herself as about to become the mother of the approaching Shiloh. She died in the same year; but her disciples for the most part were not undeceived.

Southern Alps. A lofty range in New Zealand: in the North Island, nearly 10,000 feet high; while in South Island Mount Cook reaches 13,000, and Mount Tyndall I I, 00 feet. Eternal snow, with glaciers.

Southern Cross. (Astron.) A cross-shaped constellation of the southern hemisphere.

Southing. 1. In Navigation, the difference of latitude made by a vessel to the southward. 
2. The time at which the moon passes the meridian.

South Sea Bubble. (Sonth Sea Company.)

South Sea Company. A joint-stock company formed, in I7II, of the proprietors of certain Government debts, with special privileges for trading to the South Seas in consideration of facilities promised to the Government in the negotiation of loans. In 1720 the company proposed to negotiate all the public debts at certain rates. The rivalry thus caused with the Bank of England was such that by midsummer the company's stock had reached Iooo. Other stocks rose in the like way, and a vast number of schemes were set afloat. The company became alarmed, and fixed the rate of dividend for twelve years. But the tide had turned, and by the end of September the stock had sunk to 130. The misery caused by the collapse was great, and the project of 1720 became known in history as "The Bubble."

South-wester. (Naut.) A waterproof hat, constructed to shoot the water clear of one's back.

Sow. - The main channel from a smelting furnace to the bed of sand used for casting; the small channels being called pigs, whence is derived the term pig iron.

Sowar. [Hind.] (Mil.) Native cavalry soldier in India.

Sow-bread. The turnip-like, acrid, partly subterranean stem of the cyclamen, eaten greedily by swine.

Sowens, Sowins. Explained by some as the fine powder produced by husking or making grist of oats.

Soy. A Japanese fish sauce, made of the soy bean.

Spa. By meton. often $=$ a place frequented on account of its mineral springs; from Spa, a town in Belgium, known as a watering-place from the fourteenth century.

Space. [L. spătium.] 1. In Printing, the interval between lines or words. 2. A piece of metal lower than the types, used for filling such interval.

Spadassin. [Fr., It. spadaccino.] A fighter, a bravo, bully.

Spade, Spayed. (Deer, Stages of growth of.)

Spädix. [L. spādix, in class. L. is a brokenoff palm branch with fruit.] (Bot.) An axis bearing numerous closely packed sessile flowers, inclosed within a spathe [Gr. $\sigma \pi \dot{\alpha} \theta \eta$, any bruad blade], as in arums.

Spahi. (Sepoys.)

spandrel. [It. spandĕre, L. expanděre, to spread.] (Arch.) The space on the flanks or haunches of an arch, above the intrados, but not extending above the crown of the arch.

Spanish black. A black pigment made of burnt cork.

Spanish ferreto. A reddish-brown pigment, obtained by calcining copper and sulphur in closed vessels.

Spanish main. Connected with the history of buccaneering in the sixteenth and seventeenth centuries; the mainland from the Orinoco to the Isthmus of Darien.
Spanish red. A rich warm ochre.

Spanish stripes. A woollen fabric.

Spanish white. Purified and powdered chalk.

Spanker. (Sails.)

spanner. [Ger.] A tool for tightening the nuts on screws.

Span-roof. (Compass-roof.)

Sparable (i.e. sparrow-bill). A nail used in shoemaking (from the shape).

Spar-deck. (Naut.) 1. (Decks.) 2. Applied to the upper deck of a flush-decked, two-banked vessel. 8. The forecastle gangways and quarterdeck of a deep-waisted vessel.

Sparrow-hawk. (Musket.)

Sparse. [L. sparsus, scattered.] (Bot.) Not opposite nor alternate, and in no apparent regular order ; as branches, leaves, etc.

Sparterie. [Sp. esparto, grass-hemp.] Plaited work of Spanish grass.

Spartiates. (Periceians.)

spat. Spawn of shellfish, especially of oysters.

Spathe. (Spadix.)

Spătŭla. [L., any broad, flat instrument.] An instrument for depressing the tongue, spreading ointment, etc. Spatulate (Bot.), shaped like a spatula.

Spavin. [Fr. épervin.] Bone $S$, , in horses, a bony enlargement towards the inside of the hock, at the head of the shank-bone, or between some of the small bones of the hock. Bog S., or Blood $S$., an inflammation of the synovial membrane between the tībia and astrăgălus, with ex. cessive secretion, apt to attack young, weak, or overworked horses. Thorough-pin, a similar affection, sometimes coexisting lower down. Capped hock and Capulet or Capped elbow, in. flammation on the cap of elbow or hock, from a bruise. Windgalls, or Puffs, similar enlargements, permanent in fore and hind legs of most hardworked horses. (See Stonehenge, The Horse in the Stable and in the Field, p. 468.)

Spay. To destroy the ovary [cf. L. spădo].

speaker. The presiding officer in each of the Houses of Parliament. In the House of Lords the office is filled by the Lord Chancellor. In the Lower House the S. is elected by the Commons. He can vote only in committees, or when the votes on a division are equal; and he then gives a casting vote. Among other powers, he has that of issuing writs for new elections during a recess.

Speaker leaves the chair. In House of Commons, that the House may go into a Committee of the whole House, presided over by a Chairman of Committee of Ways and Means. The order of the day having been read, the S. puts the question, "That I do now leave the chair." If this be agreed to, the $S$. leaves the chair, the mace is removed, and the Committee begins its sitting.

Speoial pleader. One who draws common law pleadings, without being either an attorney or a barrister.

Special verdiot. A General $V$. is one delivered by the jury in general words with the issue, Guilty or Not Guilty. By a Special I'. the jury declare they find the special facts 
proved, but add that they do not know on which side, upon the facts, they ought to find the issue. Specie. [L. species.] Coined metal.

species. In Log. (Difference.)

Specific gravity. (Chem.) The weight, bulk for bulk, of solids and of liquids compared with water; and of gases compared with air. (Density.)

Specifio hea of a substance is the quantity of heat required to raise a unit of its mass one degree of temperature, and the measurement may be taken on the supposition that the volume of the substance continues constant, or that it continues under a constant pressure.

Spectātum venǐunt, veniunt spectentur nt ipsæ. [L.] They (the women) come to see and to be secn (Ovid).

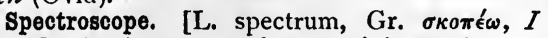
view.] An instrument for examining and comparing the spectra of different kinds of light.

Spectrum [L., an image] ; Chemical s.; Chromatio s.; Ocular S.; Solar 8.; Thermal s. (Phys.) The totality of the rays emitted from a source of light to a point or small space, and separated (or dispersed) by passage through a prism of glass or other refracting medium. When the source is the sun, the spectrum thus obtained is the Solar $S$. The rays separated by the prism have the properties of light and colour, heat, and chemical action, but in different degrees according to their different degrees of refrangibility ; and this fact is conveniently described by saying that there are three distinct kinds of rays, composing respectively the Chromatic $S$, the Thermal $S$., and the Chemical $S$. The chromatic S. occupies the middle position, the rays at the red end being the least, those at the violet end the most, refrangible, the maximum of light being in the yellow rays; the thermal S. begins beyond the red end and ceases near the violet end, the naximum of heat being outside of the chromatic $S$. , at the red end; the chemical S. begins in the green rays and ends beyond the violet rays, the maximum being in the violet rays, but it is intense outside of the chromatic S. The Ocular $S$. is the faint image seen when the eye, having been fixed on a small object of a bright colour, is turned away to a white surface; the image has a colour complementary to that of the object.

Spectrum analysis. The analysis of light by means of the spectrum produced by a prism. It has been shown that when a vapour sufficiently heated emits light of a certain refrangibility, the vapour at a lower temperature absorbs, i.e. refuses to transmit, light of the same degree of refrangibility. This principle serves to explain the dark lines of the solar spectrum. Thus, a certain line (D) has exactly the same degree of refrangibility as the light emitted from incandescent vapour of sodium; it is, therefore, inferred that incandescent sodium exists in the solar atmosphere, and stops the equivalent rays emitted by the more intensely hecited body of the sun. A similar process can be applied to the other dark lines of the solar and stellar spectra, and thus some knowledge of the elements composing those bodies is arrived at.

\section{Specular iron ore. (Hæmatite.)}

speculum [L., a mirror]; s. metal. A reflector, particularly the reflector of a reflecting telescope. Specula are made of a peculiar combination of metals (two parts of copper and one of tin), which is susceptible of a very high polish, and is called $S$. metal.

Sped. In Judg. v. 30 , is an instance of the original meaning, to succeed. Skeat refers to spowan, to succeed [A.S. spéd, haste, success].

speed-cone. (Mech.) A shaft running at a constant speed is enabled to drive a machine at different speeds by means of two sets of pulleys, those in each set being arranged in steps, with diameters so chosen that the same band can work the different pairs of pulleys, so that a small pulley on the shaft drives a large one on the machine, or a large pulley on the shaft drives a small one on the machine ; either set of pulleys is a speed-cone ; called also Speed-pulley.

Speedwell. (Veronica.)

spelicans. (Spilikin.)

Spelt, Spalt. [Ger. spalt, from spalten, to split.] (Bot.) A grain, Tritǐcum spelta; so called from the deep splits or cuts of the ears.

Spelter. [Ger. spiauter.] Commercial zinc.

Spencer. (Naut.) 1. A trysail. (Sails.) 2. A fore-and-aft sail set with a gaff, and used instead of main-topmast and mizzen staysails.

Spencer (from Lord Spencer). A short overjacket.

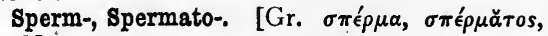
seed.]

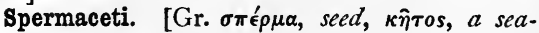
monster.] A white, brittle, fatty substance obtained from the head of the sperm-whale.
Spēro meliōra. [L.] I hope better things.
Speronara. (Naut.) A stouter-built scampavia (q.v.).

Spetches. Waste pieces of hide for making glue.

Sphacelated. (Med.) Affected with sphăcělus [Gr. $\sigma \phi a ́ k \in \lambda o s]$, gangrene, mortification.

Sphenoid bone. [Gr. $\sigma \phi \eta \nu 0 \epsilon i \delta \eta s$, of the shape of a wedge, $\sigma \phi^{\prime} \nu, \sigma \phi \eta^{\prime}$ vos.] (Anat.) A bone at the anterior part of the base of the skull, which wedges together all the other cranial bones.

Sphere [Gr. oфaípa, a globe, sphere]; Doctrine of the S.; Great S.; Oblique S.; Parallel S.; S. of projection; Right $\mathbf{S}$. The solid generated by the revolution of a circle round a diameter. The appearance presented by the heavens to a spectator is that of a sphere, in the centre of which he stands, half of which is hidden by his horizon, and which turns round a diameter passing through the poles once in twenty-four hours, carrying with it the stars, which seem to be bright points fixed on its surface. Astronomers find it convenient to speak of this appearance as if it were real, and they call it the Sphere, or the Great sphere. When one pole is overhead, it is a Parallel S.; when on the horizon, a Right $S$. ; when in any other position, an Oblique $S$. The Doctrine of the $S$. is the science of the relations between the circles drawn on the great S., their points of intersection and the arcs be- 
tween them; as the equator, ecliptic, poles, equinoctial points, etc. In Crystallog., the $S$. of projection is described within a crystal with any point as centre and any radius; the faces of the crystal are referred to it, by lines drawn at right angles to them from its oentre.

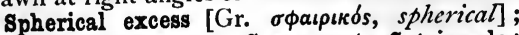
s. geometry ; s. sector; s. segment; s. triangle ; s. trigonometry. The portion of the surface of a sphere inclosed by arcs (each less than a semicircle) of three great circles is a Spherical triangle. The relations between the sides and angles of spherical triangles is the subject of $S$. geometry; those between the trigonometrical functions of the sides and angles, of S. trigonometry. The excess of the sum of the three angles of a spherical triangle above two right angles is its $S$. excess. A S. segment is the part of a sphere cut off by a plane; a $S$. sector is the part of a sphere inclosed within a conical surface whose vertex is at the centre.

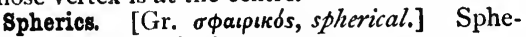
rical geometry and trigonometry.

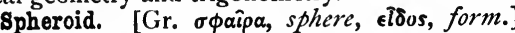
1. A body nearly spherical. 2. An ellipsoid of revolution (q.v.).

Spheroidal state. The condition of a drop of liquid when thrown upon a surface having a high temperature, in which case the liquid does not wet the surface, but takes a spheroidal form, moves about, and gradually evaporates without boiling.

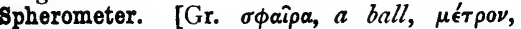
measure.] An instrument for measuring with great exactness the thickness of a plate or the curvature of a lens.

Sphinctër. [Gr. $\sigma \phi ı \gamma \kappa \tau \eta ́ \eta \rho, \sigma \phi i \gamma \gamma \omega, I$ bind tight.] (Anat.) A circular muscle which constricts orifices; as S. āni.

Sphinx. [Gr.] 1. (Myth.) A being who plagues the Thebans with drought and the maladies caused by drought, and who propounds riddles which none can solve except Edipus. These riddles are the mutterings of the thunder; and the Sphinx, whose name describes her as binding fast [Gr. $\sigma \phi i \gamma \gamma \omega, I$ bind tight], is the same as Ahi, the throttling snake, and Vritra, the thief, the great enemy of Indra. 2. (Zool.) Gen. of moths (Hawkmoths).

Sphygmo- [Gr. $\sigma$ ov $\gamma \mu$ ós, the pulse]; Sphygmograph. (Med.) An instrument which registers the force and extent of pulsations.

\section{Spiccato. (Staccato.)}

spick and span. New as a spike or nail just made, or a chip [Icel. spánn] just cut off.

Spider. (Naut.) An iron outrigger for keeping a block clear of a vessel's side. S.-hoop, an iron hoop round a mast, fitted with shackles, or belaying-pins.

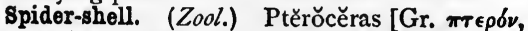
wing, képas, horn] ; gen. of molluscs with shell of a somewhat spider-like form. The common S. (P. lambis) is three or four inches long, mottled chestnut and white with orange streaks. Chinese and Indian seas. Fam. Strombǐdæ, ord. Prǒsōbranchiāta, class Gastěrǒpŏda.

Spigot. [Welsh yspigawd, from yspig, spike.]
A peg used to close a faucet, or a small hole in a cask.

Spike [cf. Ger. spick, L. spica, and spike] a gun. (Mil.) To render it unserviceable for the time, by inserting into the vent a steel pin with side springs, which, when inserted, open outwards to the shape of an arrow-head, which cannot be released. A long nail is used as a substitute.

Spike. [L. spica, an ear of corn.] (Bot.) Any inflorescence of sessile flowers along one axis ; as corn. (Inflorescence.)

Spikenard. Mark xiv. 3 ; John xii. 3 ; Nardostăchys jatamansi, ord. Valerinaceæ; the nardus of classical antiquity.

spilikin. One of a number of small thin pieces of wood, or other material, for playing the game of spilikins. These, each one marked with a number, are thrown together in a heap on a table; and each player in turn tries to remove, with a knitting-needle or similar instrument, what he can without shaking any of the rest. The game is won by the highest score.

Spill a sail, To. (Naut.) To shiver it, before furling or reefing. Spilling-lines, those used to prevent a sail bellying.

Sprlus. [Gr. $\sigma \pi i \lambda o s$, a spot, stain.] I.q. navus (q.v.).

\section{Spina Christi. (Christ's thorn.)}

spindle. 1. A millwright's term for a small shaft (q.v.). 2. The solid formed by the revolution of an arc round its chord.

Spine. [L. spina, $a$ thorn.] A hardened leafstalk, stipule, abortive branch, or any other process into the composition of which woody tissue enters.-Treas. Bot.

Spinet. [It. spinetta, from the plectra or thorns (L. spinæ) by means of which the strings were sounded.] An old musical instrument, like a harpsichord, but smaller.

spinoxism. 'The philosophy of Benedict Spinoza, a Jew of Amsterdam, born 1634; based on the proposition that "There can be no substance but God, and nothing can be conceived without God."

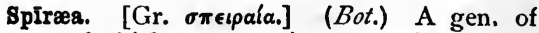
plants, of which one spec. is our meadow-sweet, S. ulmāria, or queen of the meadows, a tall plant, with fragrant yellowish-white flowers, ord. Rosaceæ.

Spiral. [L. spīra, a coil, Gr. $\sigma \pi \epsilon i p a$.$] (Math.)$ The curve traced out by a point moving in some specified way along a line which revolves round a fixed point; as the S. of Archimédes, which is traced out by a point moving uniformly along a line which revolves uniformly round a fixed point.

Spire. [L. spīra.] (Arch.) A sharp-pointed covering forming the roof of a tower, and often carried to a great height. (Broach spires.)

Spirit-level. A glass tube, whose axis is very slightly curved, nearly filled with spirit, for showing the true horizontal line by the central position of an air-bubble on its upper side.

Spirit of hartshorn. (Chem.) Impure carbonate of ammonia. (Hartshorn.) 
Spirit of salt. (Chem.) Hydrochloric acid, as being obtained from salt.

Spirit of turpentine. (Chem.) An inflammable oil distilled from turpentine.

spirit of wine. (Chem.) Pure alcohol, first obtained from wine.

spirkitting. (Naut.) In a man-of-war, the inner planking between the port-holes; in a merchantman, that between the upper deck and the plank-sheer.

Spirŭla. [L., dim. of spīra, coil.] (Zool.) Fam. and gen. of cephalopod, having internal chambered cell.

Spissitude. [L. spissitūdo, thickness.] The denseness or compactness of substances which are neither solid nor liquid.

Spit. [A.S.] (Agr.) A spade, in the terms spitful, one spit deep, etc.

Splanchno-. [Gr. $\sigma \pi \lambda \dot{\lambda} \gamma \chi \nu \alpha$, bowels.]

splay (shortened from display). (Arch.) The slanting expansion of windows internally, for the purpose of giving more light. Very common in Romanesque buildings, where the outer aperture is small, or Sconce [Fr. escoinson].

Spleen. [Gr. $\left.\sigma \pi \lambda \eta_{\nu}.\right]$ (Anat.) A spongy, highly vascular organ, in the left hypochondriac region, hetween the diaphragm and the stomach ; not secretive; probably regulating, under changes of condition, the quantity and quality of the blood.

Spleenwort. (Bot.) A name given to the gen. Asplēnium [Gr. $\tau \dot{\delta} \dot{\alpha} \sigma \pi \lambda \dot{\eta} \nu o \nu]$, a gen. of polypodiaceous ferns ; from a supposed, but in reality fanciful, potency in affections of the spleen [L. splen].

Splendour, Sun in his. (Her.) The sun bearing a human face and surrounded with rays.

Splent. (Splint.)

Splice. To connect beams, etc., by means of overlapping parts bolted together.

Splice the mainbrace, To. In Naut. slang, to serve out an extra allowance of grog.

Splint, splent. A hard, laminated coal, intermediate between cannel and pit-coal ; Glasgow, N. and S. Stafford.

Splint-bone. 1. I.q. Fībǔla (q.v.)-being like a splint, a thin piece of wood, etc., used, in treating fractures, to keep a part in position. 2. Splint, in horses, any bony growth from the cannon-bone. (Cannon.)

Splinter-bar. 1. A cross-bar in a coach, which supports the springs. 2. The bar to which the single-tree is attached.

Splinter-proof. (Mil.) Traverse place between any two guns of a battery, to cover the artillerymen working them.

Spoffish. A local word denoting overmuch activity in matters of no moment.

Spoken for. Cant. viii. 8 ; asked in marriage.

Spokeshave. A knife for trimming the spokes of wheels and other curved work.

spǒlia ŏpīma. [L., rich spoils.] Arms, etc., taken by a Roman general from the enemy's general on the field of battle.

Spondee. [L. spondẽus, Gr. $\sigma \pi o \nu \delta \delta$, a libation.] In Gr. and L. poetry, a metrical foot, in which both the syllables are long; so called from its slow movement, which made it suitable for hymns recited during the offering up of a sacrifice. spondyle. [Gr. $\sigma \phi \delta \delta \delta \delta \lambda o s$, and popularly

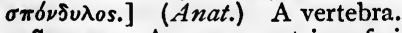

Spong. A narrow strip of inclosed land, especially by the roadside.

Spongiopileine. [Gr. ororyed, a sponge, and $\pi \hat{i} \lambda$ os, felt.] A fabric the inside of which is felt-made of sponge and wool-and the outside a coating of caoutchouc.

Sponson, or Wing. (Naut.) The projection of the deck, or platform fore and aft of paddleboxes. S.-rim, or $W_{\text {. }}$-wale, its outer edge.

Sponsors. [L. sponsor, a surety.] (Eccl.) Those who, in the name of an infant, make profession of the Christian faith at its baptism. (Fide-jussores.)

Spontaneous combustion of the human body. One supposed, in a few cases, to have arisen out of long excessive drinking of spirits ; believed in during last century; now proved to be impossible.

Spool. [Ger. spule.] A kind of reel for winding thread on

Spoor. [D. ; $c f$. Ger. spur, trace.] (Slot.)

Sporadio disease. [Gr. oropás, scattered, sporadic.] Occurring in single instances; opposed to Epidemic (q.v.).

Spŏrangium. [Gr. àryeiov, a vessel, capsule of a plant.] (Bot.) The case in which spores are formed.

Spores. [Gr. oropá, a sowing.] (Bot.) The reproductive particles of flowerless plants-e.g. fungi, algæ-analogous to seed; they do not contain an embryo, but are merely cellular.

Sporran. [Gael. sporan.] A leather pouch worn in front of the kilt by Highlanders.

Sportŭla. [L.] In Rom. Hist., the dole received by poor Clients from rich Patrons. It was first in kind, and was carried away in a wicker basket, but was afterwards commuted for money.

Spotted fever. (Med.) Continued fever, with eruption.

Spotted metal, or Metal. Of organ pipes, a mixture of tin and lead.

S.P.Q.R. The abbrev. form of the phrase, Sěnātus pǒpŭlusque Rōmānus, the Senate anit people of Rome.

Sprays. Side channels for distributing the molten metal in all parts of a mould (from being shaped like a spray of a tree).

spreader. (P unt.)

sprechery. Movables of a poor kind, gained chiefly by plunder on a march. - Scott, Waverley.

Spring, Bearing. The spring interposed between the carriage frame and the axle-box of a railway carriage.

Springe. A noose which catches birds, etc., by springing up.

\section{Spring-halt. (String-halt.)}

spring-ring. (Mech.) A flat split ring which, when not under pressure, is very slightly spiral, and with a small interval at the split; when placed round a piston within a cylinder, it becomes perfectly round, and pressing against the sides of the cylinder enables the piston to 
work air-tight without packing. A kind of S.-R. serves as a washer.

\section{Springs, Artesian. (Artesian wells.)}

Sprit. [A.S. spreót.] (Naut.) A small spar crossing a sail diagonally from the mast to the upper aftermast corner. S.-sails, (1) those extended on a sprit; (2) a squaresail formerly set on a bowsprit-yard. S. S. topsail, formerly set on a jibboom-yard.

Spruce. A decoction of the shoots of the spruce [O.E. Pruse, Prussian] fir.

Sprue. [Ger. sprühen, to throw off sparks.] The entrance to a channel called the gate through which molten metal is poured into a mould.

spud. [Dan. spyd, spear.] A chisel-shaped tool with a long handle, for destroying weeds.

Spar. (Geog.) A portion of a range of hills or mountains jutting out at right angles to the general direction of the range.

Spurge. (Bot.) Euphorbia ; a gen. of plants, type of the large ord. Euphorbiaceæ, to which belong manioc, caoutchouc. Almost all have acrid, milky juice. (Euphorbus, a Greek physician.)

Spurrey, Common, or Yarr. (Bot.) A weed of gravelly corn-fields and light soils; Spergŭla arvensis; ord. Caryophyllaceæ. One variety, cultivated in Holland and elsewhere in sandy districts on the Continent, yields excellent food for cattle.

Spur-royal. A gold coin of Edward IV., having on the reverse a star like the rowel of a spur. In later reigns its value was $15 s$.

Spurs, Batile of the. A battle fought, August I6, I 513 , between the French, and the English under Henry VIII.; so called because the French are said to have used their spurs more than their swords.

Spur-wheel. (Mech.) A toothed wheel of the ordinary construction, viz. in which the teeth are placed radially.

Spy (i.e. espy, Fr. espier, L. spěcĕre). As in Exod. ii. II, is very often simply to see, to discover by seeing ; without any idea of secrecy.

squad. [Fr. escouade, another form being escadre (squadron).] (Mil.) 1. Small number of soldiers formed up for drill. 2. The part of a company under charge of one non-commissioned officer.

Squadron. [Fr. escadre, L. ăcies quadrata, a square body of soldiers.] 1. (Mil.) A body of cavalry consisting of two troops. 2. (Naut.) A group of ships of war less than a whole fleet.

Squall, White. (Naut.) One which occurs in clear weather, and gives no warning of its approach but by the white foam it raises. -

squāma. [L.] (Zool.) A fish-scale.

Squamose. [L. squāmōsus, from squāma, $a$ scale.] (Anat.) 1. Scaly, like a fish. 2. Having edges overlapping, like scales.

square. 1. In Printing, a number of lines forming a square portion of a column. 2. An instrument formed of two pieces of wood fastened at right angles, used by joiners, etc., for testing square work. 3. (Mil.) To form $S$., an infantry evolution for the purpose of resisting cavalry ; the centre being hollow, and the sides four deep, facing outwards.

square; s. root. (Math.) To square a number is to multiply it by itself; the $S$. root of a number is one which produces the number when multiplied by itself; thus, the square of 5 is $5 \times 5$, or 25 ; the square root of 25 is 5 . (Quadrilateral.)

Square-prismatic system. (Crystallog.) The pyramidal system (q.v.).

square-rigged. (Naut.) Having square lower sails on every mast.

Squaresail. (Naut.) That set on the foreyard of a schooner, or the spread-yard of a cutter. S.-sails, (I) the courses (q.v.); (2) any fourcornered sail set on a yard suspended by the middle.

Square yards, To. (Naut.) To place them horizontally at right angles to the keel.

Squaring the cirole. (Math.) The problem of finding the side of a square equal in area to a circle of given radius. It is understood that the solution is to be obtained either by elementary geometry, or is to be expressed arithmetically by commensurable numbers : under these conditions the problem is insoluble. Two squares can, however, be determined, one greater and the other less than the circle, whose areas differ by less than any assigned quantity, however small -by a quantity bearing, for instance, a ratio to one of the squares less than the ratio of one square inch to a million square miles.

Squaw. [Algonkin Ind.] An Indian woman. -Bartlett's Americanisms.

Squid. (Ichth.) Penfish, Calamary, Teuthida [Gr. $\tau \in v \theta i s$, a cuttle-jish, or squid] ; fam. of molluscs, with pen-shaped internal shell.

\section{Squinancy. (Quinsy.)}

Squinch. Another name for Pendentive.

Sruti. (Veda.)

S.S., Collar of. Composed of a series of S.'s in gold, either linked or set in close order; the ends brought together by a buckle, from which hangs a jewel. Such collars have been much worn by officers of State, by gentlemen of various ranks ; now worn, with distinctions, by a L.C.J., L.C.B., Lord Mayor of London, heralds, sergeants-at-arms ; occurring frequently in monuments. Of a Lancastrian character, but not satisfactorily explained. (For different conjectures, see Chambers's Encyclopadia.)

Stābat Māter. [L.] The first words of a hymn on the grief of the Virgin mother as she stood by the cross of Christ. Said to have been written by Jacopone da Todi, in the fourteenth century.

Staccāto. [It., detached.] (Music.) Means that notes are to be sung or played in a detached, somewhat abrupt, manner. Spiccato [It., unhooked] is not quite so abrupt; in violin music, means to be played with the point of the bow.

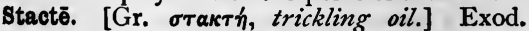
xxx. 34; the gum of the Sty̆rax officināle, a beautiful shrub of the Levant, Italy, Greece; having blossoms like those of the orange. (Storax.)

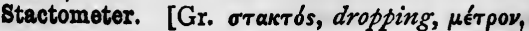


measure.] A glass instrument for measuring the number of drops in a given quantity of a fluid.

Stădĭum. [Gr. $\left.\sigma \tau a ́ \delta \iota \nu_{i}\right]$ 1. An open space for the celebration of games, surrounded by seats in tiers for the spectators, as at Olympia, etc. 2. A Greek measure of length, containing 606 feet 9 inches English.

Stadtholder. [D. stadthouder, city-holder.] Originally the title of the commander-in-chief of the army of the United Netherlands. William IV., Prince of Orange, 1747 , was the first hereditary stadtholder. In 1814 the head of the house of Orange received the title of king.

staff. (Mil.) All officers performing such duties with troops as are not included in regimental duty. Divided into general, personal, and regimental, $\mathrm{S}$.

Staff-captains. (Naut.) Masters of the fleet. Staff College. A school of instruction for officers who wish to be placed on the staff of the British army. Founded 1858. The number of students is thirty.

Staff-commanders. (Naut.) Masters of fifteen years.

Staggard. (Deer, Stages of growth of.)

Staggers. 1. A disease of the horse and some other animals, causing them to fall suddenly; a kind of apoplexy ; sometimes from overfeeding. 2. Wild, strange behaviour.

Stagmoid. Like a drop [Gr. $\sigma \tau \alpha \dot{\gamma} \mu \alpha]$.

Stagȳrite, The. Aristotle, born at Stageira, in Chalcřdice, B.c. 384. The correct spelling would be Stageirite.

Stahlianism, or Animism. Dr. Stahl's system of medicine; the anima, or soul, by erroneous or wrong action, being supposed to originate disease. One of mild laxatives, chiefly with bleeding, plethora being supposed a chief cause of disease ; to the neglect of chemistry, as a medical agent. (Stahl, author of the theory of phlggiston (q.v.), Prussian physician, died A.D. 1734.)

Stails. [Ger. stiel.] The handle of a broom, rake, etc.

Staithe. A line of rails at the end of a railway, for discharging coals, etc., into vessels.

Stake. A small anvil.

Stalactite (1), Stalagmite (2). [Gr. $\sigma \tau \alpha \lambda a ́ \sigma \sigma \omega$, $I$ let drip; (I) being an active derivative, (2) passive.] (Geol.) (I) Conical icicle-shaped concretions from the roofs ; (2) cones, ribs, or layers on the floors and walls, of calcareous caverns, caused by dropping and dribbling of water containing carbonate of calcium. Sometimes (I) and (2) meet, forming pillars.

Stal-boat. (Naut.) A fishing-boat, temp. Elizabeth.

Stallage. In Law, a duty paid for setting up movable stalls or stables in a market or fair. When the stalls are fixed, the duty is termed Pickage.

Stalls. [A.S.] (Arch.) Raised seats on each side of the chnir of a church. (Sedilia.)

Stämen. [L., (I) warp of the loom; (2) stamen.] (Bot.) The male organ of a flower, consisting of a filament or stalk, and anther, which contains the pollen. A sterile S. belongs to the series of stamens, but has not pollen.

Stāmina. [Plu. of L. stāmen, a thread of the distaff.] 1. (Bot.) A fibre of a plant, or of wood. Hence, 2, elementary principles, natural vigour.

Stammel. [O.Fr. estamette, a coarse woollen cloth.] 1. A fine worsted. 2. A pale scarlet colour.

Stamp Act, American. One of the proximate causes of the American Revolution, a scheme of internal taxation, passed by the Grenville Ministry, 1764 , repealed by the Rockingham Ministry next year.

Stampede. [Sp. estampādo, a stamping of feet.] 1. A general scamper of animals, on the Western prairies, usually from fright. 2. From animals, the term is transferred to men.-Bartlett's Americanisms.

Stamping. [Ger. stampfen.] Crushing with a heavy hammer, as ore in a stamping-mill.

Standard, or Vexillum. (Papilionaceous plants.)

Standard, Battle of the. (Eing. Hist.) A battle fought near Northallerton, Yorkshire, August 22, 1138, at which the Archbishop of York brought forward a consecrated standard. The Scotch were entirely defeated.

Standard, Royal. A flag bearing the arms of England, Scotland, and Ireland, quartered.

stand by! (Naut.) Get ready! S. B. a rope! take hold of it!

standing army. One raised and kept ready for service both at home or abroad under the immediate command of the sovereign; the permission of Parliament, being by law necessary, is renewed yearly. (Army Discipline and Regulation Act.)

Standing-jib. (Naut.) The innermost jib, or jib proper.

Standing-part of a taokle, or rope. (Naut.) The part which is made fast to the mast, deck, or block ; in opposition to the Running-part.

Standing rigging. (Naut.) Shrouds, stays, etc.

Standish. [Eng. stand and dish.] An inkstand surrounded with a flat dish for pens, etc.

Stand of arms. (Mil.) The complete weapons of each individual soldier.

Stanhope. (From Lord Stanhope.) A kind of light gig.

Stanislaus, st., Order of. (Hist.) A Polish order of knighthood, founded 1765 .

Stannaries. [L. stannum, tin.] Tin-mines, or royal rights pertaining thereto.

Stannary courts. [L. stannum, tin.] Courts in Devon and Cornwall for administering justice among persons employed in tin-mines.

Stannic acid. An acid formed from tin [L. stannum]. Its salts are called stannates.

Stannotype. [L. stannum, tin, Gr. túmos, type.] A photograph taken on a tin plate.

Stapes. (Anat.) One of the bones of the internal ear, shaped like a stirrup [stapes].

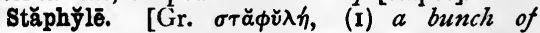
grapes, (2) uvula.] The uvula. Staphylotomy, amputation of the uvula. 
Stăphy̆löma. [Gr. $\sigma \tau \alpha \phi v ́ \lambda \omega \mu \alpha$.$] A grape-$ shaped protrusion of the outer surface of the eye, or of the iris, or of the cornea, the result of destructive inflammation.

Staple. (Staples.) 1. The thread or pile of wool, cotton, or flax. 2. A ventilating shaft sunk from the workings on one seam to those on a lower one.

Staples. Certain products in the supply of which this country was supposed to have special advantages. Thus wool and hides were staples of agricultural produce. The market for staples was carefully regulated. The word is said to be derived from O.Fr. estape, a mart for wine. The superintendence of the trade was in the hands of the Mayor of the Staple.

starboard. (A-beam.)

Starboard the helm. (Helm.)

Starbolins. (Naut.) The starboard watch. Larbolins, the port or larboard watch.

Star Chamber, Court of. A court so called, in the opinion of some, from the ornaments on the ceiling of the chamber in which it once sat ; according to others, from the Jewish bonds (Starrs) deposited in it. Notices of it go back to the reign of Edward III. The court acted by bill and information, and without jury. It was suppressed in the reign of Charles I.

Stärĕ sŭper antiquas vias. [L., to stand on the old paths.] To oppose novelties (Jer, vi. I6).

star fort. (Mil.) Closed work of which the parapet takes the usual representation of a star, with several acute salients and obtuse re-entrants.

Star of India. An order of knighthood, instituted $\mathbf{1} 86 \mathrm{I}$, for conferring honour on eminent natives of India, and on Englishmen who have distinguished themselves in the administration of that country.

Starost. A Polish title for the possessors of certain castles and estates called Starostics. The tenure was commonly renewed by the Crown to the heirs of the tenant on his demise.

\section{Starowerzi. (Raskolniks.)}

Starrs. [Heb.] Name for bonds deposited, by permission of William I., in a chamber of Westminster Palace; hence called Star Chamber.-Green's Hist. of the English People, p. 83 .

Stars and Bars. The flag of the late Southern Confederacy. - Bartlett's Americanisms.

Stars and Stripes. Flag of the U.S. ; adopted by Act of Congress, June 14, 1777: "Resolved that the flag of the thirteen United Colonies be thirteen stripes alternately red and white; that the Union be thirteen stars, white in a blue field, representing a new constellation."-Bartlett's Americanisms.

Statant. [O.Fr., from L. stare, to stand.] (Her.) Standing still, with all its feet on the ground.

Stater. [Gr. $\sigma \tau \alpha \tau \eta \dot{\rho} \rho$.] An ancient Greek coin, the value of which varied in the different Greek cities.

State rights. The rights reserved by the separate states of the American Union, when they surrendered certain prerogatives of independent states to the central authority of the confederacy. The conflict between these two interests led ulti- mately to the war of secession, which ended in the overthrow of the Confederate states of the South in $1865-66$.

State-room. (Naut.) A small sleeping-cabin or berth.

States-General. In Fr. Hist., assemblies, first called, 1302 ; discontinued, 1614; summoned again in 1789. They had, it seems, no proper jurisdiction; and their convocation by Louis XVI. led immediately to the Revolution.

Statesman. In the mountainous country of N. England, a yeoman; an old-fashioned kind of proprietor farming his own land, a link between landowner and tenant-farmer.

States of matter. (Phys.) The solid, liquid, and gaseous forms of the same substance; as ice, water, steam.

Static electricity is that developed on the surface of bodies.

Statics. [Gr. $\sigma \tau a \tau \iota k \delta$ s, causing to stand, from $\dot{\eta} \sigma \tau \alpha \tau \iota \kappa \dot{n}$, statics.] The science which treats of the conditions under which forces acting on bodies balance each other.

Station. [L. stătǐonem, residence.] (Bot. and Zool.) A continuous district, inhabited by any given animal or plant. It may be coextensive with a habitat $(q \cdot v$.

Station. Any military post held permanently by troops.

Stationary engine. (Steam-engine.)

Stationers' Hall. The hall of the Stationers' Company, which was formed into a guild early in the fifteenth century. The present duties of the company are chiefly to enter the titles of all new publications on their books, and to register assignments of copyrights.

Stationery. A term now denoting usually all materials needed for or connected with writing. Formerly the terms stationer and bookseller were nearly synonymous.

Stations. [L. stationes.] 1. In the Latin Church, places where, in processions, Mass is said, the reference being to the stations at Rome. 2. A form of devotion founded on the events of the Passion. The stations, originally seven, are now fourteen in number. They are also called Via Crucis, the way of the Cross.

Stat magni nominis umbra. [L., he stands the shadow of a great name.] He has survived his greatness.

Stătu quo, Status quo. [L.] The name of a treaty which leaves the belligerents in possession of all that each held at the beginning of the war; more fully, status quo ante bellum.

\section{Statute of Drogheda. (Poyning's Law.)}

Statutes of Limitations. Acts of Parliament which prescribe the limits within which actions must be commenced for the recovery of anything ; e.g. actions on simple contracts, for suits by the Crown, of ejectment, etc. So two years is the L. of action for a slander, six for libel, etc.

Statutes of Provisors. (Provisors, Statutes of.)

Stave (another form of staff). (Music.) The five parallel lines on which the notes are placed.

Stay. (Naut.) A rope extending from the top of a mast forward, to give it support. Backstays are led aft to a ship's sides abaft the 
shrouds. Spring-stays are extra stays nearly parallel with the stays, to give extra support. Stays are named after the mast they support, as Mainstay. S. of steamer, an iron bar between the paddle-beam knees. Staysail, a three-cornered sail set on a stay which is called a Staysail-S.

Stay. (Mech.) Long tie-bars connecting the ends of cylindrical boilers and other structures, to enable them to resist the pressure of the steam.

Stay, To. (Naut.) To tack, i.e. to come head to wind, and fill on the other tack. A vessel misses stays when, instead of filling on the other tack, she falls back. In stays, or hove in stays, in the act of staying.

Steady the helm, To. (Naut.) . To keep on the same course.

Steam [A.S. stēm]; Anhydrous 8.; Dry 8.; High-pressure S.; Iow-pressure S.; Saturated S.; Superheated S.; Surcharged S. Low-pressure steam exerts a pressure not greatly exceeding that of the atmosphere; High-pressure S. exerts a pressure that commonly equals that of several atmospheres, e.g. four or six, say 60 or 90 pounds per square inch. Saturated $S$. is steam formed in contact with its water-it then has the greatest density it can attain at the given temperature. If the steam is separated from its water and heated in a given space, it is Dry or Anhydrous $S_{\text {. ; }}$ such steam, separated from the boiler and heated in a distinct vessel, is also called Surcharged or Superheated S.

Steam-chest. The space or box adjacent to the cylinder, kept always full of steam, and from which steam is admitted into the cylinder through the steam-ports by the motion of the slide-valve, due to the action of the eccentric; called also the Valve-chest.

Steam-engine ; Beam E. ; Condensing E. ; High-pressure E.; Locomotive E.; Low-pressure I.; Marine E. ; Non-condensing E. ; Oscillating E.; Stationary E. An engine driven by steam pressure. There are many kinds of steam-engines. Of these we may notice the following :The Condensing engine, in which the waste steam is condensed, so that the piston moves with the steam on one side and a vacuum on the other; such engines were commonly worked by steam of low pressure, and are often called Lowpressure engines. In a Non-condensing $E$., the waste steam is driven into the air; it must be worked, therefore, by steam of high pressure, and is a High-pressure $E$. Steam of high pressure is, however, often used to work condensing engines. There are also Stationary $E$., commonly working by condensation; Locomotive $E$., which are non-condensing; and Marine E., which are modified stationary engines. In the Beam E. the piston communicates motion at one end to a large lever or beam, the other end of which works a pump, or by means of a crank gives a continuous rotation to the main shaft; in an Oscillating $E$. the cylinder is capable of a small oscillating movement sufficient to enable the crank to be turned directly by the piston-rod.

Steam-frigate. (Naut.) An armed steamship, commanded by a captain.
Steam-gange. A kind of manometer (q.v.) for measuring the steam pressure in the boiler.

Steam-hammer. (Mech.) A hammer consisting of a steam cylinder and piston placed vertically over an anvil, and rising and falling by steam-power.

Steam-jacket. A casing put round cylinders, steam-pipes, etc., and filled with steam to keep the interior body from cooling.

Steam-pipe. A pipe for carrying steam from the boiler to the cylinder.

Steam-ports. The passages through which steam is admitted into the cylinder from the steam-chest.

Steam-ram. A war-ship fitted with a ram, i.e. a projecting prow under the water-line, for piercing an enemy's vessel.

Steam sloop-of-war. One commanded by a commander.

Steam-whistle. A whistle in which sound is produced by turning a jet of steam through a narrow annular aperture against the edge of a hollow hemisphere placed above it.

Stearine. [Gr. $\sigma \tau$ ćă $\rho$, tallow.] A constituent of animal fat, to which it gives solidity.

Steatite. (Soap-stone.)

Stěatornīthǐdæ. [Gr. $\sigma \tau$ ćă $\rho,-\bar{\alpha} \tau o s, f a t$, ó $\rho v t s$, -ïos, bird.] (Ornith.) A fam. of birds consisting of one gen., containing one spec, the Guacharo, or Trinidac goat-sucker, a mottled brown bird, flecked with diamond-shaped white spots. It lives gregariously in caverns, and is distinguished from true goat-suckers by not being entirely (and perhaps not at all) insectivorous. Much valued for its fat by the Indians, but superstitiously dreaded for its weird habits. Venezuela, Bogota, Trinidad. Ord. Pīcārǐæ.

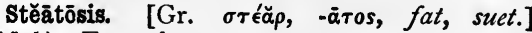
(Med.) Fatty degeneration.

Steelyard. A balance, the beam of which is divided into two unequal arms by the fixed point round which it turns. The long arm is properly graduated; the body to be weighed is hung at the end of the short arm, and counterpoised by a movable weight properly placed on the long arm; the reading of the long arm gives the required weight.

Steelyard, Merchants of the. (Hist.) A company of foreign merchants in London, to whom Henry III., I232, assigned the steelyard, that is, the balance by which a single standard weight is employed for determining the weight of bodies.

Steening, or Steining. (Arch.) The stone or brick wall with which the sides of a well are lined.

Steer. [O.E. steor, styre.] A young bullock.

Steerage. (Naut.) 1. Steering. 2. The space immediately below the quarter-deck, and before the main cabin bulkhead. 3. The between-decks just before the gun bulkhead. 4. The admiral's cabin on the middle deck of a three-decker has been so called. S. passengers, third-class $P$.

Steering-sail. I.q. studding-sail (q.v.).

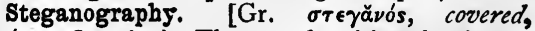
$\gamma \rho a ́ \phi \omega, I$ write.] The art of writing in ciphers 
intelligible only to those who are corresponding with each other.

\section{Steinbock. (Ibex.)}

Steining. (Steening.)

Stella. So styled by Dean Swift, who exerted a kind of enchantment over her; Esther Fohnson, a beautiful, highly gifted young girl, a dependent in the family of Sir W. Temple ; she died January, 1727-28. (Vanessa.)

Stella [L., star], Stellated bandage. (Med.) One with turnings crossed like $\mathrm{X}$.

Stelläria. [Formed from L. stella, a star.] (Bot.) A gen. of plants, ord. Caryophyllaceæ, to which belong stitchwort, or satin-flower, $\mathrm{S}$. hŏlǒstea [Gr. $\delta \lambda \delta \sigma \tau \epsilon o \nu$, which means all of bone, was probably some kind of plantain], with delicate white flowers; and chickweed, a common weed.

Stellionate. [L. stellionātus, perhaps from stellio, a lizard; hence a slippery or crafty person.] In Rom. Law, fraud committed by false sales, or sales under false pretences, as by selling the same thing to two purchasers. Six spec. of stellionate were defined.

Stelography. [Gr. $\sigma \tau \dot{\eta} \lambda \eta, a$ post, or pillar, $\gamma \rho a ́ \phi \omega, I$ urite.] An incorrect word, used to denote the art of making inscriptions on pillars.

Stem. 1. (Gram.) The radical part of a word, to which are added the forms imposed by inflexion or conjugation. 2. (Naut.) The foremost timber in a ship, to which the bow planking is fastened; it is scarfed into the keel, from which it extends upwards, supporting the bowsprit.

Stemmăta quid faciunt? [L., what do garlands (hung upon ancestral images) effect? (Juvenal).] What is the good of mere pedigree? Stemple. [Ger. stempel.] A wooden crossbar in the shaft of a mine.

Stencil. [Ger. stanze, a stamp for embossed zoork.] A thin perforated plate, which is laid flat and brushed over with colour so as to mark the surface underneath.

Stenography. [Gr. $\sigma \tau \epsilon \nu b s$, close, $\gamma \rho a ́ \phi \omega, I$ write.] The art of shorthand.

Stentorian voice. A voice like that of Stentor, the herald of the Achaians in the Iliad, which was as loud as that of fifty men.

Step. (Mech.) 1. The bearing against which a pivot presses endwise. 2. The gun-metal lining of the bearing in which a journal turns, and which shields the bearing from wear by being worn itself. 3. (Naut.) A large block of timber fixed upon the kelson, and fitted to receive the heel of a mast. To S. a mast, to erect, and secure it in the step.

Stephen, Palace of St. Built about II35; rebuilt by Edward III., I347; became the seat of the Parliaments, $155^{2}$; destroyed by fire, 1834 .

Steppes. [Russ.] (Geog.) Extensive plains not at a great elevation above the sea; as the steppes of Russia, Siberia, and Turkestan.

-ster. A suffix, the A.S. es-tre, denoting an agent; as in spin-ster, malt-ster, Brew-ster, Baxter (bake-ster), etc.

Stercorāceous. [L. stercus, stercŏris, dung.]
Stére. [Gr. $\sigma \tau \in \rho \in o ́ s$, solid.] A cubic mètre.

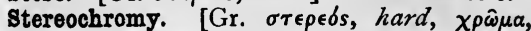
colour.] Wall-painting in water-colours, in which the picture is fixed and vitrified by being sprinkled with diluted fluoric acid.

Stereographic projection of the circles of a sphere is a perspective representation of them on a great circle, the eye or projecting point being in one of the poles of that circle.

Stereography. [Gr. $\sigma \tau \epsilon \rho \epsilon \delta s$, solid, $\gamma \rho \alpha \phi \omega, I$ draw.] The art of drawing the forms of solids upon a plane.

Stereometry. [Gr. $\left.\sigma \tau \epsilon \rho \in о \mu \epsilon \tau \rho^{\prime} a.\right]$ The art of measuring solids, particularly of finding their cubical contents.

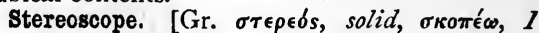
view.] A well-known toy in which two pictures of an object are arranged so that one is seen by the right, the other by the left, eye of the spectator, the result being that he sees but one image of the object, and that as if it were solid.

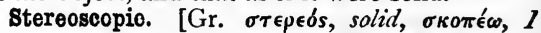
behold.] Of or belonging to a stereoscope.

Stereotomy. [Gr. $\sigma \tau \in \rho \in \delta ́ s, ~ s o l i d, \tau o \mu \hat{\eta}, ~ a ~ c u t$ ting.] The art of cutting bodies, particularly masses of stone, into any required form.

Stereotyping. [Gr. $\sigma \tau \in p \in \delta s$, hard, $\tau \dot{v} \pi$ os, type.] Making a solid plate of type by taking a plaster cast of the type set up in the common way, and then pouring melted type-metal on this cast.

Sterling. The legal description of English current coin, derived probably from Easterling, the popular name of the Baltic and German traders. The silver penny was first called easterling.

Stern-board. (Naut.) A run or leg made stern-first.

Sternhold and Hopkins. Authors of the metrical version of the Psalms, made in the reign of Edward VI., for which the version of Brady and Tate was substituted.

Sternĭdæ. (Ornith.) Terns, Sea-swallozes; gen. of swallow-like gulls. Cosmopolitan. Fam. Lărĭdæ, ord. Ansěres.

Stern-post. (Naut.) The aftermost timber in a ship ; it supports the rudder.

Stern-sheets. (Naut.) The part of a boat aft of the rowers, fitted with seats for passengers.

Sternum. [Gr. or'épov, the breast.] (Anat.) The breast-bone; flat, narrow, at the fore part of the thorax, and with which the ribs articulate.

Sternutation. [L. sternūto, I sneeze.] Sneez. ing. Sternutative, Sternutatory, substances causing to sneeze. (Ptarmic.)

Stertor, Stertorous breathing. [L. sterto, I snore.] A rough, hoarse noise (not snoring, which is confined to the nose, but) extending to the throat; a condition of disease indicating apoplexy, or epilepsy, or narcotic poisoning, or injury of the head; often mistaken, very unfortunately, for a sign of drunkenness.

Stet. [L.] Let it stand; i.e. upon second thoughts, let the words, the paragraph, etc., stand, though crossed out ; generally a direction to printers.

Stetch, Stitch. (Agr.) A system of boughts, or bouts, in ploughing. (Bought.) 


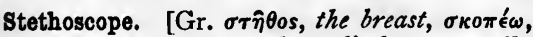
$I$ look at.] (Med.) A slender cylinder, generally of wood, seven to twelve inches long, which conveys sounds from the thorax or other cavities to the ear in auscultation.

Stet pro ratiōno vŏluntas. [L., let the will go for the reason (Juvenal).] Give unquestioning obedience.

Stevedore. (Stivadore.)

Steward. [A.S. stiward, the warder of the sty, as Howard was originally hog-ward, the swine-keeper.] In Feud. Law, the deputy of the lord in the manor court.

Steward, Iord High. Formerly, the first officer of the Crown in England. The dignity is now revived only for coronations or the trial of peers.

Sthenic diseases. [Gr. $\sigma \theta$ évos, strength.] (Med.) Accompanied with morbid increase of action in the heart and arteries.

Stiacciato. [It.] A kind of carving in very low relief.

8tibium. Antimony.

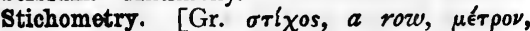
measure.] Measurement of the length of a book by the number of lines contained in it.

Stick lac. (Lac.)

Stiff. (Naut.) Not easy to capsize ; the opposite of Crank.

Stifle. [Ger. stiefel.] (Anat.) In the horse, a joint formed by the union of the lower end of the thigh-bone with the upper end of the tibia, and the back of the pătella, Stifle-bone, or kneepan; the articulation, really, of the knee.

Btigma. [Gr., mark, spot.] 1. (Bot.) The viscid upper end of the style, which receives the pollen. 2. Stigmăta is used to mean marks in the body, like those of Christ upon the cross, which have been reproduced in the hands, in some few cases, under the all-controlling power of a "dominant idea," viz. the desire to possess these marks. (See Carpenter's Mental Physiology.) The word is taken from the $\sigma \tau i \gamma \mu a \tau \alpha$ of Gal. vi. I7.

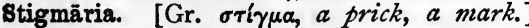
(Geol.) Root-stems of sigillaria (q.v.), pitted with marks of attached radicles. Carboniferous system.

Stigmăta. (Stigma.)

Stigmatization. The branding of slaves. (Stigma.)

Stillicide. [L. stillǐcídium, a falling by drops.]

(Med.) A morbid trickling of tears. (Epiphora.)

Still life. Inanimate objects; as fruit, flowers, furniture.

Stilted arch. (Arch.)

Strilum, or Stylum, verterre. [L.] To turn the style, or pen, generally of iron, used by the Romans for writing on wax tablets; i.e. to erase with the broad upper end what has been written; and so $=$ to correct and improve what one has said.-Horace, Sat. i. 1o, 72.

Stink-stone, Swine-stone. (Geol.) Fœtid limestone, which, when rubbed or knocked, smells of sulphuretted hydrogen.

Stipes. [L. stipes, a trunk, post.] (Bot.) The stalk of a mushroom; also of the fronds of ferns.

stippling. [D. stippelen, to dot.] The use of small dots instead of lines generally in engrav. ing or miniature-painting.

Stipule. [L. stipula, blade, stem.] (Bot.) The leafy or membranous processes sometimes arising from the base of a leaf.

Stirk, Sturck, Sturk. [O.E. styrc, a small steer (?).] A young ox or heifer (Scotland).

Stirpes, Per (I), Per capita (2). In Law, (I) a reckoning by families, not (2) by the number of individuals; said of the "taking of property ( $\mathrm{I}$ ) by representation, in opposition to (2) in one's own right as a principal" (Brown, Law Dictionary). If A leave money to his sons, $\mathrm{B}, \mathrm{C}$, and $\mathrm{D}$, of whom $\mathrm{C}$ dies in his father's lifetime, C's children (whatever their number), dividing equally between them their father's portion, would be receiving per stirpes, not per capita.

Stirrups. (Naut.) Ropes having one end nailed to the yard, and the other fitted with an eye through which the foot-ropes are rove.

Stitch. (Stetch.)

Stithy. [Icel. stedhi, anvil.] An anvil.

Stivadore, or Stevedore. [L. stipātorem, stipāre, to stuff, cram, press together.] In merchant shipping, the officer who superintends the stowage of ships.

Stiver. A Dutch coin, = English halfpenny.

Stoat (Zool.) is commonly a synonym for weasel; but denotes more properly the larger variety, which affords the fur called ermine.

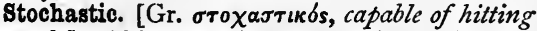
a mark.] Able to conjecture, conjectural.

Stockade. (Mil.) Closed work of stout timbers placed touching each other, pierced with musketry loopholes.

Stock and fluke. In Naut. language, the whole of a thing.

Stock of an anchor. (Naut.) A cross-beam of wood or iron, secured to the top of the shank at right angles with the flukes.

Stocks. Red and grey bricks used for the outside of buildings.

Stoics. (Hist.) A well-known body of Greek philosophers ; so called from the Stoa, or porch, in Athens, where their founder, Zēnon (Zēno), B. C. 300 , gave his lectures ; noted for the austere severity of their system. They were especially opposed to the Epicureans.

Stoke-hole. The space in front of the furnace where the stoker stands.

Stole. [Gr. $\sigma \tau 0 \lambda h, a$ piece of a dress, a robe.] (Eccl.) A narrow band, worn pendant by priests in front over both shoulders, by deacons over the left shoulder only in front and behind. In the Eastern Church, the deacon's stole is marked with the words "Hagios, Hagios, Hagios" (Ter-Sanctus), and is called Orarium.

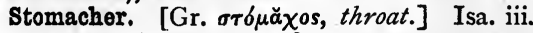
24; a part of the dress of a woman, worn on the throat and over the bosom; or an ornament only, in the same place.

Stomach-piece. (Apron.)

Stŏmăta. [Gr., plu. of $\sigma \tau \delta \mu \alpha, a$ mouth.] (Bot.) Minute openings in the epidermis of leaves (principally); breathing-pores.

stonacre. (Naut.) A sloop-rigged vessel, used for carrying stones on the Severn. 
Stone. A weight of fourteen pounds; but the London butcher's stone is eight pounds.

Stone Age. (Prehistorio archøology.)

Stonecrop. (Sedum.)

Stonefield slate. (Geol.) A Lower Oolite fissile limestone, used for roofing-stone (not real slate) in Oxfordshire; famous for its fossil mammals (amphitherium, etc.).

Stool. (Naut.) A smaller chainwale or channel abaft the chief one, to which backstays are made fast.

Stopped diapason. (Music.) An organ stop, stopped or covered at the top, generally of wood, of the same pitch as the open D., but softer in tone, the pipes also being only half the length. (Diapason.) The pipe being stopped at the top causes the air to rebound and produce a tone an octave lower than it would otherwise.

Stopper. (Naut.) Stopper of the anchor, a strong rope to steady the anchor when suspended from the cat-head. S. of the cable, or Deck-S., a rope made with a knot at one end, and lashed to the cable, the other end being fastened to a ring in the deck, to hold or S. the cable. Dog-S. (fastened to mainmast) and Wing-S. (fastened to side-beams) answer a similar purpose. Rigging-S., a rope fastened above and below a fracture, to prevent the rigging giving way.

Stopping out. Stopping up some of the lines in an etched plate with a composition, to keep out the acid, while the other lines are being deepened by it.

Stŏrax. [Gr. $\sigma \tau u ́ p \alpha \xi \xi$, L. sty̆rax.] 1. Ecclus. xxiv. 15; the gum of Sty̆rax oftícināle (stactē). 2. The S. of commerce, produced by the Liquidambar sty̆răciflora, ord. Balsam.

Storm, Magnetic. The cause-whatever it may be-of the accidental variations in the direction of the magnetic needle, which occur from time to time. The needle is observed to make deflexions to the right and left with great rapidity, at a rate comparable to that of ordinary telegraphic signalling.

storm-drum. (Naut.) A canvas cylinder, three feet in diameter and three feet high, hoisted as a warning.

Storm-dust. (Meteoric dust.)

Storm-jib. (Naut.) 1. A small jib in cutters, etc. 2. The innermost jib of a ship.

storm-kite. (Naut.) One used for carrying a rope from a stranded vessel to the shore, or vice versâ.

Storm-sail. (Naut.) One of extra strength and reduced size.

Storm-trysail. (Naut.) A fore-and-aft sail set on a gaff, but without a boom; only used in bad weather.

Storthing. The Parliament of Norway.

Story of the Seven Sages. (Panchatantra.)

Stot. [Sw. stut, a bull, D. stooten, to push, to butt.] A young bullock, i.e. one under two years old.

Stoup, Holy water. [A.S. stoppa.] In the Latin Church, the holy water basin placed at the entrance of churches.
Stover. [O.Fr. estover, provisions.] (Agr.) Hay made of sainfoin and the like.

Stowaway. One who, wishing to get out of a country, hides in a vessel about to sail, hoping to lie hid until it is too late to put back.

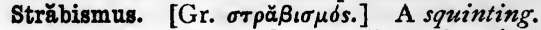
Straduarins. Meton. for a violin. (Amati.)

Straight arch. (Arch.) An arch of which the extrados is straight, but the joints of which are laid concentrically, as in a common arch.

Strain. (Phys.) The amount of elongation, compression, or distortion produced by the action of forces on a body.

Straitness. Deut. xxviii. ; Jer. xix. ; scarcity, famine.

Strake. (Naut.) A single breadth of plank extending throughout a vessel's length.

Strangles. A contagious disorder of horses, with cough, sore throat, and eruption in the jaw.

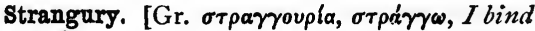
tight, oùpov, urine.] Painful discharge of urine in small quantities.

strap. A band. (Band.)

Strappādo. [O.Sp. estrapāda.] A military punishment, in which the offender was drawn to the top of a beam, and then allowed to fall suddenly.

Strapwork. (Arch.) An ornament consisting of a narrow fillet or band folded, crossed, and interlaced, chiefly found in work of the fifteenth and sixteenth centuries.

Strass (from the inventor). A colourless glass, the base of all artificial gems.

Strategy. [Gr. $\sigma \tau \rho \alpha \tilde{\tau} \eta \gamma^{\prime} \alpha$, generalship.] The science of combination before reaching the presence of an antagonist, by which an army shall have the advantage on coming into contact.

Strath. [Gael., Welsh ystrad.] In Scotland, the name of large valleys forming the watercourse of rivers, after which they are called.

Stratigraphy. [L. strātus, spread out flat, Gr. $\gamma \rho a ́ \phi \omega, I$ zurite.] In Geol., that department which arranges the rocks of the earth's crust in the order of their appearance, and explains how that sequence arose.

Strātus. [L., spread out flat.] A dense horizontal cloud, commonly resting on the surface of the land.

\section{Stream-anchor. (Anchors.)}

Stream-cable. (Cable.)

Stream the buoy. (Naut.) Drop it overboard astern, so that it may not foul the buoyrope as it sinks to the bottom.

Strelitz. [Russ.] A soldier of the ancient Muscovite militia, which, as interfering with the action of the Imperial Government, was dissolved by Peter the Great, after their revolt in 1698. The Strelitzy may be compared with the Janissaries.

Stress. (Phys.) The force exerted between contiguous bodies or parts of bodies, and distributed over the surfaces of contact of the bodies between which it acts; particularly the internal force called into play when a body undergoes any kind of strain.

Stretcher. 1. (Arch.) A stone or brick which 
lies with its longest dimensions parallel to the length of the wall (a header being one at right angles), the course in which the materials are so laid being called the stretching course. 2. (Naut.) Pieces of wood placed across the bottom of a boat, for the rowers to press against with their feet.

Stretching course. (Stretcher.)

Stria. [L., a groove.] (Nat. Hist.) A streak. Adj., Striate, Striated.

Striæ. [L.] (Zool.) Furrows, channels, as in the striated whales.

Striation. [L. stria, a groove.] (Geol.) Parallel lines or scorings in mountains at the sides of valleys; caused by the grinding against them of stones, etc., carried down by glaciers; also scratchings on the stones and boulders.

Strickle. An instrument to strike grain level with the top of the measure.

Stricture. [L. strictüra, a contracting.] (Med.) A morbid contraction, especially of the urethra ; but also of other mucous canals, e.g. œsophăgus, intestine.

Strigæ. [L., furrows.] (Arch.) The flutings of a column.

Strĭgìdæ. [L. strĭgem, owvl, Gr. $\sigma \tau \rho i \gamma \xi \xi$, from $\sigma \tau \rho i \zeta \omega,=\tau \rho ! \zeta \omega$, to screech.] (Ornith.) Owls; fam. of nocturnal birds of prey. Cosmopolitan. Ord. Accǐpǐtres.

Strigil. [L. strigilis, from stringo, I scrape.] An instrument for scraping the skin at the bath.

Strike. (Geol.) (Dip, 2.)

Strike, To. (Naut.) 1. To lower anything, as a flag or an upper mast (Acts xxvii. 17). 2. A ship strikes, if she touches the bottom, however slightly.

Strike. Part of the machinery of tradesunions. When the workmen combine to refuse work, it is called a S. When the masters refuse to allow them to work unless certain terms are agreed to, it is a Lockout.

String-course. (Arch.) Any narrow course of stone or brick work in a wall, of slight projection.

String-halt, popularly Spring-halt. In horses, a sudden catching up of one or both hind legs.

Strip a mast, To. (Naut.) To clear it of rigging.

Strip leaf. Tobacco leaves packed without the stalks.

Stripped to the girt-line. (Naut.) With all the rigging and furniture off the masts.

Strobile, Strobil. [Gr. $\sigma \tau \rho \delta \beta i \lambda o s,(\mathrm{I})$ anything twisted, (2) a fir-cone.] 1. (Bot.) A multiple fruit, as that of the hop or pine, in the form of a cone. 2. (Physiol.) An individual producing, non-sexually, individuals differing from itself; as the tapeworm.

Strocal. A shovel for filling the boiling pots with the materials for glass.

Stroke. (Mech.) The movement of the piston of a steam-engine through the length of the cylinder; it is either an up-stroke or a downstroke: a double stroke-up and down-is a revolution.

Strōma. couch.] (Anat.) The basis which supports the active elements of an organ.

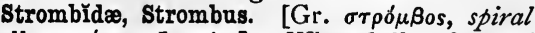
shell, $\sigma \tau \rho \in$ é $\phi, I$ twist.] Wing-shells; fam. of univalve molluscs. Trop. and warm seas. Class Gastěrŏpŏda.

Strong-back. (Naut.) 1. I.q. Samson's-post (q.v.). 2. A timber over the windlass to clear it of the turns of a chain-cable.

Strontium. (Min.) A yellowish-white metal obtained from strontianite (a mineral found at Strontian, in Scotland). Strontia is oxide of strontium.

Strŏphē. [Gr., a turning.] A division of a Greek choral ode, answering roughly to our stanza. At the end of the strophe the singers turned and went in the other direction, singing the antistrophe. When the course ended with a single stanza, the latter was called the epode.

Strouding. Coarse blanketing for making strouds, garments worn by N.-American Indians. Struma. [L., the thing piled up, a tumour, from struo, $I$ pile up.] I.q. scrofula.

Strūmōsis (coined from strūma). Formation of tubercle.

Strut. (Arch.) A piece of timber, sometimes called a brace, placed obliquely at the foot of a King-post or Queen-post, to support a rafter.

Strūthiōnes. [L. struthiōnem, ostrich, used as = strüthio-cămēlus, $\sigma \tau \rho o v \theta เ o-\kappa a ́ \mu \eta \lambda o s$, birdcamel.] (Ornith.) An ord. of running-birds, unable to fly, Rătītæ; e.g. ostrich.

Strūthřǒnìdæ. (Struthiones.) Ostriches; fam. of birds, two gen. : Strüthĭo, Africa ; Rhea, S. America. Ord. Strūthı̌ones.

Strychnos. [Gr. $\sigma \tau \rho$ vi $\chi \nu 0 s$, with the Greeks, nightshade.] (Bot.) A gen. of tropical climbing shrubs or trees, ord. Loganiaceæ; to which belongs S. nux vǒmica, a native of India. Its essential alkaloid is strychnine.

S.T.T.I. (Sit tibi terra levis.)

stub out, To. (Agr.) (Tiller, To.)

Stucco. [It.] A fine plaster, used for decorating and facing walls.

Studding-, or Stud-, or Scudding- sails. (Naut.) Those set on the sides of squaresails, on a yard and boom.

Stufa. [It., hot-house, steam-bath.] A jet of steam, such as issues from fissures in volcanic regions, often at a temperature above the boiling point of water.

Stuffing-box. (Mech.) A cylindrical space through which a piston-rod (or other moving part) passes; and filled with a packing so as to allow the rod to move freely and yet to prevent the escape of steam (or water).

Stupe. [L. stīpa, tow.] (Med.) Flax, cloth, tow, etc., dipped in hot medicaments and wrung out, for application to a part in pain.

Sturck, Sturk. (Stirk.)

Sturdy, or Gid. A disease of sheep, owing to a hydatid floating within a membranous sac, in the brain, sometimes the size of a nut ; produced by ova of the tapeworm, taken up in feeding. It may be safely extracted.

Sturionǐdø. [L.L. sturiōnem, the sturgeon, O.E. styria, styriga, Ger. stör, Sw. störia.] 
(Ichth.) Gen. of fish, Sturgeons; some spec. twelve to fifteen feet long, ganoid plates on head, and rows of the same on body. Northern regions; they ascend rivers to spawn. Fam. Acipensĕridæ [L. ăcǐpenser, the sturgeon], ord. Chondrostěì, sub-class Gănŏïděi.

Sturnìdæ. [L. sturnus, starling.] (Ornith.) Starlings; fam. of birds peculiar to E. hemisphere, but not found in Australian mainland. Ord. Passěres (Sturnoid).

Stygian. Belonging to or relating to the Styx.

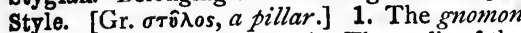
(q.v.) of a sun-dial. 2. (Bot.) The stalk of the stigma, an upward prolongation of the ovary ; it is not an essential part, and is sometimes absent.

Style [L. stȳlus, Gr. $\sigma \tau \hat{v} \lambda{ }^{\circ}$ ] ; Change of S.;

New S. ; Old S. A mode of reckoning time. In Old Style the year began on March 25, and its length was reckoned as that of the Julian year, viz. 365 days, with an additional day every fourth year; in New Style the year begins on January $I$, and its length is reckoned according to the Gregorian reformation, by which three of the additional days are dropped out every four hundred years. The Change of S., i.e. from old to new, was made in England as follows:-The year I75I, which began on March 25, was shortened by a quarter, and $175^{2}$ began on January I following; the eleven days by which the Julian reckoning had become too long were struck out in September, 1752, the days of that month being numbered consecutively 1, 2, 14, 15, etc.; i.e. the change of style took place after September 2, 1752.

Stylītēs, Stylite saints. [Gr. $\sigma \tau v \lambda i \tau \eta s$, from $\sigma \tau \hat{i} \lambda o s$, a pillar.] (Eccl. Hist.) Pillared saints, that is, devotees who dwelt on the summits of columns in Syria and Egypt. Such was Simeon Stylitès, in the fifth century.

Stylobbate. [Gr. $\sigma \tau v \lambda_{0} \beta a$ ár $\eta$, the foot of $a$ column.] (Arch.) The uninterrupted base below the pedestals of a range of columns.

Styloïd. Shaped like a style [Gr. $\sigma \tau \hat{\imath} \lambda o s]$, or pen.

Styptio. [Gr. $\sigma \tau \nu \pi \tau \iota \kappa \delta ́ s, \sigma \tau \dot{\phi} \phi \omega, I$ contract.] (Med.) Astringent, stopping bleeding.

Stythe. (Fire-damp.)

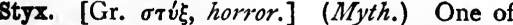
the ten arms or branches of the ocean stream which girdled the earth. It was also said to be one of the rivers of the unseen land of the dead. (Acheron; Cocytus; Iethe; Phlegethon.)

Sŭa si bŏna nörint, fëlīces. [L.] Happy, if only they knew their own blessings.

Suave mari magno. [L.] The first words of the opening of the second book of the Latin poet Lūcrêtius, De Rérum Natūrā; of which this is the general sense. "It is a delightful thing, while the great sea rages, to watch from the land another struggling with the waves: not because this is in itself a delight : yet it is a delight to watch calamities from which you feel yourself safe. So to look on a battle from some safe point of view. But nothing is more delightful than, from some serene stronghold of knowledge, to look down upon the wanderings and errors of other men, and their efforts after mere wealth and power, rather than knowledge and a quiet mind."

Suaviter in modo, fortiter in re. [L.] Gently in manner, stoutly in action.

Sub. [L., under.] 1. In composition, is often = somewhat: as sub-acute pain, which is less than acute; sub-angular, as applied to rocks, etc. 2. (Chem.) Prefixed to the name of a salt, denotes a decrease of the element thus marked; as a sub. sulphide, which contains less sulphur than the sulphide.

Subacute diseases. Of which the fever is less than acute.

\section{Subaerial. (Eölian accumulations.)}

Subahdar. The Hindu name for the governor of a subah or province. In the Indian army it denotes an officer ranking as captain in European companies. (Nawâb.)

Subaltern. [L. subalternus, subordinate.] 1. (Mil.) Any commissioned officer in the army under the rank of captain. 2. (Log.) Particular propositions in their relation to Universal proposition.

Subarration. [L. sub arrha, under earnest money.] Betrothal by the bestowal of marriage gifts or tokens, as rings, etc., upon the woman.

Subchelate. Somewhat chelate (q.v.).

Subcontrary. 1. (Geom.) (I) Two similar triangles having one angle of the one superimposed on an equal angle of the other, but so that the bases are not parallel, but are in subcontrary positions. (2) When an oblique cone has a circular base, all sections parallel to the base are circular, and it has also a second set of parallel circular sections; any section of the one set is subcontrary to any one of the other set. 2. (Log.) A term expressing the opposition between two propositions, one of which is a particular affirmative, the other a particular negative.

Subcutaneous. Under the skin [L. sub cŭte].

Subdeacon. In the early Christian Church, officers employed in subordination to the deacons. In the Latin Church they were not considered to be in holy orders until the thirteenth century. The office is not retained in the English Church.

Sub dio, or Sub Jöve. [L.] In the open air.

subdominant. [L. sub, under, dŏminantem, governing.] (Music.) The fifth below or fourth above the key-note, either as being the note $b c$ low the dominant or as being a governing note, but in a less degree.

Subduplicate ratio. (Math.) Of two numbers, the ratio of their square roots.

Subinfeudation. In Feud. Law, the creation of a subordinate tenancy by a tenant, to be held of himself and not of the lord.

Subject. [L. subjectus, thrown under.] (Log.) In a proposition, the term of which anything is affirmed or denied, i.e. predicated. (Predicate.)

Subjective and objective. In Phil., words denoting the distinction between the person forming the conception of an object, and the object of which the conception is formed, in Sir W. Hamilton's language, the former belonging to the Ego, the latter to the Non-ego.

sub judice lis est. [L.] The matter is befor the judge, is undecided (Horace) 
Sublapsarians, or Infralapsarians. [L. sub or infra, under, lapsus, a fall.] Most divines of the reformed Churches have held that God permitted the fall of man without absolutely determining it; a doctrine which has been termed Sublapsarian, in opposition to the high Calvinistic or Supralapsarian view.

Snb-lientenant. (Rank.)

Sublimate. (Chem.) The product of sublimation, which consists in raising [L. sublimis, high] a substance into vapour by heat, and then condensing it. Corrosive sublimate is mercuric chloride.

Sublime Porte. (Seraglio.)

Sublition. [L. subliněre, to lay on as a ground colour.] The act of laying a ground colour under the more perfect colour.

Sublittoral. [L. sub, littus, littoris, the shore.] Under the shore.

Subluxation. [L. luxatiōnem, $a$ dislocating.] (Med.) Partial dislocation.

Submarine forests. (Geol.) In several places along the British coasts ; generally beds of peat, or semi-lignite, with roots and trunks of oak, Scotch fir, alder, yew, etc., overlain by many feet of marine silt; showing (I) formation at a higher level than present sea-board; then (2) submersion; and (3) re-elevation; the flora the same as that now existing.

Submental. (Med.) Under the chin [L. sub mento].

Submission of the Clergy, Statute of, A.D. r 534, embodied the S. made by Convocation, two years before, that they would promulgate no new Canon without the king's licence; and their desire for a revision of existing Canons by thirtytwo men, sixteen being taken from the Houses of Parliament, and sixteen being clergy.

Subnormal. [L. sub, norma, a rule.] (Math.) The part of the axis of a curve intercepted between the ordinate and normal drawn at any point.

Subpœna. [L., under penalty.] In Law, writs carrying penalties for neglect. They may simply order the appearance of a witness, or enjoin him to produce books or papers.

Subrogation. [L. subrŏgātiōnem.] In Law, the substitution of one person for another in the exercise of rights. Hence a Surrogate.

Sub rŏsā. [L., under the rose.] Secretly, confidentially.

Subsellium, plu. Subsellia. [L.] (Eccl. Arch.) The long seats in the stalls of chancels or choirs; also known as Misĕrēeres.

Subsǐdra, plu. [L.] Helps, aids.

Snbsĭdy. [L. subsidium, an aid.] (Eng. Hist.) An extraordinary grant to the sovereign, made by authority of Parliament, and levied on the estates of those who were liable to them; frequently in quantity on all goods, as a tenth, fifteenth, etc. ; sometimes only on particular goods, as the ninth sheep, lamb, or fleece. In course of time the $\mathrm{S}$. came to be regarded as a land tax.

Sab silentio. [L., in silence.] Unnoticed.

Substance. [L. substantia, the L. equivalent of Gr. ovoía, essence.] In Log., according to some, the collection or synthesis of attributes. (Nominalists; Realists.)

Spbstantive colours. Those which require no mordant to fix them.

Subsumption. [L. sub, sumptiōnem, a taking.] The act of subsuming, or including under another. In Log., the minor clause or premiss of a syllogism.

Subtangent. [L. sub, tangentem, touching.] (Math.) The part of the axis of a curve intercepted between the ordinate and tangent drawn at any point.

Subtend. [L. subtendo, I extend underneath.] (Math.) If there are three points-A, B, and Cthe angle between the lines $A B$ and $A C$ is the angle subtended at the point $\mathrm{A}$ by the line $\mathrm{BC}$.

Subtense of an arc. [L. subtendo, I extend underneath.] Its chord.

Subtle Doctor. (Doctor.)

Subtonic, or Leading note. (Music.) The note which is a semi-tone belorv the tonic, the seventh in the scale, insensibly leading to and suggesting the tonic, or eighth.

Subulate leaf. [L. sūbŭla, an awl.] Awl. shaped, narrow and tapering to a very fine point ; e.g. leaves of furze.

succades. [L. succus, juice.] Sweetmeats.

Succēdāneum. [L., a thing substituted.] In dentistry, an amalgam for the cavities of the teeth.

Sucoentor. [L. sub, cantor, a singer.] Iń a cathedral, deputy of precentor; originally the leader of the singing on the opposite side to the $P$.

Succession, Apostolical. (Theol.) The alleged unbroken succession of priests in the Church by regular ordination from the apostles to the present time. In the theory of the Latin Church, all bodies in which this succession has been broken have neither Church nor sacraments.

Snccession, War of the. Two wars in modern European history are known by this name: (I) that of the Spanish succession, I 702-13; (2) that of the Austrian succession, ended by the Peace of Aix-la-Chapelle, 1748 .

Succession duty. A tax imposed on succession to property, real or personal, according to its value and to the relation of the successor to the testator or predecessor.

Succinic acid. An acid obtained from amber [L. succǐnum].

Snccory. (Chicory.)

Snccotash. [N.-Amer. Ind. msickquatash, corn boiled whole.] Green maize and beans boiled together.

Succǔbi. [L.] A term used in the Middle Ages to denote the female devils with which wizards were thought to have intercourse, the incubi being the male devils to which witches were supposed to submit themselves.

Succursal. [Fr. succursale, L. succurro, l help.] 1. (Eccl.) A church established to succour a parochial church; in other words, to serve as a chapel of ease. 2. A branch establishment.

Succussion. [L. succussio, succŭtio, I shake up.] (Med.) A shaking of the patient's body, 
to ascertain by the sound the existence of fluid within the body.

Sucrose. [Fr. sucre, sugar.] Cane-sugar.

Suction-chamber; S.-pipe; S.-pump. (Mech.) In the Suction-pump water is raised simply by the atmospheric pressure on the water in the well : on the up-stroke a vacuum is formed in the barrel or $S$-chamber, into which water is forced up by atmospheric pressure along the S.-pipe; on the down-stroke a valve at the top of the suctionpipe prevents the water from running back into the well; it therefore forces its way through a valve in the piston into the space above, and at the next stroke is lifted to the spout.

Sūdāmĭna [L., sweatings, coined from sūdo, $I$ sweat], or Miliary eruption [mǔlium, millet secd]. (Med.) Vesicular disorder of the skin, caused by copious perspiration.

sudder. [Hind. sudr, eminence.] A term applied in India chiefly to courts of high criminal and civil jurisdiction, called Sudder adawlut.

Sudra. (Caste.)

Suffetes. (Hist.) The highest magistrates of the Carthaginian republic, answering in name to the Hebrew shofetim, judges.

Suffix. (Affix.)

Suffragan. [L. suffrägium, $a$ vote.] (Eccl.) 1. The bishop of a diocese in reference to his metropolitan. 2. The term is also applied to bishops appointed to assist a bishop in his diocese. (Chorepiscopus.)

Suffrage. [L. suffrāgium.] A vote given in deciding some disputed question, in election to some office, etc. Suffrages, in public worship, versicles with their responses; as in the Litany, and after the Creed in Morning and Evening Prayer, and elsewhere.

Suffraginous. Belonging to the knee-joint [L. suffrāginem] of a beast.

Sûfî. (Soofis.)

Sufism. A kind of mysticism, within the Mohammedan communion; the sûfî being a kind of superior fakir [Âr. souf, wise, religious; (?) souf, wool, i.e. not silk for gar-

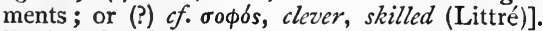
During the sixteenth and seventeenth centuries Persia was governed by a dynasty of Sophis, Sufis, or Soofis.

Sugar of lead. Acetate of lead (from its taste). Suggestio falsi. [L.] The suggestion of $a$ falsehood without actually putting it into words. (Suppressio veri.)

Suggillation. [L. sūgillo, I beat black and blue.] ( $M e d$.$) A black-and-blue mark, bruise.$ Sui gènĕris. [L., of its own kind.] Peculiar, rare.

Suktas. (Veda.)

Sulcus. [L., a furrow.] (Anat.) A groove on the surface of a bone.

Sulky. A light two-wheeled carriage for one person alone.

Sulphur. [L. sulfur.] A brittle yellow inflammable element. Its compounds with another element are called sulphides or sulphurets.

Sulphuric acid contains one equivalent of sulphur to three of oxygen, and forms salts called sulphates.
Sulphurous acid contains one equivalent of sulphur to two of oxygen, and forms salts called sulphites.

Sulphur showers are composed of yellow pollen blown from pine-forests.

Sultan. [Ar.] A title of many Mohammedan princes, the Grand Sultan being called Padishah.

Sum [L. summa, the total]; Algebraical s. The result of adding together two or more numbers. In forming the Algebraical sum of several numbers, each has its proper sign prefixed, whether positive or negative; the difference is then found between the arithmetical sum of the positive numbers and that of the negative numbers, and this difference, with the positive or negative sign prefixed, is the required algebraical sum; thus the algebraical sum of $7-$ IO - II + $22-31$ is -23 . This generalized use of the word sum is of great importance in the enunciation of general theorems.

Summa theologiæ. [L., the sum of theology.] As encyclopædic treatise on theology, drawn up by Thomas Aquinas, the Angelic Doctor, whose followers were known as Thomists.

Summum bŏnum. [L.] The chief good.

Summum jus, summa injuria. [L.] The strictest lawe may cause the worst injury; lit. highest right, highest wrong.

\section{Sumner. (Sompnour.)}

Sump. [Ger. sumpf, a swamp.] 1. A pit at the bottom of a mine for collecting the water to be pumped out. 2. A round stone-pit lined with clay for receiving metal at its first fusion.

\section{Sumpsimus. (Mumpsimus.)}

Sumpter. [Fr. sommier, from somme, saume, salma, sagma, Gr. $\sigma a ́ \gamma \mu a, p a c k$, pack-saddle.] A pack-horse, mule, etc.

Sumpter-mule. (Mil.) Carries provisions for troops on the march.

Sumptuary laws. Laws designed to restrain the expenditure of citizens. No such laws remain in this country. The S. L. regulating the wages of labour and the dress of the peasantry held their ground longest.

Sun and planet wheel. (Mech.) A combination for converting the reciprocating motion of the beam of the steam-engine into the circular motion of the fly-wheel. The sun-wheel is on the axle of the fly-wheel, the planet-wheel on the connecting rod, the teeth of the former working with those of the latter; and their centres are connected by a link to prevent displacement.

Sundew. (Drosera.)

Suni. (Sonnites.)

Sunn. An E.-Indian hemp, called also brown or Madras hemp.

Sunniah. (Shiahs.)

Sunnites. [Ar. sunna, custom.] So called as assigning equal authority with the Coran to tradition, which was first unwritten, the Shiahs, or Shiites, upholding the exclusive authority of the Coran.

Sunt lacry̆mø rērum, et mentem mortālia tangunt. [L.] Life has its sorrows, and the heart is touched by our (common) mortality.

Suŏvětaurŭlia. [L.] In Rom. Hist., a quin. 
quennial sacrifice, consisting of a sow [sus], a sheep [ovis], and a bull [taurus].

superaltar. (Retable.)

Supercargo. In a merchant-ship, the officer superintending the commercial transactions of the voyage.

Superciliary. (Anat.) Pertaining to the eyebrow [L. sŭpercillium].

Supererogation. [L. superērǒgāre, to pay over and above.] Properly, a donation to soldiers above their pay. The Latin Church maintains that all good works done by holy men over and beyond the standard necessary to be reached for their own salvation, pass into a common treasury, and become profitable to those who are less advanced.

Superfetation. [L. fœetus, offspring.] (Med.) Coexistence of two fœtuses, of different ages.

Superior planet. (Planet.)

Supernacŭlum. A monkish word, composed of L. super, above, or on, and Ger. nagel, a nail ; used by topers to denote a practice in drinking, which showed that the vessel was completely drained out.

Supernatant part of a ship. (Dead-works.)

Superphosphate. [L. super, over, and phosphate.] (Chem.) A phosphate containing the greatest possible amount of phosphoric acid. $S$. of lime is a manure made by treating ground bones, etc., with phosphoric acid.

Sŭpinātor muscles. (Pronator muscles.)

Supines. [L. supinus, on the back.] In Gram., a name denoting two cases of verbal nouns, the accusative expressing a purpose, the ablative describing a mode.

Supplejack. A walking-cane made from an American plant.

Supplication of Beggars. By Fish, lawyer of Gray's Inn, 1528 ; i.e. S. of lepers and other sick, that the money wasted in monasteries may be spent upon them; a most outspoken satire upon the old doctrines, especially purgatory. Answered by Sir T. More's Supplication of Souls i.e. S. that Christian people would not leave off praying for them; denying the truth of the attack, and endeavouring to establish the doctrine.

Supporters. (Her.) Figures standing on the scroll, placed on each side of the shield, as if to support it.

Suppository. [L. sūppǒsĭtōrius, placed underneath.] (Med.) Solid medicine for introduction into the body otherwise than at the mouth.

Suppressio veri. [L.] The suppression of truth. When it is combined with the suggestio falsi, oratory has reached its worst form.

Supralapsarians. (Sublapsarians.)

Supranaturalists. [L. supra, above, nātūra, nature.] A term used in Germany to distinguish those who are opposed to the Rationalists; i.e. to those who exclude all supernatural operations or manifestations in religion.

Suprarēnal. (Med.) Above the kidneys [L. rēnes] ; Surrenal, below them.

Supremacy, Act of, A.D. I 534, 26 Henry VIII., declared the king "the only supreme head on earth of the Church of England," compelling beneficed ecclesiastics, and laymen holding office under the Crown, to abjure the spiritual as well as the temporal jurisdiction of Rome.

Supremacy, Oath of. An oath denying the jurisdiction of the pope in this country.

Supremacy, Papal. The theory that the Bishop of Rome has an inherent jurisdiction over all powers ecclesiastical and laic.

Supremacy, Royal. In Eng. Hist., a term used to denote the authority of the Crown over all causes and persons ecclesiastical, and thus to deny the right of any foreign jurisdiction, as that of the pope, within the realm.

Suras. The Arabic name for the chapters of the Coran, each sura being held to be separately revealed.

sural. (Anat.) Pertaining to the calf [L. sūra] of the leg.

Surbase. (Arch.) The cornice of the Dado.

Surcingle. [O.E. sursengle, O.Fr. sursangle, from L. super, over, cingŭlum, a girdle.] 1. A girth which passes over anything laid on a horse's back, to secure it. 2. (Eccl.) The girdle or waistband of a cassock.

Surcoat. [Fr, sur, over, and coat.] A silk overcoat, to protect a knight's armour.

Suroulation. [L. surcullus, $a$ shoot.] The art or act of pruning.

Surd. [L., surdus, deaf.] A root which cannot be expressed as a commensurable number; as, $\sqrt{ } 2$.

Surface of revolution. (Math.) The surface of the solid space traced out by the revolution of a plane area round an axis in its plane; as a cone by a right-angled triangle revolving round its perpendicular; an anchor-ring by a circle, round an axis which does not cut it, etc.

Surmounted. (Arch.) Said of an arch or door rising higher than a semicircle.

surplusage. 1. In Law, matter irrelevant to a case. 2. In disbursements, not explained by the returns of the accountant.

\section{Surrenal. (Suprarenal.)}

Surrogate. (Subrogation.)

Sursum corda. [L.] These Latin words are translated in the English Communion Office by the words, "Lift up your hearts."

Surveillance. [Fr., from L. super, and vigilāre, to watch.] Inspection, watching.

Survey; Trigonometrical s. The determination of the relative positions of the remarkable points in a tract of ground, the situation of buildings, direction of roads and streams, boundaries of woods, fields, etc., and the delineation of their projection on a horizontal plane. In a Trigonometrical $S$. the relative positions of the principal points of a large tract of country are determined by applying the rules of trigonometry to calculate their mutual distances by means of accurately observed angles, and a measured base. (Cadastral survey ; Geodesic line; Triangulation.)

Survival of the fittest. In the Darwinian philosophy, the permanence, arising from natural selection, of certain types of animal and vegetable life; whils others die out to whose 
continued existence surrounding circumstances are unfavourable.

Survivorship. In life annuities, a reversionary benefit contingent on some life surviving some other life or lives, or on lives falling according to some assigned order.

\section{Sus Minervam. [L.] A pig (teaching)}

\section{Minerva.}

Suspending power. A power claimed by Charles II. as inherent in the Crown, and used for mitigating the severity of the Act of Uniformity, 1663 .

Suspension. [L. suspensiōnem.] (Eccl.) The withdrawal from the incumbent of the temporalities of his benefice, and of the right of exercising his spiritual office, for offences of which he may have been found guilty by an ecclesiastical court.

Suspension bridge. A bridge in which the roadway is suspended by rods from strong chains resting on piers of masonry, and having their ends firmly fixed in the earth.

Sussex marble. Petworth marble, a freshwater shell (Paludina) limestone; Wealden (q.v.).

Susurration. [L. susurräre, to whisper.] A soft murmur, whispering.

Sutler. [Ger. sudler, a dabbler, daub.] (Mil.) Camp-follower who provides troops with eatables and drinkables.

Sutra. (Veda.)

Suttee (more properly Sati, akin to Skt. sacti, holy). A term applied to Hindu widows, who submitted to be burnt with the bodies of their husbands. The custom, which has long been abolished in all English territory, has been proved to rest on a mistranslation, probably designed, of a verse in the Rig Veda. (Sacti.)

Suture. [L. sūtūra, a stitching.] 1. (Surg.) The stitching of a wound. 2. (Anat.) Articulation of bones, e.g. those of the skull, by indentation, or serrated margins.

Suum cuique tribuito. [L.] Give each man his orem.

Swage. A tool used in shaping metal-work.

Swainmote, Sweinmote. In Eng. forest law, a court held, before the verderers as judges, by the steward of the court, three times a year.

Swan. [Heb. tinshemeth (Lev. xi. 18).] (Bibl.) Probably the purple water-hen (Porphy̆rio antīquōrum), or the sacred ibis (q.v.).

Swarga. In Hind. Myth., the heaven of Indra.

Swash-buckler. A braggadocio, or bully. To swash is to strike hard; $c f$. sway, swagger.

Swastika. The mystic Cross of four L's, or reversed Z's, found as a mark on porcelain and pottery, and otherwise, from China to Peru.

Swath, Swathe. [A.S. swaðu.] (Agr.) row of mown grass, or corn.

Sweating sickness, Sũdor Anglǐcus, Ephēmĕra sūdātōria or măligna. Sudden violent fever, with nausea, thirst, delirium (? a modification of Plague); very fatal, and frequently within three or four hours; end of the fifteenth and beginning of the sixteenth centuries; said to have first appeared with the landing of the Earl of Richmond's army, Milford Haven, A.D. 1485.
Swedenborgians. Those who adopt the mystical theology of Swedenborg, a Swedish nobleman, who died in London in 1772. They also call themselves the New Church, and the New Ferusalem Church.

Sweep. A movable template for making moulds in sand, etc.

Sweeps. (Naut.) Large oars used for ships.

Sweep-washing. Extracting the residuum of precious metal from the sweepings, etc., of gold or silver refineries.

Sweet-bread. (Thymus gland.)

Sweet-fiag. (Calamus.)

Sweet-gale. (Myrica.)

Sweinmote. (Swainmote.)

Swerga. (Swarga.)

Swift, To. (Naut.) 1. To tighten the shrouds by drawing the port and starboard shrouds inboard with a strong tackle fastened about eight feet up them. 2. To pass a rope over the ends of all the capstan bars, and haul it taut. To $S$. a ship, (I) to pass cables round her; (2) to bring her aground, or careen her.

Swifters. (Naut.) The first pair of shrouds ; not confined, as the rest are, to cat-harpings (q.v.).

Swine-stone. (Stink-stone.)

Swingle. [Ger. schwengel, a swing-beam.] 1. A long knife-shaped piece of wood for beating flax so as to separate the coarse part or swingling tow. 2. The part of a flail which strikes the grain.

\section{Swingletree. (Singletree.)}

Switch, or Point. (Mech.) A movable rail of the same dimensions as an ordinary rail, but tapering off at one end; by means of a pair of switches the direction of the motion of a train can be changed, and the train transferred from one pair of rails to another.

Swivel. (Mech.) A piece fastened to another body by a pin, so as to turn round freely though the body is fixed.

Swivel-gun. (Mil.) Turning on a pivot, and thus occupying little space; used in the bow or stern on board ship or in boats.

Sword, Order of the. A Swedish order of knighthood, instituted by Gustavus Vasa.

Swordfish. (Ichth.) Gen. and spec. of sea-fish, ten or twelve feet long, and sometimes longer; bluish-black back, silvery belly, upper jaw elongated into swordlike form, nearly a third of whole length. Mediterranean, and between tropics; one spec. has been found off Britain and northward. Fam. Xı̄phr̆dæ, ord. Ăcanthoptěry̆gĭi, sub-class Tělěostě̃.

Sword of State. The sword with which the English sovereign is girt at his coronation, the three swords carried before him being the Curtana, or pointless sword of mercy, and the swords of spiritual and temporal justice.

\section{Suzerain. (Feudal system.)}

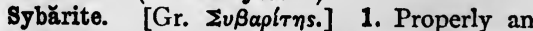
inhabitant of Sybăris, a Greek colony on the Tarentine gulf, in Italy, which is said to have become enfeebled by luxury. Hence, 2, any voluptuary.

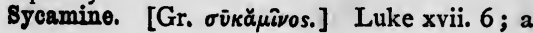


mulberry, both black and white, Mōrus nigra and alba, being common in Palestine; the Mulberry of 2 Sam. v. 23 being (?) a kind of balsam; or (?) aspen ; or, (?) according to LXX., pear tree.

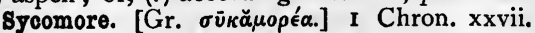
28 ; Ps. lxxviii. 47 ; not our S., but the figmulberry (Fìcus sȳcămōrus), a fig tree, allied to the banyan; valuable evergreen timber tree, yielding a small sweet fig.

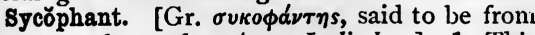

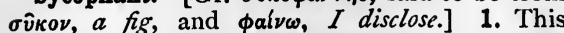
word was said to denote one who at Athens gave information against those who exported figs in defiance of the law which forbade it. Hence, 2 , informers or false accusers generally. From their cringing demeanour the word has now come to denote, 3 , mean flatterers.

syenite. (Geol.) A granitic rock, quartz + felspar + hornblende. Syēne, Upper Egypt.

syllatarium. A table of the indivisible syllabic symbols used in the Japanese and other languages instead of letters.

syllepsis. [Gr. $\sigma \dot{v} \lambda \lambda \eta \psi(s$, a taking together.] (Gram.) The agreement of an adjective with the gender of one only of two nouns with which it is linked.

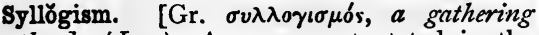
together.] (Log.) An argument stated in the form of three Propositions, the conclusion following necessarily from the two Premisses (Whately); the general proposition being in accordance with facts, and the minor premiss stating some point of agreement or difference ascertained by actual search (Mill).

Sylph. [Gr. $\sigma\{\lambda \phi \eta$, an insect or grub.] The Rosicrucian term for spirits of the air.

Sylva, Evelyn's, $A$ Discourse of Forest Trees, etc., published I664. A treatise by John Evelyn, of Wotton, scholar, philosopher, author, and a very perfect country gentleman (1620-1706); one of the founders of gardening, etc. ; to which, and to his example, this country is indebted for its fine abundant timber.

Sylviridø. [L. silva, woodland.] (Ornith.) Warblers; large fam. of small birds, as hedgesparrow, nightingale, golden-crested wren. Universally distributed, except south-west of S. America. Ord. Passěres.

Symbol. [Gr. $\sigma \dot{u} \mu \beta 0 \lambda o \nu, a$ sign.] (Math.) A note or character indicating a quantity or operation; thus, in $a+b$ the characters $a$ and $b$ denote quantities, the note + an operation, viz. the addition of the quantities.

Symbŏlism. [Gr. $\sigma^{\prime} \mu \beta o \lambda o \nu$.] The system which found a symbolical meaning in every part of the ecclesiastical ritual and architecture.Didron, Iconographie Chrétienne; Durandus, Rationale Divinorum Officiorum.

\$ymbŏlum. [Gr. $\sigma u ́ \mu \beta 0 \lambda o \nu, a$ sign, or mark.] 1. A treaty or agreement. Hence a profession of faith, or creed, especially the Apostles' Creed, to which the story related by Rufinus says that each of the apostles contributed $[\sigma \nu \mu \beta \alpha \dot{\lambda} \lambda \in \iota \nu$, to throw together] a proposition. 2. Any outward sign or emblem. Hence the elements in the Eucharist are so called, as representing the body and blood of Christ.

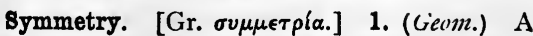
curve is symmetrical to an axis when all straight lines at right angles to the axis which meet the curve in one point meet it also in a second, and the two points are equally distant from the axis but on opposite sides of it ; so of a surface with reference to a plane, etc. 2. Algebraic expressions are symmetrical when one can be derived from another by interchange of letters; as, $b c-a^{2}, c a-b^{2}, a b-c^{2}$, where the second is derived from the first by interchanging $a$ and $b$, and the third from the second by interchanging $b$ and $c$. 3. In crystals, if one of the faces have given parameters, other faces will occur having equal parameters differently arranged, and it may be with one or more of their signs changed : such faces are symmetrical.

Sympathetio ink. An ink, the writing in which is invisible till warmed or treated with chemicals.

Sympathetio system, or Ganglionic. One of ganglionic centres and nerve-trunks, scattered through different parts of the body, but mutually connected with each other; the principal centres being two great semilunar "ganglia" in the abdominal cavity near the spine, from which the solar plexus, a series of trunks and branches, is distributed to the muscular walls of the intestinal canal and the various glandular organs connected with it. (Vide Carpenter's Mental Physiology, p. 125.)

Sympathetic tone; s. vibration. (Music.) When a portion of the atmosphere is in such a state of vibration as to transmit a loud sound, and there is within it a chord (or other body) capable of vibrating either accurately or very nearly so with the same frequency, the chord or body makes $S$. vibrations and produces a S. tone.

Syjmpathy of clocks. When two clocks are placed near each other, and rest in some degree on the same support, they will sometimes keep time together for several days without varying a second, though they might have differed considerably if otherwise situated; the fact that the vibrations of the pendulums control each other is the sympathy of the clocks.

Sympiesometer. [Gr. $\sigma v \mu \pi i \epsilon \sigma i s, a$ pressing

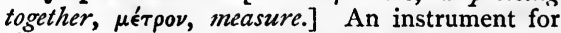
showing the pressure of the atmosphere, in which the movements showing the variations of pressure have a much wider range than in the mercurial barometer. It consists of a bent glass tube about eighteen inches long, with a chamber at top containing air, and an open cistern below containing glycerine or sulphuric acid; it is graduated by comparison with a standard barometer. It is very quick in its indications, and portable, but not suited for exact observation.

symposiarch. [Gr. $\sigma \nu \mu \pi \sigma \sigma i \alpha \rho \chi o s$, from $\sigma v \mu \pi \delta$ $\sigma \iota \nu, a$ drinking together, and $\alpha \rho \chi \omega, I$ rule.] In ancient usage, the master of a feast, sometimes called Basǐleus, and Archǐtrǐklinos (John ii. 8).

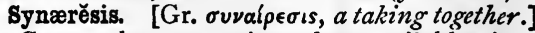
In Gram., the contraction of two syllables into one by the formation of a diphthong. Called also Crāsis [a mingling]. (Metaplasm.) 


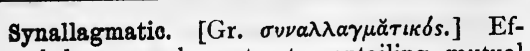
fected by mutual contract; entailing mutual obligation.

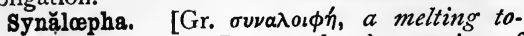
gether.] In Gr. and L. prosody, the running of the last syllable of a word ending with a vowel into the first syllable of the next also beginning with a vowel.

sy̆naxis. [Gr. oúvał̌s, an assembly.] 1. The assembling of Christian persons for the reception of the Holy Communion; and so, 2, the Holy Communion itself.

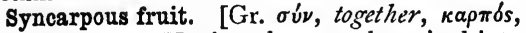
fruit.] (Bot.) Having the carpels united into an undivided body ; e.g. orange.

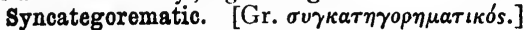
In Log., words which form only part of a term. Such are adverbs, prepositions, and nouns in the oblique cases.

Synchronism. [Gr. $\sigma u ́ v$, together, $\chi \rho \delta$ osos, time.] A representation in one picture of events occurring at different times.

Synchronize. [Gr. $\sigma u \nu \chi p o \nu i \zeta \omega, I$ am contemporary with.] To happen at the same point or duration of time. Thus the Reformation synchronized with the revival of learning.

Synchysis. [Gr. $\sigma \dot{v} \gamma \chi \breve{v} \sigma \iota s$, from $\sigma u ́ v$, with, and $\chi \chi^{\prime} \omega, I$ pour.] A confusion, as of humours in the eye, or of words in a sentence.

\section{Synclinal. (Anticlinal line.)}

Syncopation. [Gr. $\sigma v \gamma \kappa o \pi \cdot$, a cutting up.] In Music, an irregularity of rhythm, by which the last note of one bar is tied to the first of the next; the occurrence of accented notes in an unaccented part of the bar. (Driving notes.)

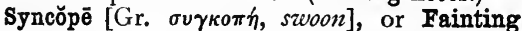
fit. 1. (Med.) Temporary arrest or diminution of the circulation of the blood, with suspension of the breathing and of the functions of the nervous system. 2. In Gr., Metaplasm.

Syncretism. [Gr. $\sigma v \gamma \kappa \rho \eta \tau \iota \sigma \mu \delta ́ s$.$] The blend-$ ing of the opinions of different philosophical schools into one system. The party of Pico della Mirandola, Bessarion, and others in the time of the Renaissance, are called Syncretists ; a name which is also given, in Eccl. Hist., to the followers of George Calixtus, who, in the sixteenth century, tried to form a scheme for uniting all bodies of Christians.

Syncretists. (Syncretism.)

Syndesmōsis. [Gr. $\sigma u ́ \nu \delta \epsilon \epsilon \mu o s$, a bond.] (Surg.) The union of one bone with another by a

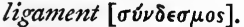

Syndic. [Gr. $\sigma \delta \nu \delta$ ikos, from $\delta i \kappa \eta$, justice.] A title often given to municipal and other officers, as the syndics of cities in Provence and Languedoc, who acted as agents of the municipality.

Syndicate. To S. a commercial project is to place the affairs under the management of a committee.

synecdŏchē. [Gr.] (Rhet.) The putting of the whole for a part, or of a part for the whole. (Trope.)

\section{Syneidesis. (Synteresis.)}

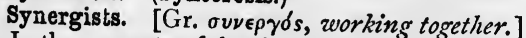
A Lutheran party of the sixteenth century, which asserted the need of the co-operation of the human will to render divine grace effectual. (Pelagians.)

Syngěněsia. [Gr. $\sigma u ́ v$, together, $\gamma^{\prime} \nu \in \sigma t s$, origin.] In the Linnæan system, class xix., and coextensive with Compositæ.

Synizësis. [Gr. $\sigma u \nu\lfloor\zeta \eta \sigma ı s$, a settlement, as of a building on the ground.] 1. In Gr., the melting of two vowels into one. 2. (Med.) A term applied to the obliteration of the pupil of the eye.

Sy̆nǒchus, Sy̆nŏcha. With older medical writers, inflammatory fever, which is continuous [Gr. $\sigma u ́ v o \times 0 s]$

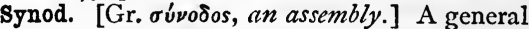
term for meetings of ecclesiastical persons.

Synodals. 1. A small payment from the clergy to the bishop, sometimes to the archdeacon; probably paid originally at the time of, but not on account of, the bishop's synod. 2. In Preface "Concerning the Service of the Church," recitals, in parish churches, of the provincial constitutions.

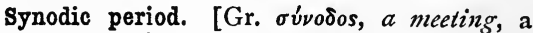
conjunction of the sun and moon.] Of the moon, the time which elapses from her leaving conjunction with the sun to her returning to it again.

\section{Synod's-men. (Questmen.)}

synonyms. [Gr. $\sigma \nu \nu \omega \nu o \mu o s$, from $\sigma \dot{v} \nu$, with, and ovoua, a name.] Words of the same language which agree in meaning. (Metaphor.)

Synoptic Gospels. A name used to denote the first three Gospels, as having generally the same succession of events, in distinction from the fourth, in which the sequence is different.

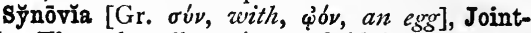
oil. The pale yellow viscous fluid by which the joints of animals are lubricated.

Syntax. [Gr. $\sigma u ́ \nu \tau \alpha \xi \iota s$, an arranging.] In Gram. and Rhet., the disposition of words and clauses in a sentence in the arrangements proper to the language to which the words belong.

Syntērēsis. In Moral Phil., a name given to that close watching and conservation [Gr. $\sigma v \nu$ $\tau \eta \dot{\rho} \eta \sigma t s]$ of first moral principles, which is the office of conscience in its character of lawgiver, and as distinguished from Syneidessis, which is

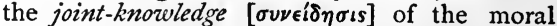
law and of some particular action, which is the office of conscience as judge. (Fleming's Student's Moral Phil., p. 153.)

Synthermal. [Gr. $\theta \epsilon ́ \rho \mu \eta$ heat.] Of equal heat.

Synthĕsis. [Gr. $\sigma u ́ v \theta \in \sigma \iota s$, a placing together.] 1. $(\log$.$) The combination of separate elements$ of thought into a whole, as of species into genera. 2. (Surg.) The uniting of divided parts. 3. (Anat.) The connexion of the bones in the skeleton. 4. (Phys.) The uniting of elements to form a compound; the opposite to Analysis.

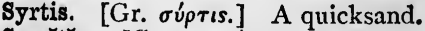

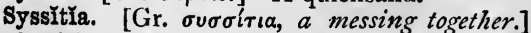

In Gr. Hist., an institution chiefly of the Doric states, which compelled the male freemen to 
have their meals in common messes instead of their own houses. (Phoiditia.)

\section{Systaltic action. (Diastole.)}

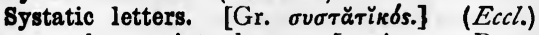
Commendatory, introductory $[\sigma \nu \nu l \sigma \tau \eta \mu l$, Rom. xvi. I]. (Litteræ formatæ.)

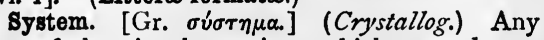
one of the six classes into which crystals are divided with reference to their axes and parameters; as the Octahedral, Pyramidal, Khombohedral, Prismatic, Oblique prismatic, Doubly oblique prismatic (vide these names respectively).

System, Alternate. (Agr.) That under which succulent-leaved crops alternate with white-straw crops, as (I) turnips, (2) wheat, (3) beans, (4) wheat.

System, Convertible. (Agr.) That under which land is tilled for a period, and then for a period sown with grass, manured, and fed by cattle.

Systǒlē. [Gr., a contraction.] 1. In Pros., a licence which shortens a long syllable. 2. (Diastole.)

Synd. (Seyd.)

syzygy. [Gr. ousũyía, union, a yoking together.] (Astron.) A point of an orbit at which conjunction or opposition takes place; used chiefly of the moon, as by Newton.
T. A letter belonging to the class called mutes, and largely interchangeable in many languages. As a L. abbrev., T. stands for Titus Ti. for Tiberius.

Taal, or Tale. [Malay.] A Chinese coin, worth about a dollar and a half. Also, a weight.

Tabard. [L.L. tabardus, O.Fr. tabar, a cloak, of green baize (Littré).] A kind of tunic emblazoned with armorial bearings, and generally open at the sides, worn by heralds on State occasions. Also an academic gown.

Tabaret. [Fr. tabouret, a stool.] A stout satin-striped silk, for covering chairs, etc.

Tabbinet. A more delicate kind of tabby' (q.v.).

Tabby. [Pers. utâbî.] A thick watered silk, used by bookbinders.

Tabefaction. [L. tābēfactus, melted, dissolved.] (Med.) A wasting away of the body.

Tabellions. [L. tabelliones, from tabella, dim. of tabula, the tablet on which they wrote.] (Kom. Hist.) The notaries, who had been known as scribes in the times of the republic, were so called under the empire.

Tabering. Nahum ii. 7 ; beating themselves (a stronger word than tap; $c f$. tabour, tambour, $\tau \dot{v} \pi \tau \omega$, etc. ; onomatop.).

Tābes. [L.] (Med.) A wasting away. Tabific, causing $\mathrm{T}$.

Tablature. [L. tăbŭla, a writing-tablet.] (Music.) The signs and characters used in music generally, but especially the old mode of notation for instruments of the lute kind, and for some wind instruments.

Table. A flat circular sheet of crown-glass.

Table; Tabulate. [L. tăbŭla.] 1. A list of facts of one kind arranged in a form adapted for reference; as a table of specific gravities, etc. 2. A list of the successive values of a function arranged in order of the successive values of the independent variable; as a table of logarithms, which gives the values of $\log$. $x$ for all values of $x$ within given limits, as from I to 10,000 ; a table of sines, which gives the values of $\sin . \theta$ for (say) every minute from $0^{\circ}$ up to $90^{\circ}$; there are likewise tables of refraction, lunar tables, etc.
A function whose successive values have been calculated and arranged on a table is said to have been Tabulated.

Table-cloth. Name given to the white cloud which frequently rests over Table Mountain, near Cape Town.

Table d'hôte. [Fr.] A dinner at which the host or landlord of an inn is supposed to preside.

Table diamond. A diamond cut with two principal faces, or Tables.

Table-land. (Geog.) A plain at a great height above the sea-level ; as the table-land of Bavaria, of Mysore, etc.

Table-turning. The alleged turning of tables independently of physical agency.

Table-wise. Said of the Altar or Communion Table, placed in the body of the church, with the ends east and west.

Taboo. Among the South Sea Islanders and others, a religious interdict, which prevents all approach to particular spots or persons. - Tylor, Primitive Culture.

Tabor. [From Ar. tambur.] A small drum ; generally one hung round the neck. (Tambour.)

Taborites. (Eccl. Hist.) Those among the followers of John Huss who after his death ranged themselves under the standard of John Ziska, were so called from Tabor, a hill in Bohemia. After a long struggle, a portion of them formed themselves into the society called Bohemian Brethren (q.v.).

Tabouret, Droit de. [Fr.] In Fr. Hist., the right possessed by certain persons of being seated at certain times in the presence of royalty.

Tabret. A kind of small drum, or tambourine, or timbrel. (Tambour.)

Tăbǔla räsa. [L.] With the Romans, a tablet of wax, smoothed for fresh writing; and so metaph. a wiping out of the past, and starting fresh. Often used to denote the condition of the human mind before it has received any impressions.

Tacamahac. The resin of the balsam poplar (tacamahac tree) and other American trees.

Tăcent, sătis laudant. [L., lit. they are silent, 
and thus praise sufficiently.] They have no fault to find, and that is praise enough from them.

Taches of gold. Exod. xxvi. 6, etc. ; plu. of tache, a catch, clasp, to unite opposite loops ; probably that which tacks, or joins [Fr. attacher].

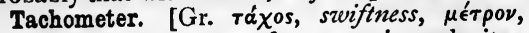
measure.] An instrument for-measuring velocity; as of a machine, of running water, etc.

Tack. (Naut.) 1. A rope for making fast the lower weather corner of a course, or staysail, when the wind is not at right angles with a vessel's course. 2. Studding-sail T. hauls out the lower outer-clue to its boom-end. 3. Fib $T$., or a fore-and-aft sail $T$., confines its forward lower end amidships. 4. A vessel sails on the T. of the side from which the wind blows. 5 . To $T$. (Stay, To.) 6. Soft T. (Soft tack.)

Tacking. (Leg.) A union of securities, all to be redeemed before an intermediate purchaser can interpose his claim.

Tackle. (Naut.) A system of pulleys. Ground-T., anchors, cables, etc.

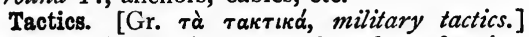
Science of adapting ground and performing military evolutions in the presence of an enemy.

Tadpole. [Lit. the foal (L. pullus, Gr. $\pi \hat{\omega} \lambda$ os) or offspring of a toad.] (Zool.) The young of batrachians, especially of frogs, in its first state from the spawn.

Tædium vitæ. The I. phrase equivalent to Fr. ennui, weariness of life.

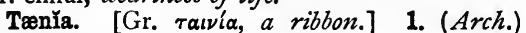
The lintel above the architrave which separates it from the frieze, in the Doric Order. 2. (Zool.) Tapezvorm; ord. of Scōlēcĭda (Annŭlŏida), a minute, rounded annuloid, adhering by hooklets or suckers to the interior of the alimentary canal of warm-blooded animals, and extending itself, by budding, to the length of, sometimes, several yards.

Taffety, Taffeta. [Pers. tâftah, woven.] A fine smooth watered silk stuff. (Tabaret; Tabby.)

Taffrail, or Tafferel. [D. tafereel, from tafel, table.] (Naut.) The upper works at the stern.

Tafia. [Malay.] White rum.

Tag. (Sheep, stages of growth of.)

Tagliacottian operation. In Surg., a method of restoring lost noses, devised by the Italian surgeon Tagliacozzi, or Taliacotius (1546-1599).

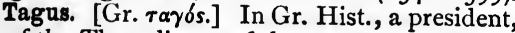
as of the Thessalian confederacy.

Tahorites. A Persian dynasty which had ruled for half a century, when it was supplanted by the Soffarides.

Tail. [O.Fr., from tailler, to cut.] (Leg.) Limitation; abridgment. Blackstone defines an estate in tail as an abridged or reduced fee, limited to certain heirs, other heirs being excluded.

Tailing. 1. The lighter parts of grain winnowed out. 2. The refuse of stamped ore, afterwards dressed again.

Taille. In O.Fr. Law, any imposition levied by the king or any other lord on his subjects. (Tallage.)

Tailor's muscle. (Sartorins.)
Tailpiece. 1. In Printing, an ornament at the end of a book or chapter, to fill up the page. 2. (Music.) Of a violin, that piece, generally of ebony, to which the strings of the violin are fastened.

\section{Tail-race. (Mill-dam.)}

Tails, Pacha of one, two, three. (Pasha.)

Tailscommon. Washed lead ore.

Tailzie, or Entail. In Scot. Law, any deed which cuts off the legal course of succession and substitutes an arbitrary one.

Take. In Printing, the quantity of copy taken in hand by a compositor at once.

Take a departure. (Naut.) To ascertain a vessel's position by means of the bearings and position of a known object.

Talapoins. The Siamese title for the priests of Fo; called in Tartary Lamas, and by Europeans Bonzes.

Talbotype (invented by Talbot). (Calotype.)

Talo. [Pers. talcq.] (Min.) A mineral allied to soap-stone, entering into several crystalline rocks (talc-schist, protogine), almost entirely silica + magnesia; silvery white, greenishwhite, green; soft ; greasy to touch ; generally massive ; when in thin plates, subtranslucent; fissile, not elastic. French chalk is powdered talc. Mica (quite a different mineral) is called "tale" in commerce.

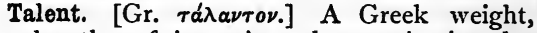
equal to that of sixty minæ; but varying in value in different cities. The Attic talent was equal to nearly $£ 200$; the Aginetan to $£ 331$.

Tale of a Tub (in which Peter, Martin, Jack, represent the Roman Church, Luther, Calvin). A satire written by Dean Swift, exhibiting mediæval corruption, and the various results of the Reformation; to divert the followers of Hobbes from injuring the vessel of the State; as a tub is thrown out to divert a whale.

Tālēs, Praying a. When the number of a jury is reduced by challenges, either party may pray for a supply of such men [L. tālēs] as are summoned on the first pannel to supply the deficiency.

Talionis, Lox. [L.] The law of exact retaliation, as in the Mosaic Law: Exod. xxi. 24; Lev. xxiv. 20 ; Deut. xix. 21.

Tälĭpes. [Coined from tālus, an ankle, and pes, a foot.] (Med.) Clubfoot.

Talisman. [Ar., dual of the noun telesm.] A figure cut in stone or other material, and supposed to possess various virtues, as of averting disease. (Palladium.)

Talis quum sis, ntinam noster esses. [L.] Since you are such (as you are), would that you were ours (or with us).

Tallage. In O.E. Law, a general name for all taxes. (Taille.)

Tall ship. (Naut.) A square-rigged vessel with topmasts.

Tally, To. (Naut.) To haul the sheets aft.

Tally ho! A cry of encouragement to hounds, on the fox being viewed. [(?) A corr. of the Fr. " a luij, ho! ho! a luij," mentioned by Dame Juliana Berners (fifteenth century) as a hunting cry.] (Yoicks!) 
Tally trade. A system of trading carried on in London and elsewhere, by which shopkeepers furnish articles on credit to their customers, the latter paying the price by weekly or monthly instalments. The effect of the system is most mischievous.

Talmud. The traditionary law of the Jews. The word is derived from the Heb. lamad, he taught. The Talmud, therefore, is a book containing doctrines and duties taught to the Jews by their authorized teachers, or rabbis. There are two Talmuds, (1) of Jerusalem, (2) of Babylon, besides the Targums, i.e. commentaries of Jonathan ben Uzziel, about B.c. 30, and of Onkelos on the Pentateuch, in the first century of our era. The Talmud of Jerusalem consists of two parts : (I) the Mischna, or text, supposed to have been compiled in the second century B.C., and (2) the Gemara, or commentary on the Mischna. The Talmud of Babylon is practically a commentary, designed to supply the defects of the. Jerusalem Talmud, and is generally preferred to it. The legends, anecdotes, or sayings in the Talmud illustrative of the $\mathrm{Law}$ are called $\mathrm{Ha}$ gada, while the word Halaka denotes the decisions of Talmudists on disputed questions. (Cabala.)

Talon. [Fr.] (Arch.) The same as Ogee.

Talookdar. In India, the holder of a talook, or district less than that of a Zemindar, with certain proprietary rights, not exactly defined.

Talpidæ. [L. talpa, mole.] (Zool.) The mole fam. N. hemisphere. Ord. Insectivvora.

Tälus. [L., the ankle, ankle-bone.] 1. (Anat.) Sometimes $=$ astrăgălus (q.v.). 2. (Geol.) The sloping heap of fragments at the base of a rock.

Tambour. [Fr., Pers. tambur.] (Mil.) 1. Large drum. (Tabor.) 2. Inclosure of palisades or stockade work of any form that may be required to afford defence, sometimes with a ditch and banquette.

Tammany. A term assumed by a branch of the democratic party of the state of New York, sometimes called S. Tammany, from a distinguished Indian Delaware chief, Tamendry, who in old age called a council to appoint a successor; but why his name was chosen is not known.

Tammuz. In Syr. Myth., a name of the sungod; also called Adonai, Gr. Adonis, or lord. The Greek form of Tammuz is Athamas.

Tammuz. Tenth month of civil, fourth of ecclesiastical, Jewish year ; June-July.

Tammy. [Fr. tamis, a sieve.] A highly glazed woollen stuff for covering sieves.

Tamp. [Fr. tampon, a bung, stopper.] (Mil.) To close with materials the gallery of a mine or a hole bored for blasting after the charge has been lodged in the chamber.

Tan. [Armor. tann, oak.] The bruised bark of oak or other trees, used for tanning.

Tangent [L. tangentem, touching]; T.-plane. (Math.) A line drawn to meet a curve and not cutting it, though produced; or, more exactly, drawn to meet it in two coincident points; as curved lines have tangent lines, so curved surfaces have T.-planes. (Trigonometrical function.)

Tangential force. (Math.) A force acting on a revolving body in a direction tangential to its path, and causing its velocity to vary from point to point.

Tangent sailing. (Great-circle sailing.)

Tangent-scale. (Mil.) Sliding bar in rear of the vent of a gun, by which any requisite elevation before firing can be attained.

Tanhaüser. In German mediæval tradition, a knight who is enticed by Venus into her cave in the Horselberg, i.e. the hill of Horsel or Ursula. Making his escape, he seeks absolution from Urban IV., who tells him that there is no more chance of forgiveness for him than there is for the budding of the staff in his hand. Tanhaüser returned to the cave; the staff budded; but the knight was sought in vain. In its main features this story is the same as that of Thomas the Rimer, who is allured by the fairy queen to her home in Ercildoune, in which the name Ursula again appears.

Tanistry. [Gael. tanais-teachd.] The Irish name for a custom of descent, defined as "descent from the oldest and worthiest of the blood." The custom itself may be found in most conditions of society in which circumstances render the inheritance of minors or incompetent persons dangerous.

Tanka. (Naut.) A Chinese covered boat worked by women, for conveying passengers to or from vessels.

Tannin, Tannic acid. (From tan.) (Chem.) The astringent principle of oak bark, nut-galls, etc.

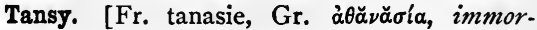
tality.] (Bot.) Common native perennial; bitter, aromatic, medicinal. Tănăcētum vulgare, ord. Compositæ. Growing in fields, by roadsides, etc., in temperate districts.

Tantălize. This verb, meaning to baulk or disappoint at the very moment of fruition, is formed from the name of Tantălus, who in the old Gr. Myth. stands in a lake, the waters of which retreat from him and turn to slime when he stoops to drink, and under branches laden with fruits, which wither when he puts forth his hand to grasp them. Some said that he was so punished because he served up the body of his son Pelops at the banquet-table of the gods; others because he stole Nectar and Ambrosia and gave them to his people. The myth expresses the action of the sun in times of great heat and drought.

Tantalnm. [L. Tantălus, a king of Phrygra.] A rare metal, obtained as a black powder.

Tanti. L. genitive of price, worth while: generally used with a negation, as "non tanti," hardly "tanti."

Tantivy. [Onomatop.] 1. The note of the hunting-horn. 2. At full speed.

Tant mieux. [Fr., L. tanto melius.] So much the better.

Tant pis. [Fr., L. tanto pejus.] So much the worse.

Tantum non. [I.] Only not; all but.

Taouism. The rationalism or ethical system 
of the Chinese Lao-Tse, a contemporary of Confucius. (Confucianism.)

Tap. 1. A short pipe for drawing liquor. 2. (Surg.) To pierce - the abdomen, chest, etc. for removing fluid accumulated in the serous cavities. 3. A conical screw made of hardened steel for cutting screws in nuts.

Tap-bolt. A set-screw (q.v.).

Taper. [A.S.] (Bot.) A term denoting parts the opposite of angular.

Tapestry carpet. A two-ply carpet, the pattern of which is produced by printing the warp or woof before weaving.

Tapioca. (Cassava.)

Taplings. The thongs coupling the pieces of a flail.

Tapnet. A rush basket in which figs are imported.

Tappet. (Mech.) A cam on an axle that lifts a vertical bar or stamper, and then lets it fall; called also a Wiper.

Tappit-hen. A crested hen. A drinking-cup; so called from the shape of the knob on the lid.

Tap the admiral, To. In Naut. slang, to draw spirits from the cask in which his corpse is being brought home. Hence, to drink anything, however bad.

Tara, Tarah, Taragh. A hill in Meath, where, up to the close of the sixth century, the inauguration of the Irish kings is said to have taken place; kings, clergy, and bards assembling every third year, and electing a supreme ruler.

Tarantism. (?) Because appearing in Taranto and S. Italy generally; or from the poison of the tarantŭla spider, common in Taranto. (Chorea.)

Tarantula. A Neapolitan dance, rapid, in $\frac{6}{8}$ time generally; the perspiring induced by it being intended to cure the bite of the tarantula spider. (Tarantism.)

Taraxăcum dandelion, i.e. dent du lion. (Bot.) A gen. of Compositæ, of which the root-stock is extensively used in medicine as an aperient and tonic, especially in liver complaints. [The word is traced by M. Devic, with some likelihood, to the Ar. tarachaquūn, wild chicory (Littré).]

Tar-brush, $\mathbf{A}$ touch of the. In Naut. slang, (I) black blood in the veins; (2) seamanlike skill in officers.

Tardigrăda, Tardigrades. [L., slow-paced, tardus, slove, grădior, I walk.] (Zool.) A fam. (i.q. Brădy̆pŏdĭdæ, sloths) of ord. Edentäta (q.v.).

Tare. [Fr.; said to be an Ar. word.] A deduction made from the weight of a parcel of goods on account of the weight of the chest or package containing them. (Tret.)

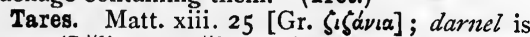
meant (Lŏlium ternŭlentum).

Targum. (Talmud.)

Tarlatan. [Fr. tarlatane.] A thin transparent muslin.

Tarnkappe. In Northern Myth., the cap which, like the helmet of Hades, makes the wearer invisible.

Tarpaulin. (Naut.) Canvas dressed with paint, tar, or oil. Sailors' waterproof clothes are called tarpaulins, or 'paulins.
Tarpeian Rock. At Rome ; so called, it is said, because Tarpeia, who betrayed the city to the Sabines, was there crushed by the shields which they threw on her, she having bargained for what they bore on their left arms, that is, their bracelets.

\section{Tarquin the Proud. (Sibylline books.)}

Tarragon. (Bot.) A herb, Artěmǐsia drăcunculus, ord. Compositæ ; D. corr. into Tar. ragon. A perennial native of Siberia, naturalized; the leaves are a ingredient in $T$. vinegar.

Tarras, Terras. [Ger. trass.] A kind of hydraulic cement used in Holland.

Tarrock. (Ornith.) Young of kittiwake (q.v.).

Tarsel, Tercel, Tiercel. [Fr. tiercelot, L. tertiŏlus, a third part from its sire.] (Ornith.) The mature male of the peregrine falcon. The red $T$. and red $F$. are the immature male and female respectively. Falco pĕregrīnus, gen. Falco, sub-fam. Falcōnīnæ, fam. Falcônidæ, ord. Accipǔtres.

Tarshish. The district of Southern Spain, known to the Greeks as Tartessos, with which an important trade was carried on from Palestine, ships of sufficient burden to undertake the voyage being called "ships of Tarshish," as we speak of an E.-Indiaman.

Tarsia, Tarsiatura. [It.] A mosaic woodwork much practised in Italy in the fifteenth century, representing landscapes, flowers, etc.

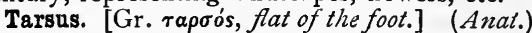
The collection of seven small bones between the tibila and metatarsus; the instep, or first part of the foot. In birds, sometimes, the third segment of the leg; in insects, the fifth principal segment.

Tartan. [Fr. tiretaine, linsey-woolsey.] Woollen cloth covered with cross-bars of different colours.

Tartan. (Naut.) A Mediterranean coaster, lateen-rigged, with one mast and a bowsprit.

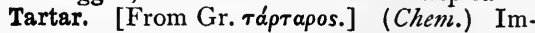
pure bitartrate of potash, deposited as a crust in wine-casks. When purified, it is called cream of T. Salt of $T$. is carbonate of potash. T. emetic is tartrate of potash and antimony. The acid derived from tartar is tarlaric acid, the salts of which are called tartrates.

Tartarian lamb. (Barometz fern.)

Tartărus. [Gr. Táprăpos.] In Gr. Myth., the abode of the wicked dead. The word denotes

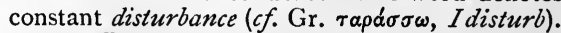

Tartuffe. [Fr. Tartufe.] The chief character in Molière's comedy of this name, which is said to be taken from the It. tartuffoli, truffles. Tartuffe is a mean parasite, from whom Bickerstaff obtained the idea of Mawworm, in his play of the Hypocrite.

Tasco. A kind of clay for making melting. pots.

Tasking. (Naut.) Examining a ship's timbers.

Tasting timber. (Naut.) Chipping and boring it, to try its quality.

Tasto. [It.] Feeling, touch; and so (I) a 
pianoforte key; (2) the touch of a piano or organ. $T$. solo, a direction to play a part in unison, without accompanying chords.

Tate and Brady. T. poet-laureate (died I7 I5), and B. chaplain to William and Mary; autlors of the metrical version of the Psalms, which supplanted that of Sternhold and Hopkins (q.v.).

Tatta, Tattee. In Hindu usage, a bamboo frame or trellis covered with khus-khus grass, over which water is poured from the outside, to cool the air as it enters the house. (Vittio vayr.)

\section{Tatterdemalion. A ragged fellow.}

Tattoo. (Mil.) Summons to all soldiers to return to their quarters, given every night by drum and fife, preceded and followed by buglecalls ; these latter are the "first" and "second" posts.

Taut. (Naut.) Tight.

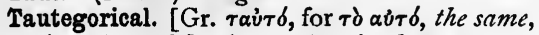
àropєúw, I speak.] A word coined to express the opposite of Allegory.

Tavernicus. [Deriv. uncertain.] The third officer of State in the Hungarian kingdom, after the Palatine and the Ban of Croatia.

Taverns, Three. In Acts xxviii. I5 $\tau \alpha \beta \in \rho \nu \hat{\omega} \nu$ is a Grecized form of the L. tabernæ, i.e. shops.

.Tawing. [O.E. tawian, to prepare.] Preparing the skins of sheep, lambs, etc., as white leather.

Taxacex. [L. taxus, a yew.] (Bot.) The yew tribe, an ord. of Gymnogens (q.v.).

Tax-cart. A light spring-cart (taxed at a low rate).

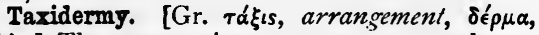
skin.] The preparation, arrangement, and preservation of the skins of animals.

Taxing-masters. In Law, certain officers in the courts, appointed to examine the claims of solicitors, and to strike out such items as they think proper to disallow ; or, as it is termed, to tax the costs. (Allocatur.)

Taxology, Taxonomy. Systematic arrangement [Gr. $\tau a ́ \xi \xi ı$ ], or classification, of plants.

Tazze. [It.] A flat, shallow vase, with a foot and handles.

Teache. A boiler used in sugar-making.

Team. (N'aut.) Vessels blockading a port are said to be in ateam. T.-boat, a paddle-wheel ferry-boat worked by horses.

Tea-poy. An ornamental table with a lifting top, inclosing caddies for tea.

Tearless battle. A battle won by the Spartan king, Archidāmos, B.C. 368 ; so called because I0,000 Arcadians are said to have been slain without the loss of a man on the Spartan side.

Teasing, Teaselling. Raising a nap on cloth by scratching it with teazels $(q . v$.$) .$

Tea-waggon. In Naut. slang, an E.-Indiaman.

Teazel. (Bot.) Used in dressing broadcloth, the flower of fuller's teazel, Dipsăcus [Gr. $\delta^{\prime} i \psi \breve{a}-$ кos] fullōnum, ord. Dipsaceæ; cultivated in north and west of England; the rigid, acuminate hooked bracts serve to raise the nap.

Tebeth. (Thebet.)

Technical education. [Gr. $\tau \in \chi \nu \iota \kappa \delta s$, artistic.]
That of artisans, whose knowledge is generally confined to a few mechanical details in all that concerns their trade, the materials with which it has to do, the results accomplished in England and elsewhere, etc. ; the object being to bring about a more intelligent interest in their work, and a spirit of invention and enterprise, as well as mechanical excellence.

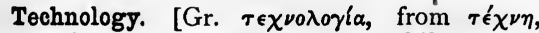
art, $\lambda \delta$ ros, discourse.] 1. A philosophical account of the useful arts. 2. An explanation of art terms.

Tecum. (Tucum.)

Tedding hay. [Probably Ger. zetten, = Ger. zetteln, to scatter in small quantities.] Making hay, tossing and spreading it.

Tedesca, Alla. [It.] (Music.) In the German style.

Tedge. (Founding.) The pipe through which molten metal is poured into a mould.

Tedium vitæ. (Tædium vitæ.)

Teel seed. A kind of sesame yielding a substitute for olive oil.

Teetotal. The term appears to have been first popularized by Joseph Turner, an artisan of Preston, who, at a temperance meeting in the autumn of 1833 , asserted that " nothing but te-te-total would do." The expression was at once and universally adopted by total abstainers. -Daily Telegraph, September 5, I882.

Teïan Poet, The. Anacreon, Greek lyrical poet; born at Teos, a seaport town of Ionia, circ. B.C. 560 .

Teil [L. trlia, lime], Isa. vi. I3; Terebinth [Gr. $\tau \epsilon \rho \epsilon \beta \iota \nu \theta o s]$, or Turpentine [corr. of Fr. térébinthine], Ecclus. xxiv. I6. In Heb. elah, mistranslated oak, which it resembles; the Pistācia těrěbinthus of the Levant; deciduous, many-branched, sometimes of considerable size ; incisions in the bark yield an agreeable balsam, turpentine-not that yielded by the fir.

Teinds. In Scotland, tithes; both words meaning tenths.

Telămōněs. (Caryatides.)

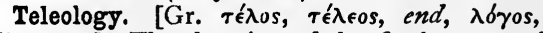
discourse.] The doctrine of the final causes of things; i.e. of the purpose of the Creator.

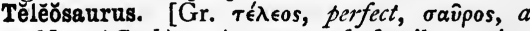
lizard.] (Geol.) A gen. of fossil saurian reptiles, resembling the gavial. Lias and Oolite.

Tělěostěi. (Ichth.) Sub-class of fish, comprising those with endo-skeletons of bone-like substance, occasionally of true bone.

Tëlěphassa. [Gr., she who shines from far.] (Myth.) The mother of Cadmus and Europa, who, vainly seeking her daughter, dies on the plains of Thessaly.

Telepheian wounds. Incurable wounds, from the wounds received by 'Telěphus from Achilles, who alone could cure them.

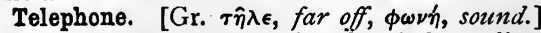
An instrument for reproducing the pitch, quality, and relative intensity of sounds at a place distant from that at which the sounds are uttered. Its action depends on the fact that a succession of electric waves can be sent along a wire from 
the transmitting end exactly corresponding to the aerial vibration, which produce the sensation of sound, and therefore capable of reproducing similar aerial vibrations, at the receiving end.

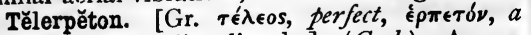
reptile, i.e. very like lizards.] (Geol.) A gen. of small fossil reptiles. Triassic sandstones of Elgin.

Telescope [Gr. $\tau \eta \lambda \epsilon \sigma \kappa \delta \pi$ os, far-seeing] ; Aohromatic T.; Astronomical T.; Galilean T.; Newtonian T.; Reflecting T.; Refracting T.; Terrestrial T. An instrument for obtaining a clear view of distant objects. It consists essentially of a large curved mirror (or speculum) or else of a lens (or object-glass), which forms an image of the object in its focus, and a lens or combination of lenses (the eye-piece), through which the image is viewed and by which it is magnified. The Refracting $T$ : has an object-glass, and the earliest form of it is the Galilean T.; in the Reflecting $T$. a speculum is used, and one of its earliest forms is the Newtonian $T$. In the Achromatic $T$. the object-glass is made of two lenses of different kinds of glass, to prevent the separation of the light into rays of different colours, which would occur if a single lens were used. (Achromatic.) In the Astronomical $T$. an eye-piece of two lenses is used, which leaves the image inverted. In the Terrestrial $T$. an eye-piece of four lenses is commonly used, for obtaining an erect image and a larger field of view. There are many other kinds of telescopes, which in many cases are named after their designers, as the Gregorian T., the Herschellian T., etc.

Telescopic star. A star so small as to be visible only through a telescope. Telescopic stars are of all magnitudes below the seventh.

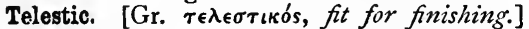
A piece of poetry, of which the last letters - of every line, taken consecutively, make a word or a sentence. (Acrostic.)

Tellurian. [L. tellürem, the earth.] An apparatus for showing the movements of the earth and moon relatively to the sun.

Tellurium. [L. tellūrem, the earth.] A bright grey metal.

\section{Tĕlönai. (Publicans.)}

Tèma. [It., L. thĕma, Gr. $\theta$ '́ $\mu a$, theme, of an argument.] In Music, a theme, subject.

Tempera [It.], or Distemper. A preparation of some opaque colouring with size, for painting walls, ceilings, etc.

Temperament. [L. tempĕrämentum, proportionate mixture.] (Music.) A system of compromise in the division of the octave in keyed instruments ; e.g. piano, whose sounds are fixed. This is made necessary by the same notes serving both as flats and as sharps. In Equal T., theoretically adopted in the piano, the twelve intervals in an octave are all of the same length, and no key has an advantage over the rest; in the Unequal $T$ : some scales are more in tune than others. (Wolf intervals.)

Temperate zone. (Zono.)

Temperature. [L. tempěrātüra, temperament.] The state of a body, as to its being sensibly hot or cold, which state is measured by a thermometer.

Tempering; Tempering colonr. The process of inducing flexibility in steel by reducing its hardness, which is done by heating it to a definite degree and then cooling it slowly-the process of cooling being performed in different ways, according to circumstances. The degree of heat is judged of by the colour of a thin film of oxide of iron formed on the steel; thus the colour is faint yellow at $430^{\circ} \mathrm{Fahr}$., purple at $530^{\circ} \mathrm{Fahr}$., etc. These are the $T$. colours.

Templars, Knights. One of the military religious orders, founded in the twelfth century for the protection of pilgrims to Palestine, and the recovery of the Holy Sepulchre from the Saracens. Their rules agreed generally with the Benedictine. The Templars made the Mosque of Omar, known as the Khubbet-es-Sakrah, or Dome of the Rock, their church, and called it the Temple of the Lord. The order was suppressed by Clement V., with great cruelty and injustice, in the fourteenth century.

Template. (Templet.)

Temple. Part of a loom used for stretching the web transversely.

Templet. 1. A short piece of timber placed in a wall under the end of a girder, to distribute the pressure more equally. 2. One of a pair of boards with circular edges, for describing the pattern of the tooth of a wheel; when one is made to roll on the other, a point on its edge describes the required line. 3. Pattern of a window, etc., cut out on paper.

Tempŏra mūtantur, nos et mūtāmur in illis. [L.] Times are changed, and we with them (Horace).

Tempus èdax rērum. [L.] Time, the devourer of things.

Tenacity. [L. těnãch̆tatem, from tenax, teneo, $I$ hold.] The resistance offered by a body to separation by forces tending to stretch it.

Tenaille. [Fr. tenailles, pincers, L. těnäcŭlum and -la.] (Mil.) Work in the ditch, of a re-entering form, between the flanks and curtain of the enceinte.

Tenancy by sufferance. The continuance of a tenancy after the expiration of the term by the tenant without agreement or disagreement on the part of the owner.

Tenancy in common (Leg.) is when property is given or conveyed to two or more persons in undivided shares, each share being distinct in title. In such cases there is no right of survivorship.

Tenant right. The alleged right of the tenant, on the expiration of his lease, to compensation for improvements which add to the letting value of the property. This question has acquired its chief prominence in Ireland.

Tend, To. (Naut.) To T. a ship, to keep the cable clear of the anchor while she is tending, i.e. swinging with the tide.

Tender. (Nait.) A small vessel attending on a larger one.

Tendon. [L. tendo, I stretch.] (Anat.) White shining fibrous tissue, by which muscles 
are attached to bones and to other parts which it is their office to move. $T$. Achillis passes from the muscles of the calf of the leg to the heel.

Tĕnĕbræ. [L., darkness.] In the Latin Church, the Office of Matins in the last three days of the Holy Week, at which a triangular candlestick with fifteen lights is used, one being extinguished after each psalm, with the exception of the last, which is held behind the altar and brought back, in token of the Resurrection.

Tenebrosi. [It., gloomy.] A school of artists founded by Caravaggio, remarkable for bold effects of light and shade.

Teneriffe. A wine resembling Madeira, made in the Canary Islands.

Tēnesmus. [Gr. $\tau \epsilon \iota \nu \in \sigma \mu o ́ s$, from $\tau \in(\nu \omega, I$ stretch.] (Med.) A straining to relieve the bowels, when it is not needed; involuntary, and owing to some local irritation.

Tenne. [Sp. tanetto, a chestnut.] (Her.) The orange or tawny colour in coats of arms, represented in engraving by vertical lines crossed by lines sloping downward from the sinister to the dexter side.

Tennis. [Fr. tenez, hold, or take it.] A game in which a ball is kept in motion by striking it with rackets.

Tenon. 1. (Naut.) The square heel of a mast, which fits into the step. 2. The end of a timber for mortising into another one. (Mortise.)

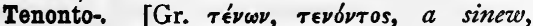
tendon.]

Tenor C. 1. (Music.) The lower $\mathrm{C}$ of the tenor voice. 2. The lowest string of the tenor violin. 3. Tenor bell. (Bell-ringing.)

Tenor olef has the $\mathrm{C}$ placed on the fourth line of the stave; as the Alto clef has the C placed on the third line.

Tension. [L. tensionem, a stretching.] 1. The force with which a stretched body endeavours to recover its shape. 2. The elastic force or pressure of a vapour, measured by the height of the column of mercury which it will support ; thus the T. of vapour of water at $212^{\circ}$ is thirty inches.

Tent. [L. tendo, I stretch.] In Surg., a plug or roll of lint for dilating wounds and preventing too rapid healing.

Tentacle. [L. tento, $I$ feel.] (Zool.) A flexible or jointed organ with which to explore or seize; especially the longer arms of decapod cuttlefish, and the filamentous appendages to the heads of annelids.

Tenter. [Fr. tendre, to stretch.] A frame for stretching cloth by hooks called tenter-hooks, so that it may dry even and square.

Tentmakers. Acts xviii. 3 ; makers of portable tents for soldiers and travellers and for harvest-gatherers on the plains of Cilicia, from the soft under hair of the goats of Cilicia. Chrysostom, in a monastery near Antioch, was for four years a $T$.

Tentōrium. [L., a tent.] (Anat.) A process of the dūra māter, separating the cerebrum from the cerebellum.

\section{Tenui Minerva. (Minerva.)}

Tenure. [From L. teněo, I hold.] In Feud. Law, the relation between lord and vassal with respect to lands, all landowners being vassals of the Crown, on the theory that the sovereign was the only landowner. The chief lay tenures were of four kinds: (I) by knight service, (2) in free socage, (3) in pure villeinage, (4) in villein socage.

Tenuto. [It.] (Music.) Held down; the finger not to be taken up from the notes.

Tephach. [Heb.] A Jewish measure of length; a handbreadth; metaph. Ps. xxxix. 5.

Tephromancy. [Gr. $\tau \epsilon ́ \phi \rho \alpha$, ashes, and $\mu \alpha \nu \tau \epsilon l \alpha$.] Divination by the figures assumed by red-hot cinders.

Ter-, Tri-. (Chem.) A prefix denoting that a salt contains three [L. ter, Gr. $\tau$ pis, thrice] atoms of the elements thus marked; as a terchloride, tri-sulphide, which contain three atoms of chlorine, sulphur, in each molecule.

Terai. The belt of jungle-land at the base of high mountain ranges, especially of the Himalayas. These belts are wonderfully fertile, but are also hot-beds of fever.

Terăphim. [Heb.] Images connected with magical rites, and consulted by the Israelites for oracular answers, but apparently not worshipped.

Teratology. [Gr. tépas, tépătos, a prodigy.] The history of monstrosities, malformations, in organic nature.

Terbium. (Yttrium.)

Tercel. (Tarsel.)

Terebinth. (Teil.)

Tĕrebrātŭlĭdæ. [L. terebra, a borer.] (Lampshells.)

Tërëdo. [L., piercer, from tĕro, $I$ pierce.] Ship-worm; bivalve mollusc, boring holes in timber. Fam. Phōlădĭdæ, class Conchĭfěra.

\section{(Pholas.)}

Těrěs atque rŏtundus. [L., smooth and round.] Well-finished, complete, as a perfect character (Hor., Sat., ii. 7, 86).

Term. [L. tĕrminus, a boundary.] 1. (Geom.) A boundary. 2. (Algeb.) One of the members of an algebraical expression or of a proportion. 3. In Logic. (Categorematic; Syncategorematic.)

Termagant. The Romance and German poets of the twelfth and thirteenth centuries supposed this to be a Saracenic deity, and coupled the name with that of (Mohammed) Mahound. It is really a corr. of the Greek Trismegistos, thrice-greatest, an epithet of Hermes. The word has passed into the meaning boisterous, noisy, violent.-Grimm, Teutonic Mythology, vol. i. p. I 50.

Terminālia. [L.] (Hist.) A festival celebrated by the Romans yearly in honour of Terminus, the god of boundaries, the Zeus Horios of the Greeks. (Herculean.)

Terminology. [A word coined from L.terminus, term, and Gr. $\lambda \sigma^{\prime}$ yos, discourse.] 'The doctrine of terms; or a treatise on terms ; or, sometimes, the terms themselves.

Terminus. (Terminalia.) 
Terminus a quo. [L.] A starting-point, the Terminus ad quem being the end or goal.

Termites. [L. termitem, a bough cut off.] (Entom.) White ants; small, soft-bodied neuropterous insects (not true ants, which are hymenopterous), forming large communities, and inhabiting mounds sometimes five feet high and as hard as stone. They are very destructive, and will eat away the whole inside of a wooden beam or piece of furniture without any apparent external injury.

Tern. (Sternidæ.)

Ternate leaf. [L. terni, three each.] (Bot.) One divided into three leaflets ; e.g. clover.

Terra cotta. [It.] Baked clay for statues, earthenware, etc.

Terræ filius. [L., a son of the earth.] A phrase denoting men of low birth, answering to the modern gentlemen of the pavement. (Hidalgo.)

Terræ mötus. [L.] An earthquake.

Terra firma. [L.] Solid ground.

Terra incognita. [L.] Unknown land.

Terra Japonica. [L., Fapanese earth.] Catechu (formerly supposed to be an earth).

Terrapene, Terrapin. (Zool.) Fresh-water tortoises, Е̌my̆dı̆dæ [Gr. é $\mu$ v́s], with a horny beak and jointed breastplate. America and Europe. The name is loosely given to many edible kinds.

Terra verde. [It.] An olive-green earth used as a pigment.

Terreplein. [Fr., platform.] (Mil.) The upper surface of a rampart behind the parapet; sometimes any level piece of ground.

Terret. A ring on a saddle for the driving reins to pass through.

Terre verte. (Terra verde.)

Terrier. [L.L. terrarium, from terra, earth.] In Feud. Law, an enumeration of lands and tenements held in a manor, with their extent, the names of the tenants, and the services due from each. By Canon LXXXVI., a T. of glebe lands, etc., of every parish is to be made and laid up in the bishop's registry. (The terrier dog is so named as being used for drawing foxes when they take to earth on being hunted.)

Terror, Reign of. In Fr. Hist., a name given to the worst time of the Revolution, generally reckoned from October, I793, to the fall of Robespierre and his fellow-Terrorists, in July, I794.

Ter-Sanctus. (Trisagion.)

\section{Tertian. (Quartan.)}

Tertiaries. (Eccl. Hist.) Societies following the third rule of St. Francis (Franciscans), seemingly connected with the Beghards and Fraticelli.

Tertiary colours. [L. tertiärius, from tertius, third.] Colours derived from the mixture of two secondaries. They are citrine, russet, and olive.

Tertiary system, or Cainozoio (Geol.), = all the regular strata and sedimentary accumulations which lie between the chalk and the beginning of the boulder, or drift, formation. (Eocene; Neozoic.)
Tertullianists. (Eccl. Hist.) Montanists of the school of Tertullian, in the second century.

Terza rima. [It., triple rime.] A measure used by the Troubadours and adopted by the early Italian poets. The rimes are so interlaced throughout the poem, that there is no pause till the end of it. The Divina Commedia of Dante is written in this metre.

Terzones. (Troubadou s.)

Terzuolo. (Musket:)

Tessellated. [L. tessellatus.] (Her.) Formed of squares of different colours.

Tessellated pavement. [L. tessella, dim. of tessěra.] (Arch.) A pavement formed of small square pieces of stone called tesserce, generally of different colours and with a central subject.

Tessěra. [L.] 1. A six-sided die, used as a ticket or tally, and also for setting military watches at night, the tessera being passed from one centurion to another. Hence, 2, a watchword.

Tesseral system [L. tessĕra, a square piece of stone, wood]; Tessular system. (Crystallog.) The octahedral system (q.v.).

Test. [L. testa, an earthen vessel.] A cupel (q.v.).

Test Act, 25 Charles II., obliged all officers, civil and military, as well as members of corporations, to receive the Holy Communion in the English Church; and to declare against transubstantiation.

Testaments, Old and New, are really the O. and N. Covenants, Settlements; T. being used as = solemn, duly attested declaration. See note on Heb. ix. in Norris's Notes on the New Testament, and refer to Revised translation.

Tester. [O.Fr. teste, head.] A flat canopy over a bed.

Tester (from the head, O.Fr. teste, impressed on it). An old coin, worth sixpence.

Test-paper. Paper impregnated with some reagent for detecting the presence of certain substances. (Litmus.)

Test-tube. A tube for holding liquids to be tested.

Testūdō. [L., a tortoise.] In Rom. Hist., a contrivance for attacking fortified places. The soldiers placed their shields so as to form a penthouse, which threw off the missiles showered down upon them.

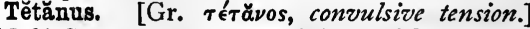
(Med.) Spasm, more or less violent, of the muscles of voluntary motion. Lockjaze, when of the muscles of the jaw or throat. Tranmatic T.,

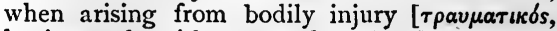

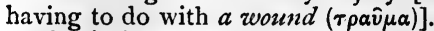

Tête-à-têto. [Fr., L. testa.] Head to head; a conference between two persons. In It. a quatro occhi.

Tête-de-pont. [Fr., head of bridge.] (Mil.) Work thrown up to cover a bridge and the communications across a river.

Tête montée. [Fr.] A head that has been turned.

Tetr-, Tetra-. (Chem.) A prefix denoting that a salt contains four [Gr. $\tau \in \tau p a ́ k \iota s$, four times] atoms of the element thus marked; as a 
totr-oxide, tetra-fluoride, which contain four atoms of oxygen, fluorine, in each molecule.

Tetrachord. [Gr. $\tau \in \tau \rho a ́ \chi 0 \rho \delta o s$, four-stringed.] (Music.) 1. (Diatonic scales.) 2. A series of four notes in the scale; such as that which, occurring twice, constitutes the major scale; so, in $\mathrm{C}$, from $\mathrm{C}$ to $\mathrm{F}$, and from $\mathrm{G}$ to $\mathrm{C}$.

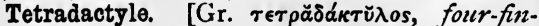
gered.] (Zool.) Four-toed; as the dog's hind foot.

Tetraětēris. [Gr.] (Chron.) A cycle of four years, attributed to Solon, for equalizing the lunar with the solar year, by means of intercalated months.

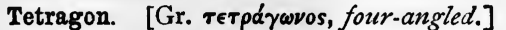
quadrilateral figure.

Tetragrammăton. [Gr., of four letters.] In Hebrew, the sacred name JeHoVaH.

Tetrahedron. (Polyhedron.)

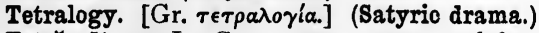

Tetrămèter. In Gr. poetry, a verse of four

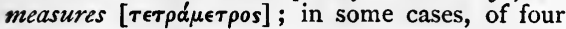
single feet ; in others, of four double feet.

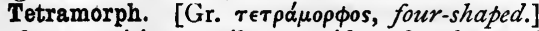
A figure uniting attributes said to be those of the evangelists (a man, lion, bull, and eagle), and standing on winged fiery wheels.

Tetrăōnĭdæ. [L. tětrăōnem, Gr. $\tau \in \tau \rho \alpha ́ \omega \nu$, probably bird of the grouse kind.] (Ornith.) Grouse, partridge, etc.; fam. of birds found everywhere except south-west of S. America, and Polynesia. Ord. Gallinæ.

Tetrăpla. [Gr. $\tau \in \tau \rho \alpha \pi \lambda \delta$ os, fourfold.] The Bible of Origen, as at first completed, in four versions, viz. that of the Septuagint, with those of Aquila, Symmăchus, and Theodotion. (Hexapla.)

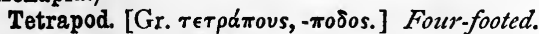

Tetrapolitan Donfession. A confession, differing slightly from the Augsburg Confession, drawn up, I 530, by the four towns, Lindau, Constance, Strasburg, and Memmingen.

Tetraptěra. [Gr. $\tau \in \tau \rho \alpha ́$ - $\pi \tau \in \rho o s$, four-winged.] (Entom.) Name given by some authorities to four-winged insects.

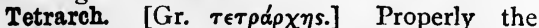
governor of the fourth part of any country ; often used for a subordinate prince without reference to its etymological meaning.

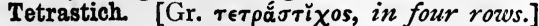
A stanza of four verses.

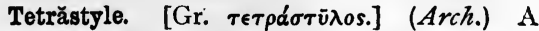
doorway with four columns in front.

Tetter. [A.S. teter; $c f$. Fr. dartre, which has the same meaning.] ( $M e d$. ) A general name for eruptive affections of the cuticle.

Teuthǐdæ. (Squid.)

Teutonic languages. The dialects belonging to the High and Low German, and Scandinavian branches of the Aryan family of languages.

Teutonic Order. The Teutonic Knights of the Hospital of St. Mary in Jerusalem. This order, founded by some charitable burghers of Lübeck and Bremen during the siege of Acre in the Third Crusade, I 189-91, rose to eminence under the fourth grand master, Herman of Salza. The order was then transferred to the Baltic. In
I525 Albert of Brandenburg renounced the title of grand master for that of Duke of Eastern Prussia, and laid the foundation for the modern kingdom of Prussia.

Tewel. [Fr. tuyau, pipe.] An iron pipe in a forge to receive the pipe of the bellows.

Textus Receptus. [L., the received text.] The ordinary text of the Old and New Testaments. That of the New Testament is the Elzevir edition published at Leyden, in 1624 . This text agreed generally with that of Beza, who closely followed Stephens, and Stephens followed the fifth edition of Erasmus, except in the Apocalypse, where he sometimes made use of the Complutensian. Hence the received text resolves itself at last into the Erasmian and the Complutensian.

\section{(Erasmus's Paraphrase.)}

Thaborites. (Taborites.)

Thaive. (Sheep, Stages of growth of.)

Thălămus [L., bed, Gr. $\theta a ́ \lambda a \mu o s]$, or Tŏrus $[\mathrm{L} .$, bed]. (Bot.) The growing point of a flower, in which the carpels are.

\section{Thaler. (Dollar.)}

Thălia. [Gr. $\theta \alpha$ d $\lambda \in t \alpha$, blooming.] In the Hesiodic theogony, one of the Muses, afterwards held to be the Muse of comedy.

Thallium. [Gr. $\theta a \lambda \lambda$ ós, a young shoot.] (Chem.) A lead-like metal discovered by the bright green line which it gives under spectrum analysis.

Thallogens [Gr. $\theta a \lambda \lambda \delta s$, a young shoot, and $\gamma \epsilon \nu \nu \alpha ́ \omega, I$ produce] (Bot.) = cryptogams of very simple structure, fungi, lichens, algæ.

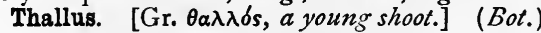
In cryptogamic botany, cellular expansion without any axis ; e.g. lïchen.

Thammuz. (Tammuz.)

Thanato-. [Gr. oávaros, death.]

Thane. [A.S. thegn.] A general name for the old nobility of England, the highest being the immediate thanes or ministers of the king. (Baron.)

Thanet sands. (Geol.) Marine Tertiary sands below the Woolwich beds, and lying on the chalk, well seen and thickest in the Isle of Thanet.

Thaumatrope. (Phenakistoscope.)

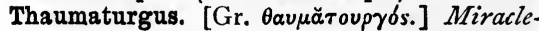
worker. Subst., 'Thaumaturgy.

Theatines. (Eccl. Hist.) A community of Regular clerks, founded 1524, by Cajetan of Thiene.

Thebaid. The heroic poem of Statius, written in the first century of our era, and relating the mythical civil war of Thebes between the sons of Edipns. The word is also used to denote the region of the Egyptian Thebes, known as the city of the hundred gates.

Theban year. (Chron.) The Egyptian year of 365 days $6 \mathrm{hrs}$.

Thebet. Esth. ii. 16 ; fourth month of civil, tenth of ecclesiastical, Jewish year; DecemberJanuary.

Theftbote. [Bote, compensation, = boot.] (Leg.) The compensation of a felony, by receiving back the stolen goods from the thief, or a compensation for them.

Theine. (Caffeine.) 
Thermis. [Gr.] In the Iliad, the goddess of law and order, who summons the council of the gods. She is the mother of the Hesperides.

Theobromine. (Cacao.)

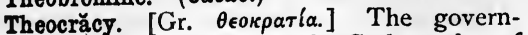
ment of a state immediately by God, as that of the Israelites before the establishment of the monarchy.

Thěǒcrāsy. [Gr. $\theta \epsilon o \kappa \rho \alpha \sigma i \alpha$, from $\theta \in \delta$ s, and

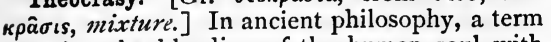
denoting the blending of the human soul with the divine Spirit in contemplation. It is the modern Quietism. (Mystics.)

Theodicæa. A word made up by Leibnitz from Gr. $\theta \epsilon \delta$ s and síkaios, just, and used as the title of his work, published in 1710 , with the design of proving that of all possible schemes for the government of the world, the one adopted is the best. This opinion is commonly known as Optimism, its opposite being Pessimism.

Theodolite. [Of doubtful origin; said to have

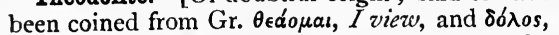
stratagem!] (Math.) A surveying instrument for measuring angles; consisting essentially of a telescope and two graduated circles, one vertical and the other horizontal. It is mounted on a tripod, and can be accurately adjusted by levels, so that the observer can read off the angle of vertical elevation of a point and the horizontal angle between two points, i.e. the projection on a horizontal plane of the angle subtended at the centre of the instrument by the line joining the two points.

Theodosians. Followers of the Monophysite Theodosius, in the sixth century.

Theodotians. (Melchisedekians.)

Thěŏgŏny. [Gr. Aeorovía.] A history of the relationship and descent of the gods, with a description of their functions. Such is the theogony of Hesiod.

Theological virtues. In Roman Catholic theology these are four Cardinal $(q . v$.$) virtues;$ but a prior division is that of (I) $T$. $V$., faith, hope, charity ; and (2) Moral, or Cardinal, = those which do, and those which do not, "immediately regard God."

Theopaschites. [Gr. $\theta \epsilon \delta s$, and $\pi \alpha \dot{\sigma} \chi \omega, 1$ suffer.] (Eccl. Hist.) The followers of Peter, a usurping Bishop of Antioch, who in the fourth century expressed strong Monophysite opinions.

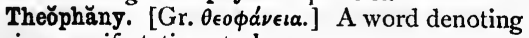
divine manifestations to human eyes.

Theophilanthropists. (Fr. Hist.) A society so styled itself which, when Christianity had been suppressed by the Convention, wished to set up a new religion in its place. They had the use of ten churches, but being deprived of these in 1802 , they soon ceased to exist.

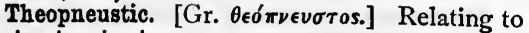
divine inspiration.

Theorbo. [It. tiorba.] (Music.) A large lute used for accompanying voices; seventeenth century; of Italian origin probably. An archlute was a T. with two sets of strings, one for the bass.

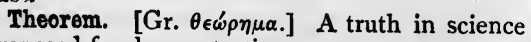
proposed for demonstration.

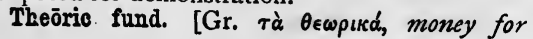

sights.] At Athens, the surplus of revenue after charges of ordinary expenditure was set aside as a fund to enable all citizens to be present gratuitously at the great dramatic festivals. This fund could not be diverted to purposes of war.

Theosophists. [Gr. $\theta \in \delta \sigma o \phi o s$, wise in the things of God.] A name applied by some to the Mystics, as believing themselves to possess an extraordinary knowledge of the divine nature by direct inspiration.

Theosophy. A professed knowledge of divine

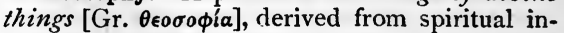
tuition or communication of God ; not philosophically by dialectic method, nor theologically by revelation.

Theǒtǒkos. (Deipara.)

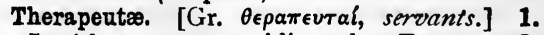
A Jewish sect, resembling the Essenes. 2. Christian ascetics in the neighbourhood of Alexandria.

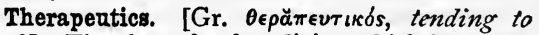
heal.] That branch of medicine which has to do with restoration to health.

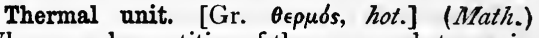
When equal quantities of the same substance in the same state are acted on by heat so that the same effect is produced, the quantities of heat are equal from whatever sources the heat may come. The quantity of heat required to change a given weight (as one pound) of ice at the freezing point into water at the freezing point, is a $T$. U.; the quantity of heat required to raise a pound of water from $0^{\circ} \mathrm{C}$. to $I^{\circ} \mathrm{C}$. is another $T$. $U$.

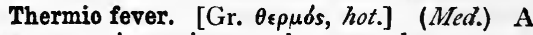
name sometimes given to the sunstroke.

Thermidor. In the Revolutionary French calendar, the eleventh month, beginning July 19 and ending August I7. In 1794 it was signalized by the fall of the Terrorists. (Terror, Reign of.)

Thermobarometer. [Gr. $\theta \in \rho \mu \delta s$, hot, Bápos,

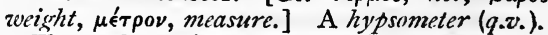

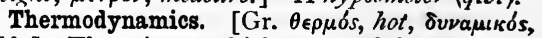
able.] The science which treats of the efficiency of heat-engines and of heat as a form of energy, tracing its sensible effects to movements of the molecules of bodies; also of the mechanical effects due to heat, and of the heat produced by mechanical agents.

Thermo-electricity. [Gr. $\theta \epsilon \rho \mu o ́ s$, hot, and electricity.] Electricity developed by the action of heat.

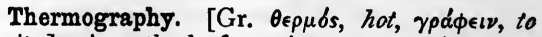
write.] A method of copying an engraving on a metal plate by the radiation of heat.

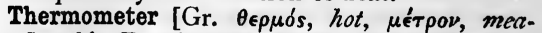
sure ] Air T. ; Centigrade T.; Differential T.; Fahrenheit's T.; Maximum T.; Metallic T.; Minimum T.; Réaumer's T. An instrument for measuring variations of temperature ; this is done by observing the expansion and contraction of mercury, spirits of wine, or other suitable liquid, inclosed in a glass bulb ending in a tube of very fine bore; the fixed points of the scale attached are the temperatures of melting ice (freezing point) and of steam under a pressure of about thirty inches of mercury (boiling point). In 
Fahrenheit's $T$. the distance between these points is divided into 180 equal parts, called degrees, freezing point being marked $32^{\circ}$, and boiling point $212^{\circ}$; in the Centigrade $T$ : the former is marked $0^{\circ}$, the latter $100^{\circ}$; while in Réaumer's the former is $0^{\circ}$, the latter $80^{\circ}$. In an $\mathrm{Air} T$. the scale of temperature is determined by the expansion of air under a constant pressure. A Differential $T$. consists of two bulbs on a level connected by a bent tube containing a coloured liquid; if the bulbs are at different temperatures, the unequal expansion of the air causes the liquid to stand at different levels in the bent tube, and supplies an accurate measure of the difference between the temperature of two neighbouring bodies. In the Metallic $T$. (Breguet's) change of temperature is indicated by a ribbon of different metals formed into a spiral whose unequal expansion or contraction causes it to coil or uncoil when its temperature changes. Maximum and Minimum T. register the highest and lowest temperatures that have occurred during a given time.

Thermomultiplier. A thermopile (q.v.).

Thermopile. An instrument for measuring minute degrees of temperature. It consists of a number of short pieces of antimony and bismuth joined end to end, forming, for instance, a zigzag. When the upper joints are exposed to a source of heat and the ends of the zigzag are joined by a wire, a current circulates whose intensity is proportioned to the heat and is measured by the deflection of the needle of a galvanometer.

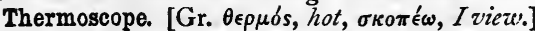
An instrument for measuring the effects of heat ; as a thermopile or a differential thermometer.

Thermotics. [Gr. $\theta \epsilon \in \rho \omega$, or perhaps $\theta \epsilon \rho \mu \sigma^{\prime} \omega, I$ make hot.] The body of doctrines respecting heat which have been established on proper scientific grounds.

Theroïd [Gr. $\theta \eta p o \epsilon i \delta \eta s]$ idiocy. When the

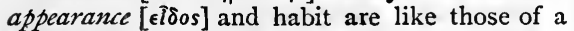

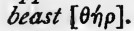

Thersites. [Gr.] In the Iliad, a deformed and noisy Achaian, whom Odysseus (Ulysses) smites for his plain speaking. Hence any insolent railer.

Thëseus, Temple of. The only temple of ancient Athens which still remains almost uninjured, perhaps from the fact that it was in the Middle Ages consecrated as a Christian Church.

Thesmǒphŏrĭa. [Gr.] At Athens and elsewhere, the festival of Dēmētēr, surnamed Thesmophŏros, or the lawgiver. (Eleusinian Mysteries.)

\section{Thesmǒthĕtæ. (Archons.)}

Thespian art. The tragic or dramatic art is sometimes so called, from Thespis, an Athenian, who, in the sixth century B.c., first gave it some definite form.

Thëtěs. [Gr.] In Athenian Hist., a class of tenants or occupiers of land, called also Hektemorians, as paying to the owner one-sixth por-

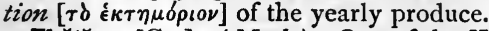

Thětǐs. [Gr.] (Myth.) One of the Nereids, who becomes the wife of Peleus and the mother of Achilles. (Paris, Judgment of.)
Thibet cloth. A goat's-hair fabric resembling camlet.

Thick and dry for weighing. (Naut.) An order to clap on nippers closely, at starting the anchor.

Thick-and-thin block. Fiddle-block. (Fiddle.)

Thill. [A.S. pille, a beam, a stake.] The draught-tree of a cart or waggon.

Thiller, Thill-horse. The horse between the shafts, or next the thill (q.v.).

Thimble. (Naut.) A ring with its outer side concave, to bind a rope round. T.eyes, holes in iron plates to reeve ropes through.

Thing. In the old Swedish and cognate languages, a popular judicial or legislative assembly. The Icelandic althing, or general parliament, met in the Thingvalla.

Thinga-men. (House-carls.)

Thingvalla. (Thing.)

Thin plates, Colours of. (Colour.)

Third Order. (Eccl. Hist.) Secular associates, not bound by vows, attached to most of the Religious Orders. (Tertiaries.)

Third Pointed style. (Geometrical style.)

Thirlage. In Scot. Law, the right, conferred, by law or contract, on the owner of a mill, to compel the tenants of a certain district to grind all their grain at his mill.

Thirty Tyrants. 1. At Athens, at the close of the Peloponnesian War, for one year, a body of rulers who upset the constitution of the city; and, 2, "by an idle and defective parallel," a crowd of usurpers, " nineteen in number, starting up in every province of the Roman empire," in the reign of Gallienus, A.D. 253-268 (Gibbon).

Thirty Years' War. (Hist.) A name given to a series of wars between the Protestant and Catholic leagues in Germany, from the insurrection of the Bohemians in 1618 , to the Peace of Westphalia, 1648.

Thistle of St. Andrew. An old Scottish order of knighthood, revived by James V. of Scotland, in 1 540 ; by James II., in 1687 ; and by Queen Anne, I703.

Thmei. An Egyptian goddess, often represented in the hands of the statues of kings. 'The Heb. Thummim is supposed to be the plural of the name.

Tholes, Thole-pins, or Thowels. (Naut.) Pins placed in the gunwale of a boat for oars to work between or on, instead of rowlocks.

Thŏlus. [Gr. $\theta$ ónos.] (Arch.) A building of circular form, or the roof of such a building.

Thomæans, or Thomites. (Eccl. Hist.) The Christians of St. Thomas, on the Malabar coast of India, are sometimes so called.

Thomas the Rimer. (Tanhaüser.)

Thomists. (Schoolmen.)

Thoorgum. (Tycoon.)

Thor. In Teut. Myth., a son of Odin, or Woden, the supreme god, and of his wife Freya. The name is a form of the word Thunor, thunder; hence Thunres-daeg, our Thursday. Thor is especially known as Miölnir, the hammerer, or pounder.

Thōrax, or Chest. [Gr. $\theta \omega \dot{\omega} \rho \alpha \xi$, breastplate, 
thorax.] (Anat.) That which lies between the neck and the abdomen; the upper of the two divisions of the body, containing the heart and lungs. In insects, the second segment. Thoracic duct, a small duct, which conveys the contents of the lacteals and absorbents into the blood.

Thorium, Thorinum. (Chem.) A heavy grey metal obtained from thorite (a Norwegian earth, named from the god Thor).

Thorney Island. Ancient name of a part of Westminster, including the site of the abbey, adjoining the Thames, covered with brushwood, and surrounded by a branch of the river.

Thorough, The. (Hist.) The name given by Strafford, in his correspondence with Archbishop Laud, to his design of establishing an absolute monarchy in this country by means of a military force.

Thorough bass. (Music.) 1. Commonly, but wrongly, used as = science of harmony. 2. A bass part, with figures added, indicating the harmonies; a kind of musical shorthand. (Figured bass.)

Thorough-brace. A leather strap supporting the body of a carriage.

Thorough-bred horse may be defined, per accidens, as one whose sire and dam are both in the Racing Calendar.

Thorough-pin. In a horse. (Spavin.)

Thoth, Taout. An Egyptian deity, represented as a human figure with the head of a lamb or ibis, and vencrated as the inventor of writing.

Thought, To take. I Sam. ix. 5 ; Matt. vi. 25, etc. ; Gr. $\mu \grave{\eta} \mu \epsilon \rho \iota \nu \eta \dot{\sigma} \sigma \eta \tau \epsilon$, retains its earlier meaning (to be over-anxious, worried), which survives in some parts of England.

Thousand and One Nights. The title of the tales more commonly known as the Arabian Nights' Tales, derived from the Persian collection called Hegar Afzaneh (the Thousand Fanciful Tales), which is at least as old as the ninth century, and is itself obtained from earlier models.

Thowels. (Tholes.)

Thrall. [A.S. thral.] One who has no civil rights in relation to his master, a bondman. (Helots ; Peonage ; Ryot ; Villein.)

Three-centred arch. (Arch.)

Three Chapters. (Eccl. Hist.) An ordinance of the Emperor Justinian, condemning certain works of Theodore of Mopsuestia, Theodoret of Cyprus, and Ibas of Edessa, on the ground of their Nestorianism.-Milman, Hist. of Iatin Christianity, bk. iii. ch. 4. (Nestorians.)

Three Dons. (Three Kings' Day.)

Three Kings' Day. Dreikönigstag, Twelfth Day in Germany; the legend being that the Magi were three kings, and worshipped Christ on that day. Their traditional names are Gaspar, Melchior, and Balthazar. Three Kings, or Three Tons, i.e. Dons, is sometimes the sign of an inn

Three sheets in the wind. In Naut. slang, reeling drunk.

Three Tons. (Three Kings' Day.)

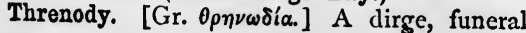
song.

Thrift. (Bot.) A native plant, common on muddy and rocky sea-shores, banks of estuaries ; found frequently on high mountains; cultivated as an edging for its rose-coloured flowers. Armeria maritima, ord. Plumbagineæ.

Throat. (Naut.) I.q. jaze of gaff (q.v.). $T$.-halliards, those for hoisting the jaw end of the gaff.

Thropple. In a horse, the windpipe.

Throttle-valve. (Mech.) A valve in the steam-pipe for regulating the supply of steam to the cylinder; under the control of the governor it moves so as to enlarge or contract the free space according as the main shaft is moving below or above its just rate.

Throwing. [A.S. thráwan, to tzvist.] 1. Twisting into a thread (as silk). 2. Shaping roughly on a potter's wheel.

Thrum. [Ger. trumm.] An end of a weaver's thread, a tuft.

\section{Thrum, To. (Fothering.)}

\section{Thrush. (Med.) (Aphthæ.)}

Thrush, Trush. In horses, ulceration of the sensitive surfaces within the frog; from various causes.

Thugs. [From the Hind. verb thugna, to deceive.] An association of thieves and murderers, which has long existed in India, but has been extirpated in all British territories. The special object of their worship was the goddess Bhowaní, the Vedic Bhuvani, a name from the same root as the Gr. Phŭsis, nature.

Thülē. A name given by ancient writers to some land lying north of Great Britain, which may be Iceland. (Atlantis, New.)

\section{Thummim. (Thmei.)}

Thundering Legion. In the expedition of Marcus Antoninus against the Marcomanni, A.D. I74, a Roman legion, whose prayer for rain is said to have brought down the storm which threw the enemy into confusion.

Thunor. (Thor.)

Thūrĭfícati. (Sacrificati.)

Thurl. [O.E. thyrl, from thyrhel, drilled through.] A long adit in a coal-pit, or a passage between two adits.

Thursday. (Thor.)

\section{Thwarting. (Athwart.)}

Thwarts. (Naut.) The seats across a boat for the rowers. T.-marks to $a$ harbour, two points on land, which being kept in a line point out a channel.

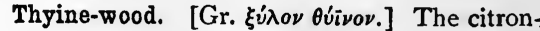
wood of the Romans; of the N.-African $\theta u^{\prime} \alpha$, Callitris quadrivalvis, allied to the cypress; very beautiful and durable, much prized in all times for works of art.

Thy̆mus gland. [Gr. $\theta \dot{u} \mu o s$.$] One of the$ sweet-breads of calf and lamb; so called from its likeness to a bunch of thyme; a temporary ductless gland, in front of the lungs, diminishing or disappearing with age.

Thyroild, properly Thyreoïd, cartilage. [Gr.

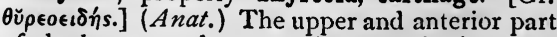
of the larynx; when prominent, Adam's apple;

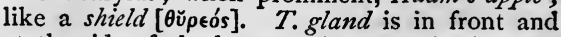
at the side of the larynx; ductless; its function but little understood. (Bronchocele.) 
Thyrsus. [Gr. $\theta$ úpoos.] A staff intwined with ivy, and borne by the Bacchanals in the orgies of Bacchus. (Bacchanalian.)

Thy̆sānoptěra. (Hemiptera.)

Tiăra. [L. tiāras] 1. The Persian head-dress, worn by the great king. 2. The mitre of the pope, which was at first a round high cap. The first gold circle was added by Nicholas I., the second by Boniface VIII., and the third by Urban V.

Tibra. [L., shin-bone.] 1. (Anat.) The bone of the leg, between the knee and the ankle, by the side of which the fibrila (q.v.) is fixed. 2 . (Music.) A pipe, flute, originally made of bone, the commonest musical instrument of the Greeks and the Romans. It regulated the dance at sacrifices, festivals, the rowing of the trireme, sometimes also the march of troops to battle (Herod., i. 17). T. dextra, played with the right hand, bass; $T$. sinistra, with the left, treble. Tibia păres [equal], both treble or both bass, impăres [unequal], one of each.

Tic douloureux. [Fr., painful spasm.] Neuralgia of the trifacial nerve.

Ticking. 1. A closely woven cloth for bedticks. 2. The best kind of artist's canvas.

Tide [A.S. tíd, Ger. zeit, time] ; Atmospheric T.; T.-day ; Derivative T.; Primary T.; T.-wave. The periodical variations in the height of the surface of the sea at any given place depending on the relative position of the moon and in a less degree of the sun. The T.-zvave is the joint result due to the coexistence of the waves produced by the action of the sun and moon. Speaking with respect to the ocean generally, it is a very flat wave, with two crests about $180^{\circ}$ of longitude apart : this is the Primary $T$.; the Derivative tides are those experienced near shore, in channels, rivers, etc., where the primary $T$. is modified by the form of the channel and its bottom, and the movement of the water partakes of the nature of a current as well as of an oscillation. The T.-day is the interval between two successive arrivals at the same place of the same crest of the tide, i.e. between one high tide and the next high tide but one. The Atmospheric $T$. consists of elevations and depressions of the atmosphere analogous to those of the ocean tides, and produced in a like manner.

Tide-gauge. A contrivance for registering continuously the height of the tide at every instant in the course of the day.

Tierce. (Canonical hours.)

Tiercel. (Tarsel.)

Tiers Etat. [Fr.] Under the Ancien régime, the third branch, or commonalty, in the French Estates, or Parliament, the other two being the nobles and the clergy.

Tiffany. A fine thin silk.

Tig. (Tyg.)

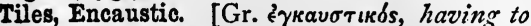
do with burning in.] Tiles with figures of different coloured clays indented on their surface, and finally exposed to an intense heat for sixty hours.

Triliacem. (Bot.) A nat. ord. of plants, of which the only British gen. is [L.] Tillia, lime or linden tree.
Till. (Boulder-clay.)

Tiller, To. [A.S. telgian, to branch.] (Agr.) To sprout from the base of the stem; spoken of wheat, etc.

Tiller. (Naut.) The bar fitted to the rudderhead, and by which it is moved. T.-head, the end furthest from the rudder.

Tilsit, Treaty of. (Tugendbur d.)

Tilt. [A.S. teld, a tent ; $c f$. Ger. zelt.] (Agr.) The cloth, or canvas cover, for a stack, cart, or waggon.

Tilth. [A.S. tilð, id., tilian, to till.] ( $\mathrm{Agr}$.) 1. The depth of soil cultivated or fit for cultivation. 2. The condition into which 1 is brought by cultivation.

Tilt-hammer. A heavy hammer used in forging; it turns round an axle at one end and is lifted by a projection or cam on the axle of a wheel, which on working clear of the hammer allows it to fall on to the mass on the anvil.

Timbers. (Naut.) A ship's ribs.

Timber trees. In Law, generally speaking, $=$ oak, ash, elm.

Timbre. [Probably L. tympănum, a drum.] The quality of a note. (Quality of a musical note.)

Timbre, Timber. [Fr. timbre, Ger. zimmer.] A package of small skins, containing a fixed number.

Time; Absolute T. ; Apparent solar T. ; Astronomical T.; Civil T.; Equation of T. ; Local T. ; Mean solar T.; Relative T.; sidereal T. Absolute time is duration, and flows on uniformly; Relative $T$. is a measure of duration effected by a comparison of motions, so that two portions of time are equal in which two exactly similar movements occur. The larger units are determined by the seeming motions of the stars and sun; the movements which measure the smaller portions of time and serve to subdivide the larger units are the oscillations of a pendulum or the vibrations of a spring. Apparent solar T., or Apparent 7 ., is time measured by the motion of the apparent (i.e. the actual) sun; Mean solar $T$., or Mean $T$., by that of the mean sun ; Sidereal $T$., by that of the first point of Aries. Local $T$. is the mean, or apparent, or sidereal time reckoned at any station with reference to the transits of the mean sun, or of the apparent sun, or of the first point of Aries, at that station. Civil 7: is reckoned from midnight, Astronomical $T$. from the following noon ; thus, 7 th September, nine o'clock a.m. civil time, = September, six days twenty-one hours astronomical time. (For Equation of $T$., vide Equation ; also vide Day and Year.)

Time-keeper. An accurate clock or chronometer.

Tìměo Dănăos, et dōna fērentes. [L.] I fear the Greeks even when bringing us presents (and am against receiving this wooden horse) (Virgil); i.e. one suspects the gifts and kindness coming suddenly from those who have hitherto acted so differently.

Timocrăcy. [Gr. тінократі́a.] A Greek term denoting two kinds of political constitution: 1 , that of Aristotle, in which property is the quali- 
fication for office; and 2, the T. of Plato, in which the best of the citizens struggle for preeminence.

Timonier. [L. temōnem, beam, pole of a carriage, etc.] (Naut.) 1. The helmsman. 2. A man, on the look-out, to direct the helmsman.

Tin. [Fr. étain, L. stannum.] A white metal. The tin of which kettles, etc., are made is tin plate, consisting of sheet iron coated with tin. Block tin is coarse tin cast into blocks. Grain tin is fine crystalline tin in small fragments. Tin-stone is native dioxide of tin; when found washed down in alluvial soils, it is called stream tin. Tin-foil is tin beaten out into thin leaves. Tin prepare liquor is stannate of sodium, used in preparing calico for the dye. Tin-salt is dichloride of tin, a mordant (q.v.).

Tincal. [Hind. tincâr.] (Chem.) Crude borax.

Tinchell. [Gael. timchioll, a circuit.] In the Scottish Highlands, the inclosing of game by a circle of sportsmen, for the purpose of a Battue.

Tincture. [L. tinctūra, $a$ dyeing.]

The colour of a shield or its bearings.

Tindal. (Naut.) Lascar boatswain's mate.

Tine. [O.E., tooth of a harrow, etc. ; $c f$. Ger. zahn, tooth.] (Antlers.)

Tinnitus aurium. [L., ringing in the ears.] (Med.) Arising from various causes; sometimes unimportant, sometimes a prelude to entire deafness.

Tinto. A red Madeira wine.

Tint-tool. A kind of graving tool for cutting lines of a certain breadth on copper or wood.

Tipping all nines, or Tipped the nines. In Naut. language, foundering or foundered from press of sail.

Tipping the grampus. In Naut. slang, ducking a man for sleeping on his watch.

Tipstaff. The name for the constables in attendance on the courts of Chancery and Common Law.

Tirailleurs. [Fr.] French sharpshooters, or skirmishers.

Tïröcĭnium. [L.] 1. First military service, military rawness, the condition of a tîro [L., $a$ raw recruit]. Hence, 2, a first beginning, an early effort.

T-iron. Rolled iron bars, whose cross section is shaped like a $T$.

Tironian notes. The old Roman shorthand, said to have been brought from Greece by Tiro, the freedman of Cicero.

Tirshatha. The title of the governor of Judæa under foreign rulers.

Tisane. (Ptisan.)

Tisri. Post-Babylonian name for Ethanim $(q . v$.$) .$

Titaninm. [L. and Gr. Titan.] A deep-blue metal, very hard and refractory.

Títans. [Gr. Tıtâves.] (Myth.) The children of Ouărnos (Urănus) and Gê, heaven and earth. Among these was Kronnos (Cronus), the father of Zeus, or Jupiter. At the close of their war with Zeus, they were thrust down into Tartarus.

Tithes. [A.S. teotha, tenth.] Anciently pay. able:-Pradial [L. prædium, an estate], of things arising immediately out of the ground : grain, fruits, herbs. Mixed, of things nourished by the earth : colts, calves, pigs, lambs, chickens, milk, cheese, eggs. Personal, of profits arising from labour and trade. Great tithes are of corn, hay, wood; Small T., of the other prædial T., together with mixed and personal. Modus décimandi, or Modus, is a local special manner of tithing, e.g. a sum of money paid annually per acre, or a less amount given in tithe, and part in labour, etc. Composition [L. compositio, settlement of a difference], the purchasing, by a single sum, of exemption from tithe. Commu. tation (q.v.), an exchanging of tithes for a rentcharge.

Tithonic. [L. tithōnius.] Belonging to Tithōnus, husband of Eos (Aurora, the dawn). (Actinic rays.)

Titmarsh, Michael Angelo. Nom de plume of William Makepeace Thackeray.

Titration. [Fr. titre, a standard.] Analysis by means of solutions of a fixed standard strength.

Titular. [L. titŭlus, a title.] In Eccl. usage, one invested with the title to a benefice, the implied meaning being generally that he has the title and nothing more.

Titular bishops. 1. Bishops without special jurisdiction. 2. Bishops who are called bishops in partibus, sc. infidelium, their titles belonging to countries possessed by heretics or heathens.

Tivy. Quickly; abbrev. of tantivy, the note of a hunting-horn.

Tmësis. [Gr., a cutting.] In Gr., the separation of a compound word into two parts by interposing a word between them; as in to us ward.

Toad-stone. [Ger. todt-stein, dead, i.e.useless, stone.] (Geol.) Beds and dykes of basalt, in Derbyshire limestone. Local name.

Tobacco charts. In Naut. language, untrustworthy charts.

Tobine. [Ger. tobin.] A stout twilled silk used for dresses.

Tobogan, Tarbogan. A sleigh used in Canada and by the Hudson's Bay Company, drawn by dogs, for travelling over snow ; made of thin boards, ten or twelve feet long, and from twelve to fifteen inches broad. Smaller ones, from five to eight feet long, are also used in Canada for sliding down hill over snow.-Bartlett's Americanismis.

To-brake. The preterite of the O.E. verb tobrcak, used in Judg. ix. 53.

Toccata. [It. toccáre, to touch, play upon.] (Music.) 1. A prelude. 2. A fantasia.

Tocher (akin to dower). In Scot. Law, a term for a father's marriage portion to a daughter at the time of marriage.

Tocsin. [Fr. toquer, to touch, sin, L. signum, in mediæval sense of bell (Littré).] An alarm. bell.

Tod. [Cf. Ger. zote, a knot or ball of wool.] 1. A bush; e.g. ivy tod. 2. Of wool, twentyeight pounds. 3. A fox, perhaps as if $=b u s h y$. tailed.

Tod-boat. (Naut.) Broad, flat, Dutch fishingboat.

Toddy. The fermented juice of the palm tree. 
-toft. In Geog., a Norse word, meaning an inclosure, a tuft of trees.

Tŏga. [L.] A loose woollen garment, worn by Romans generally, hence called gens togata, toga-clad people. Usually white; but of a dark colour in mourning. The toga pratexta, worn by magistrates and others, had a broad purple border. The toga virilis, which had no border, was put on by boys at the age of sixteen.

Toggle. (Naut.) A strong wooden pin for securing a tackle, etc.

Tohu bohn. The Hebrew words in Gen. i. 2, denoting that the earth was "without form and void." Sometimes used to express chaos generally.

Toilinette. [Fr.] Cloth the weft of which is woollen yarn, and the warp cotton and silk.

Toise. [Fr., L. tensa; the distance between the outstretched arms.] The old French T. was divided into six feet, and each foot into twelve inches; its length was 76.736 English inches; the $\mathrm{T}$. Usuelle is two metres, or 78.742 English inches.

Toison d'Or. [Fr., L. tonsionem, a shearing, aurum, gold.] Golden Fleece.

Tokay. An aromatic wine, made at Tokay, in Hungary.

Token. [A.S. tácen.] 1. Ten quires of paper. A white token is two hundred and fifty sheets of paper, printed on both sides. 2. A piece of metal, issued for currency, usually impressed with the name of the party sssuing it, who was bound to redeem it for lawful coin of the realm.

Tolbooth. (Tolsey.)

Tolerance. [L. tŏlĕrantia, endurance.] (Med.) The ability, in a diseased person, to bear strong medicines.

Toleration Act, I William and Mary, exempted those taking the new oaths of allegiance and supremacy, and making the required declaration against popery, from the penalties incurred by absence from church and by holding unlawful conventicles ; allowed Quakers to make affirmation in certain cases ; but did not relax the provisions of the Corporation and Test Acts. Those who denied the doctrine of the Trinity were excluded from its operation.

Tollendi, Per modum. (Log.) By a method of exhaustion. (Exhaustion, Method of.)

Tolsey. An O.E. name for a place where tolls were assessed or collected. The word tolbooth had probably the same origin.

Tolu. The resinous product of a spec., Toluiferum, of Myrospermum, a gen. of tropical American trees or shrubs, of the fam. Leguminosæ.

Tolutation. An obsolete word, denoting a pacing or ambling motion, from L. tolūtim, on a trot.

Tomahawk. [Amer.] A kind of hatchet thrown as a weapon by the N.-American Indians.

Tombac. [Malay tambaga, copper.] An alloy like brass, but containing more zinc. White tombac contains arsenic as well.

Tom Cox's traverse. In Naut. language, up one hatchway and down another, much talk and little work.
Tom Pepper. In Naut. language, a liar.

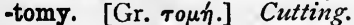

Ton. [A.S. tunne.] 1. A weight of 20 hundredweights or 2240 pounds. 2. A ton of tonnage is a certain number of cubic feet of the space which a vessel has disposable for stowage : it is frequently reckoned at thirty-five cubic feet, that being assumed as the volume of a ton of sea-water ; sometimes at forty cubic feet.

Tonality. (Music.) Not easily defined, is the characteristic of modern as distinguished from ancient music, which arises from its being written in definite keys, and from the definiteness of the diatonic scale.

Tonbridge ware (made at Tonbridge Wells). Wooden articles decorated with tesselated veneers of various coloured woods.

Tondino. [It.] (Arch.) The same as Astragal.

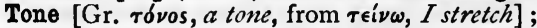
Fundamental T. A musical sound incapable of resolution, and resulting from a simple vibration. Suppose a stretched string to make any number (say 264) of complete vibrations a second ; if its length were reduced to a half, a third, a fourth, etc., other things remaining the same, it will make 528,792 , 1056 , etc., vibrations a second : the tone corresponding to the 264 vibrations is the Fundamental $T$. of the string; those corresponding to the others (viz. the octave, the fifth above the octave, the second octave, etc.) are the Harmonics, i.e. the acute harmonics, or harmonic overtones, of the fundamental tone.

Tones, Gregorian. Ecclesiastical chants said to have been introduced into the Latin Church by Pope Gregory the Great, in the sixth century. They belong probably to much more ancient times.

Tonga. (Tonquin bean.)

Tonic. [Gr. Tóvos, tone, note.] 1. (Med.) A strengthening medicine. 2. (Music.) The keynote. Tonic Sol-fa is a simplification of the writing of music by the use of letters denoting sounds, and of strokes, commas, colons, denoting time ; instead of the ordinary notation.

Tonnage. (Naut.) A ship's admeasurement. (Ton.)

Tonnage and poundage. (Eng. Hist.) Duties granted by Parliament to the Crown, the former on wines, the latter on all other kinds of merchandise. By Charles I. they were collected for fifteen years on his own authority-a right which he was compelled to surrender. They are now merged in the general customs duties.

Tonquin bean. The Coumarouna odōrata of French Guiana, belonging to the ord. Leguminosæ ; a large forest tree. The fruit is an oblong hard drupe, the kernel of which yields the sweet scent used by perfumers.

Tonsils. [L. tonsillæ.] Two suboval, complex glands, one on each side of the fauces, secreting a kind of saliva; imperfectly understood.

Tonsure. [L. tonsūra, from tondeo, $I$ shave.] (Eccl.) The shaven crown of persons in holy orders, representing, it is supposed, the crown of thorns. The tonsure of St. Paul, used in the Eastern Church, differs from that of St. Peter, 
or the Latin, in going across the whole front of the head from ear to ear.

Tontine. A method of raising annuities on the joint lives of a number of subscribers, devised by one Tonti, in the seventeenth century, the principle being that the subscribers receive an annuity in proportion to their shares, with a right of survivorship, the last receiving such a proportion of the whole sum as may have been determined at the time of the creation of the tontine.

Toon-wood. A coarse reddish wood, used in India for furniture.

Toothed wheels (Mech.) are set on parallel axles, and either is capable of driving the other by means of projections or teeth cut on their circumferences.

\section{Tooth-shell. (Limpet.)}

Top. (Naut.) A platform at the head of a tower mast. T.-armour, a fencing on the after side, about three feet high, covered with red baize or canvas painted red. T-armings, hammocks stowed in the rigging, to protect riflemen. T. a yard, or boom, to raise one end by halliards. T:-castles, a kind of wooden castle at the masthead, in ancient ships.

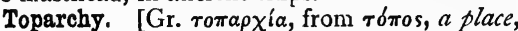
and á $\rho \chi \omega, I$ rule.] (Hist.) A state consisting of only a few cities or towns.

Top-armour. (Naut.) A railing on the top, supported by stanchions and equipped with netting.

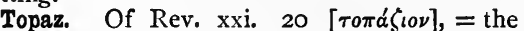
peridot and (modern) chrysolite, the former being the greener variety.

Tope. [Pâli thûpa, Skt. stûpa, accumulation; and so nearly = L. tumulus.] Buddhistic monument, for preservation of relics; height from a few feet to 300 feet; in Ceylon, China, Thibet, etc. The oldest are cupola-shaped ; on many are parasol-shaped structures, one above another, and on the top of all is some metal ornament; their use and meaning somewhat obscure.

Tope. 1. (Zool.) Găleus cănis [Gr. $\gamma a ̆ \lambda \epsilon \delta s]$; a small spec. of shark. Fam. Galeidæ. 2. (Naut.) A small Chinese junk.

Top-gallant, in Cotton MSS. Top garland. (Naut.) T.-G. forecaslle. (Decks.) T.-G. mast. (Mast.) T...G. sails. Squaresails set on T.-G. mast.

Top-hamper. (Naut.) 1. Any necessary weight on deck, or about the masts and rigging. 2. Flying-kites and their gear.

Tophet. [Heb.] A garden of the Jewish kings, defiled by sacrifices to Moloch. The name is by some derived from the Heb. toph, a drum, drums being used to drown the crics of the human victims offered to the god.

Topiary art. [L. tŏpiāria, sc. ars.] The art of gardening, particularly of trimming trees into fantastic shapes.

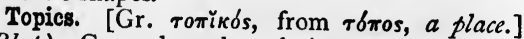
(Rhet.) General truths relating to the various subjects, in art, science, jurisprudence, etc., which may be dealt with by the orator. These were committed to menory, and the speaker was thus supposed to be furnished with a store of commonplaces, from which he could be at no loss to draw. Many of these T. are practically Axioms.

Top-lantern, or Top-light. (Naut.) One in the after part of the top in a flag or pennant ship.

\section{Topmast. (Mast.)}

Toppings. That which comes from the hemp in hatchelling.

Top-ropes. (Naut.) Those by which the topmast, or topgallant-mast, or topgallant-yard, is raised and lowered.

Topsails. (Naut.) Those set on a topmast. (Mast.)

Toque. [Fr., It. tocca.] A sort of head-dress.

Torah. [Heb., teaching.] The traditional interpretation of the Mosaic Law, uniting the statute law and the prophetic words of Jehovah.

Toreutic. [Gr. торєитько́s.] Highly finished. Specially applied to carvings in hard wood, ivory, etc.

Tormina. [L. neut. plu., = the treisting things, torqueo, I twist, torture.] (Med.) Griping pains. Tornādo. [Sp., from tornor, to turn.] A violent wind of short duration, arising suddenly from the shore and veering round from all points of the compass.

Torpēdo. [L., from torpeo, I am numb.] 1. (Ichth.) Fam. of marine fish; rays with electric organ. Temperate and tropical latitudes. Fam. Torpēdinnìdæ, sub-ord. Bătŏidèi, ord. Plăgĭostŏmătă, sub-class Chondroptěry̆gii. 2 . (Mii.) Submarine mine, either stationary or floating, for destroying ships passing over them.

Torque. (Torques.)

Torqued. [L. tōrquēre, to twist.] (Her.) A dolphin twisted into the form $\mathrm{S}$.

Torquēs. [L.] A chain or collar of metal ringlets interlaced with each other, and worn round the neck, specially by the Gauls. From depriving one of their chiefs of his collar, T. Manlius was surnamed Torquatus, B.c. $36 \mathrm{I}$. (S.S., Collar of.)

Torricellian tube (Torricelli, Ital., I 608-I647; successor of Galileo at Florence); T. vacuum. The glass tube containing mercury which is the essential part of the barometer. The $T$. vacuum is the space in the tube above the mercury, which in a good instrument is devoid of air, and contains nothing but the vapour of mercury.

Torrid zone. (Zone.)

Tors [ $c f$. Mount Taurus, L. turris, Gr. $\tau u ́ \rho \sigma t s$, a tower] are the harder portions of granite after weathering; remaining more or less exactly posed above one another.

Torse. [O.Fr.] (Her.) A wreath.

Torsion; Angle of T.; T. balance. 1. The act of twisting [L. tōrsionem]. 2. The resistance offered by the elasticity of a body to its being twisted, and so the force with which a twisted thread or wire tends to recover its form. If a thin thread or wire is held at one end and twisted by a couple (two equal opposite forces acting at opposite ends of an arm), the angle through which the arm of the couple turns before it is balanced by the elasticity of torsion is the Angle of $T$. In a $T$. balance the intensity of a 
small force or couple is estimated by observing the angle of torsion of a standard thread or wire ; used in electrical measurements.

Torsion balance. (Torsion.)

Torso. [It., L. thyrsus, $a$ stem, a staff.] A broken statue, exhibiting only the trunk of the figure.

Tort [Fr., wrong] (Leg.) has been defined as a wrong or injury that is independent of contract; e.g. the invasion of a right, the breach or neglect of a duty, public or private; as by waste, nuisance, libel, etc.

Torteau. [O.Fr.] A red roundlet or disc.

Torticollis. [L. torquëre, to twist, collum, the neck.] (Med.) Wry-neck. A rheumatic affection of the muscles of the neck.

Tortilla. [Sp.] A thin unleavened cake of maize flour.

Tortoise-shell turtle. [Fr. tortue, Sp. tortuga, from its twisted feet.] (Chelonidæ.)

Tortnons. (Math.) A curve in which, any four consecutive points being taken, the fourth does not lie in the same plane as the first three, is $T$. The thread of a screw is a $T$. curve. Such a curve is often called a curve of double curvature.

Tŏrus. [L., a swelling, a couch.] 1. (Arch.) A moulding on the bases of columns, with a semicircular profile. 2. (Thalamus.)

Tory. In the time of Charles II., this name was applied to bog-trotting plunderers and to popish outlaws, otherwise called Whiteboys, who found refuge in the bogs of Ireland. Hence it was used to denote those who would not vote for excluding a Roman Catholic prince from the throne (Macaulay, Hist. of England, vol. i. ch. 3). It thus came to designate generally the party which desires to uphold, so far as may be possible, without change, the existing order of things. The word is a corr. of the Ir. toiridhe, or tor, a pursuer (Skeat). (Abhorrers.)

Tosh, To. In Naut. parlance, to steal copper from a ship's bottom or dockyard store.

Tosorthrus. The Egyptian name of the sovereign or sovereigns known to Europeans under the name Sesostris. From the accounts of Herodǒtus, Manětho, and Diodōrus, it seems impossible to say when he reigned. The date of the Sesostris of Manetho differs from that of the S. of Herodotus by about 2000 years. Accordto Herodotus, he was a conqueror who subdued both Assyria and Asia Minor.

Tossing, Tozing. A process consisting in suspending ores by shaking them violently in water.

Tot, or Tott. (Naut.) A drinking-vessel, holding rather less than half a pint.

Totem. A corr. of an Algonkin word, meaning "that which peculiarly belongs to him ;" the family mark or coat of arms of the N. American Indians; some quadruped, bird, etc. -Bartlett's Americanisms.

Totidem verbis. [L., in so many words.] An exact report.

Tōtis vīribus. [L.] With all his strength.

Toto cælo. [L., by the whole heaven.] Wide asunder as the poles.
Tōtus mundus ăgit histrionem. [L., all the world acts the player.] "All the world's a stage." "The Globe Theatre," at which Shakespeare's plays were first acted, was so called from its sign, a figure of Atlas supporting a globe, under which was written "Totus," etc. -Mrs. Boger, Southwark and its Story, p. I26.

Toucan. [Sp. tucas, tulcan.] (Ornith.) A fam. of birds, Rhamphastidæ [Gr. \&áuфos, beak]; plumage coloured in patches; bills huge and often bright-coloured. Forests of Trop. America.

Ord. Pìcārǐæ.

Touch. (Bell-ringing.)

Touching. (Naut.) Said of sails beginning to shiver.

Touch-needle. A small bar of gold or silver, alloyed in some known proportions with copper, for trying the purity of gold or silver articles by comparison of the streaks made by them on the piece of hard black stone called touchstone.

Touchstone. (Basanite.)

Toupet. [Fr.] A tuft of hair worn on the top of the forehead; a small wig for concealing partial baldness.

Touraco, Crested. (Opisthocomi.)

Tourbillon. [Fr., a whirlwind.] A firework which turns round in the air so as to look like a scroll of fire.

Tour de force. [Fr.] A feat of streng'h, a clever thing.

Tourmaline. [Fr., (?) a Cingalese word (Littré).] Silicate of alumina and iron, with boracic acid ; prismatic, varying in colour from black to green and red; clear or opaque, widespread in granitic rocks, and of many varieties, of which the red, Rubellite, is a valuable gem.

Tourn. An O.E. word, denoting the circuit made twice yearly by the sheriff, for the purpose of holding in each hundred the Court-leet of the county.

Tournaments. (Jousts.)

Tourniquet. [Fr., a turnstile, L.L. to nǐco, I turn in a latize.] (Surg.) A bandage tightened by a screw pressing upon some point in which it is desired to stop hemorrhage.

Tous-les-mois. [Fr., all the months, i.e. available all the year round.] A kind of arrowroot, from the tubers of some S.-American spec. of canna.

Toussaint, Ia. [Fr.] All Saints' Day.

Tout ensemble. [Fr.] The general appearance.

Tout le monde. [Fr.] The whole world; everybody.

Tout vient à qui sait attendre. [Fr.] Everything comes to him who knows how to wait.

Towel. A word found in most of the Teutonic and Romance dialects, in widely varying forms, all containing a root denoting washing. (Dowlas.)

Tower bastion. (Mil.) Masonry fort placed in the inner line of fortification on the capitals of the polygon, to increase the defence by guns sheltered in its casemates.

Towers, Round. In Ireland, cylindrical edifices, from eighty to a hundred and twenty feet high, with a door eight or ten fect from the ground, and with narrow openings at the top. 
Dr. Petrie (Eccles. Arch. of Ireland, i. 12) believes that they are simply detached Campaniles of churches, built so as to be available for defence. There are sixty-two such towers in Ireland, and two in Scotland-at Abernethy and Brechin.

Town. Originally an inclosure; a farmhouse with its buildings. In Wyclif's Bible, the prodigal goes into the $T$. to feed swine. (Tun.)

Town-major. (Mil.) An officer performing in an open town the duties of a fort-major $\left(q \cdot v^{\circ}\right)$.

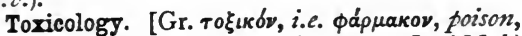
belonging to a bow, poison for arrows.] (Med.) Science of poisons, their action, results postmortem, methods of detection, etc.

Trabaccolo. (Naut.) An Adriatic merchantvessel.

Traběa. [L.] A toga ornamented with purple horizontal stripes, worn by the Consuls in public solemnities; and by equites (perhaps also by Angurs). Hence the badge of the equestrian order. The toga of the Roman emperors was wholly of purple.

Trabeated. [L. trabs, trabem, a beam.] (Arch.) Furnished with an entablature.

Tracery, Window. (Arch.) A term applied to the figures in the heads of windows, in which the lights and figures are combined by label and arch, with Mullions instead of portions of wall, the Spandrels also being pierced. (Plate tracery.)

Trachea. [Gr. $\tau \rho \bar{a} \chi \in \hat{\imath} a$, fem. of $\tau \rho \bar{a} \chi \dot{v} s$, rough.] (Anat.) The windpipe, the tube which opens through the larynx into the throat, by which the lungs communicate with the air.

Trachēlo-. [Gr. $\tau \rho$ á $\chi \eta \lambda$ os, the throat, neck.]

Trachytes [Gr. $\tau \rho \bar{a} \chi u ́ s$, roug $h$ ], or Greystones. (Geol.) Rough-feeling, greyish varieties of lava, consisting of entangled crystals of felspar.

Track-boat, Treck-boat. (Naut.) One dragged on a canal or narrow stream.

Tractarians. (Eccl. Hist.) Those who took part in the theological movement, which definitely took shape at Oxford in $\mathbf{1} \delta_{33}$; so called from the Tracts for the Times, which began to appear in that year, and ended in $\mathrm{IS}_{4} \mathrm{I}$, with Tract xc.

Traction, $\Delta$ ngle of; T.-engine. The angle made with the road by the direction of the force which draws a body along the road; a $T$. engine is a locomotive for drawing waggons along a highway.

Tractoration. Use of metallic tractors (q.v.).

Trade, Board of. A branch of the Privy Council, established under Charles II., as the Committee of the Privy C., for trade and plantations. Its powers of late years have been much enlarged.

Tradescantia. (Bot.) A gen. of lily-like plants belonging to the Commelynacex, of which the common spiderwort is one kind. A term interesting as preserving the name of the Tradescants - the father a travelled naturalist and antiquary, gardener to Charles I., whose collection formed the nucleus of the Ashmolean Museum; the son also a travelled naturalist.
Trades-nnion. An arrangement or combination entered into by the workmen of particular trades or manufactures, to regulate the price and the hours of labour, and sometimes the number of workmen engaged by an employer; recognized by law.

Trade-wind (from the use of such winds to traders). A gentle current of air in the equatorial regions, whose general direction is from N.E. to S.WV. north of the equator, and S.E. to N.W. south of the equator.

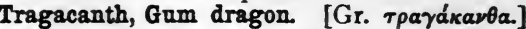
An African gum, used for stiffening crape, etc., obtained from several kinds of astrăgălus.

Tragedy. [Gr. $\tau \rho \alpha \gamma \varphi \delta_{i}^{\prime} a$.] A drama with a catastrophe, exhibited first at the Greek festivals of Dionysus (Bacchus), and said to be so named from the goat [ $\tau \rho a^{\gamma}$ os] then offered to that god. (Theoric fund.)

Trăhit sua quamque vŏluptas. [L.] Every man follows his own likings (Virgil).

Trail. (Mil.) 1. Strong beam of a field guncarriage, which supports it on the ground in rear whilst being fired, and by which it is limbered up for transport. 2. Horizontal position of a musket, carried down at arm's length.

Trailbaston, Justices of In O.E. Law, an itinerant court, set up under Edward I., for the summary punishment of disturbers of the peace, etc. So named, perhaps, from the staves [O.Fr. baston] which the marshals of the court carried or trailed after them.

Train-band. A kind of militia formerly existing in London for the protection of the city.

Train-oil. Whale-oil.

Trait-d'-union. [Fr.] A hyphen (q.v.).

Tram. [L. trāma, weft.] A silk thread formed of two or more threads twisted together, and used for the wefts of the best velvets and silks.

Trambling. Washing (tin ore) with a shovel in a frame.

Trammel. [Fr. tramail.] (Mech.) An instrument in which are two grooves at right angles to each other, used in connexion with a rod in which are two projecting points and a pencil point, all capable of adjustment; when the rod moves with a projecting point in each groore, the pencil point traces out an ellipse.

Tramontane. (Ultramontane.)

Trankeh, or Trankies. (Naut.) A large boat of the Persian Gulf.

Transcendental. [L. transcendentem, climbing beyond.] In the philosophy of Kant, that which can be determined a priori in regard to the fundamental principles of all human knowledge.

Transcendental function. (Nath.) One that cannot be expressed in finite terms by powers or the sum of powers of the variable; thus, $a^{s}$, $\log . x, \sin . x$, are transcendental functions of $x$, while $a x^{3}+b x^{7}$ is an algebraical function of $x$.

Transepts. [L. trans, across, septum, an inclosed space.] (Arch.) The arms of the cross on which the plan of cruciform churches is laid out.

Transform. [L. trans, beyond, forma, form.] (Math.) To express the same thing in a different form ; thus, given the equation to a curve referred to one set of co-ordinates, to express the 
equation to the same curve referred to another set of co-ordinates is to $\mathrm{T}$. the co-ordinates.

Transit [L. transǐtus, a passing across]; T. circle ; Inferior T.; T. instrument ; Lower T. ; Superior T. ; Upper T. 1. The passage of an inferior planet, Mercury or Venus, over the sun's disc. 2. The passage of a heavenly body across the meridian of a station; the station being in the northern (southern) hemisphere, if it take place between the pole and the south (north) point of the horizon, it is a Superior or Upper $T$., or simply a $T$. ; if between the pole and the north (south) point of the horizon, it is an Inferior or Lower $T$. A $T$. instrument is an astronomical telescope mounted so as, after adjustment, to move in the plane of the meridian; it is used for observing transits of the heavenly bodies; it is one of the principal instruments of a fixed observatory. A $T$. circle combines in one the transit instrument and the mural circle (q.v.).

Transition system. In Geol., a word once used for carboniferous limestone, etc., as marking the $T$. from the non-fossiliferous to the fossiliferous.

Transliterate. [L. trans, across, litěra, letter.] To give the words of one language in the alphabet of another ; as Gr. á $\nu a ́ \mu \nu \eta \sigma \iota s$, anamnēsis.

Transmew. [Fr. transmuer, from L. transmūtāre.] To transmute.

Transom. [L. transtrum, a cross-beam.] (Arch.) A horizontal bar across a window, or across the lights separated by the Mullions.

Transpadane. [L. transpadānus.] Beyond the river Po.

Transpose. [L. transpōno, Itransfer.] (Algeb.) To remove a quantity from one side of an equation to the other.

Transubstantiation. [L. trans, and substantia, substance.] The doctrine of the Latin Church that in the Eucharist the substance of the bread and wine is replaced by the substance of the body and blood of Christ. (Consubstantiation.)

Transversal. [L. trans, and versus, turned.] (Math.) A line which cuts a system of lines; as that which cuts the three sides (one or more produced) of a triangle.

Transverse axis; T. vibration. (Math.) Of ellipse or hyperbola, the line passing through their foci, and with respect to which they are symmetrical. (For $T$. vibration, vide Vibration.)

Transvolation. [L. trans, across, volāre, to fly.] A flying beyond or across.

\section{Trapezium. (Quadrilateral.)}

Trapezoid. (Quadrilateral.)

Trappists. (Eccl. Hist.) A religious order, founded I I 40 by a count of Perche, in the valley of $\mathrm{La}$ Trappe, and revived by the Abbé de Rancé in the reign of Louis XIV. The rule is singularly austere.

Trap-rocks. [Sw. trappa, a stair.] (Geol.) Rocks spread out in flat, stcp-like masses by successive volcanic eruptions; some hard and crystalline, basalts, greenstones, clinkstones, felstones, etc. ; some soft and earthy, claystones, trap-tuffs. Used generally for any igneous rock indeterminate at first sight.

Trash. [Ger. dreschen, to thrash.] Loppings of trees, bruised sugar-canes, etc.

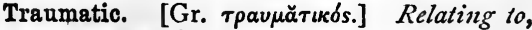
caused by, wounds.

Trave. [L. trăbem, $a$ beam.] A wooden frame to hold a horse whilst being shod. (Trevis.)

Traveller. (Naut.) An iron hoop, or ring, running on spars, stays, etc., to carry a sail, etc.

Travelling beaches. (Raised beaches.)

Traverse. [L. transversus, turned across, placed athwart.] 1. (Leg.) In pleading, signifies a denial of some material allegation of fact in the plaintiff's declaration or statement of claim. 2. To take the bearings and distances along roads and boundaries with an instrument for the purpose of plotting (q.v.) their outlines upon paper. 3. (Mil.) Mound of earth placed generally across the terreplein of a rampart, to prevent the effect of ricochet fire (q.v.).

Traverses. (Naut.) Tacks, or legs. (Tom Cox's traverse.)

Traverse sailing. (Naut.) Combining a ship's irregular or zigzag courses (due to contrary winds or other causes), so as to obtain the net result.

Traversing platform. (Mil.) For sea batteries, a movable rest for gun-carriages, which, by means of runners and a revolving frame, commands a large arc of a circle.

Travertine. (Geol.) A white calcareous rock, deposited from water holding lime in solution; e.g. that of the Anio at Tibur; Trāvertinus lapis, i.e. Tỉburtinus, stone of Tibur, Tivoli.

Travesty. [L. tra, trans, beyond, vestīre, to clothe.] A disguise; an absurd representation or misrepresentation of a thing.

Trawl. 1. A kind of drag-net for catching fish that live near the bottom. 2. A long line having short lines with baited hooks attached to it.

Tread. The upper surface of a banquette, on which one may stand.

Tread of a ship or keel. (Naut.) Its length on the keel.

Treason, Misprision of. The bare knowledge and concealment of treason, without any consent to it, such consent making the party a principal traitor.

Treasure. In Myth., the precious things belonging to the Dawn-maiden, lost or stolen, and recovered and taken back; as of Helen, Brynhild, etc. The legends of the Argonauts, of the Trojan War, of the Volsunga Saga, the Nibelungen-lied, relate to this subject.

Treasurer, Iord High. Formerly the third great officer of the Crown. The office is now executed by the five Lords Commissioners of the Treasury.

Treasure trove. [Fr. trésor trouvé, treasure found.] Money, coin, gold, silver, plate, or bullion, found hidden in the earth, the owner being unknown; which belongs to the king, or, in certain cases, by grant or prescription, to the lord of the manor; if found on the earth or in the sea, to the finder, if no owner appears. The duty of investigating cases of treasure trove belonged to the Coroner. The Treasury has now power to remit the Crown's rights.

Trebuchet. [Fr., L.L. trabutium.] In the 
Middle Ages, an engine for throwing stones, fiery materials, or other projectiles, by means of counterpoise, the sling for holding the projectile being fixed at the long end of a lever, while a heavy weight was fastened at the short end.

Trebucket. (Trebuchet.)

Treck-boat. (Track-boat.)

Treck-schuyt. (Naut.) Dutch canal-boat, carrying goods and passengers.

Tree. Acts v. 30 ; in its older sense of timber, as well as growing tree; so axle-tree, boot-tree, tree-nail, saddle-tree.

Tree-nails. Pegs of hard wood, to join timbers, etc. (Corr. into trenail, pron. trennel.)

Trench. [Fr. trancher, to cut.] (Mil.) Ditch, with the materials dug out of it formed into a covering parapet in front.

Trenchmore. A popular English dance, lively and somewhat boisterous; sixteenth and seventeenth centuries.

Trend. (Geog.) To tend, to lie in any particular direction; as of a coast-line or line of hills.

Trent, Council of. (Eccl. Hist.) A Council summoned by Paul III., in I 545, and continued in twenty-five sessions to 1563 . Its most important decrees deal with subjects involved in the controversies occasioned by the Reformation.

Trental. [L.L. trentāle, from L. triginta, thirty.] In the Latin Church, a Mass said within thirty days of a person's death.

Trepan. [Gr. трứ $\tau \rho v \pi a^{\prime} \omega, I$ bore.] Circular saw for perforating the skull, to relieve pressure on the brain.

Trepang. (Holothuroïdea.)

Trephine. An improved form of the trepan $(q . v$.

Trepidation of the fixed stars. (Astron.) An imaginary movement of the sphere of the fixed stars, in virtue of which it was supposed that the equinoctial points described circles of about $8^{\circ}$ in radius about fixed points ; invented by an Arabian astronomer (Arzachel) to account for the apparent changes in the position of the stars, which he thought were not sufficiently accounted for by a uniform precession of the equinoctial points.

Tressure. A bordering like an orle (q.v.), but only half its width. It may be double or even treble.

Trestle-trees. (Naut.) Two strong bars of wood on each side of a masthead, supporting the tops, upper mast, and cross-trees.

Tret. [Perhaps from L. trītus, part. of těro, $I$ rub away.] In Com., an allowance of four pounds out of every 104 pounds on certain goods which are liable to waste from dust, etc. (Tare.)

Trevat. A tool for cutting the pile threads of velvet.

Trevis (a misspelling for traverse), or Break. (Farr.) For performing any operation; a framework of four strong posts, braced together with transverse bars; within which the horse, secured by broad bands, is placed. (Trave.)

Trews. Trousers.

Tria căpita. In Rom. Law, the three chief things of civil or political life-libertas, civitas, fămilia ; liberty, citizenship, family rights.

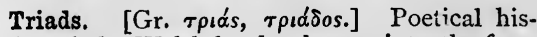
tories of the Welsh bards, thrown into the form of triplets. They are probably not older than the reign of Edward I. (Quaternion.)

Trǐa juncta in uno. [L.] Three joined in one; as in a political coalition. The motto of the Isle of Man.

Trial by jury. (Jury, Trial by.)

Triangle. [L. triangŭlum and -lus.] (Math.) A plane figure bounded by three straight lines. Triangles are classified as Scalene [Gr. $\sigma \kappa a ̆ \lambda \eta \nu o ́ s$, limping, uneven], having no two sides equal; Isosceles [i $\sigma 0 \sigma \kappa \in \lambda \eta \dot{r}$ ] Equilateral, having three sides equal: and as Acute-angled, having three acute angles; Rightangled, having one right angle; Obtuse-angled, having one obtuse angle. (Spherical excess.)

Triangulation. (Math.) The determination of each line and angle of the series or network of triangles whose angular points are the principal stations of the survey of an extensive tract of country; as the T. of the Ordnance Survey.

Triarii. (Hastati.)

Triassic system. [Gr. Tolós, a set of three; cf. Dyas.] (Geol.) The oldest of the Mesozoic deposits ; a Ger. term, the three main groups being, as developed in Europe, descendingly : 1. Keuper, saliferous marls and grits. 2. Muschelkalk ( $q . v$.$) .$ 3. Bunter sandstein, variegated sandstone.

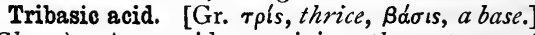
(Chem.) Any acid containing three atoms of hydrogen in its composition.

Tribolet. [Fr. triboulet.] 1. A goldsmith's tool, used in making rings. 2. A steel cylinder, round which metal is bent to form tubes.

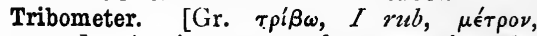
measure.] An instrument for measuring the amount of friction between metals.

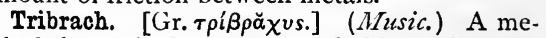

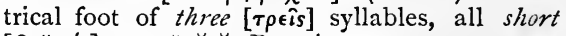

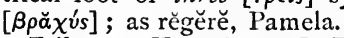

Tribune. [L. trǐbūnus.] Properly the magistrate of a tribe. 1. The plebeian tribunes at Rome were the protectors of the plebs, or commons, against the patricians, being in their own persons sacred and inviolable. 2. The military tribunes were officers sometimes elected with consular power instead of Consuls. 3. The legionary tribunes were the chief officers of the legion under the consuls. 4. In Mod. Fr. usage, the $T$. is the pulpit from which members of the Assemblies make their speeches.

Trĭbus Antǐcy̆ris căput insänäbile. [L., not to be cured by the hellebore of three Anticyras (Horace).] Utterly mad. (Naviget Anticyram.)

Triceps. [L., three-headed.] (Anat.) A muscle arising by three heads.

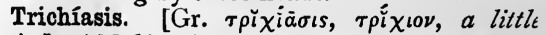
hair.] (Med.) A diseased introversion of the lashes which sweep over the eyeball.

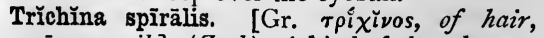
L. spira, a coil.] (Zool.) A kind of threadworm, Nēmătōda [ $\nu \eta \mu a \tau-\omega \delta \eta \eta s$, thread-like], sub-kingd. Annŭlǒida. The muscles of some animals, especially of the pig, are liable to contain large numbers encysted.

Trichiniasis. A disease, generally fatal, some- 
what like rheumatic fever in its symptoms; arising from the presence of Trichina spirailis (q.v.).

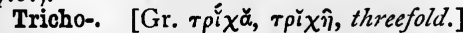

Trichoid. [Gr. $\tau \rho \iota \chi 0 \epsilon \iota \delta \eta_{s}^{\prime}$, from $\theta \rho i \xi$, $\tau \rho \check{\chi} \chi \delta s$, hair.] Resembling hair.

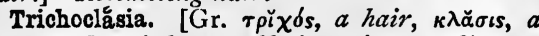
breaking.] Brittleness of hair, owing to a disease.

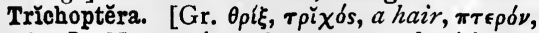
$a$ wing.] Name given by some authorities to the Phry̆găněĭdæ, caddisflies, as a separate ord.

Trichotomy. [Gr. $\tau \rho i \chi \alpha$, in three parts, $\tau \in \dot{\mu} \mu \nu \omega$, I cut.] A triple division. (Dichotomy.)

Trick-track. A game resembling backgammon.

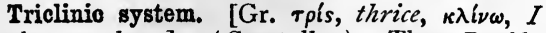
make to slant.] (Crystallog.) The Doubly oblique prismatic system (q.v.).

Triclinium. [L.] 1. In Rom. Ant, a couch (usually for three persons) for reclining at a meal. 2. The room in which such couches were laid.

Tridentine. Belonging to Tridentum, or Trent. The Tridentine decrees are the decrees of the Council of Trent (1545-1563), defining the doctrines of the Latin Church with reference to the positions of the Reformers.

Tridings, Trithings. (Ridings.)

Triennial Act. A Statute of William and Mary, ordaining that no Parliament should last longer than three years. By the Septennial Act of George I., the period was extended to seven years.

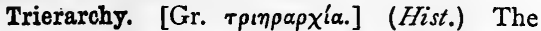
duty imposed on the wealthier Athenian citizens

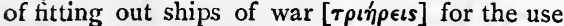
of the state. (Iiturgy.)

Triers. Thirty-five commissioners, appointed by Cromwell's Government, to judge of the fitness of any one presented to any benefice or public lecture, by inquiring into his spiritual state, his conversion, etc.

Trifacial. [L. tres, three, făcres, face.] (Anat.) The fifth pair of nerves, each of which is distributed to the face in three branches-the ophthalmic, the superior maxillary, and the inferior maxillary.

Trifid. [L. trifidus, three-cloven, findo, I cleave.] (Bot.) Split half-way into three parts.

Triforium. [L.] (Arch.) An arched story, between the pier arches and the Clerestory of a building.

Trigesimo secundo. In Printing, the L. term, expressed by the form 32mo, the paper being folded so as to make thirty-two pages in the sheet.

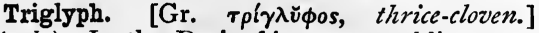
(Arch.) In the Doric frieze, a moulding consisting of two whole and two half channels, separated by flat spaces called femora.

Trigonometrical function; T. lines. (Math.) If an angle is supposed to be at the base of a right-angled triangle, its trigonometrical functions are the ratios of the sides; viz. the sine, the ratio of perpendicular to hypotenuse ; the tangent, the ratio of perpendicular to base; the secant, the ratio of hypotenuse to base; the cosine, cotangent, cosecant, are the same function of the complement of the angle. The definitions apply strictly to an acute angle only, but they admit of extension to angles of all magnitudes. There is another and an older way of defining these functions, according to which they are treated as lines, and called the $T$. lines.

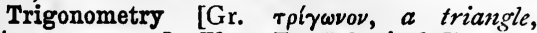

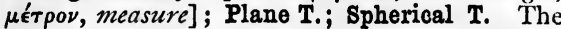
science of solving triangles, i.e. of calculating from given parts (sides or angles) of any triangles the remaining parts; Plane or Spherical $T$., according as the triangle is plane or spherical. Plane $T$. comprises the algebraical properties of angles, and their trigonometrical functions.

Trigraph. The same as Triphthong.

Trilingual. [L. tri-, and lingua, a tongue.] In three languages; e.g. the inscription on the Rosetta Stone.

Triliteral. [L. tri-, three, litera, a letter.] Combining three letters, as the roots of the Semitic languages. (Biliteral.)

Trülǐthon. [Gr. r $\rho \in \hat{i}$, three, $\lambda$ ítos, a stone.] (Archaol.) A group of stones, two uprights and a transom; e.g. Stonehenge.

Trilobite. [Gr. $\tau$ pinoßos, three-lobed, the body being divided lengthwise by two furrows.] (Geol.) Extinct fossil crustacean, with numerous genera ; from the Cambrian, through Silurian and Devonian, to the Carboniferous; related to the isopods (woodlouse, etc.) ; formerly thought to be Entomostracan.

Trŭlŏgy. [Gr. $\tau \rho \iota \lambda o \gamma i \alpha_{0}$.] In the Greek drama, three plays, each distinct, but forming a series, as treating of one subject. (Satyric drama.)

Trimèter. In class. poetry, a verse of three measures [Gr. $\tau \rho i \mu \in \tau \rho o s]$; in some cases, of three single feet ; in others, as in the iambic trimeter, of three double feet.

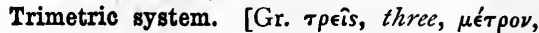
measure.] (Crystallog.) The Prismatic system $(q . v$.$) .$

Trimmer. (Arch.) A word now denoting a piece of timber, framed at right angles to the joists opposite to chimneys or the well-holes of stairs, for receiving the ends of joists intercepted by the opening.

Trimurtee, Trimurtti. (Mahâdeva.)

Trinitarians. (Eccl. Hist.) A religious order, founded 1198 , under the pontificate of Innocent III., for the purpose of ransoming captives taken by the Moors and other infidels.

Trinity House, Corporation of, Tower Hill. Chief of three British boards, the other two having jurisdiction in Scotland and Ireland; providing, out of dues levied on passing ships, all lights, beacons, buoys, for England, Wales, Channel Islands, Gibraltar, Heligoland; formed under Henry VII., incorporated by Henry VIII. ; composed of retired commanders of R.N. and of the merchant service; the working members, Elder Brethren, elected from the honorary, Younger Brethren.

\section{Trinoda Necessitas. (Bocland.)}

Trinomial. (Binomial theorem.) An algebraical sum of three [Gr. Tpeis] terms; as, $a+x y-z$.

Triphthong. In Gr., a composite sound of 
three vowels, as a diphthong is of two; as the Ger. aew. There is no such sound in English.

Tripitaka, i.e. the Three Baskets. The sacred canon of the Buddhists. It contains : (I) all that refers to morality (Vinaya); (2) the sûtras, or discourses of Buddha; (3) works treating of dogmatic philosophy or metaphysics. (2) and (3) are sometimes comprehended under the name of Dharma, or law.-Max Müller, Chips, etc., vol. i. 196.

Triple Alliance. (Hist.) 1. An alliance (1668) between England, Holland, and Sweden, for the purpose of foiling the designs of Louis XIV. on the Spanish Netherlands. 2. An alliance between England, France, and Holland, against the policy of Cardinal Alberoni in Spain (I 717). The Pretender was to quit France, Dunkirk to be demolished; Protestant succession guaranteed in England, and that of the Duke of Orleans in France. After the adhesion of the emperor, this league became the Quadruple Alliance.

Triplet. 1. In Poetry, three verses riming together; as in Tennyson's Two Voices. 2. (Music.) In common time, three notes grouped together, a 3 being placed over them; sung or played as one of the single parts in the whole measure.

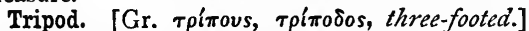
A three-legged stand for an astronomical or surveying instrument.

Tripoli. A kind of rotten-stone, first brought from Tripoli.

Triptŏlĕmus. [Gr. $\tau \rho \iota \pi \tau \delta \lambda \epsilon \mu o s$.$] In \mathrm{Gr}$. Myth., a son of Keleos, King of Eleusis, who received from Dēmētēr corn wherewith to sow the whole earth. Hence one eminently skilled in agriculture. (Eleusinian Mysteries.)

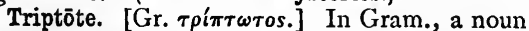
with three cases only ; as L. vis, in sing.

Triptych. [Gr. $\tau \rho^{\prime}(\pi \tau \tilde{v} \chi 0$ s.] A picture with two hanging doors by which it can be closed in front.

Triquetrous. [L. triquetrus.] (Bot.) Threeedged, trigonal.

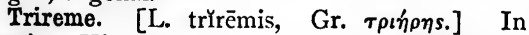
Ancient Hist., a war-vessel with three banks of oars. (Quadrireme.)

Trisăgion. [Gr., thrice holy.] The repetition

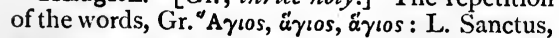
sanctus, sanctus; Eng. Holy, holy, holy; in the doxology following the Preface in the Eucharistic Office. In Eastern Liturgies, the hymn "Holy God, Holy Mighty One, Holy Immortal One."

Trisection [L. tres, three, sectiōnen, a cutting]; T. of the angle. (Math.) Division into three equal parts. In the problem of the Trisection of the angle, i.e. of any given angle, it is understood that the trisection is to be perforned by the rules of elementary geometry; under which restriction the problem does not admit of solution.

Trismus. [Gr. $\tau \rho \iota \sigma \mu \delta s, a$ grinding of the teeth.] (Med.) Tĕtanus affecting the muscles of the jaw.

Trismus infantum or nascentium. Lockjaw of newly born children, mainly from impure atmosphere; frequent and fatal in W. Indies and in other parts of the tropics.

Trithings, Tridings. (Ridings.)

Tritogeneia. (Triton.)

Tríton. [Gr.] (Myth.) An inhabitant of the sea. The word reappears in Tritogeneia as an epithet of Minerva.

Trium literārum homo. [L.] $A$ man (with a name of) three letters; i.e. fur, a thief, a rascal.

Triumph. [L. triumphus, probably same as

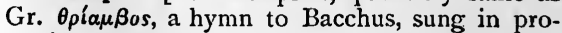
cession.] The solemn entry of a victorious general into the city, in a cliariot drawn by four horses, which took him along the Viâ Sacra, or Sacred Way, to the Capitol, where he offered sacrifice in the temple of Jupiter. (Ovation.)

Triumvirate. In Rom. Hist., a coalition of three of the most powerful citizens, (1) B.C. 60 , between J. Cæsar, Pompeius, and Crassus ; (2) between Octavius, Lepidus, and Antonius, B.c. 43. (Proscription.)

Triumvirate Ministry, 1763. That of Grenville, as First Lord of the Treasury, with Egremont and Halifax as Secretaries of State.

Trivium. [L. trivius, of three ways.] (Schol.) The mediæval name for the three liberal artsgrammar, rhetoric, and logic. (Quadrivium.)

Trocar, Trochar. [(?) Fr. trois quarts.] (Surg.) A three-sided, pointed instrument, for tapping in dropsy; having a perforator and a canula (q.v.).

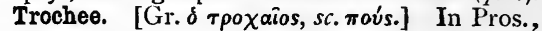
a foot consisting of a long followed by a short syllable.

Trŏchĭlĭdæ. (Trochilus.) (Ornith.) Hummingbirds ; fam. of birds, more than a hundred gen., with filamentous tongues, mostly very small, and bright-plumaged. American continent, and a few islands. Urd. Pīcārǐæ.

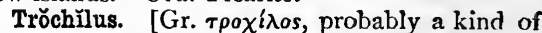
wren.] (Ornith.) Humming-bird. (Trochilidx.) Trochlear. (Anat.) 1. Pulley-shaped. 2.

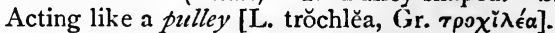

Trochoid. (Cycloid.) (Math.) If the describing point is within (not on) the circumference of the

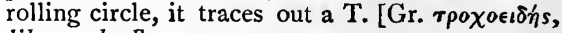
like a wheel].

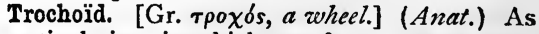
$\mathrm{T}$. articulation, in which one bone rotates upon another.

Trolley. [Akin to roll, roller.] A truck for carrying railway materials.

Trollop. [Fr. troll, to roll, stroll.] A vagrant, a woman loosely dressed, a slattern.

Trolls. In Teut. Myth., a race of beings engaged in a perpetual struggle with men, in which, in spite of their vast bodily powers, they are always defeated.

Trombone. [Fr., It. tromba, trumpet.] (Music.) 1. A large powerful instrument of the trumpet kind, with a sliding tube ; compass rather more than two octaves. 2. A powerful, full-toned reed stop in an organ; of eight feet or sixteen feet on the manuals, sixteen feet or thirty-two feet on the pedals.

Troop. [L.L. troppus.] (Mil.) Company of cavalry. Trooper, a cavalry soldier.

Troop the colours. A military display on 
important occasions at the time of guard mounting, when the colours are paraded with band playing along the front of the troops.

Trope. [Gr. $\tau \rho b \pi o s$, a turning.] (Rhet.) A general term for any forms of expression not identical with but derived from the primary signification ; as Allegory, Metaphor, etc.

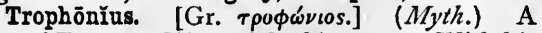
son of Erginos, King of Orchŏměnos. With his brother Agămèdes, he built the temple of Apollo at Delphi. He had a temple at Lebadēa, with a cave into which persons descended who wished to consult him. The impressions received were so terrible that the visitor was supposed to remain oppressed with melancholy for the rest of his life. Hence it was said of serious men, that they looked as if they had come out of the cave of Trophonius.

Tropical. (Kyriological.)

Tropical year. (Year.)

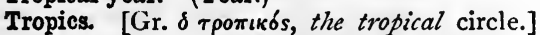
1. (Astron.) The two parallels of declination passing through the solstitial points and called respectively the Tropic of Cancer (north) and of Capricorn (south). 2. (Geog.) The two parallels of latitude situated with respect to the equator in the same way that the celestial tropics are to the equinoctial. 3. The regions lying within the tropics, the Torrid zone.

Troppo. [It., L.L. troppus.] (Music.) Too much. Non troppo, not too much.

Tros, Ty̆rïusve, mihi nullo discrīmine agētur. [L., Irojan, or Tyrian, I will treat them all with perfect impartiality.] Difference of nationality, creed, etc., should not be allowed to create a prejudice (Virgil ?).

Troth. As in the Marriage Service; the same word as truth.

Troubadours. [It. trovatōre, from trovar, Fr.

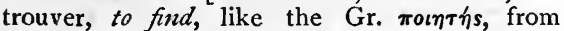
moteiv, to make, and the O.E. maker.] Poets who from the eleventh to the thirteenth centuries wrote in the Langue d'oc, out of love of their art, the gay science. Their compositions are classified under the heads of terzones, or contests between minstrels; sirventes, pieces on martial or serious subjects; chansons, or short lyrical songs; together with serenades, pastourelles, etc. Court attendants [minnisterriales, menestrels, minstrels] and others who sang for hire were called jongleurs, i.e. jŏcŭlātores, jesters; whence the word juggler.

Trou-de-loup. [Fr., wolf's hole.] (Mil.) Obstacle formed to break the regular formation of troops; a hole in the ground, shaped like an inverted cone six feet deep and the same in width, with a stake planted in the bottom.

Trough. (Naut.) A small boat, broad at both ends.

Trouvaille. [Fr.] $A$ godsend. In Gr., hermaion. (Hermes.)

Trouvères, or Trouveurs. This form of the word Troubadours distinguishes the vernacular poets of Northern France who spoke the Langue d'oyl, from those of Provence who used the Langue d'oc. They flourished chiefly in the age of Charlemagne. (Paladins; Troubadours.)
Trow. (Naut.) 1. A clinker-built, flat-floored Severn barge. 2. A kind of double boat closed at the ends, used for spearing salmon on the Tyne.

Troy weight. [(?) Troy novant, the monkish name of London; (?) corr. of le roy, pondus regis, the standard pound; (?) not probably Troyes, in France.] The weight by which gold, silver, and jewels are weighed; the grain troy is 1-700oth part of a pound avoirdupois ; 24 grains make one pennyweight, 480 an ounce, and 5760 a pound troy.

Truce, or Peace, of God. A suspension of arms, imposed by the Church during the Middle Ages, on persons engaged in private wars. The truce accepted by the barons of Aquitaine and France in IO4I was to last for four days of each week. The Quarantine of Philip Augustus restrained the family of an injured person from beginning hostilities until after forty days from the commission of the act complained of.Milman, Hist. of Latin Christianity, bk. viii. ch. 6 .

Trucidation. [L. trucīdātiōnem.] The act of killing [trucīdāre, to kill].

Truck. (Naut.) T. of a mast or flagstaff, a circular piece of wood at the upper end, usually having two sheaves, through which signal-halliards are rove. T. for pair leaders, bull's-eje $(q . v$.$) , but scored to fit the shrouds to which$ they are sized. T. of a jaw-rope. (Gaff.)

Truckle. (Coracle.)

Truck system. [Fr. troc, barter.] The payment of wages, wholly or partly, in articles of consumption.

True water. (Naut.) Its true depth.

Truffles. [Fr. truffe, L. tūber.] (Bot.) 1. All fungi, belonging to the nat. ords. Hypogæi and Tuberacei. 2. The $T$. of commerce all belong to the gen. Tuber; the English principally to $T$. æstivum, the French to $T$. melănospermum; buried in the soil of woods, princi. pally, but by no means solely, beechwoods.

Trumpeter. 1. (Psophidæ.) 2. A toy variety of the domestic pigeon.

Truncated. [L. truncātus, lopped, part. of trunco.] Having its top cut off ; in most cases by a plane parallel to the base; as a truncated cone.

Truncation. [L. truncatiōnem.] A lopping off, or maiming. In Min., the replacement of an edge by a plane equally inclined to the adjoining faces.

Trundle. A lantern-zoheel (q.v.).

Trundle-head. (Naut.) A second head tc the capstan on the lower deck.

Trunking. Extracting metallic ores from the mud in which they are contained (in a trunk, or cisterns).

Trunnion. [Fr. trognon, core of a fruit, leafless cabbage-stalk (Wedgwood).] 1. (Mech.) An axle, or gudgeon, one on each side of the cylinder of an oscillating steam-engine, by which it is supported and on which it turns. 2. (Mil.) Projecting arm on each side of a gun, by which it is secured and supported in its carriage.

Truss. [Fr. trousse.] 1. (Arch.) The collection 
of timbers forming one of the chief supports in a roof, so framed as to strengthen each other and to prevent any distortion from the weight lying upon them. 2. A triangular or polygonal frame of bars rendered rigid by stays and braces, so that its form is made incapable of change by the turning of the bars about their joints. 3. T. of straw is thirty-six pounds. 4. Of new hay, sixty pounds. 5. Of old hay, fifty-six pounds.

Try a ship, To. (Naut.) To keep her head to the sea in a gale.

Trysail. (Storm-trysail; Sails.)

Tryst. [Akin to trust.] An appointment to meet, or the place of meeting. Hence to keep tryst or to break it. In Scotland, = a fair, as Falkirk tryst, etc.

Trythings. (Ridings.)

Tschernibog. [Slav.] The black god, or god of darkness, as opposed to Bjelbog, the pale or white god. (Ahriman; Balder.)

Tschudic or Chudic languages. The dialects of the Finnic class, spoken by the Lapps and Finns; the other three branches being the Ugric, Bulgaric, and Permic.

Tsetsé (Glossinia morsítans). (Entom.) A dipterous insect of S. Africa, rather larger than a housefly; its bite almost certain death to ox, sheep, horse, dog ; harmless to man, goat, ass, antelope, pig, wild animals, and the unweaned calf.

T.-square. A flat thin rule or blade fixed at right angles to a shorter and thicker piece or stock; the stock being pressed against the side of a drawing-board the instrument can be shifted backward and forward so that with the blade the draughtsman can rule any number of lines at right angles to either edge of the board; and if the board is a true rectangle, he can draw two systems of parallel lines at right angles to each other with the T.-square.

Tua res agǐtur, păries cum proximus ardet. [L.] You are concerned when the party wall next to you is on fire. (Proximus.)

Tubbing. A lining of timber or metal round the shafts of a mine (from the shape).

Tubecasts. (Med.) Microscopic moulds, found in the urine of renal disease.

Tüber. [L., a swelling:] (Bot.) A thickened underground stem" with buds, from which new plants are produced; and, generally, abundant amylaceous deposit; e.g. potato, Jerusalem artichoke, arrow root.

Tubercle. [L. tübercŭlum, (I) a small swelling; (2) tubercle.] (Med.) A morbid granular deposit, on lungs, brain, abdomen, etc., destroying the tissue affected.

Tǔbǐcŏlæ. [L. tŭbus, a tube, cǒlo, I inhabit.] (Zool.) Annelids protected by a tube, either secreted or constructed from foreign substances; as serpŭla.

Tuibingen school. A name denoting the theological writers of the University of Tübingen, noted chiefly for their opposition to all mystical interpretations of the Old and New Testaments. -Mackay, The Tübingen School and its Antecedents.

Tubalar boiler. (Mech.) A boiler such as that of an ordinary locomotive engine; the fire is at one end, the smoke-box and chimney at the other; the connexion is made by a large number of tubes surrounded by the water, which is most effectually heated by the heated air, gases, etc., passing through them to the chimney.

Tubular bridge. A bridge consisting essentially of piers of masonry supporting a huge lintel made on the plan of a flanged beam or girder, not in one piece, but built up of bars and plates of iron riveted together. Instead, however, of the flanges being connected by a single web in the middle, the connexion is made by two webs, one on each side; the whole, therefore, takes the form of a tube, and within the tube is the roadway. There are numerous unessential modifications of this kind of bridge.

Tubulure. [L. tubŭlus, a small tube.] (Chem.)

A short tubular opening at the top of a retort.

Tub-wheel. A kind of turbine (q.v.).

Tuck. (Naut.) The after part of a ship, immediately below the stern or counter.

Tuck. [Cf. Bret. tach, a nail, Icel. taka, to take, to puncture (Skeat's Etym. Dict., s.v. "Attach").] A long rapier.

Tucket. Slight flourish on a trumpet [It. toccata].

Tuck-net. A small net used to take fish from a larger one.

Tucum. (Native name.) A fine strong fibre obtained from a Brazilian palm.

Tudor rose, or Flower. (Arch.) A flat flower, on an upright stalk, often seen in Perpendicular or Continuous English work.

Tuesday. The third day of the week, named after the god Tuisco, whose name is the same as the Greek Zeus. (Tyr.)

Tufa, or Tuft. [It. tufo, porous ground.] 1. Volcanic T.; a rock formed of volcanic ashes and scoriæ, with felspathic cement. 2. Calctuft $(q . v$.$) .$

Tuft-hunter. One who runs after great people, a hanger-on, a toady. Undergraduate noblemen at Oxford, till lately, wore a gold tuft, or tassel, on a square cap of black velvet.

Tugendbund. [Ger., union of virtue.] A Prussian association formed after the Treaty of Tilsit, in 1807 , for the general improvement of the country and to enable it the better to withstand the schemes of the French Emperor Napoleon.

Tuileries. [Fr., tileworks, from the site on which it was built.] A palace of the kings of France in Paris, begun by Catherine de' Medici, 1564, completed by Louis XIII. It has been sacked in $1792,1830,1848$, and a large part of it was destroyed by the Commune in 1871 .

Tula metal. (Made at Tula, in Russia.) An alloy of silver, copper, and lead.

Tulipomania. A passion for tulips ; in IHolland, 1637, one bulb, "Viceroy," fetched 4203 florins ; for "Semper Augustus" cunsiderably more was offered. At a sale in Croydon EIOO was given for "Fanny Kemble." (See Flower Garden Quarterly Review, 1842.)

Tulle. (First made at 7 ulle, in France.) A 
Tulwar. Indian sword, with a curved blade and a round metal plate as guard to the pommel.

Tumbler (from falling into its place). That part of a lock which, until lifted by the key, holds the shot bolt in its place.

Tumbrel, Tumbril. [A.S. tumbian, to tumble; cf. Fr. tombereau, from tomber, to fall.] 1 . (Agr.) A heavy, broad-wheeled, one-horsed cart, the body of which is so made as to turn vertically on the axle when required, and to shoot the load out behind. 2. (Mil.) Ammunition cart which accompanies guns into action, with the requirements for immediate expenditure.

Tŭmŭlus. (Barrow.)

Tun. [A.S. tún.] Formerly an inclosure with gates, within which a country house, with hall, chapel, bowers, i.e. ladies' sleeping-chambers, outbuildings, etc., was guarded; whence Town (q.v.).

Tun. [A.S. tunne, a barrel.] A liquid measure of four hogsheads, or 252 gallons. A T. of red Spanish wine is 210 gallons.

\section{Turibridge ware. (Tonbridge ware.)}

Tundra. The vast Siberian plains, beyond the tree-growing zone.-Hartwig, Polar World.

Tu ne cêde mälis, sed contra andentior ito. [L.] Yield not to evils, but go boldly to meet them (Virgil).

Tungsten. [Sw. tung, heavy, sten, stone.] A hard white brittle metal. Tungstate of soda renders fabrics uninflammable. Muslin soaked in a solution of twenty parts of this salt with three of phosphate of soda in a hundred parts of water may be ironed and prepared for wear, and is then only charred by fire.

Tungula. (Naut.) A small boat of Borneo and the Moluccas.

Tŭnǐcāta. [L.] (Zool.) Ascĭdǐoïda, class of molluscoids, provided with tunics, i.e. soft, tough investments, except one spec. A cylinder in, and diverging rays at the end of, their larval tails have been compared to the notochord in vertebrates and the tail in fishes; hence some, classing them with or next to V., have drawn conclusions favourable to the evolution theory.

Tunicated. [L. tŭnǐcatus, tŭnĭca, an unilcr garment.] (Anat. and Bot.) Covered with a membrane.

Tunǐcle. [L. tunǐcŭla, a small tunic.] In the Latin Church, a close-fitting linen vestment, formerly worn by deacons, now by bishops under the dalmatic, and by subdeacons.

Tunnel. [O.Fr. tonnel, a tun.] A level passage driven at right angles to the veins of ore which are to be reached.

Tunnel-kiln. A lime-kiln in which coal is burned, as distinguished from a flame-kiln, in which wood or peat is used.

Tunnel-net. [O.Fr. tonnel, $a$ tun.] A net with a wice mouth at one end and narrow at the other.

Tu quoque. [L., thou too.] The retort personal.

Turanian languages. (Agglutinative languages.)

Turbary. The right of cutting turf on another man's ground.
Turbeth, Turbith, Turpeth mineral (from resembling the powdered root of the turpeth plant). (Chem.) A yellow sulphate of mercury.

Turbination. [L. turbinātiōnem.] The art of spinning or whirling; as of a top.

Turbine. A horizontal water-wheel with a vertical axis, driven by a vortex [L. turbinem], i.e. receiving and discharging water in all directions round the axis.

Turbinñ̇æ, Turbines. [L. turbĭnem, whirling top.] (Ostr.) Top-shells, including Trŏchi [Gr.

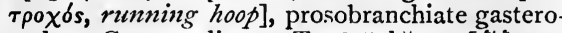

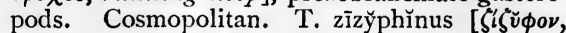
jujube-tree], in familiar use as ornaments.

Turk. In Collect for Good Friday, $=$ whole Mohammedan world; so powerful was the impression still remaining with regard to the $T$.

Turmeric. [Fr. terre mérite, a valuable powder.] A yellow root used as a dye-stuff, and in curry powder. The common T. is cultivated all over India; Curcuma longa, ord. Zingiberaceæ.

Turning. [L. tornāre.] Rounding in a lathe.

Turnsole. [Fr. tournesol, from the plant's turning to the sun.] (Litmus.)

Turn-table. (Mech.) A circular platform on which rails are laid, pivotted in a pit below the rails, supported on wheels or rollers near its circumference, and capable of being turned by appropriate machinery, for moving a railway carriage from one line of rails to another.

Turpentine. [L. těrěbinthĭnus, belonging to the terebinth tree.] A resinous substance, chiefly obtained from coniferous trees. Bor. deaux turpentine comes from the cluster pine Chian turpentine, from the turpentine tree; Strasburg turpentine, from the silver fir ; L'enice turpentine, from the larch.

Turpentine tree. (Teil.)

Turret-ship. (Naut.) One fitted with one or more armoured, revolving turrets, in which she carries guns.

Turtle, Green. (Chelonidæ.)

Tussap, Tussore silk. A coarse dark Indian silk, obtained from a wild silkworm.

Tussis. [L., a cough.] (Med.) Tiussicular, pertaining to a slight cough [L. tussicula].

Tutenag. [Ar. toûtiyâ, tutty, Pers. nâk, like.] 1. Chinese copper, an alloy of copper, zinc, and nickel. 2. Zinc.

Tutor. In Gal. iv. 2, a guardian, without any idea of teaching. Revised Version has "guardians and stewards" instead of "tutors and governors."

Tutoyer. [Fr.] To thee-thou any one; as in speaking to little children, to intimate friends, or to inferiors.

Tutty. [Ar. toûtiyâ.] (Chem.) Impure oxide of zinc.

Tutwork. Miners' work done by the piece.

Tuyère, Tweer.' [Fr., akin to tuyau, a pipe tube, L. tŭbellus, dim. of tŭbus.] A conical tube through which the blast of air is forced from the blowers into the blast furnace.

Twain-cloud. Cumulo-stratus. (Cumulus.)

Twankay. The poorest kind of green tea.

Tway-blade, i.e. two-leaf. [Cf. Ger. blatt, 
leaf, Gr. $\pi \lambda \alpha \tau \dot{v}$ s, flat.] (Bot.) Native plant, in woods and pastures (Listera ōvāta), ord. Orchidaceæ, with two large opposite ovate leaves and a raceme of small green flowers.

Tweed. A light twilled woollen or cotton stuff for coats, etc.

'Tween or 'Twixt decks. (Naut.) The deck below the gun-deck.

Twelfth Day. The Feast of the Epiphany, being the twelfth day, exclusive, after Christmas Day.

Twelve Tables, Laws of the. (Decemvirs.)

Twice-laid rope. (Naut.) Rope made from strands of old rope.

\section{Twilight of the gods. (Woden.)}

Twilled. Covered with diagonal lines produced by causing the weft-thread to pass over one and under two or more warp-threads.

Twilly. A revolving cylinder covered with long iron spikes, for cleansing and loosening wool.

Twin crystals; T. axis ; T. plane. Two crystals joined together in such a way that one would come into the position of the other by revolving it through two right angles round an axis, the $T$. axis, perpendicular to a plane, the $T$. plane, which either is or may be a face of either crystal.

Twin screw. (Naut.) A vessel fitted with two screw-propellers worked by separate engines.

Twist. Closely twisted strong sewing silk.

Twitch. To keep horses quiet for minor operations : a strong stick, with a hole pierced at the end, through which a loop of strong cord is passed ; this, having been passed over the upper lip, is twisted, causing pain. (Barnaoles.)

Two-centred arch. (Arch.)

Two-handed fellows. (Naut.) Both seamen and soldiers, or artificers.

Tycoon, Shogoon. [Jap. shiogun.] The temporal (the Mikado being the spiritual) ruler of
Japan. He stood to the $M$. in the relation of the mayor of the palace to the Merovingian kings, wielding all power, and falling back for his authority upon a M., or emperor, secluded from public observation. The office has been abolished by a recent revolution (Dickson's Fapan). (Major-domo.) The proper title of the Tycoon is Thoorgum.

Tye. (Naut.) The upper part of the jeers. (Halliards.)

Tyg, Tig. A coarse earthenware drinkingvessel, with two or more handles.

Tymoom. (Naut.) A Chinese river-boat.

Tymp. A space in the lower part of a blast furnace for clearing out the hearth.

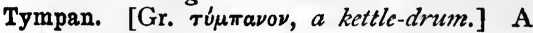
frame on which blank sheets are laid to be printed.

Tympănum. [L., a drum.] (Anat.) The middle ear.

Tyno, or Tine (q.v.). (Antlers.)

Type-metal. [Gr. Túmos, type.] An alloy of lead and antimony, for making printing type.

Type of Constans. (Ecthesis ; Henoticon.)

Typhön, Typhron. [Gr.] In Myth., a giant described as breathing fire, or as a destructive hurricane.

Typhoon. [Gr. $\tau \nu \phi \hat{\omega} \nu$.$] A tempest or hurri-$ cane of great violence, which sometimes rages in the seas of S. China.

Tyr. In Teut. Myth., the sun-god, whose name answers to that of the Vedic Dyu, from the root div, to shine. The name survives in A.S. Tiwesdaeg, Tuesday, and in the names of places, as Tewesley, Tewing.

Tyrian purple. (Common purple; Murex trunculus.)

Tything-man. (Hist.) The constable or peace officer in a tything, or tenth part of a hundred. (Frankpledge.)
ס. A letter long identified with $\mathrm{V}$, but now used as a vowel, $\mathrm{V}$ being used as a consonant. But although the character $\mathrm{V}$ was originally written with the same sign as the vowel $U$, it was by the ancients themselves considered essentially different, as were also the consonant $i(j)$ and the vowel $i$.

Ubi jūs, ĭbi rĕmědium. [L.] A maxim in Law : where there is a right there is a remedy; therefore equity intervenes where, from some technical defect, common law does not avail.

Ubiquitarians, Ubiquists. [L. ubīque, everywhere.] A name applied to those Lutherans who hold that the body of Christ is present in the Eucharist by the ubiquity or omnipresence of His humanity.

Ubi tu Caius, ego Caia. [L.] With the Romans, the community of goods between husband and wife was expressed by the offer of fire and water to the wife at her first coming into her husband's house, and by the words "Ubi tu," etc. ; i.e. Where thou art master, 1 am mistress; or rather, Where thou art father, I am mother (caius being connected with root ga, as in $\mathbf{G r}$. $\gamma \in \gamma_{\gamma} \alpha \alpha, \gamma \in \nu \nu \alpha ́ \omega$, etc.).

Udaller. [Dan. odel.] A cognate form of the Gothic and Frankish alod; a proprietor of lands in freehold.

Uekewallists. (Eccl. Hist.) Rigid Anabaptists, the followers of the Frieslander Ueke Wallis.

Uhlan. [Said to be from Turk. oglân, a youth, lad.] (Mil.) Lancer light cavalry soldier of the German army.

Ukase. [Kuss.] An ordinance of the Russian czar.

Ulëma. [Turk., learned man.] The college of the Turkish hierarchy, consisting of the Imams, 
Muftis, and Cadis, or admistrators of justice. (Alcaide.)

Ulitis. (Med.) Inflammation of the gum

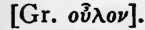

Ullage. [O.Fr. eullage, eullier, to fill up a cask to the bung (Skeat).] (Naut.) The residue left in a leaky or partly used cask or package. Ullaged, damaged, short in contents.

Jlloa, Circle of. A measurement of the meridian taken in Peru by Don Antonio Ulloa, a Spanish mathematician (1716-1795).

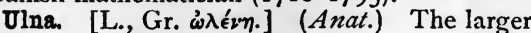
of the two bones of the forearm, the smaller being the radius. Adj., Ulnar.

Ulnagers. [L. ulna, an ell.] (Hist.) In the Middle Ages, officers appointed in each considerable port, to certify the length and quality of each piece of cloth of twenty-four yards or ellsthese terms being then synonymous-and thus to protect the purchaser against fraudulent dealers in foreign imported goods.

Ulster custom, or Tenant-right system. Gives undisturbed possession of a holding, as long as rent is paid; entitles to compensation for unexhausted improvements; and gives liberty to sell the "good will" of a farm for what it will fetch in the market.

Olster Rebellion ( $164 \mathrm{I}-\mathrm{r} 649$ ). That of Roger More, Sir Phelim O'Neil, and other Irish chieftains. An attempt to seize Dublin Castle failed; but a general rising in $U$. taking place, the country was wasted, towns were taken, many new settlers put to death, and many thousands of lives lost. In 1649 Cromwell arrived as Lord-Lieutenant and Commander-in-Chief in Ireland.

Ulster Settlement (I6II). James I.'s scheme for its colonization. Lots of 1000, 1500,2000 acres were arranged. A new order, that of baronets, was created. For every patent $f_{\mathrm{I}} \mathrm{ro0}$ was paid, and the duty added of supporting thirty foot-soldiers.

Ultima rătǐo. [L.] The last device or resource.

Ultimate analysis. Resolution of a substance into its elements.

Ultimate ends. In Moral Phil., are: 1, $U$. simpliciter, i.e. that which is aimed at for its own sake only, and never regarded as a means to another end ; and, $2, U$. secundum quid, i.e. the last aimed at in a series of actions.

Ultimate ratio. (Math.) The limit of the ratio of two variables. (Limit.)

Ultĭma Thūlē. (Thule.)

Ultímātum. [L.] A final proposal.

Ultramarine. [L. ultrà mărě, beyond the sea.] A blue pigment obtained by calcining and grinding lapis lazuli, originally brought from beyond the sea, from Asia.

Ultramontane. [L. ultrà montes, beyond the mountains.] (Eccl.) Those who maintain the most advanced theory of papal supremacy are so called, because the theologians of Italy, the country beyond the Alps, were considered more favourable to high papal doctrine than the cismontane doctors of France and Germany.

Ultrà vires. [L., beyond the power.] Any person, committee, court, etc., is said to have acted U. V. when exceeding, however unintentionally, his or its authority.

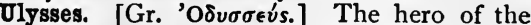
Odyssey. The name is supposed to represent

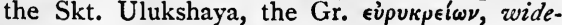
ruling.

Umbel. [L. umbella, a little shadow, dim. of umbra.] (Bot.) An inflorescence having flowerstalks springing from one centre, each bearing a single flower; $e . g$. ivy, carrot, parsnip.

Umbellǐfĕræ; Umbellātæ. (Bot.) A large nat. ord. of exogens, whose inflorescence is always an umbel ; some poisonous, as hemlock ; others esculent, as carrot, parsnip, celery ; some aromatic, as caraway, coriander, etc.

Omber. An olive-brown earth from Umbria, in Italy, used as a pigment. Burnt umber is a reddish brown, and is made by burning raw umber.

Umbilical. (Anat.) Pertaining to the navel [L. umbǐlīcus].

Umbra. [L., a shadozv.] 1. A Roman contemptuous epithet for the uninvited attendants or companions of invited guests. 2. (Penumbra.)

Una. [L., one.] In Spenser's Faëry Queene, a maiden in whom Truth (as being one) is personified, and who, attended by a lion, goes in search of St. George, and finally leads him by the house of Holiness, to Eden. (Red Cross Knight.)

Unaker. American kaolin (Cherokee nations).

Unam sanctam. [L.] Title of a bull of Pope Boniface VIII., I302, asserting that to believe every human being to be subject to the Pontiff of Rome is a thing necessary to salvation.

Unaneled. [A.S. ele, oil.] Not having received extreme unction. (Unhouseled.)

Unau. (Zool.) The two-toed sloths, Chōlapus. Trop. America. Fam. Brădypŏdŭdæ, ord. Edentāta.

Unā vōce. [L., with one voice.] Unanimously. Unbend, To. (Naut.) To loose, or untie.

Unca. (Inca.)

Uncial letters. Letters intermediate between capitals and small characters, in old MSS.; so called, perhaps, from their size, the L. uncialis denoting the twelfth part of a foot, an inch.

Onclaimed. (Derelict.)

Uncle Sam. The cant or vulgar name for the U.S. Government, sometimes called Brother Fonathan. Mr. Samuel Wilson, immediately after the last declaration of war with England, was inspector of certain army provisions. A workman, not knowing the meaning of the new signature U.S. upon certain casks, supposed it to stand for "Uncle Sam ;" and the joke passed current.-Bartlett's Americanisms.

Unconformable strata. (Geol.) (Conformable strata.)

Unconscions cerebration. Mental operation during sleep, or while the mind is engrossed by other and entirely different thoughts; known afterwards only, and by its results. (See Carpenter's Mental Physiology.)

Undergird. Acts xxvii. I7; to pass ropes round the ship, so as to strengthen her.

Underground railroad. The means of con- 
veyance by which fugitive slaves escaped to the free states and Canada.-Bartlett's Americanisms.

Underground railway. A term denoting railways carried through or about great cities, where the way must for the most part be tunnelled.

Underlayer. A vertical shaft sunk to cut an underlying lode at any required depth.

Underlying. Inclined to the perpendicular.

Undersetters (I Kings vii. 30), or Shoulders. Brackets or bars, or some kind of pedestal.

Undershot-wheel. (Water-wheel.)

Under way. (Naut.) Fairly started by the motive power.

Under weigh. (Naut.) The anchor started, and the ship ready to be got under way (q.v.).

Underwriter. One who, in return for a premium received, makes himself responsible for the payment of a certain sum in the event of the loss of a ship or of damage to it at sea. The practice of underwriting, nominally by individuals, who really formed a joint-stock company, owed its origin to the excessively high rates of insurance charged by the only two companies which, previous to 1824 , were allowed by charter to grant marine insurances. The underwriters, who then took off much or most of their business, became known as Lloyd's.

Undines. [L. unda, $a$ wave.] The Cabalistic name for the water-spirits, called by the Greeks Naiads, Nereids, and Nymphs. To this class belong the nix of the northern English counties, and the Scottish kelpie.

Undulation; Undulatory theory. (Wave.)

Unequal. Ezek. xviii. 25; as frequently in early writers, unjust, unfair. Equal, just, fair.

Unequal temperament. (Music.) (Temperament.)

Un fait accompli. [Fr., an accomplished fact.] Done, and not to be undone.

Unguibus et rostro. [L., with claivs and beak.] Tooth and nail.

Unguiculate. [L. unguĭcŭlus, dim. of unguis, a nail.] (Bot.) Furnished with a claw; as the petals of a pink.

Ungŭlāta. [L., provided with hoofs (ungŭlæe).] (Zool.) Animals with hoofs, the seventh ord. of mammals, containing those most useful to man; as among Păchy̆dermăta, the pig; among Sŏlĭdungŭla, or Sölǐpědes, the horse; among Rümunantia, the sheep. In some systems, as Cuvier's, these three sections-Păchy̆dermăta, Sŏlĭdungŭla, and Rūmǐnantǐa-form separate orders, and $P$. includes the elcphants, now usually classed as Prŏbosciděa.

Unguled. [L. ungŭla, a hoof.] (Her.) Having hoofs or claws of a different colour from the body.

Unhouseled. Without having received the howsel [A.S. húsel], the Holy Eucharist. (Unaneled.)

Uniat. A term applied in the Latin Church to Eastern Christians who acknowledge the papal supremacy.

Unicameral. Having only one [L. unus] legislative chamber [camĕra].

Unicorn. [L. uni-cornis, from ūnus, one, and cornu, horn.] 1. (Bibl.) Rěêm [Heb.], a large, wild, bovine animal. 2. (Her.) A fabulous animal, with the feet and legs of a deer, the tail of a lion, the body and head of a horse, from the forehead of which a single horn projects.

Unicorn, Sea. (Narwhal.)

Unifilar. [L. unus, one, filum, a thread.] Of a single thread.

Unifilar magnetometer. An instrument whose essential part is a magnet suspended by a singie thread [L. ünum filum], for determining the horizontal intensity of terrestrial magnetism.

Uniformitarians (Geol.) regard the existing natural agencies as quite competent to have effected all the successive changes which the earth's surface appears to have undergone. Catastrophists think they could not have been effected without convulsions and catastrophes

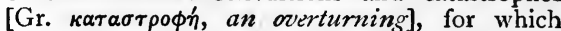
existing nature seems unable to supply effective causes.

Uniformity, Acts of, i.e. to secure uniformity in public worship : 1549 and 1562 , Edward VI. ; 1559, Elizabeth; 1662, Charles II.,-this last being in operation now ; amended, 1872 .

Uniform motion or velocity. That of a body which describes equal distances in equal times.

Unigennitus. [L., only begotten.] Title of the bull of Clement XI., September, 1713, condemning Jansenist opinions, as expressed in Quesnel's Reflexions Mrorales.

Unĭo margăritĭfĕrus. (Mussel, Pearl.)

Union. [Eccl. L. ūnio, unity.] In Eng. Hist., the union of the crowns of Scotland and England in the person of James I. The union of the two kingdoms was effected by the Statute of 1706 , under Anne. The union of Ireland with Great Britain was carried into effect in 1800 .

Union, Hypostatical. (Hypostatic union.)

Union Jack. The national flag of Great Britain and Ireland, consisting of the red cross of St. George, the red diagonal cross of St. Patrick, and the white diagonal cross of St. Andrew, all on a blue ground.

Unison. [L. unisonus, having one and the same sound.] (MIusic.) 1. Two tones are in U. when they are produced by the same number of vibrations per second. 2. Music in octaves, played or sung, is also said to be in $U$.

Unit. [L. unitas, oneness.] The magnitude by reference to which other magnitudes are expressed numerically. In England, the fundamental $U$. of distance, time, and mass are the yard, the mean solar second, and the pound avoirdupois; other units are derived from them according to tables of weights and measures, as inches and miles, hours and minutes, ounces and hundred weights, etc.

\section{United Bohemians. (Bohemian Brethren.)}

United Brethren. The same as Bohemian

Brethren.

United Presbyterian Church. (Marrow Controversy.)

Unit jar. A small insulated Leyden jar placed between the electric machine and the battery, so that its discharges show the amount of electricity passing. 
Univalve. [L. unus, one, valvæ, folding doors.] (Ostr.) Possessing one valve, or door; applied to shells composed of one piece, as the whelk's.

\section{Universal Doctor. (Doctor.)}

Universalists. (Eccl. Hist.) A name sometimes applied to Arminians, as holding that the grace of God is given to all men without favour or reserve; their opponents, the Calvinists, being called Particularists. But, generally, to those who believe in the ultimate recovery of all.

Universal joint. (Mech.) A joint enabling the rotation of one axle to communicate rotation to a second axle whose direction intersects that of the former at any given angle; the ends of the axles open out into forks, one of which is fastened by loose rivets to the ends of one arm of a cross, the other in like manner to the ends of the other arm of the cross:

Universal language. Any scheme for a system of writing which will be universally intelligible. This system must consist of signs for all conceivable things ; it implies, therefore, that the framers of it have mastered the whole of human knowledge, and can sit in judgment on it. It may be supposed that not much has been done towards the realizing of such schemes.

Universal proposition. [L. universālis.] In Log., a proposition which has the subject distributed, that is, applied to all possible members of the class ; as "All men are mortal," mortality being here predicated of all men without exception. (Quantity.)

Univocals. [L. unus, one, vox, voice.] In the Aristotelian logic of the schools, generic words, Predicable of many species. (Schoolmen.)

Unknown, The great. Sir Walter Scott, for some years after the appearance, in 1814 , of Waverley.

Unmoor, To. To weigh anchor.-Falconer.

Unmoored. (Naut.) Lying at single anchor.

Unnerving a horse's foot. Dividing the nerves distributed to it, in navicular disease.

Unpaid, The great. A familiar phrase, denoting the body of magistrates who are not stipendiary.

Unready, Ethelred the. The Un-réde, or wanting in counsel, rather than Ethel-réde, or noble in counsel.

Unreason, Abbot of. (Abbot of Misrule; Revels, Master of the.)

Unreeve. (Reeve, To.)

Unrove his life-line, $\mathrm{He}_{\boldsymbol{\theta}}$ has. In Naut. slang, he is dead.

Unstratified rocks. I.q. igneous, amorphous.

Upádána. In Buddhist theology, the attachment to existence, which, with Karma, work, is the source from which all beings have assumed their present form. According to this theology, the business of man is to uproot this upádána, and so attain a perfect calm in which he ceases to be conscious of being, this calm being called Nirvâna.

Upanishads. (Veda.)

Upas of Java. (Bot.) Antiaris toxicaria [L. toxícum, poison]; ord. Artocarpeæ, a tree allied to the fig, having poisonous secretion; in no way connected with the poisoned valley of Java, in which carbonic acid gas, fatal to all life, is continually emitted. The frequent rhetorical allusion to the "deadly upas tree" is, therefore, ridiculous.

Upchurch ware. A fine pottery, ornamented with dots or lines, usually of a blue-black; and made near U., on the Medway, during the Roman occupation.

Opper case. In Printing, capitals, etc. (as distinguished from small-letter types); kept in the upper case.

Opper masts. (Naut.) Top, top-gallant, and royal masts. All above the royals are called poles.

Upset price. In auctions, the price at which goods are started by the auctioneer, and under which they cannot be sold.

Up with the helm. (Naut.) Bring the rudder to leeward.

U.R. Written upon the voting-tablets at the Roman cŏmitia, is Uti rogas, as you propose; i.e. 1 vote for; A. being for antiquo, I reject, I vote against.

Urali. (Woorali.)

Uranium. [L. urănus, Gr. oujpavós, the heaven.] A malleable steel-white metal, whose compounds are used in glass staining, etc.

Oranography. A description of the heavens

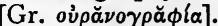

\section{Urănus. (Planet.)}

Urban Dean. (Decani.)

Urbi et orbi. [L., to the city and to the zuorld.] Papal decrees, thus addressed, are held to be promulgated to all the various churches, and are thenceforth binding.

Urbino ware. Majolica made or decorated at or near Urbino, in Italy, from the fifteenth century, but none identified before I530. The Raffaelle ware is decorated with copies from the designs of $\mathrm{R}$.

Urca. (Naut.) An armed Spanish fly-boat.

Uroeolate. [L. urcěŏlus, dim. of urceus, $a$ pitcher.] (Bot.) Contracted at the mouth; e.g. the corolla of some heaths.

Ure. [O.Fr. eiir, L. augŭrium.] Use, practice. Urim and Thummim. The word Urim is the plu. of the Heb. aur, a lisht; whence it has come to signify fire. Thummim, the plu. of thom, or tam, means fulness or perfection. The Septuagint renders the words by $\delta \dot{\eta} \lambda \omega \sigma \iota s$ and $\dot{\alpha} \lambda \dot{n} \theta \in \iota \alpha$, manifestation and truth. The U. and Th. are described as the precious stones on the high priest's breastplate, which were sup. posed to make known the divine will by casting an extraordinary lustre.

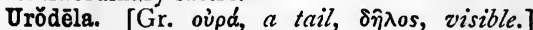
(Zool.) The second ord. of amphibians, tailed batrachians ; as newts.

Urry. [Ir. uireach.] (Geol.) A blue or black clay near a vein of coal.

Ursa Major. (Rishis, The Seven.)

Ursİdæ. [L. ursus, bear.] (Zool.) The bear fam., typ. Plantigrades $(q . v$.$) . Absent from Trop.$ and S. Africa; not found in Australia. Ord. Carnivǒra. 
Ursŭlines. (Eccl. Hist.) An order of nuns, instituted in the sixteenth century, devoted especially to education.

Urtica. [L., nettle.] (but.) U. dioica, the common stinging-nettle. Type of ord. Urticeæ.

Urticaria. [L. urtica, a nettle.] (Med.) Nettlerash, a common form of eruption on the skin, acute or chronic, always connected with some derangement of the digestive organs.

Use. [L. üsus.] (Eccl.) The mode of performing the divine offices in churches, and more especially of celebrating the Eucharist. These Uses varied at different times and in different dioceses. The most important English Use was that of Sarum, instituted by Osmund, bishop of that see in 1078. This Use was generally adopted in England, Wales, and Ireland; and the Bishop of Salisbury thus received the title of precentor of the college of bishops. There were also the Uses of York, Bangor, Hereford, and Lincoln ; but their differences were slight, being confined in some cases to musical notation.

Use, in Law, is a word, whose history must be studied in law-books, and cannot be given concisely. Originally it was simply $=$ the benefit or beneficial enjoyment of land; an ecclesiastical invention, as is generally believed ; out of which arose many advantages, immunities, abuses. Eventually it became $=$ seisin or legal estate. Charitable uses are enumerated in Statute 43 Elizabeth, and these now, in accordance with its spirit, include all gifts in aid of religion, of education, of the poor, of the young who need help in life, of public utility or order or improvement, etc. ; so long as the U. be not Superstitious, e.g. Masses for the dead.

Usequebaugh. [Ir. uisge beathe, water of life, L. aqua vitæ.] A compound distilled spirit, something like whisky, made in Ireland and Scotland. (Acheron.)

Usque ad nauseam. [L., even to nausea.] Repulsively ; till one is sick.

Usūcăpio. [L.] In Rom. I.aw, ownership acquired by long use or possession.
Usufruct. [L. ūsūfructus.] (Leg.) The right of enjoying the profits of a thing belonging to another, without impairing the substance.

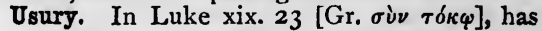
the meaning of interest [L. üsüra], simply.

Utǐle dulci, Omne tŭlit punctum, qui miscrit. [L.] $\mathrm{He}$ is in favour with every one who has combined the useful and the pleasant; lit. he has carried every vote; punctum, a point or dot in a waxen tablet, made as the sign of a vote.

Utility, Doctrine of. That of Hume, in his Inquiry concerning the Principles of Morals, I75I ; the foundation of his moral system; viz. that is virtuous which is useful or agreeable to the person himself or to others ; usefulness being only a tendency to a certain end, and that end the happiness both of ourselves and of others, with whom we have necessarily a fellow-feeling; and all this, looking no further than this present life.

Uti possǐdētis. [L., as you possess.] A phrase denoting a treaty which leaves the parties in the position which they occupy at the moment. (Status quo ante.)

Utopia. A word coined by Sir Thomas More [from Gr. ov̀, not, and rómos, a place] for an imaginary island which has a perfect government and society. More's Utopia was published in 1516. The word Utopian is now practically synonymous with unpractical or impracticable.

Utraquists. [L. uterque, both.] Those who insisted on communion in both kinds were so termed in the Council of Prague, I42I.

Utricle. [L. utrĭcŭlus, diın. of ūter, $a b a g, a$ skin.] (Anat. and Bot.) Often used as $=$ a saclike part; e.g. upper part of the vestibule of the internal ear.

Uttar. (Attar.)

Uvěa. [L. üva, a grape.] (Anat.) The posterior surface of the iris, thickly coated with pigment, and somewhat like the skin of a black grape.

Ưvula. [L., dim. of ūva, a grape.] A small fleshy process depending from the middle of the soft palate, and hanging over the base of the tongue.
V. A vocal corresponding to the aspirate $F$, and representing in many words the Greek digamma. As a Roman numeral, $\mathrm{V}$, being not really the letter $\mathrm{V}$, but the half of $\mathrm{X}$, stands for $5, \bar{V}$ for 5000 . As an abbrev., $V$. stands for vir, vixit, vale, verba, etc.

Vaccary. [L. vacca, a cow.] A cow-house or pasture.

Vaccine, Vaccination. (Cow-pox.)

Vaccinia. [L. vacca, a cow.] Cow-pox.

Vacuum [L. văcuus, empty]; V.-gauge. 1 A space empty of matter. 2. A space inclosed by a vessel from which the air, or other gas, has been in great part withdrawn; as the $V$. in the receiver of an air-pump, the Torricellian V., etc. (Torricellian tube.) A $V$.-gauge is an instrument for measuring the pressure of the attenuated vapour within the condenser of a steam-engine, of the air within the receiver of an air-pump, etc.

Vacuum, Nature abhors a. An unfortunate saying of (?) Aristotle, in explanation of phenomena really due to atmospheric pressure.

Vacuum-pan. A closed vessel used in making sugar, for evaporating syrup at a lower temperature than the ordinary boiling point (by 
the production of a partial vacuum in the pan).

Vādĕ in pācě. [L., go in peace.] In monastic houses, the form of dismissal after sentence to culprits found guilty of grave offences. (For the use which Sir W. Scott made of this custom, see his Marmion.)

Vādĕ mēcum. [L., go with me.] Any portable book or manual may be so called.

$\nabla \circledast$ victis! [L.] Woe to the conquered!

Vagabond, in Bible, has no moral connotation ; and is simply = wanderer, fugitive ; or, as

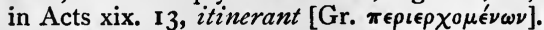

Vägina. [L., sheath.] (Anat. and Bot.) Variously applied to sheath-like tubes or passages.

Văgus, or Par văgum. (Nerves.)

Vair. [Fr., a squirrel's fur.] (Her.) A fur formed of small bell-shaped pieces of blue and silver alternately, arranged in lines so that the base of each silver bell is opposite to the base of a blue bell. Countervair has the base of each bell opposite to the base of a bell of like colour.

Vaisya. (Caste.)

Vakeel. In E. Indies, native attorney, agent in things diplomatic.

Vakka. (Naut.) A large outrigged canoe of the Friendly Isles.

Valeat quantum (valëre potest). [L.] Let it count for what (it is worth).

Valencia. A fabric having the weft of wool and the warp of silk or cotton.

Valenciennes (from the town in France). A lace with a hexagon mesh of two threads partly twisted and plaited, the pattern being worked in the net.

Valentine's Day. February 14, which bears the name of Valentine, a presbyter, said to have been beheaded at Rome under Claudius; but it is not easy to find in his life any reasons which connect him with the special associations of the day.

Valentinians. (Eccl. Hist.) The followers of the Egyptian Valentinus, who in the second century put forth an elaborate Gnostio system of Eons, composing a complete deity, which he termed Plērōma, fulness, or plenitude. Their morality resembled that of the Carpocratians.

Valerian. (Bot.) Of Pharmacy, Vălěriana off îcīnālis, a native plant, with tall stems, pinnate leaves, and umbels of white flowers; the red V., common on old garden walls, in quarries, etc., is Centranthus rŭber.

Valesians. An obscure sect of the third century, mentioned by Epiphanius.

Valetndinarian. Lit. that which relates to health [L. valētūdinnem], but applied generally to weak or bad health. Hence one who is weakly or infirm, or seeking to regain health.

Valhalla. (Myth.) The heaven in which Woden and the Asir dwell, with the Valkyries, whose office it is to conduct thither the souls of heroes slain in battle.

Valinch. A tube for drawing liquors from a cask by the bung-hole.

Valise. [Fr. valise, a saddle-bag.] A portmanteau.
Valkyries. In the Myth. of N. Europe, maidens who dwell with the Asir in Valhalla, and who, as corse-choosers, lead to the home of the gods the souls of those who fall in battle. Also called Oska-maer, Wish-maidens. (Houri ; Wish.)

Vallanris ware. An elegant pottery modelled from the antique, made at V., near Cannes.

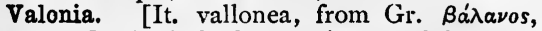
an acorn.] A kind of acorn imported from the Levant, and used in tanning.

Vălor Ecclēsǐastřcus. (Lỉber Regis.)

Valued policy. (Naut.) One in which a ship or goods are insured for a fixed sum.

Valve. [L. valvæ, plu., folding doors.] 1. (Anat.) A membrane opening to admit the passage of blood, and closing to prevent its reflux. Valvular, consisting of, pertaining to, valves. 2. (Bot.) One of the divisions of any dehiscent body.

Valve [L. valvæ, the leaves of a folding door] ; Ball-V.; Butterfly-V.; Clack-V.; DiscV.; Flap-V.; Iift-V.; Puppet-V. A small door for regulating the entrance and exit of fluids in steam and water engines. A Clack, or Flap, or Butterfly, $V$. turns round a hinge, being lifted by the fluid and falling into its place when the pressure is withdrawn. A Disc-V. is a circular disc of indiarubber secured by a bolt in the centre ; it is opened and closed against a grating by the yielding of the indiarubber to fluid pressure. A Lift or Puppet V. is a circular disc of metal with a bevelled edge, which fits a circular metal seating; it is lifted by the fluid pressure and falls into its seat when the pressure is withdrawn. A Ball- $V$. is simply a metal ball, with a properly formed seating and guides; it acts like a lift-valve.

Valve-chest. (Steam-chest.)

Vambrace, Vambrance. [Fr. avant, before, bras, arm.] Armour for the arms.

Vamp. [Fr. avant pied, before foot.] The upper leather of a shoe.

Vampire. [Ger. vampyr.] A blood-sucking spectre, resembling the Lamiæ and the Lemures. The name seems to be of Slavonic origin.

Vamplate. [Fr. avant, before, and Eng. plate.] Armour for the hand, a gauntlet.

Vanadium (from Vanadis, a Scandinavian goddess). A silvery brittle metal.

Vandyke. A scalloped cape for the neck, as seen in portraits painted by Vandyke in the reign of Charles $\mathrm{I}$.

Vandyke brown (supposed to be used by Vandyke). A semi-transparent brown pigment, obtained from a kind of peat.

Vane. [A.S. fana, a fag.] (Naut.) A piece of bunting extended on a revolving piece of wood at the masthead, to show the direction of the wind. $A$ distinguishing $V$. shows to which division of the fleet a vessel belongs. Dog. vanes, pieces of cork with feathers stuck round them, and strung upon twine, usually fastened to the top of a half-pike on the weather side of the quarter-deck.

Vanessa. So styled by Dean Swift, who exerted a kind of enchantment over her as he 
had done over Stella; Hester Vanhomrigh, the daughter of a London merchant, who died of a broken heart, 1723. (Stella.)

Vanessa, i.e. Phanessa (from Phanes, a mystic divinity in the Orphic rites, known also as Ěrōs). (Entom.) Gen. of butterfly, brightly coloured; as the Peacock B. Fam. Nymphălídæ.

Vang. (Naut.) A rope leading to either side of a ship from the outer end of a gaff.

Vanilla. [Sp. vainilla, a small pod.] The thin podlike capsule of a Trop. American plant, Vanilla planifolia, used in flavouring confectionary, etc.

Vanishing fraction. An algebraical fraction whose numerator and denominator are both functions of one variable, and become zero for the same value of that variable; as, $\frac{a^{3}-x^{3}}{a^{2}-x^{2}}$, in which the numerator and denominator both become zero when $x$ becomes equal to $a$; the value of the fraction is then $\frac{3 a}{2}$.

Vanishing point; V. line. That point to which the perspectıve representations of a group of parallel lines all converge. The $V$. line of a group of parallel planes is the line to which their perspective representations all converge.

Vanning. [L. vannus, a winnowing fan.] Washing a small portion of ore in a shovel.

Vantbrace. The same as Vambrace.

Vapour. [L. văpor, steam.] A substance in a gaseous form, which at ordinary temperatures appears as solid or liquid. The distinction between gases and vapours is conventional, the terms being used according to the state of the substance at ordinary temperatures.

Vapours. A nearly obsolete term for a disease of nervous debility; hypochondriacal, with hallucinations.

Varangians. The Greek name for the Teutonic guards of the Byzantine emperor, probably being, like the modern Oriental Feringi, a transliteration of Franks.

Varanĭdæ. (Zool.) Water-lizards. Africa and the East, including Australia.

Vare, Vare, redd̉e lĕgǐönes! [L., Varus, give me back my legions!] The exclamation of the Emperor Augustus, after the destruction of the legions under Varus by Arminius (Herman), A.D. 9.

Variable; Dependent V.; Independent V. When one magnitude is a function of a second, both are Variables; but the former is the $D e$ pendent, the latter the Independent, variable. Thus if $z=a x^{3}+b x, x$ and $z$ are both variables; but as the variations in $z$ are supposed to be produced by arbitrary variations in $x$, the former is the dependent, the latter the independent, variable.

Variables. In Naut. language, those parts of the sea where steady winds are not expected.

Variable star. (Astron.) A fixed star, whose brightness changes periodically or otherwise.

Variant. Of a word, one outwardly like, and from the same root; so to fleet is a V. of to float. A doublet being one from the same root, not outwardly like but having undergone some literal changes ; so chattels and cattle, fabric and forge, Fr. on and homme, etc.

Variation; Calculus of $\mathbf{V}$.; $\mathbf{V}$. compass ; $\mathbf{V}$. of the moon; V. of the needle; Periodic V.; Secular V. (Math.) The Calculus of variations is a kind of differential calculus, in which the same quantity is considered as an independent variable in two or more distinct points of view; e.g. the variation may take place not only from one point to another on a given curve, but also from one point to another on a neighbouring curve. The $V$. of the needle is the magnetic declination at a given place. A $V$. compass is a needle mounted so as to show the magnetic declination. The $V$. of the moon is an inequality in her longitude, due to the difference between the forces with which the sun attracts the earth and moon; it depends on twice the difference between her longitude and the sun's, vanishing at syzygies and quadratures, and being greatest at points about midway between them. The Periodic variations in the elliptic elements of a planet's orbit are those which, produced by the disturbing attraction of another planet, are nearly compensated in one revolution of the disturbing or disturbed body; the accumulation of the uncompensated residues of the periodic variations make up the secular variations or inequalities.

Variety. Varieties, with Darwin and others, are species in process of formation ; incipient species; when rendered very distinct from each other, they take the rank of Species; and this apparently is all that can be said by way of definition.

Vărĭŏla. [L. vărius, variegated.] (Med.)

\section{Small-pox.}

Variörum editions. Certain editions of classical writers, published chiefly in Holland, in the seventeenth and eighteenth centuries, with notes of numerous or various commentators.

Vărĭum et mütābǐlě semper Femină. [L.] Woman is always a fickle and changeable thing.

Värix. [L.] A dilated vein. Adj., Varicose. (Aneurism.)

Varlet. [O.Fr.] An attendant or servant. A low fellow or rascal.

Varnish (probably another form of burnish (q.v.), but traced by Sir G. C. Lewis, Astronomy of the Ancients, ch. iii. sec. 14, to Berenice, queen of Ptolemy Euergètes, King of Egypt, in the third century B.c.). A fluid which, spread on a solid surface and dried, leaves a coating impervious to air and moisture.

Varŭna. The oldest Hindu god of the heaven, whose name answers to the Greek Ourănos, Urănus.

Varvel. [Fr. vervelle.] Rings on a hawk's leg, bearing the owner's name.

Vaso-motor system of nerves. (Anat.) That distributed on the walls of the arteries; an important branch of the Sympathetic $(q \cdot v$.$) , or$ ganglionic, system.

Vassal. [Fr., derived by Sir F. Palgrave from Welsh gwâs, a young man or page.] One who holds a Fief of a superior lord. (Foudal system.) 
'Vast! (Avast !)

Vate sacro, Carent quia. Many great men and great deeds have died out of men's knowledge, because they had not the sacred bard to immortalize them (Horace).

Vathek. The History of the Caliph $V$., published 1784, by W. Beckford (1759-1844), in perfect French. An Arabian tale; short, sarcastic, of great imaginative power. A haughty, sensual, cruel monarch, abjuring his faith, offers allegiance to Eblis, in the hope of gaining the throne of the pre-adamite sultans; descends into hell, etc. (Eblis.)

Vatican. The palace of the popes in Rome, on the right bank of the Tiber ; the richest, perhaps, in the world in works of art, antiquities, etc.

\section{Vatican Codex. (Codex.)}

Vandeville (i.e. like the old country songs of Vau-de-vire, in Normandy, light and satirical). Light songs, consisting of several couplets and a refrain; introduced into theatrical pieces ; known, in time, as Lais des Vaux de Vire and Virelais. Hence plays having frequent vaudevilles were called V., and sometimes Virelais. (See Stainer and Barrett, Dictionary of Music.) (Mime.)

Vaudois. (Hist.) The inhabitants of some Alpine valleys in Piedmont, from which they were expelled in the seventeenth century. They returned and recovered their old homes by force. (Waldenses.)

Vaurien. [Fr. vaut, L. valet, he is worth, rien representing L. rem, $a$ thing, the neg. ne being omitted before the verb, and the full phrase being Il ne vaut rien.] One who is worth nothing, a scamp.

Vavassor. A word of uncertain origin, but probably connected with Vassal. In France, a general name for the immediate vassals of the higher nobles, the châtelains being vavassors with castles or fortified houses.

Ve-adar. (Adar.)

Veda. [Skt., knowledge.] The collective sacred literature of the Hindus. The name comes from the same source which gives the Gr. oif $\alpha, I$ know, the L. vidi, I have seen, and the Eng. wit. There are four Vedas: the Rig Veda, Yajur Veda, Sama Veda, and Atharva Veda. Each of these is a Sanhita, or complete collection; and these are commented upon in the Brahmanas, Suktas, Upanishads, Vedangas, and other scholia. The whole literature falls into two great classes: (I) Sruti, revelation; (2) Smriti, tradition; the latter containing the Sutras, or Vedangas, elaborate treatises on Vedic pronunciation, metre, grammar, astronomy, and ceremonial.

Vedangas. (Veda.)

Vedanta. A Hindu sect, professing to find in the Rig Veda a philosophy which much resembles the Quietism of European thinkers. (Mystics.)

Vedette. [Fr., from It. vedetta, a watchtower.] (Mil.) Cavalry sentry belonging to troops stationed at the outposts.

Veer. [Fr. virer, to turn about. So Vire! about !] (Naut.) 1. To let or pay out, as a cable. 2. To turn, or change. 3. I.q. to wear, to come on to the opposite tack by putting the vessel's head azvay from the wind; opposed to tacking. The wind veers when it goes with the sun ; backs, when against it.

Vegetable brimstone. The yellow dust of the spore-cases of more than one kind of lycopodium, used in theatres, etc.

\section{Vegetable butter. (Avocado pear.)}

Vegetable ivory. The kernels of the nutsthe Corrozzo nuts of commerce- of a very beautiful S.-American palm, the Phy̆tĕlěphas macrŏcarpa ; each nut about the size of a bantam's egg.

Vegetarianism. The theory that vegetable diet alone is the proper human diet.

Vehicle. [L. vĕhĭcŭlum, a carriage.] 1. (Med.) Any substance for taking medicine in. 2. A liquid with which the pigments are mixed for painting.

Vehmio courts. [Ger. vehmgerichte.] German criminal courts of justice during the Middle Ages. In the thirteenth century they were modelled on the system of a secret organization, their chief seat being Westphalia.

Vein. (Artery.)

Veldt. [D., same word as field.] In S. Africa ; wide, open, far-stretching grass-land, uncultivated, uninclosed.

Velitation. [L. velitātiōnem, from vēlìtes, light-armed soldiers.] Skirmishing. A dispute or contest.

Vēlntēs. [L.] The light-armed infantry belonging to a Roman Legion.

Velleity. [Fr. velléité, from a supposed L. velleitas, from velle, to wish.] Imperfect or incomplete volition; desire scarcely passing into will.

Vellicate. [L. vellicātum, sup. of vellicāre, freq. of vellěre, to pluck.] To twitch, to make to twitch convulsively.

Velocipede. [L. vēlox, szvift, pědem, a foot.] A light carriage propelled by the feet of the rider acting on cranks.

Velocity. [L. vēlōcĭta, -tem, swiftness.] (Math.) The rate of motion, uniform when the rate is constant, variable when the rate varies; the rate at any instant being the number of feet (or other unit) that would be described in a second (or other unit) if from that instant the body continued ta move uniformly. (Uniform motion.)

Velvet cork. The best kind of cork bark, soft and smooth.

Velveteen. [Fr. velvantine.] A cotton cloth in imitation of velvet.

Venation. [L. vēna, a vein.] (Bot.) The distribution of veins in leaves. (Parallel-veined leaves.)

Vendémiaire. [Fr., from L. vindēmia, vintage.] The first month of the French Republican calendar, beginning at the autumnal equinox and ending thirty days later. In this calendar the year was divided into twelve months of thirty days, with five additional days for festivals, and every fourth year six. The months: 
were divided into decades, and the days into ten hours of a hundred minutes each. The months were named from the botanical or agricultural characteristics of each, their names being consecutively Vendémiaire, Brumaire, Frimaire, Nivose, Pluviose, Ventose, Germinal, Floréal, Prairial, Messidor, Thermidor (or Fervidor), and Fructidor. This absurd scheme was set aside by Napoleon, who restored the old calendar in 1806 .

Veneering. [Ger. furnieren, to furnish.] Overlaying a coarse wood with thin leaves or veneers of superior material.

Venery. [Fr. vénerie, L. vēnāri, to hunt.] The highest branch of the art of hunting.

Venery, Beasts of. The hart, hare, wild boar, and wolf; as distinguished from beasts of the chase, which are the buck, doe, roe, fox, and marten.

Venesection. [L. vēna, a vein, sěco, I cut.] Blood-letting.

Venetian school. A school of painting marked by the beauty of its colouring. (Its head was Titian, a Venetian, born 1477.)

Venetian swell (i.e. like a V. blind). Inclosing the swell organ, is a series of shutters opened and closed by a pedal.

Vēni, vìdi, vīci. [L., I came, saw, and conquered.] Many accounts are given of the origin of this phrase, which has been attributed to Julius" Cæesar.

Venial sins. [L. vernia, pardon.] In the Latin Church, such sins as do not place the doer out of a state of grace. (Mortal sins.)

Venison. Gen. xxv., xxvii.; retains the first meaning of the word ; i.e. flesh taken in hunting [Fr. venaison, L. vēnationem].

Vent. [Fr. vent, wind.] (Mil.) Aperture through which the charge of a gun is fired; when a match was used, called the Touch-hole. "Serving" the V.-in muzzle-loading guns-is the stopping the $\mathrm{V}$. by means of the thumb or a vent-server, while the gun is being sponged out and loaded.

Ventail. [Fr. ventaille, venter, to blow fresh.] That part of the visor of a helmet which may be lifted up, for freer admission of air.

Venter. [L., womb.] In Law, = maternal parentage; so first or second $\mathrm{V}_{\mathbf{0}}=$ first or second marriage.

Ventricle. [L. ventrǐcŭlus, dim. of venter, belly.] (Anat.) Small cavity; applied, especially, to the heart.

Ventriloquist. [L. venter, belly, loquor, $I$ speak.] One who is said to be able to make his voice sound as if it came from points distant from himself; an effect supposed to be produced by his speaking from his stomach.

Venus. [L., from a root which in Skt. is van, to desire, love, or favour, and which gives A.S. wynn, pleasure, the Ger. wonne, and the Eng. zvinsome.] The Italian goddess of love, afterwards identified with the Greek Aphrödite. (Paris, Judgment of.)

Venus. (Planet.)

Veratrine. A vegetable alkaloid, obtained from hellebore [L. vērātrum].
Verbātim et litĕrātim. [L.] Word for word and letter for letter.

Verbum sap., i.e. săpienti. [L., $a$ word to the zvise.] A little hint for those who are sensible enough to need nothing more.

Verde antique. [Fr., i.e. prized by the ancient Romans.] 1. Green porphyry, felspathic with felspar-crystals. 2. Serpentine mixed with limestone is sometimes so called.

Verdict [L.L. verdictum, vērēdictum, $a$ thing truly said] is General, when in general words with the issue, as guilty or not; Special, when the jury find the facts of the case to be.proved, but do not know on which side to find, being ignorant on some points of law ; Privy, when, the judge having left or adjourned the court, the jury, desiring to be liberated, are allowed to give their V. privily to the judge, the V. to be legal only when given out publicly.

Verdigris. [L. virĭdě æris, green of copper.] (Chem.) Diacetate of copper, a poisonous green pigment.

Verditer. [Fr. vert de terre, earth-green.] A blue pigment made by decomposing nitrate of copper with chalk. Green verditer is formed by sulphate of copper and sea-salt.

Verdoy. [Fr. verdoyé.] (Her.) Charged with leaves.

Verge. [Fr., a rod.] The spindle of a watchbalance.

Vergeboard. (Bargeboard.)

Vergette. [Fr., a brush.] (Pallet.)

Verglas. [A word made up of verre, glass, glace, ice.] Glazed frost.

Veridical. [L. vērĭdicus.] Truth-telling; truthful.

Verisimilitude. [L. vērĭsĭmĭlĭtüdo.] Iikeness to truth; probability, likelihood.

Vëritas, Amicus Plato, sed magis amica. [L., Plato is dear; the truth is much dearer.] No personal, private, considerations may have any weight when it is a question of truth.

Veritas, Bureau. The French Lloyd's (q.v.).

Veritas ǒdium parit. [L.] Truth breeds hatred.

Verjuice. [Fr. verjus, vert, green, L. jus, juice.] The juice of crab apples, sour grapes, etc.

Vermicelli. [It., small worms.] A small kind of macaroni.

Vermicular motion. A peristaltic (q.v.) movement; one continued throughout the moving body, from one part to that immediately next it ; like that of a worm [L. vermis; dim. vermícǔlus].

Vermiculate. [L. vermǐcŭlātus.] To inlay; to arrange work so that it shall look as if eaten into and tracked by worms. Such work, in Arch., is called vermiculated, or vermicular, from L. vermis, a worm.

Vermiculation. [L. vermicŭlus, dim. of vermis, a worm.] In masonry, a pattern giving the appearance of a worm-eaten substance.

Vermifuge. [L. vermis, a worm, fŭgo, I banish.] I.q. anthelmintic (q.v.).

Vermilion. [Fr. vermillon, vermeil, from L. vermicŭlus, $a$ little zoorm.] Mercuric sulphide, a 
bright red pigment (from its resemblance to the dye obtained from the kermes insect).

Vernal equinox. (Equinox.)

Vernation. [L. vernus, belonging to spring.] (Bot.) The arrangement of young leaves in their leaf-bud. Astivation [æstivus, belonging to summer], the arrangement of the parts of a flower before they expand. (Prefloration; Prefoliation.)

Vernier. (Pierre V., inventor, Brussels, I631.) A graduated slip attached to an index and sliding with it along a scale, for reading a fractional part of the smallest division of the scale with much greater accuracy than could be obtained by actual mechanical subdivision.

Verōnica. [A word said to be coined from L. vera, true, and Gr. eikw $\nu$, a likeness, but it may be a corr. of Gr. Berenīkë, Berenice. (Varnish.)] 1. A saint of this name, it is said, put a handkerchief to the face of the Saviour as $\mathrm{He}$ was led away to crucifixion, and thus obtained a true likeness. The relic is still exhibited at Rome. 2. In Bot., the name denotes the Speedwell, a gen. of plants with numerous spec., ord. Scrophularineæ, including common S. (V. officinalis), abundant in Britain, with pale blue corolla ; brooklime, etc.

Verrière. In Keramics, a bowl with scalloped edges, to lay glasses in.

Verrucose. [L. verrūcōsus, verrūca, $a$ wart.] (Anat. and Bot.) Having warts.

Versailles, Palace of. Built by Louis XIV., King of France, $1661-72$; attacked by the mob, 1789. The King of Prussia proclaimed Germanic Emperor in the great hall, 1871 .

Vers de societé. Mediocre verses (Littré), written for drawing-room entertainment.

Versicles. [L. versǐcŭli, little verses.] (Eccl.) Short sentences recited by the minister, to which the people reply by similar sentences called Responses.

Verso. [L. versus, turned over.] The lefthand page in printing.

Verst, Werst. A Russian measure of itinerary length, = I $166 \frac{1}{2}$ yards ; about two-thirds of an English mile, a little more than a French kilomètre. Russian verstà, from verstati, to measure.

Vert. [Fr.] (Her.) The green colour in coats of arms, represented in engraving by lines sloping downward from the dexter to the sinister side.

Vertebrāte, Vertebrates. [L. vertebræ, provided with joints, specially in backbone, vertō turn.] (Zool.) That sub-kingd. of animals which consists of-

I. Ichthy̆opsĭda, characterized by, among other things, the possession of temporary or permanent gills, and containing

(I) Fishes,

(2) Amphibians.

II. Sauropsida, characterized by, among other things, the total absence of gills, and by the head being jointed on a single condyle, and containing

(I) Birds,

(2) Reptiles.

III. Mammalia, characterized by, among other things, the possession of milk glands, and by the head being jointed on two condyles.

The general name is due to the possession of a vertebral or spinal column, rudimentary or developed.

Vertex. [L.] 1. The angular point of a triangle, pyramid, etc., opposite to the base. 2. The point of a symmetrical curve or surface on which it is cut by the axis; as the V. of a parabola.

Vertical circle; V. elevation; V. limb; V. line; V. plane; Prime V. The Vertical line at any place is the line drawn in the direction of the plumb-line at that place. Any plane containing the vertical line is a $V$. plane. The angle of $V$. elevation of a point is the angle on a vertical plane between a line drawn from the point to the eye of the observer and the horizontal line. The $V$. limb of a surveying or astronomical instrument is a graduated arc, capable of adjustment into a vertical plane, on which angles of vertical elevations can be measured. A V. circle is a circle of the great sphere whose plane is vertical. The Prime $V$. is the vertical circle at right angles to the meridian, and therefore passing through the east and west points of the horizon.

Vertical plane. In Perspective, the plane passing through the point of sight, parallel to the plane of the picture.

Verticel [L. verticillus, the whorl of a spindle], or Whorl. (Bot.) The development of three or more leaves or other organs upon the same plane ; e.g. woodruff, bedstraw. Adj., Verticillate.

Vertigo. [L.] Dizziness, swimming in the head, supposed to arise from irregular supply of blood, excessive or defective, to the brain.

Vertumnus. A Latin deity worshipped as concerned with everything relating to change, whether in the seasons or in commerce, etc. He is called the husband of Pomona, the goddess of fruits and harvest. The name is a participial form of the verb verto, I turn.

Verve. [Fr., L. verva, a sculptured ram's head (? Littré).] Animation, spirit, chiefly such as inspires artists.

Vesical. (Med.) Pertaining to the bladder [L. vēsīca].

Vēsica piscis. [L.] An oval emblem, generally pointed at either end, often used for the seals of religious houses, or to inclose figures of Jesus Christ (Ichthys) or of the saints.

Vesicle. [L. vës:̃cŭla.] (Anat. and Bot.) A small bladder-like cavity.

Vesicular. (Geol.) Cellular, full of little cavities, like some kinds of lava.

Vesper. [L.] The evening star, called by the Greeks Hesperos. Hence Hesperrian as a name for Italy, which to the Greeks was the western land. (Hesperides.)

Vespers. (Canonical hours.)

Vespers, Sicilian. (Sicilian Vespers.)

Vespertilǐonnĭdæ. [L. vespertīlio, bat, vesper, evening.] (Zool.) Large and universally distributed fam. of insectivorous bats, frequently large-eared. 
Vespiary. [L. vespa, a wasp.] (Entom.) Wasps' nest.

Vespidæ. [L. vespa, a zvasp.] (Entom.) Wasps; fam. of hymenopterous insects, some social, others solitary.

Vestal. [L. Vestālis.] Relating to Vesta, the Latin goddess of the hrarth, where the sacred fire was never allowed to die out, and the guardian of household purity and truth. This fire on the public hearth was guarded by the Vestal virgins, who are said to have been instituted by Numa Pompilius. This goddess was called by the Greeks Hestra.

Vestigia nulla rětrorsum. [L.] No tracks of any going back; that is, all tracks pointing to the lion's den, a sign of fatal danger.

\section{Vestment. (Chasuble.)}

Vestry. [L. vestiārium, from vestis, a gar ment.] 1. The robing-room attached to a church, fur the clergy. As this room is used for meetings of the parishioners, the word is applied, 2, to the parishioners so assembled; an order by the V. meaning an order by the ratepayers.

Veterinary. [L. větěrīnarius.] A cattle-doctor, one who attends any kind of carrying or drawing animal, větěrīna [as if věhětěriña, $\mathbf{L}$. věho, I carry].

Vĕtĭtum nĕfas. [L., the forbidden impiety.] The sin which has been a special subject of law ; i.e. idol-worship among the Jews.

Vetiver. (Vittie vayr.)

Vetto. [L., I forbial.] The word by which the Roman tribunes of the people exercised their power of intercession, by which they could arrest the action of public magistrates or the passing of ordinances by the senate.

Vettura. [It., from L. vectūra, a conveying, a rilling.] A carriage.

Vetturino. [It.] The driver of a Vettura.

Větŭs Itălă. (Italic Version.)

Vexāta quæstio. [L., a vexed quesíion.] A disputed point.

Vexillum. (Papilionaceous plants.)

Via Crucis. (Stations.)

Via mědı̌a. [L.] A middle way.

Viāticum. [L., food for a journey.] In the Latin Church, the Eucharist as administered to the dying.

Vibices. [L. vïbex, -īcis, a weal.] (Med.) Large purple spots or streaks in the skin, like the marks of a whip.

Vibration [L. vibrationem] ; Amplitude of V.; Longitudinal V.; Phase of V.; Transversal V. 1. The backward and forward movement of a body; as of a pendulum. 2. The backward and forward movement of a particle of a medium or body transmitting or producing a wave-motion. 3. The movement of the body itself; as of a musical string when producing, or of the atmosphere when transmitting, a sound. The Amplitude of $V$. is the extreme distance described by a vibrating particle. (For Phase of $V$. , vide Phase.) When the particles move in the line of the propagation of the wave-as in the case of air transmitting sound-the vibrations are lonoitudinal; when the motion takes place in a plane at right angles to the direction of propaga. tion-as in the case of the ether transmitting light-the vibrations are transversal.

Vicar. (Rector.)

Vicar-Apostolic. In the Latin Church, a person in episcopal orders, authorized by the pope to exercise his office in countries where there is no organized establishment of the Roman obedience.

Vicar-General. An ecclesiastical officer, assisting the bishop in ecclesiastical causes, in visitations; "much the same as the chancellor" (Hook's Church Dictionary).

Vicar of Bray. A phrase sometimes used to denote those who are supposed to retain preferments by complying with all changes required of them, after the fashion of the Vicar of Bray, who stuck to his place during the reigns of the later Stuarts and of William III., or, as others say, during those of Henry VIII., Edward VI., Mary, and Elizabeth.

vicars-Choral. Originally deputies, now assistants, of canons in collegiate churches, in such duties as require knowledge of music.

Vicars of the Empire. (Hist.) The representatives of the emperor. The King of the Romans was perpetual vicar, when there was one. When there was not, the office was shared by the Elector of Saxony in the two Saxon circles, and in the rest of the empire by the electors palatine, and of Bavaria.

Vice-admiral. (Rank.)

Vícě versâ. [L., in turn.] Turn about; the turn being changed.

Vicinage. [O.Fr. veisinage, from L. vīcīnus, neighbouring.] Neighbourhood.

Vicious circle. In Log., an argument which comes round to the point from which it started, thus proving nothing and explaining nothing. Thus, as all conceivable arguments must start from the proposition, expressed or understood, "I am a conscious thinker," attempts to explain the action of the mind as a secretion from matter are arguments in a V. C.

Victoria (from Queen Victoria). A low fourwheeled open carriage.

Victoria cross. A British military and naval decoration, instituted 1856 , expressly as a reward for personal bravery in face of the enemy.

Victrix causa Diis plăcuit, sed victa Cătôni.

[L.] The gods love the winning, but Cato loves the losing, side (Lucan).

Vidame. [Fr., from L.L. viceě-dominnus.] In Fr. Feud. usage, an officer representing the bishop. (Viscount.)

Vidëlicet. [L., for vidēre lǐcet, you may see.] Namely; abbrev. into viz.

Viděo mĕlǐöra prŏbōque, Detĕrīōra sĕquor. [L., I see and approze the better, but follow the worse.] The frequent contrast between profession and practice.

Vidette. (Vedette.)

Vidimus. [L., we have secn.] Of business transacted, is "we have examined and approved."

Vidonia. A tart white wine from Teneriffe.

Vi et armis. [L., by force and arms.] By main force. 
Viewer. The superintendent of a coal-mine.

Vifgage. In Law, the opposite of mortgage. (Gage.)

Vigesimo-quarto. The $L$. words used to denote, in printing, a sheet folded in twenty-four pages; usually expressed by the term $24 \mathrm{mo}$.

Vigulantibus, non dormientibus, æquitas subvènit. [L.] A maxim in Law : equity comes to the help of those who are azvake, not those who sleep; men must be alive to the assertion of their claims, etc., or they will lose them. (Laches.)

Vigils. (Dedication, Feast of ; Evens.)

Vignette. [Fr., a little vine.] 1. (Arch.) A running ornament of leaves and tendrils, in hollow mouldings or casements of Decorated and Perpendicular Gothic. 2. In ancient MSS., a capital letter ornamented with tendrils; and so any similar ornament on a page or elsewhere; as a head, flower, etc. 3. From the absence of a definite border has come the recent use of $\mathrm{V}$. in engravings, photography, etc. 4. Any kind of printer's ornaments, such as flowers, vine tendrils, head and tail pieces, etc.

Vikings. [Icel. vik, $a$ creek.] The Norse name for the Sea-kings, whose assaults on this country began in the ninth century.

Vile body. Phil. iii. 21 ; of little worth, comparatively [L. vìlis, Gr. $\sigma \hat{\omega} \mu \alpha \tau \tau_{\hat{\eta}} s \tau \alpha \pi \epsilon \iota \omega \dot{\sigma} \epsilon \omega s$, lit. body of our humiliation].

Vilipend. [L. villipenděre, from vilis, cheap, poor, pendo, I weigh.] To regard as worthless, to slight, despise.

Villein. [L.L. villänus.] 1. A peasant attached to the villa or house of the feudal lord; some belonging to the soil, like the Laconian Helots, others to the person of their master, and therefore liable to be sold at any time as slaves. (Thrall.) 2. Hence, from the poverty and worthlessness of their condition, the word came to denote immoral and wicked men.

Villi. [L., tufts of hair.] (Anat.) Minute vascular processes, of velvety appearance, on the surface of certain membranes, especially of the small intestine, where they promote the absorption of chyle.

Villotte. [Fr.] An old name for the first harmonized secular pieces of music, which were vil and unrefined, as compared with the strictness of church music.

Villous. 1. Covered with villi [L.]. 2. (Bot.) Covered with long, soft hair.

Vinaigrette. [Fr.] A small bottle or box, used for holding aromatic vinegar.

Vinatico. A coarse mahogany from Madeira. Vinaya. (Tripitaka.)

Vincentian rule. A test of theological truth laid down by Vincent of Lerins, in the fifth century, in the maxim, "Quod ubique, quorl semper, quod ab omnibus tradítum," meaning that no dogma is of authority unless it has been handed down in the Christian Church, always, everywhere, and by all.

Vincible ignorance. [L. vinciblilis, that may be mastered.] In Moral Phil., is said to be affected or wilful, when perversely rejecting the means of knowledge; supine or crass, when indolently neglecting them. (Invincible ignorance.)
Vinegar plant. During acetous fermentation of liquids, certain layers are formed, of delicate interlaced threads, sometimes followed by a crop of Penicillium glaucum, a fungous mass, which in some way much aids the conversion of sugar and water into vinegar. This method of producing vinegar is much used.

Viol d'amour. [Fr.] (Music.) 1. Rather larger than the violin, and now obsolete, employed both catgut and metal strings; the latter placed under the finger-board, and sounding only by sympathy. 2. An organ stop so called, of similar quality to the gamba $(q . v$.$) . Viole, like$ vielle, a hurdy-gurdy, is the Med. L. vitŭla, vitella, $a$ viol.

Viol di gamba. (Gamba.)

Violet-wood. (Kingwood.)

Violoncello. [It., dim. of violone, double bassviol.] (Music.) The lowest bass stringed instrument, generally, in the orchestra; having four gut strings, all tuned a fifth apart.

Violone. [It.] Double bass.

Viper. [Old Testament, eph'eh (Tob. xx. 16, etc.), New Testament, čchidna.] (Bibl.) Acts xxviii. 3; a Maltese snake (Cŏrōnella lævis) which can hang on by its teeth. Fam. Cŏlubridæ.

Virāgo. Originally, as always in Latin, an heroic woman ; now a rough, violent woman.

Virelay. (Vaudeville.)

Vires acquīrit eundo. [L.] It gains strength in movement; said of Rumour.

Virgidēmiärum Lǐber. [A coined L. word, = a collection of rods; virga, a rod, vindēmia, vintage.] Six books of satires; attacking, especially, literary vices and affectations ; illustrating contemporary manners; by the learned and patient Bishop Joseph Hall (1574-1656); rated highly by Pope, not so highly by Hallam.

Virgil, The Scottish. George Buchanan, an elegant writer of Latin poetry and prose (died I 582).

Virginal. [(?) L. virğnālis, maidenly.] A spinet $(q . v$.$) , which latter title superseded the$ former.

Virole. [Fr.] (Her.) The ring of a bugle.

Virtual; V. focus; V. moment; V. velocities ; V. velocity; V. work. (Math.) If the point of application of a force receives a small displacement, the part of it which is in the line of action of the force is the $V$. velocity of the point; the product of the force into the virtual velocity of its point of application is the $V$. moment or $V$. work of the force. The principle of $V$. velocities is the fundamental condition of the equilibrium of bodies; viz. that when a body or system is in equilibrium under the action of any forces, and it receives any small displacement consistent with the connexion of the parts, the algebraical sum of the virtual moments of the forces is zero. (For $V$. focus, vide Focus.)

Virtuoso. [It.] One devoted to virtu; i.e. one skilled in the fine arts, or having taste in curiosities, etc. Often used ironically.

Virtus est mědrum vitiōrum. [L.] Virtue is a mean between two extremes or vices (Horace).

Virtūtem incolŭmem ōdimus, Sublātam ex 
ocŭlis quærimus invĩdi. [L.] True worth, when safe with us, we dislike; when taken away from our sight we seek for it grudging its loss (Horace).

Virus. [L., poison.] (Med.) The inappreciable principle in the secretion of infectious disease, which communicates that disease; Venom being a natural secretion.

Viscount. Properly vĭcě-cŏměs, the delegate of a count. In England, the title of the sheriff of a county. It is the latest title of honour in the English peerage, being first conferred by Henry VI., in 1440. (Vidame.)

Viscous. A mass is V. when it is capable of a slow continuous change of form without disruption of its parts; the word commonly implies that the substance is sticky [L. viscōsus].

Viscus (more commonly plu., viscèra). [L.] (Med.) Used of any internal organ of the body.

Vis inertiæ. (Inertia.)

Vision [L. visionnem, a seeing] ; Direct V.; Reflected V.; Refracted $\mathbf{V}$. When a body is seen by rays coming from it directly, it is seen by Direct $V$. ; when by rays that have undergone reflexion or refraction, it is seen by Reflected or Refracted $V$.

Vision, Beatifio. (Theol.) The sight or apprehension of God which the faithful enjoy in heaven.

Visitation and search. (Naut.) An examination to which all merchant-vessels are subject on the part of a duly commissioned war-vessel of a belligerent state.

Vis mäjor. [L.] In Law, some outward force which man could not have foreseen or provided against. (Force majeure.)

Vis mĕdūcātrix natüræ. [L.] The healing power of nature.

Visual angle; V. ray. [L. vīsuālis, relating to the sight.] A line drawn direct to the eye from a point seen by it is a Visual ray; the angle between the visual rays of the extreme points of a body is the $V$. angle, or the angle which the body subtends at the eye.

Vis vitæ. [L.] Vital power.

Vis viva [L., lizing force] ; Principle of Vis vitæ. The Vis viza, or Kinetic energy, of a system is half the sum of the products formed by multiplying the mass of each particle by the square of its velocity. The Principle of $V . V$. is the fact that in the motion of any material system the change of $\mathrm{V}$. V. in a given time equals the work done in the same time by the forces acting on the system.

Vita(que) mancǐpǐo nulli dătur, omnibus üsū. [L.] Life is given to all in tenancy, to none as a freehold (Lucretius).

Vitellary. [L. vitellus, yolk.] The white of an egg, as containing the yolk.

Vitreous electricity. [L. vitrěus, slassy.] Positive electricity (because it is excited by rubbing glass with silk, etc.).

Vitrify. [L. vitrum, glass, facĕre, to make.] To convert into glass.

Vitriol. [L. vitrum, glass.] 1. Sulphuric acid, also called oil of vitriol. Hence applied, 2, to sulphates, as blue vitriol, green vitriol, white vitriol, the respective sulphates of copper, iron, zinc.

vitruvian. Of or relating to Vitruvius, a
Roman architect, a contemporary of Julius Cæsar and Augustus.

Vittate. [L. vittätus, bound with a fillet.] (Bot.) Striped lengthwise.

Vittie vayr. (Bot.) The Tamil name for the fibrous roots of the khur-khur (Andrŏpögön muricātus), which contain a pleasantly odorous oil.

Vitŭligo. [L. vǐtŭlus, $a$ calf.] (Med.) A disease of the skin, giving it a white veal-like appearance, from loss of pigment.

Vivandière. [Fr., from It. vivandiére, L.L. vīvenda, victuals, whence viande.] Female sutler, who carries liquor for French troops.

Vīä vōce. [L.] By word of mouth.

Vivendi mŏdus. [L.] The measure of living, with reference to its end, which is old age or death (Cicero, De Sen.). The phrase modus vivendi is now often used to denote the tacit compromise by which differences of opinion are, to whatever extent, disregarded in order to promote peace and co-operation among men of different schools of thought.

Vīverre convenienter nātūræ. [L.] To live in agreement with nature; i.e. with universal nature; the ethical formula of the Stoics.

Viverrĭdæ. [L. viverra, ferret.] (Zool.) Fam. of carnivvora, mostly small ; as civets, ichneumons; but not ferrets, which are Mustellidæ. Africa, S. Asia, and adjacent islands.

Vives, Fives. [Corr. of Fr. avives, meaning the same.] In horses, an affection somewhat like strangles $(q . v$.$) , but chronic, and affecting older$ horses.

Vivě vălēque. [L.] Jive and be strong.

Vivier. [L. vīvārium, a place for keeping game alive.] (Naut.) A French fishing-boat, fitted with a well amidships for keeping fish alive.

Vivisection. [L. vīvus, living, sěctiōnem, $a$ cutting.] The dissection of a living animal, in physiological experiment.

Vizier, Vizir. [Ar., a porter.] A humble tit]e for the chief officers in Mohammedan states. In the Turkish empire, the councillors of the Divan are all vizirs, the chief among them being called vizir azem, or grand vizir.

Vocal flames, Singing flames. Flames inclosed within a tube, made to vibrate regularly, and so to produce a musical note.

Voce di testa. [It.] 1. Head voice, the higher range ; the lower being $\mathrm{V}$. di petto, chest voice.

2. Falsetto.

\section{Vogue la Galère. (Galère.)}

Voided. [Fr. vidé, emptied.] (Her.) Having the inner part cut away, so as to leave merely a narrow border.

\section{Voider. (Flanche.)}

Voir dire. [O.Fr., L. vērē dicĕre, to say truly.] (Leg.) Denotes an oath by which a witness is required to make true answers in reference to matters inquired of, to ascertain his interest in the cause as affecting his competency.

Volant. [Fr.] (Her.) Flying.

Volante. [Sp., a flyer.] A heavy two-wheeled carriage used in Cuba.

Volatile. [L. vǒlātǔlis, fleeting.] Wasting 
Volcanio rocks, or Ejectāmenta [L., things cast out] (Geol.), = lava, basaltic lava, trachyte, obsidian, pumice, tufa, scoriæ, and several others; mostly composed of felspar and augite.

Vole. (Arvicola.)

Vŏlenti non fit injüria. [L.] In Law : no wrong is done to any one if that person consents to the thing done; so one party to a contract may break it, if he have the consent of the other.

Volique. (Naut.) A small boat used in Asia Minor.

Volkslied. [Ger., folk's song.] Popular song.

Volsunga saga. (Sagas.)

Volt. (From Volta, the Italian electrician, I745-1826.) The unit of electro-motive force. It is equal to $\frac{1}{346}$ of one horse-power, i.e. to rather more than forty-four pounds of energy.

Volts [It., turn, time.] (Music.) Una V., once; V.S., volta subito, turn over the leaf quickly.

Voltaic arc. A luminous arch formed by the passage of a voltaic current between two carbon points.

Voltaio electricity (discovered by Volta). Electricity developed by means of chemical action.

Voltaic pile. A battery consisting of alternate discs of two metals, as silver and zinc, with cloth moistened by acid between each pair.

Volume. [L. vorlümen, the thing rolled.] The cubic contents of a body; as the V. of a sphere.

Volumetric analysis. [Eng. volume, and $\mathrm{Gr}$.

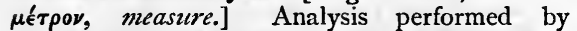
measured volumes of standard solutions of reagents. This determines the quantity as well as the nature of the substances present.

Voluspa Saga. A short Saga, which gives both a cosmogony and a Theogony. The word means the spa, or prophecy, of Vola, the inspired or mad prophetess (compare Eng. fool and folly).

volute. [L. volvo, $I$ roll.] (Arch.) The spiral scroll on each side of the capital of the Ionic order.

Volvox. [L. volvo, I rotate.] (Physiol.) A microscopic rotating organism, variously referred

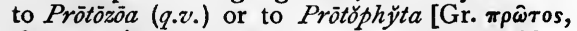
first, фvтóv, a plant], i.e. the lowest vegetables, or (Haeckel) to an intermediate kingd., Regnum

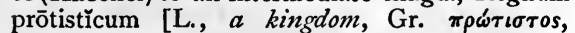
first of all], containing doubtful organisms.

Vömer. [L., ploughshare.] (Anat.) One of the bones of the cranium ; a thin quadrilateral plate forming a considerable part of the middle partition of the nose.

Vormica. [L., a sore, an encysted tumour.] (Med.) A cavity in the lungs, containing purulent matter.

Vomǐtōria. doors in ancient theatres or amphitheatres, for the ingress and egress of the public.

Vorant. [L. vorantem.] (Her.) Devouring or swallowing.

Vortex. [L., anytining whirled round, a whirlpool.] A stream which either returns into itself or moves in a spiral course towards or from an axis.

Vortices, Theory of. (Astron.) The hypothesis of Descartes, that the planets are carried round the sun by a vortex of a fine and subtile kind of matter, whose motion keeps up theirs. Though weighted with many difficulties, the theory was once very famous, and almost universally received.

Vōto, Ex. [L.] An ex-vōto gift is one vowed, devoted, either before or after recovery from illness, escape from accident, etc. (see Horace, Od. i. v.). The practice is common in the Roman communion.

Voussoirs. [Fr.] The wedge-shaped stones by which an arch is formed. (Extrados; Intrados.)

Vowel. [L. vocālis, vocal.] In Gram., a letter which may be pronounced alone ; a diph. thong consisting of two vowels whose sounds are regarded as running into one another.

Vox et prætĕrěa nihul. [L.] $A$ voice and nothing more.

Vox nihili. (Gram.) An expression = no such word, but only a mere conjecture, or a false reading, or an error of some sort. For an example, vide Abacot. So Collimation (q.v.) is not really a word, but should have been Collineation. Examples abound in the Supplices of Aschylus.

Vox porpŭli, vox Dei. [L.] The voice of the people is the voice of God.

Vritra. (Indra.)

Vulcan, Vulcānus. (Myth.) The Latin god of fire. The name is akin to the Skt. ulkâ, a fire. brand, and the L. fulgere, to glisten, and fulgur, lightning.

Vulcanists. In Geol., upholders of the Huttonian theory (q.v.); opponents of the Neptunian or Wernerian (q.v.) theory.

Vulcanized indiarubber. Indiarubber combined with sulphur, and thus rendered tougher and less affected by heat or cold.

Vulgar tongue. The vernacular; belonging to the people [L. vulgāris].

Vulgate. [L. vulgāta, sc. editio, an edition for common use.] The name given to the Latin translation of the Scriptures, most of which is the work of St. Jerome.

Vulnerary. [L. vulnerrārius, belonging to wounds.] 1. Useful in healing wounds. 2. Subst., any plant or unguent, etc., so used.

Vulning. [L. vulnus, wound.] Wounding itself. Vulned signifies wounded by some other 
W. Derives its English name from the fact of the letter $\mathrm{V}$ being identical with $\mathrm{U}$ in the Latin. Wacke. [Ger. term.] (Geol.) An earthy variety of trap-rock, argillaceous, greenish-grey; but the term is not strictly defined.

Wad, Wadd. (Chem.) 1. Plumbago. 2. An earthy oxide of manganese.

Wadding. Sheets of corded cotton, for padding garments, etc.

Wadset. [L. vadem, a surety.] In Scot. Law, a method of mortgaging landed property, now obsolete.

Waft. (Naut.) Any flag tied together at the head and centre, slightly rolled up lengthways, and hoisted in various positions aft. Hoisted on the flagstaff, or half-way up the peak, it means "a man overboard;" at the peak, "I wish to speak you ; " at the masthead, it recalls boats, or as may have been directed.

Wager of battle. The usage of deciding a civil suit by judicial combat; abolished in 1818 .

Waggon-roofed. (Arch.) Having a roof shaped like a waggon.

Wahabees. In Islam, the followers of Abdel-Wahab, who, in the eighteenth century, raised a strong protest against the corruptions of Mohammedanism. Like Mohammed himself, they spread their opinions by force as well as by persuasion. Like the Western Puritans, they opposed themselves to all splendour and luxury, and forbade tobacco-smoking, as Mohammed had forbidden wine. The sect is still powerful, and may become more formidable.

Wäinämöinen, Epic of. (Kalewala.)

Wainscot. [D. wagen-schot, wag, a wall, scot or schot, like Ger. scheit, split-timber, as if $=$ wall-boards.] 1. In the building trade, a foreign kind of oak, which works very freely under the tool, formerly used in panelling. 2 . Any imitation of it.

Waist. (Naut.) Generally speaking, the space between quarter-deck and forecastle.

Waits, also Waightes. [ $C f$. Ger. wacht, $a$ watching, walking.] 1. A name given to differen $\mathrm{t}$ classes of musical watchmen, employed in towns and in kings' households at different times of English history. 2. A kind of shawm used once by serenaders. 3. Music played in the streets on the nights of Christmas holidays.

Waîwode. In the Turkish empire, the governor of a small province or town.

Wakes. (Dedication, Feast of.)

Waldenses. (Eccl. Hist.) The followers of Peter Waldo, a merchant of Lyons, who in the twelfth century felt himself called upon to preach the pure doctrines of the Bible. They are to be distinguished from the Vaudois on the one hand, and from the Albigenses on the other. (Petrobrusians.)

Waldgraf, Waldgrave. [Ger.] Under the empire, the head forest-keeper, the wildgrave.

Wale-, or Wall-, knot. (Naut.) A large knot made by interlacing the untwisted strands at the end of a rope.

Wales. (Naut.) Extra broad and bulging strakes (q.v.). I.q. Bends.

Walhalla. (Valhalla.)

Wali. [Ar. ouāli.] Prefect, governor.

Walling-wax. A composition used for making a wall round a plate, for holding the acid used in etching.

Walloons. [One of many German names denoting foreigners; $c f$. Wales, Wallachia, Wallenstadt, Wallingford, etc.] (Geog.) The people of the part of Flanders lying between the Scheldt and the Lys.

Wall-piece. (Mil.) Large kind of firearm, from its clumsiness used only from behind the walls of a fortification.

Walpurgis Night. The night of the feast of Walburga, niece of Boniface, or Winfrid, the Apostle of the Germans. On this night the witches were supposed to hold high festival on the summit of the Brocken in the Harz Mountains.

Wambeys. (Gambeson.)

Wampum. [N.-Amer. Ind., from wompi, white.] Shells and shell-beads, used by the N.-American Indians as money, and in making ornamental belts and strings.

Wandering Jew. A legendary being who is said to be sentenced to wander over the earth till the second advent, for reviling Jesus on the way to His crucifixion. The attribute of constant wandering is common in all mythology.

Wane. Cloud, intermediate between cirrus and stratus. (Cirrus.)

Wangan. (Naut.) A Maine provision-boat.

Wanghee. [Chin. wang, yellow, hee, a root. A tough cane, said to be the root of the narrow] leaved bamboo.

Wapenshaw. A showe of reapons, or of the military power of a house or family, made at certain seasons.-Sir W. Scott, Old Mortality.

Wapentake. [A.S. wæpentac.] A territorial division, still retained in Yorkshire ; standing in the place of the division into Hundreds.

\section{War, Private. (Truce of God.)}

Warburtonian Lecture. Founded by Bishop W. (died A.D. 1779), for the defence of revelation by the argument of prophecy fulfilled.

War-caperer. In Naut. parlance, a privateer. Ward. [O.E. weard, guard.] 1. In Feud. Law, the being or condition of the king's tenants-in-chief during their nonage. 2. A projecting ridge inside a lock, to prevent the use of any key not having the corresponding notch.

Warden, Lord, of the Cinque Ports. This office was conferred by William the Conqueror on the Constable of Dover Castle. It is now practically a sinecure. (Cinque ports.)

Wardian case. (From the inventor, Ward.) A closely glazed case for growing delicate plants in large towns, etc. 
Ward-room officers. (Naut.) Those messing in the W.-R., viz. commander, lieutenants, master, chaplain, surgeon, paymaster, marine officers, and assistant-surgeons.

Warehouseman. A wholesale dealcr in Manchester or woollen goods.

Warlock. [A.S. waerloga, one who breaks faith, a wicked one, a liar (Latham).] A wizard, sprite.

Warm colours. Colours having yellow or a yellowish red for a basis.

Warp. [A.S. wearp.] 1. The threads which are stretched lengthways in the loom, and crossed by the woof. Warping is the running yarn off the reels to be tarred. 2. (Naut.) A rope or light hawser used to warp or move a vessel from one berth to another, etc., by making the warp fast to a fixed object, and hauling on it from the vessel. 3. A cast lamb; one born prematurely. 4. (Geog.) Tidal accumulation of marine silt, e.g. west of the Humber, more than 300 square miles in extent. 5. (Agr.) To flood land by means of a tidal river, in order to fertilize it by the deposition of mud.

Warrant. [Containing root of Ger. gewähren.] (Naut.) A writ of authority, inferior to a commission. Brozon paper $W$., one given by a captain, and which he can cancel. WV. officers, masters, surgeons, pursers, boatswains, gunners, carpenters, etc.

Warrant officer. (Mil.) One who ranks between a commissioned and a non-commissioned officer. (Conductor; Master-gunner.)

Warrener. The keeper of a warren, a place for guarding wild animals [from O.H.G. warôn, A.S. warian, to ware, to be careful of ].

Wash. The fermented liquor from which spirit is distilled.

Washer. [Perhaps a corr. of watcher; of the ring called a guard.] (Mech.) A flat ring of an elastic substance interposed between the nut and the body through which the bolt passes; the nut being screwed down, the elasticity of the washer neutralizes its tendency to turn on the bolt when the body is subjected to vibratory movements.

Wash-leather. Split sheepskins dressed with oil in imitation of chamois leather (used for cleaning plate, etc.).

Wassail. [A.S. wes-hál, be in health; health to thee.] An old drinking salutation. Hence the wassail-bowl carried round on New Year's Eve.

Wastrel children. Street Arabs, neglected children of great towns. W., originally = waste, uninclosed ground; now obsolete.

Watch. [Akin to wake.] (Naut.) 1. A ship's company is divided for ordinary deck duty into two parties, called Starboard $W$. and Port $W$., which are subdivided into first and second ; officers are divided into three watches. Anchor $W$., a quarter watch, kept on deck when at single anchor. 2. The periods of time during which a W. remains on deck, viz. four hours each, divided by half-hourly bells, one for first half-hour, two for the next, and so on up to eight bells. $D o g$. $W$, from 4 to 8 p.m., is divided into two watches of two hours each, so as to have a different night-W. every twenty-four hours. First $W_{.}, 8$ p.m. to midnight. Middle $W$., from midnight to 4 a.m. Morning $W$., from $4 \mathrm{a}$.m. to $8 \mathrm{a} . \mathrm{m}$. 3. A buoy floating on the surface is said to watch.

Waterbrash. (Med.) Py̆rōsis, a thin watery vomit ; tasteless or acrid.

Water-carrier. In some Southern countries, water is carried about by porters in skins or other vessels, such carriers being known in India by the name bhisti.

Water-gall. 1. A secondary or outer rainbow. 2. Prismatically coloured patches, produced by refraction of the sun's rays through floating particles of ice.

.Water-gas. An illuminating gas obtained by passing steam over ignited carbon and so decomposing it.

Water-gauge. An instrument for ascertaining the level of the water in the boiler of a steamengine.

Water-gilding. Gilding metallic surfaces by coating them with gold amalgam, and then driving off the mercury by heat.

Water-glass. A soluble silicate, used for covering surfaces with a durable glassy coat.

Watering. Wetting and calendering as cloth, so as to give a lustrous appearance in wavy lines.

Waterlandians. (Eccl. Hist.) A body of Dutch Anabaptists; so called from Waterland, a district in N. Holland. They used the confession of faith drawn up for them in 1580 by John de Ries.

Water-logged. (Naut.) Full of water, but floating.

Water-mark. A mark wrought into paper to show the quality, maker, etc.

Water-ousel. [O.Fr. oisel, = Fr. oiseau, bird, L.L. aucellus, ăvicellus, L. ăvis, a bird.] (Ornith.) Dipper; gen. of bird, Cinclus, runs at bottom of streams. N. hemisphere and Andes. Fam. Cinclìdæ, ord. Passěres.

Water-power. The energy or power of falling water applied to turn machinery.

Water-sail. (Naut.) A small, fair-weather sail, set below the lower studding-sail, or the driver-boom.

Waterscape. [Eng. water, and A.S. scipe, equivalent to the termination -ship.] In Art, a sea-view

Water-shed. [Ger. wasser-scheide, waterparting, shed representing the Gr. $\sigma \chi i \zeta \omega$, ๘ $-\sigma \chi \iota \delta-o \nu$, to cut.] In Geog., the dividing line between the river-basins or drainage areas of a country.

Water-slain. (Agr.) Land too soaked to produce a proper crop.

Water-spout. A column of water consisting of large drops like a dense rain, much agitated and descending or ascending with a spiral motion; carried along at the same time horizontally, and accompanied in general by a sound like that of the dashing of waves.

Water-table. (Dripstone.)

Water-ways. (Naut.) Deck-planks wrought next to the timbers, and serving as gutters to carry water off the deck to the scuppers.

Water-wheel. (Mech.) A wheel set in 
motion by moving water, and driving a train of machinery ; it may be either an Undershot, Overshot, or Breast wheel. The undershotwheel is driven by the impulse of the moving water against the float-boards ; in the overshotwheel the water flows from above into buckets, thereby overweighing the wheel on one side and causing it to turn; in the breast-wheel the water flows into buckets on the lower part of the wheel, and is kept from flowing out of them by a curved trough or breast, within which the buckets move, until they have passed the lowest point.

Watling street. An ancient road connecting Dover with Cardigan. By sailors in the Middle Ages it was used to denote the Milky Way. It is the path of the Wætlinga; but who these were is not known.

Wattling. [A.S. watel, hurdle.] Interweaving twigs.

Wave; Frequency of W. ; Front of W. ; Length of W.; Period of W.; W. surface; W. theory; Velocity of $W$. A vibratory motion transmitted through a medium, each particle of which vibrates, and in doing so causes the particle in front of it to vibrate in like manner; so that a state of displacement travels on continually without limit, while the motion of each particle is a small or at least limited vibration. If we suppose the motion to be transmitted along a tube, there will be at any instant two points in its length the particles between which will have simultaneously the various velocities which each of them has successively : the distance between these points is the Length of the $W_{.}$; the point furthest from the origin is the Front of the $W_{.}$; the distance passed over by the front in a unit of time is the Velocity of the $W$. ; the time in which one particle makes its vibration is the Period of the $W$. ; the number of vibrations made in the unit of time is the Frequency; the length, period, frequency, and velocity being independent of the amplitude of the vibration. If we suppose the wave transmitted in all directions through a medium, the front of the wave will be a surface, in most cases a spherical surface, with its centre in the origin of disturbance. The theory that light is due to the vibrations of the ether is the $W$. theory or Undulatory theory of light ; when light passes through a biaxal crystal, the form of the front of the wave is that of a complicated surface called the $W$. surface. (Vibration.)

Wave offering. Among the Jews, an offering waved by the priest, as a sign that it might be eaten by the worshippers, such offerings as were heaved being appropriated to the priests.

Waveson. (Flotsam.)

Wax-end. A thread pointed with a bristle and covered with shoemaker's wax, used in sewing leather.

Waxing kernels. [A.S. weaxan, to increase.] Small tumours formed by enlarged lymphatic glands.

Wayland smith, popularly $W$. S.'s Cave. A noted cromlech (q.v.) at Ashdown, Berks.

Waymarks. Jer. xxxi. 2 I [Heb. tsiyun, trans- lated title in 2 Kings xxiii. I7]; small stone pillars. Way and "high heaps" = pillars and signposts.

Waywarden. The surveyor of a road.

Weald, The. $\quad[$ A.S., = forest.] Country between the N. and S. Downs, being the chief area of the W. or Wealden group; clays, shales, sandstones, lignite, shelly limestones, etc. ; formed in old lakes or estuary of a great river running west to east.

Wealden. (Weald, The.)

Wealth, a lengthened form of Weal [A.S. wela]. General well-being. So in the Litany of the English Church. In 2 Chron. i. II riches and wealth $=$ money, with happiness, freedom from care.

Wealth of Nations, i.e. Labour. Adam Smith's work, 1776, the first great statement of the principles of political economy, which David Hume had taught in his Political Discourses, I752.

Wear, To. (Naut.) (Veer.)

Weasand. [A.S. wásend.] (Anat.) The windpipe, or trachea (Skeat).

Weasel. (Stoat.)

Weather. (Naut.) The side nearest the wind. Opposed to Lee (q.v.). W. tide, opposite of Lee tide (q.v.). W. gage. (Gage.)

Weather-moulding. (Arch.) A label or Dripstone over a door or window, to prevent the dripping of water.

Web. The thin plate connecting the flanges of a flanged beam.

Webbing. [Eng. web, weave.] A strong hempen fabric two or three inches wide.

Weber. The old name for an Ampère, i.e. the unit of electrical current, from Ampère, the French electrician (1775-1836). It is the current that one Volt can send through one $\mathrm{Ohm}$, or unit of electrical resistance, which is represented by the resistance of a column of mercury of one square millimètre in section, at a temperature of $0^{\circ} \mathrm{C}$., and of a length of 105 centimètres nearly. The unit of electrical quantity is called a Coulomb, from the French electrician so named $(1736-1806)$. It is the quantity of electricity conveyed in one second by one unit of electrical current, or ampère.

Wedge. [A.S. wecg.] 1. A triangular prism. 2. A triangular prism of iron or other material, two of whose faces are inclined at a small angle, capable, when driven by a succession of blows, of separating two masses that are held together by great forces; its action depending mainly on impact and friction, i.e. the impact drives the wedge forward, the friction prevents its return.

Wedging. Cutting clay into wedges, and working it by dashing them together to expel air, etc.

Wedgwood ware. Josiah Wedgwood, of Burslem (died 1795), made many improvements in terra cotta and stoneware; a special instance is his Fasper ware (q.v.) with reliefs in white, and also Queen's ware and Portland vase.

Wedmore, Peace of. (Danelagh.)

Wednesday. (Woden.)

Weeks, Feast of. (Pentecost.) 
Weeping-holes. Those left in retaining walls (q.v.) to drain the earth behind.

Weever. [Cf. Fr. vive.] (Ichth.) Stingfish, Sting-bull, Sea-adder, Sea-viper, Sea-cat ; lesser and greater W. (Trăchĭnus vipěra, T. drăco); two spec. of salt-water bottom fish, five inches and fifteen inches long respectively, with sharp spines on the back and gill-cover, inflicting dangerous wounds. British coasts. Fam. Trăchĭnĭdæ, ord. Ǎcanthoptery̆ğ̌i, subclass Tělěostěĩ.

Weevils. [A.S. wifel ; $c f$. Ger. wiebel.] (Entom.) Rhyncŏphŏra [Gr. póyxos, a snout, фopéw, I wear] (long-snouted); tetrămĕrous beetles. Larvæ very destructive of most vegetable substances.

Weft. (Waft; Woof.)

Weigh, To. (Naut.) To lift or move, to raise up.

Weigh-board. Clay intersecting a vein in mining.

Weigh-bridge. A machine on which loaded carts are placed to determine the weight of the contents.

Weight. [Akin to $L$. vectus, part. of věho, I carry.] 1. A mass by which, as a standard, the quantity of matter in other bodies is ascertained. 2. Quantity of matter measured by the balance. 3. The force exerted by gravity on a given quantity of matter. 4. The force or resistance which it is the purpose of a machine to overcome.

Weight, Combination; Theoretical W. When numerous fallible measures of a quantity have been made, the best value obtainable from the measures is found by multiplying each measure by a certain number and dividing the sum of the products by the sum of the multipliers : these multipliers are the Combination weights. If the combination weights are made inversely proportional to the squares of the probable errors, they are the Theoretival weights.

Weird sisters. (MIyth.) Beings concerned in the inevitable ordering of human things. (Norns.)

Weld. [Ger. wau.] (Bot.) A plant yielding a yellow dye (Resēda luteǒla). (Reseda.)

Welding. [Ger. wellen, to wave, to boil.] Joining two pieces of iron, etc., by hammering them together when heated almost to fusion.

Welk. A tubercular protuberance, generally on the face [(?) $c f$. weal, the mark of a stripe, and A.S. hwele, putrefaction], or because resembling a whelk.

Well. (Naut.) 1. A compartment in the hold, in which the pumps work. Brake of the $W$., handle of pump. To sound the $W$., to ascertain the deptl of water in it. 2. A water-tight compartment in a boat or smack, to keep fish alive in

Welsh harp. 1. One aclopted in early times from the Irish, but strung with gut and hair instead of metal. 2. The modern IV. H:

Welt. [Welsh gwald, $a$ hem.] A narrow strip of leather between the upper leather and sole of a shoe.

Wench. 2 Sam. xvii. 17 ; simply maidservant
[O.E. wenchel, an infant, a child, afterwards a girl]. The word still, in some parts of England, is quite free from any moral connotation.

Wend, To (the past tense is went). (Naut.) Of a course, to pursue it; of a ship or boat, to reverse its position.

Wendish language. An Aryan dialect spoken in Lusatia.

Wentle-trap. [Ger. wendel-treppe, winding staircase.] (Zool.) Scālārǐa [L., staircase]; gen. of mollusc, with spiral shell traversed by ribs, which in the precious W. (S. prětiosa) seem to be the only bond of the successive whorls. Indian and Chinese seas. Fam. Turritellĭdæ, class Gastěrŏpǒda.

\section{Werdand. (Norns.)}

Werewolves. In Myth., men in the form of wolves, which they assume at night or when at a distance from human habitations. Their condition is called Lycanthropy (q.v.).

Wergild. [A.S., fine-payment.] The compensation paid in money to the injured man or to his kinsmen for injuries done to his body, commonly called the were. That of the eorl was usually six times that of the ceorl, or churl.

\section{Wernerian. (Huttonian.)}

Werst. (Verst.)

Wesleyans, Wesleyan Methodists. The fol. lowers of John Wesley, whose society had its origin at Oxford, in 1729. The systematic arrangement of their work gained for them the name of Methodists, in allusion to the Methodici, a class of physicians at Rome who practised only by theory. The society became ultimately nonconformist.

Western empire. The name given to the western portion of the Roman empire after it was divided, by the will of Theodosius, A.D. 395, between his sons Honorius and Arcadius.

Westminster Assembly. Held on July I, I643; convoked by an ordinance of Lords and Commons, to consider Church doctrine and government. The W. A. drew up the W. Confession, or Confession of Faith of the Kirk of Scotland, and the National Covenant.

\section{Westminster Confession. (Confession of} Faith.)

Westphalia, Peace of. (Thirty Years' War.)

West Point. A fortress built during the War of Independenee, site of the U.S. Military Academy, on right bank of River Hudson, fiftytwo miles north of New York.

Wey. [A.S. wáge (Skeat).] Of wool, I3 stones, or 182 pounds.

Whale. [Heb. tannên (Dragon).] (Bibl.) Used loosely of monstrous, especially of aquatic, animals ; but in Lam. iv. 33 "sea-monsters" (Authorized Version) are distinctly cetaceans, or sirenians.

Whale-boat. (Naut.) One sharp at both ends and very strongly built ; it varies in length from twenty-six to fifty-six feet, and in beam from four to ten feet, and is used for harpooning whales from.

Whalebone. A firm elastic substance from the upper jaw of the whale. 
Wharfag. The fee paid for landing goods on a wharf, or for shipping them off it.

Wharp. A fine sand from the banks of the Trent, used for polishing.

Whatnot (from its holding odds and ends). (Etagère.)

Wheel. [A.S. hweól.] (Naut.) One fitted with a barrel or axle, round which the tiller ropes (or chains) work, and the revolutions of which thus regulate the position of the rudder.

Wheel, Potter's. A wooden disc revolving on the top of a vertical shaft, for shaping clay.

Wheel-barometer. A weather-glass. (Barometer.)

Wheel-lock. (Mil.) Ancient method of firing by a wheel and chain acting on a spring, which, on the wheel revolving, struck fire from the flint and ignited the priming.

Wheel of life. (Phenakistoscope.)

Wheft. (Waft.)

Wherry. [Icel. hverfr, crank, lightly built (Skeat).] (Naut.) 1. A light row-boat. 2. A decked boat used on the coasts of the United Kingdom for fishing. 3. A boat of burden on the rivers of the east coast, rigged with a large pole-mast, on which is set an enormous gaffsail. It is as large as sixty tons burthen, is worked by one or two men, draws very little water, requires very little wind, and will sail almost into the wind's eye.

\section{Whiffletree. (Singletree.)}

Whiggamore. (Whigs.)

Whigs. (Eng. Ifist.) The name of a political party, first employed in the time of Charles II., and afterwards assumed by those who were most active in placing William III. on the throne. The origin of the name is doubtful. Defoe refers it to a drink composed of water and sour milk; Bishop Burnet to a word used in criving horses in Scotland, the drivers being hence called Whiggamores. (Abhorrers; Tory.)

Whim, Whim-gin, Whimsey. (Mech.) A large capstan or windlass worked by horse or steam power, for raising ore, etc., from mines.

Whimple. To draw down, as a veil. (Wimple.)

Whimwham (a reduplication of whim). A trifle, trinket, gimcrack.

Whin, Whinstone. With Scotch miners, i.q. Greenstone, and less strictly any hard, resisting rock.

Whip. (Naut.) A rope passing through a single block, to hoist by.

Whips, Whippers-in. In the House of Commons, those who hunt up members when special votes are needed.

Whirl-bone. In the hinder quarters of the horse, the hip-joint, or round.

Whirling-table. (Mech.) An apparatus for exhibiting the propertics of central forces ; consisting essentially of a flat wheel, by whose rotation a very rapid rotation is communicated to a second wheel, on which the phenomena in question are exhibited.

Whirlpool. In the margin of Job xli. I ; retains an earlier meaning of large whale, or seamonster.
Whirlwind. A storm in which the wind moves rapidly in a circle whose centre moves forward.

Whisk. A cooper's plane.

Whiskey, Timwhiskey. Light one-horse carriage.

Whisky War. An attack made by some women a few years ago, in a village of Ohio, upon the public-houses, the spirits being thrown into the streets, to remove temptation from their husbands; out of which sprang the American Women's Temperance Christian Union; and the Blue Ribbon movement of 1878 .

Whispering gallery. A gallery surrounding a dome and exhibiting at any one point the phenomenon of concentration by reflexion of soundwaves that have been emitted at the opposite point; so that low articulate sounds are heard across the dome that would not, under ordinary circumstances, be audible at the same distance in the open air.

\section{White ant. (Termites.)}

Whitebait. (Ichth.) True character much disputed, whether (Giinther, 1880) the fry of many spec. (intermixed with sticklebacks, Gastěrostěus) or (Wood, I87I) an independent spec. of the herring tribe; Clüpěa alba, fam. Clŭpěrdæ, ord. Phȳsostŏmi, sub-class Tělěostěĩ.

Whiteboy. 1. Originally a petted favourite. 2. A name, in later years, by way of euphemism, assumed by or given to perpetrators of agrarian outrages in Ireland.-Trench, Select Glossary. (Tory.)

\section{White Canons. (Premonstratensians.)}

White Eagle, Order of the. A Polish order of knighthood, instituted, 1325 , by Vladislas V.

White elephant. An elephant of a whitish colour, rarely found, and offered as presents to sovereigns, etc. ; useless if offered to those who cannot use or keep them. Hence a burdensome or perplexing gift. The King of Assam is called Lord of the White Elephant, his subjects not being allowed to own white elephants.

White feather. A white feather in the tail of a game-cock was taken as a sign that he was not of a true game breed. Hence to show the white feather is to betray cowardice.

Whitefieldian Methodists. Methodists who followed George Whitefield, a friend and for a time a fellow-labourer of John Wesley. (Wesleyans.)

\section{White Friars. (Carmelites.)}

Whitehall. A palace which became royal property by a deed of resignation from Cardinal Wolsey to Henry VIII., I 530, up to which time, since 1248, it had been known as York Place, the town residence of the Archbishops of York. The old banqueting-hall was burnt 1619; the structure of Inigo Jones was completed 1622 . Destroyed by fire 1698 , the banqueting-hall, through which Charles I. passed to his execution, being preserved, and turned into a royal chapel 1715 .

White horse, scouring of the. The ceremony of cleaning out the gigantic figure of a horse cut out by the Danes on the turf of the Berkshire downs. - Tom Brown's School-Day:. 
White House. The official residence of the President of the United States, at Washing. ton.

White Penitents. (Penitents.)

Whitesmith. One who works in white or tinned iron.

White squall. (Squall, White.)

White staff. The wand of the Lord High

Treasurer.

Whiting. Ground and purified chalk.

Whitleather (i.e. white leather). A pliable leather dressed with alum, salt, etc.

Whitlow. [(?) From an older form, whickflaw, a flaw or sore about the quick of the nail.] (Med.) A painful inflammation, tending to suppuration, of the finger or toe, generally of the last phalanx.

Whitsunday. The Seventh Sunday, or fiftieth day, inclusive, after Easter, so corresponding with Pentecost. There is no doubt that Whitsunday is White Sunday, so called from the white robes of the persons baptized on that day. The earliest known form of the word is hwita Sunnen-dag, which is found in the old English Chronicle under the year 1067. See the letters of Professor Skeat and Mr. Evan Daniel in the Guardian for November 29, I882.

Wholesome ship. (Naut.) One that will try (q.v.), hull, and ride well.

Whorl. (Verticel.)

Why-not. A violent step taken without reason given.

\section{When the Church
Was taken with a why-not in the lurch.} Butler, Hudibras.

Wigwam. [A corr. of the N.-Amer. Ind. word for house or abode.] An Indian cabin or hut.

Wilkina, Vilkina, Saga. (Sagas.)

Willis's Rooms. (Almack's.)

Will-o'-the-wisp. (Ignis fatuus.)

Willow. [Corr. from winnow.] (Mech.) A conical wheel covered with spikes, revolving within a box studded with similar spikes, for opening and cleansing cotton.

Willy. (Mech.) A machine like a willow, for cleansing wool. (Willow.)

Wilton carpet (from the town). A carpet woven with loops which are afterwards cut open into an elastic velvet pile.

Wimple. [Fr. guimpe, from O.H.G. wimpal.] 1. In Isa. iii. 22 ; a veil, shawl. 2. A covering of silk or linen, for the neck, chin, and cheeks, formerly worn by women generally, and still retained by those of religious communities in the Latin Church.

Winch. [A.S. wince.] A handle for turning an axle, grindstone, coffee-mill, etc.

Winchester bushel. The Winchester measure of capacity, of 2150.42 cubic inches, which long held its ground against the Windsor, or royal, bushel. It is still used in the United States.

Winoing-machine. [A.S. wince, a winch.] A kind of reel for lowering cloth into a dyer's vat.

Wind. A word common to many Aryan lan- guages, denoting air in motion. Each wind had at first its special name. Thus Borěas was the north, Auster and Nŏtŏs the south, Eurus the east, Zephyr the west wind. They had also names according to the strength with which they blew : the lighter puffing breezes being called in Skt. Pavana, in Gr. Pan, in L. Favônius (perhaps Faunus); the stronger winds were represented by Hermes and Orpheus. (EDolian; Euroclydon.)

Wind, To. (Nrut.) (Wend, To.)

Windage. (Mil.) The excess of the diameter of the bore of a gun over the diameter of the shot.

Wind and water, Between. (Naut.) On the water-line. In speaking of gates, posts, etc. on the ground-line.

Windgall. In a horse. (Spavin.)

Windlass. [Cf. D. windaas.] 1. An axle turned by a winch or by levers, for raising a weight that hangs from the end of a rope which is gradually wound on to the axle. (Differential.) 2. (Naut.) A machine resembling a horizontal capstan, in the fore part of a ship, by which she can ride; used for raising the cable.

Windlestraws. [A.S. windel-streow, straw for plaiting, windan, to wind.] (Agr.) Bents.

Windrow. To arrange in lines or windrows, as newly cut hay.

Wind-sail. (Naut.) A canvas funnel to convey fresh air below.

Windsor bushel. (Winchester bushel.)

Windsor Castle. A royal palace, begun by William the Conqueror, who held his court there, 1070. St. George's Chapel was begun by Edward IV., and completed by Henry VIII.

Windsor chair. A strong, plain, polished wooden chair, with the seat hollowed out.

Windward. I.q. zueather (q.v.).

Wing. 1. (Mil.) The two halves of which any body of troops are composed. 2. The bullion shoulder ornaments formerly worn by grenadiers and light infantry. 3. (Naut.) The part of the orlop-deck and hold next the ship's side. (Sponson.)

Wings. (Ornith.) The wing of the bird being constructed on the same fundamental plan as the human arm, we employ the terms by which the arm is described, in designating the feathers of the wing. The Primaries, then, are those long quill feathers which spring from the fingers, the Secondaries spring from the wrist-end of the forearm, the Tertiaries from its elbozv-end; these together form the R'èmiges [L. for rowers]. The Scapulars cover the upper bone of the arm and the shoulder-blade [L. scăpŭla]; the Aluila, or bastard wing, is carried on a rudimentary "thumb" (sometimes provided with a claw) at the wrist. The Wing coverts (greater, less, and under) are those which cover the bases of the quill feathers.

Wing-shells. (Aviculidæ.)

Winter-proud. (Agr.) Having too forward or rank a growth for winter.

Winze. In Mining, a small ventilating shaft sunk from one level to another.

Wiper. A Cam. (Tappet.) 
Wirepuller. The comparatively unseen, but really efficient, agent in some practical matter.

Wireworms. (Entom.) Larvæ of the spring

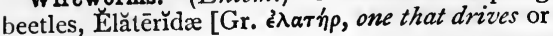
impels].

Wisby, Ordinances of. A code of maritime law; so named from Wisby, a town in the Isle of Gothland; compiled chiefly from the laws of Oleron, before the end of the fourteenth century. (Amalfian Code; Oleron, Laws of.)

Wisdom teeth. [L. dentes sapientræ.] (Anat.) The third or hindmost molars; because, 1, not appearing before nearly adult age, generally from the eighteenth to the twentieth year; or 2,

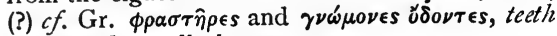
that mark or tell the age.

Wise Men of Greece, The Seven. (Rishis, The Seven.)

Wish. In Teut. Myth., the embodiment of actual enjoyment as distinguished from mere longing. In the Edda, the word occurs in the form Oski. Hence oska-stein, a wishing-stone;

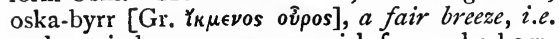
such a wind as a man may wish for; oska-barn, a wish-child.

\section{Wish-maidens. (Valkyries.)}

Wităna-gemot. [A.S., the meeting of the wise $m e n$.] The English national assembly before the Norman Conquest.

Withdrawal of a juror. A means of stopping a trial, when it is desired to do so, without carrying it as to a decision; the complete number of jurors being essentially necessary. Matters then ramain just where they were before the trial began.

Withers. [A.S. wiðer, Ger. wider-rist, withers, acting against, Ger. wider, the weight of the carriage, etc.] Of a horse, the junction of the shoulder-bones at the bottom of the neck and mane.

Withershins. In Scotland this word, the Ger. wieder-schein, or reflexion in the water, is or was used to denote the wrong way of going round a person who was to be restored to health from sickness. The leech moved from east to west, according to the course of the sun. The opposite movement was unlucky.

Without prejudice. (Leg.) When a difference has arisen between two parties, and a proposal is made by one to the other with a view to compromise, the stipulation that it is made rvithout prejudice means that, if the attempt should fall through, no prejudicial use is to be made of the admitted evidence.

Wittenagemote. (Witana-gemot.)

Woad, Woold, Weld, Dyer's woad. [A.S. wád.] (Bot.) Isătis tinctoria, ord. Cruciferæ; formerly much cultivated in Britain for the blue dye obtained from the leaves, with which the ancient Britons are said to have painted themselves; important before the introduction of indigo.

Woden. In Teut. Myth., the king or father of gods and men. The name survives in our Wednesday. Woden was to reign in Asgard, or the home of the Esir (Asuras), until the twilight of the gods should bring the present order of things to an end.
Wold. [A.S. weald, wald, forest.] 1. Plain, open country. 2. (Geol.) Wolds and downs = the hills of the chalk country of Yorkshire, Lincolnshire, and Norfolk.

Wolf intervals. (Music.) In organs, the bad fifths and thirds in keys-such as A $b, D b$-on which the imperfections are thrown, when an organ is tuned from $\mathrm{C}$ on the unequal temperament; so called from a sort of howling effect. (Temperament.)

Wolfram. [Ger.] An ore of tungsten and iron.

Wombat. (? Native name.) (Zool.) Australian

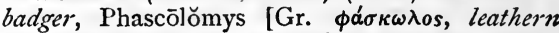
$b a g, \mu v \hat{s}$, mouse]; a gen. of marsupial rodents, about the size of a badger, heavily built, with mottled-grey fur.

\section{Wonderful Doctor. (Doctor.)}

Wonders of the world. Seven buildings were included under this title-the Egyptian pyramids, the temple of Artemis at Ephesus, the Colossus of Rhodes, the hanging gardens of Babylon, the mausoleum of Artemisia, the statue of the Olympian Zeus by Pheidias, and the Rhodian pharos or watch-tower. There is no doubt that the number was suggested by that of the wise men, or of the stars of the Great Bear.

\section{(Rishis, The Seven.)}

\section{Woodmote. (Forest courts.)}

Woodruff, Woodroof. [Possibly from wood, i.e. forest, and ruft, i.e. verticel (Skeat).] (Bot.) Aspěrǔla; a gen. of plants, ord. Rubiaceæ. Sweet $W$., A. ŏdōrāta, a native perennial, in shady woods, white-flowered, with whorled leaves, scented like hay. (Coumarin ; Maitrank.) Wood's halfpence. (Drapier's Letters.)

Woof. [A.S. wefan, to weave.] The threads which cross the warp from side to side.

Woolfell (written also Woolfel). [From wool and fell, L. pellis, a skin.] A skin with the wool on it.

Woolsack. The seat of the Lord Chancellor in the House of Lords; said to be so called as having been at first simply a square bag of wool.

Woolstapler. [Ger. stapel, a mast.] A dealer in wcol, or a sorter of wools. (Staples.)

Woolstock. A heavy wooden hammer used in fulling cloth.

Woolwich and Reading beds. (Geol.) Tertiary clays and sands, between the Thanet sands and the London clay, and extending into France, l argile plastique, etc. ; of fresh-water or estuarine origin ; the upper beds become the Oldhaven formation in the $\mathrm{I}$. of Thanet.

Woorali. (Curari.)

Work; Unit of $\mathbf{W}$. The result of exerting a force whose point of application moves wholly or partly in the direction of the force. A Unit of $W$. is the work done when a force of one unit acts at a point which moves through a unit of distance in the direction of the force. (Footpound.)

Working party. (Mil.) Troops told off either from the engineers or infantry, for digging military works, provided with pick-axes, shovels, and rammers. 
Work up the dead horse, To. (Advance money.)

Worm (from its shape). A spiral metallic pipe placed in a tub of water, to condense the vapour which passes through it from the still.

Worm and wheel. (Mech.) An endless screw. Wormwood. (Artemisia.)

Worsted. (From Worsted, a village in Norfolk.) Well-twisted yarn spun of wool with a long staple, which has been combed to lay the fibres parallel.

Wort. [A.S. wyrt.] 1. Herb, plant; very common in composition, as spleen-wort, birthwort, etc. 2. Decoction of barley.

Worthies of England. The work of a quaint old writer, Thomas Fuller, chaplain to the royalist forces in the Civil War.

Woulff's bottle. A bottle with several necks, used by chemists (from the inventor).

Wourali. (Curari.)

Wove paper. Writing-paper having an even surface without lines or water-mark.

Wrack-grass. (Zostera.)

Wraith. An apparition; formerly supposed to be that of a guardian angel. The word in Scotland was spelt warth, which brings us to ward, guard (Skeat).

Wranglers. A name (derived probably from the obsolete public disputations of candidates for degrees) applied at Cambridge to those who are placed in the first class of honours in the final mathematical examinations.

Wreath. [A.S. wrædh.] The circlet on which the crest stands, formed of two twisted silk cords, one tinctured as the principal metal in the escutcheon, the other as the principal colour.

Wreck. [Ger. wrecken, to zorack.] The vessel in which ores are washed for the thurd time.

Wrench. [Allied to wring, A.S. wringan, to strain.] A tool for tightening nuts, etc.

Wrest. [A.S. wrástan, to wrest.] A key to tighten the strings of the harp, piano, etc. ; the badge of a minstrel's profession in feudal times.

Wretchlessness. In Art. xvii., "On Predestination;" a corr. of recklessness.

Writers to the Signet. (Signet, Privy.)

Wrongous Imprisonment Act, or Scotch Haleas Corpus, I701, extends to Scotland the same protection which the Habeas Corpus gives in England.

W.s. Writer to the Signet. (Abbreviations.)

Wurtemberg Confession. A Protestant confession of faith, drawn up at Wurtemberg, in 15.52 .

Wyatt's Rebellion. In February, I 554; that of Sir Thomas Wyatt (executed) and the men of Kent ; to resist the marriage of Queen Mary with Philip of Spain.

\section{Wyclif's Bible. (Bible, English.)}

Wye, or Y. (Mech.) One of the supports of the axle of a transit telescope, theodolite telescope, etc. ; so called from its shape.

Wynd. [A.S. windan, to wind or turn.] A narrow lane or alley.-Scott, Fair Maid of Perth.

Wyvern. [O.Fr. vivre, a viper.] (Her.) An heraldic animal, in the form of a two-legged dragon.
X. As a Roman numeral, denotes ro. Xanth-, Xantho-. [Gr. $\xi \alpha \nu \theta \delta s, y e l l o w$.

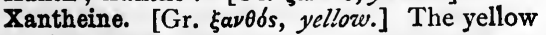
colouring matter of flowers.

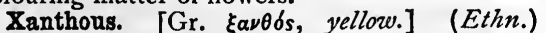
Fair-haired ; Melanic, dark-haired [ $\mu \in \hat{\lambda}$ as, blaik,

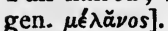

Xebec, or Zebeo. [An Ar. word.] (Naut.) A small three-masted Mediterranean vessel, with a very projecting bow and overhanging stern, generally equipped as a corsair; a Barbary xebec was square-rigged on the foremast.

Xeres. Wine from Xeres, in Spain ; sherris, sherry.

Xeringue. A kind of caoutchouc.
Xēro-. [Gr. §ॄpós, dry.]

Xeque. The Sp. form of the Ar. Scheik.

Xiphias. [Gr. $\xi$ pías, id., $\xi^{\prime} \phi o s, a$ sword.] (Swordfish.)

Xylography. [Gr. $\xi u ́ \lambda o \nu, w o o d, \gamma \rho a ́ \neq \omega, I$ zurite, or draw.] The art of engraving on wood.

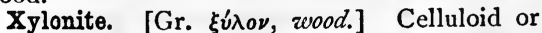
solidified gun-cotton. Used for making billiardballs, etc.

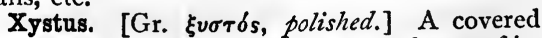
colonnade ; so called from the smoothness of its floor; used by the Greeks as a training-place for wrestlers. 


\section{Y.}

7. 1. With $\mathrm{V}$ and $\mathrm{S}$, makes up the three letters represented by the Greek digamma. 2. (Wye.)

Yacca-wood (from name of tree). A palebrown W.-Indian wood, used for cabinet-work.

Yagers. [Ger. jagers, hunters.] In the German army, light infantry armed with rifles.

Yahoos. The name under which men are degraded to the rank of filthy brutes in the fictitious country of the Houyhnhnms, which Gulliver visited in his last voyage; where the reasoning and ruling beings are the horses.

Yajur Veda. (Veda.)

Yam. [Probably an African word.] Article of food in tropical countries, the tuberous root of Dioscorea, a twining shrub, type of ord. Dioscoreaceæ. D. ālāta, common W.-Indian yam ; its tubers weigh sometimes thirty pounds. It resembles the potato.

Yankee. The form assumed by the word $E n g$ lish as pronounced by the Indians of N. America.

Yarabatana. (Mil.) An air-gun used by the Indians in S. America for projecting small arrows through a tube.

Yard. [A.S. gyrd, a rod.] 1. The fundamental English unit of length; it is the distance between two marks on a certain bar kept in the Exchequer Office in London, when the temperature is $62^{\circ} \mathrm{Fahr}$. 2. (Naut.) A long spar suspended from a mast to spread a sail. Y.-arms, its extremities. $Y_{\text {-arm }}$ and $Y_{\text {. }}$-arm, said of two vessels close alongside. Cross-jack $Y$., that on the foremast of a fore-and-aft schooner.

Yarr. (Spurrey, Common.)

Yataghan. (Mil.) Long Turkish dagger with metal scabbard, worn in the belt.

Yaw. (Naut.) Temporary deviation of a vessel from its right course.

Yawl. [D. jol; $c f$. jolly-boat.] (Naut.) 1. A man-of-war's boat, like a pinnace, but smaller. 2. A carvel-built vessel, like a cutter, but having a jigger lugsail. 3. A small fishing-vessel.

Yaws. (Med.) Frambœsia [Fr. framboise, $a$ raspberry], a skin-disease marked by raspberrylike excrescences; endemic in some tropical countries.

Y-cleped, Y-clept. [A.S. geclipôd, part. of cleopian, to call.] Called, named.

Yean. [A.S. eanian.] To bring forth young; to lamb.

Yeanling (from yean). The young of a sheep, or lamb.

Year; Anomalistio Y.; Bissextile Y.; Christian Y.; Civil Y.; Common Y.; Gregorian Y.; Julian Y.; Leap Y.; Iunar Y.; Sidereal Y.; Solar Y.; Tropical Y. [A.S. géar ; $c f$. Gr. ఓpas, ఓpa.] An interval of time determined by the proper motion of the sun, i.e. by the revolution of the earth in her orbit. The Sidereal $Y$. is the interval between two successive returns of the sun to the same point of space, its length being 365 days 6 hrs. 9 mins. $9 \cdot 6$ secs. mean solar units. The Anomalistic $Y$. is the interval between two successive returns of the earth to perihelion, its length being 365 days 6 hrs. 13 mins. $49^{\circ} 3$ secs. mean solar units. The Tropical $Y$., called also a Solar $Y$., is the interval between two successive returns of the sun to the first point of Aries, its length being 365 days 5 hrs. 48 mins. $49 \% 7$ secs. mean solar units. The Civil $Y$. is that adopted in common life for the computation of time ; it consists of 365 days, with an additional day added now and then to keep it right with the tropical year, which regulates the seasons; the year in which the additional day is inserted is the Bissextile or Leap $Y$. A Common $Y$. is a year of $3^{6} 5$ days; a Lunar $Y$. is twelve lunar months. (For Gregorian and Julian Y., vide Calendar.) The Christian $Y$. begins with Advent.

Year-books. The oldest extant English reports, from Edward II. to Henry VIII. inclusive ; but not without interruptions.

Yellow admiral. (Naut.) A retired postcaptain who, not having served his time as such, cannot be promoted to flag rank.

Yellow arsenic. (Orpiment.)

Yellow flag. (Naut.) Signal of quarantine. A black disc or square in its centre means plague or other disease on board.

Yellowing. (Naut.) Passing over captains at a flag promotion.

Yellowstone National Park. An area of 3575 square miles (i.e. a little larger than Norfolk and Suffolk) about the sources of the Yellow River, in Montana and Wyoming; withdrawn by U.S. Congress, February, I872, "from settlement, occupancy, or sale," and set apart as a public park for the people for ever. General elevation, 7000 to 8000 feet, with mountains 10,060 to I2,000 feet; and having deep gorges, snowy sierras, great lakes, and geysers.

Yeoman. (Naut.) The man in charge of a storeroom.

Yeoman of the guard. [Cf. Ger. gau, country district.] 1. (Mil.) One of a corps in attendance on the sovereign, instituted A.D. I485, officered, with the exception of the commander, who is a nobleman, by retired officers from the army. 2. $\mathrm{Y}$, in north of England, i.q. statesman (q.v.).

Yeoman's service. As in Hamlet, act v. sc. 2 ; the faithful service in war rendered by the yeomen or small freeholders: the mass of the infantry being composed of "good yeomen" (Henry V., act iii. sc. I). "The middle people of England make good soldiers, which the peasants of France do not: ... and herein the device of King Henry VII. was profound . . . to keep the plough in the hands of the owners" (Bacon's Essays: Of Kingdoms and Estates).

Yezdigird, Era of. An era beginning June 16, 632 .

Yezidis. (Jezids.)

Yggdrăsil. In Teut. and Scand. Myth., the ash tree which has its roots in Niflheim, the home of the clouds or mists, and whose branches 
embrace the whole world. The origin of the name is disputed.

Yoicks! A cry of encouragement to foxhounds while drawing; (?) a corr. of Fr. oyez! oyez! i.e. listen to the dogs. Dame Juliana Berners mentions, in her Book of Hunting (fifteenth century), the cry, "Oyez, oyez à Bemounde," the name of a hound. (Tally ho!)

Young England. A name of the last generation, designating those who, mostly young men of culture and position, looking down upon commercial tastes and employments, affected or seemed to affect a return to mediæval manners.
Yow-yow. A smaller sampaan (q.v.).

Yttrium, Terbium, Erbium. Rare metals found at Ytterby, in Sweden.

Yucca (its name in St. Domingo). (Bot.) A gen. of Liliāceæ; N. and S. America. Y. gloriōsa is common Adam's needle, cultivated in England, having sword-shaped evergreen leaves, and a large branching panicle of whitish flowers.

Yugs. (Jogues.)

Yule. [A.S. iula.] The Scotch name for Christmas.
Z. A letter representing the sounds $d s$ or $t s$, and therefore a double letter.

Zabaism. (Sabaism.)

Zaffre. [Ar. saphre, sapphire.] (Chem.) An impure oxide of cobalt, used in making smalt.

Zaim. A Turkish chief of a mounted militia bearing the same name.

Zany. [It. zanni = Giovanni, merry John ; cf. merry-Andrew.] A buffoon.

\section{Zaphara. (Zaffre.)}

Zarnich. (Orpiment.)

Zax. [A.S. seax, a knife.] A tool for cutting slate.

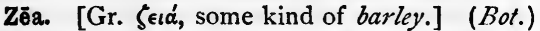
Maize; a gen. of plants, probably American. Certainly cultivated by the Indians when the New World was discovered. Ord. Grāmināceæ. Common M., or Indian corn, is Z. mays, the most productive of cereals, much grown in $\mathrm{S}$. Europe. (Hominy.)

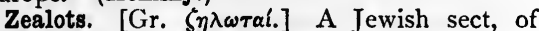
the Maccabean age, specially vehement in their defence of the Law. (Canaanite.)

Zeboc. (Xebec.)

Zebu. (Zool.) Bos Indicus; the humped cattle of E. Africa, India, China; various breeds, ranging from about two feet high to the full size of the ordinary ox.

\section{Zecchino. (Sequin.)}

Zechstein. [Ger., mine-stcne; cf. zax.] (Geol.) To be cut through before the copper slate is reached; the equivalent of the limestone of the Permian age, in north of England. (Zax.)

Zedoary. A fragrant, bitter, aromatic stimulant, from the root of the Curcuma zerumbet, of the E. Indies. Ord. Zingiberacex. Given in cramp, colic, torpor, etc. Called also the broad-leaved turmeric.

Zeit-geist. [Ger.] Spirit of the age.

Zemindars. [Hind., from Pers. zemin, land.] The great landowners of the Mogul empire. The nature of their tenure has been much disputed.

Zenāna. A Pers. word, probably the same as the Gr. ruvaikív, the part of the house set apart for the women. (Harem.)

Zend-Avesta. The sacred books embodying hand. the religious system of Zoroaster, avesta meaning $a$ settled text. (Ahriman.)

Zendiks. In Arabia, a name given to atheists or sorcerers.

Zendism. The same as Zoroastrianism, or the religion of Zoroaster. (Ahriman.)

Zenith; Z. distance; Z. sector; Z. telescope. (A corr. of Ar. sanit, road, tract, whence also Azimuth.) The point vertically overhead, in which the plumb-line produced would meet the great sphere. The $Z$. distance of a heavenly body is its angular distance from the $Z$. measured along a vertical circle. A $Z$. sector is a telescope furnished with an arc of a few degrees very exactly graduated, and mounted so as to measure the meridian- $Z$. distances of stars near the $Z$. of the station; the positions of such stars are very little affected by atmospheric refraction, and are therefore proper to be used for the very accurate determination of the latitude of the station. A $Z$. telescope is capable of being set to any $Z$. distance and of turning round a long and very firm vertical axis; in the focus are the usual five wires and a micrometer wire capable of reading up to (say) $45^{\prime}$; two stars are used that come on to the meridian nearly together and on opposite sides of the zenith; the instrument is reversed between the two observations, and the latitude is inferred from the difference of the readings and the known north polar distances of the stars.

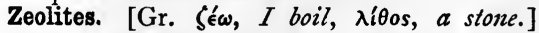
(Geol.) Hydrated silicates of alumina; e.g. natrolite, mesotype, etc., found in the cavities of volcanic rocks.

Zephyr. The zvest wind; so called as blowing from the west, the land of darkness, the

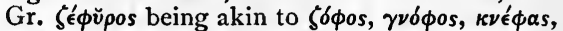
$\nu \in \phi \in \lambda \eta$, L. nübes, words denoting gloom, mist, and cloud.

Zephyr cloth. A light waterproof material made in Belgium.

\section{Zerda. (Lycaon.)}

Zereth. [Heb.] A Jewish measure of length ; a span, between the extremities of the extended 
Zernabog, Zernebock. (Tschernibog.)

Zero. [It. zefiro, Ar. sifr, cipher.] The point from which a graduation begins; as the zero or zero-point of a thermometer.

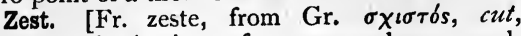
cloven.] 1. A piece of orange or lemon peel, used for flavouring liquor. Hence, 2, relish, enthusiasm.

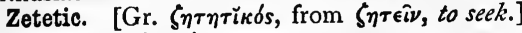
Advancing by inquiry.

Zeus Hŏrios. (Terminalia.)

Zeus Horkios. (Semo Sancus.)

Zeus Pistios. (Semo Sancus.)

Ziega. [Ger, zieger.] Curd made with acetic acid after rennet has ceased to coagulate the milk.

Zif. [Heb., blossom.] I Kings vi. 37 ; eighth month of civil, second of ecclesiastical, Jewish year; April-May.

Zillah. [Hind. zilâ.] In India, the district of a commissioner or circuit judge.

Zincode. [Zinc, and Gr. ósos, a way.] (Chem.) The positive pole of a galvanic battery.

Zincography. [Zinc, and Gr. $\gamma \rho a ́ \phi \omega, I$ write, or draw.] Engraving on zinc in the style of woodcuts.

\section{Ziogoon. (Tycoon.)}

Zirconium. A very rare metal, obtained as a black powder from zircon (native name of a Cingalese earth)

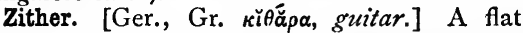
stringed instrument, with twenty-eight brass strings, played with the right thumb, a plectrum bringing out the melody.

Zizel. (Zool.) The pouched marmot, a rodent, differing from the marmot proper, in having cheek-pouches, and in not being gregarious. N. hemisphere. Spermŏphǐlus [Gr. $\sigma \pi \epsilon \rho^{\prime} \mu \alpha$, seed, $\phi \iota \lambda \epsilon ́ \omega, I$ love], fam. Scūūrĭdæ.

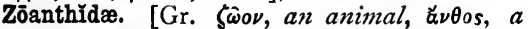
flower.] (Zool.) Fam. of polypes, comprising the black corals and madrepores.

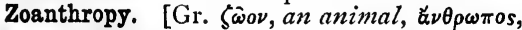
a man.] A name devised for the madness which sometimes makes men fancy themselves changed into brute animals.

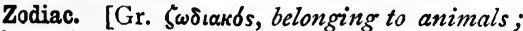

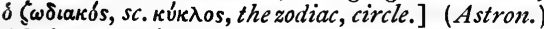
A belt or zone in the heavens, whose general direction is that of the ecliptic, and within which the sun, moon, and planets have their proper motions; the stars within the belt are divided into twelve constellations, the Ram, the Bull, the Twins, etc., which are more commonly known by their Latin names, Aries, Taurus, Gemini, etc. In the time of the Greek astronomers the sun entered Aries at about the time of the vernal equinox ; but now, in consequence of precession, he is not in the neighbourhood of the bright star of the Ram (a Ariětis) till towards the end of April ; the vernal equinox is, however, still called the First point of Aries.

Zodiacal light. A light of a lenticular shape, seen after sunset in the months of March, April, and May; extending not less than $40^{\circ}$ from the sun obliquely upward, and following the general course of the ecliptic.

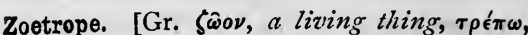
I turn.] A contrivance for producing the appearance of motion in figures by rotating plates. (Anorthoscope.)

Zohak. In the Shahnamah of Firdusi, a tyrant who has serpents growing from his shoulders, and who is slain by Feridun. The name is a contraction from the Zend Azi-dahaka, the biting snake, representing the Vedic Ahi (Vritra) and Dahak, the biter [Gr. $\delta a ́ k \nu \omega$, to bite].

Zohar. [Heb., splendour.] A cabalistic commentary on the Pentateuch, of uncertain date, but supposed to be of great antiquity. (Talmud.)

Zoilism. Captious criticism, like that of Zoilus, a Greek rhetorician of the fourth century B.C.

Zollverein. [Ger., toll-union.] A fiscal union of German states, formed at Munich, August 23, 1837 , and greatly enlarged in 1866 .

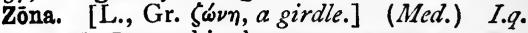
Herpes zōstēr, or shingles.

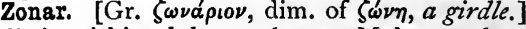
A distinguishing belt worn by non-Mohammedans in the Levant.

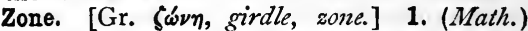
A portion of a surface of revolution, as of a sphere, included between two planes at right angles to its axis. 2. (Geog.) Portions of the earth's surface bounded by the Arctic and Ant. arctic circles and by the tropics of Cancer and Capricorn: they are five in number, viz. an Arctic and an Antarctic Z., extending about $23^{\circ} 28^{\prime}$ from the North and South Poles, at any place within which there will be certain days on which the sun does not rise and others on which he does not set; a Torrid Z., extending $23^{\circ} 28^{\prime}$ on either side of the equator, at every place within which the sun is vertically overhead at midday twice a year; and two intermediate Temperate zones, one in the northern, the other in the southern hemisphere.

Zone; Z. circle; Axis of Z. (Crystallog.) When three or more faces of a crystal have their poles in a great circle of the sphere of projection, they form a $\mathrm{Z}$. ; the great circle is the $Z$. circle; the diameter at right angles to the plane of the $Z$. circle is the Axis of the $Z$.

Zone of variable temperature. The sun is found to affect rocks to a depth of about ninety feet ; and this upper ninety feet is known as the Z. of V. T.

Zoo-. [Gr. Swo-, living.]

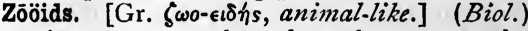
Organisms more or less dependent upon the parent organism, produced by gemmation, or fission; as the separated portions of hydra.

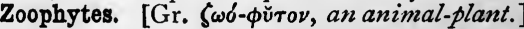
(Zool.) General name for plant-like animals; as sponges (Prōtōzōa), corals and sea-anemones (Cœlentěrāta), and sea-mats (Polȳzōa).

\section{Zoroaster. (Ahriman.)}

Zōstēr. (Herpes zoster.)

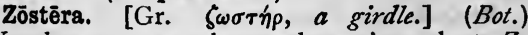
Wrack-grass; a submersed marine plant, $\mathbf{Z}$. marina, ord. Naiadaceæ. Its ribbon-like stems used as beds, and in packing glass. 
Zosterites. Fossil impressions of zöstēra (q.v.); in the Devonian system.

Zouaves. Light infantry in the French army ; said to be so called from a tribe of that name in Algeria, and originally raised in that country, but now exclusively recruited in France.

Zounds. A corr. of the phrase God's wounds, as S'death and S'blood are corr. of God's death and God's blood.

Zuchetto. [It.] (Eccl.) In the Latin Church, a skull-cap, that of a bishop being purple, that of the pope white.

Zuinglians. In Eccl. Hist., the followers of Zuinglius, the most advanced of the Reformers of the age of Luther. (Lutherans.)

Zumbra. (Naut.) A Spanish skiff or yawl.

Zunu. Goitred sheep of Angola; a breed with a roll of fat at the back of the head, and another on the throat, like a goitre; ears, back, and upper half of tail light brown, otherwise white. W. coast of Africa. Ovis Stěătǐnǐon [Gr, $\sigma \tau \epsilon \in \alpha \rho,-\bar{\alpha} \tau o s, f a t]$.

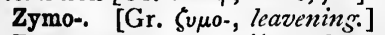

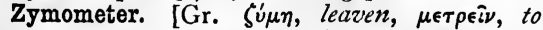
measure.] An instrument for measuring the degree of fermentation by mcans of the heat developed.

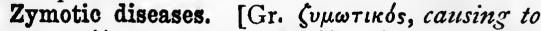
ferment, $v^{\prime} \mu \eta$, leaven.] (Mcd.) Discases caused apparently by some virus received into the body and spreading by a kind of fermentation; e.g. small-pox, measles, scarlatina, influenza, typhus, and many others.

Zyziphus. (Spina Christi.) 


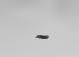




\title{
HISTOR Y
}

OF THE

\section{PEOPLE OF THE UNITED STATES,}

From the Revolution to the Civil War.

\author{
By JOHN BACH McMASTER.
}

"It is a glad, yet strange, surprise to find that a task which was looming up for a proper workman has already been undertaken and nearly completed by one who is unknown to letters until lie asks the American public to examine his pages and decide whether they are worthy of the place which they aim to occupy in the annals of the nation. . . . Heretofore the story of the nation's inception and growth has been frequently described, but has never been made interesting. Mr. McMaster not only descrives events and people with remarkable felicity, but has the power to lead the reader on from point to point, so that his pages have the swiftly-moving panoramic attraction which one feels in a railway-train, as it brings new scenes every moment to the eye."-Boston Herald.

"It is a storehouse of facts concerning the life, feelings, and limitations of the people, attractively grouped, and stated with precision and masculine energy. ... Bids fair to be the authoritative listory of the United States for the period which it covers."-The Nation.

"No one can linger long over this volume without perceiving that we have in it a fresh and valuable addition to our national literature, which calls for immediate recognition. The plan on which the work is constructed is similar to that of which the late lamented Mr. Green made such brilliant use in his 'History of the English People.' ... This truly admirable scheme promises to be carried out, if we may judge by this first volume, with an amplitude of research and thoroughness of scholarship which will give weight to the author's views, and a vigor and picturesqueness of style which will give them currency."-Boston Fournal.

"A history that is flavorless and colorless may make no enemies, but it will find few readers. Mr. McMaster will provoke criticism, but that will be no evidence that he is a partisan or a bigot. There wil be no question that he has rescued from oblivion a vast mass of those interesting data which, small in themselves, are of the greatest value in reflecting the actual condition of a people at a given time." -New York Fournal of Commerce.

" His theme is an important one, and we congratulate him on his success. His style is interesting and lively, and he gives such a graphic picture of our forefathers that it is a pleasure to follow him. The social life of our ancestors is so quaintly interesting and so widely different from the life of to-day that the chapters devoted to its description can not fail to entertain, if only by the marked contrast exhibited. . . The author has one great quality, and that is the power to arrange his ideas and marshal his facts. It has rarely been our province to notice a book with so many excellences and so few defects."-New York Herald.

" $\mathrm{He}$ carries out in a complete, vivid, and delightful way, his promise to describe the dress, the occupations, the amusements, the literary canons of the several epochs comprehended within the scope of his survey. . The cardinal qualities of style, lucidity, animation, and energy, are everywhere present. Seldom, indeed, has a book in which matter of substantial value has been so happily united to attractiveness of form been offered by an American author to his fellow-citizens."-New York Sun.

"His work, if the succeeding volumes are of a piece with this, will not be merely the most instructive of American histories, but a valuable contribution to narrative literature. His subject all historians may envy him; his information indicates diligent and well-directed preparation; his style is always clear, often picturesque, and sometimes eloquent."-New York World.

"In compact, crisp, concentrated statement, we have the events of the first century of our national existence vividly portrayed. The procession of events is marshaled with care, and it moves along smoothly and even brilliantly in the easy flow and apt statement of the well-fortified writer."-Boston Commonwealth.

" His style is clear and vigorous, if not always condensed. He has the faculty of felicitous comparison and contrast in a marked degree. Whatever may be said in criticism of it, no one will impute to it dullness in any part. He has the faculty of enchaining the attention and of holding it."-Boston Gazette.

"Not since Macaulay's famous third chapter on the state of England in 1685 has there been published a piece of historical writing showing a wider range of information, a surer literary touch, than the first chapter of Mr. McMaster's."-The Examiner.

"It differs from any work of the kind yet attempted in that it relates specifically to the industry, customs, social conditions, and progress of the people, instead of making them matters merely incidental to the political narrative."-Christian at Work.

"The narrative style, colored but not strained, spirited but with no attempt at eloquence, and free from rhetorical faults, is particularly attractive."-The Evangelist.

"The author, with well-chosen words, and in picturesque style, presents a succession of living pictures, showing us just how life went on day by day, how people occupied themselves, and what they thought. All this is real history. It makes fascinating reading. Not the first or the faintest shadow of dullness is to be found on any of these pages. . . . One great charm of the book consists in its artistic grouping of topics and of facts. The pictures explain and complete each other. There is a wonderful combination of colors, and of light and shade, the effect of which can be seen only by those who read and see the whole." -The Churchman.

To be completed in five volumes. Volume I now ready. Octavo, cloth, gilt top. Price, \$2.50.

D. APPLETON \& CO., Publishers, I, 3, \& 5 Bond Street, New York. 
I.

\section{A BIOGRAPHY OF}

\section{WILLIAM CULLEN BRYANT,}

With Extracts from his Private Correspondence.

\section{BY PARKE GODWIN.}

Containing a full account, from authentic sources, of the poet's ancestry; of his boyhood among the Hampshire hills ; of his early poems ; of his ten years' life as a country lawyer; of his long editorial career in New York; of his intercourse with contemporaries; of his travels abroad and at home; of the origin of many of his poems; of his political opinions; of his speeches and addresses; and of the honors he received.

With two Portraits on Steel: one from a Painting by Morse, taken when Mr. Bryant was in his thirty-first year; and one from a Pholograph by Sarony, taken in 1873.

In two volumes, square 8vo, cloth, gilt top. Price, $\$ 6.00$.

II.

\section{THE POETICAL WORKS OF WILLIAM CULLEN BRYANT.}

\section{EDITED BY PARKE GODWIN.}

In two volumes, square 8vo, uniform with the "Biography," cloth, gilt top. Price, \$600.

This is a wholly new and exhaustive edition of Bryant's Poctical Works, printed with unusual elegance. It contains : 1. All Mr. Bryant's poems that have hitherto appeared, with his latest corrections. 2. Sixty or more never before collected, including some thirty beautiful hymns, and a companion piece to "Sella " and "The Little People of the Snow." 3. Copious notes by Parke Godwin, giving various changes in the more important poems, an account of their origin, and other interesting information.

TO BE FOLLOWED, IN UNIFORM STYLE, BY

ORATIONS AND ADDRESSES. In one volume.

SKETCHES OF TRAVEL. In one volume.

New York: D. APPLETON \& CO., 1, 3, \& 5 Bond Street. 


\title{
LANDMARKS OF ENGLISH LITERATURE.
}

\author{
By, HENRY J. NICOLL.
}

12mo. - - - - - - - - - Vellum cloth, 81.75.

"The plan adopted in this book has been to deal solely with the very greatest names in the several departments of English literature-with those writers whose works are among the most imperishable glories of Britain, and with whom it is a disgrace for even the busiest to remain unacquainted."-From Preface.

"We can warmly recommend this excellent manual."-St. James's Gazelte.

"The 'Landmarks of English Literature' is a work of exceptional value. It reveals scholarship and high literary ability. Mr. Nicoll has a proper conception of the age in which he lives, and of its requirements in the special line in which he has attempted to work."-New York Herald.

"Mr. Nicoll is not ambitious, save to state things precisely as they arc, to give the common orthodox judgment on great authors and their places in history, and he has brought to his task a mild enthusiasm of style and a conscientiousness of exact statement that can not be overpraised. He writes out of a full mind, and yet he writes on a level with the ordinary intelligence." - New York Times.

"It would be hard to find anywhere an example of a more pithy, compact, yet attractive presentation of the real landmarks of the literature than is comprised in this duodecimo of 460 pages." - New York Home Journal.

"The work abounds in personal incident and anecdote connected with various authors, which assist the reader in making their acquaintance, and which give to the book a more lively aspect than one of cold criticism." - New York Observer.

"A book to be most heartily commended."-Boston Traveller.

"It has ample narrative and happy criticisms, and is filled with instructive and entertaining matter admirably presented. It would be hard to suggest improvement in style or arrangement."-Boston Commonwealth.

"The plan of the author is an excellent one. He has carried it out admirably. The book has a good table of contents and chronology, and an index of the authors."-Boston Gazette.

"Displays scholarship and high literary ability. His criticism is as sound as his selections have been judicious."-Chicago Tribune.

"It will be welcome, since it occupies territory of its own. Mr. Nicoll is a practiced critic and descriptive writer. The book goes from biography to criticism, and back again, in animated paragraphs."-Cincinnati Commercial Gazette.

"For those who desire a cicerone, Mr. Nicoll may be confidently recommended." Philadelphia Press.

For sale by all booksellers; or sent by mail, post-paid, on receipt of price.

New York: D. APPLETON \& CO., 1, 3, \& 5 Bond Street. 


\section{APPLETON \& CO.'S PUBLICATIONS.}

New revised edition of Bancroft's History of the United States.

HISTORY OF THE UNITED STATES, from the Discovery of the Continent to the Establishment of the Constitution in 1789. By GEORGE BANCROFT. An entirely new edition, partly rewritten and thoroughly revised. In six volumes, 8vo. Volume I now ready. Printed from new type, and bound in eloth, uncut, gilt top, $\$ 2.50$; sheep, $\$ 3.50$; half calf,

$\$ 4.50$. The other volumes will follow at short intervals.

This edition of Bancrofi's world-famous History of the UNited States has been for some time passing through the hands of the author, who has made extensive changes in the text, condensing in places, enlarging in others, and carefully revising. It is practically a new work, embodying, as it does, the results of the latest rescarches, and enjoying the advantage of the author's long and mature experience.

The original octavo edition is in twelve volumes. The present edition will be completed in six volumes, octavo, averaging over 600 pages each, the price being correspondingly reduced.

"The American Constitution is the most wonderful workk ever struck off at a given time by the brain and purpose of man."-W. E. Gladstone.

\section{HISTORY OF THE FORMATION OF THE CONSTITU-}

TION OF THE UNITED STATES OF AMERICA. BY

George Bancroft. Two volumes, 8 vo. Cloth, $\$ 5.00$; sheep, $\$ 7.00$; half calf, $\$ 9.00$.

***These volumes, while published separately, really form the eleventh and twelfth volumes of the "History of the United States," being directly connected with the tenth volume, last published.

"Mr. George Bancroft, in his eighty-second year-an age which few men reach, and at which few of those who do reach it retain the disposition or the capacity for protracted literary labor-sends out to the world a work which, in its clearness and strength of diction, its breadth of scope, its wealth of fresh material, and its philosophic grasp of events and their causes, would have reflected honor upon his prime. His 'History of the Formation of the Constitution of the United States of America' is a contribution to our literature of singular value and importance."-Boston Journal.

"The work evinces all the patient and persevering industry in the investigation of historical facts, all the philosophical acumen in tracing and discriminating their value and bearings, all the faculty for energetic and incisive statement, that were conspicuous in the best of Mr. Bancroft's historical productions, together with unabated narrative and descriptive powers. But it is gentler and more urbane in its judgments of men and motives, more chastened in its estimates of conflicting political principles, less redundant in its style, and it is pervaded by a sedateness and elevation of thought and a ripeness and mellowness of tone which invest it with an air of dignity that has been rarely equaled by any historian."-Harper's Magazine.

"This long-expected continuation of the magnum npus of Mr. Bancroft has come at last, and, alike in perfection of style and fullness of contents, it abundantly justifies the more than Horatian delay brought by the venerable author to its preparation. In the grave and judicial summing up of its judgments on the great men and the great events nere passed in revicw, it does not suffer at all by comparison with the immortal work of Thucydides, and it differs from the poignant brevity of Tacitus only because Mr. Bancroft is broader and more liberal in his philosophy."-New York Herald.

For sale by all booksellers; or sent by mail, post-paid, on roceipt of price.

New York: D. APPLETON \& CO., 1, 3, \& 5 Bond Street. 


\section{APPLETON \& CO.'S PUBLICATIONS.}

RAGNAROK (The Darkness of the Gods): the Age of Fire and Gravel. By Ianatius Donnelly, author of "Atlantis: the Antediluvian World." Illustrated. $12 \mathrm{mo}$, cloth, $\$ 2.00$.

"In this remarkable volume Mr. Dounelly, with an originality and vigor of which we had a taste in 'Atlantis,' unceremoniously knocks in the head all the elaborate theorizing as to the glacial period and other scientific forms of argument, and boldly proceeds to prove that the world owes its various physical changes to collisions with comets, more or less terrific in force, and to the calamitous and long-continued visitations of snow and flood and fire, the result of the encounter."-Troy Times.

"It is a bold enterprise, and its very boldness gives it a peculiar fascination. The vast range of the survey and the multitude of witnesses of every age and clime which the author passes in review yield the reader a decidedly new sensation, something like that of making a voyage round the earth in mid-air." - Home Journal.

"It is impossible to withhold respect for the ingenious logic and industrious scholarship which mark its pages."-Chicago Tribune.

"This theory . . . is set forth with the dexterity and earnestness with which in a previous work the author tried to prove the whilom existence of the fabled Atlantis, and it is equally certain to rouse the curiosity and enchain the attention of a large body of readers." $-N$. I. Sun.

WINNERS IN LIFE'S RACE; or, The Great Backboned Family. By Arabella B. Buckley, author of the "Fairy-Land of Science" and "Life and her Children." With numerous Illustrations. 12mo, cloth, gilt side and back, $\$ 1.50$.

"An account of vertebrate animals, written with such natural spirit and vivacity that it might convert even a literary person to natural science."-Saturday Review.

"Miss Buckley has spared no pains to incorporate in her book the latest results of scientific research. The illustrations in the book deserve the highest praise; they are numerous, accurate, and striking."-London Spectator.

"It is evident that the author has resorted to recent and eminent authorities for the facts which are marshaled with praiseworthy clearness in orderly succession." - The Nation, New York.

STELLAR THEOLOGY AND MASONIC ASTRONOMY; Or, The Origin and Meaning of Ancient and Modern Mysteries Explained. By RoBert HewitT Brown, $32^{\circ}$. With numerous Illustrations by the author, including Diagram of the Zodiac, and the Summer and Winter Solstices, in colors. Small 4to, cloth, $\$ 2.00$.

\section{HERBERT SPENCER ON THE AMERICANS, AND THE} AMERICANS ON HERBERT SPENCER. Being a full Report of his Interview, and of the Proceedings at the Farewell Banquet (November 9, 1882), with the Speeches of Evarts, Spencer, Sumner, Schurz, Marsh, Fiske, and Beecher, carefully revised by their authors. $12 \mathrm{mo}$. Thick paper, 25 cents ; paper, 10 cents.

For sale by all booksellers; or sent by mail, post-paid, on receipt of price.

New York: D. APPLETON \& CO., 1, 3, \& 5 Boud Street. 


\section{APPLETON \& CO.'S PUBLICATIONS.}

STUDEN'S'S CONCORDANCE to the Revised Version of the

New Testament. Compiled upon an original plan, showing all the changes in all words referred to. With Appendices of the chief authorized words and passages omitted in the revision, of rare and disused words, and a List of Readings and Renderings preferred by the American Committee. Small 4to, cloth, $\$ 2.50$.

"A concordance of the revised version to answer its end should in a measure comprise both versions - to the extent, at least, of affording some clew to the changed words. This has been done in the present work, by giving under each wora the words which in any text of the new version are substituted for the same word in the old."-Extract from Preface.

THE ACTS OF THE APOSTLES. With Notes, Critical, Explanatory, and Practical. Designed for the Use of Pastors and People. By Henro Cowles, D. D. $12 \mathrm{mo}$, cloth, $\$ 1.00$.

THE HOME NEEDLE. By Ella Rodman Church. With Diagrams. Volume 9 in "Appletons' HoMe Books." 12mo, cloth, 60 cents.

CONTENTS.-I. "Go Teach the Orphan Girl to Sew"; II. Beginning right ; Undergarments ; III. Undergarments (continued); IV. "The Song of the Shirt"; V. Rudiments of Dress-Making; VI. Dress-Making in Detail ; VII. Sewing and Finishing; VIII. The Milliner's Art ; IX. Children's Garments ; X. House-linen ; XI. The Mending Basket; XII. A Patchwork Chapter.

HOME OCCUPATIONS. By JaNet E. Rudtz-ReEs. With Illustrations.

Volume 10 in "Appletons' Home Books." 12mo, cloth, 60 cents.

CONTEN I'S.-I. Introductory ; II. What can be Done with Leather; III. The Possibilities of Tissue-paper ; IV. Modeling in Wax-Flowers; V. Modeling in Wax-Fruits etc. ; VI. The Preservation of Flowers and Grasses ; VII. Spatter-work; VIII. Framemaking; IX. Collections; X. Making Scrap-books; XI. The Uses of Cardboard; XII. What can be Done with Beads; XIII. Amateur Photography; XIV. Miscellaneous Occupations.

\section{NEW METHOD OF LEARNING THE FRENCH LAN-}

GUAGE. By F. Berger, author of "The English Method," adopted by the Paris public schools. $12 \mathrm{mo}$, cloth, $\$ 1.00$.

The marked success of Mr. Berger's English Method in France, where it is used extensively in public schools, lyceums, and colleges, has induced the author to prepare the pres ent volume for students of French.

For sale by all booksellers; or sent by mail, post-paid, on receipt of price.

New York: D. APPLETON \& CO., 1, 3, \& 5 Bond Street. 


\section{APPLETON \& CO.'S PUBLICATIONS.}

THE HOUSEHOLD BOOK OF POETRY. Edited by Charles

A. Dana. Entirely new edition, from new type, with nearly two hundred additional poems. Steel Engravings. Square 8vo. Cloth, gilt, $\$ 5.00$.

"When the first edition of 'The Household Book of Poetry' was published by Mr. Dana in 1857 , no other collection could so much as aspire to rival it. Since then we have had Bryant's collection and Emerson's collection, both by poets of fame, and both presumably eclipsing the effort of a writer who is not, so far as the world knows, a poet. Nevertheless Mr. Dana's collection remains the best of the three. The book deservedly keeps the lead in popular favor which it took at the start."--Nev York Times.

"Every intelligent reader and student of poetry has of course his own favorites, but we are safe in saying that no popular anthology is so well calculated as this to gratify and instruct the general public, or to provide for the genuine lover of verse so much that is good and worthy of preservation."-Boston Traveller.

"Mr. Dana has added nearly two hundred poems to his well-arranged collection, including many short poems by authors who have not published volumes. The collection now includes eleven hundred and seventy-five selections from three hundred and seventyseven authors, eighty-five of whom are Americans, and fifty-two women. This edition gives a list of authors, a list of the poems, and an index of first lines, and is printed with new type."-New York World.

FIFTY PERFECT POEMS. A Collection of Fifty Acknowledged Masterpieces, by English and American Poets, selected and edited by Charles A. Dana and Rossiter Johnson. With Seventy Original Illustrations from Drawings by Alfred Fredericks, Frank Millet, Will Low, T. W. Dewing, W. T. Smedley, F. O. C. Darley, Swain Gifford, Harry Fenn, Appleton Brown, William Sartain, Arthur Quartley, J. D. Woodward, Walter Satterlee, S. G. McOutcheon, and J. E. Kelley. The illustrations are printed on Japanese silk paper, and mounted on the page. The volume is bound in silk. Large 8 vo. $\$ 10.00$.

"The title of this volume may perhaps appear a little audacious to those who recall Pope's familiar dictum as to the impossibility of a faultless pice. In the absolute sense of the term, there is, of course, no perfect poem, because there is no perfect thing of any kind. But, as every art has its limitations, in whatsoever work the imperfections are caused by these limitations alone, the artist may fairly be said to have succeeded to perfection. On this principle the poems here collected have been chosen."-From Preface.

THE BRYANT BIRTHDAY-BOOK. With Portrait of Bryant and Twelve Engravings illustrative of the Months. . Printed with red lines. $18 \mathrm{mo}$. Cloth, red edges, $\$ 1.25$.

"The Bryant Birthday-Book" is a little larger than the Longfellow, Whittier, and other birthday-books, and a handsomer volume. It is printed with red lines, and contains a portrait of Bryant and twelve illustrations appropriate for the months. The binding is elegant and unique.

For sale by all booksellers; or sent by mail, post-paid, on receipt of price.

New York: D. APPLETON \& CO., 1, 3, \& 5 Boud Street. 
FLORIDA FOR TOURISTS, INVALIDS, AND SETTLERS: Containing Practical Information regarding Climate, Soil, and Productions; Cities, Towns, and People; Scenery and Resorts; the Culture of the Orange and other Tropical Fruits; Farming and Gardening; Sports ; Routes of Travel, etc., etc. By George M. BarBOUR. With Map and numerous Illustrations. 12mo. New edition, in red cloth, flexible, $\$ 1.50$.

IN THE BRUSH; OR, OLD-TIME SOCIAL AND POLITICAL LIFE IN THE SOUThWest. By H. W. Pierson, D. D. Illustrated by W. L. Sheppard. New cheap edition. $16 \mathrm{mo}$, paper. Price, 50 cents.

"It has peculiar attractions in its literary methods, its rich and quiet humor, and the genial spirit of its author." - The Critic.

"The book smacks of the soil, and of a state of things most unique and interesting, yet now rapidly fading from memory and reminiscence. . . . Its vivid, lively, and withal most truthful descriptions of a state of society now passed away for ever, will be read with interest."-The Evangelist.

THE YOUNG PEOPLE OF SHAKESPEARE'S DRAMAS. For Youthful Readers. By Amelia E. BARr. With Illustrations. 12mo. Cloth, $\$ 1.50$.

This work consists of scenes selected from Shakespeare's plays, in which youthful characters appear, accompanied with explanatory comments, and following each selection is an historic sketch, enabling the reader to compare the historical facts with the Shakespearean version. It is well calculated to please young readers.

"A happy thought inspired the task, and it is a source for congratulation that it was undertaken by one who has performed it in a spirit of such thoughtful and intelligent sympathy with the subject."-Boston Gazstte.

THE NERVOUS SYSTEM. Ninth Volume of "Health Primers." Square 16mo. Cloth, 40 cents.

Volumes of the "Health Primers" published are: Exercise and Training; Alcohol: Its Use and Abuse; The House and its Surroundings; Premature Death : Its Promotion or Prevention; Personal Appearance in Health and Disease; Baths and Bathing; The Skin and its Troubles; The Heart and its Functions; The Nervous System. 40 cents each.

BACHELOR BLUFF : his opinions, SENTIMENTS, AND DISPUTATIONS.

By Oliver Bell Bunce. 16mo. Cloth, $\$ 1.25$.

Mr. Bunce has not only. written a very bright book, but an honest and manly one. Apart from the sound lessons the book imparts, there is something more to be said. What Mr. Bunce writes is given in the very best of English, and most felicitous is he not only in the choice of language, but in the brightness of his phrasing." - New York l'imes.

For sale by all booksellers; or sent by mail, post-paid, on receipt of price.

New York: D. APPLETON \& CO., 1, 3, \& 5 Bond Street. 


\section{APPLETON \& CO.'S PUBLICATIONS.}

HISTORY OF THE WORLD, FROM THE EARLIEST RECORDS TO THE FAIL OF THE WeSterN EMPIRE. By Philip Smith, B. A. 3 vols., 8vo, vellum cloth, gilt top, $\$ 2.00$ per vol.

New edition, in elegant style, and at greatly reduced price.

"These volumes embody the resnlts of many years of arduous and conscientious study. The work is entitled to be called the ablest and most satisfactory book on the subject in our language. The anthor's methods are dignified and judicious, and he has availed himself of all the recent light thrown by philological research on the annals of the East. The work is well supplied with maps."-Dr. C. K. Adams's Manual of Historical Literature.

\section{MONTESQUIEU'S CONSIDERATIONS ON THE CAUSES OF THE GRANDEUR AND DECADENCE OF THE ROMANS. A New} Translation, together with an Introduction, Critical and Illustrative Notes, and an Analytical Index. By JEHU BAKER. Being incidentally a Rational Discussion of the Phenomena and the Tendencies of History in General. 12mo. Cloth, $\$ 2.00$.

"Mr. Jehu Baker has rendered a great service to English-speaking people by prodncing a new and admirable translation of Montesquieu's 'Considerations on the Grandeur and Decadence of the Romans.' But Mr. Baker has by no means confined himself to the simple work of translation. Many foot-notes have been added throughout the volume, each chapter is followed by an extended and elaborate note, and a careful analytical index greatly increases the value of the work for purposes of reference."-Boston Courier.

THE PROPHETS OF ISRAEL, AND THEIR PLACE IN HISTORY, TO THE CLOSE OF THE EIGHTH CENTURY B. C. By W. Robertson SMith, M. A., LL. D., author of "The Old Testament in the Jewish Church." $12 \mathrm{mo}$. Cloth, \$1.75.

"It is not every Professor of Hebrew whose academical lectnres would furnish forth such a rich feast as now lies before us. Even the happy few who know something of the facts of the Bible will learn mnch from the felicitousness of the present exposition. For Mr. Robertson Smith is not only a 'full man,' but has a singular gift of making a hard subject intelligible. . . . He loves to blow away the mists of controversy and slow the truth in all its attractive simplicity." -The Academy.

THE VISION OF ESTHER. By Charles De Kay. A sequel to "The Vision of Nimrod ; an Oriental Romance in Verse." $12 \mathrm{mo}$. Cloth, $\$ 1.50$.

"This work belongs to a new time, to a new class of readers and thinkers, and to a future group of poets. It will grow upon the thought and attention of the public as independent effort always does. Mr. De Kay has un unusual mastery of language; and it would be hard to find more beautifully written verse, of a vigorons and natural sort, than one can easily discover in this poem. It need only be added that 'Esther,' like the poetry of M. Sully-Prudhomme, is one of the signs of the time. The movement of thought, of discovery, of aspiration, is in a straight line. No one can fail to see the line. The poet must run as the world runs; and Mr. De Kay is at least one American poet who has felt the fire of his age. He will live longer than the imitators of Lougfellow and Bryant."-New York Times.

L. L. L.; OR, FIFTY LAW LESSONS. Embracing all the Technical Points of Business Law. By Arthur B. Clark, Principal B. \& S. Business College, Newark, N. J. $12 \mathrm{mo}$. Cloth, $\$ 1.25$.

For sale by all booksellers; or mailed, post-paid, on receipt of price.

New York: D. APPLETON \& CO., 1, 3, \& 5 Bond Street. 


\section{APPLETON \& CO.'S PUBLICATIONS.}

MYTH AND SCIENCE. By Trro Vignoli. 12mo. Cloth, $\$ 1.50$.

Contents: The Ideas and Sources of Myth; Animal Sensation and Perception; Human Sensation and Perception; Statement of the Problem; The Animal and Human Exercise of the Intellect in the Perception of Things; The Intrinsic Law of the Faculty of Apprehension; The Historical Evolution of Myth and Science; Of Dreams, Illusions, Normal and Abnormal Hallucinations, Delirium, and Madness.

"His book is ingenious; . . . his theory of how science gradually differentiated from and conquered myth is extremely well wrought out, and is probably in essentials correct." -Saturday Review.

\section{PHYSical Education; or, The Health Laws of Nature. By Frix}

L. OswaLd, M. D. $12 \mathrm{mo}$. Cloth, $\$ 1.00$.

The greater part of the contents of this volume appeared in a series of papers in "The Popular Science Monthly," where they attracted wide attention on account of the freshness of many of the ideas and the foree with which they were presented. No recent book on this subject is marked with so much special learning, original illustration, and incisive argument.

Contents: Diet; In-door Life; Out-door Life ; Gymnastics; Clothing; Sleep; Recreation; Remedial Education; Hygienic Precautions; Popular Fallacies.

“The title would seem to point to a dry, technical essay, on a much-discussed subject, but the reader who, entertaining that idea, passes it by, misses a strong, pungent book, full of common-sense suggestions, many of which, however, run counter to the popular idea, The author believes that the principal cause of human degeneration is the use of unnatural food."-Boston Transcript.

"There is no question about the great value of these essays as instructors in what is most healthful in diet, gymnastics, in-door and out-door sports, clothing, sleep, and recreation, and as furnishing hints on remedial education and hygienic precautions."-Utica Herald.

"Dr. Oswald is as epigrammatic as Emerson, as spicy as Montaigne, and as caustic as Heine."-Philadelphia Press.

HISTORY OF FRANCE. New volume in "History Primers," edited by J. R. Green. By Charlotte M. Yonge. 18mo, cloth, flexible. 45 cents.

\section{THE SONG WAVE: A Collection of Choice Music, with Elementary}

Instruction. For the School-Room, Institute-Hall, and Home Circle.

Containing a brief, practical, and comprehensive course of elementary instruction, with a great variety of selections, adapted to all occasions, including standing favorites and many new songs. $8 \mathrm{vo}$, boards, 80 cents.

DIE ANNA-LISE: A German Play by Hermann Hersch, with an Interlinear Translation, and Directions for learning to read German. By C. F. Kroen, A. M., Professor of Modern Languages in the Stevens Institute of Technology. 12mo. Cloth, $\$ 1.00$.

For sale by all booksellers; or sent by mail, post-paid, on receipt of price.

New York: D. APPLETON \& CO., 1, 3, \& 5 Bond Street. 


\section{APPLETON \& CO.'S PUBLICATIONS.}

ILLUSIONS : A Psychological Study. By James SulLY, author of "Sensation and Intuition," etc. ("International Scientific Series.") 12mo, cloth. Price, $\$ 1.50$.

This volume takes a wide survey of the field of error, embracing in its view not only the illusions commonly regarded as of the nature of mental aberrations or hallucinations, but also other illusions arising from that capacity for error which belongs essentially to rational human nature. The author has endeavored to keep to a strictly scientific treatment-that is to say, the description and classification of acknowledged errors, and the exposition of them by a reference to their psychical and physical conditions.

"The latest number of Appletons' 'International Scientific Series' bears the title of 'Illusions,' and is an interesting contribution by Mr. James Sully to the study of mental pathology. The author's field of inquiry covers all the phenomena of illusion observed in sensc-perception, in the introspection of the mind's own feelings, in the reading of others' feelings, in memory, and in bclief. The author's conclusions are often illustrated by concrete example or anecdote, and his general treatment of the subject, while essentially scientific, is sufficiently clear and animated to attract the general reader."-New York Sun.

"This is not a technical work, but one of wide popular interest, in the principles and results of which every one is concerned. The illusions of perception of the senses and of dreams are first considered, and then the author passes to the illusions of introspection, errors of insight, illusions of memory, and illusions of belief. The work is a noteworthy contribution to the original progress of thought, and may be relied upon as representing the present state of knowledge on the important subject to which it is devoted." - Popular Science Monthly.

A SELECTION FROM THE LETTERS OF MADAME DE REMUSAT.

1804-1814. Edited by her Grandson, PAUL DE RÉmusat, Senator. Uniform with “Memoirs of Madame de Rémusat," 1802-1808. 12mo, cloth. Price, \$1.25.

" 'A Selection from the Letters of Madame de Rémusat to her Husband and Son' has been published by the Appletons. Coming closcly upon the fascinating memoirs of that lady, they possess the same interest, and will add to the reader's knowledge of social and political life in France in the days of the first Napoleon. They deal, of course, largcly with family matters, but for all that we get vivid glimpses of public life, and, from $\mathrm{Ma}$ dame de Rémusat's intimate acquaintance with political affairs, we can pick up here and there hints which do not appear in French history, and yet are absolutely necessary to a thorough understanding of it."-Boston Evening T'ranscript.

THE ART OF SPEECH. Vol. II. Studies in Eloquence and Logic. By L. T. Townsend, D. D., Professor in Boston University, and Dean of Chautauqua School of Theology. Uniform with Vol. I. Studies in Poetry and Prose. 18mo, cloth. Price, 60 cents.

Contents of Voc. II: Part I. Studies in Eloquence: Introductory; History of Eloquence; Life and Character of Demosthenes ; Oration on the Crown ; Inferences; Inferences (continued); Inferences (continued); Inferences (concluded).-Part II. Studies in Logic: Introductory; Argumentation; Classification; Practical Observations.-Supple. mental Notes.

For sale by all booksellers; or sent by mail, post-paid, on receipt of price.

New York: D. APPLETON \& CO., 1, 3, \& 5 Bond Street. 


\section{APPLETON \& CO.'S PUBLICATIONS.}

THE LAND OF GILEAD. With Excursions in the Lebanon. By LaURence

Ourphant. With Illustrations and Maps. Crown 8vo, cloth. Price, $\$ 2.00$.

"His journeys took him quite off the beaten tracks of tourists and archæological explorers; he got an 'inside view,' so to call it, of native life and manners; he saw something of the wandering Bedouins; and we know of no recent book on Palestine which is really so instructive, from which the reader can derive so large a fund of entertainment."-Eclectic Magazine.

NEW YORK ILLUSTRATED. An entirely new edition of this work, extended to more than double the number of pages of previous editions, and including many new illustrations, making a most superb pictorial volume descriptive of the great metropolis. With new cover. Large 8vo. Price, 75 cents.

SOCIAL ETIQUETTE OF NEW YORK. New and enlarged edition. Containing two additional chapters-"Extended Visits," and "Customs and Costumes at Theatres, Concerts, and Operas"-with the chapter on "Etiquette of Weddings" rewritten in accordance with the latest fashionable usage. $18 \mathrm{mo}$, cloth, gilt. Price, $\$ 1.00$.

A TREATISE ON THE DISEASES OF THE NERVOUS SYSTEM.

By William A. Hammond, M. D., Surgeon-General U. S. Army (retired list); Professor of Diseases of the Mind and Nervous System in the University of the City of New York. One volume, 8vo, 928 pages, with about 150 Illustrations. Price, in cloth, $\$ 5.00$; sheep, $\$ 6.00$.

This, the seventh edition of Dr. Hammond's well-known work, has been thoroughly revised, and enlarged by the addition of new chapters and of a section on Diseases of the Sympathetic System.

The work has received the honor of a French translation by Dr. Labadie-Lagrave, of Paris, and an Italian translation by Professor Diodato Borrelli, of the Royal University, is now going through the press at Naples.

A TEXT-Book OF PRACTICAL MEdicine, with Particular Reference to Physiology and Pathological Anatomy. By Dr. Felix von Niemexer, Professor of Pathology and Therapeutics, Director of Medical Clinic of the University of Tübingen. Translated from the eighth German edition by George H. Humphreys, M. D., and Charles E. Hacklex, M. D. New revised edition, with additions. Two volumes, 8vo, 767, 861 pages. Price, in cloth, $\$ 9.00$; in library leather, $\$ 11.00$.

Since Dr. Niemeyer's death a new edition of his text-book has appeared in Germany, edited by Dr. Eugene Seitz. This has been freely drawn upon in the present revised American edition, and additions have been made from other sources of a character calculated to render the work more useful to American readers.

New York: D. APPLETON \& CO., 1, 3, \& 5 Bond Street. 
MILTARY HISTORY OF ULYSSES S. GRANT. From April, 1861, to April, 1865. By General Adam BadeaU, Aide-de-Camp to the General-in-Chief. Volumes II and III. This work is now complete in three octavo volumes, contain. ing over 2,000 pages, illustrated with a Steel Portrait and thirty-three Maps. Price, in cloth, $\$ 12.00$; sheep, $\$ 15.00$; half morocco, $\$ 20.00$. Sold only by subscription.

RISE AND FALL OF THE CONFEDERATE GOVERNMENT. By

Jefrerson Davis. Complete in two volumes, 8vo. Illustrated with Portraits of Mr. Davis, his Cabinet, Aides, and Generals, and with Maps and Plans. Price, per volume, in cloth, $\$ 5.00$; sheep, $\$ 6.00$; half turkey, $\$ 7.00$; full turkey, $\$ 10.00$. Sold by subscription only.

"Every impartial reader must; recognize the ability with which it is composed, the sincerity with which his opinions are held, and the good faith with which they are set forth, and the value which it possesses as the authentic commentary on the most momentous episode in the history of the United States since their independence was acknowledged and their Constitution was framed."-London Athenceum.

ANECDOTAL HISTORY OF THE BRITISH PARLIAMENT. From the Earliest Periods to the Present Time, with Notices of Eminent Parliamentary Men and Examples of their Oratory. Compiled by G. II. Jennixgs. Crown 8vo, cloth. Price, $\$ 2.50$.

"As pleasant a companion for the leisure hours of a studious and thoughtful man as anything in book-shape since Selden."-London Telegraph.

YOUNG IRELAND. A Fragment of Irish History, 1840-1850. By the Hon. Sir Charles Gavan Duffy, K. C. M. G. New cheap edition. 12mo, cloth. Price, $\$ 1.50$.

"Never did any book appear so opportunely. But, whenever it had appeared, with so lucid and graphic a style, so large a knowledge of the Irish question, and so statesmanlike a grasp of its conditions, it would have been a book of great mark."-London Spectator.

A HISTORY OF GREECE. From the Earliest Times to the Present. By T. T. Timarenis. With Maps and Illustrations. Two volumes, $12 \mathrm{mo}$, cloth. Price, $\$ 3.50$.

HISTORY OF HERODOTUS. An English Version, edited, with Copious Notes and Appendices, by George Rawlinson, M. A. With Maps and Illustrations. New edition. In four volumes, 8vo, vellum cloth. Price, $\$ 8.00$.

THE DICTIONARY OF ROMAN AND GREEK ANTIQUITIES. With nearly 2,000 Engravings on Wood, from Ancient Originals, illustrative of the Indus. trial Arts and Social Life of the Greeks and Romans. By Astrony Rich, B. A. Crown 8vo, cloth. Price, $\$ 3.00$.

This work is now offered at the above greatly reduced price.

New York: D. APPLETON \& CO., 1, 3, \& 5 Bond Street. 


\title{
THE HISTORY OF
}

\section{England in the Eighteenth Century.}

\author{
BY \\ WILLIAM E. H. LECKY, M. A.
}

VOLUMES III AND IV, EXTENDING FROM THE ACCESSION OF GEORGE

III TO 1784, THE OPENING YEAR OF PITT'S FIRST MINISTRY,

AND COVERING THE PERIOD OF THE AMERICAN

REVOLUTION. PUBLISHED BY ARRANGE-

MENT WITH THE AUTHOR.

\section{Large 12mo. Uniform with Vols. $I$ and $I I$, of which new editions are now ready. The 4 vols., cloth, \$2.25 each.}

"This section of the work covers the first twenty-two years of the reign of George III, a period which, in its bearing on constitutional, political, and social problems, was the most pregnant in the modern history of Great Britain. It was during these momentous years that the relation of the Crown to a Ministry representing the House of Commons was definitely fixed, that the necessity of parliamentary reform and expediency of abolishing Catholic disabilities were distinctly recognized, and that the influence of the newspaper press acquired unprecedented weight among political agencies, and called for new guarantees of freedom by changes in the law of libel. This was the period of Burke's most potent and exemplary activity, of the Middlesex election in which Wilkes played a part analogous to that taken by Bradlaugh in our own day, of the ministries of Bute, Grenville, Rockingham, Chatham, Shelburne, and the younger Pitt.

"At home and abroad this quarter of a century was memorable for conquests and revolutions. The affairs of the East India Company were administered by Clive, and the vast accessions of territory in Bengal were supplemented by those resulting from the war with Hyder Ali. In America the discontent of the thirteen colonies had ripened into open revolt, and all the phases of the contest are cxhibited in these volumes, up to the last year of exhaustion and inaction which preceded the final peace. Simultaneous with this movement on the other side of the Atlantic was the growth of political discontent in Ireland, which culminated in the demand for lerislative independence. All of these topics are carefully discussed by Mr. Lecky, and the spirit which he evinces is so candid and impartial that his conclusions will be listened to with attention and respect, even where they run counter to the reader's individual opinions and predilections." - New York Sun.

"The directness and lucidity of style, the copiousness of information, and the manifest endeavor to be strictly accurate and impartial, which were strongly marked characteristics of the earlier volumes, are dominant features also in these. His work, so far as it has progressed, will be by common consent awarded its place as the most important and impartial history of the period."-Boston Journal.

"The two new volumes of Lecky's 'History of England' will prove of special interest to Americans, as they cover the period of the American Revolution, and treat of statesmen, soldiers, authors, and philosophers, whose memories are enshrined in the hearts of the American people. His history of this period will present many points of interest when compared with that of the American historian Bancroft, whose latest work, by a happy coincidence, is simultaneously published with Mr. Lecky's."-Chicago Journal.

For sale by all booksellers; or, sent by mail, post-paid, on receipt of price.

New York: D. APPLETON \& CO., 1, 3, \& 5 Bond Street. 


\title{
History of the Rise and InfLUence of
}

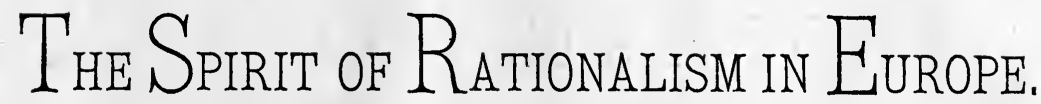

BY

\author{
WILLIAM E. H. LECKY, M. A.
}

2 vols., small 8vo. - - - Cloth, $\$ 4.00$; half calf, extra, $\$ 6.00$.

\section{The Nation.}

"Mr. Lecky is an exceedingly intelligent, cultivated, and accomplished man, of quick and true perception, of boundless and well-digested reading, of swift and vigorous reasoning power, of singular liberality and candor. $\mathrm{He}$ is intellectual, and at the same time enthusiastic; broad without being shallow, and rapid without noise. A man of earnest conviction, he is entirely free from bigotry; as an historian he is almost faultless, and as a critic he is without a peer. His book is animated by a vital idea which gave it birth, and which quickens every paragraph to the end; but the idea is too large and luminous to have the character of a dogma. The work will no doubt be extensively read. The wealth of its contents, and the singular grace of its style, always flowing, often picturesque, sometimes burning with suppressed eloquence, will insure a multitude of admirers. We hope they will."

\section{Chicago Home Circle.}

"Mr. Lecky launches out upon his subject with a majesty and confidence which prove him equal to the task. He handles nice distinctions which other writers on similar subjects have found it convenient to shun. It is not often that we meet so close and strong a reasoner. Independent and just himself in the exercise and expression of thought, he grants the same privilege to others. $\mathrm{He}$ is a dangerous opponent, for he argues from primary principles; but it is not so much his object to get the better of his opponent as to get at the truth; and this is his power. No one will regret a perusal of this great work."

\section{Richmond Whig.}

"We found that we held in our hand the book of a master. It is an able, well-digested, well-written, well-wrought book, containing much learning, and many interesting and illustrative facts, cited from every department of human knowledge."

\section{Cincinnati Western Christian Advocate.}

"It is a comprehensive and philosophic delineation of rational developments and triumphs in Europe, especially since the Reformation. It is a production of great ability, evincing extensive research and careful analysis of historic facts and their causes."

D. APPLETON \& CO., Publishers, 1, 3, \& 5 Bond Street, Now York. 


\title{
HISTORY OF \\ EUROPEAN MORALS, \\ From Augustus to CHARLEMAGNE.
}

\author{
BY \\ WILLIAM E. H. LECKY, M. A.
}

2 vols., $12 \mathrm{mo}$. - - - Cloth, $\$ 3.00$; half calf, extra, $\$ 7.00$.

OPINIONS OF THE PRESS.

"It has been subjected to such critical attack, and sustained by such able defense, that its worth is universally known. It is a mine of information in a restricted but important province, and will long be quoted for its thoroughness in opening a study which, though touched by other writers, never before had such exhaustive consideration. Those who have not read it will find their study of it richly rewarded."-Albany Evening Times.

"In his methods, Mr. Lecky is a model of clearness and force. Holding firmly the doctrine of evolution in morals, he finds the origin of typical vices and virtues in the ideal standards of the people, tracing the specific virtues and vices of each epoch considered to the special characteristics of a preceding epoch, which have been handed down as ideals. That his conclusions do not command universal acceptance is undoubtedly true, but they do command respect wherever honest thought and faithful labor, in search after truth, are appreciated."-Detroit Free Press.

"There is a vast fund of information in the work, which the student of the broad theme that it treats will find of great interest, and one to which he may refer, as occasion requires, with a certainty of finding something to the point. The volumes are arranged with foot-notes, giving authorities, references, and quotations."-Evening Wisconsin.

"The controversial part of the first chapter having given rise to a good deal of discussion, and to some little acrimony of feeling, perhaps, the author has softened it by the omission of a few lines, and strengthened his position by the insertion of some brief passages, explaining the meaning, or enforcing it."New York Evening Post.

"The excellence of this work is already attested, and it has long ago been considered a standard. The controversial portion of the work is clear in its statements, and so masterly in its handling of the salient points that none but an exceedingly obtuse person could fail to catch the full force of the argument presented. The author's object is to trace the changes that have taken place in moral standard and moral type through the different ages, and he concerns himself mostly with the period between Augustus and Charlemagne."-Indianapolis Journal.

For sale by all booksellers; or sent by mail, post-paid, on receipt of price.

New York: D. APPLETON \& CO., 1, 3, \& 5 Bond Street. 


\section{THE LEADERS OF Public Opinion in Ireland: \\ SWIFT, FLOOD, GRATTAN, O'CONNELL. WILLIAM E. H. LECKY, M.A.}

1 vol., 12mo. - - - - - - - - - - - Cloth, \$1.75.

"A writer of Lecky's mind, with his rich imagination, his fine ability to appreciate imagination in others, and his disposition to be himself an orator upon the written page, could hardly have found a period in British history more harmonious with his literary style than that which witnessed the rise, the ripening, and the fall of the four men whose impress upon the development of the national spirit of Ireland was not limited by the local questions whose discussion constituted their fame. Especially has O'Connell found in Mr. Lecky a fond biographer, and a most conscientions and impartial judge. The volume is elegant and brilliant in style, and treats with equal ability and warmth the three other men whose names appear with that of O'Connell."-New York Evening Post.

"Mr. Lecky, while feeling strongly, writes with judicial calmness; a foreigner could not be more impartial. His paper upon Swift is charming merely as a literary study, but it is even more valuable for the light it throws upon the genuine patriotism of the unhappy dean. Mr. Lecky, indeed, has all the qualities of a biographer, and his sketches of Grattan and Flood are quite striking in their keen analogies. It is for O'Connell, however, that he has reserved his best work, and we especially commend this portion of the book."-Nevo York Christian Union.

"To those who know anything of Mr. Lecky as a writer, it is not necessary to say that this volume is full of careful research, presented in correct, clear, and often beautiful language. The same finished, graceful style which distinguishes the historian of 'Rationalism' and of 'European Morals' gives its charm to this slighter work. Mr. Lecky discusses Irish opinion with all the enthusiasm of a Nationalist, not in the vulgar sense of that term, but as one animated by a deep and passionate love of country. At the same time, his work is altogether free from prejudices of sect or party. His study of the past and present of Irish public life is both interesting and valuable."-London Standard.

"These sketches are very well done indeed. They are bright, vigorous, sympathetic, and laudatory, but always with discernment. The faults of his leaders are neither concealed nor defended."-London Observer.

"A very instructive little book, furnished with an important preface, which would be useful as a separate pamphlet, but which is far more useful as showing the necessity of examining present difficulties by the light of such historical researches as appear in Mr. Lecky's eloquent and impartial volume."-London Examiner.

D. APPLETON \& CO., Publishers, 1, 3, \& 5 Bond Street, New York. 


\section{VALUABLE HAND-BOOKS.}

\section{ERRORS IN THE USE OF ENGLISH.}

By the late William B. Hodgson, LL. D., Professor of Political Economy in the

University of Edinburgh. American revised edition. $12 \mathrm{mo}$, cloth, $\$ 1.50$.

"This posthumous work of Dr. Hodgson deserves a hearty welcome, for it is sure to do good service for the object it has in view-improved accuracy in the use of the English language. . . Perhaps its chief use will be in very distinctly proving with what wonderful carelessness or incompetency the English language is generally written. For the exampies of error here brought together are not picked from obscure or inferior writings. Among the grammatical sinners whose trespasses are here recorded appear many of our best-known authors and publications."-The Academy.

\section{THE ORTHOËPIST :}

A Pronouncing Manual, containing about Three Thousand Five Hundred Words, including a Considerable Number of the Names of Foreign Authors, Artists, etc., that are often mispronounced. By Alfred Arres. 18mo, cloth, extra, $\$ 1.00$.

"One of the neatest and most accurate pocket manuals on pronunciation is 'The Orthoëpist,' by Alfred Ayres. It seems almost impossible to secure uniformity in pronunciation. It is the study of a life to master that of our tongue. The mere labor of examining a heavy dictionary prevents many from being accurate. This little book ought to be on every library-table. It undoubtedly gives the pronunciations accepted by the best speakers." $-N$. $Y$. Christian Advocate.

\section{THE VERBALIST:}

A Manual devoted to Brief Discussions of the Right and the Wrong Use of Words, and to some other Matters of Interest to those who would Speak and Write with Propriety, including a Treatise on Punctuation. By AlFred Arres, author of "The Orthoëpist." 18mo, cloth, extra, $\$ 1.00$.

"A great deal that is worth knowing, and of which not even all educated people are aware, is to be learned from this well-digested little book."-Philadelphia North American.

"Mr. Ayres is the author of a little book published about a year ago, whose title is 'The Orthoëpist," and which has had an exceptionally large sale, on account of its usefulness and of the good judgment displayed in its decisions of knotty points in pronunciation. His later volume may be looked upon as supplementary to that, since it endesvors to point out the correct use of words and phrases, in speaking and writing, and throws out innumerable suggestions that may prove valuable even to those who are the best informed and most correct in their habits of speech." - Utica Morning Herald.

"The author's views are sound, sensible, and conclsely and clearly stated."-Boston Transcript.

\section{THE RHYMESTER;}

Or, The Rules of Rhyme. A Guide to English Versification. With a Dictionary of Rhymes, an Examination of Classical Measures, and Comments upon Burlesque, Comic Verse, and Song-Writing. By the late Tox Hoop. Edited, with Additions, by Arthur Penn. Uniform with "The Verbalist." 18mo, cloth, gilt or red edges, $\$ 1.00$.

Three whole chapters have been added to this work by the American editor, one on the sonnet, one on the rondea $u$ and the ballade, and a third on other fixed forms of verse.

"Ten or a dozen years ago, the late Tom Hood, also a poet, and the son of a poet, pnblished 'The Rules of Rhyme,' of which we have a substantial reprint in 'The Rhymester,' with additions and sidelights from its American editor, Arthur Penn. The example of Hood's melodies, his own skill as a cunning versifler, and the accomplished editing of booklet a useful guide to English versification, the most useful one, indeed, that we are acquainted with." -The Critic.

For sale by all booksellers; or sent by mail, post-paid, on receipt of price.

New York: D. APPLETON \& C0., 1, 3, \& 5 Bond Street. 


\section{DISTINGUISHING EXCELLENCES}

\section{OF THE AMERICAN CYCLOPEDIA.}

I. Açuracy and Freshness of Information.-The value of a work of this kind is exactly proportioned to its correctness ; and to insure that, as well as the latest information, no expense or literary labor has been considered too great.

II. Impartiality.-The work has been pronounced by distinguished men and leading reviews in all parts of the Union strictly fair and national. Eschewing all expressions of opinion on controverted points of science, philosophy, religion, and politics, it has aimed at an accurate representation of facts and institutions, of the results of physical research, of the prominent events in the history of the world, of the most significant productions of literature and art, and of the celebrated individuals whose names have become associated with the conspicuous phenomena of their age, doing justice to all men, all creeds, all sections.

III. Completeness.-It treats of every subject, in a terse and condensed style, but fully and exhaustively.

IV. Its american Character.-The american Cyclopedia is found especially to meet the intellectual wants of the American people. It is not, therefore, modeled after any European works; but, while it embraces all their excellences, it has added to them an unmistakable American character, and is the production mainly of American mind.

V. Its Practical Bearing.-The day of philosophical abstraction and speculation has passed away. In this age of action, the work has been made thoroughly practical.

VI. Its Strue.-The cold, formal, and repulsive style of older works of this kind has given place to a style sparkling and emphatically readable-a style that interests and pleases as well as instructs. Many of the writers hold the foremost rank in general literature, and their articles have been characterized by the best critics as models of elegance, force, and beauty.

VII. Convenience of Form.-No ponderous work, with small type that strains the eyes and wearies the brain, is here presented. The volumes are just the right size to handle conveniently, the paper is thick and white, the type large, the binding good and durable.

VIII. Cheapness. Lithe work has been regarded as a miracle of cheapness. In order to enlarge its sphere of usefulness, and make it, in a true sense, a book for the people, it is offered to the public at the lowest possible price.

To sum up the above and other advantages of this work, it claims that it surpasses all other works in the fullness and ability of the articles relating to the United States; that no other book contains so many reliable biographies of the leading men of this and other nations; that the best minds of the country have enriched its pages with the latest data, and the most recent discoveries in manufactures, mechanics, and general science; that it is a library in itself; that it is well printed, and in convenient form; that it is reliable, impartial, complete, thoroughly American, deeply interesting and instructive, and cheap.

\section{APPLETON \& 00., Publishers, 1, 3, \& 5 Bond St., New York.}




\section{EMINENT MODERN SCIENTISTS.}

\section{HERBERT SPENCER'S WORKS.}

Synthetic Philosophy, 8 vols., 12mo, $\$ 15.25$; Miscellaneous Works, 6 vols., $12 \mathrm{mo}, \$ 10.75$.

First Principles................\$2 00

Principles of Biology. 2 vols...... 400

Principles of Psychology. 2 vols... 400

Principles of Sociology. 2 vols.... 400

The Data of Ethics. Being Part I,

Vol. I, of Principles of Morality.... 125

Education....................\$1 25

Untversal Progress............. 200

Essays......................... 200

StUDY of Sociology............. 150

Social Statics.................. 200 other Works.

Descriptive Socrology: A Cyclopædia of Social Facts. Royal folio. Eight Numbers: seven $\$ 4.00$ each, and one (double number) $\$ 7.00$. Total. $3500^{*}$

Prinlosophy of Style. 12mo. Flexible cloth.................... 50 On the Americans. 12mo. Paper... 10

\section{CHARLES DARWIN'S WORKS.}

13 vols., $12 \mathrm{mo}$, cloth, $\$ 25.00$; or separate volumes, as follows:

Origin of Species................\$2 $00 \mid$ Climbing Plants.................\$1 25

Descent of Man............... 300 Orchids Fertilized by Insects...... 175

Jourat of RESEARCHES........... 200

EMrotional Expression.............. 350

Antmals and Plants under Domesti-

catron. 2 vols............... 500

Insectivorous Plants.............. 200

Fertilization in the Vegetable KingDox........................ 200

Forms of Flowers............... 150

Power of Movement in Plants..... 200

Vhgetable Mould and Earth-Worms. 150

\section{THOMAS H. HUXLEY'S WORKS.}

12 vols., $12 \mathrm{mo}$, cloth, $\$ 19.50$.

Man's Place in Nature...........\$1 25 Lay Sermons, Adpresses, and Re-

On the Origin of Species.......... 100

More Criticisurs on Darwin, and Administrative NihilisM............

a Manual of tile Avatomy of Vertebrated Animals. Illustrated... 250

A Manual of the Anatomx of InvervIEws..................... $\$ 175$ Critiques and Addresses............ 150

50 American AdDresses.............. 125 Physiography................... 250 The Crayfish: An Introduction to Zoölogy .................... 175 tebrated Animals. Illustrated... 250 Science and Culture, and other Essays 150 Elements of Physiology and Hygiene. By T. H. Huxley and W. J. Youmans.... 150

\section{JOHN TYNDALL'S WORKS.}

\section{1 vols., $12 \mathrm{mo}$, cloth, $\$ 21.75$.}

Heat as a Mode of Motion........\$2 50 । Faraday as a Discoverer.........\$1 00 ON Sound................... 200 , ON Forms of W W Fragments of Science........... 250 Radiant Heat.................. 500 Light aNd Eleotricity ............ 125 Six Lectures on Light........... 150 Lessons in Electricity............. 100 Essays on the Floating Matte. In Hours of Exercise in the Alps.... 200 the Alr................. 150

New York: D. APPLETON \& CO., 1, 3, \& 5 Bond Street. 

